\title{
MINERALOGY AND GEOCHEMISTRY OF PEGMATITES ON MOUNT BEGBIE, BRITISH COLUMBIA
}

\author{
by \\ Andrea Dixon \\ B.S., Michigan Technological University, 2011 \\ A THESIS SUBMITTED IN PARTIAL FULFILLMENT OF \\ THE REQUIREMENTS FOR THE DEGREE OF \\ MASTER OF SCIENCE \\ in
}

THE FACULTY OF GRADUATE AND POSTDOCTORAL STUDIES

(Geological Sciences)

THE UNIVERSITY OF BRITISH COLUMBIA

(Vancouver)

October 2013

(C) Andrea Dixon, 2013 


\section{Abstract}

The pegmatite field on Mount Begbie, near Revelstoke, B.C., is a Li-rich pegmatite field in the southern Canadian Cordillera that is relatively well-known among prospectors, but until now, under-studied by academics. Mapping the pegmatite field on the northeastern slope of the mountain revealed a dense population of S-type granitic pegmatites belonging to the LCT family with diverse ranges of mineralogy corresponding to barren, beryl-columbite, beryl-columbitephosphate, and lepidolite-subtype compositions. Typically, the pegmatites are not strongly metamorphosed and show only rare foliation, meaning they primarily postdate the exhumation of the Thor-Odin Culmination that occurred during the Late Paleocene to Early Eocene. They are likely related to other granitic bodies (i.e., the Ladybird granite suite) resulting from the exhumation event rather than any other known intrusions in the Monashee complex. The dikes in the study area are elongate, with most at least $10 \mathrm{~m}$ long and are usually not more than one meter wide; the largest is approximately $520 \mathrm{~m}$ long and $10 \mathrm{~m}$ wide. Orientations of the pegmatites are dictated in part by conjugate shear planes developed in the host rock prior to the emplacement of the dikes; nearly all strike between $295^{\circ}$ and $330^{\circ}$ and have a subvertical dip. Fractionation is variable within the most primitive of the pegmatites and it may be controlled by localized fluid accumulation or the composition of the original source rock. Despite variability, fractionation within the pegmatite field increases from the southeast to the northwest, suggesting the source pluton may be located to the southeast of the study area at depth. Detailed examination of the minerals tourmaline, sekaninaite, beryl, rare-element oxides, and zircon as well as the mostly qualitative study of phosphates and other minerals provides insight into the geochemistry and mineralogy of the individual dikes. The results suggest that some of the primitive dikes are more fractionated than they appear and highlight other pegmatites as having unusual compositions for typical beryl-columbite and beryl-columbite-phosphate-subtype pegmatites. Elevated contents of Be and $\mathrm{Li}$ in sekaninaite and the presence of qitianlingite in the Mount Begbie pegmatite field are somewhat unique compared to other cordierite and rareelement oxide localities worldwide. 


\section{Preface}

This thesis is original, unpublished, independent work by the author, Andrea Dixon with assistance from Stefan Kruse in adapting the base geological map and from Jan Cempírek in data interpretation in Chapter 5 and 6. 


\section{Table of Contents}

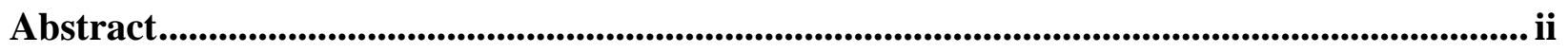

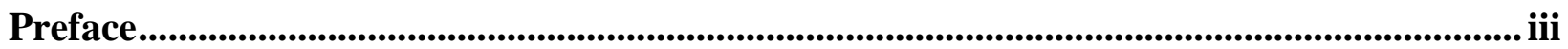

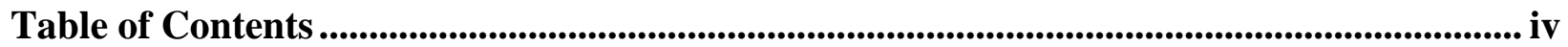

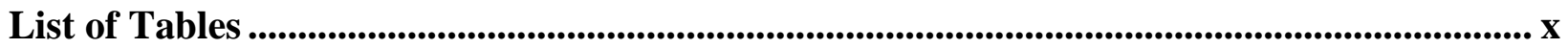

List of Figures...................................................................................................................................... xi

Acknowledgements ............................................................................................................................. Xxiv

Chapter 1: Introduction ................................................................................................................ 1

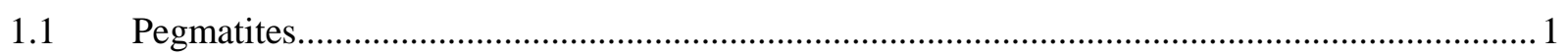

1.1.1 Describing and Classifying Pegmatites ..................................................................... 1

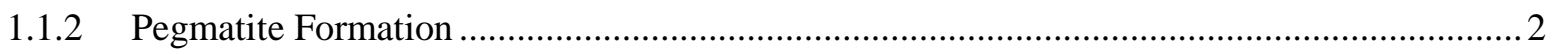

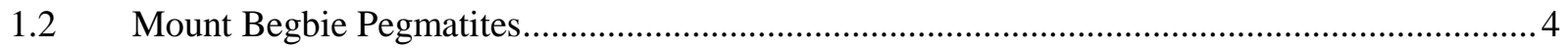

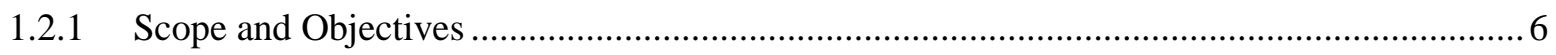

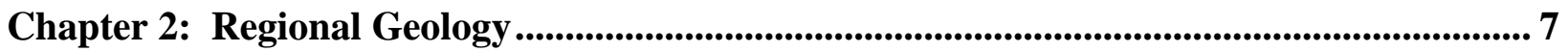

2.1 Geological Setting and History ...........................................................................................

2.2 P-T-t Conditions of Metamorphic Overprint........................................................................... 8

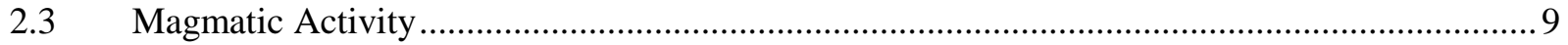

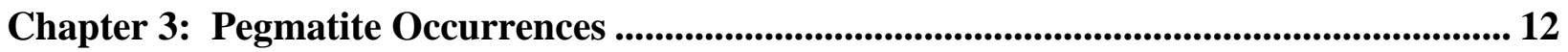

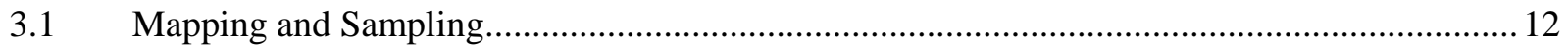

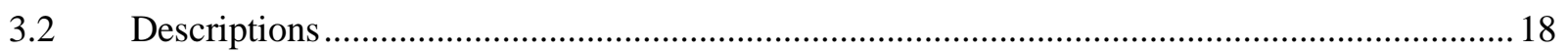

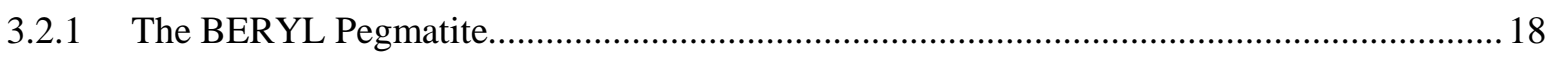

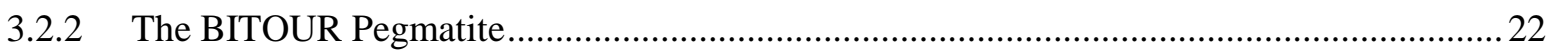

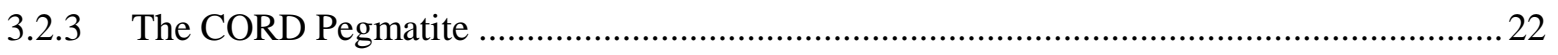

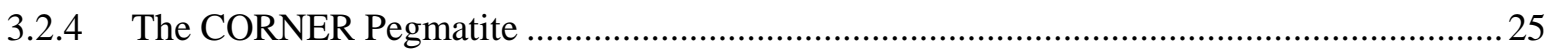

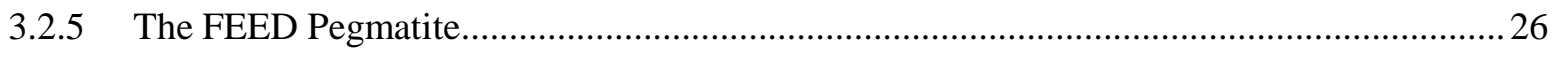

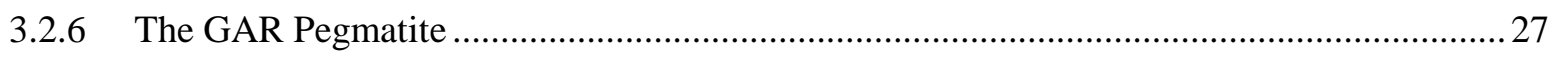

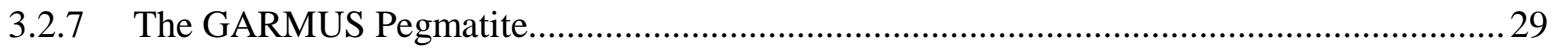

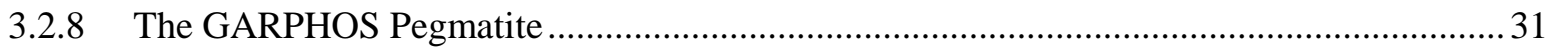

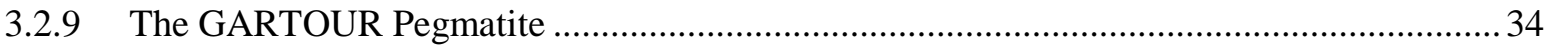




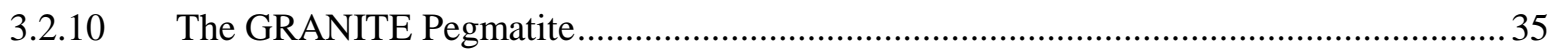

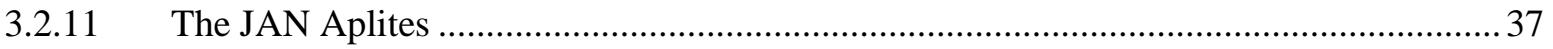

3.2.12 The JUNCT Pegmatite................................................................................................. 38

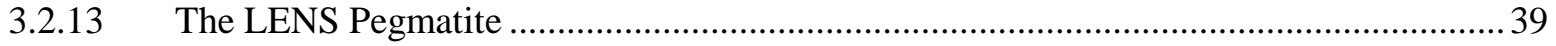

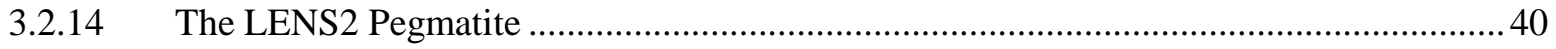

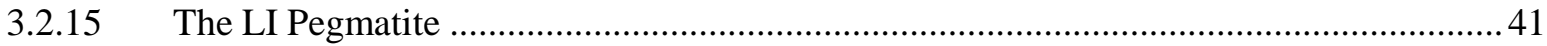

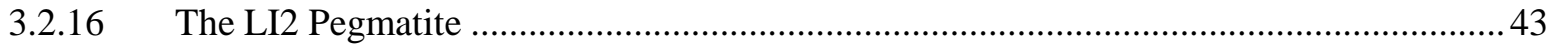

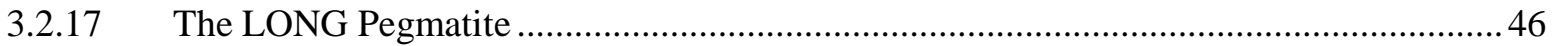

3.2.18 The META Migmatitic Pegmatite …..................................................................................... 47

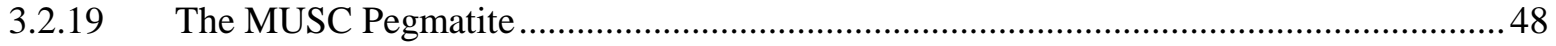

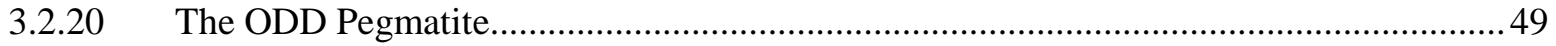

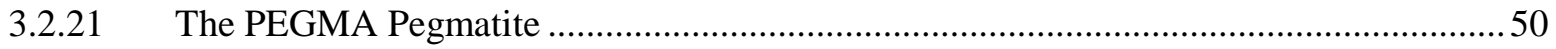

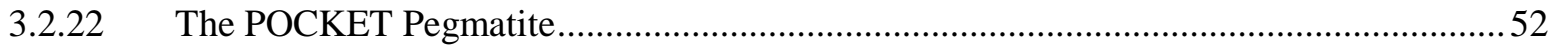

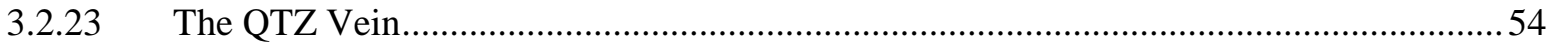

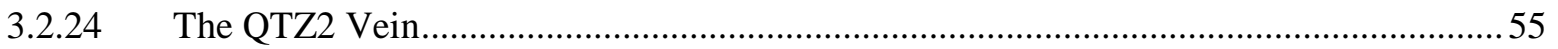

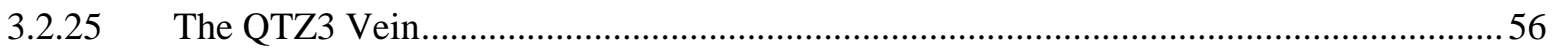

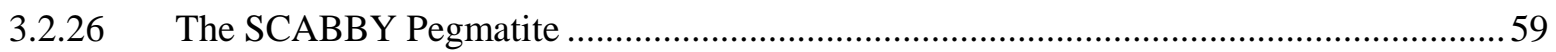

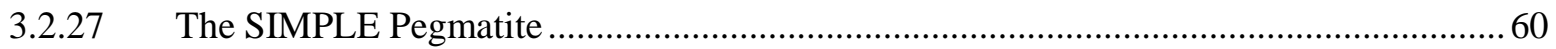

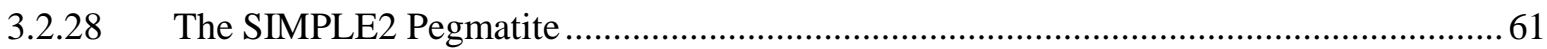

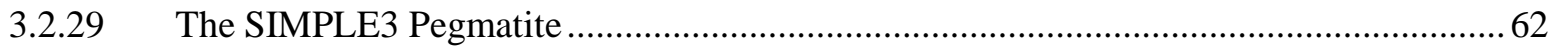

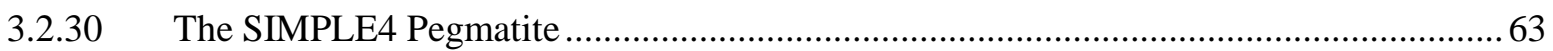

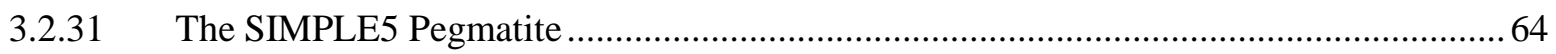

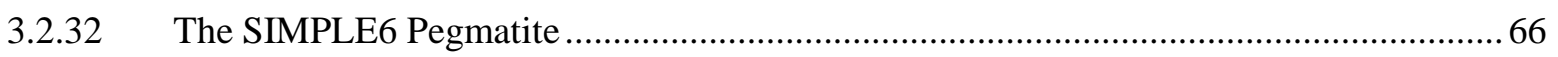

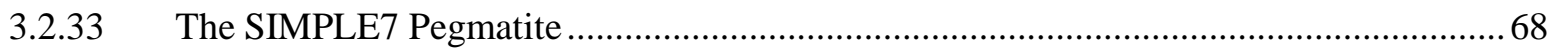

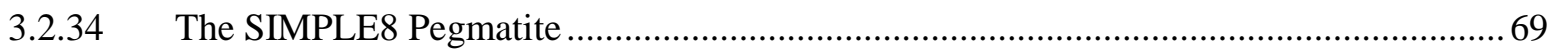

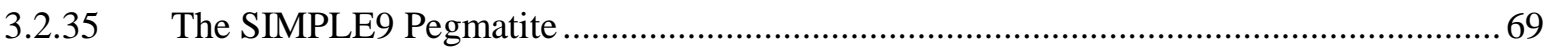

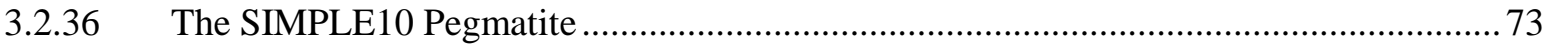

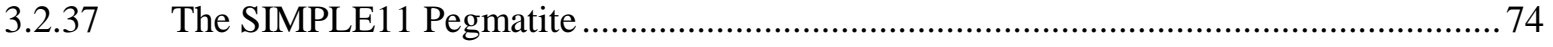

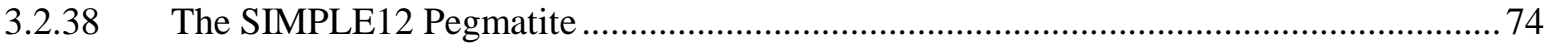

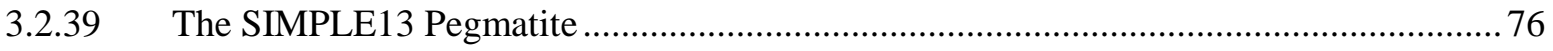

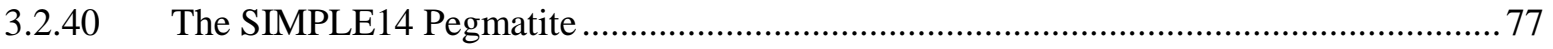

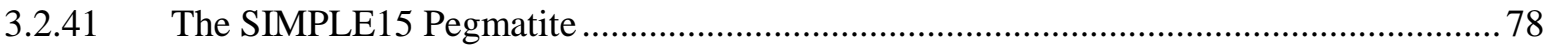

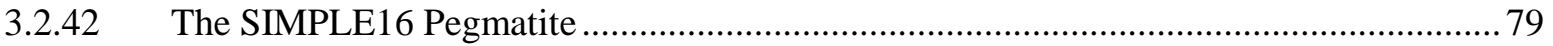

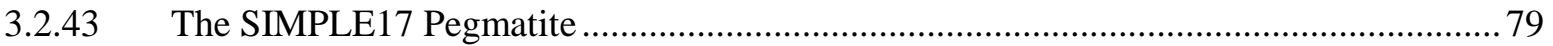




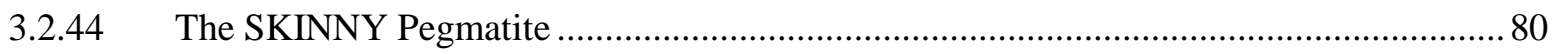

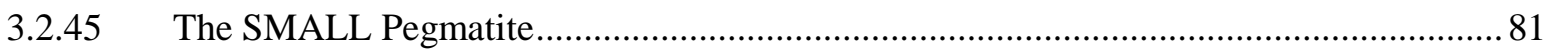

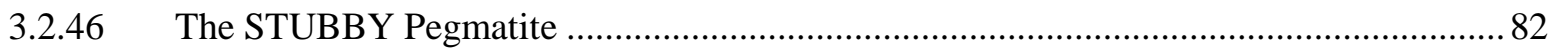

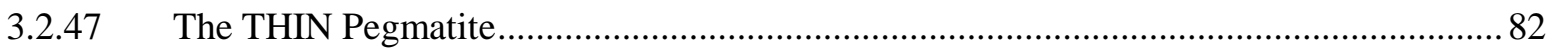

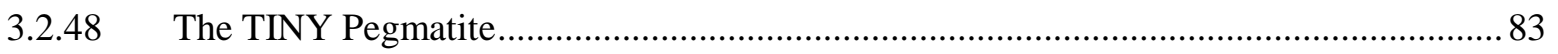

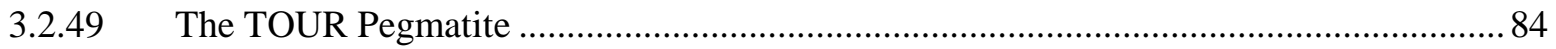

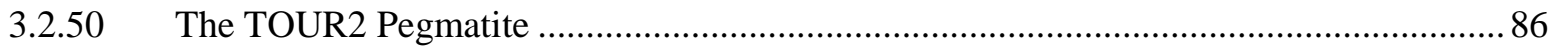

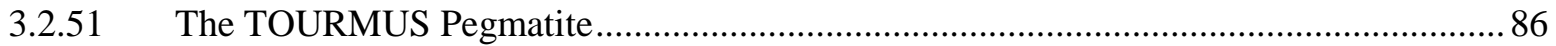

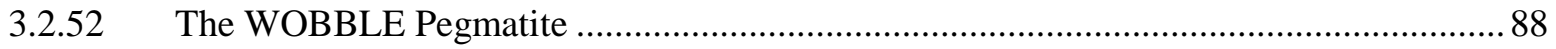

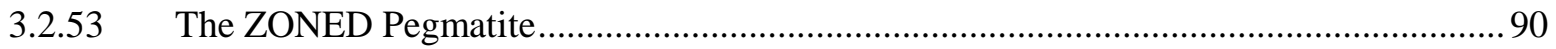

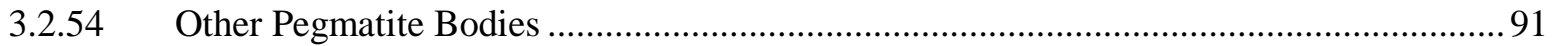

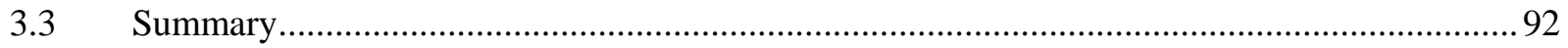

Chapter 4: Whole-Rock Geochemistry ........................................................................................ 93

Chapter 5: Mineralogy .......................................................................................................... 103

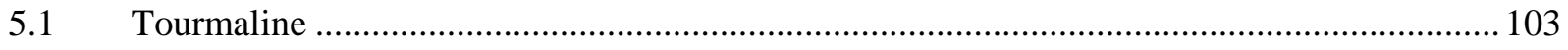

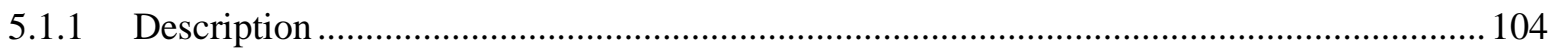

5.1.2 The BERYL Pegmatite Tourmaline …................................................................................ 107

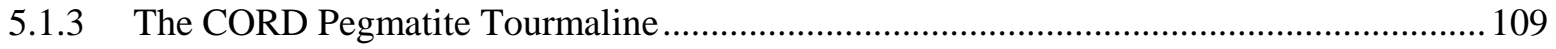

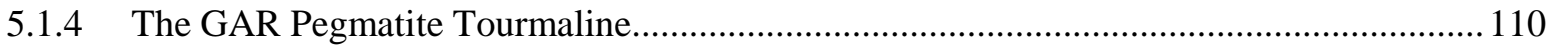

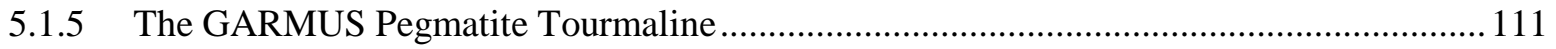

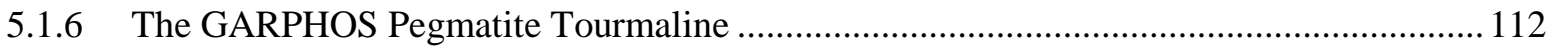

5.1.7 The GARTOUR Pegmatite Tourmaline............................................................................ 116

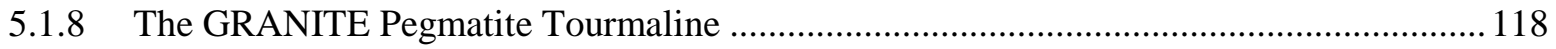

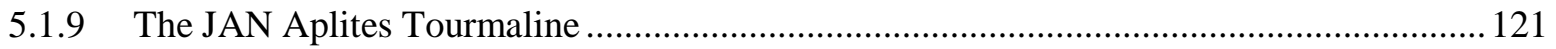

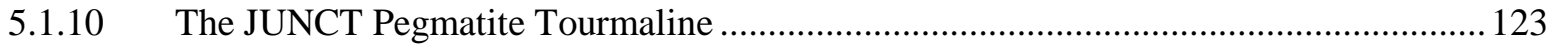

5.1.11 The LENS Pegmatite Tourmaline.................................................................................. 124

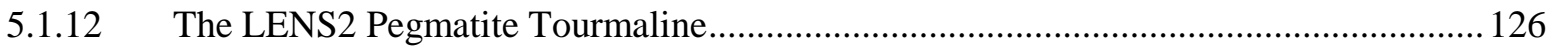

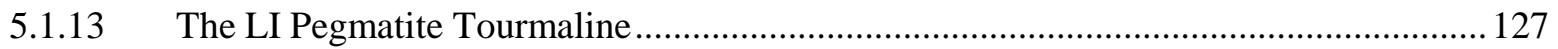

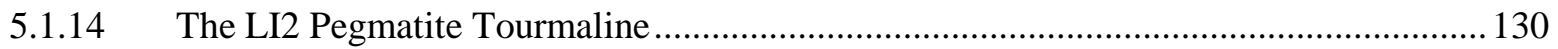

5.1.15 The LONG Pegmatite Tourmaline................................................................................ 133

5.1.16 The MUSC Pegmatite Tourmaline …............................................................................. 135

5.1.17 The PEGMA Pegmatite Tourmaline........................................................................ 136

5.1.18 The POCKET Pegmatite Tourmaline ........................................................................ 138 


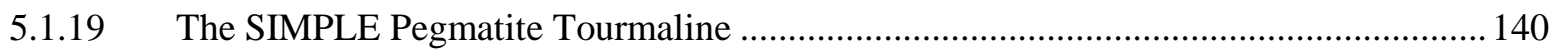

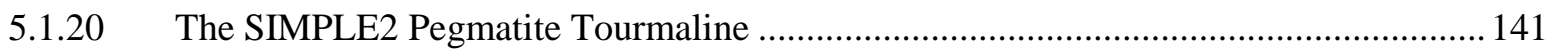

5.1.21 The SIMPLE3 Pegmatite Tourmaline .......................................................................... 142

5.1.22 The SIMPLE4 Pegmatite Tourmaline ............................................................................ 143

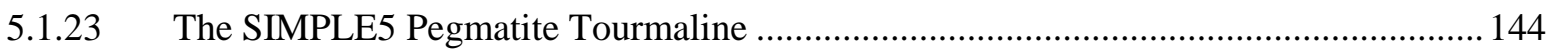

5.1.24 The SIMPLE6 Pegmatite Tourmaline ......................................................................... 145

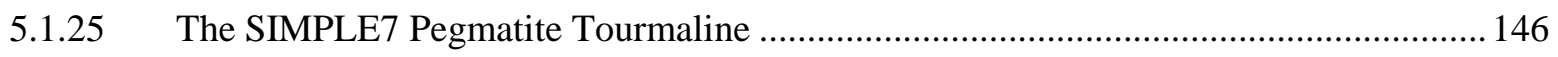

5.1.26 The SIMPLE9 Pegmatite Tourmaline ..................................................................... 147

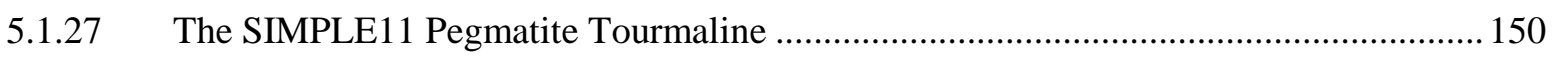

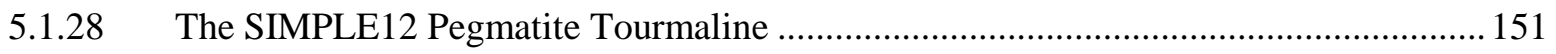

5.1.29 The SIMPLE13 Pegmatite Tourmaline .................................................................... 152

5.1.30 The SIMPLE14 Pegmatite Tourmaline ......................................................................... 153

5.1.31 The SIMPLE16 Pegmatite Tourmaline .......................................................................... 155

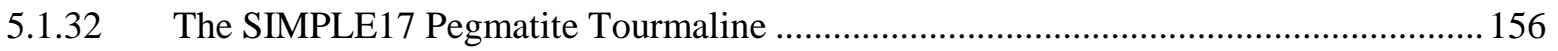

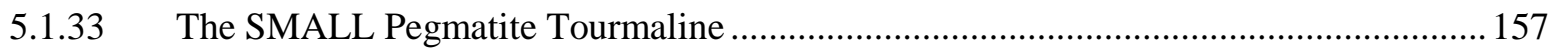

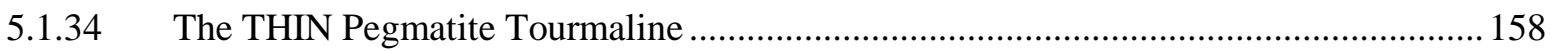

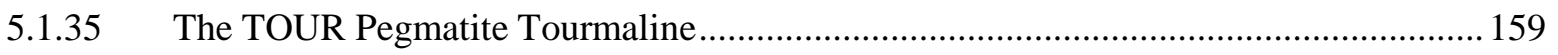

5.1.36 The TOURMUS Pegmatite Tourmaline .................................................................... 160

5.1.37 The WOBBLE Pegmatite Tourmaline......................................................................... 161

5.1.38 The ZONED Pegmatite Tourmaline ........................................................................... 162

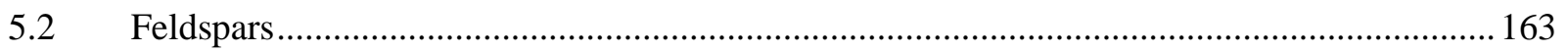

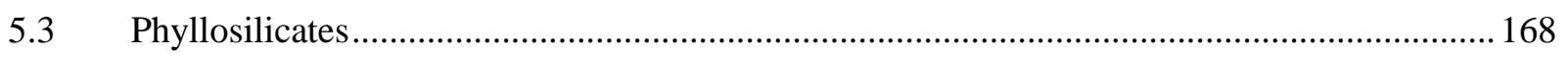

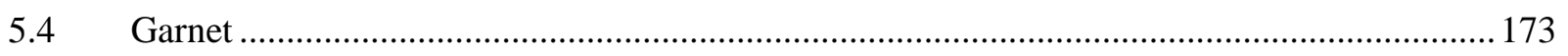

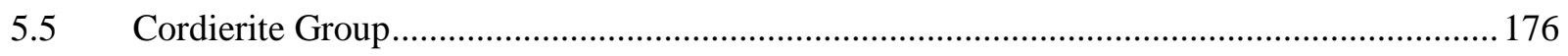

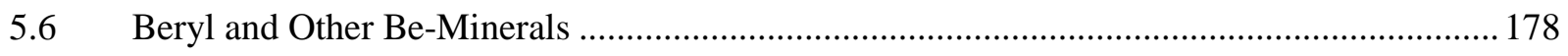

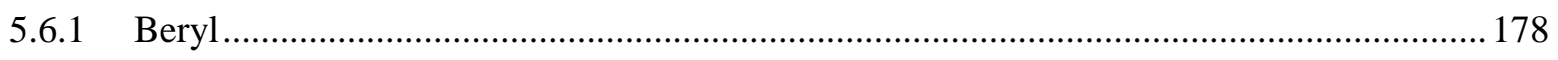

5.6.2 Other Be Minerals: Bertrandite, Chrysoberyl, and Euclase ........................................... 179

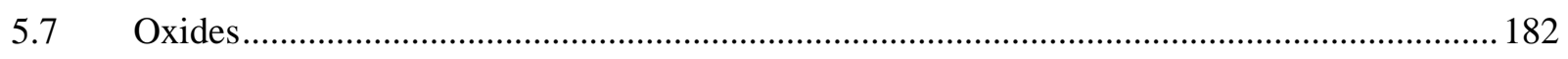

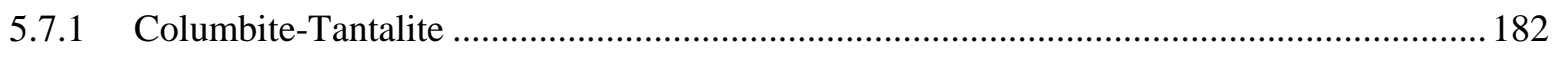

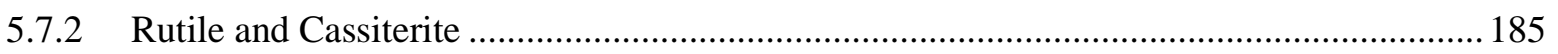

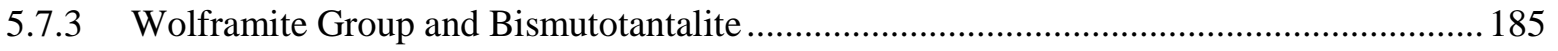

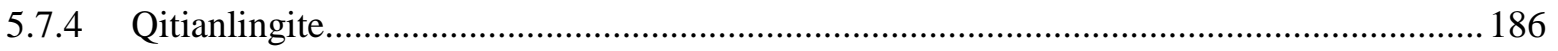

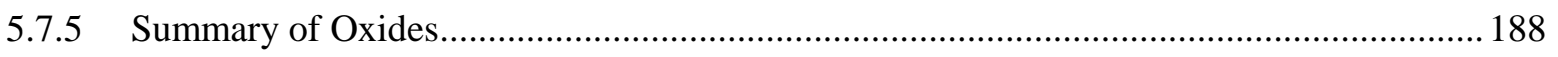

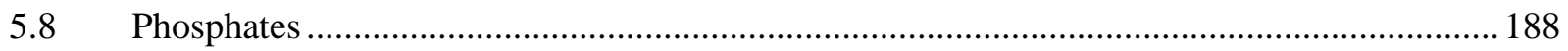




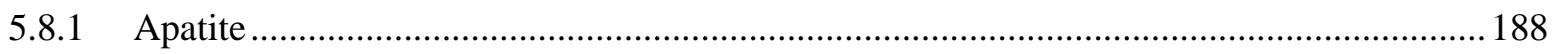

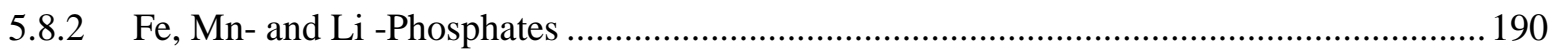

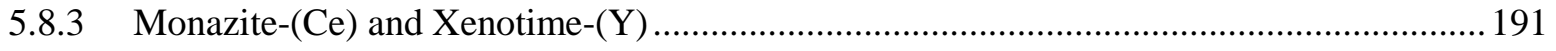

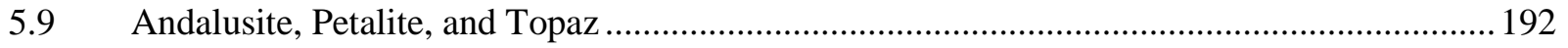

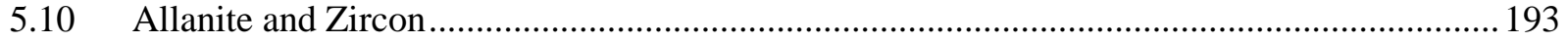

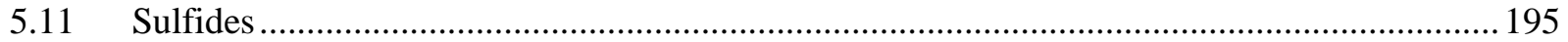

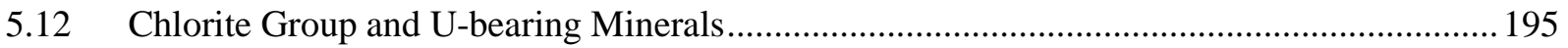

Chapter 6: Discussion .................................................................................................................. 198

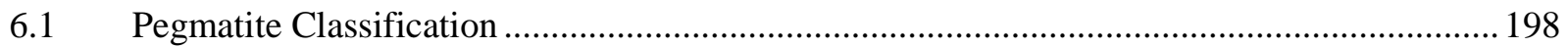

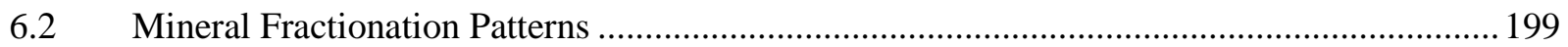

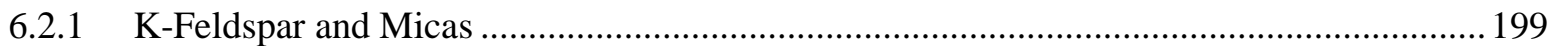

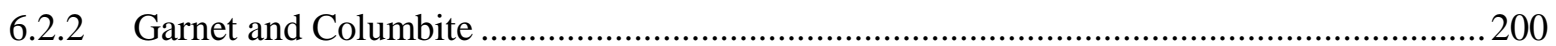

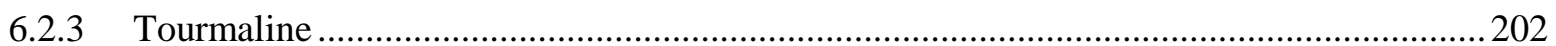

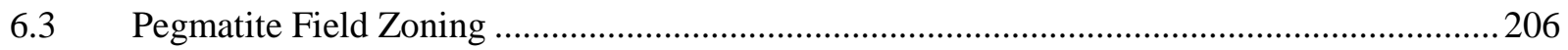

6.4 Comparison to Other Pegmatite Fields............................................................................. 208

Chapter 7: Conclusions ............................................................................................................... 210

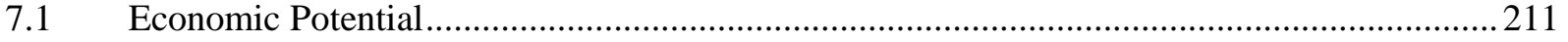

Chapter 8: Suggestions for Future Work ..................................................................... 212

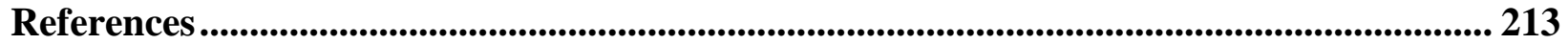

Appendices....................................................................................................................................... 221

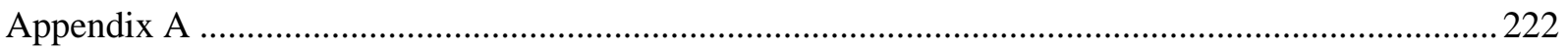

A.1 Mount Begbie Pegmatites 24” × 36”.............................................................................. 222

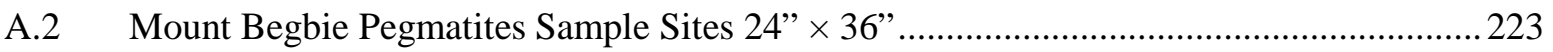

A.3 All Pegmatite Coordinates and Sample Sites .................................................................. 224

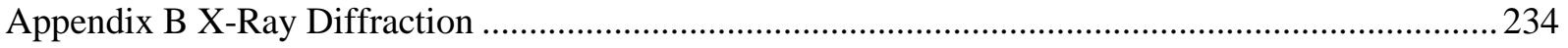

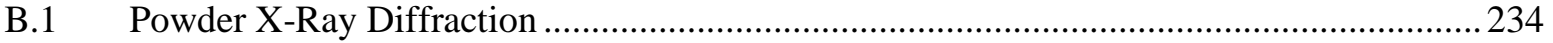

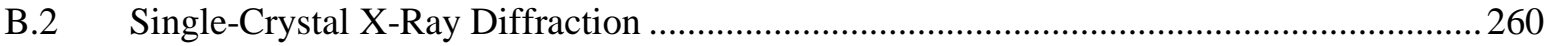

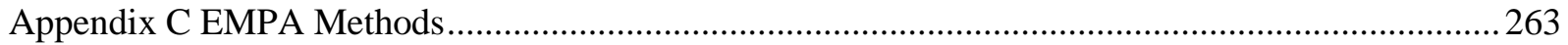

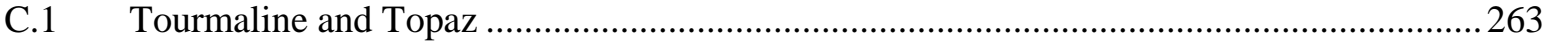

C.2 K-Feldspar, Muscovite, Lepidolite, and Biotite ................................................................. 264

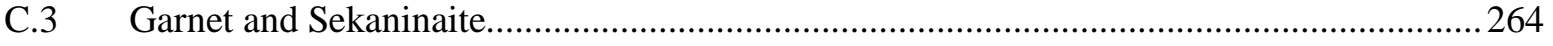

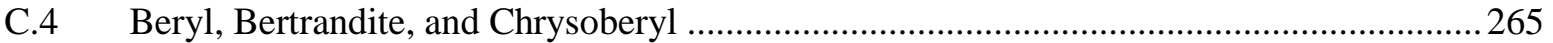


C.5 Columbite-Tantalite, Rutile, Cassiterite, Wolframite, and Qitianlingite............................265

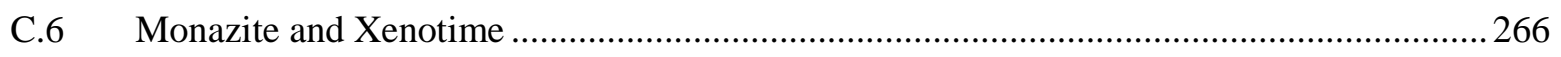

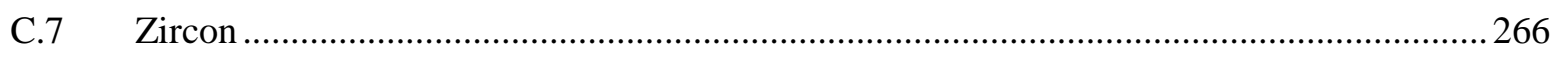

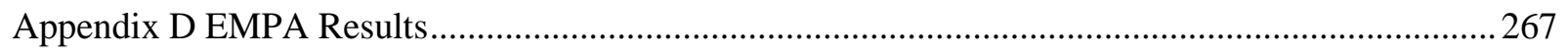

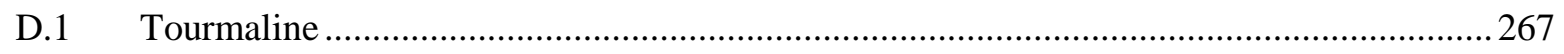

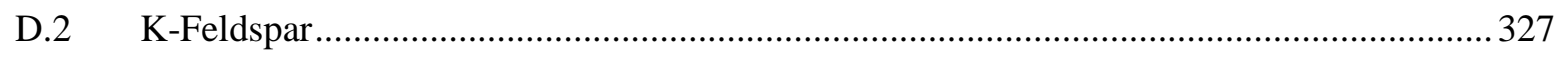

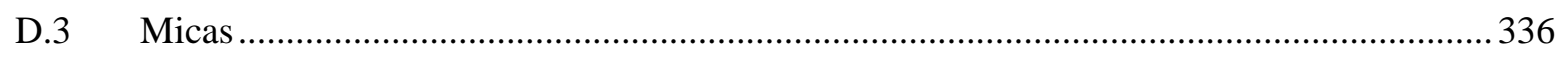

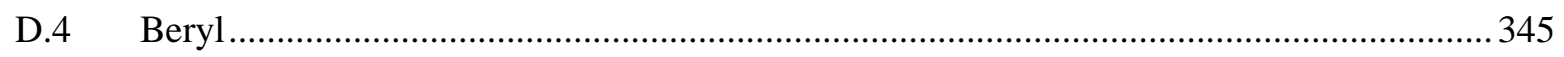

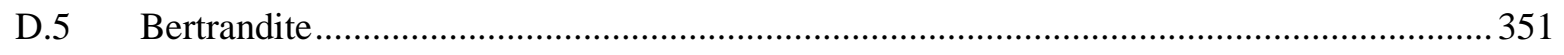

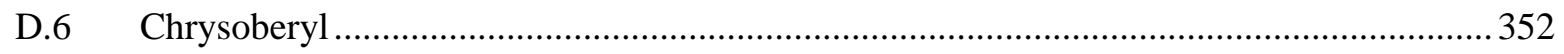

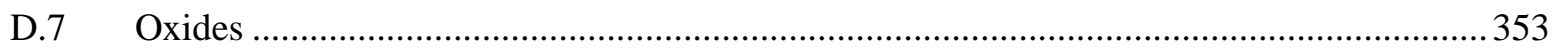

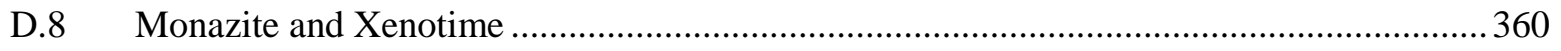

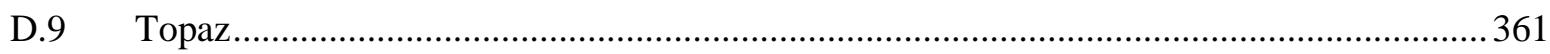

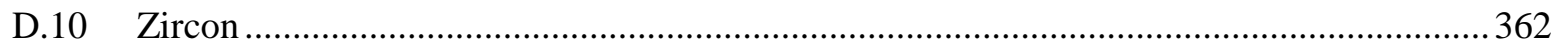

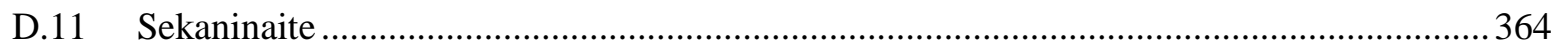




\section{List of Tables}

Table 4.1: Major element whole rock geochemistry for the GRANITE pegmatite (samples

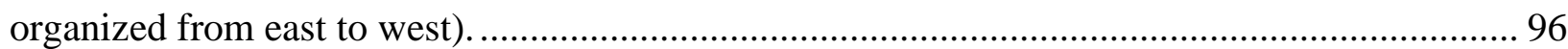

Table 4.2: Minor element whole rock geochemistry for the GRANITE pegmatite (samples

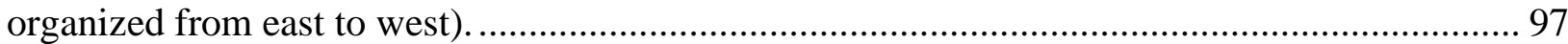




\section{List of Figures}

Figure 2.1: Setting of the study area within the Thor-Odin culmination and in context with the Canadian Cordillera. For more details of the study area, please see Fig. 3.1 and Appendix B.1. Figure modified after Kruse et al. (2005) and Kruse (2007).

Figure 2.2: A cross-section through the northern part of the Thor-Odin culmination showing the location of Mount Begbie, the Columbia River Fault, and the general location of the Galena Bay stock, Kuskanax batholith and similar rocks. Figure modified after Kruse (2007). 10

Figure 3.1 (preceding page): Map of pegmatites and related bodies within the study area, modified after Kruse et al. (2005), Kruse (2006), Kruse (2007), and Government of Canada (2012). 1. BERYL 2. BITOUR 3. CORD 4. CORNER 5. FEED 6. GAR 7. GARMUS 8. GARPHOS 9. GARTOUR 10. GRANITE 11. JAN 12. JUNCT 13. LENS 14. LENS2 15. LI 16. LI2 17. LONG 18. META 19. MUSC 20. ODD 21. PEGMA 22. POCKET 23. QTZ 24. QTZ2 25. QTZ3 26. SCABBY 27. SIMPLE 28. SIMPLE2 29. SIMPLE3 30. SIMPLE4 31. SIMPLE5 32. SIMPLE6 33. SIMPLE7 34. SIMPLE8 35. SIMPLE9 36. SIMPLE10 37. SIMPLE11 38. SIMPLE12 39. SIMPLE13 40. SIMPLE14 41. SIMPLE15 42. SIMPLE16 43. SIMPLE17 44. SKINNY 45. SMALL 46. STUBBY 47. THIN 48. TINY 49. TOUR 50. TOUR2 51. TOURMUS 52. WOBBLE 53. ZONED. For full legend explanation, see

Figure 3.2 (preceding page): Map of all sampling sites, modified after Kruse et al. (2005), Kruse (2006), Kruse (2007), and Government of Canada (2012). For full explanation of map contents, see Appendix A.

Figure 3.3a: The BERYL pegmatite. The southeastern end is seen from slightly beyond the rubble filled creek looking to the southeast. The yellow notebook in the center of the left-hand image is $18 \mathrm{~cm}$ tall.

Figure 3.3b: The main length of the BERYL pegmatite as seen from near the northwestern end looking to the southeast. 19

Figure 3.3c: Beryl crystals from the BERYL pegmatite..................................................... 20

Figure 3.3d: Muscovite book from the BERYL pegmatite.................................................... 20

Figure 3.3e: Thin vein of garnet crystals from the BERYL pegmatite.................................... 21

Figure 3.3f: Columbite (circled in black) next to tourmaline from the BERYL pegmatite......... 21 
Figure 3.4: The BITOUR pegmatite as seen from the northwestern end of the pegmatite looking to the southeast. 22

Figure 3.5a: Overview of the CORD pegmatite, as seen from the southeastern end of the pegmatite looking to the northwest. The backpack near the top of the image is $\sim 60 \mathrm{~cm}$ long.... 23 Figure 3.5b: A close-up of the alpine vein-like southeastern end of the pegmatite.................... 24

Fig. 3.5c: Dark blue tourmaline in the CORD pegmatite. ..................................................... 24

Figure 3.5d: Altered cordierite crystals in the CORD pegmatite........................................... 25

Figure 3.5e: Andalusite (pink) in the CORD pegmatite..................................................... 25

Figure 3.6: The CORNER pegmatite (extends towards the upper right corner of the image) where it branches from the LONG pegmatite (pegmatite along the bottom of the image). ......... 26 Figure 3.7: The FEED pegmatite as seen from its southeastern end and looking to the north.... 27 Figure 3.8a: The GAR pegmatite as seen from where it branches from the GRANITE pegmatite. The view is to the northwest. Note the offset of the dike to the south in the upper half of the

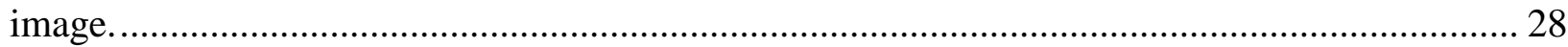

Figure 3.8b: A large sekaninaite crystal seen in an outcrop of GAR near its split from the GRANITE pegmatite. The chisel head is $\sim 3 \mathrm{~cm}$ across. 29

Figure 3.9a: The GARMUS pegmatite as seen from its southeastern terminus and looking to the northwest. 30

Figure 3.9b: Beryl (center) and garnet (red) in the GARMUS pegmatite. 30

Figure 3.10a: The GARPHOS pegmatite as seen from its southeastern-most traceable extent, looking to the northwest. The large boulder outcropping from the snow in the upper left of the picture is the GRANITE pegmatite.

Figure 3.10b: The GARPHOS pegmatite as seen near its midpoint and looking towards where it split from the GRANITE pegmatite under the snow field (Fig. 3.10a) ................................... 32 Figure 3.10c: Green elbaite-rimmed black tourmaline in the GARPHOS pegmatite................. 33 Figure 3.10d: Oxidized, dark gray phosphates (triplite-zwieselite) to the left and right of the base of the large black tourmaline crystal (slightly right of center). A beryl crystal can be seen next to the finger in the GARPHOS pegmatite. 33 Figure 3.11a: The GARTOUR pegmatite as seen from near the mid-point of the pegmatite and

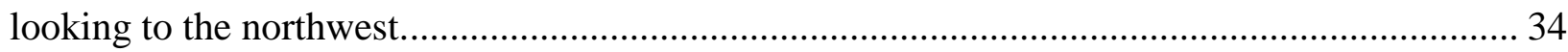
Figure 3.11a: Dark red-brown garnets in the GARTOUR pegmatite. 35 
Figure 3.12a: The GRANITE pegmatite as seen from near its mid-point and looking to the southeast. The moraine in the upper left of the background of the image marks the eastern extent of the study area. 36

Figure 3.12b: The northwestern end of the traceable extent of the GRANITE pegmatite, outcropping as a narrow wall on the left half of the image. The pegmatite on the right side is the MUSC pegmatite. 36

Figure 3.13a: The JAN aplites seen crosscutting the host rock......................................... 37

Figure 3.13b: A close up view of one of the JAN aplites................................................... 38 Figure 3.14: The largest eastern branch of the JUNCT pegmatite as seen near its mid-point and looking to the northwest. It joins the JUNCT pegmatite just beyond the crest of the small hill in the center of the image...... 39 Figure 3.15: The LENS pegmatite seen from its southeastern end and looking towards the northwest. Beyond it, the mapped quartz veins can be seen QTZ (left), QTZ2 (center), and QTZ3 (right).... 40

Figure 3.16: The LENS2 pegmatite as seen from its northwestern terminus and looking to the southeast.

Figure 3.17a: The LI pegmatite as seen from standing at the bottom of the knob and looking to the south. 42

Figure 3.17b: Lepidolite in the core of the LI pegmatite on top of the knob. 43

Figure 3.18a: The LI2 pegmatite as seen from near its southeastern end and looking to the northwest. 44

Figure 3.18b: Dark gray oxidized phosphates (triplite-zwieselite) in the LI2 pegmatite. 45

Figure 3.18c: The core of the LI2 pegmatite showing pink lepidolite and pale green tourmaline. 45

Figure 3.19: The LONG pegmatite as seen from near its southeastern end and looking towards the northwest. 46 Figure 3.20: The META migmatitic pegmatite as seen near its thickest section near its mid-point and looking towards the northwest.

Figure 3.21: The MUSC pegmatite as seen from its southeastern end and looking towards the northwest. GRANITE outcrops in the right side of the image. 
Figure 3.22: The ODD pegmatite as seen from slightly to the northwest of it and looking towards the southeast.

Figure 3.23: The PEGMA pegmatite as seen from a point where its two main branches join and looking to the southeast. 51

Figure 3.24a: The POCKET pegmatite as seen from its southeastern terminus looking towards the northwest.

Figure 3.24b: The largest miarolitic cavity in the POCKET pegmatite. The pencil is $\sim 15 \mathrm{~cm}$ long.

Figure 3.25: The QTZ vein as seen from between its southeastern end point and its mid-point and looking towards the northwest.

Figure 3.26: The QTZ2 vein as seen from near its southeastern end and looking towards the northwest.

Figure 3.27a: The QTZ3 vein as seen near its southeastern end and looking towards the northwest 57

Figure 3.27b: The intersection between a quartz vein (top of the image; oriented vertically) and an aplite (bottom of the image; oriented horizontally) in the QTZ3 vein 58

Figure 3.28: The SCABBY pegmatite as seen from its southeastern end and looking to the northwest.

Figure 3.29: The SIMPLE pegmatite as seen from its southeastern end and looking to the northwest. The STUBBY pegmatite is in the foreground with the notebook on top of it. 60 Figure 3.30: The SIMPLE2 pegmatite as seen from the south and looking to the north............. 61 Figure 3.31: The SIMPLE3 pegmatite as seen from the south and looking to the north............ 62 Figure 3.32: The SIMPLE4 pegmatite as seen from near its southeastern end and looking to the northwest. 63 Figure 3.33a: The SIMPLE5 pegmatite where it strikes $\sim 320^{\circ}$. The view is to the northwest. . 64 Figure 3.33b: The SIMPLE5 pegmatite where it strikes $\sim 275^{\circ}$. The view is to the west........... 65 Figure 3.34a: The SIMPLE6 pegmatite as seen from the end of one of its southeastern branches at the top of the slope. 66 Figure 3.34b: The SIMPLE6 pegmatite as seen from the southeastern end of the branch at the bottom of the slope. 
Figure 3.35a: The southern end of the SIMPLE7 pegmatite at the ridge top looking to the north.

Figure 3.35b: The northern end of the SIMPLE7 pegmatite underneath the ridge, looking to the south. 68

Figure 3.36: The SIMPLE8 pegmatite as seen from its eastern end and looking to the west. .... 69 Figure 3.37a: The main body of the SIMPLE9 pegmatite as seen from its southeastern end and looking towards the northwest. 70

Figure 3.37b: The northwestern end of the SIMPLE9 branch. The length of one of the black gloves piled near the center of the image is $\sim 22 \mathrm{~cm}$.

Figure 3.37c: Partially altered cordierite (dark green) with black tourmaline and muscovitequartz intergrowths in the SIMPLE9 pegmatite. .....

Figure 3.37d: Beryl (light blue, in center of the garnet), garnet, and black tourmaline in the SIMPLE9 pegmatite.

Figure 3.38: The SIMPLE10 pegmatite as seen from its southeastern end and looking to the northwest.

Figure 3.39: The SIMPLE11 pegmatite as seen from near its southeastern end and looking along its length to just before it joins with the GRANITE pegmatite. 74

Figure 3.40: The SIMPLE12 pegmatite as seen from its southeastern end and looking to the northwest.

Figure 3.41: The SIMPLE13 pegmatite as seen from its southeastern end and looking towards the west.

Figure 3.42: The SIMPLE14 pegmatite as seen from its eastern end and looking towards the west. 77

Figure 3.43: The visible extent of the SIMPLE15 outcrop.................................................... 78

Figure 3.44: The eastern end of the SIMPLE16 pegmatite; the view is to the west. 79

Figure 3.45: The SIMPLE17 pegmatite as seen from near its northwestern end and looking to the southeast. The pegmatite is oriented diagonally in the image from the lower left corner to the upper right corner. 80

Figure 3.46: The SKINNY pegmatite as seen from near its southeastern end and looking to the northwest. 
Figure 3.47: The SMALL pegmatite as seen from near its southeastern end looking towards the west. The portion of the dike near the top center of the photograph has muscovite-quartz intergrowths in its core......

Figure 3.48: The THIN pegmatite as seen near its southeastern end and looking towards the northwest.

Figure 3.49: The TINY pegmatite (foreground) as seen from near its northwestern end and looking towards where it joins the GRANITE pegmatite to the south (background). 84 Figure 3.50a: The TOUR pegmatite as seen from its northwestern end and looking towards the southeast. 85

Figure 3.50b: Cordierite-quartz intergrowth in the TOUR pegmatite. 85 Figure 3.51: The TOUR2 pegmatite as seen from near its southeastern end and looking towards the northwest. 86

Figure 3.52a: The TOURMUS pegmatite as seen from where it branches from the GRANITE pegmatite and looking towards the northwest. The three pegmatites in the background from left to right are GARMUS, LI2, and SIMPLE. 87 Figure 3.52b: A white beryl crystal (centered between the fingers) in the TOURMUS pegmatite. 88

Figure 3.53a: A representative section of the WOBBLE pegmatite with its blocky core near the yellow notebook and meandering veinlets on the left half of the image. 89

Figure 3.53b: Tourmaline-quartz intergrowths in the core of WOBBLE. 89 Figure 3.54a: The ZONED pegmatite as seen from its southeastern end and looking to the west.

Figure 3.54b: Rose quartz in the core of the ZONED pegmatite. 91 Figure 3.55a: Unmapped pegmatites. The left image is of the XENO pegmatite; the right image is of the MORE pegmatites—-three MORE dikes are visible in this image.............................. 91 Figure 3.55b: A cordierite-quartz intergrowth in an unmapped pegmatite. ............................ 92 Figure 4.1: Location of sample sites for whole rock geochemistry. For a full explanation of the map contents, please see Appendix A 95

Figure 4.2: Element ratios indicating increasing fractionation to the northwest for the GRANITE pegmatite. 98 
Figure 4.3: Other fractionation indicators (concentrations of $\mathrm{Li}, \mathrm{Be}, \mathrm{Cs}$, and $\mathrm{Pb}$ and the ASI ratio), show subtle increases in fractionation from the southeast to the northwest.

Figure 4.4: The spike in concentration of P and F at sample 12-GRANITE-S03 is likely caused by the abundant apatite observed in the sample. Likewise, the variable concentration B correlates with observed abundances of tourmaline observed in the field and hand sample. B was below the detection limit for 12-GRANITE-S02. 99 Figure 4.5: A representative hand sample from 12-GRANITE-S03 in plain light (top) and under short-wave UV light (bottom). Apatite is nearly colorless under plain light and fluoresces orange yellow under short-wave UV light. Black minerals in plain light are tourmaline and biotite. The abundance of apatite at this site likely contributed to elevated P and F concentrations. 100 Figure 4.6: A representative hand sample from 12-GRANITE-S09 plain light (top) and under short-wave UV light (bottom). Black minerals in plain light are tourmaline crystals. Apatite is nearly colorless under plain light and fluoresces orange yellow under short-wave UV light. . The abundance of tourmaline at this site likely contributed to elevated B concentrations......... 100 Figure 4.7: Chondrite normalized concentrations of the rare earth elements including Y. Note the both strongly positive and negative anomaly for Eu.................................................... 101

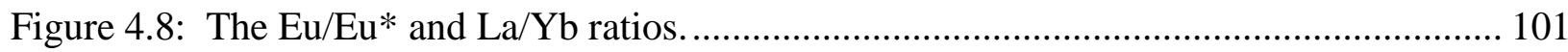

Figure 4.9: Pb-Ba diagram showing a relatively horizontal spread of values. ....................... 102 Figure 5.1: A BSE image of a tourmaline crystal from the BERYL pegmatite in which secondary mica and Fe-oxides can clearly be seen within the vertically and horizontally oriented partings. 105

Figure 5.2: Left: Zoning seen in a thin section of a tourmaline crystal that appeared homogeneous in hand sample from BERYL. Field of view is $10 \mathrm{~mm}$. Right: Light gray wavy zoning seen in a BSE image of tourmaline crystal that appeared homogeneous in hand sample from GRANITE. 106

Figure 5.3: Ternary diagrams showing the classification of tourmaline sampled from the BERYL dike. 108 Figure 5.4: Ternary diagrams showing the classification of tourmaline sampled from the CORD dike. 109 Figure 5.5: Ternary diagrams showing the classification of tourmaline sampled from the GAR dike. 110 
Figure 5.6: Ternary diagrams showing the classification of tourmaline sampled from the GARMUS dike.

Figure 5.7a: Ternary diagrams showing the geochemistry of tourmaline sampled from the GARPHOS dike.

Figure 5.7b: A tourmaline from the GARPHOS core zone in thin section using plain light with the tourmaline types labeled. The crystal is $24 \mathrm{~mm} \times 17 \mathrm{~mm}$. 113

Figure 5.7c: Plots showing the compositional trends of the different tourmaline types. 115 Figure 5.8a: Ternary diagrams showing the classification of tourmaline sampled from the GARTOUR dike.

Figure 5.8b: A BSE image of the tourmaline from the GARTOUR pegmatite with the core, inner rim and outer rim indicated.

Figure 5.9a: A BSE image of a tourmaline crystal from 12-GRANITE-S06 showing oscillatory zoning. Bright white grain on the right edge of the crystal is a zircon. 118

Figure 5.9b: Ternary diagrams showing the geochemistry of tourmaline samples from the GRANITE dike.

Figure 5.9c: Diagrams highlighting the fluctuating geochemistry in tourmaline samples from the 12-GRANITE-S06 and 12-GRANITE-S07 sample sites. Symbols are the same as those in Fig. 5.9a. 120

Figure 5.10a: The tourmaline with the white core and dark blue rim on the left is from the wall zone and is $\sim 1.5 \mathrm{~mm}$ long. The two green-rimmed crystals with the dark blue cores are from the center of the aplite; the combined length of the green-rimmed crystals is $\sim 1.2 \mathrm{~mm}$. 121 Figure 5.10b: Ternary diagrams showing the classification of tourmaline sampled from the JAN aplites. 122

Figure 5.11: Ternary diagrams showing the classification of tourmaline sampled from the JUNCT pegmatite.

Figure 5.12a: Ternary diagrams showing the classification of tourmaline sampled from the LENS pegmatite.

Figure 5.12b: A BSE image of tourmaline from the LENS pegmatite. Very faint oscillatory zoning can be seen in the middle of the crystal (late generation). 125

Figure 5.13: Ternary diagrams showing the classification of tourmaline sampled from the LENS2 pegmatite. 126 
Figure 5.14a: Black zoned tourmaline from the LI pegmatite as seen in thin section using plain light. Crystal is $16 \mathrm{~mm}$ wide by $15 \mathrm{~mm}$ tall.

Figure 5.14b: Ternary diagrams showing the classification of tourmaline sampled from the LI pegmatite. 128

Figure 5.14c: Plots showing the geochemical evolution of tourmaline sampled from the LI pegmatite.

Figure 5.15a: Ternary diagrams showing the classification of tourmaline sampled from the LI2 pegmatite. 131

Figure 5.15b: Plots showing the geochemical evolution of tourmaline sampled from the LI2 pegmatite.

Figure 5.16a: Ternary diagrams showing the classification of tourmaline sampled from the LONG pegmatite.

Figure 5.16b: A BSE image of a tourmaline crystal from the center of the LONG pegmatite. 134 Figure 5.17: Ternary diagrams showing the classification of tourmaline sampled from the MUSC pegmatite. 135

Fig. 5.18: Ternary diagrams showing the classification of tourmaline sampled from the PEGMA pegmatite.

Figure 5.19: Ternary diagrams showing the classification of tourmaline sampled from the POCKET pegmatite.

Figure 5.20: Ternary diagrams showing the classification of tourmaline sampled from the SIMPLE pegmatite. 140

Figure 5.21: Ternary diagrams showing the classification of tourmaline sampled from the SIMPLE2 pegmatite.

Figure 5.22: Ternary diagrams showing the classification of tourmaline sampled from the SIMPLE3 pegmatite.

Figure 5.23: Ternary diagrams showing the classification of tourmaline sampled from the SIMPLE4 pegmatite.

Figure 5.24: Ternary diagrams showing the classification of tourmaline sampled from the SIMPLE5 pegmatite.

Figure 5.25: Ternary diagrams showing the classification of tourmaline sampled from the SIMPLE6 pegmatite. 
Figure 5.26: Ternary diagrams showing the classification of tourmaline sampled from the SIMPLE7 pegmatite.

Figure 5.27a: Ternary diagrams showing the classification of tourmaline sampled from the SIMPLE9 pegmatite.

Figure 5.27b: Plots showing the classification of tourmaline sampled from the SIMPLE9 pegmatite. Legend is the same as seen in Fig. 5.27a.

Figure 5.27c: Pale blue late overgrowth on tourmaline from the center of the SIMPLE9 pegmatite as seen in thin section using plain light. Field of view is $4.2 \mathrm{~mm}$.

Figure 5.28: Ternary diagrams showing the classification of tourmaline sampled from the SIMPLE11 pegmatite. 150

Figure 5.29: Ternary diagrams showing the classification of tourmaline sampled from the SIMPLE12 pegmatite.

Figure 5.30: Ternary diagrams showing the classification of tourmaline sampled from the SIMPLE13 pegmatite.

Figure 5.31: Ternary diagrams showing the classification of tourmaline sampled from the SIMPLE14 pegmatite. 154

Figure 5.32: Ternary diagrams showing the classification of tourmaline sampled from the SIMPLE16 pegmatite. 155

Figure 5.33: Ternary diagrams showing the classification of tourmaline sampled from the SIMPLE17 pegmatite. 156

Figure 5.34: Ternary diagrams showing the classification of tourmaline sampled from the SMALL pegmatite. 157

Figure 5.35: Ternary diagrams showing the classification of tourmaline sampled from the THIN pegmatite...... 158

Figure 5.36: Ternary diagrams showing the classification of tourmaline sampled from the SIMPLE11 pegmatite. 159

Figure 5.37: Ternary diagrams showing the classification of tourmaline sampled from the TOURMUS pegmatite. 160

Figure 5.38: Ternary diagrams showing the classification of tourmaline sampled from the WOBBLE pegmatite. 
Figure 5.39: Ternary diagrams showing the classification of tourmaline sampled from the ZONED pegmatite.

Figure 5.40: A BSE image of late K-feldspar (Kfs) on albite (Ab) .................................... 163

Figure 5.41: Plots showing $\mathrm{Rb}_{2} \mathrm{O}$ vs. $\mathrm{Cs}_{2} \mathrm{O}$ and berlinite substitution in K-feldspar................ 164

Figure 5.42a: Map showing where K-feldspar samples had the greatest concentrations of Rb.165

Figure 5.42b: Map showing where K-feldspar samples had the greatest concentrations of Cs. 166

Figure 5.42c: Map showing where K-feldspar samples had the greatest concentrations of P... 167

Figure 5.43: Photomicrograph of fine-grained muscovite from the SKINNY pegmatite with a habit that is unusual for the study area. Dashed black line in the bottom left corner is $\sim 1.0 \mathrm{~mm}$

long 168

Figure 5.44: Classification diagram for micas. 169

Figure 5.45: Plot showing $\mathrm{Rb}_{2} \mathrm{O}$ vs. $\mathrm{Cs}_{2} \mathrm{O}$ for mica. 170

Figure 5.46a: Map showing elevated Rb content in mica. 171

Figure 5.46b: Map showing elevated Cs content in mica. 172

Figure 5.47: Plots showing the compositional variations of garnet within the study area. 174

Figure 5.48: Map showing where garnet samples had the greatest ratio of $\mathrm{Mn} /(\mathrm{Mn}+\mathrm{Fe}) \ldots \ldots 175$

Figure 5.49: A BSE image of sekaninaite from the GAR pegmatite and its most common decomposition products.

Figure 5.50: Compositional diagram showing sekaninaite classification (left) and substitution schemes (right). 177

Figure 5.52: Plots showing possible element substitution sites other than the Y site (left) and the sum of divalent cations vs. the sum of monovalent cations (right). 179

Figure 5.53: A BSE image of skeletal bertrandite (Brt) and plagioclase (Pl) after beryl (Brl) from the SIMPLE9 pegmatite. Bright gray spots are unidentified clay minerals. 180 Fig. 5.54: Chrysoberyl (Cbl) in thin section under cross-polarized light as an inclusion in beryl $(\mathrm{Brl})$ at the contact of an albite crystal (Ab). Field of view is $10 \mathrm{~mm}$. 181

Figure 5.55: Photomicrograph of the constituent minerals in the "pocket” prior to removal for identification for powder X-ray diffraction. Black dashed line in the lower left corner of the image shows the length of $1 \mathrm{~mm}$.

Figure 5.56: Diagram showing the classification and compositional trends of the columbitetantalite specimens analyzed. 
Figure 5.57: BSE image of manganocolumbite (Clb) grading into manganotantalite (Tnt) from the LI pegmatite.

Figure 5.58: Left: Thin section through hübnerite (brown) with secondary muscovite (white) and tourmaline (blue) replacing sekaninaite in the GAR pegmatite; field of view is $4.2 \mathrm{~mm}$. Right: BSE image of bismutotantalite (Btn) in the fluor-elbaite rim of a green elbaite (Elb) crystal partially surrounded by lepidolite (Lpd); white scale bar is $500 \mu \mathrm{m}$. 186

Figure 5.59: BSE image of a crystal with zones of qitianlingite and ferrocolumbite from the BERYL pegmatite.

Figure 5.60: Ternary diagram showing the classification of qitianlingite and other analyzed oxides.

Figure 5.61: BSE image showing a typical example altered apatite from the LI pegmatite. Scale bar is $100 \mu \mathrm{m}$. 190

Figure 5.62: A BSE image of triplite (Tp) rimmed by apatite (Ap) next to a perthite-like grain of K-feldspar (Kfs) and albite (Ab)..... 190

Figure 5.63: Left: Chondrite normalized values of REE in monazite and xenotime. Right:

Points on the 1:1 line indicate cheralite substitution in monazite. 192

Figure 5.64: A BSE image of allanite (Aln) from the LONG pegmatite. 193

Figure 5.65: Plot of Zr vs. Hf. 194

Figure 5.66: A BSE image of galena inclusions in a Fe-sulfide inclusion in an Fe-oxide from the LONG pegmatite.. 195

Figure 5.67: Photomicrograph of uranophane from the BERYL pegmatite. Field of view is $\sim 4$ $\mathrm{mm}$.

Figure 5.68: A BSE image of uraninite (Urn) inclusions in zircon (Zrn) with columbite (Clb) and monazite (Mnz) all as inclusions in triplite from the GARPHOS pegmatite 197 Figure 6.1: Fractionation trends in columbite from Mount Begbie pegmatites (left) and general fractionation trends seen in columbite from complex and beryl pegmatites (right; modified after Černý 1989). 201

Figure 6.2: Tourmaline evolution trends from the LI and LI2 pegmatites (left; legend is same as Fig. 5.15a) and from lepidolite subtype-pegmatites (right; modified after Selway et al. 1999). 202 
Figure 6.3: Tourmaline evolution trends from the GARPHOS pegmatite (left; legend is same as Fig. 5.7c) compared to tourmaline from lepidolite subtype-pegmatites (right; modified after Selway et al. 1999).

Figure 6.4: Comparison of the tourmaline evolution of the LI and LI2 (left) and GARPHOS pegmatites (right). Legends as mentioned above. 204 Figure 6.5: Comparison of all of compositional evolution of Li-, Be-, and primitive pegmatites.

Figure 6.6: Distribution of fractionated pegmatites. 207

Figure 6.7: Map of the Fregeneda-Almendra pegmatite field, modified after Vieira et al. (2011). 


\section{Acknowledgements}

I wish to thank my supervisors, Lee Groat for his support, guidance, and optimism, especially through the initial twists and turns that my thesis took during my first year in Canada, and Jan Cempírek for his help in the field, in the lab, and above all, his coaching and instrumental help towards the end of my thesis. I have learned a great deal from both of you and enjoyed all of our discussions.

I would also like to thank Julie Selway, Robert Gordon, Wanita Campbell, and the others at Caracle Creek International Consulting Inc., who graciously helped me after the initial project for my thesis fell through. Additionally, I would like to thank Lorax Environmental for their financial support through the Jay McNee Memorial Scholarship.

This project would not have been possible without the support of Brad Wilson, who showed me around his claims and allowed me to take samples - thank you. I would also like to say thank you to Lloyd Addie, Herb Hyder, David Javorsky, and Osama Eissa for sharing what they know about the geology and mineralogy on their Mount Begbie claims with me as well as thank you to Stefan Kruse and Paul Williams for their extensive knowledge and maps of the Thor-Odin Culmination.

I greatly appreciate the help and support I received from Mati Raudsepp, Edith Czech, Elisabetta Pani, Jenny Lai, and Brian Patrick at UBC while collecting data using the SEM, EMP, powder X-ray diffractometer, and single crystal X-ray diffractometer. I also would like to thank Ravinder Sidhu for her help while collecting data using the EMP at the University of Manitoba.

I would like to thank my lab mates, Tashia Dzikowski, David Turner, Leo Millonig, Mallory Dalsin, Andrew Fagan, Dana Caudle, Avee Ya’acoby, Jim Evans, Thomas Chudy, Lei Xie, and particularly Jillian Treadwell for your assistance/tolerance with sample preparation, conversations, tea parties, and helping me devour pie and other baked goods.

I am grateful to Gilly Regev, Tom Shoshani, Jonny Shoshani, and Sean Gjos for opening their home to me while I have been living in Vancouver. It has been wonderful getting to know all of you.

Last but not least, I wish to thank my friends, family, and especially my fiancé John for your love, support, and Skype dates. 


\section{Chapter 1: Introduction}

\subsection{Pegmatites}

While pegmatites are not typically a subject of daily discourse, they are commonly part of modern daily life. They are important sources of raw materials for humble ceramic and glass objects (feldspars) to the exotic-sounding ingredients of modern electronic devices (rare earth elements and high field strength elements). A myriad of gemstones worn for special events or evenings out can also be sourced from pegmatites.

The term "pegmatite” typically denotes coarse grain sizes in intrusive igneous rocks. To form such coarse grain sizes, a special set of conditions is necessary which leads to other features beyond a coarse texture. For the purposes here, the term pegmatite follows the definition set out by London (2008), “an essentially igneous rock, commonly of granitic composition, that is distinguished from other igneous rocks by its extremely coarse but variable grain size, or by an abundance of crystals with skeletal, graphic, or other strongly directional growth habits. Pegmatites occur as sharply bounded homogeneous to zoned bodies within igneous or metamorphic host rocks.”

\subsubsection{Describing and Classifying Pegmatites}

When a pegmatite field is discovered, describing and classifying the field and the individual pegmatites it contains is beneficial for scientific and economic purposes - from understanding Earth processes to sourcing valuable commodities. The initial step for any classification scheme is to identify the igneous rock type that the pegmatites most closely resemble. Granitic pegmatites are by far the most common but pegmatites can arise from magmas of all compositions; e.g., the next most abundant pegmatites have gabbroic compositions (London 2008).

The following is an examination of the internal structures of the pegmatites, as the internal structures determine the distribution of minerals within the pegmatites. On an individual scale, pegmatites may be simple, zoned, or complex. On the scale of the pegmatite field, such examinations may also show a regional distribution of some minerals (Simmons et al. 2003, Simmons \& Webber 2008). 
Granitic pegmatite fields are further delineated by geological location in addition to indicators given by their mineralogy, i.e., paragenetic indicators (Černý \& Ercit 2005, Simmons $\&$ Webber 2008). The current classification scheme uses some of these indicators to group granitic pegmatites into five classes: abyssal, muscovite, muscovite-rare element, rare-element, and miarolitic. This scheme is generally widely accepted, although some researchers have noted a greater diversity in pegmatites and pegmatite genesis as well as a lack of correlation between depth and geochemistry as outlined by the scheme (Martin \& De Vito 2005, Simmons \& Webber 2008). Despite its defects and lack of a better alternative, the current scheme provides a common framework for pegmatite research around the world.

With the exception of the muscovite class, each of the classes mentioned in the scheme can be further divided into subclasses and families; some of these are commonly split into types and subtypes. For example, pegmatites in the rare-element and miarolitic classes can be grouped into three families based on the principal rare-elements present: LCT (lithium - cesium - tantalum), NYF (niobium - yttrium - fluorine), and mixed LCT + NYF (pegmatites with geochemical signatures that appears to be a hybrid of the LCT and NYF families). The LCT family contains two dominant subclasses, eight types, and seven subtypes (Černý \& Ercit 2005). For further information on pegmatite classification, please see Černý (1991) and Černý \& Ercit (2005). Of interest to this thesis are granitic pegmatites of the rare-element class and the LCT family.

Rare-element pegmatites are thought to have formed from granite magmas at low to moderate depths and at relatively low to moderate temperatures. LCT family pegmatites are often assumed to be linked to granite plutons formed from the partial melting of metamorphic rocks which were derived from sedimentary and igneous rocks (S-, I-, and mixed S + I type granites). Other researchers have suggested that some pegmatites could be a product of direct anatexis of the same rock types. Granitic magmas from these sources have slightly higher amounts of $\mathrm{Al}_{2} \mathrm{O}_{3}$ in comparison to the combined quantities of $\mathrm{Na}_{2} \mathrm{O}, \mathrm{K}_{2} \mathrm{O}$, and $\mathrm{CaO}$ in bulk geochemistry determinations (Černý \& Ercit 2005, London 2008, Simmons \& Webber 2008).

\subsubsection{Pegmatite Formation}

Although the current classification scheme proposes general conditions for pegmatite formation, the process is more complex than cooling magma at a specific depth and temperature. It has long been held - and is still widely accepted - that pegmatites are the result of fractional 
crystallization from granites, a similar concept to ordinary magma evolution from a mafic to felsic melt, albeit not nearly as dramatic (Simmons et al. 2003, London 2008). Other current theories of pegmatite formation hold that pegmatites can result from direct anatexis (as previously mentioned), precipitation from hydrothermal fluids, crystallization from residual magmatic fluids influenced by hydrothermal fluids, crystallization from a hydrous silicate gel (particularly in the latter stages of pegmatite formation), and/or crystallization from a flux-rich silicate magmas (Simmons \& Webber 2008, Thomas et al. 2012). The following is a summary of London's (2008) model of pegmatites which discusses how various mineral phases and textures could be the result of fractional crystallization from granitic magma.

Initially, it was assumed that the coarse textures seen in pegmatites were the result of a relatively stable, extra-long, and slow cooling process, in the same manner that large crystals typically form in igneous rocks. However, this assumption could not explain all of the textures seen, such as the graphic intergrowth of quartz and feldspar, commonly known as graphic granite, or the formation of fine-grained layers and related dikes called aplites, all of which can be present within the same pegmatite (Fenn 1986, Rockhold et al. 1987, London 2008, Simmons $\&$ Webber 2008). To explain all of these textures, a new explanation was gradually created starting with fractional crystallization and involving rapid crystallization from volatile-enriched magma and strong undercooling.

During fractional crystallization, common rock-forming elements are readily removed early in the process, leaving behind incompatible elements and molecules: $\mathrm{F}, \mathrm{Cl}, \mathrm{Li}, \mathrm{Na}, \mathrm{K}, \mathrm{Rb}$, Cs, Be, $\mathrm{H}_{2} \mathrm{O}, \mathrm{OH}^{-}, \mathrm{CO}_{2}, \mathrm{HCO}_{3}{ }^{-}, \mathrm{CO}_{3}{ }^{2-}, \mathrm{SO}_{4}{ }^{2-}, \mathrm{PO}_{4}{ }^{3-}$, and $\mathrm{H}_{3} \mathrm{BO}_{3}$ (Thomas et al. 2012). These elements and molecules play a role similar to that of a fluxing agent, encouraging the diffusion of other elements through the magma. These incompatible elements and molecules may also eventually crystallize and re-dissolve, creating further fluctuations in the geochemistry of the melt, allowing a potentially diverse set of minerals to form (Simmons et al. 2003, London 2008, Thomas et al. 2012).

Undercooling happens when a liquid is subjected to temperatures below its freezing point but does not freeze. As a pegmatite magma propagates away from its parent magma, it enters rocks that are progressively cooler and at shallower depths. This cooler and shallower environment can prevent a viscous, highly evolved granitic magma from flowing despite being 
liquid. In this solid-like state, the overall temperature of the magma can drop below the point in which one would expect the magma to freeze.

Once the magma is in this state, the combined effects of undercooling and an incompatible element and molecule-enriched magma allows for quick crystallization. Cooling from the outside inwards, a narrow boundary may form between the growing crystals and the central magma body allowing for the exchange of ions; incompatible elements and molecules are expelled from the growing crystals and compatible elements are extracted from the magma and incorporated into the crystals. Such a boundary layer may become oversaturated with incompatible elements and molecules dissolving some of the recently formed crystals. Crystals that are not dissolved continue to grow, with some reaching the large crystal sizes for which pegmatites are known.

Near the end of crystallization, the central portion of the magma could be entirely composed of the boundary layer fluid. This fluid may be expelled from the center, partially dissolving and replacing existing crystals with new minerals; crystallizing into unique mineral assemblages; or it might be completely depleted in elements - both compatible and incompatible - and will crystallize as pure quartz.

In contrast to the model put forth by London (2008), other researchers suggest that a highly evolved granitic magma may have a low viscosity and that undercooling as well as a narrow boundary layer are not necessarily important. Slight variations in the temperature and pressure

conditions for a highly evolved magma with low viscosity could be enough to promote pegmatite formation (Thomas et al. 2012).

The existing models do address some of the more fundamental questions regarding formation, textures, and crystal sizes of pegmatites in comparison to the original hypothesis that pegmatites are the product of long and slow crystallization periods. More knowledge about pegmatites is needed to confirm the London (2008) model as well as to develop and expand upon others regarding pegmatite formation.

\subsection{Mount Begbie Pegmatites}

Mount Begbie is a mountain within the Canadian Cordillera, located approximately $12 \mathrm{~km}$ south of Revelstoke, British Columbia. A study of the pegmatite field on Mount Begbie presents an opportunity to add to current pegmatite knowledge, as the pegmatites on Mount Begbie have 
not been scientifically studied. This study is also an opportunity to expand on the limited scientific knowledge of pegmatites of the Canadian Cordillera.

In general, pegmatites within the Canadian portion of the North American Cordillera have largely been overlooked, even though Cordilleran pegmatites in the United States have been significant producers of strategic raw minerals and gemstones for over a century, such as the Harding Mine in New Mexico as well as the Pala and Mesa Grande districts in San Diego County, California (London 2008). Highly fractionated pegmatite fields in northwestern Canada have been only recently discovered and described, such as the Little Nahanni Pegmatite Group and the O’Grady Batholith in the Northwest Territories (e.g., Groat et al. 2003, Ercit et al. 2003). This is the first comprehensive study of pegmatites within this section of the Canadian Cordillera.

Unlike the Little Nahanni Pegmatite Group and the O’Grady Batholith pegmatites, the Mount Begbie pegmatites are relatively well known, having been noted since at least the late 1800s and qualitatively described by prospectors and mineral collectors for over half a century (Jones 1959). These reports describe the dikes as being typically homogeneous, lenticular, silllike sheets, typically not more than 2 meters wide, that sometimes cut across bedding planes, faults, and fractures. In terms of minerals, the dikes were said to have abundant black tourmaline up to $5 \mathrm{~cm}$ long, with one or two dikes containing black, red, and green tourmaline along with green beryl, garnet, and lepidolite. Additionally, prospectors and mineral collectors observed rose quartz, prominent feldspar crystals up to $40 \mathrm{~cm}$ long, and blocky, opaque white to bluegreen beryl crystals up to $15 \mathrm{~cm}$ long with occasional transparent yellow or blue patches in some of the dikes (Jones 1959, B. Wilson, pers. commun., H. Hyder, pers. commun., \& D. Javorsky, pers. commun.).

Despite a long history of mineral collecting, scientifically gathered information on the pegmatites is scarce, much like information for other Canadian Cordillera pegmatites. The dearth of research partially stems from a lack of accessibility; until recently, the majority of the pegmatites have been covered by Mount Begbie's glacier and snowfield. The existing research is primarily found within papers about the regional geology and tectonic history of the region. In most cases, the information is limited to descriptions of "conformable" versus "unconformable" relations to their host rocks in efforts to understand regional tectonism and metamorphism (e.g., Vanderhaege et al. 1999, Johnston et al. 2000). Rarely, physical and geochemical descriptions 
of the granitic bodies themselves have appeared. These few papers have mentioned that they have an S-type composition, that in some cases black tourmaline may comprise up to 5\% of the pegmatite volume and be up to $10 \mathrm{~cm}$ long, that aplitic portions contain more abundant tourmaline, and one geochemical sample contained 13 ppm Li (Craig 1966, Reesor \& Moore 1971, Mulligan 1972, Hinchey \& Carr 2008).

\subsubsection{Scope and Objectives}

In light of this dearth of information, this is the first systematic scientific study of the Mount Begbie pegmatites. The study area was selected on the basis of the observations made by prospectors, mineral collectors, and previous researchers. The area is located on a relatively gentle slope between the tree line to the north, the toe of Mount Begbie's glacier to the south, and lateral moraines to the east and west on the northeastern slope and encompasses nearly 0.5 $\mathrm{km}^{2}$ (Fig. 2.1).

With the area selected, the objectives for this study are to: (1) locate, map, and sample pegmatites located there; (2) characterize the pegmatites and related granitic bodies from field observations and hand samples as to their physical dimensions and whether or not they are homogeneous, zoned, or complex; (3) analyze their mineralogy and geochemistry to determine the correct pegmatite class, family, and regional zonation trends; (4) identify the type of parent magma, a possible source pluton, and the pegmatites' place within the tectono-magmatic history of the region; and (5) based on the results, comment on the economic potential for both strategic raw materials and gemstones for these North American Cordillera pegmatites. 


\section{Chapter 2: Regional Geology}

\subsection{Geological Setting and History}

Mount Begbie is part of the Shuswap Metamorphic Complex located in the southern part of the Omineca Belt of the Canadian Cordillera (Okulitch 1984, Wheeler \& McFeely 1991). The pegmatites are hosted in rocks belonging to the cover assemblage of the Monashee complex in the northern part of the Thor-Odin culmination (Fig. 2.1) (Kruse et al. 2005).

The Cordillera formed as a result of the accretion of terranes along the western edge of ancestral North America; the Omineca Belt is the section of the Cordillera comprised of both ancestral North America and the innermost of the accreted terranes (Carr 1991, Hinchey et al. 2006). By the Middle Jurassic, the accretion of terranes resulted in crustal thickening and metamorphism of the region throughout the Cretaceous (Hinchey et al. 2006, Johnson 2006). In the southern Omineca, regional extension and uplift during the Eocene led to the exposure of basement rocks, including those of the Shuswap Metamorphic Complex (Hinchey et al 2006, Norlander et al. 2002).

The Monashee complex is the lowest structural unit of the Shuswap Metamorphic Complex and exposes ancestral North America. It contains two culminations, the Frenchman Cap in the north and the Thor-Odin in the south, both comprised of gneiss cores and a cover sequence of unconformably overlying metasediments (Norlander et al. 2002, Kruse \& Williams 2007). Both the core and the cover sequence of the Thor-Odin culmination have experienced considerable deformation, high-grade metamorphism, late Paleocene-early Eocene anatexis, and Eocene brittle faulting (Johnston et al. 2000, Kruse \& Williams 2005, Hinchey et al. 2006). 


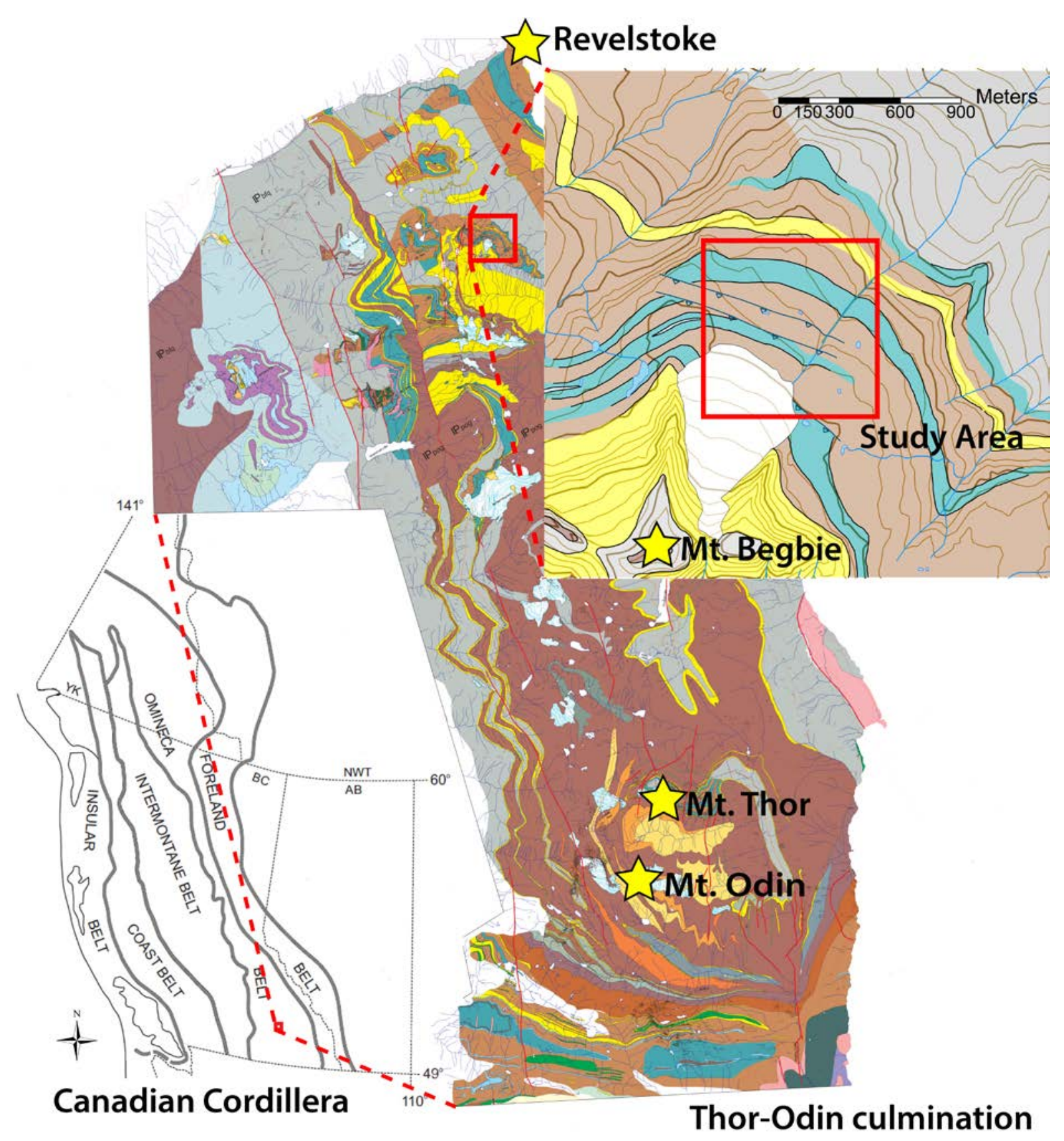

Figure 2.1: Setting of the study area within the Thor-Odin culmination and in context with the Canadian Cordillera. For more details of the study area, please see Fig. 3.1 and Appendix B.1. Figure modified after Kruse et al. (2005) and Kruse (2007).

\subsection{P-T-t Conditions of Metamorphic Overprint}

Between 50-60 Ma, the Thor-Odin culmination experienced rapid exhumation and decompression (Norlander et al. 2002, Spalla et al. 2011). For discussions of the possible 
mechanisms regarding this process, see Johnston et al. (2000), Norlander et al. (2002), and Hinchey et al. (2006). Prior to this event, the P-T-t conditions were around $700-800{ }^{\circ} \mathrm{C}$ and $9-10$ kbar (Norlander et al. 2002, Goergen \& Whitney 2012). Conditions may have reached $850{ }^{\circ} \mathrm{C}$ and 8-12.5 kbar, however, the earlier P-T-t history is largely obscured by subsequent deformation and recrystallization of the rock during the exhumation event (Spalla et al. 2011). The end of the main exhumation event during the late Paleocene and early Eocene brought the PT-t conditions to $\sim 600{ }^{\circ} \mathrm{C}$ and 2.5-5 kbar (Norlander et al. 2002, Spalla et al. 2011, Goergen \& Whitney 2012). Findings by Lorencak et al. (2001) suggest the Thor-Odin culmination cooled to 250-300 ${ }^{\circ} \mathrm{C}$ by $\sim 45 \mathrm{Ma}$ and exhumation of the area slowed significantly by $\sim 38 \mathrm{Ma}$. Subsequent cooling and exhumation was variable and a function of movement along regional fault systems (Lorencak et al. 2001).

\subsection{Magmatic Activity}

Anatexis of the Thor-Odin culmination is thought to have been largely triggered by the decompression and exhumation event (Carr 1992, Norlander et al. 2002). The resulting partial melt is characterized by abundant migmatites, pegmatites, and plutons in middle crust exposures, particularly in the southern portion of the culmination, where they comprise the Ladybird granite suite (Carr 1992) ${ }^{1}$. Geochronological results from the Ladybird granite suite and elsewhere within the culmination indicate that a significant portion of the crust was molten during the decompression and crystallization of the partial melt continued for some time afterwards (Norlander et al. 2002, Hinchey et al. 2006, Vanderhaeghe et al. 1999, Spalla et al. 2011, Johnston et al.2000).

The initial formation of granitic bodies was coeval with the development of the most recent metamorphic fabrics during the exhumation event (Vanderhaeghe 1999, Spalla et al. 2011). Continuing deformation encouraged further in situ granitic melt formation as well as migration

\footnotetext{
${ }^{1}$ It is worth noting that many of these bodies were originally thought to be Paleozoic or older because the zircons used for $\mathrm{U}-\mathrm{Pb}$ geochronology show a distinctly older core surrounded by a significantly younger rim. The young rim was interpreted as overgrowth during Jurassic metamorphic events after the emplacement of the granitic bodies (Okulitch 1985). This thesis follows the interpretation set forth by Carr (1992) that the old cores from zircons are thought to be inherited from the existing crust with the overgrowths forming during the anatectic events of the late Paleocene and early Eocene.
} 
of the melt along weakened planes. It is thought that a residual granitic melt (segregated from the main body of melt with assistance from the deformation) migrated to higher structural levels along a network established by earlier melt at lower structural levels (Vanderhaeghe 1999, Hinchey \& Carr 2006). Within the higher structural levels, the melt formed concordant and discordant pegmatite sills and dikes with localized shear zone overprints (Vanderhaeghe 1999, Spalla et al. 2011).

Two Jurassic granitic bodies that have been mapped closer to Mount Begbie than the Ladybird granite suite are the Kuskanax batholith and the Galena Bay stock (Kruse et al. 2005, Read \& Brown 1981, Parrish \& Wheeler 1983). Despite their relatively closer proximity to Mount Begbie, it seems unlikely for them to have contributed to the genesis of the pegmatites. The Kuskanax batholith appears to have been metamorphosed soon after its intrusion 173 Ma and is truncated by the more recent Columbia River Fault (Fig. 2.2). The Galena Bay stock ( $150 \mathrm{Ma}$ ) intrudes the fault and displays evidence of continuing movement from the fault (Read \& Brown 1981, Parrish \& Wheeler 1983). If the Kuskanax batholith and Galena Bay stock have contributed to the genesis of the pegmatites, a significant portion of the plutons would have to have remained fluid and to have intruded the Thor-Odin culmination before the formation of the Columbia River Fault.

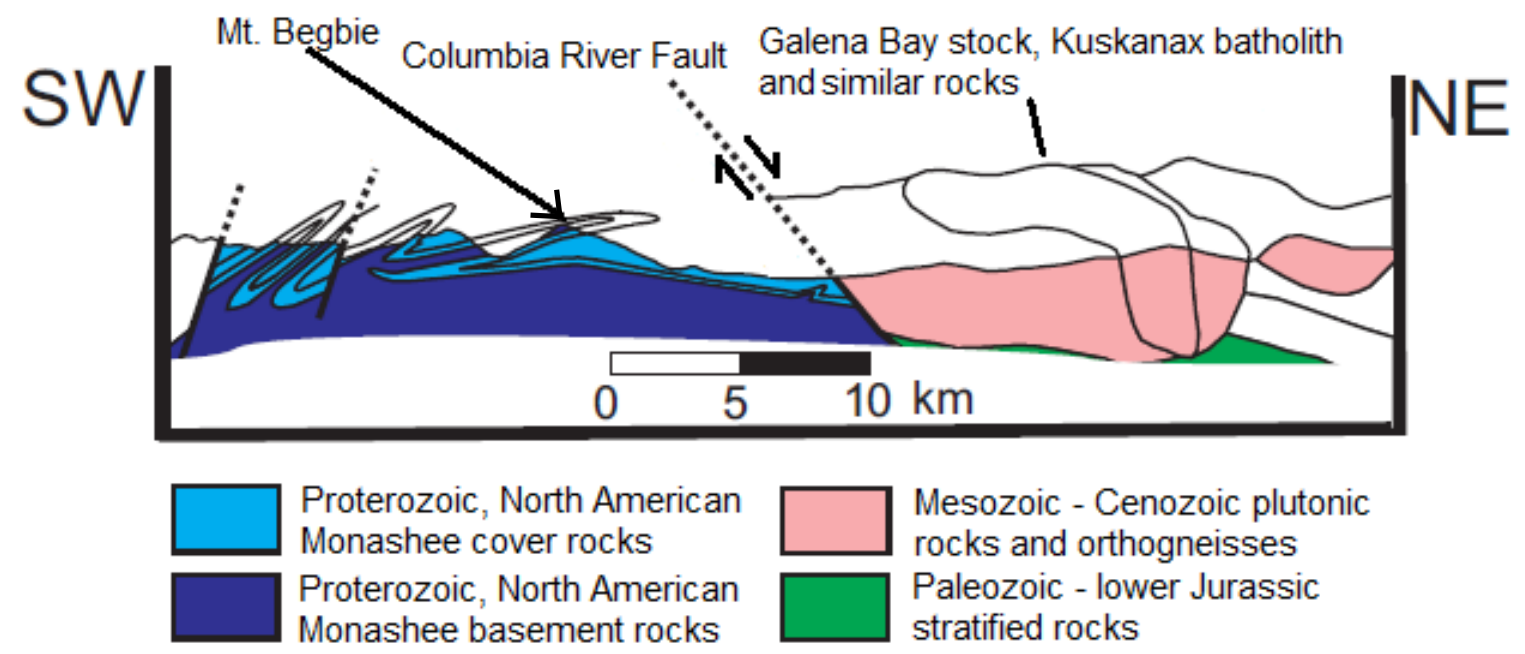

Figure 2.2: A cross-section through the northern part of the Thor-Odin culmination showing the location of Mount Begbie, the Columbia River Fault, and the general location of the Galena Bay stock, Kuskanax batholith and similar rocks. Figure modified after Kruse (2007). 
The pegmatites in this study are not metamorphosed and show only rare foliation; hence, it is improbable that they formed prior to the exhumation and decompression event that started in the late Paleocene. Carr (1992) and Lorencak et al. (2001) suggest the Ladybird granite suite wraps around the Monashee complex and extends to the north and west of Mount Begbie. Vanderhaege (1999) and Vanderhaege et al. (1999) indicate there may be migmatitic rock similar to the Ladybird granite suite protolith at depth below Mount Begbie. Given the large probable areal extent of the Ladybird granite suite and the potentially migmatitic character of the rock beneath Mount Begbie, it is more likely the pegmatites are related to the Ladybird granite suite than any other known intrusion. 


\section{Chapter 3: Pegmatite Occurrences}

\subsection{Mapping and Sampling}

From August 23-29, 2012, pegmatites and related bodies were mapped on a northeasternfacing, relatively gentle and bald slope between the tree line to the north, the toe of Mount Begbie's glacier ${ }^{2}$ to the south, and lateral moraines to the east and west (Fig. 3.1 and Appendix A.1). Due to instability of the weather and time constraints, some pegmatites in the extreme southeastern corner of the study area were not mapped.

Pegmatites were differentiated from migmatites and other veins by the following criteria: it showed relatively pristine primary magmatic features (i.e., little to no foliation) and if it displayed the basic mineral assemblage common to pegmatites in the area (quartz + feldspar $+/$ tourmaline +/- mica). Unusually large migmatitic pegmatites and veins were also mapped. All were mapped by marking points on a handheld GPS unit at their end points, selected midpoints, bends, and sample sites. The coordinates of the point and relevant comments pertaining to the type of point were noted (Appendix A.3). Photographs of the pegmatite, migmatite, or vein were taken from one of the end points and of any interesting features encountered.

Samples of feldspar were taken from a representative group of pegmatites displaying the basic mineral assemblage; tourmaline and mica samples were also taken if present and removing them from outcrop was possible. Pegmatites were also sampled if the mineralogy indicated fractionation or zoning within the dike. Minerals such as garnet, cordierite, beryl, columbite, apatite and other phosphates were sampled (when possible) in addition to tourmaline, feldspar, and mica from more fractionated pegmatites (Fig. 3.2 and Appendix A.2).

Upon returning from the field, all coordinates were plotted and edited using ArcGIS 10 software. Topography, rivers, lakes, and the glacier were added as a base layer using publicly available topography maps published by the Government of Canada (2012). Regional geology was added and modified after the map compilation of the Thor-Odin culmination by Kruse et al. (2005) and Kruse (2006, 2007).

\footnotetext{
${ }^{2}$ Note on the glacier: It was an oversight not to map the current extent of the glacier while mapping the pegmatites, as the glacier has retreated considerably ( 100 m or more) since the topographic map of the area was made. The topographic map used in this thesis is current for March 26, 2012; it is possible the extent of the glacier has not been updated since the original aerial photos were taken in 1947 and 1951 (Government of Canada 2012, Craig 1966).
} 


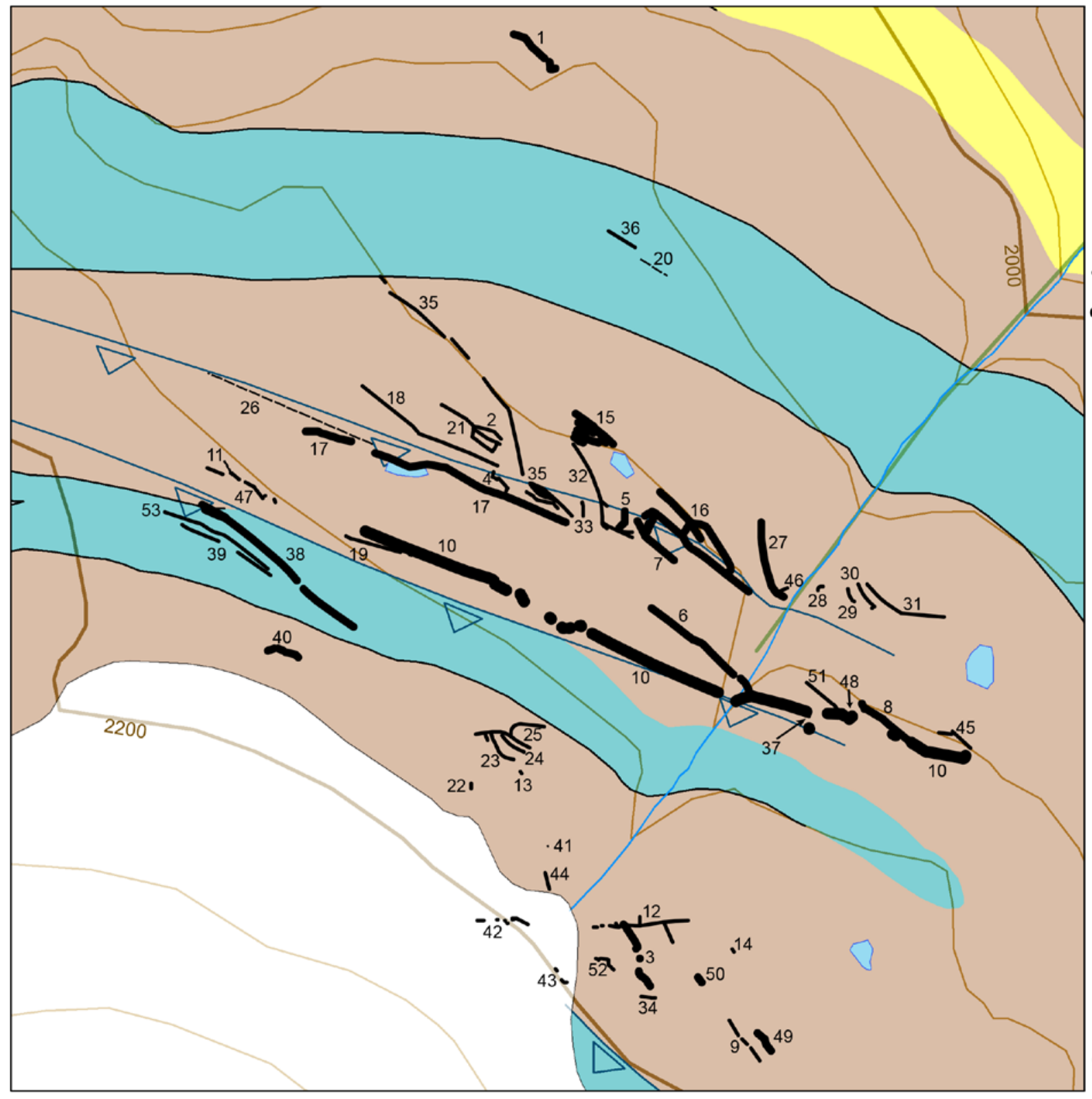

\section{Mount Begbie Pegmatites}

\section{Pegmatite Outcrop}

--- Pegmatites with Approximate Orientations

$-\leq 1 \mathrm{~m}$ wide

1 to $\leq 5 \mathrm{~m}$ wide

$>5 \mathrm{~m}$ wide

Regional Geology

- $E_{t v i}$ Lamprophyre dike

${ }_{\nabla} D_{E}$ Ductile shear zone

$\mathrm{P}_{\mathrm{ps}}$ Pelitic and semi-pelitic schists

$\mathrm{P}_{\mathrm{cs}}$ Calc-silicate gneiss

$\mathrm{P}_{\mathrm{q}}$ Quartzite

\section{Geographical Features}

$\square$ Previous Glacial Extent

- Rivers

$\square$ Lakes

Elevation

- $40 \mathrm{~m}$ contours

$200 \mathrm{~m}$ contours
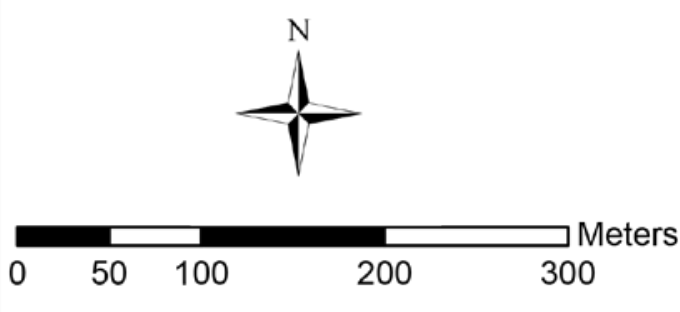
Figure 3.1 (preceding page): Map of pegmatites and related bodies within the study area, modified after Kruse et al. (2005), Kruse (2006), Kruse (2007), and Government of Canada (2012). 1. BERYL 2. BITOUR 3. CORD 4. CORNER 5. FEED 6. GAR 7. GARMUS 8. GARPHOS 9. GARTOUR 10. GRANITE 11. JAN 12. JUNCT 13. LENS 14. LENS2 15. LI 16. LI2 17. LONG 18. META 19. MUSC 20. ODD 21. PEGMA 22. POCKET 23. QTZ 24. QTZ2 25. QTZ3 26. SCABBY 27. SIMPLE 28. SIMPLE2 29. SIMPLE3 30. SIMPLE4 31. SIMPLE5 32. SIMPLE6 33. SIMPLE7 34. SIMPLE8 35. SIMPLE9 36. SIMPLE10 37. SIMPLE11 38. SIMPLE12 39. SIMPLE13 40. SIMPLE14 41. SIMPLE15 42. SIMPLE16 43. SIMPLE17 44. SKINNY 45. SMALL 46. STUBBY 47. THIN 48. TINY 49. TOUR 50. TOUR2 51. TOURMUS 52. WOBBLE 53. ZONED. For full legend explanation, see Appendix A. 


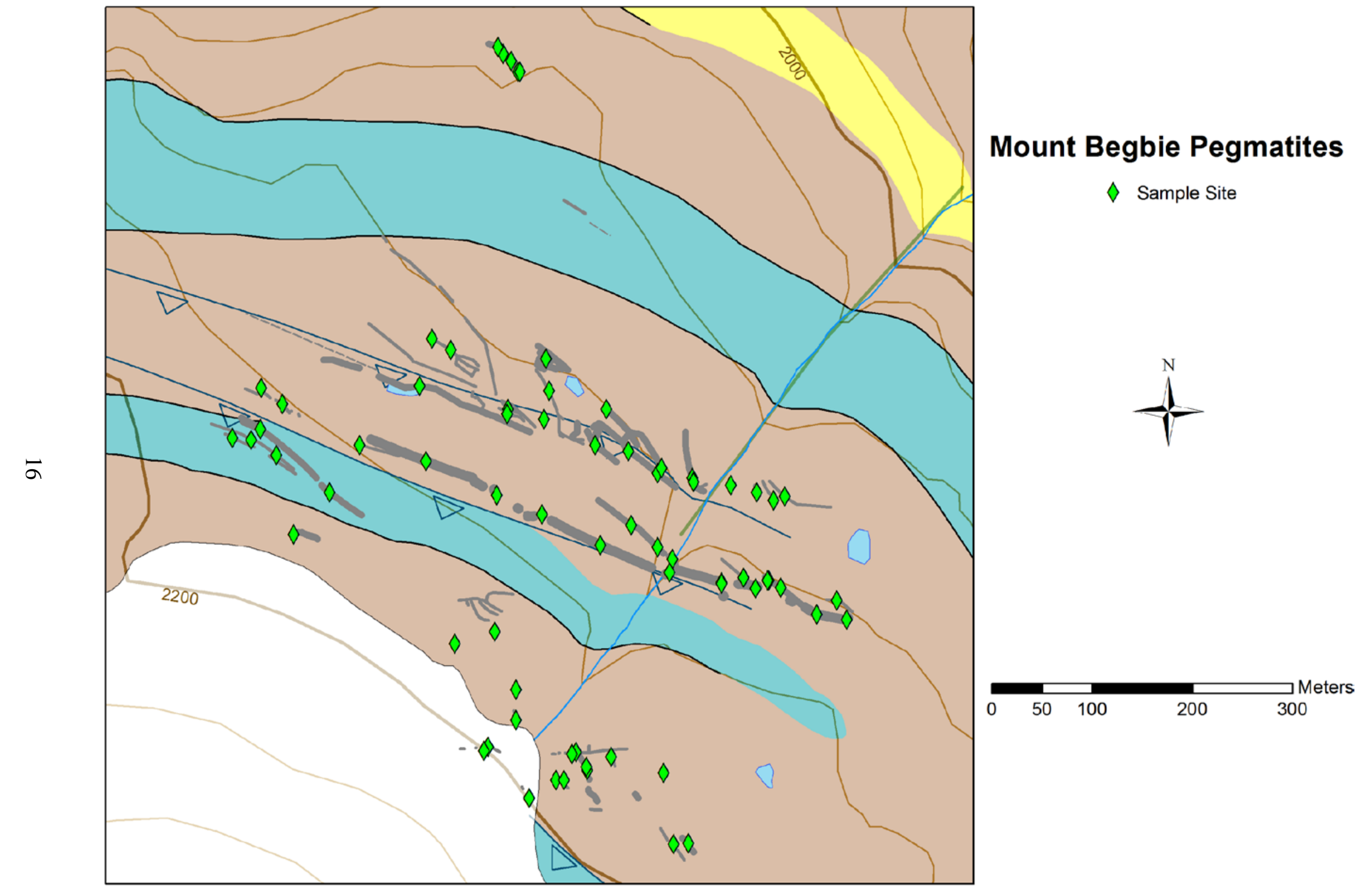


Figure 3.2 (preceding page): Map of all sampling sites, modified after Kruse et al. (2005), Kruse (2006), Kruse (2007), and Government of Canada (2012). For full explanation of map contents, see Appendix A. 


\subsection{Descriptions}

Individual pegmatite bodies were given names based on prominent minerals or other notable feature (e.g., zoning) observed in the first outcrop encountered. The names of the dikes are not necessarily reflective of its overall nature. Mineral abbreviations used follow Whitney \& Evans (2010) unless otherwise specified. Locations of the pegmatites can be found in Appendix A.

\subsubsection{The BERYL Pegmatite}

This dike is exposed in a cliff immediately below the edge of the tree line (Fig.. 3.3a \& b). The outcrop is cut by a tiny cobble-filled creek near its eastern end; immediately adjacent to the creek, it is scarred from the repeated visits of numerous mineral collectors. The eastern end is covered by vegetation and the western end is truncated by a large vertical joint with related narrow veinlets extending beyond the joint. The dike has an average width between 4 and 5 meters and was traced for $\sim 43$ meters. It has a strike of $\sim 310^{\circ}$ and dips to the northeast at $\sim 60^{\circ}$.

The principal mineral assemblage for the dike is quartz + feldspar + biotite. Major accessory phases are beryl (Fig.. 3.3c), black tourmaline, muscovite (Fig. 3.3d), garnet (Fig. 3.3e), and apatite. Tourmaline crystals were measured up to $30 \mathrm{~cm}$ in length and beryl crystals were measured up to $15 \mathrm{~cm}$ long. Minor accessory phases include: monazite, columbite (Fig. 3.3f), cassiterite, xenotime, qitianlingite, altered cordierite, zircon, uranophane, euclase, manganese and iron oxides. Bertrandite, pyrrhotite, uraninite, phurcalite, rutherfordine, and oxyplumboroméite are unconfirmed trace accessory minerals in the dike.

The dike has six discernible zones that are highly variable in width; generally the widths of the zones are greater on the hanging wall than on the footwall. The zones consist of: a border zone made up of Qz + Fsp + Bt; a wall zone comprised of the Qz + Fsp + Bt + Tur; an outer intermediate zone with a coarser-grained assemblage of the wall zone; a blocky inner intermediate zone containing of $\mathrm{Qz}+\mathrm{Ab}+\mathrm{Bt}+\mathrm{Tur}+\mathrm{Ms}+/-\mathrm{Brl}+/-\mathrm{Kfs}$; an outer core of nearly pure quartz; and an inner core composed solely of blocky perthite. 


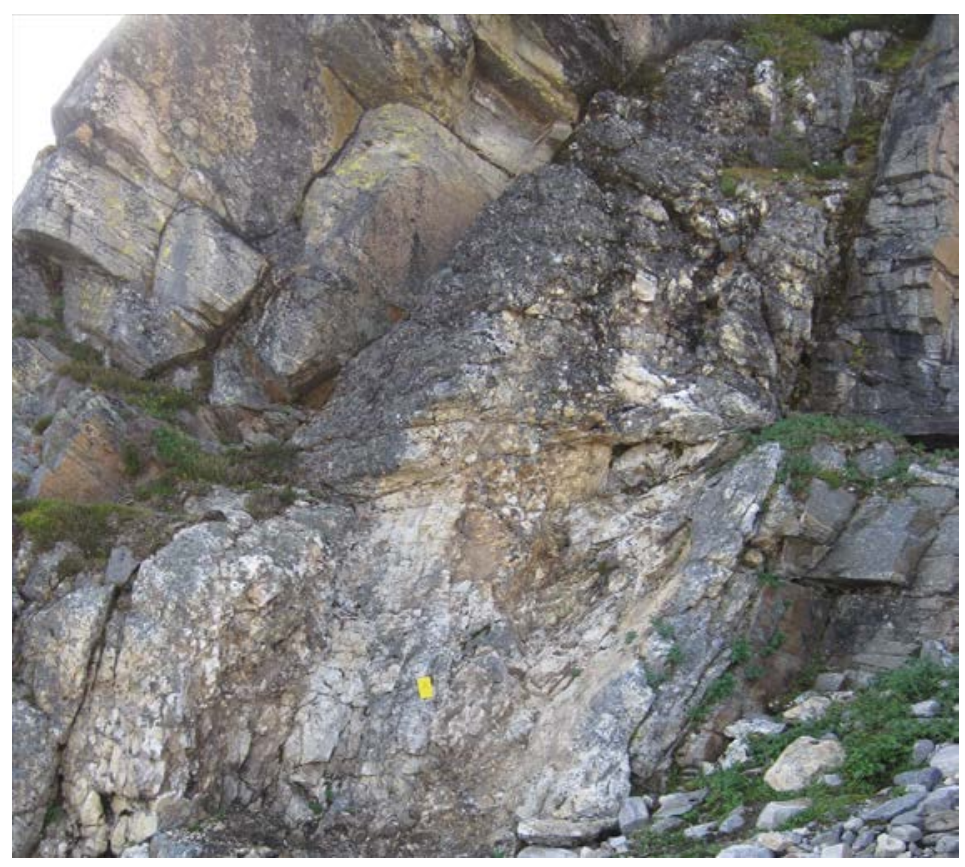

Figure 3.3a: The BERYL pegmatite. The southeastern end is seen from slightly beyond the rubble filled creek looking to the southeast. The yellow notebook in the center of the left-hand image is $18 \mathrm{~cm}$ tall.

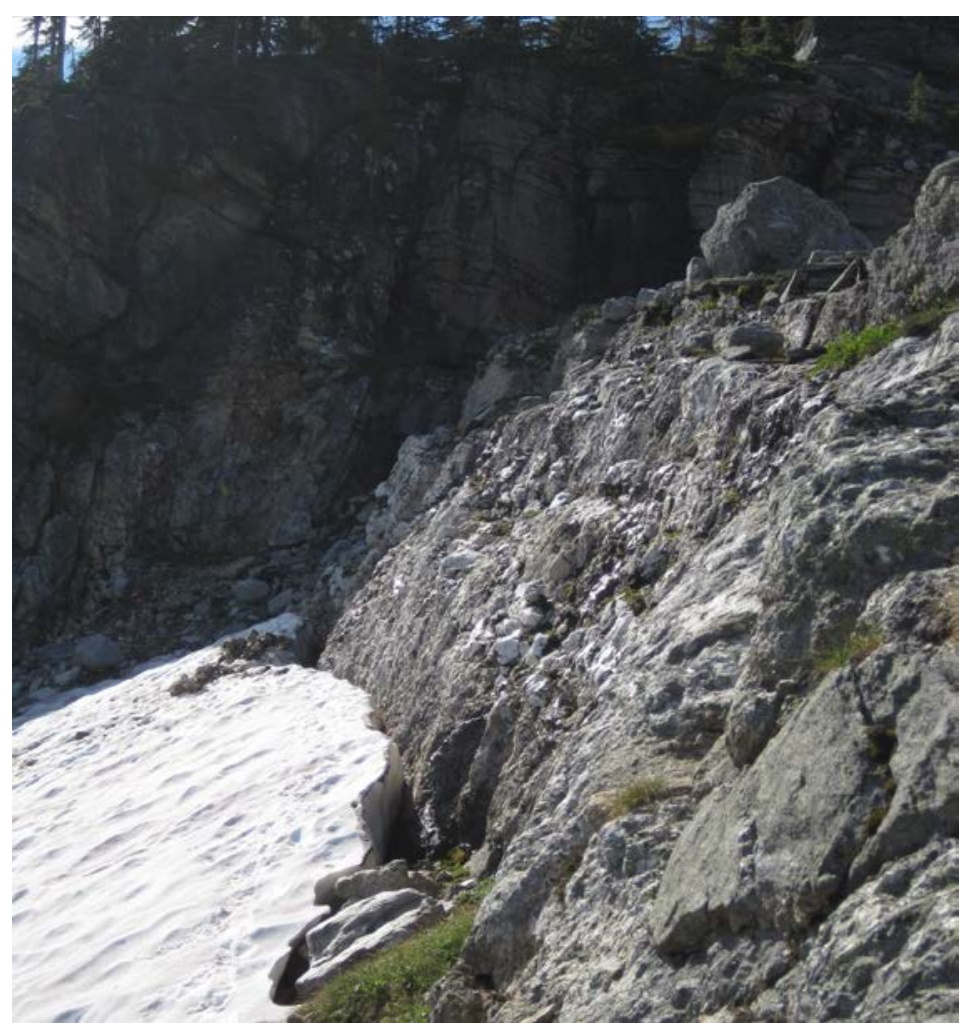

Figure 3.3b: The main length of the BERYL pegmatite as seen from near the northwestern end looking to the southeast. 


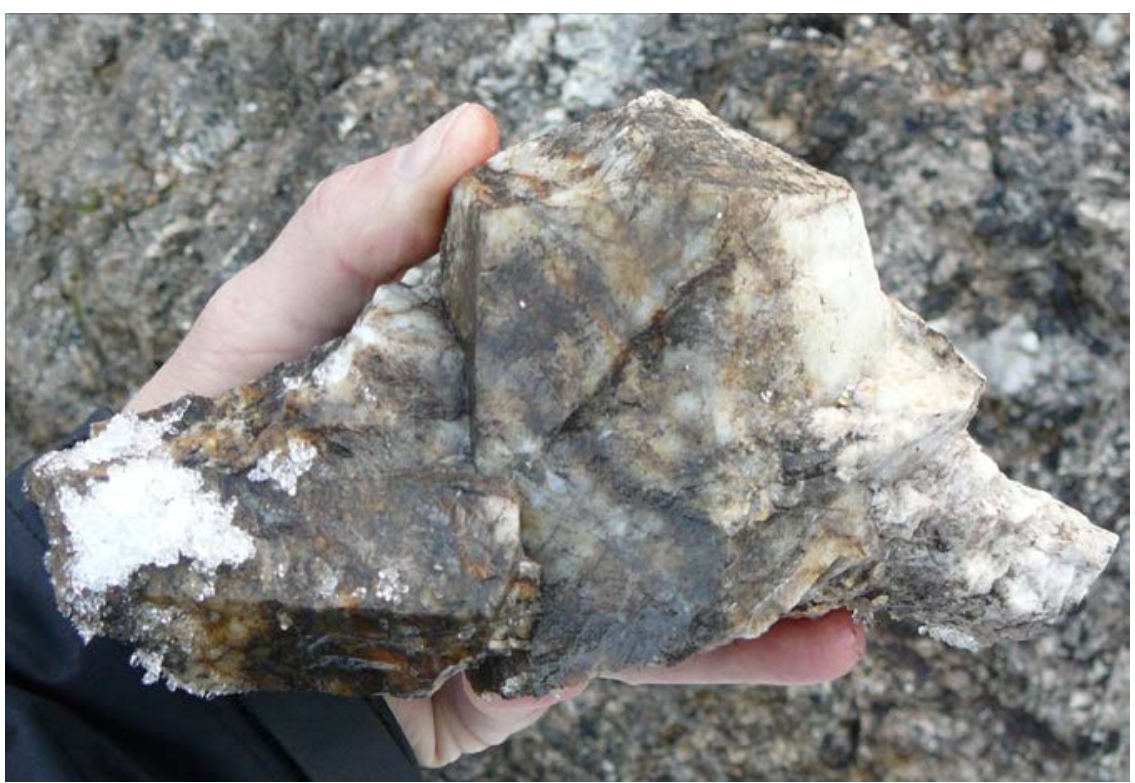

Figure 3.3c: Beryl crystals from the BERYL pegmatite.

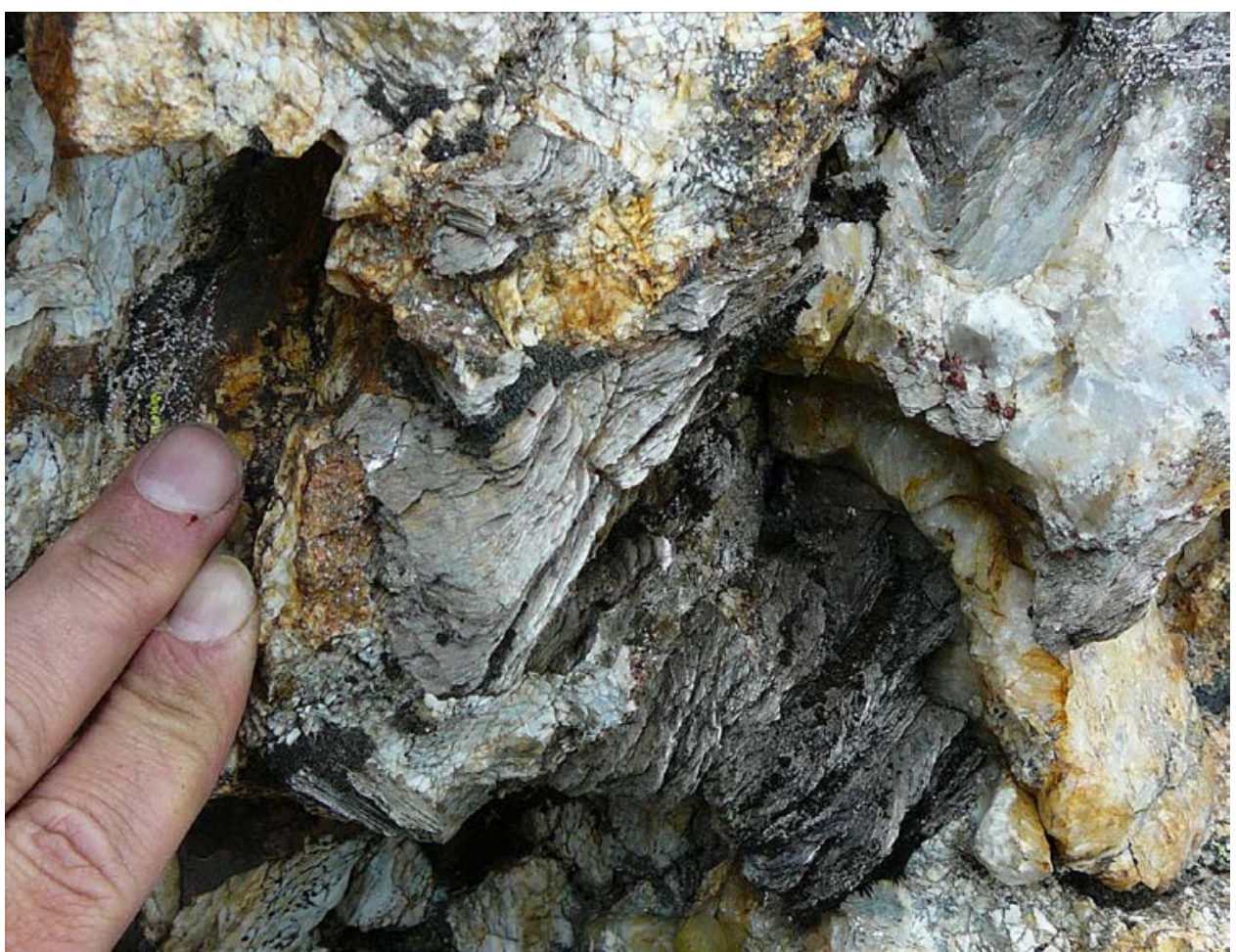

Figure 3.3d: Muscovite book from the BERYL pegmatite. 


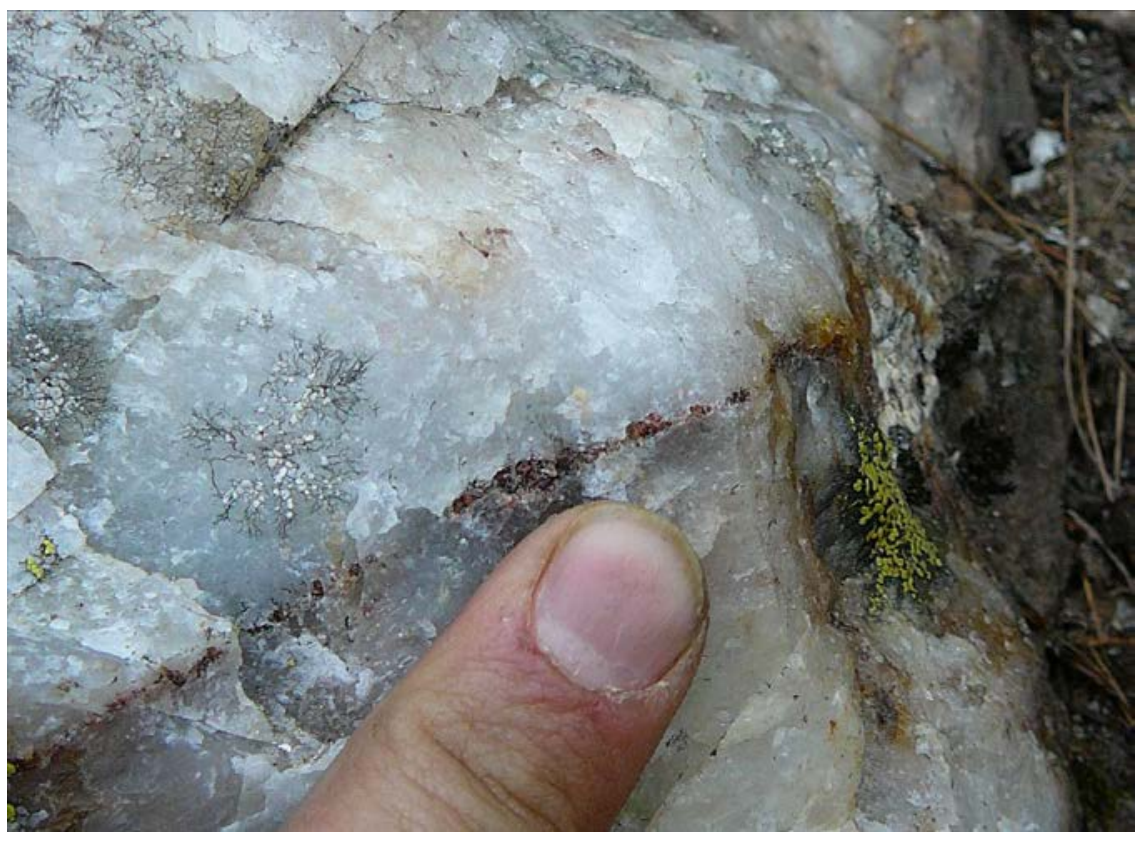

Figure 3.3e: Thin vein of garnet crystals from the BERYL pegmatite.

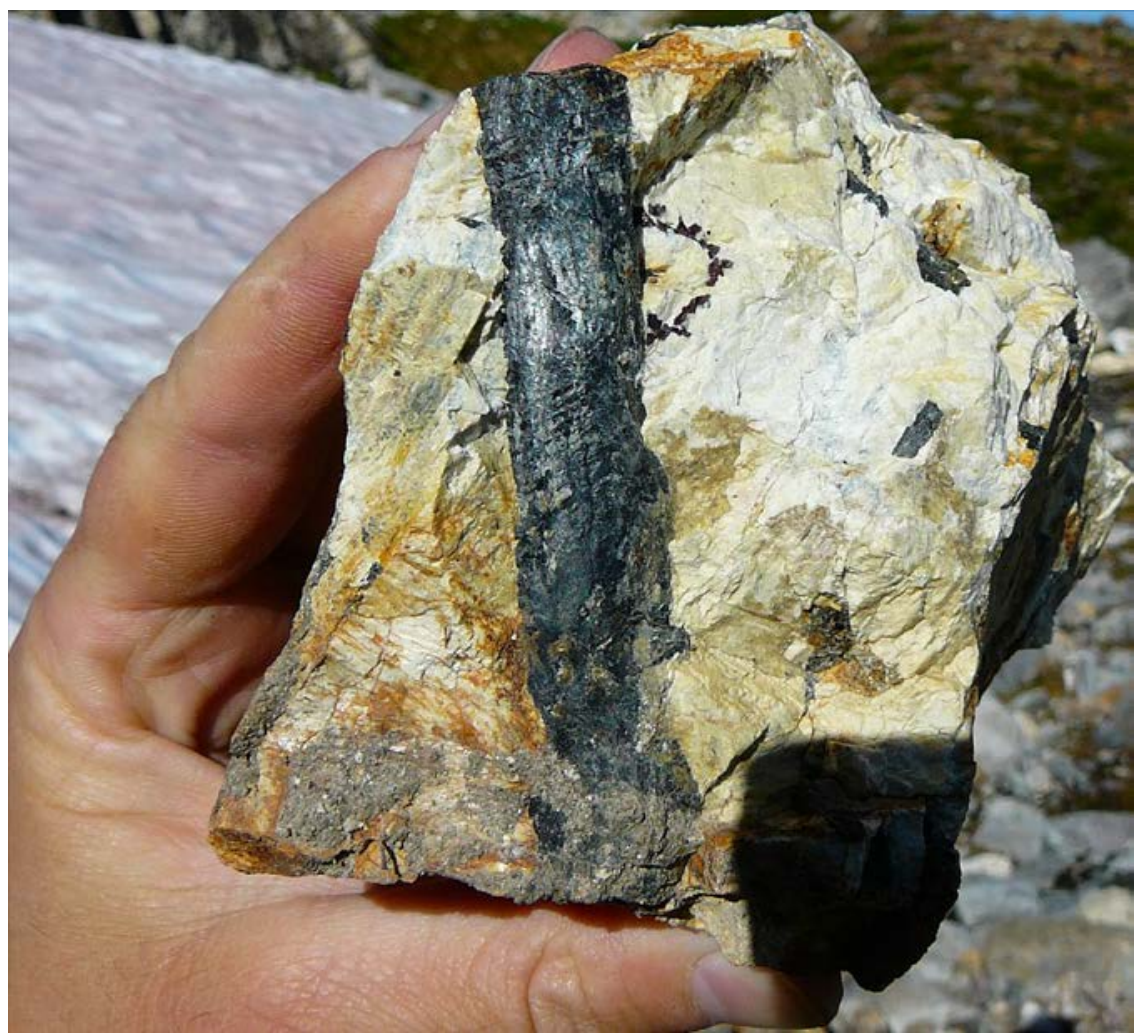

Figure 3.3f: Columbite (circled in black) next to tourmaline from the BERYL pegmatite. 


\subsubsection{The BITOUR Pegmatite}

This dike is exposed in a slope beneath a ridge that hosts many pegmatites (Fig. 3.4). It is $\sim 24 \mathrm{~m}$ long and widens to nearly $50 \mathrm{~cm}$ from a very narrow, pinched eastern end before splitting into two $5 \mathrm{~cm}$ wide, parallel dikes that subsequently converge towards the west. Where the two dikes join again, it has a width of $\sim 50 \mathrm{~cm}$ before narrowing down into thin veinlets connecting to the PEGMA dike. It has a strike of approximately $295^{\circ}$ and has a variable dip towards the southwest. The principal mineral assemblage observed is quartz + feldspar + biotite + tourmaline. The dike did not appear to be zoned and no samples were taken from it.

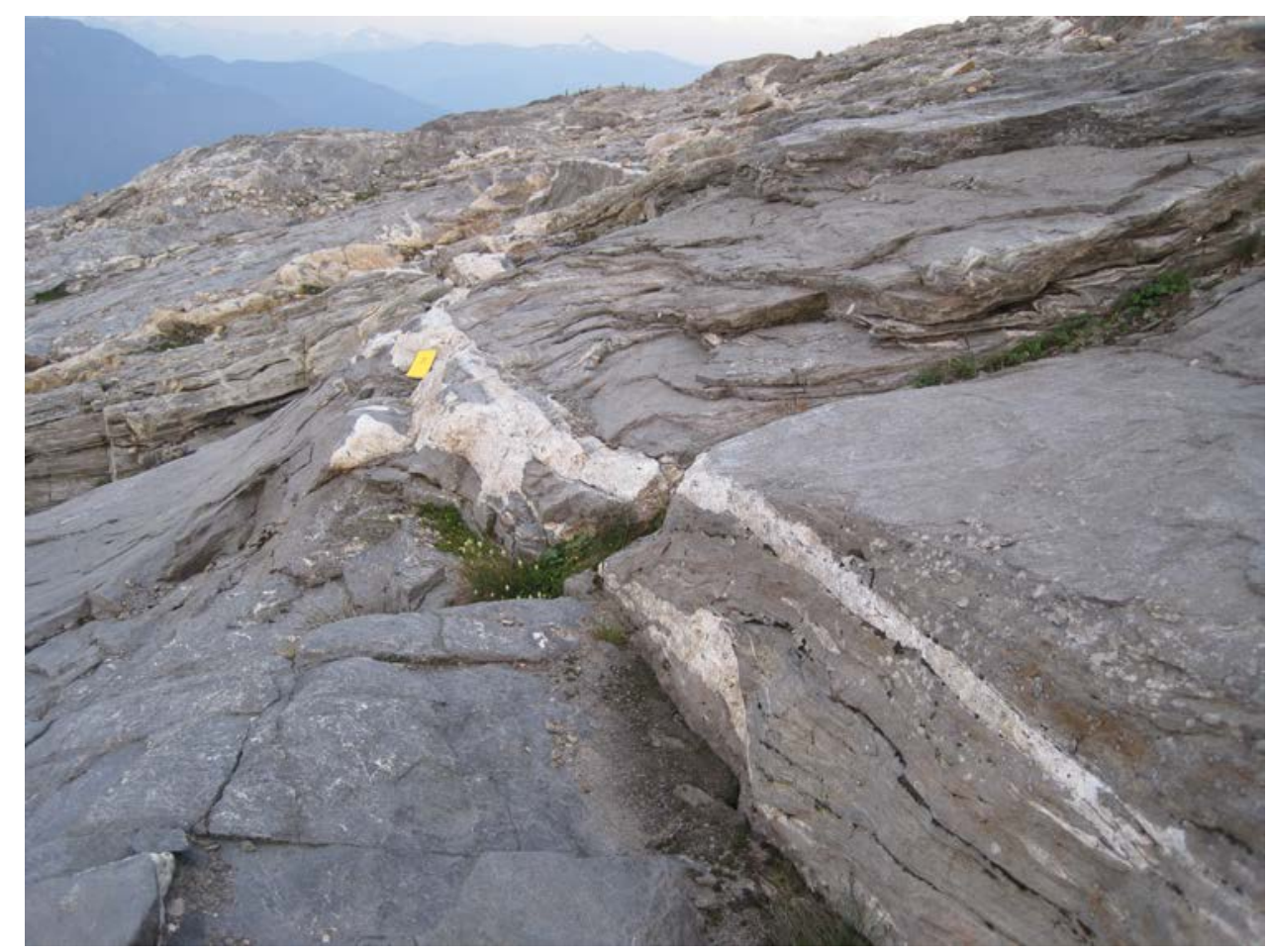

Figure 3.4: The BITOUR pegmatite as seen from the northwestern end of the pegmatite looking to the southeast.

\subsubsection{The CORD Pegmatite}

This dike is exposed in the southeastern part of the map area. At its southern end, the dike resembles an alpine vein composed largely of rose quartz and actinolite before transitioning to an aplite dike $60 \mathrm{~cm}$ wide (Fig. 3.5a \& b). It attains a width of $2 \mathrm{~m}$ before being lost to erosion in places near the midpoint of the dike. In its northern extent beyond the erosional sections, the dike is approximately $1.5 \mathrm{~m}$ wide and joins the JUNCT pegmatite. Overall, the dike can be 
traced for approximately $55 \mathrm{~m}$ and has a strike of $\sim 340^{\circ}$ with a subvertical dip. The dike only appears to be zoned in the southern end where rose quartz composes the core with an actinolitefeldspar border.

The principal mineral assemblage observed in this body is quartz + feldspar, with major accessory phases of blue and black tourmaline (Fig. 3.5c), muscovite, altered cordierite (Fig. 3.5d), and andalusite (Fig. 3.5e). Minor accessory phases include: beryl, muscovite, chlorite, and iron oxides after cordierite; apatite; zircon; monazite; and xenotime. Nickel oxides are an unconfirmed trace accessory phase.

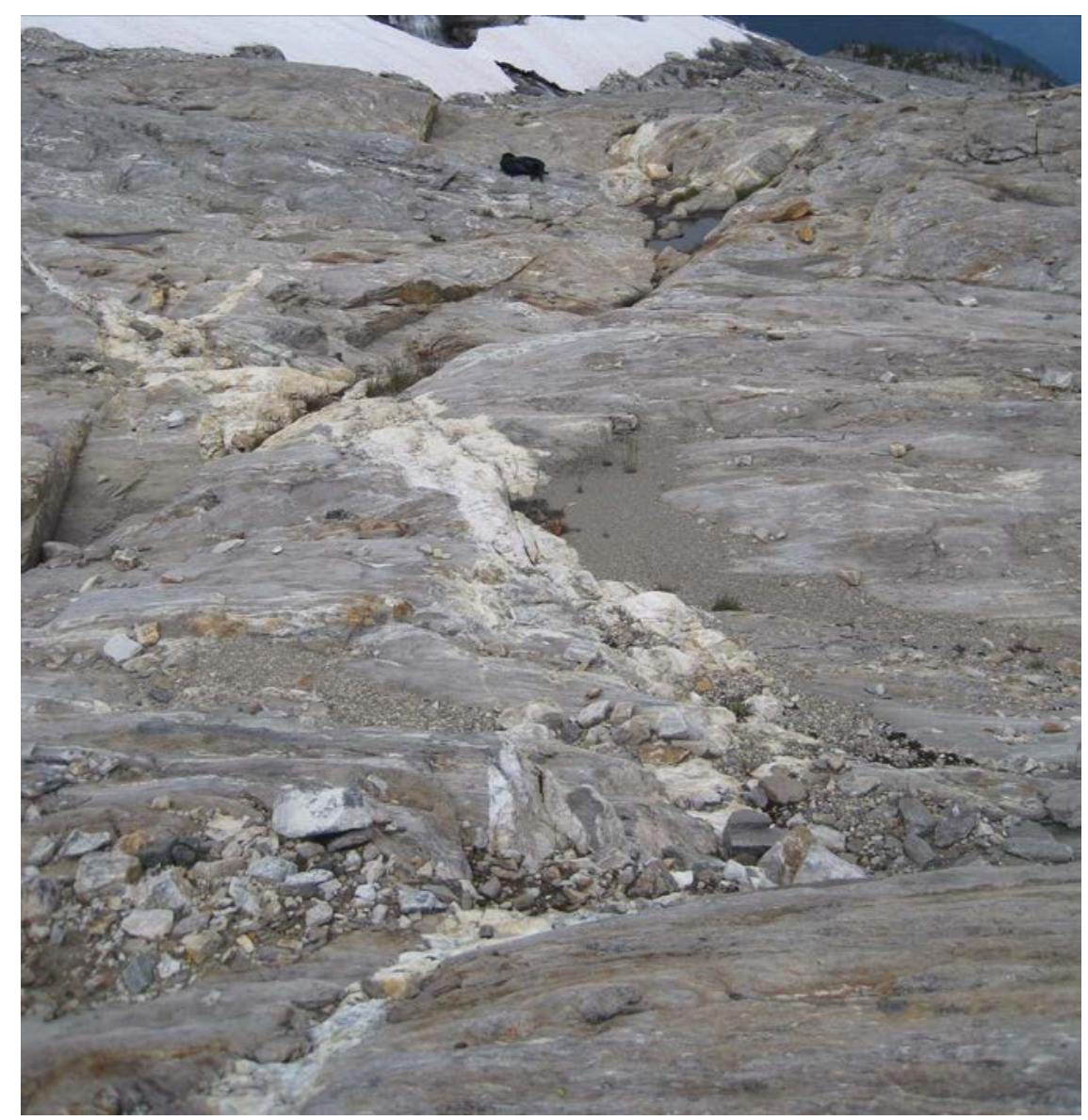

Figure 3.5a: Overview of the CORD pegmatite, as seen from the southeastern end of the pegmatite looking to the northwest. The backpack near the top of the image is $\sim 60 \mathrm{~cm}$ long. 


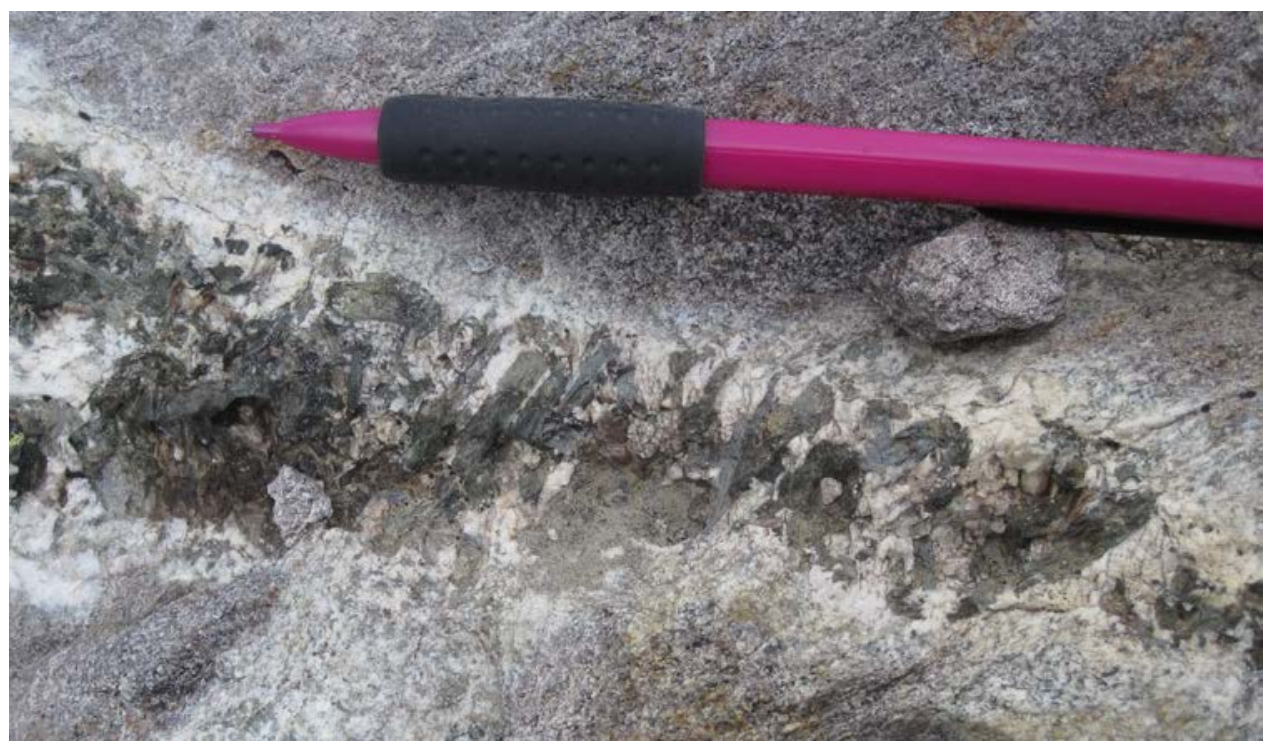

Figure 3.5b: A close-up of the alpine vein-like southeastern end of the pegmatite.

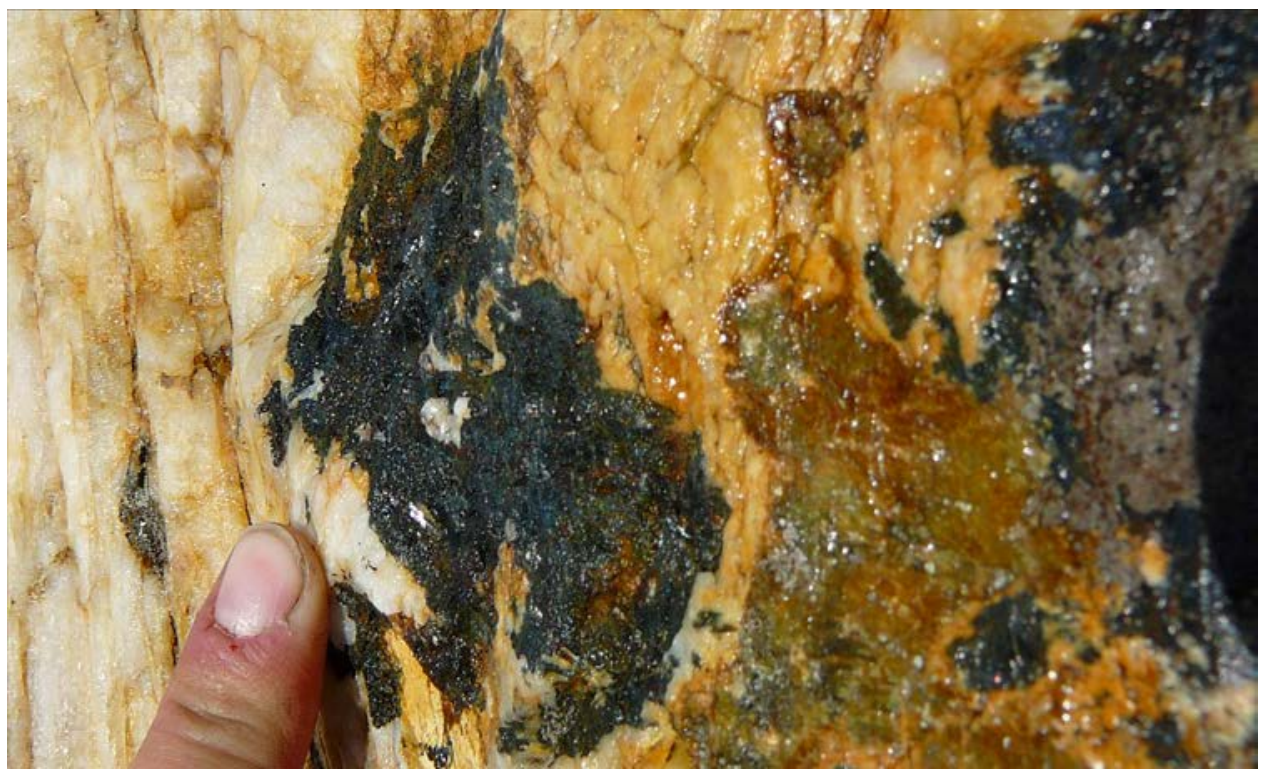

Fig. 3.5c: Dark blue tourmaline in the CORD pegmatite. 


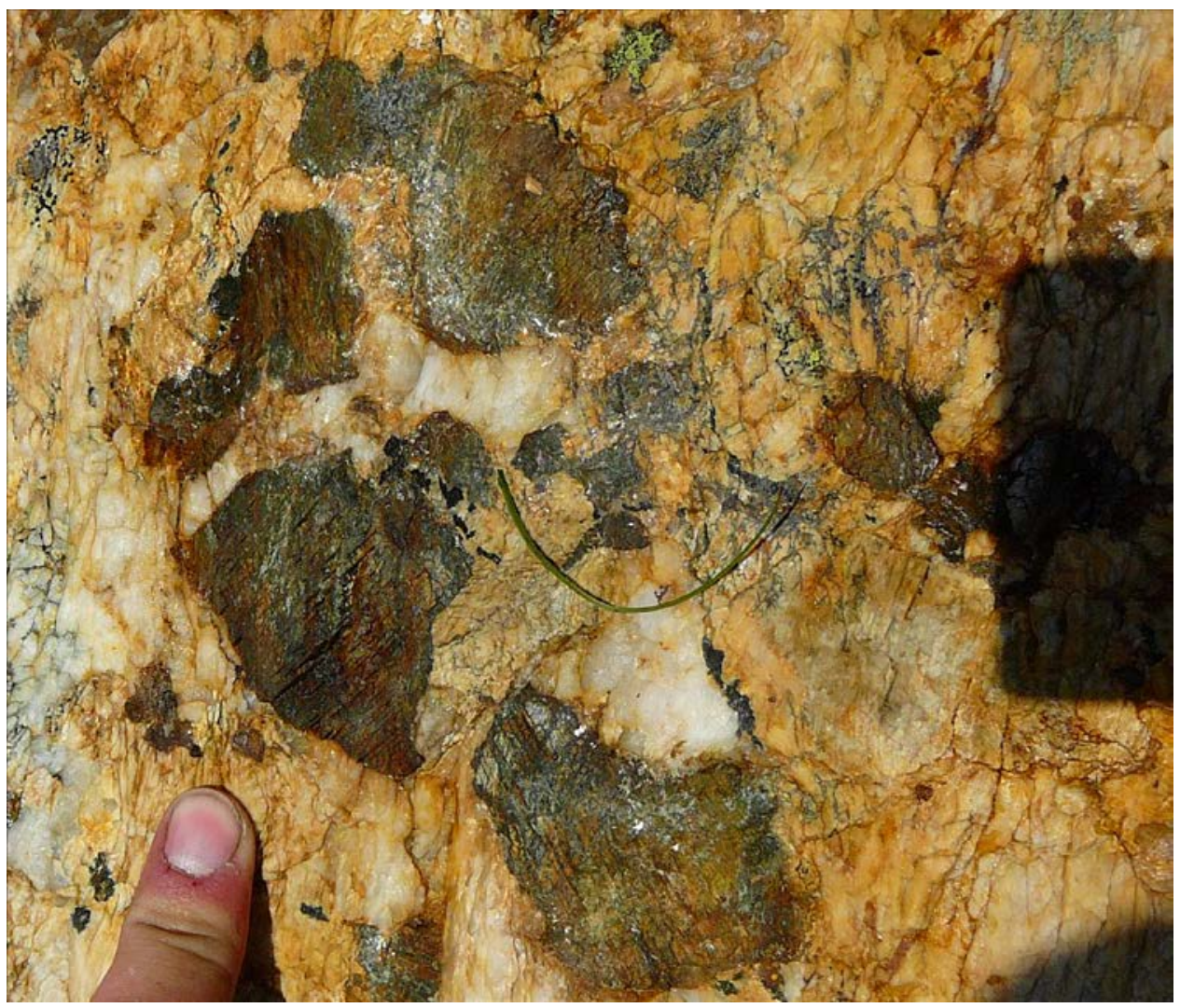

Figure 3.5d: Altered cordierite crystals in the CORD pegmatite.

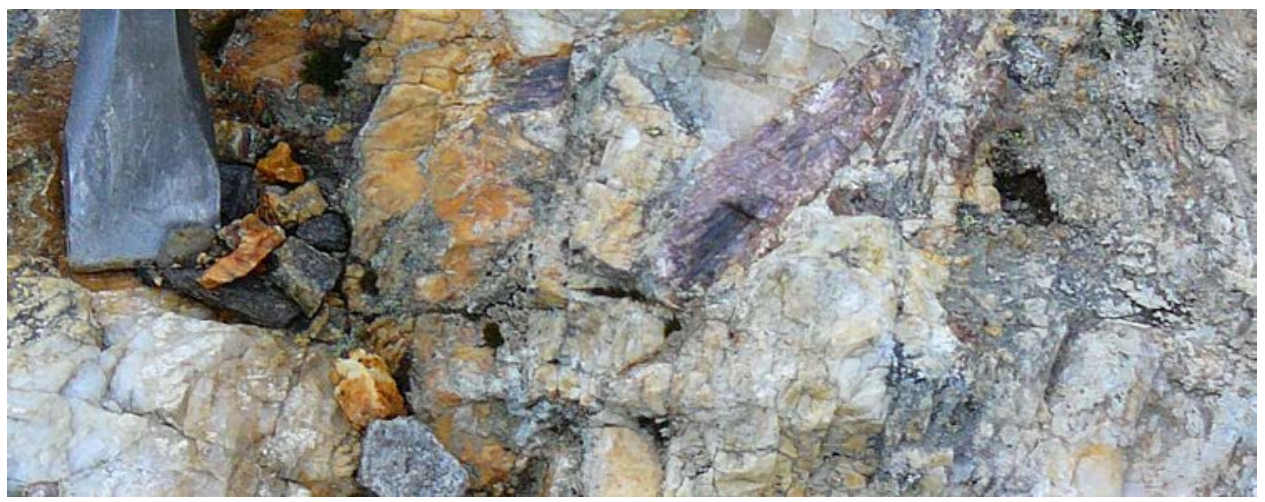

Figure 3.5e: Andalusite (pink) in the CORD pegmatite.

\subsubsection{The CORNER Pegmatite}

This pegmatite is a branch or a feeder for the LONG pegmatite (Fig. 3.6). It is both concordant and discordant with the foliation of the host rock; it is primarily exposed as a concordant sill where sheets of the host rock have spalled off in irregular pieces, giving the pegmatite the appearance of having many corners. It is approximately $20 \mathrm{~cm}$ wide and can be 
traced for $\sim 20 \mathrm{~m}$. It has a strike of $\sim 315^{\circ}$, a highly variable dip from subvertical to subhorizontal, and a dip direction from the southwest to the northeast. The principal mineral assemblage observed is quartz + feldspar + tourmaline and it did not display any zoning. No samples were taken from this pegmatite.

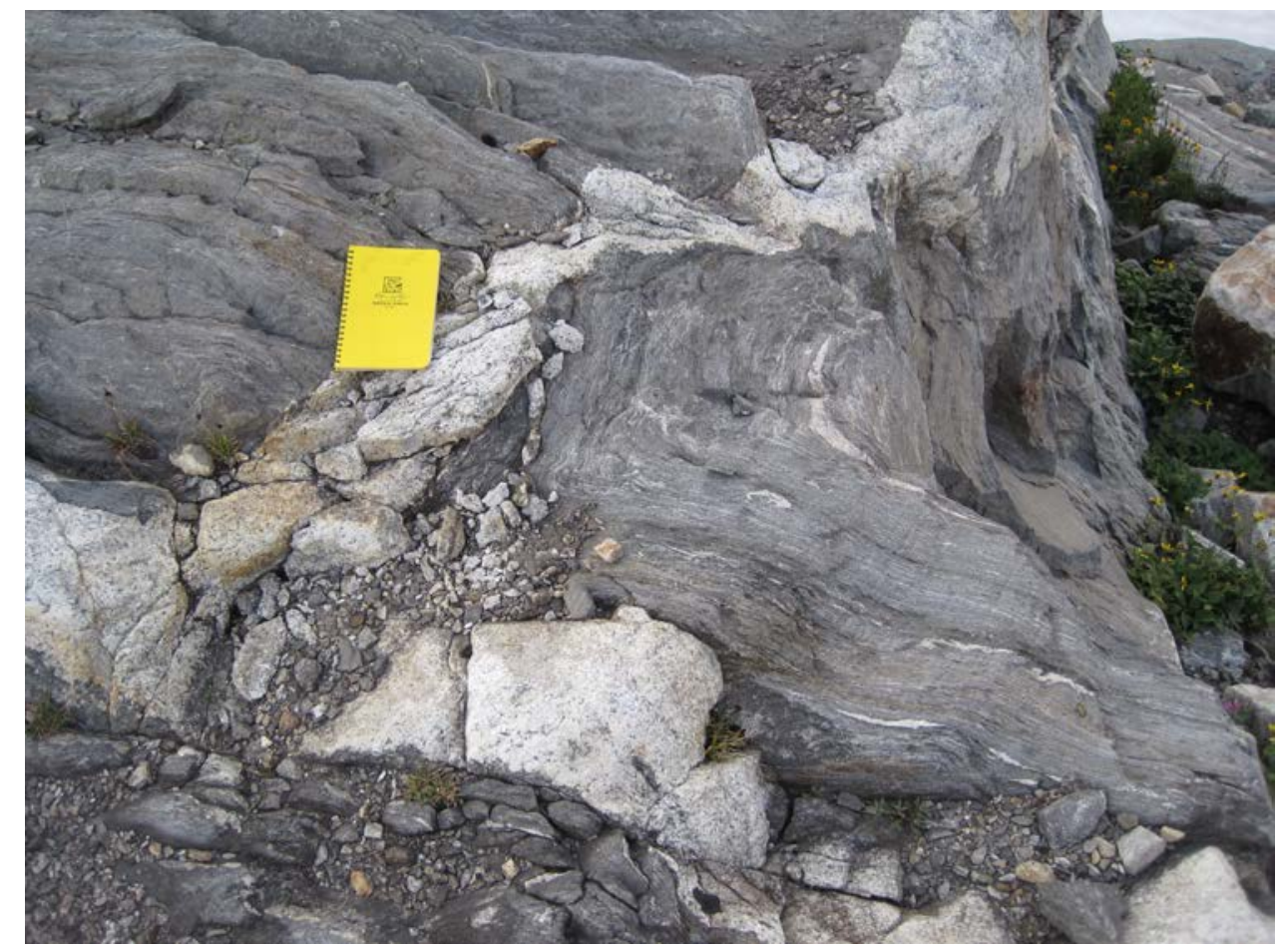

Figure 3.6: The CORNER pegmatite (extends towards the upper right corner of the image) where it branches from the LONG pegmatite (pegmatite along the bottom of the image).

\subsubsection{The FEED Pegmatite}

This dike is exposed on a jagged slope near a narrow gorge and somewhat resembles a migmatite, displaying copious mixing with the host rock (Fig. 3.7). Its central portion has dimensions of $\sim 1.5 \times \sim 4.5 \mathrm{~m}$ while its considerably narrower and branching ends (up to $15 \mathrm{~cm}$ wide) curve towards SIMPLE6 to the south and GARMUS to the east for a total extent of $\sim 15 \mathrm{~m}$. It has a simple composition, consisting primarily of feldspar + quartz and very minor tourmaline and does not display any zoning. No samples were taken from this pegmatite. 


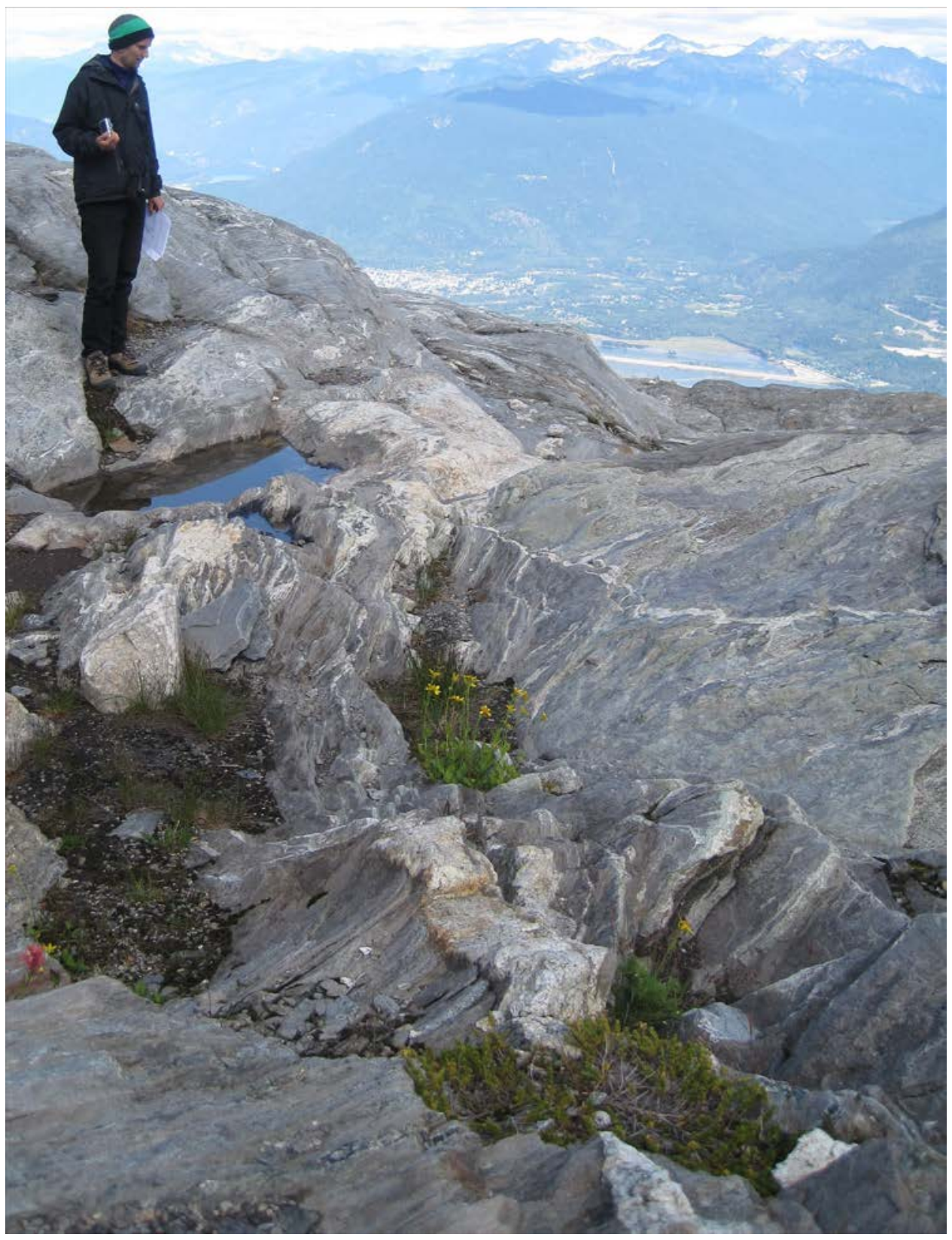

Figure 3.7: The FEED pegmatite as seen from its southeastern end and looking to the north.

\subsubsection{The GAR Pegmatite}

This dike is a branch from the largest dike, (GRANITE; Fig. 3.1). At the base of the branch, the pegmatite is nearly $12 \mathrm{~m}$ wide and encompasses a large xenolith. It narrows to $\sim 3 \mathrm{~m}$ before the outcrop is intersected by a minor fault, displacing the continuing dike by $\sim 6 \mathrm{~m}$ to the south (Fig. 3.8a). Beyond the fault, the dike narrows down to a few millimeters; the total length of the pegmatite is nearly $105 \mathrm{~m}$. It has a strike of $\sim 310^{\circ}$ with a subvertical dip. 
The dike does not appear to be zoned and has a principal composition of quartz + feldspar + tourmaline. Major accessory minerals are garnet, sekaninaite (Fig. 3.8b), muscovite, biotite, and iron oxides. Minor accessory minerals include beryl, chlorite, and clays after sekaninaite and hübnerite. A possible Ca-analogue of hollandite is an unconfirmed trace accessory phase.

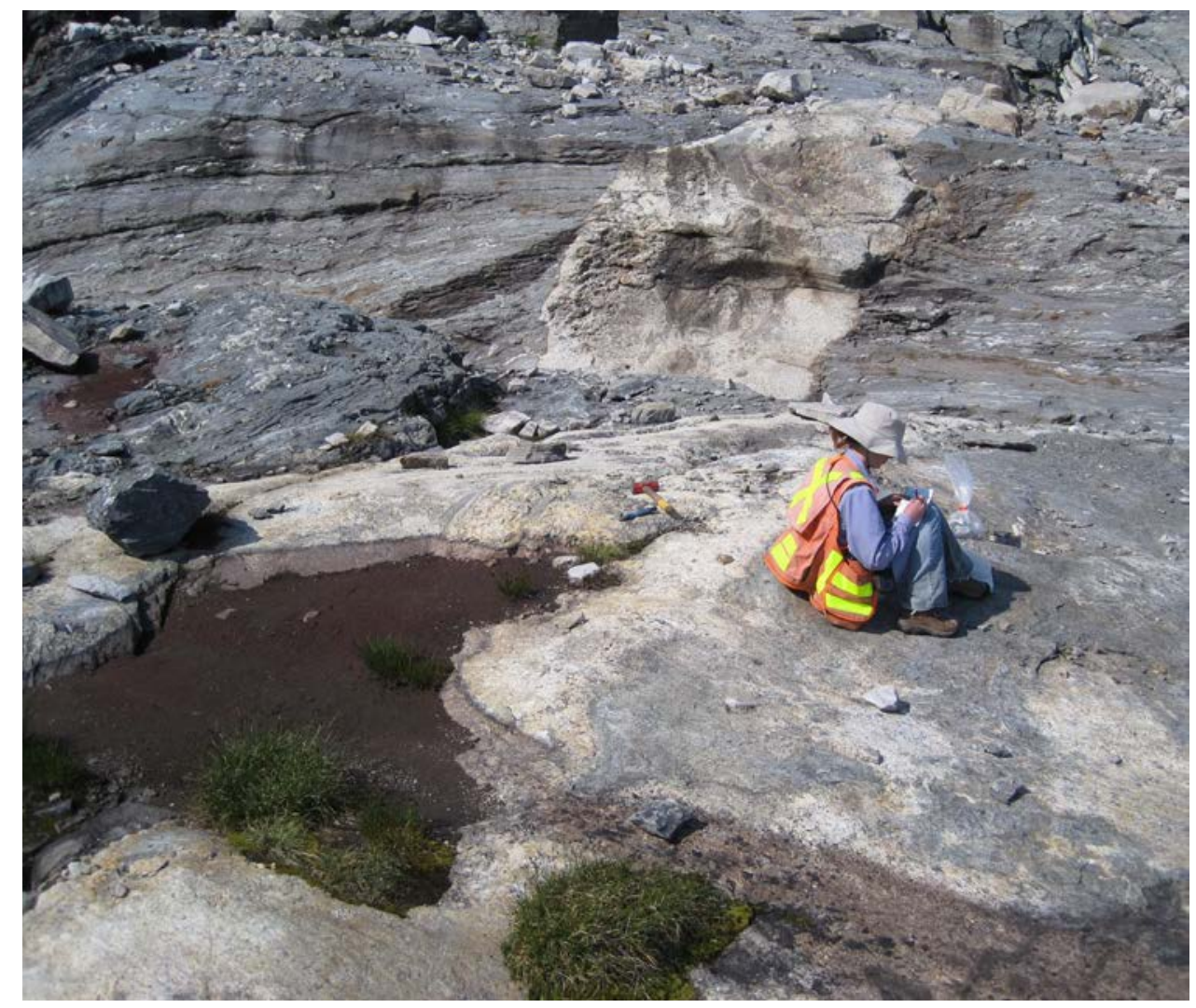

Figure 3.8a: The GAR pegmatite as seen from where it branches from the GRANITE pegmatite. The view is to the northwest. Note the offset of the dike to the south in the upper half of the image. 


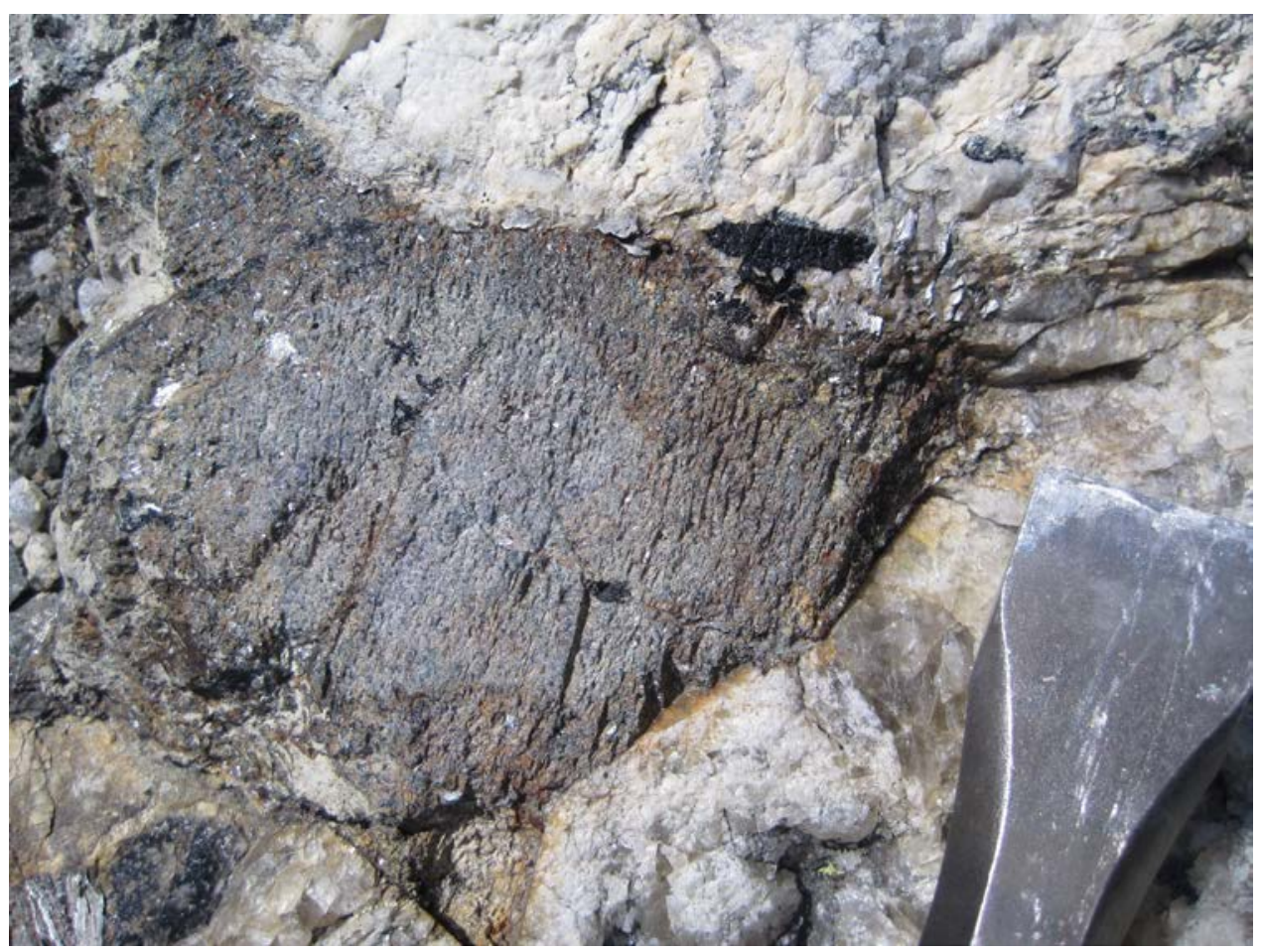

Figure 3.8b: A large sekaninaite crystal seen in an outcrop of GAR near its split from the GRANITE pegmatite. The chisel head is $\sim 3 \mathrm{~cm}$ across.

\subsubsection{The GARMUS Pegmatite}

This pegmatite is exposed near the center of the study area. It has two long branches to the north and one branch to the south emanating from the middle section of the dike. On average, the dike is $\sim 2 \mathrm{~m}$ wide and widens to nearly $6.75 \mathrm{~m}$ near its southern terminus before abruptly narrowing to $\sim 50 \mathrm{~cm}$ (Fig. 3.9a). The total length of the dike, including its northern branches, is nearly $43 \mathrm{~m}$. It has a strike of $\sim 315^{\circ}$ and a subvertical dip.

The dike is principally composed of quartz + feldspar + tourmaline. Major accessory phases of the dike include garnet, muscovite, beryl (Fig. 3.9b), and andalusite. Minor accessory phases of the dike are biotite, apatite, chrysoberyl, columbite, rutile, cassiterite, zircon, and iron oxides. Gahnite and ishikawaite are unconfirmed trace accessory phases. The pegmatite is zoned with quartz + feldspar being the primary assemblage of the border zone. Tourmaline can be found within the intermediate zone whereas garnet, muscovite, beryl, and andalusite occur only within the core. 


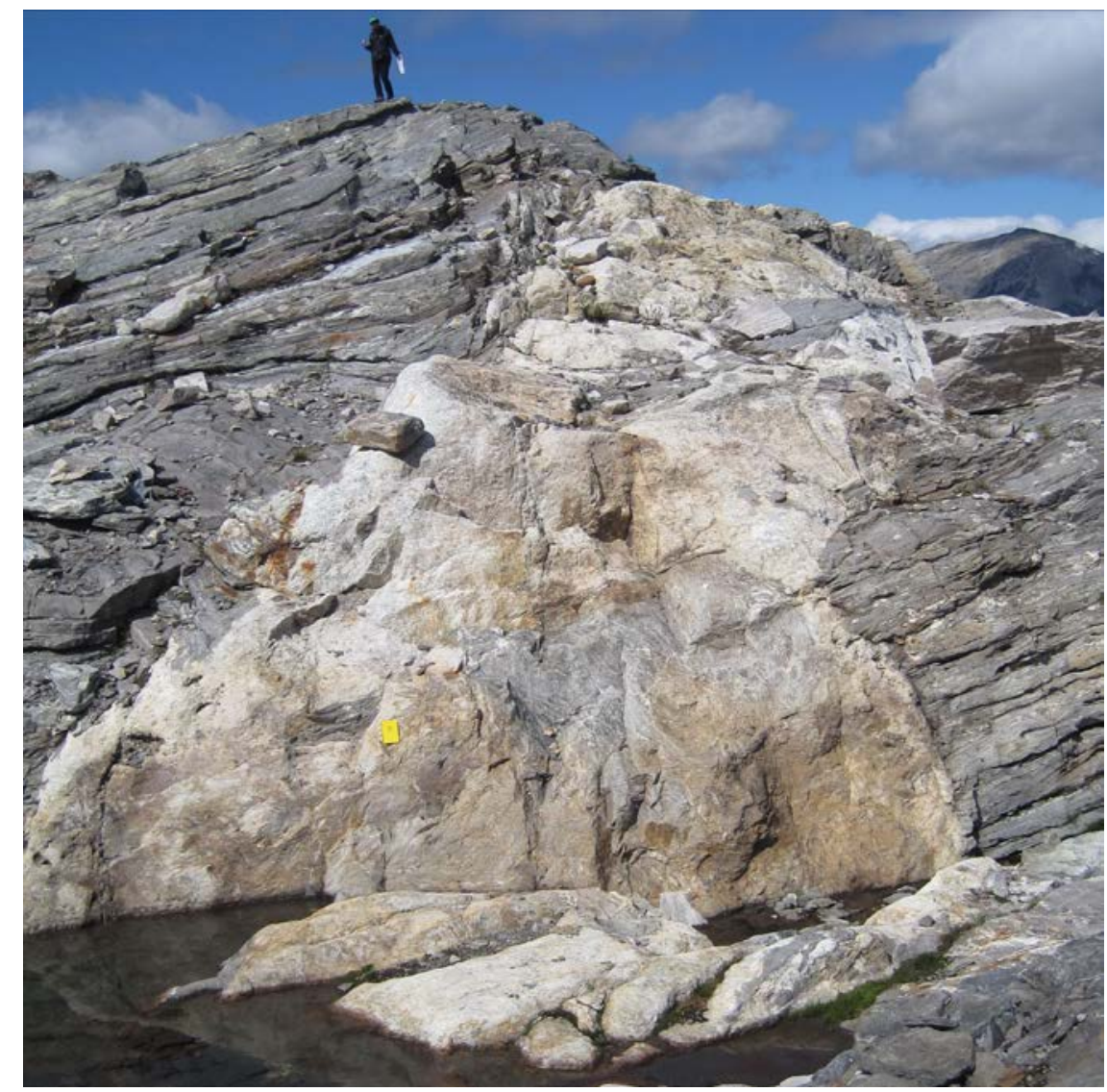

Figure 3.9a: The GARMUS pegmatite as seen from its southeastern terminus and looking to the northwest.

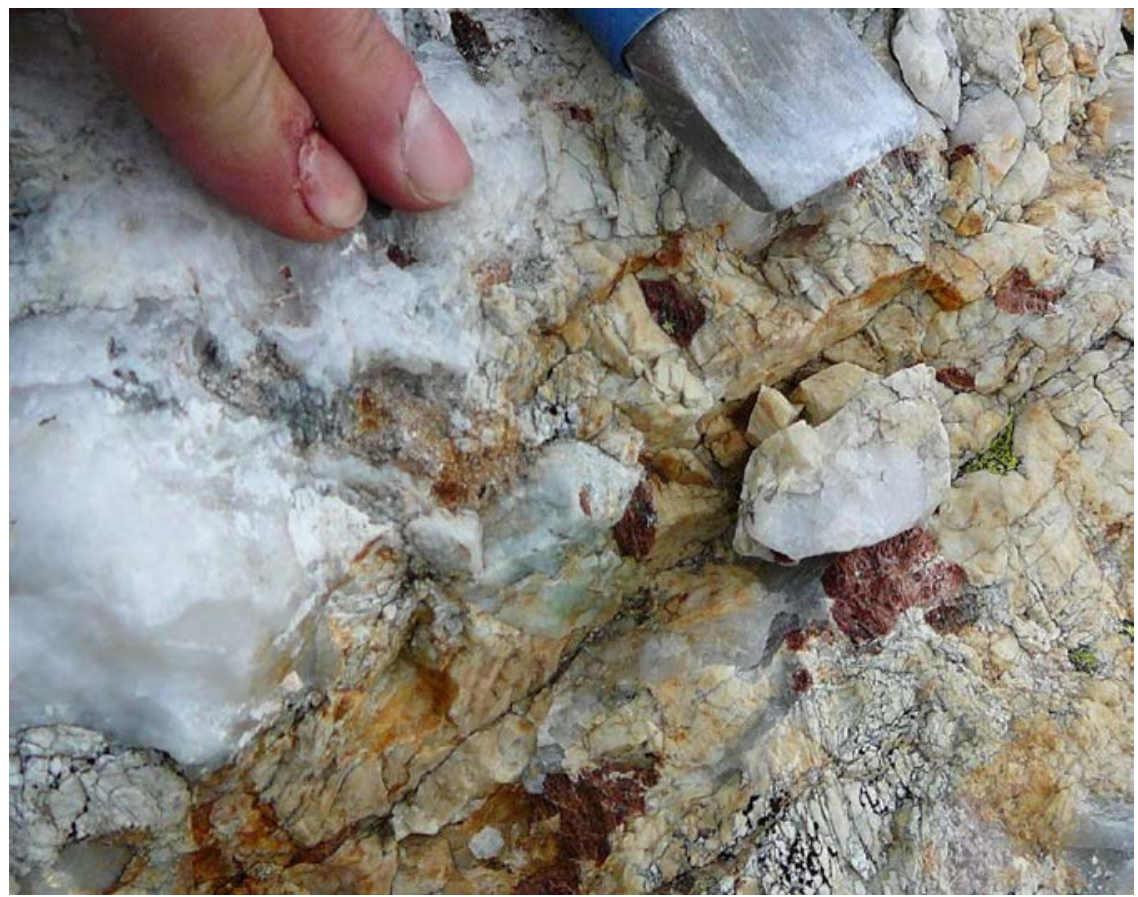

Figure 3.9b: Beryl (center) and garnet (red) in the GARMUS pegmatite. 


\subsubsection{The GARPHOS Pegmatite}

This dike appears to be a branch from the eastern end of the GRANITE pegmatite but its exact relation to GRANITE was obscured by a large snow field at the time of mapping (Fig. 3.10a $\&$ b). The pegmatite is typically $1-2 \mathrm{~m}$ wide before narrowing to $\sim 20 \mathrm{~cm}$ at its end; it has a length of $\sim 50 \mathrm{~m}$. It has a strike of $\sim 310^{\circ}$ and is very steeply dipping to the southwest.

The GARPHOS pegmatite has a principal composition of quartz + feldspar + tourmaline (Fig. 3.10c). The major accessory phases are muscovite, garnet, apatite, beryl and triplite (Fig. 3.10d). Minor accessory phases include topaz, triplite-zwieselite, monazite, xenotime, zircon, hübnerite, columbite, rutile, qitianlingite, uraninite, and kaolinite group clays. Autunite is an unconfirmed trace accessory phase. The dike is zoned, with the border being relatively barren and the intermediate and core zones containing the accessory mineral phases.

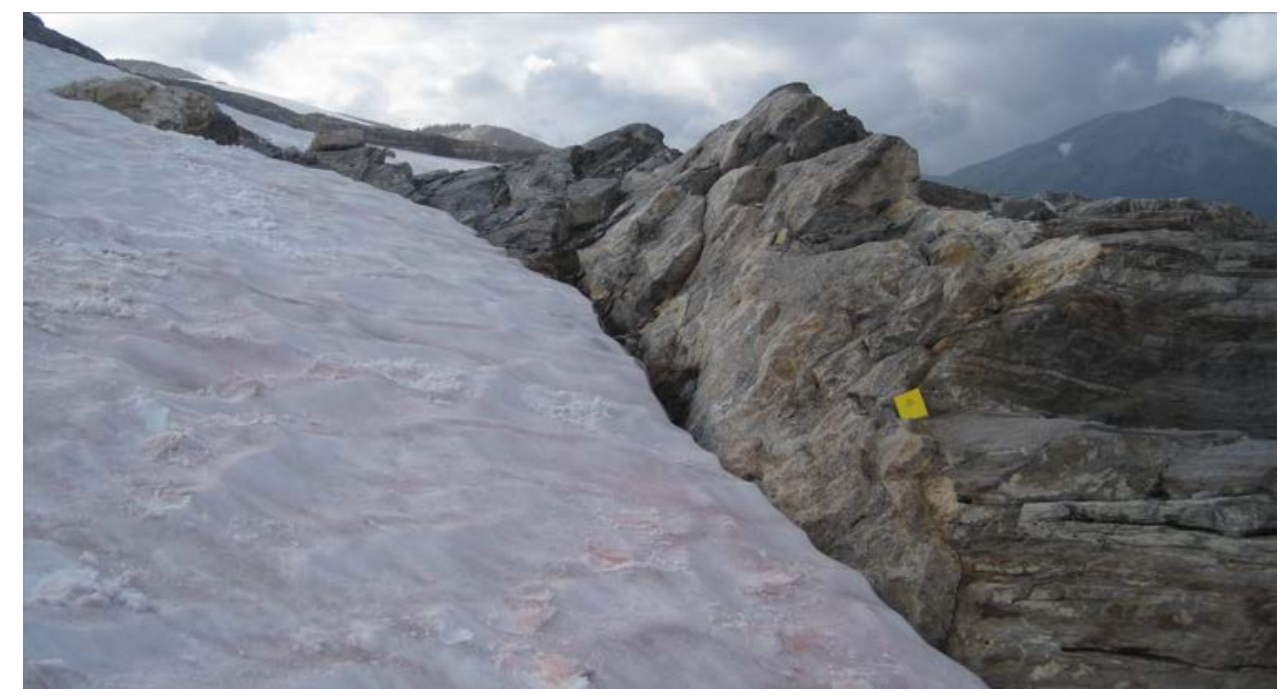

Figure 3.10a: The GARPHOS pegmatite as seen from its southeastern-most traceable extent, looking to the northwest. The large boulder outcropping from the snow in the upper left of the picture is the GRANITE pegmatite. 


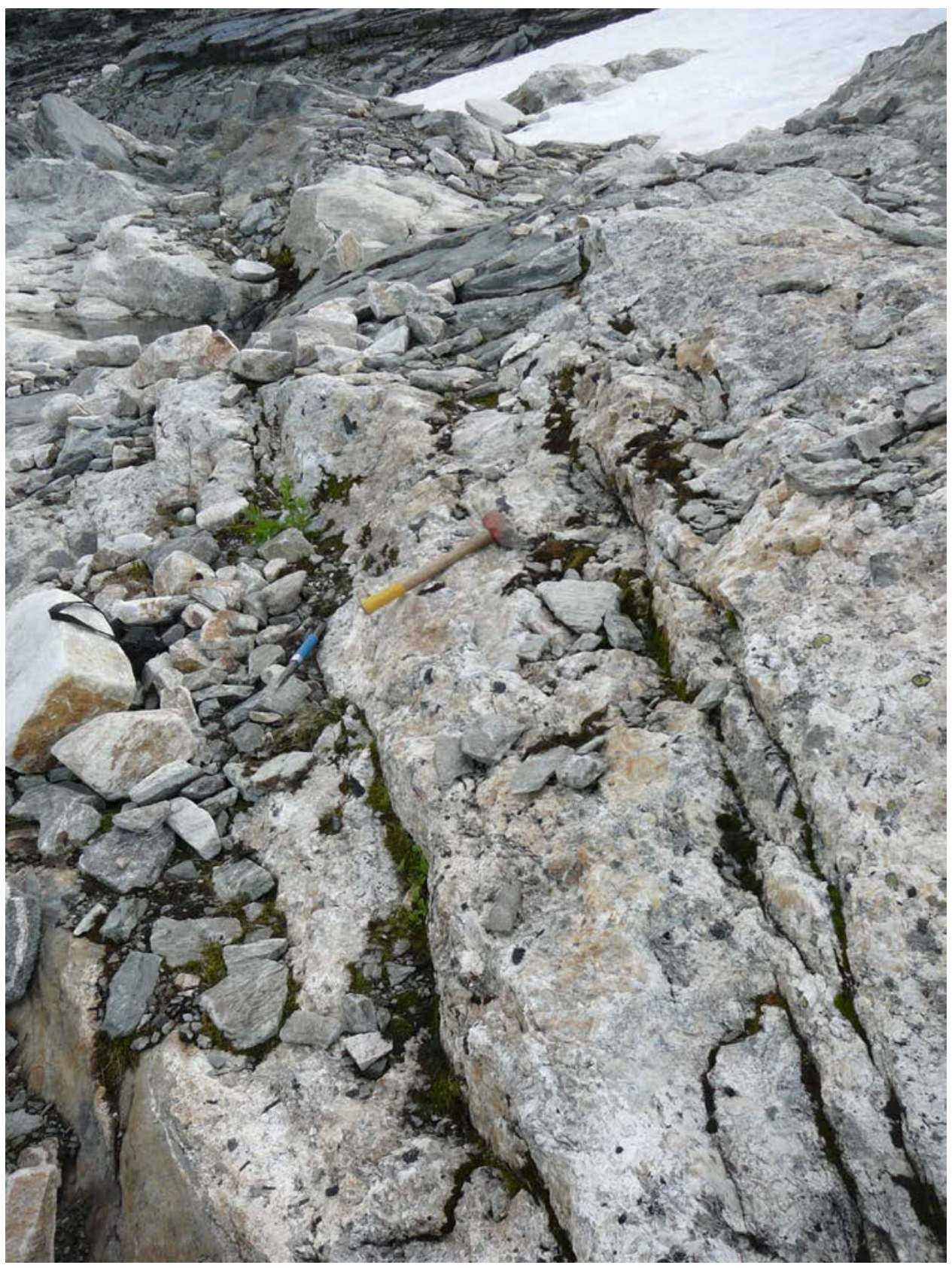

Figure 3.10b: The GARPHOS pegmatite as seen near its midpoint and looking towards where it split from the GRANITE pegmatite under the snow field (Fig. 3.10a). 


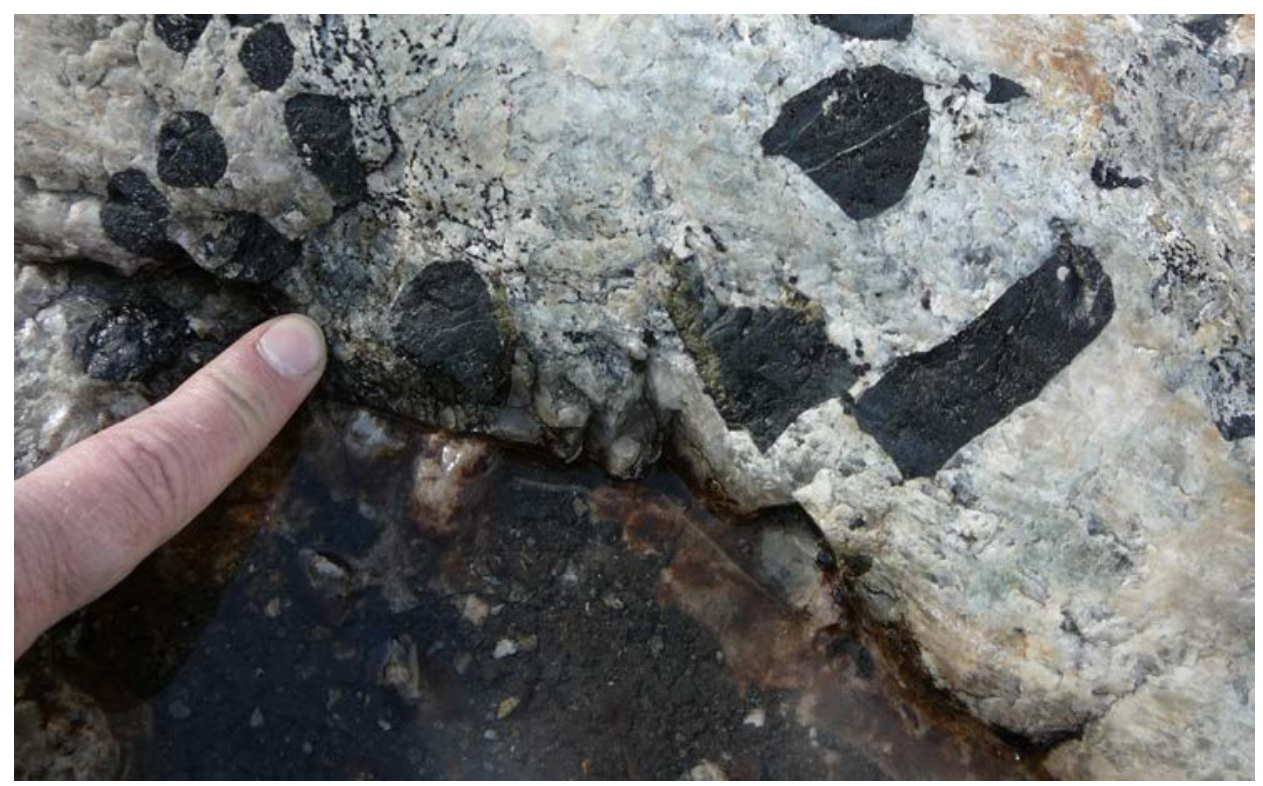

Figure 3.10c: Green elbaite-rimmed black tourmaline in the GARPHOS pegmatite.

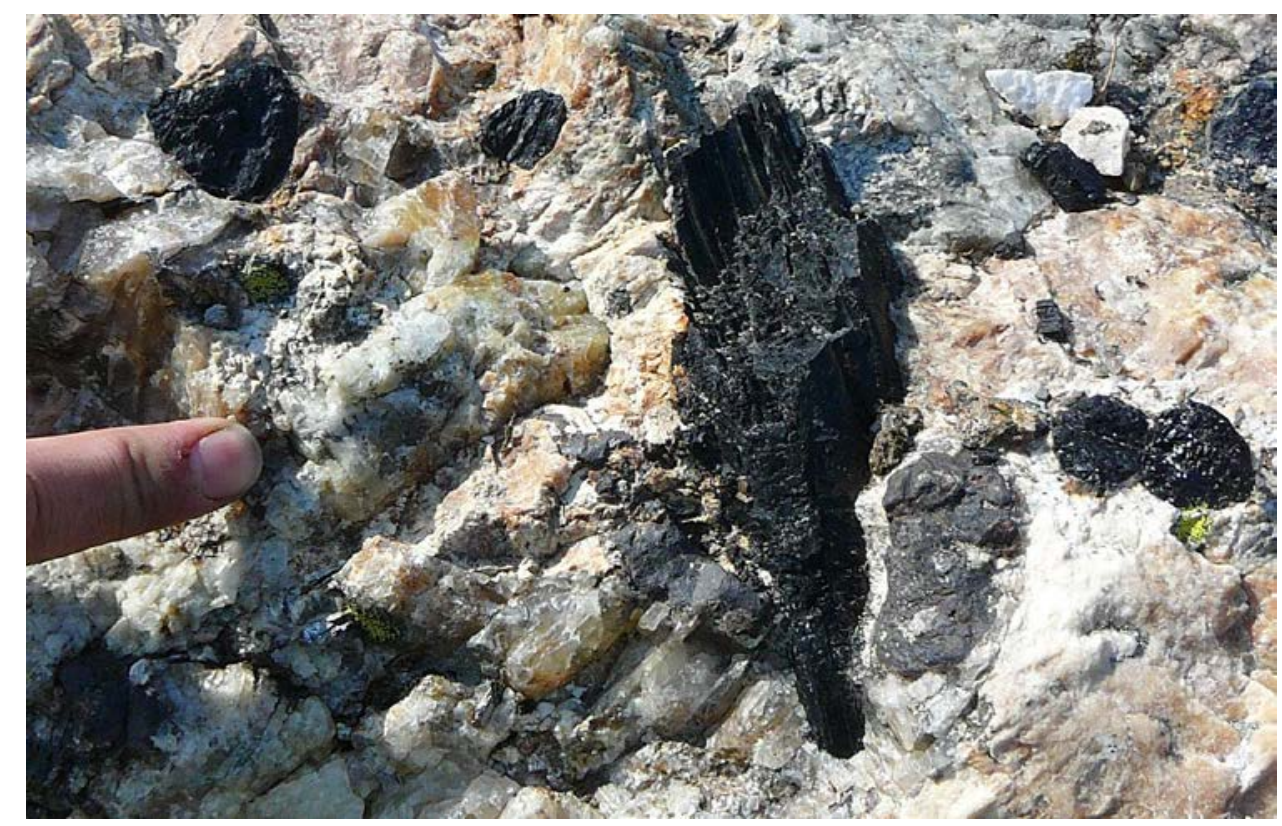

Figure 3.10d: Oxidized, dark gray phosphates (triplite-zwieselite) to the left and right of the base of the large black tourmaline crystal (slightly right of center). A beryl crystal can be seen next to the finger in the GARPHOS pegmatite. 


\subsubsection{The GARTOUR Pegmatite}

This pegmatite has long outcrops between snow patches in the southeastern extent of the study area (Fig. 3.11a). It is typically $60 \mathrm{~cm}$ wide and can be traced for approximately $40 \mathrm{~m}$; it has a strike of $\sim 325^{\circ}$ and is very steeply dipping to the northeast. It has rare, $2 \mathrm{~cm}$ pockets that may be an artefact from large, decomposing muscovite crystals. There are numerous, $3 \mathrm{~cm}$ diameter patches of quartz-tourmaline intergrowths along the length of the pegmatite.

The principal mineral assemblage of the dike is quartz + feldspar + tourmaline, with major accessory phases of garnet (Fig. 3.11b) and muscovite. Trace accessory phases include beryl and xenotime. The pegmatite is zoned, with the accessory phases occurring only within the core.

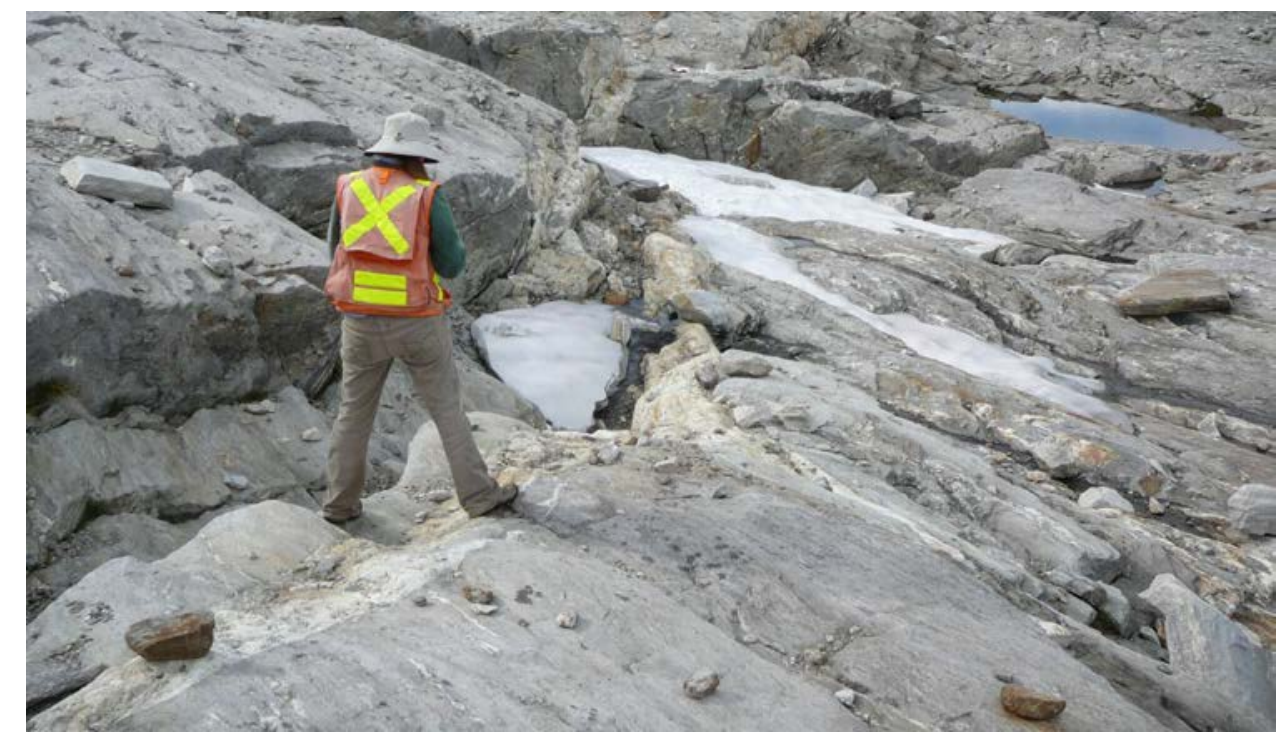

Figure 3.11a: The GARTOUR pegmatite as seen from near the mid-point of the pegmatite and looking to the northwest. 


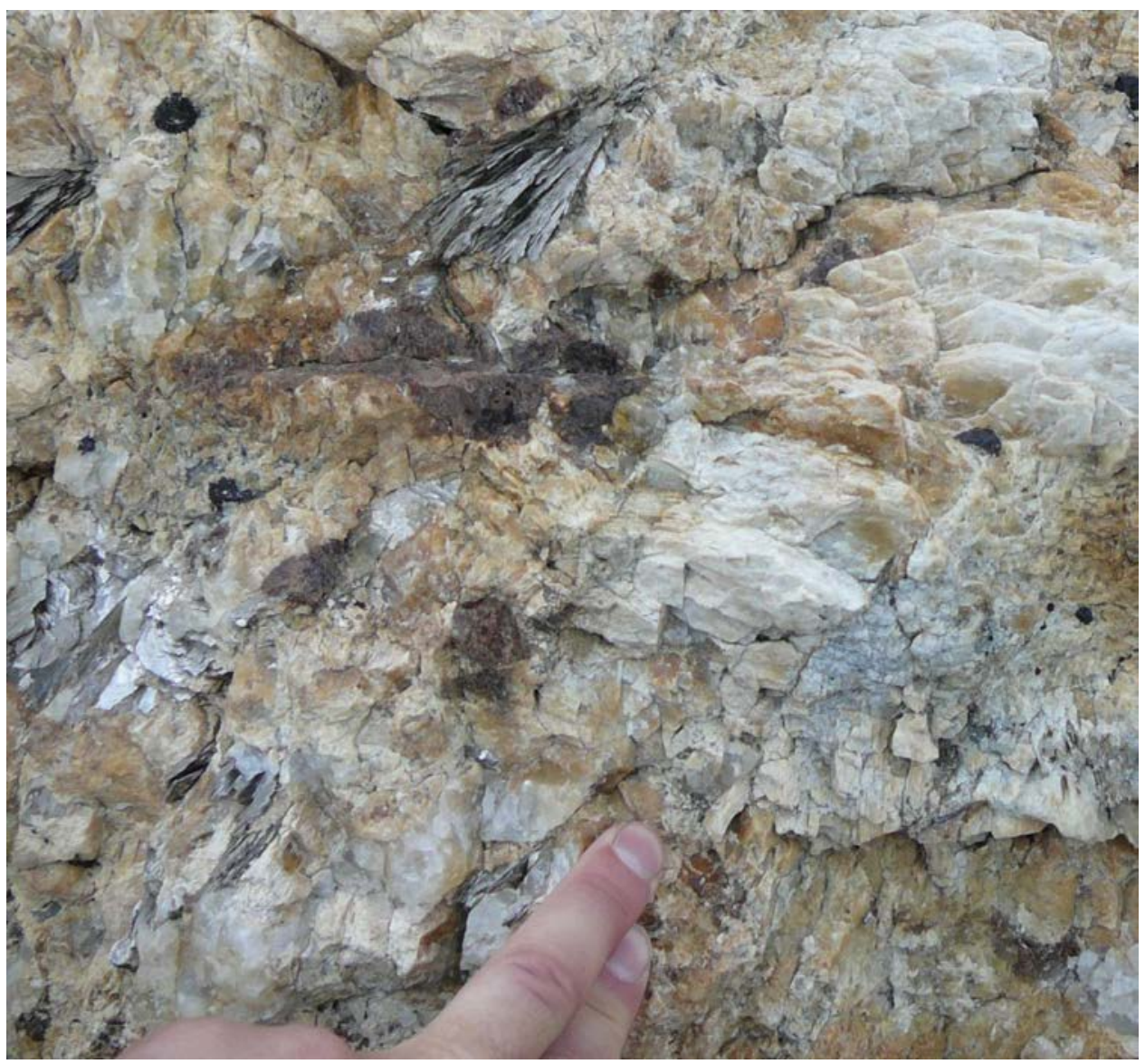

Figure 3.11a: Dark red-brown garnets in the GARTOUR pegmatite.

\subsubsection{The GRANITE Pegmatite}

This dike is exposed as long, beige-colored ridge nearly bisecting the center of the study area and is locally obscured by snowfields and moraine material (Fig. 3.12a \& b). It is typically fine-grained, resembling an ordinary granite with rare phenocrysts of feldspar, quartz, and tourmaline. The pegmatite is somewhat foliated in its eastern extent, slightly resembling an orthogneiss in places, but for the most part is not deformed elsewhere. It is offset by 11 meters to the south by the same minor fault that offset the GAR pegmatite. It has a variable width, ranging from $\sim 20 \mathrm{~cm}$ after branching into two parallel dikes in its western extent to $\sim 10 \mathrm{~m}$ wide for its middle section. From its eastern extent where it exits a moraine to its western extent to where it enters a snowfield, the dike is approximately $520 \mathrm{~m}$ long. It has a strike of $\sim 290^{\circ}$ and is very steeply dipping to subvertical to the southwest. Where the dike narrows to the west, the dip is apparently controlled by the foliation of the host rock. 
The principal mineral assemblage for this pegmatite is quartz + feldspar + biotite with major accessory phases of muscovite, tourmaline, apatite, and iron oxides. Minor accessory phases include chlorite, monazite, xenotime, rutile, zircon, and calcite. Pyrrhotite and sillimanite are unconfirmed trace accessory minerals. The dike does not display any discernible zoning.

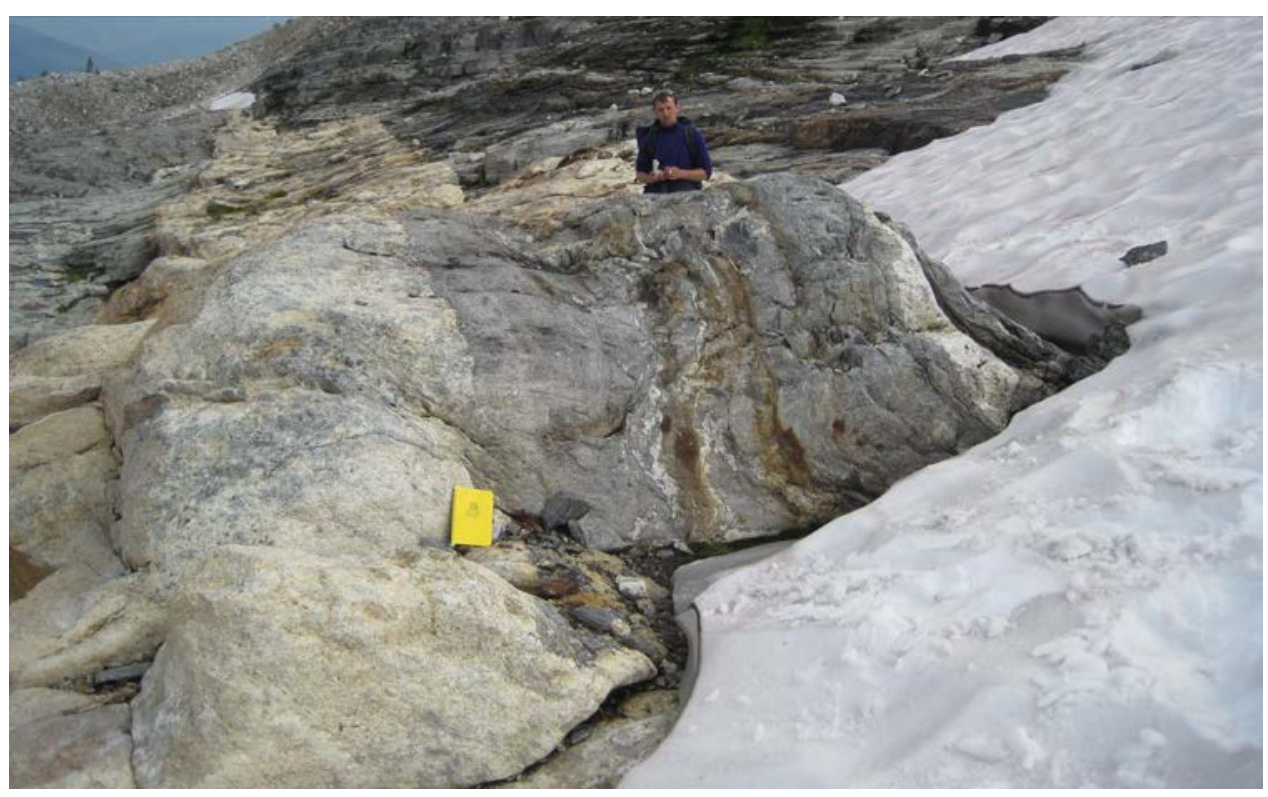

Figure 3.12a: The GRANITE pegmatite as seen from near its mid-point and looking to the southeast. The moraine in the upper left of the background of the image marks the eastern extent of the study area.

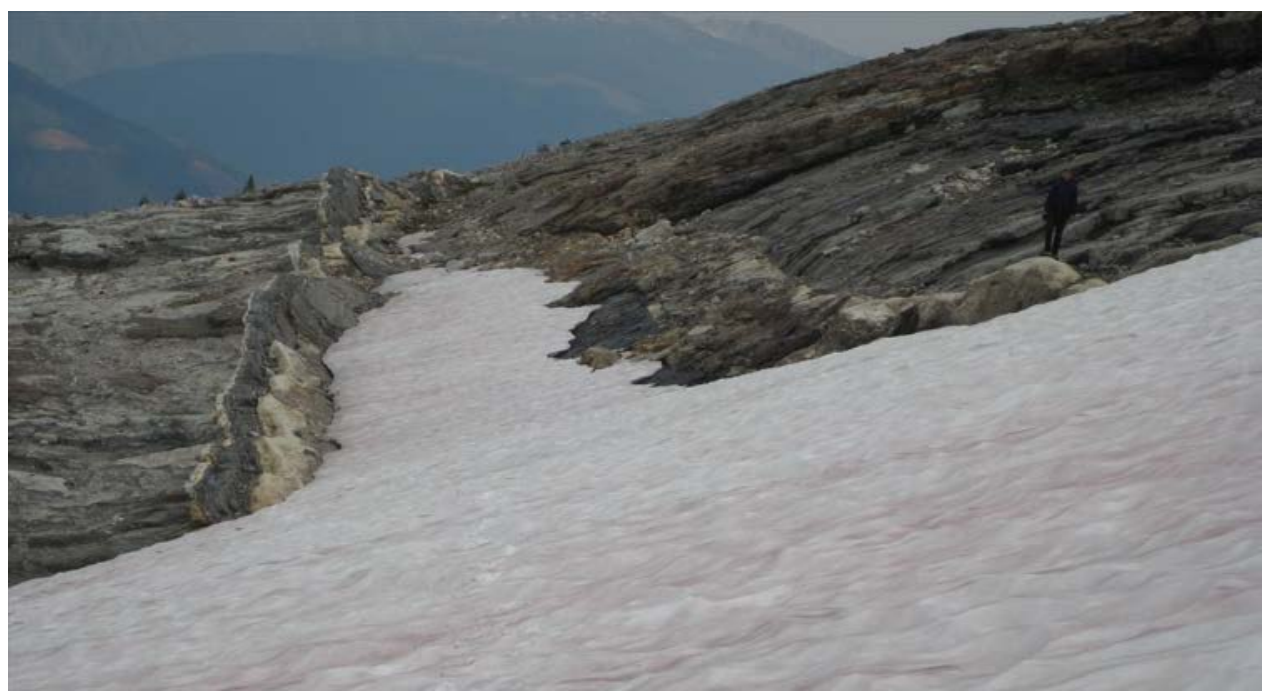

Figure 3.12b: The northwestern end of the traceable extent of the GRANITE pegmatite, outcropping as a narrow wall on the left half of the image. The pegmatite on the right side is the MUSC pegmatite. 


\subsubsection{The JAN Aplites}

This pegmatite occurrence is actually two parallel, very thin aplite dikes cross cutting the THIN pegmatite and continuing on in the host metasediments (Fig. 3.13a). They are not more than $3 \mathrm{~cm}$ wide, spaced approximately $1 \mathrm{~m}$ apart, and extend for at least 10 meters. These dikes have a strike of $\sim 330^{\circ}$ and have a vertical dip. The aplites are not zoned and the crystals with them are randomly oriented, rather than showing a preferred orientation (Fig. 3.13b). They are principally composed of quartz + feldspar + tourmaline with accessory biotite, garnet, and rutile.

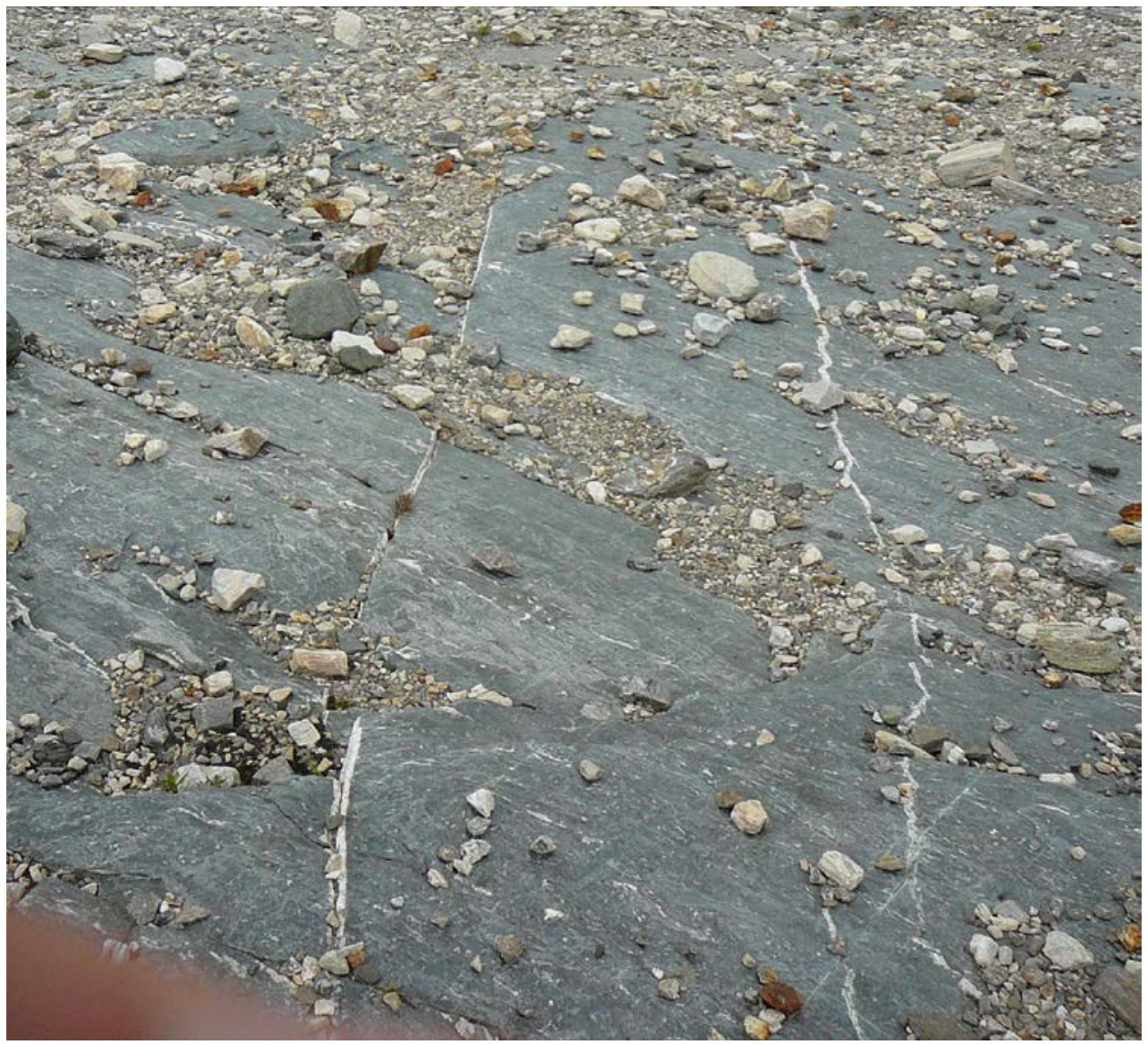

Figure 3.13a: The JAN aplites seen crosscutting the host rock. 


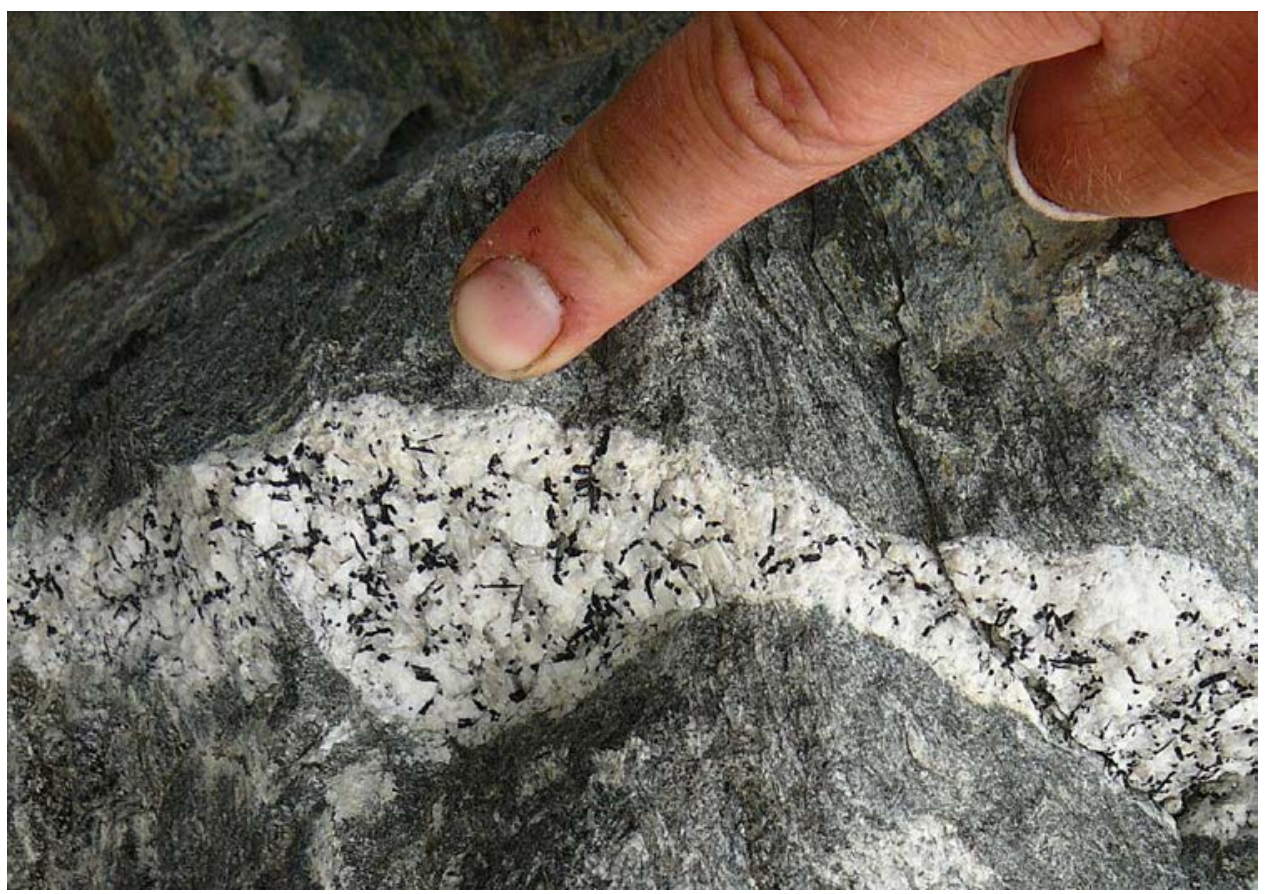

Figure 3.13b: A close up view of one of the JAN aplites.

\subsubsection{The JUNCT Pegmatite}

This pegmatite intersects with the CORD pegmatite near its western end. It has three branches extending from it, with the largest of the branches on its eastern end jutting to the south, not including the CORD pegmatite (Fig. 3.14). The main part of the dike has a strike of $\sim 85^{\circ}$, a subvertical dip, and is usually no more than $30 \mathrm{~cm}$ wide along its $75 \mathrm{~m}$ length. The large eastern branch is nearly 5 meters wide from where it splits from the main dike before narrowing down to a few millimeters over a distance of $\sim 17 \mathrm{~m}$.

The main assemblage for the dike is quartz + feldspar + tourmaline with biotite, muscovite as major accessory minerals. Apatite, altered cordierite and late chlorite are minor mineral phases for the pegmatite. Zoning was not observed within this dike. 


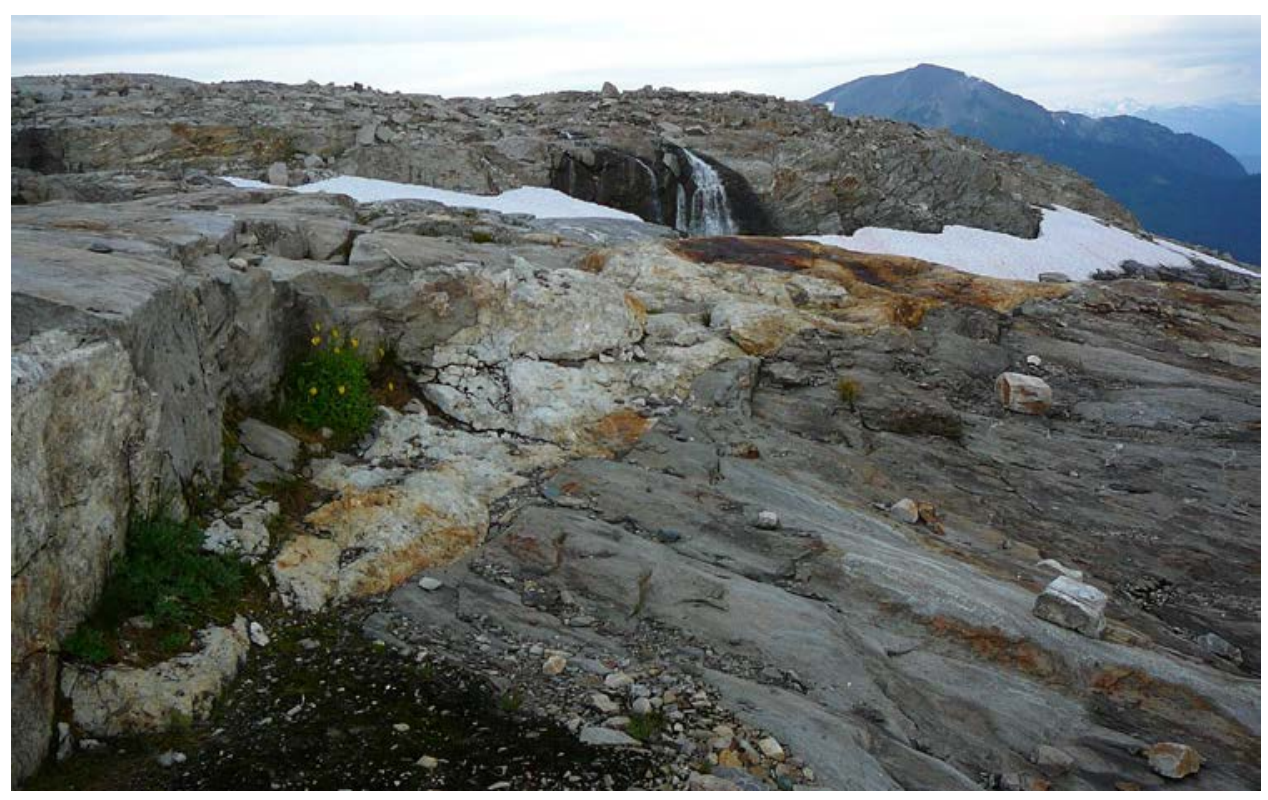

Figure 3.14: The largest eastern branch of the JUNCT pegmatite as seen near its mid-point and looking to the northwest. It joins the JUNCT pegmatite just beyond the crest of the small hill in the center of the image.

\subsubsection{The LENS Pegmatite}

This pegmatite is exposed to the south of the QTZ veins and has an oblong shape (Fig. 3.15). It has dimensions of approximately $1.5 \mathrm{~m} \times 60 \mathrm{~cm}$, a strike of $\sim 330^{\circ}$, and has a subvertical dip. The pegmatite is zoned, with grain size increasing from the border to the core; tourmaline crystals in the core can reach $15 \mathrm{~cm}$ in length. The principal mineral assemblage is quartz + feldspar + tourmaline. 


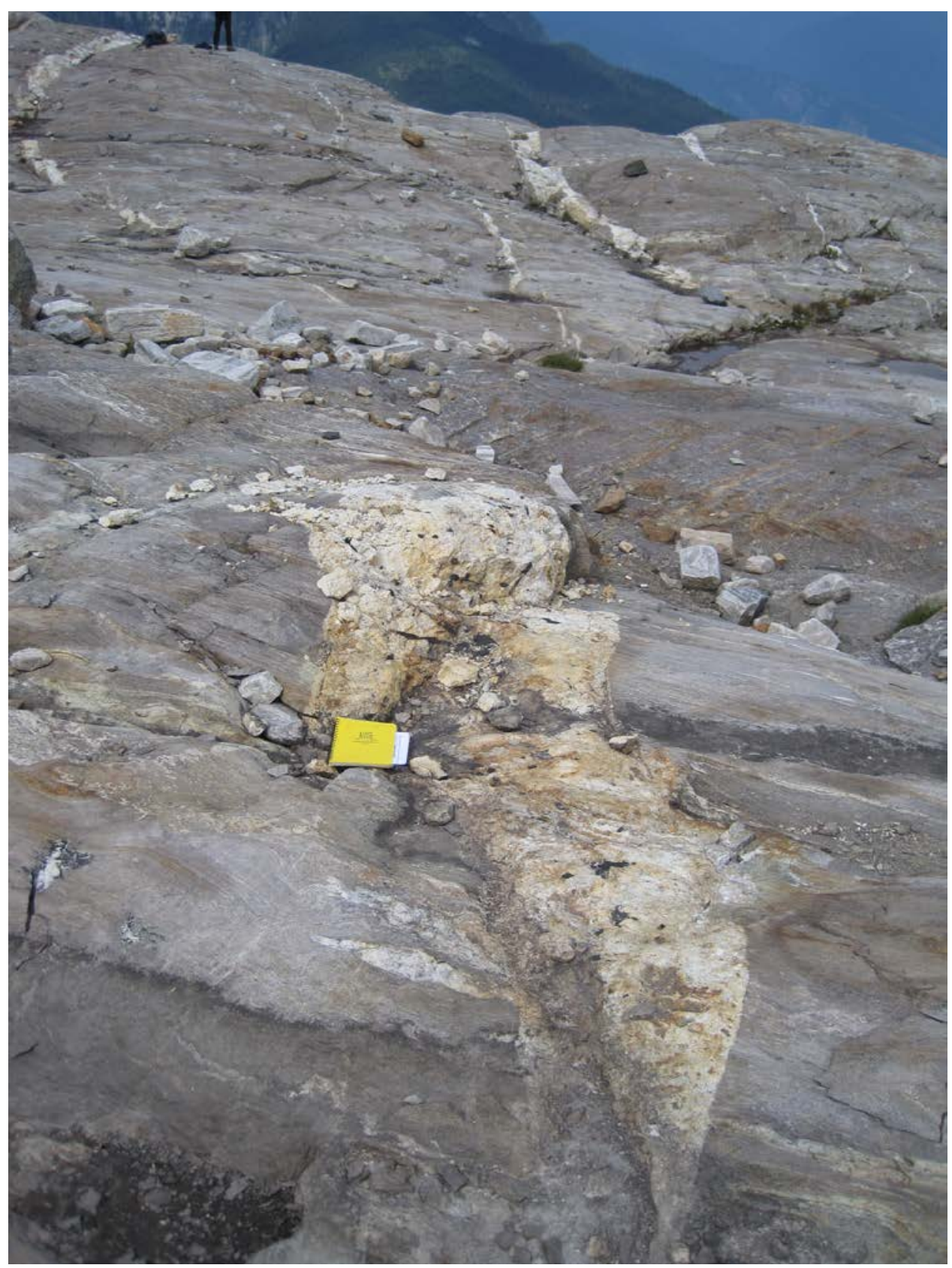

Figure 3.15: The LENS pegmatite seen from its southeastern end and looking towards the northwest. Beyond it, the mapped quartz veins can be seen QTZ (left), QTZ2 (center), and QTZ3 (right).

\subsubsection{The LENS2 Pegmatite}

This pegmatite is found within the southeastern part of the study area and greatly resembles a migmatite, due to the number of xenoliths present (Fig. 3.16). It has dimensions of $\sim 2 \mathrm{~m} \times 1$ $\mathrm{m}$, a strike of $\sim 325^{\circ}$, and a subvertical dip. It has pegmatitic and aplitic textures; tourmaline 
being more prevalent within the aplite. Tourmaline also replaces some of the xenoliths within the pegmatite. Beyond textural changes between aplite and pegmatite, zoning was not observed in the dike. The principal mineral assemblage for the dike is quartz + feldspar with tourmaline, zircon, and iron oxides as accessory minerals.

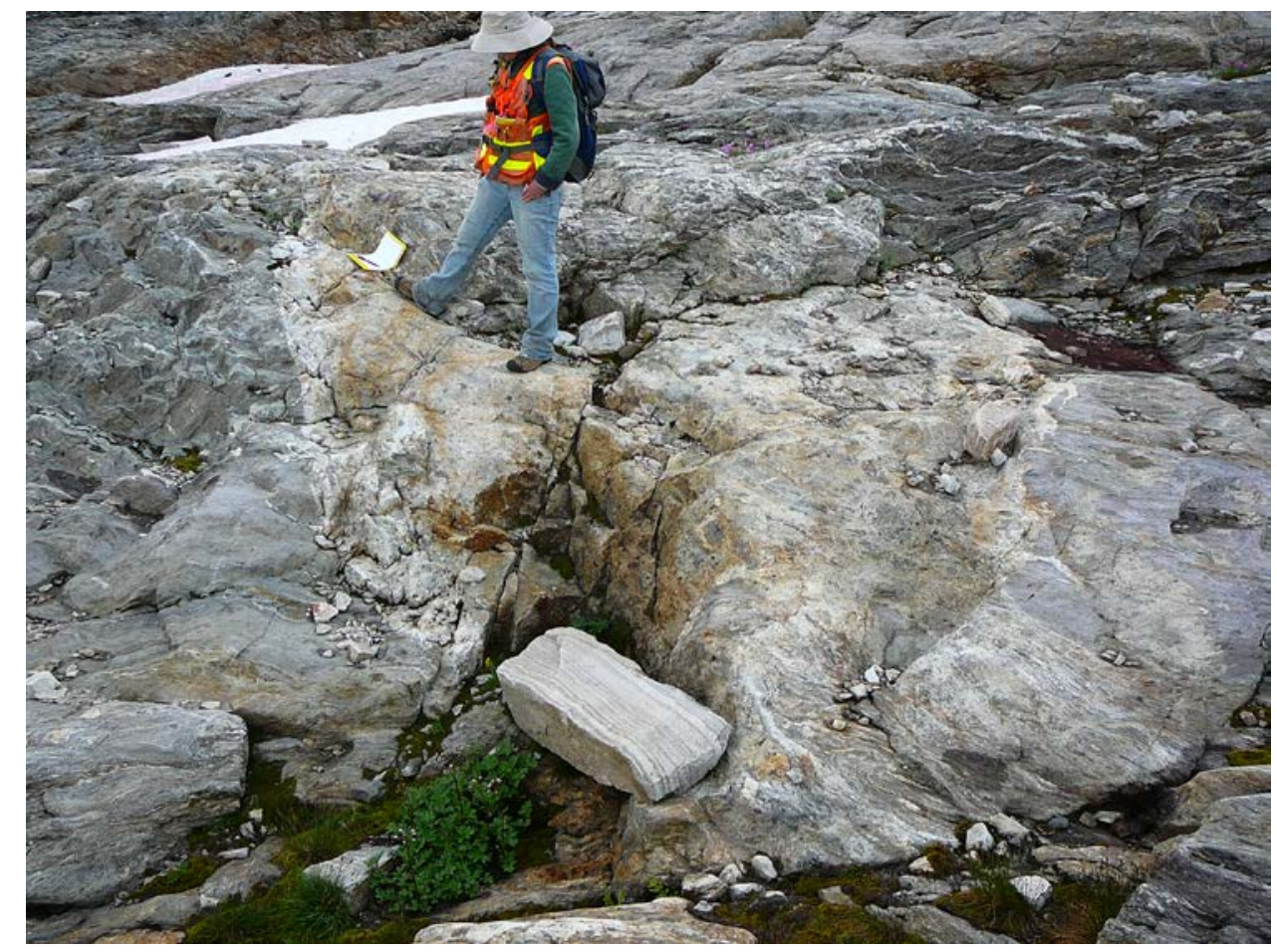

Figure 3.16: The LENS2 pegmatite as seen from its northwestern terminus and looking to the southeast.

\subsubsection{The LI Pegmatite}

This pegmatite is exposed near the center of the study area on top of a small knob (Fig. 3.17a). It has many branches, sprawling in nearly every direction from the knob. The longest branches have a strike of $\sim 310^{\circ}$ and have a subvertical dip. Branches not on strike have a general extent of $16 \mathrm{~m}$ while the branches on strike extend for approximately $38 \mathrm{~m}$. A reaction trail in the host rock can be traced from the longest southeasterly-oriented branch to the northwesterly branch of the LI2 pegmatite. If it is assumed that LI and LI2 are outcrops of the same pegmatite body at depth, the total length of the outcrops along the reaction trail is $\sim 200 \mathrm{~m}$.

The principal mineral assemblage for this pegmatite is quartz + feldspar + tourmaline. Major accessory minerals include muscovite, apatite, garnet, lepidolite (Fig. 3.17b), and petalite. 
Zircon, qitianlingite, rutile, tantalite, columbite, cassiterite, hübnerite, manganese and iron oxides are minor accessory minerals. Lithiophilite and uraninite are unconfirmed minor accessory minerals. The pegmatite is zoned, with lepidolite, opaque pink tourmaline and minor cleavelandite were observed in the core of the outcrop; black tourmaline and garnet were noted outside of the core. All samples collected from the pegmatite for further analysis came from or near the core.

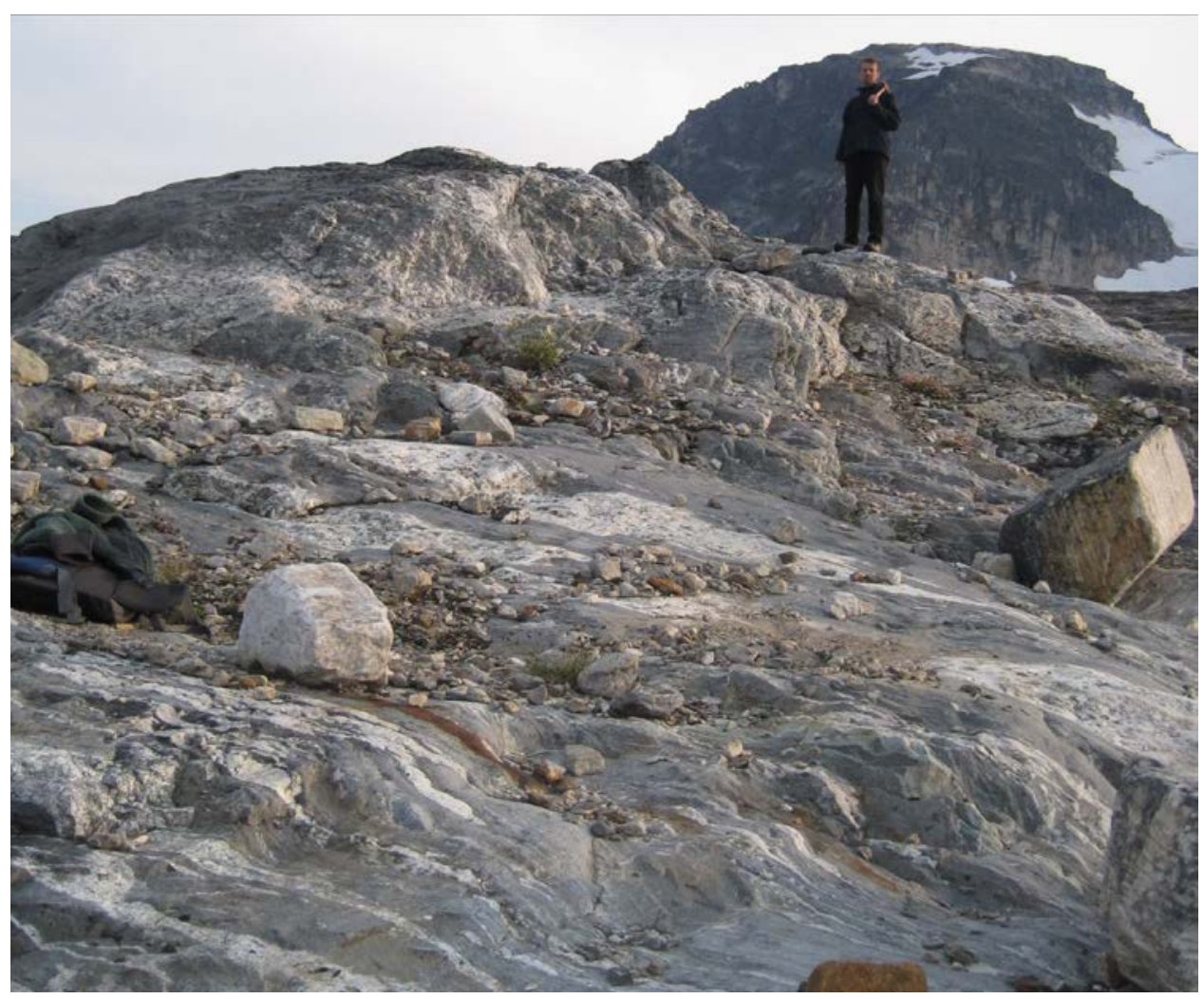

Figure 3.17a: The LI pegmatite as seen from standing at the bottom of the knob and looking to the south. 


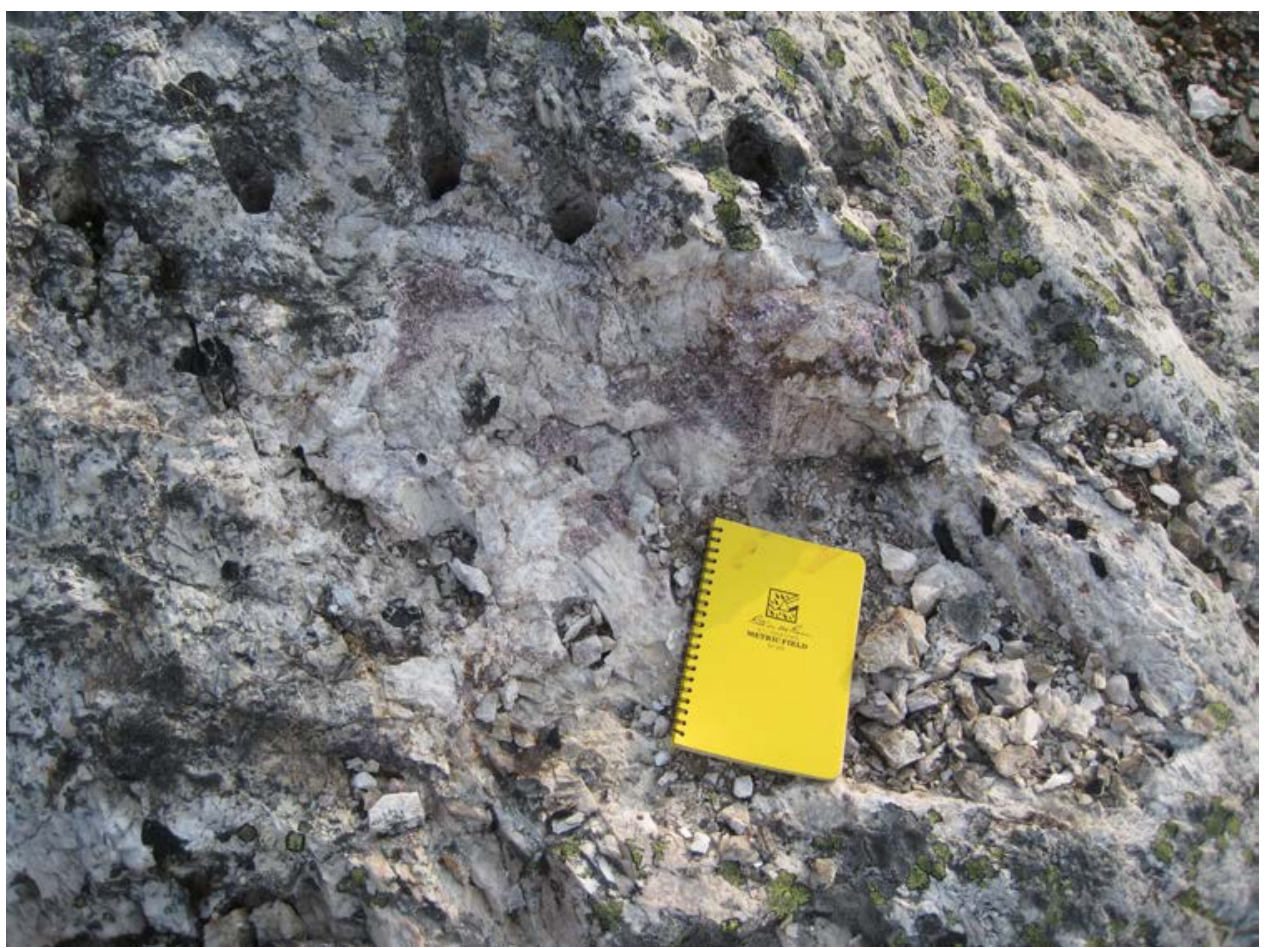

Figure 3.17b: Lepidolite in the core of the LI pegmatite on top of the knob.

\subsubsection{The LI2 Pegmatite}

This pegmatite is exposed near the center of the study area long a very low ridge and along the northeastern and southwestern sides of a large synformal bend in the foliation of the host rock (Fig. 3.18a). Branches of the pegmatite rejoin to the east and west of the synformal feature and split again to the west. Where the branches are joined, the dike is usually not more than $2 \mathrm{~m}$ wide; the branches generally do not exceed $1 \mathrm{~m}$ in width. It strikes $\sim 320^{\circ}$ and its dip is primarily subvertical but varies with the foliation of the host rock. Its total length along strike is $\sim 105 \mathrm{~m}$. A reaction trail in the host rock can be traced from the northwesterly-oriented branch to the longest southeasterly branch of the LI2 pegmatite. If it is assumed that LI and LI2 are outcrops of the same pegmatite body at depth, the total length of the outcrops along the reaction trail is $\sim 200 \mathrm{~m}$.

The principal mineral assemblage for this dike is quartz + feldspar + tourmaline with accessory minerals of muscovite, biotite, lepidolite, garnet, apatite, triplite-zwieselite (Fig. 3.18b), columbite, rutile, zircon, and manganese and iron oxides. Unconfirmed accessory minerals include lithiophilite, lipscombite, hureaulite, amblygonite, xenotime, and clays. 
The pegmatite has four distinct zones: a narrow border zone with the assemblage Qt + Fsp + Tur ; a wall zone with Qt + Fsp + Bt +Tur +/- Brl; an intermediate zone of Qt + Fsp + Ms + black Tur + green Tur + Grt + phosphates; and a core with Qt + Fsp + Ms + Bt + Lpd + blue Tur + green Tur + pink Tur + black Tur +/- Brl +/- Grt (Fig. 3.18c).

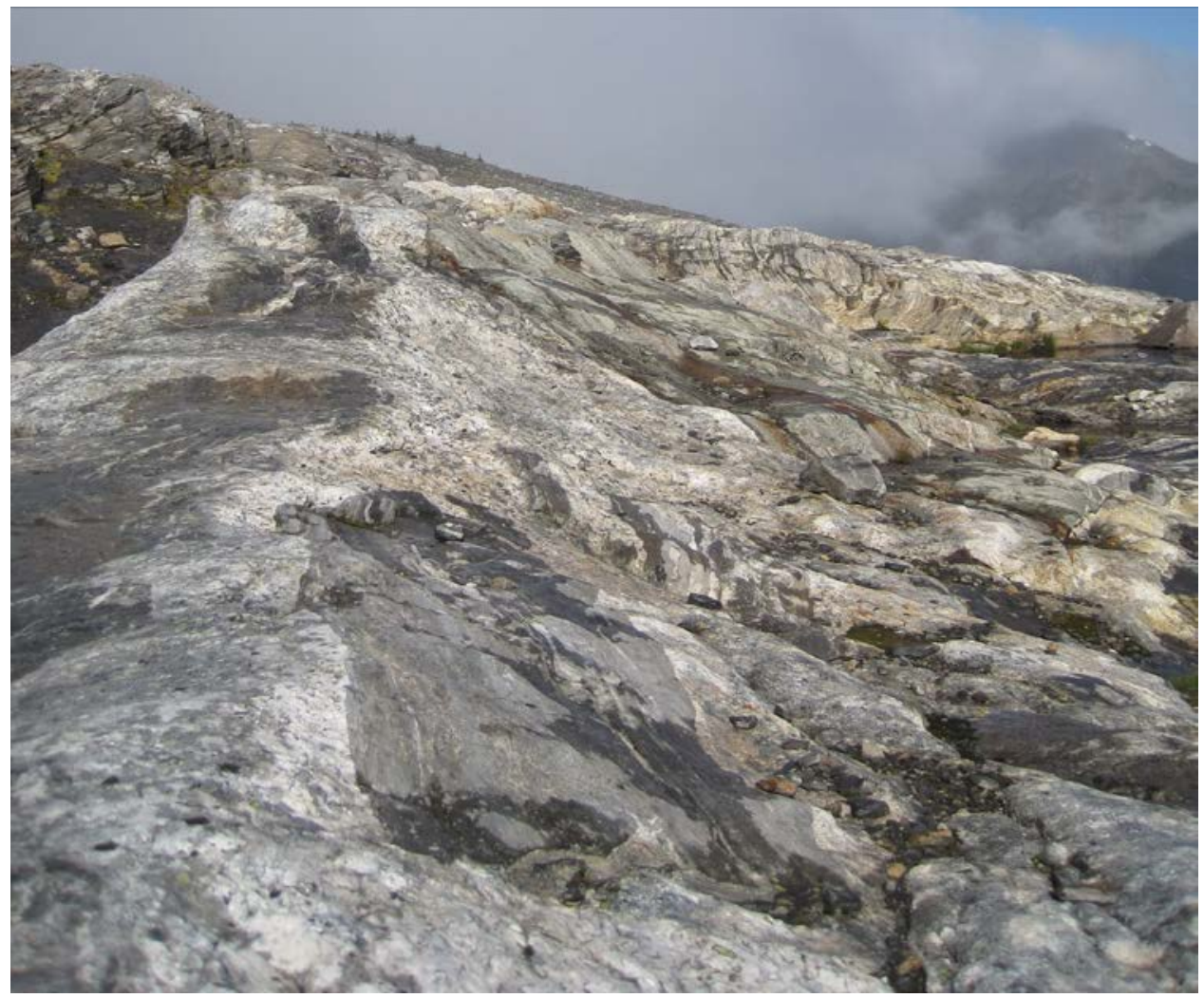

Figure 3.18a: The LI2 pegmatite as seen from near its southeastern end and looking to the northwest. 


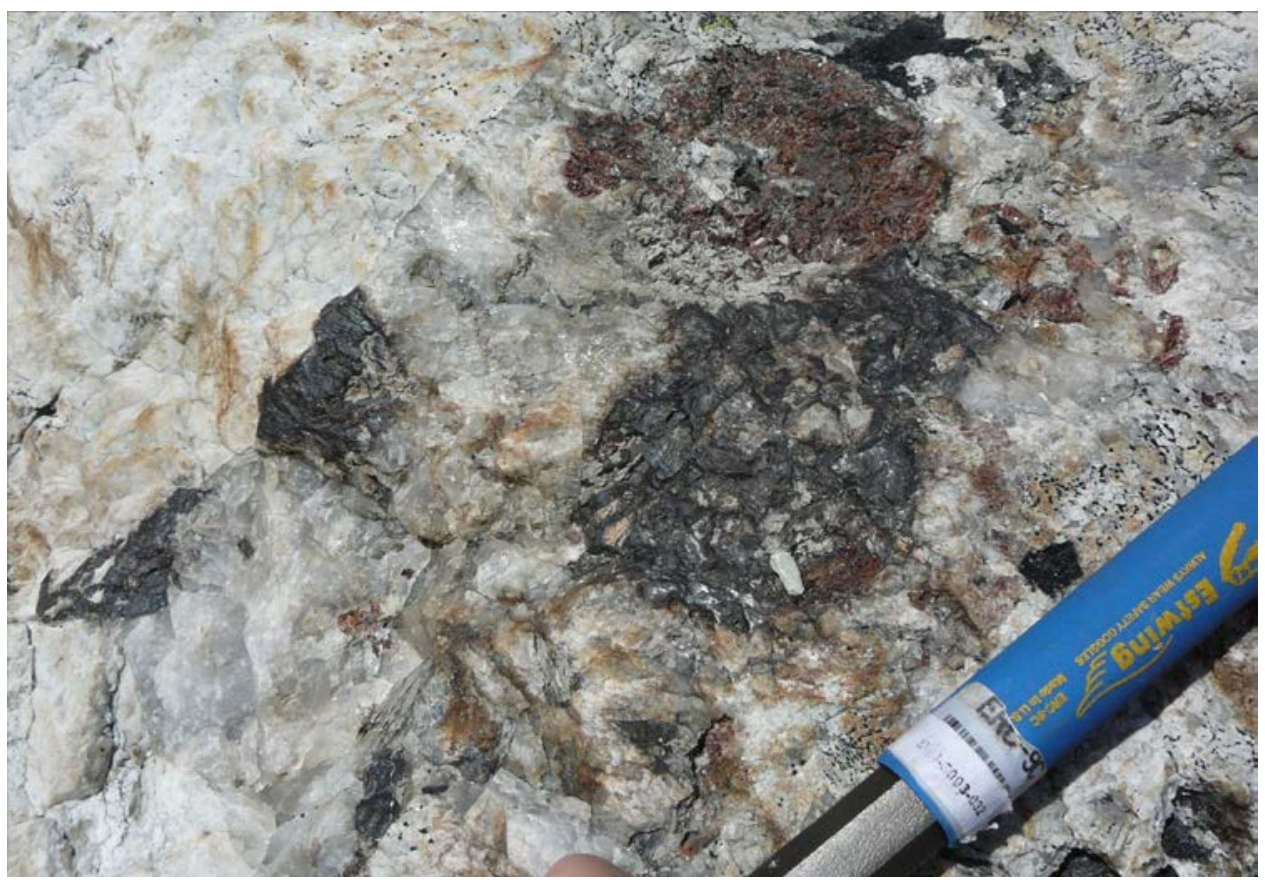

Figure 3.18b: Dark gray oxidized phosphates (triplite-zwieselite) in the LI2 pegmatite.

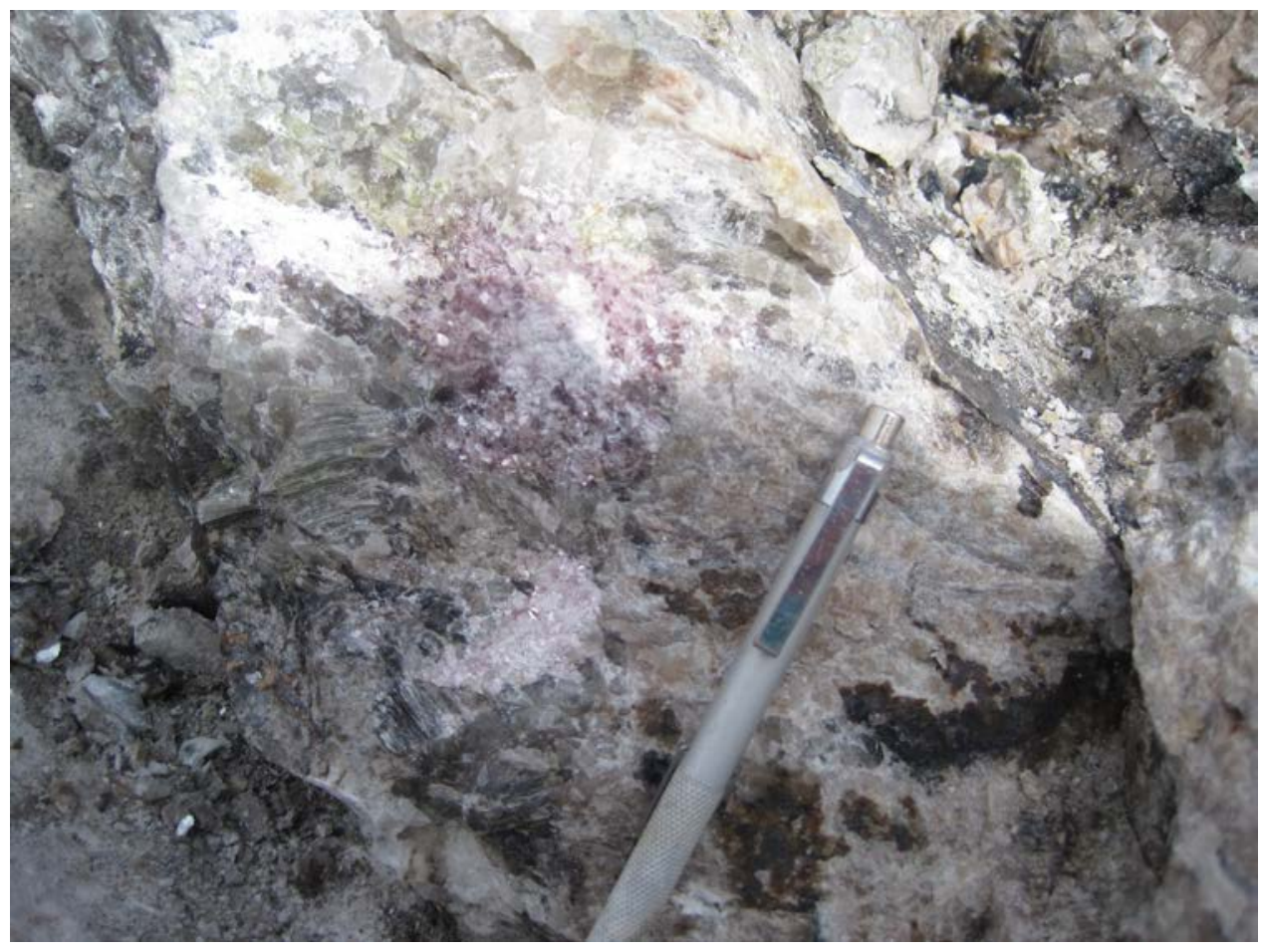

Figure 3.18c: The core of the LI2 pegmatite showing pink lepidolite and pale green tourmaline. 


\subsubsection{The LONG Pegmatite}

This dike is located in the western half of the study area (Fig. 3.19) and connects with the CORNER pegmatite. The southeastern end of the dike is $\sim 1$ m wide. For most of the northwestern end of the dike, it is split into two parallel branches before rejoining near the end of the traceable outcrop. One branch primarily remains concealed by the host metasediment and is only revealed occasionally in more eroded areas. The other branch is typically more visible and can be nearly $1.5 \mathrm{~m}$ wide. The dike can be traced for nearly $220 \mathrm{~m}$, has a strike of $290^{\circ}$ and a subvertical dip that is occasionally variable depending on the foliation of the host rock.

The principal mineral assemblage of this pegmatite is quartz + feldspar + tourmaline with major accessory minerals of garnet, rutile, iron oxides and sulfides. Trace accessory minerals include allanite and galena. The dike is subtly zoned with garnet and larger crystals of tourmaline in its core.

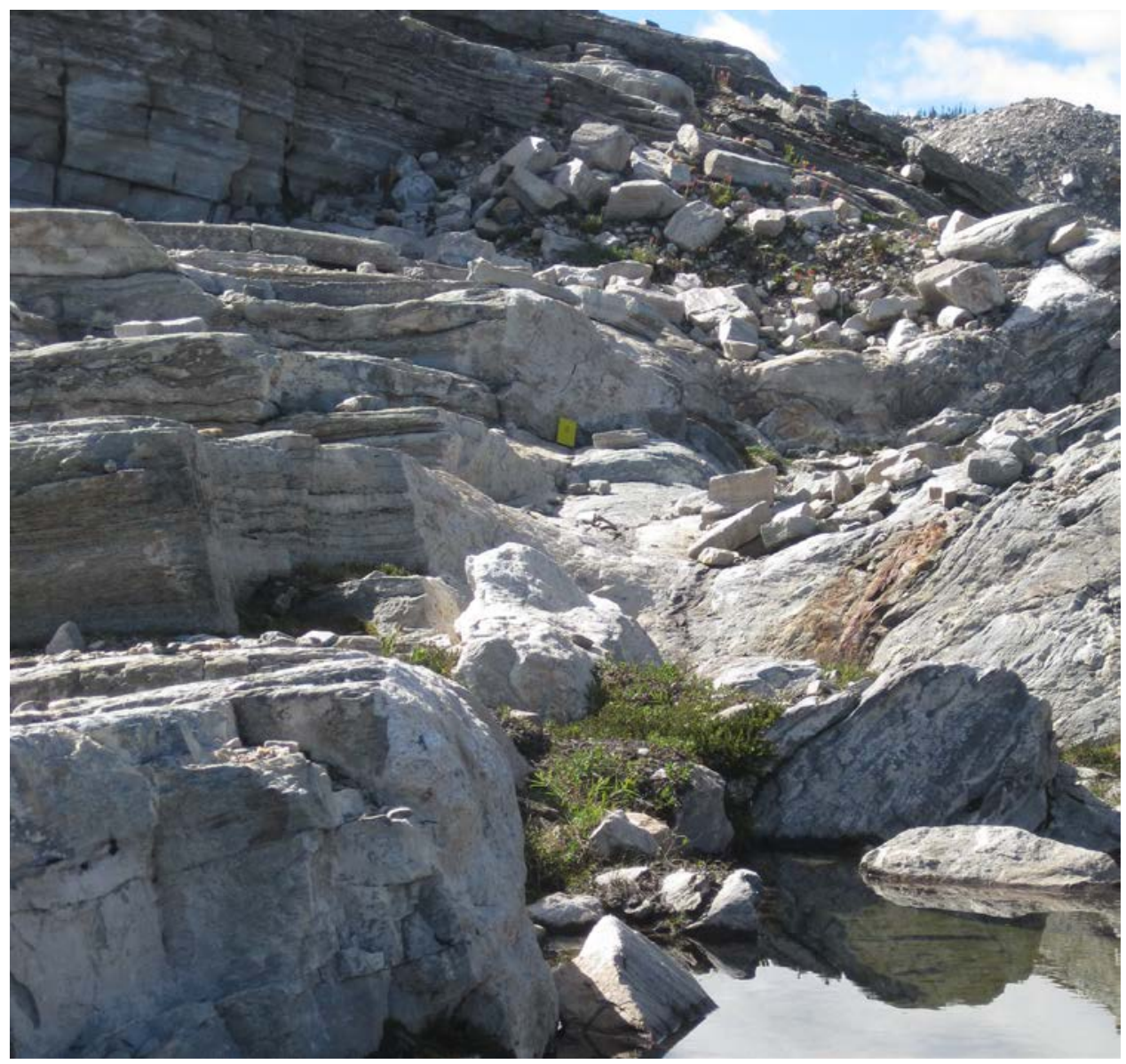

Figure 3.19: The LONG pegmatite as seen from near its southeastern end and looking towards the northwest. 


\subsubsection{The META Migmatitic Pegmatite}

This is the only migmatitic pegmatite mapped in the study area and it is exposed along a ridge near the LONG and PEGMA pegmatites. It varies from a few centimeters to nearly $1 \mathrm{~m}$ wide along its length. It is typically at least $50 \mathrm{~cm}$ wide and can be traced for nearly $125 \mathrm{~m}$, making it larger than most other migmatitic leucosome layers in the area, which are generally much shorter and thinner. It has a strike of approximately $300^{\circ}$ and its dip is always concordant with the foliation, which is primarily shallowly dipping to nearly $45^{\circ}$ towards the southwest (Fig. 3.20). It is composed of quartz + feldspar with very rare biotite, muscovite, and tourmaline. No samples were taken from this granitic body.

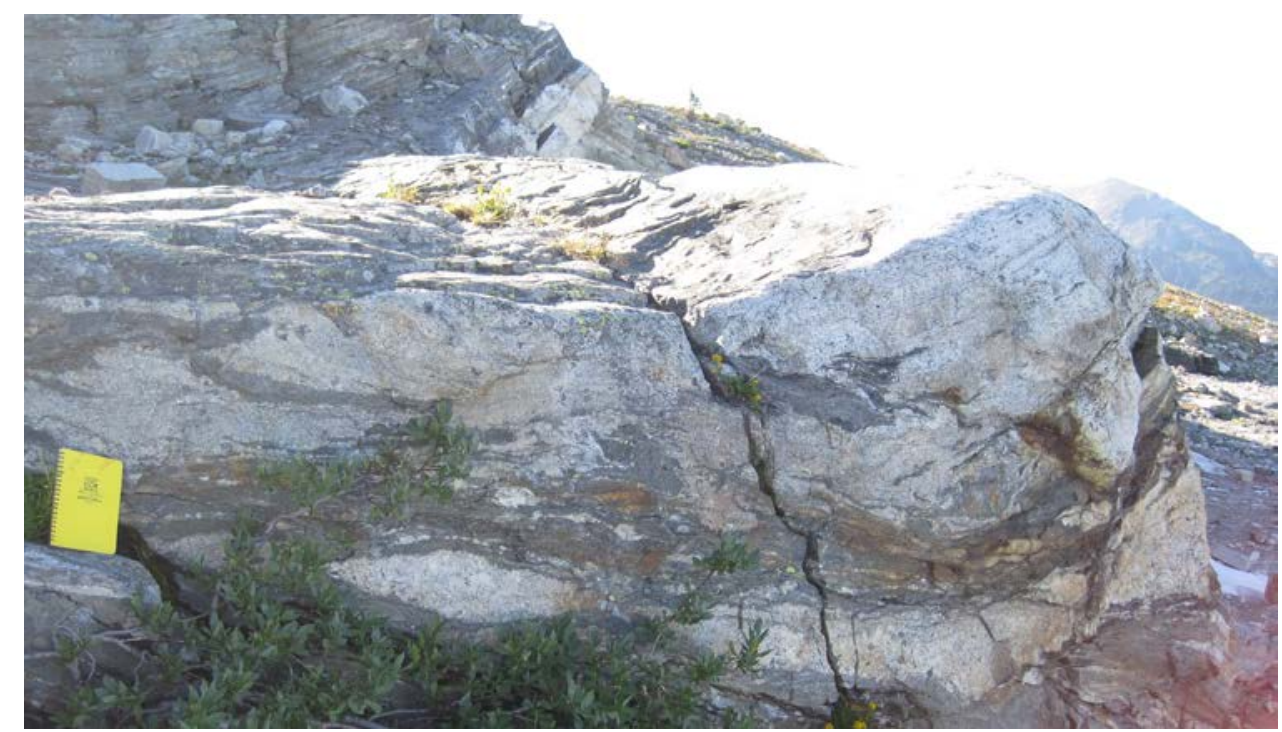

Figure 3.20: The META migmatitic pegmatite as seen near its thickest section near its midpoint and looking towards the northwest. 


\subsubsection{The MUSC Pegmatite}

This pegmatite is subparallel to the GRANITE pegmatite and is located slightly to the south of the northwestern extent of GRANITE. The outcrop is partially obscured by cobbles and plant matter near its eastern end (Fig. 3.21). It is nearly $1 \mathrm{~m}$ wide and can be traced for nearly 54 m. It has a strike of $\sim 290^{\circ}$ and is steeply dipping to the southwest to subvertical. Its primary mineral assemblage is quartz + feldspar + muscovite with accessory tourmaline and biotite. It is zoned with a small quartz core.

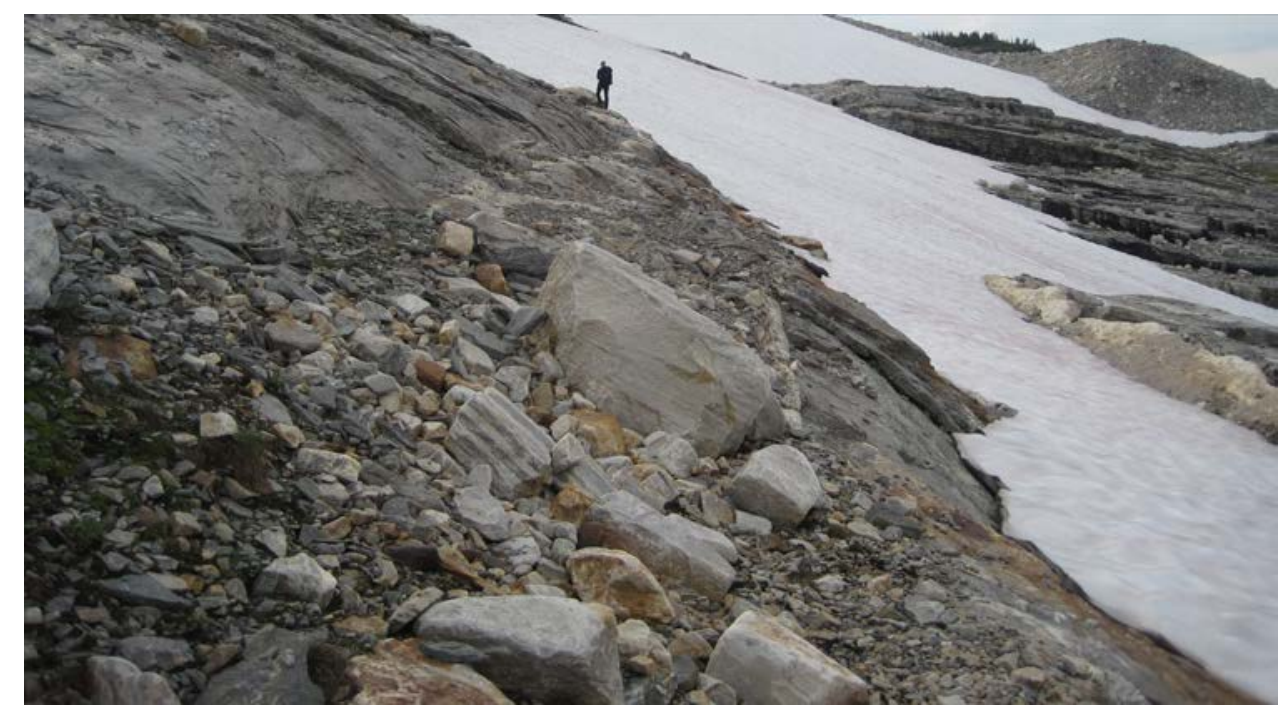

Figure 3.21: The MUSC pegmatite as seen from its southeastern end and looking towards the northwest. GRANITE outcrops in the right side of the image. 


\subsubsection{The ODD Pegmatite}

This pegmatite is exposed in a short cliff topping a talus pile near the SIMPLE10 pegmatite in the northern part of the study area (Fig. 3.22). It was not very well documented due to the precarious footing. Its length is uncertain but it appeared to be $\sim 2 \mathrm{~m}$ wide with a strike of $\sim 300^{\circ}$ and to be very steeply dipping to the southwest. It did not display any discernible zoning and had a primary mineral assemblage of quartz + feldspar with accessory tourmaline. This dike is odd with respect to the others within the study area because it had only had trace (rather than abundant) accessory tourmaline, the feldspar crystals seemed to be distorted, and it appeared to have slickensides. No samples were taken from this pegmatite.

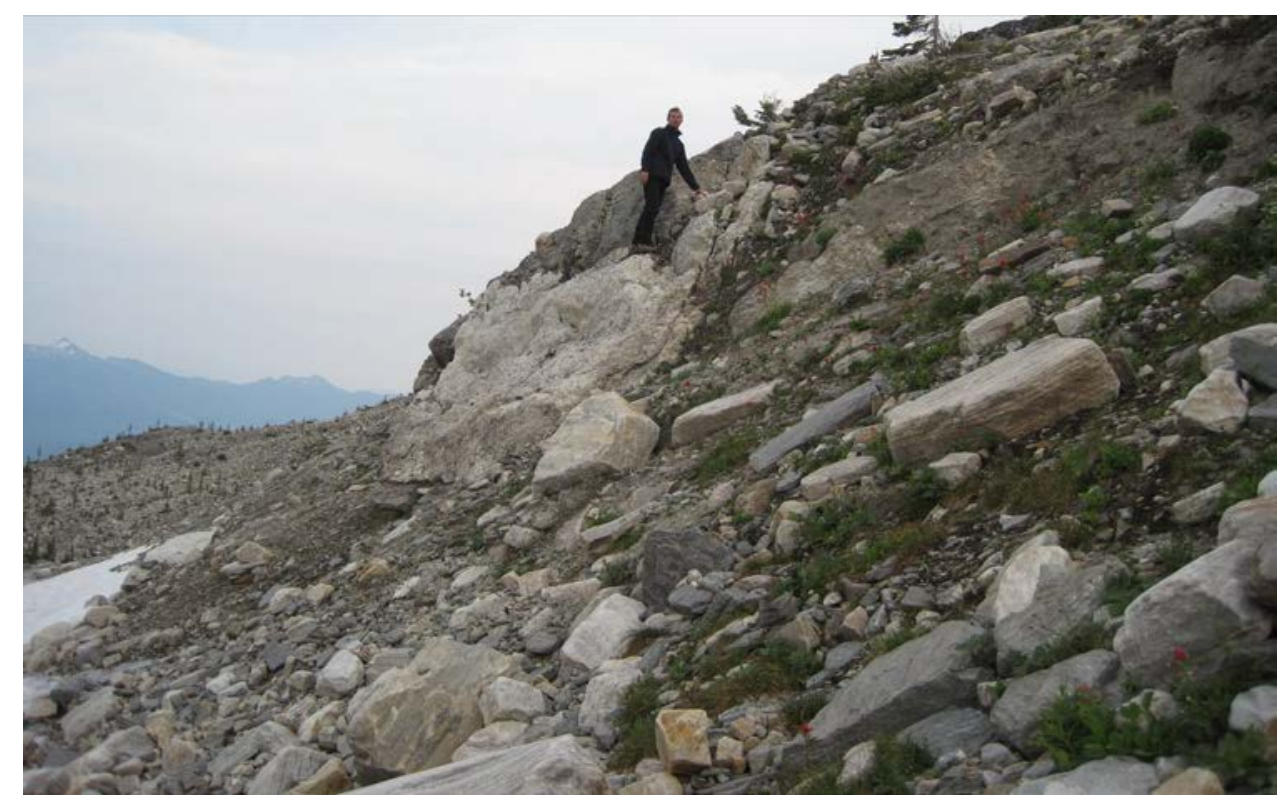

Figure 3.22: The ODD pegmatite as seen from slightly to the northwest of it and looking towards the southeast. 


\subsubsection{The PEGMA Pegmatite}

This pegmatite outcrops slightly to the south of the BITOUR pegmatite. In its southeastern and northwestern extent, it is exposed as a single pegmatite while in its middle section towards the southeast, it splits into two main branches around the northeast and southwest edges of a synformal feature in the foliation of the host rock (Fig. 3.23). To the immediate northwest of the synformal feature and before it continues to the northwest as a single dike, it splits in to a myriad of branches, some of which extend towards the end branches of the BITOUR pegmatite. It has a changing character, resembling a hybrid between a migmatite and a pegmatite to the southeast and around the synformal feature; appearing as a much more pegmatite-like body at the northwestern end of the synformal feature where it splits into numerous branches; and looking undeniably like a pegmatite at the end of its traceable northwestern extent.

The dike is of variable width but is typically less than $1 \mathrm{~m}$ wide and can be traced for 55 m. It has a strike of $\sim 310^{\circ}$ and its dip seems to be somewhat controlled by the foliation of the host rock, ranging from subvertical to shallowly dipping to the southwest.

The principal mineral assemblage for this pegmatite is quartz + feldspar + biotite + tourmaline with accessory muscovite, zircon, apatite, xenotime, and clay minerals. It is zoned, with the assemblage Qt + Fsp + Bt + Tur in a finer grained border zone and Q $t$ + Fsp + Tur in a much blockier, coarser-grained core. Tourmaline crystals in the core can reach to $10 \mathrm{~cm}$ in length. Samples for this pegmatite were gathered where it started to resemble a more pegmatitelike body and in its pegmatitic northwestern end. 

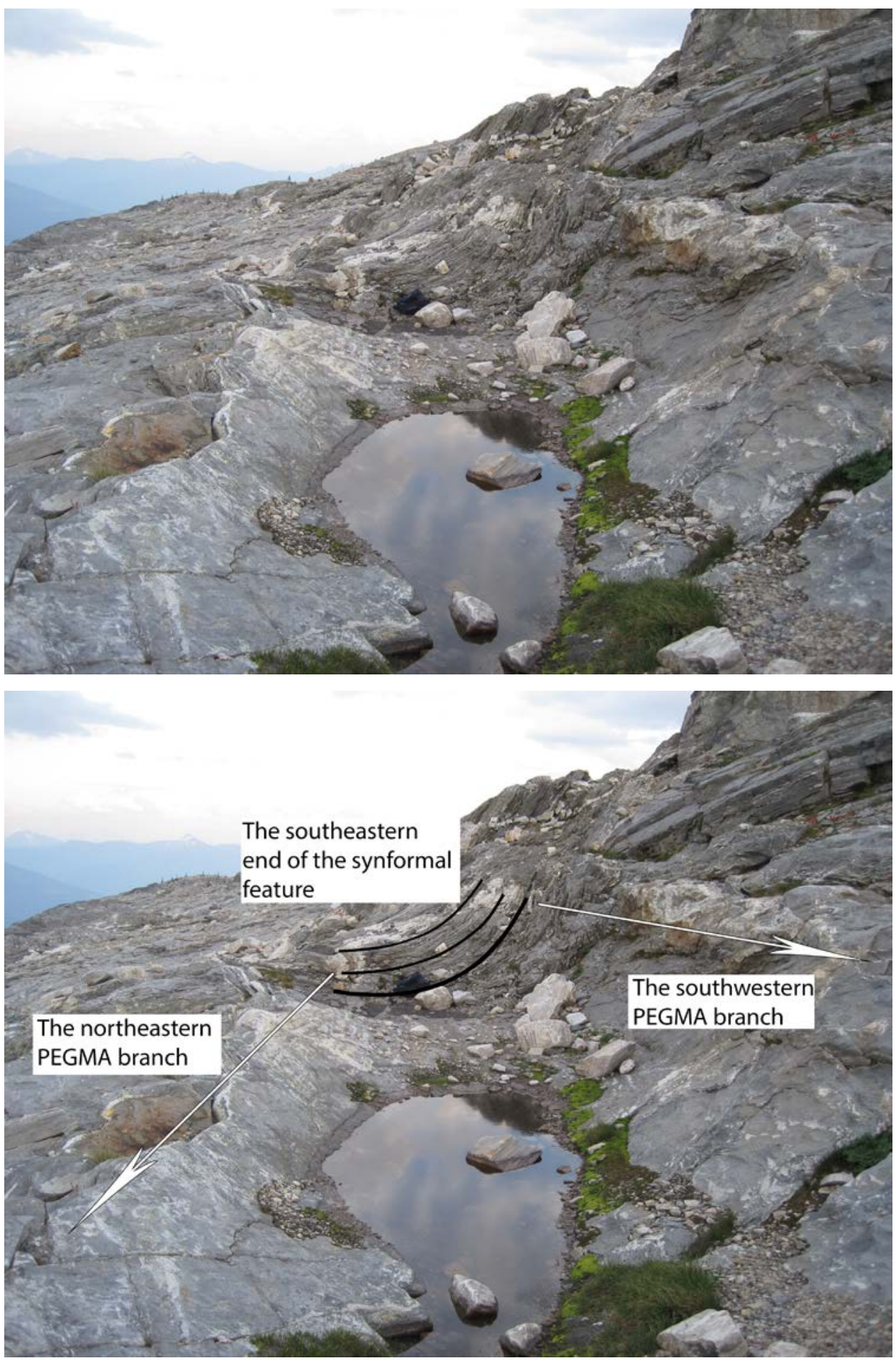

Figure 3.23: The PEGMA pegmatite as seen from a point where its two main branches join and looking to the southeast. 


\subsubsection{The POCKET Pegmatite}

This pegmatite is exposed south of the QTZ veins and to the west of LENS on a small ridge (Fig. 3.24a). It has a series of small, elongated quartz-filled miarolitic cavities in its core (Fig. 3.24b). The outcrop is short and wide, with dimensions of $\sim 4 \mathrm{~m} \times 1.5 \mathrm{~m}$ for its middle and narrowing to $15 \mathrm{~cm}$ at its ends. The dike has a strike of $\sim 345^{\circ}$ and a subvertical dip.

Its principal mineral assemblage is quartz + feldspar + biotite + tourmaline with accessory apatite, and unconfirmed iron oxides. It has several large crystals in its core that are completely altered to fine-grained micas. Given the largely intact shape of the large crystals, they may have once been apatite or cordierite.

The pegmatite is zoned with the assemblage Qt + Fsp + Bt + Tur in its border zone. The assemblage is much the same for its wall and intermediate zones being only slightly coarser grained. The core is very blocky and is composed largely of feldspar and the altered mineral and containing long and narrow, quartz-filled miarolitic cavities. 


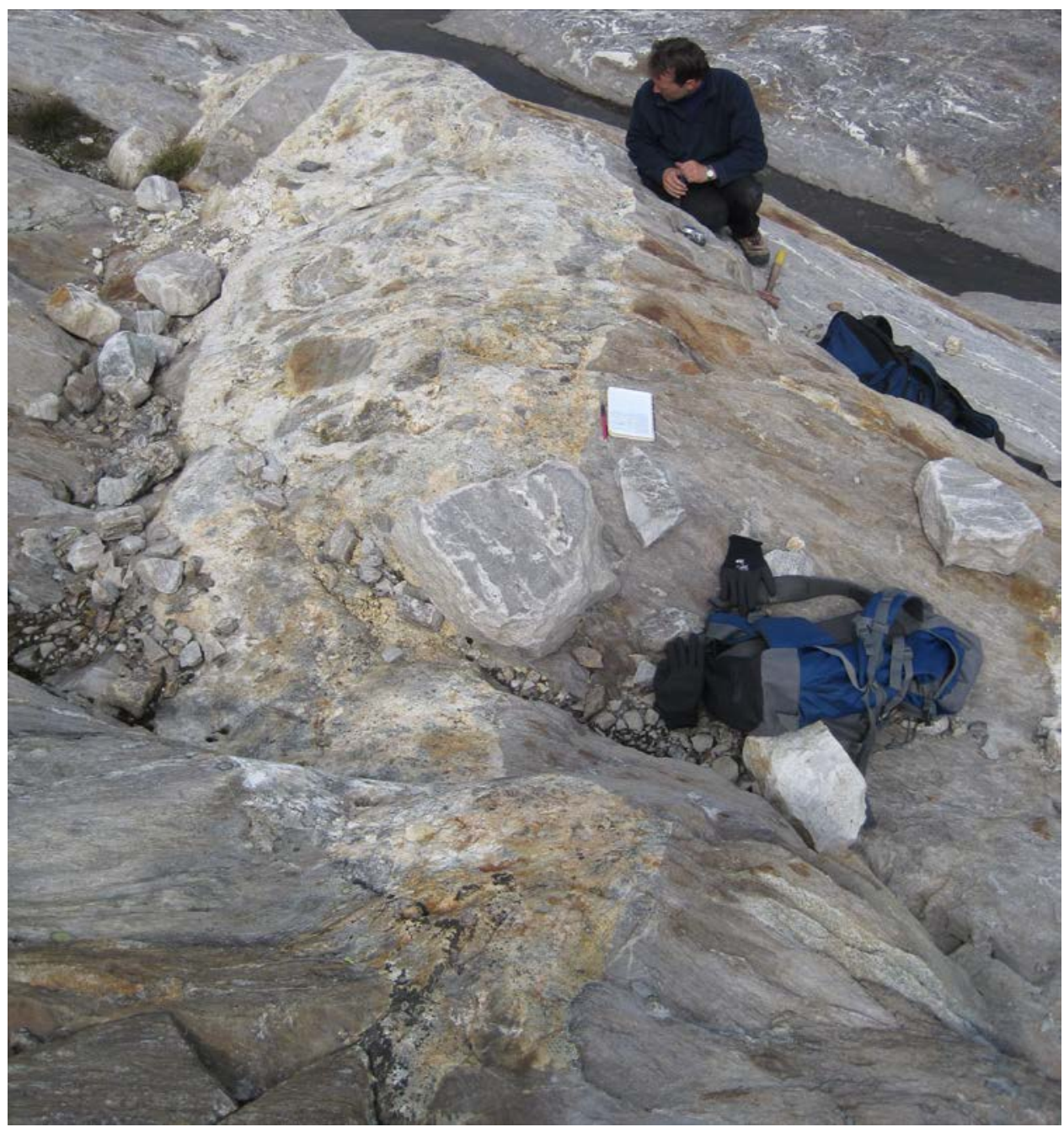

Figure 3.24a: The POCKET pegmatite as seen from its southeastern terminus looking towards the northwest.

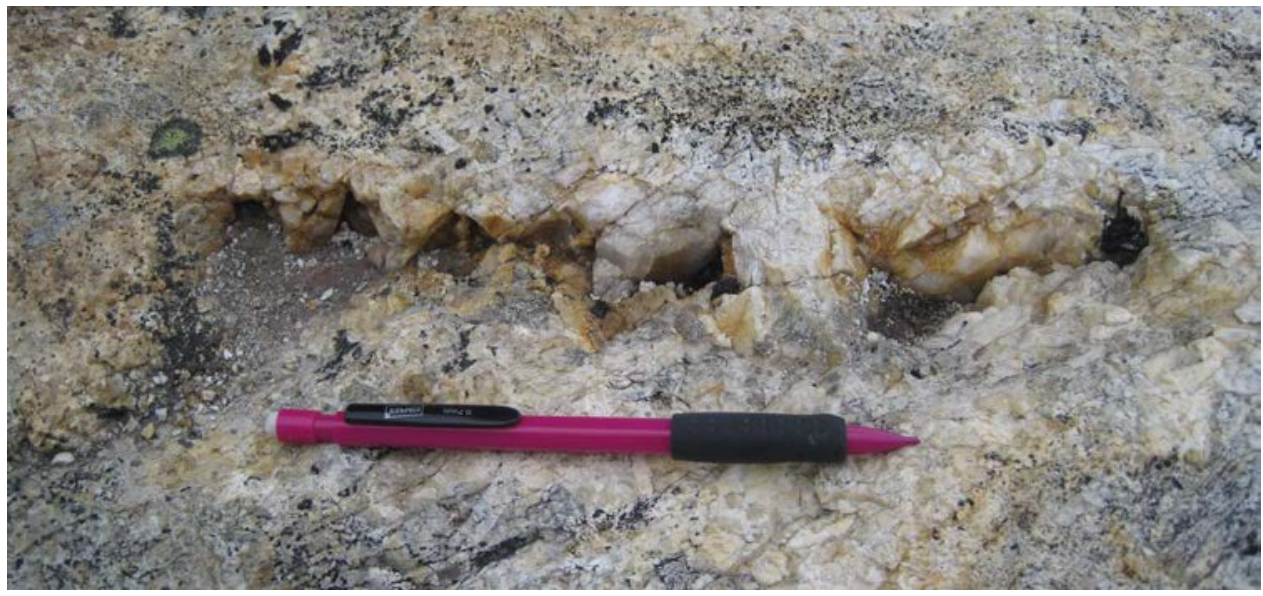

Figure 3.24b: The largest miarolitic cavity in the POCKET pegmatite. The pencil is $\sim 15 \mathrm{~cm}$ long. 


\subsubsection{The QTZ Vein}

This quartz vein is exposed on the top of a ridge slightly to the north of the LENS and POCKET pegmatites (Fig. 3.25). This vein is the western-most in a series of curving, subparallel quartz veins, including QTZ2 and QTZ3 (Fig. 3.15). It is nearly $1 \mathrm{~m}$ wide in its middle before slowly tapering to $\sim 2 \mathrm{~cm}$ thick at its ends. The vein is $\sim 29 \mathrm{~m}$ long, has as strike of $\sim 330^{\circ}$ along its straightest section, and has a subvertical dip. It is composed almost entirely of quartz and contains rare feldspar crystals where it is widest. Its northwestern-most end almost appears to be aplitic. No samples were taken from this vein.

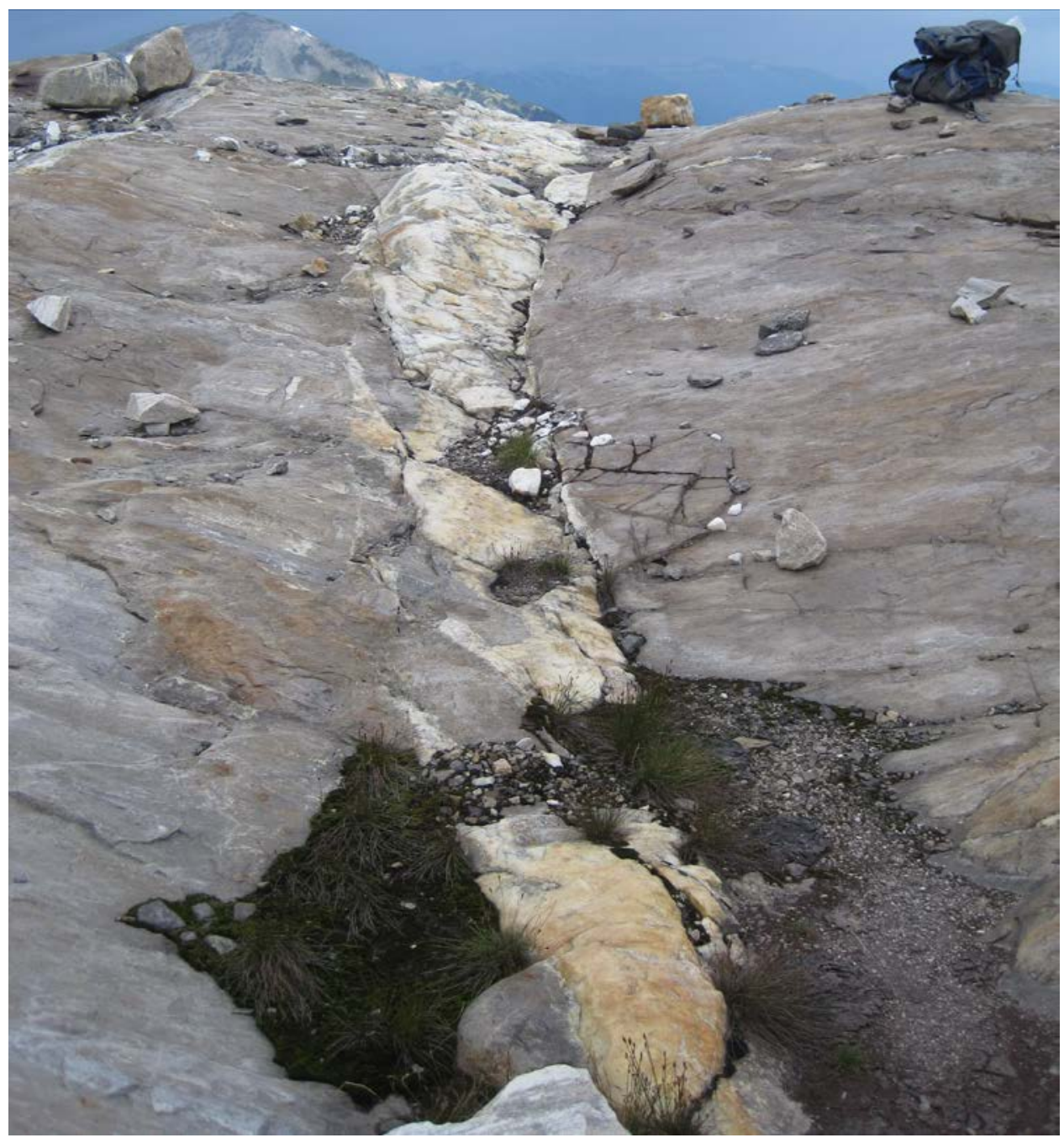

Figure 3.25: The QTZ vein as seen from between its southeastern end point and its mid-point and looking towards the northwest. 


\subsubsection{The QTZ2 Vein}

This vein is the center vein of a series of curving, subparallel quartz veins which include QTZ and QTZ3 (Fig. 3.15 \& Fig. 3.26). It outcrops on the top of a ridge, slightly to the north of the LENS and POCKET pegmatites. It is $\sim 60 \mathrm{~cm}$ wide in its middle and slowly tapers to a few centimeters wide at its ends. It extends for approximately $22 \mathrm{~m}$, has a strike of $\sim 310^{\circ}$, and a subvertical dip. It is composed entirely of quartz; where the vein is widest, it has a rosy hue. No samples were taken from this vein.

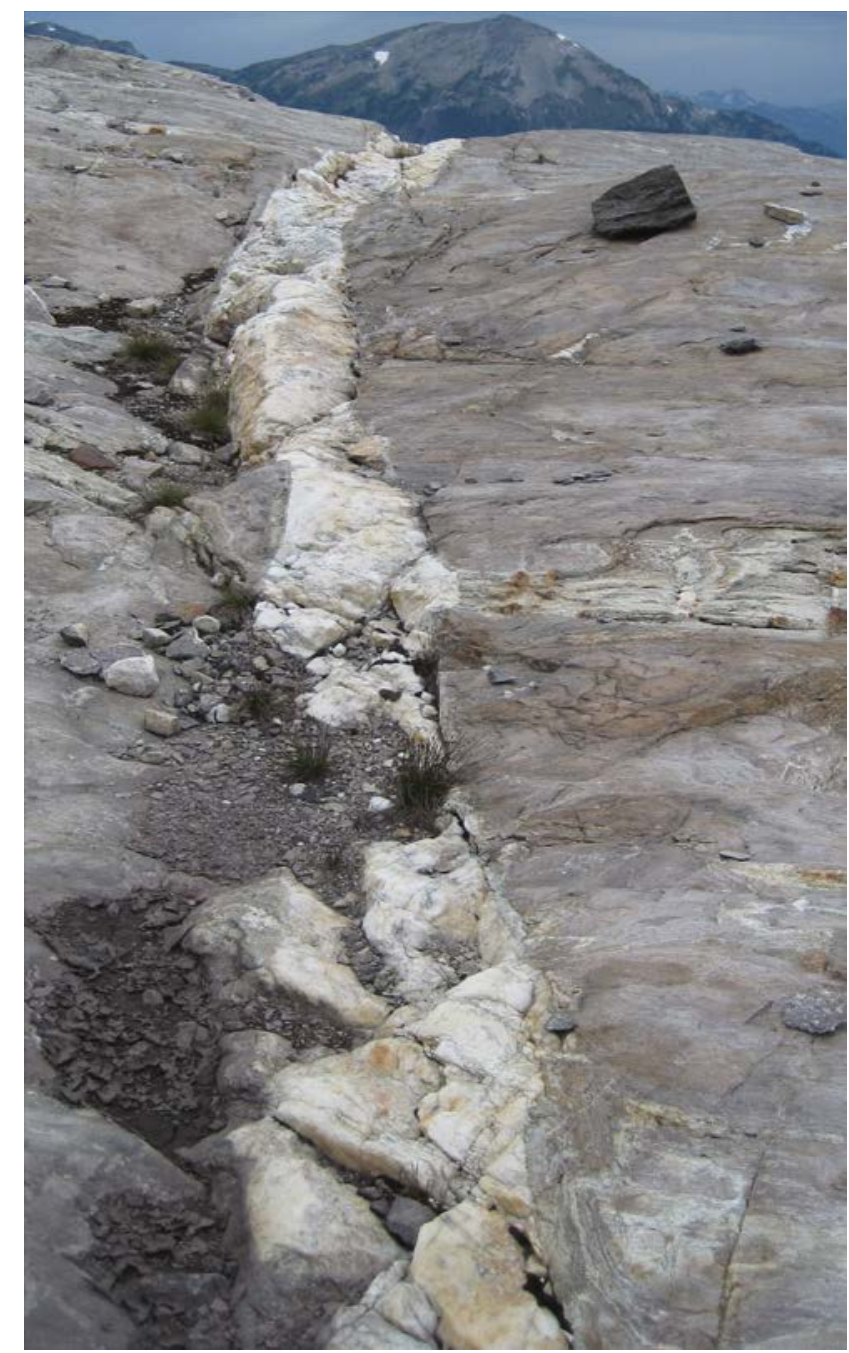

Figure 3.26: The QTZ2 vein as seen from near its southeastern end and looking towards the northwest. 


\subsubsection{The QTZ3 Vein}

This vein is the eastern most of series of curving, subparallel quartz veins which also includes QTZ and QTZ2 (Fig. 3.15 \& Fig. 3.27a). It is exposed within the short cliff face of a ridge as well as outcropping on top of the ridge. Unlike the other veins, it appears to have a relatively complex relationship with nearby aplites, either intersecting with them or perhaps being related to them. In its center on top of the ridge, the vein is nearly $90 \mathrm{~cm}$ wide and takes on an aplite-like texture. To the southeast from this point, the vein slowly tapers down to only a few centimeters wide. To the northwest from the center point, the quartz-rich aplite-like vein can be traced over the ridge and along the cliff face. Along the cliff face, it bears much greater resemblance to an aplite than a quartz vein (Fig. 3.27b). The aplite can be traced along the cliff face to the east and the west; it nearly intersects the QTZ vein in the west.

The vein and associated aplites can be traced for $\sim 55 \mathrm{~m}$. Its strike along the ridge top where it is straightest is $\sim 310^{\circ}$ and has a subvertical dip. Along the cliff face, the vein has strike of $\sim 80^{\circ}$. Its dip along the cliff face was not discerned. The vein is primarily composed of quartz which takes on a rosy hue where the vein is widest. The aplitic portions have the composition of quartz + feldspar + biotite; some of the biotite is altering to chlorite. No samples were taken from this vein. 


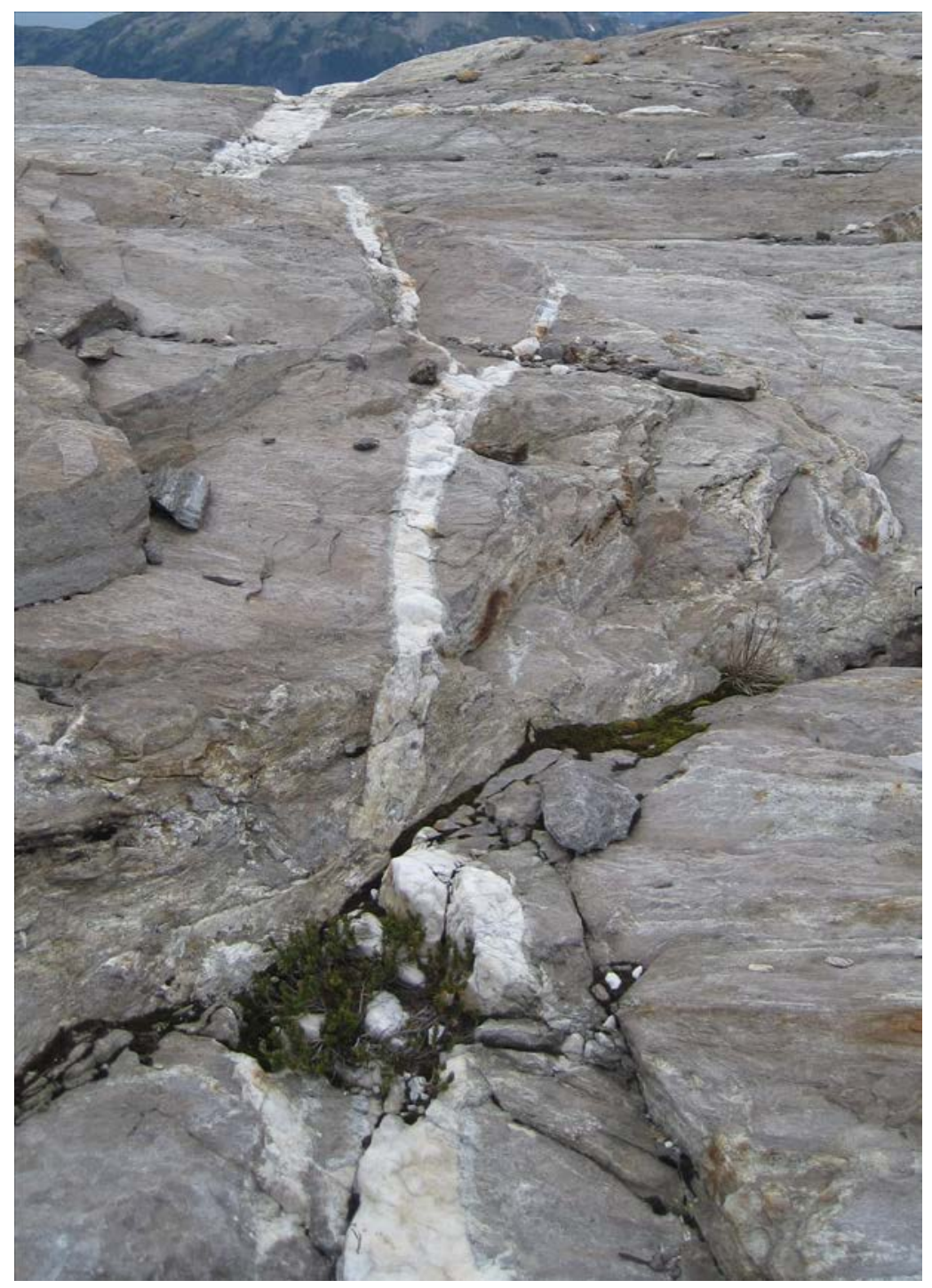

Figure 3.27a: The QTZ3 vein as seen near its southeastern end and looking towards the northwest. 


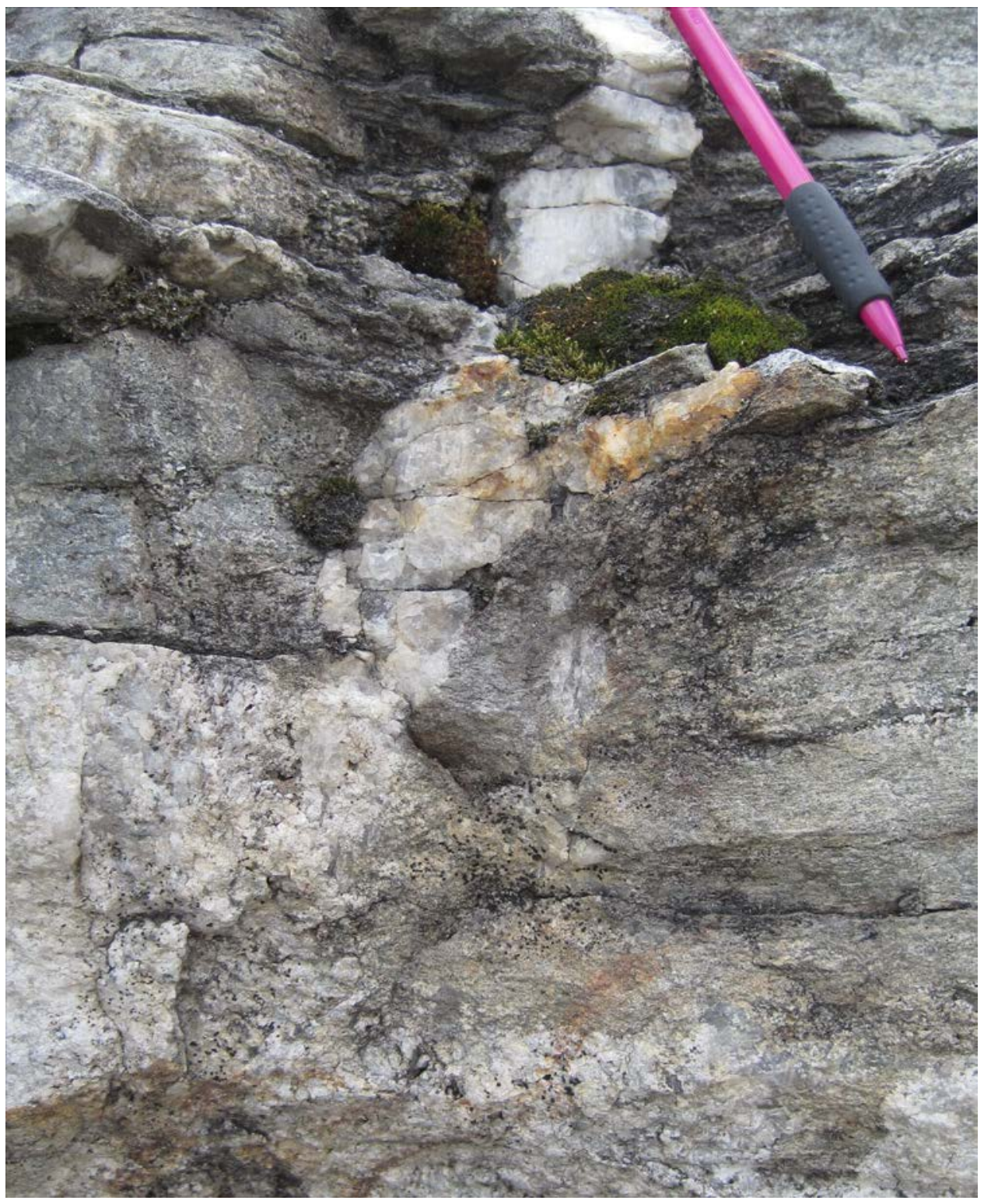

Figure 3.27b: The intersection between a quartz vein (top of the image; oriented vertically) and an aplite (bottom of the image; oriented horizontally) in the QTZ3 vein. 


\subsubsection{The SCABBY Pegmatite}

This pegmatite is exposed near the northwestern end of the LONG pegmatite (Fig. 3.28). When viewed from standing high on the slope above it, the pegmatite appears to be of substantial size. Upon closer inspection, the dike is mostly eroded away. It is nearly $6 \mathrm{~cm}$ thick in patches near its northwestern extent. It can be traced for $\sim 143 \mathrm{~m}$ along a strike of $\sim 295^{\circ}$. Its dip is nearly always perpendicular to the foliation of the host rock and ranges from subhorizontal to moderately dipping to the southwest. No samples were taken from this pegmatite.

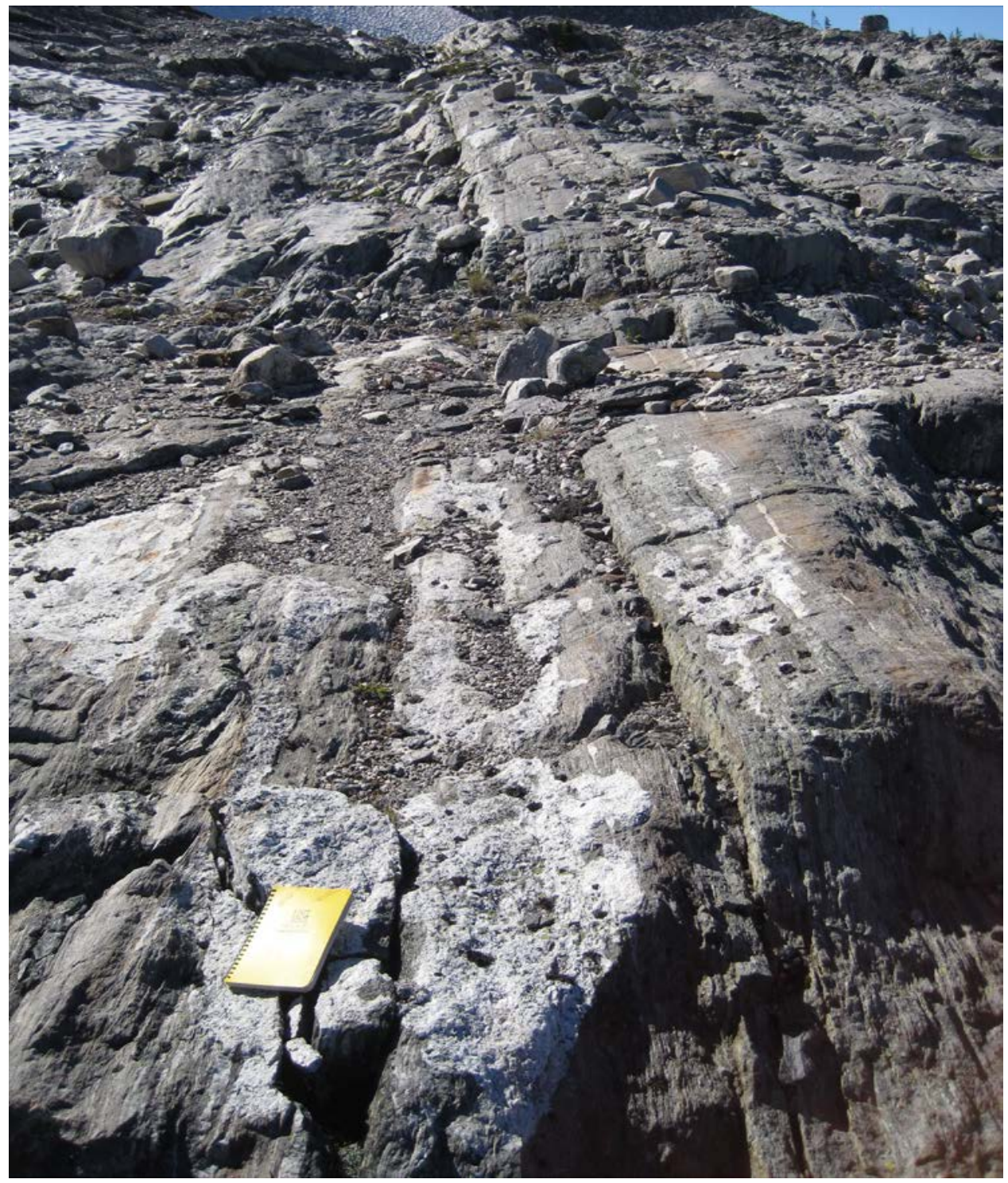

Figure 3.28: The SCABBY pegmatite as seen from its southeastern end and looking to the northwest. 


\subsubsection{The SIMPLE Pegmatite}

This pegmatite outcrops to the east of the LI2 pegmatite and to the immediate west of a small creek. It intersects with the STUBBY pegmatite near its southeastern terminus (Fig. 3.29). It is coarser grained in its ends but has a primarily aplitic middle section. The pegmatite reaches nearly $2 \mathrm{~m}$ wide and can be traced for $\sim 64 \mathrm{~m}$. Its northwestern end tapers considerably and spreads into numerous smaller veins while its southwestern end is hidden in the creek, 5-10 meters to the southeast from its intersection with STUBBY. SIMPLE has a strike of $\sim 355^{\circ}$ and a subvertical to vertical dip.

Other than textural changes near its ends, the dike did not display any obvious zoning. Its principal mineral assemblage is quartz + feldspar + tourmaline + muscovite + biotite and it has trace monazite. Two tourmaline samples were taken, one from the aplite and one from a tiny pegmatitic vein in the aplite.

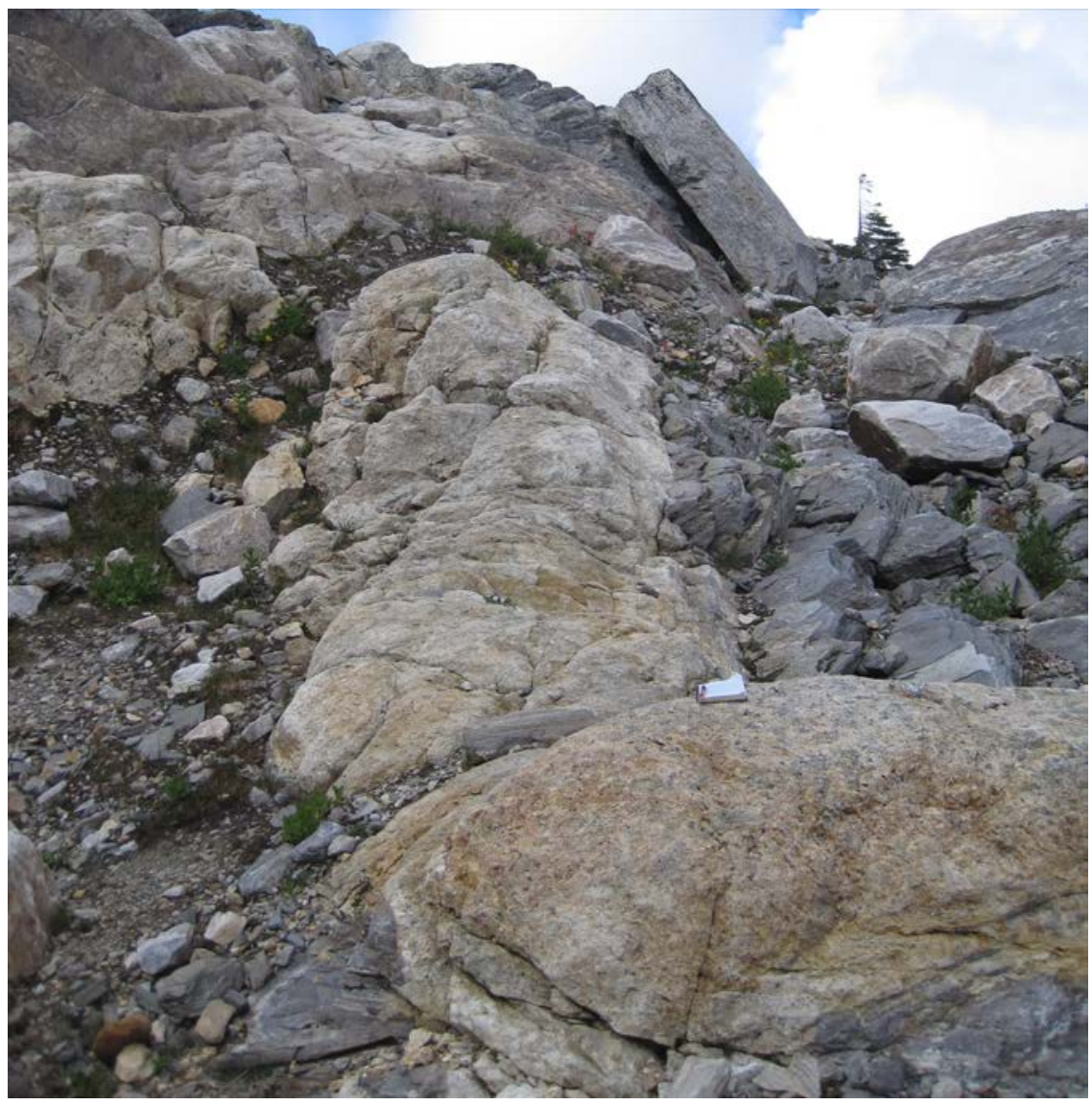

Figure 3.29: The SIMPLE pegmatite as seen from its southeastern end and looking to the northwest. The STUBBY pegmatite is in the foreground with the notebook on top of it. 


\subsubsection{The SIMPLE2 Pegmatite}

This is a small pegmatite exposed on a ridge (Fig. 3.30) and is located between the SIMPLE and SIMPLE3 pegmatites. Like the SIMPLE dike, its ends are coarser grained than its more aplitic middle. The aplite section in its middle is $\sim 1 \mathrm{~m}$ thick. It can be trace for $\sim 5 \mathrm{~m}$, with a strike of $\sim 65^{\circ}$ and $\sim 40^{\circ}$ dip to the southeast. Its principal mineral assemblage is quartz + feldspar + biotite with trace, fine grained tourmaline. Some of the biotite is altered to chlorite. No zoning was observed in this pegmatite.

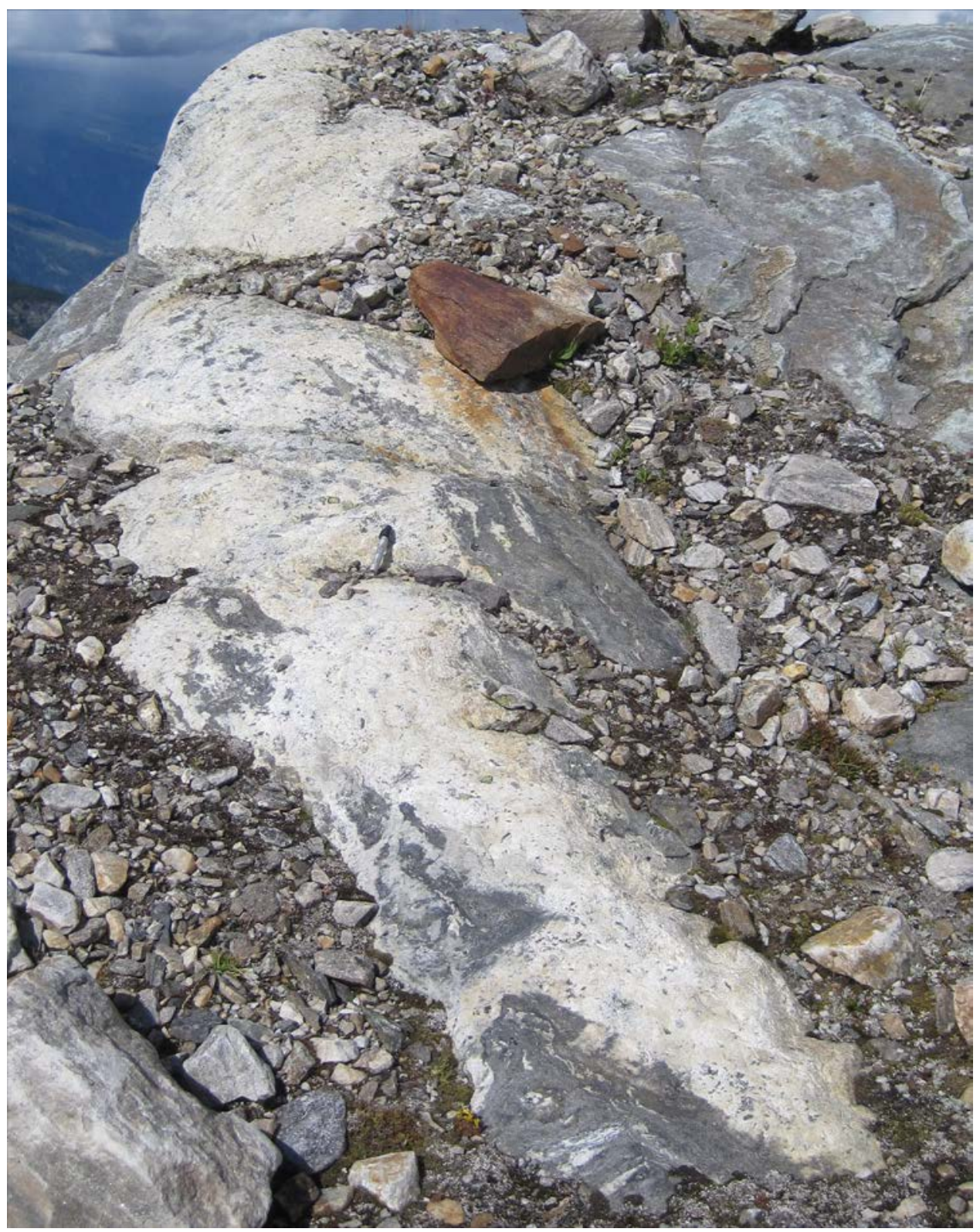

Figure 3.30: The SIMPLE2 pegmatite as seen from the south and looking to the north. 


\subsubsection{The SIMPLE3 Pegmatite}

This pegmatite is exposed on top of a small ridge between the SIMPLE2 and SIMPLE4 pegmatites (Fig. 3.31). It is a narrow dike, not more than $20 \mathrm{~cm}$ wide and can be traced for $\sim 11$ $\mathrm{m}$. It has as strike of $\sim 340^{\circ}$ and a shallow dip of $\sim 15^{\circ}$ to the northeast—always subparallel to the foliation of the host rock. It has a principal mineral assemblage of quartz + feldspar + tourmaline. No zoning was observed in this dike.

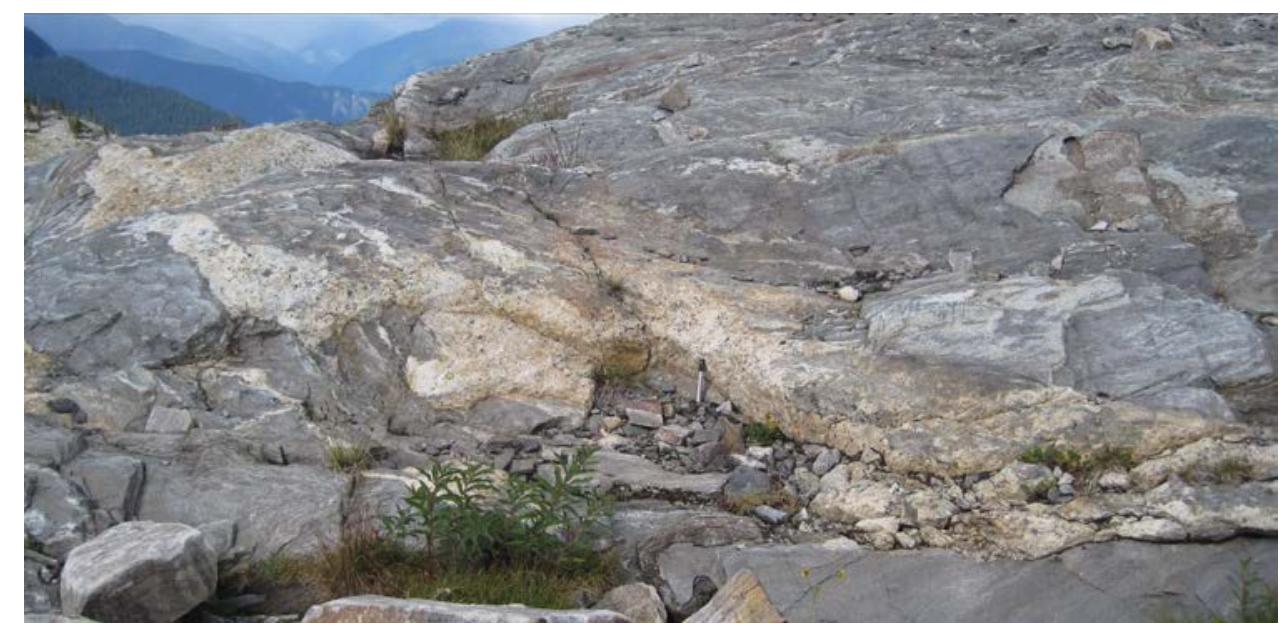

Figure 3.31: The SIMPLE3 pegmatite as seen from the south and looking to the north. 


\subsubsection{The SIMPLE4 Pegmatite}

This pegmatite is exposed on a ridge between the SIMPLE3 and SIMPLE5 pegmatites (Fig. 3.32). It grades from pegmatitic texture at its southeastern end to aplitic in texture at its northwestern end. Its width varies from $20 \mathrm{~cm}$ to nearly $1 \mathrm{~m}$ and can be traced for nearly $22 \mathrm{~m}$. It has a strike of $\sim 330^{\circ}$ and is very steeply dipping to the southeast. It has a principal mineral assemblage of quartz + feldspar + tourmaline. Other than textural changes, no zoning was observed in this dike.

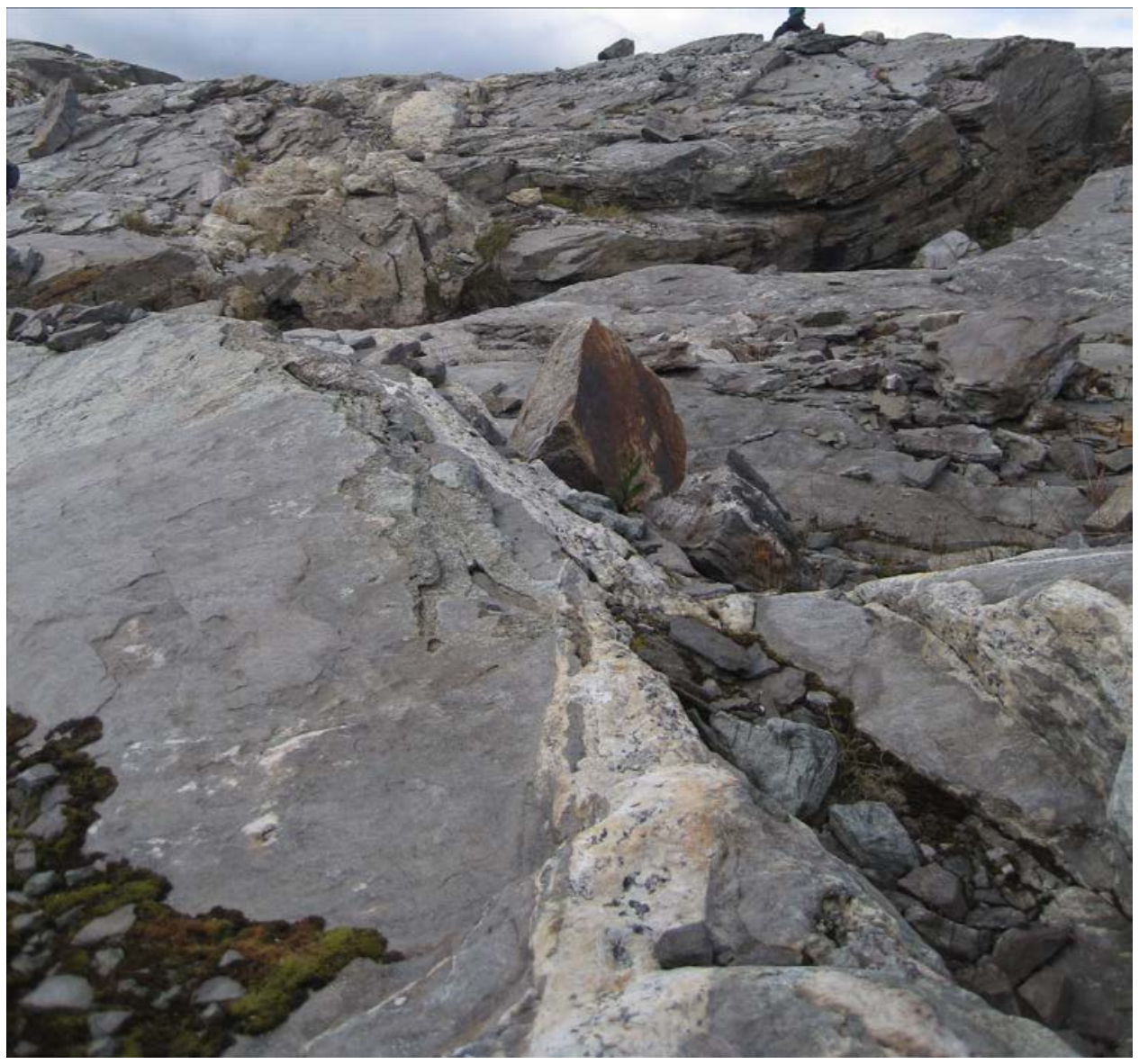

Figure 3.32: The SIMPLE4 pegmatite as seen from near its southeastern end and looking to the northwest. 


\subsubsection{The SIMPLE5 Pegmatite}

This pegmatite is exposed on a ridge and is located to the east of the SIMPLE4 pegamtite. It has two distinct parts: a section that is nearly $7 \mathrm{~m}$ wide incorporating much of the host rock with a strike of $\sim 320^{\circ}$ (Fig. 3.33a) and a section that has a width that is typically $20 \mathrm{~cm}$ but can be up to $50 \mathrm{~cm}$ wide, striking $275^{\circ}$ (Fig. 3.33b). Both sections have a subvertical dip and its total length is $\sim 70 \mathrm{~m}$. The texture for the dike is aplitic with a few porphyritic feldspar crystals. Its principal mineral assemblage is quartz + feldspar + tourmaline with unconfirmed trace tantalite.

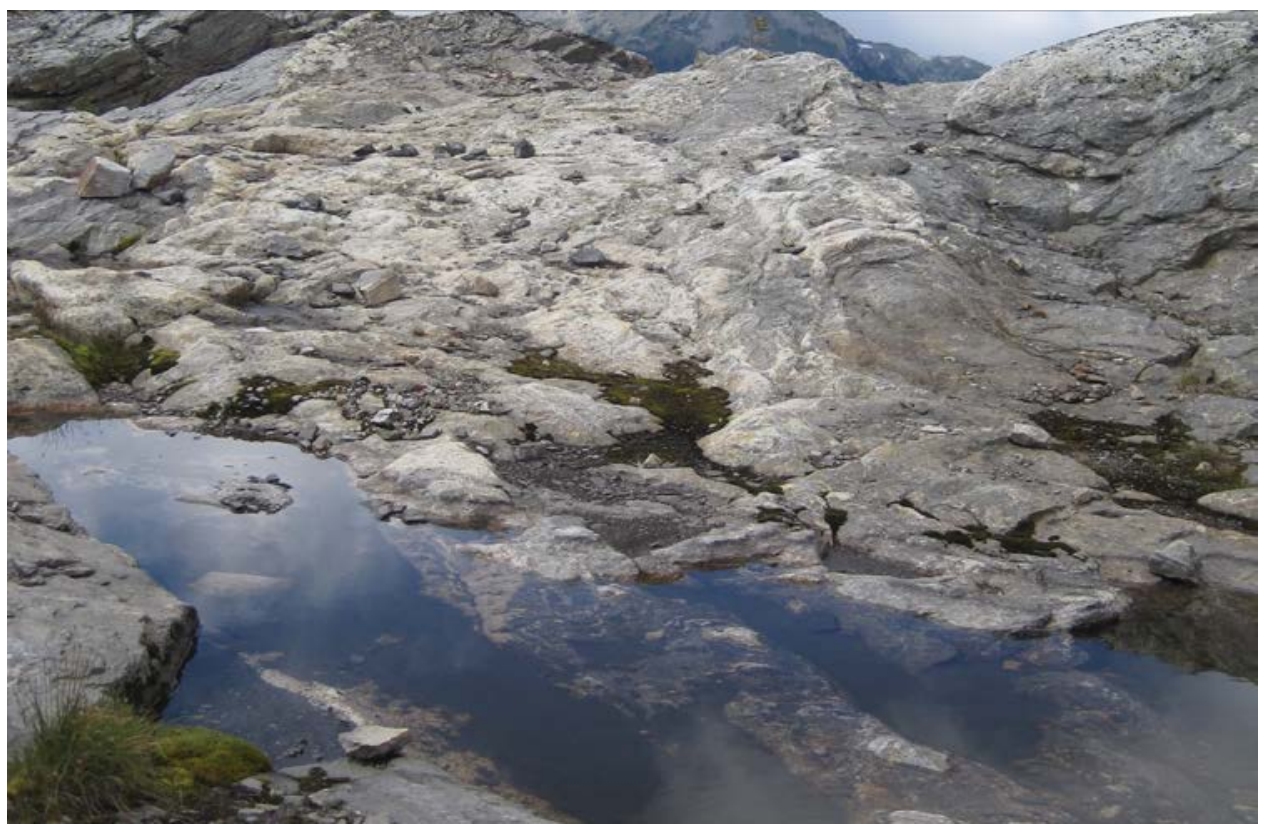

Figure 3.33a: The SIMPLE5 pegmatite where it strikes $\sim 320^{\circ}$. The view is to the northwest. 


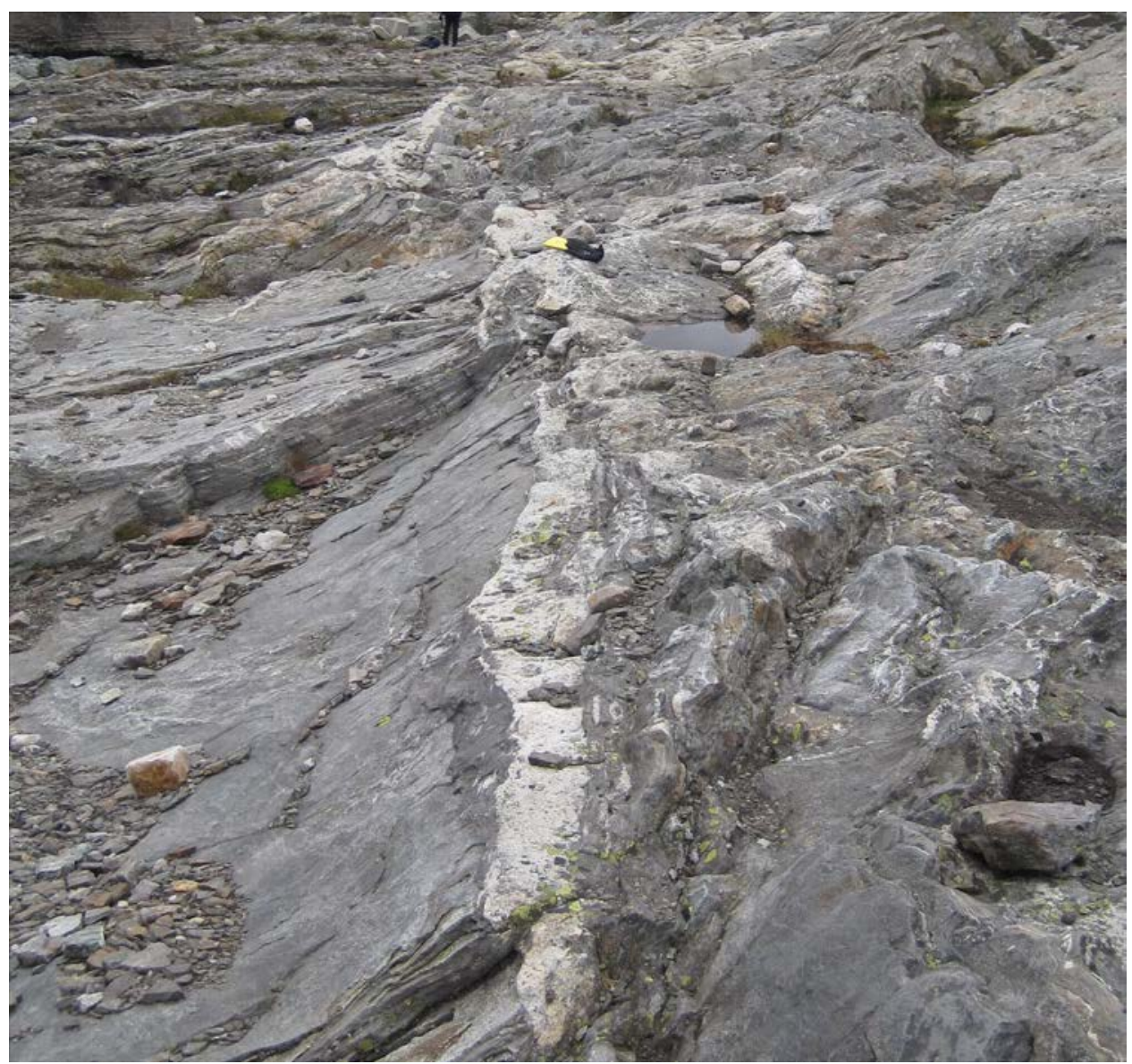

Figure 3.33b: The SIMPLE5 pegmatite where it strikes $\sim 275^{\circ}$. The view is to the west. 


\subsubsection{The SIMPLE6 Pegmatite}

This pegmatite is exposed on a steep slope near the center of the study area. Its southeastern end is exposed at the top of the slope near the FEED pegmatite (Fig. 3.34a) and can be traced for $~ 94 \mathrm{~m}$ to its northwestern end near the LI pegmatite at the bottom of the slope (Fig. 3.34b). It has three, short branches that extend to the southeast from the main body of the pegmatite. It is typically about $40 \mathrm{~cm}$ wide, except where the branches join the main pegmatite. In those places, the width tends to be $\sim 1 \mathrm{~m}$ wide. The short branches are up to $3 \mathrm{~m}$ wide and tend to incorporate many xenoliths. In general, it has a strike of $\sim 335^{\circ}$ and a subvertical dip. The principal mineral assemblage for the dike is quartz + feldspar with accessory tourmaline. The dike is slightly zoned texturally with blocky feldspar and quartz where the branches join the main dike.

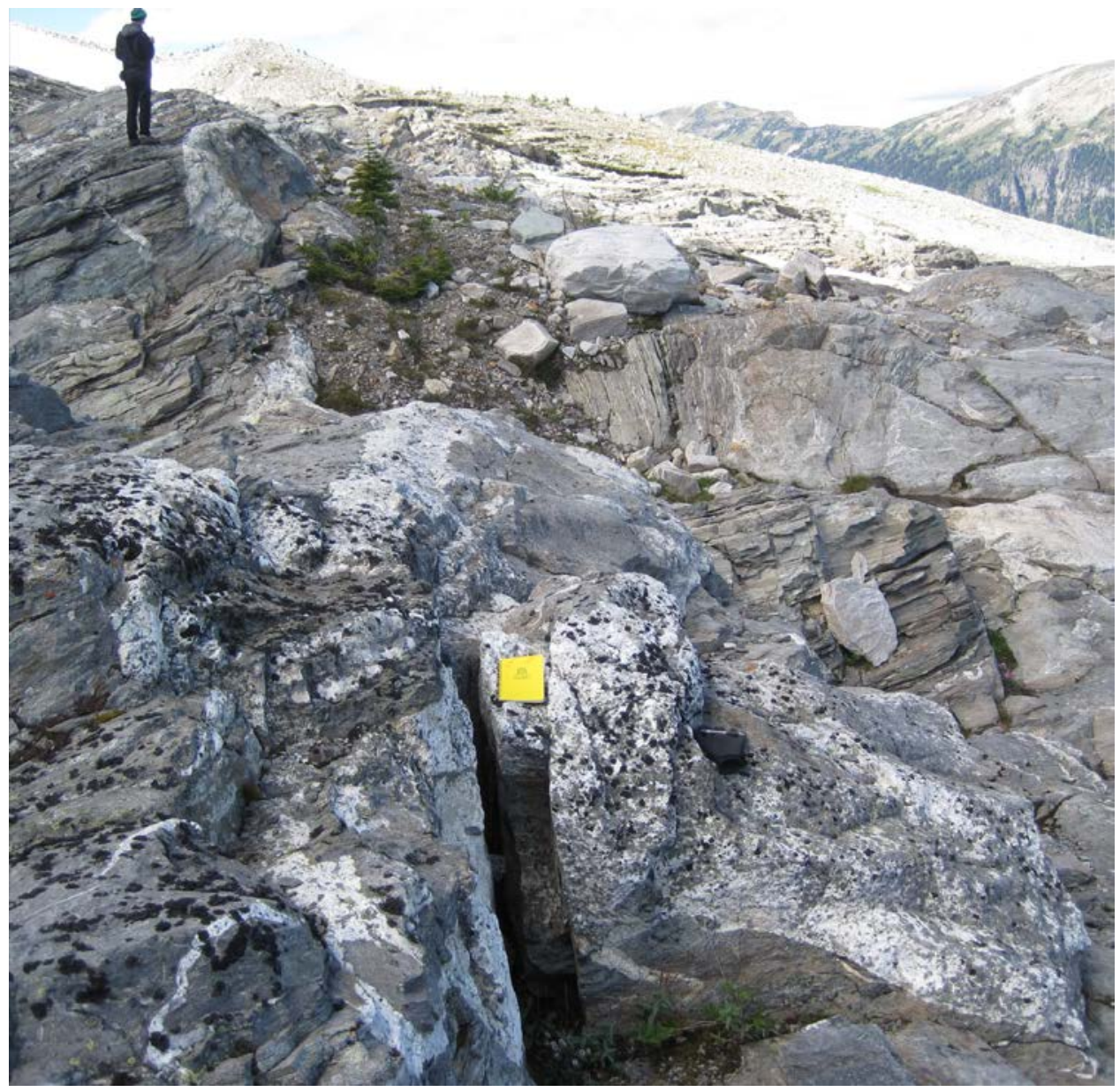

Figure 3.34a: The SIMPLE6 pegmatite as seen from the end of one of its southeastern branches at the top of the slope. 


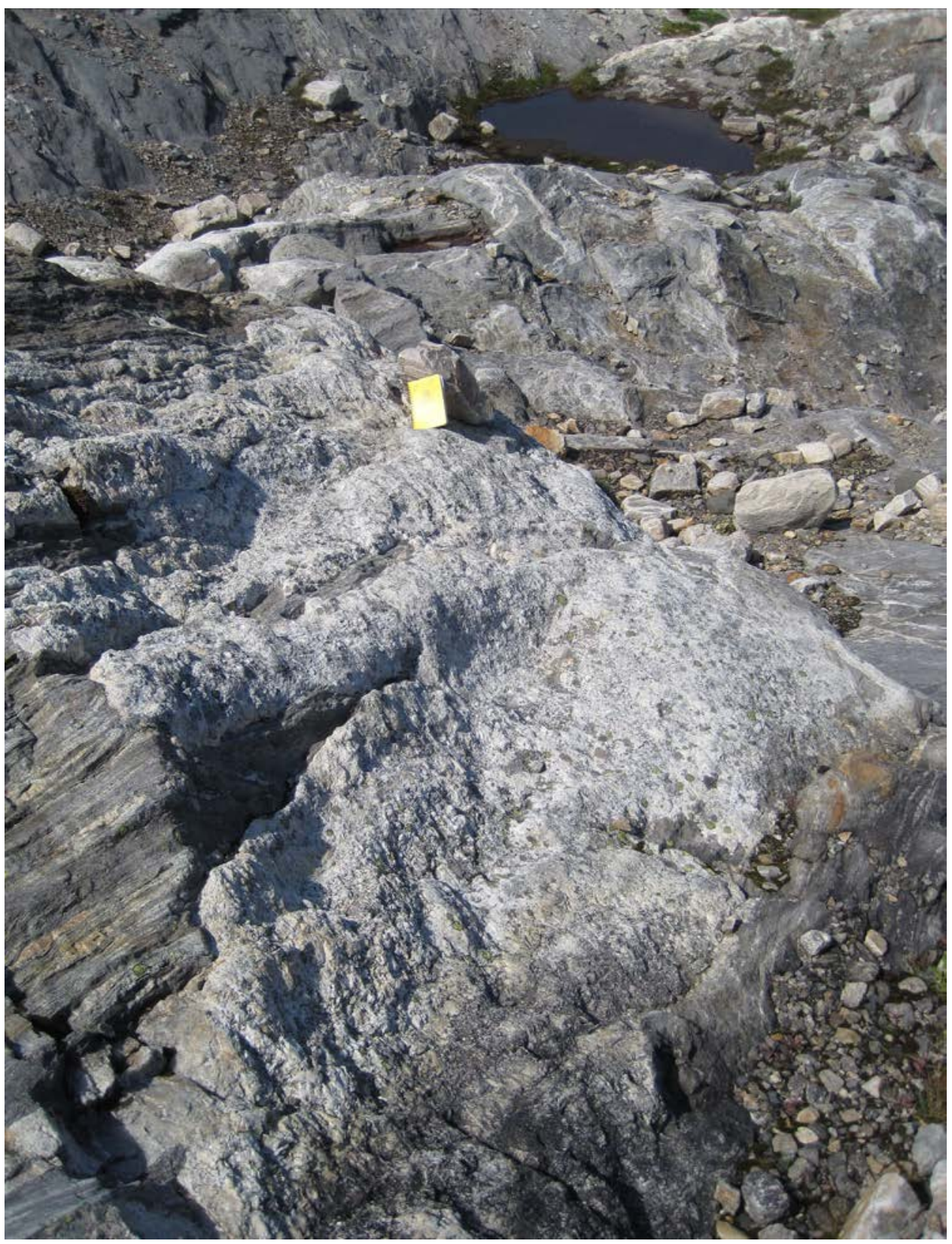

Figure 3.34b: The SIMPLE6 pegmatite as seen from the southeastern end of the branch at the bottom of the slope. 


\subsubsection{The SIMPLE7 Pegmatite}

This pegmatite is exposed on a ridge between the SIMPLE6 pegmatite and the SIMPLE9 pegmatite (Fig. 3.35a). The pegmatite is roughly $30 \mathrm{~cm}$ wide and $\sim 11 \mathrm{~m}$ long with a strike of approximately $350^{\circ}$ and subvertical dip. It terminates rather abruptly on its northern end due to erosion (Fig. 3.35b). The principal mineral assemblage composing this pegmatite is quartz + feldspar + biotite with accessory tourmaline. No zoning was observed in this pegmatite.

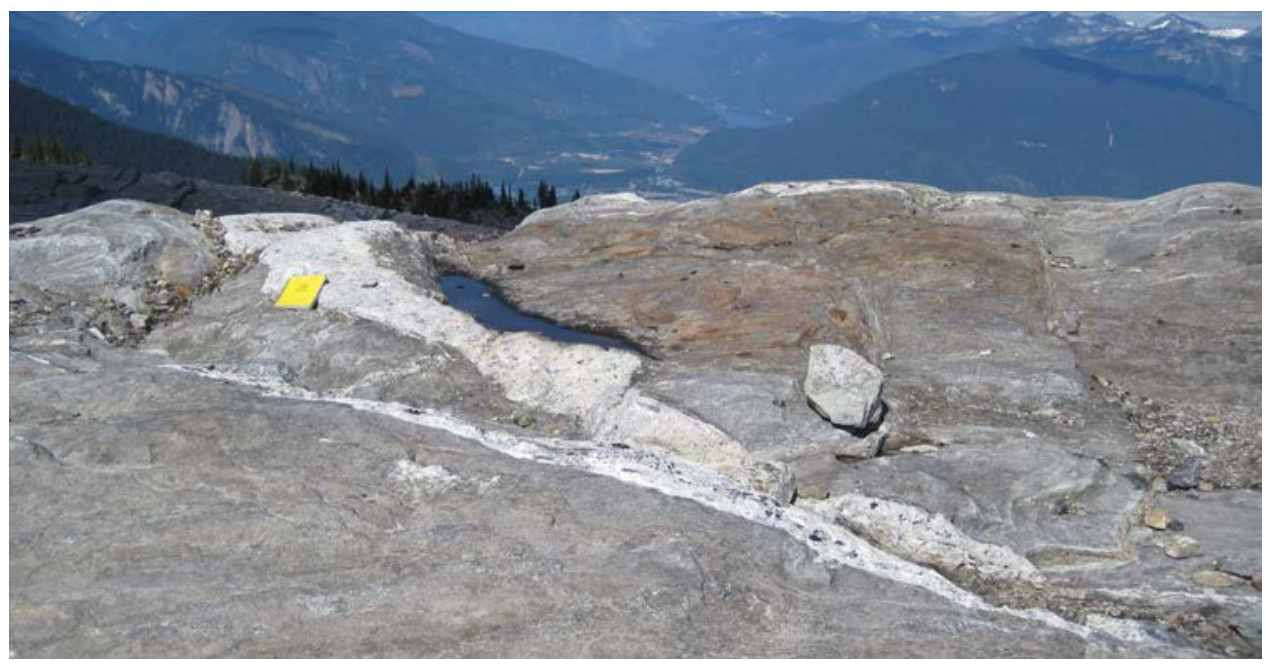

Figure 3.35a: The southern end of the SIMPLE7 pegmatite at the ridge top looking to the north.

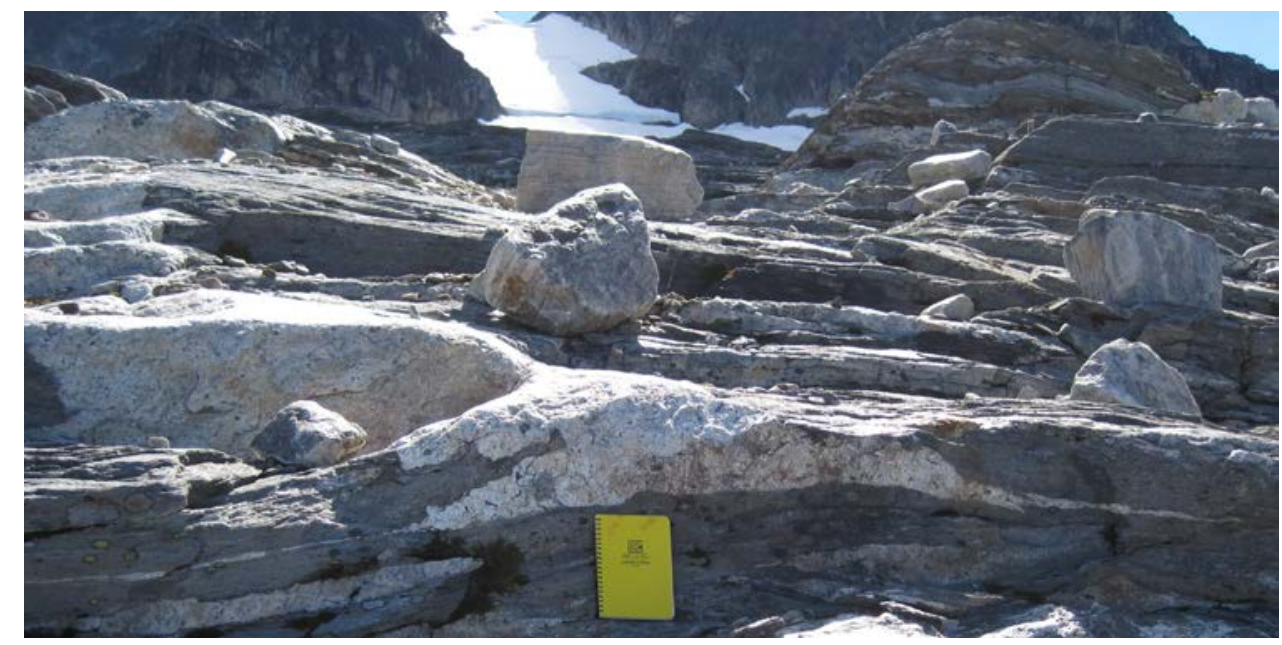

Figure 3.35b: The northern end of the SIMPLE7 pegmatite underneath the ridge, looking to the south. 


\subsubsection{The SIMPLE8 Pegmatite}

This pegmatite is exposed in the southeastern part of the study area slightly to the south of the CORD pegmatite. It is nearly $75 \mathrm{~cm}$ wide in its center and tapers to a few centimeters wide at its end (Fig. 3.36). The dike is $\sim 11 \mathrm{~m}$ long with a strike of approximately $275^{\circ}$ and a subvertical dip. It has a basic mineral assemblage of quartz + feldspar with minor tourmaline. Zoning was not observed and no samples were taken.

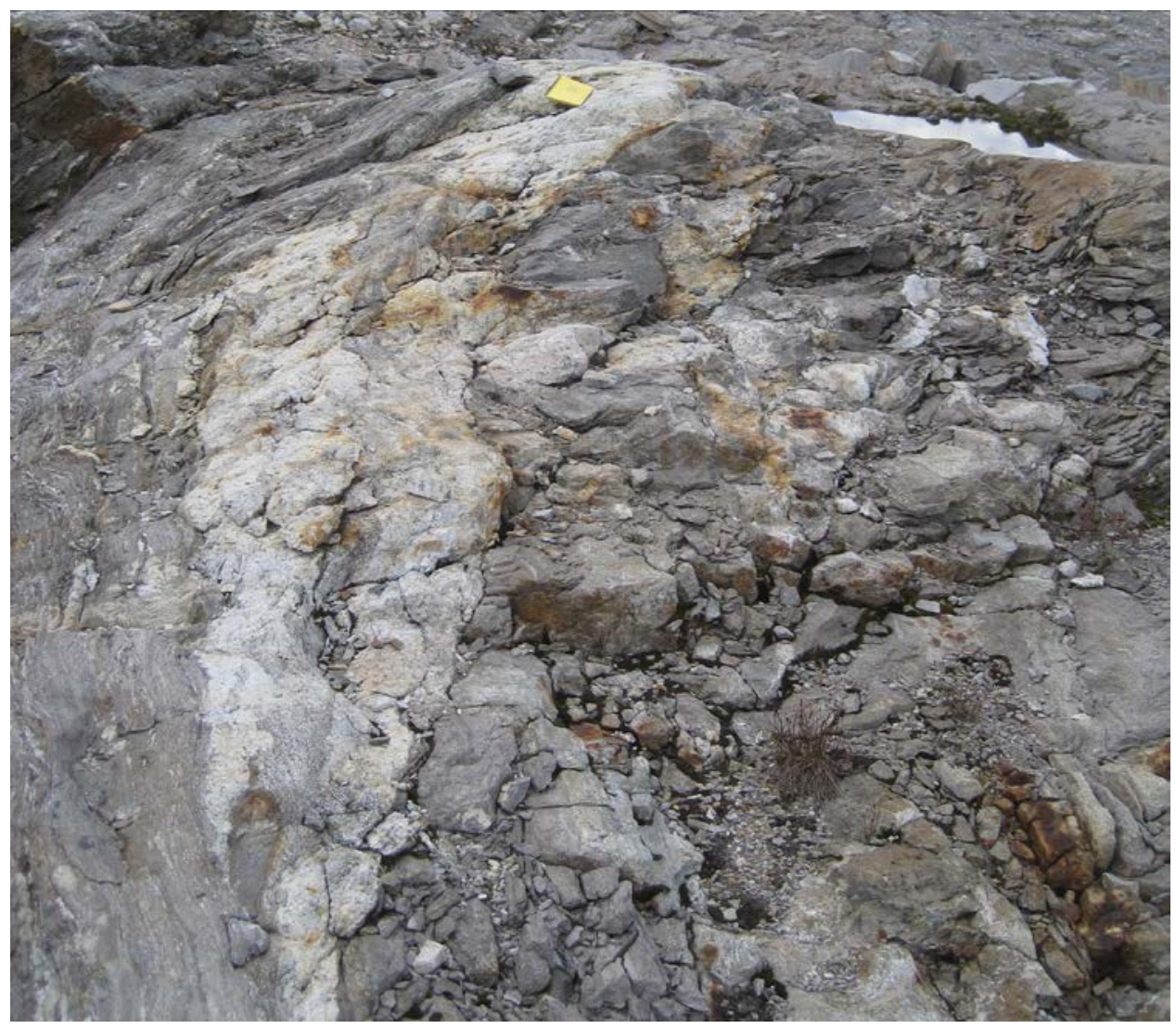

Figure 3.36: The SIMPLE8 pegmatite as seen from its eastern end and looking to the west.

\subsubsection{The SIMPLE9 Pegmatite}

This pegmatite outcrops near the center of the study area and can be traced to the northwest for 252 meters before being covered by the lateral moraine marking the western boundary of the study area. The outcrop is not entirely continuous along its length, being occasionally interrupted by snowfields and erosion. The dike is variable in width, generally between $50 \mathrm{~cm}$ and $1 \mathrm{~m}$ wide; it reaches nearly $7.5 \mathrm{~m}$ wide where it outcrops in the southeast (Fig. 3.37a). The dike has one branch near its southeastern end that can be traced along a low cliff (Fig. 3.37b). 
The overall strike of the dike is $\sim 315^{\circ}$ and it generally has a subvertical dip; away from the main outcrop in the southeast, the pegmatite appears to be very steeply dipping to the northeast.

Its principal mineral assemblage is quartz + feldspar + tourmaline with major accessory minerals of biotite, muscovite, partially altered cordierite (Fig. 3.37c), beryl (Fig. 3.37d), and garnet. Minor accessory mineral phases include muscovite; biotite; chlorite after biotite; muscovite, beryl, smectite group and kaolinite group clays, and iron oxides as alteration products from cordierite; bertrandite as an alteration product in primary beryl; monazite; xenotime; and zircon. Rutile is an uncofirmed accessory mineral.

The dike is subtly zoned; the core of the dike is blocky and contains all mineral types while the border zone primarily consists of feldspars, quartz, and tourmaline with trace monazite, xenotime, and zircon. The pegmatite also has patchy occurrences of aplite primarily composed of feldspars and quartz with minor biotite, tourmaline, and trace garnet.

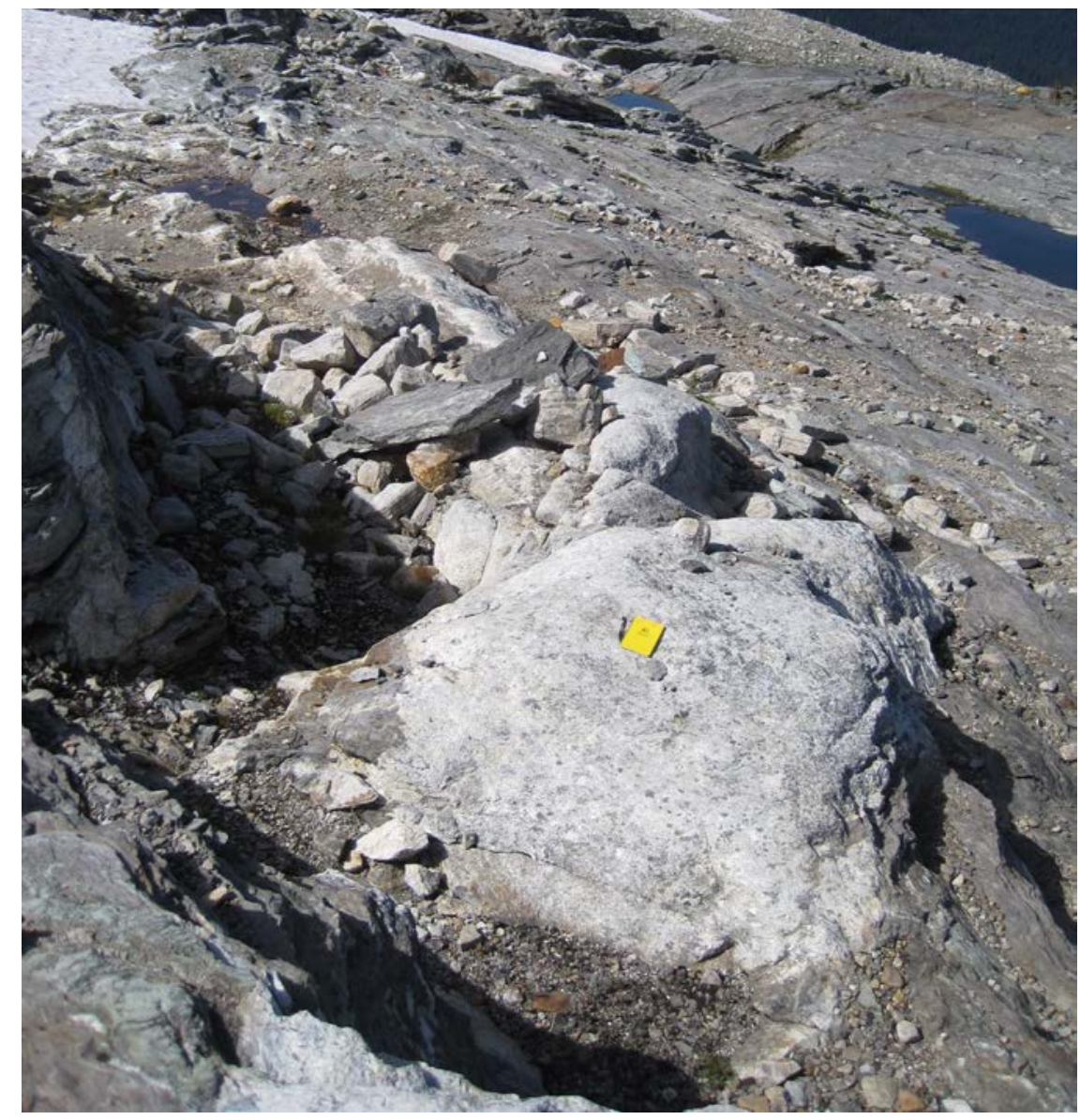

Figure 3.37a: The main body of the SIMPLE9 pegmatite as seen from its southeastern end and looking towards the northwest. 


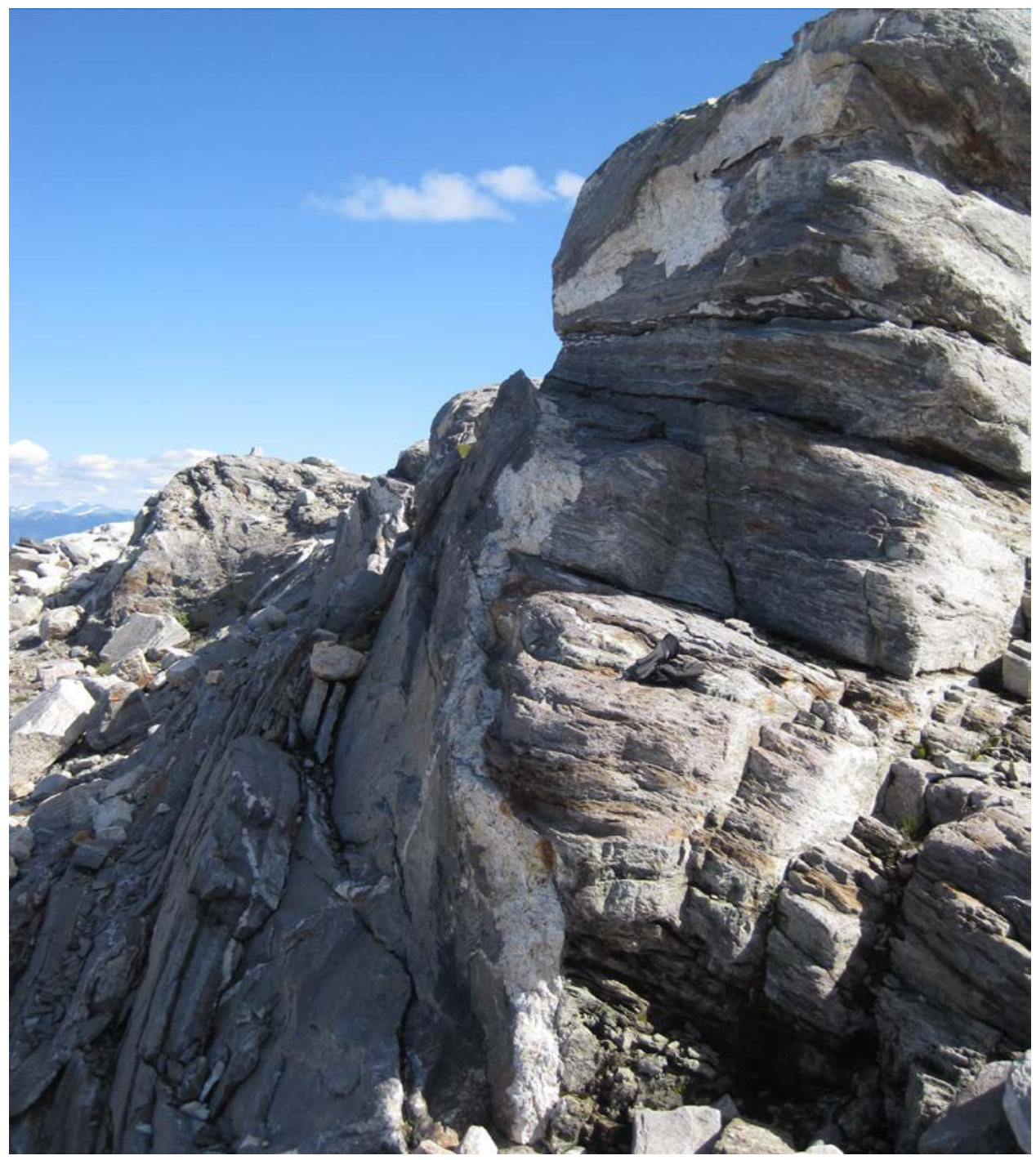

Figure 3.37b: The northwestern end of the SIMPLE9 branch. The length of one of the black gloves piled near the center of the image is $\sim 22 \mathrm{~cm}$. 


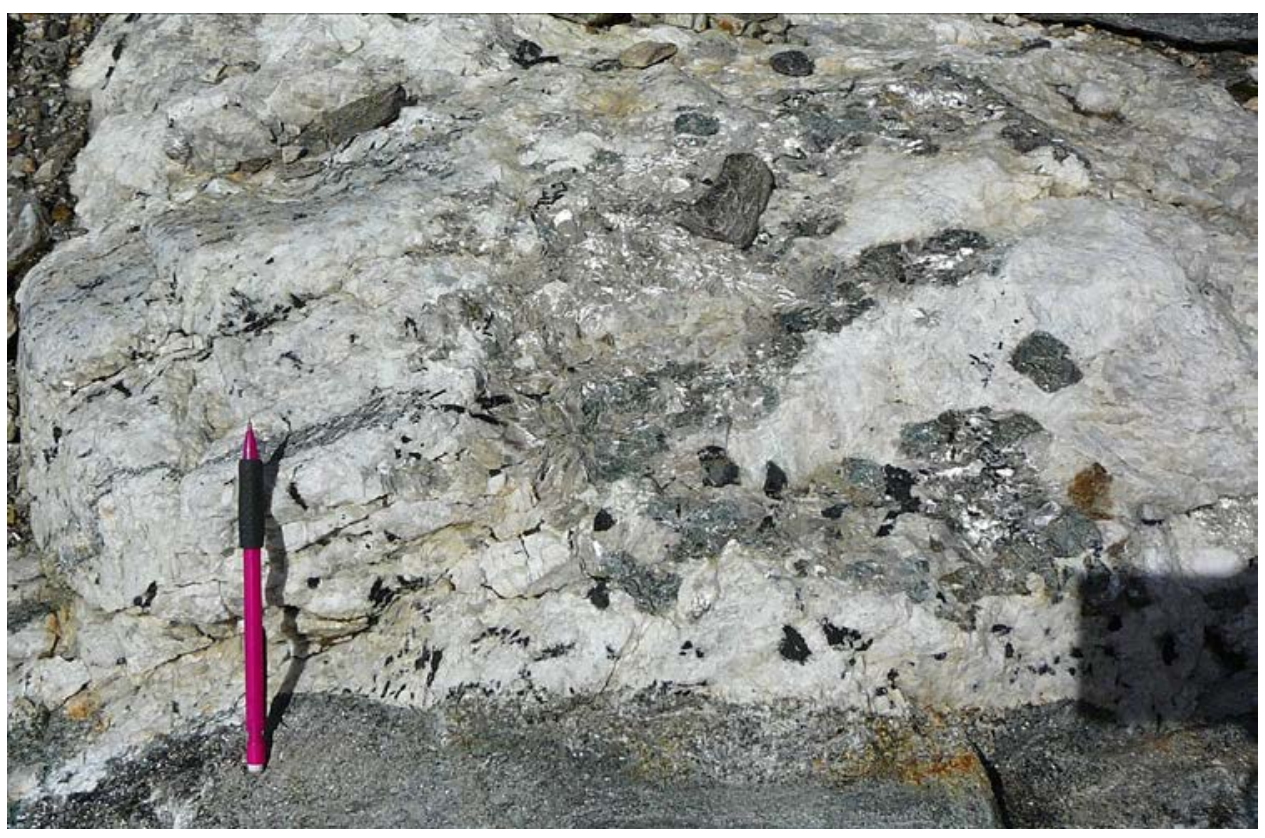

Figure 3.37c: Partially altered cordierite (dark green) with black tourmaline and muscovitequartz intergrowths in the SIMPLE9 pegmatite.

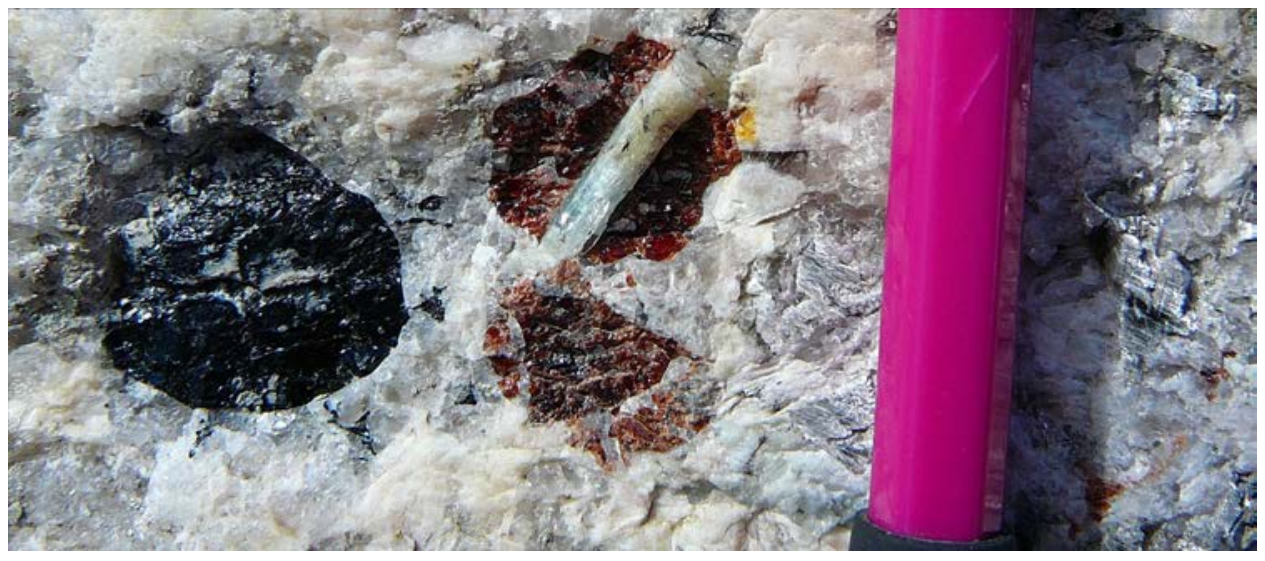

Figure 3.37d: Beryl (light blue, in center of the garnet), garnet, and black tourmaline in the SIMPLE9 pegmatite. 


\subsubsection{The SIMPLE10 Pegmatite}

This pegmatite is exposed in a low ridge in the northern part of the study area near the ODD pegmatite (Fig. 3.38). It has a variable width between $50 \mathrm{~cm}$ and $1 \mathrm{~m}$ and can be traced for $\sim 25 \mathrm{~m}$. It has a strike of approximately $300^{\circ}$ and is very steeply dipping to the southwest to subvertical. The dike has a principal mineral assemblage of quartz + feldspar with accessory tourmaline. No zoning was observed in this pegmatite and no samples were taken.

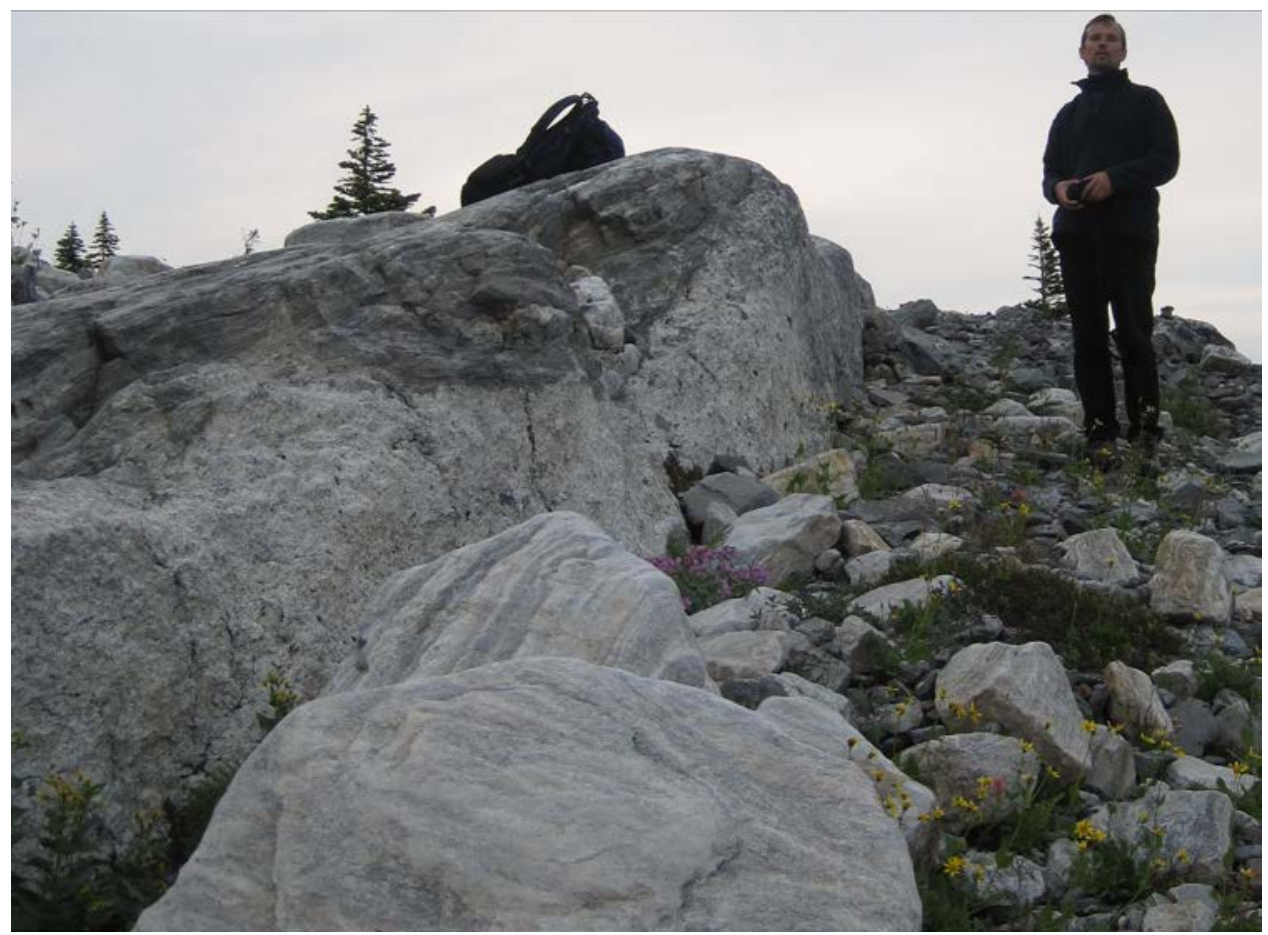

Figure 3.38: The SIMPLE10 pegmatite as seen from its southeastern end and looking to the northwest. 


\subsubsection{The SIMPLE11 Pegmatite}

This pegmatite is a branch of the GRANITE pegmatite exposed slightly to the south of GRANITE (Fig. 3.39). It extends to the southeast from where it joins GRANITE for 16 m before being covered by a snowfield. It has a width of $\sim 50 \mathrm{~cm}$ at its widest, a strike of approximately $259^{\circ}$, and a very steeply dipping to the southwest to subvertical dip. It has a priciple mineral assemblage of quartz + feldspar with accessory tourmaline and biotite along with trace iron oxides and sulfides. No zoning was observed in this pegmatite.

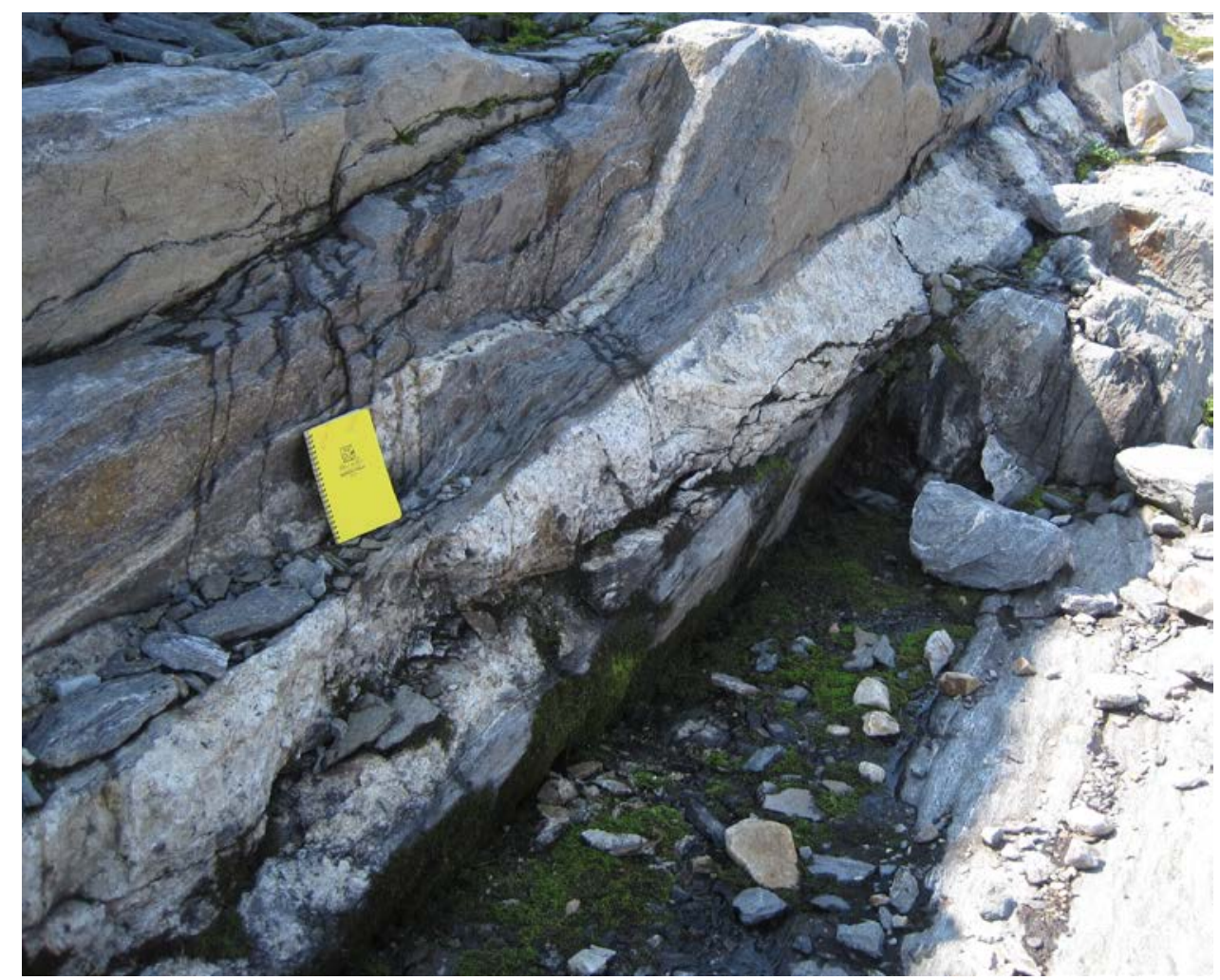

Figure 3.39: The SIMPLE11 pegmatite as seen from near its southeastern end and looking along its length to just before it joins with the GRANITE pegmatite.

\subsubsection{The SIMPLE12 Pegmatite}

This is the northernmost pegmatite in a series of three pegmatites (SIMPLE12, ZONED, and SIMPLE13) exposed on a slope in the western part of the study area. The dike has two branches at its northwestern end and where the branches join, it is spotted with rusty stains. It can be traced for nearly $155 \mathrm{~m}$ to where it enters a snowfield at its northwestern extent. Snow also obscures a portion of the dike near its middle. At its widest, the pegmatite is $\sim 1.5 \mathrm{~m}$; its 
ends narrow to only a few centimeters across (Fig. 3.40). It has a strike of approximately $305^{\circ}$ and a subvertical dip.

The principal mineral assemblage of the dike is quartz + feldspar with accessory tourmaline, biotite, and iron oxides. The presence of zircons and muscovite in the dike is unconfirmed. The dike is subtly zoned in its pegmatitic sections, with rare tourmaline fans in the core of the dike. Aplitic sections of the dike do not appear to be zoned and bear resemblance to the GRANITE pegmatite.

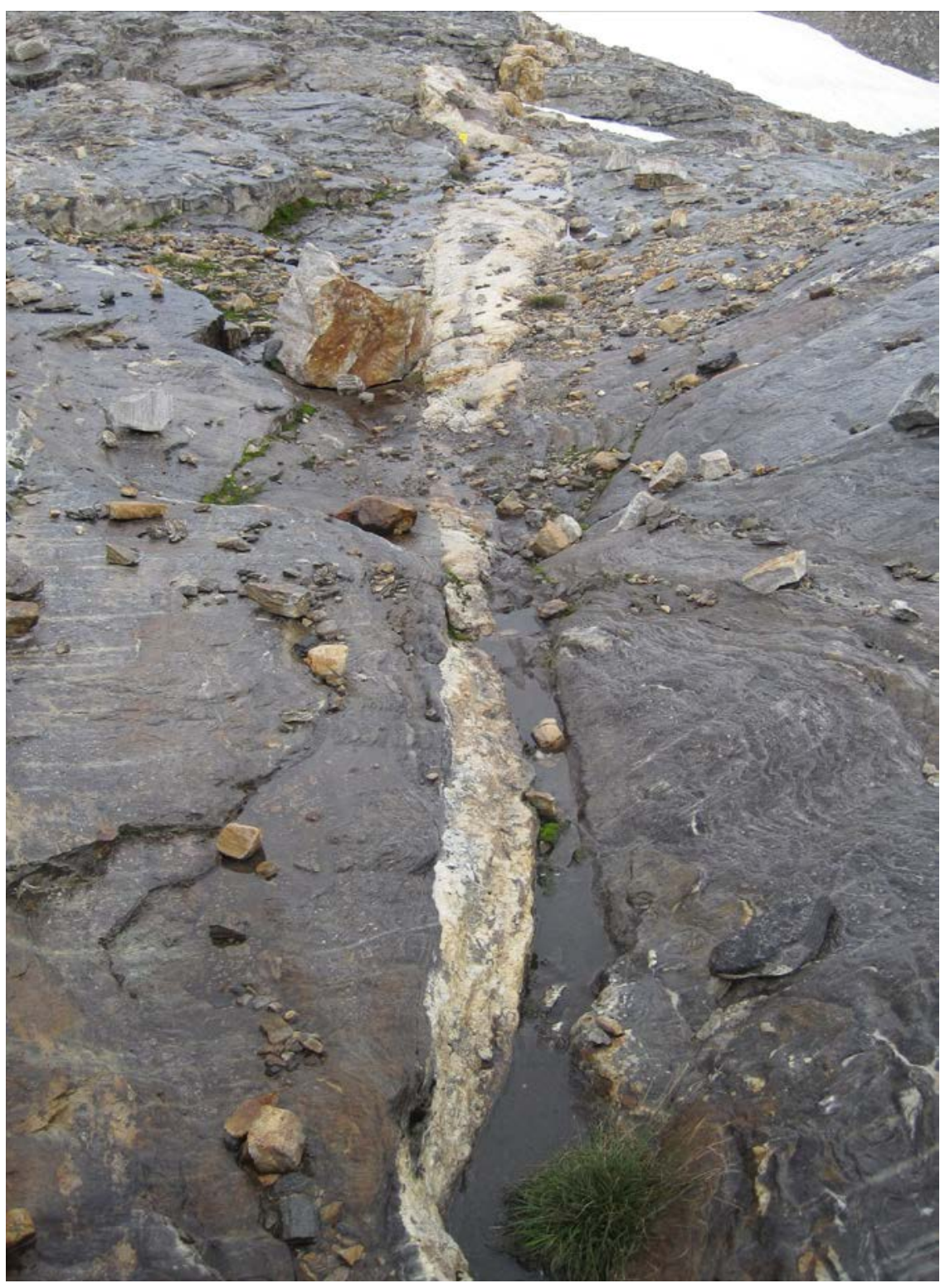

Figure 3.40: The SIMPLE12 pegmatite as seen from its southeastern end and looking to the northwest. 


\subsubsection{The SIMPLE13 Pegmatite}

This is the southernmost pegmatite in a series of three pegmatites (SIMPLE12, ZONED, and SIMPLE13) exposed on a slope in the western part of the study area (Fig. 3.41). It can be traced for nearly $81 \mathrm{~m}$; the outcrop is obscured by vegetation and erosion along its middle section. The pegmatite is approximately $60 \mathrm{~cm}$ wide and narrows to a few centimeters at its ends. Its strike is $\sim 300^{\circ}$ with a subvertical dip. Its principal mineral assemblage is quartz + feldspar with accessory tourmaline and iron oxides. Zoning was not observed in this pegmatite.

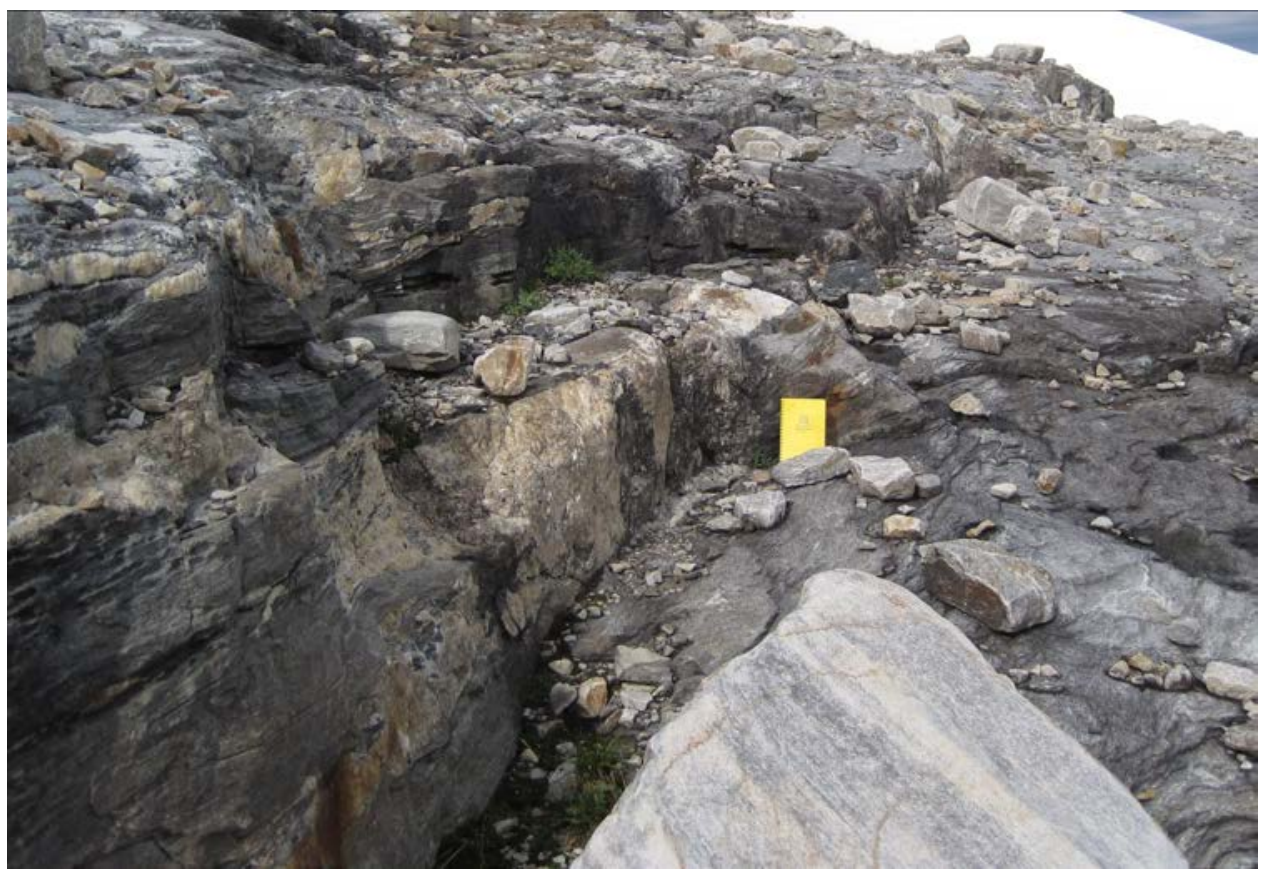

Figure 3.41: The SIMPLE13 pegmatite as seen from its southeastern end and looking towards the west. 


\subsubsection{The SIMPLE14 Pegmatite}

This pegmatite outcrops along the edge of a ridge near a tall cairn (Fig. 3.42) and slightly to the north of the proglacial pond. The outcrop is frequently interrupted by erosion but could be traced for $\sim 26 \mathrm{~m}$. A recrystallization trail in the host rock could be traced for a long distance beyond the western terminus of the dike. The eastern end of the pegmatite is split into two short branches; each branch is $\sim 1 \mathrm{~m}$ wide while the main body of the dike is $\sim 2 \mathrm{~m}$ wide. Its overall strike is $\sim 290^{\circ}$ with a subvertical dip. The principal mineral assemblage for the dike is quartz + feldspar with accessoy tourmaline, biotite, and garnet. No zoning was observed in the dike.

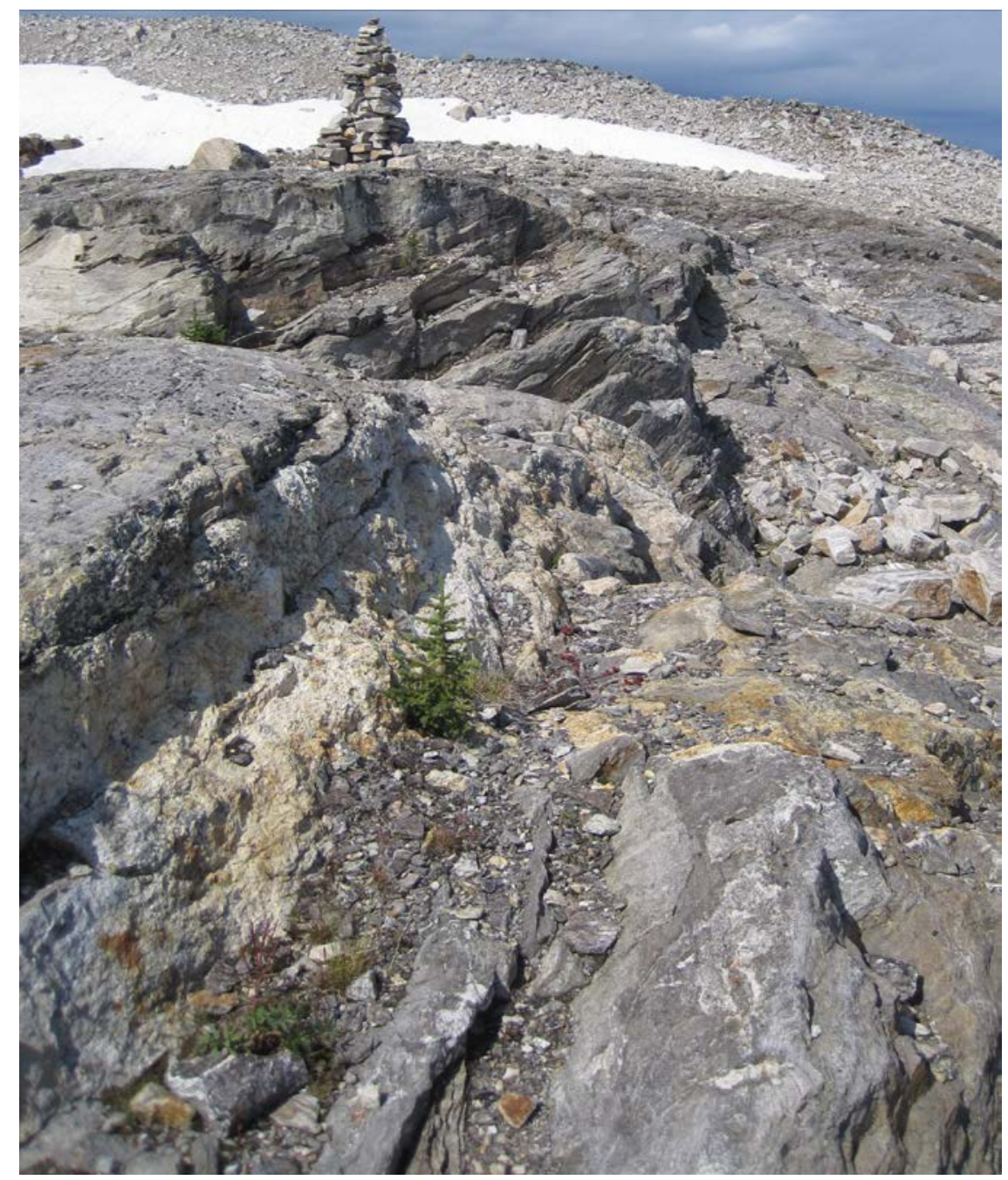

Figure 3.42: The SIMPLE14 pegmatite as seen from its eastern end and looking towards the west. 


\subsubsection{The SIMPLE15 Pegmatite}

This pegmatite is exposed for a short distance between large rocks in a boulder field north of the glacier. Only a $1.5 \mathrm{~m}$ long section of the $50 \mathrm{~cm}$ wide dike was visible (Fig. 3.43). It has a strike of $\sim 310^{\circ}$; the dip could not be ascertained from the outcrop but is presumed to be subvertical or vertical. Its principal mineral assemblage is quartz + feldspar with accessory tourmaline; feldspar was the only mineral sampled from the dike. Zoning was not observed in the pegmatite.

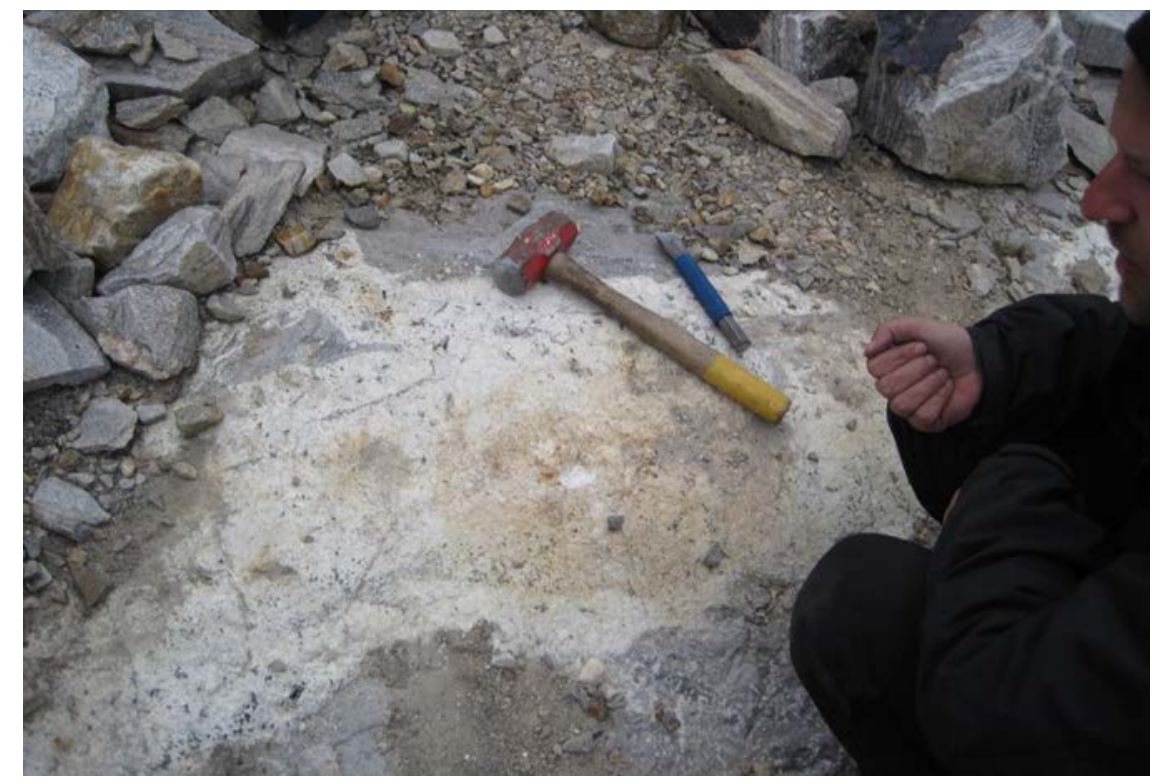

Figure 3.43: The visible extent of the SIMPLE15 outcrop. 


\subsubsection{The SIMPLE16 Pegmatite}

This pegmatite outcrops in a boulder field in the southern part of the study area. It is frequently hidden by boulders but could be traced for approximately 41 meters. It appears to branch multiple times underneath the boulders with each branch being approximately $30 \mathrm{~cm}$ wide. It has an overall strike of $\sim 90^{\circ}$ and is very steeply dipping the south to subvertical (Fig. 3.44). It has a principal composition of quartz + feldspar + tourmaline with accessory muscovite, biotite, chlorite, and rutile. Columbite and zircon are unconfirmed accessory minerals. Zoning was not observed in the pegmatite.

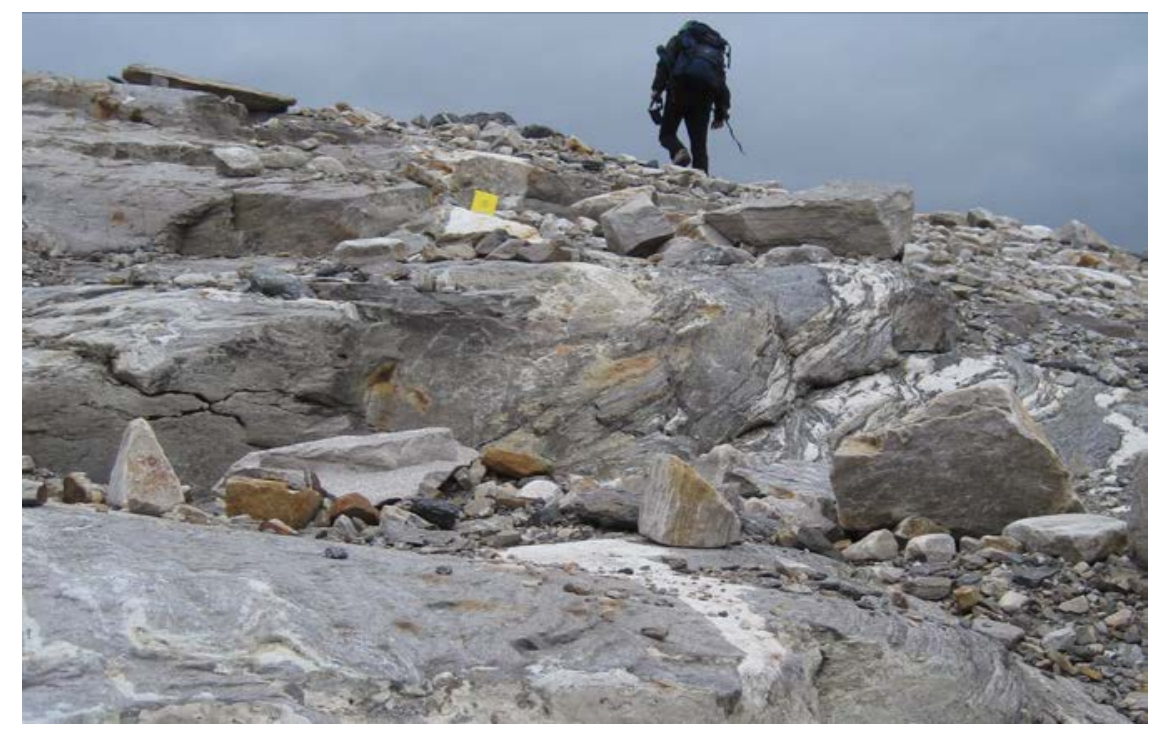

Figure 3.44: The eastern end of the SIMPLE16 pegmatite; the view is to the west.

\subsubsection{The SIMPLE17 Pegmatite}

This pegmatite outcrops on either side of a small, rubble filled creek. It can be traced for $\sim 14 \mathrm{~m}$, if the $\sim 7 \mathrm{~m}$ interruption caused by the stream is included (Fig. 3.45). It has a maximum width of $\sim 50 \mathrm{~cm}$ and narrows to $\sim 5-10 \mathrm{~cm}$ at its ends. It has a strike of approximately $320^{\circ}$ and a subvertical dip. It has a principal composition of quartz + feldspar + tourmaline, with the tourmaline crystals reaching $10 \mathrm{~cm}$ long and 2-3 cm wide. Zoning was not observed in this pegmatite. 


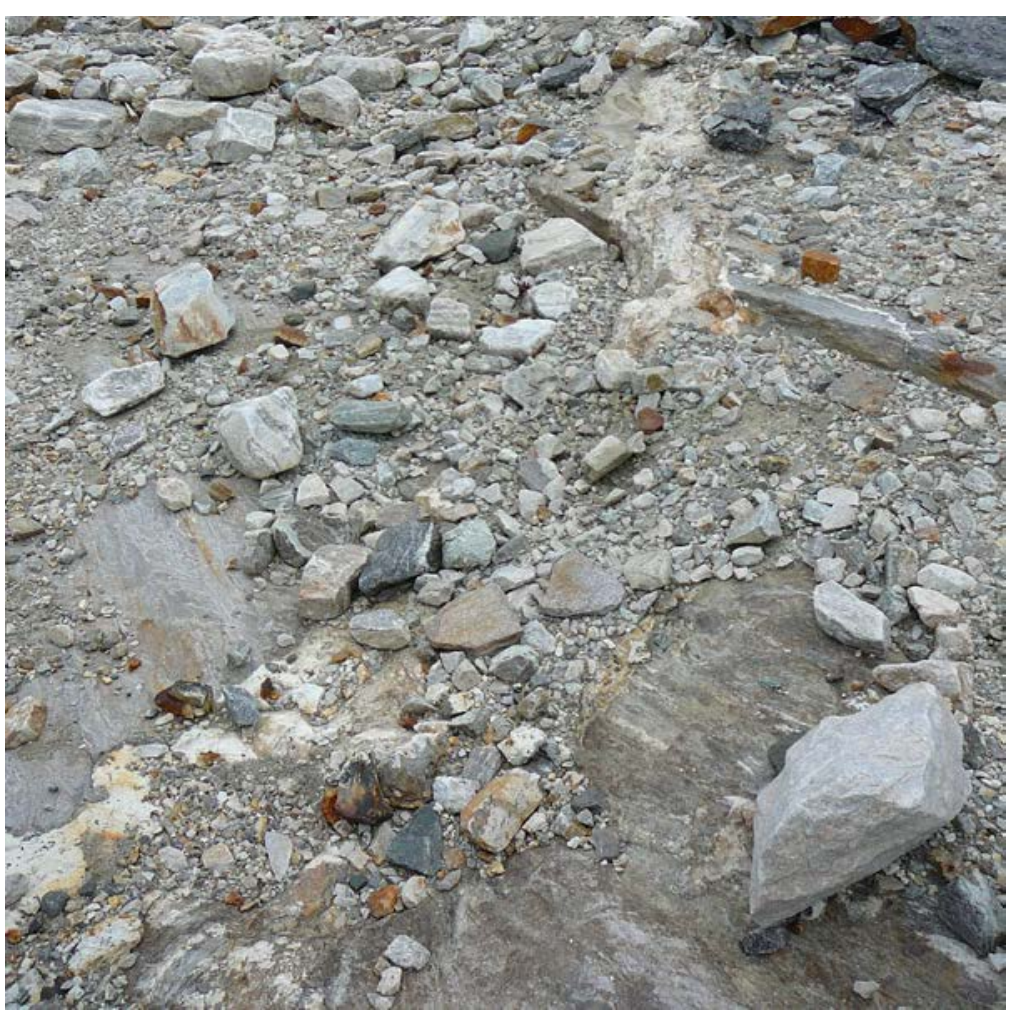

Figure 3.45: The SIMPLE17 pegmatite as seen from near its northwestern end and looking to the southeast. The pegmatite is oriented diagonally in the image from the lower left corner to the upper right corner.

\subsubsection{The SKINNY Pegmatite}

This pegmatite outcrops near a ridge near small, likely seasonal, waterfall. It is approximately $13 \mathrm{~m}$ long, with a width of $\sim 10 \mathrm{~cm}$, tapering to a few centimeters at its ends. It has a strike of $\sim 345^{\circ}$ and vertical dip (Fig. 3.46). The dike is subtly zoned, with narrow, finegrained border zones and a coarser grained core. Its principal mineral assemblage is quartz + feldspar + tourmaline with rare grains of feldspar being blue-gray perthite. The dike has accessory garnet, muscovite, biotite, rutile, and unconfirmed accessory zircon. 


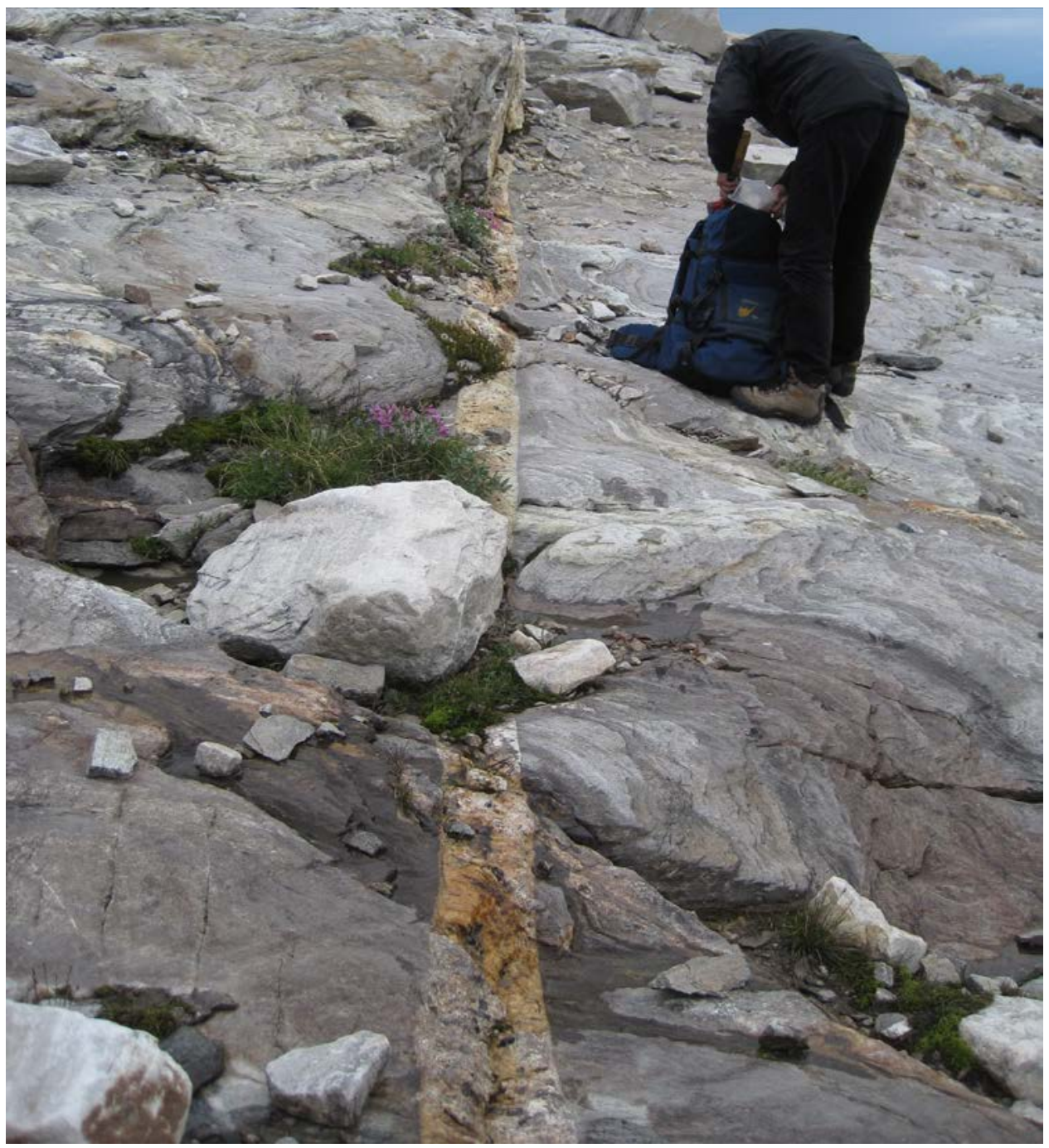

Figure 3.46: The SKINNY pegmatite as seen from near its southeastern end and looking to the northwest.

\subsubsection{The SMALL Pegmatite}

This dike is exposed slightly to the north of the southeastern end of the GRANITE pegmatite. The outcrop is interrupted by a creek covered in plant life and large boulders near its southeastern extent (Fig. 3.47). It can be traced for 30 meters and typically has a width of about $1 \mathrm{~m}$. The pegmatite has a strike of approximately $315^{\circ}$ and is steeply dipping to the southwest. It has a principal mineral assemblage of quartz + feldspar + tourmaline with accessory biotite, muscovite, and garnet. Beryl, columbite, zircon, andalusite, and xenotime are unconfirmed accessory minerals. The dike displays an unusual zoning pattern for this field of pegmatites - muscovite is prevalent in its southeastern end while biotite is much more common 
in its northwestern extent. Where muscovite is prevalent, some of it is hosted as muscovitequartz intergrowths in the core.

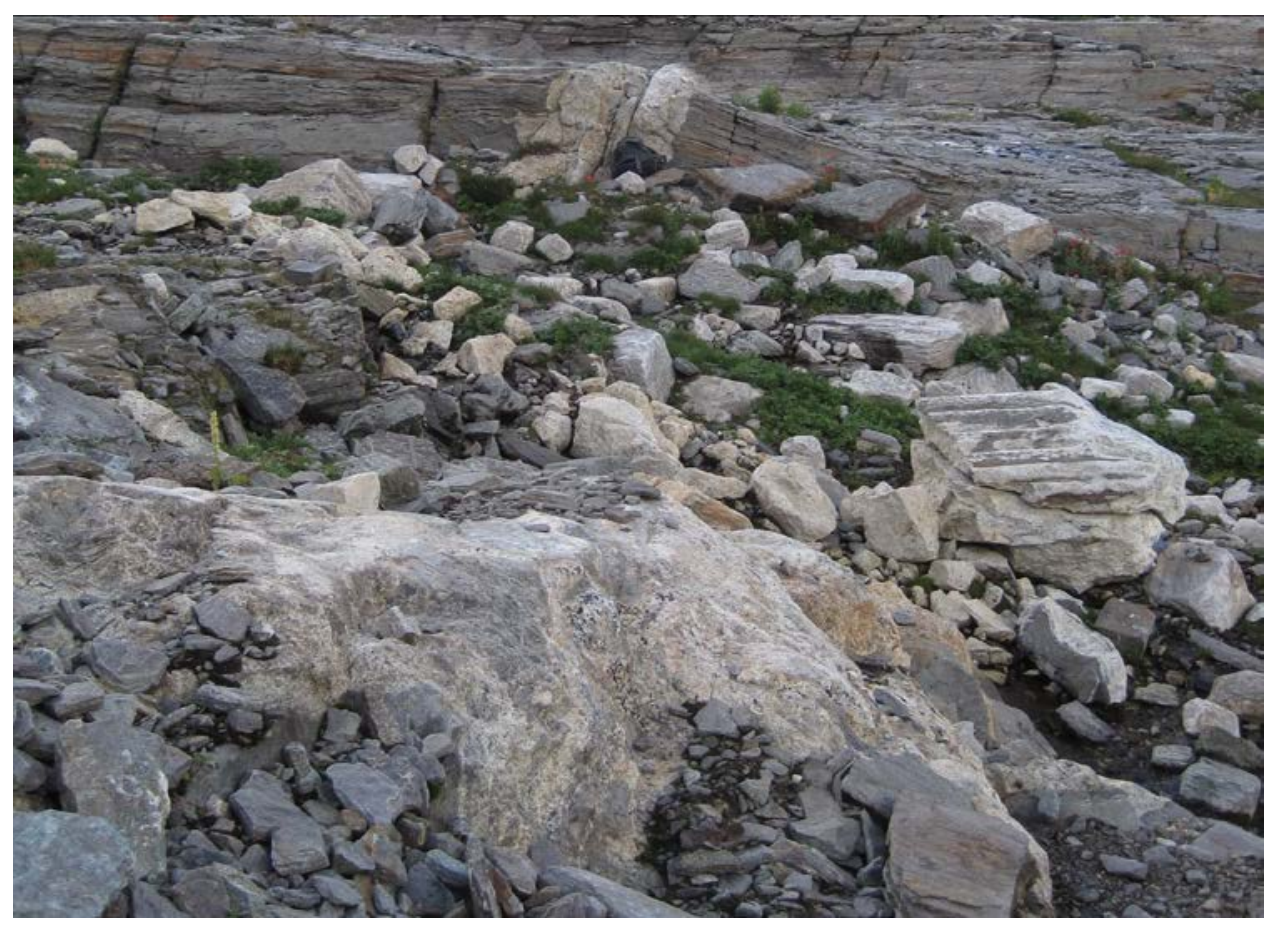

Figure 3.47: The SMALL pegmatite as seen from near its southeastern end looking towards the west. The portion of the dike near the top center of the photograph has muscovite-quartz intergrowths in its core.

\subsubsection{The STUBBY Pegmatite}

This pegmatite intersects the southeastern end of the SIMPLE pegmatite (Fig. 3.29). The dike is $\sim 1$ wide and extends for $10 \mathrm{~m}$ on a strike of $65^{\circ}$ with a subvertical dip. It has a composition of quartz + feldspar + tourmaline. No zoning was observed in the dike and no samples were taken from it.

\subsubsection{The THIN Pegmatite}

This pegmatite is exposed in the western part of the study area and is crosscut by the JAN aplites. Despite the outcrop being frequently subject to erosion and covered by snow, it can be traced for nearly $63 \mathrm{~m}$ (Fig. 3.48). It has a typical width of $\sim 20 \mathrm{~cm}$, a strike of approximately 
$300^{\circ}$, and a subvertical dip. The dike has the assemblage of quartz + feldspar + tourmaline and is zoned with a quartz core visible in its middle section.

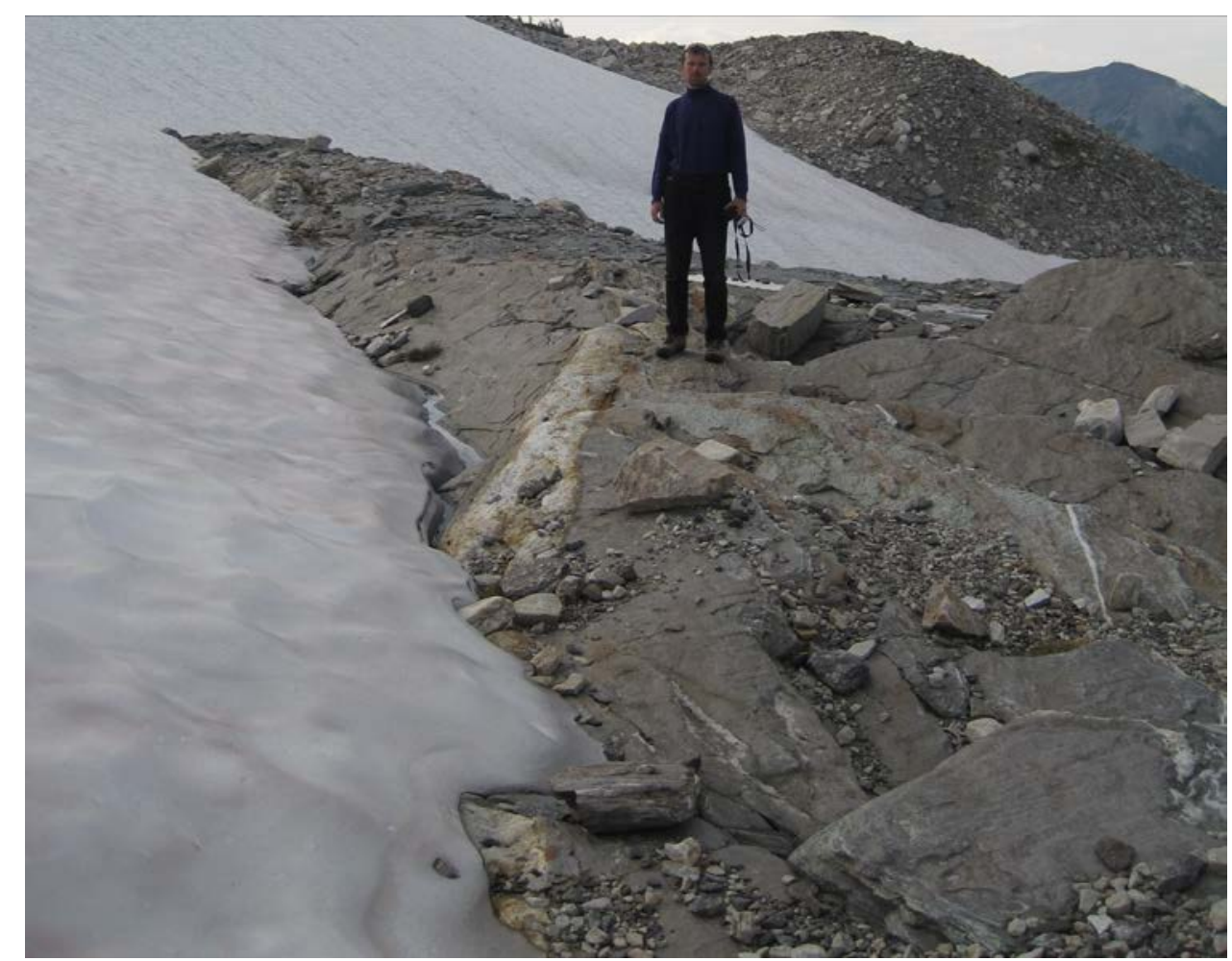

Figure 3.48: The THIN pegmatite as seen near its southeastern end and looking towards the northwest.

\subsubsection{The TINY Pegmatite}

This pegmatite is a short branch from the GRANITE pegmatite near the larger branch TOURMUS (Fig. 3.49). The dike is not more than $20 \mathrm{~cm}$ wide and extends for approximately 3 $\mathrm{m}$. It has a strike of $\sim 310^{\circ}$ and is very steeply dipping to the southwest. The pegmatite is composed of quartz + feldspar + tourmaline + slightly chloritized biotite. It is subtly zoned with narrow, fine-grained border zones and a coarser grained core. No samples were taken from this dike. 


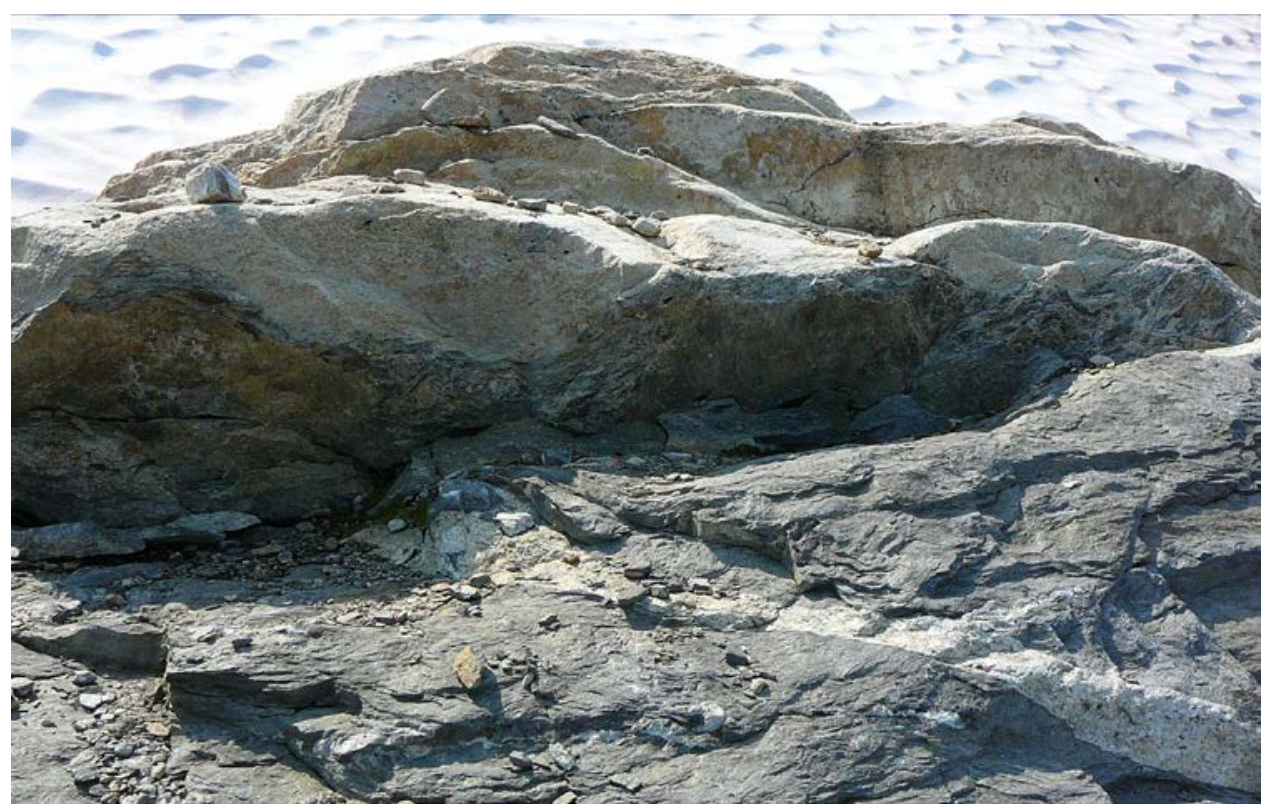

Figure 3.49: The TINY pegmatite (foreground) as seen from near its northwestern end and looking towards where it joins the GRANITE pegmatite to the south (background).

\subsubsection{The TOUR Pegmatite}

This pegmatite outcrops in the southeastern part of the study area to the east of the GARTOUR pegmatite. It can be traced $~ 18 \mathrm{~m}$ between its very narrow southeastern end and 40 cm wide erosional northwestern end; along the middle section, it has a width of $~ 3 \mathrm{~m}$ (Fig. 3.50a). It has a strike of approximately $325^{\circ}$ and a subvertical dip. The principal mineral assemblage is quartz + feldspar + tourmaline with accessory muscovite, apatite, altered cordierite, and iron oxides. Zircon is an unconfirmed accessory mineral. The pegmatite is zoned, with a very blocky core with quartz-cordierite intergrowths (Figure 3.50b) and muscovite fans. The border zone is finer grained and noticeably lacks cordierite. 


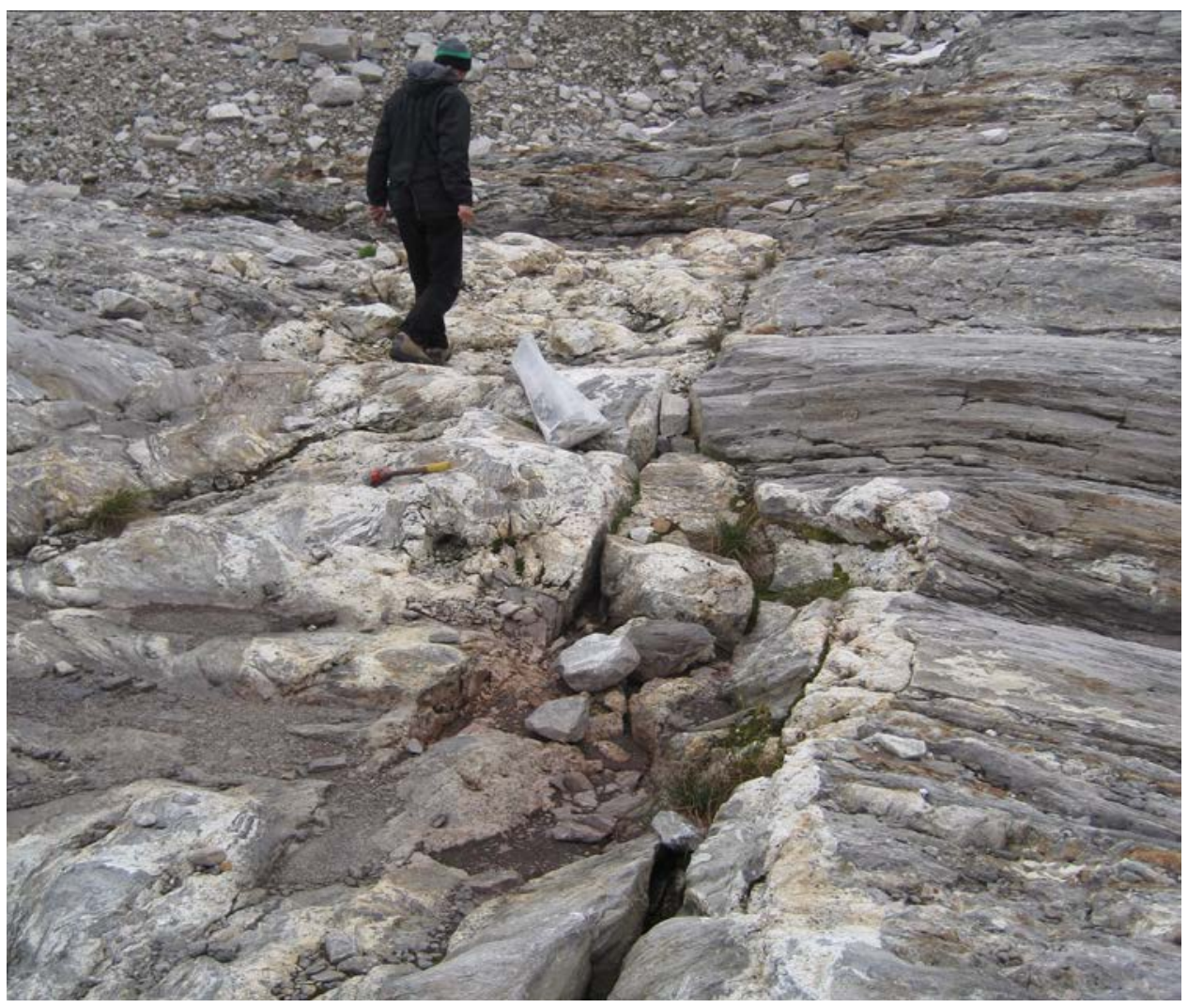

Figure 3.50a: The TOUR pegmatite as seen from its northwestern end and looking towards the southeast.

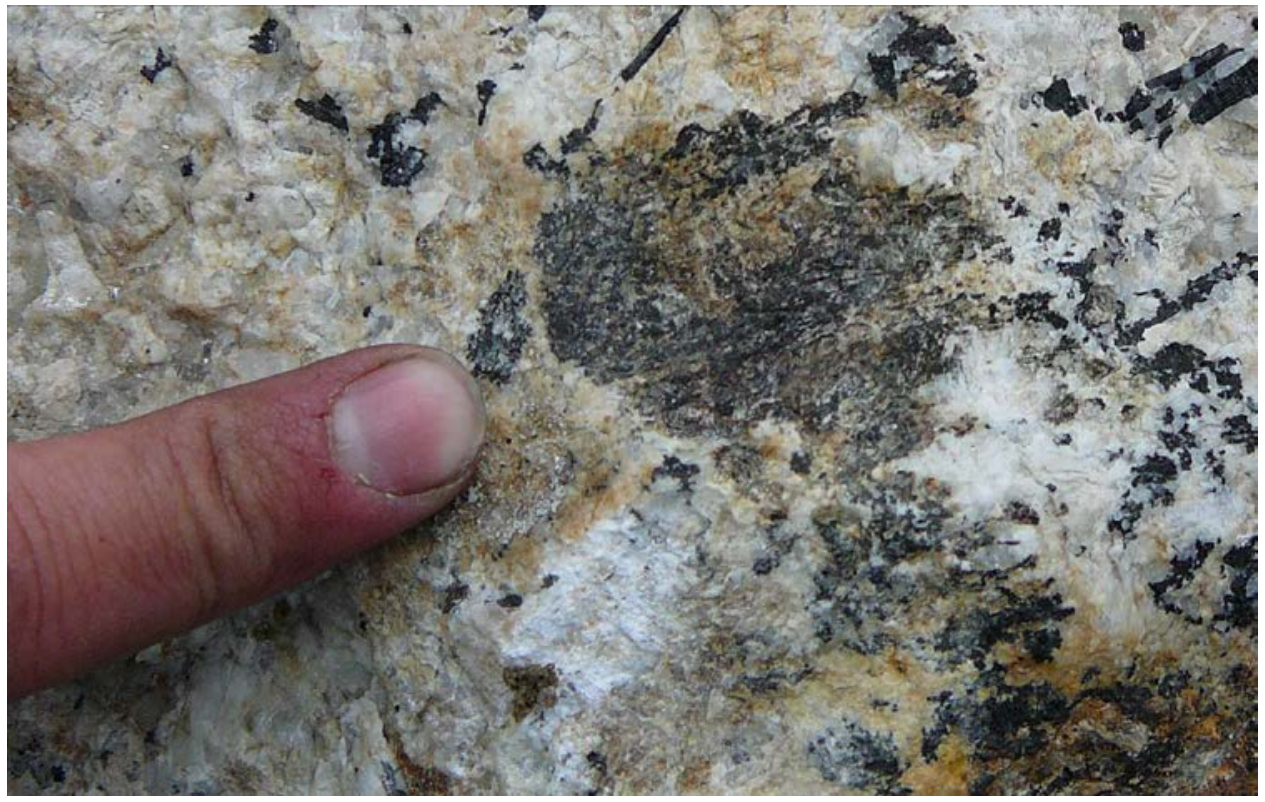

Figure 3.50b: Cordierite-quartz intergrowth in the TOUR pegmatite. 


\subsubsection{The TOUR2 Pegmatite}

This pegmatite outcrops mid-way between the GARTOUR and JUNCT pegmatites. The dike is filled with xenoliths and is $\sim 3$ wide and nearly $5 \mathrm{~m}$ long (Fig. 3.51). It has as strike of approximately $325^{\circ}$; the dike is presumed to be subvertical but could not be discerned from the outcrop. It has a composition of quartz + feldspar + tourmaline. Zoning was not observed in the dike and no samples were taken.

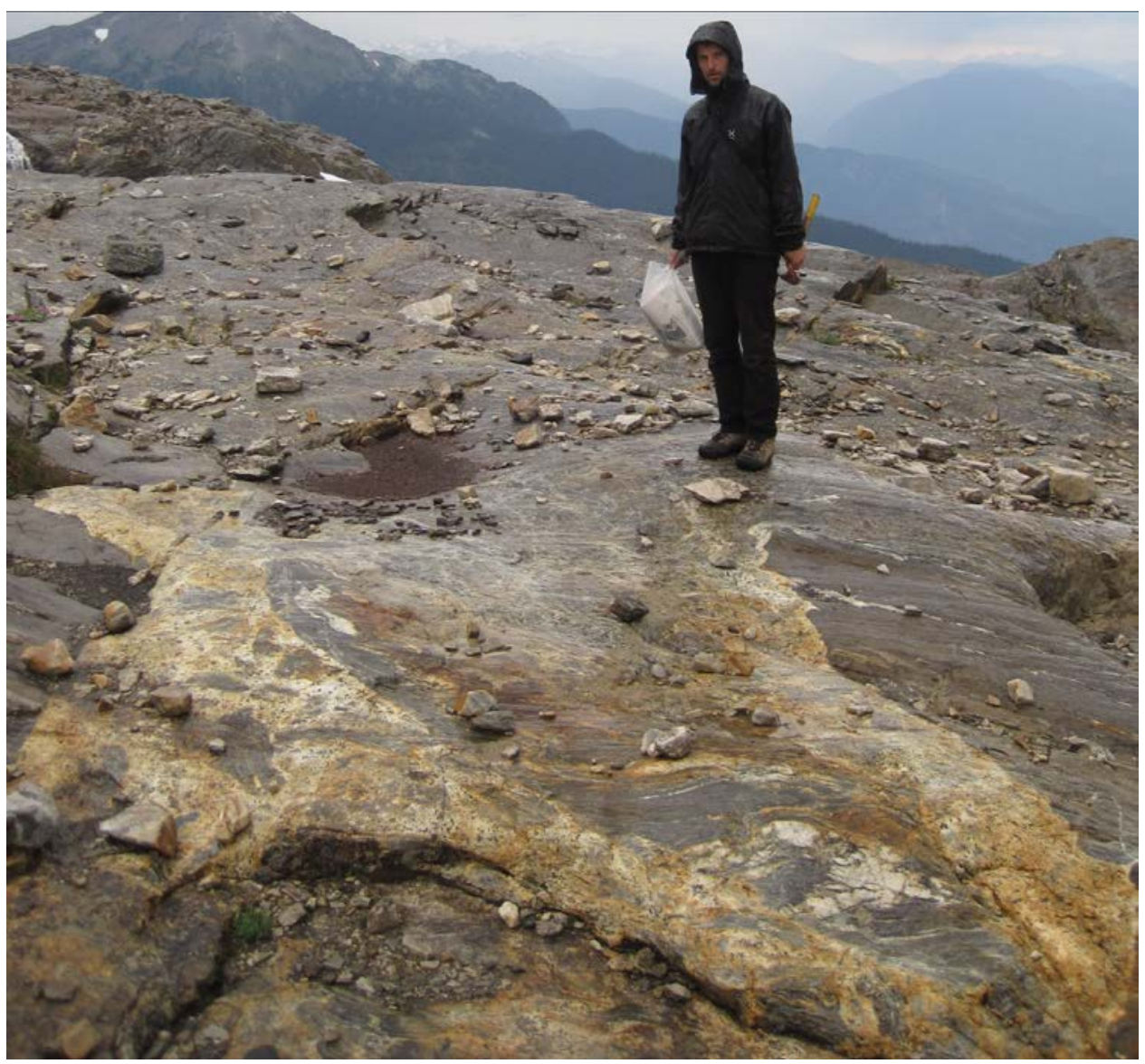

Figure 3.51: The TOUR2 pegmatite as seen from near its southeastern end and looking towards the northwest.

\subsubsection{The TOURMUS Pegmatite}

This pegmatite branches off from the GRANITE pegmatite near the TINY pegmatite in the eastern part of the study area. Where it splits from the GRANITE dike, it is made up of a series of thin dikes and veinlets no more than $20 \mathrm{~cm}$ wide but covers an area of $\sim 3 \mathrm{~m}$ (Fig. 3.52a). The 
main body of the dike is usually not more than $1 \mathrm{~m}$ wide and extends for $\sim 38 \mathrm{~m}$. It has a strike of approximately $310 \mathrm{~m}$ and a subvertical dip.

The dike has a principal assemblage of quartz + feldspar + tourmaline with accessory muscovite, biotite, garnet, apatite, beryl (Fig. 3.52b), triplite-zwieselite, and zircon. The dike is zoned similarly to the SMALL pegmatite with muscovite in its southeastern end and biotite as the principal mica in its northwestern end. Where muscovite is prevalent, some of it is hosted as muscovite-quartz intergrowths in the core. The border zone is finer grained and noticeably lacks beryl and triplite-zwieselite.

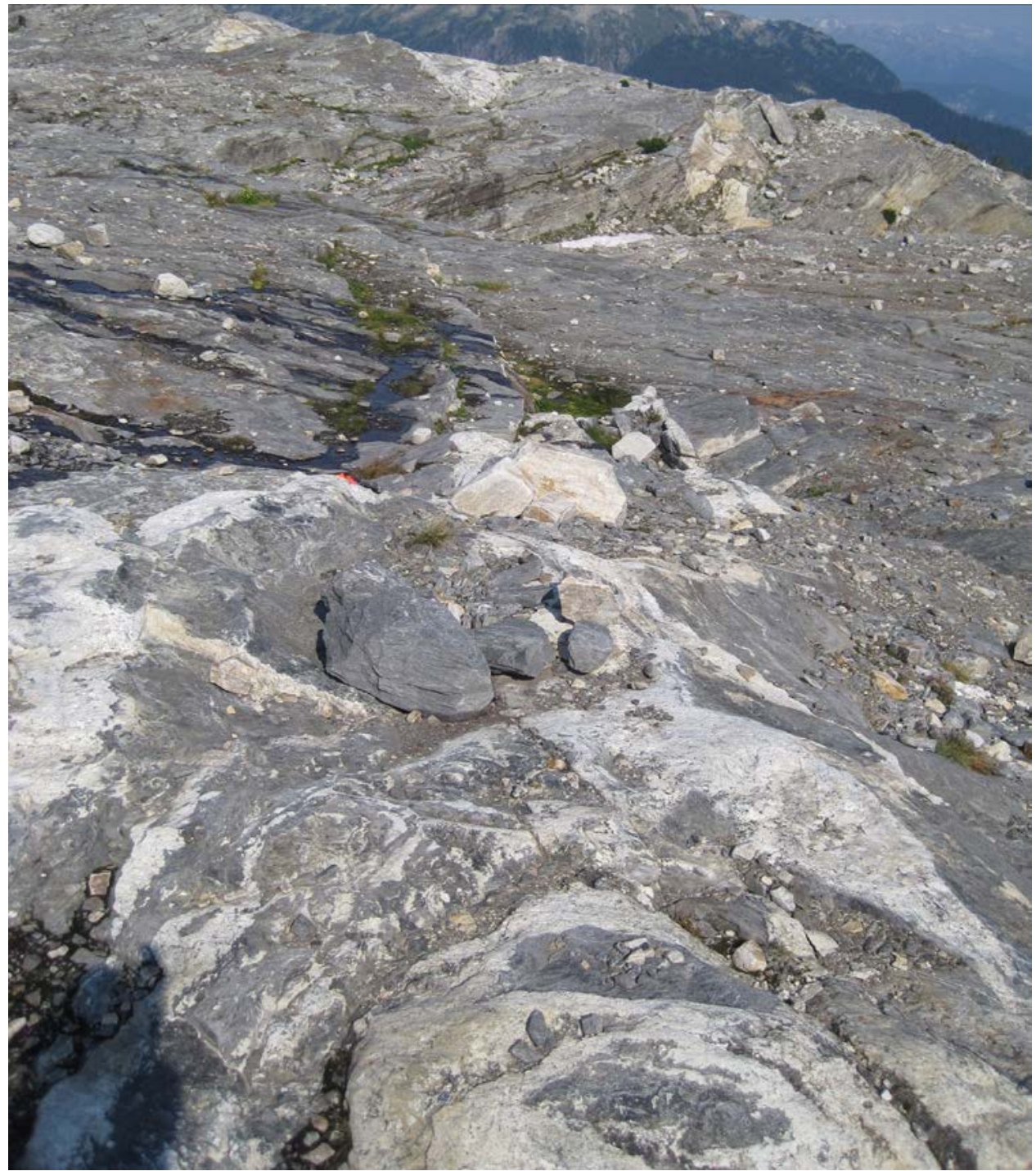

Figure 3.52a: The TOURMUS pegmatite as seen from where it branches from the GRANITE pegmatite and looking towards the northwest. The three pegmatites in the background from left to right are GARMUS, LI2, and SIMPLE. 


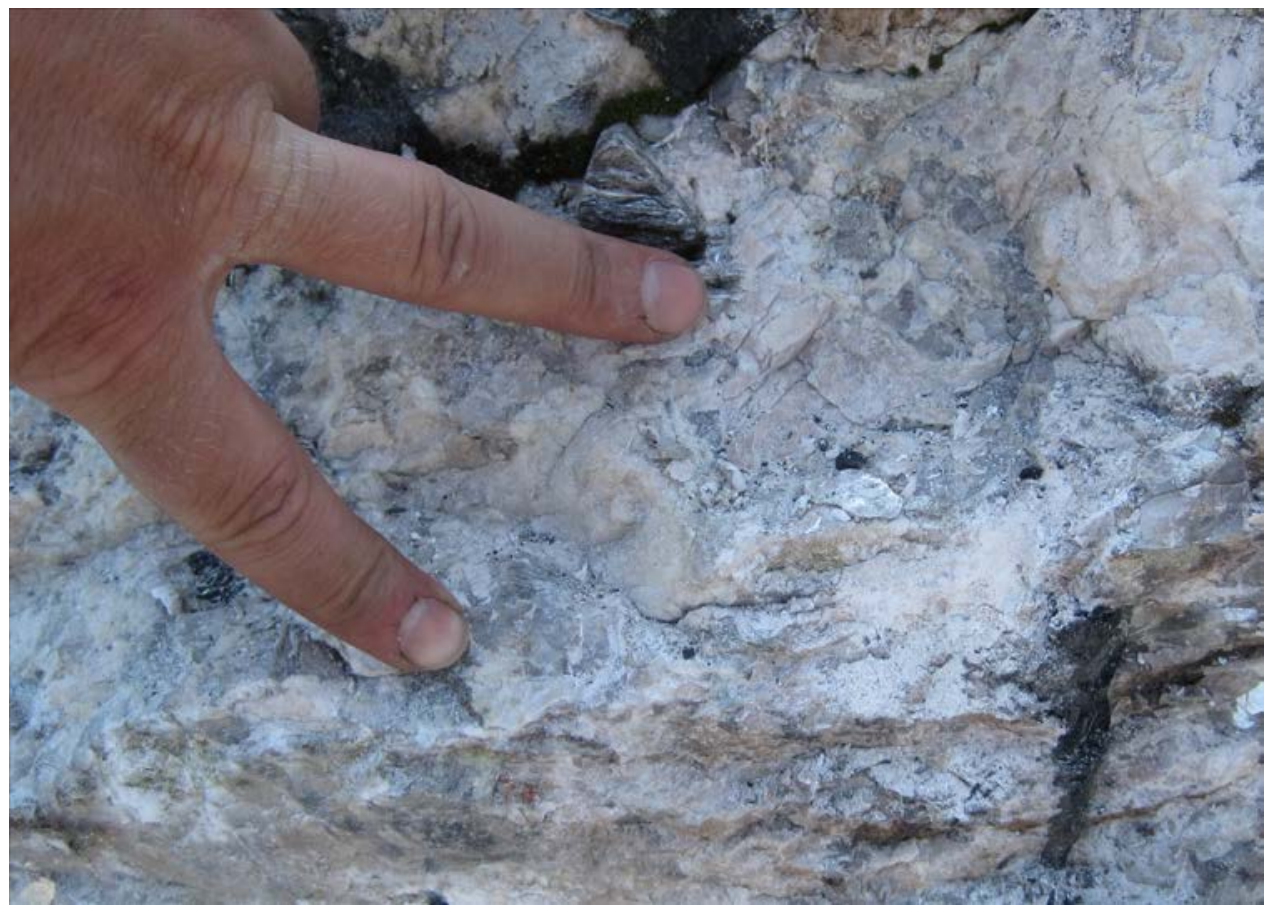

Figure 3.52b: A white beryl crystal (centered between the fingers) in the TOURMUS pegmatite.

\subsubsection{The WOBBLE Pegmatite}

This pegmatite is exposed in the southeastern part of the study area to the west of the CORD pegmatite. It has a meandering character and is composed of many small dikelets (Fig.

3.53a). At its widest, the main body of the dike is $\sim 30 \mathrm{~cm}$ wide. Overall, the dike can be traced for nearly $20 \mathrm{~m}$, has a strike of $\sim 320 \mathrm{~m}$. Its dip was not ascertained from the outcrop but it is assumed to be subvertical. It has a principal mineral assemblage of quartz + feldspar + tourmaline with accessory garnet. It has a blocky core with fine grained tourmaline-quartz intergrowths (Fig. 3.53b). 


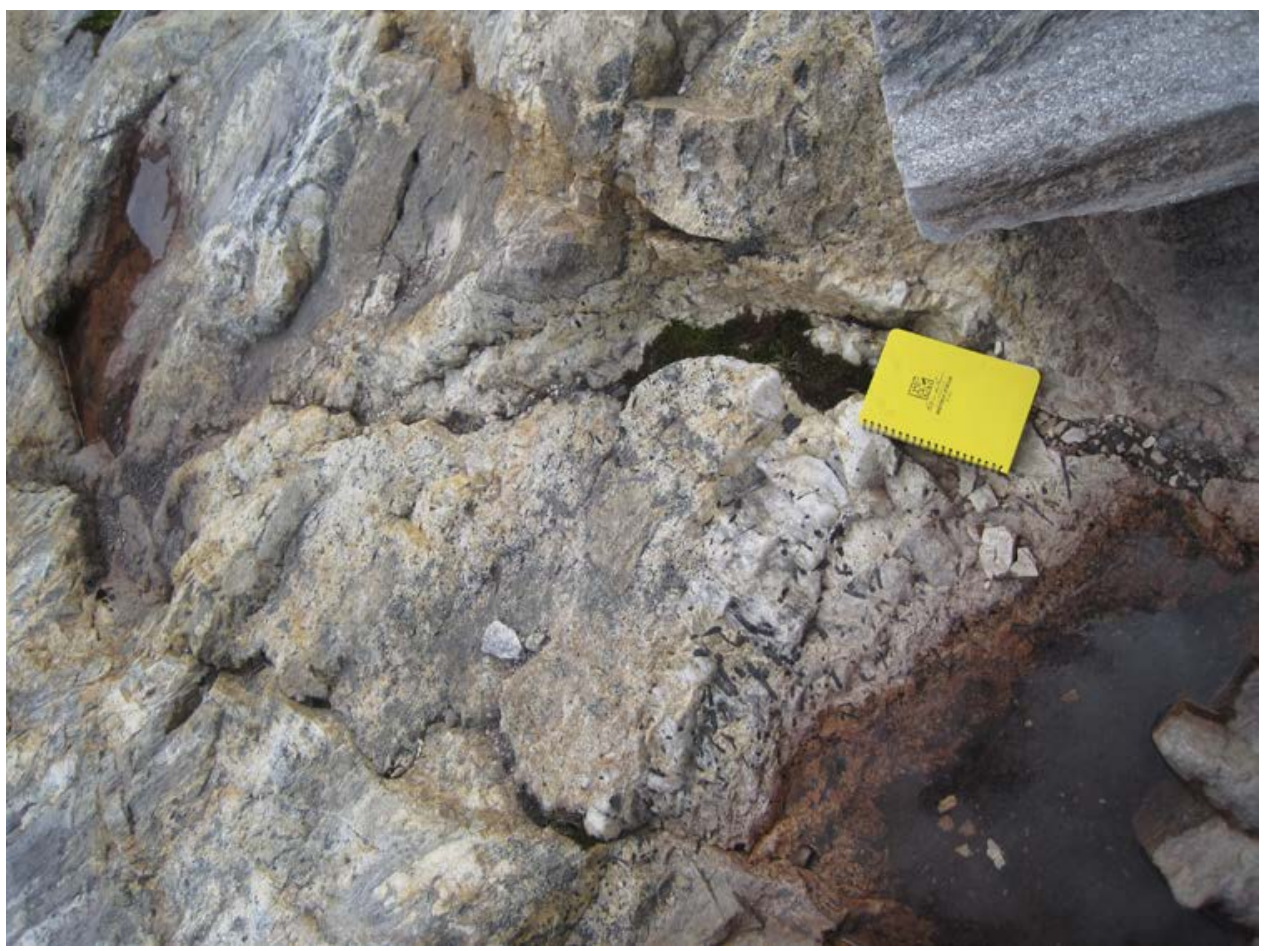

Figure 3.53a: A representative section of the WOBBLE pegmatite with its blocky core near the yellow notebook and meandering veinlets on the left half of the image.

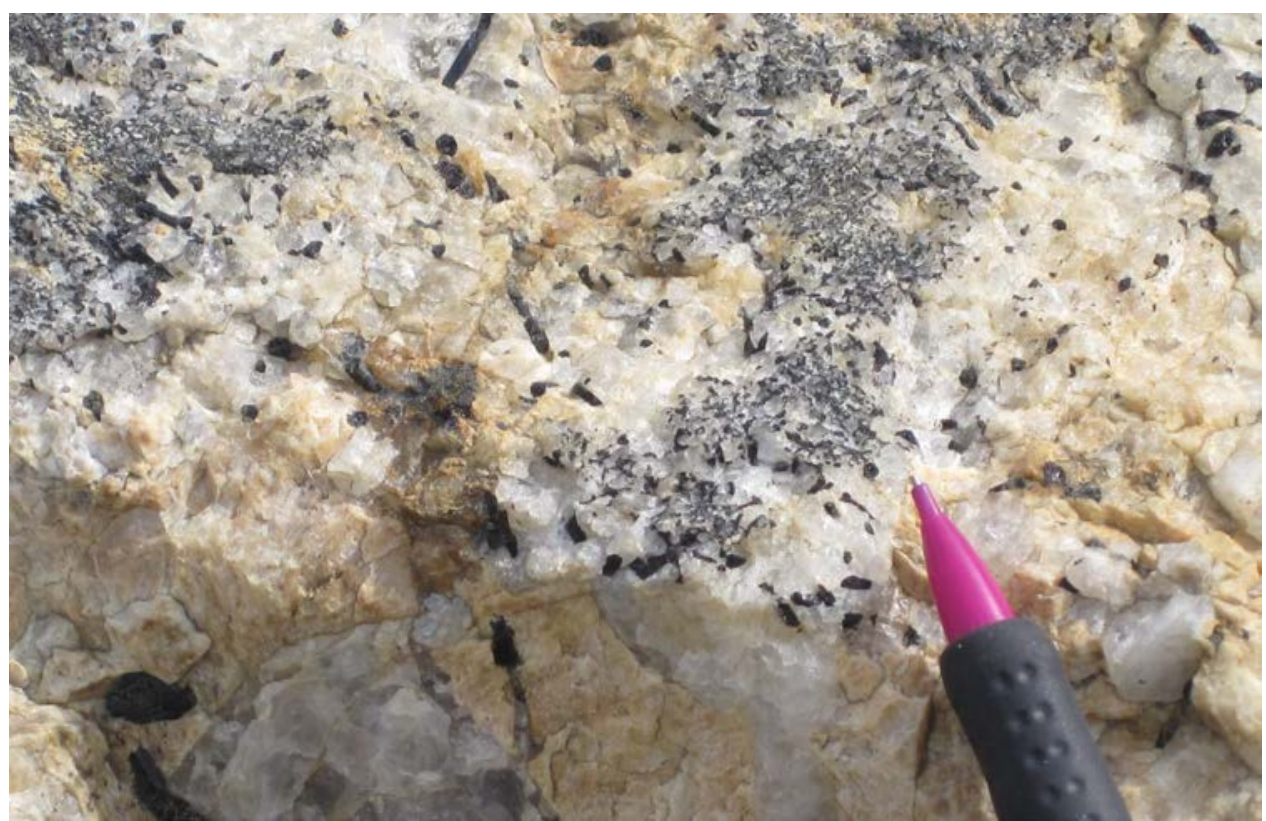

Figure 3.53b: Tourmaline-quartz intergrowths in the core of WOBBLE. 


\subsubsection{The ZONED Pegmatite}

This is the central pegmatite in a series of three pegmatites (SIMPLE12, ZONED, and SIMPLE13) exposed on a slope in the western part of the study area (Fig. 3.54a). It can be traced for approximately $95 \mathrm{~m}$, has a strike of $\sim 305^{\circ}$, and a $45^{\circ}$ to subvertical dip to the south. This pegmatite is easily distinguished from other pegmatites in the study area by its large quartz core that occassionally has a rosy hue (Fig. 3.54b). At its widest, the quartz core $\sim 60 \mathrm{~cm}$ wide flanked by border zones of 15 to $20 \mathrm{~cm}$ wide. The quartz core hosts rare feldspar crystals that reach nearly $30 \mathrm{~cm}$ in length. The pricinpal mineral assemblage for this pegmatite is quartz + feldspar with accessory tourmaline and biotite.

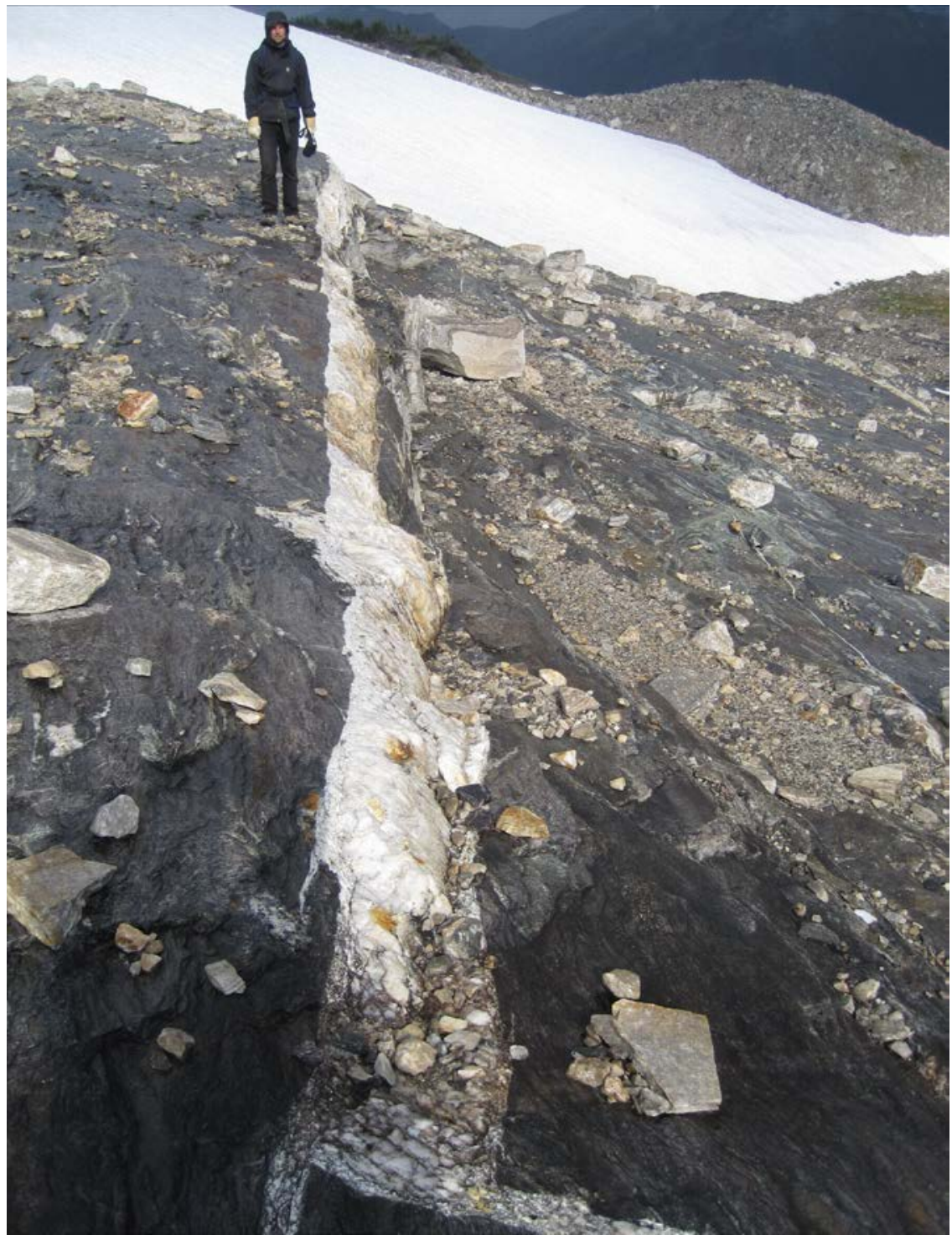

Figure 3.54a: The ZONED pegmatite as seen from its southeastern end and looking to the west. 


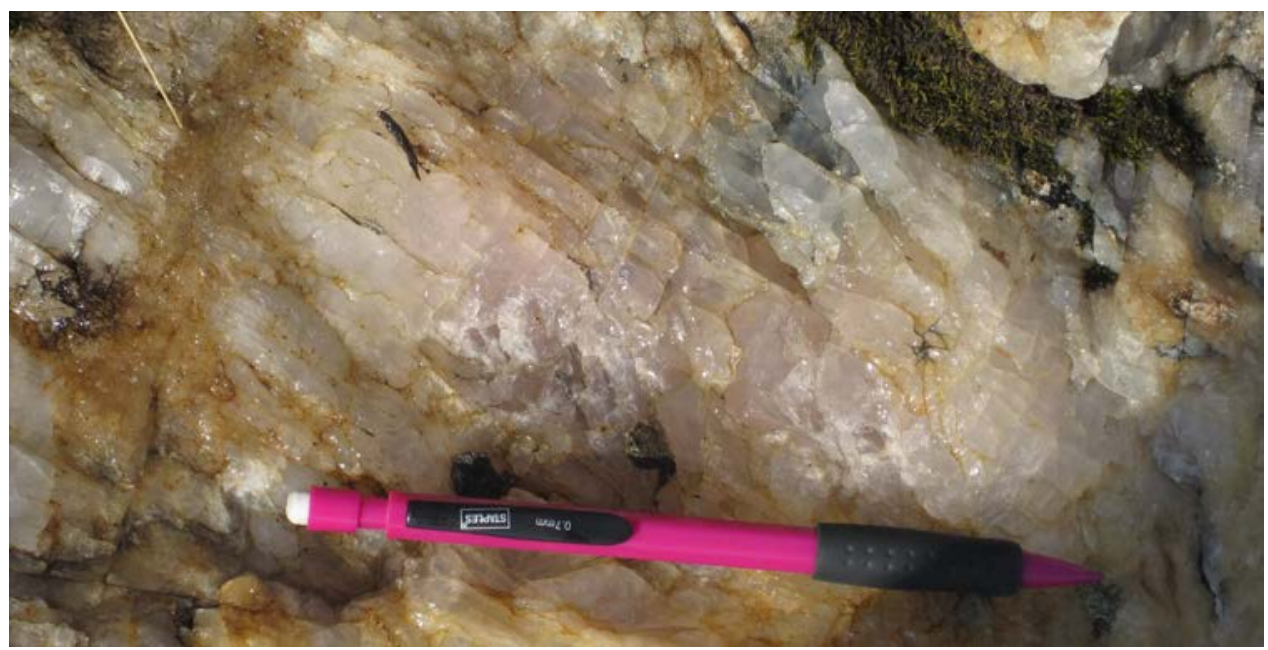

Figure 3.54b: Rose quartz in the core of the ZONED pegmatite.

\subsubsection{Other Pegmatite Bodies}

Additional pegmatites in the area were noted and photographed but were not mapped due to time and weather constraints (Fig. 3.55a \& b). At a glance, they are compositionally similar to other pegmatites in the study area, primarily containing coarse-grained tourmaline crystals in a matrix of quartz and feldspar. Future work should include mapping and sampling these pegmatites.

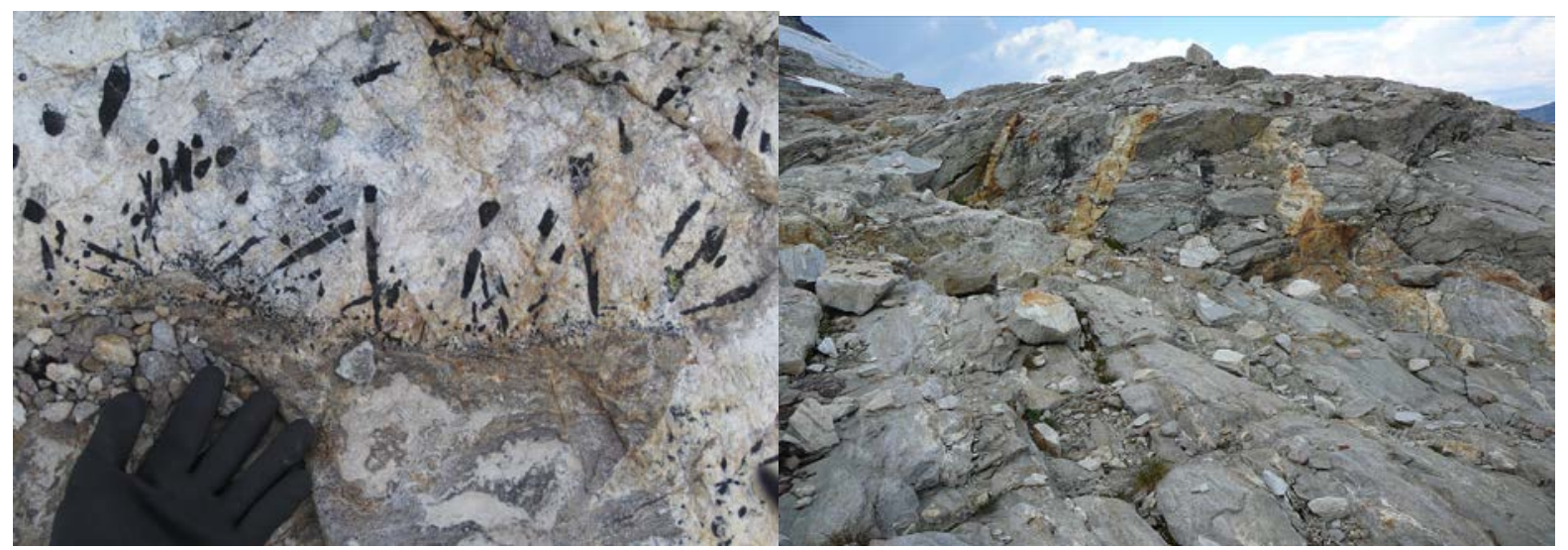

Figure 3.55a: Unmapped pegmatites. The left image is of the XENO pegmatite; the right image is of the MORE pegmatites-three MORE dikes are visible in this image. 


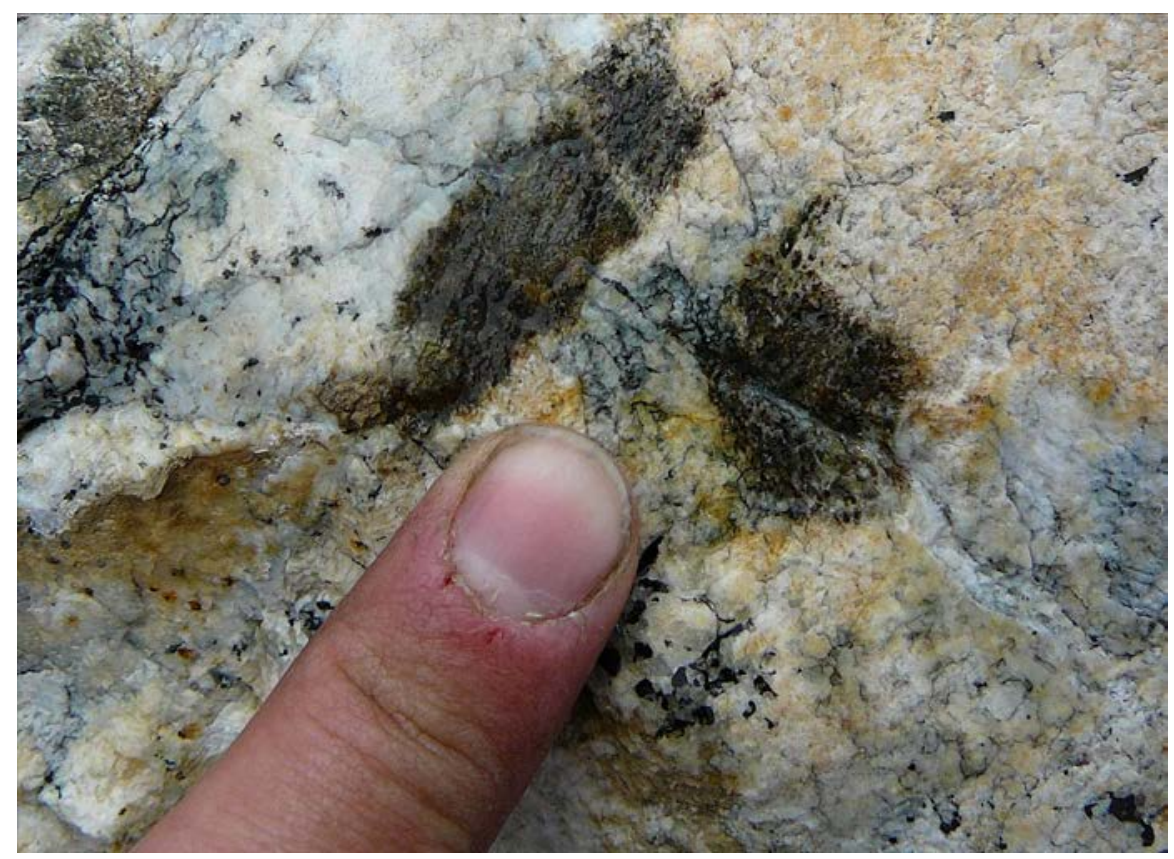

Figure 3.55b: A cordierite-quartz intergrowth in an unmapped pegmatite.

\subsection{Summary}

In general, the pegmatites in the study area are long and narrow bodies, with most having dimensions less than one meter wide with a length of at least $10 \mathrm{~m}$. Twenty of the bodies mapped exceed $50 \mathrm{~m}$ in length, whereas seven pegmatites were less than $10 \mathrm{~m}$ in length. Nearly all strike between $295^{\circ}$ and $330^{\circ}$ with a subvertical dip. These orientations appear to be controlled by exhumation-related shear zones that were previously mapped by other workers.

The most basic mineral assemblages observed in the pegmatites are quartz + feldspar + black tourmaline or quartz + feldspar + biotite (e.g., SIMPLE2, SIMPLE3, and SIMPLE4). Intermediate assemblages add muscovite, garnet, beryl, cordierite, and oxides to the basic assemblage (e.g., BERYL, TOUR, and CORD). Highly fractionated assemblages (e.g. GARPHOS, LI, and LI2) contain all of these features as well as phosphates other than apatite, monazite, and xenotime; lepidolite; and multi-colored tourmaline.

Many pegmatites exhibit subtle zoning with blockier cores than fine-grained border zones. Intermediate and core zones usually display increasing fractionation. Where quartz is a major component of the core of the dike, some of the quartz may be the variety rose quartz. 


\section{Chapter 4: Whole-Rock Geochemistry}

Nine hand samples were taken at intervals from the central part of the fine-grained, primitive GRANITE pegmatite (Fig. 4.1). The reason for collecting samples from the GRANITE pegmatite is two-fold: (1) analyses for major and trace elements allow for the assessment of the fractionation of the dike and (2) since the dike stretches through a significant portion of the study area (Fig. 3.1 \& Appendix A), the analyses provide a baseline fractionation trend for all of the pegmatites. The selected samples were largely free from signs of weathering and despite their small size (each weighing less than one kilogram), were reasonably representative of the GRANITE pegmatite at the sample location. Bulk sampling from the pegmatite was not feasible due to weight restrictions. The whole-rock geochemistry results can be seen in Table 4.1 and Table 4.2 .

In Figure 4.2, the $\mathrm{Zr} / \mathrm{Hf}, \mathrm{Nb} / \mathrm{Ta}, \mathrm{Na} / \mathrm{K}$, and $\mathrm{Rb} / \mathrm{Sr}$ ratios were plotted against the sample locality to assess overall fractionation trends. Decreases in the $\mathrm{Zr} / \mathrm{Hf}, \mathrm{Nb} / \mathrm{Ta}$, and $\mathrm{Na} / \mathrm{K}$ ratios ratios indicate increasing fractionation, whereas increasing $\mathrm{Rb} / \mathrm{Sr}$ ratios indicate increasing fractionation in peraluminous granites and pegmatites (London 2008). The $\mathrm{Zr} / \mathrm{Hf}$ ratio shows a marked decrease from the southeast to northwest sample sites in the GRANITE pegmatite, whereas the decrease in the $\mathrm{Nb} / \mathrm{Ta}$ and $\mathrm{Na} / \mathrm{K}$ ratios is more subtle. The $\mathrm{Rb} / \mathrm{Sr}$ shows a dramatic increase along the southeast to the northwest end of the pegmatite. The results show that the overall fractionation of the pegmatite increases somewhat towards the northwest.

Similar trends suggesting increasing fractionation can be observed in Figure 4.3, although the results are much more variable. Concentrations of $\mathrm{Li}, \mathrm{Be}, \mathrm{Cs}$, and $\mathrm{Pb}$ can be expected to increase with increasing fractionation for S-type granites (London 2008, Finger \& Schiller 2012). Likewise, the aluminum saturation index (ASI; ASI $=\operatorname{mol~Al}_{2} \mathrm{O}_{3} /\left(\mathrm{Na}_{2} \mathrm{O}+\mathrm{K}_{2} \mathrm{O}+\mathrm{CaO}-1.67 \times\right.$ $\left.\mathrm{P}_{2} \mathrm{O}_{5}\right)$ ) can also be expected to increase for S-type granites and pegmatites with increasing fractionation (Chappell \& White 1992). Upon careful inspection, concentrations of the trace elements of $\mathrm{Li}, \mathrm{Be}, \mathrm{Cs}$, and $\mathrm{Pb}$ increase somewhat in the pegmatite from the southeast to the northwest. Similarly, the ASI shows a slight overall increase.

The variability in the trends can be explained by localized abundances of accessory mineral phases. In particular, this variable concentration trend stands out for sample site 12-GRANITES03 in which elevated P and F concentrations are observed (Fig. 4.4). These correlate with a high 
abundance of apatite (Fig. 4.5). Locally abundant tourmaline is also likely responsible for the fluctuating concentration of B (Fig. 4.4 and 4.6). Local abundances of certain minerals, such as apatite and tourmaline, are likely caused by larger fluctuations in the geochemistry of the dike. Chondrite normalized concentrations of rare earth elements using values from McDonough \& Sun (1995) show both positive and negative Eu anomalies irregularly spaced within the dike (Fig. 4.7). The $\mathrm{Eu} / \mathrm{Eu}^{*}$ ratio reflects the variable Eu anomaly whereas the $\mathrm{La} / \mathrm{Yb}$ ratio shows a slight overall decrease from the southeast to the northwest, following the general fractionation trend of the pegmatite (Fig. 4.8). This may indicate uneven fractionation within the dike or possibly localized accumulations of fluid-rich melt (T. Chudy, pers. commun.). An alternative explanation may be that the composition of the GRANITE pegmatite is closely linked to the variations of composition within the source material. According to Finger \& Schiller (2012), a relatively horizontal spread within a Pb-Ba diagram (Fig. 4.9) may show that the composition of granitic rock is determined by the composition of the source rock with little fractionation occurring in the resulting magma.

In general, the geochemical data shows that the GRANITE pegmatite fractionates from the southeast to the northwest, in a manner consistent with S-type granites. The quantities of trace elements are highly variable, reflecting locally abundant minerals. It is possible that the patterns of mineralization could be controlled either by fluctuating degrees of fractionation within the dike, localized fluid accumulation, or perhaps mirroring the composition of the original source rock. The relatively small size of the samples also likely contributes to the large variation in concentration of some elements. 


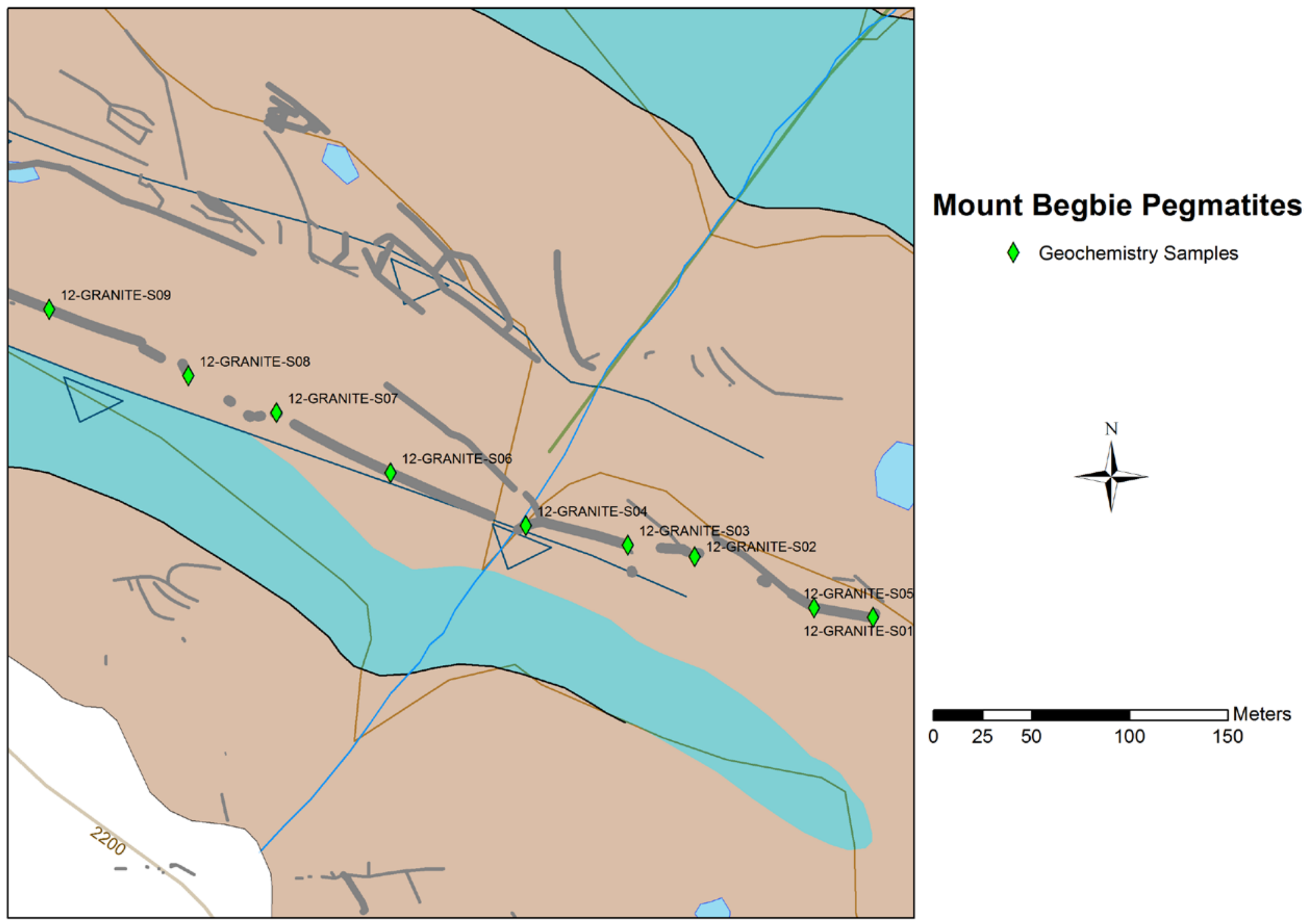

Figure 4.1: Location of sample sites for whole rock geochemistry. For a full explanation of the map contents, please see Appendix A. 
Table 4.1: Major element whole rock geochemistry for the GRANITE pegmatite (samples organized from east to west).

\begin{tabular}{|c|c|c|c|c|c|c|c|c|c|}
\hline Sample & $\begin{array}{l}12- \\
\text { GRANITE- } \\
\text { S01 }\end{array}$ & $\begin{array}{l}12- \\
\text { GRANITE- } \\
\text { S05 }\end{array}$ & $\begin{array}{l}12- \\
\text { GRANITE- } \\
\text { S02 }\end{array}$ & $\begin{array}{l}12- \\
\text { GRANITE- } \\
\text { S03 }\end{array}$ & $\begin{array}{l}12- \\
\text { GRANITE- } \\
\text { S04 }\end{array}$ & $\begin{array}{l}12- \\
\text { GRANITE- } \\
\text { S06 }\end{array}$ & $\begin{array}{l}12- \\
\text { GRANITE- } \\
\text { S07 }\end{array}$ & $\begin{array}{l}12- \\
\text { GRANITE- } \\
\text { S08 }\end{array}$ & $\begin{array}{l}12- \\
\text { GRANITE- } \\
\text { S09 }\end{array}$ \\
\hline Description & Pegmatite* & Pegmatite & $\begin{array}{c}\text { Foliated } \\
\text { Pegmatite }^{\S}\end{array}$ & Pegmatite & Pegmatite & Pegmatite & Pegmatite & Pegmatite & Pegmatite \\
\hline
\end{tabular}

\begin{tabular}{|c|c|c|c|c|c|c|c|c|c|}
\hline $\mathrm{P}_{2} \mathrm{O}_{5} \mathrm{wt} . \%$ & 0.052 & 0.103 & 0.067 & 1.322 & 0.115 & 0.11 & 0.074 & 0.119 & 0.148 \\
\hline $\mathrm{SiO}_{2}$ & 71.08 & 71.79 & 73.64 & 70.53 & 72.65 & 73.22 & 74.22 & 73.23 & 72.63 \\
\hline $\mathrm{TiO}_{2}$ & 0.04 & 0.02 & 0.04 & 0.01 & 0.01 & 0.03 & 0.03 & 0.02 & 0.01 \\
\hline $\mathrm{Al}_{2} \mathrm{O}_{3}$ & 16.83 & 15.14 & 15.17 & 14.99 & 14.59 & 14.35 & 14.72 & 14.66 & 14.54 \\
\hline $\mathrm{Cr}_{2} \mathrm{O}_{3}$ & $<0.01$ & $<0.01$ & $<0.01$ & $<0.01$ & $<0.01$ & $<0.01$ & $<0.01$ & $<0.01$ & $<0.01$ \\
\hline $\mathrm{Fe}_{2} \mathrm{O}_{3}$ & 0.18 & 0.10 & 0.15 & $<0.01$ & 0.05 & 0.06 & 0.26 & $<0.01$ & 0.04 \\
\hline $\mathrm{MgO}$ & 0.38 & 0.09 & 0.26 & 0.11 & 0.17 & 0.09 & 0.11 & 0.17 & 0.13 \\
\hline $\mathrm{CaO}$ & 2.33 & 0.76 & 1.32 & 3.16 & 0.26 & 0.34 & 0.36 & 0.94 & 0.23 \\
\hline $\mathrm{MnO}$ & $<0.01$ & $<0.01$ & $<0.01$ & 0.02 & $<0.01$ & $<0.01$ & $<0.01$ & $<0.01$ & $<0.01$ \\
\hline $\mathrm{FeO}$ & 0.70 & 0.32 & 0.57 & 0.38 & 0.64 & 0.32 & 0.45 & 0.45 & 0.32 \\
\hline $\mathrm{Na}_{2} \mathrm{O}$ & 4.46 & 2.45 & 2.88 & 3.01 & 2.08 & 2.16 & 3.59 & 2.57 & 1.88 \\
\hline $\mathrm{K}_{2} \mathrm{O}$ & 2.73 & 8.24 & 4.88 & 5.70 & 8.53 & 8.54 & 4.99 & 6.75 & 9.22 \\
\hline $\mathrm{BaO}$ & 0.03 & 0.04 & 0.03 & 0.02 & 0.05 & 0.05 & 0.02 & 0.02 & 0.04 \\
\hline $\mathrm{SrO}$ & 0.01 & 0.01 & 0.01 & 0.01 & 0.01 & 0.01 & 0.01 & 0.01 & 0.01 \\
\hline LOI & 0.73 & 0.70 & 0.84 & 0.47 & 0.50 & 0.40 & 0.89 & 0.68 & 0.32 \\
\hline Total & 99.55 & 99.76 & 99.86 & 99.73 & 99.66 & 99.68 & 99.72 & 99.62 & 99.52 \\
\hline
\end{tabular}

Note: Sample analyses were conducted by ALS Minerals in North Vancouver, B.C. The samples were analyzed for the major elements using XRF; the amount of $\mathrm{FeO}$ was established by $\mathrm{H}_{2} \mathrm{SO}_{4}-\mathrm{HF}$ acid digestion and titrimetric finish. ${ }^{*} \mathrm{Pegmatite}$ sample from small dike occurring directly beneath the main dike. ${ }^{\delta}$ Foliated pegmatite part of the main dike with an appearance similar to an orthogneiss. 
Table 4.2: Minor element whole rock geochemistry for the GRANITE pegmatite (samples organized from east to west).

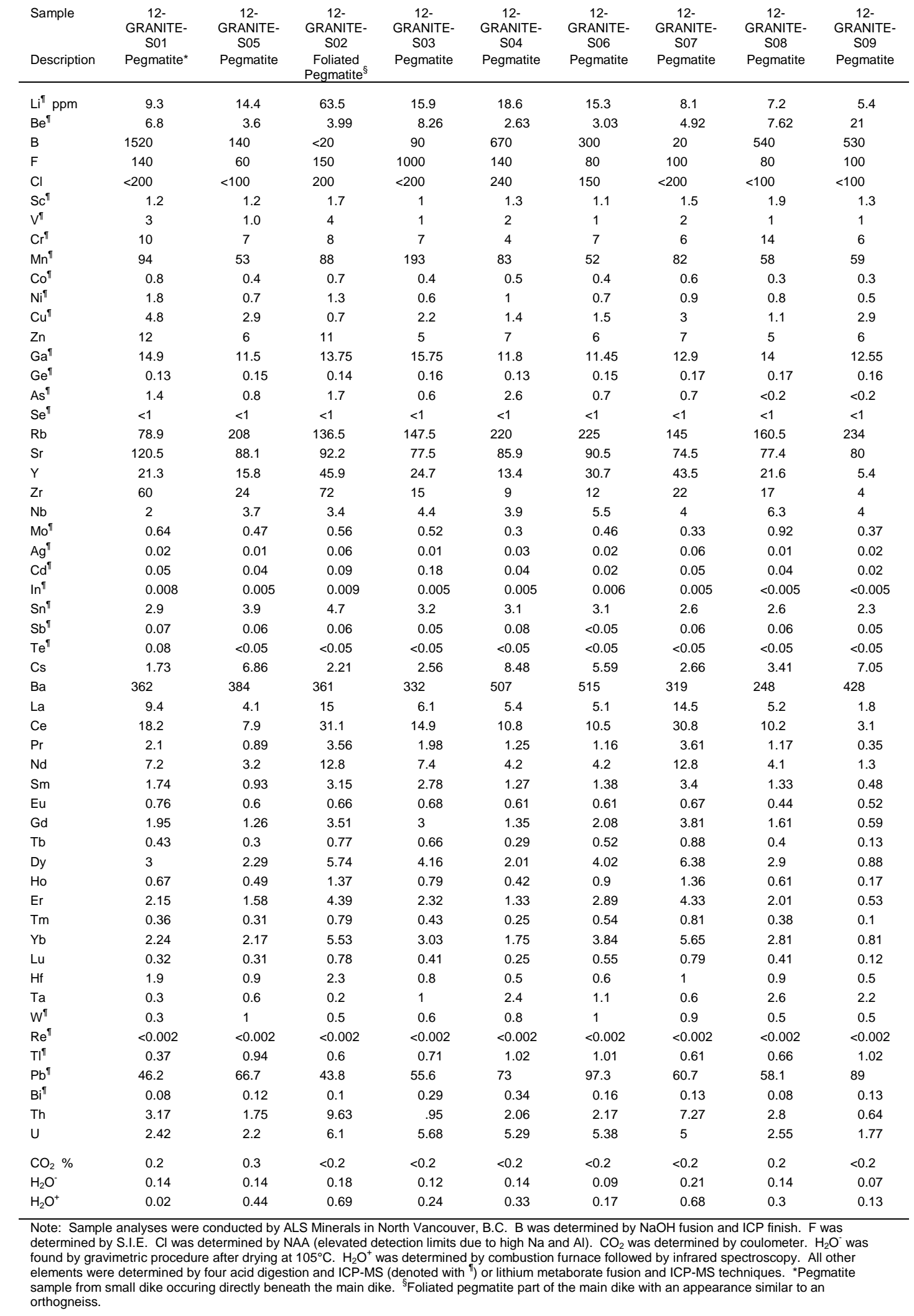



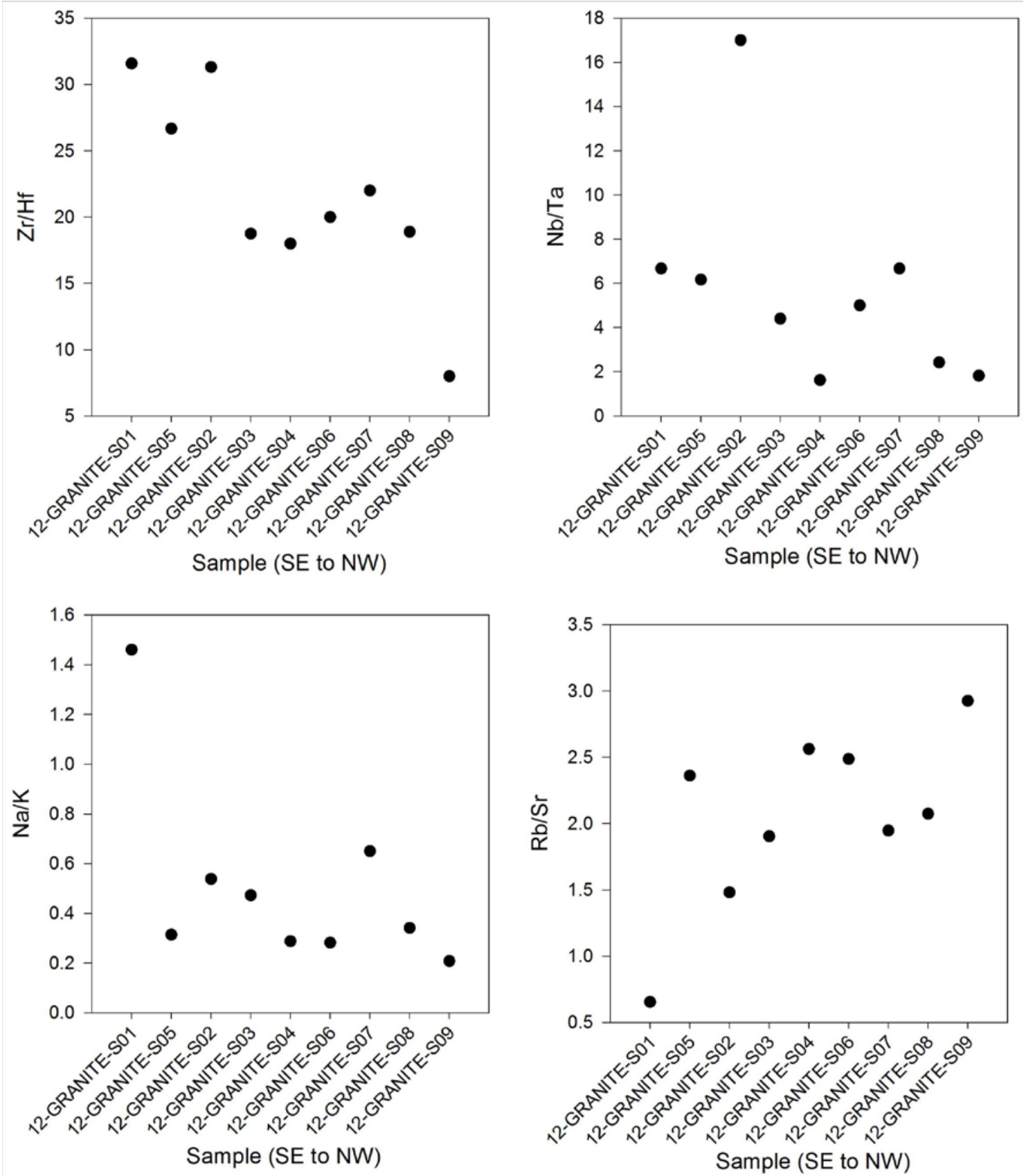

Figure 4.2: Element ratios indicating increasing fractionation to the northwest for the GRANITE pegmatite. 

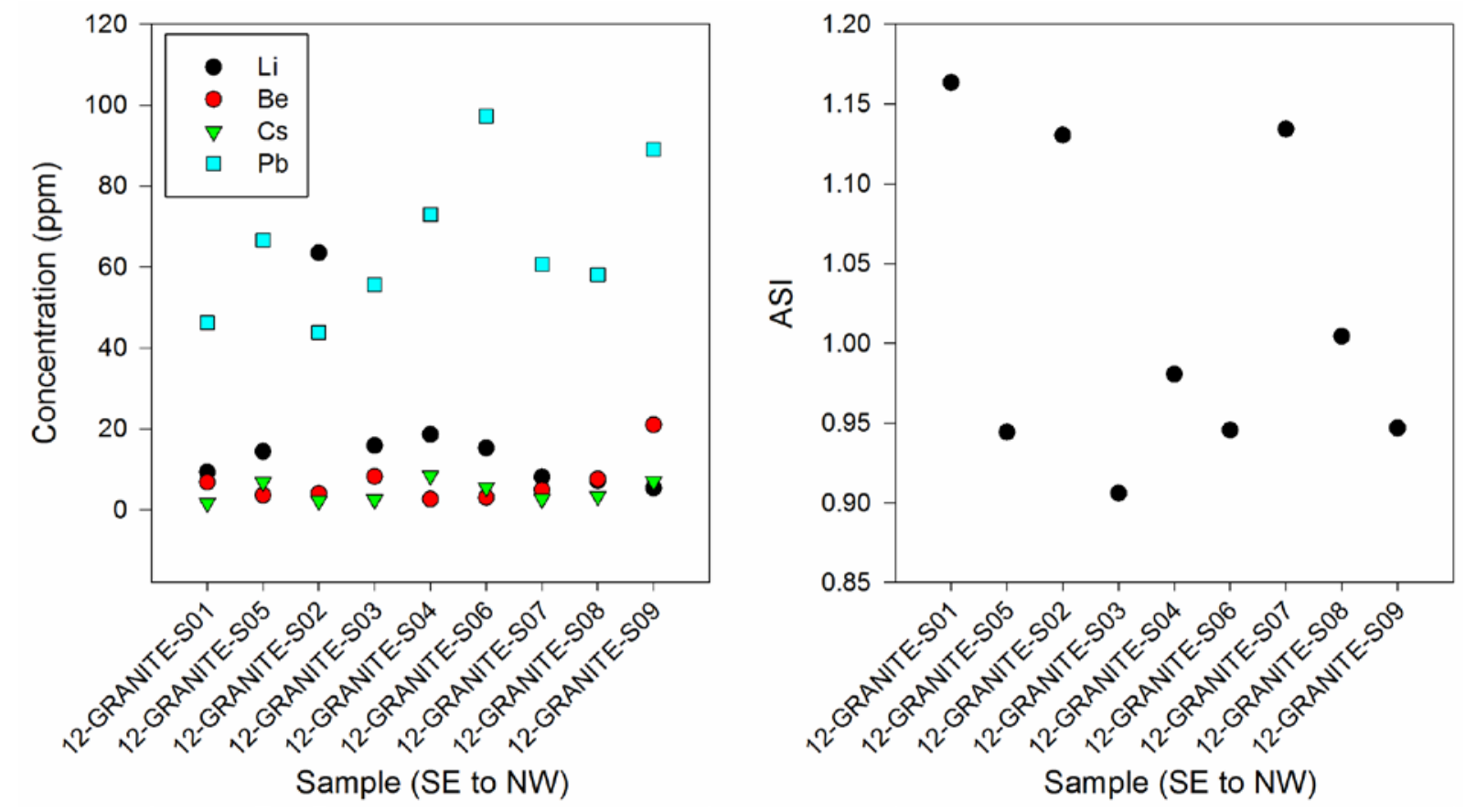

Figure 4.3: Other fractionation indicators (concentrations of $\mathrm{Li}, \mathrm{Be}, \mathrm{Cs}$, and $\mathrm{Pb}$ and the ASI ratio), show subtle increases in fractionation from the southeast to the northwest.

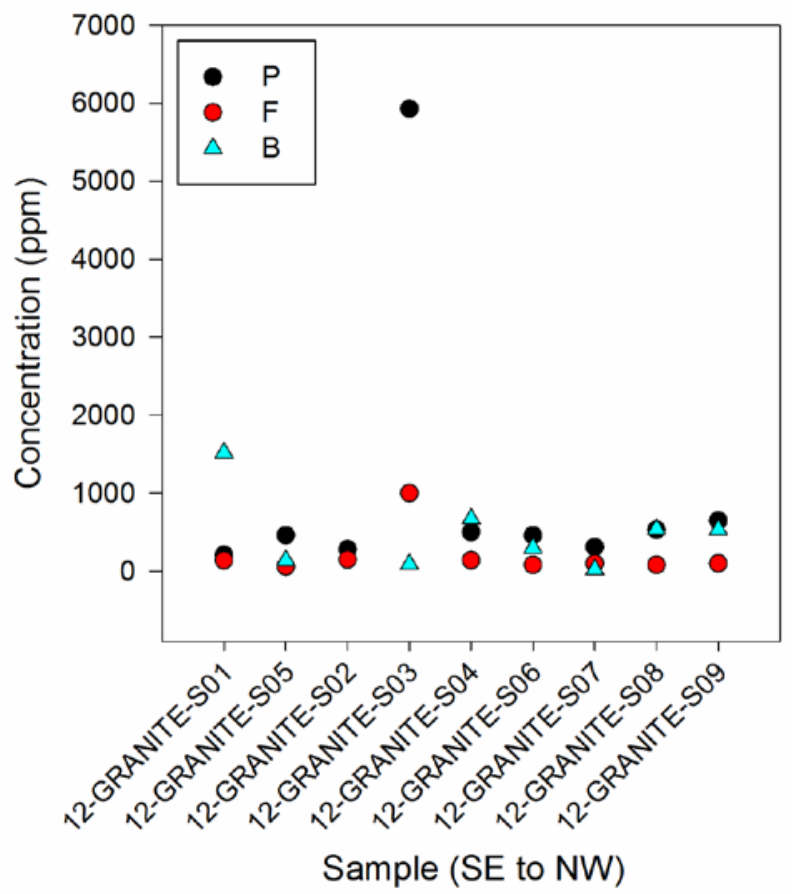

Figure 4.4: The spike in concentration of $\mathrm{P}$ and $\mathrm{F}$ at sample 12-GRANITE-S03 is likely caused by the abundant apatite observed in the sample. Likewise, the variable concentration B correlates with observed abundances of tourmaline observed in the field and hand sample. B was below the detection limit for 12-GRANITE-S02. 


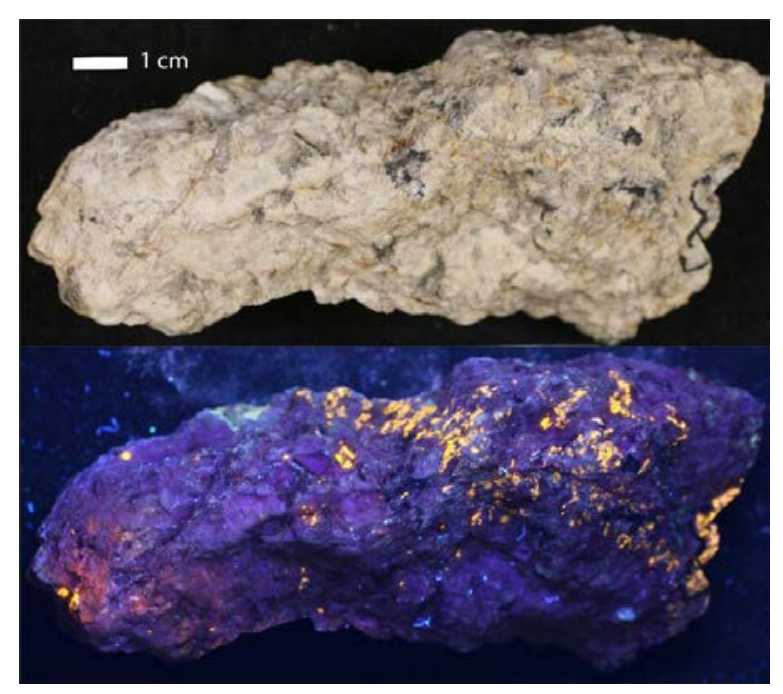

Figure 4.5: A representative hand sample from 12-GRANITE-S03 in plain light (top) and under short-wave UV light (bottom). Apatite is nearly colorless under plain light and fluoresces orange yellow under short-wave UV light. Black minerals in plain light are tourmaline and biotite. The abundance of apatite at this site likely contributed to elevated P and F concentrations.

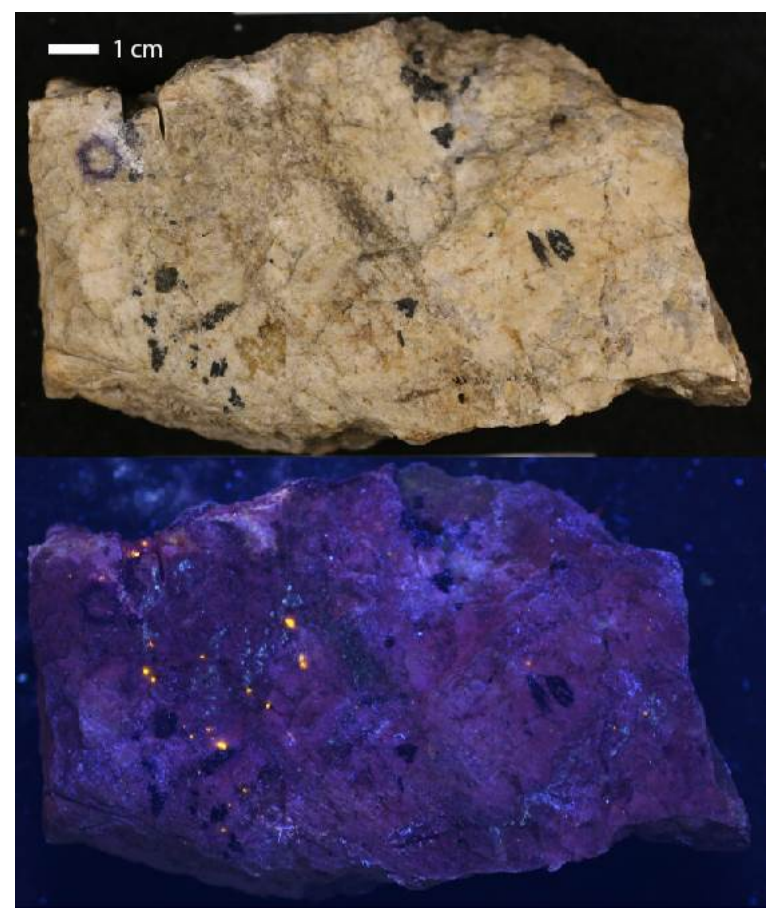

Figure 4.6: A representative hand sample from 12-GRANITE-S09 plain light (top) and under short-wave UV light (bottom). Black minerals in plain light are tourmaline crystals. Apatite is nearly colorless under plain light and fluoresces orange yellow under short-wave UV light. . The abundance of tourmaline at this site likely contributed to elevated B concentrations. 


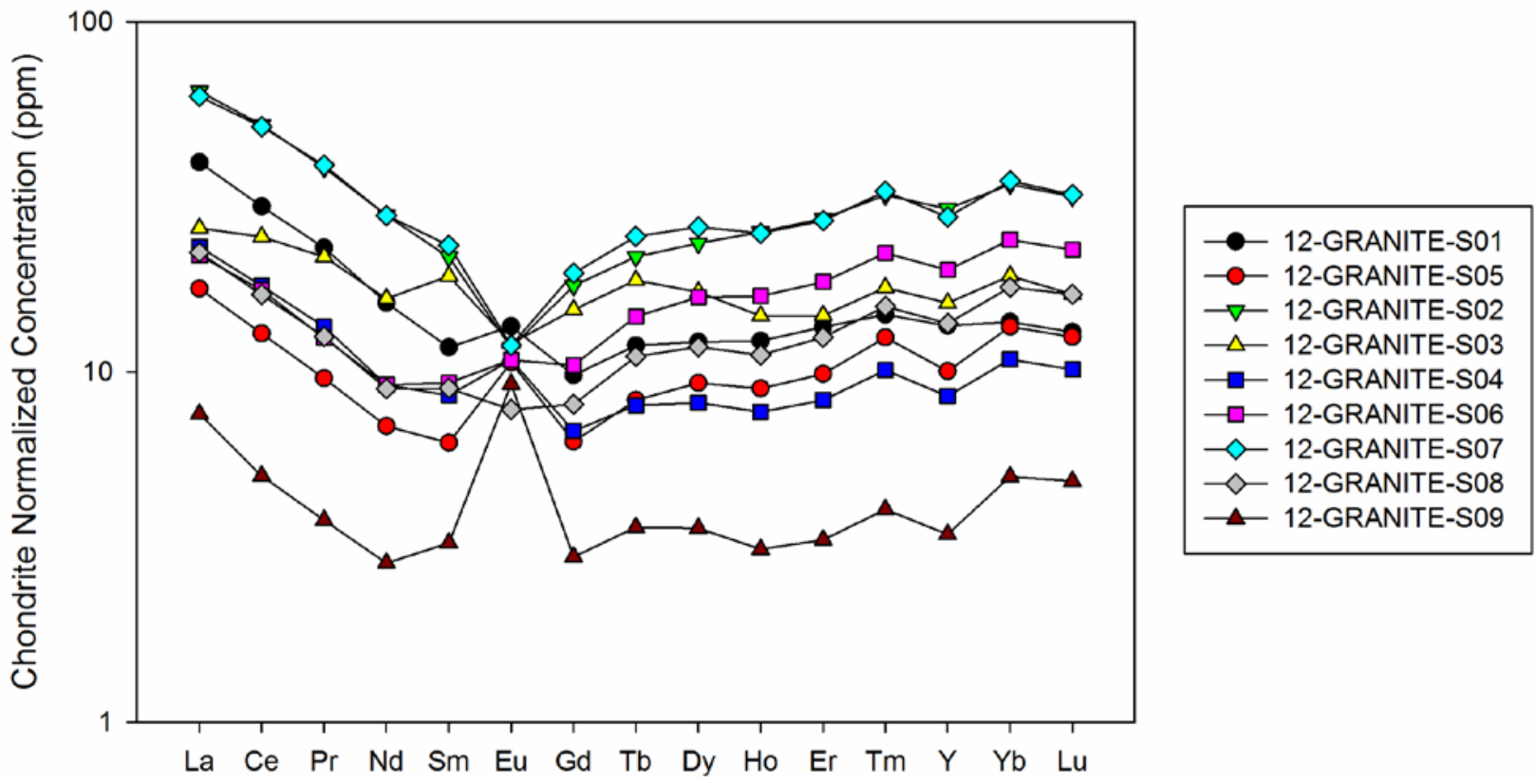

Figure 4.7: Chondrite normalized concentrations of the rare earth elements including Y. Note the both strongly positive and negative anomaly for Eu.

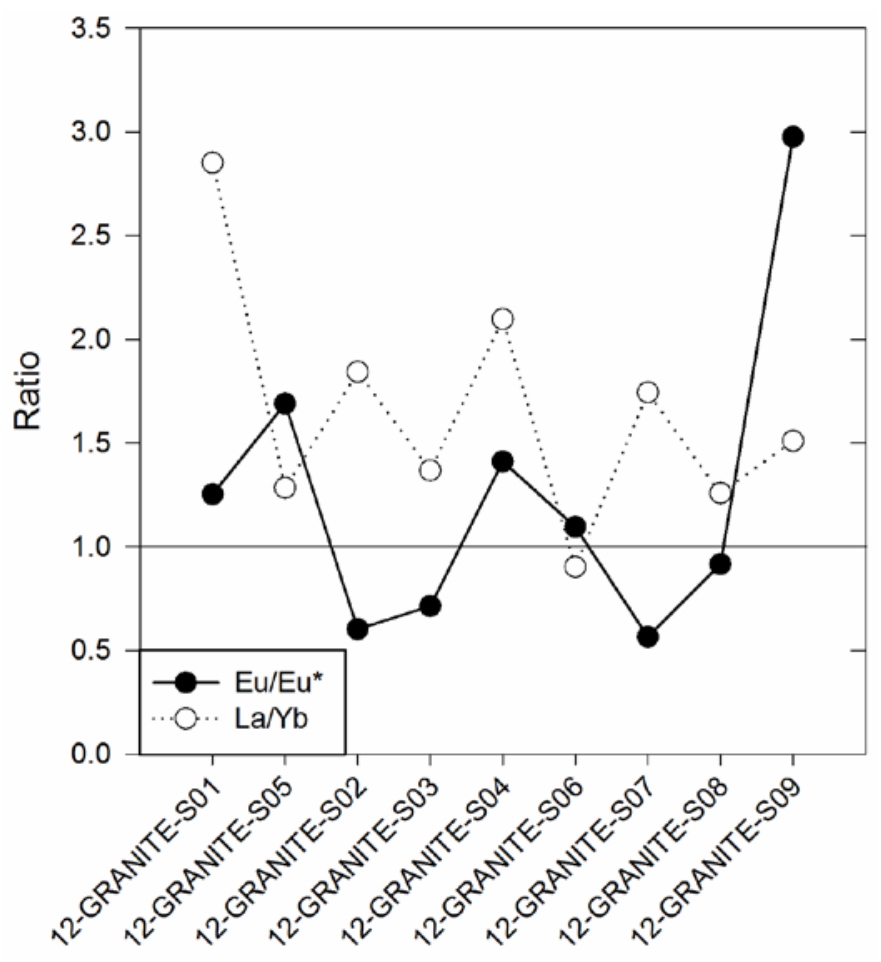

Sample (SE to NW)

Figure 4.8: $\mathrm{The} \mathrm{Eu} / \mathrm{Eu}^{*}$ and $\mathrm{La} / \mathrm{Yb}$ ratios. 


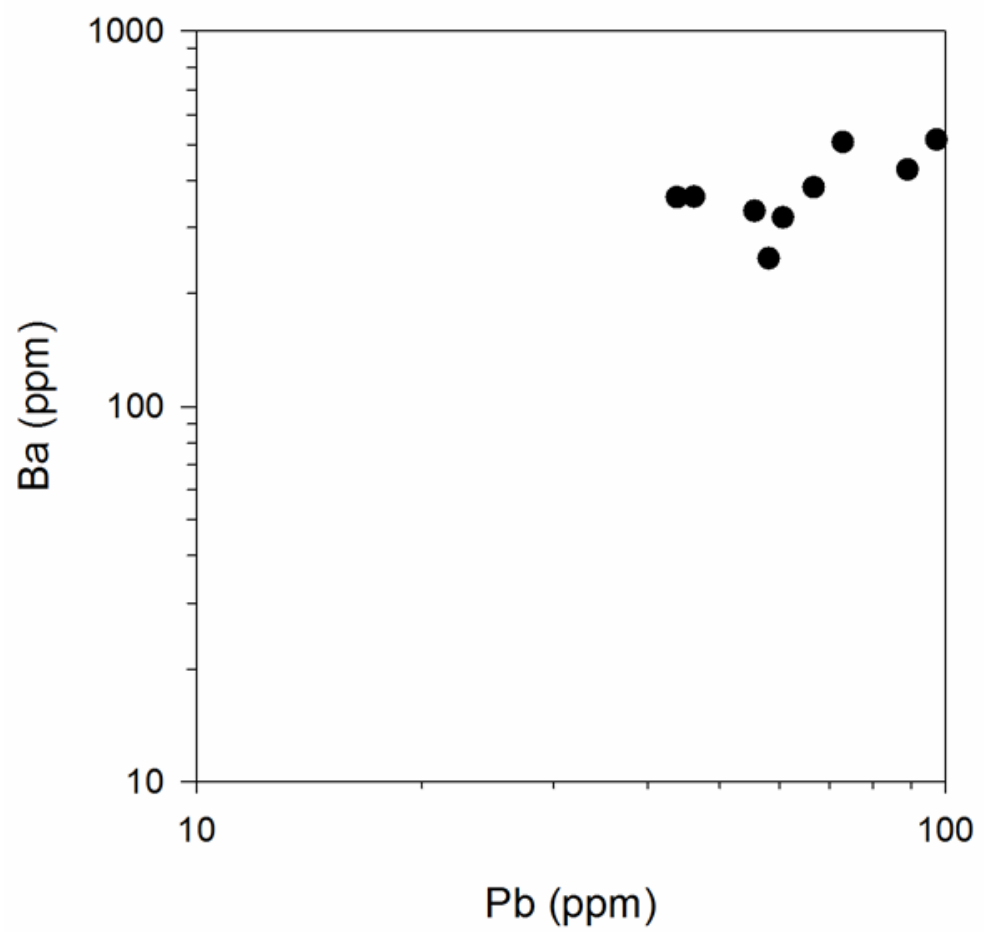

Figure 4.9: $\mathrm{Pb}-\mathrm{Ba}$ diagram showing a relatively horizontal spread of values. 


\section{Chapter 5: Mineralogy}

A wide range of the principal minerals of the pegmatites were examined in hand sample and in thin section combined with the use of a scanning electron microscope (SEM) equipped with an energy-dispersion X-ray spectrometer (EDS), and an electron microprobe (EMP). Some mineral phases, such as phosphates and secondary minerals, were identified using single crystal and powder X-Ray diffraction before being studied with the SEM and EMP. This was done in order to identify the minerals present within the dikes and to delineate fractionation trends within the pegmatite field. The methodology and full results of these analyses can be found in Appendix B, C, and D.

\subsection{Tourmaline}

Tourmaline was examined in detail because it is well suited to charting pegmatite fractionation as it can accommodate numerous varieties of elements in its crystal structure. Growing tourmaline crystals incorporate new elements into its structure based upon the evolving bulk composition of the cooling pegmatite melt and minute compositional fluctuations at the crystal-melt boundary (van Hinsberg et al. 2011). The tourmaline supergroup has the following general formula, site coordinations, and common substitutions:

$$
\begin{aligned}
& \mathrm{XY}_{3} \mathrm{Z}_{6}\left[\mathrm{~T}_{6} \mathrm{O}_{18}\right]\left[\mathrm{B} \mathrm{O}_{3}\right]_{3} \mathrm{~V}_{3} \mathrm{~W} \\
& { }^{\mathrm{IX}} \mathrm{X}=\mathrm{Ca}^{+2}, \mathrm{Na}^{+1}, \mathrm{~K}^{+1}, \mathrm{~Pb}^{+2}, \square \\
& { }^{\mathrm{VI}} \mathrm{Y}=\mathrm{Mg}^{+2}, \mathrm{Fe}^{+2}, \mathrm{Al}^{+3}, \mathrm{Li}^{+1}, \mathrm{Ti}^{+4}, \mathrm{Mn}^{+2}, \mathrm{Fe}^{+3}, \mathrm{Zn}^{+2} \\
& { }^{\mathrm{VI}} \mathrm{Z}=\mathrm{Al}^{+3}, \mathrm{Cr}^{+3}, \mathrm{Fe}^{+3}, \mathrm{Mg}^{+2}, \mathrm{~V}^{+3} \\
& { }^{\mathrm{IV}} \mathrm{T}=\mathrm{Si}^{+4}, \mathrm{~B}^{+3}, \mathrm{Al}^{+3} \\
& { }^{\mathrm{III}} \mathrm{B}=\mathrm{B}^{+3} \\
& { }^{\mathrm{IV}} \mathrm{V}=\mathrm{OH}^{-1}, \mathrm{O}^{-2} \\
& { }^{\mathrm{II}} \mathrm{W}=\mathrm{OH}^{-1}, \mathrm{~F}^{-1}, \mathrm{O}^{-2}
\end{aligned}
$$


Classification of tourmaline is based first on the occupancy of the X site, then on occupancy in the W site, and lastly on the occupancy of the Y site (Henry et al. 2011, van Hinsberg et al. 2011).

The tourmaline species present in a pegmatite vary somewhat by the composition of the host rock and by the pegmatite type. Composition of tourmaline can be influenced by fluids circulating into the pegmatite from the host rock. It is not unreasonable to expect that the tourmaline will be enriched in the same elements as the host rock (Selway 1999).

The composition of the pegmatite melt is usually a greater controlling factor in tourmaline evolution rather than fluid circulation from the host rock. For example, in lepidolite subtype pegmatites, the tourmaline species expected to be present are foitite-schorl, schorl-foitite, elbaiteschorl, elbaite, elbaite-rossmanite, rossmanite-elbaite, and elbaite from the outermost to innermost zones of the pegmatite, respectively (Selway 1999). In more primitive pegmatite types, the tourmaline species can be expected to be fairly uniform and homogeneous, existing mainly as part of the schorl-dravite series (Robles et al. 1999, Lottermoser \& Lu 1997).

\subsubsection{Description}

Generally, the tourmaline in the study area is black and ranges from very fine $(<1 \mathrm{~mm}$; border zones and JAN aplites) to very coarse grained ( $30 \mathrm{~cm}$ long; BERYL pegmatite). Colored tourmaline can be perceived in the core zones of the CORD (blue), GARPHOS (black with green rims), LI and LI2 (black with blue-green rims, pink, and green) pegmatites. Crystals are usually discrete rather than intergrowths or aggregates, oriented perpendicular to the border zones or xenoliths, prismatic, subhedral to euhedral, and apparently homogeneous. Tourmaline crystals from the JAN aplites and from the central portions of many pegmatites have orientations that appear to be more random. Blue tourmaline aggregates were observed in the CORD pegmatite and tourmaline-quartz intergrowths were relatively common features in the GRANITE and WOBBLE pegmatites.

Another common feature to all tourmaline specimens from the study area is well-developed parting. In most samples examined, at least two parting planes were encountered: a very strongly developed parting plane perpendicular to the $\mathbf{c}$ axis and a lesser-developed parting plane oriented subparallel to the $\mathbf{c}$ axis. The partings are occasionally filled with secondary micas, iron 
oxides, and quartz (Fig. 5.1). The development of partings indicates that there was deformation throughout the field sometime after the tourmaline crystallized.

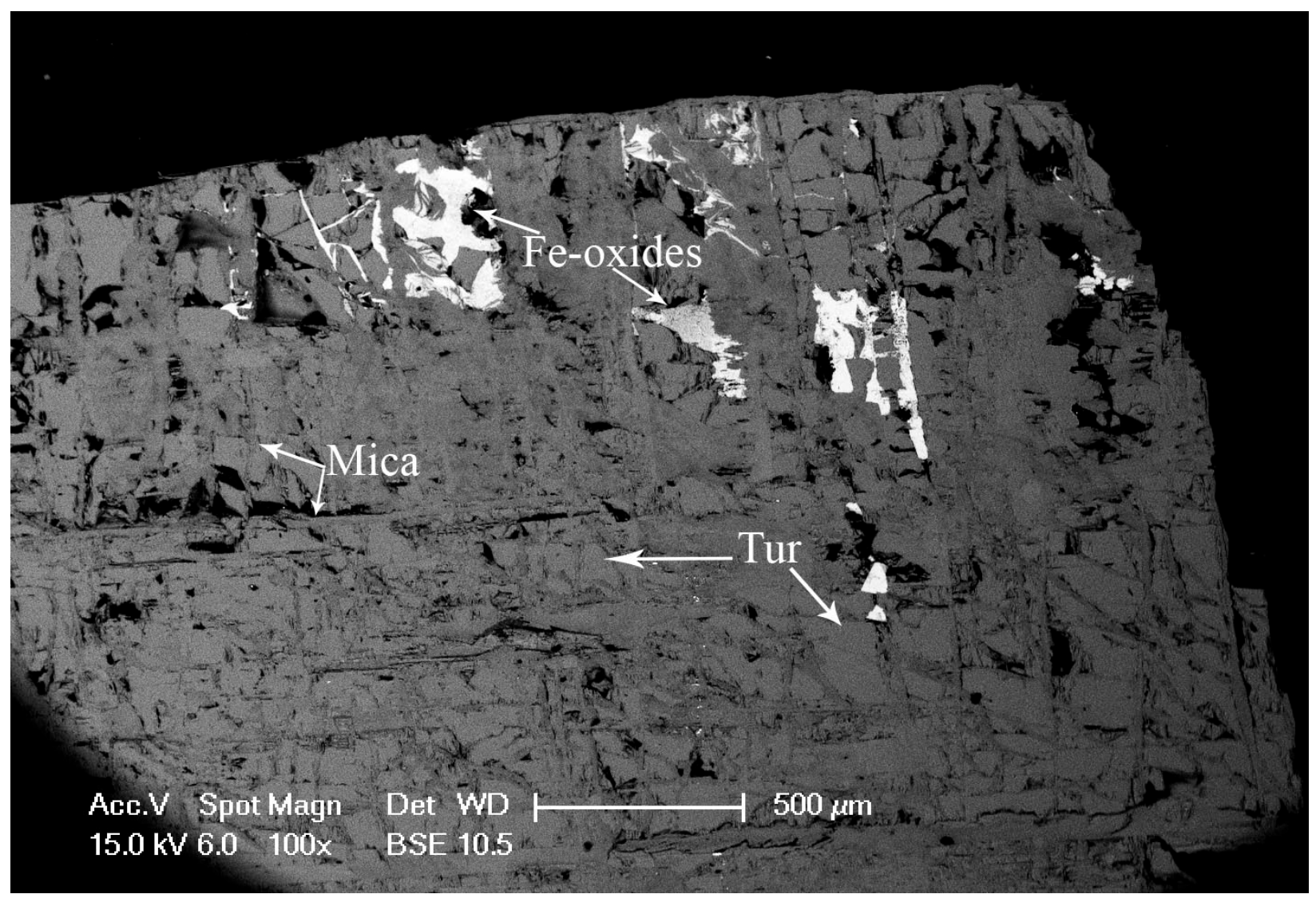

Figure 5.1: A BSE image of a tourmaline crystal from the BERYL pegmatite in which secondary mica and Fe-oxides can clearly be seen within the vertically and horizontally oriented partings.

Typically it is difficult to see any features (such as zoning) that might be indicative of chemical change of the environment surrounding it during crystallization in hand sample but it can be seen in the more fractionated pegmatites. As already mention above, the GARPHOS pegmatite contains crystals of tourmaline with black cores and green rims; in the slender pink and green tourmaline from the LI and LI2 pegmatites, white to pale pink cores in green tourmaline and clear rims on pink tourmaline can be distinguished.

Despite being difficult to observe in most areas in the field, zoning is a relatively common feature of the tourmaline and is often revealed in thin section or in back-scattered electron (BSE) 
images (Fig. 5.2). The chemical zoning is most pronounced in the $X_{M g}$ ratio $\left[X_{M g}=M g /(M g+\right.$ $\mathrm{Fe}+\mathrm{Mn})]$ in geochemically primitive pegmatites; the tourmaline from Li-bearing fractionated pegmatites also exhibits high variations in the $\mathrm{X}_{\mathrm{Mn}}$ ratio $\left[\mathrm{X}_{\mathrm{Mn}}=\mathrm{Mn} /(\mathrm{Mg}+\mathrm{Fe}+\mathrm{Mn})\right]$ and contents of $\mathrm{Li}+\mathrm{Al}$.
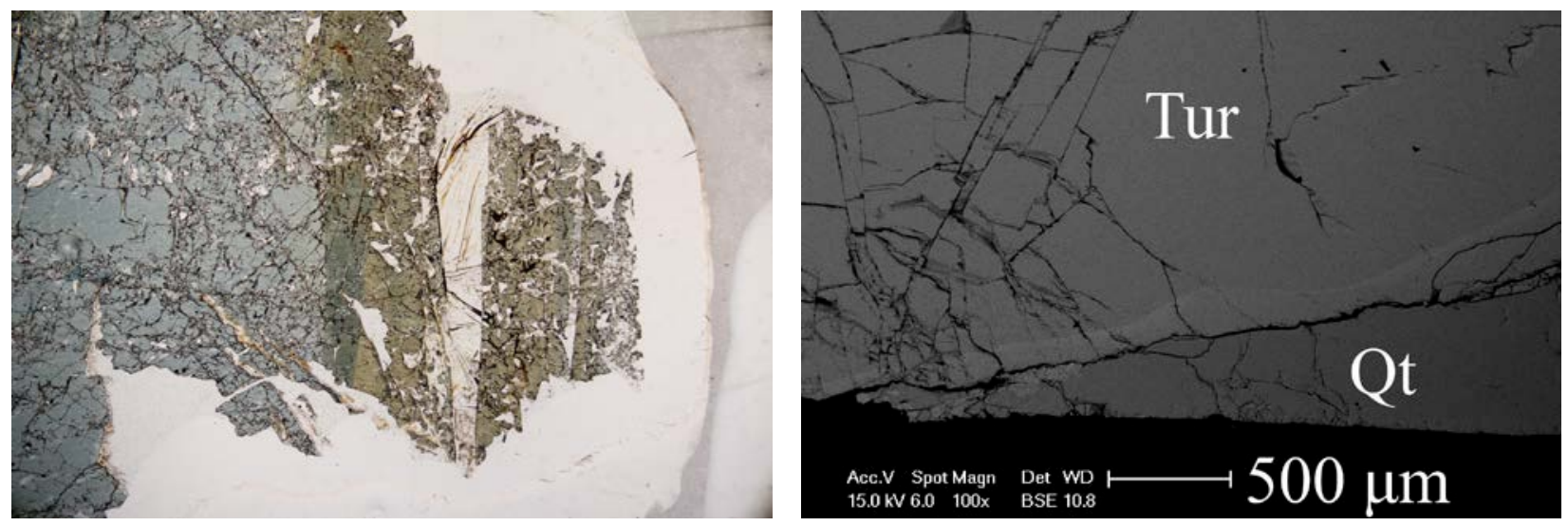

Figure 5.2: Left: Zoning seen in a thin section of a tourmaline crystal that appeared homogeneous in hand sample from BERYL. Field of view is $10 \mathrm{~mm}$. Right: Light gray wavy zoning seen in a BSE image of tourmaline crystal that appeared homogeneous in hand sample from GRANITE.

Another feature that is shared by many tourmaline crystals and is difficult to see while in the field is the incorporation of inclusions. While more infrequent than the presence of zoning, tourmaline crystals can sometimes contain inclusions of quartz, feldspar, primary biotite (partially replaced by the surrounding tourmaline), zircon, monazite, xenotime, columbite, and on very rare occasions bismutotantalite (Fig. 5.58).

Tourmaline crystals were examined from the BERYL, CORD, GAR, GARMUS, GARPHOS, GARTOUR, GRANITE, JAN, JUNCT, LENS, LENS2, LI, LI2, LONG, MUSC, PEGMA, POCKET, SIMPLE, SIMPLE2, SIMPLE3, SIMPLE4, SIMPLE5, SIMPLE6, SIMPLE7, SIMPLE9, SIMPLE11, SIMPLE12, SIMPLE13, SIMPLE14, SIMPLE16, SIMPLE17, SMALL, THIN, TOUR, TOURMUS, WOBBLE, and ZONED pegmatites. 


\subsubsection{The BERYL Pegmatite Tourmaline}

Border zone tourmaline from the BERYL pegmatite is Mg-rich schorl with the highest $\mathrm{X}_{\mathrm{Mg}}$ $(\sim 0.5)$ and $\mathrm{OH}$ contents from all tourmalines sampled in the pegmatite (Fig. 5.3). The tourmaline from the wall zone and intermediate zones (schorl, foitite, fluor-schorl) generally show increased X-site vacancy (towards foitite), Fe and Mn relative to the border zone tourmaline, as well as the calculated Li contents. In individual crystals, the F, Na, and Fe contents increase from the crystal core to the rim, changing from foitite to schorl to fluor-schorl. Tourmaline from the core of the pegmatite has the highest Fe content and shows a similar trend. The composition of the border zone tourmaline suggests Mg contamination of the primitive (low initial F content) pegmatite melt from the host rock. The tourmaline from the wall, intermediate, and core zones follows the fractionation of $\mathrm{Fe} / \mathrm{Mg}, \mathrm{F}$ and $\mathrm{Li}$ in the melt; contents of $\mathrm{Fe}, \mathrm{Li}$, and $\mathrm{F}$ increase from the pegmatite border to the core. 

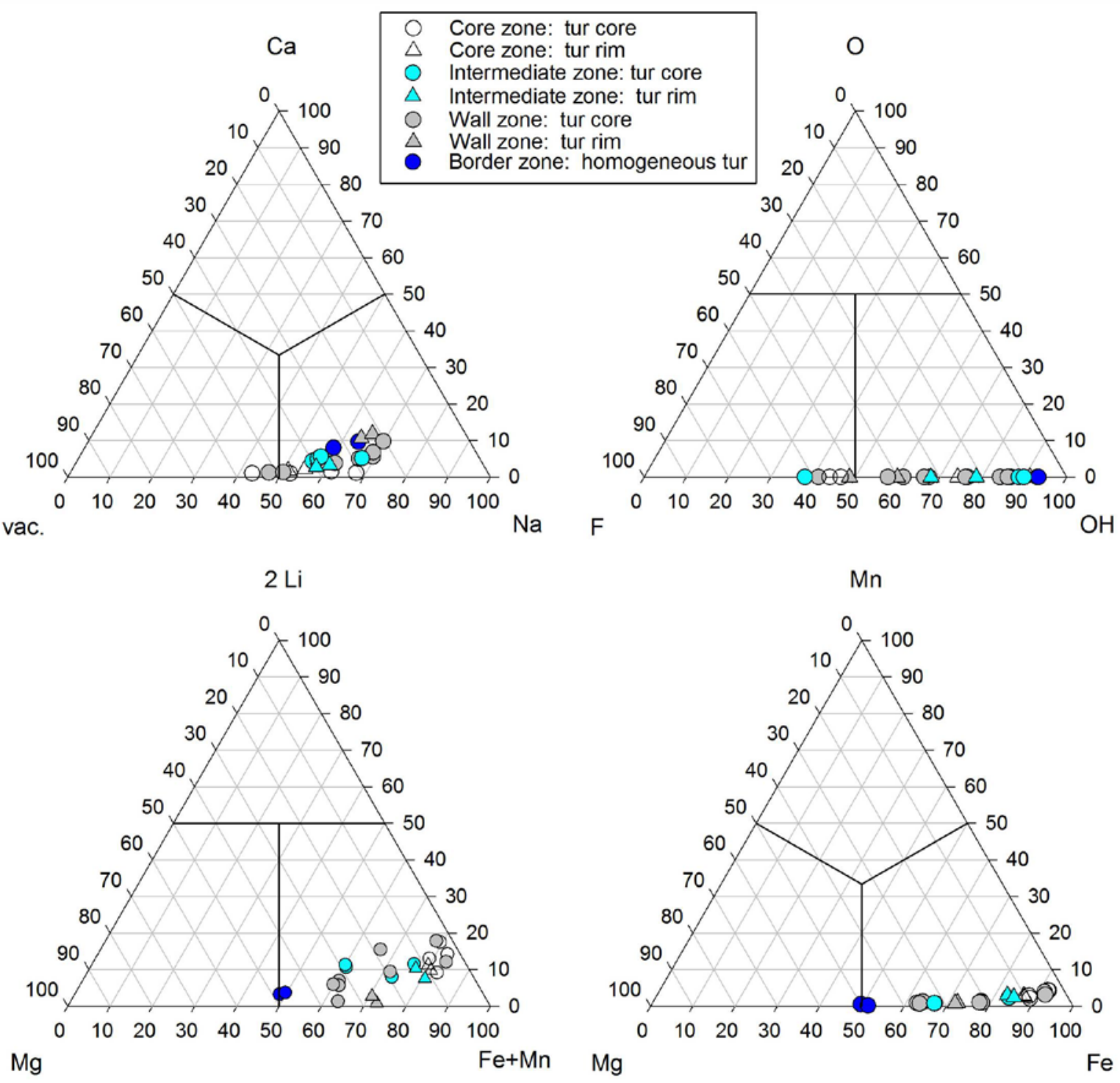

Figure 5.3: Ternary diagrams showing the classification of tourmaline sampled from the BERYL dike. 


\subsubsection{The CORD Pegmatite Tourmaline}

The examined tourmaline samples from the CORD pegmatite are compositionally zoned with Na, Mg-rich cores and ${ }^{X_{\square}}$, Fe-enriched rims (Fig. 5.4). The composition changes from dravite in crystal cores to schorl and foitite in crystal rims. The high calculated Li contents for all samples suggest that the pegmatite may be more fractionated than seen in this study. Some of the tourmaline samples from the center of the pegmatite are dark blue in color (Fig. 3.5c). Blue dravite with low levels of $\mathrm{Fe}^{3+}$ and $\mathrm{Ti}$ is typical for low-Li pegmatites as reported by Novák (1998).
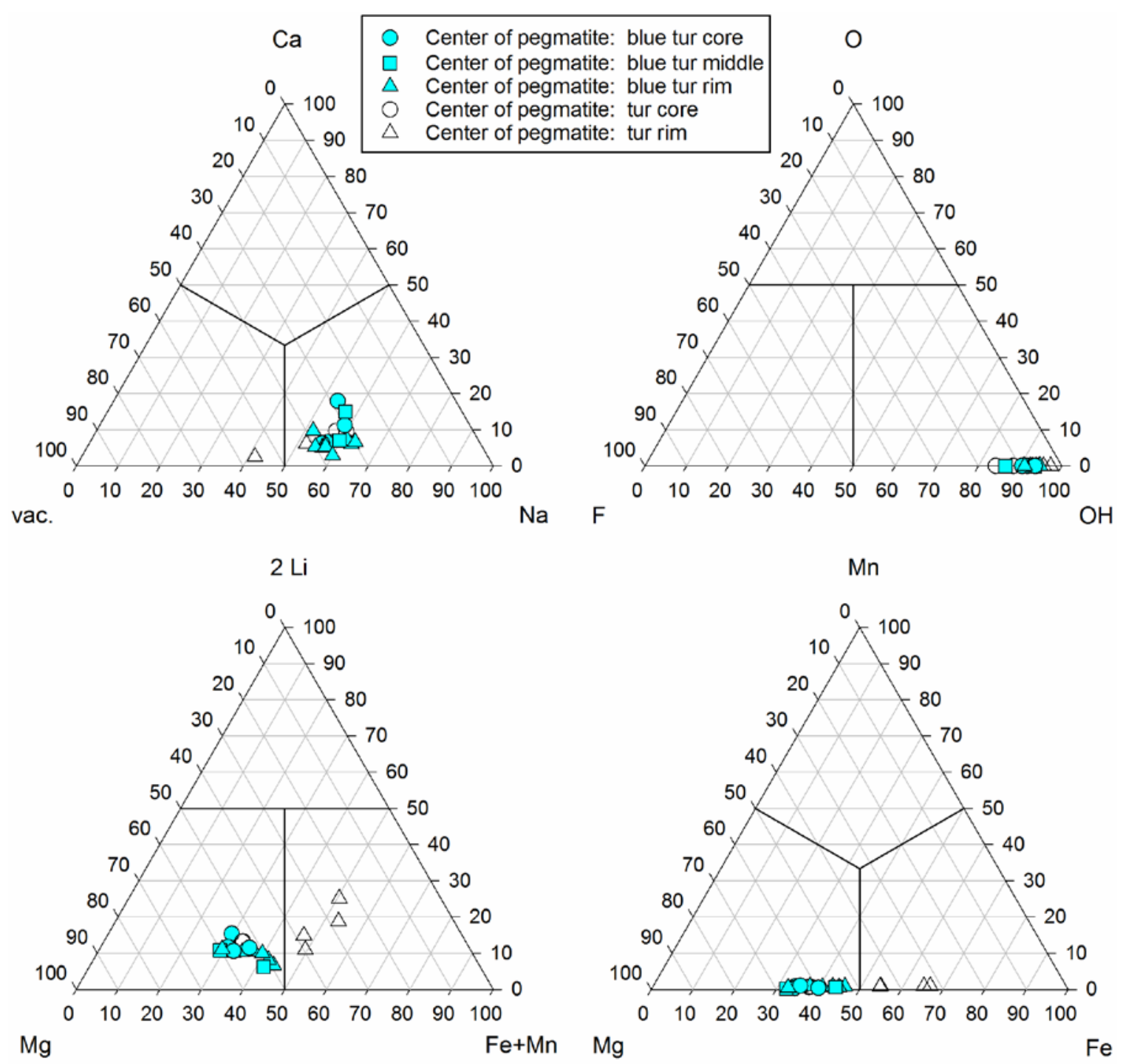

Figure 5.4: Ternary diagrams showing the classification of tourmaline sampled from the CORD dike. 


\subsubsection{The GAR Pegmatite Tourmaline}

Tourmaline studied from the GAR pegmatite is Na-rich and exhibits some compositional zoning, with increasing Fe content from the pegmatite border zone to the core; the composition changes from dravite to schorl (Fig. 5.5). Zoned tourmaline that is replacing sekaninaite follows the opposite trend with Fe-rich cores (schorl) and Mg-rich rims (Fe-rich dravite).

$\mathrm{Ca}, \mathrm{Al}$ and ${ }^{\mathrm{W}} \mathrm{O}$ contents are greater in the border zone tourmaline than in the other tourmaline samples examined. Tourmaline from the core zone of the pegmatite displays increasing $\mathrm{Na}$ and $\mathrm{F}$ contents from core to rim; tourmaline replacing sekaninaite shows increasing $\mathrm{F}$ from core to rim.
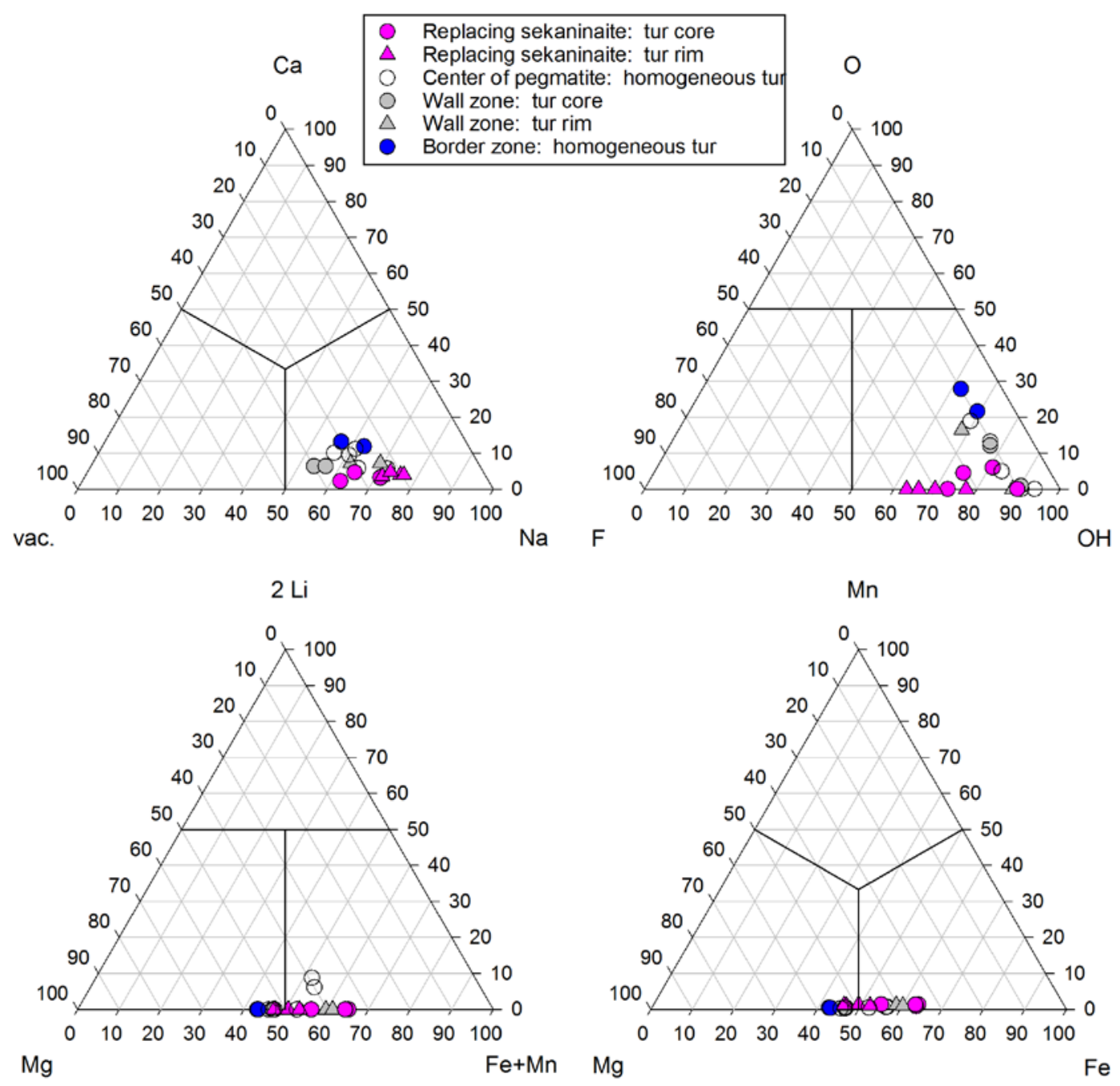

Figure 5.5: Ternary diagrams showing the classification of tourmaline sampled from the GAR dike. 


\subsubsection{The GARMUS Pegmatite Tourmaline}

GARMUS pegmatite tourmaline samples are Na-rich and exhibit compositional zoning, with increasing Fe content from the pegmatite border zone to the wall zone; the composition changes from dravite to schorl (Fig. 5.6).

$\mathrm{Mg}, \mathrm{Ca}$, and $\mathrm{F}$ contents are greater in the border zone tourmaline than in the other tourmaline samples examined. Tourmaline from the wall zone of the pegmatite displays lower $\mathrm{Na}$ and $\mathrm{F}$ contents in crystal cores compared to the border zone and shows a slight $\mathrm{Na}$, Ca, and F enrichment from core to rim.

Despite its high fractionation level (presence of beryl, columbite, and spessartine) the composition of tourmaline is relatively primitive, possibly because the pegmatite does not have tourmaline in its core.

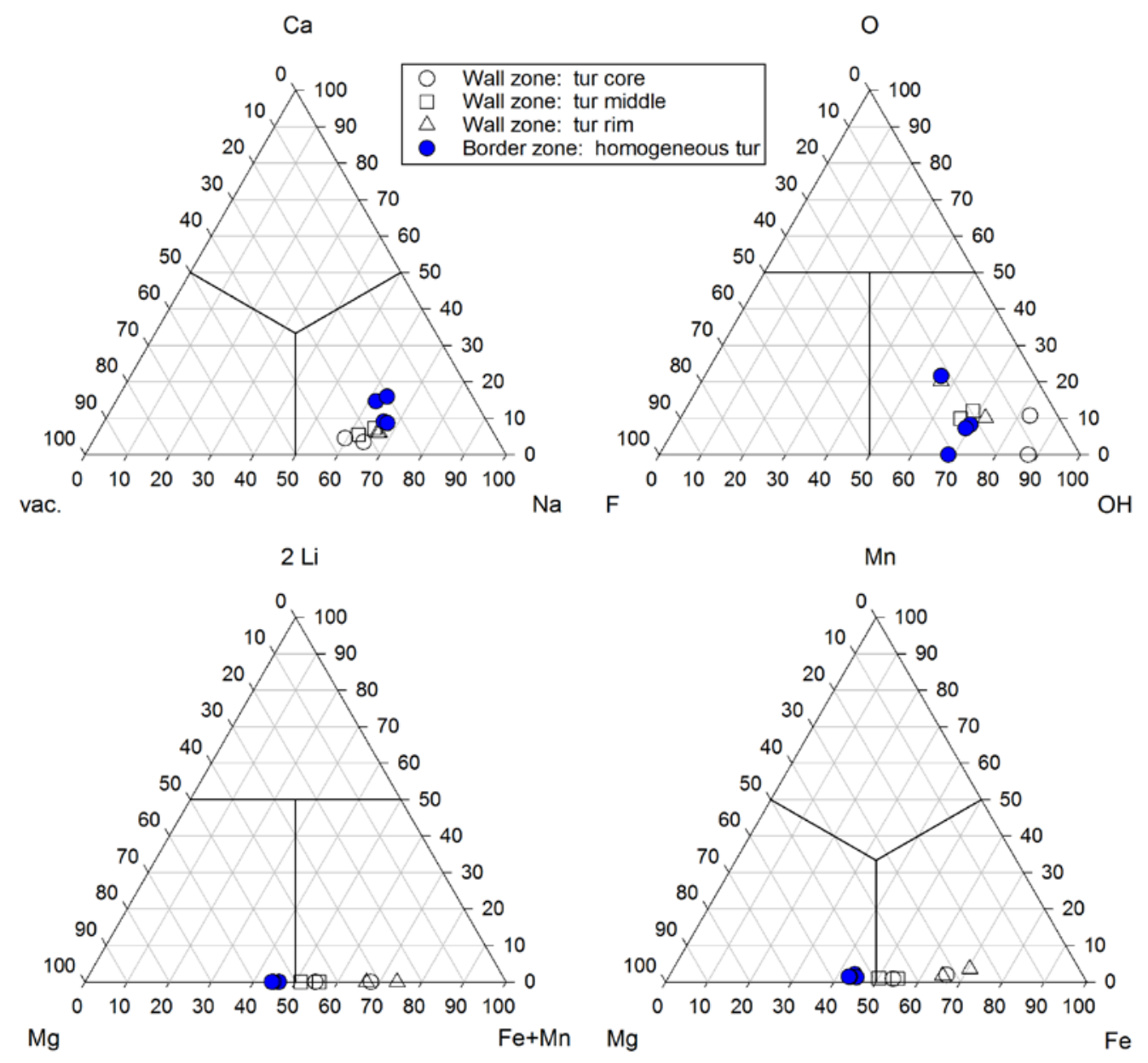

Figure 5.6: Ternary diagrams showing the classification of tourmaline sampled from the GARMUS dike. 


\subsubsection{The GARPHOS Pegmatite Tourmaline}

Tourmaline samples from border zone of the GARPHOS pegmatite are Ca- and Mg-rich relative to all other samples; samples from the intermediate zone of the pegmatite have slightly elevated Ca and Mg contents compared to tourmaline samples from the core zone (Fig. 5.7a). All tourmaline crystals exhibit compositional zoning, with increasing $\mathrm{X}_{\mathrm{Fe}}$ and $\mathrm{OH}$ content from the crystal core to rim in the border and intermediate zones of the pegmatite. Composition of the tourmaline from the pegmatite border zone to the wall zone changes from dravite to Fe-rich dravite and Mg-schorl from crystal core to rim.

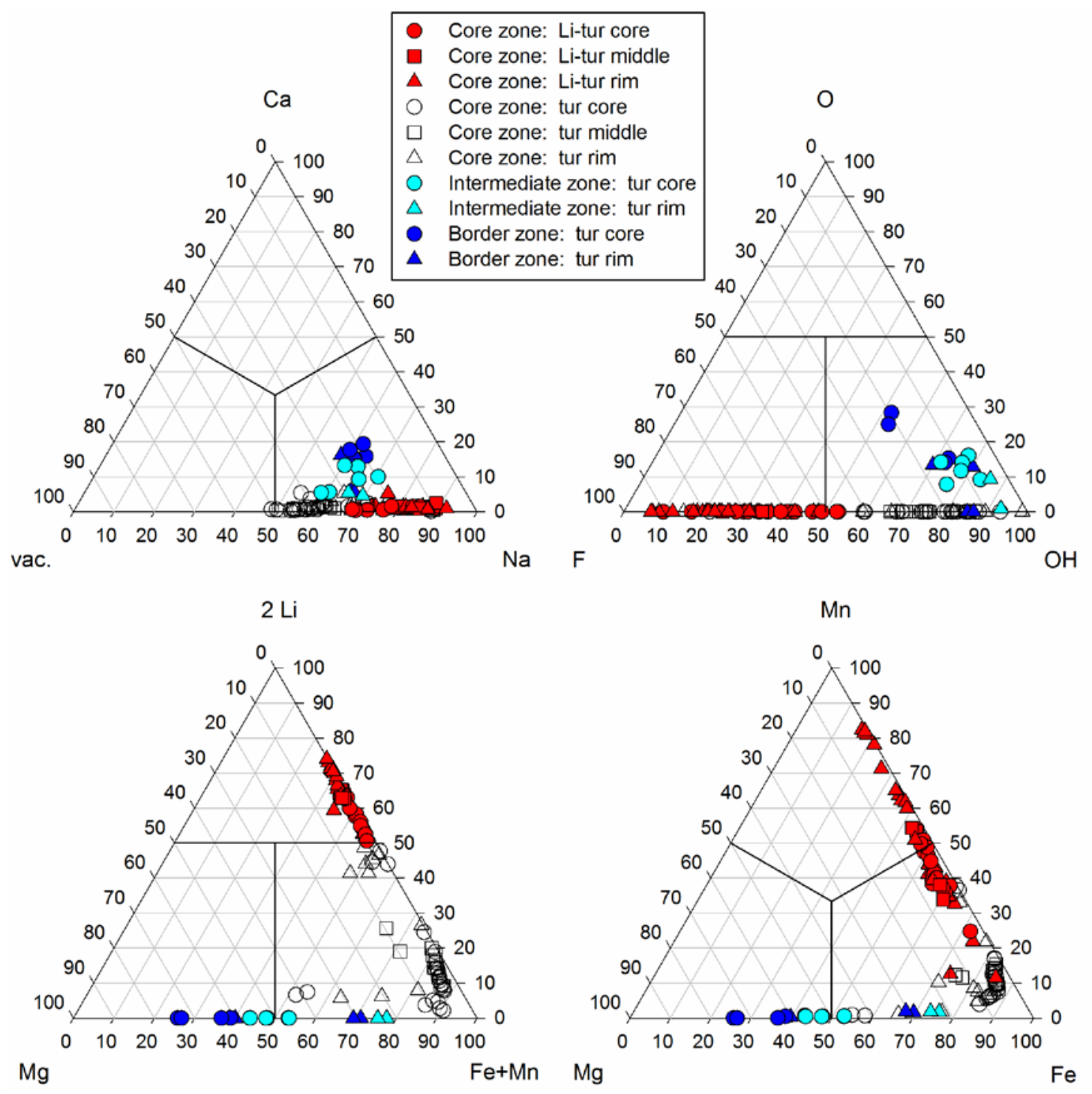

Figure 5.7a: Ternary diagrams showing the geochemistry of tourmaline sampled from the GARPHOS dike. 
Core zone tourmaline samples are significantly zoned with black cores and green rims in hand sample (Fig. 3.10c). In thin section the cores are blue-brown and rimmed with green, blue, yellow, and colorless zones. Six different textural and compositional types were distinguished (Fig. 5.7b): tourmaline I (tur I) is present as blue-brown cores rimmed by dark green tourmaline II (tur II); tourmaline III (tur III) forms a narrow blue zone (distinguishable only in the largest of the collected crystals) rimmed by yellow, inclusion-rich tourmaline IV (tur IV); tourmaline V (tur V) is colorless and often forms skeletal overgrowths on tourmaline IV; and tourmaline VI (tur VI) is present as skeletal replacement and fracture filling in earlier tourmaline generations.

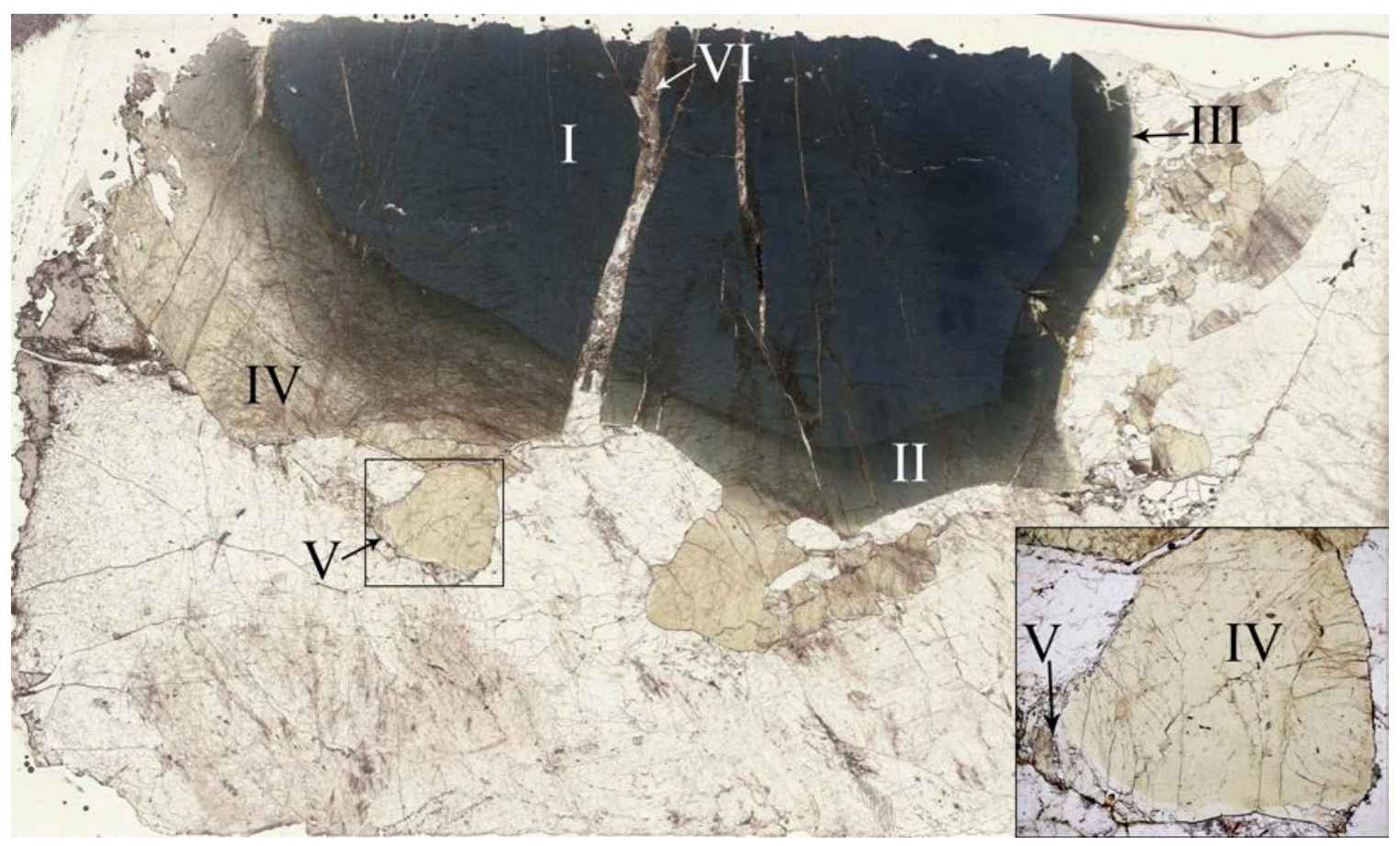

Figure 5.7b: A tourmaline from the GARPHOS core zone in thin section using plain light with the tourmaline types labeled. The crystal is $24 \mathrm{~mm} \times 17 \mathrm{~mm}$.

Tourmaline I is Mg-rich schorl-foitite in crystal cores; the $\mathrm{Na},{ }^{\mathrm{T}} \mathrm{Al}$ (tetrahedrally coordinated $\mathrm{Al}$ ), ${ }^{\mathrm{Y}} \mathrm{Al}\left(\mathrm{Y}\right.$ site $\mathrm{Al}$ ), $\mathrm{X}_{\mathrm{Fe}}$, and $\mathrm{X}_{\mathrm{Mn}}$ increases towards the crystal rims (Fig. 5.7c). The green tourmaline II is schorl-foitite; has increased amount of $\mathrm{Li}, \mathrm{Na},{ }^{\mathrm{T}} \mathrm{Al},{ }^{\mathrm{Y}} \mathrm{Al}$, and $\mathrm{X}_{\mathrm{Mn}}$; and decreased amounts of Fe and Mg compared to tourmaline I. Composition of tourmaline III seems to represent the most evolved stage of tourmaline II and therefore may only a represent color variant of tourmaline II. 
Overall, the yellow, inclusion-rich tourmaline IV is (Fe,Mn)-rich elbaite and shows a decrease in ${ }^{\mathrm{T}} \mathrm{Al}, \mathrm{Fe}$, and $\mathrm{Mg}$ and increases in $\mathrm{Na}, \mathrm{Mn},{ }^{\mathrm{Y}} \mathrm{Al}$, and $\mathrm{Li}$ compared to tourmaline II and III (Fig. 5.7c). It generally evolves towards Fe-poor and Mn-rich compositions; some of the rims display a slight increase of $\mathrm{Fe}, \mathrm{Mg}$, and ${ }^{\mathrm{Y}} \mathrm{Al}$ and a decrease in $\mathrm{Mn}$. This suggests partial dissolution of earlier generations (or some Fe-Mg phase in the pegmatite core) causing similar composition trends as those seen for tourmaline VI.

Tourmaline $\mathrm{V}$ is elbaite and exhibits increases in $\mathrm{Na}, \mathrm{Li}, \mathrm{Mn}$, and ${ }^{\mathrm{Y}} \mathrm{Al}$ while showing decreases in $\mathrm{Fe}, \mathrm{Mg}$, and ${ }^{\mathrm{T}} \mathrm{Al}$ compared to all other types. Tourmaline VI is schorl-elbaite and displays a decrease in $\mathrm{Li},{ }^{\mathrm{Y}} \mathrm{Al}$ and $\mathrm{Mn}$ while showing an increase in $\mathrm{Fe}$ and $\mathrm{Mg}$ relative to most earlier crystallized elbaite. It is enriched in $\mathrm{Na}$ and ${ }^{\mathrm{T}} \mathrm{Al}$, similar to that of tourmaline $\mathrm{V}$; its $\mathrm{Fe}$ enrichment can be explained by dissolution of the earlier host tourmaline types (Fig. 5.7c). 

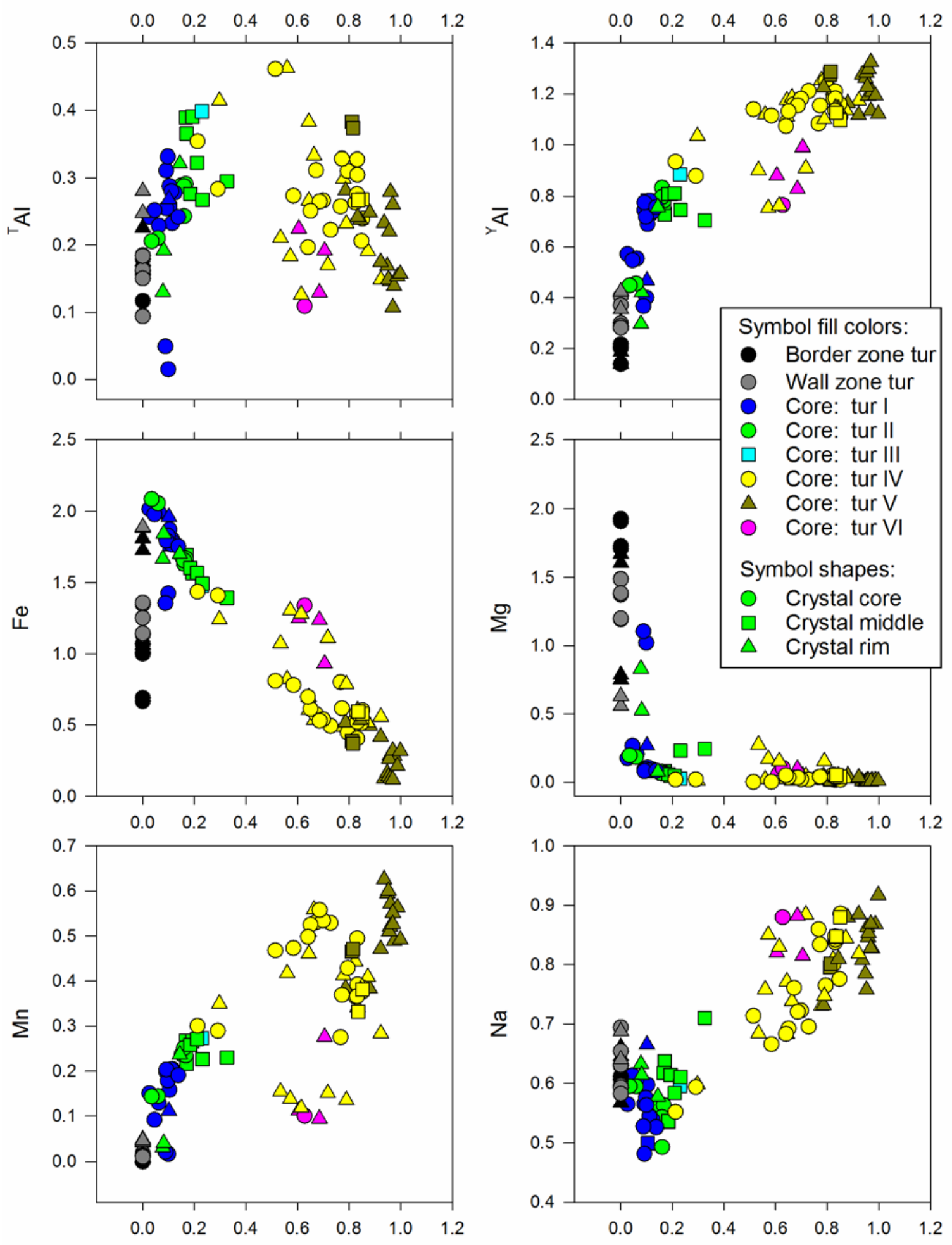

$\mathrm{Li}$

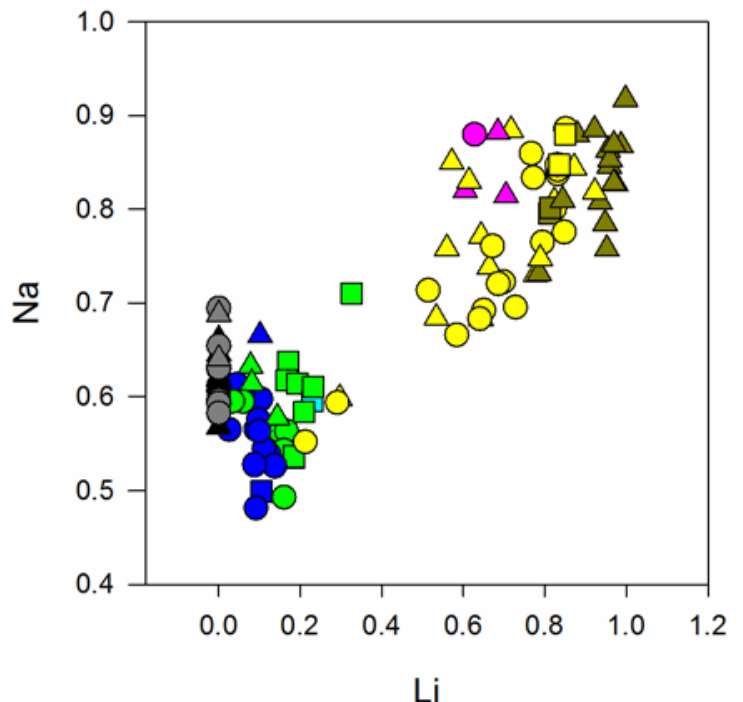

Figure 5.7c: Plots showing the compositional trends of the different tourmaline types. 


\subsubsection{The GARTOUR Pegmatite Tourmaline}

The tourmaline sample examined from the GARTOUR pegmatite exhibits compositional zoning with increasing $\mathrm{Na}, \mathrm{Mg}$, and $\mathrm{F}$ contents towards the rim from the core of the crystal. Composition of the crystal is foitite-schorl in the core and changes to dravite in the rim (Fig. $5.8 a)$.
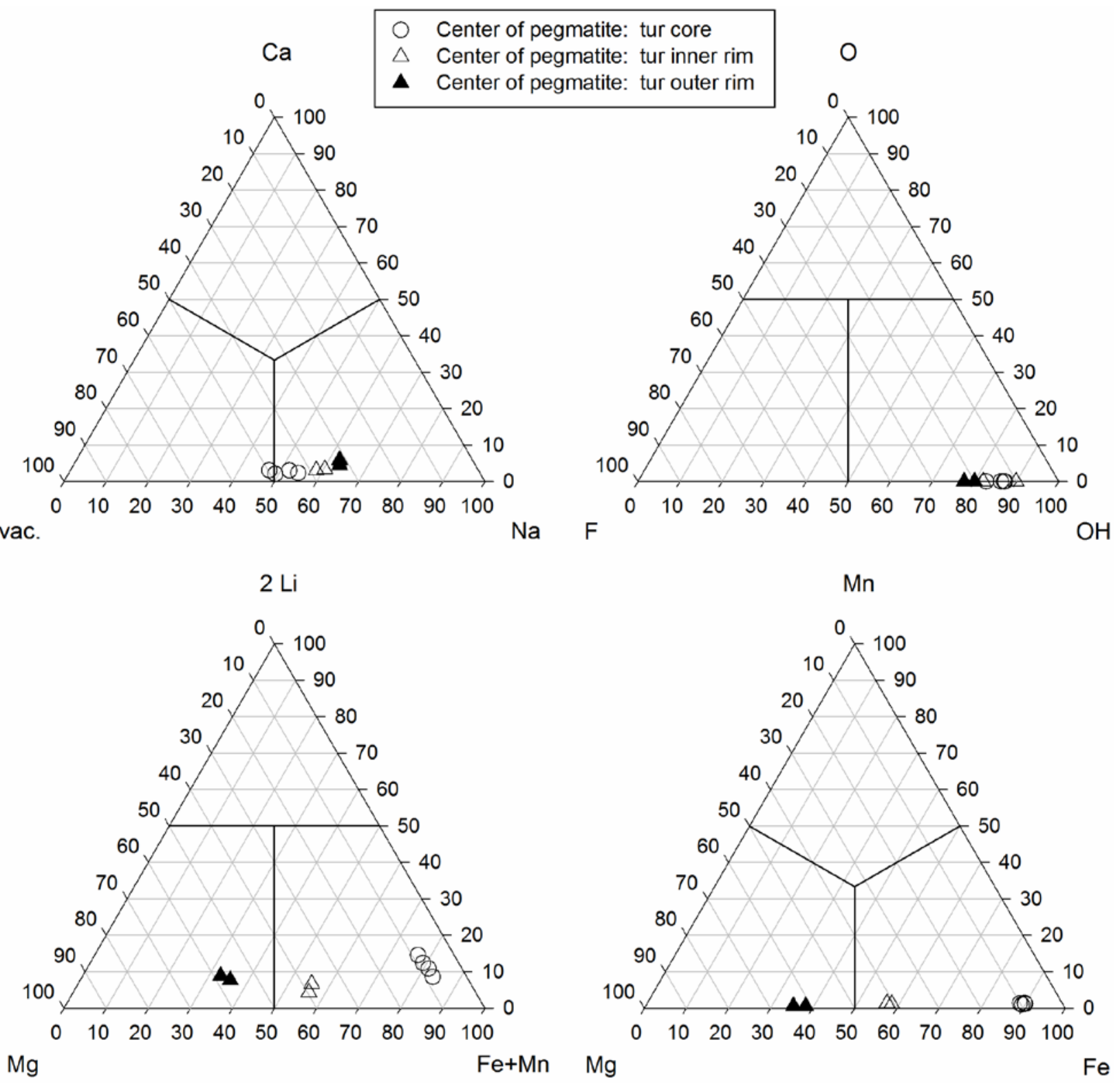

Figure 5.8a: Ternary diagrams showing the classification of tourmaline sampled from the GARTOUR dike. 
Unlike the tourmaline from most other pegmatites, the compositional zoning is inverted, i.e., schorl to dravite, rather than dravite to schorl as seen in most other pegmatites. Close inspection of the BSE image (Fig. 5.8b) reveals the outermost rim to be a euhedral overgrowth on the inner rim and core. This suggests the possibility the outer rim tourmaline is a separate generation from the core of the crystal and opening of the system to Mg contamination from the host rock.

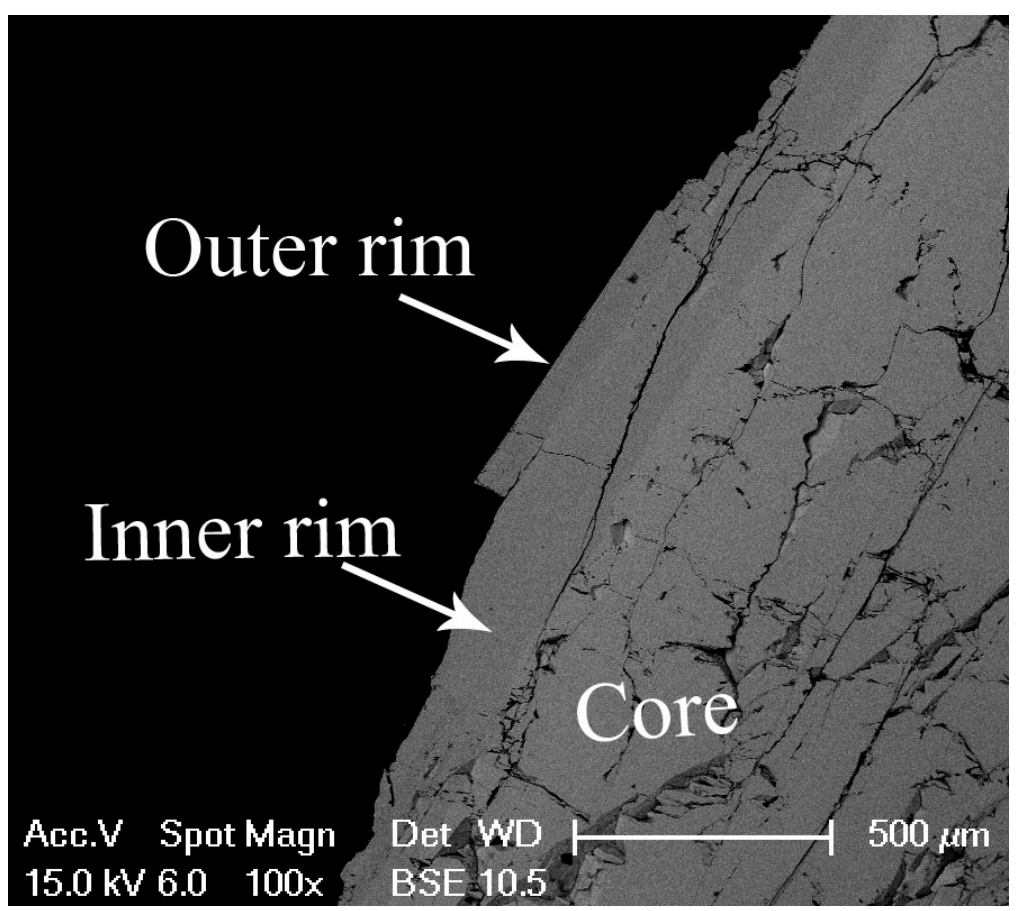

Figure 5.8b: A BSE image of the tourmaline from the GARTOUR pegmatite with the core, inner rim and outer rim indicated. 


\subsubsection{The GRANITE Pegmatite Tourmaline}

Tourmaline from the GRANITE pegmatite was sampled along the length of the dike (520 m) from the same locations the whole rock geochemistry and feldspar samples were gathered. There was not any tourmaline evident at sample site 12-GRANITE-S02.

Despite the overall fractionation trends of the dike from the southeast to the northwest, the tourmaline composition shows only a little variation. Tourmaline crystals are mainly homogeneous with oscillatory zoning observed only rarely (Fig. 5.9a). Within the concentrated scatter of the data, there is a slight increase of the Fe content from the southeast to the northwest, consistent with the geochemical trend of the dike. The tourmaline compositions range from dravite with a high ${ }^{\mathrm{W}} \mathrm{O}$ component to schorl. The elevated $\mathrm{Ca}$ and generally high $\mathrm{Mg}$ contents could result from contamination from the host rock (Fig. 5.9b).

The highest Fe contents were found in the tourmaline samples from 12-GRANITE-S06 (which shows oscillatory zoning; Fig. 5.9a) and 12-GRANITE-S07 (samples include tourmaline from the main GRANITE pegmatite and a tiny, very coarse grained branch $\sim 15 \mathrm{~cm}$ wide and 1.5 $\mathrm{m}$ long). Both of these localities have fluctuating contents of $\mathrm{Fe}^{2+}, \mathrm{Fe}^{3+}, \mathrm{Mg},{ }^{\mathrm{Y}} \mathrm{Al},{ }^{\mathrm{T}} \mathrm{Al}$, and $\mathrm{Na}$ (Fig. 5.9c). Compared to other pegmatites, the overall degree of fractionation of $\mathrm{Mn}, \mathrm{Fe}$, and $\mathrm{Mg}$ in tourmaline is low.

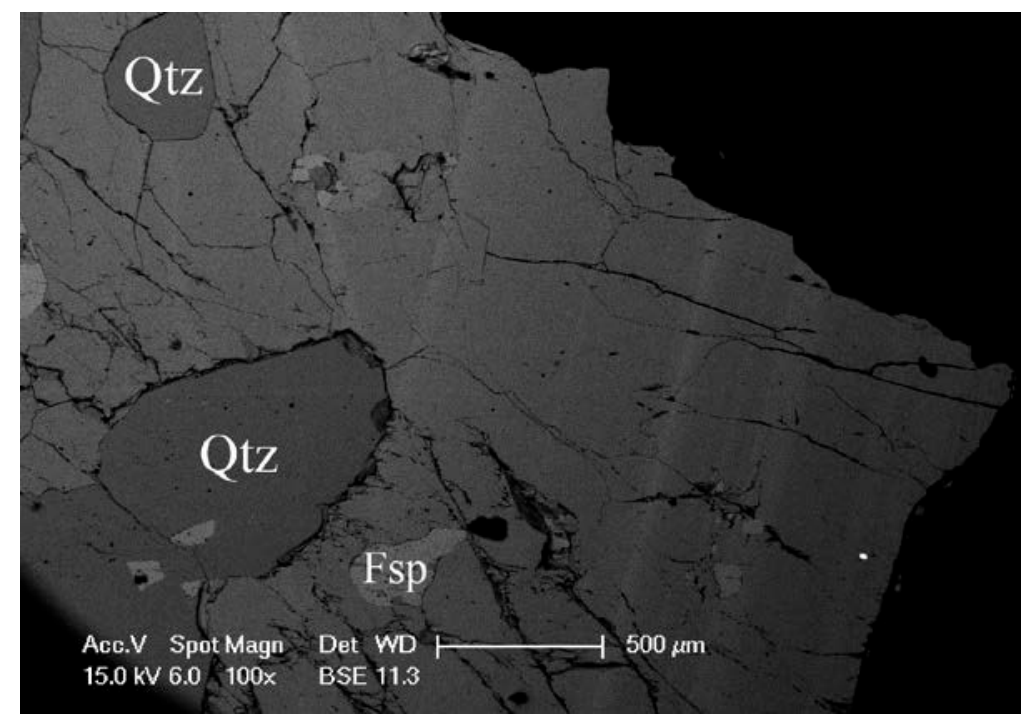

Figure 5.9a: A BSE image of a tourmaline crystal from 12-GRANITE-S06 showing oscillatory zoning. Bright white grain on the right edge of the crystal is a zircon. 

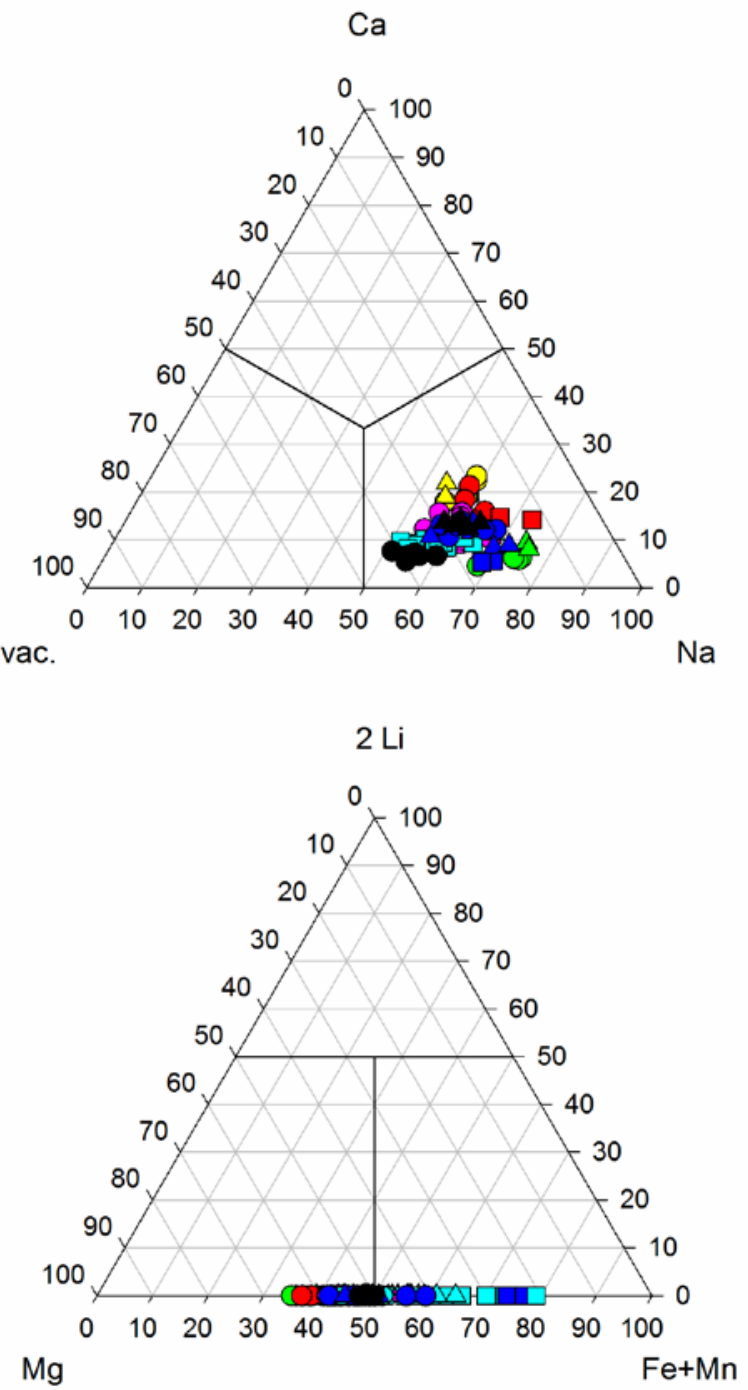
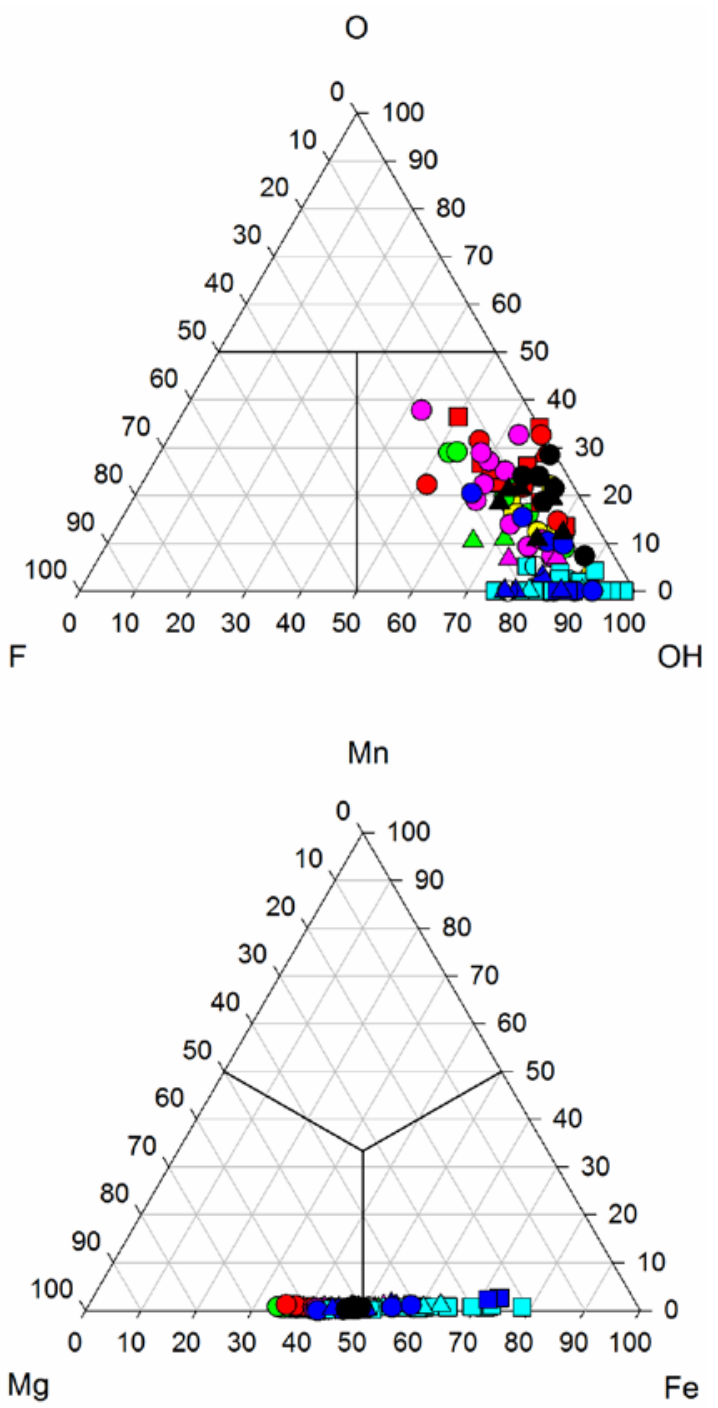

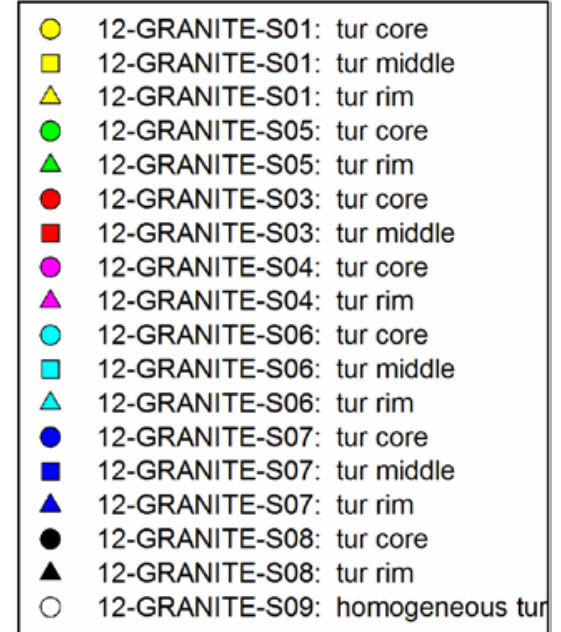

Figure 5.9b: Ternary diagrams showing the geochemistry of tourmaline samples from the GRANITE dike. 

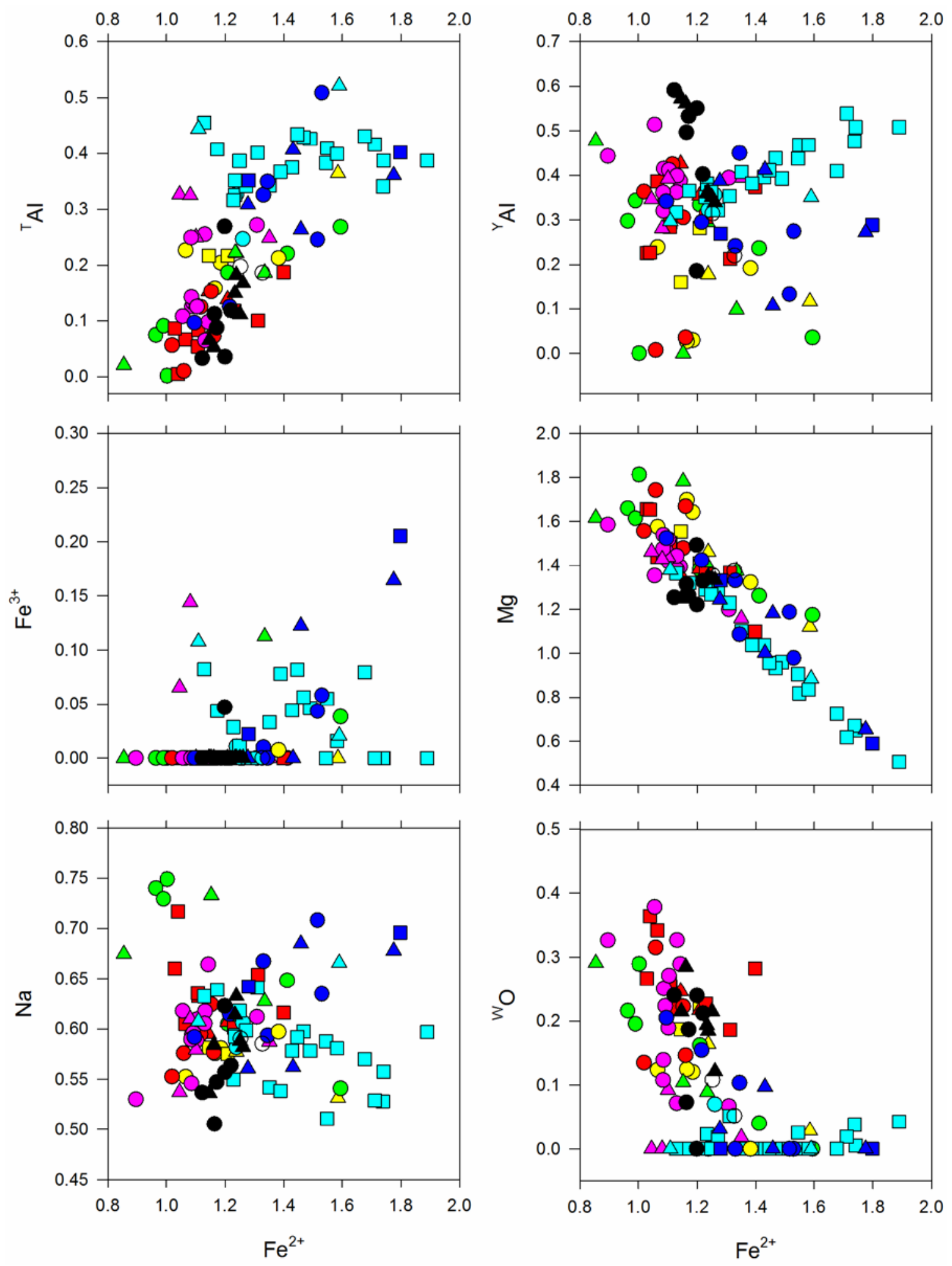

Figure 5.9c: Diagrams highlighting the fluctuating geochemistry in tourmaline samples from the 12-GRANITE-S06 and 12-GRANITE-S07 sample sites. Symbols are the same as those in Fig. 5.9a. 


\subsubsection{The JAN Aplites Tourmaline}

Tourmaline from the JAN aplite has distinct textural zoning (Fig. 5.10a) except for the homogeneous tourmaline from the border zone which is $\mathrm{Ca}$ - and $\mathrm{Mg}$ enriched and F-poor compared to zoned tourmaline from wall zone and the cores of the tourmaline from the center of the aplite. It has a composition of Mg-rich schorl (Fig. 5.10b).

The white core of the zoned tourmaline from the wall zone (Fig. 5.10a) has high $\mathrm{X}_{\square}$ and $\mathrm{X}_{\mathrm{Fe}}$, and high calculated Li. Its blue rim is more Na-rich with elevated Ca, lower $\mathrm{X}_{\mathrm{Fe}}$, and no $\mathrm{Li}$. It has a composition of Li-rich schorl to foitite changing to Mg-rich schorl (Fig. 5.10b).

The dark blue core of the zoned tourmaline from the center of the pegmatite (Fig. 5.10a) has variable contents of $\mathrm{Na}$ and $\mathrm{X}_{\square}$, low $\mathrm{Ca}\left(<0.1\right.$ apfu Ca), and high $\mathrm{X}_{\mathrm{Fe}} \sim 0.7$ to 0.95 and can be classified as schorl. The green middle zone is Ca-enriched ( $\sim .15$ to $0.27 \mathrm{apfu}$ ) and Mg-rich ( $\mathrm{X}_{\mathrm{Mg}} \sim 0.70$ ) compared to the crystal core; it can be classified as Ca-rich dravite. The dark green rim of the crystal is even more enriched in $\mathrm{Ca}$ ( $\sim 0.35$ to $0.40 \mathrm{apfu})$ and has slightly decreased contents of $\mathrm{Mg}\left(\mathrm{X}_{\mathrm{Mg}} \sim 0.63\right)$; it belongs to $\mathrm{Ca}$,Fe-rich dravite, close to the uvite boundary (Fig. $5.10 \mathrm{~b})$.
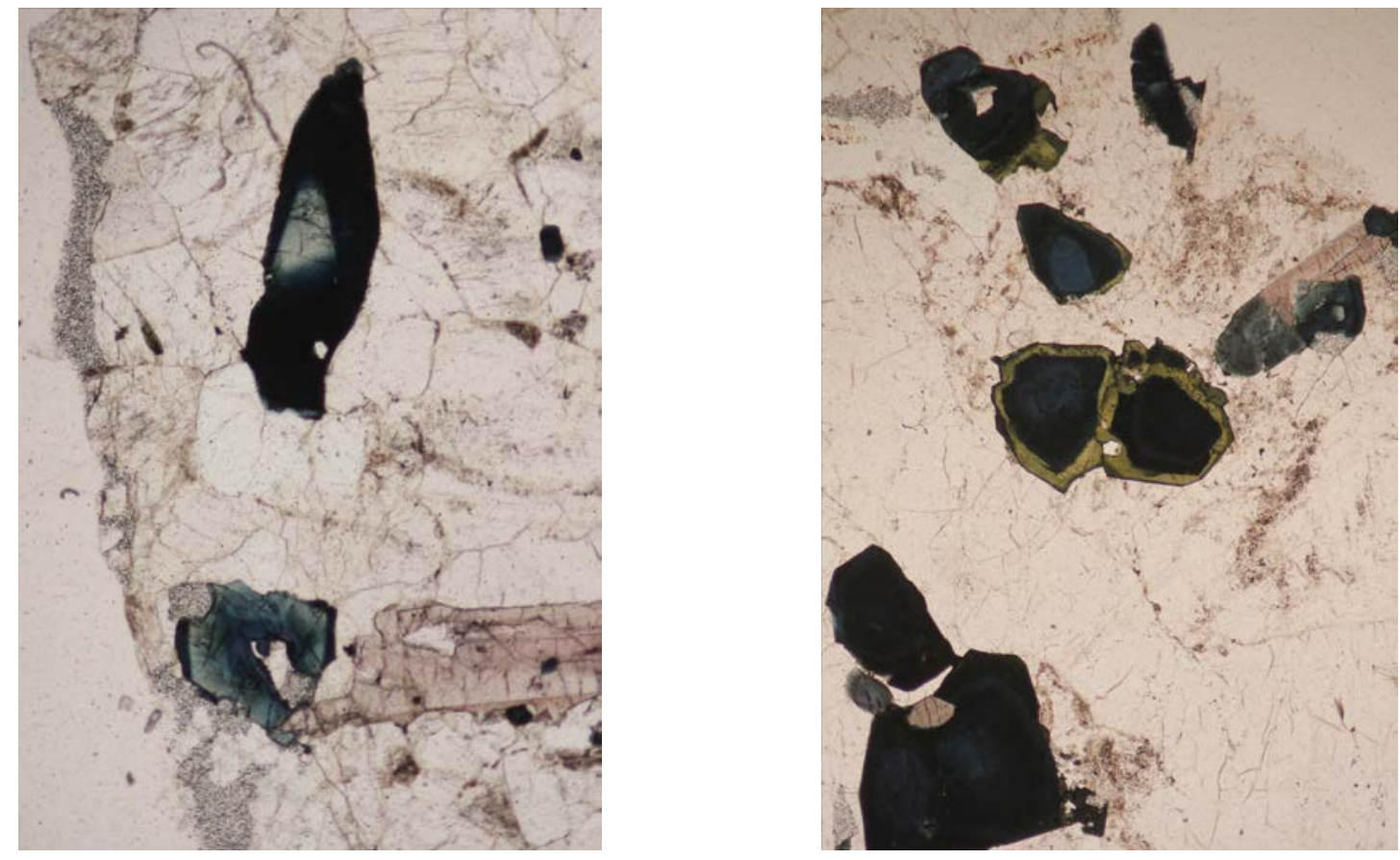

Figure 5.10a: The tourmaline with the white core and dark blue rim on the left is from the wall zone and is $\sim 1.5 \mathrm{~mm}$ long. The two green-rimmed crystals with the dark blue cores are from the center of the aplite; the combined length of the green-rimmed crystals is $\sim 1.2 \mathrm{~mm}$. 

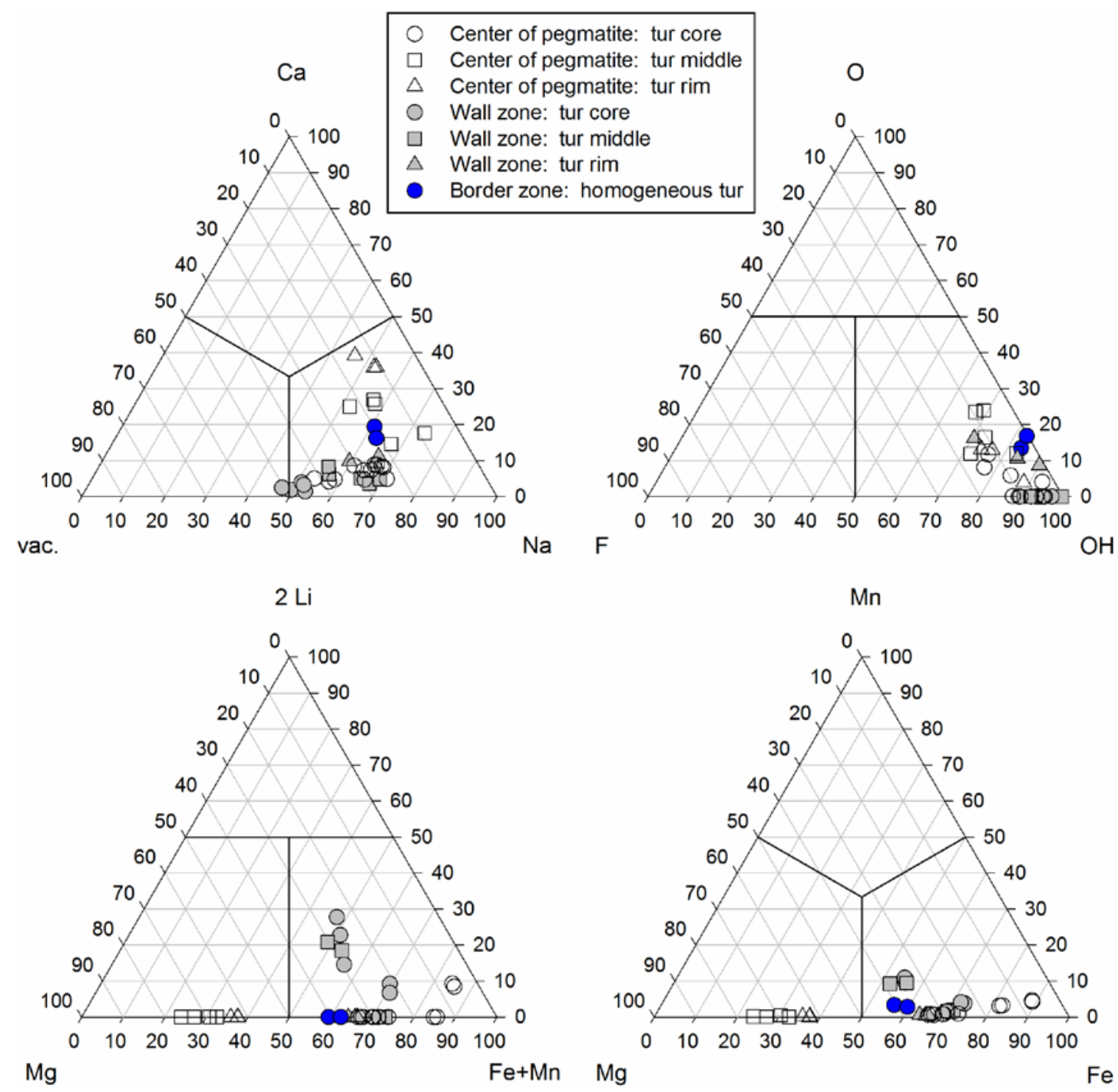

Figure 5.10b: Ternary diagrams showing the classification of tourmaline sampled from the JAN aplites.

The tourmaline from the JAN aplite shows distinct zoning (Fig. 5.10a) strongly resembling that of the schorl-elbaite tourmaline seen in some of the GARPHOS samples but its compositional zoning is based on distinctly different factors. Its initial $\mathrm{X}_{\mathrm{Fe}}$ is unusually high compared to the other pegmatites in the study area, suggesting a high degree of melt fractionation, which is also supported by the garnet composition (almost pure spessartine) from this locality. The middle and rims of the tourmaline crystals indicate strong enrichment in $\mathrm{Ca}$ and Mg without an increase in F. This is most likely due to contamination of late-stage fluids from the host rock. 


\subsubsection{The JUNCT Pegmatite Tourmaline}

The border zone tourmaline sample (Fe-rich dravite) examined from the JUNCT pegmatite exhibits high $\mathrm{Ca}$ and $\mathrm{Mg}$ compared to the crystal core of the tourmaline sample from the core zone of the pegmatite (Mg-rich schorl). The crystal rim of the core zone tourmaline shows increased Ca and Mg compared to the crystal core, indicating contamination from the host rock (Fig. 5.11).

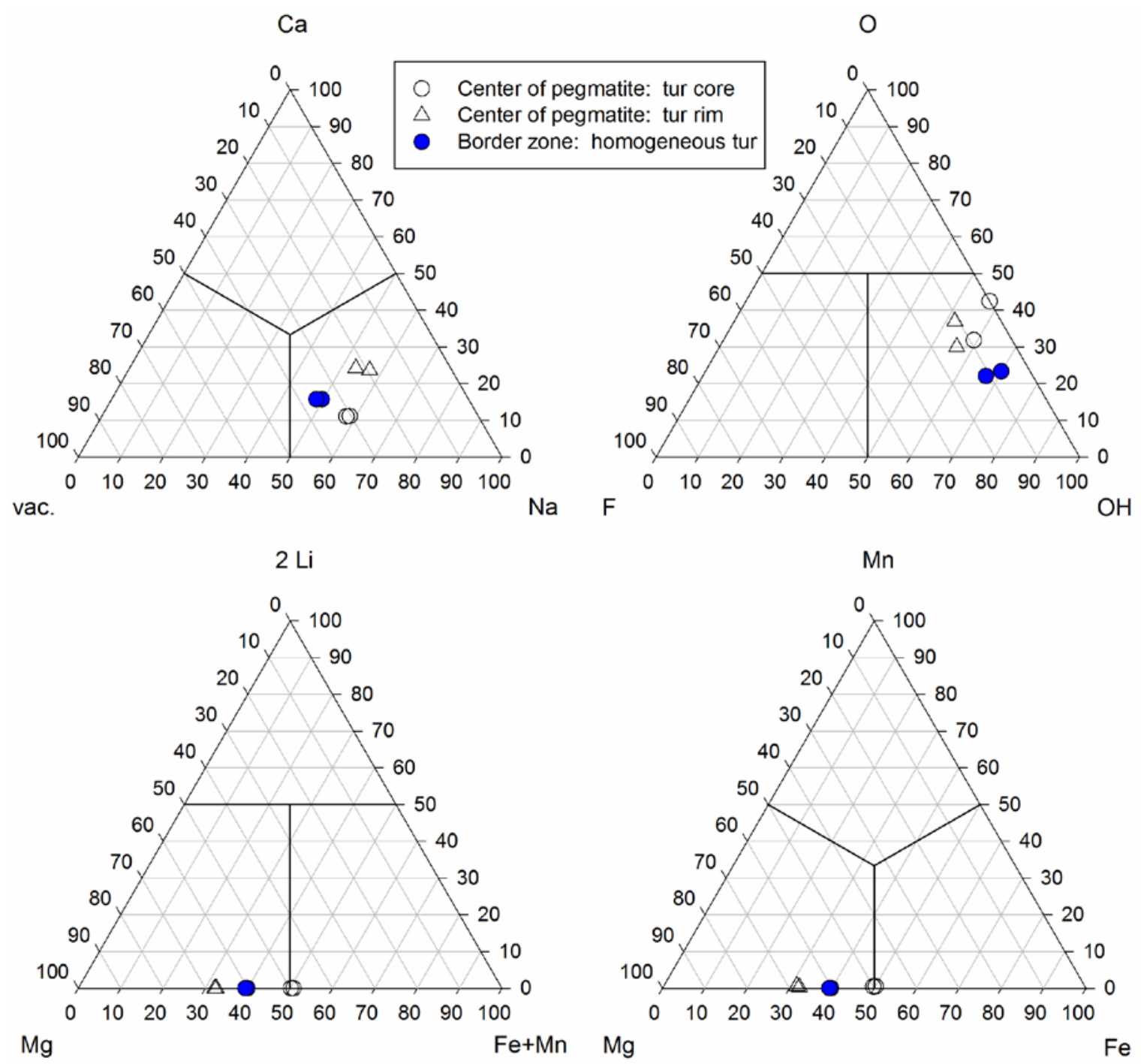

Figure 5.11: Ternary diagrams showing the classification of tourmaline sampled from the JUNCT pegmatite. 


\subsubsection{The LENS Pegmatite Tourmaline}

Tourmaline sampled from the LENS pegmatite is schorl with a zone of Fe-rich dravite. The border zone sample is Mg-rich in comparison to most of the tourmaline from the center of the pegmatite (Fig. 5.12a). The extreme variation of $\mathrm{X}_{\mathrm{Mg}}$ together with an increase in the $\mathrm{F}$ content in the rim of one of the centrally located tourmaline crystals is most probably caused by oscillatory zoning in the late generation of tourmaline (Fig. 5.12b).
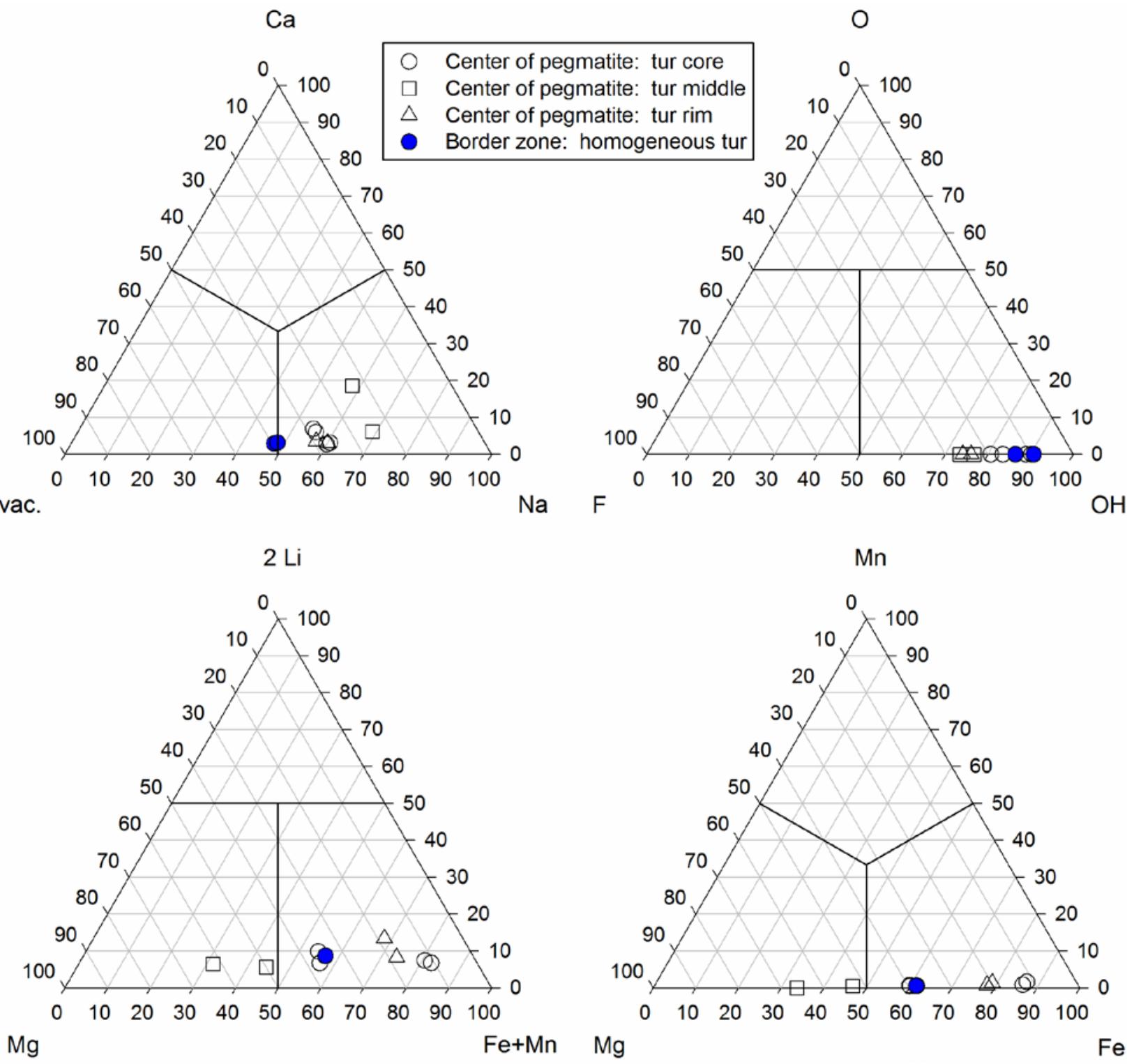

Figure 5.12a: Ternary diagrams showing the classification of tourmaline sampled from the LENS pegmatite. 


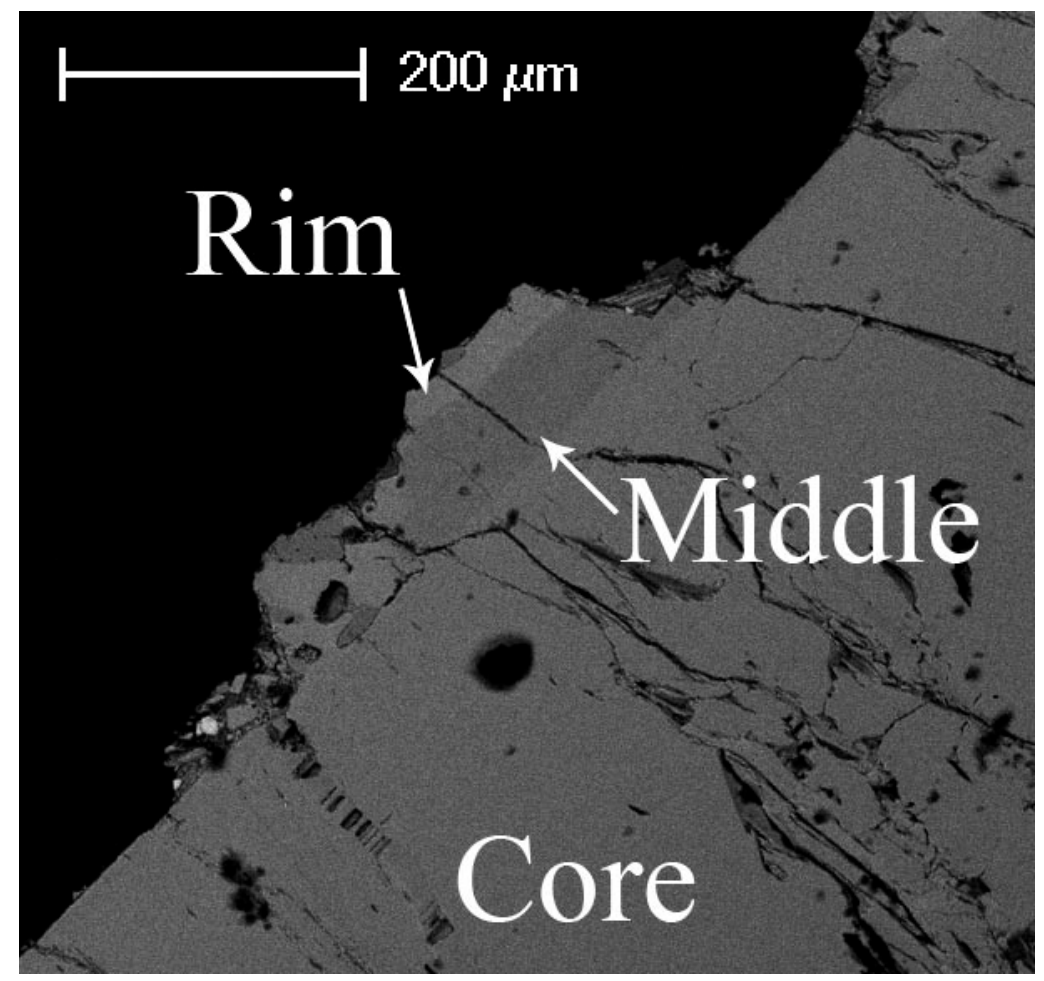

Figure 5.12b: A BSE image of tourmaline from the LENS pegmatite. Very faint oscillatory zoning can be seen in the middle of the crystal (late generation). 


\subsubsection{The LENS2 Pegmatite Tourmaline}

Tourmaline from the border zone of the LENS2 pegmatite is Ca, F-rich dravite with a high oxy-dravite and uvite component while tourmaline from the center of the pegmatite shows compositions of both ${ }^{\mathrm{W}} \mathrm{O}$, Fe-rich dravite and ${ }^{\mathrm{W}} \mathrm{O}$, Mg-rich schorl (Fig. 5.13).
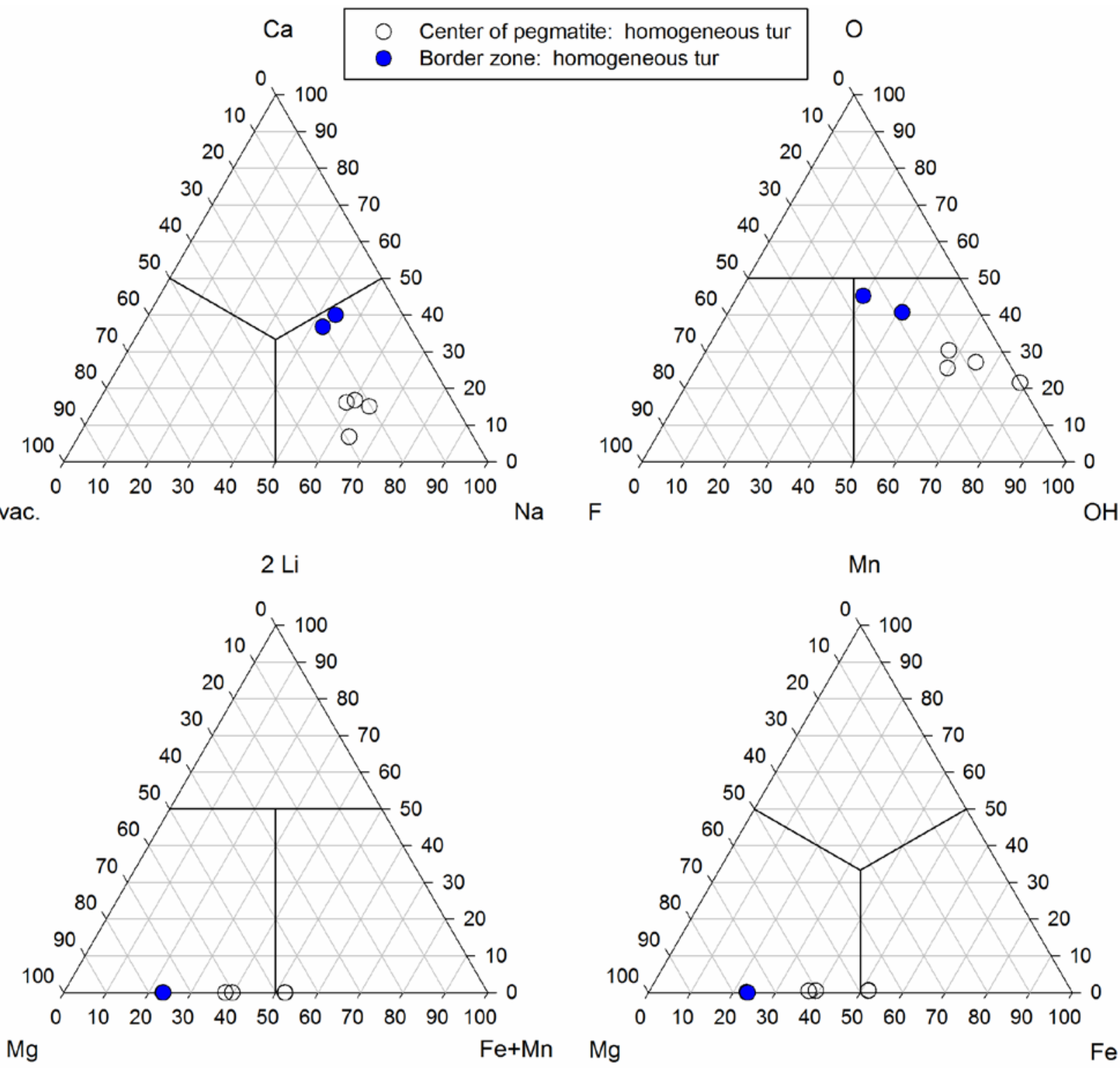

Figure 5.13: Ternary diagrams showing the classification of tourmaline sampled from the LENS2 pegmatite. 


\subsubsection{The LI Pegmatite Tourmaline}

Black tourmaline sampled from the core zone of the LI pegmatite is zoned in thin section (Fig. 5.14a) has a large violet-gray core with a wide gray-brown rim overgrown with colorless to pale blue skeletal tourmaline. The crystal core is foitite-schorl and increases in $\mathrm{Na}, \mathrm{Li}, \mathrm{Fe}, \mathrm{Mn}$, and F towards schorl in the gray-brown rim and continues to fluor-elbaite in the skeletal overgrowth.

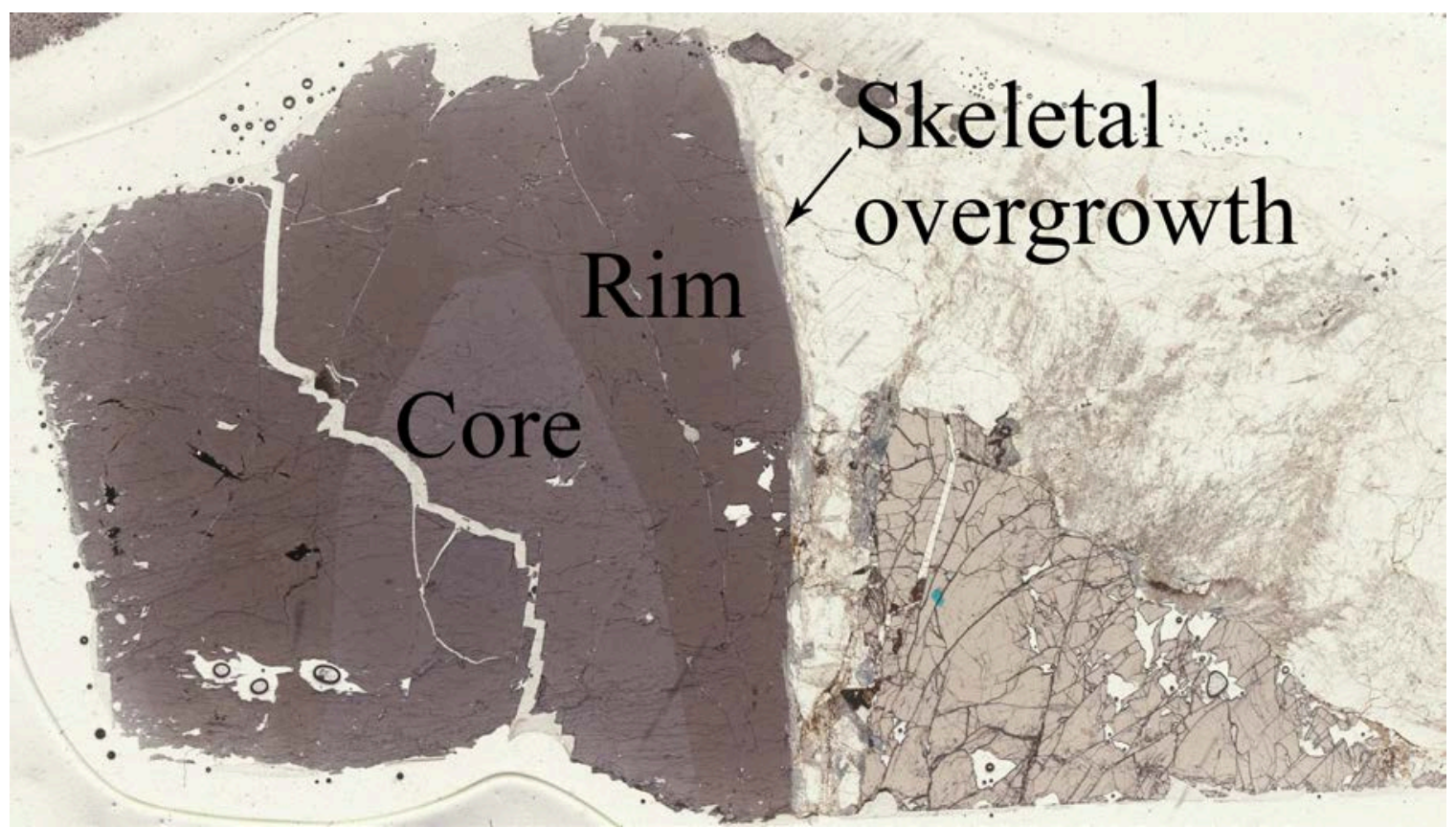

Figure 5.14a: Black zoned tourmaline from the LI pegmatite as seen in thin section using plain light. Crystal is $16 \mathrm{~mm}$ wide by $15 \mathrm{~mm}$ tall.

Other tourmaline crystals sampled from the pegmatite core are pale green, pale pink, or colorless; they occur as isolated subhedral, prismatic crystals in albite and quartz. All are fluorelbaite; cores are Na, Fe, F-rich (Fig. 5.14b) while the rims are gradually depleted in $\mathrm{Na}$ and Fe, with increasing $\mathrm{X}_{\mathrm{Mn}}$ (Fig. 5.14c). Outer rims of the fluor-elbaite crystals usually show a decrease in $\mathrm{F}$ and $\mathrm{Ca}$ and a compositional trend towards rossmanite; some of the crystal rims also display a slight enrichment in Ca and F (liddicoatite component; Fig. 5.14c). 


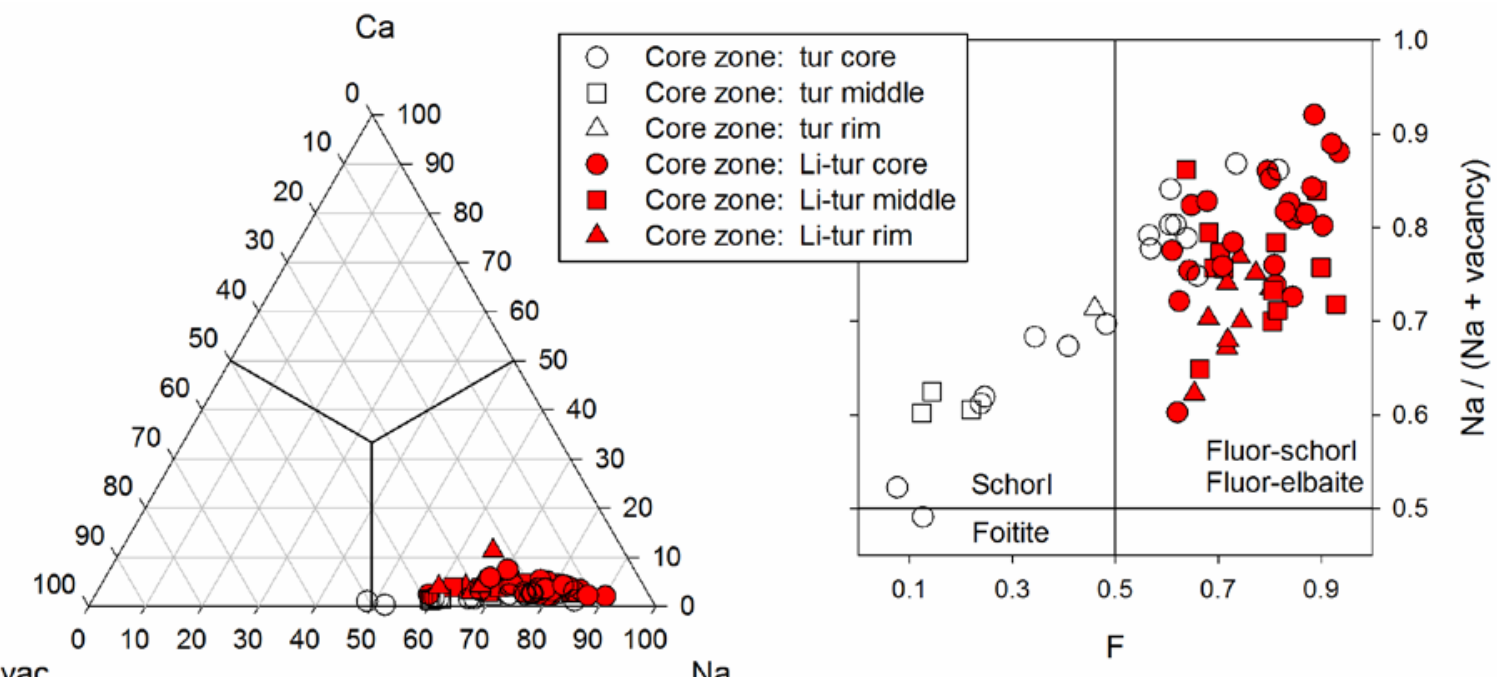
vac

$\mathrm{Na}$

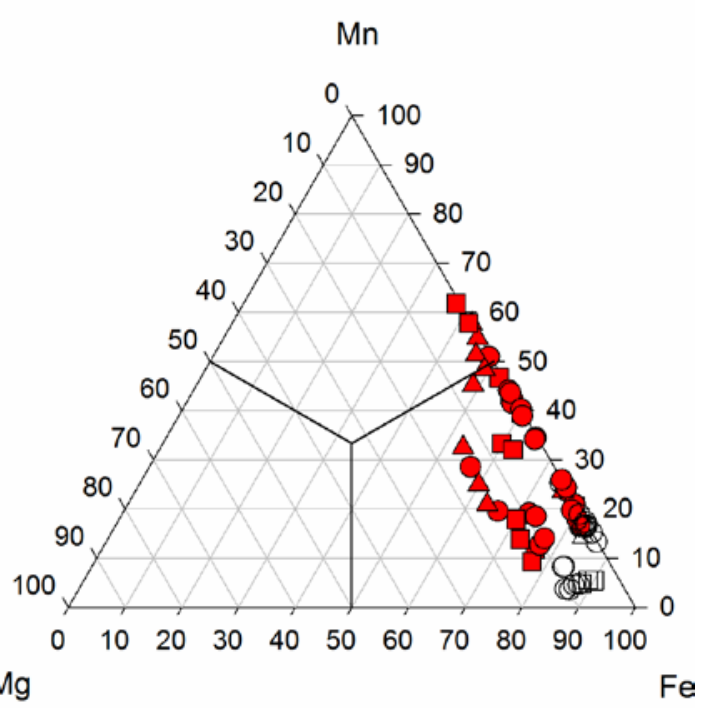

Figure 5.14b: Ternary diagrams showing the classification of tourmaline sampled from the LI pegmatite. 

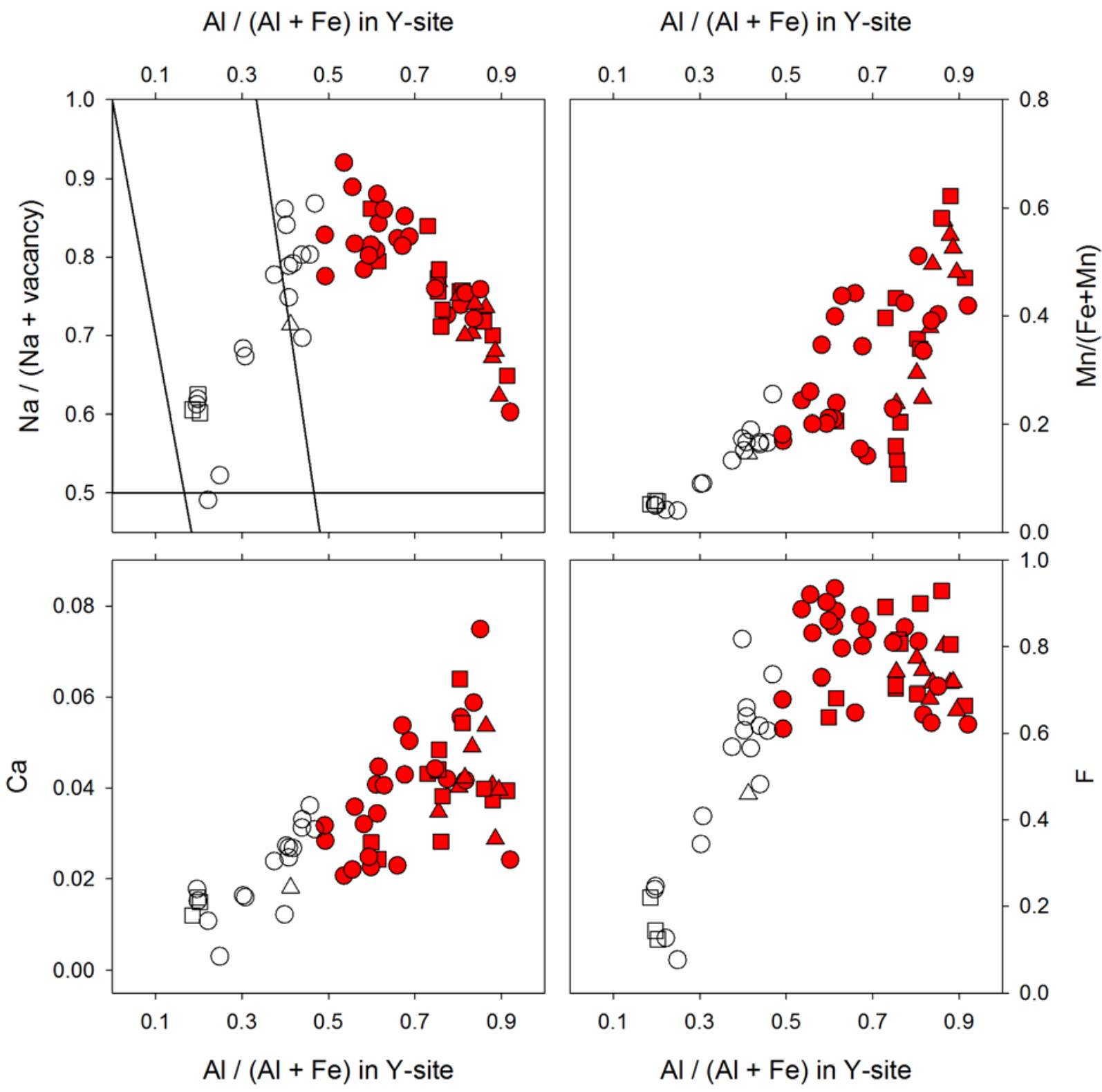

Figure 5.14c: Plots showing the geochemical evolution of tourmaline sampled from the LI pegmatite. 


\subsubsection{The LI2 Pegmatite Tourmaline}

Tourmaline from the LI2 dike was sampled from the wall zone to the core zone; wall zone and intermediate tourmaline is black in hand sample while the tourmaline from the core zone is black, blue, green, pink, and colorless in hand sample.

The wall zone and intermediate zone tourmaline is ${ }^{\mathrm{W}} \mathrm{O}$, Mg-rich compared to tourmaline from the core of the pegmatite; their compositions range from Fe-rich dravite to Mg-rich schorl (Fig. 5.15a).

Black tourmaline sampled from the pegmatite core is Fe-rich with increasing $\mathrm{Mn}, \mathrm{Li}$, and F contents from crystal core to rim. Composition of the black tourmaline samples have schorl cores transitioning to elbaite-schorl and then changing to fluor-elbaite rims (Fig. 5.15a).

Tourmaline with colors other than black from the core of the pegmatite show increased $\mathrm{Li}$, $\mathrm{Mn}$, and F compared to all other sampled tourmaline. The crystal cores are typically $\mathrm{Na}$, Fe, Frich compared to the crystal rims, which show an increase in ${ }^{\mathrm{X}} \square$, and $\mathrm{Mn}$ and a decrease in $\mathrm{Na}, \mathrm{F}$ and $\mathrm{Ca}$. Some of the crystal rims show a slight increase of $\mathrm{Ca}$ and $\mathrm{F}$ towards the liddicoatite component. Overall, the compositions range from elbaite to fluor-elbaite and to rossmanite.

In the cores of some of the green tourmaline samples, an increase in the Bi content (up to 0.96 wt. $\% \mathrm{Bi}_{2} \mathrm{O}_{3} ; 0.04$ apfu $\mathrm{Bi}$ ) was noted. 


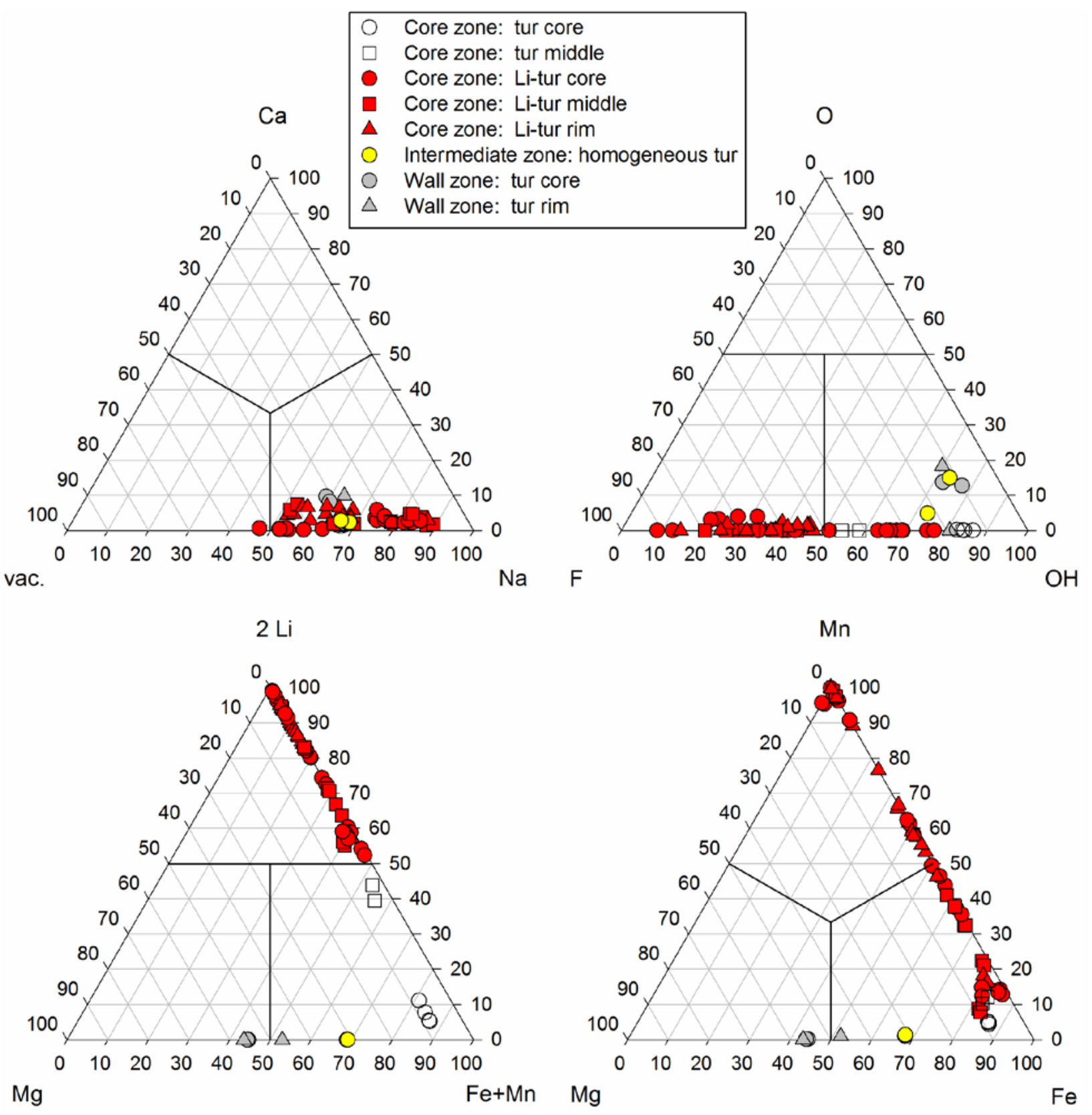

Figure 5.15a: Ternary diagrams showing the classification of tourmaline sampled from the LI2 pegmatite. 


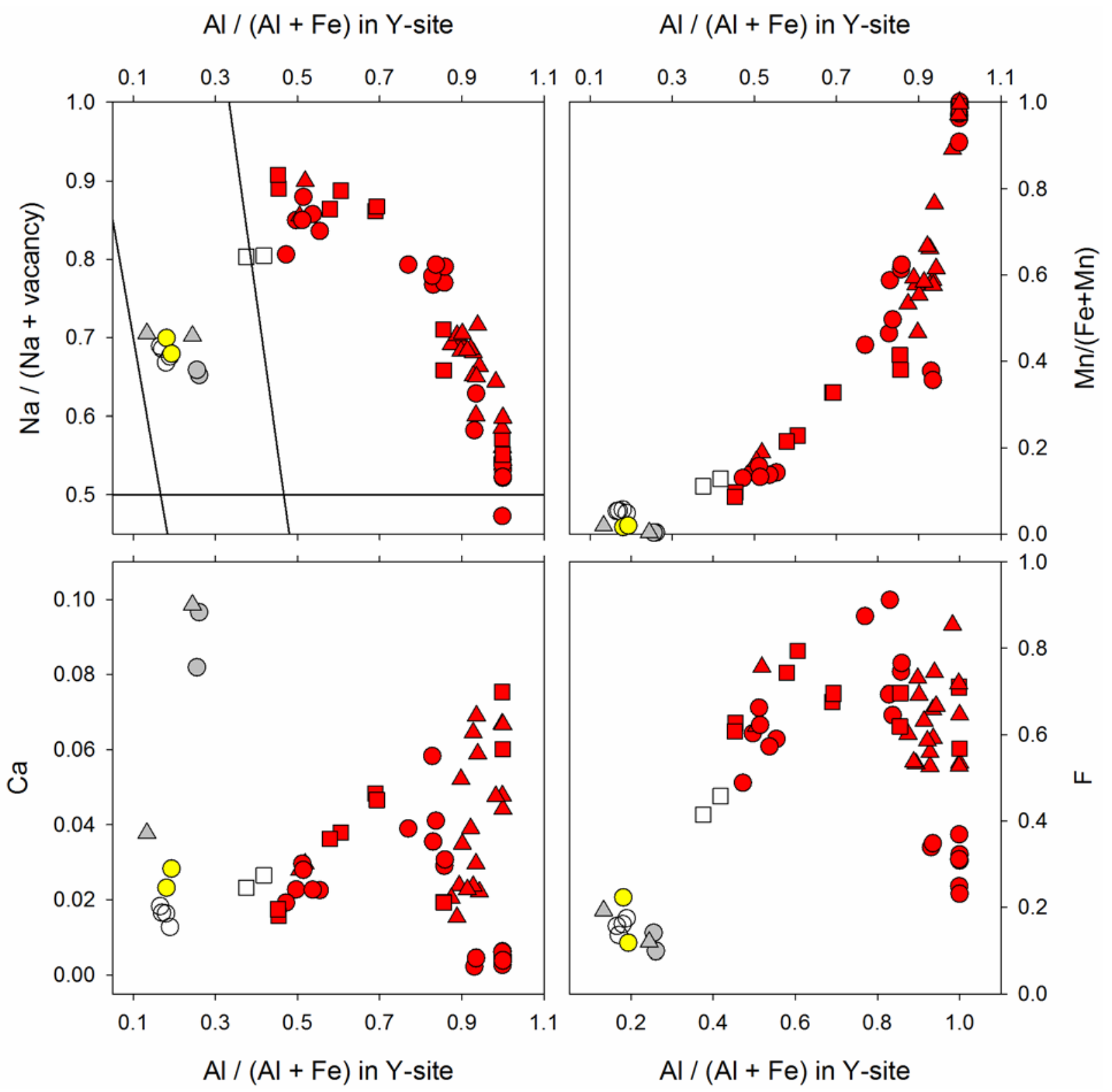

Figure 5.15b: Plots showing the geochemical evolution of tourmaline sampled from the LI2 pegmatite. 


\subsubsection{The LONG Pegmatite Tourmaline}

Tourmaline from the border zone of the pegmatite and the crystal core of the tourmaline from the center of the dike is Ca- and Fe-rich dravite (Fig. 5.16a). The middle and rim of the tourmaline crystal (Fig. 5.16b) from the center of the pegmatite displays increasing $\mathrm{Fe}$ and $\mathrm{Na}$ contents; the middle of the crystal is more ${ }^{\mathrm{W}} \mathrm{OH}$ - and ${ }^{\mathrm{W}} \mathrm{O}$-rich than the crystal rim and crystal core which are slightly more F-rich. Late tourmaline filling fractures (5.16b) in the tourmaline shows a slight increase in the $\mathrm{Ca}$ and ${ }^{\mathrm{W}} \mathrm{OH}$ contents compared to the tourmaline crystal rim (Fig. 5.16a). Compositionally, the tourmaline crystal analyzed from the center of the pegmatite changes from Fe-rich dravite to Mg-rich schorl from core to late stage fracture fill (Fig. 5.16).

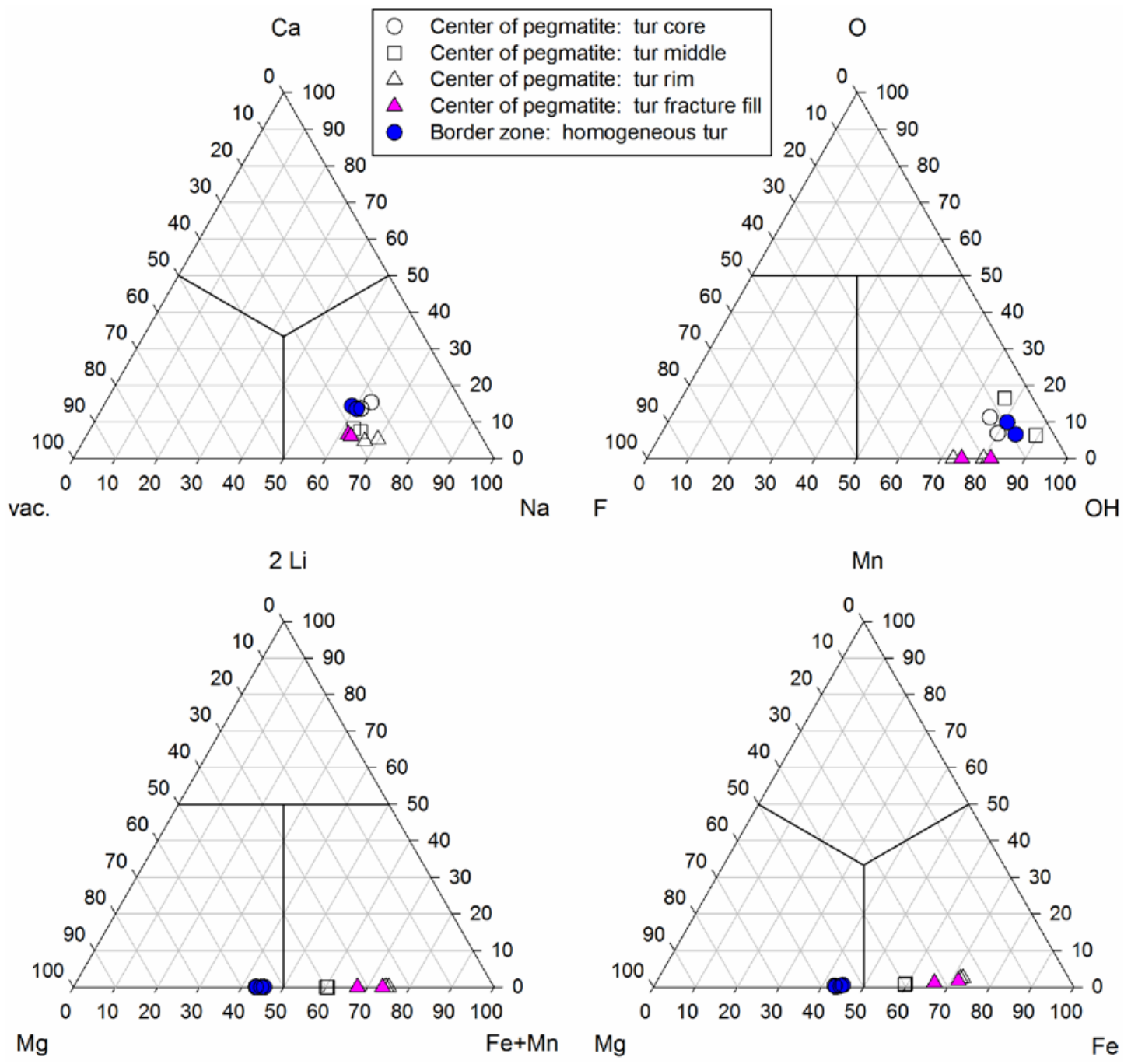

Figure 5.16a: Ternary diagrams showing the classification of tourmaline sampled from the LONG pegmatite. 


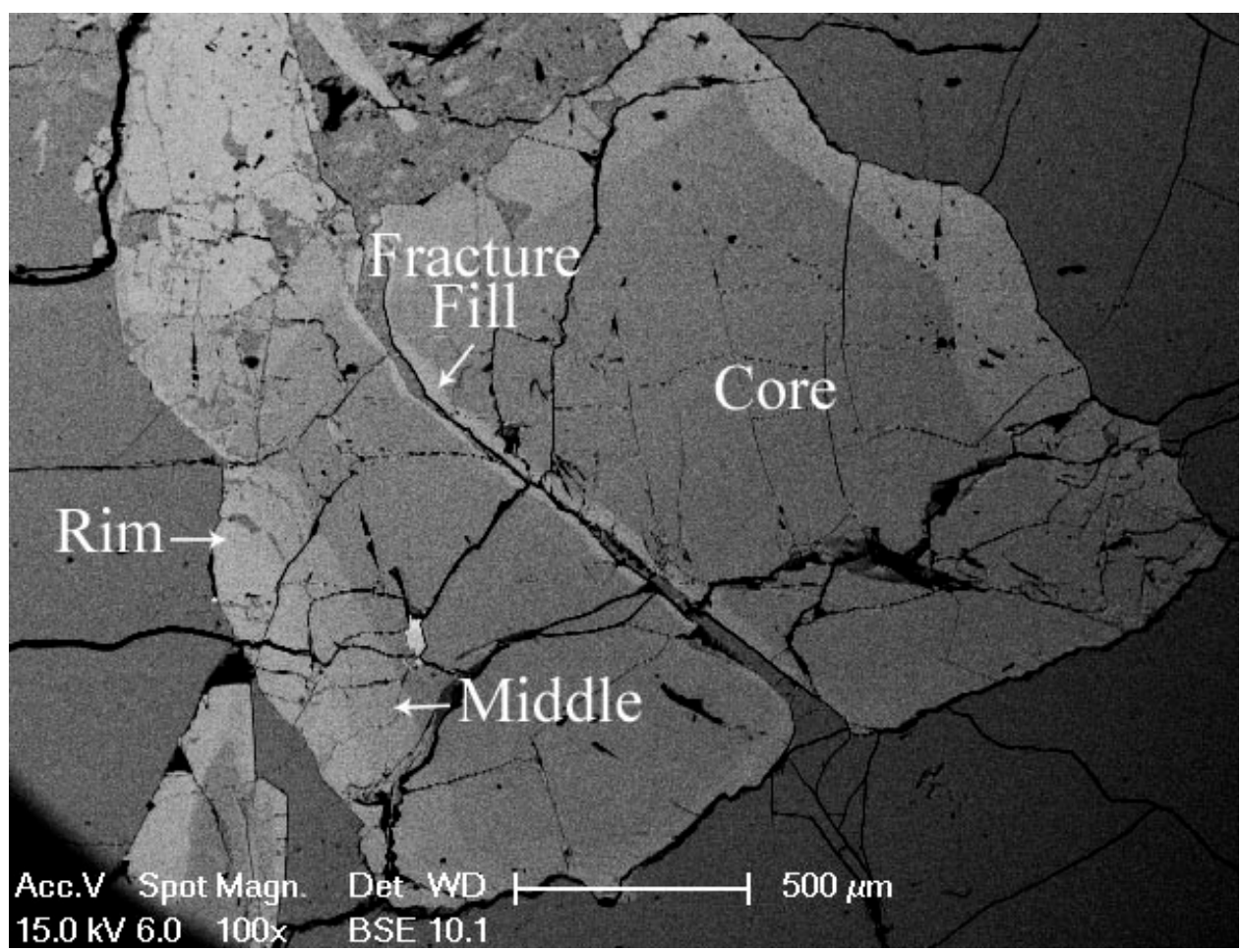

Figure 5.16b: A BSE image of a tourmaline crystal from the center of the LONG pegmatite. 


\subsubsection{The MUSC Pegmatite Tourmaline}

Tourmaline from the MUSC pegmatite appears to be homogeneous in hand sample and in BSE images. It displays slightly elevated contents of $\mathrm{Ca}$ and ${ }^{\mathrm{W}} \mathrm{O}$; its overall composition is $\mathrm{Mg}$ rich schorl (Fig. 5.17).
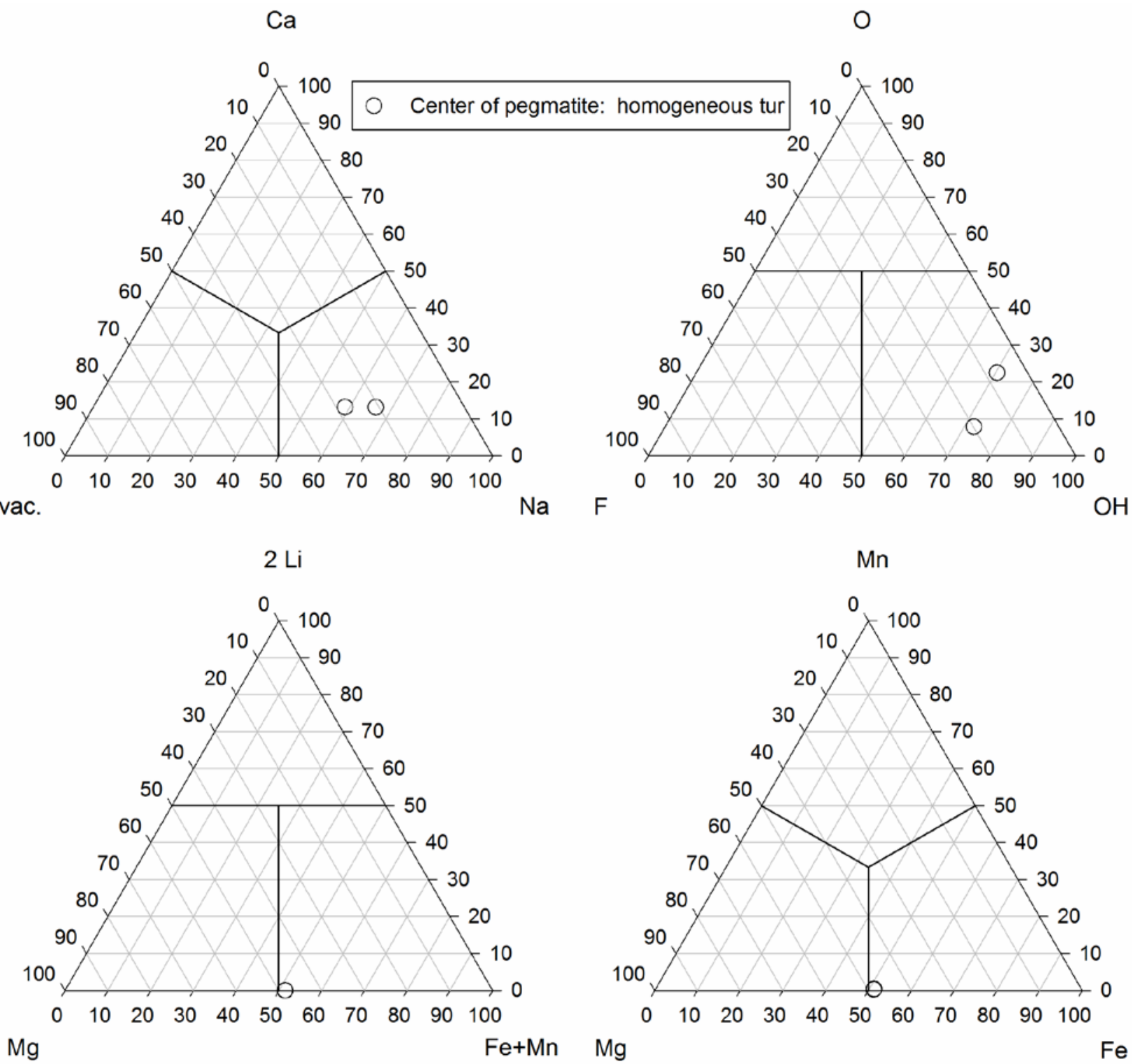

Figure 5.17: Ternary diagrams showing the classification of tourmaline sampled from the MUSC pegmatite. 


\subsubsection{The PEGMA Pegmatite Tourmaline}

Tourmaline from the PEGMA pegmatite shows compositional zoning in tourmaline crystals sampled from the border zone and the center of the pegmatite. Border zone tourmaline is exhibits slightly elevated ${ }^{X_{\square}}, \mathrm{Ca}$, and ${ }^{\mathrm{W}} \mathrm{OH}$ compared to tourmaline from the center of dike. Some of the crystal rims from the border zone tourmaline display increased $\mathrm{Ca}$ and $\mathrm{F}$ contents compared to the crystal cores. Its composition varies from ${ }^{\mathrm{X}} \square, \mathrm{Ca}, \mathrm{Fe}$-rich dravite to Mg-rich schorl (Fig. 5.18).

Tourmaline sampled from the center of the dike shows slightly elevated contents of ${ }^{\mathrm{W}} \mathrm{O}$, $\mathrm{Mn}$, and Na compared to the border zone tourmaline samples. The middles of the tourmaline crystals typically display increases of $\mathrm{Fe}, \mathrm{Mn}, \mathrm{Ca}$, and ${ }^{\mathrm{W}} \mathrm{OH}$ than the crystal cores. Crystal rims exhibit increased ${ }^{\mathrm{W}} \mathrm{O}, \mathrm{F}, \mathrm{Na}, \mathrm{Fe}$, and Mn contents than the crystal middles. The composition of tourmaline from the center part of the dike varies from Fe-rich dravite to Mg-rich schorl (Fig. 5.18). 

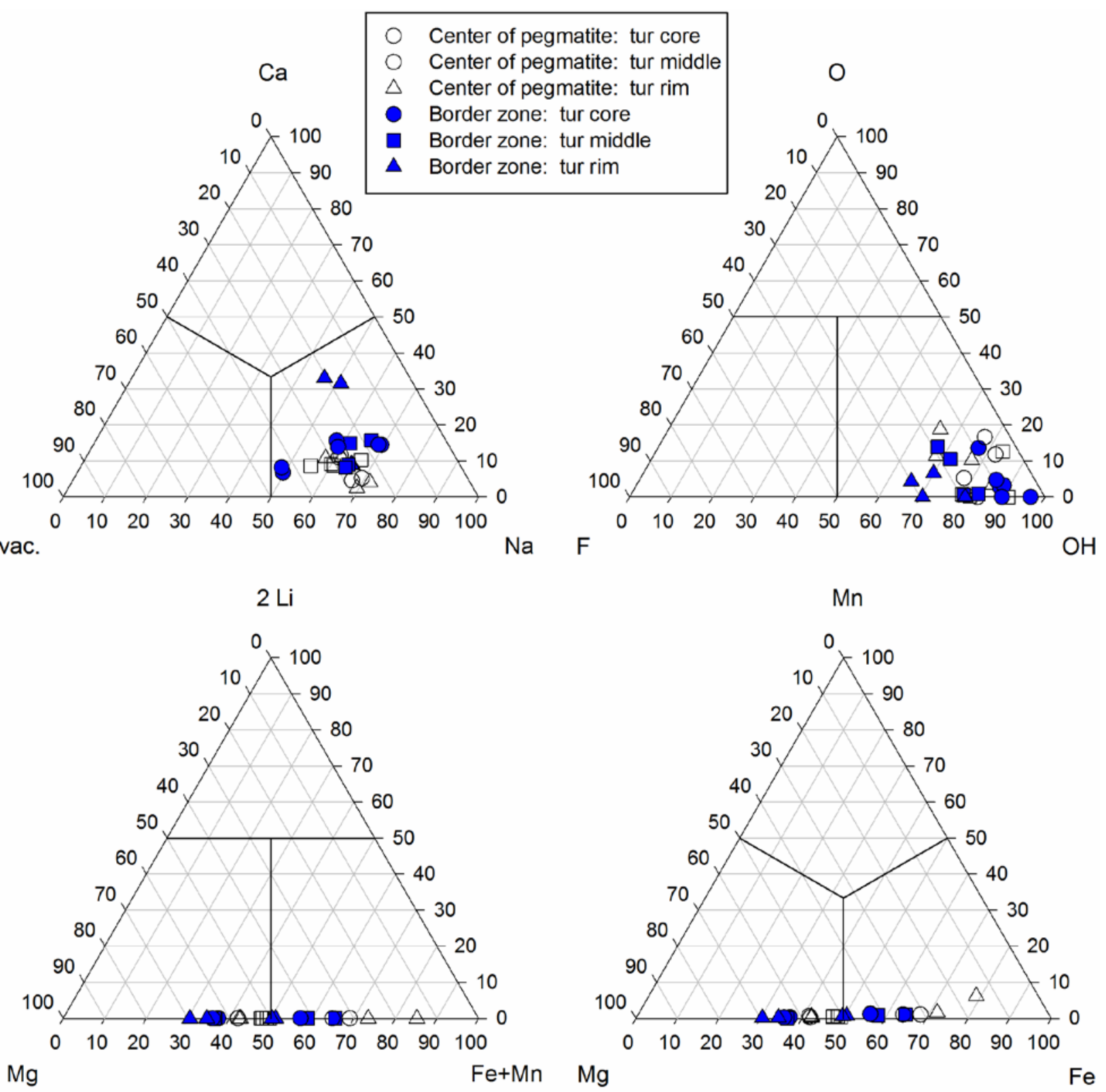

Fig. 5.18: Ternary diagrams showing the classification of tourmaline sampled from the PEGMA pegmatite. 


\subsubsection{The POCKET Pegmatite Tourmaline}

The tourmaline crystal analyzed from the border zone has elevated $\mathrm{Ca}, \mathrm{Mg}$, and ${ }^{\mathrm{W}} \mathrm{O}$ contents compared to the tourmaline from the center of the pegmatite. Its composition is $\mathrm{Ca}$, and Fe-rich dravite with a high oxy-dravite component (Fig. 5.19).

Tourmaline examined from the center of the pegmatite displays crystal cores with increased ${ }^{\mathrm{X}} \square$ and Fe contents compared to the border zone. One of the crystal cores exhibits a much greater ${ }^{\mathrm{W}} \mathrm{OH}$ content than the other crystal core examined, which has a high ${ }^{\mathrm{W}} \mathrm{O}$ content. The crystal rim of the tourmaline from the center of the pegmatite is Mg- and Na-rich compared to the crystal cores and also displays a slightly elevated ${ }^{\mathrm{W}} \mathrm{O}$ and Ca content. The elevated content of $\mathrm{Mg}$ and the slight increase in Ca could be from the system opening to contamination from the host rock. The compositions of the tourmaline from the center of the pegmatite change from Mg-rich schorl-foitite with a high oxy-schorl component to Fe-rich dravite with a high oxydravite component (Fig. 5.19). 

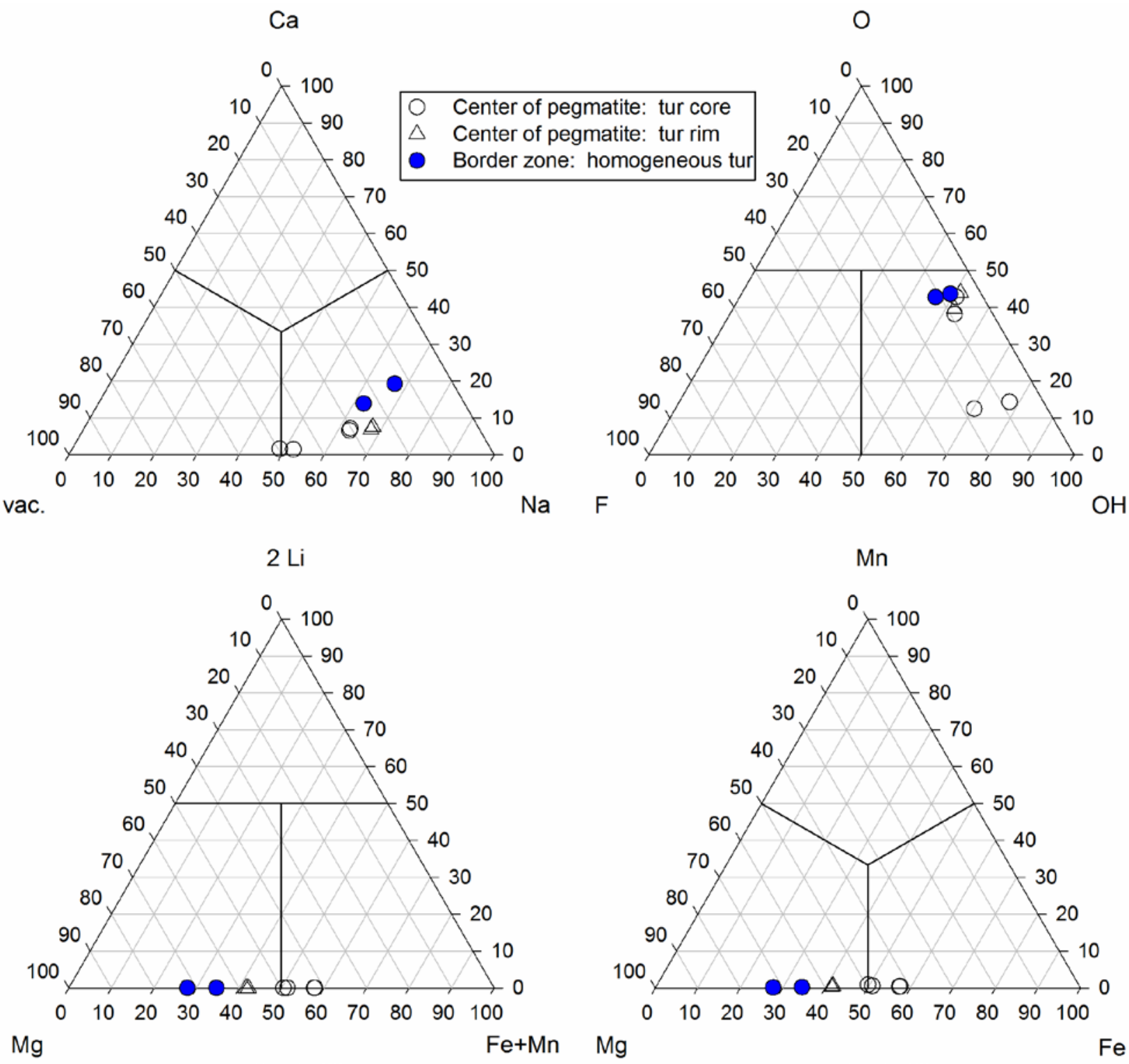

Figure 5.19: Ternary diagrams showing the classification of tourmaline sampled from the POCKET pegmatite. 


\subsubsection{The SIMPLE Pegmatite Tourmaline}

Tourmaline sampled from the SIMPLE pegmatite is homogeneous in hand sample and in BSE images. Samples are Fe-rich dravite; they show slightly elevated $\mathrm{Ca},{ }^{\mathrm{X}},{ }^{\mathrm{W}} \mathrm{O}$, and F contents and very elevated Fe contents than would be expected if samples were end-member dravite (Fig. 5.20).
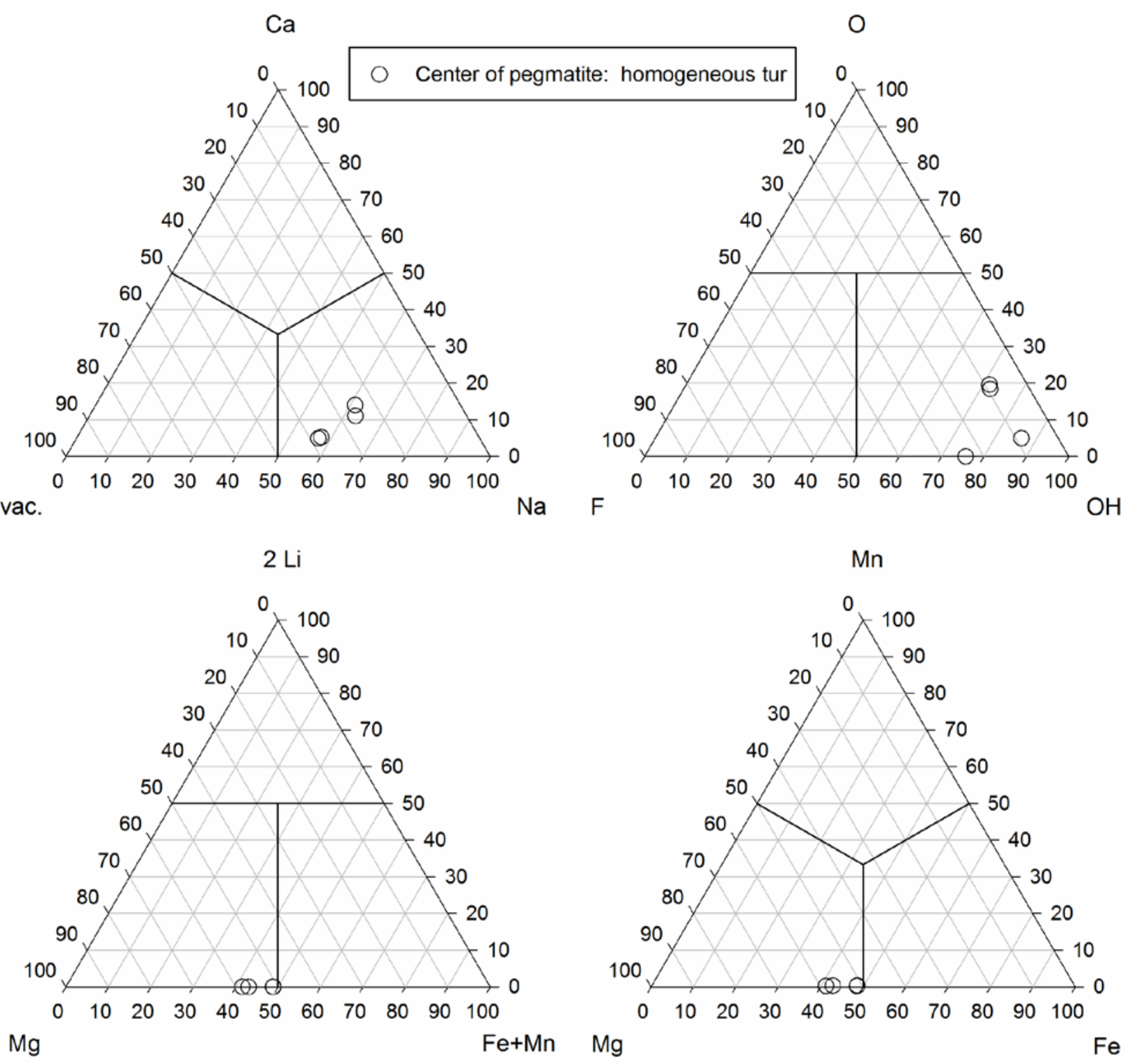

Figure 5.20: Ternary diagrams showing the classification of tourmaline sampled from the SIMPLE pegmatite. 


\subsubsection{The SIMPLE2 Pegmatite Tourmaline}

Tourmaline sampled from the SIMPLE2 pegmatite is homogeneous in hand sample and in BSE images; its composition straddles the boundary between schorl and dravite. The sample examined displays slightly elevated $\mathrm{Ca}, \mathrm{X}_{\square}$, and F content than might be expected for a crystal showing nearly an even mixture of end-member schorl and dravite (Fig. 5.20).

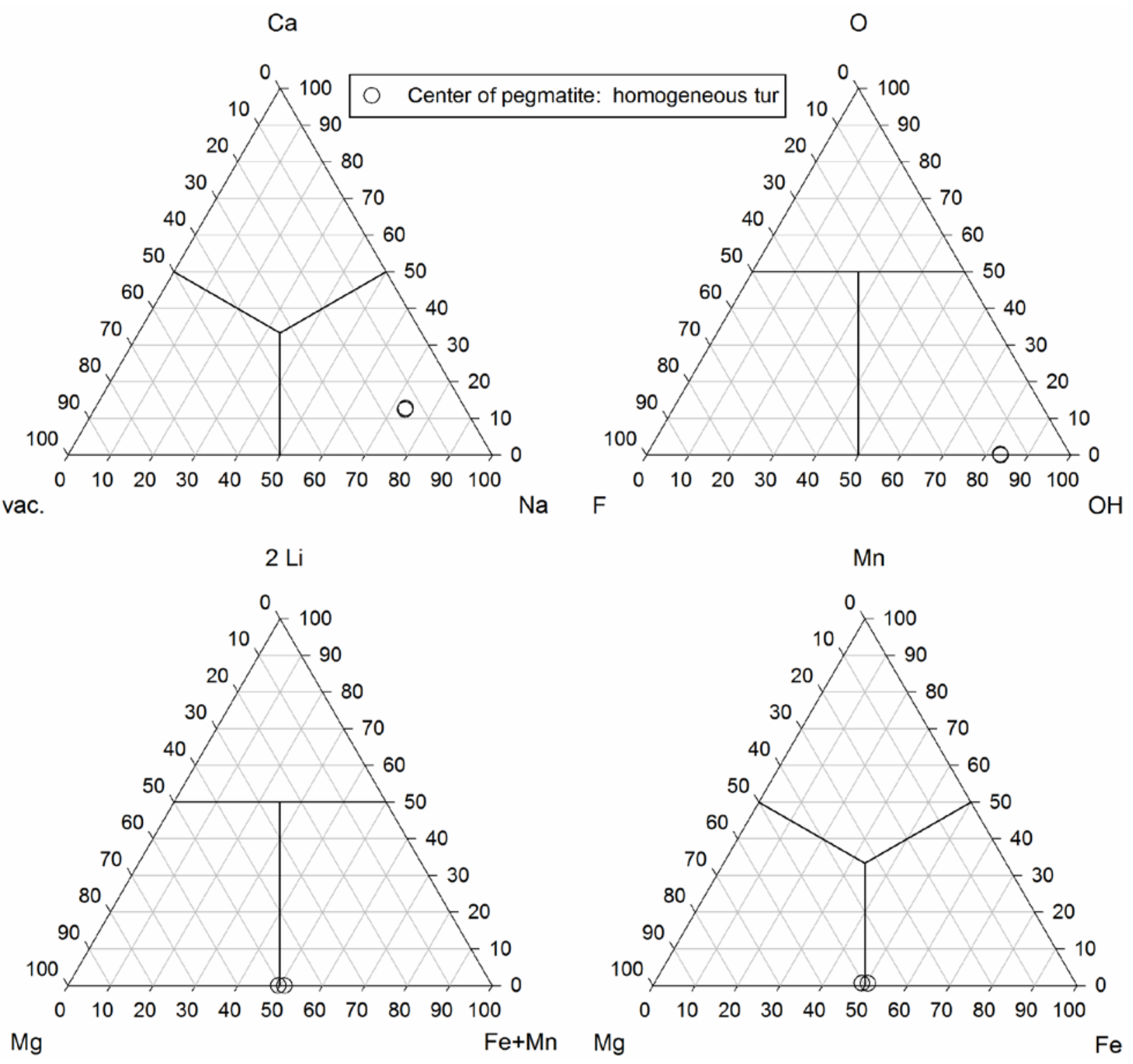

Figure 5.21: Ternary diagrams showing the classification of tourmaline sampled from the SIMPLE2 pegmatite. 


\subsubsection{The SIMPLE3 Pegmatite Tourmaline}

The tourmaline crystal sampled from the center of the SIMPLE3 pegmatite is Ca and Ferich dravite and displays slight compositional zoning. The crystal core shows greater $\mathrm{F}$ and $\mathrm{Mg}$ contents and very slightly increased $\mathrm{Na}$ than the crystal rim; the crystal rim displays greater ${ }^{\mathrm{W}} \mathrm{OH}$ and Fe contents and very slightly increased $X_{\square}$ compared to the crystal core (Fig. 5.22).

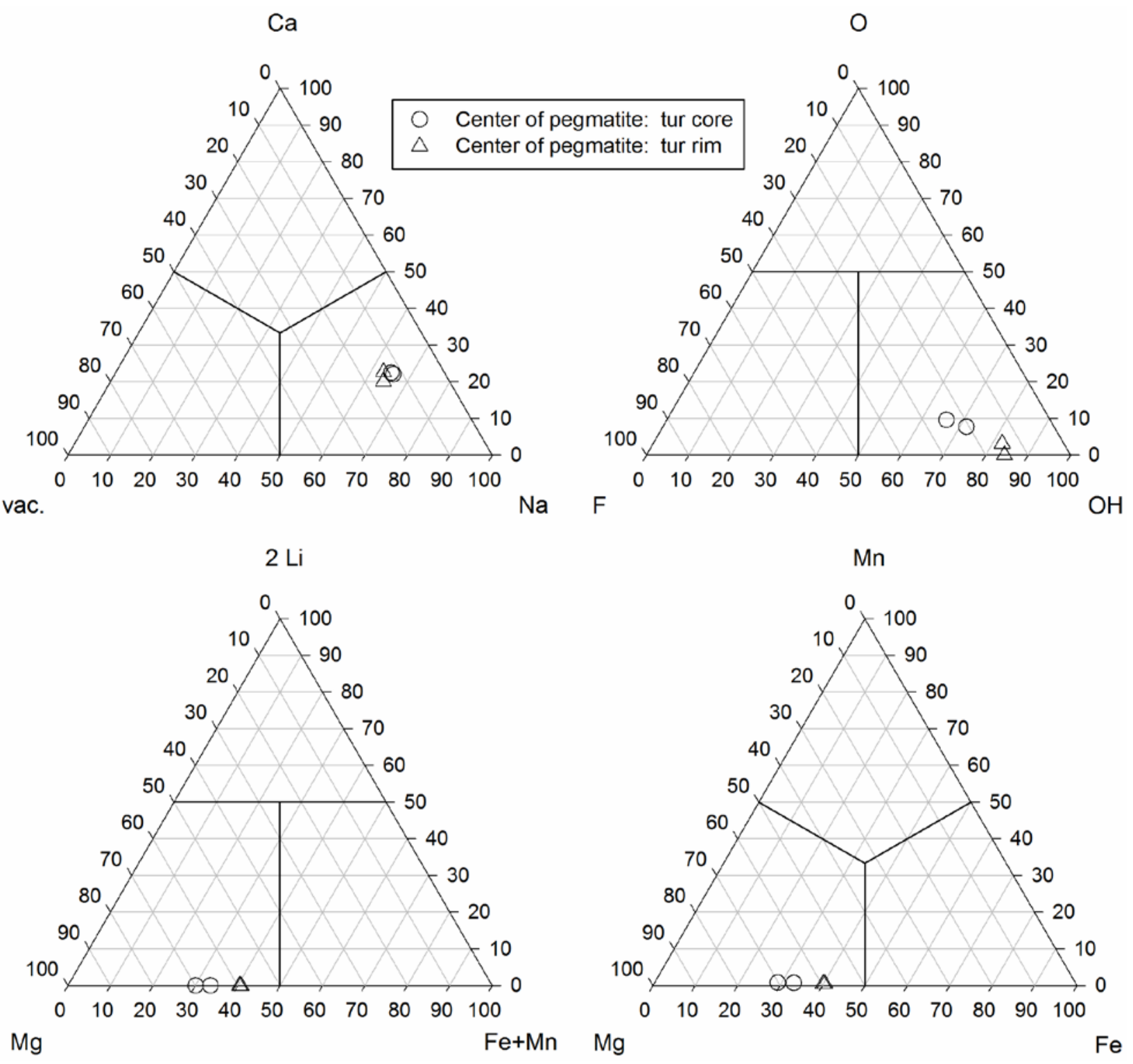

Figure 5.22: Ternary diagrams showing the classification of tourmaline sampled from the SIMPLE3 pegmatite. 


\subsubsection{The SIMPLE4 Pegmatite Tourmaline}

The tourmaline sample from the center of the SIMPLE4 pegmatite is Ca, ${ }_{\square}$, and Fe-rich dravite with a minor oxy-dravite component and exhibits slight compositional zoning. The crystal rim has an increased content of Fe and ${ }^{\mathrm{W}} \mathrm{OH}$ compared to the crystal core (Fig. 5.23).
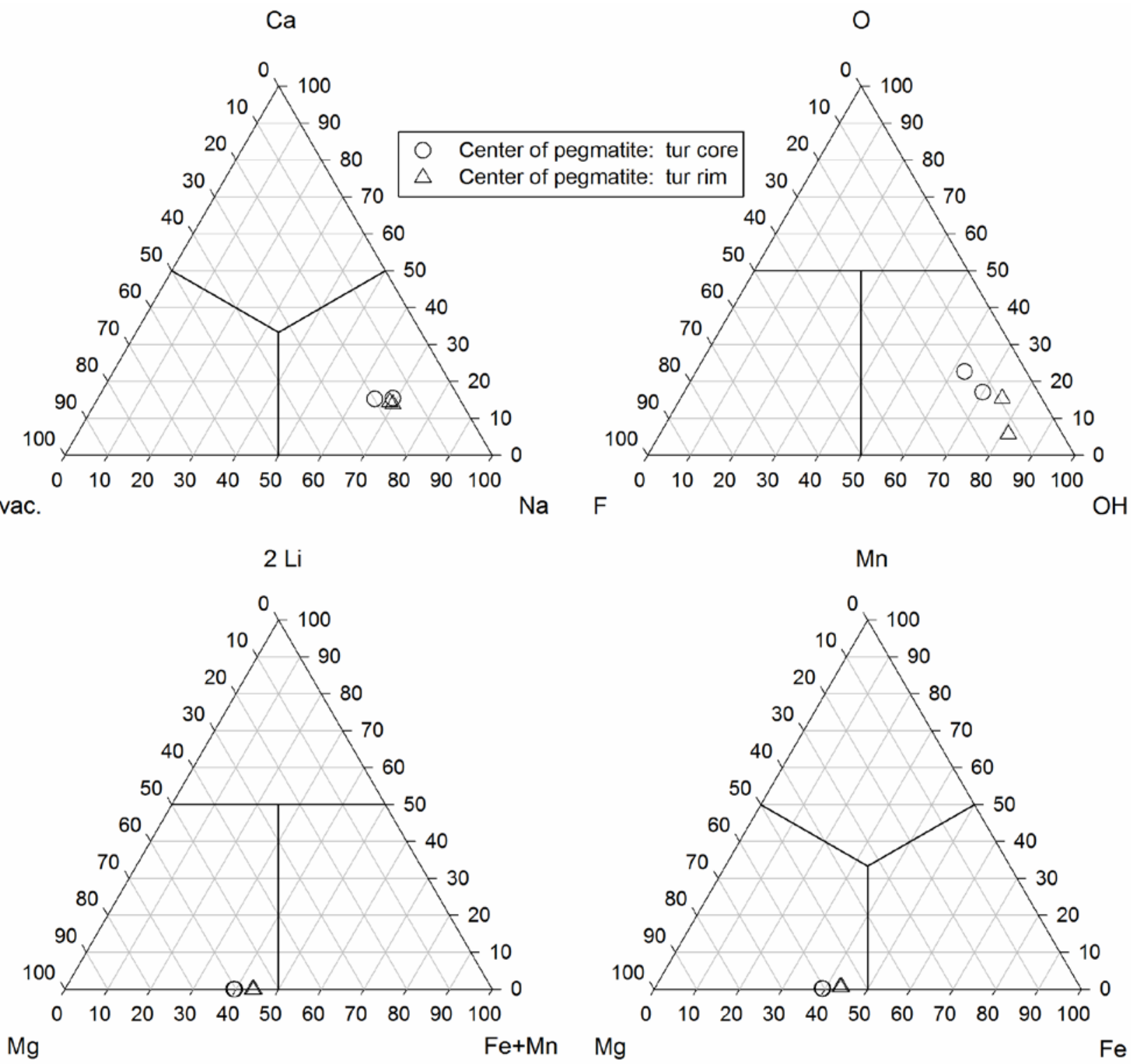

Figure 5.23: Ternary diagrams showing the classification of tourmaline sampled from the SIMPLE4 pegmatite. 


\subsubsection{The SIMPLE5 Pegmatite Tourmaline}

Tourmaline sampled from the SIMPLE5 pegmatite is homogeneous in hand sample and in BSE images. Its composition is Fe-rich dravite with a major oxy-dravite component; it displays slightly elevated $\mathrm{X}_{\square}$ and Ca contents than an end-member dravite (Fig. 5.24).
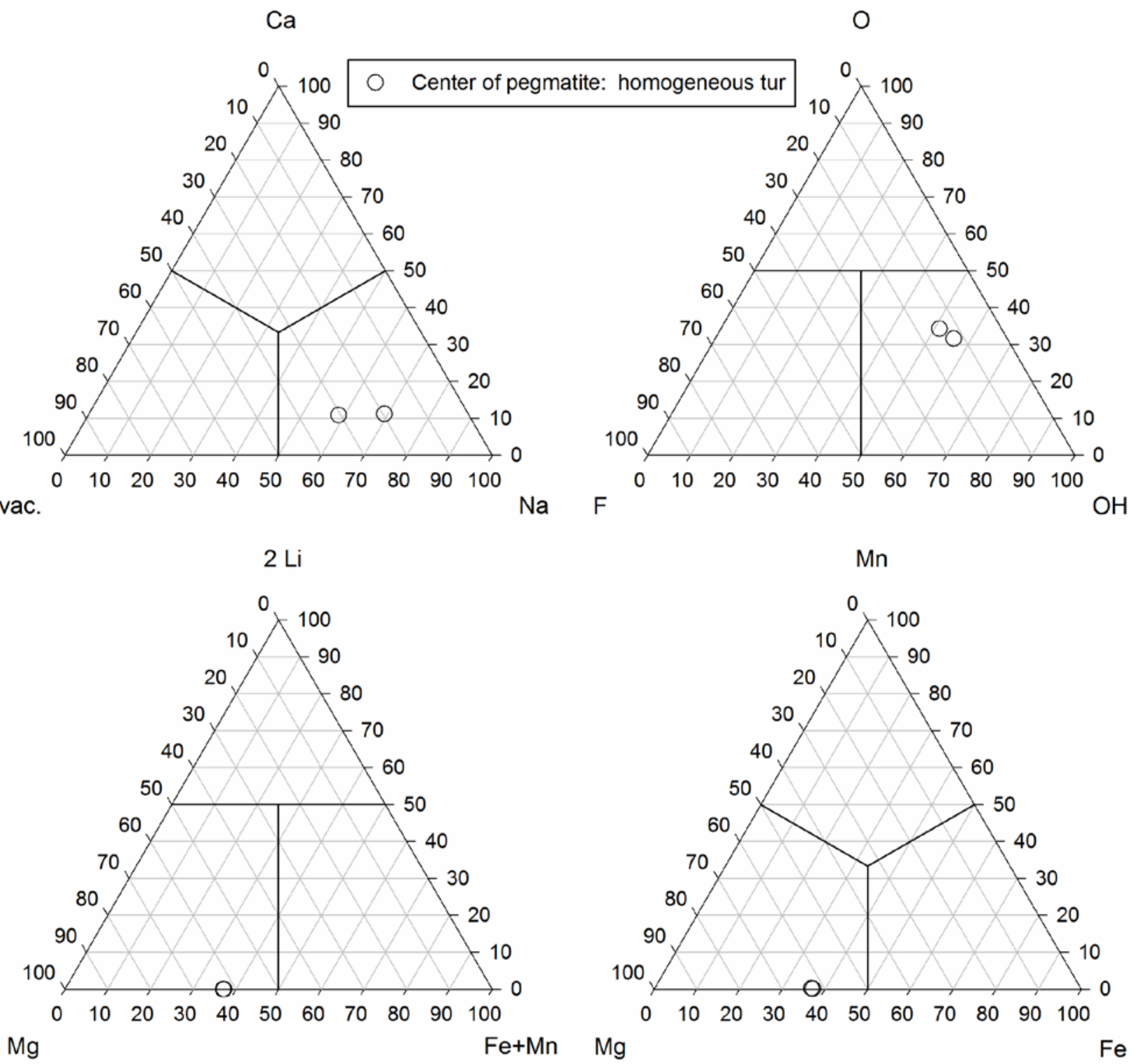

Figure 5.24: Ternary diagrams showing the classification of tourmaline sampled from the SIMPLE5 pegmatite. 


\subsubsection{The SIMPLE6 Pegmatite Tourmaline}

Tourmaline sampled from the SIMPLE6 pegmatite is homogeneous in hand sample and in BSE images. Its composition is Fe-rich dravite with slightly elevated contents of $\mathrm{F}$, Ca, and ${ }_{\square}$ than might be expected in end-member dravite (Fig. 5.25).
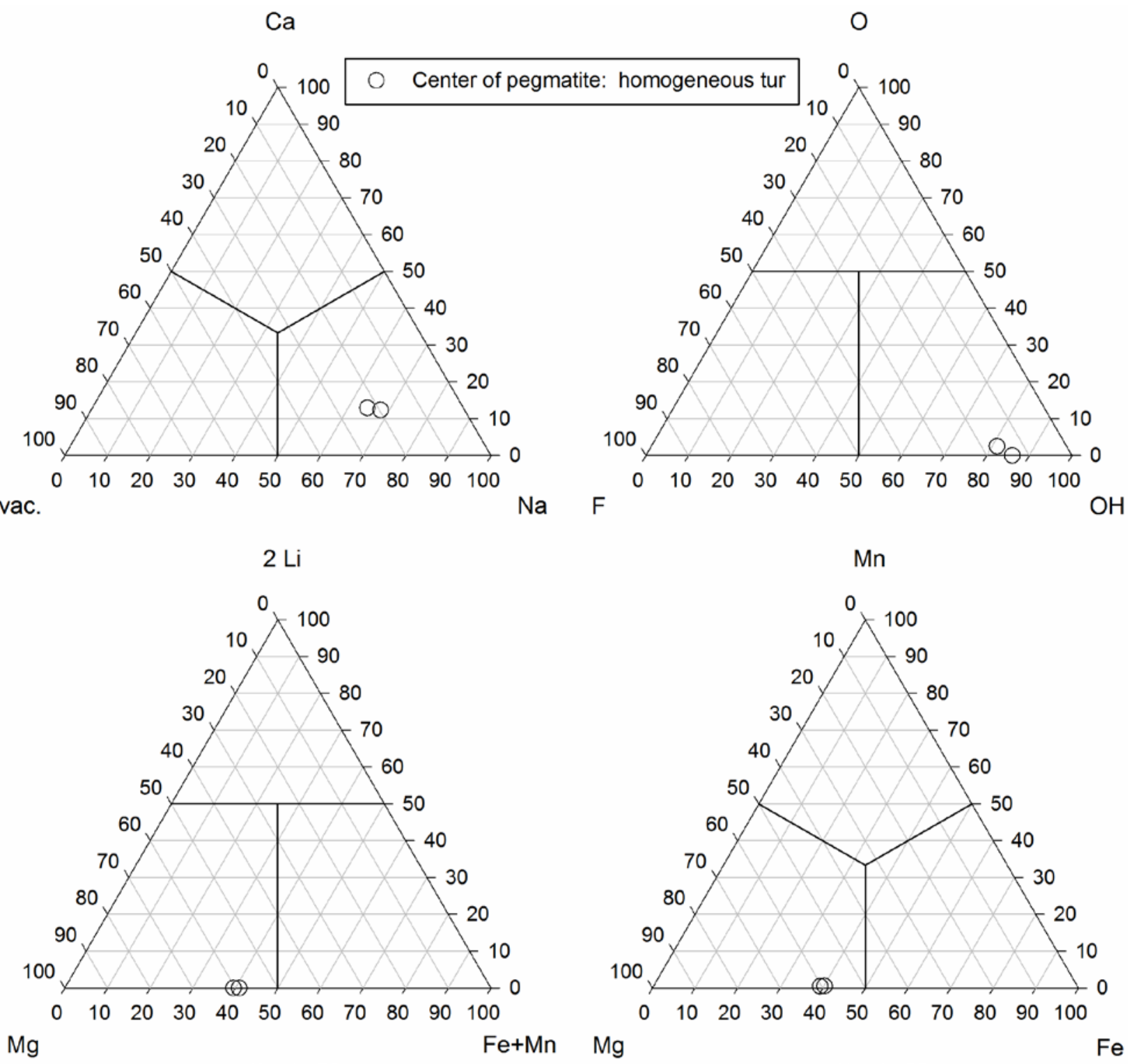

Figure 5.25: Ternary diagrams showing the classification of tourmaline sampled from the SIMPLE6 pegmatite. 


\subsubsection{The SIMPLE7 Pegmatite Tourmaline}

Tourmaline from the SIMPLE7 pegmatite displays compositional zoning. The crystal core has increased $\mathrm{X}_{\square}$ and ${ }^{\mathrm{W}} \mathrm{O}$, a slightly elevated content of $\mathrm{Mg}$, and slightly decreased content of Ca compared to points analyzed between the crystal core and rim which show elevated $\mathrm{Ca}, \mathrm{Fe}, \mathrm{Na}$, and ${ }^{\mathrm{W}} \mathrm{OH}$ contents and slightly decreased Mg contents. The crystal rim has increased ${ }^{\mathrm{X}_{\square}, \mathrm{Fe}}$, and ${ }^{\mathrm{W}} \mathrm{OH}$ contents and decreased $\mathrm{Na}$ and Ca contents compared to the rest of the crystal. The overall composition of the crystal changes from Fe-rich dravite with a major ${ }^{\mathrm{W}} \mathrm{O}$ component to $\mathrm{Ca}$ and Fe-rich dravite with a minor ${ }^{\mathrm{W}} \mathrm{O}$ component to Mg- and ${ }^{\mathrm{x}_{\square}}$-rich schorl (Fig. 5.26).

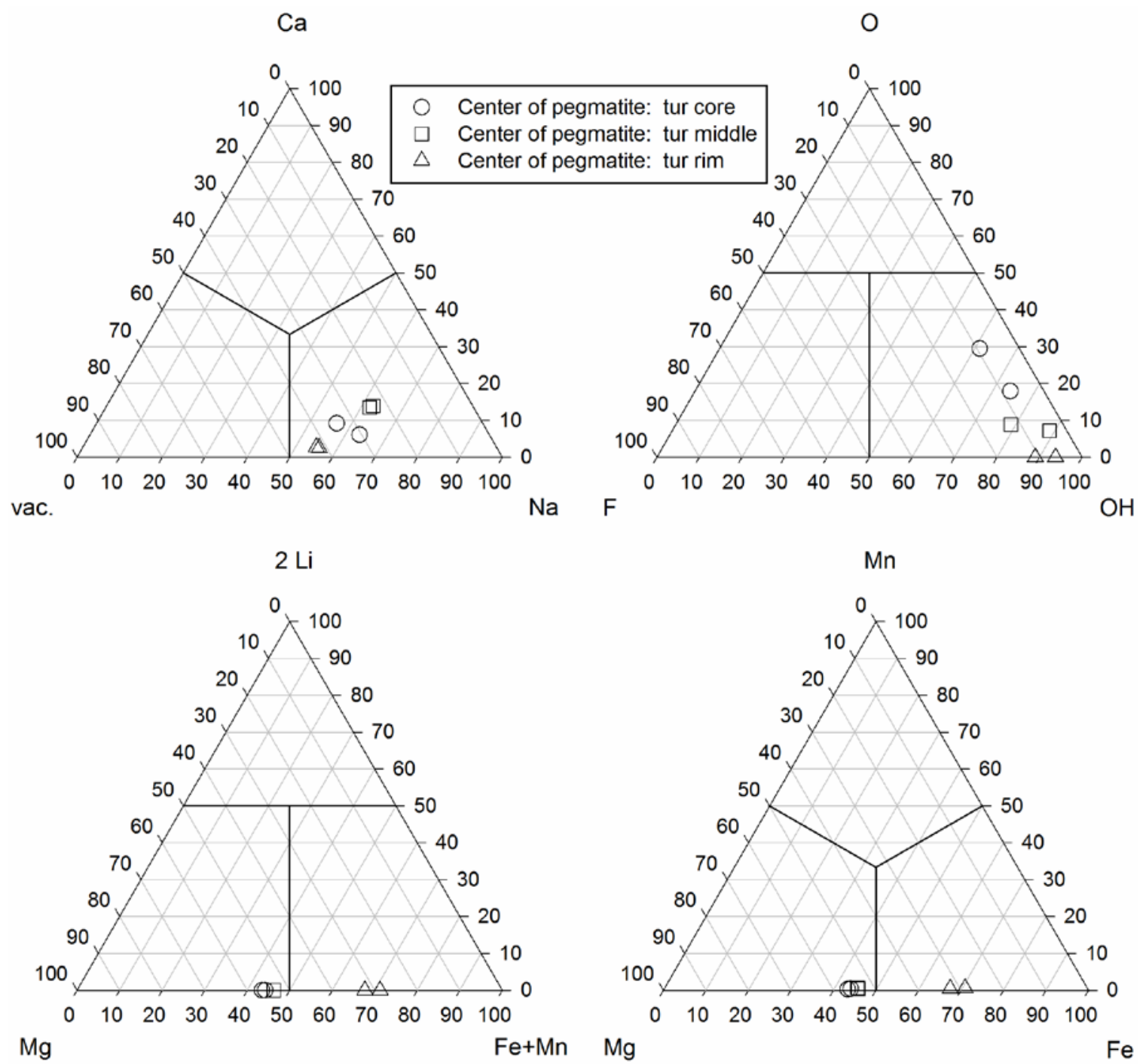

Figure 5.26: Ternary diagrams showing the classification of tourmaline sampled from the SIMPLE7 pegmatite. 


\subsubsection{The SIMPLE9 Pegmatite Tourmaline}

Tourmaline from the host rock in contact with the SIMPLE9 pegmatite displays compositional zoning and is $\mathrm{Ca}$ and Mg-rich compared to all tourmaline analyzed within the SIMPLE9 pegmatite. From the crystal core to the middle of the crystal, Fe and $\mathrm{X}_{\square \text { contents }}$ increase; from the middle of the crystal to the crystal rim, Fe content continues to increase while the $\mathrm{X}_{\square}$ and $\mathrm{Ca}$ contents decrease and the Na content increases. The composition of the host rock tourmaline is Ca- and Fe-rich dravite (Fig. 5.27a).

Tourmaline from the border zone of the SIMPLE9 pegmatite exhibits lower Ca and Mg contents and higher ${ }^{\mathrm{W}} \mathrm{OH}$ and Fe contents compared to the host rock tourmaline. From the crystal cores to the rim, the $\mathrm{X}_{\square}$ content increases. However, the crystal rims have the same Na content as their cores whereas the Fe content is higher. The composition of the border zone tourmaline transitions from Fe-rich dravite with a high magnesio-foitite component to Mg-rich schorl (Fig. 5.27a \& b).

The tourmaline samples from the center of the pegmatite show lower Ca and Mg contents and higher Fe contents compared to the border zone and host rock tourmaline. From the crystal cores to the crystal rims, the Fe content increases along with a slight increase in the Li and $\mathrm{Mn}$ contents while the $\mathrm{X}_{\square}$ content decreases slightly. Late stage overgrowth of tourmaline on the crystal rims (Fig. 5.27c) show an increase of Mg content and a very slight increase of Ca content compared to the crystal rim, possibly suggesting an opening of the system to contamination from the host rock. The composition of the tourmaline from the center of the pegmatite transitions from Mg-rich schorl to schorl from crystal cores to rims and towards Mg-rich schorl and dravite in the late stage overgrowth tourmaline (Fig. 5.27a \& b). 

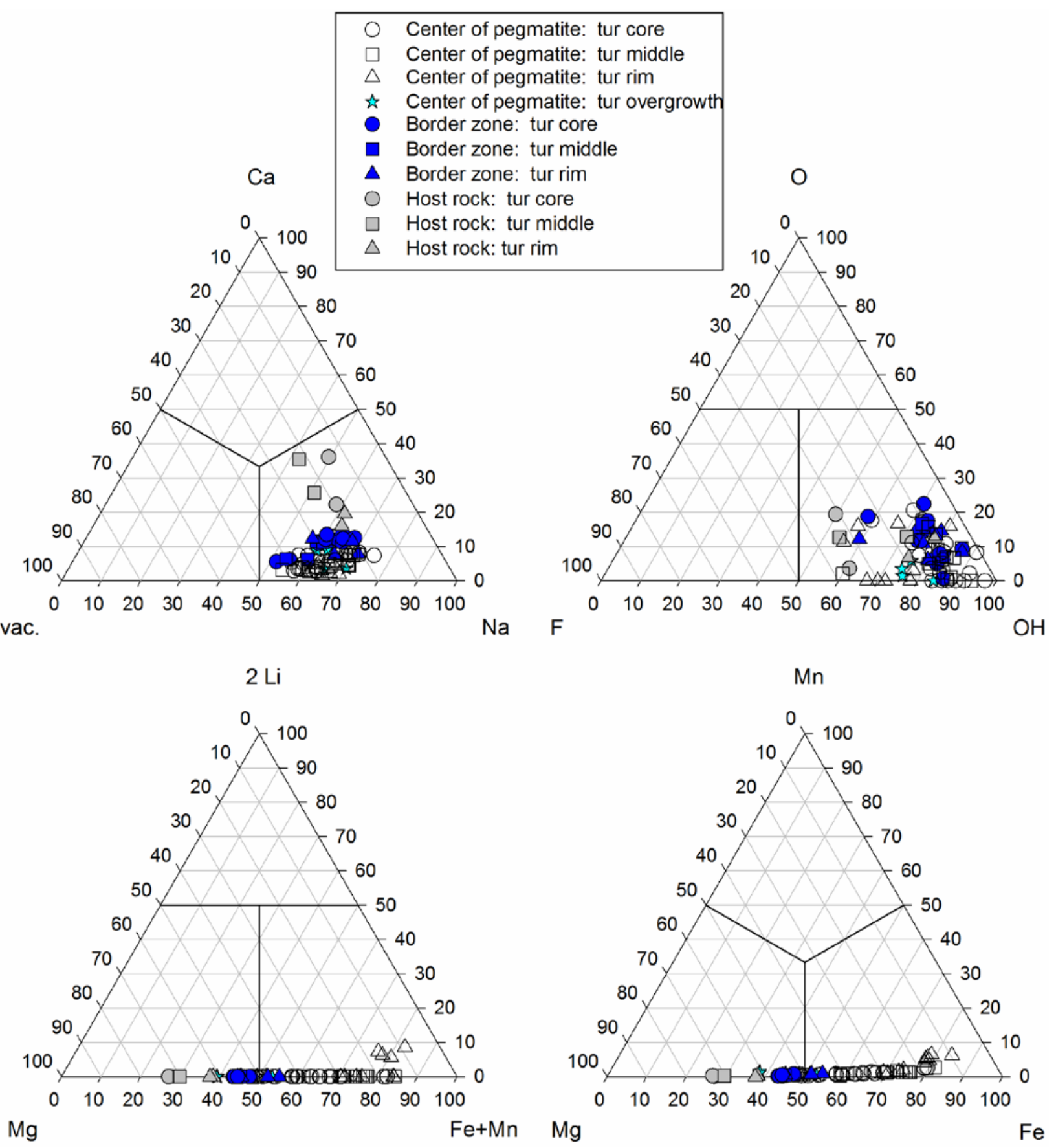

Figure 5.27a: Ternary diagrams showing the classification of tourmaline sampled from the SIMPLE9 pegmatite. 

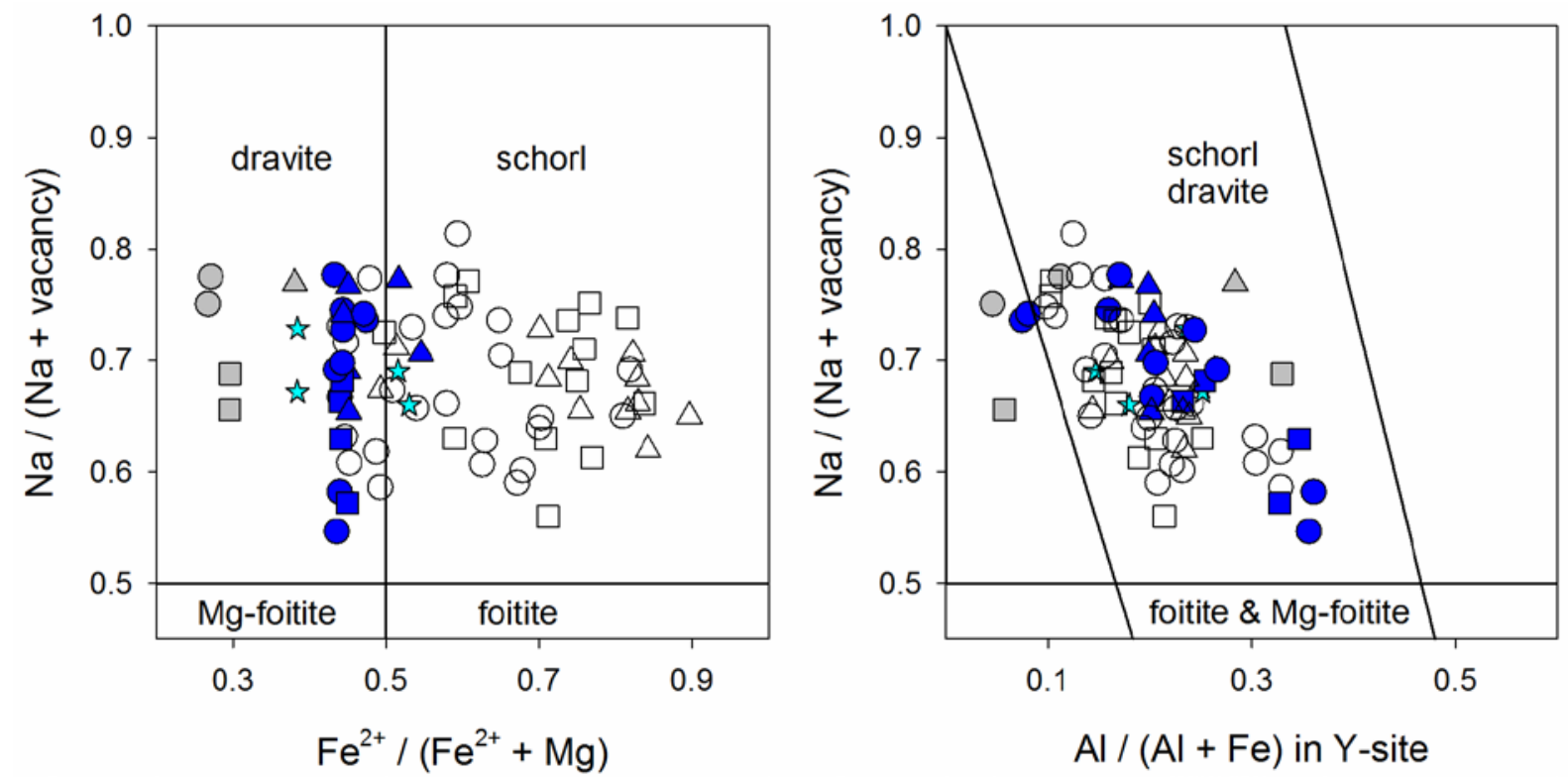

Figure 5.27b: Plots showing the classification of tourmaline sampled from the SIMPLE9 pegmatite. Legend is the same as seen in Fig. 5.27a.

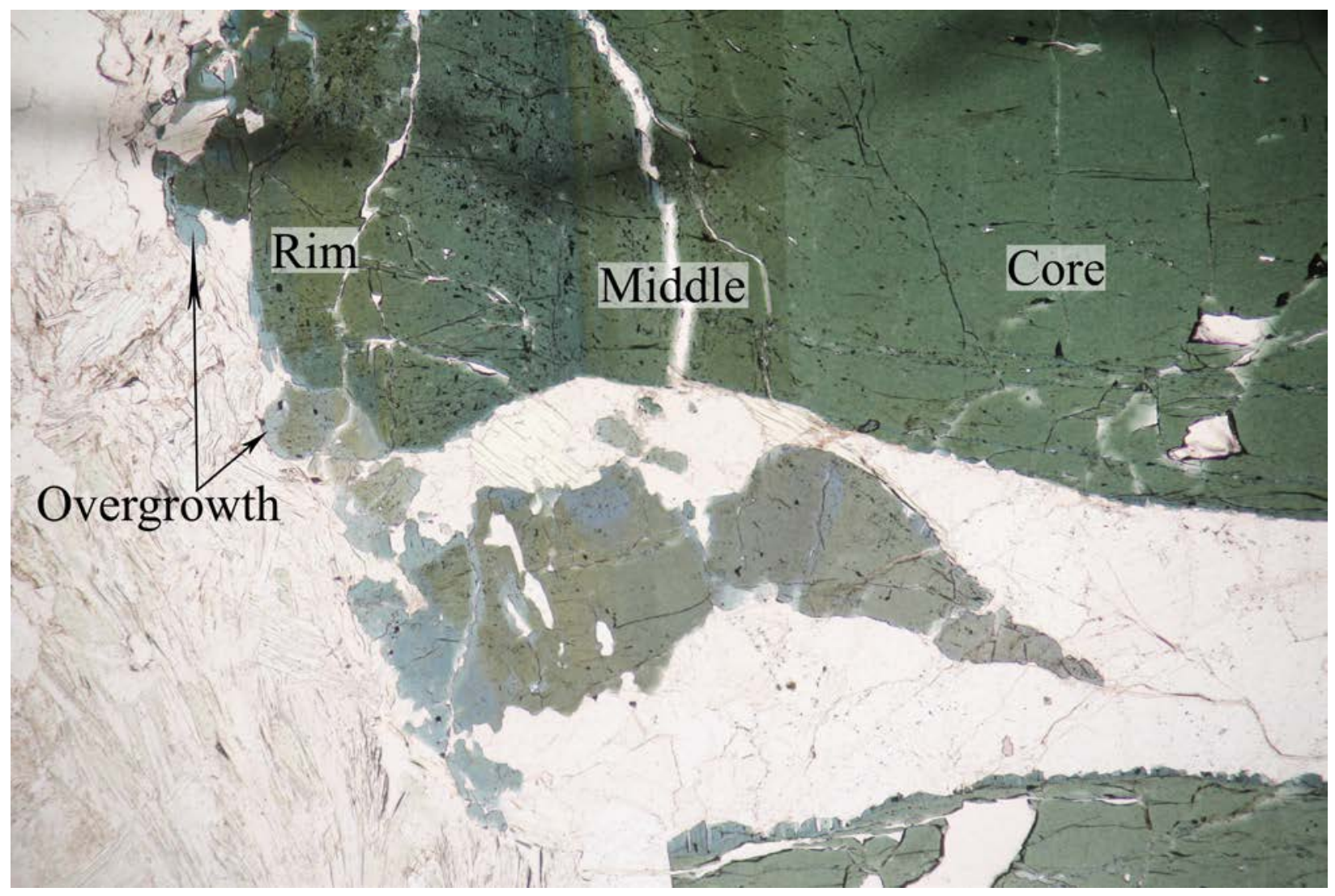

Figure 5.27c: Pale blue late overgrowth on tourmaline from the center of the SIMPLE9 pegmatite as seen in thin section using plain light. Field of view is $4.2 \mathrm{~mm}$. 


\subsubsection{The SIMPLE11 Pegmatite Tourmaline}

Tourmaline sampled from the SIMPLE11 pegmatite is homogeneous in hand sample and in BSE images. Its composition is Ca and Fe-rich dravite. One of the points analyzed shows an elevated content of ${ }^{\mathrm{W}} \mathrm{O}$ and $\mathrm{F}$ compared to the other analytical point (Fig. 5.28).
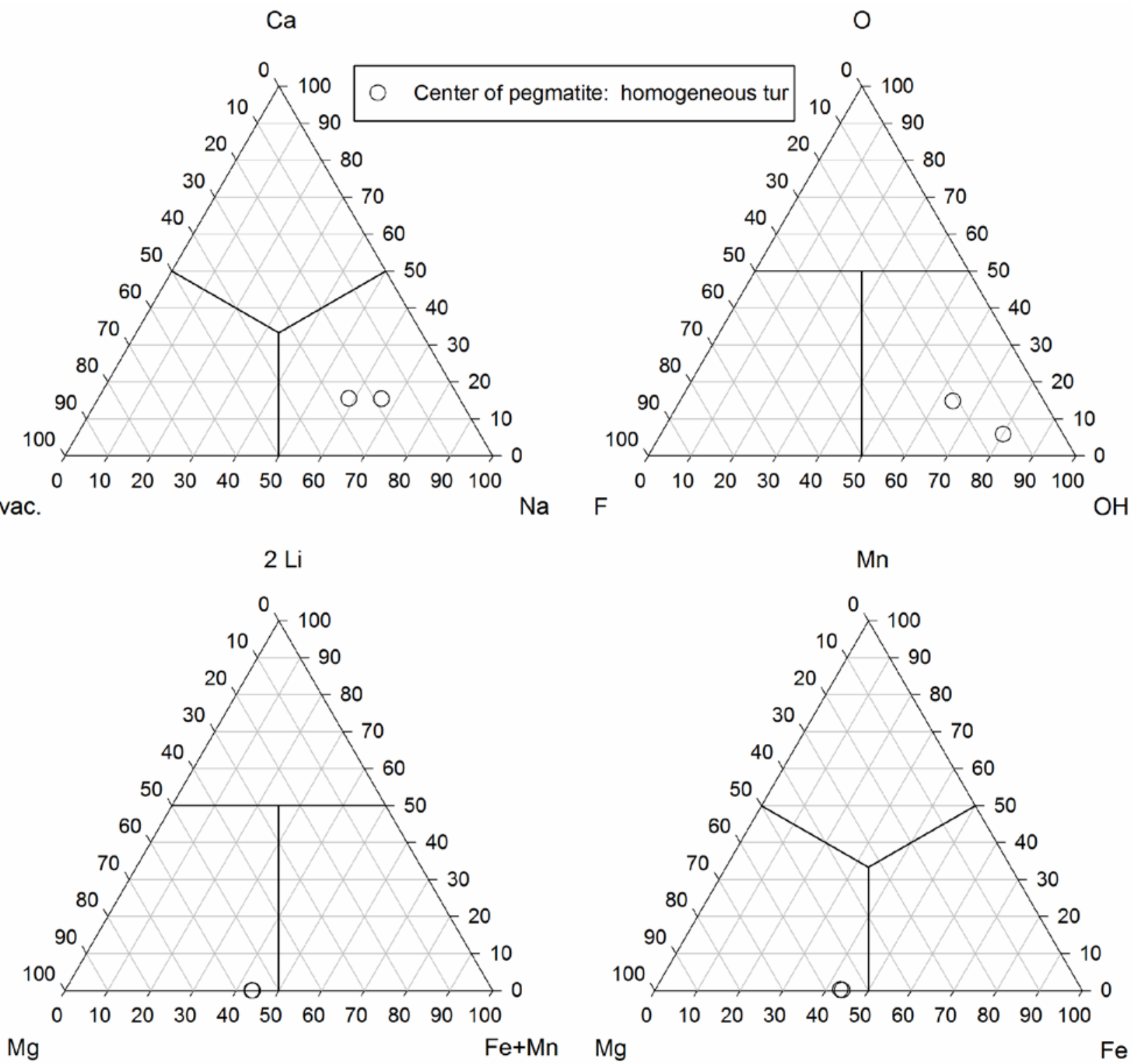

Figure 5.28: Ternary diagrams showing the classification of tourmaline sampled from the SIMPLE11 pegmatite. 


\subsubsection{The SIMPLE12 Pegmatite Tourmaline}

Tourmaline sampled from the center SIMPLE12 pegmatite displays compositional zoning; some of the zoning is oscillatory. In general, the crystal cores show decreased $\mathrm{Ca}$ and $\mathrm{Mg}$ contents than the middle of the crystal and crystal rims. Some points from the middle of the crystal display greatly increased Fe contents and slightly elevated ${ }^{X_{\square}}$ and Ca contents compared to most other analyzed points. Crystal rims exhibit slightly elevated Ca and Mg contents compared to all other analyzed points, possibly suggesting an opening of the system to contamination from the host rock. W-site occupancy is variable for all analytical points examined. The general trend for the composition changes from Mg-rich schorl to schorl to Ferich dravite with slightly elevated Ca content than might be expected for end-member dravite (Fig. 5.29).

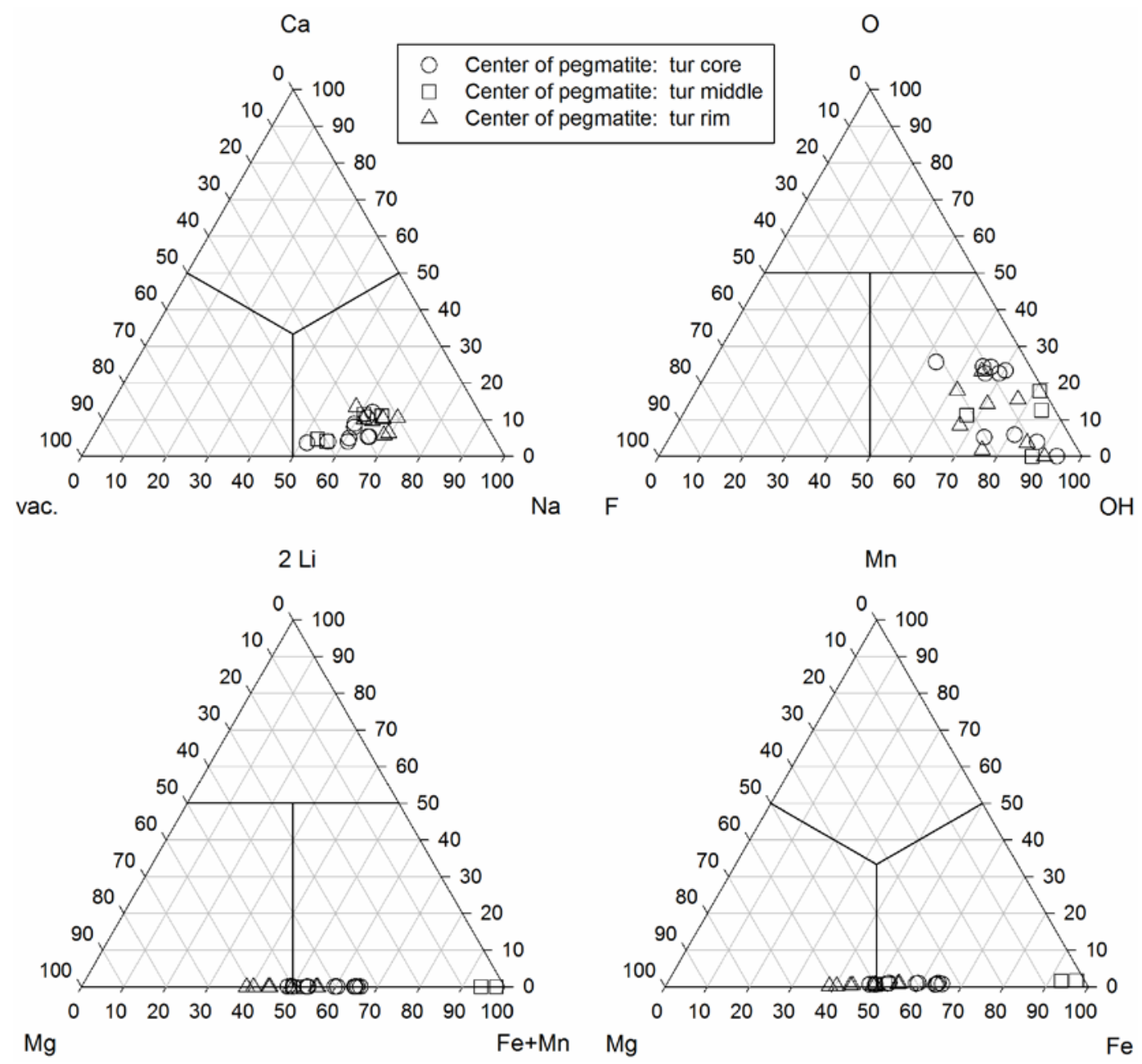

Figure 5.29: Ternary diagrams showing the classification of tourmaline sampled from the SIMPLE12 pegmatite. 


\subsubsection{The SIMPLE13 Pegmatite Tourmaline}

The tourmaline sampled from the SIMPLE13 pegmatite is homogeneous in hand sample and in BSE images. The sample from the border zone of the pegmatite shows elevated $\mathrm{Na}, \mathrm{Ca}$, Mg, and F contents compared to the sample from the center of the pegmatite. Tourmaline from the center of the pegmatite displays increased ${ }^{\mathrm{X}} \square, \mathrm{Mn}, \mathrm{Fe}$, and ${ }^{\mathrm{W}} \mathrm{OH}$ contents and decreased Ca and F contents compared to the tourmaline from border zone of the pegmatite. The composition for the sampled tourmaline is Mg-rich schorl for the border zone and schorl for the center of the pegmatite (Fig. 5.30).

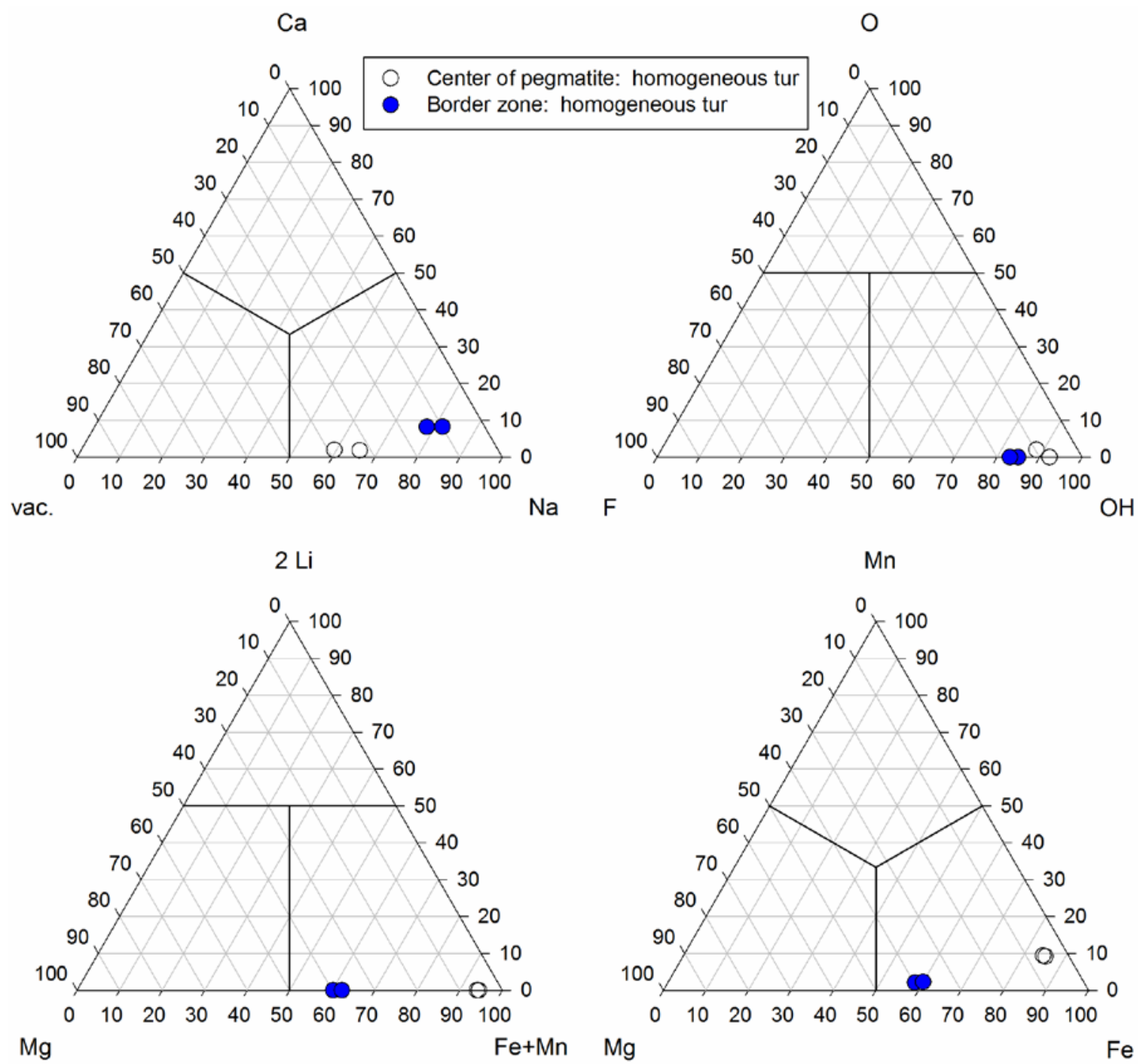

Figure 5.30: Ternary diagrams showing the classification of tourmaline sampled from the SIMPLE13 pegmatite. 


\subsubsection{The SIMPLE14 Pegmatite Tourmaline}

Tourmaline samples from the SIMPLE14 pegmatite display compositional zoning. The crystal core and middle from the border zone sample is ${ }^{\mathrm{W}} \mathrm{O}$ and Mg-rich. The crystal rim shows an increase in ${ }^{\mathrm{W}} \mathrm{OH}$ and Fe contents, a slight increase in ${ }^{\mathrm{X}_{\square}}$ content, as well as a decrease in ${ }^{\mathrm{W}} \mathrm{O}$ content. Its composition transitions from oxy-schorl-dravite to Mg-rich schorl with a high oxyschorl component (Fig. 5.31).

The tourmaline samples from the center of the pegmatite have a crystal core that is $\mathrm{Mg}$ rich with slightly elevated $\mathrm{Ca}$ and $\mathrm{Na}$ contents and a crystal core that is Fe-rich with a slightly elevated ${ }^{\mathrm{X}_{\square}}$ content. Both crystal cores have a high ${ }^{\mathrm{W}} \mathrm{O}$ content compared to the crystal rim. The crystal rim displays increased $\mathrm{Mg}$ and ${ }^{\mathrm{W}} \mathrm{OH}$ contents compared to the crystal core from the center of the pegmatite. Their compositions are Fe-rich dravite with a high oxy-dravite component and schorl with a high oxy-schorl component (Fig. 5.31). 

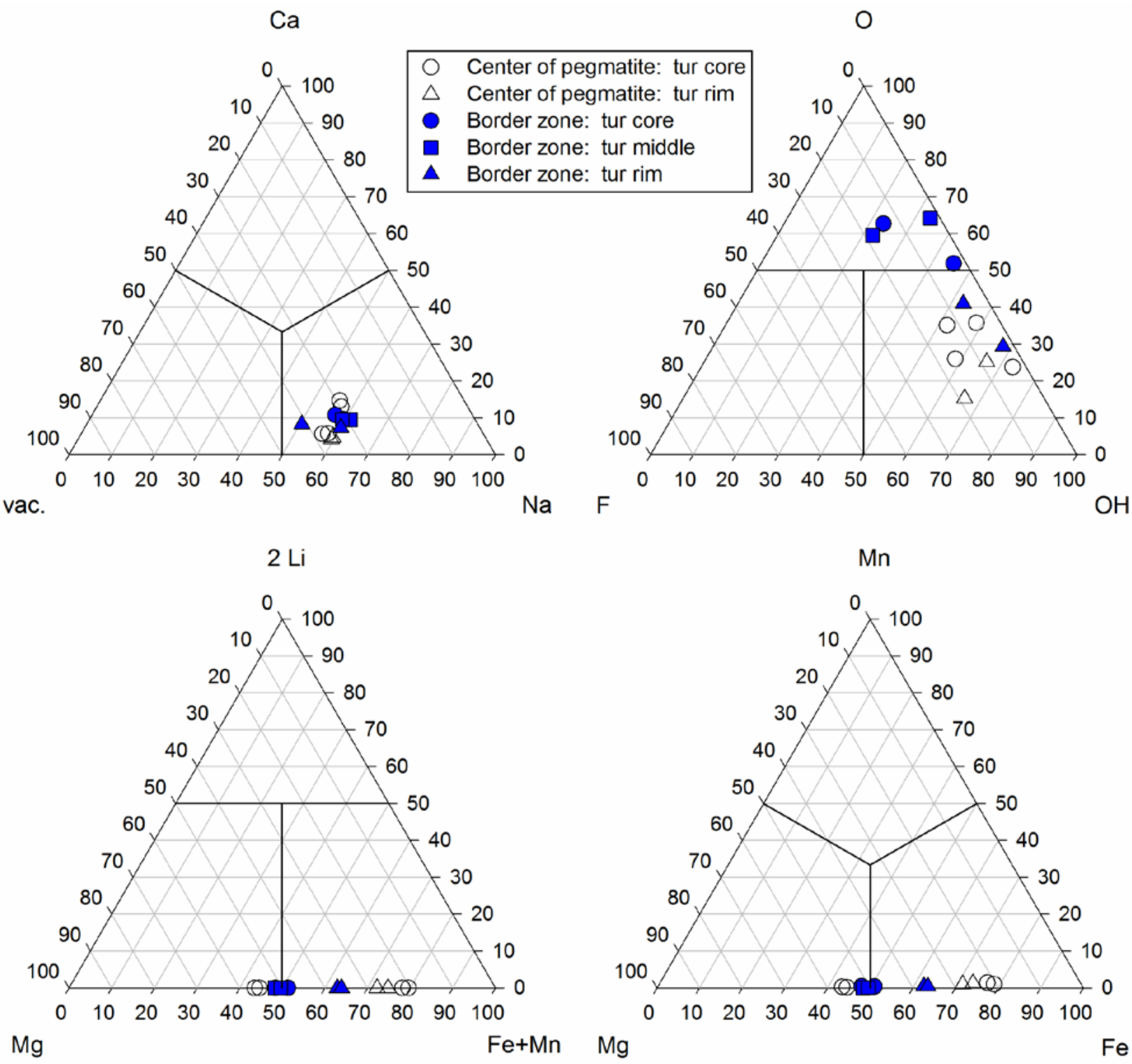

Figure 5.31: Ternary diagrams showing the classification of tourmaline sampled from the SIMPLE14 pegmatite. 


\subsubsection{The SIMPLE16 Pegmatite Tourmaline}

Tourmaline sampled from the center of the SIMPLE16 pegmatite displays compositional zoning with greatly increasing $\mathrm{Ca},{ }^{\mathrm{W}} \mathrm{O}$, and $\mathrm{Mg}$ contents and slightly increasing Na content from crystal core to rim. The crystal core has greater contents of Fe, ${ }^{\mathrm{W}} \mathrm{OH}$, and ${ }^{\mathrm{X}} \square$ than the analytical points from the middle and rim of the crystal. Its composition transitions from Mg-rich schorl with a high oxy-schorl component to Fe-rich dravite with a high oxy-dravite component. This transition from schorl to dravite rather than dravite to schorl, as is common with most tourmaline in pegmatites may suggest system was open to contamination from the host rock in the later stages of crystallization (Fig. 5.32).
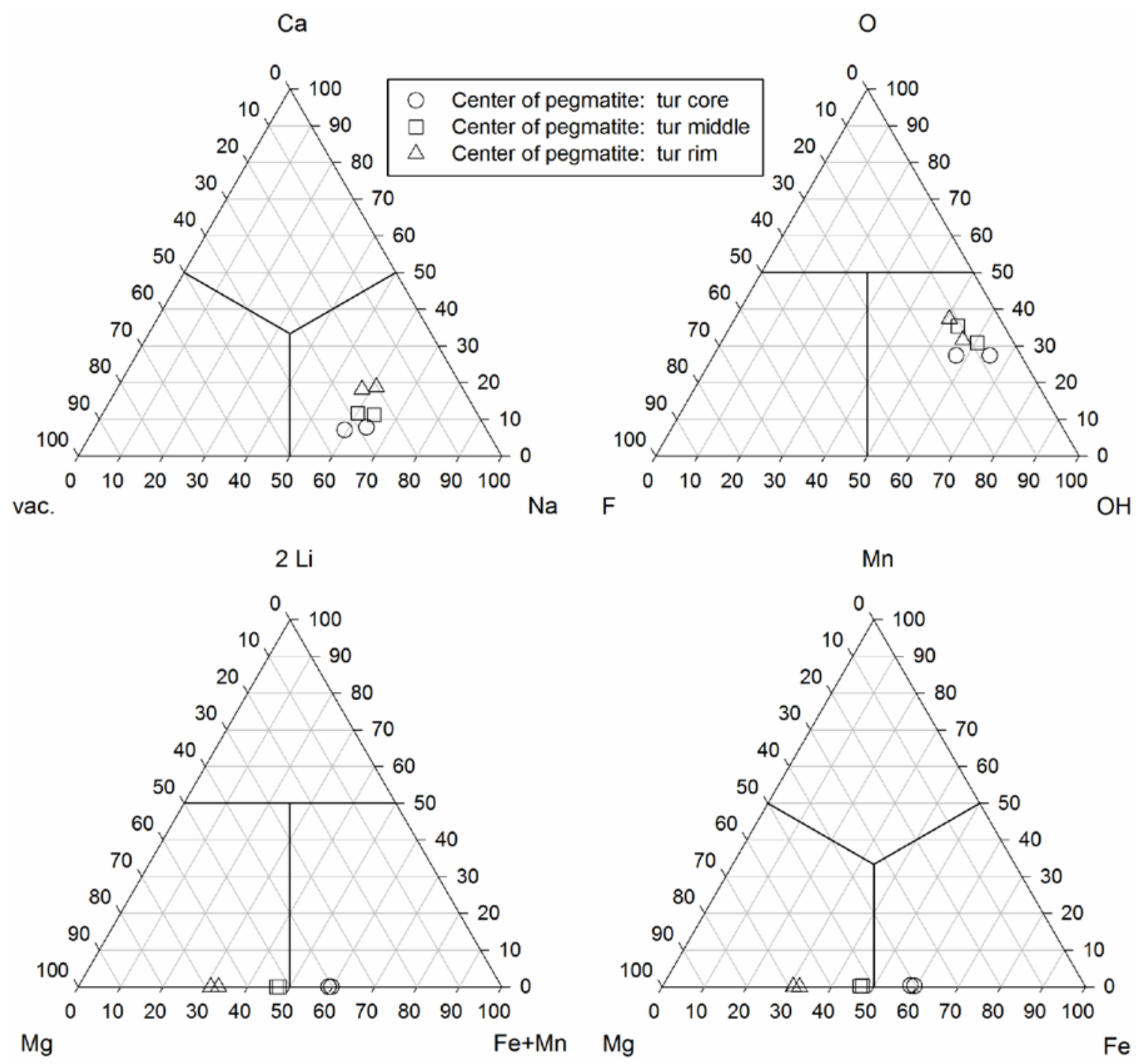

Figure 5.32: Ternary diagrams showing the classification of tourmaline sampled from the SIMPLE16 pegmatite. 


\subsubsection{The SIMPLE17 Pegmatite Tourmaline}

Tourmaline sampled from the center of the SIMPLE17 pegmatite displays compositional zoning; the crystal cores have greater contents of Fe and ${ }^{X_{\square}}$ compared to most other analytical points. The crystal rim from one of the crystals is nearly identical to the crystal cores other than a very slight increase of the Mg content. The crystal rim and the middle analytical points of the other crystal show increasing $\mathrm{Ca}, \mathrm{Mg}$, and $\mathrm{F}$ compared its crystal core and analytical points from the other crystal, which show greater ${ }^{\mathrm{W}} \mathrm{O}$ and ${ }^{\mathrm{W}} \mathrm{OH}$ contents across all parts of the crystal. The compositions of the tourmaline crystals sampled from the center of the pegmatite are Mg-rich schorl with a high oxy-schorl component and Fe-rich dravite with a high oxy-dravite component transitioning to Mg and Ca-rich uvite with an elevated oxy-uvite component (Fig. 5.33).

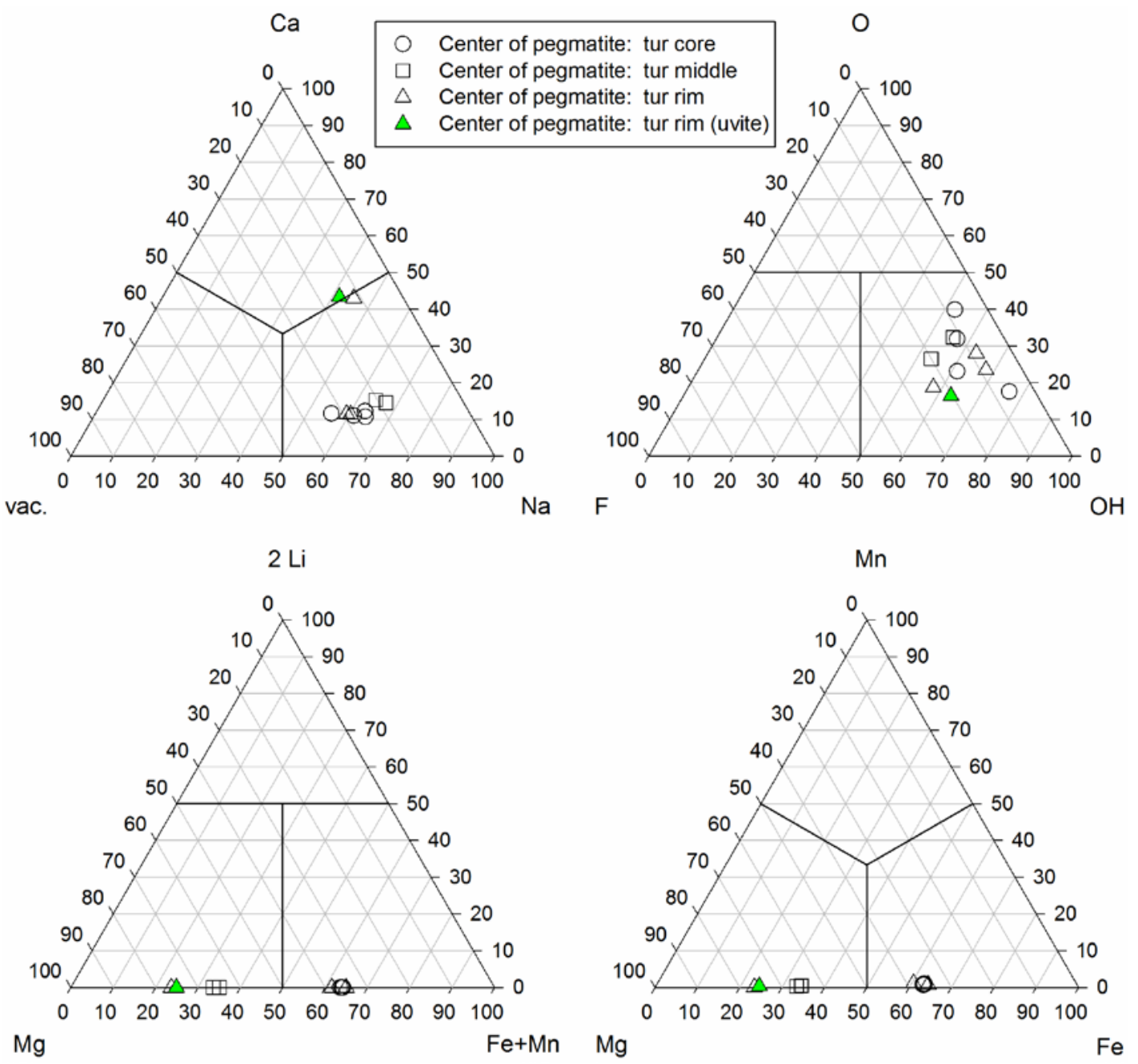

Figure 5.33: Ternary diagrams showing the classification of tourmaline sampled from the SIMPLE17 pegmatite. 


\subsubsection{The SMALL Pegmatite Tourmaline}

Tourmaline analyzed from the center of the SMALL pegmatite is homogeneous in hand sample and in BSE images; samples not analyzed in time for this thesis display optical zoning in thin section and the rims of these crystals are Mn-rich. The sample analyzed is Fe-rich dravite with slightly elevated Ca, F, and $\mathrm{X}_{\square}$ than might be expected in end-member dravite (Fig. 5.34).

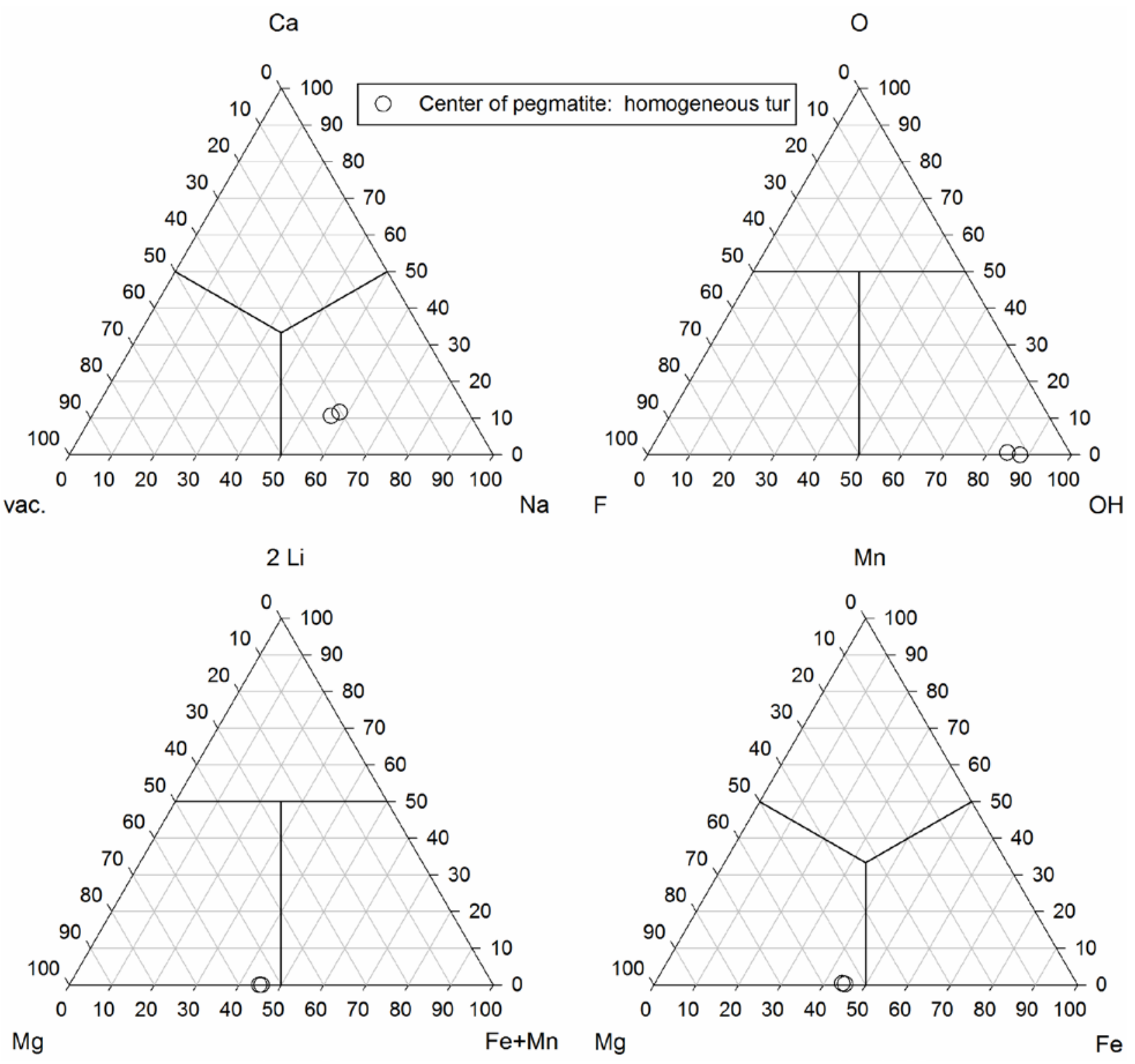

Figure 5.34: Ternary diagrams showing the classification of tourmaline sampled from the SMALL pegmatite. 


\subsubsection{The THIN Pegmatite Tourmaline}

A tourmaline crystal from the border zone was examined from the THIN pegmatite, as tourmaline was not present within the core of the dike. The tourmaline sample is homogeneous in hand sample and in BSE image. Its composition is Fe-rich dravite with a greater Ca content than might be expected from end-member dravite (Fig. 5.35).

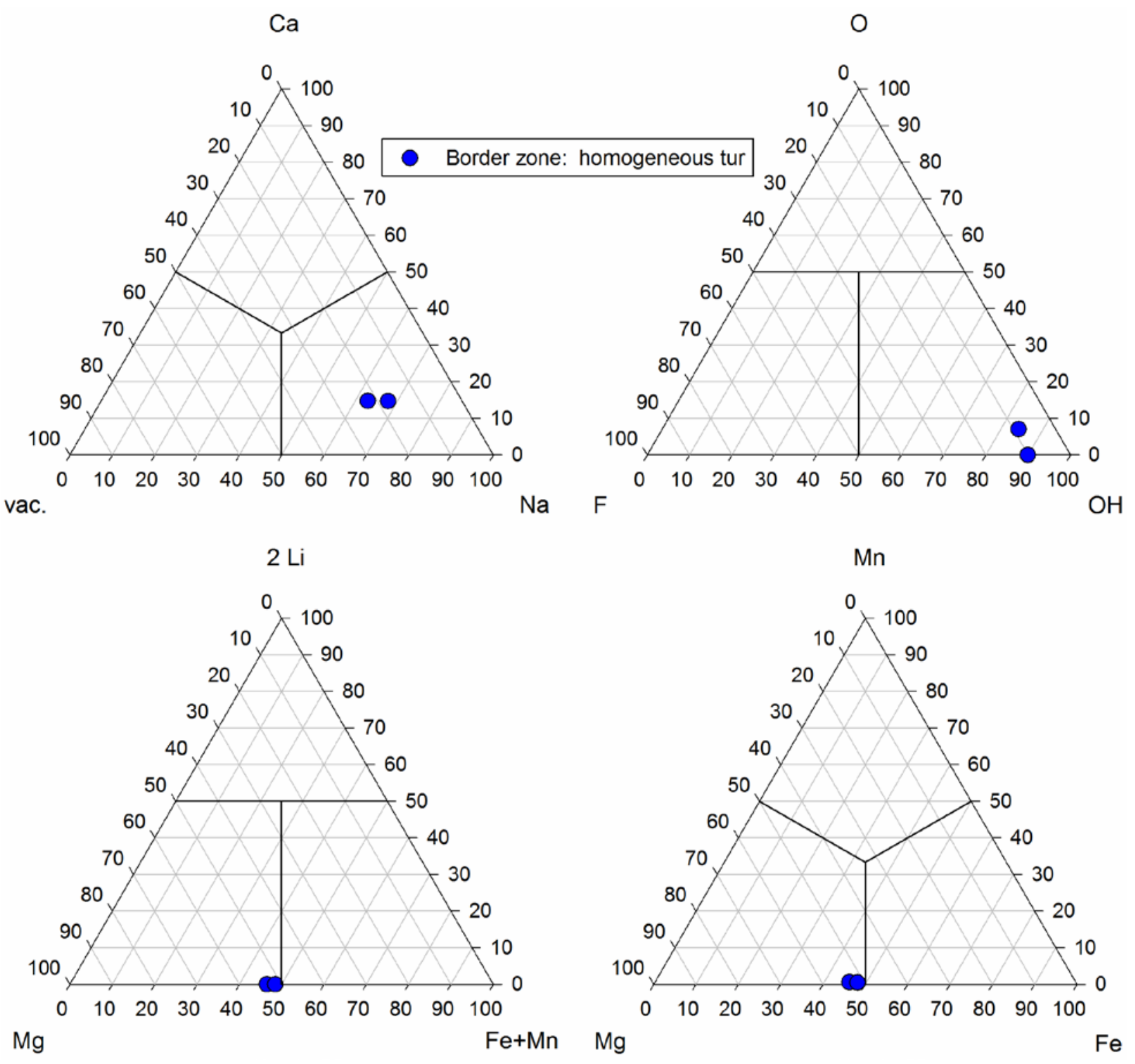

Figure 5.35: Ternary diagrams showing the classification of tourmaline sampled from the THIN pegmatite. 


\subsubsection{The TOUR Pegmatite Tourmaline}

Tourmaline from the border zone of the pegmatite is compositionally zoned; the crystal core has increased $\mathrm{Ca},{ }^{\mathrm{X}_{\square}},{ }^{\mathrm{W}} \mathrm{O}$, and Mg compared to the crystal rim which has increased $\mathrm{Na}, \mathrm{Fe}$, ${ }^{\mathrm{W}} \mathrm{OH}$, and $\mathrm{F}$. Its composition transitions from Fe and Ca-rich dravite with a high oxy-dravite component to Mg-rich schorl with a high oxy-schorl component (Fig. 5.36).

The tourmaline sampled from the center of the pegmatite appears to be homogenous in hand sample and BSE image; it is optically zoned in a thin section not analyzed in time for this thesis. Compared to tourmaline analyzed from the border zone, it has increased $\mathrm{X}_{\square}$, and Fe and decreased Ca. Its composition is foitite-schorl with a high oxy-foitite-schorl component (Fig. 5.36).
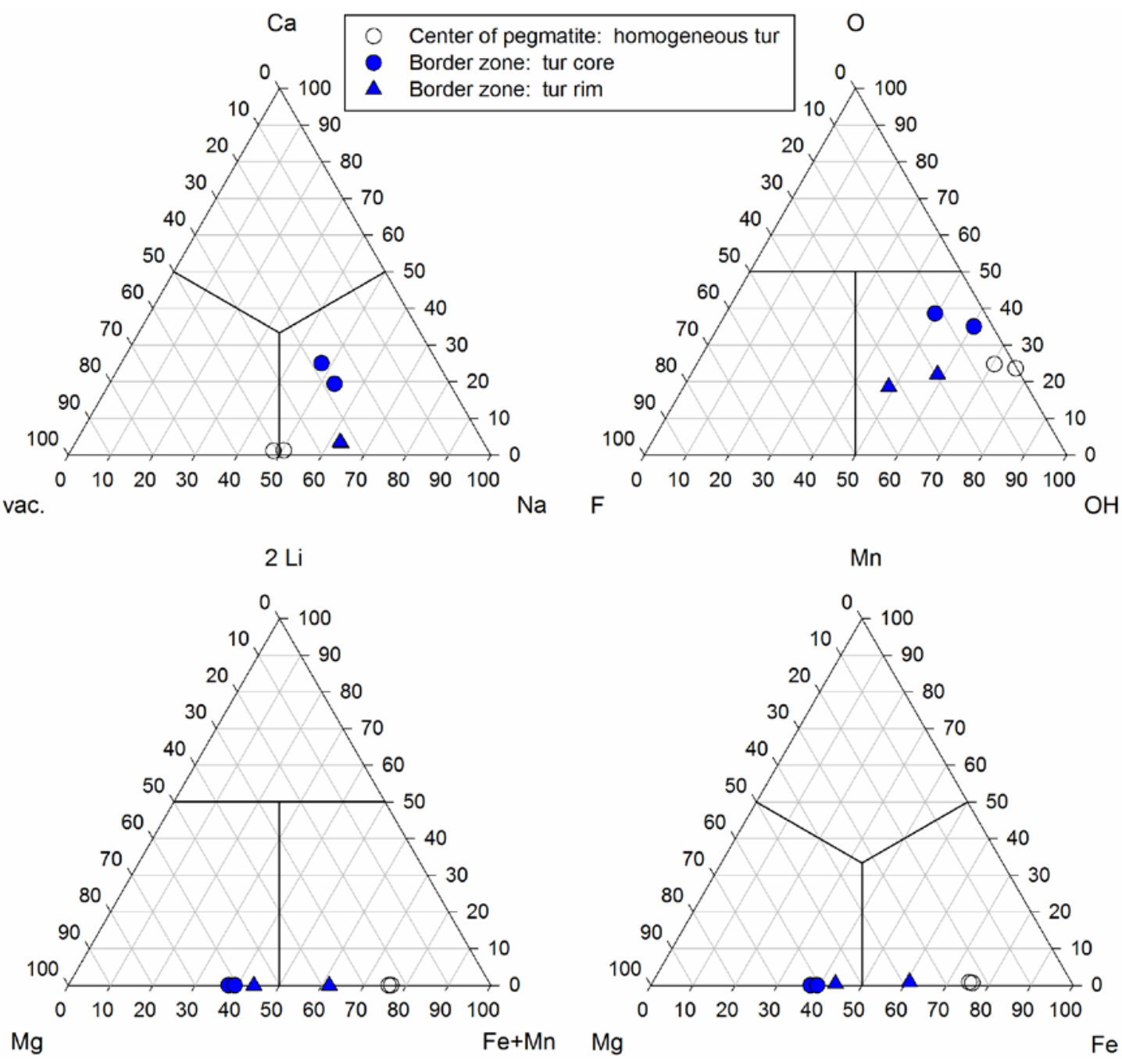

Figure 5.36: Ternary diagrams showing the classification of tourmaline sampled from the SIMPLE11 pegmatite. 


\subsubsection{The TOURMUS Pegmatite Tourmaline}

The tourmaline sample examined from the border zone of the TOURMUS pegmatite is homogeneous in hand sample and in BSE image. It has greater $\mathrm{Mg}, \mathrm{Ca}$, and ${ }^{\mathrm{W}} \mathrm{O}$ than tourmaline from the center of the pegmatite. Its composition is $\mathrm{X}_{\square}$ and Fe-rich dravite with a minor oxydravite component (Fig. 5.37).

Tourmaline samples from the center of the pegmatite are compositionally zoned with $\mathrm{Na}$, and F contents increasing from the typically ${ }^{\mathrm{X}_{\square}}$ and ${ }^{\mathrm{W}} \mathrm{OH}$-rich cores. Compared to the border zone, the tourmaline from the center of the pegmatite contains greater Fe, slightly elevated Mn, and in one sample, increasing Li from the middle of the crystal to the crystal rim. Their compositions range from Mg-rich schorl to Li-rich schorl with a high fluor-schorl component to Li-rich fluor-schorl (Fig. 5.37).
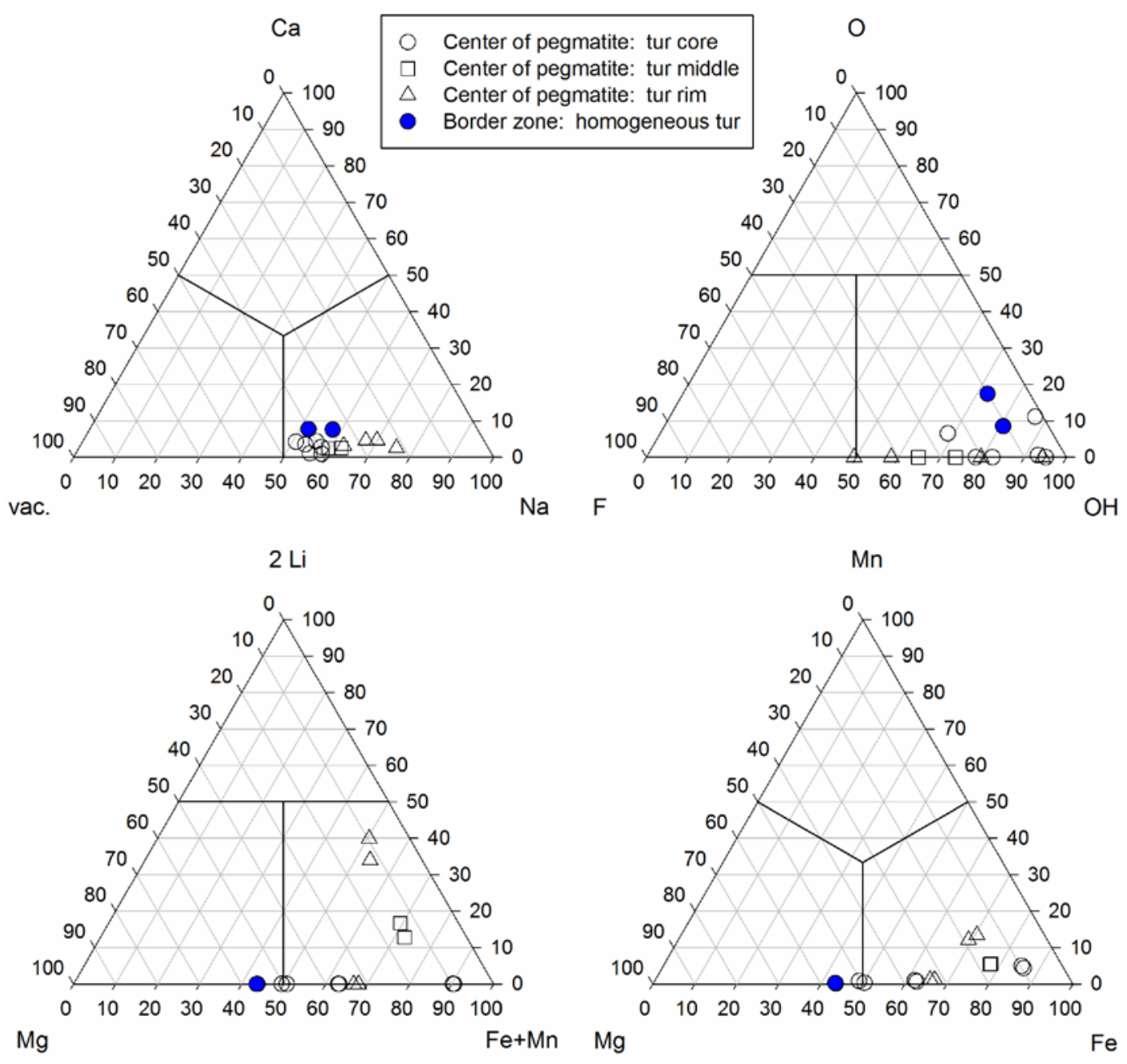

Figure 5.37: Ternary diagrams showing the classification of tourmaline sampled from the TOURMUS pegmatite. 


\subsubsection{The WOBBLE Pegmatite Tourmaline}

Tourmaline sampled from the border zone of the WOBBLE pegmatite appears to be homogeneous in hand sample and in BSE images. Its composition is Fe and Ca-rich dravite with a high oxy-dravite component. Tourmaline sampled from the center of the WOBBLE pegmatite is compositionally zoned and shows decreased $\mathrm{Na}$, Ca, and ${ }^{\mathrm{W}} \mathrm{O}$ contents and increased ${ }^{\mathrm{X}_{\square}},{ }^{\mathrm{W}} \mathrm{OH}$, and Fe contents compared to the border zone tourmaline. The Na content of the tourmaline increases from the crystal core to the rim. Its composition is Mg-rich foitite-schorl with a high oxy-schorl component (Fig. 5.38).

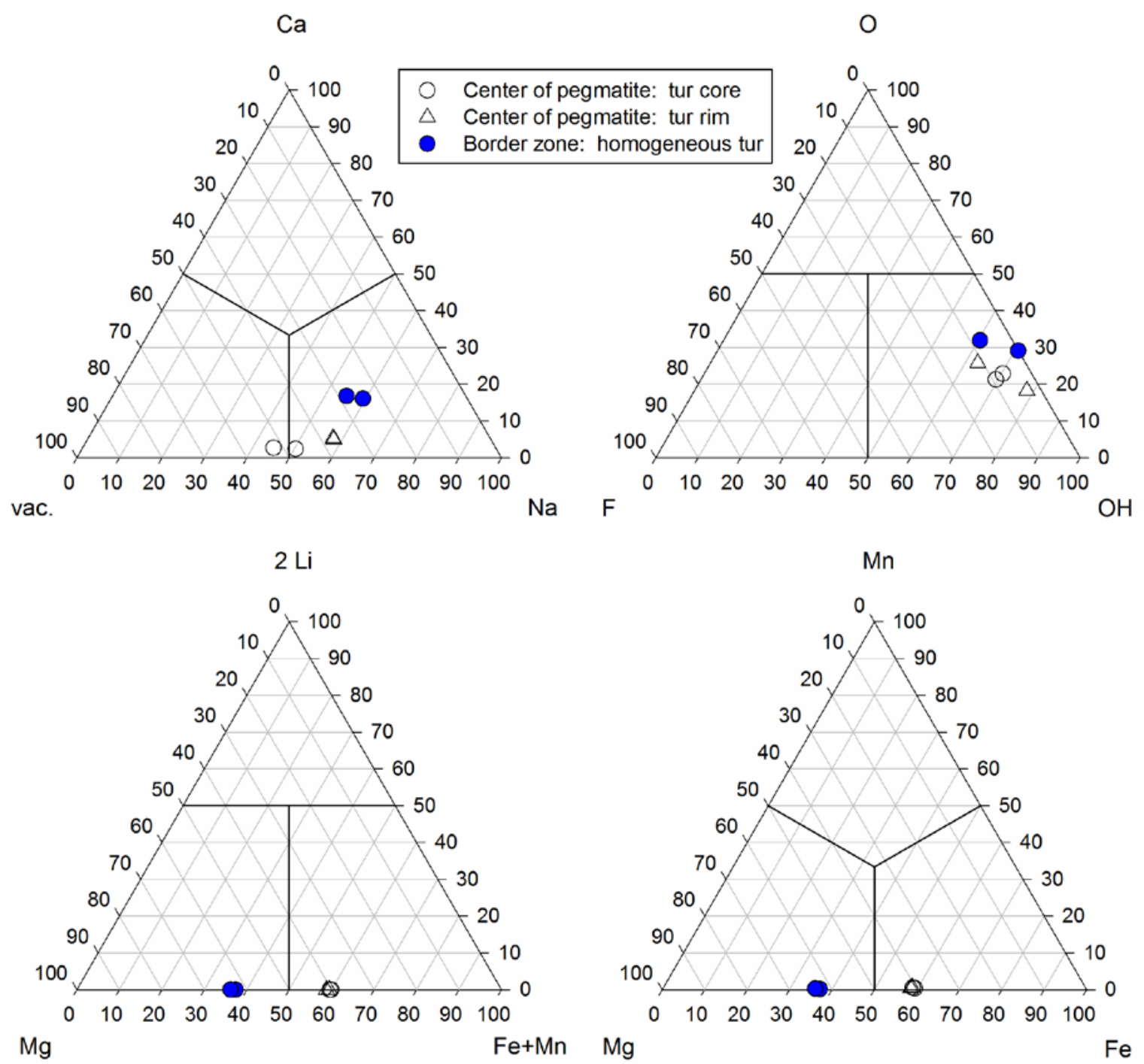

Figure 5.38: Ternary diagrams showing the classification of tourmaline sampled from the WOBBLE pegmatite. 


\subsubsection{The ZONED Pegmatite Tourmaline}

Tourmaline sampled from the border zone and the center of the ZONED pegmatite appears homogeneous in hand sample and in BSE images. Tourmaline from the border zone has greater $\mathrm{Na}, \mathrm{Ca}, \mathrm{F}$, and $\mathrm{Mg}$ contents than the tourmaline from the center of the pegmatite which has slightly greater ${ }^{\mathrm{x}} \square, \mathrm{Fe},{ }^{\mathrm{W}} \mathrm{OH}$, and ${ }^{\mathrm{W}} \mathrm{O}$ contents than the border zone. The composition of both tourmaline samples is Fe-rich dravite (Fig. 5.39).
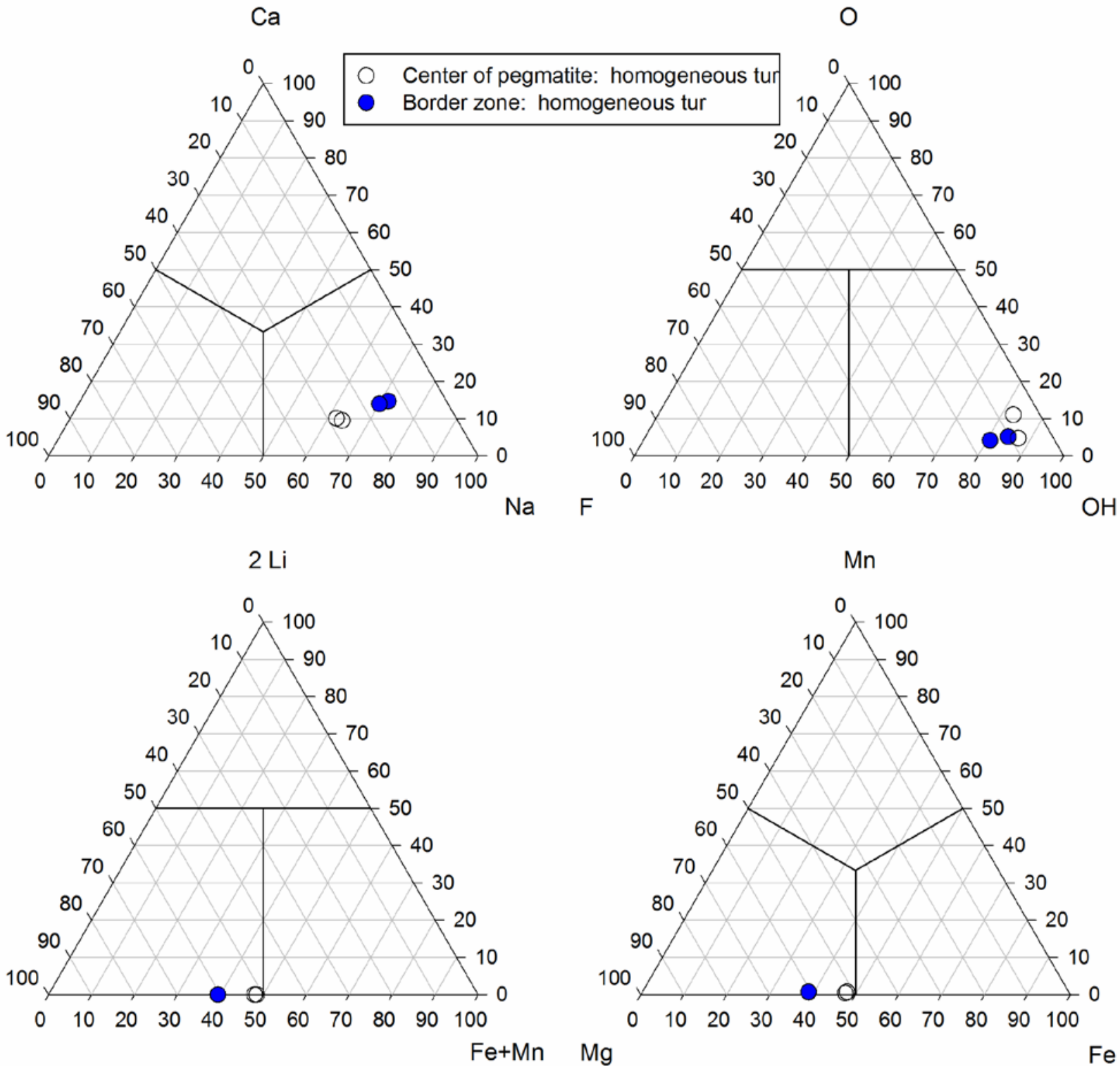

Figure 5.39: Ternary diagrams showing the classification of tourmaline sampled from the ZONED pegmatite. 


\subsection{Feldspars}

The composition of K-feldspar was studied in detail because the content of Rb and Cs in K-feldspar can be used as markers of pegmatite fractionation. Most K-feldspar samples were perthitic and analytical points were carefully placed in K-feldspar only. In some samples the albite occurred as patchy alteration; these areas were avoided as well. In one sample from a tiny pocket in the LI2 pegmatite, late K-feldspar (adularia) was observed as euhedral skeletal crystals on albite (Fig. 5.40).

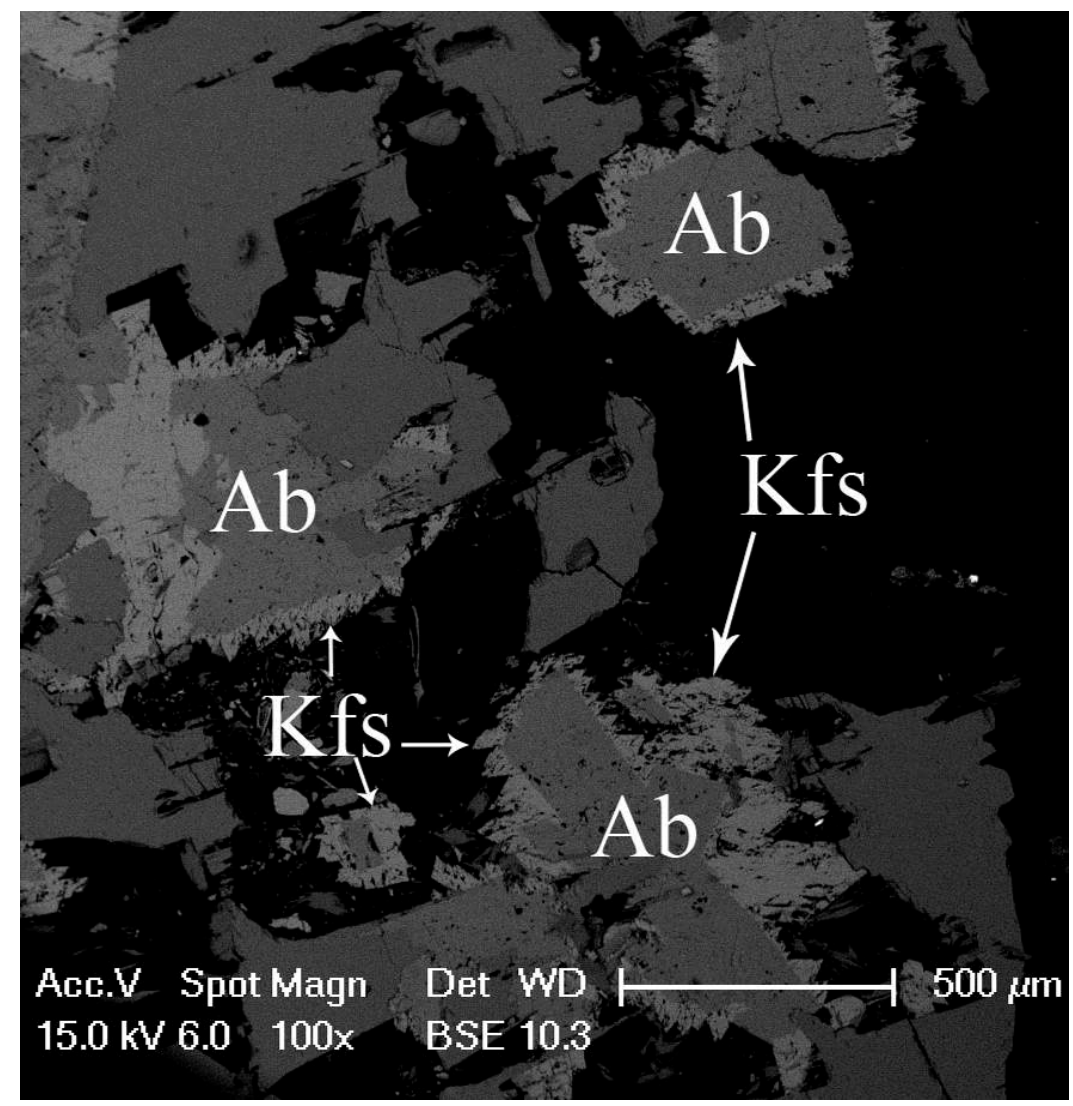

Figure 5.40: A BSE image of late K-feldspar (Kfs) on albite (Ab).

The contents of Rb and Cs in K-feldspar are very low, in most cases they are close to the detection limit of the EMP (Fig. 5.41); however, the most fractionated pegmatites still exhibit elevated contents of Rb and Cs. The GARMUS pegmatite displays elevated Cs contents with relatively low Rb contents; this might be due to the altered nature of the sample analyzed.

Most of the K-feldspar samples show elevated contents of $\mathrm{P}$ due to berlinite substitution (P $+\mathrm{Al} \leftrightarrow 2 \mathrm{Si}$ ). The amount of berlinite substitution approximately matches the degree of 
pegmatite fractionation. The analytical points with the highest $\mathrm{P}$ contents are from the SKINNY, GARPHOS, POCKET, and LI2 pegmatites (Fig. 5.41).

Maps of the elevated Cs and Rb contents (Fig. 5.42a \& b) show a good match with the locations of the most fractionated pegmatites. In addition to showing fractionation trends in the area, the map of the elevated P contents (Fig. 5.42c) show a good match with major phosphatebearing localities. The maps also suggest other pegmatites (LENS, PEGMA, SIMPLE13, and SKINNY) that might be worth further mineralogical investigations in the future.
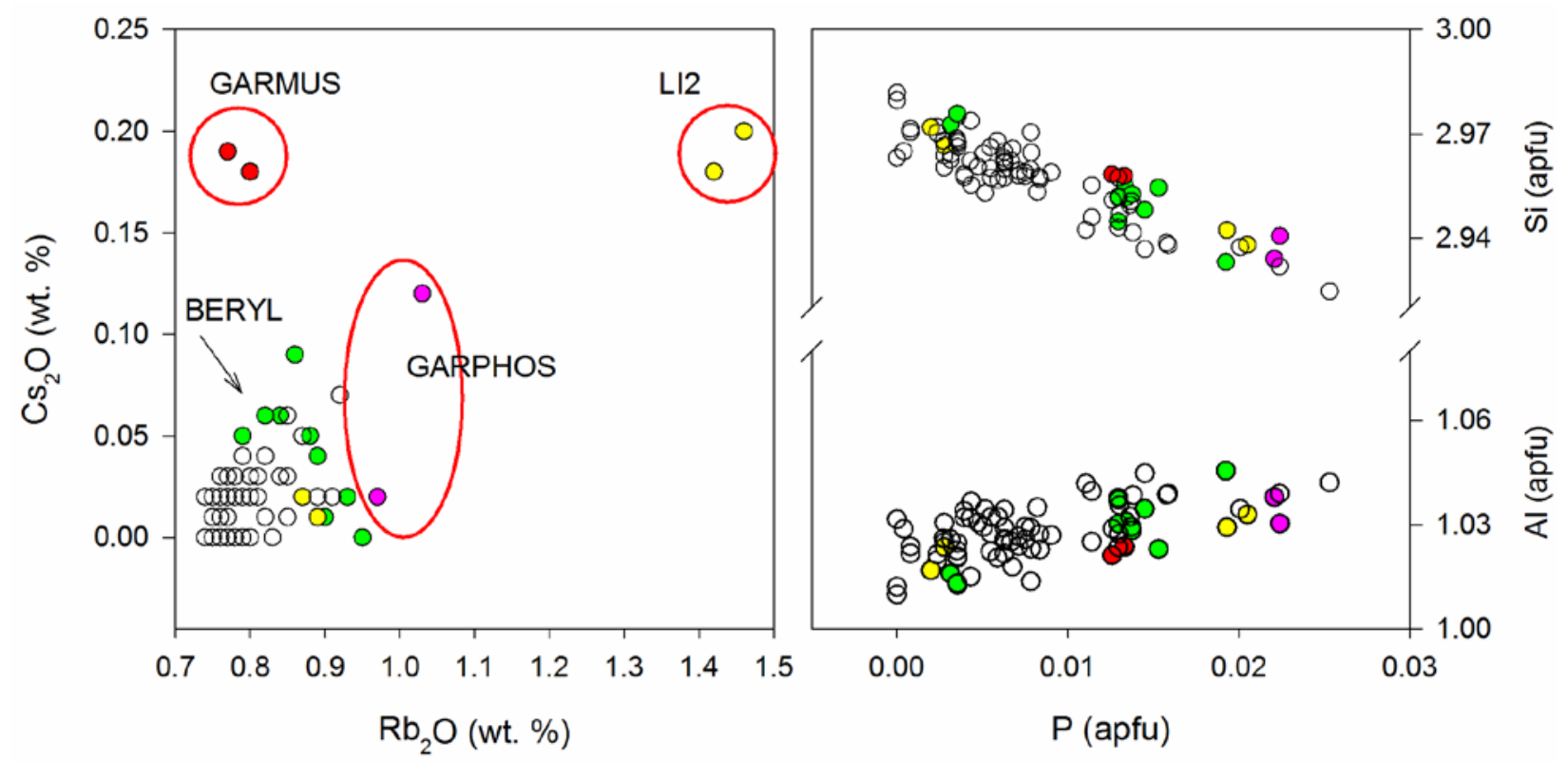

Figure 5.41: Plots showing $\mathrm{Rb}_{2} \mathrm{O}$ vs. $\mathrm{Cs}_{2} \mathrm{O}$ and berlinite substitution in K-feldspar. 


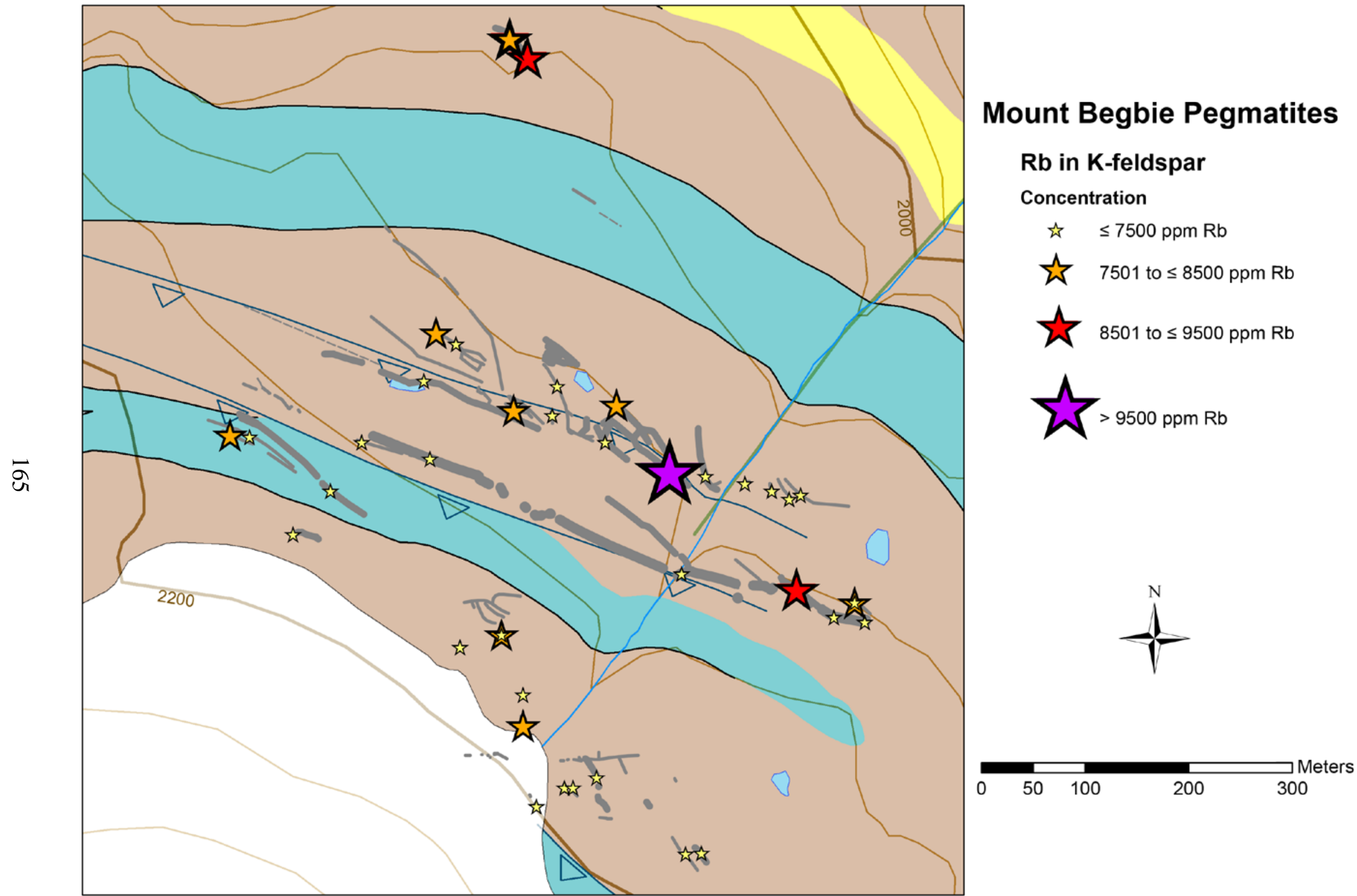

Figure 5.42a: Map showing where K-feldspar samples had the greatest concentrations of Rb. 


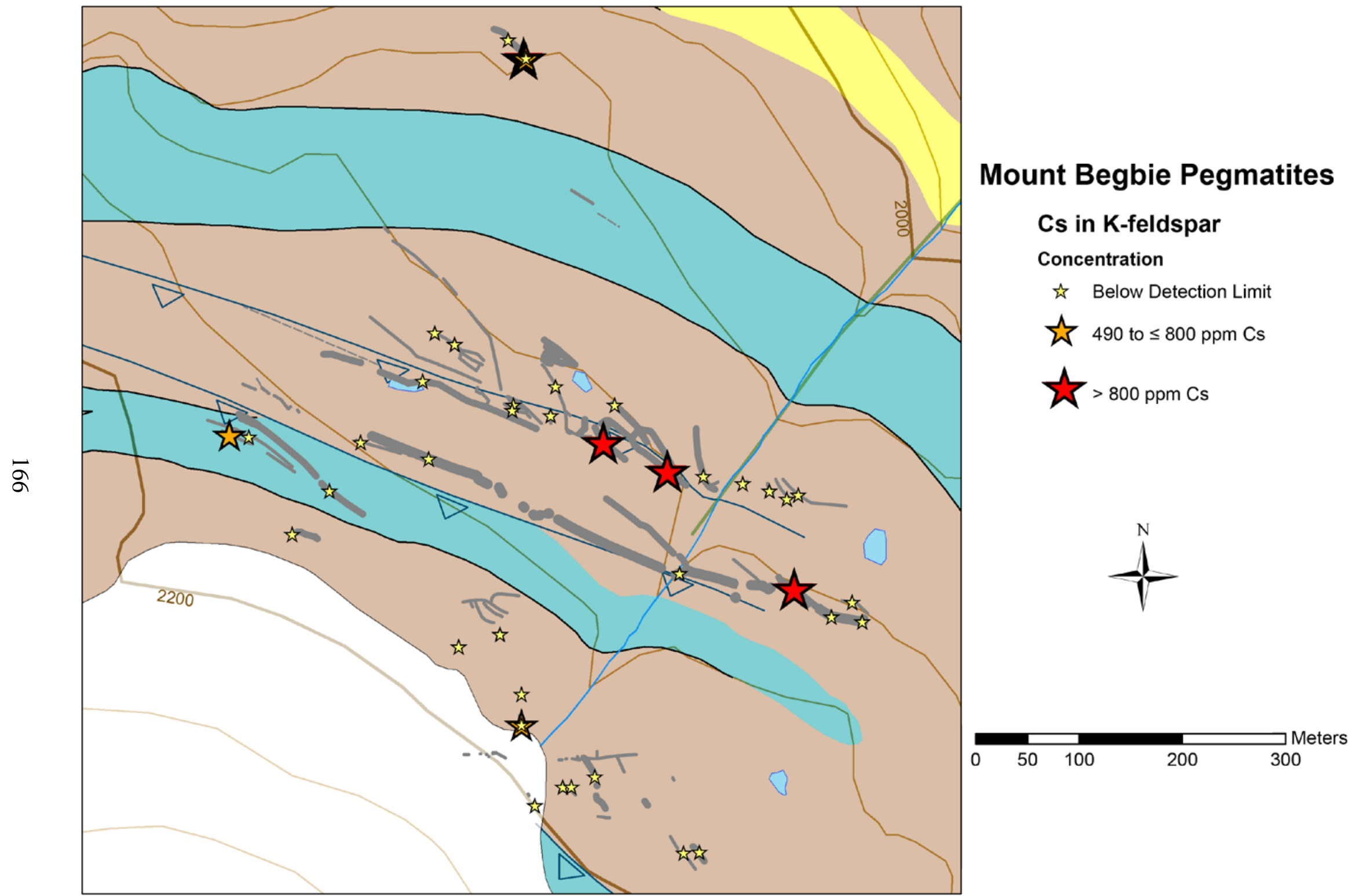

Figure 5.42b: Map showing where K-feldspar samples had the greatest concentrations of Cs. 


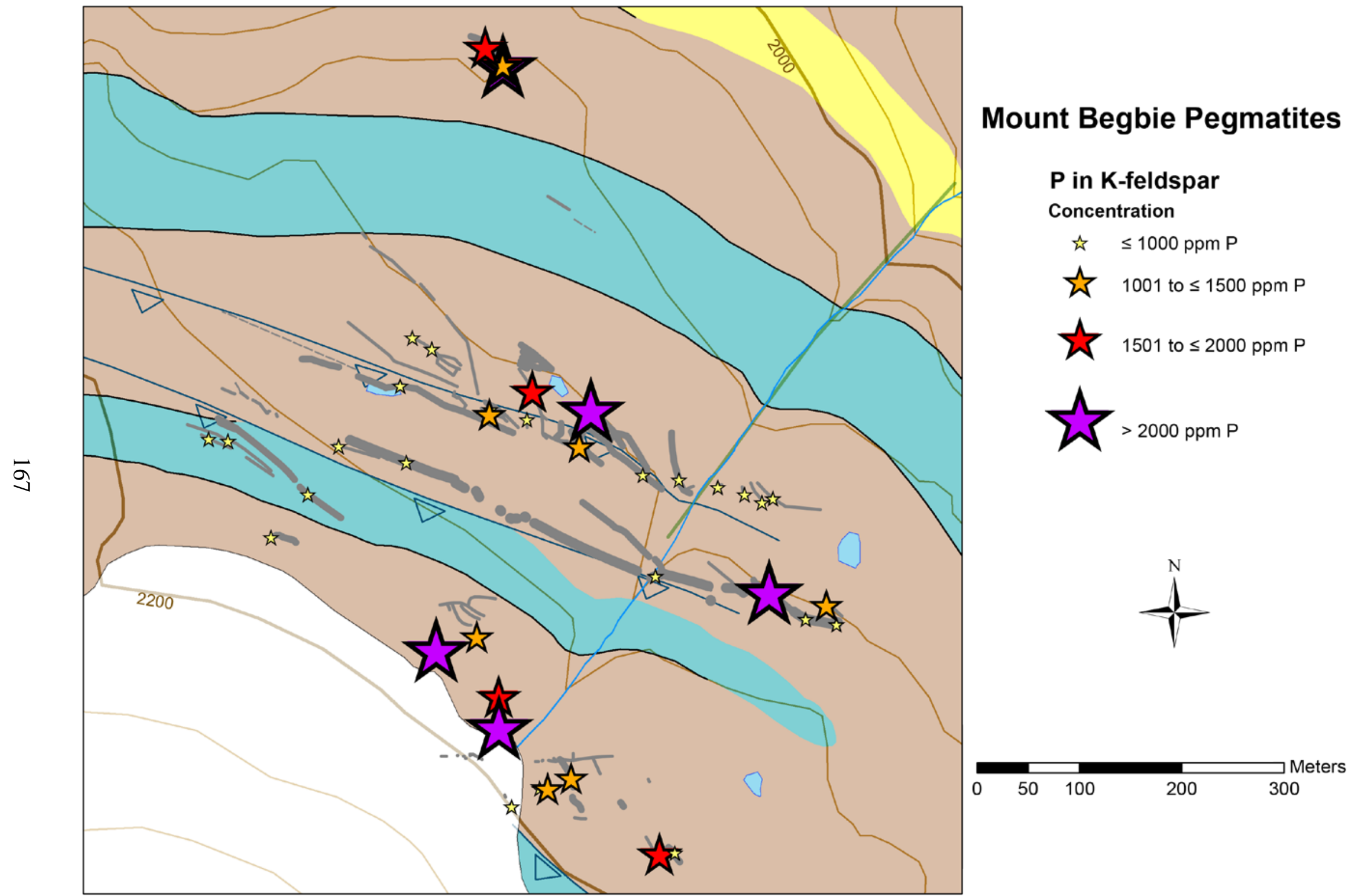

Figure 5.42c: Map showing where K-feldspar samples had the greatest concentrations of P. 


\subsection{Phyllosilicates}

The composition of mica was studied in detail because the content of $\mathrm{Rb}$ and $\mathrm{Cs}$ in micas, in the same way as K-feldspar, can be used as markers of pegmatite fractionation. Samples were selected for analyses if they showed limited to no alteration and if they were coarse grained. A few muscovite samples were analyzed if they displayed a habit not typically encountered in the study area (Fig. 5.43). Muscovite samples from the core zone were chosen over biotite, if possible; if not, biotite was analyzed instead. A few biotite samples were analyzed from the border and intermediate zones of the pegmatites. The analyses show the micas belong to the series of biotite (annite/phlogopite-siderophilite/eastonite), lepidolite (trilithionite-polylithionite), and muscovite-trilithionite (Fig. 5.44).

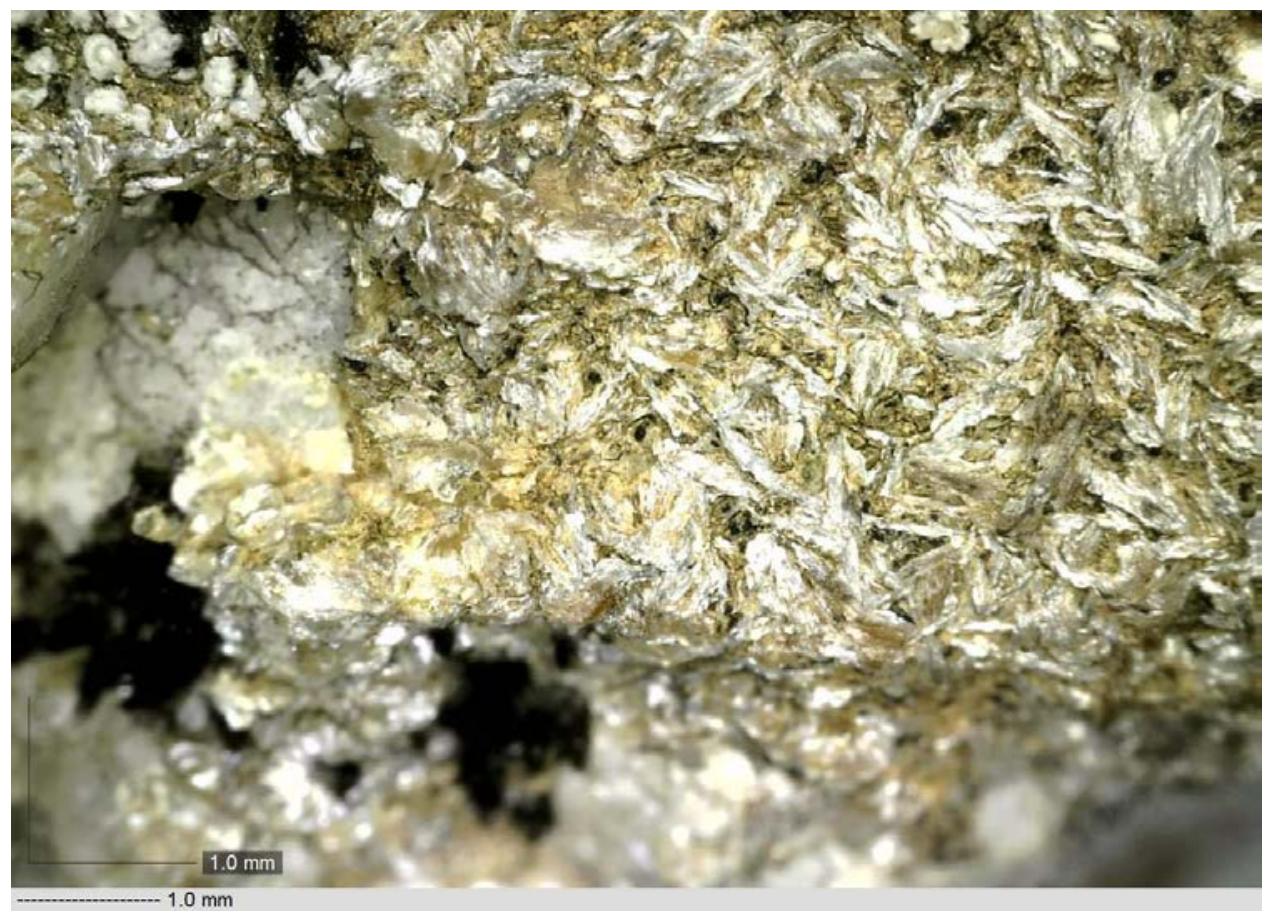

Figure 5.43: Photomicrograph of fine-grained muscovite from the SKINNY pegmatite with a habit that is unusual for the study area. Dashed black line in the bottom left corner is $\sim 1.0 \mathrm{~mm}$ long. 


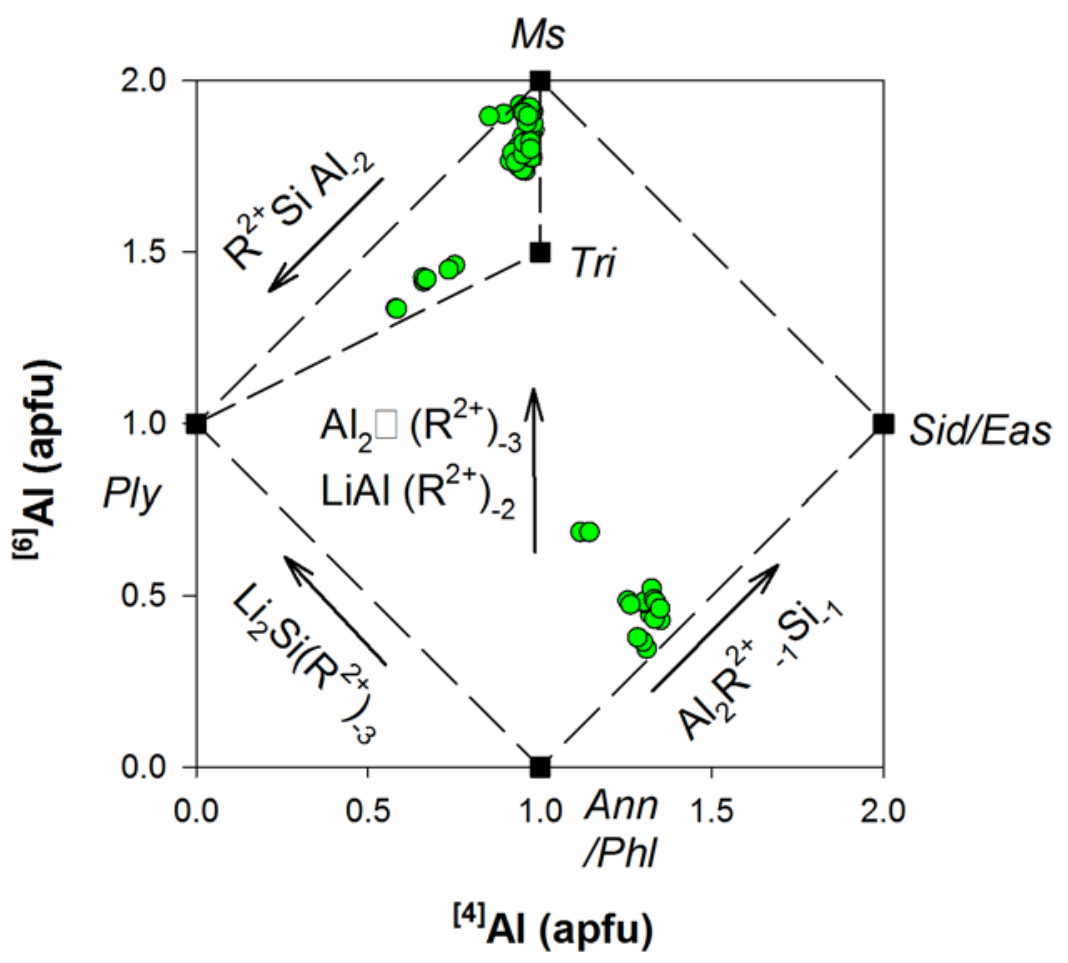

Figure 5.44: Classification diagram for micas.

The contents of Rb and Cs in micas are low and in many cases the Cs content is close to the detection limit of the EMP (Fig. 5.45); however, the most fractionated pegmatites still exhibit elevated contents of $\mathrm{Rb}$ and $\mathrm{Cs}$. The highest $\mathrm{Rb}$ and $\mathrm{Cs}$ contents were found in lepidolite from the LI2 pegmatite; elevated contents were found in muscovite from several localities (Fig. 5.46a \& b). Biotite has a variable Fe/Mg ratio and F contents ( 0 to $\sim 0.6$ apfu F) and usually exhibits low Rb and Cs contents; the highest Rb and Cs content was found in the intermediate zone of the BERYL pegmatite.

A map of the elevated Rb contents (Fig. 5.46a) show a good match with the locations of the most fractionated pegmatites; a map of Cs contents only indicates the locations of the most highly fractionated pegmatites (Fig. 5.46b). The Rb map supports the potential significance of the SKINNY and TOURMUS pegmatites and confirms the elevated fractionation level of the GAR pegmatite (also indicated by the high $\mathrm{Li}$, Be, and Mn contents and high $\mathrm{X}_{\mathrm{Fe}}$ in sekaninaite). 


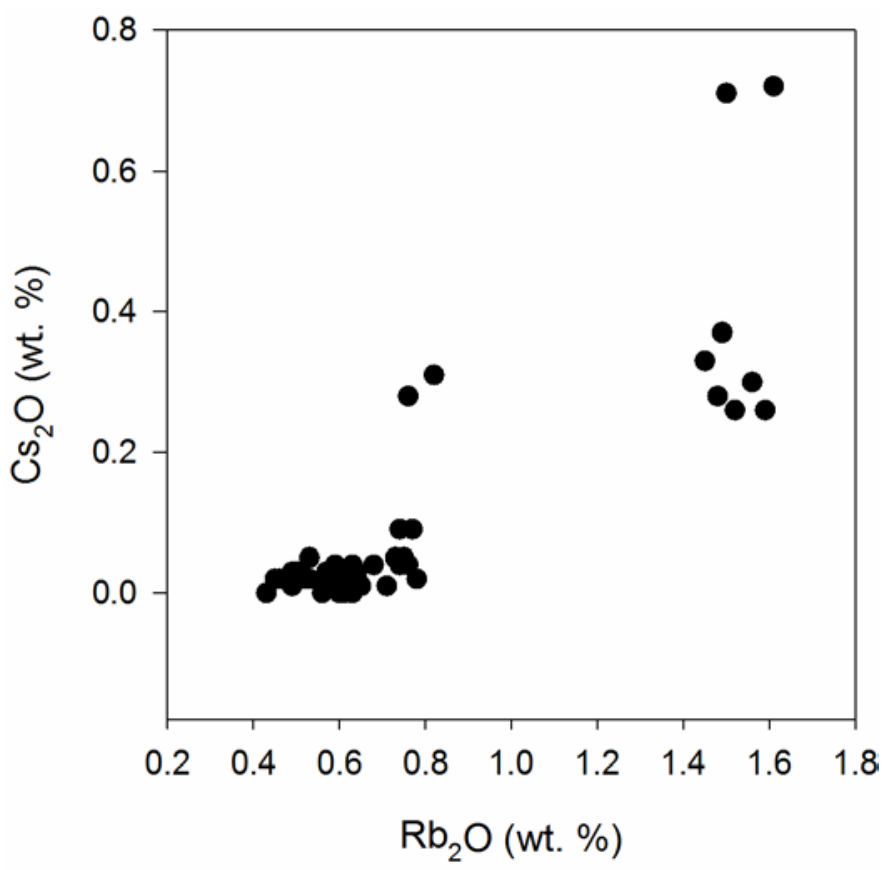

Figure 5.45: Plot showing $\mathrm{Rb}_{2} \mathrm{O}$ vs. $\mathrm{Cs}_{2} \mathrm{O}$ for mica. 


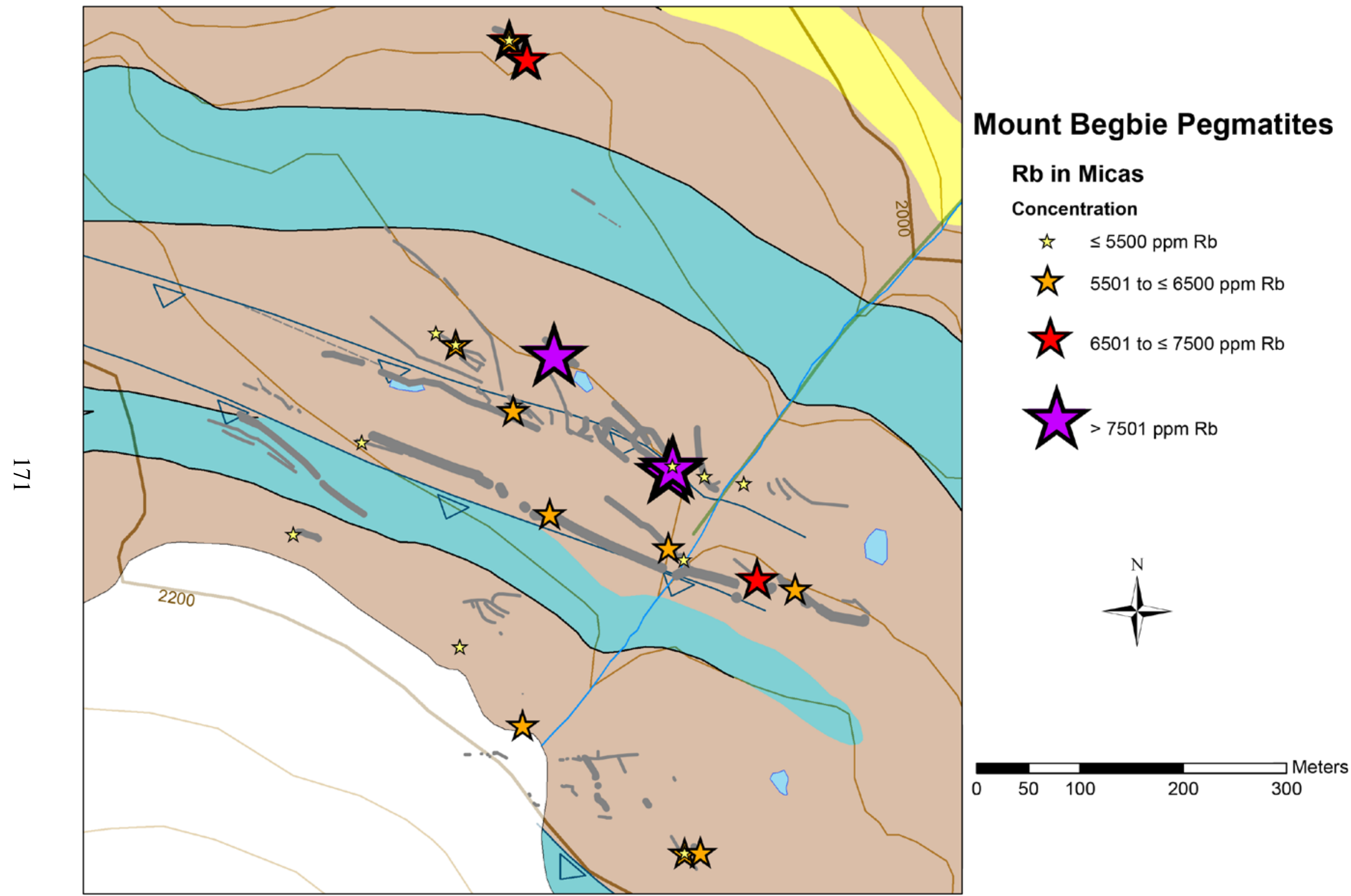

Figure 5.46a: Map showing elevated Rb content in mica. 


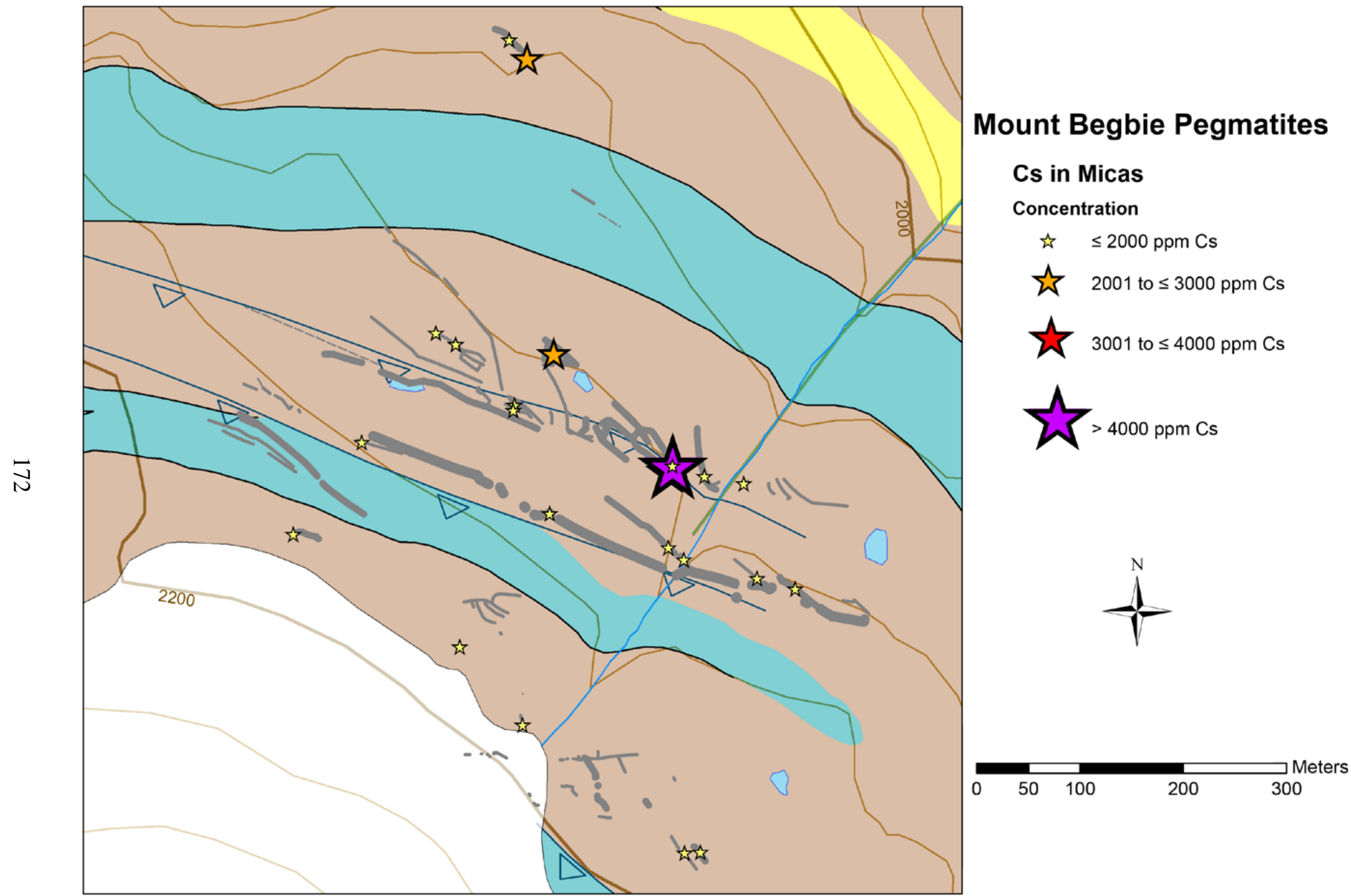

Figure 5.46b: Map showing elevated Cs content in mica. 


\subsection{Garnet}

Garnet was found in the BERYL, GAR, GARMUS, GARPHOS, GARTOUR, JAN, LI, LI2, LONG, SIMPLE14, TOURMUS, and WOBBLE pegmatites. In most cases, it forms dark red euhedral crystals within albite close to the center of the pegmatite. However, there are some exceptions: the garnet from the JAN pegmatite is light pink; late garnet veinlets in blocky quartz can be found in the BERYL pegmatite; replacing sekaninaite in the GAR pegmatite; quartzgarnet intergrowths can be found in the LI2 pegmatite; and garnets are sometimes associated with phosphate minerals in the GARPHOS pegmatite. Most garnet samples are spessartine, although almandine was found in the WOBBLE and GARTOUR pegmatites.

The garnet samples display high variation in the $\mathrm{Mn} /(\mathrm{Mn}+\mathrm{Fe})$ ratio and very low contents of other elements typically found in garnet (Fig. 5.47). The highest Mn content was found in the JAN aplite (thin veinlet with slightly elevated Li in tourmaline) but otherwise the Mn content increases with increasing fractionation of the pegmatites (Fig. 5.48). Some of the highest contents were found in the elbaite pegmatite (GARPHOS) and spatially associated Be-rich pegmatites (TOURMUS and GAR); the lepidolite-bearing LI2 pegmatite has slightly lower Mn contents, especially in middle portion, intermediate between the lepidolite and phosphate-rich outcrops. The Ca and Mg contents decrease whereas both the Ti and P contents slightly increase with increasing $\mathrm{Mn} / \mathrm{Fe}$ fractionation. 


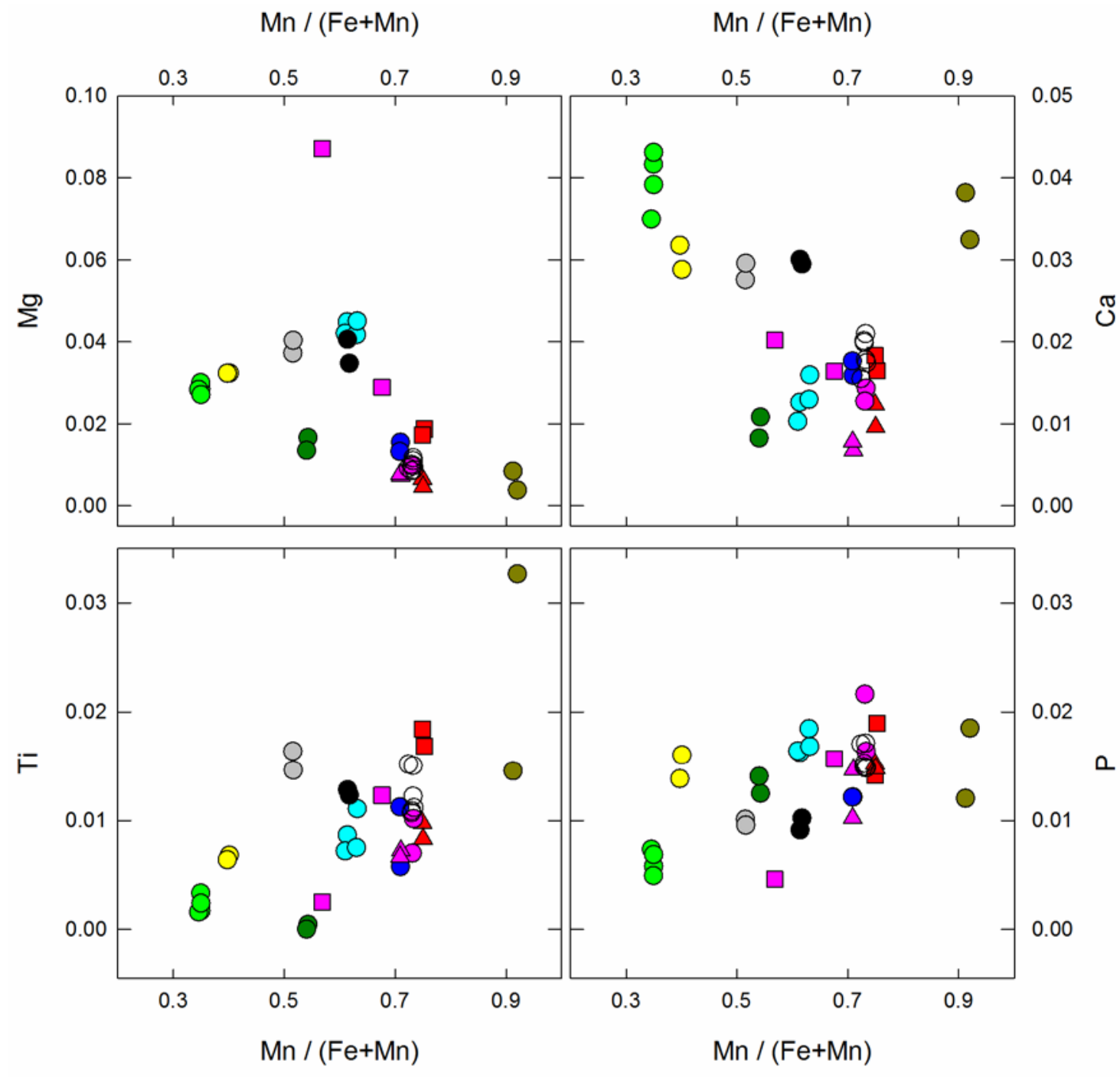

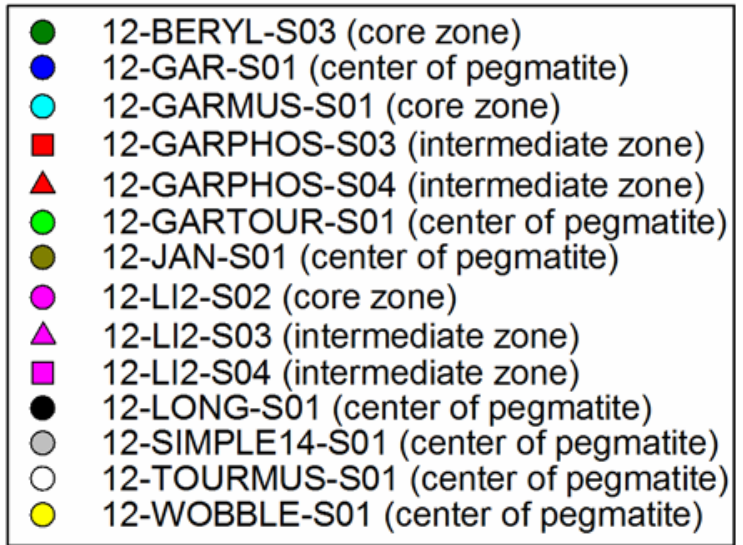

Figure 5.47: Plots showing the compositional variations of garnet within the study area. 


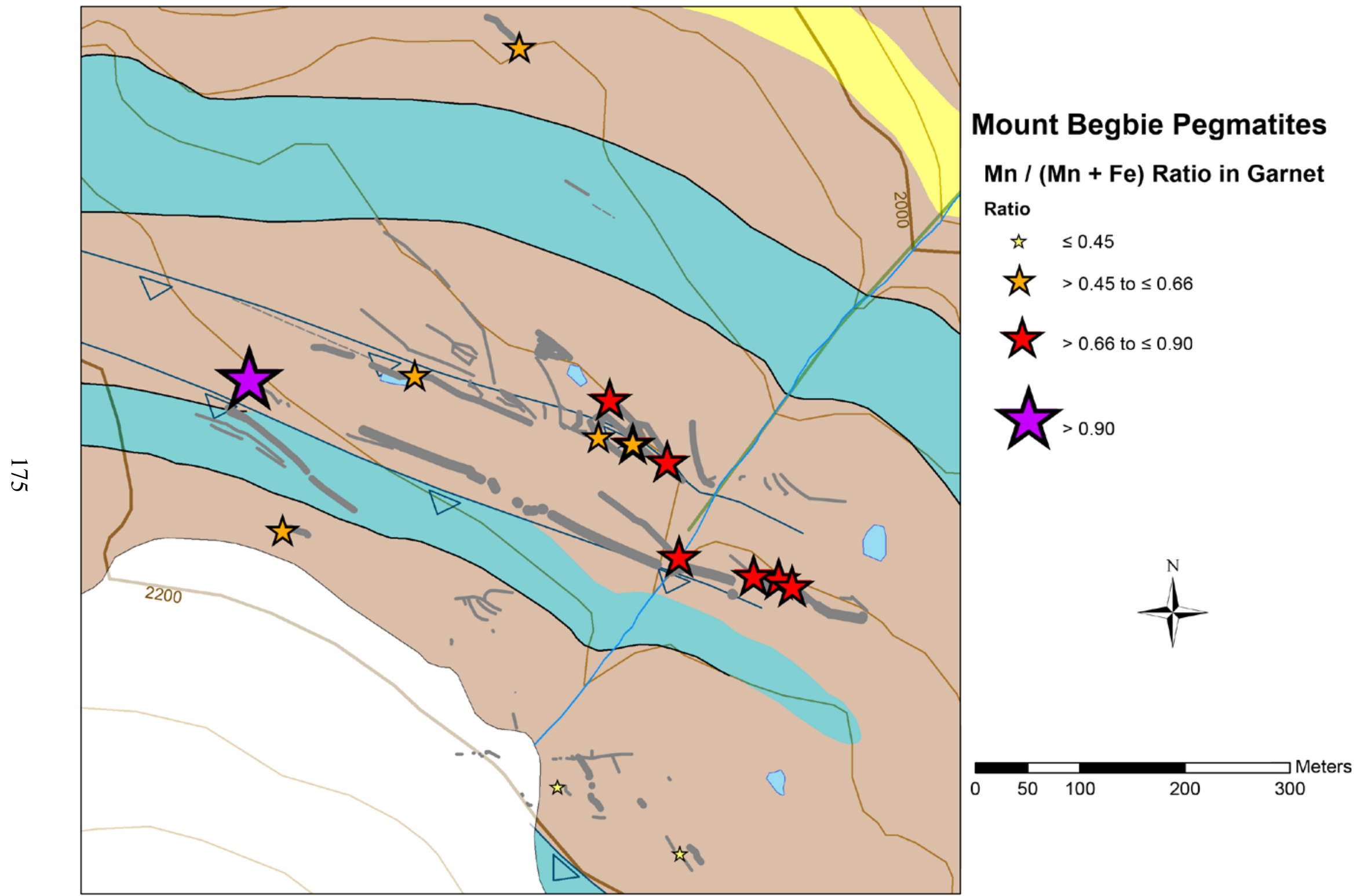

Figure 5.48: Map showing where garnet samples had the greatest ratio of $\mathrm{Mn} /(\mathrm{Mn}+\mathrm{Fe})$. 


\subsection{Cordierite Group}

Minerals of the cordierite group (cordierite and sekaninaite) of different morphologies were found in the BERYL, CORD, GAR, JUNCT, SIMPLE9, and TOUR pegmatites in varying states of decomposition. Most frequently, they form euhedral crystals $\sim 2$ to $4 \mathrm{~cm}$ long, exceptionally up to $9 \mathrm{~cm}$ long (GAR; Fig. 3.8b). Cordierite from the TOUR pegmatite was found as cordierite-quartz intergrowth aggregates (Fig. 3.50b). The first euhedral form is frequent from cordierite-sekaninaite localities worldwide (e.g., Černý et al. 1997, Jobin-Bevans \& Černý 1998, Povondra et al. 1984, Schreyer et al. 1979); the second form is rarely described, most descriptions are from migmatites and desilicated pegmatites (Černý \& Povondra 1966, Černý et al. 1967).

Compositional data were collected only from the large crystal from the GAR pegmatite, as it was the freshest sample, only slightly altered along fractures into a mixture of muscovite, chlorite, secondary beryl, iron oxides, and minor biotite (Fig. 5.49). The analytical results indicate that the mineral is Mn,Mg-rich sekaninaite with high contents of Na (Fig. 5.50).

The contents of $\mathrm{Al}$ and $(\mathrm{Fe}+\mathrm{Mg}+\mathrm{Mn})$ are lower than ideal values which, together with the Na content, indicates the presence of $\mathrm{Li}$ and $\mathrm{Be}$; these were calculated using the procedure published by Bertoldi et al. 2004. The calculation shows the presence of significant Li up to $\sim 0.3$ apfu. However, the calculation results indicate randomly occurring elevated contents of Be (and locally negative values) which are positively correlated with $\mathrm{Si}$ and $\mathrm{Al}$ contents suggesting strong dependence on analytical precision and quality of the sample. The low $\mathrm{Al}$ and $(\mathrm{Fe}+\mathrm{Mg}+$ $\mathrm{Mn}$ ) contents show that the sample must be Li-bearing but it is not possible to precisely estimate Be using EMP data only - the presence of beryl as a secondary alteration product strongly suggests that the sekaninaite contains significant amounts of Be as well. 


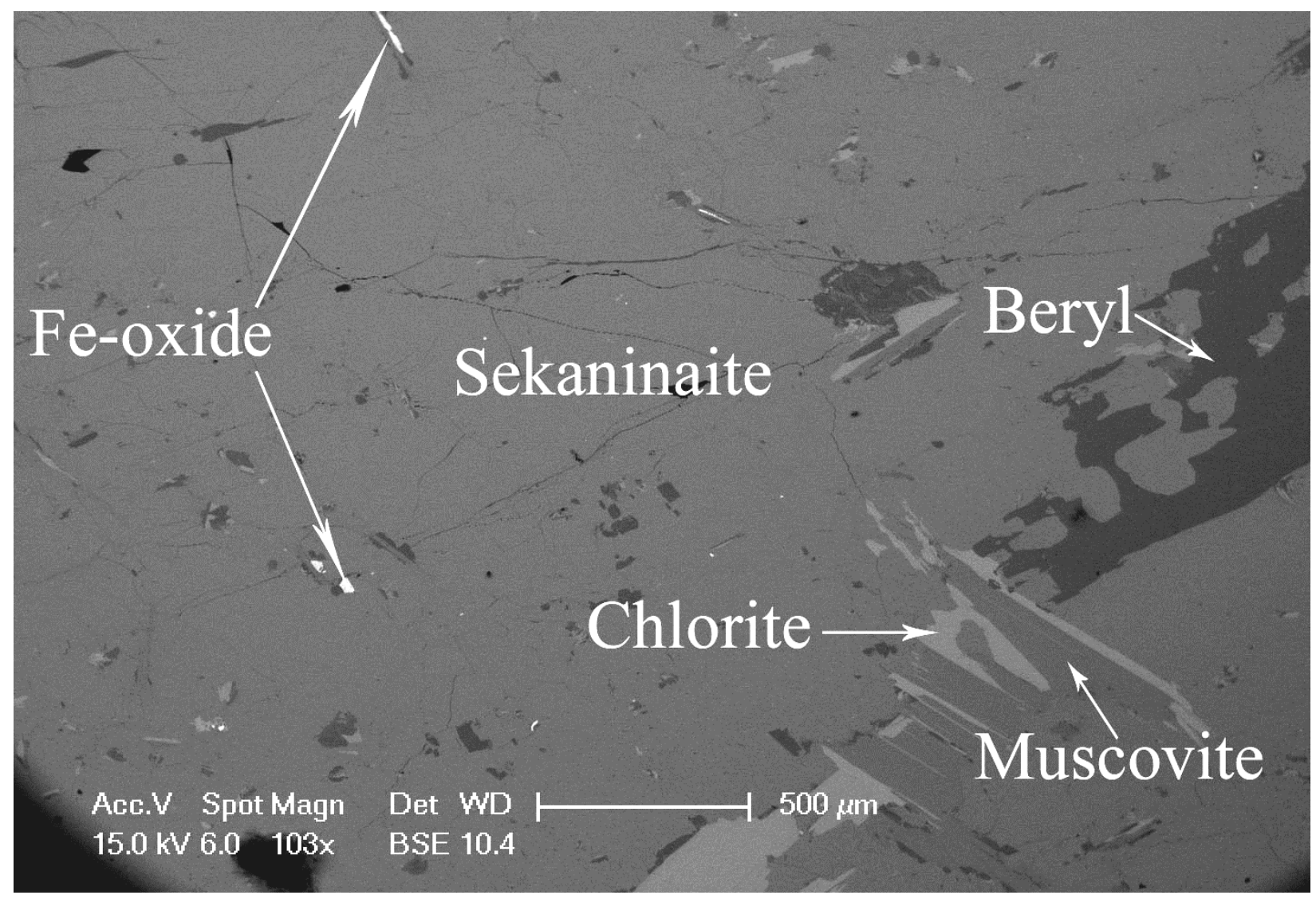

Figure 5.49: A BSE image of sekaninaite from the GAR pegmatite and its most common decomposition products.
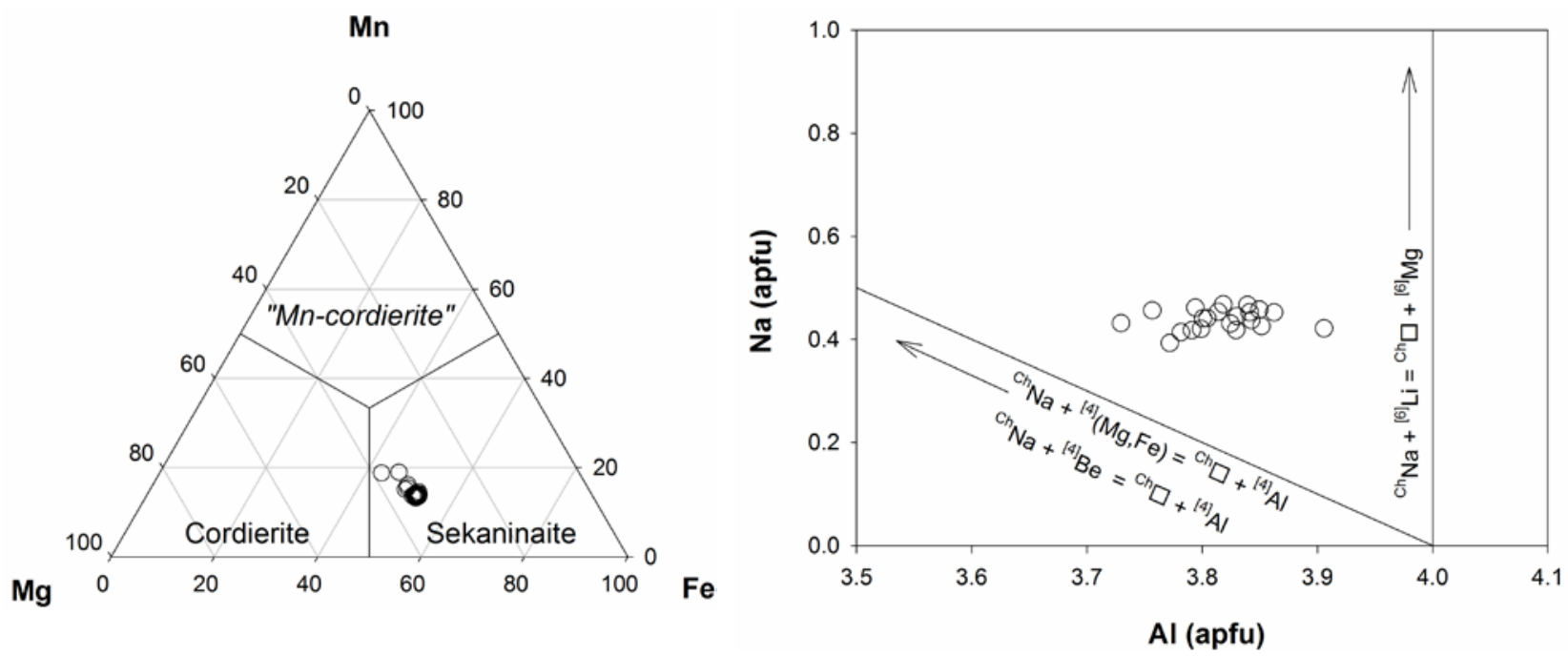

Figure 5.50: Compositional diagram showing sekaninaite classification (left) and substitution schemes (right). 


\subsection{Beryl and Other Be-Minerals}

\subsubsection{Beryl}

Primary beryl is typically subhedral, prismatic, translucent, and ranges in color from creamy white to pale blue. It is found in the BERYL, GARMUS, GARPHOS, GARTOUR, LI2 SIMPLE9, and TOURMUS pegmatites and tentatively identified in thin section from the SMALL pegmatite. One specimen collected from the BERYL pegmatite has a transparent yellow gemmy patch. In primary beryl-bearing localities, crystals are typically a few centimeters in size; crystals from the BERYL and LI2 dike can be much larger - the largest specimen collected from the BERYL pegmatite is $15 \mathrm{~cm}$ long and $10 \mathrm{~cm}$ wide, the largest beryl crystal collected from the LI2 is $9 \mathrm{~cm}$ long and $5 \mathrm{~cm}$ wide.

There are two types of secondary beryl: one is late stage beryl crystals that are acicular, typically forming overgrowths on larger beryl crystals and was only observed in the BERYL pegmatite; the other is microscopic beryl that is one of the products from the decomposition of cordierite. The latter type of secondary beryl was observed within the confines of the previous cordierite crystal from the BERYL, CORD, GAR, and SIMPLE9 pegmatites. The thin crystals of secondary beryl were identified using single-crystal X-ray diffraction and the microscopic beryl was identified using EDS and EMP analyses.

The beryl from the GARTOUR pegmatite is of uncertain origin and has not been analyzed. The only tiny grain $(\sim 400 \mu \mathrm{m}$ long) identified was found enclosed in muscovite from a small pocket.

Most of the compositions of the beryl samples are displaced from the 1:1 line on a plot of the $\mathrm{Al}$ vs. the sum of other $\mathrm{Y}$ site cations $(\mathrm{Mg}+\mathrm{Mn}+\mathrm{Fe}$; Fig. 5.52), suggesting some of the substitutions are occurring at the $\mathrm{Z}$ site in addition to the $\mathrm{Y}$ site. The slightly low Si content ( $\sim 0.02$ apfu less than the expected $6 \mathrm{apfu}$ ) and occasionally elevated ( 0.02 apfu greater than the expected $6 \mathrm{apfu}$ ) needed to fill the Z site helps confirm this possibility (Brand et al. 2009).

The majority of the beryl crystals likely contain $\mathrm{Fe}^{3+}$ in addition to $\mathrm{Fe}^{2+}$ to maintain charge balance in the crystal, as most of the analyses plot below the 1:1 line for the sum of divalent cations vs. the sum of monovalent cations (Brand et al. 2009; Fig. 5.52). Likewise, beryl crystals from the BERYL, GARMUS, GARPHOS, and TOURMUS pegmatite appear to contain Li, 
rather than $\mathrm{Fe}^{3+}$ to maintain charge balance in the crystal as those analyses plot above the 1:1 line.

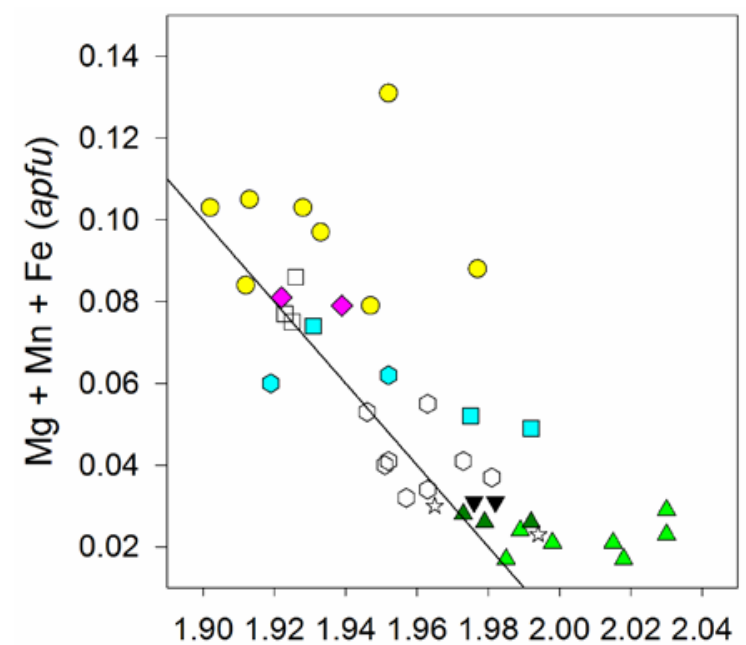

$\mathrm{Al}(\mathrm{apfu})$
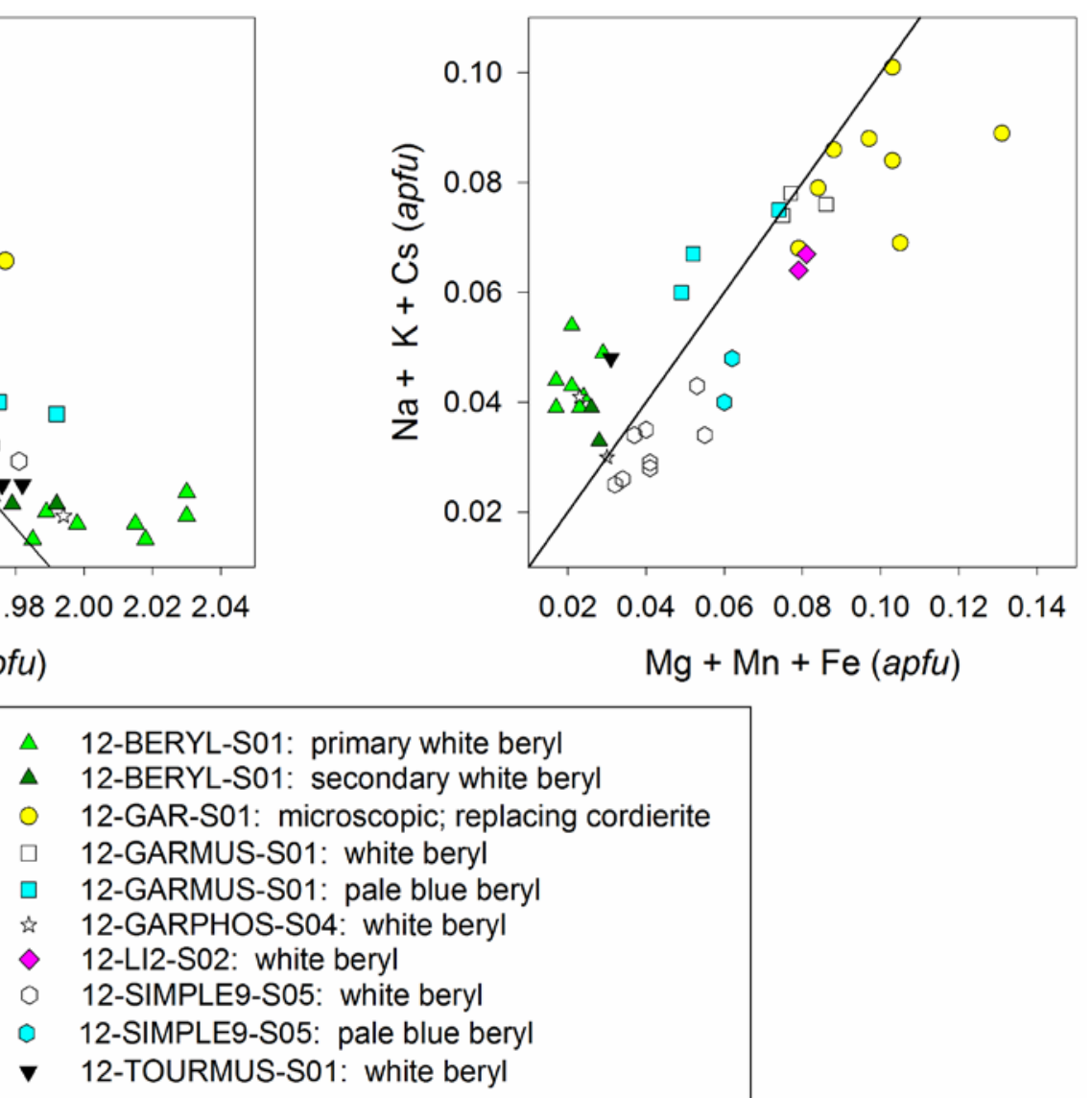

Figure 5.52: Plots showing possible element substitution sites other than the Y site (left) and the sum of divalent cations vs. the sum of monovalent cations (right).

\subsubsection{Other Be Minerals: Bertrandite, Chrysoberyl, and Euclase}

Skeletal bertrandite was found in a white beryl crystal altering to plagioclase and clay minerals from the SIMPLE9 pegmatite (Fig. 5.53). EMP analyses show low contents of Al ( 0.004 to 0.018 apfu Al) and $\mathrm{Ca}(\sim 0.011$ to 0.029 apfu Ca) present; this may be contamination from the plagioclase. Bertrandite is a relatively common alteration product after beryl (Černý 2002). 


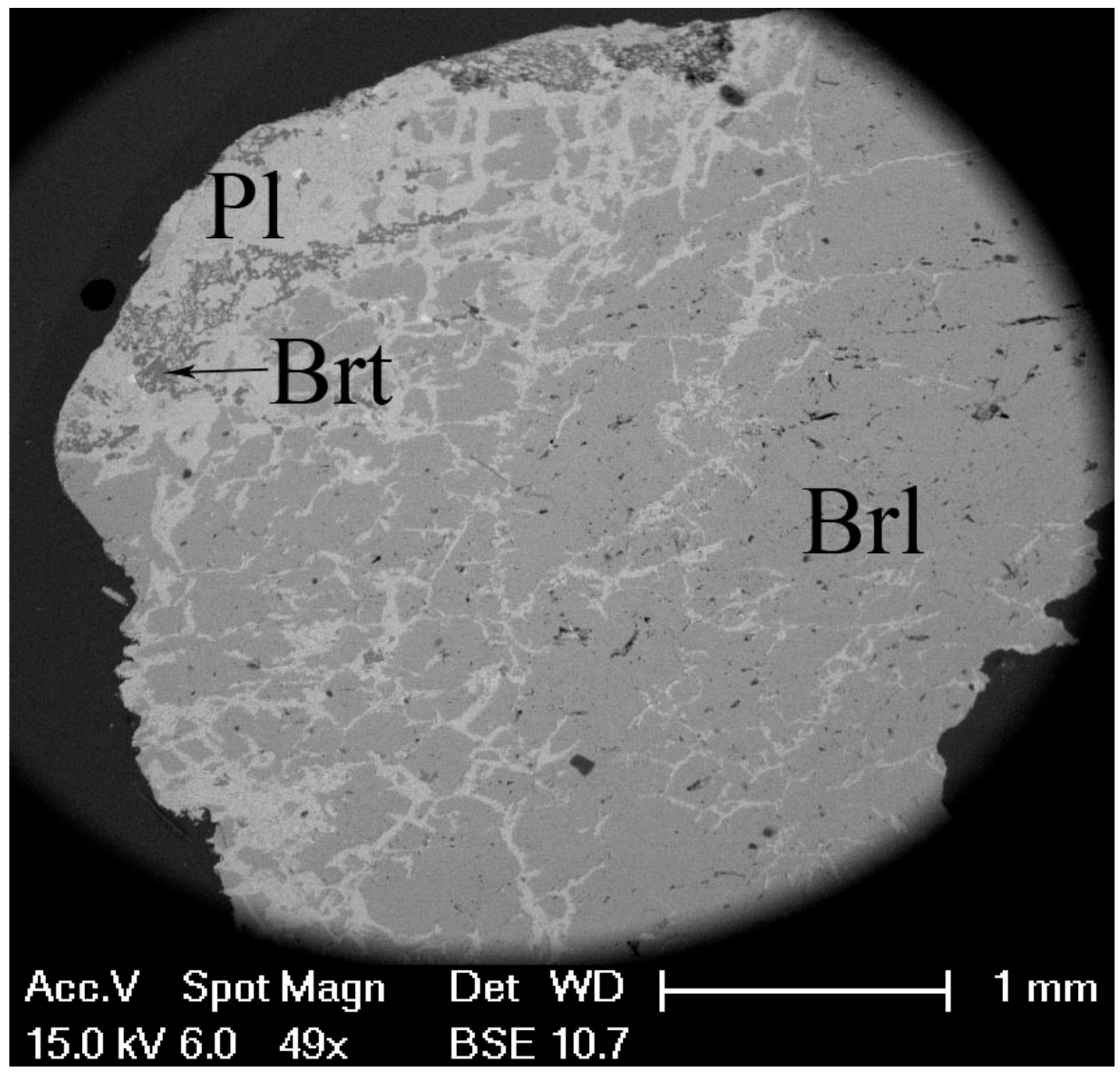

Figure 5.53: A BSE image of skeletal bertrandite (Brt) and plagioclase (Pl) after beryl (Brl) from the SIMPLE9 pegmatite. Bright gray spots are unidentified clay minerals.

Heavily fractured chrysoberyl was observed in the GARMUS pegmatite as inclusions in a fractured and partially recrystallized pale blue beryl crystal in contact with a slightly altered albite crystal (Fig. 5.54). EMP analyses show very low contents of Ti ( 0.001 to 0.004 apfu Ti) and somewhat elevated contents of Fe ( 0.020 to $\sim 0.035$ apfu Fe). Chrysoberyl can be a primary magmatic Be phase in high temperature, low to moderately fractionated pegmatites or a metamorphic-metasomatic alteration product after beryl + albite + muscovite (Beurlen et al. 2013). Further investigation is needed to determine if this chrysoberyl occurrence is primary or secondary, as low-level alteration and fracturing is common across all mineral grains in this thin 
section. Chrysoberyl has been tentatively identified in a thin section from the SMALL pegmatite using SEM only.

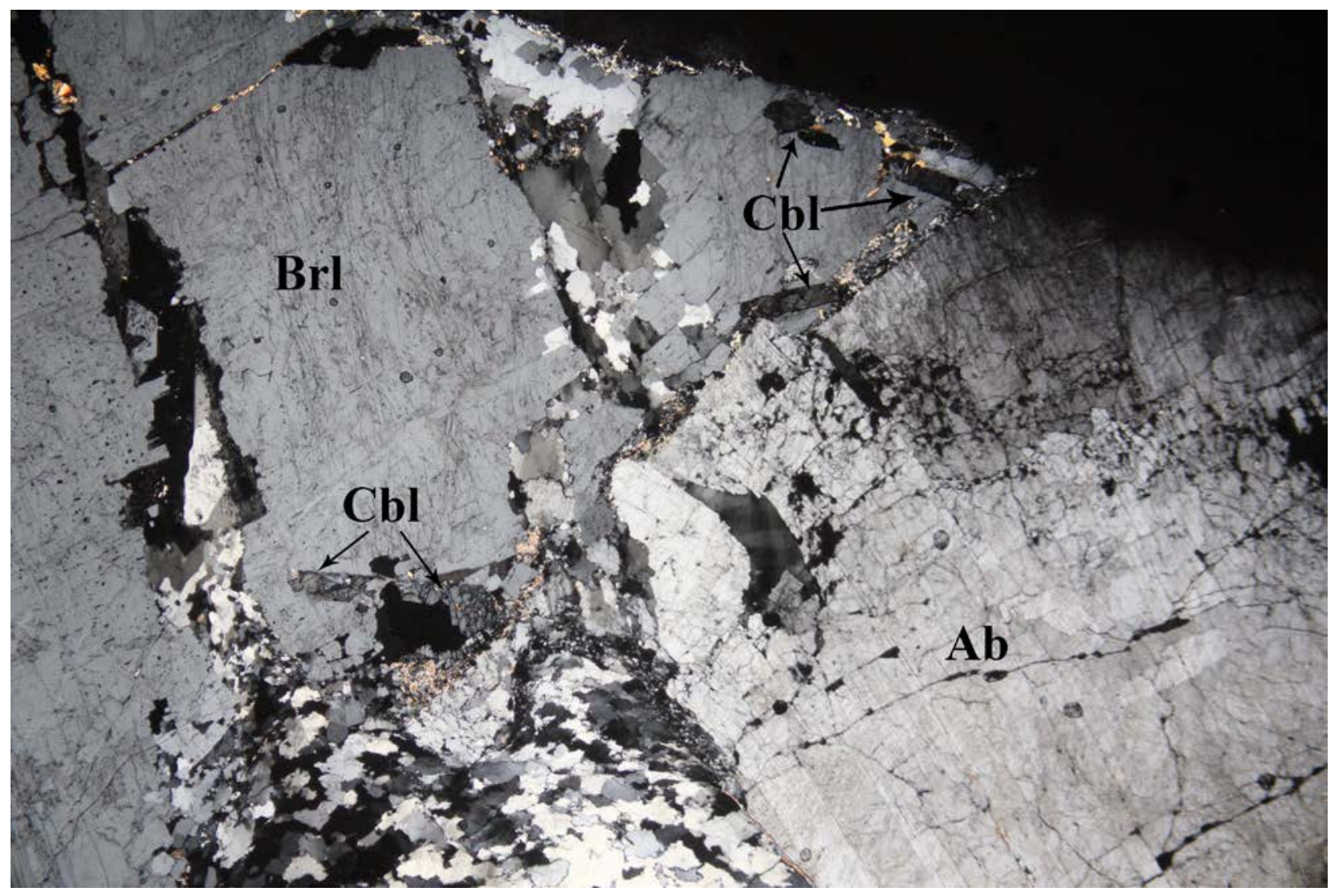

Fig. 5.54: Chrysoberyl (Cbl) in thin section under cross-polarized light as an inclusion in beryl (Brl) at the contact of an albite crystal (Ab). Field of view is $10 \mathrm{~mm}$.

Euclase was identified using powder X-ray diffraction of the contents of a small "pocket" and cracks within a beryl crystal from the BERYL pegmatite. Other constituents of the "pocket" include garnet, muscovite, albite, and tourmaline (Fig. 5.55). 


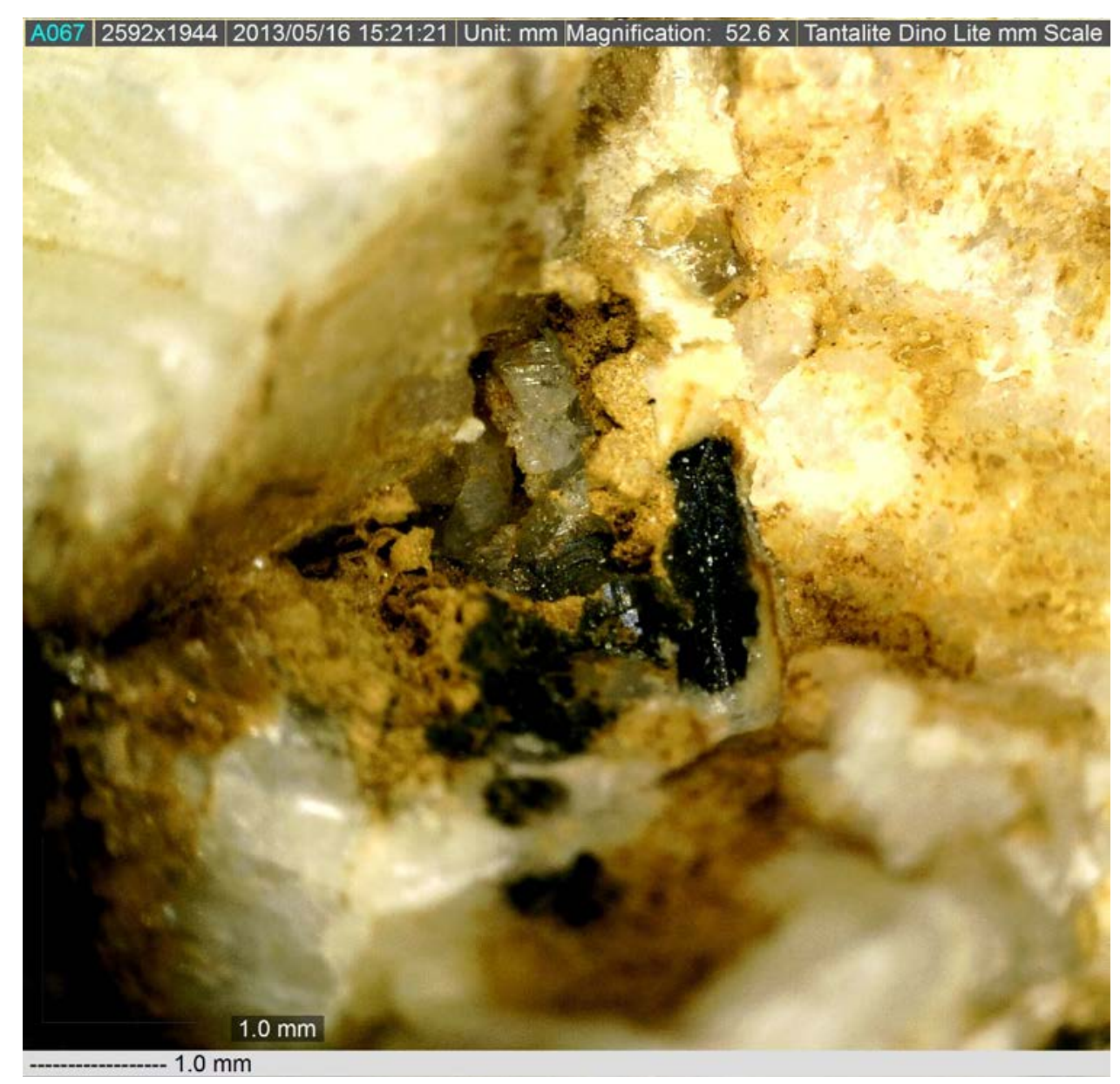

Figure 5.55: Photomicrograph of the constituent minerals in the "pocket" prior to removal for identification for powder X-ray diffraction. Black dashed line in the lower left corner of the image shows the length of $1 \mathrm{~mm}$.

\subsection{Oxides}

\subsubsection{Columbite-Tantalite}

Minerals of the columbite-tantalite series were found in the BERYL, LI, LI2, GARMUS, SMALL and GARPHOS pegmatites.

In the BERYL pegmatite, columbite occurs in the intermediate zone and very near the core zone of the dike as inclusions in tourmaline and beryl and at tourmaline and beryl contacts. The samples have low and variable $\mathrm{X}_{\mathrm{Ta}} \sim 0.067$ to $\sim 0.28\left[\mathrm{X}_{\mathrm{Ta}}=\mathrm{Ta} /(\mathrm{Ta}+\mathrm{Nb})\right]$ and medium $\mathrm{X}_{\mathrm{Mn}}$ ( $\sim .36$ to 0.53 ) on the ferrocolumbite-manganocolumbite boundary (Fig. 5.56). Columbite from the BERYL pegmatite contains up to $15.64 \mathrm{wt} \% \mathrm{WO}_{3}\left(0.265\right.$ apfu $\left.\mathrm{W}^{6+}\right)$. 


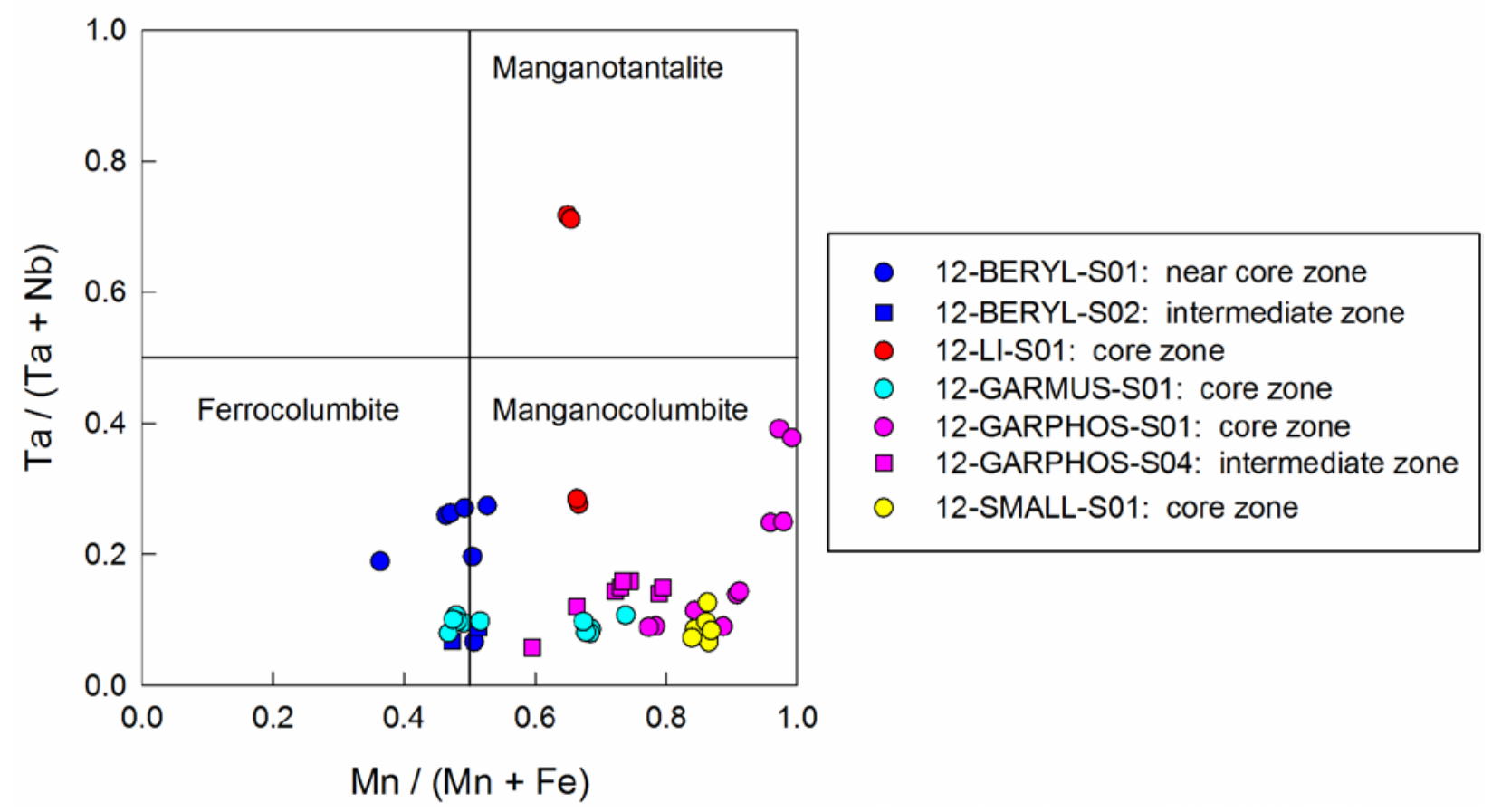

Figure 5.56: Diagram showing the classification and compositional trends of the columbitetantalite specimens analyzed.

In the LI and LI2 pegmatites, columbite occurs in the intermediate and core zones in association with garnet, cleavelandite, and inclusions in tourmaline. The sample analyzed from the LI pegmatite grades from manganocolumbite to manganotantalite (Fig. 5.57); $\mathrm{X}_{\mathrm{Ta}}$ varies from $\sim 0.28$ to $\sim 0.72$ and the $\mathrm{X}_{\mathrm{Mn}}$ varies only slightly from $\sim 0.65$ to $\sim 0.67$ (Fig. 5.56). Manganocolumbite-manganotantalite from the LI pegmatite contains up to $2.81 \mathrm{wt}$. $\% \mathrm{WO}_{3}$ (0.012 apfu $\left.\mathrm{W}^{6+}\right)$. 


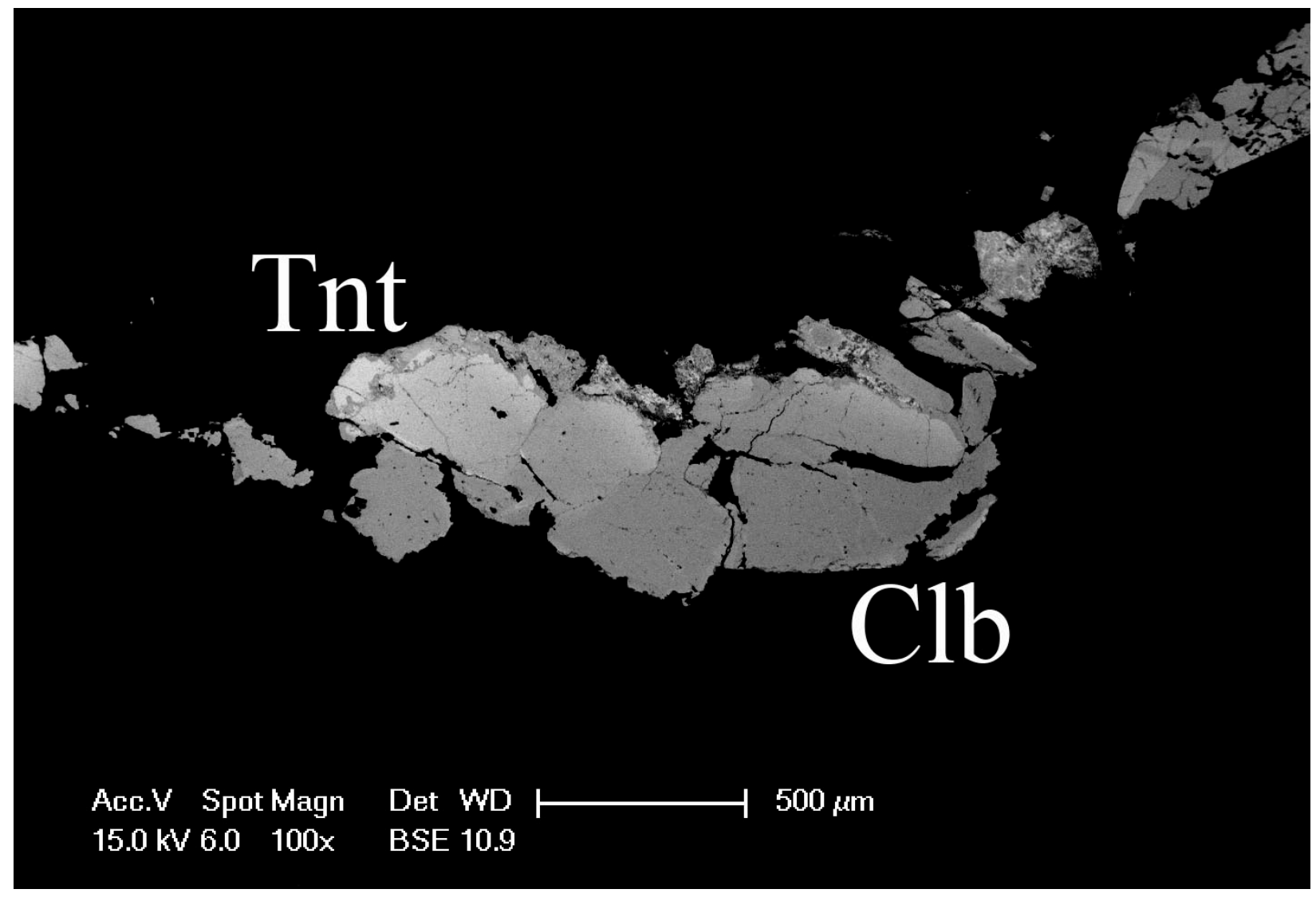

Figure 5.57: BSE image of manganocolumbite (Clb) grading into manganotantalite (Tnt) from the LI pegmatite.

In the GARMUS pegmatite, columbite occurs in the core zone in association with garnet. The sample appears homogeneous in BSE yet displays a distinct variation in its $\mathrm{X}_{\mathrm{Mn}}$ values, with slightly over half ranging between $\sim 0.47$ and $\sim 0.52$ (mostly ferrocolumbite) and all others ranging between $\sim 0.63$ and 0.74 (manganocolumbite); the $\mathrm{X}_{\mathrm{Ta}}$ values are only slightly variable, ranging between $\sim 0.08$ and $\sim 0.11$ (Fig. 5.56). The manganocolumbite $\mathrm{X}_{\mathrm{Mn}}$ values come from analytical points near the rim of the crystal and U-rich inclusions. Only semi-quantitative data from the GARMUS ferrocolumbite-maganocolumbite and the W-rich manganocolumbite from the SMALL pegmatite sample were collected within the time constraints of this thesis.

In the GARPHOS pegmatite, columbite occurs in the intermediate zone in association with zircon, monazite, and triplite-zwieselite and in the core zone as inclusions in tourmaline. Intermediate zone samples have $\mathrm{X}_{\mathrm{Mn}}$ values between $\sim 0.60$ and $\sim 0.79 ; \mathrm{X}_{\mathrm{Ta}}$ values are between $\sim 0.06$ and $\sim 0.16$. Core zone samples have $\mathrm{X}_{\mathrm{Mn}}$ values between $\sim 0.77$ and $\sim 0.99 ; \mathrm{X}_{\mathrm{Ta}}$ values are 
between $\sim 0.09$ and $\sim 0.39$ (Fig. 5.56). Manganocolumbite from the GARPHOS pegmatite contains up to 17.01 wt. $\% \mathrm{WO}_{3}\left(0.277\right.$ apfu $\left.\mathrm{W}^{6+}\right)$.

\subsubsection{Rutile and Cassiterite}

Rutile is observed to be in samples from the GARMUS, GARPHOS, GRANITE, JAN, LI, LI2, LONG, SIMPLE5, SIMPLE17, SMALL and SKINNY pegmatites. It was most frequently found in association with columbite and after biotite. It was analyzed in the GRANITE and GARPHOS pegmatites to examine the compositional differences that might be present between the most primitive pegmatite and one of the most fractionated pegmatites.

Rutile from the GRANITE pegmatite has up to of 2.21 wt. \% $\mathrm{Fe}_{2} \mathrm{O}_{3}\left(0.023\right.$ apfu $\left.\mathrm{Fe}^{3+}\right), 2.36$ wt. $\% \mathrm{Nb}_{2} \mathrm{O}_{5}\left(0.015\right.$ apfu $\left.\mathrm{Nb}^{5+}\right)$, and 2.03 wt. $\% \mathrm{WO}_{3}\left(0.007\right.$ apfu $\left.\mathrm{W}^{6+}\right)$. The rutile from the GARPHOS pegmatite has 11.08 wt. $\% \mathrm{Fe}_{2} \mathrm{O}_{3}$, and 19.14 wt. $\% \mathrm{Nb}_{2} \mathrm{O}_{5}$; the formula is $\mathrm{Ti}_{0.72} \mathrm{Fe}_{0.12} \mathrm{Nb}_{0.13} \mathrm{O}_{2}$. The substitution mechanism for $\mathrm{Fe}$ and $\mathrm{Nb}$ into rutile is $\mathrm{Fe}^{3+}+\mathrm{Nb}^{5+}$ for $2 \mathrm{Ti}^{4+}$.

Cassiterite was observed to be in samples from the BERYL, GARMUS and LI pegmatites. It was found in association with columbite from the BERYL pegmatite, a very small inclusion in a beryl crystal from the GARMUS pegmatite, and a very tiny inclusion in tourmaline from the LI pegmatite. It was analyzed in samples from the BERYL pegmatite because of its relatively larger sizes (up to $100 \mu \mathrm{m}$ ) and slightly greater frequency of occurrence. It has up to $4.99 \mathrm{wt}$ \% $\mathrm{Ta}_{2} \mathrm{O}_{5}\left(0.034\right.$ apfu $\left.\mathrm{Ta}^{5+}\right)$.

\subsubsection{Wolframite Group and Bismutotantalite}

Hübnerite, a species of the wolframite group, found in the GAR, GARPHOS, LI, and SMALL pegmatites, typically forms relatively large crystals (nearly $3 \mathrm{~mm}$ in length) compared to other oxide minerals encountered. In the GAR pegmatite, it is associated with muscovite and tourmaline replacing sekaninaite (Fig. 5.58). In the GARPHOS pegmatite, hübnerite was found in the intermediate zone associated with muscovite, spessartine, columbite, and triplitezwieselite. Hübnerite was also observed in the core zone of the LI pegmatite associated with spessartine, muscovite, and tourmaline. Due to the time constraints of this thesis, hübnerite was analyzed only from the LI and GARPHOS pegmatites. Samples analyzed from the LI pegmatite contains up to 4.58 wt. $\% \mathrm{Nb}_{2} \mathrm{O}_{5}\left(0.128 \mathrm{apfu} \mathrm{Nb}^{5+}\right)$ and 4.50 wt. \% FeO $\left(0.214 \mathrm{apfu} \mathrm{Fe}{ }^{2+}\right)$. 


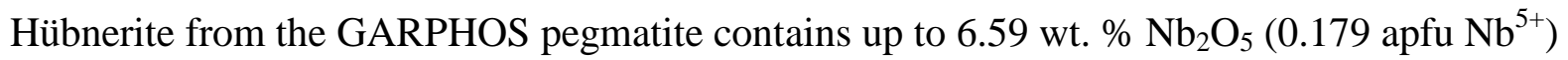
and 15.94 wt. \% FeO (0.535 apfu $\left.\mathrm{Fe}^{2+}\right)$.

Bismutotantalite was observed as an inclusion in the fluor-elbaite rim of a Bi-containing green elbaite crystal in lepidolite from the core zone the LI2 pegmatite (Fig. 5.58). It was identified using EDS; its composition was not analyzed using EMP.
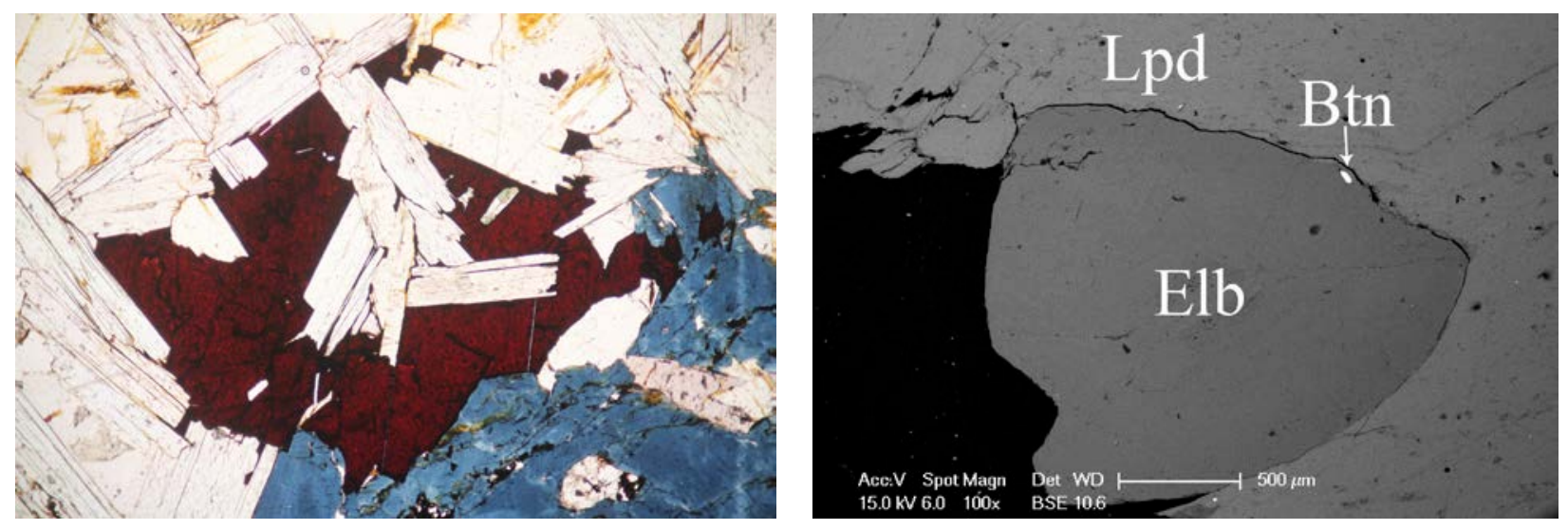

Figure 5.58: Left: Thin section through hübnerite (brown) with secondary muscovite (white) and tourmaline (blue) replacing sekaninaite in the GAR pegmatite; field of view is $4.2 \mathrm{~mm}$. Right: BSE image of bismutotantalite (Btn) in the fluor-elbaite rim of a green elbaite (Elb) crystal partially surrounded by lepidolite (Lpd); white scale bar is $500 \mu \mathrm{m}$.

\subsubsection{Qitianlingite}

Qitianlingite, $(\mathrm{Fe}, \mathrm{Mn})_{2}(\mathrm{Nb}, \mathrm{Ta})_{2} \mathrm{WO}_{10}$, was found in the BERYL, GARPHOS, and LI pegmatites in or very near the core zones of those pegmatites as zones within columbite in the BERYL pegmatite and zones within columbite inclusions in tourmaline from the GARPHOS and LI pegmatites (Fig. 5.59). In GARPHOS and BERYL is extremely rare and its composition is close to the ideal end-member formula (Fig. 5.60). The qitianlingite samples from LI have compositions close to the ideal end-member formula and part of the analytical data shows a transitional trend towards wolframite.

Minerals with W-rich compositions are frequently classified as wolframoixiolite (e.g. Alekseev et al. 2011). The good match of the Mount Begbie analytical data with the qitianlingite ideal end-member formula allowed their classification as qitianlingite, rather than the poorly defined (IMA-discredited) wolframoixiolite. 


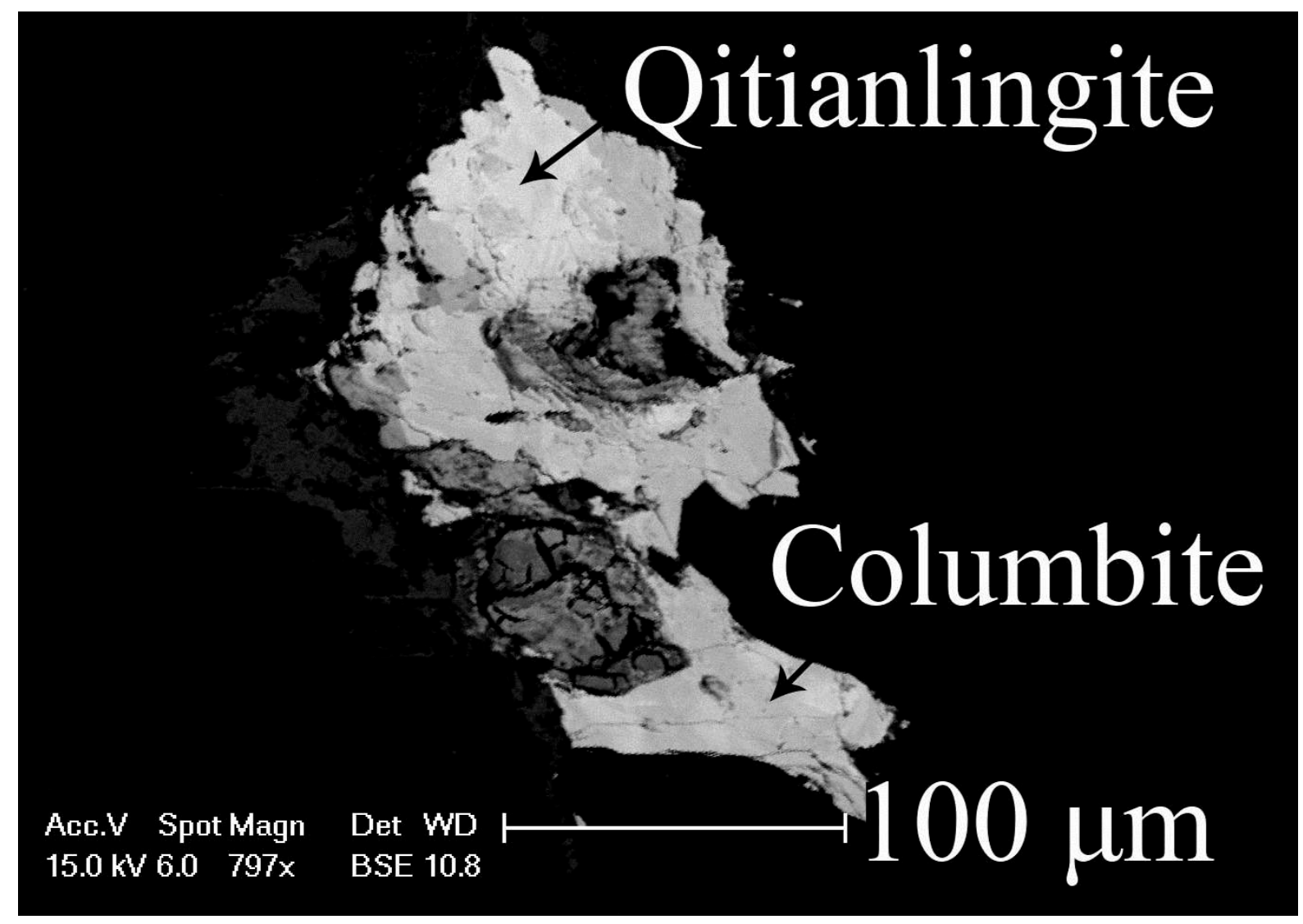

Figure 5.59: BSE image of a crystal with zones of qitianlingite and ferrocolumbite from the BERYL pegmatite.

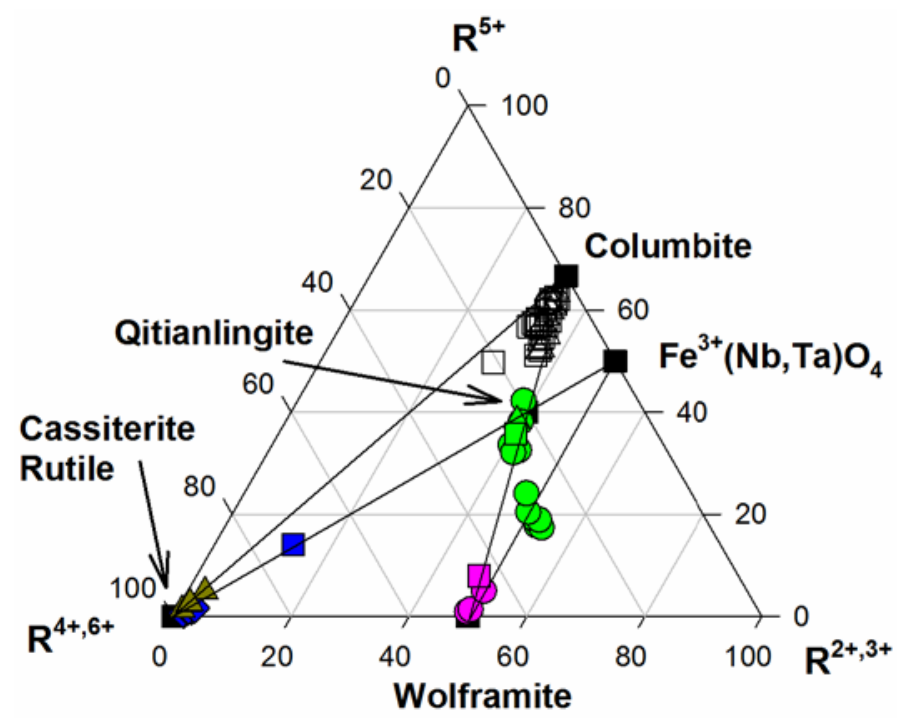

Symbol Shape Legend
$\triangle \quad$ BERYL
$\square \quad$ GARPHOS
$\quad$ GRANITE
$0 \quad$ LI
Symbol Fill Legend
$\Delta \quad$ Cassiterite
$\square \quad$ Columbite
$\square$ Rutile
$\square \quad$ Qitianlingite
$\square$ Wolframite

Figure 5.60: Ternary diagram showing the classification of qitianlingite and other analyzed oxides. 


\subsubsection{Summary of Oxides}

In general there is an extensive solid solution among the oxide minerals present. Rutile and cassiterite show a solid solution towards $\mathrm{Fe}^{3+}(\mathrm{Nb}, \mathrm{Ta}) \mathrm{O}_{4}$ (Fe-analogue of heftetjernite). Hübnerite (wolframite group) shows a limited solid solution towards columbite. Columbite shows a solid solution towards rutile and towards wolframite. Qitianlingite lies on a solid solution line between columbite and wolframite; it exhibits variable contents of $\mathrm{W}$ and (Mn,Fe), representing a solid solution towards wolframite.

Rutile is an oxide common to many rock types and rutile with elevated $\mathrm{Nb}$ content is relatively common accessory mineral in pegmatites from around the world (e.g., rutile in lunar rocks, Marvin 1971; Borborema pegmatitic province in Brazil, Beurlen et al. 2007). Cassiterite is nearly as widespread as rutile but is restricted to environments associated with granites and granitic fluids (e.g., tin-mineralized topaz granites of the Qitianling tin district in China, Xie et al. 2013; Fregeneda-Almendra pegmatites at the Spain-Portugal border, Roda-Robles et al. 1999). Wolframite group minerals and $\mathrm{W}$-rich columbite group minerals are common to medium- and low-T hydrothermal mineral deposits (e.g., the Sweet Home Mine in the Alma mining district, Colorado; Romer \& Lüders 2006) and Li-rich rare metal granites and pegmatites (e.g., Beauvoir granite in France, Linnen 1998 and references therein; Glen Gairn granitic complex in Scotland, Tindle \& Webb 1989; Bory pegmatite field in the Czech Republic, Novák et al. 2008). Bismutotantalite is a relatively rare mineral, associated only with highly evolved granitic pegmatites (e.g., La Elvirita granitic pegmatites in Argentina, Galliski et al. 2001). Qitianlingite is perhaps even more rare than bismutotantalite, being relatively recently described from a pegmatite in Qitianling, China (Anthony et al. 1997) and occasionally found in greisen environments (e.g. the Hensbarro topaz granite in Cornwall, Williamson et al. 1997; Breves CuAu-(W-Bi-Sn) deposit in Brazil, Tallarico et al. 2004).

\subsection{Phosphates}

\subsubsection{Apatite}

Apatite is an abundant mineral observed in samples from BERYL, CORD, GARMUS, GARPHOS, GRANITE, JUNCT, LI, LI2, SMALL, PEGMA, POCKET, TOUR, and TOURMUS pegmatites. Apatite is likely present in all other pegmatites but is difficult to discern 
in the study area due to the fact it is typically fine grained, nearly colorless, and anhedral, giving it an appearance very similar to quartz. Apatite is more easily identified from the Mount Begbie pegmatites with the use of a shortwave UV light which causes it to fluoresce bright orange (Fig. 4.5).

Bright orange fluorescence could be caused by the presence of $\mathrm{Mn}^{2+}$ (Waychunas 2002) which is a common constituent in all apatite examined with SEM. Mn contents are greatest in the more fractionated pegmatites (LI, LI2, and GARPHOS) and elevated contents were found in BERYL, GARMUS, 12-GRANITE-S08, SMALL, TOUR, and TOURMUS (all using EDS only). EDS also revealed elevated levels of $S$ in the moderately to more highly fractionated pegmatites (TOURMUS, LI, LI2, and GARPHOS).

Another common feature common to most apatite samples examined with the SEM is alteration. Grains can be heavily pitted, suggesting dissolution (Fig. 5.61). The elevated S content is somewhat correlated with the more altered apatite grains but may not be related to the alteration.

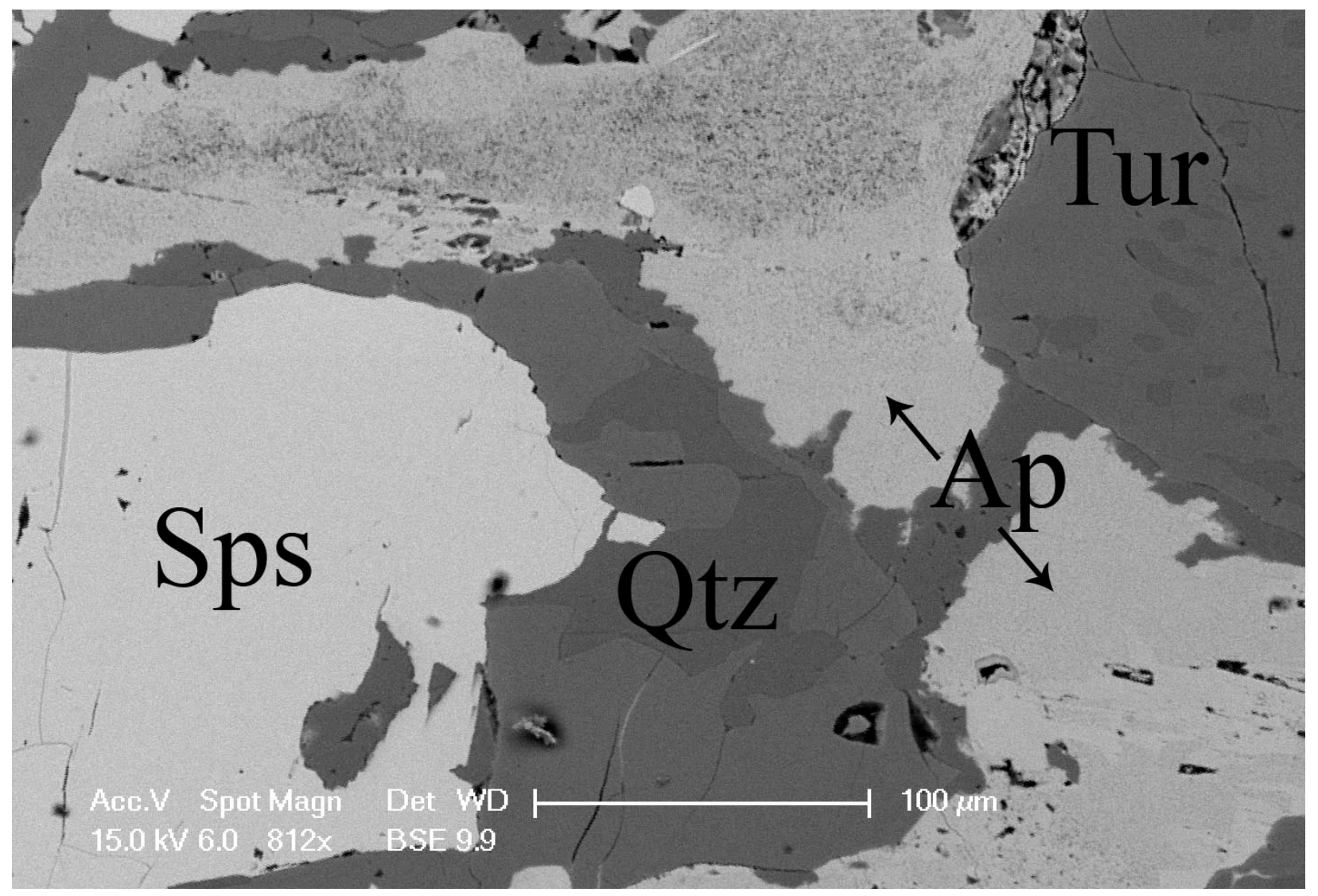


Figure 5.61: BSE image showing a typical example altered apatite from the LI pegmatite. Scale bar is $100 \mu \mathrm{m}$.

\subsubsection{Mn, Fe - and Li -Phosphates}

$\mathrm{Mn}, \mathrm{Fe}$-phosphates were found in as dark brown altered massive nodules in the GARPHOS, LI, LI2, and TOURMUS pegmatites. The most common Mn, Fe-phosphate encountered is triplite (Fig. 5.62); it was found in the GARPHOS, LI2, and TOURMUS pegmatites. In the lepidolite pegmatites (LI and LI2) small quantities of lithiophilite-triphylite were found. Amblygonite was optically identified in a thin section from the core of the LI2 pegmatite. Results from powder X-ray diffraction suggest hureaulite and lipscombite may also be present in the LI2 and GARPHOS pegmatites as alteration products of triplite. The composition of the Fe,Mn- and Li-phosphates were not studied in detail.

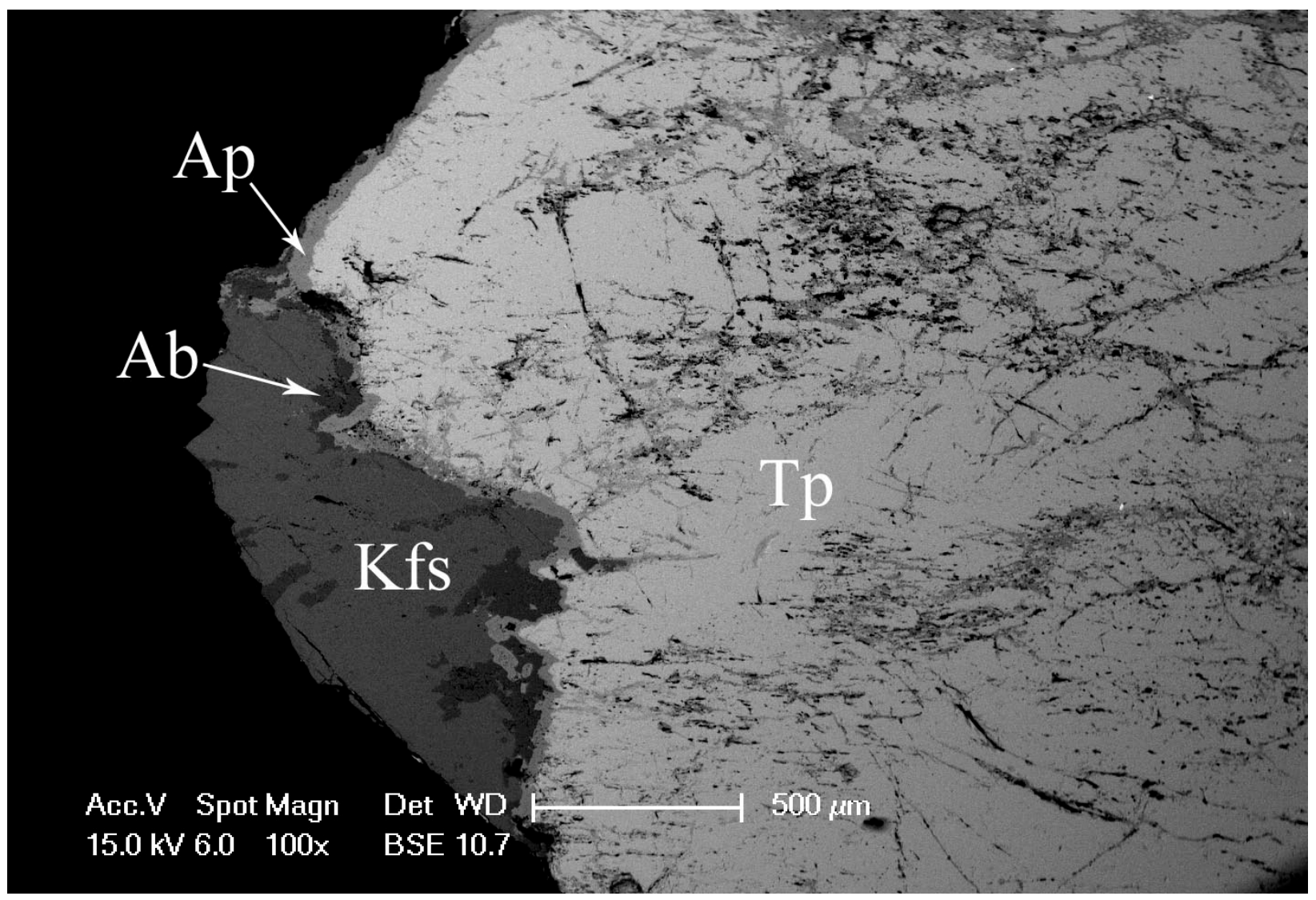

Figure 5.62: A BSE image of triplite (Tp) rimmed by apatite (Ap) next to a perthite-like grain of K-feldspar (Kfs) and albite (Ab). 


\subsubsection{Monazite-(Ce) and Xenotime-(Y)}

Monazite-(Ce) and xenotime-(Y) are very fine-grained, common REE-phosphate minerals in nearly all low to moderately fractionated pegmatite samples (BERYL, CORD, GARTOUR, GRANITE, PEGMA, SIMPLE, SIMPLE9, and SMALL) and locally in more highly fractionated pegmatites (GARPHOS); the presence of monazite and xenotime in the LI2 pegmatites is not confirmed. Monazite-(Ce) and xenotime-(Y) were analyzed in a primitive pegmatite (GRANITE), a moderately fractionated pegmatite (SIMPLE9), and highly fractionated pegmatite (GARPHOS) to determine if there are any significant compositional differences in the minerals between pegmatites.

Monazite fractionates light REE over middle and heavy REE; in comparison, xenotime preferentially incorporates middle and heavy REE (Hoshino et al. 2012, Masau et al. 2000). This same trend can be seen in the chondrite-normalized values for REE content analyzed in monazite and xenotime here (Fig. 5.63). Rare-earth elements heavier than Dy are below detection limits in monazite whereas in xenotime, REE heavier than Gd show slightly increasing contents.

In general, the chondrite-normalized values for the monazite-(Ce) samples from the GRANITE pegmatite show greater contents of REE than samples from the SIMPLE9 and GARPHOS pegmatites. Similarly, the SIMPLE9 pegmatite monazite-(Ce) displays greater contents of REE than those samples analyzed from the GARPHOS pegmatite. The opposite trend can be observed in the chondrite-normalized values for xenotime-(Y) samples; the SIMPLE9 pegmatite samples have an overall greater content of REE than samples from the GRANITE pegmatite.

Chondrite-normalized values for monazite-(Ce) samples from the GARPHOS pegmatite display a pattern similar to the lanthanide tetrad effect. The tetrad effect is common in highly fractionated granites and pegmatites (Irber 1999).

The analyzed monazite-(Ce) has relatively low contents of Ce ( 0.268 to $\sim 0.451 \mathrm{apfu})$ and relatively high contents of La ( 0.041 to $\sim 0.243 \mathrm{apfu})$, $\mathrm{Nd}$ ( $\sim 0.087$ to $\sim 0.258 \mathrm{apfu}), \mathrm{Sm}$ ( $\sim 0.031$ to $\sim 0.072 \mathrm{apfu}$ ), and locally elevated contents of Th ( 0.019 to $\sim 0.140 \mathrm{apfu})$. Slightly lower contents in $\mathrm{Y}$ ( $\sim 0.687$ to $\sim 0.743$ apfu $\mathrm{Y})$ in the analyzed xenotime-(Y) are balanced by elevated contents of Dy ( 0.042 to $\sim 0.059$ apfu Dy), Yb ( 0.046 to $\sim 0.076$ apfu Yb) and locally abundant $\mathrm{U}(\sim 0.002$ to $\sim 0.055$ apfu $\mathrm{U})$. 
Where the content of Th is elevated in monazite, cheralite substitution (2REE ${ }^{3+} \leftrightarrow$ $\left.(\mathrm{Th}, \mathrm{U})^{4+}+\mathrm{Ca}^{2+}\right)$ which is relatively common in monazite found in fractionated S-type granites (Hoshino et al. 2012), appears to be operating in the samples analyzed, as the ratio of Ca to $\mathrm{Th}+\mathrm{U}$ is 1:1 (Fig. 5.63). Cheralite substitution occurs in monazite samples from the 12GARPHOS-S04 sample site and one monazite sample from the 12-GRANITE-S09 sample site.
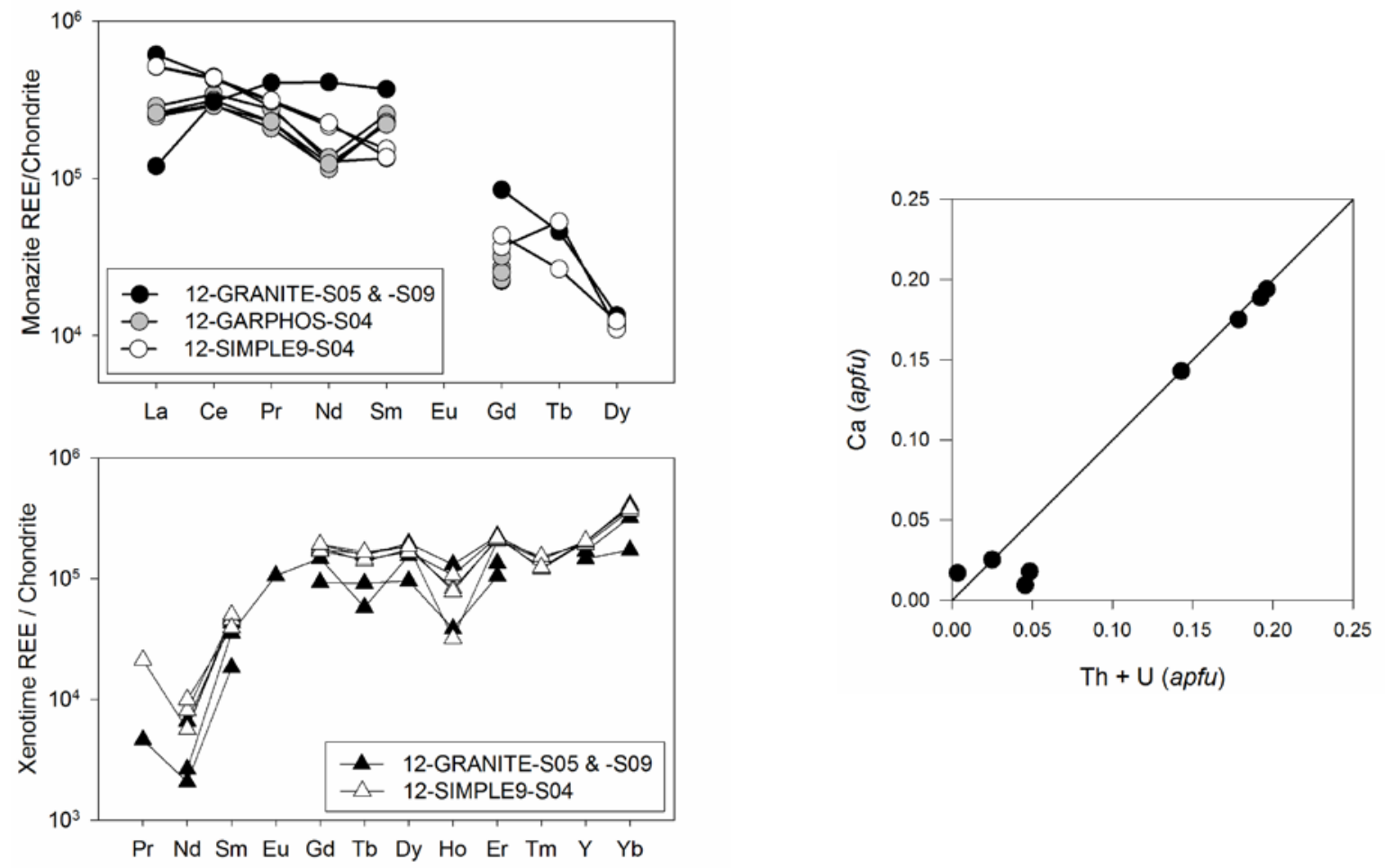

Figure 5.63: Left: Chondrite normalized values of REE in monazite and xenotime. Right: Points on the 1:1 line indicate cheralite substitution in monazite.

\subsection{Andalusite, Petalite, and Topaz}

Andalusite was observed in the central part of the CORD pegmatite (Fig. 3.5e) near its join with the JUNCT pegmatite and in the core zone of the GARMUS pegmatite. In both localities, the andalusite crystals are prismatic, pink, and up to $\sim 5 \mathrm{~cm}$ long. Andalusite from the CORD pegmatite has dark blue inclusions and streaks; the inclusions resemble corundum typical for this assemblage from other localities (J. Cempírek, pers. commun.) but the inclusions here were identified as andalusite using EDS. It is unknown if the blue coloring is the result of unusual 
zoning or perhaps a closely related aluminosilicate (kyanite or silimanite) resulting from events preceding or proceeding the crystallization of the andalusite.

Petalite from the LI pegmatite was positively identified using powder X-ray diffraction (Appendix B.1). Hand samples of petalite strongly resemble blocky albite; only careful scrutiny reveals the cleavage planes and rare crystal faces. Occasional patches in the petalite are nearly colorless and transparent. The presence of petalite in the LI pegmatite suggests the possibility other Li-minerals may be found there, such as spodumene and eucryptite - two of the possible breakdown products of petalite (Černý \& London 1983).

Topaz was observed in thin sections from the core zone of the GARPHOS pegmatite and is associated with schorl-cored elbaite-rimmed tourmaline. Grains of topaz are subhedral and up to $\sim 2 \mathrm{~mm}$ long. EMP analyses indicate the topaz is F-rich ( 1.833 to 2.000 apfu).

\subsection{Allanite and Zircon}

Allanite was observed as small grains (up to $\sim 300 \mu \mathrm{m}$ long) in fractures of feldspars next to slightly larger grains of tourmaline (up to $\sim 500 \mu \mathrm{m}$ in diameter) from the border zone of the LONG pegmatite (Fig. 5.64). It was identified using EDS.

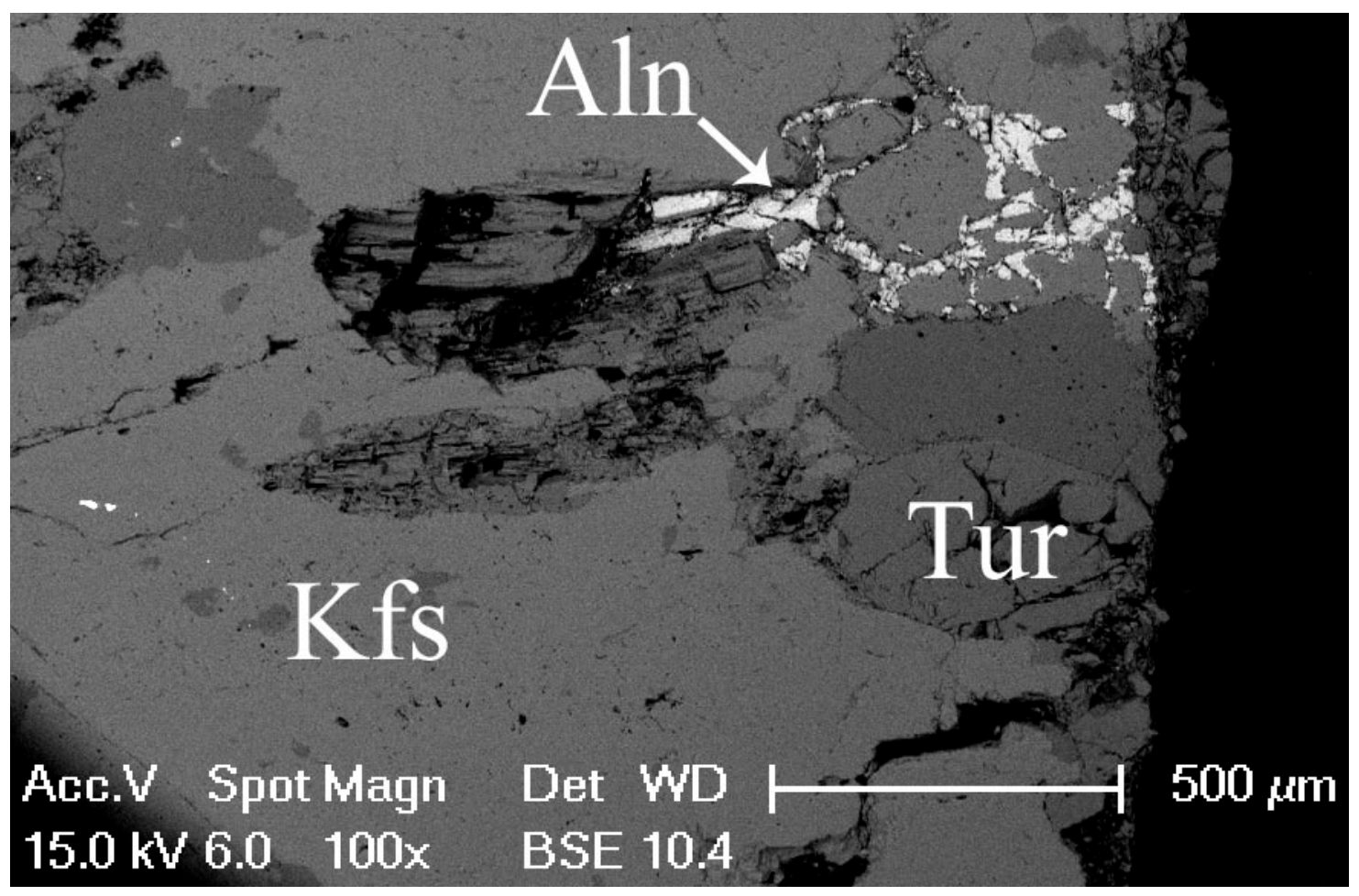

Figure 5.64: A BSE image of allanite (Aln) from the LONG pegmatite. 
Zircon is relatively abundant throughout the study area and forms tiny euhedral grains, usually not greater than $\sim 50 \mu \mathrm{m}$ across; one zircon grain collected from the BERYL pegmatite is $\sim 5 \mathrm{~mm}$ long and has a dark red-brown color. Zircon occurs throughout all pegmatite zones in association with a wide range of minerals and it is one of the most common inclusions in tourmaline. Zircons were observed in samples collected from the BERYL, CORD, GARMUS, GARPHOS, GRANITE, LENS2, LI, LI2, PEGMA, SIMPLE9, SMALL, and TOURMUS pegmatites using thin sections and SEM, and tentatively identified in thin sections from the SIMPLE12, SIMPLE16, SKINNY, and TOUR pegmatites.

Zircon grains were analyzed with EMP from the dikes which seemed to contain the greatest quantities of zircon (the BERYL, GARPHOS, GRANITE, LI ${ }^{3}$, PEGMA, SIMPLE9, and TOURMUS pegmatites). The Zr contents are slightly low ( 0.861 to $\sim 0.981 \mathrm{apfu}$ ) with slightly elevated Hf ( $\sim 013$ to $0.051 \mathrm{apfu}$ ) and locally elevated contents of U (up to $\sim 0.141 \mathrm{apfu}$ ). As been shown as an indicator of fractionation (London 2008), the Hf content is slightly greater in the more fractionated pegmatites (Fig. 5.65).

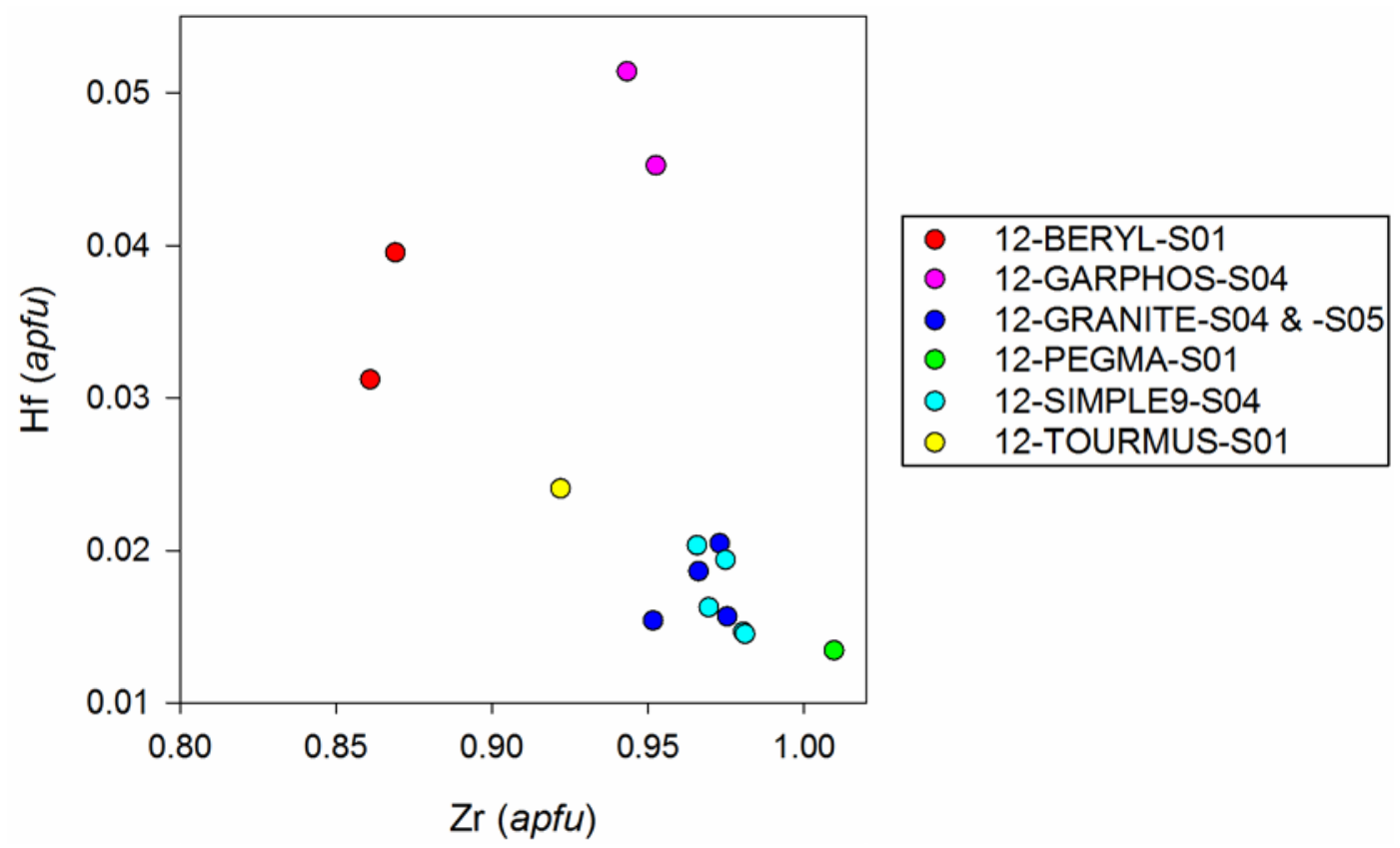

Figure 5.65: Plot of Zr vs. Hf.

\footnotetext{
${ }^{3}$ Unfortunately, analyses of the zircon grains from the LI pegmatite overlapped with tourmaline and were too altered to give meaningful results.
} 


\subsection{Sulfides}

Occurrences of sulfide minerals within the study area are very uncommon. Most often, they are small (up to $\sim 500 \mu \mathrm{m}$ ) Fe-sulfide inclusions in what appears to be primary iron oxides from pegmatites with low fractionation: the GRANITE, LONG, and SIMPLE11 pegmatites. One extremely tiny $(\sim 50 \mu \mathrm{m})$ Fe-sulfide crystal - tentatively identified as pyrrhotite using EDS was observed in a sample of the BERYL pegmatite, apparently independent of iron oxides. Galena grains were observed as inclusions in a Fe-sulfide inclusion - tentatively identified as pyrite using EDS - in a crystal of primary iron oxide (Fig. 5.66).

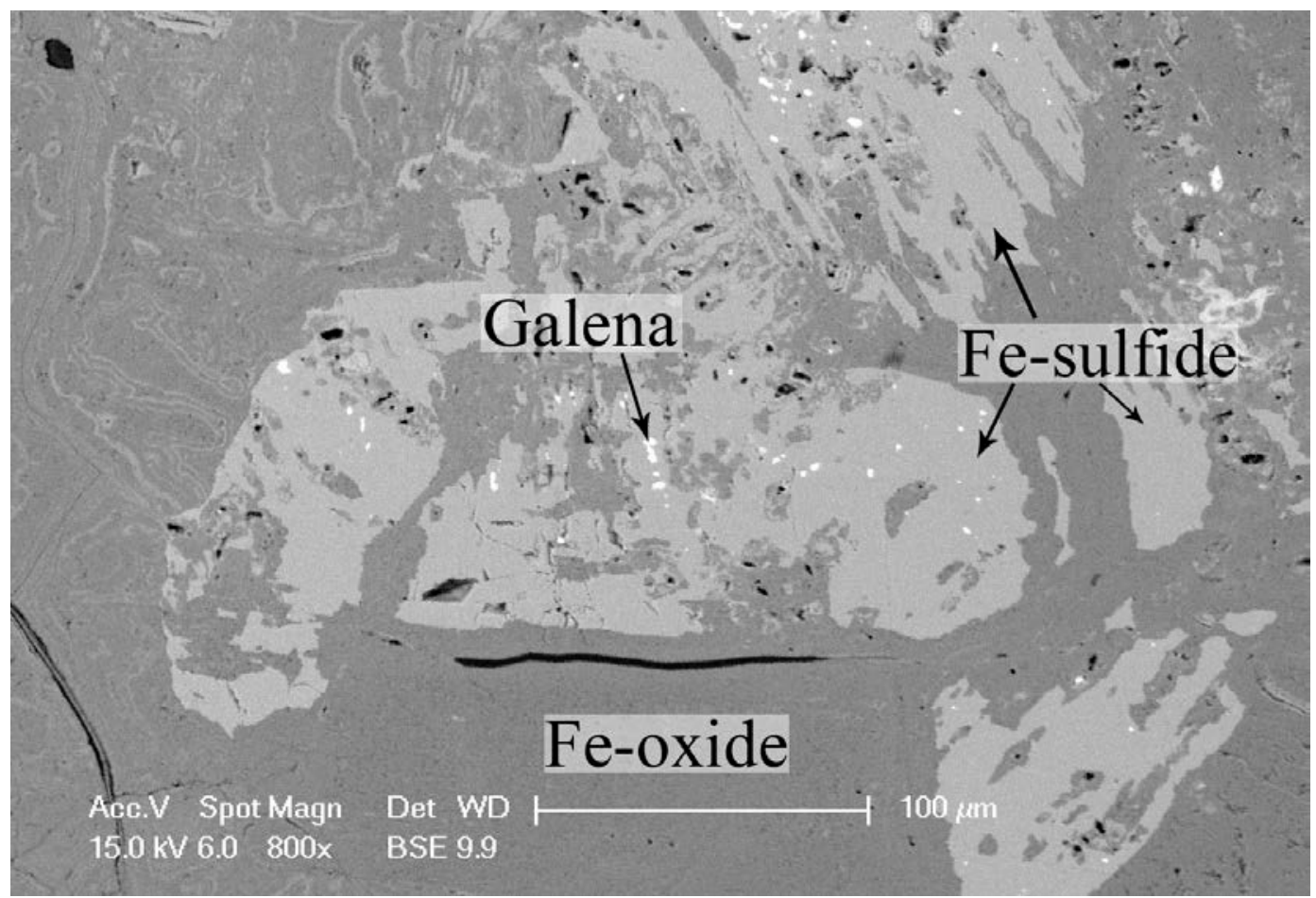

Figure 5.66: A BSE image of galena inclusions in a Fe-sulfide inclusion in an Fe-oxide from the LONG pegmatite.

\subsection{Chlorite Group and U-bearing Minerals}

Chlorite group minerals are the most widespread secondary phase in the study area, occurring as alteration products after cordierite-sekaninaite and biotite. In most cases, alteration after biotite is limited to the border zones of pegmatites.

Small yellow crusts with black speckles and spheres of yellow acicular crystals of Ubearing minerals can occasionally be found coating the surface and small crevices in mineral 
samples from the intermediate and core zones of the BERYL pegmatite. Uranophane (Fig. 5.67) has been identified from the BERYL pegmatite using powder XRD and EDS; phurcalite, rutherfordine, uraninite have been tentatively identified using the same techniques. Another phase of $\mathrm{U}+$ Ca silicate has also been found that appears to be somewhat compositionally different than uranophane; deeper investigation is needed to determine what it might be.

Grains of uraninite have been positively identified from the GARPHOS pegmatite using EDS; grains of autunite and uraninite have been tentatively identified using EDS on samples from the GARPHOS and LI pegmatites, respectively. Autunite and uraninite are associated with Fe,Mn-phosphates, columbite, monazite, xenotime and zircon; they are most often found as inclusions in zircon (Fig. 5.68).

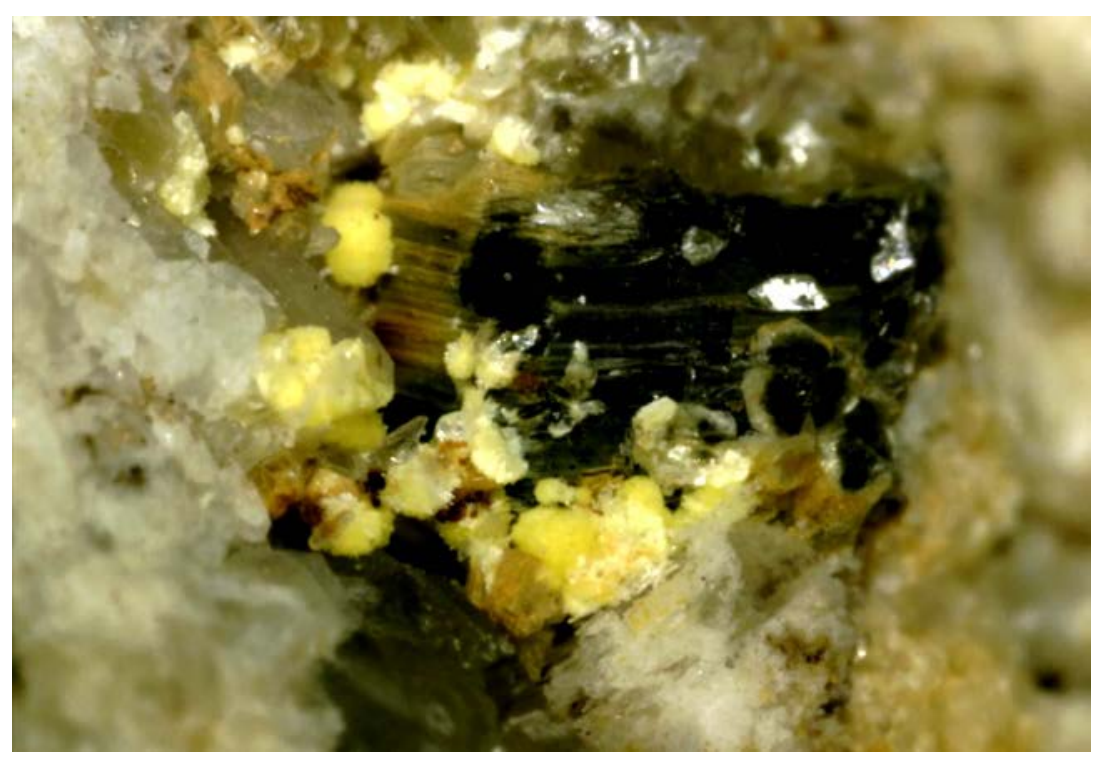

Figure 5.67: Photomicrograph of uranophane from the BERYL pegmatite. Field of view is $\sim 4$ $\mathrm{mm}$. 


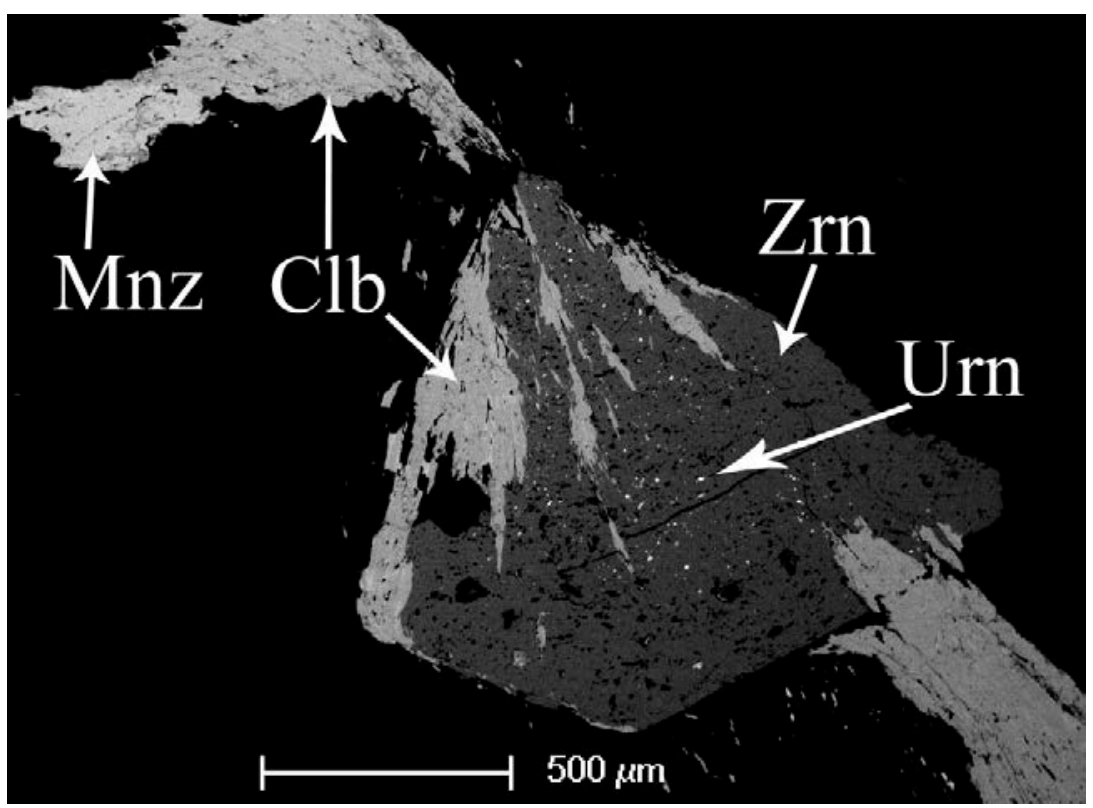

Figure 5.68: A BSE image of uraninite (Urn) inclusions in zircon (Zrn) with columbite (Clb) and monazite (Mnz) all as inclusions in triplite from the GARPHOS pegmatite. 


\section{Chapter 6: Discussion}

\subsection{Pegmatite Classification}

Considering the pegmatites in this study as a whole, they belong to the rare-element class as defined by Černý \& Ercit (2005). The majority of the pegmatites in the study area are barren with tourmaline, biotite, and locally occurring garnet as the main accessory phases. The BERYL, CORD, GAR, GARMUS, GARPHOS, GARTOUR, LI, LI2, SIMPLE9, SMALL, TOURMUS pegmatites all exhibit an evolved mineralogy that allows them to be classified as rare-element pegmatites (after Černý \& Ercit 2005).

From a geochemical point of view, the mapped rare-element pegmatites show two distinct signatures. The BERYL pegmatite has mineralization that generally fits closer to the NYF family: absence of phosphates other than apatite, monazite, and xenotime; low fractionation of $\mathrm{Nb} / \mathrm{Ta}$ as well as Fe/Mn in columbite; and presence of $\mathrm{U}$ mineralization. However, the presence of cassiterite and cordierite within the dike are uncommon for pegmatites of the NYF family and are more generally associated with pegmatites of the LCT family. It can be classified as a beryl-columbite subtype of beryl-type pegmatites.

The peraluminous Be-bearing pegmatites without other significant rare-element mineralization include the CORD, GARTOUR, and SIMPLE9 dikes. The presence of cordierite and muscovite seems to indicate they belong in the LCT family, rather than in the NYF family. Their classification is not possible based on the primitive mineral assemblages and are discussed here as beryl-bearing pegmatites. Similar but more fractionated are the GAR, GARMUS, and SMALL pegmatites. The presence of fractionated rare-metal oxides (hübnerite and/or manganocolumbite) is a clear geochemical signature of the LCT family. These pegmatites can be classified as beryl-columbite subtype pegmatites.

The beryl- and phosphate-bearing pegmatites with elbaitic tourmaline located near the southeastern end of the GRANITE pegmatite (GARPHOS and TOURMUS) belong to the LCT family and can be classified either as Li-bearing beryl-columbite-phosphate subtype of beryl type pegmatites or as a phosphate-bearing elbaite subtype of complex type pegmatites. Neither the classifications fits the ideal geochemical signature as beryl-columbite-phosphate pegmatites are typically Li-poor and elbaite pegmatites are typically depleted in $\mathrm{P}$ and more rich in $\mathrm{B}$ (borates are characteristic of the subtype). Especially in the GARPHOS pegmatite, the mineral 
assemblages in the two main sample sites differ significantly, making classification difficult; the more primitive part of the dike (12-GARPHOS-S04) has the mineral assemblage of beryl, Mn-Fe phosphates, columbite, and spessartine whereas the more fractionated part of the dike (12GARPHOS-S01) has Mn-rich elbaite-rimmed tourmaline, topaz, spessartine and columbite. At the current knowledge of mineralization of both pegmatites, the former classification (berylcolumbite-phosphate subtype) seems to be more appropriate than the latter.

The most fractionated pegmatites, LI and LI2, belong to the LCT family, complex type of rare-element pegmatites, specifically the lepidolite subtype.

\subsection{Mineral Fractionation Patterns}

\subsubsection{K-Feldspar and Micas}

The analytical results from K-feldspar and micas clearly show the most fractionated pegmatites in maps of the Rb, Cs, and P concentrations (Fig. 5.42a, b, \& c). Despite the fact that non-ideal analytical approach was available for this study (EMP instead of LA-ICP-MS), the combination of Rb, Cs, and P mark all rare-element pegmatites. The Cs in the K-feldspar map highlights the BERYL, GARMUS, GARPHOS, and LI2 pegmatites. The Rb in K-feldspar highlights the BERYL, GARPHOS, and LI2 pegmatites. The P in the K-feldspar highlights all the Mn-Fe phosphate-bearing pegmatites, the most fractionated pegmatites, and a few potential targets for further study. The Rb and Cs in micas unequivocally indicate the most fractionated rare-element pegmatites: BERYL, LI, and LI2; interestingly, the TOURMUS pegmatite shows greater fractionation in micas than the GARPHOS pegmatite. Less fractionated pegmatites only display slightly elevated concentrations of trace elements: SIMPLE9 (Rb in K-feldspar and micas), GAR (only Rb in micas), and SMALL (Rb and P in K-feldspar) pegmatites.

Possible higher fractionation is indicated in the SIMPLE13 (elevated Rb and Cs in Kfeldspar), SKINNY (elevated Rb, Cs, and P in K-feldspar; Rb in mica), and POCKET (P in Kfeldspar) pegmatites.

In general, the observed contents of Rb and Cs in both K-feldspar and micas throughout the

study area are low compared to highly fractionated pegmatites (e.g., the Tanco pegmatite; Brown 2001) with the exception of the LI2 pegmatite. It is possible to conclude that EMP analysis of 
K-feldspar and micas is a method that can be effectively used for detection of the most fractionated pegmatites, which are usually of most economic interest.

\subsubsection{Garnet and Columbite}

The degree of fractionation in garnet gives very similar results to the analyses of Kfeldspar and micas. The garnets from pegmatites with low fractionation generally have an almandine composition with $\mathrm{X}_{\mathrm{Mn}}$ below 0.5 (Fig. 5.48). All fractionated pegmatites contain spessartine with $\mathrm{X}_{\mathrm{Mn}}$ between 0.55 and 0.8 . The elevated $\mathrm{X}_{\mathrm{Mn}}$ in the LONG pegmatite suggests that further study may yield more interesting mineralogical results. The highly anomalous garnet composition (almost pure spessartine) from the JAN aplite veinlets indicate that these may represent highly fractionated melt that escaped from a larger, fractionated pegmatite which is not exposed at the surface.

Columbite-group minerals only occur in the more fractionated rare-element pegmatites. The $\mathrm{Mn} / \mathrm{Fe}$ ratio clearly marks the most evolved pegmatites whereas the $\mathrm{Ta} / \mathrm{Nb}$ ratio typically increases during crystallization of the pegmatite from the intermediate to the core zones. The high $\mathrm{Mn} / \mathrm{Fe}$ ratio of columbite in the SMALL pegmatite indicates it may be more highly fractionated than initially observed in the field (Fig. 6.1).

Compositional evolution of the columbite from BERYL closely resembles the trends seen from F-poor beryl-type pegmatites (Fig. 6.1). This agrees with the overall mineralogy of the BERYL pegmatite with minor apatite and only elevated $\mathrm{F}$ contents in tourmaline and micas. Likewise, evolution of columbite from the GARPHOS and LI pegmatites fits well to the trends observed in F-rich complex pegmatites. The high Mn/Fe ratios in GARMUS and SMALL suggest their higher fractionation and potentially elevated $\mathrm{F}$ contents. 

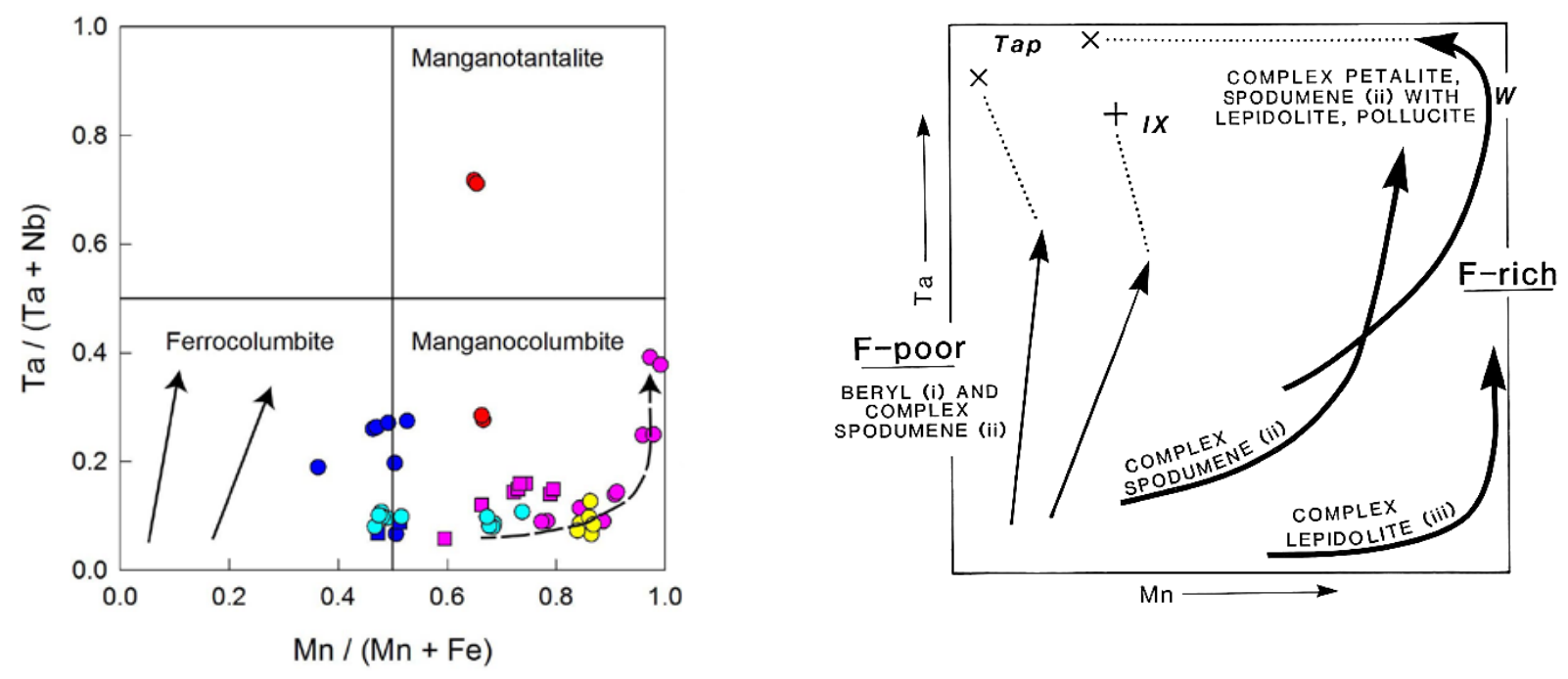

$$
\begin{aligned}
& \text { 12-BERYL-S01: near core zone } \\
& \text { - 12-BERYL-S02: intermediate zone } \\
& \text { 12-LI-S01: core zone } \\
& \text { 12-GARMUS-S01: core zone } \\
& \text { 12-GARPHOS-S01: core zone } \\
& \text { 12-GARPHOS-S04: intermediate zone } \\
& \text { 12-SMALL-S01: core zone }
\end{aligned}
$$

Figure 6.1: Fractionation trends in columbite from Mount Begbie pegmatites (left) and general fractionation trends seen in columbite from complex and beryl pegmatites (right; modified after Černý 1989). 


\subsubsection{Tourmaline}

Tourmaline from the LI and LI2 pegmatites exhibit very similar compositional evolution to the typical trends described for lepidolite-subtype pegmatites ("lepidolite pegmatites") by Selway et al. (1999). During crystallization the $\mathrm{Al} /(\mathrm{Al}+\mathrm{Fe})$ gradually increases from the most primitive to the most evolved tourmaline and show the typical trend (Fig. 6.2):

\section{foitite $\rightarrow$ schorl $\rightarrow$ fluor-schorl $\rightarrow$ fluor-elbaite $\rightarrow$ rossmanite.}

The trend observed for the LI and LI2 pegmatites for a plot of the Na vs. F is offset towards greater $\mathrm{F}$ in late tourmaline stages (fluor-elbaite and rossmanite) and is missing the very late Fe-enriched stages compared to the usual trend for lepidolite pegmatites (Fig. 6.2; Selway et al. 1999).
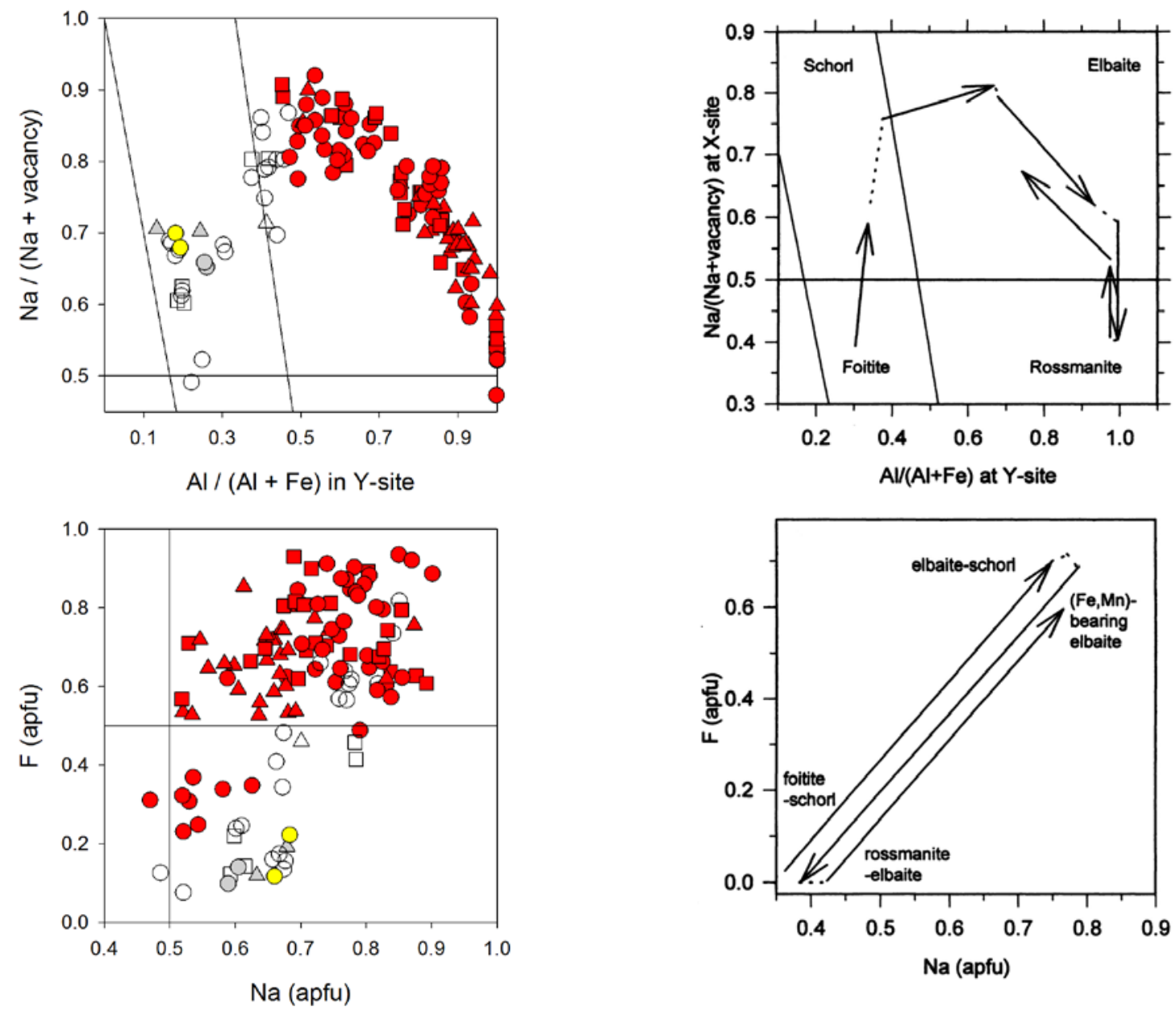

Figure 6.2: Tourmaline evolution trends from the LI and LI2 pegmatites (left; legend is same as Fig. 5.15a) and from lepidolite subtype-pegmatites (right; modified after Selway et al. 1999). 
Tourmaline from the GARPHOS pegmatite exhibits a similar compositional evolution to the typical trends described for lepidolite pegmatites by Selway et al. (1999) but the evolution differs in several aspects (Fig. 6.3). The evolution of tourmaline for the GARPHOS pegmatite from border zone to core zone is:

\section{Ca-rich dravite $\rightarrow$ Mg-rich schorl $\rightarrow$ Mg-rich schorl-foitite $\rightarrow$ schorl-foitite $\rightarrow$ (Fe,Mn)-elbaite $\rightarrow$ Mn-rich fluor-elbaite.}

During tourmaline crystallization, the $\mathrm{Al} /(\mathrm{Al}+\mathrm{Fe})$ ratio gradually increases for both GARPHOS and lepidolite pegmatites. The first difference is displayed by the composition of tourmaline in the border and wall zones, which is characterized by a transition from Ca-rich dravite to Mg-rich schorl accompanied with a rapid decrease in the $\mathrm{Na} /(\mathrm{Na}+$ vacancy) ratio. The subsequent trend from Mg-rich schorl-foitite to (Fe,Mn)-elbaite is identical to the evolution of tourmaline in lepidolite pegmatites. The most evolved tourmaline is Mn-rich fluor-elbaite which does not farther evolve to Mn-poor rossmanite, contrary to the trend displayed by the lepidolite pegmatites. Late enrichment in Fe is common to both GARPHOS and lepidolite pegmatites. The gradual increase of Mn leading to its extreme enrichment and Fe-depletion in fluor-elbaite in the GARPHOS pegmatite is the most striking difference compared to the lepidolite pegmatites; the difference is well visible when comparing the tourmaline compositions of the LI, LI2 and GARPHOS pegmatites (Fig. 6.4). The extreme Mn-enrichment is typical for tourmaline in elbaite-subtype pegmatites (Novák \& Povondra 1995). Like the trend observed for the LI and LI2 pegmatites, a plot of the Na vs. F for GARPHOS is offset, except in this case the offset is towards greater $\mathrm{Na}$ in early tourmaline stages (dravite and schorl).

Comparison of tourmaline evolution in all of the studied pegmatites where tourmaline was analyzed, shows differences among the Li-bearing pegmatites (the "Li-pegmatites”), pegmatites where Be is the main "rare element” (the "Be-pegmatites”), and primitive pegmatites (Fig. 6.5). In general, the compositional trends of the Be-pegmatites and the primitive pegmatites from Ferich dravite to Al-rich schorl overlap except the F contents of the most evolved samples from Bepegmatites are elevated in comparison to those from primitive pegmatites. The border and wall zone tourmaline from the Li-pegmatites is similar to the Be-pegmatites, especially due to initial Mg-contamination of the melt from the host rock. All other tourmaline types from the Lipegmatites display distinct Na-, Al-, Li-, and F-enrichment. 

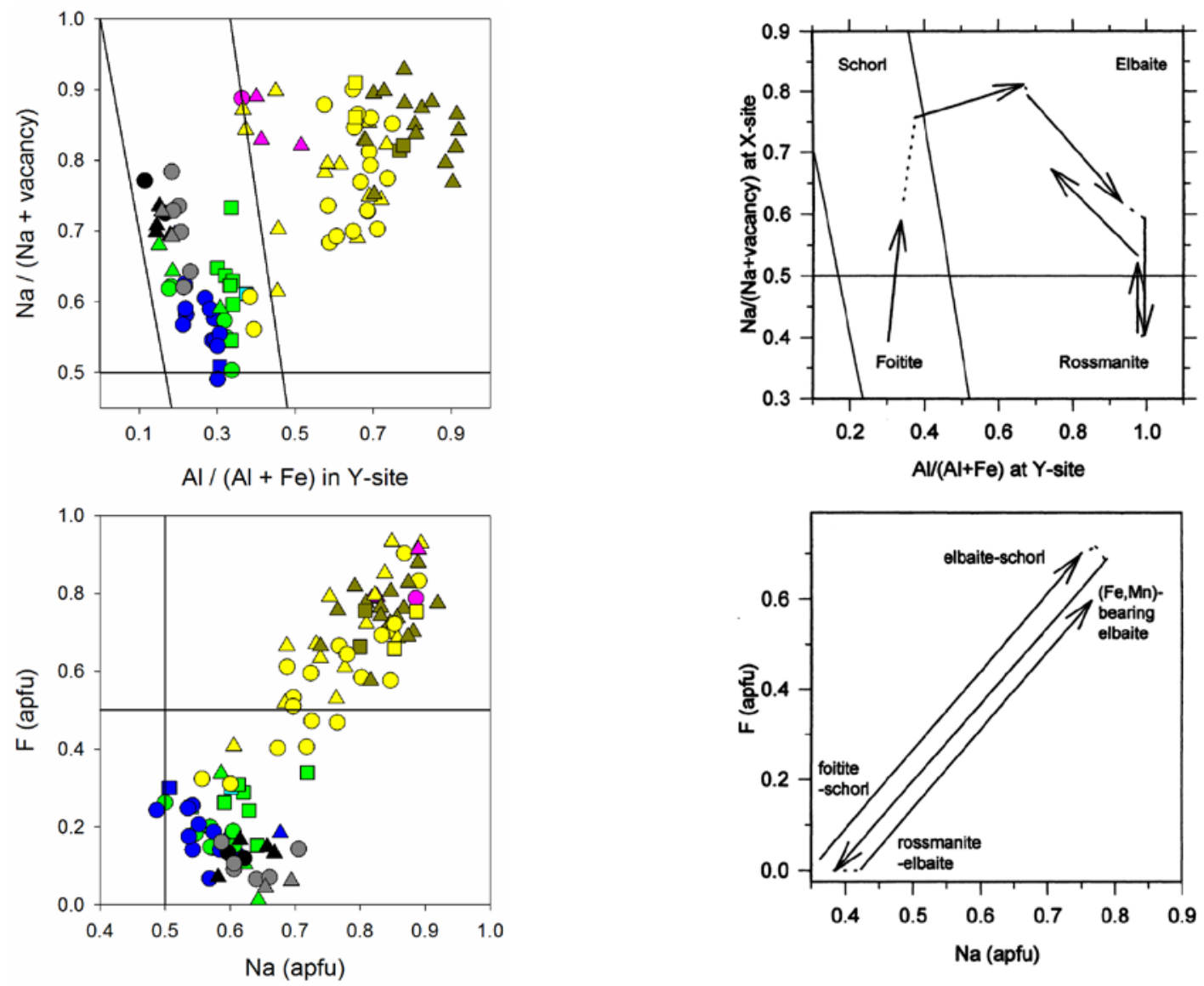

Figure 6.3: Tourmaline evolution trends from the GARPHOS pegmatite (left; legend is same as Fig. 5.7c) compared to tourmaline from lepidolite subtype-pegmatites (right; modified after Selway et al. 1999).
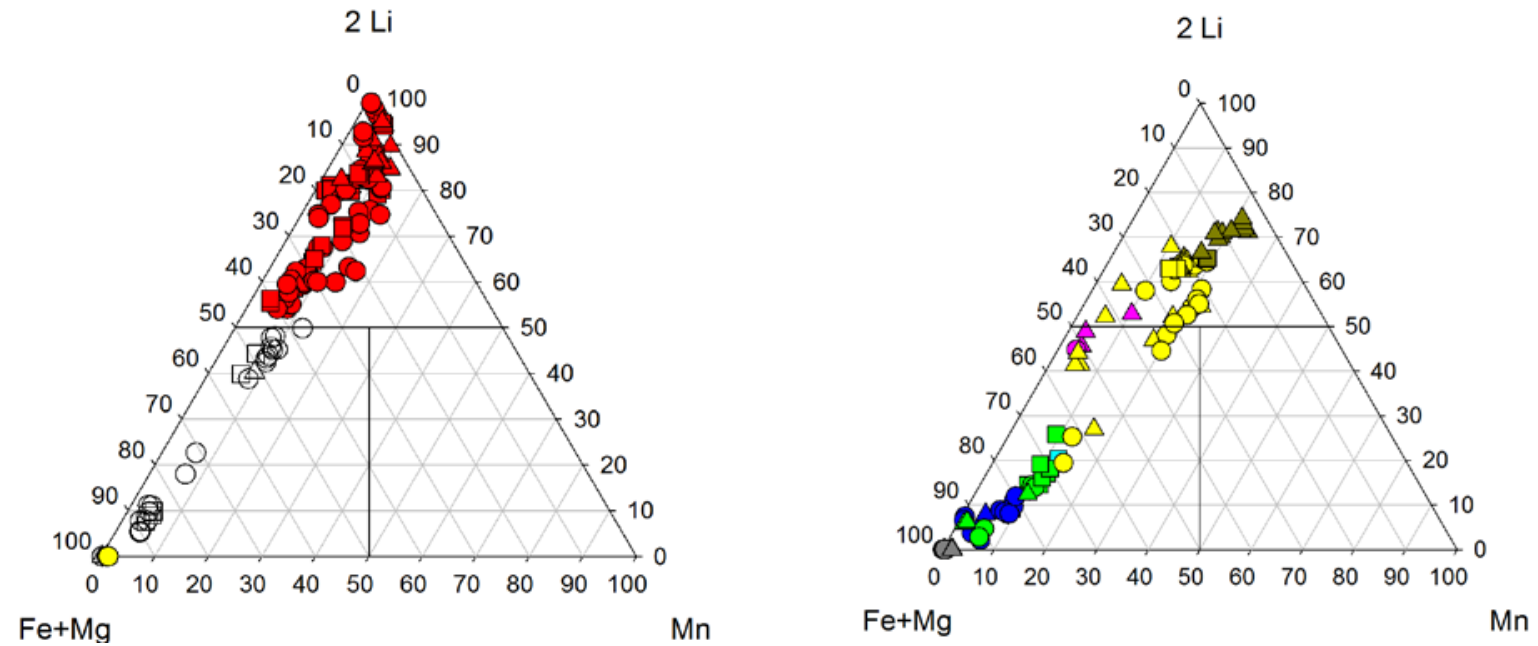

Figure 6.4: Comparison of the tourmaline evolution of the LI and LI2 (left) and GARPHOS pegmatites (right). Legends as mentioned above. 

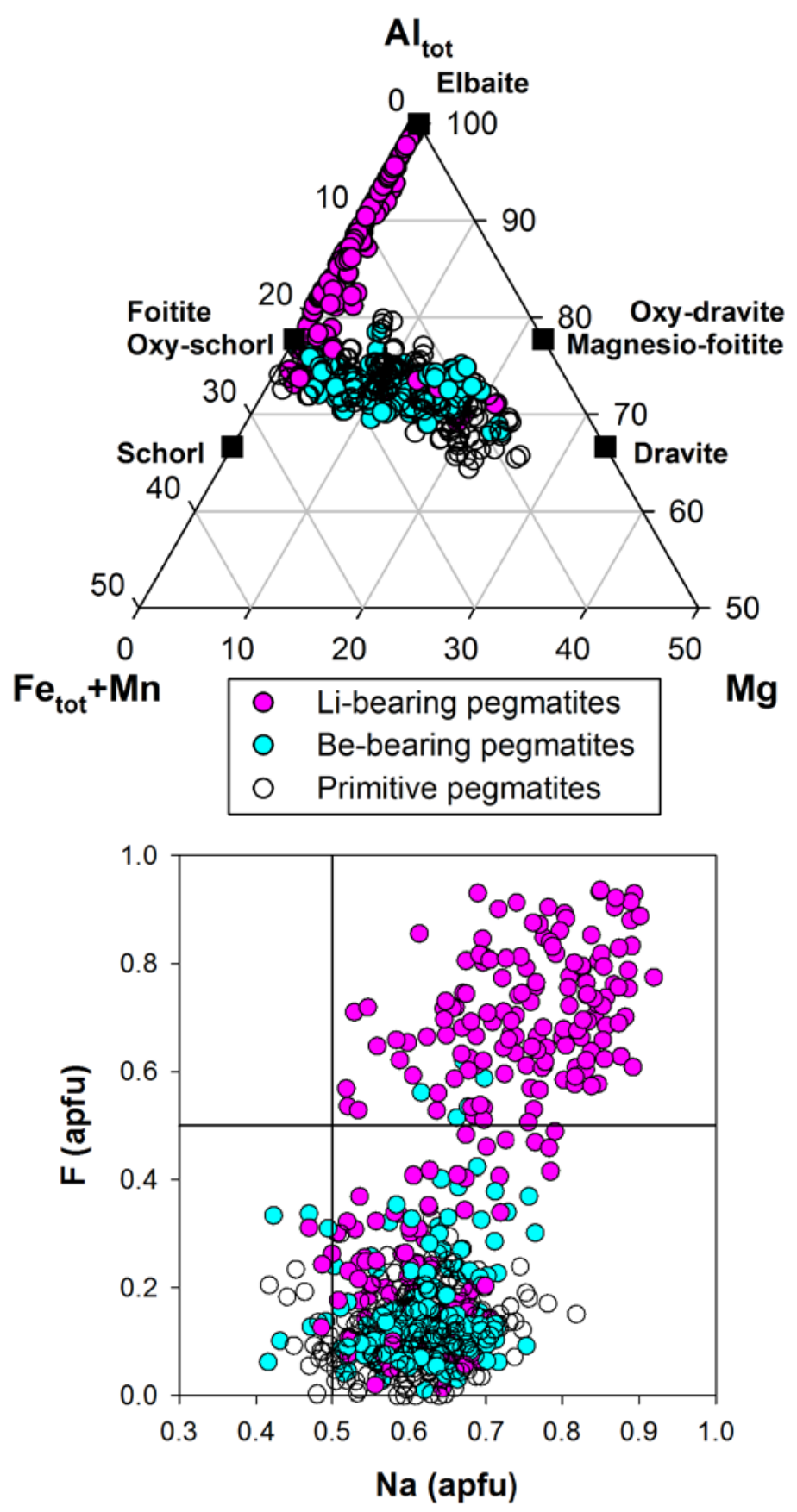

Figure 6.5: Comparison of all of compositional evolution of Li-, Be-, and primitive pegmatites. 


\subsection{Pegmatite Field Zoning}

The pegmatites in the studied area generally follow two main strikes. The primitive pegmatites are generally subparallel to the GRANITE pegmatite (strike $\sim 290^{\circ}$ ) whereas the rareelement pegmatites are largely subparallel to the LI and LI2 pegmatites (strike $\sim 310^{\circ}$ ).

The distribution of beryl-bearing, beryl-columbite, beryl-columbite-phosphate, and lepidolite subtype pegmatites in the study area is irregular (Fig. 6.6). The most primitive berylbearing pegmatites (CORD and GARTOUR) are located in the southern part of the map area with the exception of the SIMPLE9 pegmatite is located more centrally.

Beryl-columbite pegmatites are either adjacent to the GRANITE pegmatite (SMALL and GAR) or along strike with the GAR pegmatite (GARMUS). The most important of the berylcolumbite pegmatites, BERYL, is isolated in the northern part of the study area.

The beryl-columbite-phosphate pegmatites (GARPHOS and TOURMUS) are adjacent to the GRANITE pegmatite and the most fractionated pegmatites which belong to the lepidolite subtype (LI and LI2) are on strike with them.

In general, the degree of pegmatite fractionation increases to the northwest, as indicated by the whole rock geochemistry from the GRANITE pegmatite. The strike from the southeast to the northwest of the most fractionated pegmatites (TOURMUS, GARPHOS, LI2, and LI) confirms this observation. The position of the source pluton is unknown but based on the zoning of the pegmatite field it is possible to speculate that it is located to the southeast of the study area at depth. The BERYL pegmatite may be part of a different system as it contains a unique mineralogy and has a dip (to the north) that opposes most of the dips of the other pegmatites (subvertical or to the south) or it could have originated during the same magmatic event through a different tectonic system. 


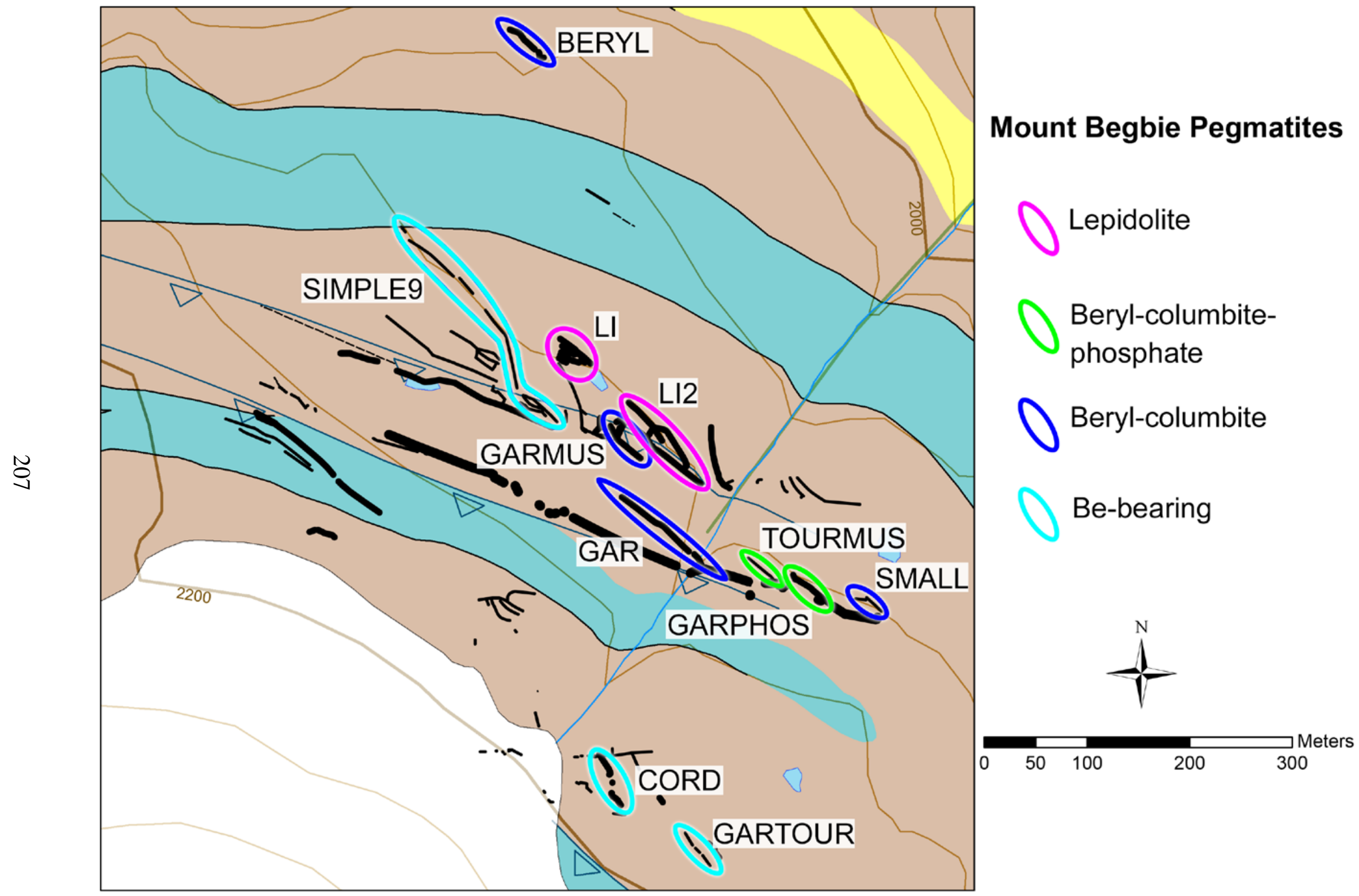

Figure 6.6: Distribution of fractionated pegmatites. 


\subsection{Comparison to Other Pegmatite Fields}

The Mount Begbie pegmatite field is rather unique within Canadian Cordillera and the Canadian Shield by the presence of lepidolite subtype pegmatites (cf. Černý 1990); it appears to have more commonalities with pegmatite fields elsewhere in the world.

The peraluminous and (Fe,Mn,P)-rich assemblage including andalusite, Fe,Mn-phosphate, W-rich oxides, and sekaninaite evolving to lepidolite subtype pegmatites is reminiscent of the Bory pegmatite district in the Czech Republic (e.g., Novák et al 2008).

The Bory pegmatite district comprises three types of granitic pegmatites with distinctly different degrees of fractionation, much like the trends observed at the Mount Begbie pegmatite field. The most abundant pegmatites in the Bory district are primitive, symmetrically zoned barren pegmatite dikes with schorl, muscovite, apatite, and local occurrences of andalusite and large crystals of sekaninaite. Less common are the more evolved, phosphate-bearing pegmatites characterized by the presence of primary Fe,Mn-phosphates (triplite, zwieselite, triphylite, graftonite, beusite); their mineral assemblages and internal structure indicate close affinity to the beryl-columbite-phosphate subtype. There are three pegmatites of the lepidolite-subtype within the whole district; they contain abundant elbaite, minor amblygonite-montebrasite, cookeite and spodumene+quartz pseudomorphs after petalite. The greatest differences between the Mount Begbie pegmatite field and the Bory pegmatite district are the absence of beryl and common occurrence of ilmenite in the latter (Novák et al 2008).

Another pegmatite field similar to the one studied in this thesis are the pegmatites in the Fregeneda-Almendra pegmatite field of Spain and Portugal (Roda-Robles et al. 1999, Vieira et al. 2011). The Fregeneda-Almendra pegmatites show a zonal distribution, from barren to enrichment in $\mathrm{Li}, \mathrm{Sn}, \mathrm{Rb}, \mathrm{Nb}>\mathrm{Ta}, \mathrm{B}$ and $\mathrm{P}$. They display a zonal sequence from the Lumbrales granite outward: (1) barren pegmatites with quartz, K-feldspar > albite, muscovite, tourmaline +/- andalusite +/- garnet; (2) intermediate pegmatites characterized by the occurrence of beryl and Fe-Mn-Li phosphates; and (3) fertile pegmatites with lepidolite, cassiterite, columbite, albite $>$ K-feldspar, montebrasite and spodumene and quartz veins with albite and cassiterite. The field is similar to the Mount Begbie pegmatites by the degree of fractionation, high concentration of multiple dikes in a small area (Fig. 6.7), and mineralogy (beryl, Fe,Mn-phosphates, and lepidolite); the main differences include a higher fractionation degree of $\mathrm{Ta} / \mathrm{Nb}$ in oxides, an 
abundance of cassiterite and spodumene and a presence of Sn-bearing quartz-albite veins in the Fregeneda-Almendra pegmatites (Roda-Robles et al. 1999, Vieira et al. 2011).

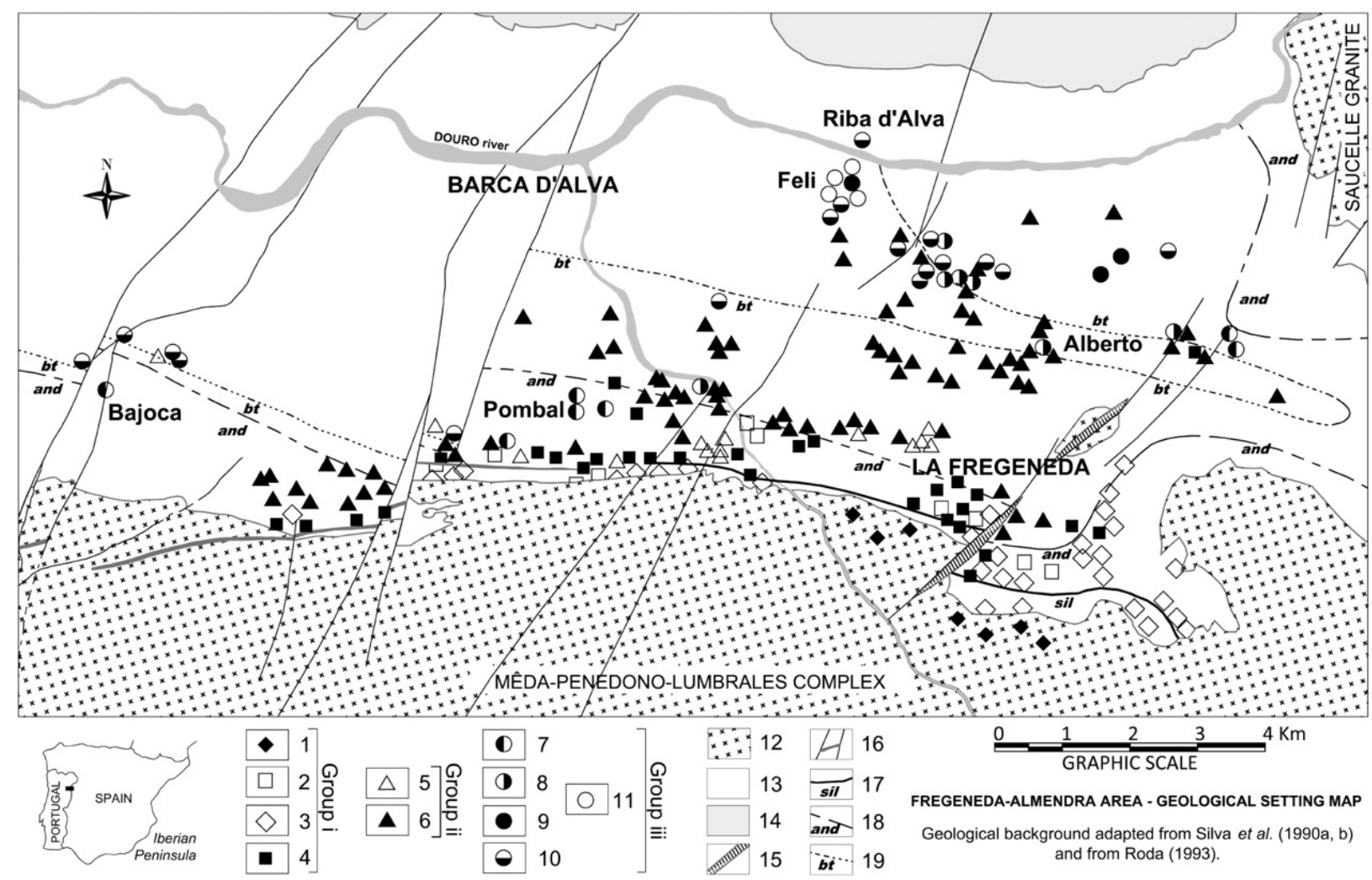

Group i legend: 1 = simple interior; 2 = quartz + andalusite conformable dikes; 3 = simple dikes and apophyses; $4=$ simple conformable. Group ii legend: $5=$ K-feldspar discordant dikes; $6=$ simple discordant. Group iii legend: 7 = petalite-bearing discordant; $8=$ spodumene-bearing discordant; $9=\mathrm{Li}$ mica + spodumene-bearing discordant; $10=$ Li-mica-bearing discordant; $11=$ Sn-bearing discordant; $12=$ syntectonic Variscan granites; 13 = Pre-Ordovician Schist-Greywacke complex; $14=$ Ordovician formations; 15 = quartz segregations fractures; 16 = porphyry granite/rhyolite and faults; 17 = sillimanite isograd; 18 = andalusite isograd; 19 = biotite isograd.

Figure 6.7: Map of the Fregeneda-Almendra pegmatite field, modified after Vieira et al. (2011).

Several other pegmatite fields exhibit remarkable similarity with the beryl-columbite and beryl-columbite-phosphate pegmatites in the Mount Begbie pegmatite field. For example, Lahti (2000) described evolution of columbite group minerals from the Eräjärvi district in southern Finland which corresponds to that observed in this study; the similarity stems especially from a relatively high fractionation level in both pegmatite fields. Equivalent compositional trends were also described by Wise \& Brown (2010) from the Sebago pegmatite group in southern Maine for the beryl, beryl-columbite, and beryl-columbite-phosphate pegmatites. 


\section{Chapter 7: Conclusions}

Mapping the pegmatite field on the northern slope of Mount Begbie, near Revelstoke, B.C., revealed a dense population of pegmatites with diverse mineralogy and a relatively young, though uncertain, history. As the pegmatites are not strongly metamorphosed and show only rare foliation, it is improbable for them to have formed prior to the late Paleocene to Eocene exhumation and decompression event that exposed the Thor-Odin Culmination. However, they are more likely related to the other granitic bodies resulting from the exhumation event (the abundant migmatites and the Ladybird granite suite) than any other known intrusion.

In general, the pegmatites in the study area are elongate, with most having length of at least $10 \mathrm{~m}$ and not being more than one meter wide. Nearly all strike between $295^{\circ}$ and $330^{\circ}$ and have a subvertical dip; these orientations are somewhat dictated by weakened planes in the host rock caused by shearing during the exhumation and decompression event.

Many pegmatites exhibit subtle zoning with coarser cores than their finer grained border zones; intermediate and core zones usually display increasing fractionation. The most primitive mineral assemblages observed in the pegmatites are quartz + feldspar + black tourmaline or quartz + feldspar + biotite. Intermediate assemblages (corresponding to beryl-bearing and berylcolumbite subtype pegmatites) add muscovite, garnet, beryl, cordierite, and HFSE-oxides to the basic assemblage. Highly fractionated assemblages (corresponding with the beryl-columbitephosphate and lepidolite subtype pegmatites) contain all of these features as well as phosphates other than apatite, monazite, and xenotime, lepidolite, petalite, and multi-colored tourmaline.

Geochemically, the pegmatites - including the most primitive GRANITE pegmatite fractionate in a manner consistent with S-type granites. Fractionation variability within individual pegmatites (particularly the more primitive ones) could be controlled either by localized fluid accumulation or the composition of the original source rock. Despite being variable, fractionation for the pegmatite field increases from the southeast to the northwest. This suggests the source pluton may be located to the southeast of the study area at depth.

Maps of elevated $\mathrm{Cs}$ and $\mathrm{Rb}$ concentrations in K-feldspar and micas, $\mathrm{P}$ concentrations in $\mathrm{K}$-feldspar, and the $\mathrm{X}_{\mathrm{Mn}}$ value in garnet match the fractionation trend observed in the field and confirm the elevated fractionation of the GAR and TOURMUS pegmatites (which appear to be relatively primitive looking in the field). These maps also suggest the LENS, PEGMA, 
SIMPLE13, and SKINNY pegmatites as well as the JAN aplites are worth greater investigation in the future.

The results of the detailed study of the minerals tourmaline, cordierite, beryl, oxides, and zircon as well as the mainly qualitative study of phosphates and other minerals agree with the trace element concentration maps and the garnet $\mathrm{X}_{\mathrm{Mn}}$ value map mentioned above. They also provide insight to the geochemistry and mineralogy of the individual dikes. In particular, the results suggest the GARMUS and SMALL pegmatites may provide interesting future studies and highlight the BERYL and GARPHOS pegmatites as being unusual for the typical description of beryl-columbite and beryl-columbite-phosphate subtype pegmatites, respectively.

Additionally, the elevated contents of $\mathrm{Be}$ and $\mathrm{Li}$ in sekaninaite and the presence of qitianlingite in the Mount Begbie pegmatite field are somewhat unique in comparison to other cordierite and rare-element oxide localities worldwide. This pegmatite field represents one of three known Li-rich pegmatite fields in the Canadian Cordillera, with the Little Nahanni and O’Grady Batholith pegmatite fields being the other two.

\subsection{Economic Potential}

As one of a few, relatively well known, Li-rich pegmatite fields in the Canadian Cordillera, the Mount Begbie pegmatites have already provided excellent specimens for enterprising prospectors and miners conducting small-scale mineral and gem collecting. The potential for rare-metal mining operations may also exist in the pegmatite field.

The greatest rare-metal mining potential may lie with the BERYL pegmatite. Beryl mineralization is much more extensive in the BERYL pegmatite than in any other part of the study area. As can be seen in Fig. 3.3a, the BERYL pegmatite is significantly wider at the bottom of the outcrop than at the top. This suggests the dike is larger at depth; beryl mineralization in the dike beyond the exposed outcrop is likely to continue as well.

Another rare-metal mining potential exists in W-rich-oxides. Although crystals of W-rich oxides are not as immediately noticeable as beryl crystals, their presence is nearly as widespread as beryl in the pegmatite field. The minerals hübnerite, qitianlingite, W-rich columbite, cassiterite, and topaz distributed throughout the Mount Begbie pegmatites are also associated with W-Sn deposits worldwide (cf. Xie et al. 2013, Roda-Robles et al. 1999, Romer \& Lüders 2006, Tindle \& Webb 1989, Williamson et al. 1997, Tallarico et al. 2004). 


\section{Chapter 8: Suggestions for Future Work}

Future work on the Mount Begbie pegmatite field should include completing mapping and sampling the southern part of the study area. Mapping beyond the confines of the area within this study is likely to reveal additional highly fractionated pegmatites on Mount Begbie and elsewhere within the Thor-Odin Culmination (H. Hyder \& L. Addie, pers. commun.).

Analyses of tourmaline and trace minerals from the SKINNY and SMALL pegmatites were not fully completed within the time constraints of this study. Furthermore, in-depth investigations of the BERYL, GAR, GARPHOS, JAN, LENS, PEGMA, SIMPLE13, and TOURMUS pegmatites would create a completely comprehensive data set. With regards to the BERYL and GARPHOS pegmatite, this will help clarify their classification. It may even reveal links between the NYF and LCT pegmatite families (BERYL) and beryl-columbite-phosphate and elbaite-subtype pegmatites (GARPHOS). Lastly, the resulting dataset may even assist in determining the economic potential of pegmatite field.

Additionally, detailed studies on the primary and secondary phosphate minerals will help to further delineate the geochemistry of individual pegmatites; this may also be able to confirm the exact relationship between the LI and LI2 pegmatites. Similarly, meticulous examination of the cordierite-sekaninaite mineralization with LA-ICP-MS or SIMS to investigate the apparently elevated contents of Be and Li will further the geochemical understanding of individual cordierite-bearing dikes. It will even afford an opportunity to investigate the role of $\mathrm{Li}$ and $\mathrm{Be}$ within the sekaninaite-cordierite mineral series.

Boron isotope studies on Mount Begbie using data from the host rocks and the pegmatites would give a clearer picture of the origin of the pegmatite melt. 40Ar/39Ar dating should be completed on muscovite samples from various locations within the pegmatite field; along with the isotope study this will help to confirm the crystallization of the pegmatites within the context of the exhumation and decompression event. The results of a geochronology study may reveal separate pegmatite systems, explaining the widely ranging fractionation patterns observed. Together, both studies should be able to clarify the relationship of the pegmatites to the host rock, Ladybird granite suite, or a yet unknown pluton. 


\section{References}

Alekseev, V. I., Gembitskaya, I. M., Marin, Yu. B. (2011): Wolframoixiolite and niobian ferberite from zinnwaldite granitic rocks of the Chukchi Peninsula. Geology of Ore Deposits, 53, 639-648.

Anthony, J. W., Bideaux, R. A., Bladh, K. W., \& Nichols, M. C., [Eds.] (1997): Handbook of Mineralogy. Chantilly, VA: Mineralogical Society of America

Bertoldi, C., Proyer, A., Garbe-Schönberg, D., Behrens, H., \& Dachs, E. (2004): Comprehensive chemical analyses of natural cordierites: implications for exchange mechanisms. Lithos, 78, 389-409.

Beurlen, H., Barreto, S. B., Silva, D., Wirth, R., \& Olivier, P. (2007): Titanian ixiolite - niobian rutile intergrowths from the Borborema pegmatitici province, northeastern Brazil. The Canadian Mineralogist, 47, 1367-1387.

Beurlen, H., Thomas, R., Melgarejo, J. C., Da Silva, J. M. R., Rhede, D., Soares, D. R., \& Da Silva, M. R. R. (2013): Chrysoberyl-sillimanite association from the Roncadeira pegmatite, Borborema Province, Brazil: implications for gemstone exploration. Journal of Geosciences, 58, 79-90.

Bourhis, L. J., Dolomanov, O. V., Gildea, R. J., Howard, J. A. K., Puschmann, H. (2011a): olex2.refine (in preparation).

Bourhis, L. J., Dolomanov, O. V., Gildea, R. J., Howard, J. A. K., Puschmann, H. (2011b): olex2.solve (in preparation).

Brand, A. A, Groat, L. A., Linnen, R. L., Garland, M. I., Breaks, F. W., \& Giuliani, G. (2009): Emerald mineralization associated with the Mavis Lake pegmatite group, near Dryden, Ontario. The Canadian Mineralogist, 47, 315-336.

Brown, J. A. (2001): Mineralogy and geochemistry of alkali feldspars from the Tanco pegmatite, southeastern Manitoba. Master of Science Thesis, University of Manitoba.

Carr, S. (1991): Three crustal zones in the Thor-Odin - Pinnacles area, southern Omineca Belt, British Columbia. Canadian Journal of Earth Science, 28, 2003-2023.

Carr, S. (1992): Tectonic setting and U-Pb geochronology of the early Tertiary Ladybird leucogranite suite, Thor-Odin - Pinnacles area, southern Omineca Belt, British Columbia. Tectonics, 11, 258-278. 
Černý, P. (1990): Distribution, affiliation and derivation of rare-element granitic pegmatites in the Canadian Shield. Geologische Rundschau, 79, 183-226.

Černý, P. (2002): Mineralogy of beryllium in granitic pegmatites. In Beryllium: Mineralogy, Petrology, and Geochemistry (E. S. Grew, ed.). Reviews in Mineralogy and Geochemistry, 50, 405-444.

Černý, P., (1989): Characteristics of pegmatite deposits of tantalum. In Lanthanides, Tantalum and Niobium (P. Möller, P. Černý \& F. Saupé, eds.). Spriner-Verlag, Berlin, Germany.

Černý, P. \& Ecrit, T. S. (2005): The classification of granitic pegmatites revisited. The Canadian Mineralogist, 43, 2005-2026.

Černý, P. \& London, D. (1983): Crystal chemistry and stability of petalite. TMPM Tschermaks Mineralogische und Petrograpische Mitteilungen, 31, 81-96.

Černý, P., \& Povondra, P. (1966): Beryllian cordierite from Věžná Na, K + Be $\rightarrow$ Al. Neues Jahrbuch für Mineralogie - Monatshefte, 44, 36-44.

Černý, P., Jakes, P., Černá, I. (1967): Pseudographic cordierite-quartz intergrowths in pegmatites and metamorphic rocks. Acta Universitatis Carolinae - Geologica, 2, 133-151.

Černý, P., Chapman, R., Schreyer, W., Ottolinie, L., Bottazzi, P., \& McCammon, C.A. (1997): Lithium in sekaninaite from the type locality, Dolní Bory, Czech Republic. The Canadian Mineralogist, 35, 167-173.

Chappell, B. W., \& White, A. J. R. (1992): I- and S-type granites in the Lachlan Fold Belt. Transactions of the Royal Society of Edinburgh: Earth Sciences. 83, 1-26.

Craig, D. B. (1966): Structure and petrology within Shuswap Metamorphic Complex, Revelstoke, British Columbia. Doctoral dissertation, University of Wisconsin, Madison. Dolomanov, O. V., Bourhis, L. J., Gildea, R. J., Howard, J. A. K., \& Puschman, H. (2009): OLEX2: a complete structure solution, refinement and analysis program. Journal of Applied Crystallography, 42, 339-341.

Ercit, T. S., Groat, L. A., \& Gault, R. A. (2003): Granitic pegmatites of the O'Grady Batholith, N.W.T., Canada: a case study of the evolution of the elbaite subtype of rare-element granitic pegmatite. The Canadian Mineralogist, 41, 117-137.

Fenn, P. M. (1986): On the origin of graphic granite. American Mineralogist, 71, 325-330.

Finger, F. \& Schiller, D. (2012): Lead contents of the S-type granites and their petrogenetic significance. Contributions to Mineralogy and Petrology, 164, 747-755. 
Galliski, M. A., Márquez-Zavalía, M. F., Cooper, M. A., Černý, P., \& Hawthorne, F. C. (2001): Bismutotantalite from northwestern Argentina: description and crystal structure. The Canadian Mineralogist, 39, 103-110.

Giuliani, G., France-Lanord, C., Zimmerman, J. L., Cheilletz, A., Arboleda, C., Charoy, B., Coget, P., Fontan, F., \& Giard, D. (1997): Fluid composition, $\delta$ D of channel H2O, and $\delta 180$ of lattice oxygen in beryls: genetic implications for Brazilian, Colombian, and Afghanistani emerald deposits. International Geology Reviews, 39, 400-424.

Goergen, E. T. \& Whitney, D. L. (2012): Long length scales of element transport during reaction texture development in orthoamphibolite-cordierite gneiss: Thor-Odin dome, British Columbia, Canada. Contributions to Mineralogy and Petrology, 163, 337-352. Government of Canada (2012): Toporama 082L16, Revelstoke, ( $7^{\text {th }}$ ed.). Sherbrooke, QC: Government of Canada, Natural Resources Canada, Earth Sciences Sector, Mapping Information Branch, Centre for Topographic Information - Sherbrooke.

Groat, L. A., Mulja, T., Mauthner, M. H. F., Ercit, T. S., Raudsepp, M., Gault, R. A., \& Rollo, H. A. (2003): Geology and mineralogy of the Little Nahanni rare-element granitic pegmatites, Northwest Territories. The Canadian Mineralogist, 41, 139-160.

Henry, D. J., Novák, M., Hawthorne, F. C., Ertl, A., Dutrow, B. L., Uher, P., Pezzotta, F. (2011): Nomenclature of the tourmaline-supergroup minerals. American Mineralogist, 96, 895913.

Hinchey, A. M., \& Carr, S. D. (2006): The S-type Ladybird leucogranitic suite of southeastern British Columbia: geochemical and isotopic evidence for a genetic link with migmatite formation in the North American basement gneisses of the Monashee complex. Lithos, 90, 223-248.

Hinchey, A. M., Carr, S. D., McNeill, P. D., \& Rayner, N. (2006): Paleocene-Eocene high-grade metamorphism, anatexis, and deformation in the Thor-Odin dome, Monashee complex, southeastern British Columbia. Canadian Journal of Earth Sciences, 43, 1341-1365.

Hoshino, M., Watanabe, Y., \& Ishihara, S. (2012): Crystal chemistry of monazite from the granitic rocks of Japan: petrogenetic implications. The Canadian Mineralogist, 50, 13311346. 
Irber, W. (1999): The lanthanide tetrad effect and its correlation with K/Rb, Eu/Eu*, Sr/Eu, $\mathrm{Y} / \mathrm{Ho}$, and $\mathrm{Zr} / \mathrm{Hf}$ of evolving peraluminous granite suites. Geochimica et Cosmochimica Acta, 63, 489-508.

Jobin-Bevans, S. \& Černý, P. (1998): The beryllian cordierite + beryl + spessartine assemblage, and secondary beryl in altered cordierite, Greer Lake granitic pegmatites, southeastern Manitoba. The Canadian Mineralogist, 36, 447-462.

Johnson, B. J. (2006): Extensional shear zones, granitic melts, and linkage of overstepping normal faults bounding the Shuswap metamorphic core complex, British Columbia. Geological Society of America Bulletin, 118, 366-382.

Johnston, D. H., Williams, P. F., Brown, R. L., Crowley, J. L. \& Carr, S. D. (2000): Northeastward extrusion and extensional exhumation of crystalline rocks of the Monashee complex, southeastern Canadian Cordillera. Journal of Structural Geology, 22, 603-625.

Jones, A. G. (1959): Vernon map-area British Columbia. Canada Geological Survey, Memoir 296.

Kruse, S. (2006): Geology of the northern Thor-Odin Culmination, Monashee Complex, British Columbia. University of New Brunswick.

Kruse, S., \& Williams, P. F. (2005): Brittle faulting in the Thor-Odin culmination, Monashee complex, southern Canadian Cordillera: constraints on geometry and kinematics. Canadian Journal of Earth Sciences, 42, 2141-2160.

Kruse, S., McNeill, P., \& Williams, P. F. [compilers] (2005): A geological map of the ThorOdin culmination, Monashee Mountains, B.C. The University of New Brunswick, Available from http://www.unb.ca/fredericton/science/geology/faculty/monashee/ ThorOdinMap_july_27_05_11X17.pdf [cited 19 January 2012].

Kruse, S. \& Williams, P. F. (2007): The Monashee reflection: re-examination of a Lithoprobe crustal-scale seismic reflection in the southern Canadian Cordillera. Geosphere, 3, 26-41.

Lahti, S. I., (2000): Compositional variation in columbite-group minerals from different types of granitic pegmatites of the Eräjärvi district, South Finland. Journal of the Czech Geological Society, 45, 107-118.

Linnen, R. (1998): The solubility of Nb-Ta-Zr-Hf-W in granitic melts with $\mathrm{Li}$ and $\mathrm{Li}+\mathrm{F}$ : constraints for mineraliztion in rare metal granites and pegmatites. Economic Geology, 93, 1013-1025. 
London, D. (2008): Pegmatites. The Canadian Mineralogist, Special Publication 10.

Lottermoser, B. G., \& Lu, J. (1997): Petrogenesis of rare-element pegmatites in the Olary Block, South Australia, part 1. Mineralogy and chemical evolution. Mineralogy and Petrology, 19, 1-19.

Lorencak, M., Seward, D., Vanderhaege, O., Teyssier, C., \& Burg, J. P. (2001): Lowtemperature cooling history of the Shuswap metamorphic core complex, British Columbia: constrains from apatite and zircon fission-track ages. Canadian Journal of Earth Sciences, 38, 1615-1625.

Masau, M., Černý, P., \& Chapman, R. (2000): Dysprosian xenotime-(Y) from the Annie Claim \#3 granitic pegmatite, southeastern Manitoba, Canada: evidence of the tetrad effect? The Canadian Mineralogist, 38, 899-905.

Martin, R. F., \& De Vito, C. (2005): The patterns of enrichment in felsic pegmatites ultimately depend on tectonic setting. The Canadian Mineralogist, 43, 2027-2048.

Marvin, U. B. (1971): Lunar niobian rutile. Earth and Planetary Science Letters, 11, 7-9.

McDonough, W. F. \& Sun, S.- s. (1995): The composition of the Earth. Chemical Geology, 120, 223-253.

Mulligan, R. (1972): Lithium distribution in Canadian granitoid rocks. Canadian Journal of Earth Sciences, 10, 316-323.

Norlander, B. H., Whitney, D. L., Teyssier, C., \& Vanderhaeghe, O. (2002): Partial melting and decompression of the Thor-Odin dome, Shuswap metamorphic core complex, Canadian Cordillera. Lithos, 61, 103-125.

Novák, M. \& Povondra, P. (1995): Elbaite pegmatites in the Moldanubicum: a new subtype of the rare-element class. Mineralogy and Petrology, 55, 159-176.

Novák, M., Johan, Z., Škoda, R., Černý, P., Šrein, V., Veselovský, F. (2008): Primary oxide minerals in the system $\mathrm{WO}_{3}-\mathrm{Nb}_{2} \mathrm{O}_{5}-\mathrm{TiO}_{2}-\mathrm{Fe}_{2} \mathrm{O}_{3}-\mathrm{FeO}$ and their breakdown products from the pegmatite No. 3 at Dolní Bory-Hatě, Czech Republic. European Journal of Mineralogy, 20, 487-499.

Okulitch, A. V. (1984): The role of the Shuswap Metamorphic Complex in Cordilleran tectonism: a review. Canadian Journal of Earth Sciences, 21, 1171-1193.

Okulitch, A. V. (1985): Paleozoic plutonism in southeastern British Columbia. Canadian Journal of Earth Sciences, 22, 1409-1424. 
Parrish, R. R., \& Wheeler, J. O. (1983): A U-Pb zircon age from the Kuskanax batholith, southeastern British Columbia. Canadian Journal of Earth Sciences, 20, 1751-1756.

Pouchou, J.L. \& Pichoir, F. (1985): PAP $\phi(\rho Z)$ procedure for improved quantitative microanalysis. Microbeam Analysis, 1985, 104-106.

Povondra, P., Čech, F., \& Burke, E.A.J. (1984): Sodian-beryllian cordierite from Gammelmorskärr, Kemiö Island, Finland and its decomposition products. Neues Jahrbuch für Mineralogie - Monatshefte, 1984, 125-136.

Read, P. B., \& Brown, R. L., (1981): Columbia River fault zone: southeastern margin of the Shuswap and Monashee complexes, southern British Columbia. Canadian Jounral of Earth Sciences, 18, 1127-1145.

Reesor, J. E., \& Moore, J. M. Jr. (1971): Petrology and structure of Thor-Odin gneiss dome, Shuswap Metamorphic Complex, British Columbia. Geological Survey of Canada, Bulletin 195. 149 pages.

Rockhold, J. R., Nabelek, P. I., \& Glascock, M. D. (1987): Origin of rhythmic layering in the Calamity Peak satellite pluton of the Harney Peak Granite, South Dakota: the role of boron. Geochimica et Cosmochimica Acta, 51, 487-496.

Roda-Robles, E., Perez, A. P., Roldan, F. V., \& Fontan, F. (1999): The granitic pegmatites of the Fregeneda area (Salamanca, Spain): characteristics and petrogenesis. Mineralogical Magazine, 63 (4), 535-558.

Romer, R., L. \& Lüders, V. (2006): Direct dating of hydrothermal W mineralization: U-Pb age for hübnerite $\left(\mathrm{MnWO}_{4}\right)$, Sweet Home Mine, Colorado. Geochimica et Cosmochimica Acta, 70, 4725-4733.

Schreyer, W., Gordillo, C. E., \& Werding, G. (1979): A new sodian-beryllian cordierite from Soto, Argentina, and the relationship between distortion index, Be content, and state of hydration. Contributions to Mineralogy and Petrology, 70, 421-428.

Selway, J. B. (1999): Compositional evolution of tourmaline in granitic pegmatites. Doctoral dissertation. University of Manitoba.

Selway, J. B., Novák, M., Černý, P., \& Hawthorne, F. C. (1999): Compositional evolution of tourmaline in lepidolite-subtype pegmatites. European Journal of Mineralogy, 11, 569584. 
Simmons, W. B., Webber, K. L., Falster, A.U., \& Nizamoff, J. W. (2003): Pegmatology: Pegmatite mineralogy, petrology and petrogenesis. New Orleans, LA: Rubellite Press. Simmons, W. B., \& Webber, K. L. (2008): Pegmatite genesis: state of the art. European Journal of Mineralogy, 20, 421-438.

Spalla, M. I., Zanoni, D., Williams, P. F., Gosso, G. (2011): Deciphering cryptic P - T - d - t histories in the western Thor-Odin dome, Monashee Mountains, Canadian Cordillera: a key to unraveling pre-Cordilleran tectonic signatures. Journal of Structural Geology, 33, 399-412.

Tallarico, F. H. B., McNaughton, N. J., Groves, D. I., Fletcher, I R., Fig.ueiredo, B. R., Carvalho, J. B., Rego, J. L., \& Nunes, A. R. (2004): Geological and SHRIMP II U-Pb constraints on the age and origin of the Breves $\mathrm{Cu}-\mathrm{Au}-(\mathrm{W}-\mathrm{Bi}-\mathrm{Sn})$ deposit, Carajás, Brazil. Mineralium Deposita, 39, 68-86.

Thomas, R., Davidson, P., \& Beurlen, H. (2012): The competing models of the origin and internal evolution of granitic pegmatites in the light of melt and fluid inclusion research. Mineralogy and Petrology, 106, 55-73

Tindle, A. G., \& Webb, P. C. (1989): Niobian wolframite from Glen Gairn in the Eastern Highlands of Scotland: a microprobe investigation. Geochimica et Cosmochimica Acta, 53, 1921-1935.

Tischendorf, G. (1997): On Li-bearing micas: estimating Li from electron microprobe analyses and an improved diagram for graphical representation. Mineralogical Magazine, 61, 809834.

Vanderhaeghe, O. (1999): Pervasive melt migration from migmatites to leucogranite in the Shuswap metamorphic complex, Canada: control of regional deformation. Tectonophysics, 312, 35-55.

Vanderhaeghe, O., Teyssier C., \& Wysoczanski, R. (1999): Structural and geochronological constraints on the role of partial melting during the formation of the Shuswap metamorphic core complex at the latitude of the Thor-Odin dome, British Columbia. Canadian Journal of Earth Sciences, 36, 917-943

van Hinsberg, V. J., Henry, D. J., \& Marschall, H. R. (2011): Tourmaline: An ideal indicator of its host environment. The Canadian Mineralogist, 49, 1-16. 
Vieira, R., Roda-Robles, E., Pesquera, A., \& Lima, A. (2011): Chemical variation and significance of micas from the Fregeneda-Almendra pegmatitic field (Central-Iberian Zone, Spain and Portugal). American Mineralogist, 96, 637-645.

Waychunas, G. (2002): Apatite luminescence. Reviews in Mineralogy and Geochemistry, 48, 701-742.

Wheeler, J. O., \& McFeely, P. [compilers] (1991): Tectonic assemblage map of the Canadian Corillera and adjacent parts of the United States of America. Geological Survey of Canada Map 1712A, scale 1:2,000,000.

Whitney, D. L., \& Evans, B. W. (2010): Abbreviations for names of rock-forming minerals. American Mineralogist, 95, 185-187.

Williamson, B. J., Stanley, C. J., \& Wilkison, J. J. (1997): Implications from inclusions in topaz for greisenisation and mineralization in the Hensbarrow topaz granite, Cornwall, England. Contributions to Mineralogy and Petrology, 127, 119-128.

Wise, M. A. \& Brown, C. D. (2010): Mineral chemistry, petrology and geochemistry of the Sebago granite-pegmatite system, southern Maine, USA. Journal of Geosciences, 55, 326.

Xie, L., Wang, R., Chen, J., Zhu, J., Zhan, W., Lu, J., \& Zhang, R. (2013): A tin-mineralized topaz rhyolite dike with coeval topaz granite enclaves at Qiguling in the Qitianling tin district, southern China. Lithos, 170-171, 252-268. 
Appendices 


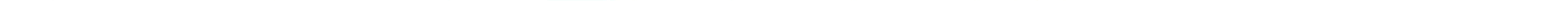




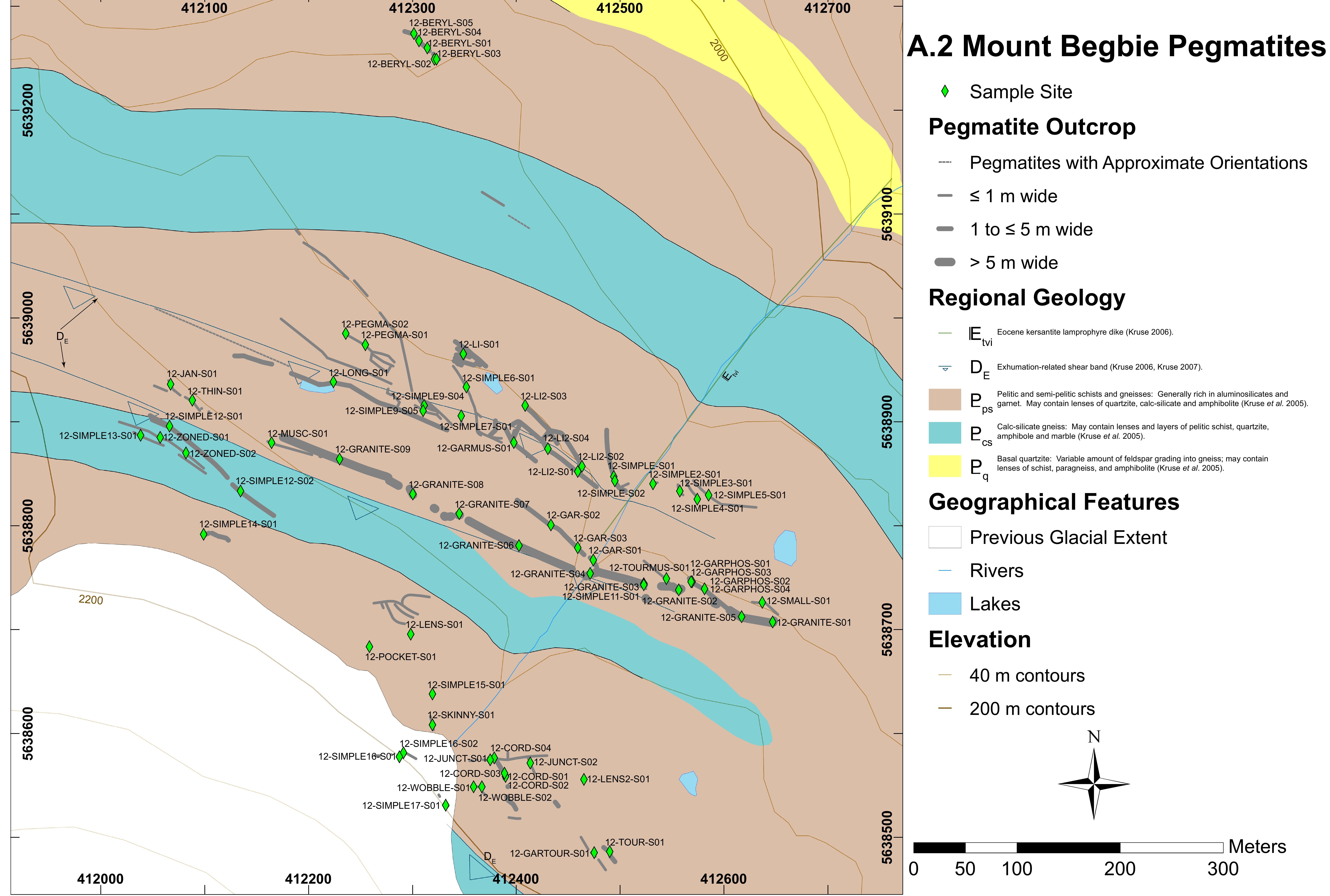




\section{A.3 All Pegmatite Coordinates and Sample Sites}

ALL PEGMATITE COORDINATES AND SAMPLE SITES (UTM, WGS 84)

\begin{tabular}{|c|c|c|c|c|c|}
\hline Pegmatite & Point Name & Zone & Easting & Northing & Elevation \\
\hline \multirow[t]{10}{*}{ BERYL } & 12-BERYL-E & 11 & 412325 & 5639256 & 2078 \\
\hline & 12-BERYL-M01 & 11 & 412320 & 5639261 & 2067 \\
\hline & 12-BERYL-MO2 & 11 & 412316 & 5639264 & 2066 \\
\hline & 12-BERYL-PEG & 11 & 412299 & 5639274 & 2058 \\
\hline & 12-BERYL-S01* & 11 & 412314 & 5639266 & 2067 \\
\hline & 12-BERYL-SO2* & 11 & 412321 & 5639255 & 2066 \\
\hline & 12-BERYL-S03* & 11 & 412323 & 5639255 & 2064 \\
\hline & 12-BERYL-S04* & 11 & 412306 & 5639273 & 2069 \\
\hline & 12-BERYL-S05* & 11 & 412301 & 5639280 & 2066 \\
\hline & 12-BERYL-W & 11 & 412292 & 5639283 & 2065 \\
\hline \multirow[t]{4}{*}{ BITOUR } & 12-BITOUR-E & 11 & 412282 & 5638962 & 2123 \\
\hline & 12-BITOUR-MO1 & 11 & 412276 & 5638968 & 2121 \\
\hline & 12-BITOUR-MO2 & 11 & 412270 & 5638970 & 2122 \\
\hline & 12-BITOUR-W & 11 & 412260 & 5638969 & 2123 \\
\hline \multirow[t]{14}{*}{ CORD } & 12-CORD-MO1 & 11 & 412397 & 5638533 & 2189 \\
\hline & 12-CORD-MO2 & 11 & 412392 & 5638537 & 2187 \\
\hline & 12-CORD-MO3 & 11 & 412391 & 5638540 & 2186 \\
\hline & 12-CORD-MO4 & 11 & 412392 & 5638550 & 2188 \\
\hline & 12-CORD-M05 & 11 & 412389 & 5638558 & 2187 \\
\hline & 12-CORD-M06 & 11 & 412389 & 5638562 & 2186 \\
\hline & 12-CORD-N & 11 & 412381 & 5638575 & 2183 \\
\hline & 12-CORD-S & 11 & 412400 & 5638528 & 2189 \\
\hline & 12-CORD-S01* & 11 & 412390 & 5638559 & 2184 \\
\hline & 12-CORD-SO2* & 11 & 412390 & 5638559 & 2184 \\
\hline & 12-CORD-S03* & 11 & 412389 & 5638562 & 2184 \\
\hline & 12-CORD-S04* & 11 & 412379 & 5638577 & 2182 \\
\hline & 12-ACT-PEG & 11 & 412400 & 5638525 & 2190 \\
\hline & 12-CRACK-PEG & 11 & 412399 & 5638526 & 2190 \\
\hline \multirow[t]{6}{*}{ CORNER } & 12-CORNER-M01 & 11 & 412287 & 5638923 & 2132 \\
\hline & 12-CORNER-MO2 & 11 & 412280 & 5638931 & 2134 \\
\hline & 12-CORNER-M03 & 11 & 412279 & 5638930 & 2134 \\
\hline & 12-CORNER-M04 & 11 & 412275 & 5638932 & 2134 \\
\hline & 12-CORNER-N & 11 & 412276 & 5638936 & 2133 \\
\hline & 12-LONG-J02 & 11 & 412284 & 5638917 & 2136 \\
\hline
\end{tabular}

* Denotes sites where samples were taken 
ALL PEGMATITE COORDINATES AND SAMPLE SITES (UTM, WGS 84) CONT'D

\begin{tabular}{|c|c|c|c|c|c|}
\hline Pegmatite & Point Name & Zone & Easting & Northing & Elevation \\
\hline \multirow[t]{3}{*}{ FEED } & 12-FEED-N & 11 & 412380 & 5638905 & 2127 \\
\hline & 12-FEED-PEG & 11 & 412380 & 5638896 & 2127 \\
\hline & 12-FEED-S & 11 & 412375 & 5638891 & 2128 \\
\hline \multirow[t]{10}{*}{ GAR } & 12-GAR-MO1 & 11 & 412472 & 5638772 & 2114 \\
\hline & 12-GAR-MO2 & 11 & 412466 & 5638775 & 2115 \\
\hline & 12-GAR-MO4 & 11 & 412441 & 5638800 & 2112 \\
\hline & 12-GAR-M05 & 11 & 412437 & 5638802 & 2113 \\
\hline & 12-GAR-PEG & 11 & 412473 & 5638773 & 2116 \\
\hline & 12-GAR-S01* & 11 & 412475 & 5638769 & 2119 \\
\hline & 12-GAR-S02* & 11 & 412434 & 5638803 & 2116 \\
\hline & 12-GAR-S03* & 11 & 412460 & 5638781 & 2118 \\
\hline & 12-GAR-W & 11 & 412401 & 5638828 & 2118 \\
\hline & 12-GRANIT-SP02 & 11 & 412480 & 5638758 & 2118 \\
\hline \multirow[t]{6}{*}{ GARMUS } & 12-GARMUS-N1 & 11 & 412403 & 5638900 & 2129 \\
\hline & 12-GARMUS-N2 & 11 & 412399 & 5638895 & 2131 \\
\hline & 12-GARMUS-N3 & 11 & 412390 & 5638897 & 2126 \\
\hline & 12-GARMUS-S & 11 & 412419 & 5638866 & 2128 \\
\hline & 12-GARMUS-S01* & 11 & 412398 & 5638883 & 2123 \\
\hline & 12-GARMUS-SP01 & 11 & 412396 & 5638885 & 2130 \\
\hline \multirow[t]{6}{*}{ GARPHOS } & 12-GARPHOS-E & 11 & 412606 & 5638722 & 2113 \\
\hline & 12-GARPHOS-S01* & 11 & 412570 & 5638748 & 2115 \\
\hline & 12-GARPHOS-S02* & 11 & 412571 & 5638748 & 2111 \\
\hline & 12-GARPHOS-S03* & 11 & 412570 & 5638748 & 2111 \\
\hline & 12-GARPHOS-S04* & 11 & 412583 & 5638741 & 2111 \\
\hline & 12-GARPHOS-W & 11 & 412568 & 5638752 & 2118 \\
\hline \multirow[t]{8}{*}{ GARTOUR } & 12-GARTOUR-MO1 & 11 & 412470 & 5638489 & 2188 \\
\hline & 12-GARTOUR-MO2 & 11 & 412473 & 5638486 & 2189 \\
\hline & 12-GARTOUR-MO3 & 11 & 412477 & 5638482 & 2188 \\
\hline & 12-GARTOUR-MO4 & 11 & 412480 & 5638479 & 2189 \\
\hline & 12-GARTOUR-N & 11 & 412463 & 5638501 & 2190 \\
\hline & 12-GARTOUR-PEG & 11 & 412476 & 5638485 & 2184 \\
\hline & 12-GARTOUR-S01* & 11 & 412476 & 5638485 & 2184 \\
\hline & 12-GARTOUR-S & 11 & 412487 & 5638469 & 2191 \\
\hline \multirow[t]{3}{*}{ GRANITE } & 12-GRANIT-SP01 & 11 & 412552 & 5638744 & 2121 \\
\hline & 12-GRANIT-SP02 & 11 & 412480 & 5638758 & 2118 \\
\hline & 12-GRANIT-SP03 & 11 & 412560 & 5638742 & 2121 \\
\hline
\end{tabular}

* Denotes sites where samples were taken 
ALL PEGMATITE COORDINATES AND SAMPLE SITES (UTM, WGS 84) CONT'D

\begin{tabular}{|c|c|c|c|c|c|}
\hline Pegmatite & Point Name & Zone & Easting & Northing & Elevation \\
\hline \multirow[t]{29}{*}{ GRANITE (cont'd) } & 12-GRANITE & 11 & 412363 & 5638803 & 2134 \\
\hline & 12-GRANITE-E & 11 & 412650 & 5638711 & 2109 \\
\hline & 12-GRANITE-MO1 & 11 & 412526 & 5638732 & 2119 \\
\hline & 12-GRANITE-MO2 & 11 & 412468 & 5638754 & 2118 \\
\hline & 12-GRANITE-MO3 & 11 & 412454 & 5638761 & 2121 \\
\hline & 12-GRANITE-MO4 & 11 & 412354 & 5638808 & 2133 \\
\hline & 12-GRANITE-M05 & 11 & 412345 & 5638814 & 2134 \\
\hline & 12-GRANITE-M06 & 11 & 412336 & 5638812 & 2135 \\
\hline & 12-GRANITE-MO7 & 11 & 412331 & 5638812 & 2136 \\
\hline & 12-GRANITE-M08 & 11 & 412321 & 5638820 & 2138 \\
\hline & 12-GRANITE-M09 & 11 & 412300 & 5638833 & 2142 \\
\hline & 12-GRANITE-M10 & 11 & 412297 & 5638839 & 2148 \\
\hline & 12-GRANITE-M11 & 11 & 412286 & 5638842 & 2149 \\
\hline & 12-GRANITE-M12 & 11 & 412277 & 5638847 & 2149 \\
\hline & 12-GRANITE-M13 & 11 & 412274 & 5638851 & 2148 \\
\hline & 12-GRANITE-M14 & 11 & 412255 & 5638857 & 2149 \\
\hline & 12-GRANITE-M15 & 11 & 412174 & 5638889 & 2144 \\
\hline & 12-GRANITE-S01* & 11 & 412649 & 5638709 & 2108 \\
\hline & 12-GRANITE-S02* & 11 & 412558 & 5638740 & 2121 \\
\hline & 12-GRANITE-S03* & 11 & 412524 & 5638746 & 2119 \\
\hline & 12-GRANITE-S04* & 11 & 412472 & 5638756 & 2115 \\
\hline & 12-GRANITE-S05* & 11 & 412619 & 5638714 & 2111 \\
\hline & 12-GRANITE-S06* & 11 & 412403 & 5638783 & 2131 \\
\hline & 12-GRANITE-S07* & 11 & 412345 & 5638814 & 2134 \\
\hline & 12-GRANITE-S08* & 11 & 412300 & 5638833 & 2142 \\
\hline & 12-GRANITE-S09* & 11 & 412229 & 5638867 & 2146 \\
\hline & 12-GARPHOS-E & 11 & 412606 & 5638722 & 2113 \\
\hline & 12-KINK-PEG & 11 & 412276 & 5638850 & 2152 \\
\hline & 12-SIMP11-J01 & 11 & 412508 & 5638751 & 2119 \\
\hline JAN & 12-JAN-S01 & 11 & 412065 & 5638940 & 2152 \\
\hline \multirow[t]{6}{*}{ JUNCT } & 12-JUNCT-E & 11 & 412430 & 5638580 & 2182 \\
\hline & 12-JUNCT-MO1 & 11 & 412358 & 5638575 & 2182 \\
\hline & 12-JUNCT-MO2 & 11 & 412362 & 5638576 & 2182 \\
\hline & 12-JUNCT-MO3 & 11 & 412368 & 5638576 & 2183 \\
\hline & 12-JUNCT-PEG & 11 & 412379 & 5638577 & 2181 \\
\hline & 12-JUNCT-SO1* & 11 & 412375 & 5638575 & 2185 \\
\hline
\end{tabular}

* Denotes sites where samples were taken 
ALL PEGMATITE COORDINATES AND SAMPLE SITES (UTM, WGS 84) CONT'D

\begin{tabular}{|c|c|c|c|c|c|}
\hline Pegmatite & Point Name & Zone & Easting & Northing & Elevation \\
\hline \multirow{8}{*}{ JUNCT (cont'd) } & $12-J U N C T-S 02 * \star$ & 11 & 412414 & 5638572 & 2186 \\
\hline & 12-JUNCT-S & 11 & 412418 & 5638563 & 2186 \\
\hline & 12-JUNCT-SPO1 & 11 & 412375 & 5638575 & 2185 \\
\hline & 12-JUNCT-SPO3 & 11 & 412392 & 5638576 & 2183 \\
\hline & 12-JUNCT-SPO4 & 11 & 412411 & 5638579 & 2183 \\
\hline & 12-JUNCT-W & 11 & 412355 & 5638575 & 2182 \\
\hline & 12-JUNCT-W1 & 11 & 412373 & 5638578 & 2183 \\
\hline & 12-JUNCT-W2 & 11 & 412392 & 5638583 & 2184 \\
\hline LENS & 12-LENS-S01* & 11 & 412298 & 5638697 & 2185 \\
\hline LENS2 & 12-LENS2-S01* & 11 & 412466 & 5638556 & 2182 \\
\hline \multirow[t]{23}{*}{ LI } & 12-LI-E & 11 & 412399 & 5638927 & 2120 \\
\hline & 12-LI-E1 & 11 & 412366 & 5638960 & 2119 \\
\hline & 12-LI-E2 & 11 & 412365 & 5638959 & 2120 \\
\hline & 12-LI-J01 & 11 & 412366 & 5638963 & 2116 \\
\hline & 12-LI-J02 & 11 & 412355 & 5638972 & 2113 \\
\hline & 12-LI-MO1 & 11 & 412348 & 5638963 & 2117 \\
\hline & 12-LI-MO2 & 11 & 412357 & 5638925 & 2119 \\
\hline & 12-LI-MO3 & 11 & 412359 & 5638959 & 2116 \\
\hline & 12-LI-MO4 & 11 & 412362 & 5638965 & 2114 \\
\hline & 12-LI-M05 & 11 & 412355 & 5638967 & 2116 \\
\hline & 12-LI-MO6 & 11 & 412357 & 5638970 & 2115 \\
\hline & 12-LI-PEG & 11 & 412350 & 5638969 & 2112 \\
\hline & 12-LI-S & 11 & 412348 & 5638961 & 2118 \\
\hline & 12-LI-S01* & 11 & 412349 & 5638969 & 2115 \\
\hline & 12-LI-S1 & 11 & 412344 & 5638960 & 2117 \\
\hline & 12-LI-S2 & 11 & 412347 & 5638959 & 2117 \\
\hline & 12-LI-SP01 & 11 & 412347 & 5638964 & 2116 \\
\hline & 12-LI-SP02 & 11 & 412349 & 5638962 & 2117 \\
\hline & 12-LI-W & 11 & 412342 & 5638969 & 2115 \\
\hline & 12-LI-W1 & 11 & 412341 & 5638966 & 2115 \\
\hline & 12-LI-W2 & 11 & 412340 & 5638963 & 2116 \\
\hline & 12-LI-W3 & 11 & 412341 & 5638982 & 2111 \\
\hline & 12-LI-W4 & 11 & 412343 & 5638975 & 2114 \\
\hline
\end{tabular}

* Denotes sites where samples were taken

** Sample taken and site coordinates estimated 
ALL PEGMATITE COORDINATES AND SAMPLE SITES (UTM, WGS 84) CONT'D

\begin{tabular}{|c|c|c|c|c|c|}
\hline Pegmatite & Point Name & Zone & Easting & Northing & Elevation \\
\hline \multirow[t]{15}{*}{ LI2 } & 12-LI2-E & 11 & 412478 & 5638841 & 2114 \\
\hline & 12-LI2-J01 & 11 & 412432 & 5638896 & 2117 \\
\hline & 12-LI2-J02 & 11 & 412432 & 5638895 & 2124 \\
\hline & 12-LI2-MO1 & 11 & 412377 & 5638952 & 2115 \\
\hline & 12-LI2-MO2 & 11 & 412440 & 5638883 & 2125 \\
\hline & 12-LI2-MO3 & 11 & 412444 & 5638893 & 2125 \\
\hline & 12-LI2-MO4 & 11 & 412437 & 5638873 & 2130 \\
\hline & 12-LI2-PEG & 11 & 412460 & 5638855 & 2115 \\
\hline & 12-LI2-S01* & 11 & 412460 & 5638855 & 2115 \\
\hline & 12-LI2-S02* & 11 & 412464 & 5638860 & 2116 \\
\hline & 12-LI2-S03* & 11 & 412409 & 5638919 & 2117 \\
\hline & 12-LI2-S04* & 11 & 412431 & 5638877 & 2125 \\
\hline & 12-LI2-SP01 & 11 & 412425 & 5638886 & 2117 \\
\hline & 12-LI2-SP01-W & 11 & 412396 & 5638901 & 2116 \\
\hline & 12-CREEK-PEG & 11 & 412404 & 5638919 & 2115 \\
\hline \multirow[t]{11}{*}{ LONG } & 12-LONG-E & 11 & 412333 & 5638896 & 2135 \\
\hline & 12-LONG-J01 & 11 & 412209 & 5638940 & 2135 \\
\hline & 12-LONG-J02 & 11 & 412284 & 5638917 & 2136 \\
\hline & 12-LONG-MO1 & 11 & 412264 & 5638924 & 2140 \\
\hline & 12-LONG-MO2 & 11 & 412154 & 5638962 & 2140 \\
\hline & 12-LONG-MO3 & 11 & 412163 & 5638960 & 2140 \\
\hline & 12-LONG-MO4 & 11 & 412182 & 5638951 & 2139 \\
\hline & 12-LONG-M05 & 11 & 412136 & 5638968 & 2142 \\
\hline & 12-LONG-S01* & 11 & 412223 & 5638942 & 2135 \\
\hline & 12-LONG-SPO1 & 11 & 412239 & 5638939 & 2139 \\
\hline & 12-LONG-W & 11 & 412127 & 5638968 & 2144 \\
\hline \multirow[t]{6}{*}{ META } & 12-META-BDF & 11 & 412239 & 5638958 & 2129 \\
\hline & 12-META-E & 11 & 412279 & 5638941 & 2132 \\
\hline & 12-META-THICK & 11 & 412212 & 5638972 & 2128 \\
\hline & 12-META-V & 11 & 412217 & 5638966 & 2127 \\
\hline & 12-META-W & 11 & 412257 & 5638951 & 2132 \\
\hline & 12-META-W1 & 11 & 412172 & 5639004 & 2134 \\
\hline MORE & 12-MORE-PEGS & 11 & 412487 & 5638447 & 2195 \\
\hline \multirow[t]{4}{*}{ MUSC } & 12-MUSC-E & 11 & 412211 & 5638870 & 2154 \\
\hline & 12-MUSC-MO1 & 11 & 412202 & 5638872 & 2155 \\
\hline & 12-MUSC-S01* & 11 & 412163 & 5638883 & 2156 \\
\hline & 12-MUSC-W & 11 & 412159 & 5638885 & 2156 \\
\hline
\end{tabular}

* Denotes sites where samples were taken 
ALL PEGMATITE COORDINATES AND SAMPLE SITES (UTM, WGS 84) CONT'D

\begin{tabular}{|c|c|c|c|c|c|}
\hline \multicolumn{2}{|c|}{ Pegmatite Point Name } & \multirow{2}{*}{$\frac{\text { Zone }}{11}$} & \multirow{2}{*}{$\frac{\text { Easting }}{412403}$} & \multirow{2}{*}{$\frac{\text { Northing }}{5639098}$} & \multirow{2}{*}{$\frac{\text { Elevation }}{2110}$} \\
\hline ODD & 12-ODD-PEG & & & & \\
\hline \multirow[t]{10}{*}{ PEGMA } & 12-PEGMA-E & 11 & 412281 & 5638958 & 2124 \\
\hline & 12-PEGMA-J01 & 11 & 412260 & 5638970 & 2126 \\
\hline & 12-PEGMA-M01 & 11 & 412272 & 5638962 & 2126 \\
\hline & 12-PEGMA-MO2 & 11 & 412275 & 5638952 & 2128 \\
\hline & 12-PEGMA-MO3 & 11 & 412268 & 5638957 & 2127 \\
\hline & 12-PEGMA-MO4 & 11 & 412259 & 5638964 & 2128 \\
\hline & 12-PEGMA-S01* & 11 & 412254 & 5638978 & 2125 \\
\hline & 12-PEGMA-SO2* & 11 & 412235 & 5638989 & 2122 \\
\hline & 12-PEGMA-SP01 & 11 & 412279 & 5638959 & 2125 \\
\hline & 12-PEGMA-W & 11 & 412235 & 5638989 & 2122 \\
\hline \multirow[t]{3}{*}{ POCKET } & 12-POCKET-N & 11 & 412258 & 5638689 & 2195 \\
\hline & 12-POCKET-S & 11 & 412260 & 5638688 & 2195 \\
\hline & 12-POCKET-SO1* & 11 & 412258 & 5638685 & 2196 \\
\hline \multirow[t]{4}{*}{ QTZ } & 12-QTZ-E & 11 & 412292 & 5638708 & 2189 \\
\hline & 12-QTZ-MO1 & 11 & 412283 & 5638711 & 2189 \\
\hline & 12-QTZ-MO2 & 11 & 412277 & 5638721 & 2190 \\
\hline & 12-QTZ-W & 11 & 412274 & 5638728 & 2189 \\
\hline \multirow[t]{3}{*}{ QTZ2 } & 12-QTZ2-E & 11 & 412295 & 5638715 & 2187 \\
\hline & 12-QTZ2-MO1 & 11 & 412288 & 5638723 & 2186 \\
\hline & 12-QTZ2-W & 11 & 412282 & 5638729 & 2185 \\
\hline \multirow[t]{10}{*}{ QTZ3 } & 12-QTZ3-E & 11 & 412294 & 5638712 & 2184 \\
\hline & 12-QTZ3-E1 & 11 & 412273 & 5638725 & 2184 \\
\hline & 12-QTZ3-E2 & 11 & 412316 & 5638734 & 2179 \\
\hline & 12-QTZ3-MO1 & 11 & 412288 & 5638724 & 2184 \\
\hline & 12-QTZ3-M02 & 11 & 412281 & 5638728 & 2182 \\
\hline & 12-QTZ3-M03 & 11 & 412291 & 5638733 & 2181 \\
\hline & 12-QTZ3-MO4 & 11 & 412297 & 5638736 & 2179 \\
\hline & 12-QTZ3-SP01 & 11 & 412285 & 5638726 & 2183 \\
\hline & 12-QTZ3-SP02 & 11 & 412269 & 5638729 & 2184 \\
\hline & 12-QTZ3-W & 11 & 412262 & 5638728 & 2184 \\
\hline \multirow[t]{2}{*}{ SCABBY } & 12-SCABBY-E & 11 & 412180 & 5638958 & 2140 \\
\hline & 12-SCABBY-W & 11 & 412049 & 5639014 & 2146 \\
\hline \multirow[t]{2}{*}{ SIMPLE } & 12-SIMPLE-E & 11 & 412506 & 5638837 & 2103 \\
\hline & 12-SIMPLE-PEG & 11 & 412490 & 5638869 & 2113 \\
\hline
\end{tabular}

* Denotes sites where samples were taken 
ALL PEGMATITE COORDINATES AND SAMPLE SITES (UTM, WGS 84) CONT'D

\begin{tabular}{|c|c|c|c|c|c|}
\hline Pegmatite & Point Name & Zone & Easting & Northing & Elevation \\
\hline \multirow[t]{3}{*}{ SIMPLE (cont'd) } & 12-SIMPLE-S01* & 11 & 412495 & 5638850 & 2110 \\
\hline & 12-SIMPLE-SO2* & 11 & 412496 & 5638846 & 2107 \\
\hline & 12-SIMPLE-W & 11 & 412488 & 5638896 & 2110 \\
\hline \multirow[t]{4}{*}{ SIMPLE2 } & 12-SIMPLE2-N & 11 & 412537 & 5638845 & 2107 \\
\hline & 12-SIMPLE2-PEG & 11 & 412537 & 5638844 & 2108 \\
\hline & 12-SIMPLE2-S & 11 & 412533 & 5638842 & 2108 \\
\hline & 12-SIMPLE2-S01* & 11 & 412533 & 5638843 & 2106 \\
\hline \multirow[t]{3}{*}{ SIMPLE3 } & 12-SIMPLE3-N & 11 & 412557 & 5638843 & 2108 \\
\hline & 12-SIMPLE3-S & 11 & 412562 & 5638833 & 2106 \\
\hline & 12-SIMPLE3-S01* & 11 & 412559 & 5638836 & 2107 \\
\hline \multirow[t]{3}{*}{ SIMPLE4 } & 12-SIMPLE4-N & 11 & 412565 & 5638847 & 2109 \\
\hline & 12-SIMPLE4-S & 11 & 412578 & 5638829 & 2106 \\
\hline & 12-SIMPLE4-S01* & 11 & 412576 & 5638828 & 2106 \\
\hline \multirow[t]{4}{*}{ SIMPLE5 } & 12-SIMPLE5-E & 11 & 412633 & 5638821 & 2106 \\
\hline & 12-SIMPLE5-N & 11 & 412572 & 5638847 & 2107 \\
\hline & 12-SIMPLE5-S & 11 & 412599 & 5638824 & 2108 \\
\hline & 12-SIMPLE5-S01* & 11 & 412587 & 5638832 & 2106 \\
\hline \multirow[t]{9}{*}{ SIMPLE6 } & 12-SIMPLE6-E1 & 11 & 412386 & 5638884 & 2130 \\
\hline & 12-SIMPLE6-E2 & 11 & 412386 & 5638888 & 2128 \\
\hline & 12-SIMPLE6-E3 & 11 & 412366 & 5638891 & 2127 \\
\hline & 12-SIMPLE6-E4 & 11 & 412366 & 5638909 & 2122 \\
\hline & 12-SIMPLE6-J01 & 11 & 412373 & 5638890 & 2125 \\
\hline & 12-SIMPLE6-J02 & 11 & 412362 & 5638896 & 2128 \\
\hline & 12-SIMPLE6-J03 & 11 & 412361 & 5638913 & 2119 \\
\hline & 12-SIMPLE6-W & 11 & 412339 & 5638958 & 2113 \\
\hline & 12-SIMP6-S01* & 11 & 412352 & 5638937 & 2117 \\
\hline \multirow[t]{3}{*}{ SIMPLE7 } & 12-SIMPLE7-N & 11 & 412346 & 5638912 & 2127 \\
\hline & 12-SIMPLE7-S & 11 & 412347 & 5638901 & 2130 \\
\hline & 12-SIMP7-S01* & 11 & 412347 & 5638909 & 2128 \\
\hline \multirow[t]{3}{*}{ SIMPLE8 } & 12-SIMPLE8-E & 11 & 412404 & 5638519 & 2191 \\
\hline & 12-SIMPLE8-PEG & 11 & 412400 & 5638519 & 2190 \\
\hline & 12-SIMPLE8-W & 11 & 412393 & 5638520 & 2190 \\
\hline \multirow[t]{3}{*}{ SIMPLE9 } & 12-SIMPLE9-B & 11 & 412305 & 5638927 & 2131 \\
\hline & 12-SIMPLE9-B1 & 11 & 412288 & 5638985 & 2114 \\
\hline & 12-SIMPLE9-E & 11 & 412338 & 5638901 & 2132 \\
\hline
\end{tabular}

* Denotes sites where samples were taken 
ALL PEGMATITE COORDINATES AND SAMPLE SITES (UTM, WGS 84) CONT'D

\begin{tabular}{|c|c|c|c|c|c|}
\hline Pegmatite & Point Name & Zone & Easting & Northing & Elevation \\
\hline \multirow[t]{18}{*}{ SIMPLE9 (cont'd) } & 12-SIMPLE9-E2 & 11 & 412327 & 5638907 & 2132 \\
\hline & 12-SIMPLE9-W2 & 11 & 412302 & 5638920 & 2132 \\
\hline & 12-SIMPLE9-X & 11 & 412299 & 5638934 & 2126 \\
\hline & 12-SIMP9-M01 & 11 & 412323 & 5638911 & 2131 \\
\hline & 12-SIMP9-MO2 & 11 & 412268 & 5639010 & 2112 \\
\hline & 12-SIMP9-MO3 & 11 & 412256 & 5639026 & 2112 \\
\hline & 12-SIMP9-MO4 & 11 & 412243 & 5639041 & 2112 \\
\hline & 12-SIMP9-M05 & 11 & 412237 & 5639043 & 2113 \\
\hline & 12-SIMP9-M06 & 11 & 412215 & 5639064 & 2115 \\
\hline & 12-SIMP9-MO7 & 11 & 412194 & 5639078 & 2117 \\
\hline & 12-SIMP9-M08 & 11 & 412190 & 5639086 & 2116 \\
\hline & 12-SIMP9-S01 & 11 & 412307 & 5638917 & 2133 \\
\hline & 12-SIMP9-S02 & 11 & 412315 & 5638923 & 2130 \\
\hline & 12-SIMP9-S03 & 11 & 412312 & 5638924 & 2131 \\
\hline & 12-SIMPLE9-S04* & 11 & 412311 & 5638919 & 2126 \\
\hline & 12-SIMPLE9-S05* & 11 & 412310 & 5638914 & 2130 \\
\hline & 12-SIMP9-SP01 & 11 & 412325 & 5638914 & 2128 \\
\hline & 12-SIMPLE-W1 & 11 & 412186 & 5639091 & 2115 \\
\hline \multirow[t]{2}{*}{ SIMPLE10 } & 12-SIMP-10 & 11 & 412388 & 5639114 & 2093 \\
\hline & 12-SIMP10-W & 11 & 412367 & 5639127 & 2095 \\
\hline \multirow[t]{3}{*}{ SIMPLE11 } & 12-SIMP11-E & 11 & 412526 & 5638742 & 2120 \\
\hline & 12-SIMP11-J01 & 11 & 412508 & 5638751 & 2119 \\
\hline & 12-SIMPLE11-S01* & 11 & 412524 & 5638745 & 2120 \\
\hline \multirow[t]{9}{*}{ SIMPLE12 } & 12-SIMP12-E & 11 & 412165 & 5638813 & 2179 \\
\hline & 12-SIMP12-J01 & 11 & 412064 & 5638899 & 2171 \\
\hline & 12-SIMP12-MO1 & 11 & 412108 & 5638863 & 2175 \\
\hline & 12-SIMP12-MO2 & 11 & 412120 & 5638850 & 2175 \\
\hline & 12-SIMP12-M03 & 11 & 412125 & 5638843 & 2176 \\
\hline & 12-SIMPLE12-S01* & 11 & 412064 & 5638899 & 2171 \\
\hline & 12-SIMPLE12-S02* & 11 & 412133 & 5638836 & 2176 \\
\hline & 12-SIMP12-W & 11 & 412047 & 5638906 & 2168 \\
\hline & 12-SIMP12-W1 & 11 & 412045 & 5638910 & 2167 \\
\hline \multirow[t]{5}{*}{ SIMPLE13 } & 12-SIMP13-E & 11 & 412099 & 5638854 & 2178 \\
\hline & 12-SIMP13-M01 & 11 & 412058 & 5638881 & 2178 \\
\hline & 12-SIMP13-MO2 & 11 & 412073 & 5638872 & 2179 \\
\hline & 12-SIMPLE13-S01* & 11 & 412036 & 5638890 & 2175 \\
\hline & 12-SIMP13-W & 11 & 412029 & 5638894 & 2176 \\
\hline
\end{tabular}

* Denotes sites where samples were taken 
ALL PEGMATITE COORDINATES AND SAMPLE SITES (UTM, WGS 84) CONT'D

\begin{tabular}{|c|c|c|c|c|c|}
\hline Pegmatite & Point Name & Zone & Easting & Northing & Elevation \\
\hline \multirow[t]{9}{*}{ SIMPLE14 } & 12-SIMP14-E & 11 & 412121 & 5638789 & 2191 \\
\hline & 12-SIMP14-E1 & 11 & 412120 & 5638790 & 2192 \\
\hline & 12-SIMP14-J01 & 11 & 412119 & 5638791 & 2192 \\
\hline & 12-SIMP14-MO1 & 11 & 412111 & 5638793 & 2192 \\
\hline & 12-SIMP14-MO2 & 11 & 412109 & 5638794 & 2192 \\
\hline & 12-SIMP14-MO3 & 11 & 412105 & 5638796 & 2193 \\
\hline & 12-SIMP14-MO4 & 11 & 412102 & 5638796 & 2193 \\
\hline & 12-SIMPLE14-S01* & 11 & 412097 & 5638794 & 2195 \\
\hline & 12-SIMP14-W & 11 & 412097 & 5638794 & 2194 \\
\hline SIMPLE15 & 12-SIMPLE15-S01* & 11 & 412319 & 5638639 & 2185 \\
\hline \multirow[t]{10}{*}{ SIMPLE16 } & 12-SIMP16-E & 11 & 412303 & 5638577 & 2184 \\
\hline & 12-SIMP16-M01 & 11 & 412291 & 5638581 & 2189 \\
\hline & 12-SIMP16-MO2 & 11 & 412285 & 5638580 & 2189 \\
\hline & 12-SIMP16-MO3 & 11 & 412279 & 5638581 & 2190 \\
\hline & 12-SIMP16-MO4 & 11 & 412268 & 5638580 & 2191 \\
\hline & 12-SIMPLE16-S01* & 11 & 412291 & 5638582 & 2190 \\
\hline & 12-SIMPLE16-S02* & 11 & 412287 & 5638578 & 2191 \\
\hline & 12-SIMP16-SP01 & 11 & 412294 & 5638582 & 2188 \\
\hline & 12-SIMP16-W & 11 & 412263 & 5638580 & 2191 \\
\hline & 12-SIMP16-W1 & 11 & 412291 & 5638582 & 2190 \\
\hline \multirow[t]{4}{*}{ SIMPLE17 } & 12-SIMP17-E & 11 & 412334 & 5638531 & 2187 \\
\hline & 12-SIMP17-MO1 & 11 & 412330 & 5638533 & 2189 \\
\hline & 12-SIMPLE17-S01* & 11 & 412332 & 5638531 & 2188 \\
\hline & 12-SIMP17-W & 11 & 412325 & 5638542 & 2191 \\
\hline \multirow[t]{3}{*}{ SKINNY } & 12-SKINNY-N & 11 & 412317 & 5638618 & 2184 \\
\hline & 12-SKINNY-S & 11 & 412320 & 5638605 & 2184 \\
\hline & 12-SKINNY-S01* & 11 & 412319 & 5638609 & 2184 \\
\hline \multirow[t]{4}{*}{ SMALL } & 12-SMALL-E & 11 & 412654 & 5638717 & 2107 \\
\hline & 12-SMALL-PEG & 11 & 412640 & 5638730 & 2107 \\
\hline & 12-SMALL-S01* & 11 & 412639 & 5638728 & 2108 \\
\hline & 12-SMALL-W & 11 & 412629 & 5638729 & 2106 \\
\hline \multirow[t]{2}{*}{ STUBBY } & 12-STUBBY-E & 11 & 412509 & 5638844 & 2104 \\
\hline & 12-STUBBY-W & 11 & 412500 & 5638840 & 2106 \\
\hline \multirow[t]{2}{*}{ THIN } & 12-THIN-MO1 & 11 & 412061 & 5638934 & 2152 \\
\hline & 12-THIN-MO2 & 11 & 412068 & 5638935 & 2151 \\
\hline
\end{tabular}

* Denotes sites where samples were taken 
ALL PEGMATITE COORDINATES AND SAMPLE SITES (UTM, WGS 84) CONT'D

\begin{tabular}{|c|c|c|c|c|c|}
\hline Pegmatite & Point Name & Zone & Easting & Northing & Elevation \\
\hline \multirow{9}{*}{ THIN (cont'd) } & 12-THIN-MO3 & 11 & 412074 & 5638930 & 2153 \\
\hline & 12-THIN-MO4 & 11 & 412079 & 5638928 & 2153 \\
\hline & 12-THIN-MO5 & 11 & 412086 & 5638924 & 2154 \\
\hline & 12-THIN-MO6 & 11 & 412093 & 5638915 & 2155 \\
\hline & 12-THIN-MO7 & 11 & 412095 & 5638917 & 2156 \\
\hline & 12-THIN-M08 & 11 & 412102 & 5638914 & 2157 \\
\hline & 12-THIN-MO9 & 11 & 412103 & 5638912 & 2157 \\
\hline & 12-THIN-SO1* & 11 & 412086 & 5638924 & 2154 \\
\hline & 12-THIN-W & 11 & 412049 & 5638939 & 2152 \\
\hline \multirow[t]{2}{*}{ TINY } & 12-TINY-W & 11 & 412558 & 5638744 & 2120 \\
\hline & 12-GRANIT-SP03 & 11 & 412560 & 5638742 & 2121 \\
\hline \multirow[t]{4}{*}{ TOUR } & 12-TOUR-M01 & 11 & 412492 & 5638482 & 2187 \\
\hline & 12-TOUR-N & 11 & 412485 & 5638491 & 2186 \\
\hline & 12-TOUR-S & 11 & 412496 & 5638477 & 2186 \\
\hline & 12-TOUR-S01* & 11 & 412491 & 5638486 & 2188 \\
\hline \multirow[t]{2}{*}{ TOUR2 } & 12-TOUR2-N & 11 & 412438 & 5638535 & 2185 \\
\hline & 12-TOUR2-S & 11 & 412441 & 5638531 & 2186 \\
\hline \multirow[t]{4}{*}{ TOURMUS } & 12-TOURMUS-MO1 & 11 & 412546 & 5638751 & 2118 \\
\hline & 12-TOURMUS-SO1* & 11 & 412546 & 5638751 & 2118 \\
\hline & 12-TOURMUS-W & 11 & 412524 & 5638769 & 2116 \\
\hline & 12-GRANIT-SP01 & 11 & 412552 & 5638744 & 2121 \\
\hline \multirow[t]{6}{*}{ WOBBLE } & 12-WOBBLE-M01 & 11 & 412367 & 5638545 & 2190 \\
\hline & 12-WOBBLE-MO2 & 11 & 412361 & 5638550 & 2190 \\
\hline & 12-WOBBLE-N & 11 & 412357 & 5638550 & 2190 \\
\hline & 12-WOBBLE-S & 11 & 412371 & 5638541 & 2191 \\
\hline & 12-WOBBLE-S01* & 11 & 412359 & 5638549 & 2190 \\
\hline & 12-WOBBLE-SO2* & 11 & 412367 & 5638549 & 2191 \\
\hline XENO & 12-XENO-PEG & 11 & 412496 & 5638491 & 2181 \\
\hline \multirow[t]{7}{*}{ ZONED } & 12-ZONED-E & 11 & 412097 & 5638859 & 2177 \\
\hline & 12-ZONED-MO1 & 11 & 412055 & 5638888 & 2175 \\
\hline & 12-ZONED-MO2 & 11 & 412043 & 5638895 & 2175 \\
\hline & 12-ZONED-PEG & 11 & 412062 & 5638886 & 2180 \\
\hline & 12-ZONED-SO1* & 11 & 412055 & 5638888 & 2175 \\
\hline & 12-ZONED-SO2* & 11 & 412080 & 5638873 & 2177 \\
\hline & 12-ZONED-W & 11 & 412015 & 5638904 & 2174 \\
\hline
\end{tabular}

* Denotes sites where samples were taken 


\section{Appendix B X-Ray Diffraction}

\section{B.1 Powder X-Ray Diffraction}

Powder X-ray diffraction experiments were conducted to identify small and unusual crystalline masses using smear mounts. Samples were prepared by grinding in ethanol to a fine powder and smearing the resulting material onto an acrylic slide. Data was collected with a Bruker D8 Focus Bragg-Brentano diffractometer equipped with a Fe monochromator foil, 0.6 $\mathrm{mm}\left(0.3^{\circ}\right)$ divergence slit, incident- and diffracted-beam Soller slits and a LynxEye detector. The long fine-focus Co X-ray tube was operated at $35 \mathrm{kV}$ and $40 \mathrm{~mA}$, using a take-off angle of $6^{\circ}$. Powder-diffraction data were collected over ranges of 3 to $80^{\circ} 2 \theta$, with CoK $\alpha$ radiation. Scanning steps of $0.04^{\circ} 2 \theta$ with a time per step of $0.5 \mathrm{~s}$ were used and the sample was spun at 50 rpm.

Phases were identified from the resulting powder X-ray diffraction patterns by peak matching using Search-Match software by Bruker (EVA 3.0) and the International Centre for Diffraction Database PDF-4. The results are shown below. 
12-BERYL-S01

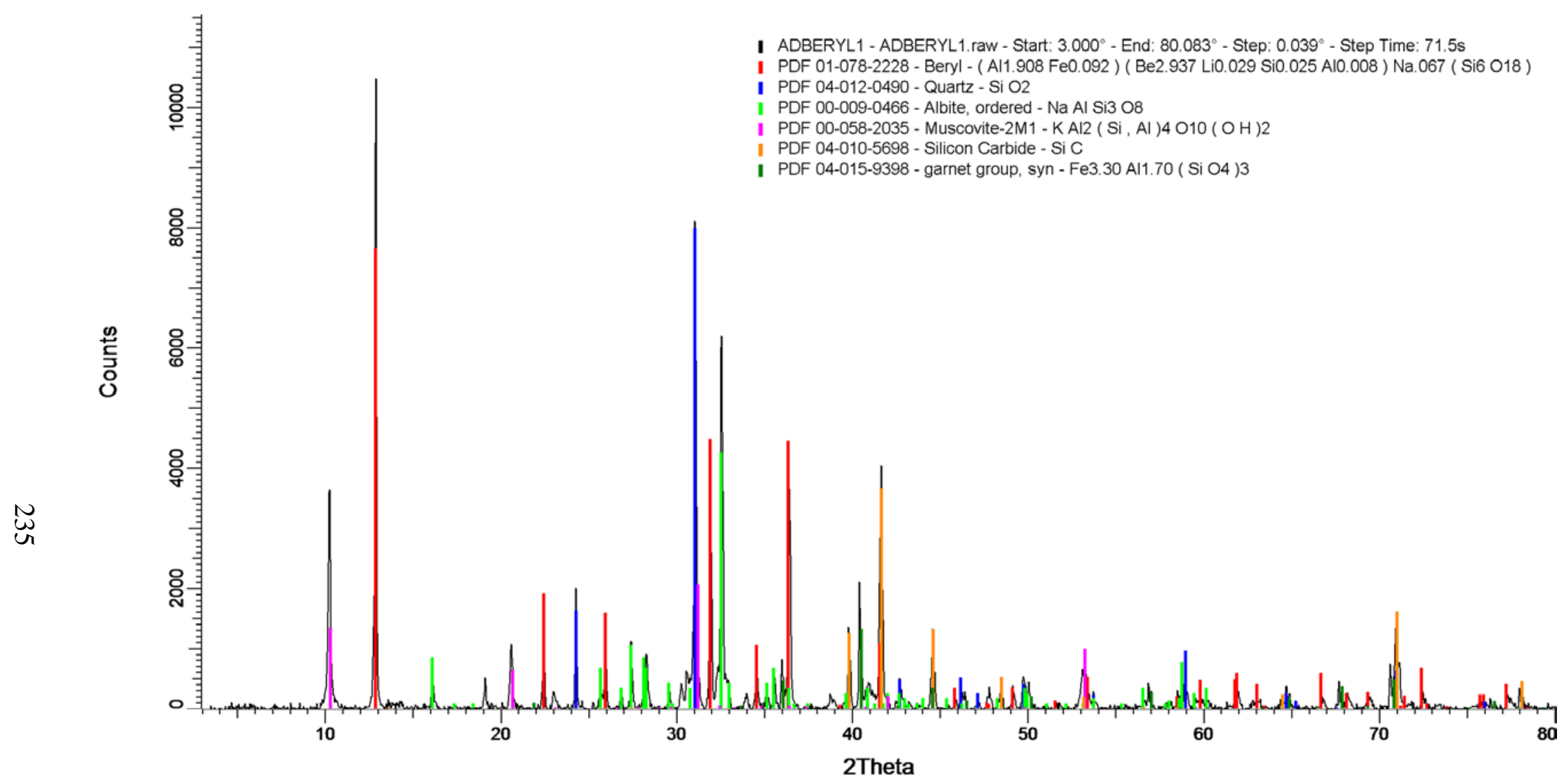

Note: Silicon carbide peaks are contamination from the tool used to remove specimens for powder XRD. 
12-BERYL-S01

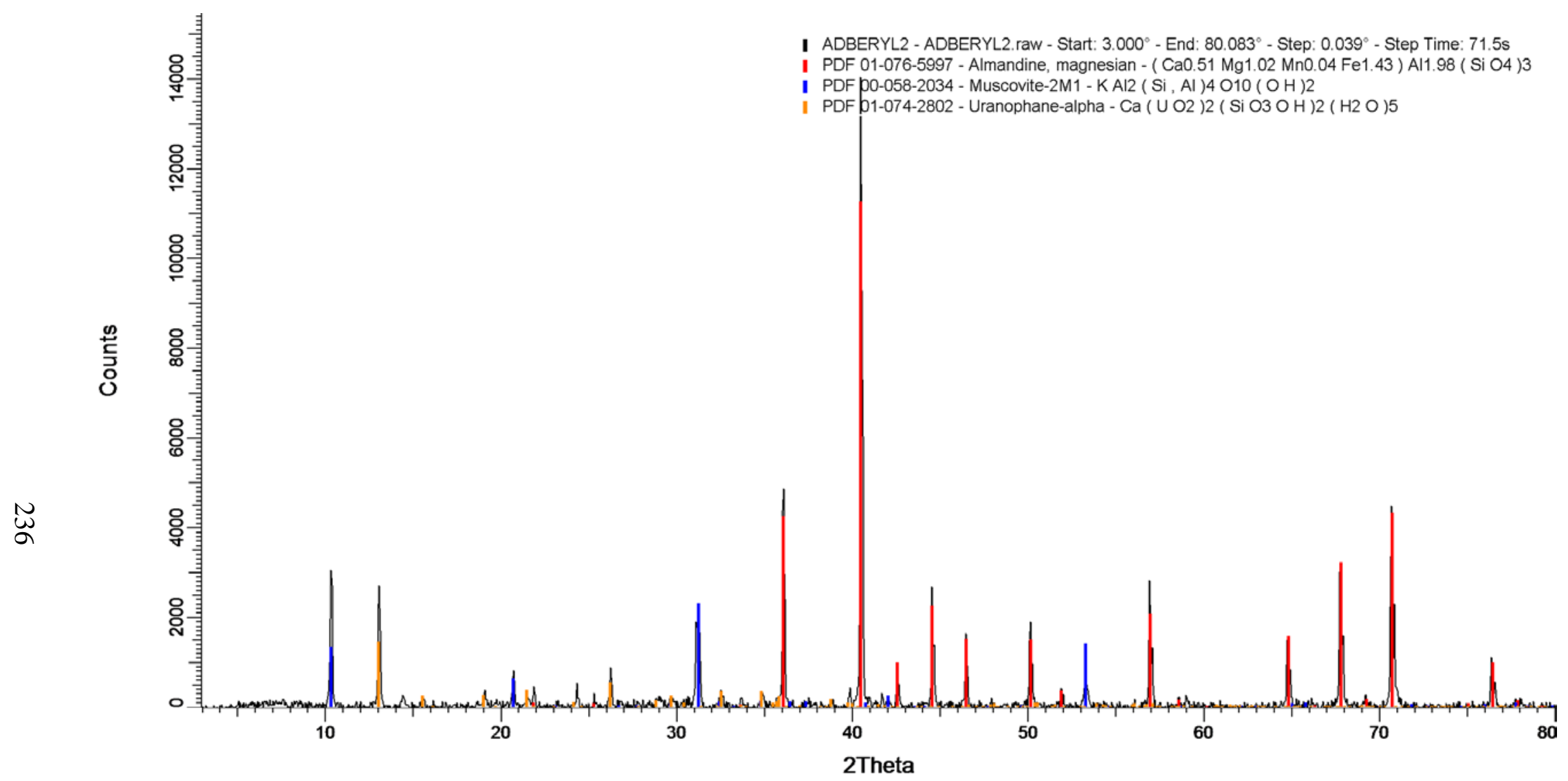


12-BERYL-S01

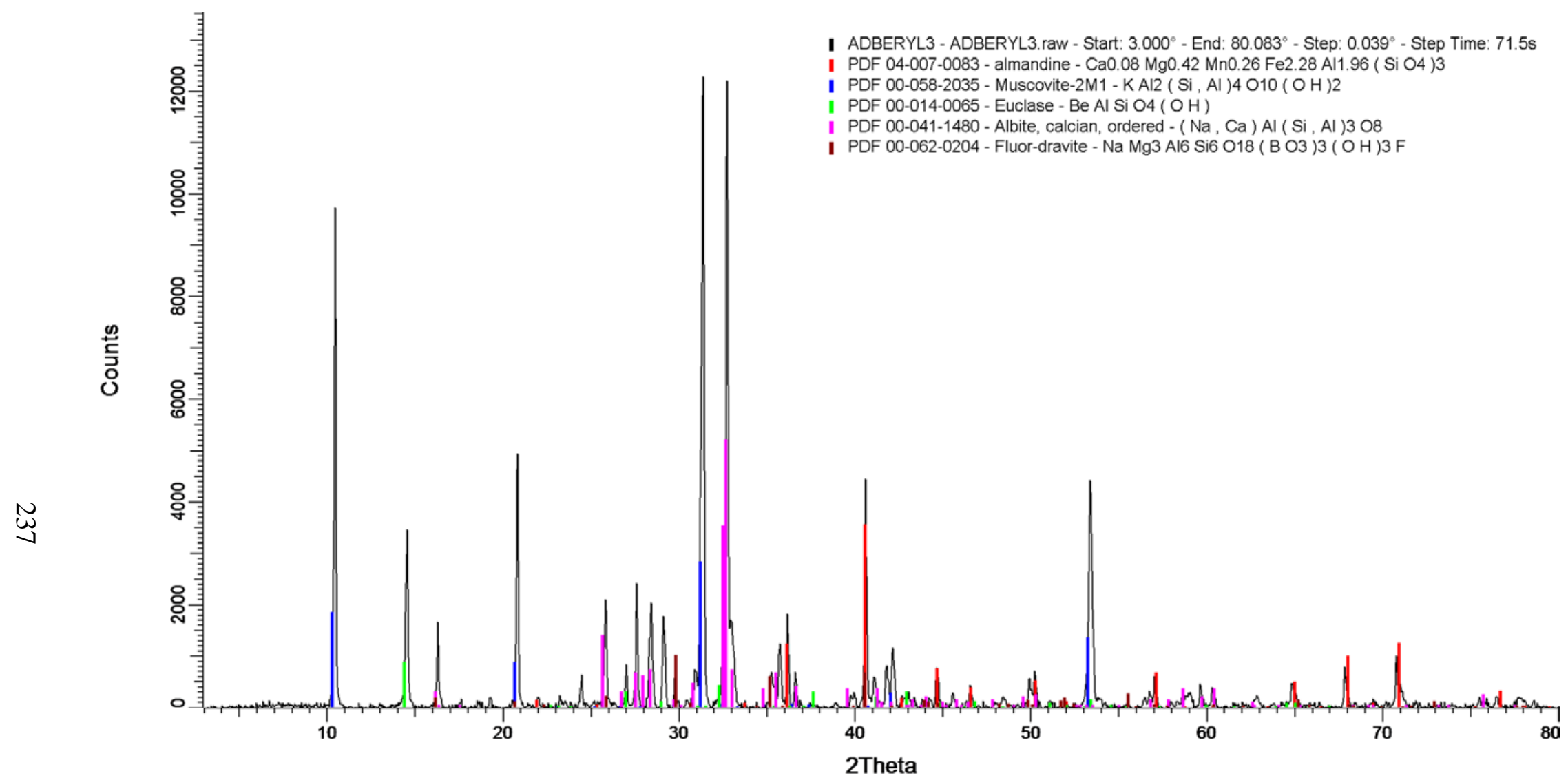

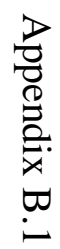


12-BERYL-S01

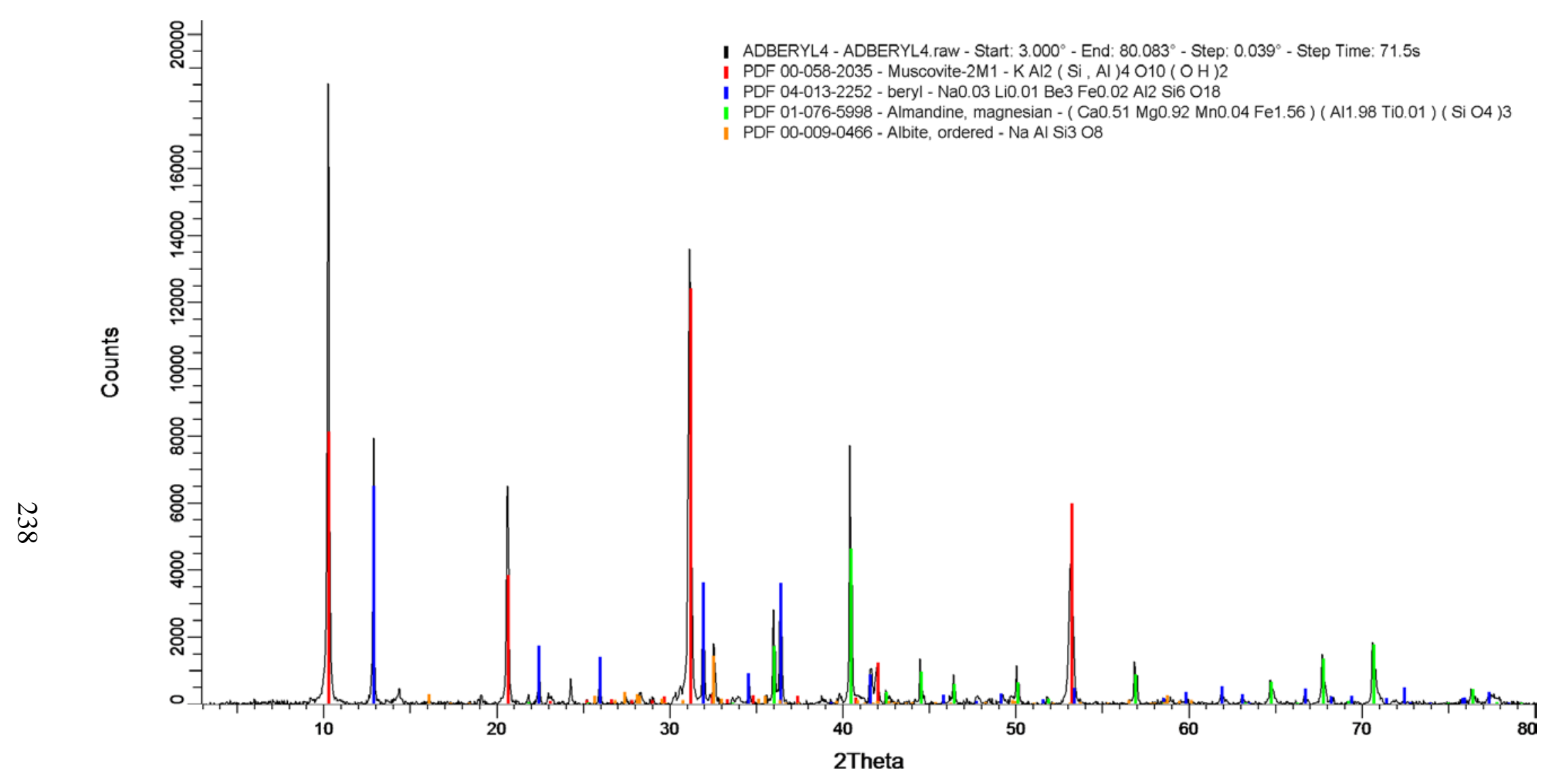


12-BERYL-S01

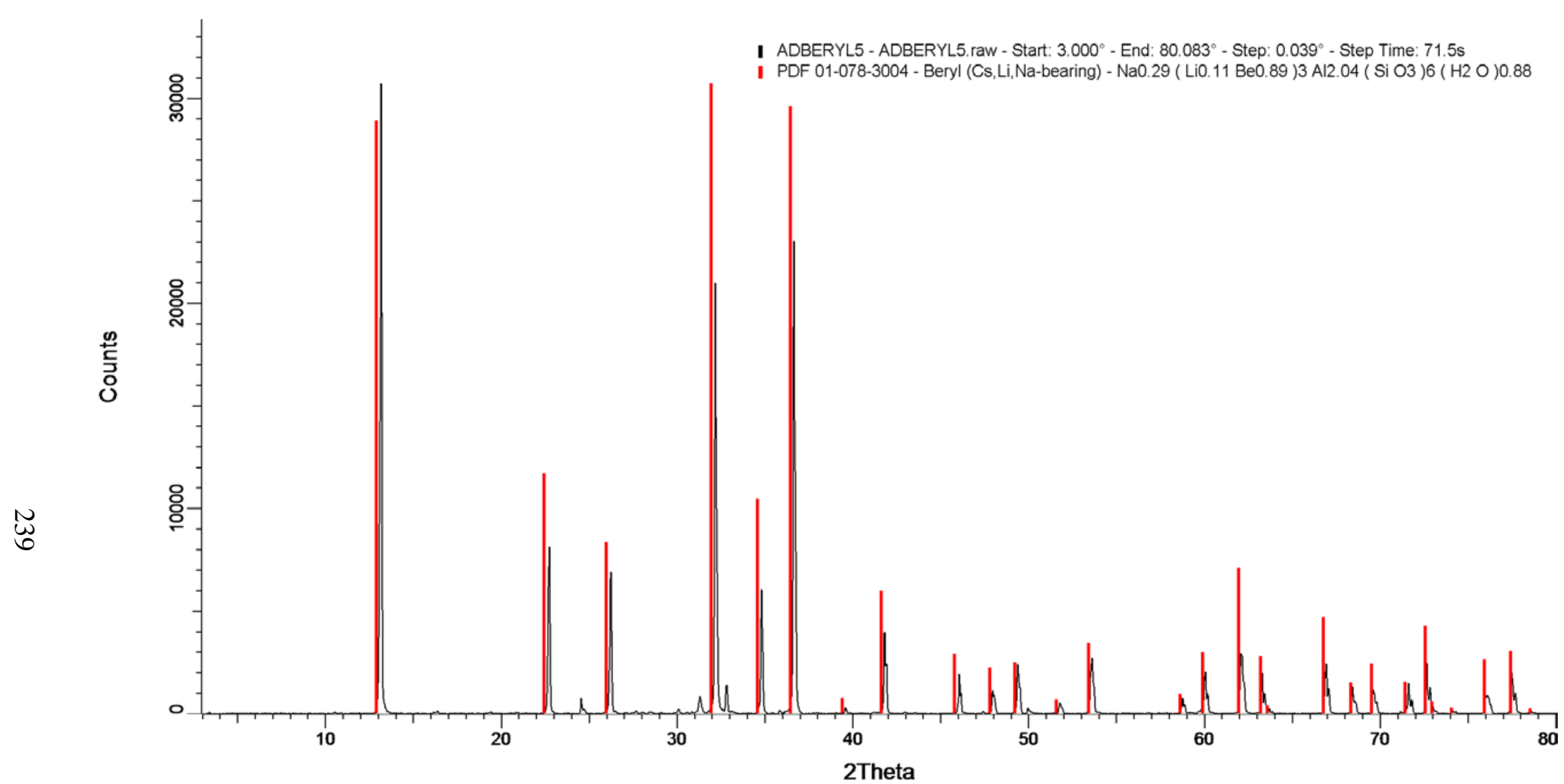

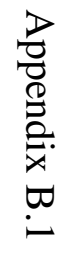


12-BERYL-S03 (core zone)

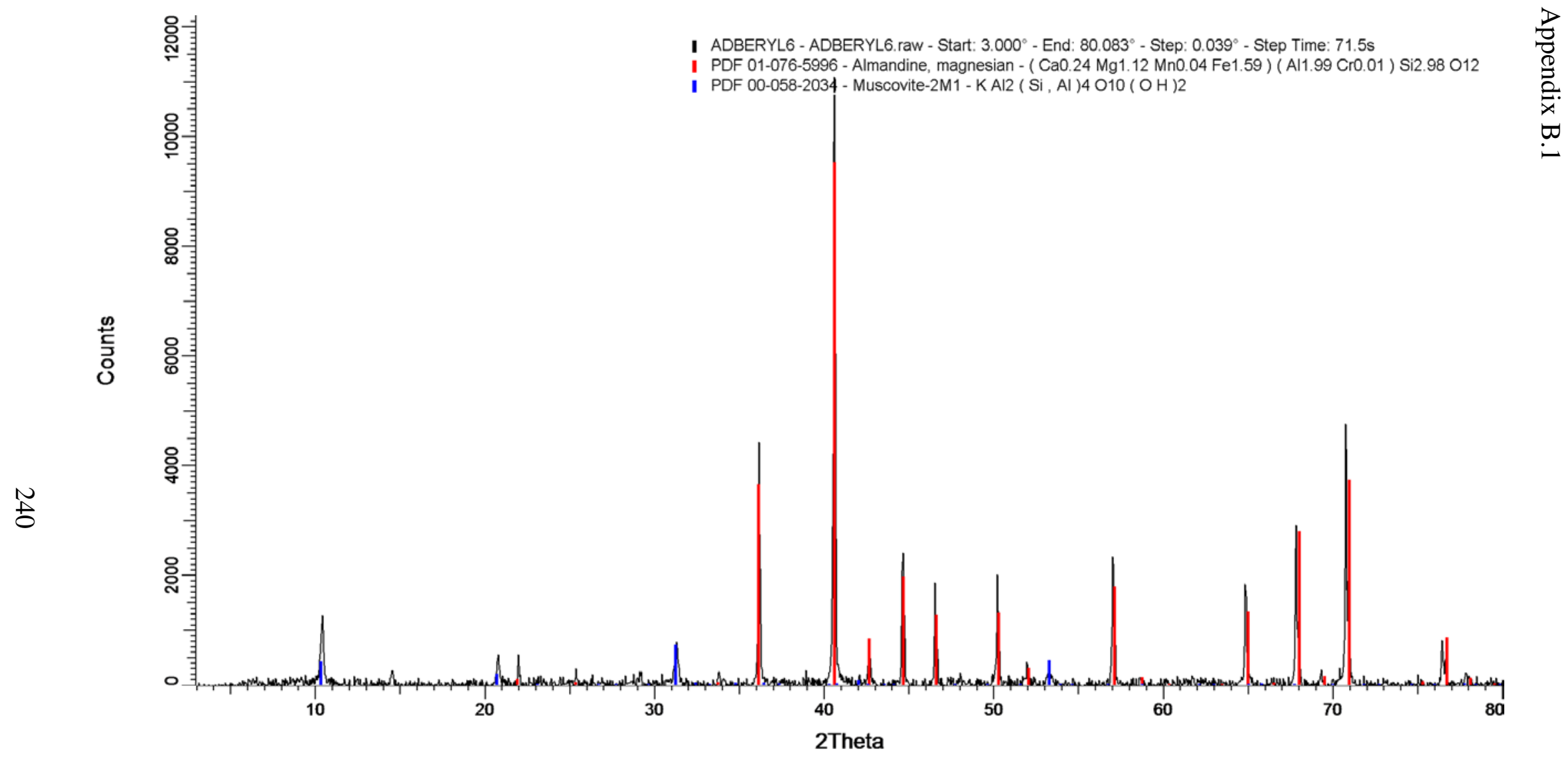




\section{2-BERYL-S01}

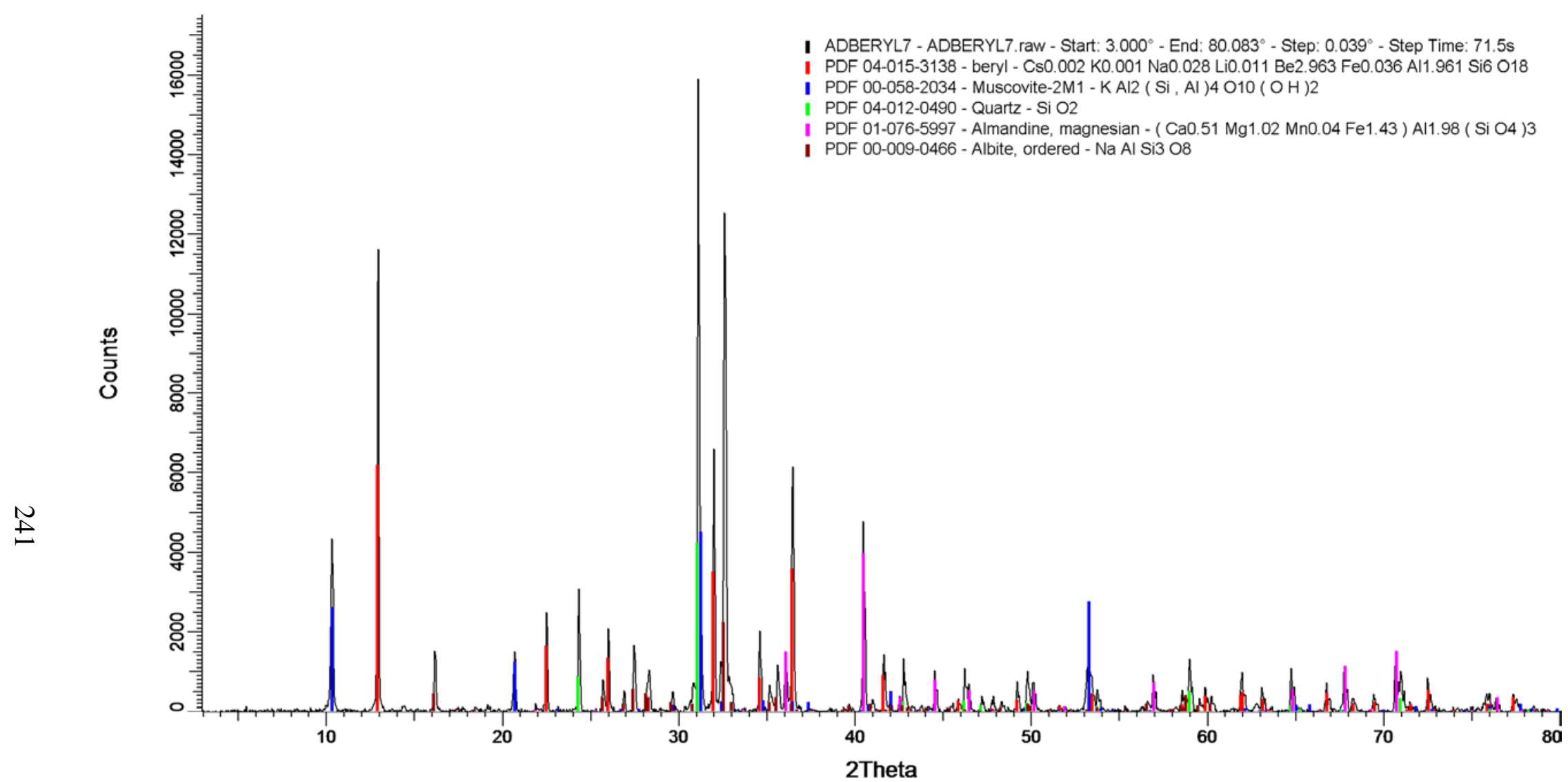




\section{2-BERYL-S01}

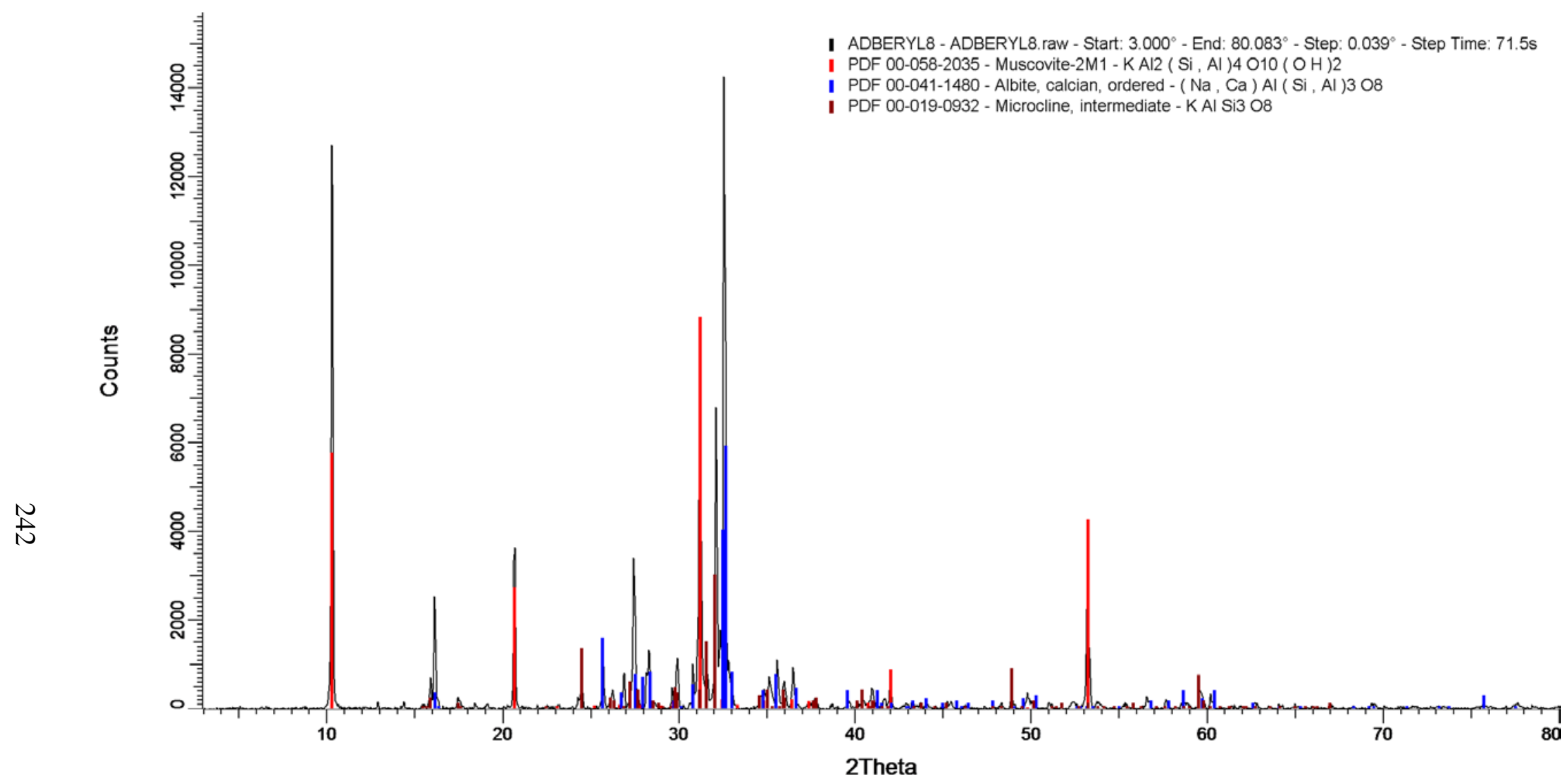




\section{2-BERYL-S01}

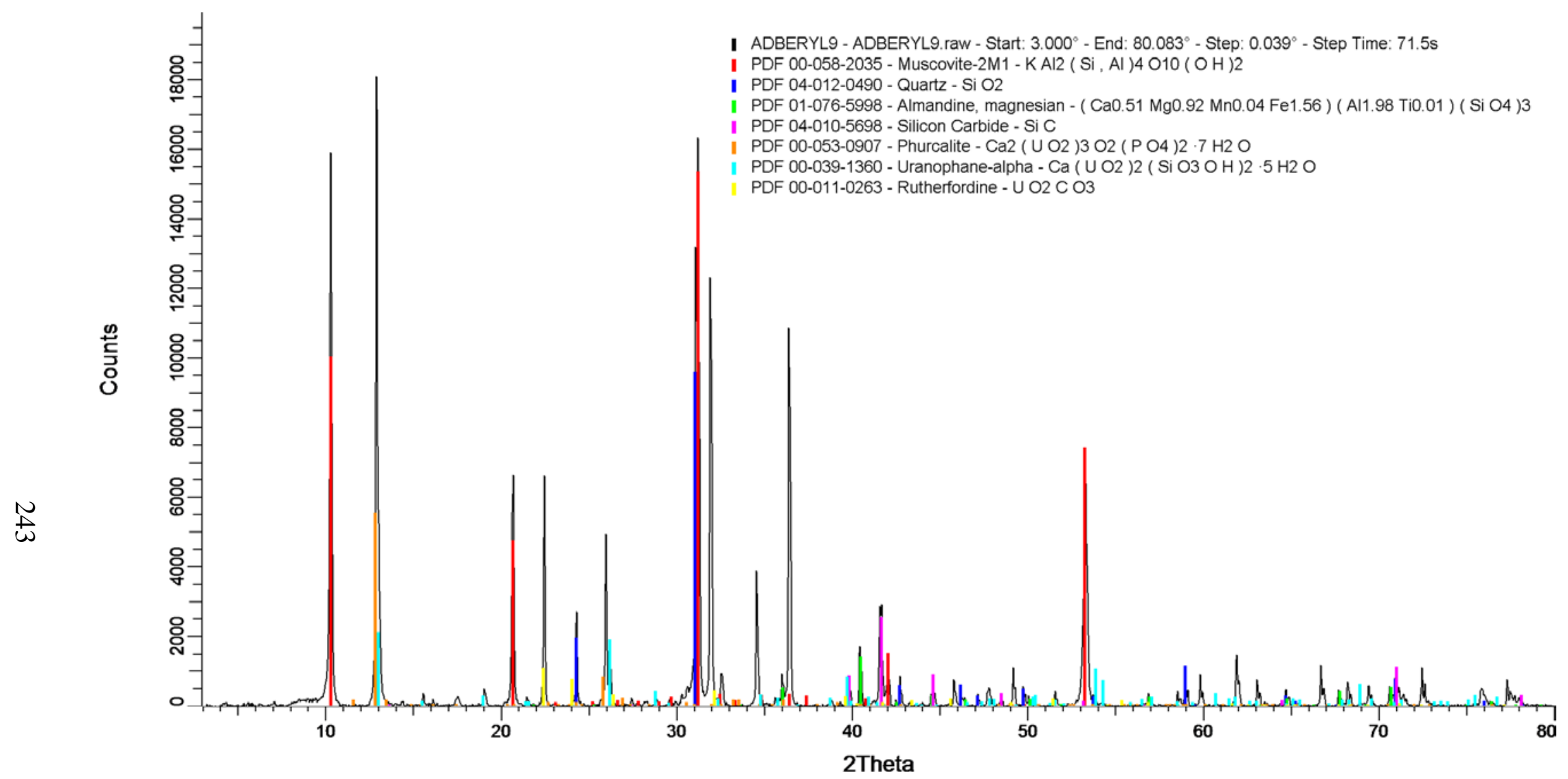

Note: Silicon carbide peaks are contamination from the tool used to remove specimens for powder XRD. 


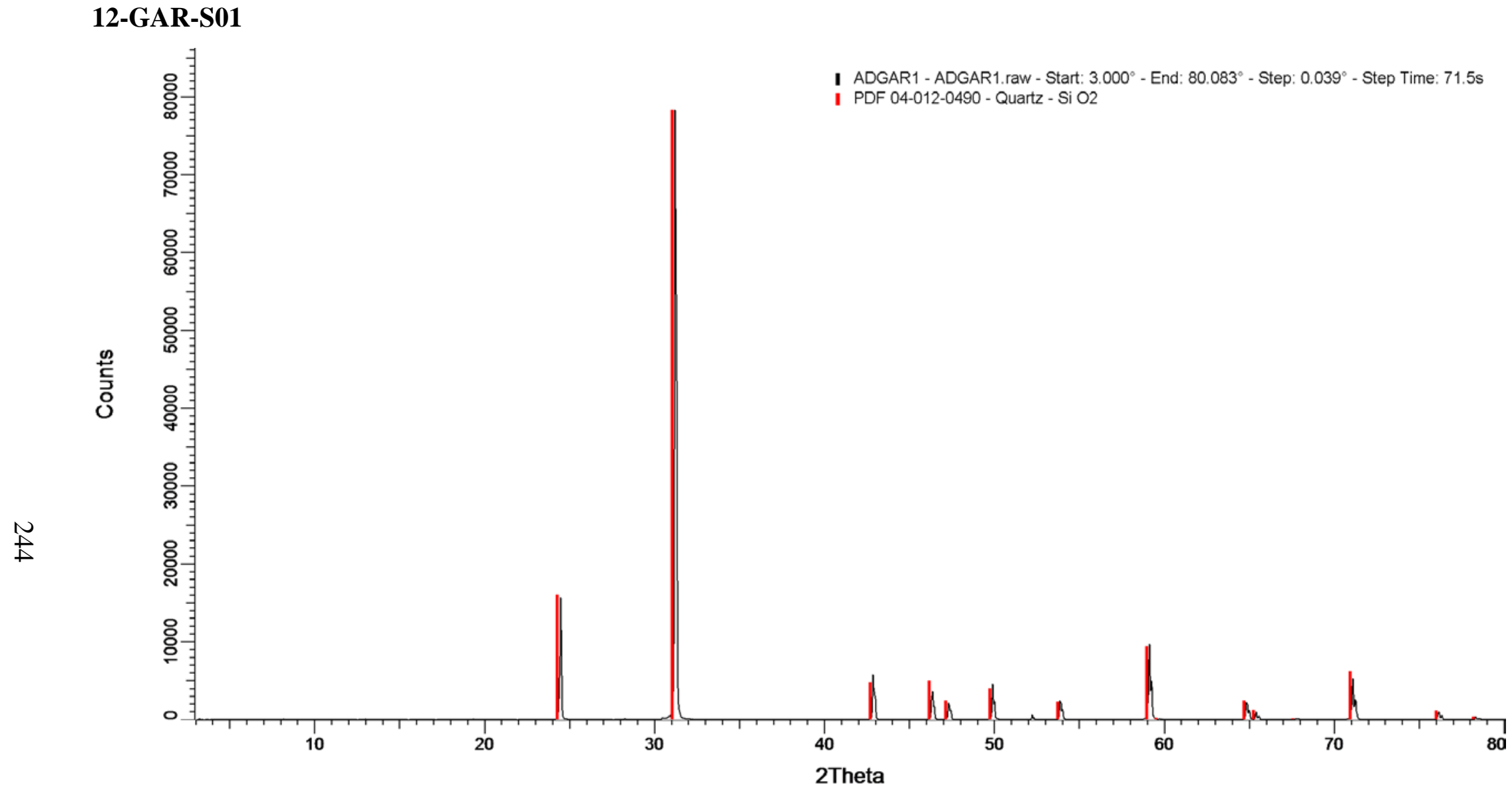


12-GAR-S03

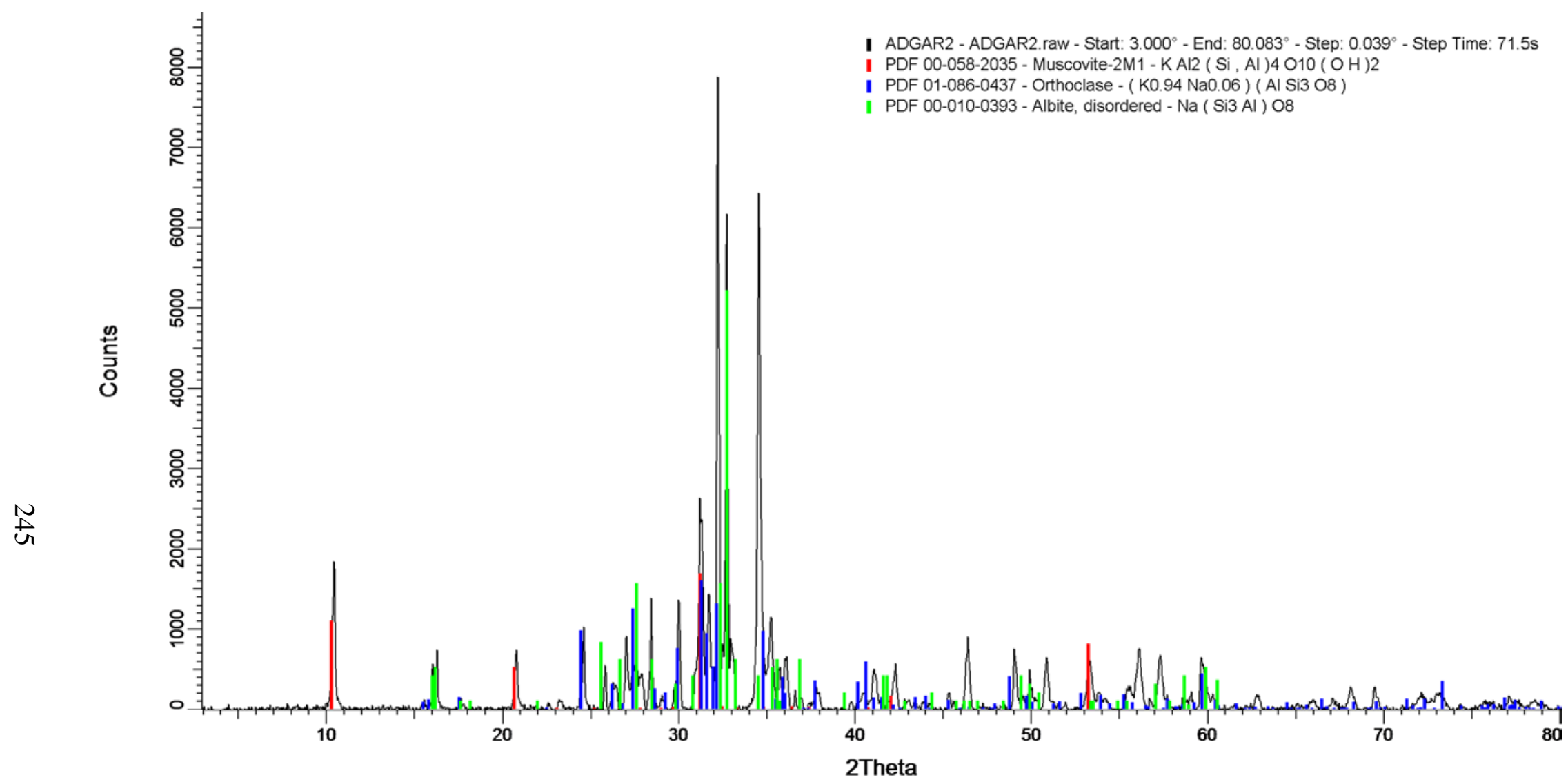


12-GAR-S03

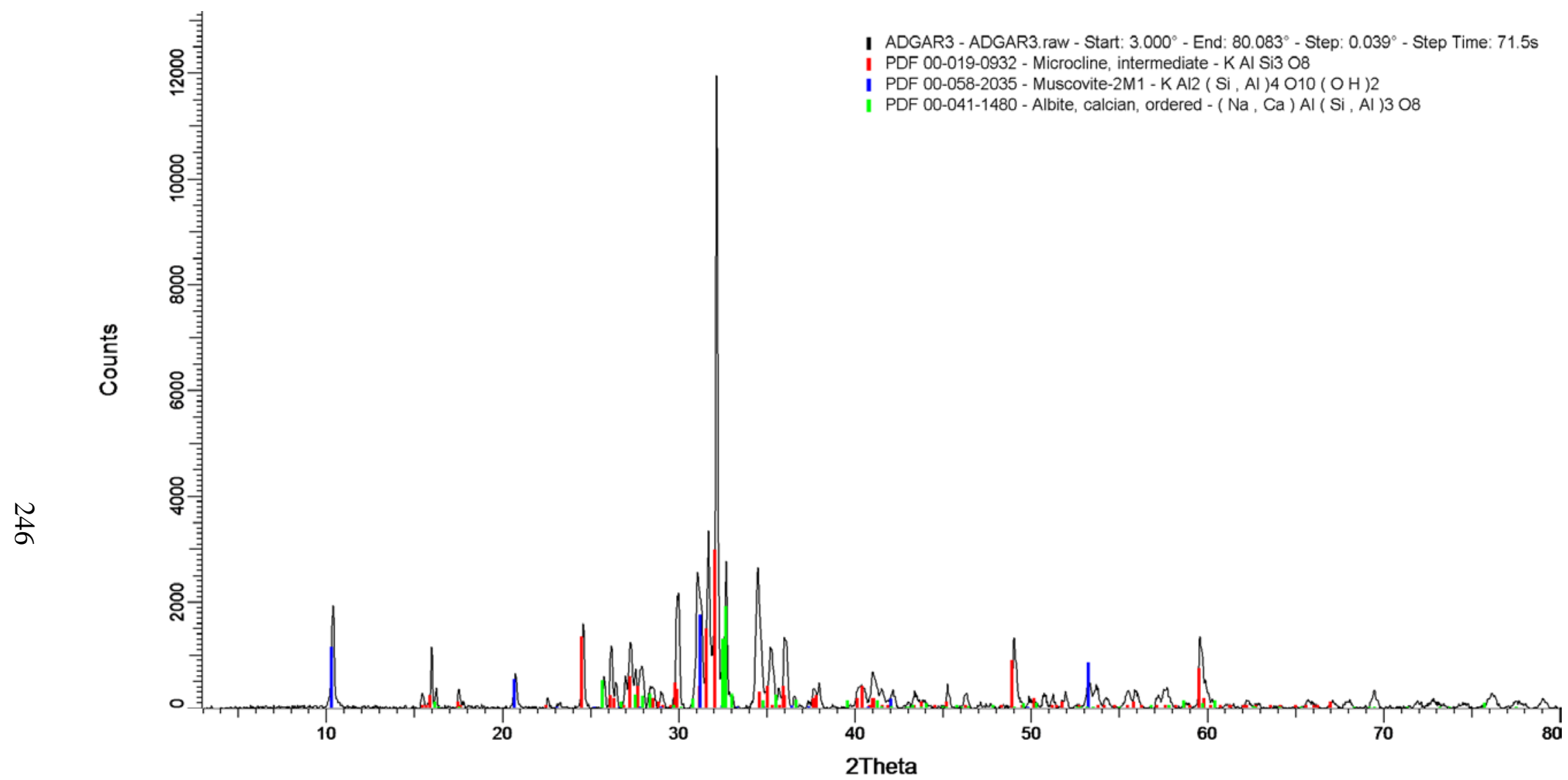


12-GARPHOS-S04
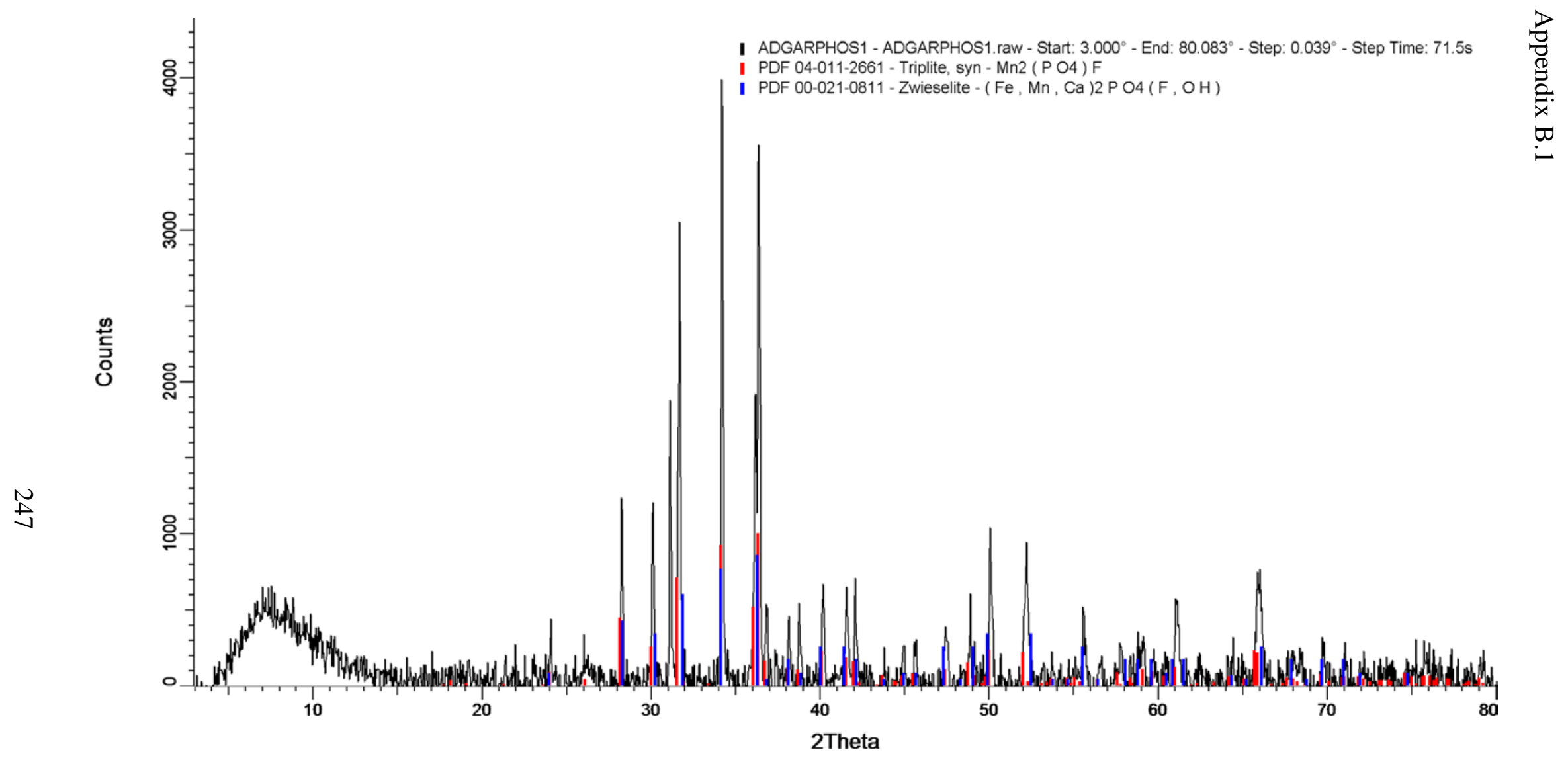
12-GARPHOS-S04

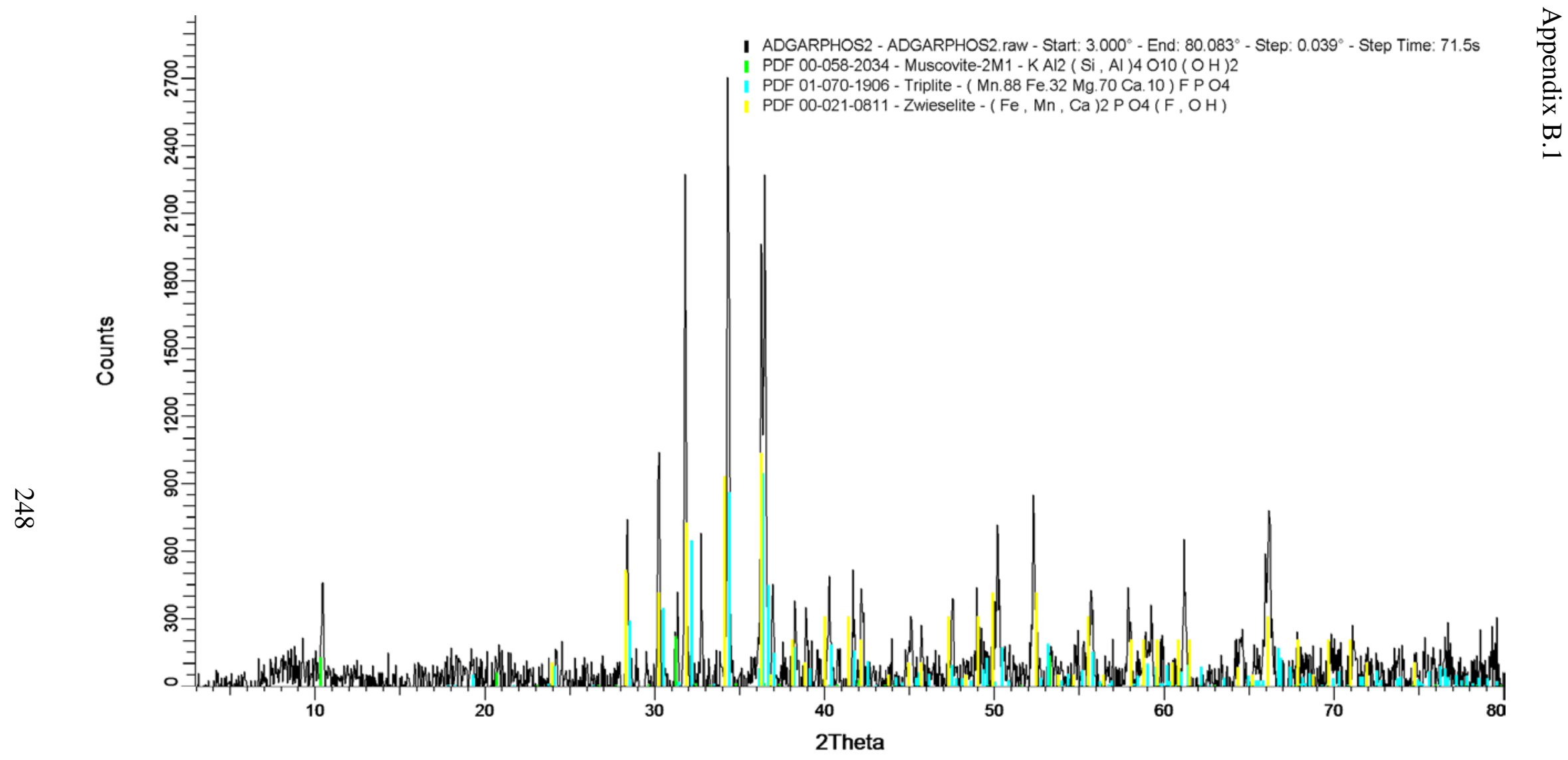


12-GARPHOS-S04

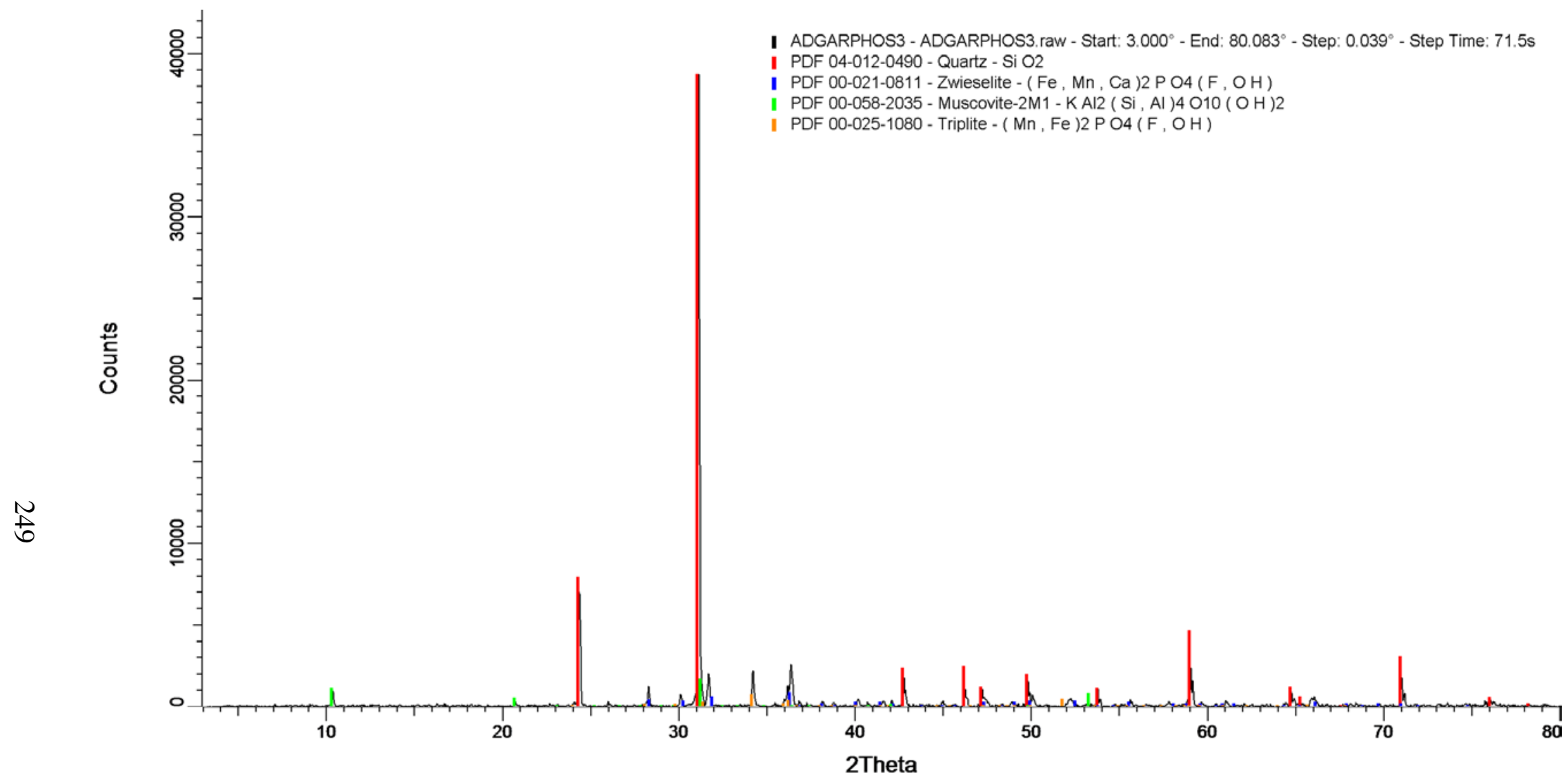


12-GARPHOS-S04

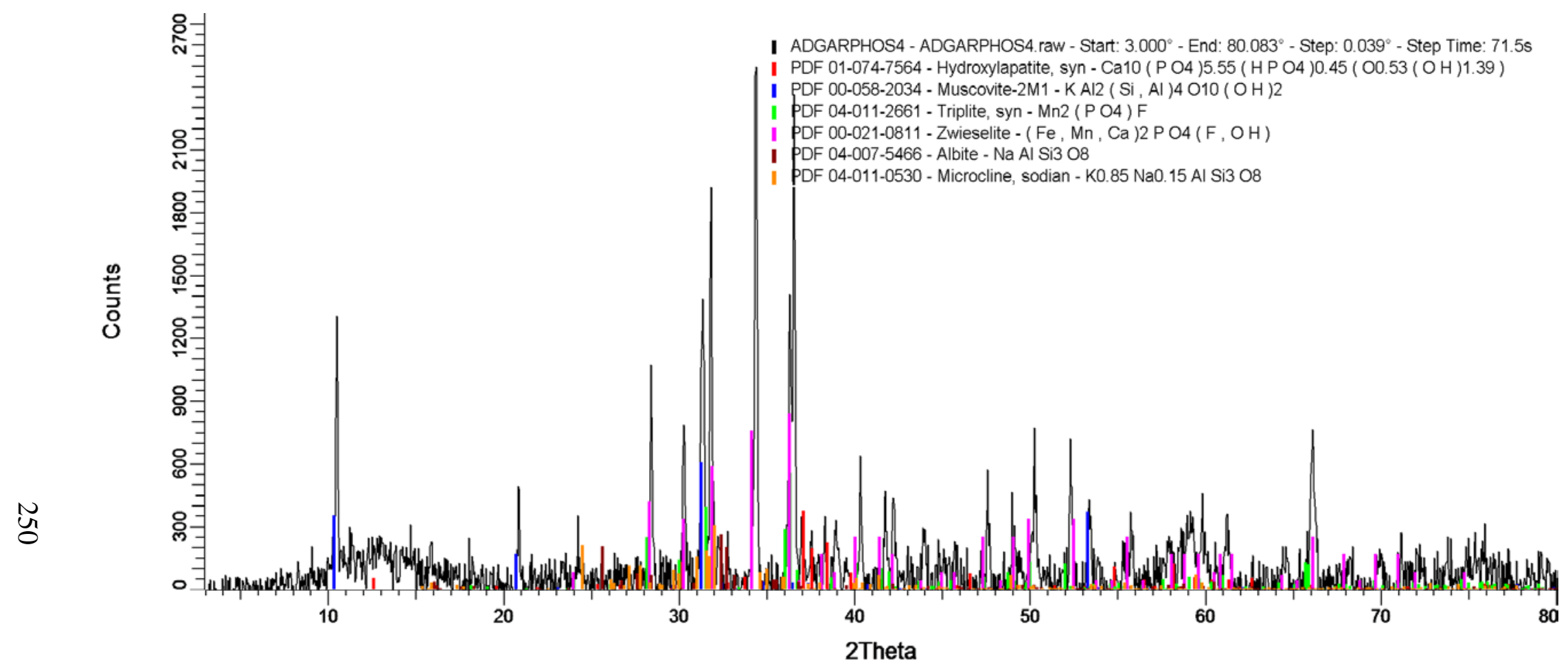




\section{2-GARPHOS-S04}

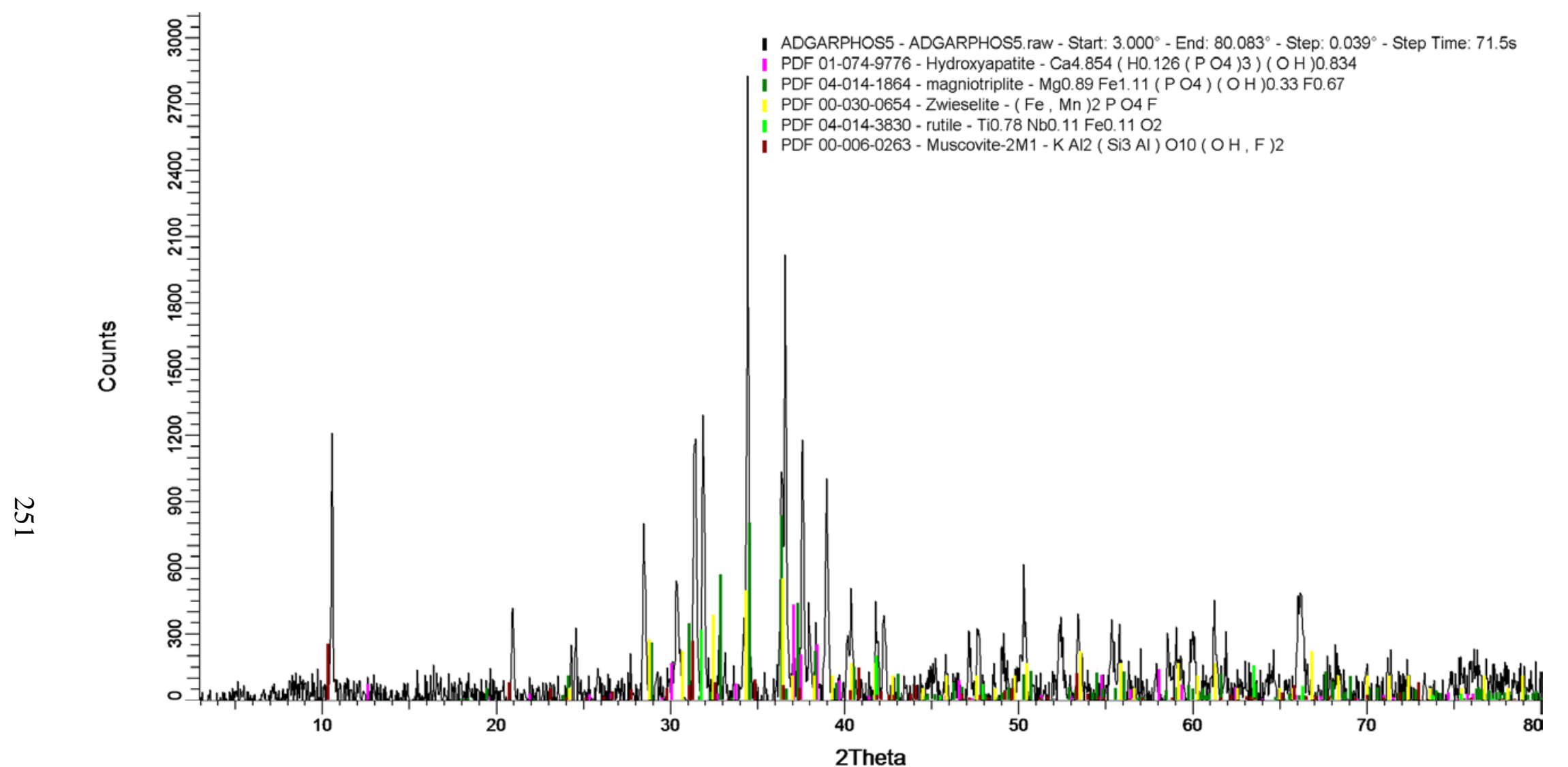

Note: A positive identification of rutile may not be likely; the presence of a related oxide mineral is probable. 


\section{2-LI-S01}

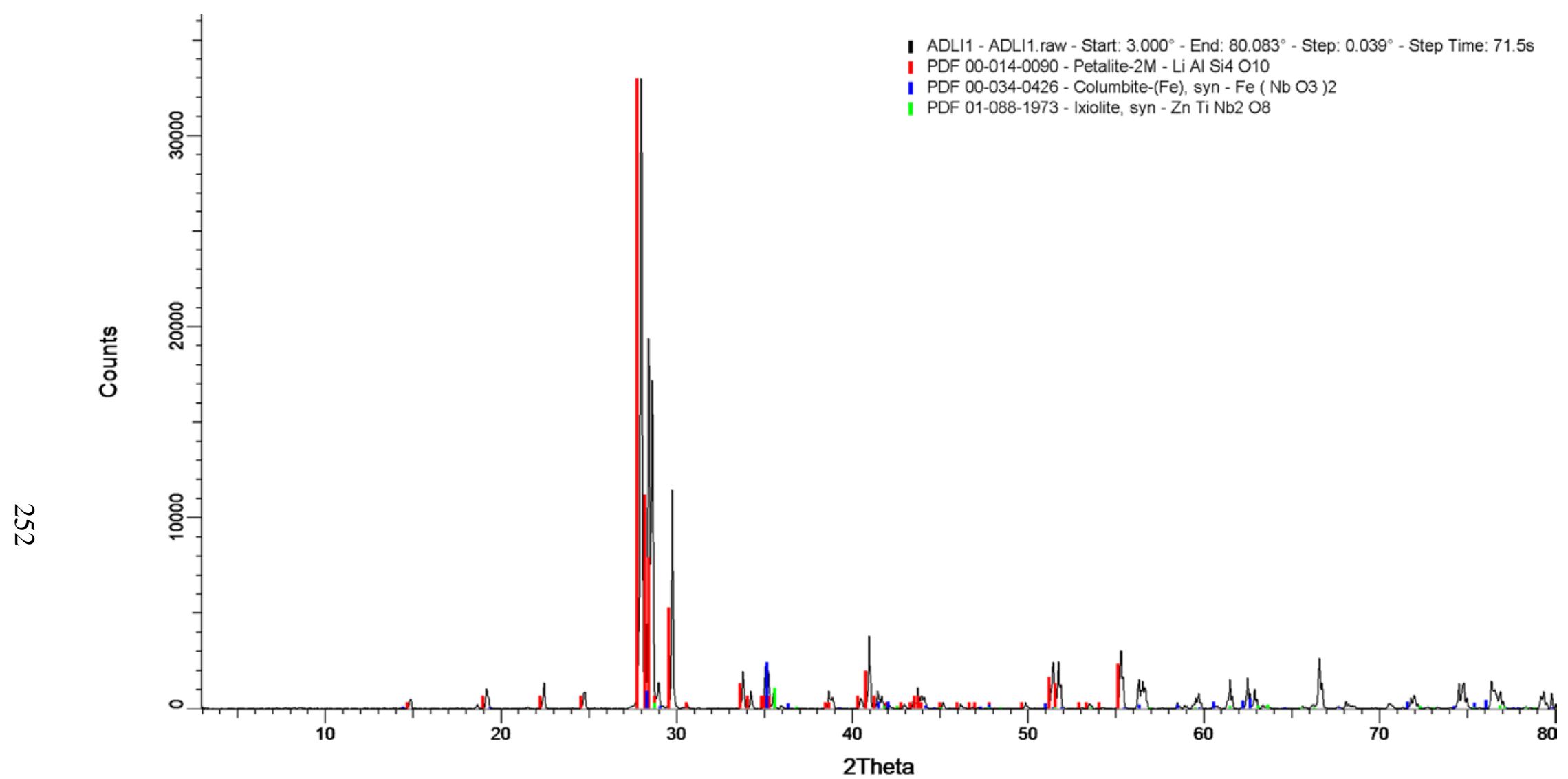

Note: A positive identification of columbite and ixiolite are unlikely; a related oxide might be responsible for the peaks beyond the upper angles for the petalite pattern. 
12-LI-S01

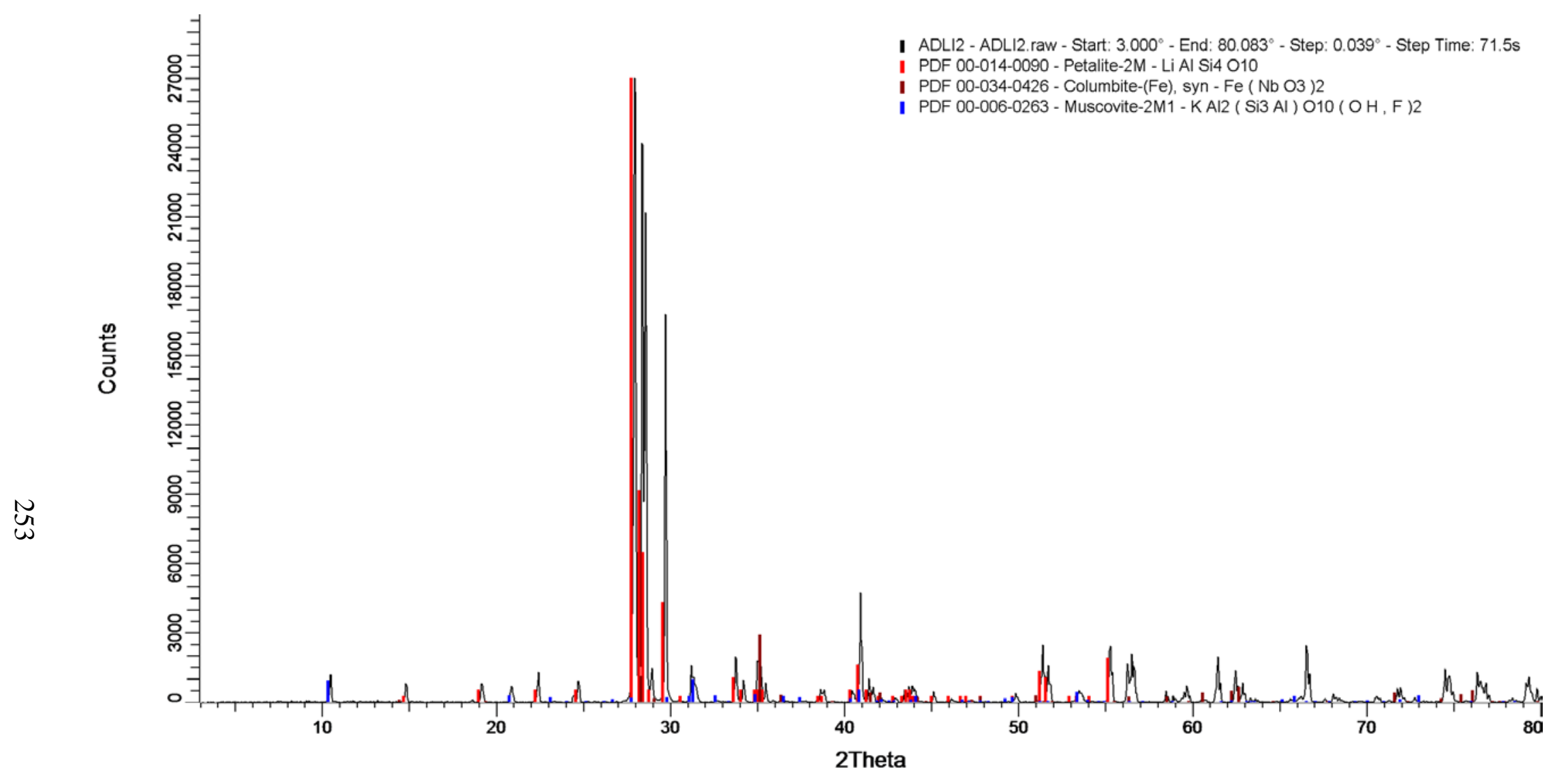

Note: A positive identification of columbite is unlikely; a related oxide might be responsible for the peaks in the not matched by the petalite or muscovite patterns. 
12-LI2-S03

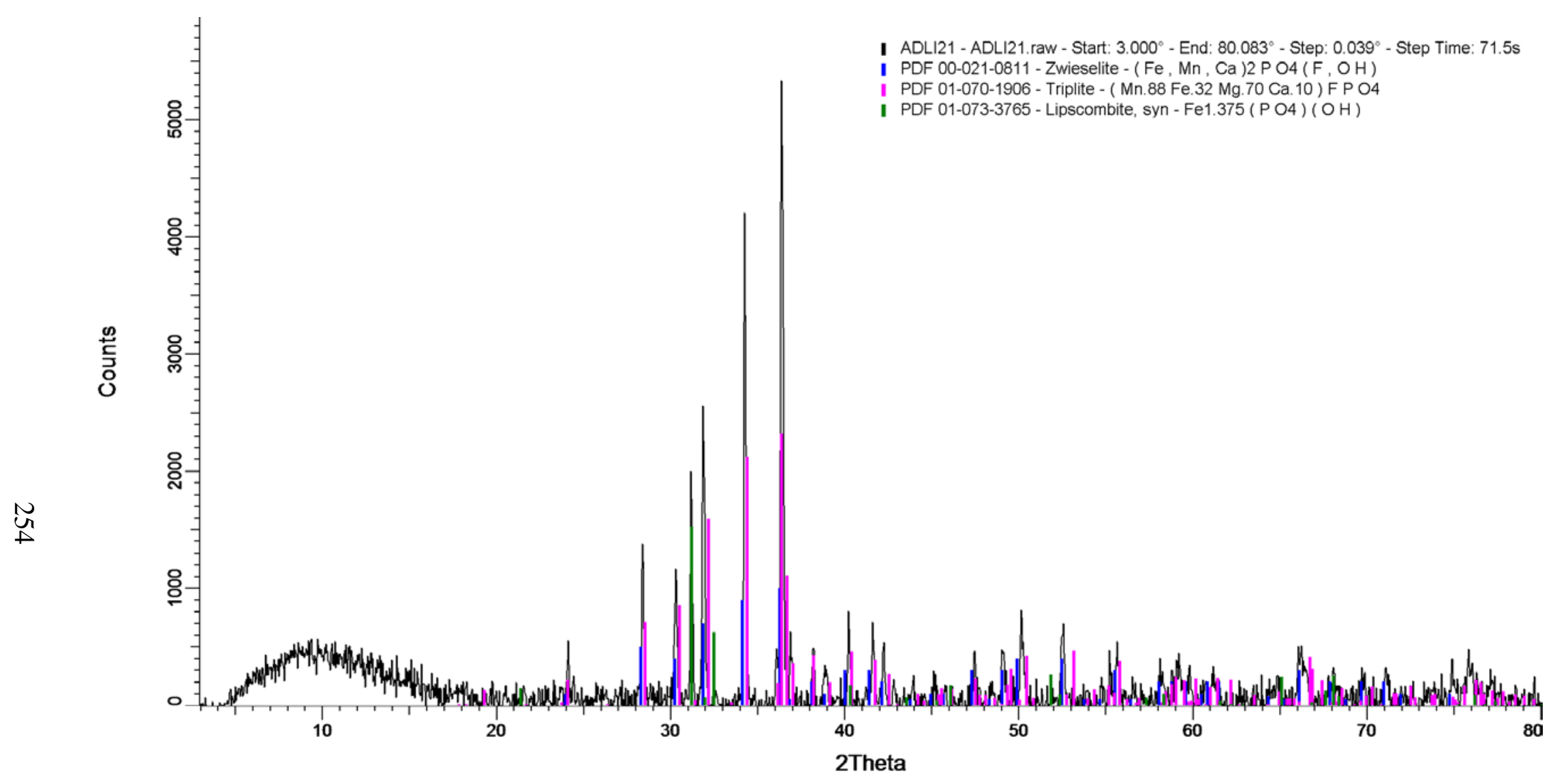


12-LI2-S03

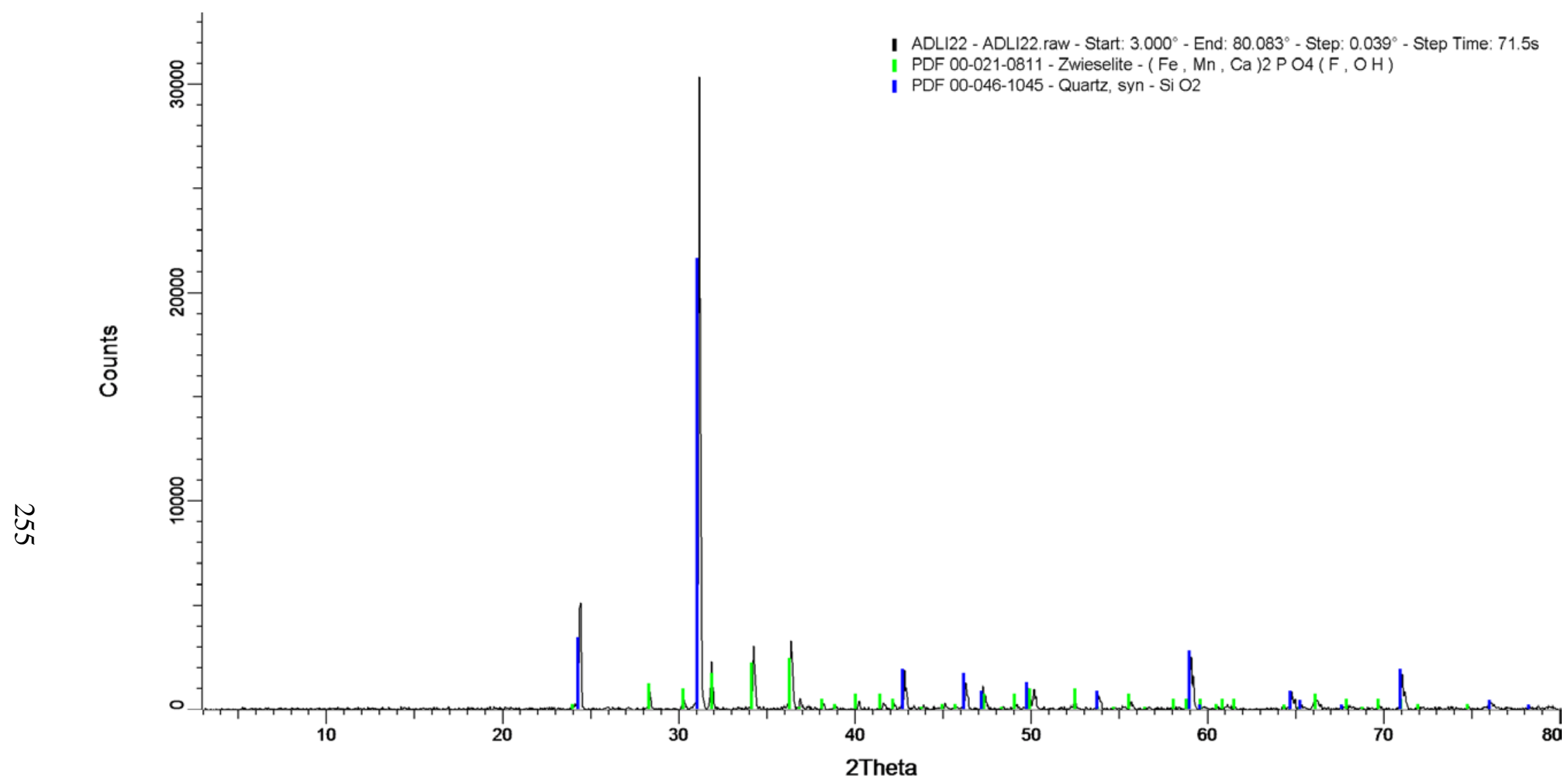


12-LI2-S01

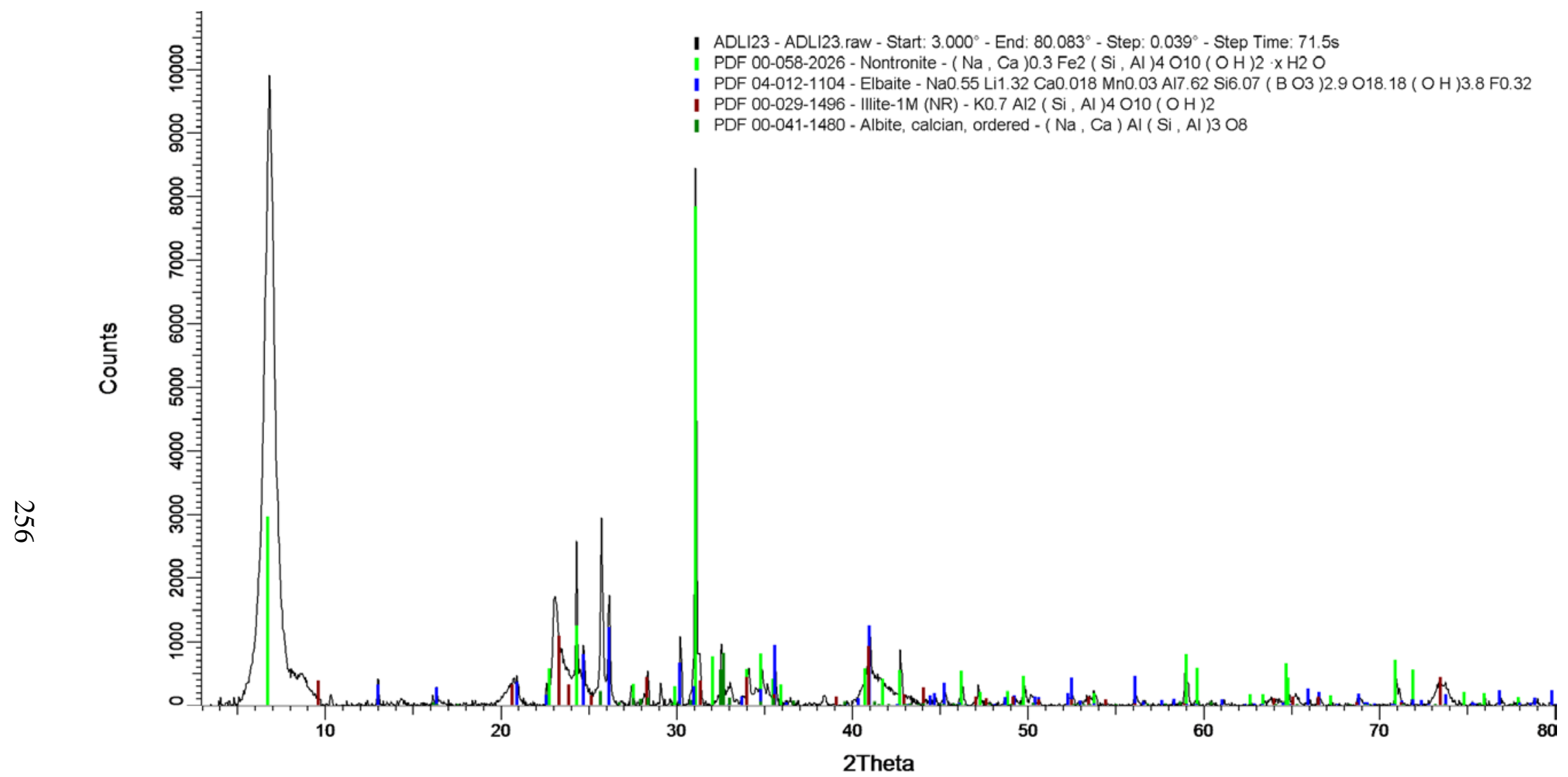

Note: A positive identification for nontronite and illite are not probable with powder XRD smear mounts; the presence of an unidentified $15 \AA$ clay is extremely likely. Future examination of the sample with powder XRD should ensure the sample is glycolated to get a better pattern. 


\section{2-LI2-S02 (intermediate zone)}

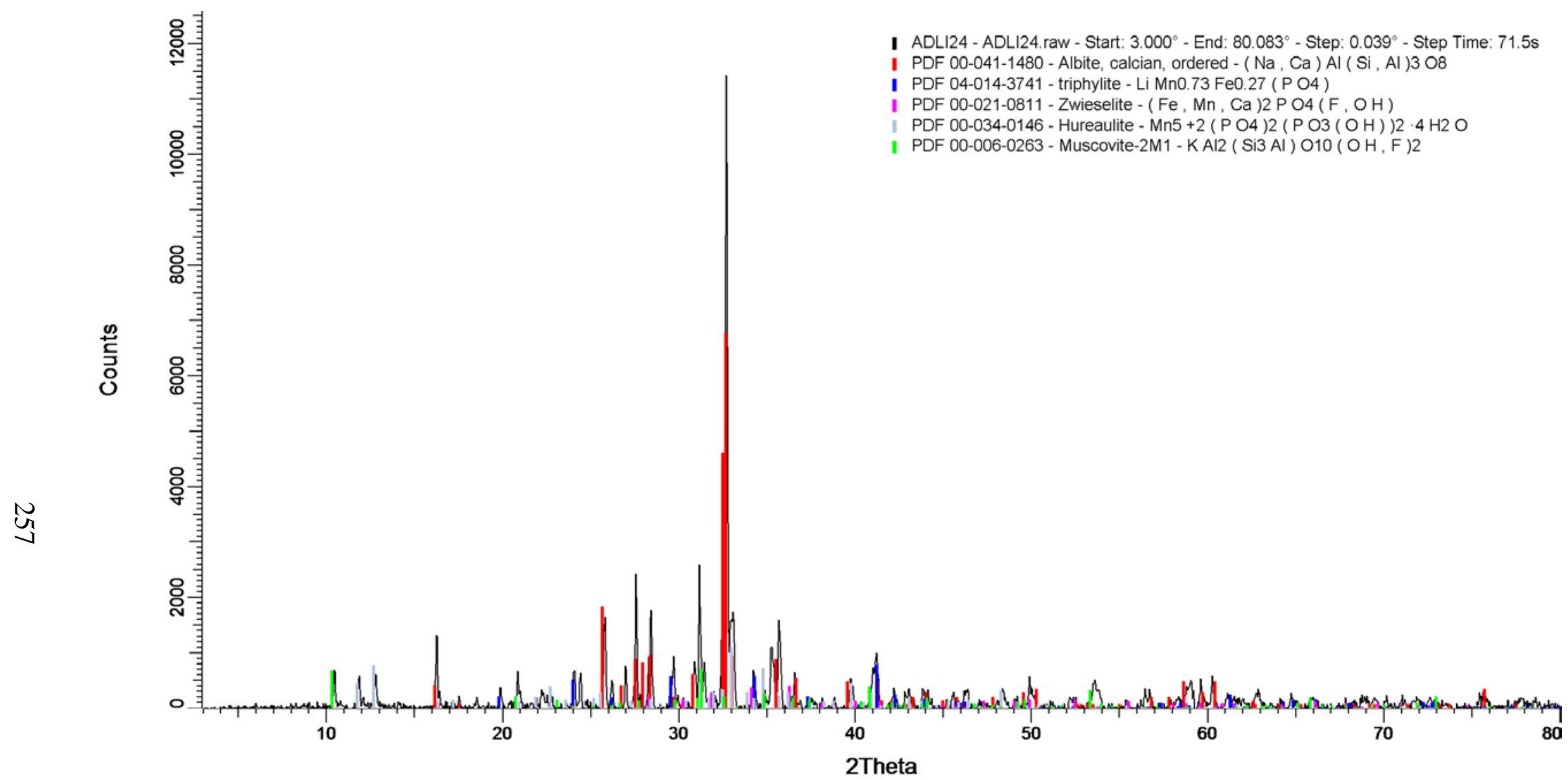




\section{2-SIMPLE16-S01}

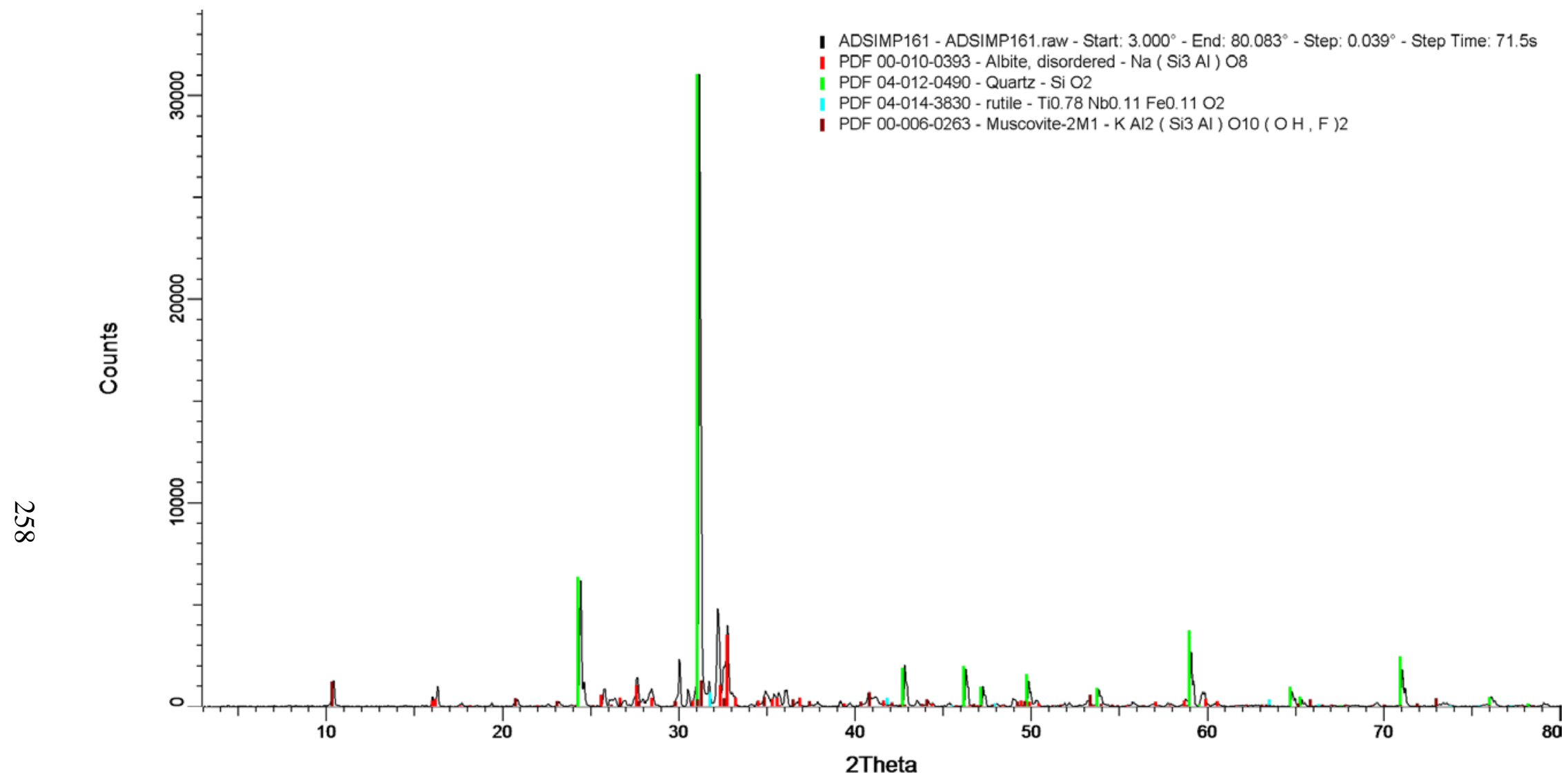

Note: A positive identification of rutile may not be likely; the presence of a related oxide mineral is probable. 
12-TOURMUS-S01

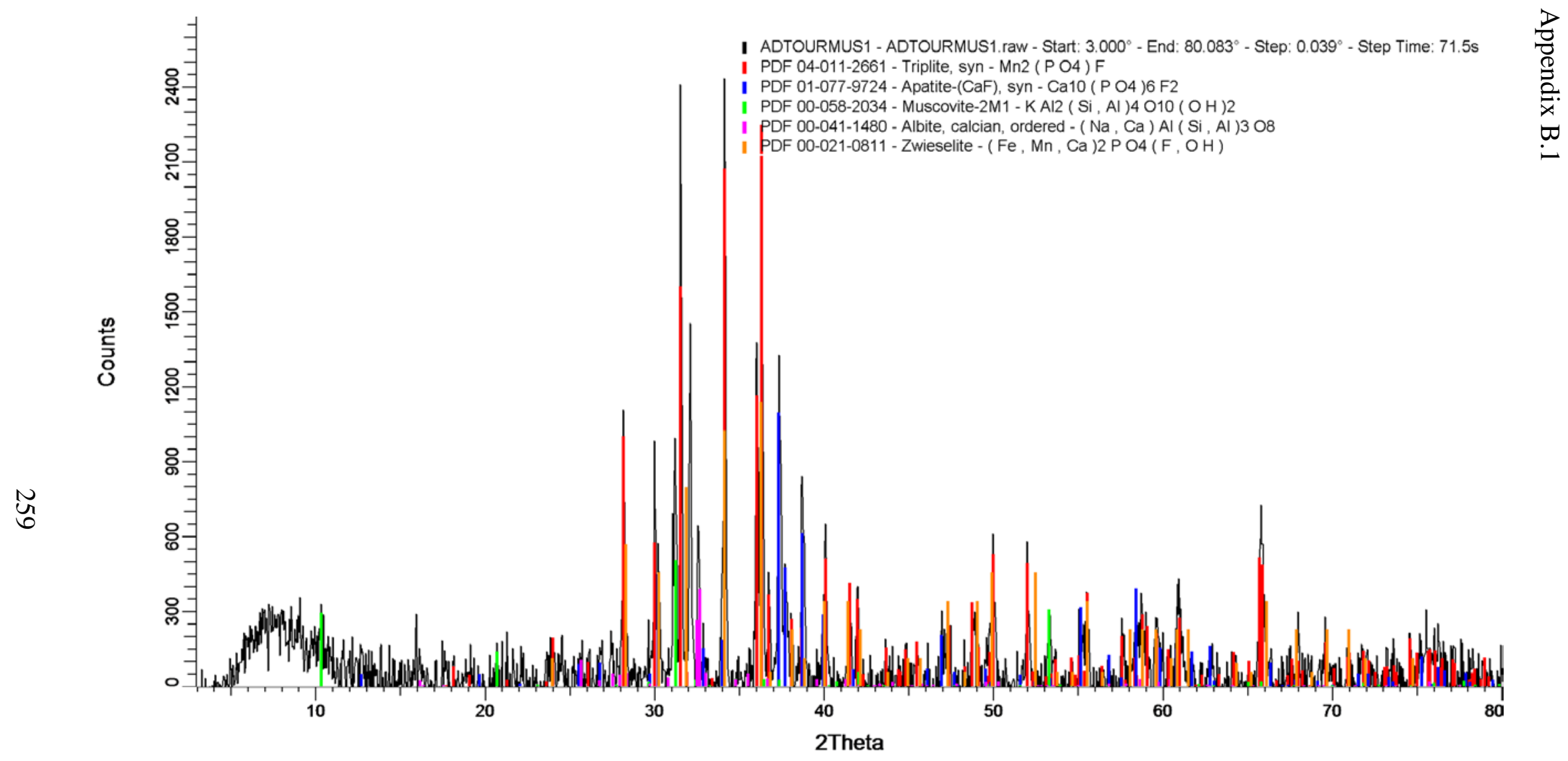




\section{B.2 Single-Crystal X-Ray Diffraction}

The single-crsytal X-ray diffraction experiment for the positive identification of secondary beryl was performed using a Bruker APEX-II CCD diffractometer at 296.15 K. The structure was solved using Olex2 with the solution program olex2.solve utilizing charge flipping; subsequent refinement was carried out with the olex2.refine refinement package using GaussNewton minimization (Dolomanov et al. 2009, Bourhis et al. 2011a, \& Bourhis et al. 2011b). During the refinement process, $\mathrm{O}$ atoms were used to denote the possible locations of molecules and cations residing in the channel sites. Settings used in Olex2 prevented the use of cations from being used in the structure model. The experimental details and results can be seen below. The structural results correspond with EMP analyses 22be-1, 22be-2, and 22be-3.

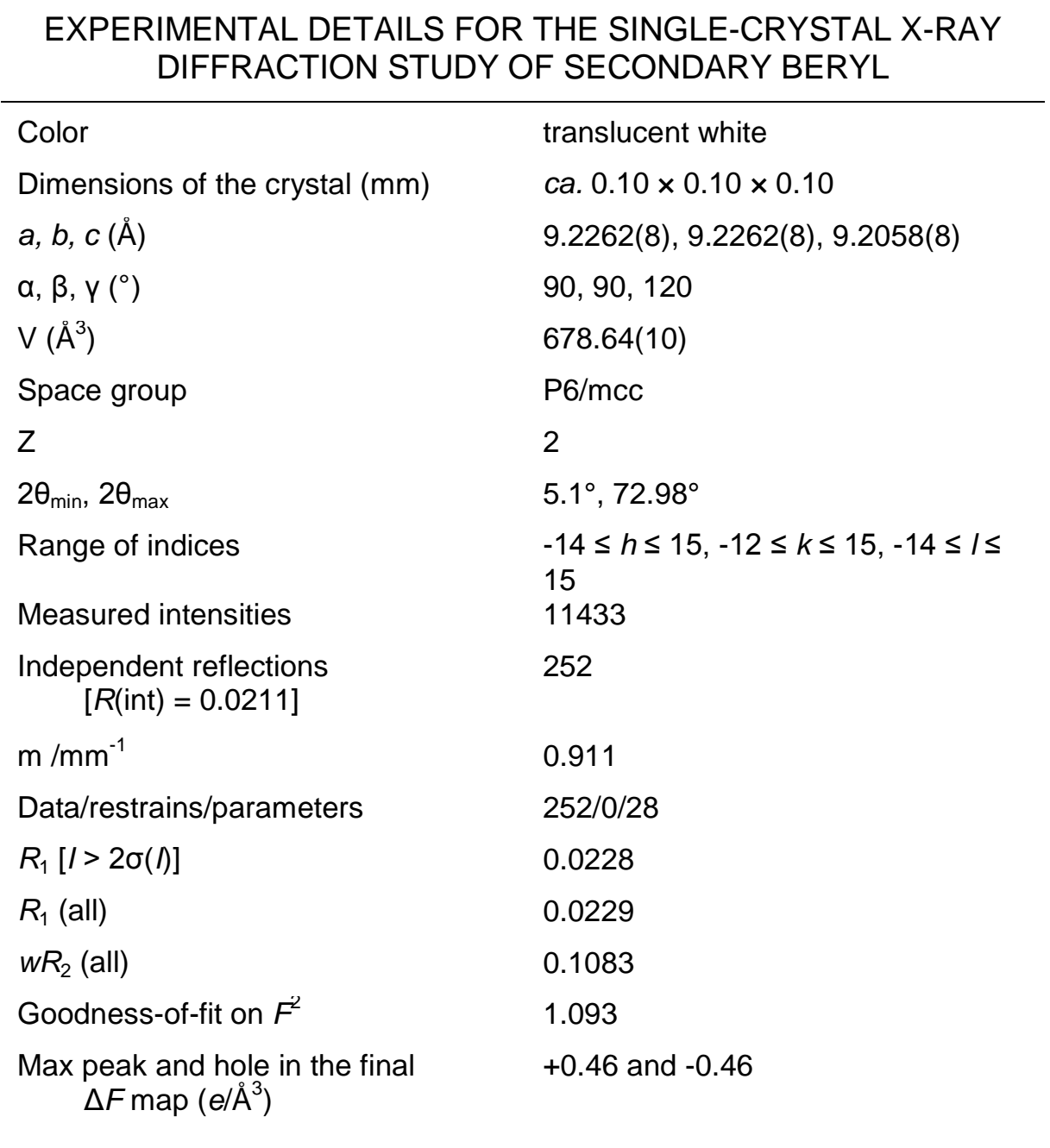


FINAL FRACTIONAL COORDINATES AND DISPLACEMENT PARAMETERS $\left(\AA^{2}\right)$ OF ATOMS IN SECONDARY BERYL

\begin{tabular}{|c|c|c|c|c|c|c|c|c|c|c|}
\hline Site & $x$ & $y$ & $z$ & $U_{11}$ & $U_{22}$ & $U_{33}$ & $U_{12}$ & $U_{13}$ & $U_{23}$ & $U_{\text {eq }}$ \\
\hline $\mathrm{Be}$ & 0 & 0.5 & 0.75 & $0.0015(16)$ & $0.0016(12)$ & $0.0078(16)$ & $0.0008(8)$ & -0 & 0 & $0.0036(8)$ \\
\hline $\mathrm{Al}$ & 0.333333 & 0.666667 & 0.75 & $0.0079(5)$ & $0.0079(5)$ & $0.0079(8)$ & $0.0039(3)$ & -0 & 0 & $0.0079(5)$ \\
\hline Si & $0.11598(6)$ & $0.38791(6)$ & 0.5 & $0.0035(6)$ & $0.0037(5)$ & $0.0037(6)$ & $0.0018(3)$ & -0 & 0 & $0.0036(5)$ \\
\hline O1 & $0.23657(16)$ & $0.3099(2)$ & 0.5 & $0.0068(9)$ & $0.0069(8)$ & $0.0078(9)$ & $0.0044(6)$ & -0 & 0 & $0.0067(5)$ \\
\hline $\mathrm{O} 2$ & $0.14596(15)$ & $0.49910(14)$ & $0.64521(12)$ & $0.0053(5)$ & $0.0060(7)$ & $0.0055(7)$ & $0.0028(4)$ & $0.0013(4)$ & $0.001(4)$ & $0.0056(5)$ \\
\hline $\mathrm{O}\left(\mathrm{H}_{2} \mathrm{O}\right)$ & 0 & 0 & 0.75 & - & - & - & - & - & - & $0.0033(5)$ \\
\hline $\mathrm{O}(\mathrm{Na})$ & 0 & 0 & 0.5 & - & - & - & - & - & - & $0.0160(20)$ \\
\hline
\end{tabular}



SECONDARY BERYL

\begin{tabular}{|c|c|c|c|}
\hline $\mathrm{Al}-\mathrm{O} 2^{3}$ & $1.9070(12)$ & $\mathrm{O} 2-\mathrm{Al}-\mathrm{O} 2^{3}$ & $170.48(7)$ \\
\hline $\mathrm{Al}-\mathrm{O} 2$ & $1.9070(12)$ & $\mathrm{O} 2^{4}-\mathrm{Al}-\mathrm{O} 2^{3}$ & $90.81(7)$ \\
\hline $\mathrm{Al}-\mathrm{O} 2^{4}$ & $1.9070(12)$ & $\mathrm{O} 2^{4}-\mathrm{Al}-\mathrm{O} 2$ & $96.67(4)$ \\
\hline $\mathrm{Al}-\mathrm{O} 2^{5}$ & $1.9070(12)$ & $\mathrm{O} 2^{5}-\mathrm{Al}-\mathrm{O} 2^{3}$ & $76.55(7)$ \\
\hline $\mathrm{Al}-\mathrm{O} 2^{6}$ & $1.9070(12)$ & $\mathrm{O} 2^{5}-\mathrm{Al}-\mathrm{O} 2$ & $96.67(4)$ \\
\hline $\mathrm{Al}-\mathrm{O} 2^{\prime}$ & $1.9070(12)$ & $\mathrm{O} 2^{5}-\mathrm{Al}-\mathrm{O} 2^{4}$ & $96.67(4)$ \\
\hline Si - O1 & $1.5989(14)$ & $\mathrm{O} 2^{6}-\mathrm{Al}-\mathrm{O} 2^{3}$ & $96.67(4)$ \\
\hline $\mathrm{Si}-\mathrm{O} 1^{1}$ & $1.6005(13)$ & $\mathrm{O} 2^{6}-\mathrm{Al}-\mathrm{O} 2$ & $90.81(7)$ \\
\hline $\mathrm{Si}-\mathrm{O} 2^{2}$ & $1.6223(12)$ & $\mathrm{O} 2^{6}-\mathrm{Al}-\mathrm{O} 2^{4}$ & $76.55(7)$ \\
\hline $\mathrm{Si}$ - O2 & $1.6223(12)$ & $\mathrm{O} 2^{6}-\mathrm{Al}-\mathrm{O} 2^{5}$ & $170.48(7)$ \\
\hline \multirow[t]{19}{*}{$\mathrm{Be}-\mathrm{O} 2^{8}$} & $1.6599(11)$ & $\mathrm{O} 2^{7}-\mathrm{Al}-\mathrm{O} 2^{3}$ & $96.67(4)$ \\
\hline & & $\mathrm{O} 2^{7}-\mathrm{Al}-\mathrm{O} 2$ & $76.55(7)$ \\
\hline & & $\mathrm{O} 2^{\prime}-\mathrm{Al}-\mathrm{O} 2^{4}$ & $170.48(7)$ \\
\hline & & $\mathrm{O} 2^{7}-\mathrm{Al}-\mathrm{O} 2^{5}$ & $90.81(7)$ \\
\hline & & $\mathrm{O} 2^{7}-\mathrm{Al}-\mathrm{O} 2^{6}$ & $96.67(4)$ \\
\hline & & $\mathrm{O} 2^{2}-\mathrm{Si}-\mathrm{O} 1$ & $110.34(6)$ \\
\hline & & $\mathrm{O} 2^{2}-\mathrm{Si}-\mathrm{O}^{1}$ & 108.56(6) \\
\hline & & O2 - Si - O1 & $110.34(6)$ \\
\hline & & $\mathrm{O} 2-\mathrm{Si}-\mathrm{O} 1^{1}$ & $108.56(6)$ \\
\hline & & $\mathrm{O} 2-\mathrm{Si}-\mathrm{O}^{2}$ & $110.97(8)$ \\
\hline & & $\mathrm{Al}^{3}-\mathrm{O} 2-\mathrm{Si}^{2}$ & $136.74(7)$ \\
\hline & & $\mathrm{Be}^{8}-\mathrm{O} 2-\mathrm{Si}^{2}$ & $126.85(8)$ \\
\hline & & $\mathrm{Be}^{8}-\mathrm{O} 2-\mathrm{Al}^{3}$ & $96.36(5)$ \\
\hline & & $\mathrm{O} 2-\mathrm{Be}-\mathrm{O} 2^{8}$ & $131.51(8)$ \\
\hline & & $\mathrm{O} 2^{9}-\mathrm{Be}-\mathrm{O} 2^{8}$ & $90.73(8)$ \\
\hline & & $\mathrm{O} 2^{9}-\mathrm{Be}-\mathrm{O} 2$ & 108.93(9) \\
\hline & & $\mathrm{O} 2^{7}-\mathrm{Be}-\mathrm{O} 2^{8}$ & $108.93(9)$ \\
\hline & & $\mathrm{O} 2^{\prime}-\mathrm{Be}-\mathrm{O} 2$ & $90.73(8)$ \\
\hline & & $\mathrm{O} 2^{7}-\mathrm{Be}-\mathrm{O} 2^{9}$ & 131.51(8) \\
\hline
\end{tabular}

Note: Symmetry transformations are used to generate equivalent atoms ${ }^{1}-y+x,+x,+z ;{ }^{2}+x,+y, 1-z ;{ }^{3} 1-y, 1-x$, $3 / 2-z ;{ }^{4} 1-y, 1+x-y,+z ;{ }^{5}+y-x, 1-x,+z ;{ }^{6}+y-x,+y, 3 / 2-z ;{ }^{7}+x$, $1+x-y, 3 / 2-z ;{ }^{8}-x,-x+y, 3 / 2-z ;{ }^{9}-x, 1-y,+z$. 


\section{Appendix C EMPA Methods}

\section{C.1 Tourmaline and Topaz}

Electron microprobe analyses of tourmaline (except for those containing $\mathrm{Bi}$ ) and for topaz were done on a fully automated CAMECA SX-50 instrument operating in the wavelengthdispersion mode with the following operating conditions: excitation voltage, $15 \mathrm{kV}$; beam current, 20 nA; peak count time, 20 s (40 s for F and Cl); background count-time, 10 s (20 s for F and $\mathrm{Cl}$ ); spot diameter, $5 \mu \mathrm{m}$. Data reduction was done using the 'PAP' $\phi(\rho \mathrm{Z})$ method (Pouchou \& Pichoir 1985). B was fixed at the nominal value (3.25 wt. \%). For the elements considered, the following standards, X-ray lines, and crystals were used: synthetic fluorophlogopite, $\mathrm{FK}_{\alpha}$, TAP; albite, $\mathrm{NaK}_{\alpha}$, TAP; kyanite, $\mathrm{Al} K_{\alpha}$, TAP; diopside, $\mathrm{MgK}_{\alpha}$, TAP; diopside, $\mathrm{Si}_{\alpha}$, TAP; scapolite, $\mathrm{ClK}_{\alpha}$, PET; orthoclase, $\mathrm{KK}_{\alpha}$, PET; diopside, $\mathrm{Ca} K_{\alpha}$, PET; rutile, Ti $K_{\alpha}$, PET; synthetic magnesiochromite, $\mathrm{Cr} K_{\alpha}$, LIF; synthetic rhodonite, $\mathrm{MnK}_{\alpha}$, LIF; synthetic fayalite, Fe $K_{\alpha}$, LIF; gahnite, $\mathrm{Zn} K_{\alpha}$, LIF.

EMP analyses of tourmaline containing Bi were done on a CAMECA SX-100 instrument operating the wavelength dispersion mode with the following operating conditions: excitation voltage, $15 \mathrm{kV}$; beam current, $20 \mathrm{nA}$; peak count time, $20 \mathrm{~s}$ (30 s for F); background count-time, $10 \mathrm{~s}$ (15 s for F); spot diameter, $5 \mu \mathrm{m}$. B was fixed at a value of $3.11 \mathrm{wt} \%$. For the elements considered, the following standards, X-ray lines, and crystals were used: F-riebeckite, $\mathrm{FK}_{\alpha}$, LTAP; albite, $\mathrm{NaK}_{\alpha}$, TAP; andalusite, $\mathrm{Al} K_{\alpha}$, TAP; olivine, $\mathrm{MgK}_{\alpha}$, LTAP; diopside, $\mathrm{Si} K_{\alpha}$, TAP; tugtuphite, $\mathrm{ClK}_{\alpha}$, LPET; orthoclase, $\mathrm{KK}_{\alpha}$, LPET; diopside, $\mathrm{Ca}_{\alpha}$, LPET; sphene, $\mathrm{Ti} K_{\alpha}$, LPET; chromite, $\mathrm{CrK}_{\alpha}$, LLIF; spessartine, $\mathrm{MnK}_{\alpha}$, LLIF; fayalite, FeK ${ }_{\alpha}$, LLIF; gahnite, ZnK $K_{\alpha}$, LLIF; $\mathrm{Bi}_{2} \mathrm{O}_{3}, \mathrm{Bi} M_{\alpha}$, LPET. 


\section{C.2 K-Feldspar, Muscovite, Lepidolite, and Biotite}

EMP analyses K-feldspar, muscovite, lepidolite, and biotite were done on a CAMECA SX100 instrument, operating the wavelength dispersion mode with the following operating conditions: excitation voltage, $15 \mathrm{kV}$; beam current, $20 \mathrm{nA}$; peak count time, $20 \mathrm{~s}$ (30 s for F); background count-time, $10 \mathrm{~s}$ (15 s for F); spot diameter, $10 \mu \mathrm{m}$. For the elements considered, the following standards, X-ray lines, and crystals were used: F-riebeckite, $\mathrm{FK}_{\alpha}$, LTAP; albite, $\mathrm{Na} K_{\alpha}$, TAP; olivine, $\mathrm{MgK}_{\alpha}$, LTAP diopside, $\mathrm{Si}_{\alpha}$, TAP; andalusite, $\mathrm{Al} K_{\alpha}$, TAP; orthoclase, $\mathrm{KK}_{\alpha}$, LPET; diopside, $\mathrm{CaK}_{\alpha}$, LPET; $\mathrm{SrTiO}_{3}, \mathrm{SrL}_{\alpha}$, LPET; apatite, $\mathrm{PK}{ }_{\alpha}$, LPET; pollucite, CsL $L_{\alpha}$, LPET; fayalite, FeK $K_{\alpha}$, LLIF; spessartine, $\mathrm{MnK} K_{\alpha}$, LLIF; sphene, TiK $\alpha_{\alpha}$, LLIF; $\mathrm{Ba}_{2} \mathrm{NaNb}_{5} \mathrm{O}_{15}, \mathrm{Ba}_{\beta}$, LLIF; gahnite, $\mathrm{Zn} K_{\alpha}$, LLIF; PbTe, $\mathrm{Pb}_{\beta}$, LPET; Rb-leucite, $\mathrm{Rb} L_{\alpha}$, LTAP.

\section{C.3 Garnet and Sekaninaite}

EMP analyses of garnet and cordierite were done on a fully automated CAMECA SX-50 instrument, operating in the wavelength-dispersion mode with the following operating conditions: excitation voltage, $15 \mathrm{kV}$; beam current, $20 \mathrm{nA}$; peak count time, $20 \mathrm{~s}$; background count-time, $10 \mathrm{~s}$; spot diameter, $5 \mu \mathrm{m}$. Data reduction was done using the 'PAP' $\phi(\rho Z)$ method (Pouchou \& Pichoir 1985). For the elements considered, the following standards, X-ray lines and crystals were used: albite, $\mathrm{NaK}_{\alpha}$, TAP; almandine, $\mathrm{MgK}_{\alpha}$, TAP; almandine, $\mathrm{AlK}_{\alpha}$, TAP; almandine, $\mathrm{Si} K_{\alpha}$, TAP; orthoclase, $\mathrm{KK}_{\alpha}$, PET; apatite, $\mathrm{P} K_{\alpha}$, PET; rutile, Ti $K_{\alpha}$, PET; grossular, $\mathrm{Ca}_{\alpha}$, PET; magnesiochromite, $\mathrm{Cr} K_{\alpha}$, LIF; synthetic rhodonite, $\mathrm{MnK}_{\alpha}$, LIF; almandine, Fe $K_{\alpha}$, LIF. 


\section{C.4 Beryl, Bertrandite, and Chrysoberyl}

EMP analyses of beryl, bertrandite, and chrysoberyl were done on a fully automated CAMECA SX-50 instrument operating in the wavelength-dispersion mode with the following operating conditions: excitation voltage, $15 \mathrm{kV}$; beam current, $20 \mathrm{nA}$, peak count time, 50s, background count-time, 25s ( $\mathrm{Na}, \mathrm{Al}$, Si peak count time, 20s, background count-time, 10s); spot diameter (standards and specimen), $10 \mu \mathrm{m}$. Data reduction was done using the 'PAP' $\phi(\rho \mathrm{Z})$ method (Pouchou \& Pichoir 1985). For the elements considered, the following standards, X-ray lines, and crystals were used: albite, $\mathrm{Na}_{\alpha}, \mathrm{Al} K_{\alpha}, \mathrm{Si} K_{\alpha}$, TAP; diopside, $\mathrm{MgK}_{\alpha}$, TAP; diopside, $\mathrm{Ca} K_{\alpha}$, PET; orthoclase, $\mathrm{KK}_{\alpha}$, PET; elemental Sc, Sc $K_{\alpha}$, PET; rutile, Ti $K_{\alpha}$, PET; elemental V, $\mathrm{VK} K_{\alpha}$, PET; synthetic magnesiochromite, $\mathrm{Cr}_{\alpha}$, LIF; synthetic rhodonite, MnK $K_{\alpha}$, LIF; synthetic fayalite, $\mathrm{Fe} K_{\alpha}$, LIF; pollucite, $\mathrm{Cs} L_{\alpha}$, PET.

\section{C.5 Columbite-Tantalite, Rutile, Cassiterite, Wolframite, and Qitianlingite}

EMP analyses of columbite-tantalite, rutile, cassiterite, wolframite, and qitianlingite were done on a CAMECA SX-100 instrument, operating the wavelength dispersion mode with the following operating conditions: excitation voltage, $15 \mathrm{kV}$; beam current, $20 \mathrm{nA}$; peak count time, $20 \mathrm{~s}$ (10 s for Th, $30 \mathrm{~s}$ for F); background count-time, $10 \mathrm{~s}$ (15 s for F); spot diameter, 10

$\mu \mathrm{m}$. For the elements considered, the following standards, X-ray lines, and crystals were used: apatite, $\mathrm{F} K_{\alpha}$, LTAP, LPC0; albite, $\mathrm{Na} K_{\alpha}$, TAP; olivine, $\operatorname{Mg} K_{\alpha}$, LTAP; diopside, $\mathrm{Si}_{\alpha}$, TAP; andalusite, $\mathrm{Al} K_{\alpha}$, TAP; diopside, $\mathrm{Ca}_{\alpha}$, LPET; fayalite, Fe $K_{\alpha}$, LLIF; spessartine, $\mathrm{Mn} K_{\alpha}$, LLIF; sphene, $\mathrm{TiK}_{\alpha}, \mathrm{LPET}$; $\mathrm{ScPO}_{4}, \mathrm{ScK}_{\alpha}$, LPET; cobalt, $\mathrm{AsL}_{\alpha}$, TAP; $\mathrm{YPO}_{4}, \mathrm{YL}_{\alpha}$, LPET; $\mathrm{Ba}_{2} \mathrm{NaNb}_{5} \mathrm{O}_{15}$, $\mathrm{Nb} L_{\alpha}$, LPET; $\mathrm{SnO}_{2}, \mathrm{SnL}_{\alpha}$, LPET; stibiotantalite, $\mathrm{Sb} L_{\alpha}$, LPET; $\mathrm{LaPO}_{4}, \mathrm{La}_{\alpha}$, LLIF; $\mathrm{CePO}_{4}, \mathrm{CeL}_{\alpha}$, LLIF; $\mathrm{PrPO}_{4}, \mathrm{PrL}_{\beta}$, LLIF; $\mathrm{NdPO}_{4}, \mathrm{NdL}_{\beta}$, LLIF; $\mathrm{SmPO}_{4}, \mathrm{SmL}_{\beta}$, LLIF; $\mathrm{EuPO}_{4}, \mathrm{EuL}_{\beta}, \mathrm{LLIF}$; $\mathrm{GdPO}_{4}, \mathrm{Gd}_{\beta}$, LLIF; TbPO ${ }_{4}, \mathrm{~Tb} L_{\alpha}$, LLIF; $\mathrm{DyPO}_{4}, \mathrm{Dy}_{\beta}$, LLIF; HoPO ${ }_{4}, \mathrm{HoL}_{\beta}$, LLIF; $\mathrm{ErPO}_{4}$, $\mathrm{ErL}_{\alpha}$, LLIF; $\mathrm{TmPO}_{4}, \mathrm{Tm} L_{\alpha}$, LLIF; $\mathrm{YbPO}_{4}, \mathrm{YbM}_{\alpha}$, TAP; $\mathrm{MnNb}_{2} \mathrm{Ta}_{2} \mathrm{O}_{9}, \mathrm{Ta}_{\alpha}, \mathrm{TAP} ; \mathrm{CaWO}_{4}$, $\mathrm{WM}_{\alpha}$, LPET; $\mathrm{Bi}_{2} \mathrm{O}_{3}, \mathrm{Bi}_{\alpha}$, LPET; $\mathrm{ThO}_{2}$, ThM $M_{\alpha}$, LPET; $\mathrm{UO}_{2}, \mathrm{UM}_{\alpha}$, LPET; $\mathrm{ZrO}_{2}, \mathrm{ZrL}_{\alpha}$, LPET. 


\section{C.6 Monazite and Xenotime}

EMP analyses of monazite and xenotime were done on a CAMECA SX-100 instrument, operating the wavelength dispersion mode with the following operating conditions: excitation voltage, 15 kV; beam current, 20 nA; peak count time, 20 s (10 s for Th, 30 s for F); background count-time, $10 \mathrm{~s}$ (15 s for F); spot diameter, $1 \mu \mathrm{m}$. For the elements considered, the following standards, X-ray lines, and crystals were used: apatite, FK ${ }_{\alpha}$, LTAP, LPC0; albite, NaK $K_{\alpha}$, TAP; olivine, $\mathrm{MgK}_{\alpha}$, LTAP; diopside, $\mathrm{Si} K_{\alpha}$, TAP; andalusite, $\mathrm{Al} K_{\alpha}$, TAP; orthoclase, $\mathrm{KK}_{\alpha}$, LPET; diopside, $\mathrm{CaK}_{\alpha}$, LPET; apatite, $\mathrm{P} K_{\alpha}$, LPET; fayalite, $\mathrm{Fe}_{\alpha}$, LLIF; spessartine, MnK $K_{\alpha}$, LLIF; sphene, $\mathrm{TiK}_{\alpha}, \mathrm{LPET} \mathrm{ScPO}_{4}, \mathrm{ScK}_{\alpha}$, LPET; cobalt, AsL $L_{\alpha}$, TAP; $\mathrm{YPO}_{4}, \mathrm{YL}_{\alpha}, \mathrm{LPET}$; $\mathrm{Ba}_{2} \mathrm{NaNb}_{5} \mathrm{O}_{15}$, $\mathrm{Nb} L_{\alpha}, \mathrm{LPET} ; \mathrm{SnO}_{2}, \mathrm{Sn} L_{\alpha}, \mathrm{LPET}$; stibiotantalite, $\mathrm{Sb} L_{\alpha}, \mathrm{LPET} ; \mathrm{LaPO}_{4}, \mathrm{LaL}_{\alpha}, \mathrm{LLIF} ; \mathrm{CePO}_{4}, \mathrm{Ce}_{\alpha}$, LLIF; $\mathrm{PrPO}_{4}, \mathrm{Pr}_{\beta}, \mathrm{LLIF} ; \mathrm{NdPO}_{4}, \mathrm{Nd} L_{\beta}$, LLIF; $\mathrm{SmPO}_{4}, \mathrm{Sm}_{\beta}, \mathrm{LLIF} ; \mathrm{EuPO}_{4}, \mathrm{Eu} L_{\beta}, \mathrm{LLIF}$; $\mathrm{GdPO}_{4}, \mathrm{Gd} L_{\beta}$, LLIF; TbPO ${ }_{4}, \mathrm{~Tb} L_{\alpha}$, LLIF; DyPO ${ }_{4}, \mathrm{Dy} L_{\beta}, \mathrm{LLIF} ; \mathrm{HoPO}_{4}, \mathrm{HoL}_{\beta}, \mathrm{LLIF} ; \mathrm{ErPO}_{4}$, $\mathrm{Er}_{\alpha}, \mathrm{LLIF} ; \mathrm{TmPO}_{4}, \mathrm{Tm}_{\alpha}, \mathrm{LLIF} ; \mathrm{YbPO}_{4}, \mathrm{YbM}_{\alpha}$, TAP; $\mathrm{MnNb}_{2} \mathrm{Ta}_{2} \mathrm{O}_{9}, \mathrm{Ta}_{\alpha}$, TAP; $\mathrm{CaWO}_{4}$, $\mathrm{WM}_{\alpha}, \mathrm{LPET} ; \mathrm{Bi}_{2} \mathrm{O}_{3}, \mathrm{Bi}_{\alpha}, \mathrm{LPET} ; \mathrm{ThO}_{2}, \mathrm{Th} M_{\alpha}, \mathrm{LPET} ; \mathrm{UO}_{2}, \mathrm{UM}_{\alpha}$, LPET; $\mathrm{ZrO}_{2}, \mathrm{ZrL}_{\alpha}, \mathrm{LPET}$.

\section{C.7 Zircon}

EMP analyses of monazite and xenotime were done on a CAMECA SX-100 instrument, operating the wavelength dispersion mode with the following operating conditions: excitation voltage, $15 \mathrm{kV}$; beam current, $20 \mathrm{nA}$; peak count time, $20 \mathrm{~s} \mathrm{(10} \mathrm{s} \mathrm{for} \mathrm{Th);} \mathrm{background} \mathrm{count-}$ time, $10 \mathrm{~s}$; spot diameter, $1 \mu \mathrm{m}$. For the elements considered, the following standards, X-ray lines, and crystals were used: diopside, $\mathrm{Si}_{\alpha}$, TAP; andalusite, $\mathrm{Al} K_{\alpha}$, TAP; olivine, $\mathrm{Mg} K_{\alpha}$, LTAP; fayalite, $\mathrm{FeK}_{\alpha}$, LLIF; spessartine, $\mathrm{MnK}_{\alpha}$, LLIF; $\mathrm{ZrO}_{2}, \mathrm{ZrL}_{\alpha}$, LPET; YPO $\mathrm{YPL}_{\alpha}$, LPET; sphene, TiK $K_{\alpha}$, LPET; $\mathrm{ScPO}_{4}, \mathrm{ScK}_{\alpha}$, LPET; $\mathrm{LaPO}_{4}, \mathrm{LaL}_{\alpha}$, LLIF; $\mathrm{CePO}_{4}, \mathrm{Ce}_{\alpha}, \mathrm{LLIF}_{\mathrm{PrPO}}$, $\operatorname{Pr} L_{\beta}$, LLIF; $\mathrm{NdPO}_{4}, \mathrm{Nd}_{\beta}, \mathrm{LLIF} ; \mathrm{SmPO}_{4}, \mathrm{Sm} L_{\beta}$, LLIF; $\mathrm{EuPO}_{4}, \mathrm{Eu} L_{\beta}, \mathrm{LLIF} ; \mathrm{GdPO}_{4}, \mathrm{Gd} L_{\beta}, \mathrm{LLIF}$; $\mathrm{TbPO}_{4}, \mathrm{~Tb}_{\alpha}, \mathrm{LLIF}_{\mathrm{DyPO}}, \mathrm{Dy}_{\beta}, \mathrm{LLIF}_{\mathrm{H}} \mathrm{HoPO}_{4}, \mathrm{HoL}_{\beta}, \mathrm{LLIF} ; \mathrm{ErPO}_{4}, \mathrm{ErL}_{\alpha}, \mathrm{LLIF}_{\mathrm{TmPO}}$, $\mathrm{Tm}_{\alpha}, \mathrm{LLIF} ; \mathrm{YbPO}_{4}, \mathrm{YbM}_{\alpha}, \mathrm{TAP} ; \mathrm{Bi}_{2} \mathrm{O}_{3}, \mathrm{Bi} M_{\alpha}$, LPET; $\mathrm{ThO}_{2}, \mathrm{Th}_{\alpha}, \mathrm{LPET} ; \mathrm{UO}_{2}, \mathrm{UM}_{\alpha}, \mathrm{LPET}$; $\mathrm{HfSiO}_{4}, \mathrm{HfL}_{\alpha}$, LLIF; PbTe, PbM ${ }_{\beta}$, LPET. 


\section{Appendix D EMPA Results}

Appendix D.1: Electron-microprobe analyses of tourmaline.

\begin{tabular}{|c|c|c|c|c|c|c|c|c|c|c|c|c|}
\hline Site & BERYL-S02 & & & & ERYLSO3A & & RYL-S03B & & & & RYL-S03B & \\
\hline 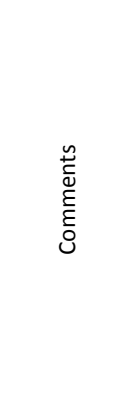 & 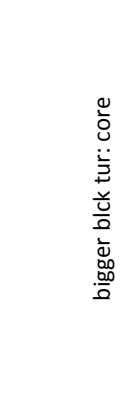 & 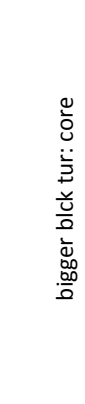 & 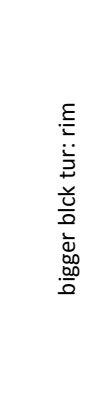 & 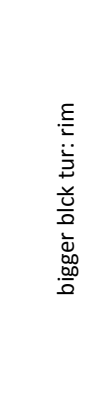 & 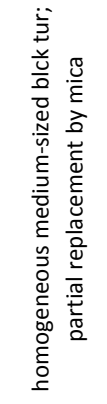 & 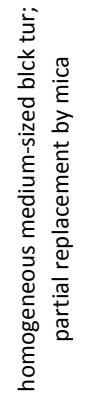 & 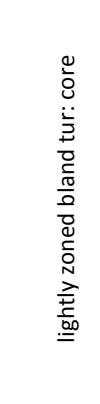 & 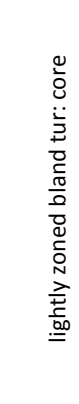 & 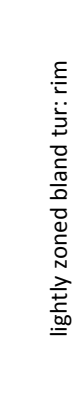 & 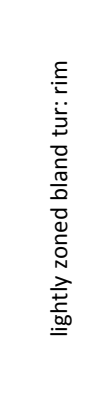 & 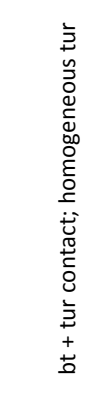 & 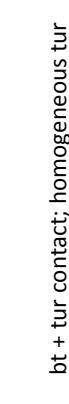 \\
\hline Point & $27 \mathrm{t}-1$ & $27 \mathrm{t}-2$ & $27 \mathrm{t}-3$ & $27 \mathrm{t}-4$ & $28 \mathrm{t}-1$ & $28 \mathrm{t}-2$ & $29 \mathrm{t}-1$ & $29 \mathrm{t}-2$ & $29 t-3$ & $29 t-4$ & $30 t-1$ & $30 \mathrm{t}-2$ \\
\hline $\mathrm{SiO}_{2}$ (wt.\%) & 34.31 & 34.50 & 34.59 & 34.91 & 33.38 & 33.54 & 35.11 & 34.35 & 34.12 & 33.90 & 35.10 & 34.55 \\
\hline $\mathrm{TiO}_{2}$ & 0.19 & 0.17 & 0.41 & 0.35 & 0.67 & 0.57 & 0.80 & 0.84 & 0.30 & 0.56 & 0.98 & 1.34 \\
\hline $\mathrm{B}_{2} \mathrm{O}_{3}{ }^{*}$ & 10.39 & 10.39 & 10.41 & 10.44 & 10.32 & 10.32 & 10.40 & 10.30 & 10.16 & 10.15 & 10.38 & 10.26 \\
\hline $\mathrm{Al}_{2} \mathrm{O}_{3}$ & 35.68 & 35.80 & 35.01 & 34.92 & 34.25 & 34.53 & 32.44 & 32.52 & 31.78 & 31.64 & 31.69 & 30.87 \\
\hline $\mathrm{Cr}_{2} \mathrm{O}_{3}$ & 0.00 & 0.00 & 0.02 & 0.00 & 0.02 & 0.00 & 0.00 & 0.00 & 0.01 & 0.00 & 0.02 & 0.00 \\
\hline \multicolumn{13}{|l|}{$\mathrm{Bi}_{2} \mathrm{O}_{3}$} \\
\hline $\mathrm{Fe}_{2} \mathrm{O}_{3} *$ & 0.00 & 0.00 & 0.00 & 0.00 & 0.00 & 0.00 & 0.00 & 0.00 & 0.00 & 0.00 & 0.00 & 0.00 \\
\hline $\mathrm{FeO} *$ & 13.10 & 12.93 & 13.37 & 13.51 & 8.62 & 8.68 & 11.55 & 11.55 & 13.60 & 13.43 & 11.85 & 12.07 \\
\hline $\mathrm{FeO}$ (tot) & 13.10 & 12.93 & 13.37 & 13.51 & 8.62 & 8.68 & 11.55 & 11.55 & 13.60 & 13.43 & 11.85 & 12.07 \\
\hline $\mathrm{MnO}$ & 0.41 & 0.31 & 0.43 & 0.39 & 0.09 & 0.03 & 0.20 & 0.22 & 0.17 & 0.14 & 0.16 & 0.14 \\
\hline $\mathrm{ZnO}$ & 0.13 & 0.02 & 0.00 & 0.10 & 0.03 & 0.00 & 0.13 & 0.00 & 0.10 & 0.13 & 0.07 & 0.03 \\
\hline $\mathrm{MgO}$ & 0.75 & 0.75 & 0.88 & 0.89 & 4.88 & 4.59 & 3.55 & 3.55 & 2.83 & 2.90 & 3.87 & 3.84 \\
\hline $\mathrm{Li}_{2} \mathrm{O}^{*}$ & 0.16 & 0.15 & 0.20 & 0.18 & 0.06 & 0.07 & 0.14 & 0.11 & 0.02 & 0.05 & 0.13 & 0.16 \\
\hline $\mathrm{CaO}$ & 0.06 & 0.06 & 0.13 & 0.10 & 0.54 & 0.44 & 0.28 & 0.31 & 0.58 & 0.65 & 0.38 & 0.54 \\
\hline $\mathrm{Na}_{2} \mathrm{O}$ & 1.59 & 1.31 & 1.67 & 1.55 & 1.93 & 1.78 & 2.02 & 2.09 & 1.92 & 1.97 & 2.09 & 2.10 \\
\hline $\mathrm{K}_{2} \mathrm{O}$ & 0.02 & 0.03 & 0.04 & 0.06 & 0.05 & 0.03 & 0.04 & 0.05 & 0.01 & 0.04 & 0.05 & 0.04 \\
\hline $\mathrm{F}$ & 0.13 & 0.19 & 0.49 & 0.17 & 0.25 & 0.13 & 0.73 & 0.61 & 0.74 & 0.95 & 0.79 & 1.09 \\
\hline $\mathrm{Cl}$ & 0.01 & 0.00 & 0.00 & 0.00 & 0.00 & 0.00 & 0.00 & 0.00 & 0.01 & 0.00 & 0.01 & 0.00 \\
\hline $\mathrm{H}_{2} \mathrm{O}^{*}$ & 3.52 & 3.49 & 3.36 & 3.52 & 3.44 & 3.50 & 3.24 & 3.27 & 3.15 & 3.05 & 3.20 & 3.02 \\
\hline$-(\mathrm{O}=\mathrm{F}, \mathrm{Cl})$ & -0.06 & -0.08 & -0.21 & -0.07 & -0.10 & -0.05 & -0.31 & -0.26 & -0.31 & -0.40 & -0.34 & -0.46 \\
\hline Total & 100.39 & 100.02 & 100.81 & 101.02 & 98.43 & 98.15 & 100.33 & 99.52 & 99.19 & 99.17 & 100.45 & 99.59 \\
\hline T Si (apfu) & 5.741 & 5.773 & 5.774 & 5.814 & 5.620 & 5.649 & 5.869 & 5.795 & 5.837 & 5.805 & 5.877 & 5.854 \\
\hline TAl & 0.259 & 0.227 & 0.226 & 0.186 & 0.380 & 0.351 & 0.131 & 0.205 & 0.163 & 0.195 & 0.123 & 0.146 \\
\hline B & 3 & 3 & 3 & 3 & 3 & 3 & 3 & 3 & 3 & 3 & 3 & 3 \\
\hline $\mathrm{Z} \mathrm{Al}$ & 6.000 & 6.000 & 6.000 & 6.000 & 6.000 & 6.000 & 6.000 & 6.000 & 6.000 & 6.000 & 6.000 & 6.000 \\
\hline $\mathrm{YTi}$ & 0.024 & 0.021 & 0.051 & 0.044 & 0.085 & 0.072 & 0.101 & 0.107 & 0.038 & 0.072 & 0.124 & 0.171 \\
\hline Y Al & 0.776 & 0.834 & 0.662 & 0.668 & 0.416 & 0.503 & 0.260 & 0.261 & 0.244 & 0.190 & 0.131 & 0.018 \\
\hline $\mathrm{YCr}$ & 0.000 & 0.000 & 0.003 & 0.001 & 0.003 & 0.000 & 0.000 & 0.001 & 0.001 & 0.000 & 0.003 & 0.000 \\
\hline $\mathrm{Y} \mathrm{Fe}^{3+}$ & 0.000 & 0.000 & 0.000 & 0.000 & 0.000 & 0.000 & 0.000 & 0.000 & 0.000 & 0.000 & 0.000 & 0.000 \\
\hline $\mathrm{Y} \mathrm{Fe}^{2+}$ & 1.834 & 1.809 & 1.866 & 1.881 & 1.214 & 1.222 & 1.615 & 1.629 & 1.945 & 1.923 & 1.659 & 1.710 \\
\hline Y Mn & 0.059 & 0.044 & 0.061 & 0.056 & 0.013 & 0.004 & 0.028 & 0.032 & 0.025 & 0.020 & 0.023 & 0.020 \\
\hline YZn & 0.017 & 0.003 & 0.000 & 0.012 & 0.003 & 0.000 & 0.016 & 0.000 & 0.012 & 0.017 & 0.009 & 0.004 \\
\hline Y Mg & 0.186 & 0.186 & 0.220 & 0.220 & 1.225 & 1.152 & 0.884 & 0.894 & 0.723 & 0.740 & 0.966 & 0.971 \\
\hline Y Li & 0.105 & 0.102 & 0.136 & 0.118 & 0.041 & 0.046 & 0.096 & 0.077 & 0.012 & 0.038 & 0.084 & 0.107 \\
\hline X Ca & 0.010 & 0.010 & 0.022 & 0.018 & 0.097 & 0.080 & 0.051 & 0.056 & 0.106 & 0.118 & 0.068 & 0.098 \\
\hline $\mathrm{XNa}$ & 0.516 & 0.426 & 0.542 & 0.501 & 0.630 & 0.582 & 0.655 & 0.682 & 0.638 & 0.654 & 0.678 & $0.69 c$ \\
\hline$x K$ & 0.005 & 0.006 & 0.009 & 0.012 & 0.010 & 0.007 & 0.009 & 0.011 & 0.003 & 0.008 & 0.011 & 0.008 \\
\hline$X$ vac & 0.469 & 0.558 & 0.427 & 0.469 & 0.264 & 0.331 & 0.286 & 0.250 & 0.252 & 0.220 & 0.243 & 0.204 \\
\hline $\mathrm{VOH}$ & 3.000 & 3.000 & 3.000 & 3.000 & 3.000 & 3.000 & 3.000 & 3.000 & 3.000 & 3.000 & 3.000 & 3.000 \\
\hline Vo & 0.000 & 0.000 & 0.000 & 0.000 & 0.000 & 0.000 & 0.000 & 0.000 & 0.000 & 0.000 & 0.000 & 0.000 \\
\hline W F & 0.067 & 0.100 & 0.257 & 0.087 & 0.131 & 0.067 & 0.385 & 0.325 & 0.399 & 0.514 & 0.421 & 0.586 \\
\hline W Cl & 0.003 & 0.000 & 0.001 & 0.000 & 0.000 & 0.000 & 0.001 & 0.000 & 0.002 & 0.000 & 0.002 & 0.001 \\
\hline $\mathrm{WOH}$ & 0.930 & 0.899 & 0.742 & 0.913 & 0.869 & 0.933 & 0.614 & 0.675 & 0.599 & 0.486 & 0.577 & 0.413 \\
\hline wo & 0.000 & 0.000 & 0.000 & 0.000 & 0.000 & 0.000 & 0.000 & 0.000 & 0.000 & 0.000 & 0.000 & 0.000 \\
\hline Classif. & schorl & foitite & schorl & schorl & dravite & schorl & schorl & schorl & schorl & $\begin{array}{l}\text { fluor- } \\
\text { schorl }\end{array}$ & schorl & $\begin{array}{l}\text { fluor } \\
\text { schor }\end{array}$ \\
\hline
\end{tabular}

*Note: tourmaline formula was calculated on the basis of 31 anions $(O, O H, F, C l), B=3$ apfu, and $L i=15-(T+Z+Y)$ or $T+Z+Y=15$ for for $L i$-bearing

samples and Li-free samples, respectively; ratio of $\mathrm{Fe}_{2} \mathrm{O}_{3}$ and $\mathrm{FeO}$ calculated to fit electroneutral formula. 
Appendix D.1 (contd.): Electron-microprobe analyses of tourmaline.

\begin{tabular}{|c|c|c|c|c|c|c|c|c|c|c|c|c|}
\hline Site & BERYL-S03C & & BERYL-S03E & & BERYL-S04 & & BERYL-S04 & & RYL-S04 & & & \\
\hline 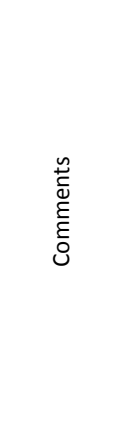 & 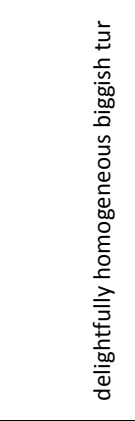 & 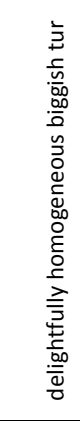 & 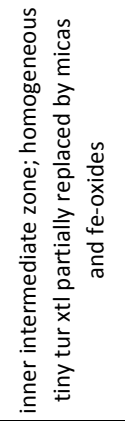 & 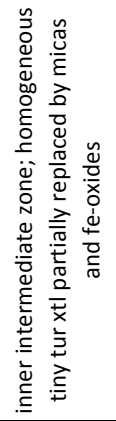 & 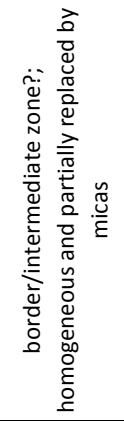 & 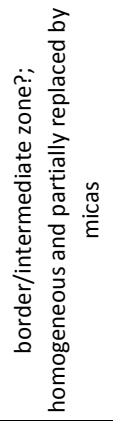 & 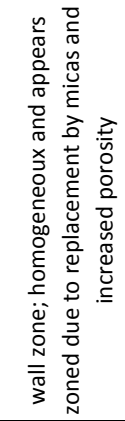 & 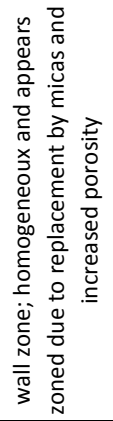 & 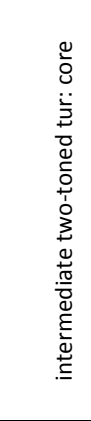 & 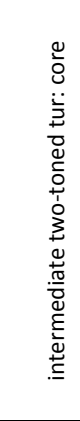 & 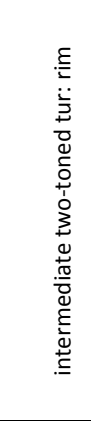 & 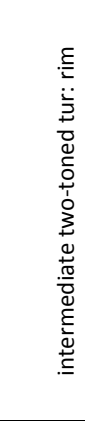 \\
\hline Point & $31 \mathrm{t}-1$ & $31 \mathrm{t}-2$ & $32 \mathrm{t}-1$ & $32 \mathrm{t}-2$ & $33 t-1$ & $33 t-2$ & $34 \mathrm{t}-1$ & $34 \mathrm{t}-2$ & $35 t-1$ & $35 t-2$ & $35 t-3$ & $35 t-4$ \\
\hline $\mathrm{SiO}_{2}$ (wt.\%) & 33.86 & 34.38 & 34.89 & 34.20 & 34.87 & 34.54 & 34.71 & 35.16 & 35.00 & 34.61 & 34.01 & 33.99 \\
\hline $\mathrm{TiO}_{2}$ & 0.49 & 0.88 & 0.23 & 0.15 & 0.43 & 0.45 & 0.89 & 0.86 & 0.59 & 0.51 & 0.47 & 0.44 \\
\hline $\mathrm{B}_{2} \mathrm{O}_{3} *$ & 10.28 & 10.33 & 10.42 & 10.32 & 10.41 & 10.34 & 10.40 & 10.46 & 10.50 & 10.40 & 10.32 & 10.30 \\
\hline $\mathrm{Al}_{2} \mathrm{O}_{3}$ & 34.13 & 33.57 & 35.00 & 34.87 & 35.05 & 34.79 & 33.78 & 33.78 & 34.49 & 34.39 & 34.66 & 34.61 \\
\hline $\mathrm{Cr}_{2} \mathrm{O}_{3}$ & 0.03 & 0.00 & 0.01 & 0.00 & 0.00 & 0.00 & 0.00 & 0.05 & 0.01 & 0.00 & 0.02 & 0.01 \\
\hline \multicolumn{13}{|l|}{$\mathrm{Bi}_{2} \mathrm{O}_{3}$} \\
\hline $\mathrm{Fe}_{2} \mathrm{O}_{3} *$ & 0.00 & 0.00 & 0.00 & 0.00 & 0.00 & 0.00 & 0.00 & 0.00 & 0.00 & 0.00 & 0.00 & 0.00 \\
\hline $\mathrm{FeO} *$ & 13.34 & 12.88 & 13.43 & 13.73 & 13.46 & 13.70 & 12.86 & 12.39 & 10.91 & 10.67 & 12.90 & 13.32 \\
\hline $\mathrm{FeO}$ (tot) & 13.34 & 12.88 & 13.43 & 13.73 & 13.46 & 13.70 & 12.86 & 12.39 & 10.91 & 10.67 & 12.90 & 13.32 \\
\hline $\mathrm{MnO}$ & 0.37 & 0.22 & 0.62 & 0.63 & 0.57 & 0.46 & 0.16 & 0.16 & 0.13 & 0.13 & 0.46 & 0.38 \\
\hline $\mathrm{ZnO}$ & 0.09 & 0.03 & 0.14 & 0.22 & 0.11 & 0.05 & 0.08 & 0.03 & 0.04 & 0.06 & 0.10 & 0.14 \\
\hline MgO & 1.25 & 1.96 & 0.31 & 0.30 & 0.40 & 0.42 & 1.95 & 1.94 & 2.96 & 2.91 & 1.23 & 1.13 \\
\hline $\mathrm{Li}_{2} \mathrm{O}^{*}$ & 0.22 & 0.15 & 0.33 & 0.26 & 0.22 & 0.21 & 0.18 & 0.31 & 0.20 & 0.21 & 0.19 & 0.13 \\
\hline $\mathrm{CaO}$ & 0.29 & 0.24 & 0.09 & 0.06 & 0.07 & 0.08 & 0.19 & 0.22 & 0.28 & 0.31 & 0.18 & 0.15 \\
\hline $\mathrm{Na}_{2} \mathrm{O}$ & 2.02 & 1.68 & 1.88 & 2.04 & 1.43 & 1.53 & 1.76 & 1.88 & 1.74 & 1.74 & 1.82 & 1.73 \\
\hline $\mathrm{K}_{2} \mathrm{O}$ & 0.03 & 0.04 & 0.03 & 0.05 & 0.03 & 0.02 & 0.03 & 0.04 & 0.04 & 0.04 & 0.03 & 0.05 \\
\hline $\mathrm{F}$ & 1.16 & 0.43 & 1.05 & 1.00 & 0.64 & 0.45 & 0.30 & 0.27 & 0.22 & 0.19 & 0.40 & 0.59 \\
\hline $\mathrm{Cl}$ & 0.00 & 0.01 & 0.02 & 0.00 & 0.00 & 0.00 & 0.00 & 0.00 & 0.00 & 0.00 & 0.00 & 0.01 \\
\hline $\mathrm{H}_{2} \mathrm{O}^{*}$ & 3.00 & 3.35 & 3.09 & 3.09 & 3.29 & 3.35 & 3.45 & 3.48 & 3.52 & 3.50 & 3.37 & 3.27 \\
\hline$-(\mathrm{O}=\mathrm{F}, \mathrm{Cl})$ & -0.49 & -0.19 & -0.45 & -0.42 & -0.27 & -0.19 & -0.13 & -0.11 & -0.09 & -0.08 & -0.17 & -0.25 \\
\hline Total & 100.07 & 99.98 & 101.10 & 100.50 & 100.70 & 100.21 & 100.60 & 100.91 & 100.53 & 99.59 & 100.01 & 100.00 \\
\hline T Si (apfu) & 5.723 & 5.786 & 5.817 & 5.759 & 5.824 & 5.805 & 5.800 & 5.840 & 5.795 & 5.781 & 5.728 & 5.735 \\
\hline TAl & 0.277 & 0.214 & 0.183 & 0.241 & 0.176 & 0.195 & 0.200 & 0.160 & 0.205 & 0.219 & 0.272 & 0.265 \\
\hline B & 3 & 3 & 3 & 3 & 3 & 3 & 3 & 3 & 3 & 3 & 3 & 3 \\
\hline $\mathrm{ZAl}$ & 6.000 & 6.000 & 6.000 & 6.000 & 6.000 & 6.000 & 6.000 & 6.000 & 6.000 & 6.000 & 6.000 & 6.000 \\
\hline $\mathrm{YTi}$ & 0.063 & 0.112 & 0.028 & 0.019 & 0.054 & 0.057 & 0.112 & 0.107 & 0.073 & 0.064 & 0.060 & 0.055 \\
\hline Y Al & 0.521 & 0.446 & 0.696 & 0.680 & 0.724 & 0.695 & 0.452 & 0.454 & 0.526 & 0.552 & 0.608 & 0.617 \\
\hline $\mathrm{Y} C \mathrm{Cr}$ & 0.004 & 0.000 & 0.001 & 0.000 & 0.000 & 0.000 & 0.001 & 0.006 & 0.001 & 0.000 & 0.003 & 0.001 \\
\hline $\mathrm{Y} \mathrm{Fe}^{3+}$ & 0.000 & 0.000 & 0.000 & 0.000 & 0.000 & 0.000 & 0.000 & 0.000 & 0.000 & 0.000 & 0.000 & 0.000 \\
\hline $\mathrm{Y} \mathrm{Fe}^{2+}$ & 1.886 & 1.814 & 1.872 & 1.933 & 1.880 & 1.926 & 1.797 & 1.721 & 1.511 & 1.491 & 1.817 & 1.880 \\
\hline Y Mn & 0.054 & 0.031 & 0.088 & 0.090 & 0.080 & 0.065 & 0.022 & 0.023 & 0.019 & 0.018 & 0.066 & 0.054 \\
\hline Y Zn & 0.011 & 0.004 & 0.018 & 0.027 & 0.013 & 0.006 & 0.010 & 0.004 & 0.004 & 0.007 & 0.013 & 0.018 \\
\hline Y Mg & 0.315 & 0.492 & 0.078 & 0.076 & 0.098 & 0.106 & 0.485 & 0.481 & 0.730 & 0.724 & 0.308 & 0.283 \\
\hline Y Li & 0.147 & 0.101 & 0.218 & 0.176 & 0.150 & 0.145 & 0.121 & 0.204 & 0.135 & 0.143 & 0.127 & 0.091 \\
\hline X Ca & 0.052 & 0.044 & 0.016 & 0.012 & 0.012 & 0.014 & 0.035 & 0.038 & 0.050 & 0.056 & 0.033 & 0.027 \\
\hline $\mathrm{XNa}$ & 0.663 & 0.549 & 0.609 & 0.666 & 0.463 & 0.498 & 0.569 & 0.604 & 0.559 & 0.563 & 0.596 & 0.564 \\
\hline x K & 0.007 & 0.009 & 0.007 & 0.011 & 0.007 & 0.005 & 0.007 & 0.009 & 0.008 & 0.008 & 0.007 & 0.010 \\
\hline$X$ vac & 0.278 & 0.399 & 0.369 & 0.312 & 0.518 & 0.483 & 0.390 & 0.348 & 0.383 & 0.373 & 0.364 & 0.399 \\
\hline $\mathrm{VOH}$ & 3.000 & 3.000 & 3.000 & 3.000 & 3.000 & 3.000 & 3.000 & 3.000 & 3.000 & 3.000 & 3.000 & 3.000 \\
\hline Vo & 0.000 & 0.000 & 0.000 & 0.000 & 0.000 & 0.000 & 0.000 & 0.000 & 0.000 & 0.000 & 0.000 & 0.000 \\
\hline W F & 0.619 & 0.230 & 0.556 & 0.534 & 0.337 & 0.239 & 0.158 & 0.140 & 0.113 & 0.101 & 0.214 & 0.317 \\
\hline W Cl & 0.000 & 0.004 & 0.004 & 0.001 & 0.000 & 0.000 & 0.000 & 0.000 & 0.000 & 0.000 & 0.000 & 0.004 \\
\hline W OH & 0.380 & 0.766 & 0.439 & 0.466 & 0.663 & 0.761 & 0.842 & 0.860 & 0.887 & 0.899 & 0.786 & 0.679 \\
\hline wo & 0.000 & 0.000 & 0.000 & 0.000 & 0.000 & 0.000 & 0.000 & 0.000 & 0.000 & 0.000 & 0.000 & 0.000 \\
\hline Classif. & $\begin{array}{l}\text { fluor- } \\
\text { schorl }\end{array}$ & schorl & $\begin{array}{l}\text { fluor- } \\
\text { schorl }\end{array}$ & $\begin{array}{l}\text { fluor- } \\
\text { schorl }\end{array}$ & foitite & schorl & schorl & schorl & schorl & schorl & schorl & schorl \\
\hline
\end{tabular}


Appendix D.1 (contd.): Electron-microprobe analyses of tourmaline.

\begin{tabular}{|c|c|c|c|c|c|c|c|c|c|c|c|c|}
\hline \multirow[b]{2}{*}{ 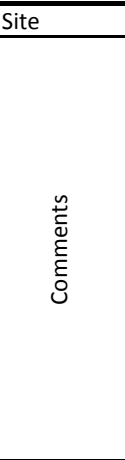 } & \multirow[b]{2}{*}{ 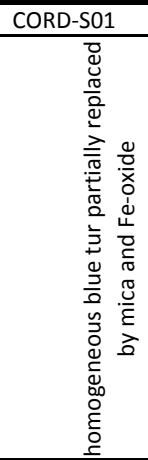 } & \multicolumn{3}{|c|}{ CORD-S01 } & & \multicolumn{3}{|c|}{ CORD-S03 } & \multicolumn{2}{|l|}{ GAR-S01 } & \multicolumn{2}{|c|}{ AR-S01 } \\
\hline & & 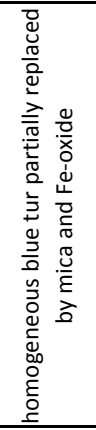 & 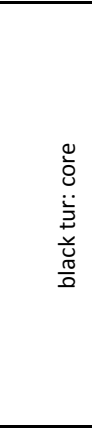 & 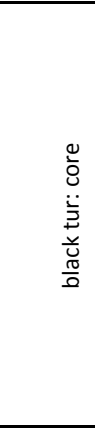 & 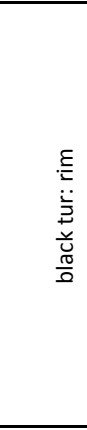 & 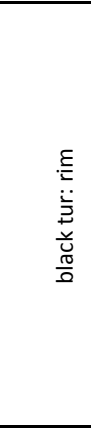 & 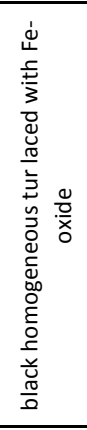 & 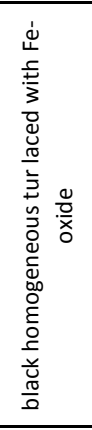 & 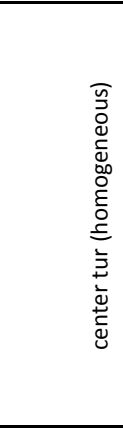 & 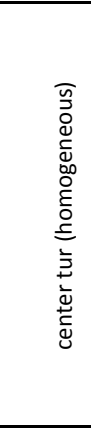 & 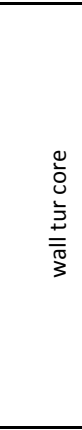 & 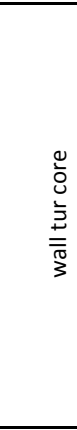 \\
\hline Point & $36 \mathrm{t}-1$ & $36 \mathrm{t}-2$ & $38 t-1$ & $38 t-2$ & $38 t-3$ & $38 t-4$ & $37 t-1$ & $37 t-2$ & $39 t-1$ & $39 t-2$ & $41 t-1$ & $41 t-2$ \\
\hline $\mathrm{SiO}_{2}$ (wt.\%) & 37.09 & 36.41 & 36.02 & 36.59 & 35.96 & 36.39 & 35.71 & 35.86 & 35.94 & 35.81 & 35.17 & 35.39 \\
\hline $\mathrm{TiO}_{2}$ & 0.01 & 0.00 & 0.22 & 0.20 & 0.20 & 0.33 & 0.32 & 0.61 & 0.42 & 0.43 & 0.21 & 0.14 \\
\hline $\mathrm{B}_{2} \mathrm{O}_{3} *$ & 10.89 & 10.82 & 10.78 & 10.90 & 10.65 & 10.72 & 10.64 & 10.72 & 10.56 & 10.56 & 10.54 & 10.51 \\
\hline $\mathrm{Al}_{2} \mathrm{O}_{3}$ & 35.40 & 35.71 & 35.37 & 35.59 & 34.73 & 34.91 & 36.32 & 35.56 & 32.73 & 33.10 & 34.40 & 34.34 \\
\hline $\mathrm{Cr}_{2} \mathrm{O}_{3}$ & 0.00 & 0.02 & 0.00 & 0.00 & 0.00 & 0.00 & 0.05 & 0.05 & 0.00 & 0.03 & 0.06 & 0.03 \\
\hline \multicolumn{13}{|l|}{$\mathrm{Bi}_{2} \mathrm{O}_{3}$} \\
\hline $\mathrm{Fe}_{2} \mathrm{O}_{3} *$ & 0.00 & 0.00 & 0.00 & 0.00 & 0.00 & 0.00 & 0.00 & 0.00 & 0.00 & 0.00 & 0.00 & 0.00 \\
\hline $\mathrm{FeO} *$ & 5.68 & 5.70 & 6.35 & 6.41 & 9.15 & 8.83 & 9.31 & 9.93 & 10.43 & 10.41 & 8.39 & 8.22 \\
\hline $\mathrm{FeO}$ (tot) & 5.68 & 5.70 & 6.35 & 6.41 & 9.15 & 8.83 & 9.31 & 9.93 & 10.43 & 10.41 & 8.39 & 8.22 \\
\hline $\mathrm{MnO}$ & 0.14 & 0.06 & 0.13 & 0.11 & 0.16 & 0.12 & 0.13 & 0.14 & 0.12 & 0.12 & 0.05 & 0.08 \\
\hline $\mathrm{ZnO}$ & 0.00 & 0.00 & 0.00 & 0.03 & 0.00 & 0.04 & 0.00 & 0.01 & 0.04 & 0.09 & 0.00 & 0.06 \\
\hline $\mathrm{MgO}$ & 6.07 & 6.11 & 5.83 & 5.92 & 4.19 & 4.06 & 2.56 & 2.93 & 4.48 & 4.42 & 5.36 & 5.21 \\
\hline $\mathrm{Li}_{2} \mathrm{O}^{*}$ & 0.31 & 0.23 & 0.27 & 0.27 & 0.21 & 0.30 & 0.33 & 0.37 & 0.19 & 0.12 & 0.00 & 0.00 \\
\hline $\mathrm{CaO}$ & 0.39 & 0.36 & 0.55 & 0.56 & 0.32 & 0.36 & 0.15 & 0.29 & 0.33 & 0.33 & 0.36 & 0.36 \\
\hline $\mathrm{Na}_{2} \mathrm{O}$ & 1.82 & 1.78 & 1.91 & 1.84 & 1.78 & 1.63 & 1.29 & 1.77 & 2.22 & 2.00 & 1.66 & 1.74 \\
\hline $\mathrm{K}_{2} \mathrm{O}$ & 0.04 & 0.02 & 0.02 & 0.03 & 0.02 & 0.03 & 0.03 & 0.03 & 0.04 & 0.04 & 0.03 & 0.04 \\
\hline $\mathrm{F}$ & 0.16 & 0.12 & 0.22 & 0.31 & 0.17 & 0.09 & 0.12 & 0.05 & 0.11 & 0.17 & 0.17 & 0.20 \\
\hline $\mathrm{Cl}$ & 0.00 & 0.00 & 0.01 & 0.00 & 0.00 & 0.00 & 0.00 & 0.00 & 0.01 & 0.01 & 0.00 & 0.00 \\
\hline $\mathrm{H}_{2} \mathrm{O} *$ & 3.68 & 3.67 & 3.61 & 3.61 & 3.59 & 3.66 & 3.61 & 3.67 & 3.59 & 3.56 & 3.55 & 3.42 \\
\hline$-(\mathrm{O}=\mathrm{F}, \mathrm{Cl})$ & -0.07 & -0.05 & -0.10 & -0.13 & -0.07 & -0.04 & -0.05 & -0.02 & -0.05 & -0.08 & -0.07 & -0.09 \\
\hline Total & 101.63 & 100.97 & 101.19 & 102.25 & 101.08 & 101.44 & 100.51 & 101.97 & 101.14 & 101.14 & 99.88 & 99.65 \\
\hline T Si (apfu) & 5.918 & 5.849 & 5.806 & 5.834 & 5.867 & 5.899 & 5.835 & 5.813 & 5.918 & 5.894 & 5.799 & 5.851 \\
\hline $\mathrm{T}$ Al & 0.082 & 0.151 & 0.194 & 0.166 & 0.133 & 0.101 & 0.165 & 0.187 & 0.082 & 0.106 & 0.201 & 0.149 \\
\hline B & 3 & 3 & 3 & 3 & 3 & 3 & 3 & 3 & 3 & 3 & 3 & 3 \\
\hline $\mathrm{ZAl}$ & 6.000 & 6.000 & 6.000 & 6.000 & 6.000 & 6.000 & 6.000 & 6.000 & 6.000 & 6.000 & 6.000 & 6.000 \\
\hline Y Ti & 0.001 & 0.000 & 0.026 & 0.024 & 0.025 & 0.040 & 0.040 & 0.074 & 0.052 & 0.054 & 0.026 & 0.017 \\
\hline Y Al & 0.576 & 0.612 & 0.525 & 0.522 & 0.544 & 0.567 & 0.828 & 0.607 & 0.269 & 0.314 & 0.485 & 0.540 \\
\hline $\mathrm{YCr}$ & 0.000 & 0.003 & 0.000 & 0.000 & 0.000 & 0.000 & 0.006 & 0.007 & 0.000 & 0.004 & 0.008 & 0.003 \\
\hline $\mathrm{YFe}^{3+}$ & 0.000 & 0.000 & 0.000 & 0.000 & 0.000 & 0.000 & 0.000 & 0.000 & 0.000 & 0.000 & 0.000 & 0.000 \\
\hline $\mathrm{YFe}^{2+}$ & 0.758 & 0.766 & 0.856 & 0.855 & 1.249 & 1.197 & 1.272 & 1.346 & 1.436 & 1.433 & 1.157 & 1.137 \\
\hline $\mathrm{Y} M \mathrm{Mn}$ & 0.019 & 0.008 & 0.018 & 0.014 & 0.023 & 0.017 & 0.018 & 0.019 & 0.016 & 0.017 & 0.007 & 0.011 \\
\hline Y Zn & 0.000 & 0.000 & 0.000 & 0.003 & 0.000 & 0.004 & 0.000 & 0.001 & 0.005 & 0.011 & 0.000 & 0.008 \\
\hline Y Mg & 1.444 & 1.463 & 1.400 & 1.408 & 1.019 & 0.982 & 0.623 & 0.707 & 1.099 & 1.084 & 1.317 & 1.283 \\
\hline Y Li & 0.201 & 0.148 & 0.174 & 0.173 & 0.140 & 0.192 & 0.214 & 0.240 & 0.123 & 0.082 & 0.000 & 0.000 \\
\hline X Ca & 0.066 & 0.063 & 0.095 & 0.096 & 0.055 & 0.062 & 0.025 & 0.051 & 0.058 & 0.059 & 0.064 & 0.064 \\
\hline $\mathrm{X} \mathrm{Na}$ & 0.564 & 0.554 & 0.597 & 0.568 & 0.563 & 0.513 & 0.409 & 0.558 & 0.707 & 0.638 & 0.530 & 0.557 \\
\hline x K & 0.008 & 0.005 & 0.004 & 0.007 & 0.005 & 0.007 & 0.006 & 0.007 & 0.009 & 0.008 & 0.007 & 0.008 \\
\hline$X$ vac & 0.361 & 0.379 & 0.305 & 0.328 & 0.376 & 0.417 & 0.559 & 0.385 & 0.226 & 0.295 & 0.399 & 0.372 \\
\hline $\mathrm{VOH}$ & 3.000 & 3.000 & 3.000 & 3.000 & 3.000 & 3.000 & 3.000 & 3.000 & 3.000 & 3.000 & 3.000 & 3.000 \\
\hline Vo & 0.000 & 0.000 & 0.000 & 0.000 & 0.000 & 0.000 & 0.000 & 0.000 & 0.000 & 0.000 & 0.000 & 0.000 \\
\hline W F & 0.082 & 0.060 & 0.114 & 0.158 & 0.089 & 0.044 & 0.061 & 0.027 & 0.059 & 0.091 & 0.088 & 0.106 \\
\hline W Cl & 0.001 & 0.001 & 0.003 & 0.000 & 0.000 & 0.000 & 0.000 & 0.000 & 0.002 & 0.003 & 0.001 & 0.001 \\
\hline $\mathrm{WOH}$ & 0.917 & 0.939 & 0.884 & 0.842 & 0.910 & 0.956 & 0.939 & 0.973 & 0.939 & 0.907 & 0.901 & 0.771 \\
\hline W O & 0.000 & 0.000 & 0.000 & 0.000 & 0.000 & 0.000 & 0.000 & 0.000 & 0.000 & 0.000 & 0.009 & 0.121 \\
\hline Classif. & dravite & dravite & dravite & dravite & schorl & schorl & foitite & schorl & schorl & schorl & dravite & dravite \\
\hline
\end{tabular}


Appendix D.1 (contd.): Electron-microprobe analyses of tourmaline.

\begin{tabular}{|c|c|c|c|c|c|c|c|c|c|c|c|c|}
\hline \multirow[b]{2}{*}{$\begin{array}{l}\text { Site } \\
\end{array}$} & \multirow[b]{2}{*}{ 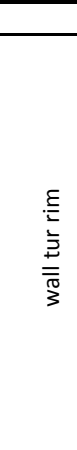 } & \multicolumn{2}{|c|}{ GAR-S01 } & \multicolumn{2}{|c|}{ GAR-S01-2 } & \multicolumn{7}{|c|}{ GAR-S01-5 } \\
\hline & & $\begin{array}{l}\frac{E}{2} \\
\frac{E}{3} \\
\frac{ \pm}{\bar{\pi}} \\
3\end{array}$ & 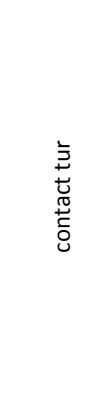 & 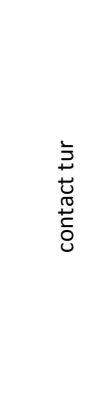 & 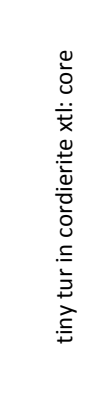 & 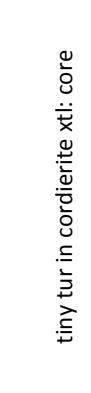 & 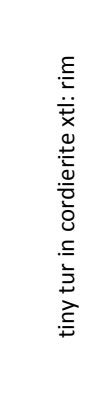 & 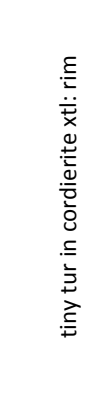 & 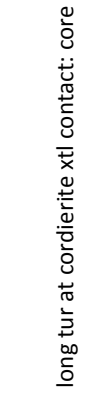 & 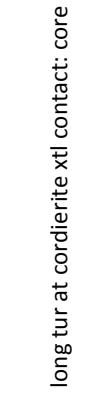 & 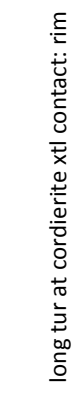 & 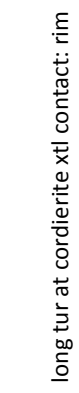 \\
\hline Point & $41 \mathrm{t}-3$ & $41 \mathrm{t}-4$ & $42 t-1$ & $42 t-2$ & GRt-1 & GRt-2 & GRt-3 & GRt-4 & GR5t1 & GR5t2 & GR5t3 & GR5t4 \\
\hline $\mathrm{SiO}_{2}$ (wt.\%) & 35.07 & 34.53 & 35.60 & 35.64 & 35.34 & 34.71 & 35.76 & 35.47 & 35.47 & 34.85 & 34.83 & 35.01 \\
\hline $\mathrm{TiO}_{2}$ & 0.35 & 0.42 & 0.43 & 0.42 & 0.08 & 0.07 & 0.02 & 0.00 & 0.00 & 0.00 & 0.00 & 0.02 \\
\hline $\mathrm{B}_{2} \mathrm{O}_{3} *$ & 10.37 & 10.36 & 10.54 & 10.60 & 10.39 & 10.37 & 10.46 & 10.48 & 10.40 & 10.34 & 10.36 & 10.37 \\
\hline $\mathrm{Al}_{2} \mathrm{O}_{3}$ & 32.82 & 32.86 & 33.75 & 34.10 & 32.66 & 32.91 & 31.92 & 32.38 & 31.82 & 33.66 & 31.82 & 31.99 \\
\hline $\mathrm{Cr}_{2} \mathrm{O}_{3}$ & 0.00 & 0.00 & 0.00 & 0.02 & 0.00 & 0.04 & 0.03 & 0.00 & 0.00 & 0.03 & 0.01 & 0.02 \\
\hline \multicolumn{13}{|l|}{$\mathrm{Bi}_{2} \mathrm{O}_{3}$} \\
\hline $\mathrm{Fe}_{2} \mathrm{O}_{3} *$ & 0.00 & 0.43 & 0.00 & 0.00 & 0.00 & 0.53 & 0.58 & 0.54 & 1.11 & 0.00 & 1.41 & 0.88 \\
\hline $\mathrm{FeO}^{*}$ & 10.82 & 11.14 & 7.76 & 7.87 & 12.00 & 11.74 & 9.16 & 8.99 & 10.41 & 11.11 & 9.46 & 10.02 \\
\hline $\mathrm{FeO}$ (tot) & 10.82 & 11.52 & 7.76 & 7.87 & 12.00 & 12.21 & 9.68 & 9.47 & 11.41 & 11.11 & 10.73 & 10.81 \\
\hline $\mathrm{MnO}$ & 0.22 & 0.19 & 0.09 & 0.08 & 0.25 & 0.16 & 0.20 & 0.22 & 0.25 & 0.23 & 0.25 & 0.19 \\
\hline $\mathrm{ZnO}$ & 0.00 & 0.09 & 0.03 & 0.01 & 0.06 & 0.06 & 0.00 & 0.05 & 0.07 & 0.00 & 0.00 & 0.05 \\
\hline $\mathrm{MgO}$ & 4.19 & 4.03 & 5.81 & 5.81 & 3.69 & 3.70 & 5.78 & 5.80 & 4.68 & 3.52 & 5.30 & 5.03 \\
\hline $\mathrm{Li}_{2} \mathrm{O}^{*}$ & 0.00 & 0.00 & 0.00 & 0.00 & 0.00 & 0.00 & 0.00 & 0.00 & 0.00 & 0.00 & 0.00 & 0.00 \\
\hline $\mathrm{CaO}$ & 0.40 & 0.40 & 0.67 & 0.75 & 0.19 & 0.18 & 0.20 & 0.22 & 0.26 & 0.12 & 0.22 & 0.27 \\
\hline $\mathrm{Na}_{2} \mathrm{O}$ & 2.10 & 1.90 & 1.93 & 1.75 & 2.17 & 2.17 & 2.20 & 2.33 & 1.96 & 1.88 & 2.34 & 2.21 \\
\hline $\mathrm{K}_{2} \mathrm{O}$ & 0.05 & 0.01 & 0.06 & 0.05 & 0.04 & 0.03 & 0.03 & 0.03 & 0.03 & 0.05 & 0.02 & 0.04 \\
\hline $\mathrm{F}$ & 0.29 & 0.22 & 0.19 & 0.17 & 0.25 & 0.19 & 0.43 & 0.70 & 0.51 & 0.39 & 0.57 & 0.64 \\
\hline $\mathrm{Cl}$ & 0.00 & 0.00 & 0.01 & 0.00 & 0.01 & 0.01 & 0.00 & 0.01 & 0.00 & 0.01 & 0.00 & 0.01 \\
\hline $\mathrm{H}_{2} \mathrm{O}^{*}$ & 3.29 & 3.47 & 3.29 & 3.38 & 3.41 & 3.49 & 3.41 & 3.28 & 3.35 & 3.34 & 3.31 & 3.27 \\
\hline$-(\mathrm{O}=\mathrm{F}, \mathrm{Cl})$ & -0.12 & -0.09 & -0.08 & -0.07 & -0.10 & -0.08 & -0.18 & -0.30 & -0.22 & -0.17 & -0.24 & -0.27 \\
\hline Total & 99.85 & 99.96 & 100.08 & 100.58 & 100.43 & 100.27 & 100.00 & 100.21 & 100.12 & 99.37 & 99.65 & 99.76 \\
\hline T Si (apfu) & 5.878 & 5.790 & 5.872 & 5.844 & 5.911 & 5.817 & 5.940 & 5.883 & 5.928 & 5.855 & 5.843 & 5.869 \\
\hline TAl & 0.122 & 0.210 & 0.128 & 0.156 & 0.089 & 0.183 & 0.060 & 0.117 & 0.072 & 0.145 & 0.157 & 0.131 \\
\hline B & 3 & 3 & 3 & 3 & 3 & 3 & 3 & 3 & 3 & 3 & 3 & 3 \\
\hline $\mathrm{ZAl}$ & 6.000 & 6.000 & 6.000 & 6.000 & 6.000 & 6.000 & 6.000 & 6.000 & 6.000 & 6.000 & 6.000 & 6.000 \\
\hline Y Ti & 0.044 & 0.053 & 0.053 & 0.052 & 0.009 & 0.008 & 0.003 & 0.000 & 0.001 & 0.000 & 0.000 & 0.003 \\
\hline Y Al & 0.361 & 0.285 & 0.432 & 0.433 & 0.350 & 0.318 & 0.190 & 0.213 & 0.195 & 0.521 & 0.133 & 0.189 \\
\hline $\mathrm{YCr}$ & 0.001 & 0.000 & 0.001 & 0.002 & 0.000 & 0.005 & 0.004 & 0.000 & 0.000 & 0.004 & 0.001 & 0.002 \\
\hline $\mathrm{YFe}^{3+}$ & 0.000 & 0.054 & 0.000 & 0.000 & 0.000 & 0.067 & 0.073 & 0.067 & 0.139 & 0.000 & 0.178 & 0.111 \\
\hline $\mathrm{Y} \mathrm{Fe}^{2+}$ & 1.517 & 1.562 & 1.071 & 1.080 & 1.679 & 1.645 & 1.272 & 1.246 & 1.455 & 1.561 & 1.327 & 1.405 \\
\hline Y Mn & 0.032 & 0.027 & 0.012 & 0.010 & 0.035 & 0.023 & 0.028 & 0.032 & 0.036 & 0.033 & 0.036 & 0.027 \\
\hline YZn & 0.000 & 0.012 & 0.004 & 0.002 & 0.007 & 0.008 & 0.000 & 0.006 & 0.008 & 0.000 & 0.000 & 0.006 \\
\hline Y Mg & 1.046 & 1.007 & 1.427 & 1.421 & 0.920 & 0.925 & 1.430 & 1.435 & 1.166 & 0.882 & 1.325 & 1.257 \\
\hline Y Li & 0.000 & 0.000 & 0.000 & 0.000 & 0.000 & 0.000 & 0.000 & 0.000 & 0.000 & 0.000 & 0.000 & 0.000 \\
\hline X Ca & 0.073 & 0.072 & 0.119 & 0.132 & 0.033 & 0.031 & 0.036 & 0.040 & 0.047 & 0.022 & 0.040 & 0.048 \\
\hline $\mathrm{XNa}$ & 0.682 & 0.618 & 0.617 & 0.558 & 0.705 & 0.706 & 0.708 & 0.750 & 0.636 & 0.611 & 0.761 & 0.719 \\
\hline$x K$ & 0.010 & 0.003 & 0.013 & 0.011 & 0.009 & 0.006 & 0.007 & 0.007 & 0.007 & 0.010 & 0.004 & 0.010 \\
\hline$X$ vac & 0.236 & 0.307 & 0.252 & 0.300 & 0.253 & 0.256 & 0.249 & 0.203 & 0.310 & 0.357 & 0.195 & 0.223 \\
\hline $\mathrm{VOH}$ & 3.000 & 3.000 & 3.000 & 3.000 & 3.000 & 3.000 & 3.000 & 3.000 & 3.000 & 3.000 & 3.000 & 3.000 \\
\hline Vo & 0.000 & 0.000 & 0.000 & 0.000 & 0.000 & 0.000 & 0.000 & 0.000 & 0.000 & 0.000 & 0.000 & 0.000 \\
\hline W F & 0.154 & 0.114 & 0.097 & 0.090 & 0.130 & 0.101 & 0.226 & 0.366 & 0.270 & 0.208 & 0.300 & 0.338 \\
\hline W Cl & 0.000 & 0.000 & 0.002 & 0.000 & 0.002 & 0.002 & 0.000 & 0.003 & 0.000 & 0.002 & 0.001 & 0.002 \\
\hline W OH & 0.681 & 0.886 & 0.622 & 0.693 & 0.808 & 0.897 & 0.774 & 0.631 & 0.730 & 0.745 & 0.699 & 0.660 \\
\hline wo & 0.165 & 0.000 & 0.279 & 0.216 & 0.060 & 0.000 & 0.000 & 0.000 & 0.000 & 0.045 & 0.000 & 0.000 \\
\hline Classif. & schorl & schorl & dravite & dravite & schorl & schorl & dravite & dravite & schorl & schorl & schorl & schorl \\
\hline
\end{tabular}


Appendix D.1 (contd.): Electron-microprobe analyses of tourmaline.

\begin{tabular}{|c|c|c|c|c|c|c|c|c|c|c|c|c|}
\hline \multirow[b]{2}{*}{$\begin{array}{l}\text { Site } \\
\end{array}$} & \multicolumn{2}{|c|}{ GAR-S03 } & \multicolumn{3}{|c|}{ GARMUS-S01 } & \multirow[b]{2}{*}{ 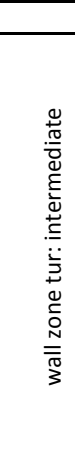 } & \multirow[b]{2}{*}{ 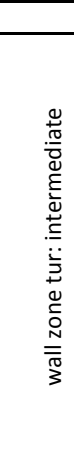 } & \multirow[b]{2}{*}{ 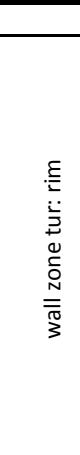 } & \multicolumn{3}{|c|}{ GARMUS-S01 } & GARMUS-S \\
\hline & 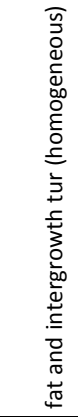 & 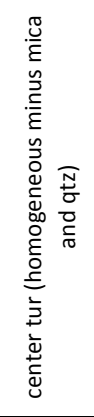 & 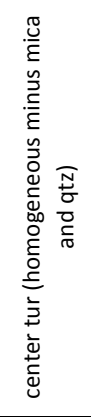 & 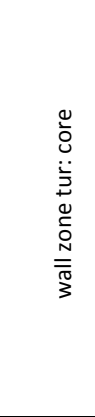 & 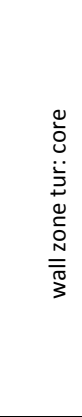 & & & & 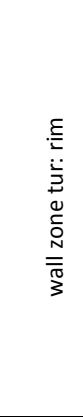 & 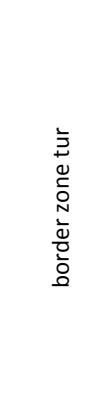 & 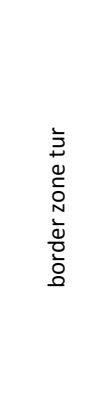 & 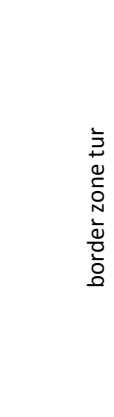 \\
\hline Point & $43 t-2$ & $44 t-1$ & $44 t-2$ & $45 t-1$ & $45 t-2$ & $45 t-3$ & $45 t-4$ & $45 t-5$ & $45 t-6$ & $46 t-1$ & $46 t-2$ & $47 \mathrm{t}-1$ \\
\hline $\mathrm{SiO}_{2}$ (wt.\%) & 35.37 & 35.54 & 35.25 & 34.96 & 34.93 & 34.85 & 34.67 & 33.75 & 33.65 & 35.03 & 34.92 & 35.16 \\
\hline $\mathrm{TiO}_{2}$ & 0.42 & 0.43 & 0.51 & 0.33 & 0.13 & 0.46 & 0.62 & 0.76 & 0.75 & 0.57 & 0.77 & 0.42 \\
\hline $\mathrm{B}_{2} \mathrm{O}_{3} *$ & 10.42 & 10.53 & 10.50 & 10.45 & 10.33 & 10.36 & 10.32 & 10.30 & 10.26 & 10.42 & 10.35 & 10.49 \\
\hline $\mathrm{Al}_{2} \mathrm{O}_{3}$ & 32.29 & 33.52 & 33.60 & 33.43 & 33.34 & 32.85 & 33.02 & 33.79 & 34.16 & 32.23 & 30.55 & 33.08 \\
\hline $\mathrm{Cr}_{2} \mathrm{O}_{3}$ & 0.00 & 0.00 & 0.02 & 0.04 & 0.02 & 0.02 & 0.00 & 0.02 & 0.04 & 0.05 & 0.05 & 0.08 \\
\hline \multicolumn{13}{|l|}{$\mathrm{Bi}_{2} \mathrm{O}_{3}$} \\
\hline $\mathrm{Fe}_{2} \mathrm{O}_{3} *$ & 0.00 & 0.00 & 0.00 & 0.37 & 0.00 & 0.00 & 0.00 & 0.00 & 0.00 & 0.00 & 0.62 & 0.00 \\
\hline $\mathrm{FeO} *$ & 10.12 & 8.59 & 8.35 & 9.73 & 11.62 & 9.29 & 9.81 & 11.36 & 11.81 & 8.64 & 9.26 & 8.22 \\
\hline $\mathrm{FeO}$ (tot) & 10.12 & 8.59 & 8.35 & 10.06 & 11.62 & 9.29 & 9.81 & 11.36 & 11.81 & 8.64 & 9.82 & 8.22 \\
\hline $\mathrm{MnO}$ & 0.09 & 0.09 & 0.05 & 0.15 & 0.32 & 0.19 & 0.16 & 0.30 & 0.60 & 0.39 & 0.26 & 0.26 \\
\hline $\mathrm{ZnO}$ & 0.00 & 0.03 & 0.05 & 0.13 & 0.12 & 0.01 & 0.01 & 0.10 & 0.04 & 0.00 & 0.04 & 0.09 \\
\hline $\mathrm{MgO}$ & 5.13 & 5.50 & 5.57 & 4.64 & 3.20 & 5.08 & 4.47 & 3.27 & 2.44 & 5.96 & 6.28 & 5.93 \\
\hline $\mathrm{Li}_{2} \mathrm{O}^{*}$ & 0.00 & 0.00 & 0.00 & 0.00 & 0.00 & 0.00 & 0.00 & 0.00 & 0.00 & 0.00 & 0.00 & 0.00 \\
\hline $\mathrm{CaO}$ & 0.53 & 0.57 & 0.63 & 0.26 & 0.19 & 0.41 & 0.31 & 0.34 & 0.34 & 0.82 & 0.89 & 0.51 \\
\hline $\mathrm{Na}_{2} \mathrm{O}$ & 1.84 & 1.74 & 1.87 & 1.82 & 1.94 & 1.98 & 1.89 & 2.00 & 1.99 & 1.88 & 1.94 & 2.05 \\
\hline $\mathrm{K}_{2} \mathrm{O}$ & 0.05 & 0.05 & 0.06 & 0.04 & 0.05 & 0.03 & 0.03 & 0.06 & 0.05 & 0.04 & 0.03 & 0.02 \\
\hline $\mathrm{F}$ & 0.22 & 0.19 & 0.23 & 0.24 & 0.12 & 0.44 & 0.36 & 0.32 & 0.42 & 0.42 & 0.58 & 0.45 \\
\hline $\mathrm{Cl}$ & 0.00 & 0.00 & 0.00 & 0.00 & 0.00 & 0.00 & 0.00 & 0.00 & 0.01 & 0.00 & 0.01 & 0.00 \\
\hline $\mathrm{H}_{2} \mathrm{O} *$ & 3.45 & 3.42 & 3.34 & 3.49 & 3.41 & 3.28 & 3.28 & 3.31 & 3.16 & 3.32 & 3.29 & 3.34 \\
\hline$-(\mathrm{O}=\mathrm{F}, \mathrm{Cl})$ & -0.09 & -0.08 & -0.10 & -0.10 & -0.05 & -0.19 & -0.15 & -0.14 & -0.18 & -0.17 & -0.25 & -0.19 \\
\hline Total & 99.83 & 100.12 & 99.94 & 100.00 & 99.67 & 99.09 & 98.79 & 99.55 & 99.53 & 99.59 & 99.60 & 99.91 \\
\hline T Si (apfu) & 5.900 & 5.867 & 5.834 & 5.814 & 5.875 & 5.844 & 5.839 & 5.697 & 5.699 & 5.843 & 5.861 & 5.827 \\
\hline T Al & 0.100 & 0.133 & 0.166 & 0.186 & 0.125 & 0.156 & 0.161 & 0.303 & 0.301 & 0.157 & 0.139 & 0.173 \\
\hline B & 3 & 3 & 3 & 3 & 3 & 3 & 3 & 3 & 3 & 3 & 3 & 3 \\
\hline $\mathrm{ZAl}$ & 6.000 & 6.000 & 6.000 & 6.000 & 6.000 & 6.000 & 6.000 & 6.000 & 6.000 & 6.000 & 5.904 & 6.000 \\
\hline Y Ti & 0.053 & 0.053 & 0.063 & 0.041 & 0.016 & 0.059 & 0.078 & 0.097 & 0.096 & 0.071 & 0.097 & 0.052 \\
\hline Y Al & 0.247 & 0.390 & 0.389 & 0.366 & 0.484 & 0.337 & 0.393 & 0.419 & 0.519 & 0.180 & 0.000 & 0.287 \\
\hline $\mathrm{YCr}$ & 0.000 & 0.000 & 0.003 & 0.006 & 0.003 & 0.003 & 0.000 & 0.002 & 0.005 & 0.006 & 0.007 & 0.010 \\
\hline $\mathrm{Y} \mathrm{Fe}^{3+}$ & 0.000 & 0.000 & 0.000 & 0.046 & 0.000 & 0.000 & 0.000 & 0.000 & 0.000 & 0.000 & 0.078 & 0.000 \\
\hline $\mathrm{YFe}^{2+}$ & 1.411 & 1.186 & 1.157 & 1.353 & 1.635 & 1.303 & 1.381 & 1.603 & 1.673 & 1.205 & 1.300 & 1.140 \\
\hline $\mathrm{Y} M \mathrm{Mn}$ & 0.013 & 0.013 & 0.007 & 0.021 & 0.046 & 0.028 & 0.023 & 0.043 & 0.086 & 0.055 & 0.037 & 0.036 \\
\hline Y Zn & 0.000 & 0.004 & 0.006 & 0.016 & 0.015 & 0.001 & 0.001 & 0.013 & 0.005 & 0.000 & 0.005 & 0.011 \\
\hline Y Mg & 1.276 & 1.355 & 1.375 & 1.150 & 0.802 & 1.269 & 1.123 & 0.823 & 0.616 & 1.482 & 1.571 & 1.465 \\
\hline Y Li & 0.000 & 0.000 & 0.000 & 0.000 & 0.000 & 0.000 & 0.000 & 0.000 & 0.000 & 0.000 & 0.000 & 0.000 \\
\hline X Ca & 0.095 & 0.101 & 0.112 & 0.046 & 0.035 & 0.073 & 0.055 & 0.061 & 0.061 & 0.147 & 0.159 & 0.091 \\
\hline $\mathrm{X} \mathrm{Na}$ & 0.596 & 0.556 & 0.601 & 0.586 & 0.633 & 0.644 & 0.616 & 0.656 & 0.653 & 0.609 & 0.631 & 0.659 \\
\hline x K & 0.010 & 0.011 & 0.012 & 0.009 & 0.011 & 0.007 & 0.006 & 0.013 & 0.011 & 0.009 & 0.007 & 0.005 \\
\hline$X$ vac & 0.299 & 0.333 & 0.275 & 0.360 & 0.321 & 0.275 & 0.323 & 0.270 & 0.274 & 0.236 & 0.203 & 0.245 \\
\hline $\mathrm{VOH}$ & 3.000 & 3.000 & 3.000 & 3.000 & 3.000 & 3.000 & 3.000 & 3.000 & 3.000 & 3.000 & 3.000 & 3.000 \\
\hline Vo & 0.000 & 0.000 & 0.000 & 0.000 & 0.000 & 0.000 & 0.000 & 0.000 & 0.000 & 0.000 & 0.000 & 0.000 \\
\hline W F & 0.115 & 0.101 & 0.120 & 0.124 & 0.065 & 0.235 & 0.194 & 0.173 & 0.226 & 0.219 & 0.310 & 0.236 \\
\hline W Cl & 0.000 & 0.001 & 0.001 & 0.000 & 0.000 & 0.000 & 0.001 & 0.001 & 0.003 & 0.000 & 0.003 & 0.000 \\
\hline $\mathrm{WOH}$ & 0.835 & 0.766 & 0.690 & 0.876 & 0.827 & 0.666 & 0.684 & 0.724 & 0.569 & 0.698 & 0.687 & 0.691 \\
\hline W O & 0.050 & 0.132 & 0.189 & 0.000 & 0.108 & 0.099 & 0.121 & 0.102 & 0.202 & 0.083 & 0.000 & 0.073 \\
\hline Classif. & schorl & dravite & dravite & schorl & schorl & schorl & schorl & schorl & schorl & dravite & dravite & dravite \\
\hline
\end{tabular}


Appendix D.1 (contd.): Electron-microprobe analyses of tourmaline.

\begin{tabular}{|c|c|c|c|c|c|c|c|c|c|c|c|c|}
\hline Site & 01 & $\mathrm{PHOS}-\mathrm{SO}$ & & & & & & & & & & \\
\hline 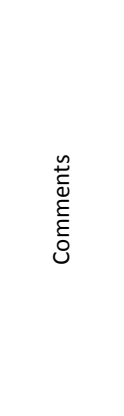 & 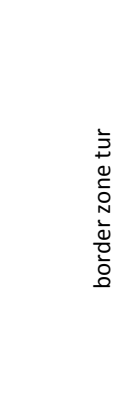 & 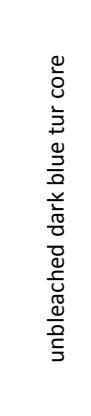 & 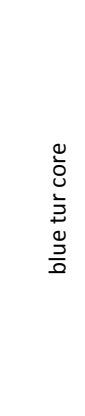 & 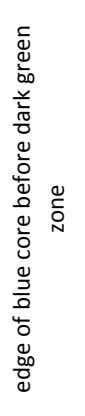 & 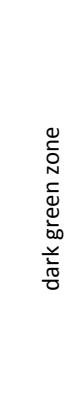 & 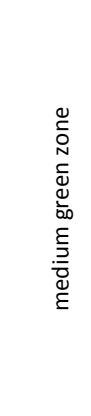 & 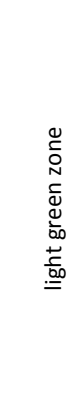 & 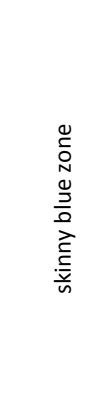 & 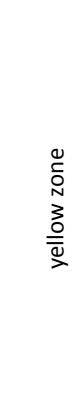 & 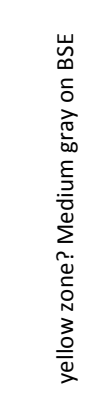 & 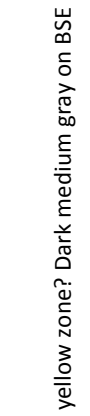 & 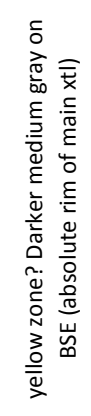 \\
\hline Point & $47 \mathrm{t}-2$ & GP1-1 & GP1-2 & GP1-3 & GP1-4 & GP1-5 & GP1-6 & GP1-7 & GP1-8 & GP1-9 & GP1-10 & GP1-12 \\
\hline $\mathrm{SiO}_{2}$ (wt.\%) & 35.57 & 34.10 & 33.54 & 34.00 & 33.24 & 33.47 & 33.19 & 33.49 & 33.37 & 34.20 & 33.54 & 35.15 \\
\hline $\mathrm{TiO}_{2}$ & 0.42 & 0.26 & 0.27 & 0.25 & 0.55 & 0.51 & 0.50 & 0.44 & 0.17 & 0.36 & 0.36 & 0.23 \\
\hline $\mathrm{B}_{2} \mathrm{O}_{3}{ }^{*}$ & 10.49 & 10.28 & 10.25 & 10.29 & 10.25 & 10.37 & 10.28 & 10.39 & 10.38 & 10.58 & 10.53 & 10.72 \\
\hline $\mathrm{Al}_{2} \mathrm{O}_{3}$ & 33.12 & 34.92 & 35.28 & 35.34 & 35.50 & 36.26 & 36.14 & 36.94 & 37.75 & 38.71 & 38.96 & 39.51 \\
\hline $\mathrm{Cr}_{2} \mathrm{O}_{3}$ & 0.06 & 0.00 & 0.03 & 0.00 & 0.03 & 0.00 & 0.01 & 0.00 & 0.00 & 0.04 & 0.00 & 0.02 \\
\hline \multicolumn{13}{|l|}{$\mathrm{Bi}_{2} \mathrm{O}_{3}$} \\
\hline $\mathrm{Fe}_{2} \mathrm{O}_{3} *$ & 0.00 & 0.00 & 0.00 & 0.00 & 0.00 & 0.00 & 0.00 & 0.00 & 0.00 & 0.00 & 0.00 & 0.00 \\
\hline $\mathrm{FeO} *$ & 7.95 & 12.75 & 12.71 & 12.52 & 11.96 & 11.67 & 11.08 & 10.57 & 8.87 & 5.06 & 5.96 & 3.59 \\
\hline $\mathrm{FeO}$ (tot) & 7.95 & 12.75 & 12.71 & 12.52 & 11.96 & 11.67 & 11.08 & 10.57 & 8.87 & 5.06 & 5.96 & 3.59 \\
\hline $\mathrm{MnO}$ & 0.26 & 1.43 & 1.38 & 1.41 & 1.51 & 1.88 & 1.86 & 1.93 & 2.47 & 3.31 & 2.98 & 3.00 \\
\hline $\mathrm{ZnO}$ & 0.05 & 0.17 & 0.24 & 0.21 & 0.26 & 0.24 & 0.45 & 0.42 & 0.36 & 0.13 & 0.13 & 0.01 \\
\hline $\mathrm{MgO}$ & 5.80 & 0.38 & 0.38 & 0.33 & 0.33 & 0.26 & 0.18 & 0.11 & 0.05 & 0.10 & 0.09 & 0.15 \\
\hline $\mathrm{Li}_{2} \mathrm{O}^{*}$ & 0.00 & 0.17 & 0.13 & 0.15 & 0.25 & 0.25 & 0.28 & 0.34 & 0.44 & 0.97 & 0.84 & 1.19 \\
\hline $\mathrm{CaO}$ & 0.49 & 0.03 & 0.03 & 0.02 & 0.05 & 0.07 & 0.07 & 0.08 & 0.08 & 0.13 & 0.14 & 0.09 \\
\hline $\mathrm{Na}_{2} \mathrm{O}$ & 2.08 & 1.63 & 1.72 & 1.52 & 1.94 & 1.90 & 1.87 & 1.83 & 1.84 & 2.42 & 2.37 & 2.32 \\
\hline $\mathrm{K}_{2} \mathrm{O}$ & 0.03 & 0.04 & 0.04 & 0.03 & 0.02 & 0.05 & 0.03 & 0.03 & 0.04 & 0.02 & 0.02 & 0.01 \\
\hline$F$ & 0.42 & 0.26 & 0.27 & 0.56 & 0.28 & 0.46 & 0.54 & 0.57 & 0.77 & 1.17 & 1.01 & 1.31 \\
\hline $\mathrm{Cl}$ & 0.01 & 0.00 & 0.00 & 0.00 & 0.00 & 0.00 & 0.00 & 0.00 & 0.00 & 0.00 & 0.00 & 0.00 \\
\hline $\mathrm{H}_{2} \mathrm{O}^{*}$ & 3.22 & 3.42 & 3.41 & 3.28 & 3.40 & 3.36 & 3.29 & 3.32 & 3.22 & 3.09 & 3.15 & 3.08 \\
\hline$-(\mathrm{O}=\mathrm{F}, \mathrm{Cl})$ & -0.18 & -0.11 & -0.11 & -0.24 & -0.12 & -0.19 & -0.23 & -0.24 & -0.32 & -0.49 & -0.43 & -0.55 \\
\hline Total & 99.79 & 99.73 & 99.55 & 99.69 & 99.46 & 100.55 & 99.56 & 100.22 & 99.48 & 99.81 & 99.66 & 99.83 \\
\hline T Si (apfu) & 5.893 & 5.767 & 5.689 & 5.745 & 5.635 & 5.611 & 5.610 & 5.602 & 5.586 & 5.617 & 5.537 & 5.701 \\
\hline T Al & 0.107 & 0.233 & 0.311 & 0.255 & 0.365 & 0.389 & 0.390 & 0.398 & 0.414 & 0.383 & 0.463 & 0.299 \\
\hline B & 3 & 3 & 3 & 3 & 3 & 3 & 3 & 3 & 3 & 3 & 3 & 3 \\
\hline $\mathrm{Z} \mathrm{Al}$ & 6.000 & 6.000 & 6.000 & 6.000 & 6.000 & 6.000 & 6.000 & 6.000 & 6.000 & 6.000 & 6.000 & 6.000 \\
\hline Y Ti & 0.052 & 0.033 & 0.034 & 0.032 & 0.070 & 0.065 & 0.063 & 0.055 & 0.021 & 0.045 & 0.045 & 0.028 \\
\hline Y Al & 0.362 & 0.727 & 0.744 & 0.783 & 0.728 & 0.773 & 0.808 & 0.885 & 1.034 & 1.111 & 1.119 & 1.254 \\
\hline $\mathrm{YCr}$ & 0.008 & 0.000 & 0.005 & 0.000 & 0.005 & 0.000 & 0.001 & 0.000 & 0.000 & 0.005 & 0.000 & 0.003 \\
\hline $\mathrm{Y} \mathrm{Fe}^{3+}$ & 0.000 & 0.000 & 0.000 & 0.000 & 0.000 & 0.000 & 0.000 & 0.000 & 0.000 & 0.000 & 0.000 & 0.000 \\
\hline $\mathrm{Y} \mathrm{Fe}^{2+}$ & 1.102 & 1.804 & 1.804 & 1.769 & 1.695 & 1.635 & 1.567 & 1.478 & 1.241 & 0.695 & 0.823 & 0.487 \\
\hline Y Mn & 0.036 & 0.205 & 0.198 & 0.202 & 0.216 & 0.267 & 0.267 & 0.274 & 0.350 & 0.461 & 0.417 & 0.412 \\
\hline $\mathrm{YZn}$ & 0.006 & 0.021 & 0.030 & 0.027 & 0.033 & 0.029 & 0.056 & 0.051 & 0.044 & 0.016 & 0.016 & 0.001 \\
\hline Y Mg & 1.434 & 0.096 & 0.095 & 0.083 & 0.083 & 0.064 & 0.046 & 0.028 & 0.012 & 0.025 & 0.022 & 0.037 \\
\hline Y Li & 0.000 & 0.114 & 0.091 & 0.105 & 0.170 & 0.167 & 0.193 & 0.229 & 0.297 & 0.643 & 0.559 & 0.778 \\
\hline X Ca & 0.087 & 0.005 & 0.005 & 0.003 & 0.010 & 0.013 & 0.013 & 0.015 & 0.015 & 0.022 & 0.025 & 0.016 \\
\hline $\mathrm{X} \mathrm{Na}$ & 0.668 & 0.534 & 0.565 & 0.499 & 0.637 & 0.617 & 0.614 & 0.595 & 0.598 & 0.771 & 0.758 & 0.731 \\
\hline x K & 0.007 & 0.008 & 0.009 & 0.007 & 0.005 & 0.012 & 0.006 & 0.007 & 0.008 & 0.005 & 0.005 & 0.002 \\
\hline $\mathrm{X}$ vac & 0.238 & 0.452 & 0.421 & 0.490 & 0.349 & 0.359 & 0.366 & 0.383 & 0.380 & 0.201 & 0.212 & 0.252 \\
\hline $\mathrm{VOH}$ & 3.000 & 3.000 & 3.000 & 3.000 & 3.000 & 3.000 & 3.000 & 3.000 & 3.000 & 3.000 & 3.000 & 3.000 \\
\hline Vo & 0.000 & 0.000 & 0.000 & 0.000 & 0.000 & 0.000 & 0.000 & 0.000 & 0.000 & 0.000 & 0.000 & 0.000 \\
\hline W F & 0.221 & 0.141 & 0.146 & 0.300 & 0.153 & 0.242 & 0.288 & 0.300 & 0.407 & 0.610 & 0.529 & 0.670 \\
\hline W Cl & 0.001 & 0.000 & 0.000 & 0.000 & 0.000 & 0.000 & 0.001 & 0.000 & 0.000 & 0.000 & 0.000 & 0.000 \\
\hline $\mathrm{WOH}$ & 0.562 & 0.859 & 0.854 & 0.700 & 0.847 & 0.758 & 0.711 & 0.700 & 0.593 & 0.390 & 0.470 & 0.330 \\
\hline wo & 0.216 & 0.000 & 0.000 & 0.000 & 0.000 & 0.000 & 0.000 & 0.000 & 0.000 & 0.000 & 0.000 & 0.000 \\
\hline Classif. & dravite & schorl & schorl & schorl & schorl & schorl & schorl & schorl & schorl & $\begin{array}{l}\text { fluor- } \\
\text { elbaite }\end{array}$ & $\begin{array}{l}\text { fluor- } \\
\text { schorl }\end{array}$ & $\begin{array}{l}\text { fluor- } \\
\text { elbaite }\end{array}$ \\
\hline
\end{tabular}


Appendix D.1 (contd.): Electron-microprobe analyses of tourmaline.

\begin{tabular}{|c|c|c|c|c|c|c|c|c|c|c|c|c|}
\hline \multicolumn{13}{|l|}{ Site } \\
\hline 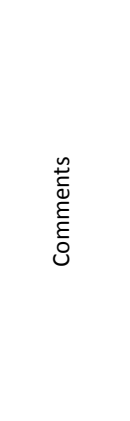 & 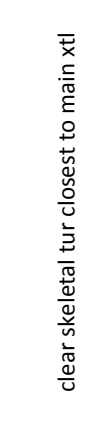 & 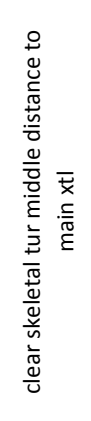 & 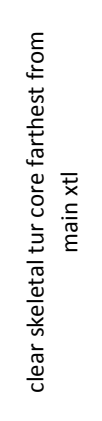 & 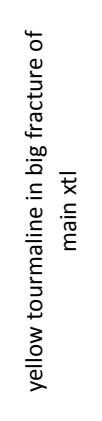 & 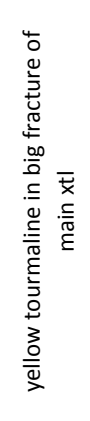 & 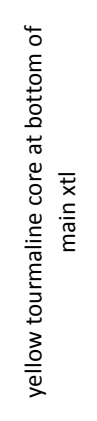 & 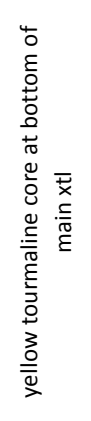 & 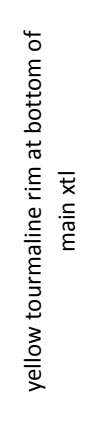 & 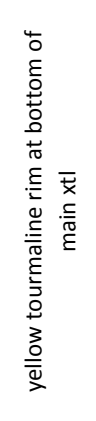 & 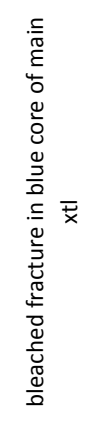 & 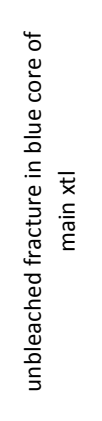 & 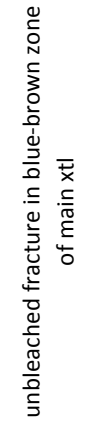 \\
\hline Point & GP1-13 & GP1-14 & GP1-15 & GP1-16 & GP1-17 & GP1-18 & GP1-19 & GP1-20 & GP1-21 & GP1-22 & GP1-23 & GP1-24 \\
\hline $\mathrm{SiO}_{2}$ (wt.\%) & 35.13 & 34.73 & 35.31 & 35.16 & 34.78 & 35.18 & 35.16 & 35.68 & 35.97 & 33.81 & 34.16 & 33.73 \\
\hline $\mathrm{TiO}_{2}$ & 0.34 & 0.16 & 0.31 & 0.32 & 0.46 & 0.29 & 0.35 & 0.25 & 0.19 & 0.29 & 0.23 & 0.34 \\
\hline $\mathrm{B}_{2} \mathrm{O}_{3} *$ & 10.74 & 10.53 & 10.70 & 10.52 & 10.46 & 10.75 & 10.77 & 10.75 & 10.72 & 10.29 & 10.31 & 10.27 \\
\hline $\mathrm{Al}_{2} \mathrm{O}_{3}$ & 39.48 & 38.24 & 38.88 & 36.88 & 36.30 & 39.66 & 39.63 & 39.42 & 38.88 & 35.53 & 35.62 & 35.45 \\
\hline $\mathrm{Cr}_{2} \mathrm{O}_{3}$ & 0.01 & 0.00 & 0.03 & 0.01 & 0.01 & 0.00 & 0.00 & 0.00 & 0.04 & 0.00 & 0.00 & 0.05 \\
\hline \multicolumn{13}{|l|}{$\mathrm{Bi}_{2} \mathrm{O}_{3}$} \\
\hline $\mathrm{Fe}_{2} \mathrm{O}_{3} *$ & 0.00 & 0.00 & 0.00 & 0.00 & 0.00 & 0.00 & 0.00 & 0.00 & 0.00 & 0.00 & 0.00 & 0.00 \\
\hline $\mathrm{FeO} *$ & 3.24 & 4.38 & 3.91 & 6.74 & 9.00 & 3.30 & 3.00 & 0.91 & 1.20 & 11.92 & 11.57 & 11.79 \\
\hline $\mathrm{FeO}$ (tot) & 3.24 & 4.38 & 3.91 & 6.74 & 9.00 & 3.30 & 3.00 & 0.91 & 1.20 & 11.92 & 11.57 & 11.79 \\
\hline $\mathrm{MnO}$ & 3.23 & 3.64 & 2.66 & 1.97 & 0.80 & 3.13 & 3.62 & 4.57 & 4.32 & 1.66 & 1.71 & 1.64 \\
\hline $\mathrm{ZnO}$ & 0.09 & 0.02 & 0.00 & 0.05 & 0.10 & 0.12 & 0.00 & 0.00 & 0.02 & 0.28 & 0.20 & 0.27 \\
\hline $\mathrm{MgO}$ & 0.11 & 0.19 & 0.23 & 0.21 & 0.33 & 0.13 & 0.07 & 0.04 & 0.01 & 0.29 & 0.31 & 0.26 \\
\hline $\mathrm{Li}_{2} \mathrm{O}^{*}$ & 1.27 & 0.97 & 1.26 & 1.06 & 0.91 & 1.22 & 1.28 & 1.44 & 1.45 & 0.22 & 0.24 & 0.24 \\
\hline $\mathrm{CaO}$ & 0.09 & 0.02 & 0.07 & 0.02 & 0.02 & 0.05 & 0.06 & 0.06 & 0.03 & 0.03 & 0.04 & 0.04 \\
\hline $\mathrm{Na}_{2} \mathrm{O}$ & 2.58 & 2.13 & 2.54 & 2.54 & 2.55 & 2.44 & 2.68 & 2.58 & 2.50 & 1.72 & 1.51 & 1.71 \\
\hline $\mathrm{K}_{2} \mathrm{O}$ & 0.01 & 0.02 & 0.01 & 0.02 & 0.03 & 0.02 & 0.02 & 0.01 & 0.04 & 0.03 & 0.03 & 0.03 \\
\hline$F$ & 1.40 & 1.27 & 1.13 & 1.51 & 1.51 & 1.30 & 1.37 & 1.52 & 1.59 & 0.28 & 0.49 & 0.37 \\
\hline $\mathrm{Cl}$ & 0.02 & 0.00 & 0.00 & 0.00 & 0.00 & 0.01 & 0.00 & 0.00 & 0.00 & 0.00 & 0.00 & 0.00 \\
\hline $\mathrm{H}_{2} \mathrm{O}^{*}$ & 3.04 & 3.03 & 3.15 & 2.92 & 2.90 & 3.09 & 3.06 & 2.99 & 2.94 & 3.42 & 3.33 & 3.37 \\
\hline$-(\mathrm{O}=\mathrm{F}, \mathrm{Cl})$ & -0.59 & -0.54 & -0.48 & -0.63 & -0.63 & -0.55 & -0.58 & -0.64 & -0.67 & -0.12 & -0.21 & -0.16 \\
\hline Total & 100.18 & 98.80 & 99.72 & 99.30 & 99.50 & 100.12 & 100.50 & 99.57 & 99.24 & 99.64 & 99.54 & 99.40 \\
\hline T Si (apfu) & 5.685 & 5.734 & 5.737 & 5.808 & 5.776 & 5.690 & 5.673 & 5.767 & 5.831 & 5.711 & 5.757 & 5.709 \\
\hline $\mathrm{TAl}$ & 0.315 & 0.266 & 0.263 & 0.192 & 0.224 & 0.310 & 0.327 & 0.233 & 0.169 & 0.289 & 0.243 & 0.291 \\
\hline B & 3 & 3 & 3 & 3 & 3 & 3 & 3 & 3 & 3 & 3 & 3 & 3 \\
\hline $\mathrm{Z} \mathrm{Al}$ & 6.000 & 6.000 & 6.000 & 6.000 & 6.000 & 6.000 & 6.000 & 6.000 & 6.000 & 6.000 & 6.000 & 6.000 \\
\hline Y Ti & 0.041 & 0.020 & 0.038 & 0.040 & 0.057 & 0.035 & 0.043 & 0.030 & 0.023 & 0.037 & 0.029 & 0.043 \\
\hline Y Al & 1.215 & 1.174 & 1.181 & 0.990 & 0.881 & 1.250 & 1.209 & 1.276 & 1.262 & 0.784 & 0.833 & 0.781 \\
\hline $\mathrm{YCr}$ & 0.002 & 0.000 & 0.003 & 0.001 & 0.002 & 0.000 & 0.000 & 0.000 & 0.005 & 0.000 & 0.000 & 0.007 \\
\hline $\mathrm{YFe}^{3+}$ & 0.000 & 0.000 & 0.000 & 0.000 & 0.000 & 0.000 & 0.000 & 0.000 & 0.000 & 0.000 & 0.000 & 0.000 \\
\hline $\mathrm{Y} \mathrm{Fe}^{2+}$ & 0.439 & 0.605 & 0.532 & 0.931 & 1.250 & 0.447 & 0.405 & 0.123 & 0.163 & 1.684 & 1.631 & 1.670 \\
\hline Y Mn & 0.443 & 0.509 & 0.365 & 0.276 & 0.112 & 0.429 & 0.495 & 0.626 & 0.594 & 0.237 & 0.244 & 0.235 \\
\hline Y Zn & 0.010 & 0.003 & 0.000 & 0.007 & 0.012 & 0.014 & 0.000 & 0.000 & 0.002 & 0.035 & 0.025 & 0.034 \\
\hline Y Mg & 0.026 & 0.046 & 0.056 & 0.051 & 0.082 & 0.030 & 0.018 & 0.009 & 0.003 & 0.072 & 0.078 & 0.065 \\
\hline Y Li & 0.823 & 0.644 & 0.824 & 0.705 & 0.605 & 0.794 & 0.831 & 0.935 & 0.948 & 0.151 & 0.160 & 0.166 \\
\hline $\mathrm{XCa}$ & 0.015 & 0.004 & 0.012 & 0.004 & 0.003 & 0.008 & 0.011 & 0.011 & 0.006 & 0.006 & 0.007 & 0.007 \\
\hline $\mathrm{X} \mathrm{Na}$ & 0.809 & 0.683 & 0.800 & 0.814 & 0.820 & 0.764 & 0.837 & 0.807 & 0.784 & 0.563 & 0.493 & 0.563 \\
\hline x K & 0.001 & 0.004 & 0.002 & 0.003 & 0.007 & 0.003 & 0.005 & 0.002 & 0.007 & 0.007 & 0.007 & 0.007 \\
\hline X vac & 0.175 & 0.309 & 0.186 & 0.178 & 0.171 & 0.224 & 0.147 & 0.180 & 0.203 & 0.424 & 0.493 & 0.424 \\
\hline $\mathrm{V} \mathrm{OH}$ & 3.000 & 3.000 & 3.000 & 3.000 & 3.000 & 3.000 & 3.000 & 3.000 & 3.000 & 3.000 & 3.000 & 3.000 \\
\hline vo & 0.000 & 0.000 & 0.000 & 0.000 & 0.000 & 0.000 & 0.000 & 0.000 & 0.000 & 0.000 & 0.000 & 0.000 \\
\hline W F & 0.718 & 0.665 & 0.583 & 0.787 & 0.791 & 0.664 & 0.701 & 0.776 & 0.817 & 0.148 & 0.262 & 0.199 \\
\hline W Cl & 0.004 & 0.000 & 0.001 & 0.000 & 0.000 & 0.001 & 0.001 & 0.000 & 0.001 & 0.000 & 0.000 & 0.001 \\
\hline $\mathrm{WOH}$ & 0.278 & 0.335 & 0.416 & 0.213 & 0.209 & 0.335 & 0.298 & 0.224 & 0.182 & 0.852 & 0.738 & 0.801 \\
\hline wo & 0.000 & 0.000 & 0.000 & 0.000 & 0.000 & 0.000 & 0.000 & 0.000 & 0.000 & 0.000 & 0.000 & 0.000 \\
\hline Classif. & $\begin{array}{l}\text { fluor- } \\
\text { elbaite }\end{array}$ & $\begin{array}{l}\text { fluor- } \\
\text { elbaite }\end{array}$ & $\begin{array}{l}\text { fluor- } \\
\text { elbaite }\end{array}$ & $\begin{array}{l}\text { fluor- } \\
\text { elbaite }\end{array}$ & $\begin{array}{l}\text { fluor- } \\
\text { schorl }\end{array}$ & $\begin{array}{l}\text { fluor- } \\
\text { elbaite }\end{array}$ & $\begin{array}{l}\text { fluor- } \\
\text { elbaite }\end{array}$ & $\begin{array}{l}\text { fluor- } \\
\text { elbaite }\end{array}$ & $\begin{array}{l}\text { fluor- } \\
\text { elbaite }\end{array}$ & schorl & schorl & schorl \\
\hline
\end{tabular}


Appendix D.1 (contd.): Electron-microprobe analyses of tourmaline.

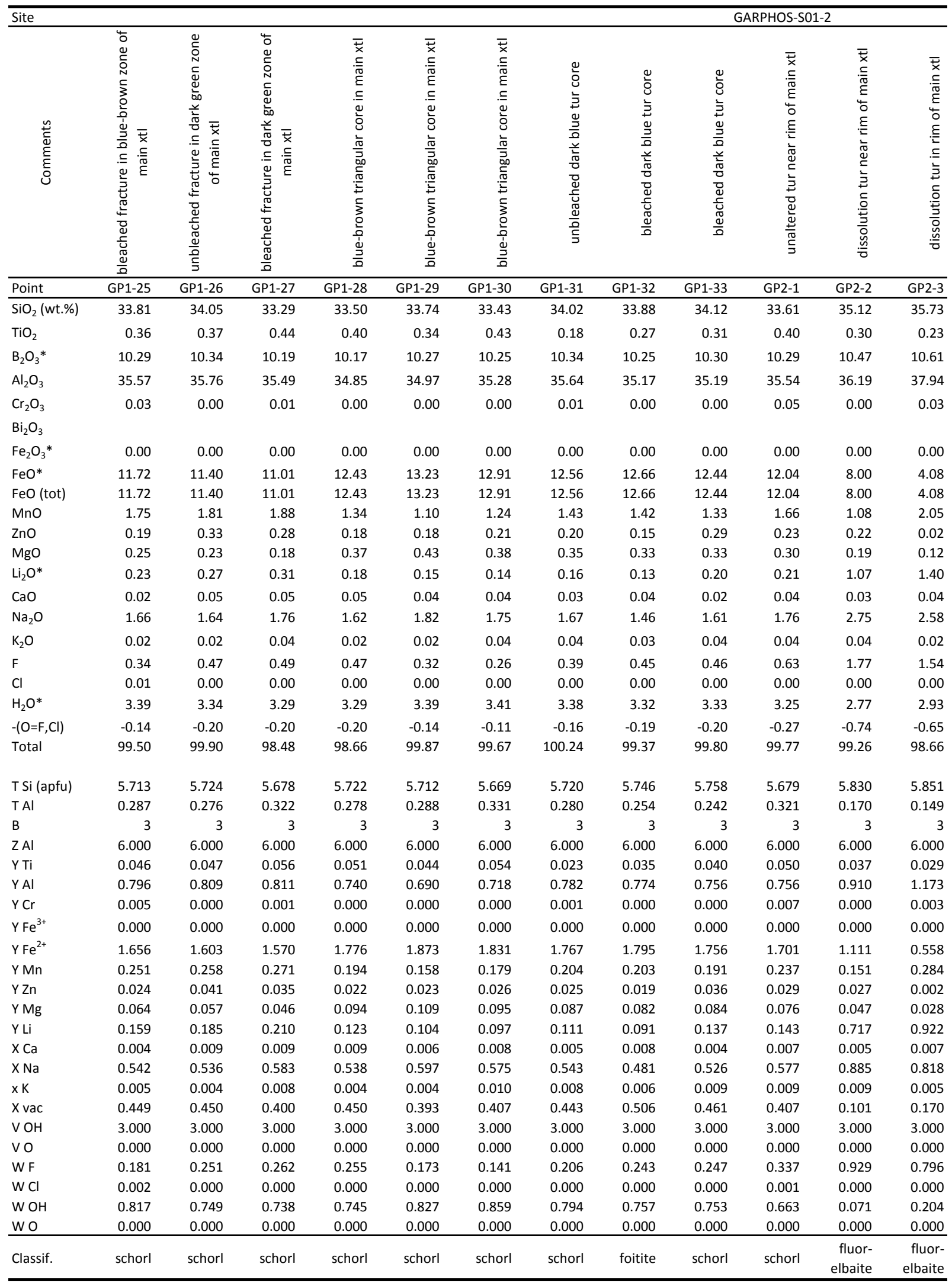


Appendix D.1 (contd.): Electron-microprobe analyses of tourmaline.

\begin{tabular}{|c|c|c|c|c|c|c|c|c|c|c|c|c|}
\hline \multicolumn{13}{|l|}{ Site } \\
\hline 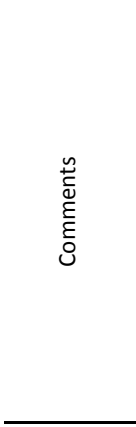 & 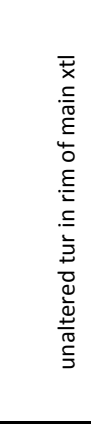 & 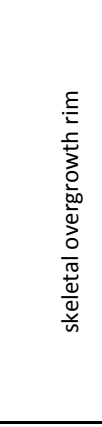 & 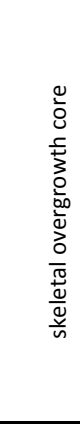 & 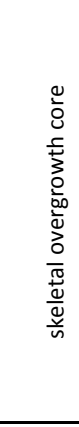 & 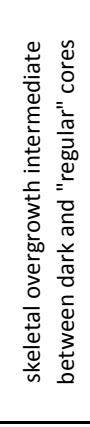 & 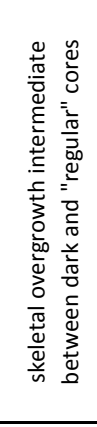 & 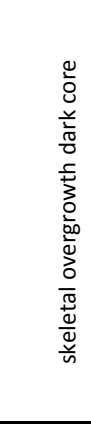 & 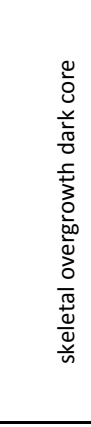 & 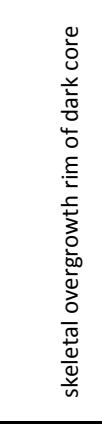 & 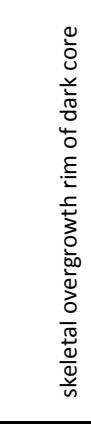 & 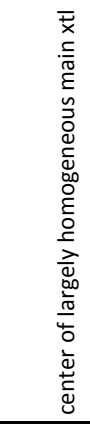 & 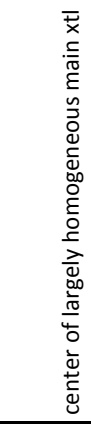 \\
\hline Point & GP2-4 & GP2-5 & GP2-7 & GP2-8 & GP2-9 & GP2-10 & GP2-11 & GP2-12 & GP2-13 & GP2-14 & GP2-15 & GP2-16 \\
\hline $\mathrm{SiO}_{2}$ (wt.\%) & 34.83 & 35.92 & 34.42 & 33.51 & 34.32 & 34.25 & 35.01 & 35.04 & 36.19 & 36.16 & 33.53 & 35.34 \\
\hline $\mathrm{TiO}_{2}$ & 0.17 & 0.22 & 0.14 & 0.27 & 0.34 & 0.23 & 0.25 & 0.18 & 0.17 & 0.24 & 0.37 & 0.30 \\
\hline $\mathrm{B}_{2} \mathrm{O}_{3} *$ & 10.68 & 10.66 & 10.45 & 10.51 & 10.62 & 10.58 & 10.56 & 10.60 & 10.75 & 10.72 & 10.12 & 10.43 \\
\hline $\mathrm{Al}_{2} \mathrm{O}_{3}$ & 39.21 & 38.20 & 37.68 & 39.01 & 39.71 & 39.57 & 37.90 & 38.00 & 39.00 & 38.46 & 33.66 & 34.98 \\
\hline $\mathrm{Cr}_{2} \mathrm{O}_{3}$ & 0.03 & 0.01 & 0.02 & 0.02 & 0.00 & 0.03 & 0.04 & 0.02 & 0.03 & 0.00 & 0.00 & 0.05 \\
\hline \multicolumn{13}{|l|}{$\mathrm{Bi}_{2} \mathrm{O}_{3}$} \\
\hline $\mathrm{Fe}_{2} \mathrm{O}_{3}{ }^{*}$ & 0.00 & 0.00 & 0.00 & 0.00 & 0.00 & 0.00 & 0.00 & 0.00 & 0.00 & 0.00 & 0.00 & 0.00 \\
\hline $\mathrm{FeO}^{*}$ & 3.92 & 2.09 & 5.61 & 5.86 & 2.83 & 2.69 & 4.38 & 5.84 & 1.00 & 2.10 & 14.05 & 9.61 \\
\hline $\mathrm{FeO}$ (tot) & 3.92 & 2.09 & 5.61 & 5.86 & 2.83 & 2.69 & 4.38 & 5.84 & 1.00 & 2.10 & 14.05 & 9.61 \\
\hline $\mathrm{MnO}$ & 4.05 & 3.77 & 3.36 & 3.34 & 3.36 & 3.38 & 2.70 & 1.98 & 4.39 & 3.56 & 1.03 & 0.71 \\
\hline $\mathrm{ZnO}$ & 0.18 & 0.04 & 0.19 & 0.26 & 0.00 & 0.00 & 0.04 & 0.11 & 0.00 & 0.02 & 0.09 & 0.15 \\
\hline $\mathrm{MgO}$ & 0.06 & 0.05 & 0.02 & 0.01 & 0.08 & 0.10 & 0.07 & 0.15 & 0.02 & 0.06 & 0.68 & 0.42 \\
\hline $\mathrm{Li}_{2} \mathrm{O}^{*}$ & 1.01 & 1.46 & 0.87 & 0.77 & 1.23 & 1.23 & 1.29 & 1.16 & 1.46 & 1.49 & 0.04 & 0.94 \\
\hline $\mathrm{CaO}$ & 0.08 & 0.03 & 0.08 & 0.14 & 0.10 & 0.09 & 0.06 & 0.07 & 0.02 & 0.04 & 0.07 & 0.01 \\
\hline $\mathrm{Na}_{2} \mathrm{O}$ & 2.34 & 2.68 & 2.06 & 2.22 & 2.51 & 2.52 & 2.78 & 2.70 & 2.42 & 2.63 & 1.70 & 2.72 \\
\hline $\mathrm{K}_{2} \mathrm{O}$ & 0.00 & 0.00 & 0.04 & 0.02 & 0.02 & 0.03 & 0.02 & 0.04 & 0.04 & 0.02 & 0.05 & 0.03 \\
\hline $\mathrm{F}$ & 1.23 & 1.56 & 0.76 & 0.77 & 1.28 & 1.45 & 1.60 & 1.74 & 1.48 & 1.49 & 0.34 & 1.49 \\
\hline $\mathrm{Cl}$ & 0.00 & 0.00 & 0.01 & 0.00 & 0.00 & 0.01 & 0.00 & 0.00 & 0.01 & 0.00 & 0.01 & 0.00 \\
\hline $\mathrm{H}_{2} \mathrm{O}^{*}$ & 3.10 & 2.94 & 3.24 & 3.26 & 3.06 & 2.96 & 2.89 & 2.83 & 3.01 & 2.99 & 3.33 & 2.89 \\
\hline$-(\mathrm{O}=\mathrm{F}, \mathrm{Cl})$ & -0.52 & -0.66 & -0.32 & -0.33 & -0.54 & -0.61 & -0.67 & -0.73 & -0.62 & -0.63 & -0.15 & -0.63 \\
\hline Total & 100.37 & 98.96 & 98.63 & 99.65 & 98.90 & 98.51 & 98.91 & 99.75 & 99.35 & 99.36 & 98.91 & 99.44 \\
\hline T Si (apfu) & 5.667 & 5.854 & 5.727 & 5.539 & 5.617 & 5.626 & 5.761 & 5.743 & 5.851 & 5.861 & 5.758 & 5.891 \\
\hline TAl & 0.333 & 0.146 & 0.273 & 0.461 & 0.383 & 0.374 & 0.239 & 0.257 & 0.149 & 0.139 & 0.242 & 0.109 \\
\hline B & 3 & 3 & 3 & 3 & 3 & 3 & 3 & 3 & 3 & 3 & 3 & 3 \\
\hline $\mathrm{ZAl}$ & 6.000 & 6.000 & 6.000 & 6.000 & 6.000 & 6.000 & 6.000 & 6.000 & 6.000 & 6.000 & 6.000 & 6.000 \\
\hline $\mathrm{YTi}$ & 0.021 & 0.027 & 0.018 & 0.033 & 0.042 & 0.028 & 0.031 & 0.023 & 0.020 & 0.029 & 0.048 & 0.038 \\
\hline Y Al & 1.185 & 1.192 & 1.114 & 1.139 & 1.277 & 1.288 & 1.110 & 1.083 & 1.283 & 1.208 & 0.572 & 0.764 \\
\hline $\mathrm{YCr}$ & 0.003 & 0.001 & 0.003 & 0.002 & 0.000 & 0.003 & 0.006 & 0.003 & 0.004 & 0.000 & 0.000 & 0.006 \\
\hline $\mathrm{Y} \mathrm{Fe}^{3+}$ & 0.000 & 0.000 & 0.000 & 0.000 & 0.000 & 0.000 & 0.000 & 0.000 & 0.000 & 0.000 & 0.000 & 0.000 \\
\hline $\mathrm{Y} \mathrm{Fe}^{2+}$ & 0.534 & 0.285 & 0.780 & 0.810 & 0.387 & 0.370 & 0.602 & 0.800 & 0.136 & 0.284 & 2.017 & 1.340 \\
\hline Y Mn & 0.559 & 0.521 & 0.473 & 0.468 & 0.465 & 0.471 & 0.376 & 0.275 & 0.601 & 0.488 & 0.151 & 0.101 \\
\hline $\mathrm{YZn}$ & 0.022 & 0.004 & 0.023 & 0.031 & 0.000 & 0.000 & 0.005 & 0.013 & 0.000 & 0.003 & 0.012 & 0.018 \\
\hline Y Mg & 0.013 & 0.012 & 0.004 & 0.003 & 0.020 & 0.026 & 0.018 & 0.036 & 0.006 & 0.014 & 0.175 & 0.105 \\
\hline Y Li & 0.663 & 0.958 & 0.584 & 0.514 & 0.810 & 0.814 & 0.851 & 0.766 & 0.952 & 0.974 & 0.026 & 0.628 \\
\hline $\mathrm{XCa}$ & 0.014 & 0.005 & 0.015 & 0.025 & 0.017 & 0.016 & 0.011 & 0.012 & 0.004 & 0.007 & 0.013 & 0.002 \\
\hline $\mathrm{XNa}$ & 0.738 & 0.846 & 0.665 & 0.713 & 0.795 & 0.802 & 0.886 & 0.859 & 0.757 & 0.827 & 0.564 & 0.880 \\
\hline x K & 0.001 & 0.001 & 0.008 & 0.005 & 0.005 & 0.006 & 0.005 & 0.009 & 0.008 & 0.005 & 0.010 & 0.006 \\
\hline$X$ vac & 0.247 & 0.148 & 0.312 & 0.258 & 0.183 & 0.176 & 0.099 & 0.120 & 0.230 & 0.161 & 0.413 & 0.112 \\
\hline $\mathrm{VOH}$ & 3.000 & 3.000 & 3.000 & 3.000 & 3.000 & 3.000 & 3.000 & 3.000 & 3.000 & 3.000 & 3.000 & 3.000 \\
\hline Vo & 0.000 & 0.000 & 0.000 & 0.000 & 0.000 & 0.000 & 0.000 & 0.000 & 0.000 & 0.000 & 0.000 & 0.000 \\
\hline W F & 0.634 & 0.805 & 0.398 & 0.405 & 0.662 & 0.754 & 0.832 & 0.903 & 0.755 & 0.764 & 0.186 & 0.787 \\
\hline W Cl & 0.000 & 0.000 & 0.004 & 0.001 & 0.001 & 0.002 & 0.000 & 0.000 & 0.002 & 0.000 & 0.002 & 0.000 \\
\hline W OH & 0.366 & 0.195 & 0.598 & 0.594 & 0.337 & 0.244 & 0.168 & 0.097 & 0.243 & 0.236 & 0.813 & 0.213 \\
\hline wo & 0.000 & 0.000 & 0.000 & 0.000 & 0.000 & 0.000 & 0.000 & 0.000 & 0.000 & 0.000 & 0.000 & 0.000 \\
\hline Classif. & $\begin{array}{l}\text { fluor- } \\
\text { elbaite }\end{array}$ & $\begin{array}{l}\text { fluor- } \\
\text { elbaite }\end{array}$ & schorl & schorl & $\begin{array}{l}\text { fluor- } \\
\text { elbaite }\end{array}$ & $\begin{array}{l}\text { fluor- } \\
\text { elbaite }\end{array}$ & $\begin{array}{l}\text { fluor- } \\
\text { elbaite }\end{array}$ & $\begin{array}{l}\text { fluor- } \\
\text { elbaite }\end{array}$ & $\begin{array}{l}\text { fluor- } \\
\text { elbaite }\end{array}$ & $\begin{array}{l}\text { fluor- } \\
\text { elbaite }\end{array}$ & schorl & $\begin{array}{l}\text { fluor- } \\
\text { schorl }\end{array}$ \\
\hline
\end{tabular}


Appendix D.1 (contd.): Electron-microprobe analyses of tourmaline.

\begin{tabular}{|c|c|c|c|c|c|c|c|c|c|c|c|c|}
\hline \multicolumn{13}{|l|}{ Site } \\
\hline 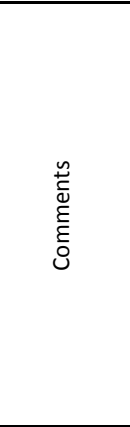 & 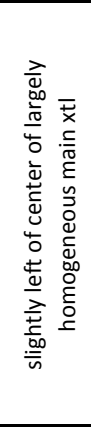 & 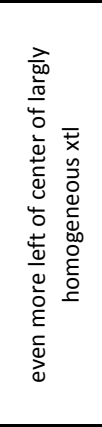 & 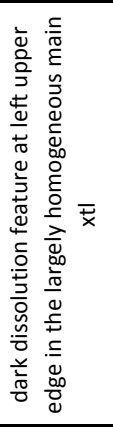 & 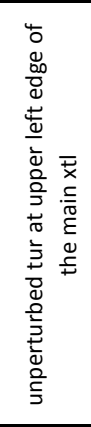 & 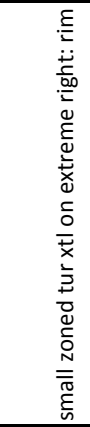 & 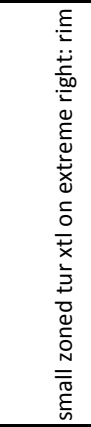 & 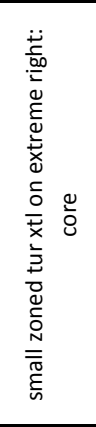 & 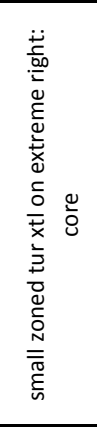 & 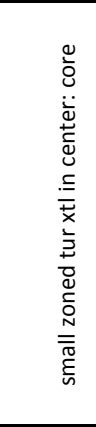 & 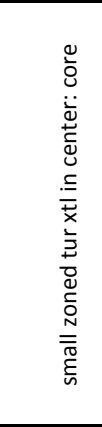 & 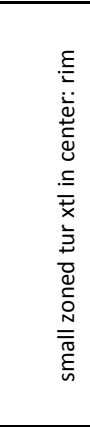 & 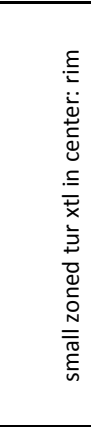 \\
\hline Point & GP2-17 & GP2-18 & GP2-19 & GP2-20 & GP2-21 & GP2-22 & GP2-23 & GP2-24 & GP2-25 & GP2-26 & GP2-27 & GP2-28 \\
\hline $\mathrm{SiO}_{2}$ (wt.\%) & 34.01 & 33.40 & 34.88 & 33.14 & 35.12 & 34.97 & 34.67 & 35.45 & 35.19 & 35.13 & 35.70 & 35.35 \\
\hline $\mathrm{TiO}_{2}$ & 0.37 & 0.38 & 0.38 & 0.66 & 0.22 & 0.27 & 0.20 & 0.11 & 0.19 & 0.24 & 0.26 & 0.26 \\
\hline $\mathrm{B}_{2} \mathrm{O}_{3}{ }^{*}$ & 10.24 & 10.10 & 10.33 & 10.05 & 10.61 & 10.63 & 10.59 & 10.66 & 10.67 & 10.65 & 10.73 & 10.74 \\
\hline $\mathrm{Al}_{2} \mathrm{O}_{3}$ & 33.91 & 33.52 & 35.07 & 33.04 & 38.40 & 38.95 & 38.62 & 38.70 & 38.78 & 38.55 & 39.03 & 39.73 \\
\hline $\mathrm{Cr}_{2} \mathrm{O}_{3}$ & 0.00 & 0.03 & 0.00 & 0.00 & 0.00 & 0.00 & 0.00 & 0.00 & 0.02 & 0.02 & 0.01 & 0.01 \\
\hline \multicolumn{13}{|l|}{$\mathrm{Bi}_{2} \mathrm{O}_{3}$} \\
\hline $\mathrm{Fe}_{2} \mathrm{O}_{3}{ }^{*}$ & 0.00 & 0.00 & 0.00 & 0.00 & 0.00 & 0.00 & 0.00 & 0.00 & 0.00 & 0.00 & 0.00 & 0.00 \\
\hline $\mathrm{FeO} *$ & 14.08 & 13.76 & 8.80 & 13.57 & 3.62 & 3.79 & 4.20 & 3.61 & 3.96 & 3.88 & 1.92 & 0.90 \\
\hline $\mathrm{FeO}$ (tot) & 14.08 & 13.76 & 8.80 & 13.57 & 3.62 & 3.79 & 4.20 & 3.61 & 3.96 & 3.88 & 1.92 & 0.90 \\
\hline $\mathrm{MnO}$ & 0.90 & 0.63 & 0.66 & 0.76 & 2.76 & 2.77 & 3.81 & 3.83 & 3.87 & 4.03 & 3.72 & 4.17 \\
\hline $\mathrm{ZnO}$ & 0.02 & 0.11 & 0.05 & 0.00 & 0.00 & 0.04 & 0.04 & 0.05 & 0.00 & 0.05 & 0.01 & 0.05 \\
\hline $\mathrm{MgO}$ & 0.82 & 1.04 & 0.40 & 1.05 & 0.21 & 0.19 & 0.14 & 0.08 & 0.09 & 0.14 & 0.05 & 0.04 \\
\hline $\mathrm{Li}_{2} \mathrm{O}^{*}$ & 0.09 & 0.07 & 1.01 & 0.15 & 1.34 & 1.19 & 1.02 & 1.11 & 1.07 & 1.04 & 1.47 & 1.48 \\
\hline $\mathrm{CaO}$ & 0.08 & 0.08 & 0.00 & 0.14 & 0.08 & 0.10 & 0.03 & 0.04 & 0.03 & 0.03 & 0.05 & 0.05 \\
\hline $\mathrm{Na}_{2} \mathrm{O}$ & 1.85 & 1.84 & 2.70 & 1.98 & 2.77 & 2.31 & 2.39 & 2.20 & 2.29 & 2.28 & 2.75 & 2.72 \\
\hline $\mathrm{K}_{2} \mathrm{O}$ & 0.02 & 0.01 & 0.03 & 0.05 & 0.01 & 0.04 & 0.02 & 0.01 & 0.01 & 0.03 & 0.02 & 0.02 \\
\hline $\mathrm{F}$ & 0.24 & 0.22 & 1.72 & 0.34 & 1.35 & 1.28 & 0.90 & 1.03 & 1.15 & 0.91 & 1.48 & 1.44 \\
\hline $\mathrm{Cl}$ & 0.00 & 0.00 & 0.00 & 0.00 & 0.00 & 0.00 & 0.00 & 0.00 & 0.00 & 0.00 & 0.00 & 0.00 \\
\hline $\mathrm{H}_{2} \mathrm{O}^{*}$ & 3.42 & 3.38 & 2.75 & 3.31 & 3.02 & 3.06 & 3.23 & 3.19 & 3.13 & 3.24 & 3.00 & 3.02 \\
\hline$-(\mathrm{O}=\mathrm{F}, \mathrm{Cl})$ & -0.10 & -0.09 & -0.72 & -0.14 & -0.57 & -0.54 & -0.38 & -0.44 & -0.49 & -0.39 & -0.63 & -0.61 \\
\hline Total & 99.96 & 98.47 & 98.05 & 98.10 & 98.95 & 99.06 & 99.48 & 99.65 & 99.97 & 99.83 & 99.58 & 99.39 \\
\hline T Si (apfu) & 5.771 & 5.748 & 5.871 & 5.732 & 5.752 & 5.719 & 5.689 & 5.778 & 5.734 & 5.735 & 5.780 & 5.721 \\
\hline TAl & 0.229 & 0.252 & 0.129 & 0.268 & 0.248 & 0.281 & 0.311 & 0.222 & 0.266 & 0.265 & 0.220 & 0.279 \\
\hline B & 3 & 3 & 3 & 3 & 3 & 3 & 3 & 3 & 3 & 3 & 3 & 3 \\
\hline $\mathrm{ZAl}$ & 6.000 & 6.000 & 6.000 & 6.000 & 6.000 & 6.000 & 6.000 & 6.000 & 6.000 & 6.000 & 6.000 & 6.000 \\
\hline$Y \mathrm{Ti}$ & 0.047 & 0.050 & 0.048 & 0.086 & 0.027 & 0.034 & 0.024 & 0.013 & 0.024 & 0.030 & 0.032 & 0.032 \\
\hline Y Al & 0.554 & 0.547 & 0.828 & 0.467 & 1.163 & 1.226 & 1.159 & 1.211 & 1.180 & 1.154 & 1.228 & 1.298 \\
\hline $\mathrm{YCr}$ & 0.000 & 0.004 & 0.000 & 0.000 & 0.000 & 0.000 & 0.000 & 0.001 & 0.002 & 0.002 & 0.001 & 0.002 \\
\hline $\mathrm{YFe}^{3+}$ & 0.000 & 0.000 & 0.000 & 0.000 & 0.000 & 0.000 & 0.000 & 0.000 & 0.000 & 0.000 & 0.000 & 0.000 \\
\hline $\mathrm{Y} \mathrm{Fe}^{2+}$ & 1.999 & 1.981 & 1.239 & 1.963 & 0.496 & 0.519 & 0.577 & 0.493 & 0.539 & 0.530 & 0.261 & 0.121 \\
\hline Y Mn & 0.129 & 0.092 & 0.095 & 0.112 & 0.383 & 0.384 & 0.530 & 0.529 & 0.534 & 0.558 & 0.510 & 0.572 \\
\hline Y Zn & 0.003 & 0.013 & 0.007 & 0.000 & 0.000 & 0.005 & 0.005 & 0.006 & 0.000 & 0.007 & 0.001 & 0.006 \\
\hline Y Mg & 0.207 & 0.268 & 0.100 & 0.271 & 0.052 & 0.046 & 0.033 & 0.020 & 0.022 & 0.034 & 0.013 & 0.009 \\
\hline Y Li & 0.062 & 0.045 & 0.685 & 0.101 & 0.879 & 0.786 & 0.672 & 0.728 & 0.698 & 0.686 & 0.955 & 0.960 \\
\hline X Ca & 0.015 & 0.015 & 0.001 & 0.027 & 0.014 & 0.017 & 0.005 & 0.008 & 0.005 & 0.005 & 0.008 & 0.009 \\
\hline $\mathrm{X} \mathrm{Na}$ & 0.607 & 0.613 & 0.882 & 0.665 & 0.879 & 0.731 & 0.760 & 0.695 & 0.722 & 0.720 & 0.863 & 0.853 \\
\hline x K & 0.004 & 0.003 & 0.007 & 0.012 & 0.003 & 0.008 & 0.004 & 0.002 & 0.002 & 0.005 & 0.004 & 0.004 \\
\hline$X$ vac & 0.373 & 0.369 & 0.110 & 0.296 & 0.104 & 0.244 & 0.230 & 0.295 & 0.271 & 0.270 & 0.125 & 0.134 \\
\hline $\mathrm{VOH}$ & 3.000 & 3.000 & 3.000 & 3.000 & 3.000 & 3.000 & 3.000 & 3.000 & 3.000 & 3.000 & 3.000 & 3.000 \\
\hline Vo & 0.000 & 0.000 & 0.000 & 0.000 & 0.000 & 0.000 & 0.000 & 0.000 & 0.000 & 0.000 & 0.000 & 0.000 \\
\hline W F & 0.126 & 0.119 & 0.913 & 0.184 & 0.701 & 0.663 & 0.468 & 0.533 & 0.595 & 0.472 & 0.760 & 0.737 \\
\hline W Cl & 0.001 & 0.000 & 0.000 & 0.000 & 0.000 & 0.001 & 0.000 & 0.000 & 0.000 & 0.000 & 0.001 & 0.000 \\
\hline W OH & 0.873 & 0.881 & 0.087 & 0.816 & 0.299 & 0.335 & 0.532 & 0.467 & 0.405 & 0.528 & 0.238 & 0.263 \\
\hline wo & 0.000 & 0.000 & 0.000 & 0.000 & 0.000 & 0.000 & 0.000 & 0.000 & 0.000 & 0.000 & 0.000 & 0.000 \\
\hline Classif. & schorl & schorl & $\begin{array}{l}\text { fluor- } \\
\text { schorl }\end{array}$ & schorl & $\begin{array}{l}\text { fluor- } \\
\text { elbaite }\end{array}$ & $\begin{array}{l}\text { fluor- } \\
\text { elbaite }\end{array}$ & elbaite & $\begin{array}{l}\text { fluor- } \\
\text { elbaite }\end{array}$ & $\begin{array}{l}\text { fluor- } \\
\text { elbaite }\end{array}$ & elbaite & $\begin{array}{l}\text { fluor- } \\
\text { elbaite }\end{array}$ & $\begin{array}{l}\text { fluor- } \\
\text { elbaite }\end{array}$ \\
\hline
\end{tabular}


Appendix D.1 (contd.): Electron-microprobe analyses of tourmaline.

\begin{tabular}{|c|c|c|c|c|c|c|c|c|c|c|c|c|}
\hline Site & & RPHOS-SC & & & & & & & & & & \\
\hline 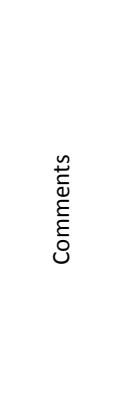 & 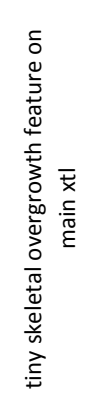 & 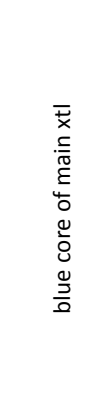 & 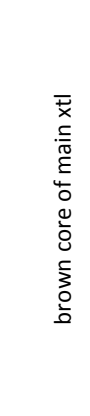 & 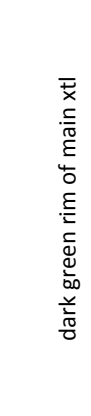 & 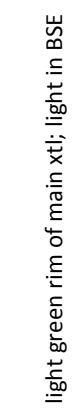 & 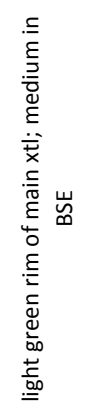 & 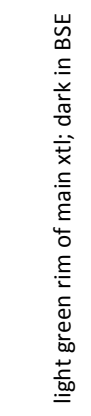 & 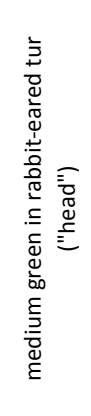 & 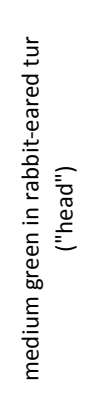 & 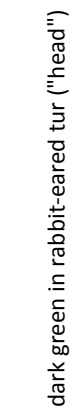 & 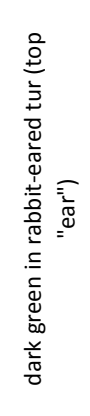 & 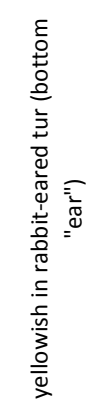 \\
\hline Point & GP2-31 & GP3-1 & GP3-2 & GP3-3 & GP3-4 & GP3-5 & GP3-6 & GP3-7 & GP3-8 & GP3-9 & GP3-10 & GP3-11 \\
\hline $\mathrm{SiO}_{2}$ (wt.\%) & 35.29 & 36.42 & 36.12 & 35.42 & 34.25 & 35.65 & 35.70 & 34.49 & 34.51 & 33.83 & 33.92 & 35.26 \\
\hline $\mathrm{TiO}_{2}$ & 0.24 & 0.28 & 0.50 & 0.62 & 0.65 & 0.43 & 0.24 & 0.64 & 0.42 & 0.61 & 0.52 & 0.43 \\
\hline $\mathrm{B}_{2} \mathrm{O}_{3} *$ & 10.56 & 10.57 & 10.55 & 10.49 & 10.25 & 10.70 & 10.76 & 10.51 & 10.46 & 10.16 & 10.17 & 10.54 \\
\hline $\mathrm{Al}_{2} \mathrm{O}_{3}$ & 37.76 & 33.11 & 33.04 & 32.91 & 33.09 & 37.16 & 38.50 & 35.90 & 35.82 & 33.05 & 33.04 & 35.68 \\
\hline $\mathrm{Cr}_{2} \mathrm{O}_{3}$ & 0.06 & 0.02 & 0.00 & 0.04 & 0.00 & 0.00 & 0.03 & 0.01 & 0.02 & 0.00 & 0.06 & 0.02 \\
\hline \multicolumn{13}{|l|}{$\mathrm{Bi}_{2} \mathrm{O}_{3}$} \\
\hline $\mathrm{Fe}_{2} \mathrm{O}_{3} *$ & 0.00 & 0.00 & 0.00 & 0.00 & 0.00 & 0.00 & 0.00 & 0.00 & 0.00 & 0.00 & 0.00 & 0.00 \\
\hline $\mathrm{FeO} *$ & 3.74 & 10.37 & 9.84 & 12.04 & 13.01 & 7.90 & 5.83 & 10.08 & 10.75 & 14.37 & 14.61 & 9.46 \\
\hline $\mathrm{FeO}$ (tot) & 3.74 & 10.37 & 9.84 & 12.04 & 13.01 & 7.90 & 5.83 & 10.08 & 10.75 & 14.37 & 14.61 & 9.46 \\
\hline $\mathrm{MnO}$ & 2.93 & 0.12 & 0.16 & 0.23 & 0.29 & 1.12 & 0.99 & 1.64 & 1.61 & 0.99 & 0.99 & 0.99 \\
\hline $\mathrm{ZnO}$ & 0.03 & 0.02 & 0.00 & 0.08 & 0.02 & 0.06 & 0.02 & 0.16 & 0.14 & 0.16 & 0.12 & 0.05 \\
\hline $\mathrm{MgO}$ & 0.11 & 4.16 & 4.50 & 3.37 & 2.08 & 1.14 & 0.64 & 0.99 & 0.94 & 0.73 & 0.77 & 0.69 \\
\hline $\mathrm{Li}_{2} \mathrm{O}^{*}$ & 1.32 & 0.15 & 0.13 & 0.12 & 0.12 & 0.82 & 1.21 & 0.49 & 0.35 & 0.09 & 0.05 & 0.86 \\
\hline $\mathrm{CaO}$ & 0.03 & 0.21 & 0.31 & 0.31 & 0.17 & 0.15 & 0.30 & 0.11 & 0.09 & 0.13 & 0.12 & 0.09 \\
\hline $\mathrm{Na}_{2} \mathrm{O}$ & 2.65 & 1.77 & 1.65 & 1.97 & 1.87 & 2.17 & 2.39 & 2.21 & 1.90 & 1.79 & 1.80 & 2.66 \\
\hline $\mathrm{K}_{2} \mathrm{O}$ & 0.02 & 0.03 & 0.04 & 0.05 & 0.04 & 0.00 & 0.03 & 0.04 & 0.01 & 0.06 & 0.05 & 0.04 \\
\hline$F$ & 1.79 & 0.13 & 0.34 & 0.02 & 0.19 & 1.01 & 1.55 & 0.65 & 0.59 & 0.28 & 0.35 & 1.31 \\
\hline $\mathrm{Cl}$ & 0.00 & 0.00 & 0.00 & 0.00 & 0.00 & 0.00 & 0.00 & 0.00 & 0.00 & 0.00 & 0.00 & 0.00 \\
\hline $\mathrm{H}_{2} \mathrm{O}^{*}$ & 2.79 & 3.59 & 3.48 & 3.61 & 3.44 & 3.21 & 2.98 & 3.32 & 3.33 & 3.37 & 3.34 & 3.01 \\
\hline$-(\mathrm{O}=\mathrm{F}, \mathrm{Cl})$ & -0.75 & -0.05 & -0.14 & -0.01 & -0.08 & -0.42 & -0.65 & -0.27 & -0.25 & -0.12 & -0.15 & -0.55 \\
\hline Total & 98.56 & 100.89 & 100.52 & 101.25 & 99.41 & 101.11 & 100.52 & 100.96 & 100.70 & 99.51 & 99.77 & 100.53 \\
\hline T Si (apfu) & 5.809 & 5.985 & 5.951 & 5.870 & 5.808 & 5.789 & 5.768 & 5.705 & 5.732 & 5.790 & 5.795 & 5.817 \\
\hline T Al & 0.191 & 0.015 & 0.049 & 0.130 & 0.192 & 0.211 & 0.232 & 0.295 & 0.268 & 0.210 & 0.205 & 0.183 \\
\hline B & 3 & 3 & 3 & 3 & 3 & 3 & 3 & 3 & 3 & 3 & 3 & 3 \\
\hline $\mathrm{ZAl}$ & 6.000 & 6.000 & 6.000 & 6.000 & 6.000 & 6.000 & 6.000 & 6.000 & 6.000 & 6.000 & 6.000 & 6.000 \\
\hline$Y \mathrm{Ti}$ & 0.030 & 0.035 & 0.062 & 0.077 & 0.083 & 0.052 & 0.029 & 0.079 & 0.052 & 0.079 & 0.067 & 0.054 \\
\hline Y Al & 1.136 & 0.400 & 0.367 & 0.297 & 0.421 & 0.902 & 1.100 & 0.705 & 0.745 & 0.455 & 0.448 & 0.753 \\
\hline $\mathrm{YCr}$ & 0.008 & 0.003 & 0.000 & 0.006 & 0.000 & 0.001 & 0.003 & 0.001 & 0.003 & 0.000 & 0.009 & 0.003 \\
\hline $\mathrm{YFe}^{3+}$ & 0.000 & 0.000 & 0.000 & 0.000 & 0.000 & 0.000 & 0.000 & 0.000 & 0.000 & 0.000 & 0.000 & 0.000 \\
\hline $\mathrm{Y} \mathrm{Fe}^{2+}$ & 0.515 & 1.425 & 1.356 & 1.668 & 1.845 & 1.073 & 0.787 & 1.394 & 1.494 & 2.057 & 2.087 & 1.304 \\
\hline Y Mn & 0.409 & 0.017 & 0.022 & 0.032 & 0.041 & 0.154 & 0.136 & 0.230 & 0.227 & 0.144 & 0.143 & 0.138 \\
\hline Y Zn & 0.004 & 0.002 & 0.001 & 0.010 & 0.002 & 0.007 & 0.002 & 0.019 & 0.017 & 0.021 & 0.015 & 0.006 \\
\hline Y Mg & 0.026 & 1.020 & 1.104 & 0.833 & 0.527 & 0.277 & 0.154 & 0.245 & 0.232 & 0.185 & 0.196 & 0.171 \\
\hline Y Li & 0.872 & 0.099 & 0.088 & 0.078 & 0.081 & 0.534 & 0.789 & 0.326 & 0.231 & 0.059 & 0.035 & 0.571 \\
\hline X Ca & 0.006 & 0.037 & 0.054 & 0.054 & 0.031 & 0.027 & 0.053 & 0.019 & 0.017 & 0.024 & 0.023 & 0.017 \\
\hline $\mathrm{X} \mathrm{Na}$ & 0.844 & 0.563 & 0.527 & 0.633 & 0.614 & 0.684 & 0.747 & 0.710 & 0.610 & 0.594 & 0.595 & 0.850 \\
\hline$x \mathrm{~K}$ & 0.004 & 0.005 & 0.009 & 0.011 & 0.009 & 0.000 & 0.006 & 0.009 & 0.002 & 0.012 & 0.010 & 0.007 \\
\hline $\mathrm{X}$ vac & 0.146 & 0.395 & 0.409 & 0.302 & 0.346 & 0.289 & 0.194 & 0.262 & 0.371 & 0.369 & 0.373 & 0.126 \\
\hline $\mathrm{VOH}$ & 3.000 & 3.000 & 3.000 & 3.000 & 3.000 & 3.000 & 3.000 & 3.000 & 3.000 & 3.000 & 3.000 & 3.000 \\
\hline Vo & 0.000 & 0.000 & 0.000 & 0.000 & 0.000 & 0.000 & 0.000 & 0.000 & 0.000 & 0.000 & 0.000 & 0.000 \\
\hline W F & 0.931 & 0.067 & 0.175 & 0.012 & 0.104 & 0.518 & 0.792 & 0.339 & 0.308 & 0.152 & 0.188 & 0.685 \\
\hline W Cl & 0.001 & 0.000 & 0.000 & 0.000 & 0.000 & 0.000 & 0.000 & 0.000 & 0.000 & 0.000 & 0.000 & 0.000 \\
\hline W OH & 0.067 & 0.933 & 0.825 & 0.988 & 0.896 & 0.482 & 0.208 & 0.661 & 0.692 & 0.848 & 0.812 & 0.315 \\
\hline wo & 0.000 & 0.000 & 0.000 & 0.000 & 0.000 & 0.000 & 0.000 & 0.000 & 0.000 & 0.000 & 0.000 & 0.000 \\
\hline Classif. & $\begin{array}{l}\text { fluor- } \\
\text { elbaite }\end{array}$ & schorl & schorl & schorl & schorl & $\begin{array}{l}\text { fluor- } \\
\text { schorl }\end{array}$ & $\begin{array}{l}\text { fluor- } \\
\text { elbaite }\end{array}$ & schorl & schorl & schorl & schorl & $\begin{array}{l}\text { fluor- } \\
\text { schorl }\end{array}$ \\
\hline
\end{tabular}


Appendix D.1 (contd.): Electron-microprobe analyses of tourmaline.

\begin{tabular}{|c|c|c|c|c|c|c|c|c|c|c|c|c|}
\hline \multicolumn{13}{|l|}{ Site } \\
\hline 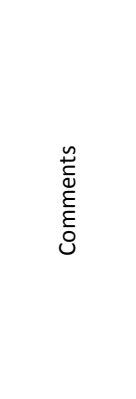 & 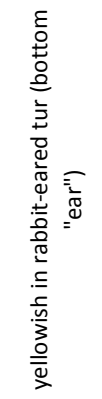 & 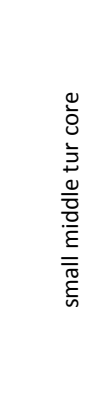 & 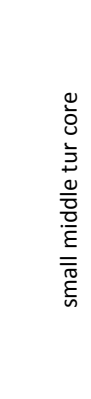 & 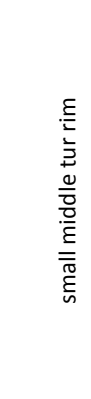 & 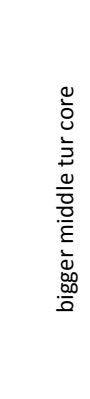 & 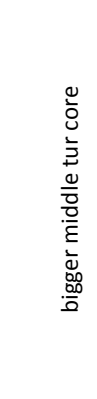 & 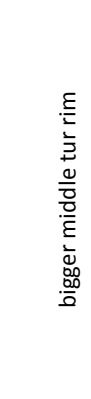 & 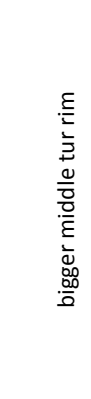 & 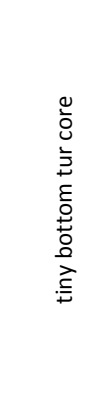 & $\begin{array}{l}0 \\
0 \\
0 \\
\vdots \\
\pm \\
\varepsilon \\
0 \\
\pm \\
0 \\
0 \\
\text { D. }\end{array}$ & 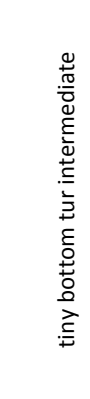 & 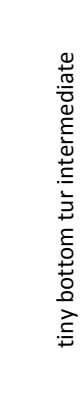 \\
\hline Point & GP3-12 & GP3-13 & GP3-14 & GP3-15 & GP3-17 & GP3-18 & GP3-19 & GP3-20 & GP3-21 & GP3-22 & GP3-23 & GP3-24 \\
\hline $\mathrm{SiO}_{2}$ (wt.\%) & 35.35 & 36.24 & 35.57 & 35.91 & 35.52 & 36.00 & 35.79 & 35.59 & 34.76 & 35.33 & 35.41 & 35.60 \\
\hline $\mathrm{TiO}_{2}$ & 0.49 & 0.32 & 0.32 & 0.29 & 0.25 & 0.24 & 0.39 & 0.26 & 0.33 & 0.35 & 0.34 & 0.42 \\
\hline $\mathrm{B}_{2} \mathrm{O}_{3} *$ & 10.46 & 10.87 & 10.86 & 10.71 & 10.74 & 10.78 & 10.79 & 10.74 & 10.65 & 10.73 & 10.74 & 10.79 \\
\hline $\mathrm{Al}_{2} \mathrm{O}_{3}$ & 35.17 & 39.09 & 39.67 & 38.14 & 38.70 & 38.26 & 38.88 & 38.74 & 38.91 & 38.81 & 38.60 & 38.95 \\
\hline $\mathrm{Cr}_{2} \mathrm{O}_{3}$ & 0.03 & 0.03 & 0.00 & 0.00 & 0.04 & 0.03 & 0.00 & 0.03 & 0.02 & 0.04 & 0.00 & 0.02 \\
\hline \multicolumn{13}{|l|}{$\mathrm{Bi}_{2} \mathrm{O}_{3}$} \\
\hline $\mathrm{Fe}_{2} \mathrm{O}_{3}{ }^{*}$ & 0.00 & 0.00 & 0.00 & 0.00 & 0.00 & 0.00 & 0.00 & 0.00 & 0.00 & 0.00 & 0.00 & 0.00 \\
\hline $\mathrm{FeO}^{*}$ & 9.22 & 3.85 & 3.88 & 3.08 & 4.53 & 5.17 & 3.98 & 4.47 & 4.52 & 4.30 & 4.28 & 4.42 \\
\hline $\mathrm{FeO}$ (tot) & 9.22 & 3.85 & 3.88 & 3.08 & 4.53 & 5.17 & 3.98 & 4.47 & 4.52 & 4.30 & 4.28 & 4.42 \\
\hline $\mathrm{MnO}$ & 0.84 & 2.85 & 2.89 & 3.43 & 3.83 & 3.65 & 2.80 & 2.49 & 2.67 & 2.67 & 2.78 & 2.43 \\
\hline $\mathrm{ZnO}$ & 0.04 & 0.06 & 0.00 & 0.01 & 0.08 & 0.06 & 0.00 & 0.02 & 0.04 & 0.00 & 0.08 & 0.04 \\
\hline $\mathrm{MgO}$ & 0.62 & 0.18 & 0.15 & 0.15 & 0.15 & 0.21 & 0.21 & 0.15 & 0.17 & 0.16 & 0.17 & 0.22 \\
\hline $\mathrm{Li}_{2} \mathrm{O}^{*}$ & 0.92 & 1.32 & 1.29 & 1.41 & 1.00 & 0.99 & 1.30 & 1.28 & 1.18 & 1.27 & 1.31 & 1.29 \\
\hline $\mathrm{CaO}$ & 0.04 & 0.09 & 0.09 & 0.06 & 0.02 & 0.04 & 0.08 & 0.04 & 0.09 & 0.08 & 0.15 & 0.06 \\
\hline $\mathrm{Na}_{2} \mathrm{O}$ & 2.58 & 2.50 & 2.71 & 2.81 & 2.20 & 2.18 & 2.59 & 2.69 & 2.63 & 2.70 & 2.80 & 2.71 \\
\hline $\mathrm{K}_{2} \mathrm{O}$ & 0.04 & 0.02 & 0.02 & 0.02 & 0.02 & 0.02 & 0.03 & 0.01 & 0.00 & 0.03 & 0.03 & 0.03 \\
\hline $\mathrm{F}$ & 1.61 & 1.27 & 1.14 & 1.71 & 0.99 & 1.20 & 1.13 & 1.41 & 1.34 & 1.41 & 1.47 & 1.29 \\
\hline $\mathrm{Cl}$ & 0.03 & 0.01 & 0.00 & 0.00 & 0.00 & 0.00 & 0.01 & 0.01 & 0.01 & 0.00 & 0.00 & 0.00 \\
\hline $\mathrm{H}_{2} \mathrm{O}^{*}$ & 2.84 & 3.15 & 3.21 & 2.88 & 3.23 & 3.15 & 3.19 & 3.04 & 3.04 & 3.03 & 3.01 & 3.11 \\
\hline$-(\mathrm{O}=\mathrm{F}, \mathrm{Cl})$ & -0.68 & -0.54 & -0.48 & -0.72 & -0.42 & -0.50 & -0.48 & -0.60 & -0.57 & -0.59 & -0.62 & -0.54 \\
\hline Total & 99.58 & 101.31 & 101.33 & 99.90 & 100.89 & 101.49 & 100.70 & 100.38 & 99.78 & 100.32 & 100.54 & 100.85 \\
\hline T Si (apfu) & 5.874 & 5.794 & 5.696 & 5.825 & 5.749 & 5.804 & 5.763 & 5.758 & 5.672 & 5.724 & 5.732 & 5.733 \\
\hline TAl & 0.126 & 0.206 & 0.304 & 0.175 & 0.251 & 0.196 & 0.237 & 0.242 & 0.328 & 0.276 & 0.268 & 0.267 \\
\hline B & 3 & 3 & 3 & 3 & 3 & 3 & 3 & 3 & 3 & 3 & 3 & 3 \\
\hline $\mathrm{ZAl}$ & 6.000 & 6.000 & 6.000 & 6.000 & 6.000 & 6.000 & 6.000 & 6.000 & 6.000 & 6.000 & 6.000 & 6.000 \\
\hline $\mathrm{YTi}$ & 0.061 & 0.038 & 0.038 & 0.035 & 0.030 & 0.029 & 0.047 & 0.031 & 0.040 & 0.043 & 0.042 & 0.051 \\
\hline Y Al & 0.762 & 1.161 & 1.182 & 1.117 & 1.131 & 1.073 & 1.142 & 1.146 & 1.154 & 1.134 & 1.097 & 1.126 \\
\hline $\mathrm{YCr}$ & 0.004 & 0.004 & 0.000 & 0.000 & 0.005 & 0.004 & 0.000 & 0.004 & 0.003 & 0.005 & 0.000 & 0.003 \\
\hline $\mathrm{YFe}^{3+}$ & 0.000 & 0.000 & 0.000 & 0.000 & 0.000 & 0.000 & 0.000 & 0.000 & 0.000 & 0.000 & 0.000 & 0.000 \\
\hline $\mathrm{Y} \mathrm{Fe}^{2+}$ & 1.281 & 0.514 & 0.520 & 0.418 & 0.613 & 0.698 & 0.536 & 0.605 & 0.617 & 0.582 & 0.579 & 0.595 \\
\hline Y Mn & 0.118 & 0.386 & 0.392 & 0.471 & 0.525 & 0.498 & 0.381 & 0.342 & 0.369 & 0.366 & 0.381 & 0.332 \\
\hline $\mathrm{YZn}$ & 0.005 & 0.008 & 0.000 & 0.001 & 0.010 & 0.007 & 0.000 & 0.002 & 0.005 & 0.000 & 0.009 & 0.005 \\
\hline Y Mg & 0.154 & 0.042 & 0.036 & 0.036 & 0.036 & 0.051 & 0.051 & 0.037 & 0.040 & 0.039 & 0.041 & 0.053 \\
\hline Y Li & 0.614 & 0.848 & 0.832 & 0.922 & 0.650 & 0.640 & 0.843 & 0.832 & 0.772 & 0.831 & 0.851 & 0.835 \\
\hline $\mathrm{XCa}$ & 0.007 & 0.016 & 0.016 & 0.010 & 0.004 & 0.007 & 0.014 & 0.008 & 0.015 & 0.015 & 0.026 & 0.009 \\
\hline $\mathrm{XNa}$ & 0.830 & 0.775 & 0.842 & 0.885 & 0.692 & 0.683 & 0.810 & 0.843 & 0.833 & 0.847 & 0.879 & 0.847 \\
\hline $\mathrm{xK}$ & 0.008 & 0.005 & 0.005 & 0.004 & 0.005 & 0.005 & 0.007 & 0.003 & 0.000 & 0.005 & 0.007 & 0.005 \\
\hline$X$ vac & 0.155 & 0.204 & 0.138 & 0.101 & 0.299 & 0.306 & 0.170 & 0.146 & 0.151 & 0.133 & 0.088 & 0.138 \\
\hline $\mathrm{VOH}$ & 3.000 & 3.000 & 3.000 & 3.000 & 3.000 & 3.000 & 3.000 & 3.000 & 3.000 & 3.000 & 3.000 & 3.000 \\
\hline Vo & 0.000 & 0.000 & 0.000 & 0.000 & 0.000 & 0.000 & 0.000 & 0.000 & 0.000 & 0.000 & 0.000 & 0.000 \\
\hline W F & 0.844 & 0.641 & 0.576 & 0.879 & 0.509 & 0.610 & 0.574 & 0.722 & 0.690 & 0.720 & 0.753 & 0.657 \\
\hline W Cl & 0.008 & 0.003 & 0.000 & 0.000 & 0.001 & 0.001 & 0.002 & 0.002 & 0.002 & 0.001 & 0.001 & 0.001 \\
\hline $\mathrm{WOH}$ & 0.148 & 0.357 & 0.424 & 0.121 & 0.490 & 0.389 & 0.424 & 0.276 & 0.308 & 0.279 & 0.246 & 0.342 \\
\hline wo & 0.000 & 0.000 & 0.000 & 0.000 & 0.000 & 0.000 & 0.000 & 0.000 & 0.000 & 0.000 & 0.000 & 0.000 \\
\hline Classif. & $\begin{array}{l}\text { fluor- } \\
\text { schorl }\end{array}$ & $\begin{array}{l}\text { fluor- } \\
\text { elbaite }\end{array}$ & $\begin{array}{l}\text { fluor- } \\
\text { elbaite }\end{array}$ & $\begin{array}{l}\text { fluor- } \\
\text { elbaite }\end{array}$ & $\begin{array}{l}\text { fluor- } \\
\text { elbaite }\end{array}$ & $\begin{array}{l}\text { fluor- } \\
\text { elbaite }\end{array}$ & $\begin{array}{l}\text { fluor- } \\
\text { elbaite }\end{array}$ & $\begin{array}{l}\text { fluor- } \\
\text { elbaite }\end{array}$ & $\begin{array}{l}\text { fluor- } \\
\text { elbaite }\end{array}$ & $\begin{array}{l}\text { fluor- } \\
\text { elbaite }\end{array}$ & $\begin{array}{l}\text { fluor- } \\
\text { elbaite }\end{array}$ & $\begin{array}{l}\text { fluor- } \\
\text { elbaite }\end{array}$ \\
\hline
\end{tabular}


Appendix D.1 (contd.): Electron-microprobe analyses of tourmaline.

\begin{tabular}{|c|c|c|c|c|c|c|c|c|c|c|c|c|}
\hline \multicolumn{2}{|l|}{ Site } & \multicolumn{3}{|c|}{ GARPHOS-S01/S02 } & \multicolumn{5}{|c|}{ GARPHOS-S03 } & \multicolumn{3}{|c|}{ GARPHOS-S03 } \\
\hline 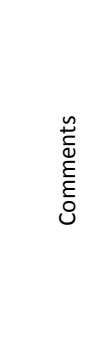 & 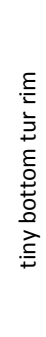 & 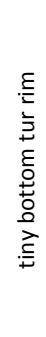 & 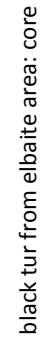 & 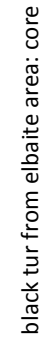 & 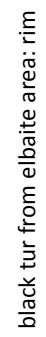 & 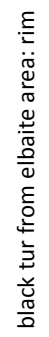 & 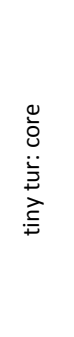 & 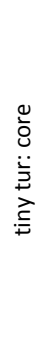 & 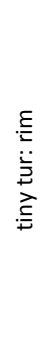 & 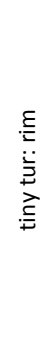 & 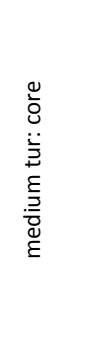 & 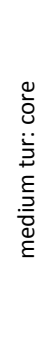 \\
\hline
\end{tabular}

\begin{tabular}{|c|c|c|c|c|c|c|c|c|c|c|c|c|}
\hline Point & GP3-25 & GP3-26 & $48 \mathrm{t}-1$ & $48 \mathrm{t}-2$ & $48 \mathrm{t}-3$ & $48 \mathrm{t}-4$ & $49 \mathrm{t}-1$ & $49 \mathrm{t}-2$ & $49 \mathrm{t}-3$ & $49 \mathrm{t}-4$ & $50 \mathrm{t}-1$ & $50 \mathrm{t}-2$ \\
\hline $\mathrm{SiO}_{2}$ (wt.\%) & 36.37 & 35.59 & 33.58 & 34.16 & 36.38 & 36.10 & 35.96 & 35.99 & 35.34 & 35.17 & 35.64 & 35.38 \\
\hline $\mathrm{TiO}_{2}$ & 0.22 & 0.18 & 0.23 & 0.29 & 0.21 & 0.37 & 0.57 & 0.52 & 0.55 & 0.55 & 0.47 & 0.58 \\
\hline $\mathrm{B}_{2} \mathrm{O}_{3} *$ & 10.81 & 10.78 & 10.34 & 10.38 & 10.73 & 10.74 & 10.65 & 10.63 & 10.50 & 10.44 & 10.53 & 10.52 \\
\hline $\mathrm{Al}_{2} \mathrm{O}_{3}$ & 38.78 & 39.91 & 36.78 & 36.31 & 37.93 & 38.15 & 33.47 & 33.31 & 32.75 & 32.27 & 32.15 & 32.64 \\
\hline $\mathrm{Cr}_{2} \mathrm{O}_{3}$ & 0.00 & 0.03 & 0.00 & 0.00 & 0.03 & 0.03 & 0.02 & 0.04 & 0.04 & 0.09 & 0.03 & 0.00 \\
\hline \multicolumn{13}{|l|}{$\mathrm{Bi}_{2} \mathrm{O}_{3}$} \\
\hline $\mathrm{Fe}_{2} \mathrm{O}_{3} *$ & 0.00 & 0.00 & 0.00 & 0.00 & 0.00 & 0.00 & 0.00 & 0.00 & 0.00 & 0.00 & 0.00 & 0.00 \\
\hline $\mathrm{FeO} *$ & 1.57 & 0.86 & 10.21 & 10.08 & 2.35 & 2.34 & 4.92 & 5.08 & 7.70 & 7.52 & 7.75 & 7.23 \\
\hline $\mathrm{FeO}$ (tot) & 1.57 & 0.86 & 10.21 & 10.08 & 2.35 & 2.34 & 4.92 & 5.08 & 7.70 & 7.52 & 7.75 & 7.23 \\
\hline $\mathrm{MnO}$ & 4.14 & 4.04 & 2.11 & 2.04 & 3.84 & 3.59 & 0.00 & 0.00 & 0.07 & 0.05 & 0.10 & 0.00 \\
\hline $\mathrm{ZnO}$ & 0.03 & 0.07 & 0.54 & 0.59 & 0.13 & 0.10 & 0.04 & 0.06 & 0.04 & 0.00 & 0.05 & 0.00 \\
\hline MgO & 0.07 & 0.02 & 0.08 & 0.08 & 0.03 & 0.05 & 7.98 & 7.89 & 6.54 & 6.76 & 6.95 & 7.02 \\
\hline $\mathrm{Li}_{2} \mathrm{O}^{*}$ & 1.53 & 1.49 & 0.31 & 0.43 & 1.49 & 1.53 & 0.00 & 0.00 & 0.00 & 0.00 & 0.00 & 0.00 \\
\hline $\mathrm{CaO}$ & 0.06 & 0.07 & 0.04 & 0.06 & 0.04 & 0.06 & 0.91 & 0.87 & 0.92 & 0.92 & 1.10 & 1.00 \\
\hline $\mathrm{Na}_{2} \mathrm{O}$ & 2.78 & 2.65 & 1.69 & 1.83 & 2.77 & 2.92 & 2.00 & 1.92 & 1.78 & 1.86 & 1.91 & 1.82 \\
\hline $\mathrm{K}_{2} \mathrm{O}$ & 0.03 & 0.02 & 0.03 & 0.03 & 0.03 & 0.01 & 0.05 & 0.05 & 0.06 & 0.06 & 0.05 & 0.07 \\
\hline $\mathrm{F}$ & 1.36 & 1.45 & 0.61 & 0.59 & 1.62 & 1.51 & 0.38 & 0.42 & 0.13 & 0.31 & 0.23 & 0.25 \\
\hline $\mathrm{Cl}$ & 0.00 & 0.00 & 0.00 & 0.00 & 0.00 & 0.00 & 0.00 & 0.00 & 0.01 & 0.01 & 0.00 & 0.01 \\
\hline $\mathrm{H}_{2} \mathrm{O}^{*}$ & 3.09 & 3.03 & 3.28 & 3.30 & 2.94 & 2.99 & 3.23 & 3.24 & 3.44 & 3.33 & 3.39 & 3.38 \\
\hline$-(\mathrm{O}=\mathrm{F}, \mathrm{Cl})$ & -0.57 & -0.61 & -0.26 & -0.25 & -0.68 & -0.64 & -0.16 & -0.18 & -0.06 & -0.13 & -0.10 & -0.11 \\
\hline Total & 100.25 & 99.58 & 99.57 & 99.93 & 99.82 & 99.86 & 100.03 & 99.83 & 99.80 & 99.21 & 100.24 & 99.79 \\
\hline T Si (apfu) & 5.847 & 5.740 & 5.646 & 5.717 & 5.893 & 5.843 & 5.870 & 5.886 & 5.847 & 5.856 & 5.883 & 5.846 \\
\hline T Al & 0.153 & 0.260 & 0.354 & 0.283 & 0.107 & 0.157 & 0.130 & 0.114 & 0.153 & 0.144 & 0.117 & 0.154 \\
\hline B & 3 & 3 & 3 & 3 & 3 & 3 & 3 & 3 & 3 & 3 & 3 & 3 \\
\hline $\mathrm{Z} \mathrm{Al}$ & 6.000 & 6.000 & 6.000 & 6.000 & 6.000 & 6.000 & 6.000 & 6.000 & 6.000 & 6.000 & 6.000 & 6.000 \\
\hline Y Ti & 0.026 & 0.022 & 0.029 & 0.037 & 0.025 & 0.045 & 0.070 & 0.064 & 0.068 & 0.069 & 0.059 & 0.072 \\
\hline Y Al & 1.193 & 1.325 & 0.935 & 0.879 & 1.133 & 1.121 & 0.309 & 0.306 & 0.234 & 0.188 & 0.138 & 0.201 \\
\hline Y Cr & 0.000 & 0.004 & 0.000 & 0.000 & 0.004 & 0.004 & 0.003 & 0.005 & 0.006 & 0.012 & 0.004 & 0.000 \\
\hline $\mathrm{YFe}^{3+}$ & 0.000 & 0.000 & 0.000 & 0.000 & 0.000 & 0.000 & 0.000 & 0.000 & 0.000 & 0.000 & 0.000 & 0.000 \\
\hline $\mathrm{Y} \mathrm{Fe}^{2+}$ & 0.210 & 0.116 & 1.436 & 1.410 & 0.319 & 0.317 & 0.671 & 0.695 & 1.066 & 1.047 & 1.070 & 0.999 \\
\hline Y Mn & 0.563 & 0.551 & 0.300 & 0.290 & 0.526 & 0.492 & 0.000 & 0.000 & 0.010 & 0.007 & 0.014 & 0.000 \\
\hline Y Zn & 0.003 & 0.008 & 0.067 & 0.073 & 0.016 & 0.011 & 0.005 & 0.007 & 0.005 & 0.000 & 0.006 & 0.000 \\
\hline Y Mg & 0.016 & 0.005 & 0.020 & 0.020 & 0.007 & 0.012 & 1.942 & 1.923 & 1.612 & 1.678 & 1.709 & 1.728 \\
\hline Y Li & 0.987 & 0.969 & 0.212 & 0.291 & 0.969 & 0.998 & 0.000 & 0.000 & 0.000 & 0.000 & 0.000 & 0.000 \\
\hline X Ca & 0.010 & 0.013 & 0.008 & 0.011 & 0.007 & 0.010 & 0.159 & 0.152 & 0.162 & 0.164 & 0.194 & 0.177 \\
\hline X Na & 0.868 & 0.827 & 0.551 & 0.593 & 0.869 & 0.917 & 0.634 & 0.610 & 0.570 & 0.601 & 0.611 & 0.581 \\
\hline x K & 0.006 & 0.004 & 0.005 & 0.007 & 0.006 & 0.002 & 0.011 & 0.011 & 0.012 & 0.014 & 0.011 & 0.015 \\
\hline $\mathrm{X}$ vac & 0.116 & 0.156 & 0.436 & 0.389 & 0.119 & 0.071 & 0.196 & 0.227 & 0.256 & 0.221 & 0.184 & 0.226 \\
\hline $\mathrm{VOH}$ & 3.000 & 3.000 & 3.000 & 3.000 & 3.000 & 3.000 & 3.000 & 3.000 & 3.000 & 3.000 & 3.000 & 3.000 \\
\hline Vo & 0.000 & 0.000 & 0.000 & 0.000 & 0.000 & 0.000 & 0.000 & 0.000 & 0.000 & 0.000 & 0.000 & 0.000 \\
\hline W F & 0.689 & 0.741 & 0.323 & 0.310 & 0.828 & 0.773 & 0.195 & 0.219 & 0.069 & 0.163 & 0.119 & 0.132 \\
\hline W Cl & 0.000 & 0.001 & 0.000 & 0.000 & 0.000 & 0.001 & 0.001 & 0.000 & 0.002 & 0.003 & 0.000 & 0.002 \\
\hline $\mathrm{WOH}$ & 0.311 & 0.258 & 0.677 & 0.690 & 0.172 & 0.226 & 0.522 & 0.531 & 0.801 & 0.699 & 0.728 & 0.725 \\
\hline wo & 0.000 & 0.000 & 0.000 & 0.000 & 0.000 & 0.000 & 0.283 & 0.250 & 0.129 & 0.135 & 0.153 & 0.141 \\
\hline Classif. & $\begin{array}{l}\text { fluor- } \\
\text { elbaite }\end{array}$ & $\begin{array}{l}\text { fluor- } \\
\text { elbaite }\end{array}$ & schorl & schorl & $\begin{array}{l}\text { fluor- } \\
\text { elbaite }\end{array}$ & $\begin{array}{l}\text { fluor- } \\
\text { elbaite }\end{array}$ & dravite & dravite & dravite & dravite & dravite & dravite \\
\hline
\end{tabular}


Appendix D.1 (contd.): Electron-microprobe analyses of tourmaline.

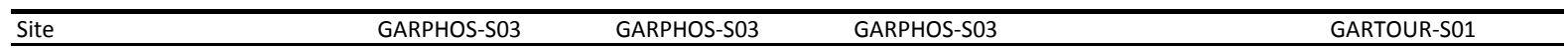

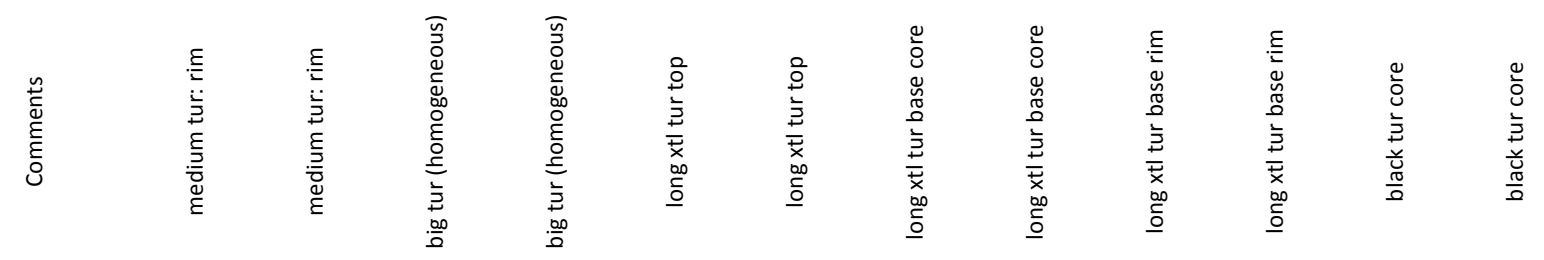

\begin{tabular}{|c|c|c|c|c|c|c|c|c|c|c|c|c|}
\hline Point & $50 t-3$ & $50 \mathrm{t}-4$ & $51 \mathrm{t}-1$ & $51 \mathrm{t}-2$ & $52 t-1$ & $52 \mathrm{t}-2$ & $53 \mathrm{t}-1$ & $53 t-2$ & $53 t-3$ & $53 \mathrm{t}-4$ & $54 \mathrm{t}-1$ & $54 \mathrm{t}-2$ \\
\hline $\mathrm{SiO}_{2}$ (wt.\%) & 34.52 & 34.26 & 35.26 & 35.15 & 35.58 & 35.60 & 34.88 & 35.16 & 33.81 & 33.84 & 34.63 & 34.37 \\
\hline $\mathrm{TiO}_{2}$ & 0.11 & 0.11 & 0.55 & 0.48 & 0.35 & 0.41 & 0.56 & 0.55 & 0.60 & 0.58 & 0.71 & 0.62 \\
\hline $\mathrm{B}_{2} \mathrm{O}_{3} *$ & 10.30 & 10.31 & 10.50 & 10.44 & 10.47 & 10.48 & 10.42 & 10.50 & 10.22 & 10.28 & 10.44 & 10.34 \\
\hline $\mathrm{Al}_{2} \mathrm{O}_{3}$ & 32.59 & 32.82 & 33.06 & 32.88 & 33.22 & 33.06 & 32.94 & 33.16 & 33.27 & 33.31 & 34.98 & 34.65 \\
\hline $\mathrm{Cr}_{2} \mathrm{O}_{3}$ & 0.00 & 0.03 & 0.00 & 0.00 & 0.00 & 0.03 & 0.00 & 0.02 & 0.00 & 0.00 & 0.03 & 0.03 \\
\hline \multicolumn{13}{|l|}{$\mathrm{Bi}_{2} \mathrm{O}_{3}$} \\
\hline $\mathrm{Fe}_{2} \mathrm{O}_{3}{ }^{*}$ & 0.53 & 0.95 & 0.00 & 0.00 & 0.00 & 0.00 & 0.00 & 0.00 & 0.00 & 0.00 & 0.00 & 0.00 \\
\hline $\mathrm{FeO}^{*}$ & 12.84 & 12.26 & 8.19 & 8.22 & 9.70 & 9.80 & 8.99 & 9.05 & 13.26 & 13.38 & 13.61 & 13.54 \\
\hline $\mathrm{FeO}$ (tot) & 13.31 & 13.12 & 8.19 & 8.22 & 9.70 & 9.80 & 8.99 & 9.05 & 13.26 & 13.38 & 13.61 & 13.54 \\
\hline $\mathrm{MnO}$ & 0.30 & 0.35 & 0.13 & 0.08 & 0.08 & 0.10 & 0.09 & 0.08 & 0.31 & 0.33 & 0.15 & 0.20 \\
\hline $\mathrm{ZnO}$ & 0.06 & 0.03 & 0.03 & 0.00 & 0.00 & 0.02 & 0.02 & 0.02 & 0.08 & 0.00 & 0.08 & 0.00 \\
\hline $\mathrm{MgO}$ & 2.99 & 3.13 & 6.03 & 5.99 & 4.82 & 4.85 & 5.52 & 5.61 & 2.21 & 2.51 & 0.83 & 0.86 \\
\hline $\mathrm{Li}_{2} \mathrm{O}^{*}$ & 0.00 & 0.00 & 0.00 & 0.00 & 0.00 & 0.00 & 0.00 & 0.00 & 0.00 & 0.00 & 0.23 & 0.18 \\
\hline $\mathrm{CaO}$ & 0.33 & 0.31 & 0.73 & 0.74 & 0.32 & 0.31 & 0.52 & 0.56 & 0.30 & 0.25 & 0.17 & 0.17 \\
\hline $\mathrm{Na}_{2} \mathrm{O}$ & 1.97 & 2.02 & 1.96 & 1.85 & 1.84 & 1.81 & 2.02 & 2.16 & 1.94 & 2.10 & 1.58 & 1.43 \\
\hline $\mathrm{K}_{2} \mathrm{O}$ & 0.05 & 0.03 & 0.05 & 0.05 & 0.06 & 0.02 & 0.03 & 0.05 & 0.06 & 0.03 & 0.05 & 0.03 \\
\hline $\mathrm{F}$ & 0.28 & 0.25 & 0.12 & 0.17 & 0.20 & 0.31 & 0.13 & 0.27 & 0.08 & 0.11 & 0.32 & 0.23 \\
\hline $\mathrm{Cl}$ & 0.00 & 0.00 & 0.00 & 0.00 & 0.00 & 0.00 & 0.00 & 0.01 & 0.00 & 0.01 & 0.01 & 0.01 \\
\hline $\mathrm{H}_{2} \mathrm{O}^{*}$ & 3.42 & 3.44 & 3.42 & 3.39 & 3.41 & 3.40 & 3.45 & 3.37 & 3.40 & 3.49 & 3.45 & 3.45 \\
\hline$-(\mathrm{O}=\mathrm{F}, \mathrm{Cl})$ & -0.12 & -0.10 & -0.05 & -0.07 & -0.08 & -0.13 & -0.06 & -0.12 & -0.04 & -0.05 & -0.14 & -0.10 \\
\hline Total & 100.18 & 100.19 & 99.99 & 99.36 & 99.97 & 100.06 & 99.52 & 100.44 & 99.49 & 100.16 & 101.12 & 100.01 \\
\hline T Si (apfu) & 5.825 & 5.774 & 5.837 & 5.850 & 5.906 & 5.906 & 5.815 & 5.817 & 5.752 & 5.720 & 5.764 & 5.779 \\
\hline T Al & 0.175 & 0.226 & 0.163 & 0.150 & 0.094 & 0.094 & 0.185 & 0.183 & 0.248 & 0.280 & 0.236 & 0.221 \\
\hline B & 3 & 3 & 3 & 3 & 3 & 3 & 3 & 3 & 3 & 3 & 3 & 3 \\
\hline $\mathrm{ZAl}$ & 6.000 & 6.000 & 6.000 & 6.000 & 6.000 & 6.000 & 6.000 & 6.000 & 6.000 & 6.000 & 6.000 & 6.000 \\
\hline Y Ti & 0.014 & 0.013 & 0.069 & 0.060 & 0.044 & 0.051 & 0.070 & 0.068 & 0.076 & 0.074 & 0.088 & 0.079 \\
\hline Y Al & 0.304 & 0.294 & 0.287 & 0.300 & 0.405 & 0.370 & 0.289 & 0.282 & 0.425 & 0.355 & 0.625 & 0.647 \\
\hline $\mathrm{Y} \mathrm{Cr}$ & 0.000 & 0.004 & 0.000 & 0.000 & 0.000 & 0.004 & 0.000 & 0.002 & 0.000 & 0.000 & 0.004 & 0.004 \\
\hline $\mathrm{YFe}^{3+}$ & 0.067 & 0.121 & 0.000 & 0.000 & 0.000 & 0.000 & 0.000 & 0.000 & 0.000 & 0.000 & 0.000 & 0.000 \\
\hline $\mathrm{Y} \mathrm{Fe}^{2+}$ & 1.811 & 1.728 & 1.134 & 1.144 & 1.347 & 1.359 & 1.253 & 1.252 & 1.886 & 1.891 & 1.894 & 1.904 \\
\hline Y Mn & 0.043 & 0.049 & 0.019 & 0.012 & 0.011 & 0.014 & 0.013 & 0.011 & 0.044 & 0.047 & 0.021 & 0.028 \\
\hline Y Zn & 0.008 & 0.004 & 0.003 & 0.000 & 0.000 & 0.002 & 0.002 & 0.002 & 0.009 & 0.000 & 0.010 & 0.000 \\
\hline Y Mg & 0.753 & 0.787 & 1.488 & 1.485 & 1.193 & 1.199 & 1.372 & 1.383 & 0.559 & 0.632 & 0.207 & 0.216 \\
\hline Y Li & 0.000 & 0.000 & 0.000 & 0.000 & 0.000 & 0.000 & 0.000 & 0.000 & 0.000 & 0.000 & 0.151 & 0.122 \\
\hline X Ca & 0.060 & 0.056 & 0.129 & 0.133 & 0.057 & 0.055 & 0.093 & 0.100 & 0.055 & 0.046 & 0.030 & 0.031 \\
\hline $\mathrm{X} \mathrm{Na}$ & 0.645 & 0.661 & 0.630 & 0.596 & 0.593 & 0.582 & 0.654 & 0.694 & 0.640 & 0.688 & 0.511 & 0.465 \\
\hline x K & 0.012 & 0.007 & 0.010 & 0.010 & 0.013 & 0.004 & 0.007 & 0.011 & 0.014 & 0.006 & 0.010 & 0.007 \\
\hline$X$ vac & 0.283 & 0.276 & 0.231 & 0.261 & 0.337 & 0.359 & 0.246 & 0.195 & 0.291 & 0.260 & 0.449 & 0.497 \\
\hline $\mathrm{VOH}$ & 3.000 & 3.000 & 3.000 & 3.000 & 3.000 & 3.000 & 3.000 & 3.000 & 3.000 & 3.000 & 3.000 & 3.000 \\
\hline Vo & 0.000 & 0.000 & 0.000 & 0.000 & 0.000 & 0.000 & 0.000 & 0.000 & 0.000 & 0.000 & 0.000 & 0.000 \\
\hline W F & 0.148 & 0.133 & 0.065 & 0.091 & 0.106 & 0.161 & 0.070 & 0.141 & 0.045 & 0.058 & 0.171 & 0.123 \\
\hline W Cl & 0.001 & 0.000 & 0.000 & 0.000 & 0.000 & 0.000 & 0.000 & 0.002 & 0.000 & 0.003 & 0.002 & 0.004 \\
\hline $\mathrm{WOH}$ & 0.851 & 0.867 & 0.774 & 0.768 & 0.777 & 0.761 & 0.838 & 0.715 & 0.862 & 0.930 & 0.828 & 0.873 \\
\hline wo & 0.000 & 0.000 & 0.161 & 0.141 & 0.117 & 0.079 & 0.092 & 0.142 & 0.094 & 0.009 & 0.000 & 0.000 \\
\hline Classif. & schorl & schorl & dravite & dravite & schorl & schorl & dravite & dravite & schorl & schorl & schorl & foitite \\
\hline
\end{tabular}


Appendix D.1 (contd.): Electron-microprobe analyses of tourmaline.

\begin{tabular}{lll}
\hline Site & GRANITE-S01 & GRANITE - S01
\end{tabular}

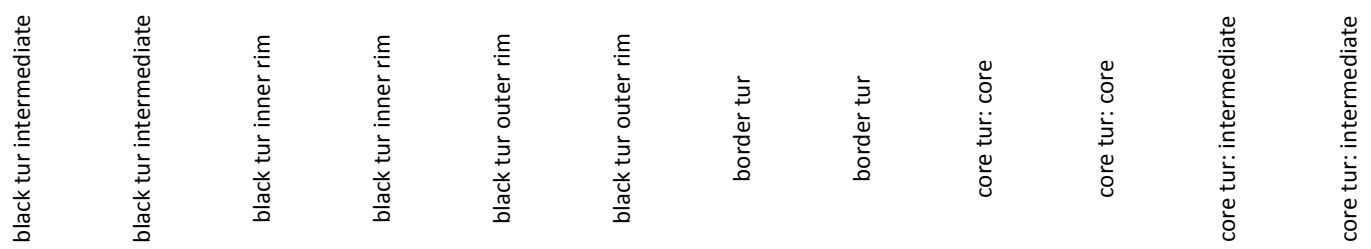

\begin{tabular}{|c|c|c|c|c|c|c|c|c|c|c|c|c|}
\hline Point & $54 \mathrm{t}-3$ & $54 \mathrm{t}-4$ & $54 \mathrm{t}-5$ & $54 \mathrm{t}-6$ & $54 \mathrm{t}-7$ & $54 \mathrm{t}-8$ & $10 \mathrm{t}-1$ & $10 \mathrm{t}-2$ & $11 \mathrm{t}-1$ & $11 \mathrm{t}-2$ & $11 \mathrm{t}-3$ & $11 \mathrm{t}-4$ \\
\hline $\mathrm{SiO}_{2}$ (wt.\%) & 34.24 & 34.51 & 35.16 & 35.33 & 36.86 & 36.52 & 34.85 & 35.15 & 34.79 & 34.23 & 34.66 & 34.55 \\
\hline $\mathrm{TiO}_{2}$ & 0.53 & 0.57 & 0.02 & 0.05 & 0.08 & 0.09 & 1.02 & 0.81 & 0.76 & 0.73 & 1.01 & 0.89 \\
\hline $\mathrm{B}_{2} \mathrm{O}_{3} *$ & 10.33 & 10.39 & 10.51 & 10.61 & 10.74 & 10.71 & 10.45 & 10.46 & 10.47 & 10.29 & 10.42 & 10.39 \\
\hline $\mathrm{Al}_{2} \mathrm{O}_{3}$ & 34.82 & 34.72 & 34.95 & 35.18 & 33.73 & 33.99 & 31.81 & 31.57 & 33.05 & 32.64 & 32.43 & 32.46 \\
\hline $\mathrm{Cr}_{2} \mathrm{O}_{3}$ & 0.00 & 0.00 & 0.01 & 0.02 & 0.01 & 0.01 & 0.00 & 0.00 & 0.04 & 0.00 & 0.01 & 0.00 \\
\hline \multicolumn{13}{|l|}{$\mathrm{Bi}_{2} \mathrm{O}_{3}$} \\
\hline $\mathrm{Fe}_{2} \mathrm{O}_{3} *$ & 0.00 & 0.00 & 0.00 & 0.00 & 0.00 & 0.00 & 0.00 & 0.00 & 0.00 & 0.00 & 0.00 & 0.00 \\
\hline $\mathrm{FeO} *$ & 13.77 & 13.90 & 9.64 & 9.76 & 6.41 & 6.89 & 8.52 & 8.38 & 7.67 & 8.56 & 8.20 & 8.85 \\
\hline $\mathrm{FeO}$ (tot) & 13.77 & 13.90 & 9.65 & 9.76 & 6.41 & 6.89 & 8.52 & 8.38 & 7.67 & 8.56 & 8.20 & 8.85 \\
\hline $\mathrm{MnO}$ & 0.17 & 0.21 & 0.19 & 0.23 & 0.11 & 0.10 & 0.08 & 0.06 & 0.09 & 0.04 & 0.06 & 0.07 \\
\hline $\mathrm{ZnO}$ & 0.05 & 0.04 & 0.04 & 0.10 & 0.07 & 0.00 & 0.04 & 0.00 & 0.05 & 0.00 & 0.02 & 0.01 \\
\hline MgO & 0.76 & 0.78 & 3.77 & 4.00 & 6.57 & 6.23 & 6.62 & 6.85 & 6.37 & 5.60 & 6.25 & 5.86 \\
\hline $\mathrm{Li}_{2} \mathrm{O}^{*}$ & 0.15 & 0.20 & 0.12 & 0.08 & 0.18 & 0.16 & 0.00 & 0.00 & 0.00 & 0.00 & 0.00 & 0.00 \\
\hline $\mathrm{CaO}$ & 0.12 & 0.13 & 0.17 & 0.19 & 0.34 & 0.26 & 1.26 & 1.31 & 1.01 & 1.05 & 1.11 & 1.10 \\
\hline $\mathrm{Na}_{2} \mathrm{O}$ & 1.49 & 1.66 & 1.81 & 1.88 & 1.98 & 2.00 & 1.80 & 1.79 & 1.72 & 1.76 & 1.80 & 1.78 \\
\hline $\mathrm{K}_{2} \mathrm{O}$ & 0.03 & 0.03 & 0.01 & 0.03 & 0.02 & 0.02 & 0.05 & 0.05 & 0.02 & 0.06 & 0.05 & 0.05 \\
\hline $\mathrm{F}$ & 0.26 & 0.24 & 0.19 & 0.34 & 0.44 & 0.39 & 0.16 & 0.12 & 0.21 & 0.08 & 0.24 & 0.25 \\
\hline $\mathrm{Cl}$ & 0.00 & 0.01 & 0.00 & 0.01 & 0.00 & 0.00 & 0.01 & 0.00 & 0.00 & 0.00 & 0.00 & 0.01 \\
\hline $\mathrm{H}_{2} \mathrm{O}^{*}$ & 3.44 & 3.47 & 3.54 & 3.50 & 3.50 & 3.51 & 3.42 & 3.44 & 3.40 & 3.32 & 3.31 & 3.32 \\
\hline$-(\mathrm{O}=\mathrm{F}, \mathrm{Cl})$ & -0.11 & -0.10 & -0.08 & -0.15 & -0.18 & -0.16 & -0.07 & -0.05 & -0.09 & -0.03 & -0.10 & -0.11 \\
\hline Total & 100.04 & 100.76 & 100.07 & 101.16 & 100.87 & 100.70 & 100.02 & 99.94 & 99.57 & 98.32 & 99.49 & 99.49 \\
\hline T Si (apfu) & 5.763 & 5.775 & 5.811 & 5.788 & 5.962 & 5.927 & 5.796 & 5.842 & 5.773 & 5.783 & 5.783 & 5.779 \\
\hline T Al & 0.237 & 0.225 & 0.189 & 0.212 & 0.038 & 0.073 & 0.204 & 0.158 & 0.227 & 0.217 & 0.217 & 0.221 \\
\hline B & 3 & 3 & 3 & 3 & 3 & 3 & 3 & 3 & 3 & 3 & 3 & 3 \\
\hline $\mathrm{ZAl}$ & 6.000 & 6.000 & 6.000 & 6.000 & 6.000 & 6.000 & 6.000 & 6.000 & 6.000 & 6.000 & 6.000 & 6.000 \\
\hline Y Ti & 0.067 & 0.072 & 0.002 & 0.006 & 0.010 & 0.011 & 0.128 & 0.101 & 0.095 & 0.093 & 0.127 & 0.112 \\
\hline Y Al & 0.671 & 0.622 & 0.620 & 0.580 & 0.392 & 0.429 & 0.029 & 0.027 & 0.239 & 0.282 & 0.160 & 0.178 \\
\hline $\mathrm{Y} \mathrm{Cr}$ & 0.000 & 0.000 & 0.001 & 0.003 & 0.002 & 0.002 & 0.000 & 0.000 & 0.006 & 0.000 & 0.001 & 0.000 \\
\hline $\mathrm{YFe}^{3+}$ & 0.000 & 0.000 & 0.000 & 0.000 & 0.000 & 0.000 & 0.000 & 0.000 & 0.000 & 0.000 & 0.000 & 0.000 \\
\hline $\mathrm{Y} \mathrm{Fe}^{2+}$ & 1.938 & 1.945 & 1.333 & 1.337 & 0.867 & 0.935 & 1.185 & 1.165 & 1.065 & 1.209 & 1.144 & 1.237 \\
\hline Y Mn & 0.025 & 0.030 & 0.027 & 0.032 & 0.015 & 0.013 & 0.011 & 0.009 & 0.013 & 0.006 & 0.009 & 0.010 \\
\hline Y Zn & 0.007 & 0.005 & 0.005 & 0.012 & 0.009 & 0.000 & 0.005 & 0.000 & 0.007 & 0.000 & 0.003 & 0.002 \\
\hline Y Mg & 0.191 & 0.193 & 0.930 & 0.977 & 1.585 & 1.507 & 1.642 & 1.698 & 1.576 & 1.410 & 1.555 & 1.461 \\
\hline Y Li & 0.101 & 0.132 & 0.082 & 0.054 & 0.120 & 0.102 & 0.000 & 0.000 & 0.000 & 0.000 & 0.000 & 0.000 \\
\hline X Ca & 0.021 & 0.023 & 0.031 & 0.034 & 0.059 & 0.045 & 0.224 & 0.234 & 0.180 & 0.190 & 0.198 & 0.198 \\
\hline X Na & 0.485 & 0.538 & 0.581 & 0.597 & 0.621 & 0.629 & 0.581 & 0.576 & 0.552 & 0.575 & 0.581 & 0.577 \\
\hline $\mathrm{xK}$ & 0.007 & 0.007 & 0.003 & 0.006 & 0.004 & 0.004 & 0.010 & 0.010 & 0.004 & 0.014 & 0.010 & 0.011 \\
\hline $\mathrm{X}$ vac & 0.487 & 0.432 & 0.385 & 0.363 & 0.316 & 0.322 & 0.185 & 0.180 & 0.264 & 0.221 & 0.211 & 0.214 \\
\hline $\mathrm{VOH}$ & 3.000 & 3.000 & 3.000 & 3.000 & 3.000 & 3.000 & 3.000 & 3.000 & 3.000 & 3.000 & 3.000 & 3.000 \\
\hline Vo & 0.000 & 0.000 & 0.000 & 0.000 & 0.000 & 0.000 & 0.000 & 0.000 & 0.000 & 0.000 & 0.000 & 0.000 \\
\hline W F & 0.137 & 0.127 & 0.101 & 0.177 & 0.225 & 0.200 & 0.085 & 0.063 & 0.112 & 0.040 & 0.128 & 0.134 \\
\hline W Cl & 0.000 & 0.003 & 0.000 & 0.002 & 0.000 & 0.000 & 0.002 & 0.000 & 0.000 & 0.000 & 0.001 & 0.002 \\
\hline W OH & 0.863 & 0.870 & 0.899 & 0.821 & 0.775 & 0.800 & 0.792 & 0.813 & 0.764 & 0.740 & 0.684 & 0.699 \\
\hline wo & 0.000 & 0.000 & 0.000 & 0.000 & 0.000 & 0.000 & 0.120 & 0.125 & 0.124 & 0.220 & 0.187 & 0.164 \\
\hline Classif. & schorl & schorl & schorl & schorl & dravite & dravite & dravite & dravite & dravite & dravite & dravite & dravite \\
\hline
\end{tabular}


Appendix D.1 (contd.): Electron-microprobe analyses of tourmaline.

\begin{tabular}{|c|c|c|c|c|c|c|c|c|c|c|c|c|}
\hline Site & & & TE-S05 & & & & TE & & & & & \\
\hline 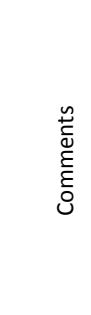 & 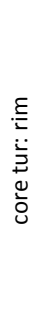 & 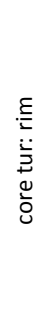 & 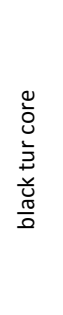 & 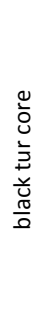 & 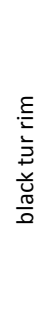 & 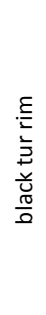 & 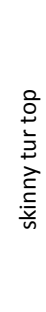 & 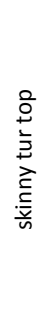 & 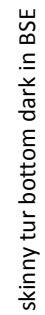 & 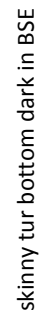 & 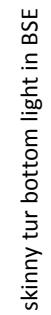 & 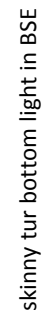 \\
\hline
\end{tabular}

\begin{tabular}{|c|c|c|c|c|c|c|c|c|c|c|c|c|}
\hline Point & $11 t-5$ & $11 t-6$ & $17 \mathrm{t}-1$ & $17 \mathrm{t}-2$ & $17 \mathrm{t}-3$ & $17 \mathrm{t}-4$ & GN5-1 & GN5-2 & GN5-3 & GN5-4 & GN5-5 & GN5-6 \\
\hline $\mathrm{SiO}_{2}$ (wt.\%) & 32.95 & 33.71 & 34.89 & 34.83 & 34.77 & 34.28 & 36.22 & 36.09 & 35.89 & 36.38 & 35.37 & 35.84 \\
\hline $\mathrm{TiO}_{2}$ & 1.13 & 1.01 & 0.48 & 0.48 & 0.44 & 0.53 & 1.95 & 0.52 & 0.33 & 0.25 & 1.58 & 1.60 \\
\hline $\mathrm{B}_{2} \mathrm{O}_{3} *$ & 10.16 & 10.22 & 10.43 & 10.48 & 10.39 & 10.31 & 10.49 & 10.59 & 10.56 & 10.58 & 10.38 & 10.41 \\
\hline $\mathrm{Al}_{2} \mathrm{O}_{3}$ & 32.14 & 31.46 & 33.21 & 33.34 & 31.89 & 32.50 & 30.38 & 32.93 & 33.15 & 33.55 & 30.06 & 29.62 \\
\hline $\mathrm{Cr}_{2} \mathrm{O}_{3}$ & 0.06 & 0.03 & 0.03 & 0.00 & 0.03 & 0.02 & 0.00 & 0.00 & 0.00 & 0.01 & 0.00 & 0.00 \\
\hline \multicolumn{13}{|l|}{$\mathrm{Bi}_{2} \mathrm{O}_{3}$} \\
\hline $\mathrm{Fe}_{2} \mathrm{O}_{3} *$ & 0.00 & 0.30 & 0.00 & 0.00 & 0.89 & 0.00 & 0.00 & 0.00 & 0.00 & 0.00 & 0.00 & 0.00 \\
\hline $\mathrm{FeO}^{*}$ & 11.08 & 11.21 & 8.68 & 8.90 & 9.54 & 10.01 & 7.23 & 7.01 & 7.18 & 6.21 & 8.23 & 8.37 \\
\hline $\mathrm{FeO}$ (tot) & 11.08 & 11.48 & 8.68 & 8.90 & 10.35 & 10.01 & 7.23 & 7.01 & 7.18 & 6.21 & 8.23 & 8.37 \\
\hline $\mathrm{MnO}$ & 0.15 & 0.13 & 0.08 & 0.07 & 0.11 & 0.08 & 0.10 & 0.12 & 0.09 & 0.14 & 0.05 & 0.09 \\
\hline $\mathrm{ZnO}$ & 0.01 & 0.04 & 0.00 & 0.00 & 0.05 & 0.08 & 0.00 & 0.00 & 0.00 & 0.01 & 0.06 & 0.00 \\
\hline MgO & 4.40 & 4.63 & 5.56 & 5.67 & 5.52 & 5.02 & 7.34 & 6.78 & 6.58 & 6.60 & 7.14 & 7.28 \\
\hline $\mathrm{Li}_{2} \mathrm{O}^{*}$ & 0.00 & 0.00 & 0.00 & 0.00 & 0.00 & 0.00 & 0.00 & 0.00 & 0.00 & 0.00 & 0.00 & 0.00 \\
\hline $\mathrm{CaO}$ & 1.19 & 1.04 & 0.76 & 0.79 & 0.62 & 0.64 & 0.35 & 0.33 & 0.34 & 0.26 & 0.53 & 0.45 \\
\hline $\mathrm{Na}_{2} \mathrm{O}$ & 1.60 & 1.64 & 1.87 & 1.89 & 1.94 & 1.98 & 2.33 & 2.32 & 2.28 & 2.12 & 2.26 & 2.32 \\
\hline $\mathrm{K}_{2} \mathrm{O}$ & 0.04 & 0.05 & 0.08 & 0.06 & 0.05 & 0.04 & 0.02 & 0.04 & 0.05 & 0.03 & 0.06 & 0.03 \\
\hline $\mathrm{F}$ & 0.14 & 0.12 & 0.21 & 0.15 & 0.34 & 0.20 & 0.36 & 0.23 & 0.26 & 0.34 & 0.45 & 0.34 \\
\hline $\mathrm{Cl}$ & 0.00 & 0.00 & 0.01 & 0.00 & 0.01 & 0.01 & 0.00 & 0.01 & 0.00 & 0.00 & 0.00 & 0.01 \\
\hline $\mathrm{H}_{2} \mathrm{O}^{*}$ & 3.41 & 3.47 & 3.35 & 3.46 & 3.42 & 3.42 & 3.19 & 3.34 & 3.34 & 3.22 & 3.28 & 3.33 \\
\hline$-(\mathrm{O}=\mathrm{F}, \mathrm{Cl})$ & -0.06 & -0.05 & -0.09 & -0.07 & -0.15 & -0.09 & -0.15 & -0.10 & -0.11 & -0.14 & -0.19 & -0.14 \\
\hline Total & 98.41 & 99.01 & 99.56 & 100.03 & 99.87 & 99.04 & 99.82 & 100.21 & 99.95 & 99.55 & 99.26 & 99.54 \\
\hline T Si (apfu) & 5.636 & 5.732 & 5.813 & 5.777 & 5.813 & 5.779 & 5.998 & 5.925 & 5.909 & 5.979 & 5.920 & 5.982 \\
\hline T Al & 0.364 & 0.268 & 0.187 & 0.223 & 0.187 & 0.221 & 0.002 & 0.075 & 0.091 & 0.021 & 0.080 & 0.018 \\
\hline B & 3 & 3 & 3 & 3 & 3 & 3 & 3 & 3 & 3 & 3 & 3 & 3 \\
\hline $\mathrm{ZAl}$ & 6.000 & 6.000 & 6.000 & 6.000 & 6.000 & 6.000 & 5.929 & 6.000 & 6.000 & 6.000 & 5.850 & 5.808 \\
\hline Y Ti & 0.145 & 0.129 & 0.060 & 0.059 & 0.055 & 0.067 & 0.242 & 0.064 & 0.041 & 0.030 & 0.199 & 0.201 \\
\hline Y Al & 0.116 & 0.036 & 0.334 & 0.295 & 0.098 & 0.236 & 0.000 & 0.297 & 0.343 & 0.477 & 0.000 & 0.000 \\
\hline $\mathrm{YCr}$ & 0.009 & 0.005 & 0.004 & 0.000 & 0.004 & 0.003 & 0.000 & 0.000 & 0.001 & 0.002 & 0.000 & 0.000 \\
\hline $\mathrm{YFe}^{3+}$ & 0.000 & 0.038 & 0.000 & 0.000 & 0.112 & 0.000 & 0.000 & 0.000 & 0.000 & 0.000 & 0.000 & 0.000 \\
\hline $\mathrm{YFe}^{2+}$ & 1.586 & 1.594 & 1.209 & 1.234 & 1.334 & 1.411 & 1.002 & 0.963 & 0.989 & 0.853 & 1.152 & 1.168 \\
\hline Y Mn & 0.022 & 0.019 & 0.012 & 0.010 & 0.015 & 0.011 & 0.015 & 0.017 & 0.012 & 0.019 & 0.007 & 0.013 \\
\hline Y Zn & 0.001 & 0.004 & 0.000 & 0.000 & 0.006 & 0.010 & 0.000 & 0.000 & 0.001 & 0.001 & 0.008 & 0.000 \\
\hline Y Mg & 1.121 & 1.174 & 1.381 & 1.402 & 1.375 & 1.261 & 1.812 & 1.659 & 1.614 & 1.617 & 1.783 & 1.810 \\
\hline Y Li & 0.000 & 0.000 & 0.000 & 0.000 & 0.000 & 0.000 & 0.000 & 0.000 & 0.000 & 0.000 & 0.000 & 0.000 \\
\hline X Ca & 0.219 & 0.190 & 0.135 & 0.140 & 0.112 & 0.116 & 0.062 & 0.058 & 0.061 & 0.045 & 0.095 & 0.081 \\
\hline X Na & 0.531 & 0.541 & 0.605 & 0.607 & 0.627 & 0.648 & 0.749 & 0.740 & 0.729 & 0.675 & 0.733 & 0.750 \\
\hline x K & 0.008 & 0.010 & 0.017 & 0.012 & 0.011 & 0.008 & 0.004 & 0.009 & 0.009 & 0.006 & 0.012 & 0.007 \\
\hline$X$ vac & 0.242 & 0.259 & 0.243 & 0.242 & 0.250 & 0.228 & 0.185 & 0.193 & 0.200 & 0.273 & 0.160 & 0.163 \\
\hline $\mathrm{VOH}$ & 3.000 & 3.000 & 3.000 & 3.000 & 3.000 & 3.000 & 3.000 & 3.000 & 3.000 & 3.000 & 3.000 & 3.000 \\
\hline VO & 0.000 & 0.000 & 0.000 & 0.000 & 0.000 & 0.000 & 0.000 & 0.000 & 0.000 & 0.000 & 0.000 & 0.000 \\
\hline W F & 0.074 & 0.067 & 0.108 & 0.081 & 0.182 & 0.108 & 0.189 & 0.118 & 0.136 & 0.174 & 0.237 & 0.178 \\
\hline W Cl & 0.001 & 0.000 & 0.002 & 0.000 & 0.002 & 0.003 & 0.000 & 0.003 & 0.001 & 0.000 & 0.001 & 0.002 \\
\hline $\mathrm{WOH}$ & 0.896 & 0.933 & 0.728 & 0.829 & 0.816 & 0.850 & 0.521 & 0.663 & 0.668 & 0.535 & 0.657 & 0.711 \\
\hline WO & 0.029 & 0.000 & 0.162 & 0.089 & 0.000 & 0.040 & 0.289 & 0.216 & 0.195 & 0.291 & 0.104 & 0.109 \\
\hline Classif. & schorl & schorl & dravite & dravite & dravite & schorl & dravite & dravite & dravite & dravite & dravite & dravite \\
\hline
\end{tabular}


Appendix D.1 (contd.): Electron-microprobe analyses of tourmaline.

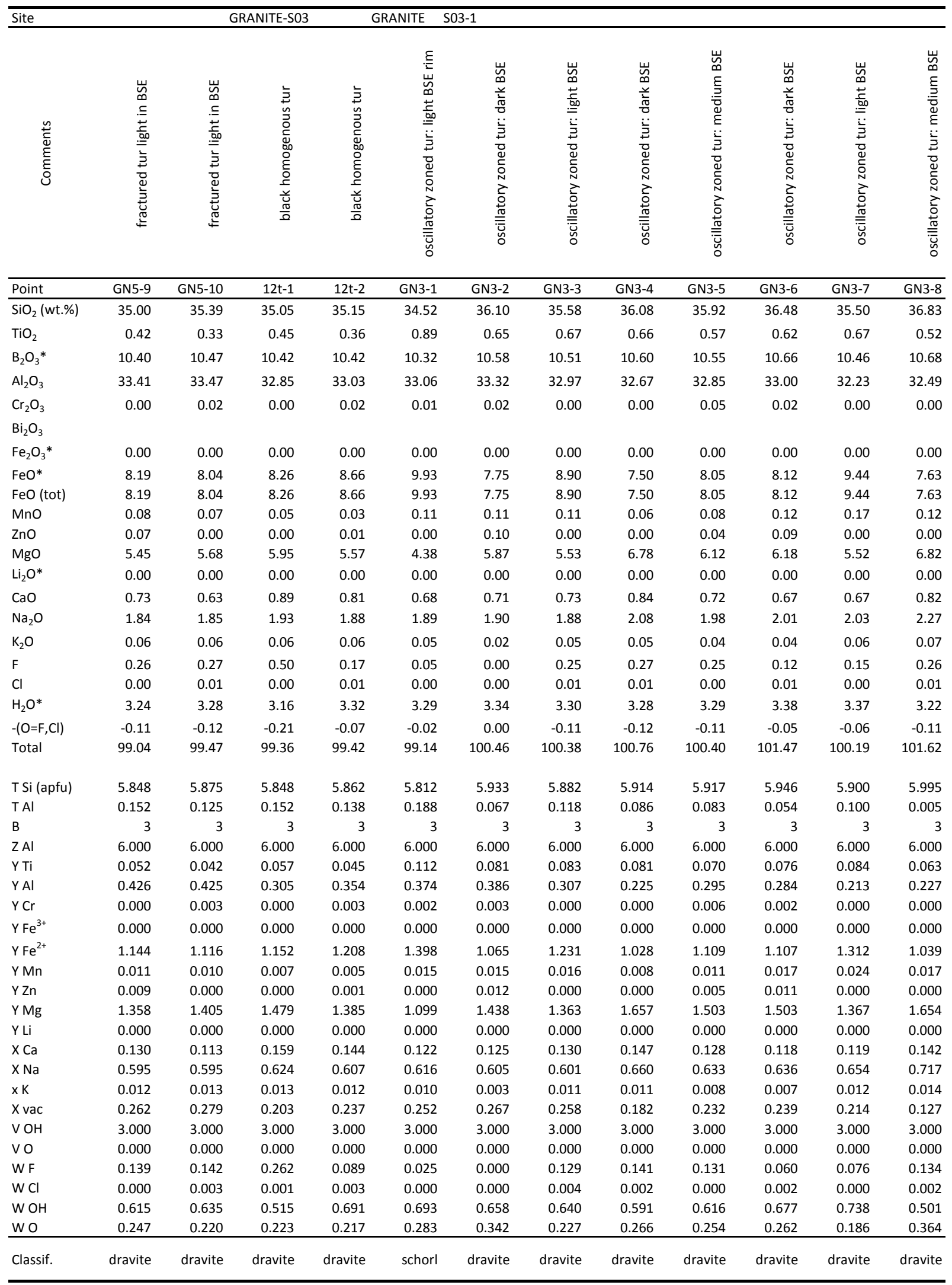


Appendix D.1 (contd.): Electron-microprobe analyses of tourmaline.

\begin{tabular}{|c|c|c|c|c|c|c|c|c|c|c|c|c|}
\hline \multirow[b]{2}{*}{$\begin{array}{l}\text { Site } \\
\end{array}$} & \multicolumn{9}{|c|}{ GRANITE S04-1 } & \multicolumn{3}{|c|}{ GRANITE - S04 } \\
\hline & 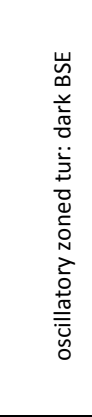 & 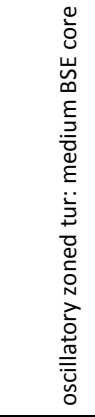 & 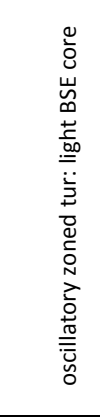 & 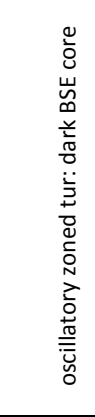 & 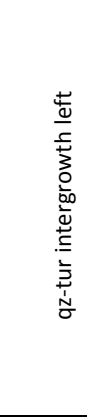 & 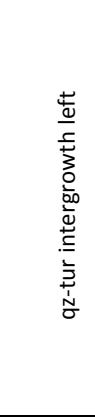 & 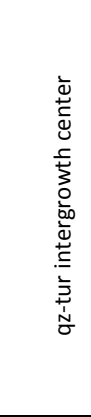 & 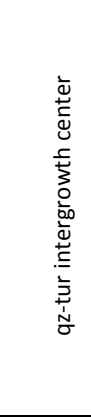 & 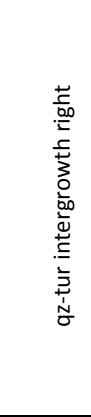 & 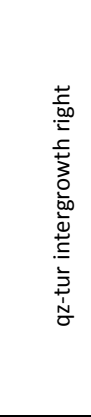 & 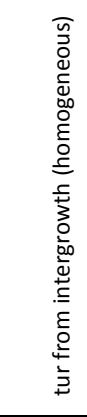 & 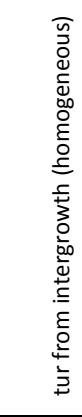 \\
\hline Point & GN3-9 & GN3-10 & GN3-11 & GN3-12 & GN4-1 & GN4-2 & GN4-3 & GN4-4 & GN4-5 & GN4-6 & $13 t-1$ & $13 t-2$ \\
\hline $\mathrm{SiO}_{2}$ (wt.\%) & 36.40 & 36.37 & 35.73 & 37.63 & 35.34 & 35.65 & 35.58 & 35.29 & 35.22 & 35.58 & 35.85 & 35.88 \\
\hline $\mathrm{TiO}_{2}$ & 0.31 & 1.23 & 0.91 & 0.34 & 0.43 & 0.59 & 0.34 & 0.33 & 0.50 & 0.48 & 0.48 & 0.61 \\
\hline $\mathrm{B}_{2} \mathrm{O}_{3}^{*}$ & 10.64 & 10.55 & 10.48 & 10.90 & 10.46 & 10.56 & 10.53 & 10.47 & 10.42 & 10.49 & 10.56 & 10.51 \\
\hline $\mathrm{Al}_{2} \mathrm{O}_{3}$ & 33.36 & 31.00 & 31.24 & 33.32 & 33.38 & 33.38 & 33.14 & 33.03 & 33.25 & 33.92 & 33.42 & 33.15 \\
\hline $\mathrm{Cr}_{2} \mathrm{O}_{3}$ & 0.01 & 0.03 & 0.00 & 0.02 & 0.02 & 0.01 & 0.00 & 0.06 & 0.00 & 0.04 & 0.01 & 0.01 \\
\hline \multicolumn{13}{|l|}{$\mathrm{Bi}_{2} \mathrm{O}_{3}$} \\
\hline $\mathrm{Fe}_{2} \mathrm{O}_{3} *$ & 0.00 & 0.00 & 0.00 & 3.32 & 0.00 & 0.00 & 0.00 & 0.00 & 0.00 & 0.00 & 0.00 & 0.00 \\
\hline $\mathrm{FeO} *$ & 7.46 & 7.69 & 8.37 & 3.62 & 7.82 & 7.93 & 7.99 & 7.81 & 7.92 & 7.62 & 8.29 & 8.18 \\
\hline $\mathrm{FeO}$ (tot) & 7.46 & 7.69 & 8.37 & 6.61 & 7.82 & 7.93 & 7.99 & 7.81 & 7.92 & 7.62 & 8.29 & 8.18 \\
\hline $\mathrm{MnO}$ & 0.16 & 0.21 & 0.13 & 0.22 & 0.03 & 0.10 & 0.09 & 0.03 & 0.04 & 0.09 & 0.07 & 0.08 \\
\hline $\mathrm{ZnO}$ & 0.01 & 0.05 & 0.03 & 0.02 & 0.00 & 0.02 & 0.03 & 0.01 & 0.00 & 0.00 & 0.06 & 0.00 \\
\hline $\mathrm{MgO}$ & 6.39 & 7.10 & 6.75 & 6.58 & 5.80 & 6.01 & 6.18 & 6.22 & 5.69 & 5.48 & 5.68 & 5.60 \\
\hline $\mathrm{Li}_{2} \mathrm{O}^{*}$ & 0.00 & 0.00 & 0.00 & 0.00 & 0.00 & 0.00 & 0.00 & 0.00 & 0.00 & 0.00 & 0.00 & 0.00 \\
\hline $\mathrm{CaO}$ & 0.55 & 1.21 & 1.03 & 0.48 & 0.69 & 0.75 & 0.89 & 0.88 & 0.67 & 0.62 & 0.57 & 0.61 \\
\hline $\mathrm{Na}_{2} \mathrm{O}$ & 1.75 & 1.80 & 1.79 & 1.69 & 1.84 & 1.87 & 1.84 & 1.70 & 1.88 & 1.92 & 2.08 & 1.93 \\
\hline $\mathrm{K}_{2} \mathrm{O}$ & 0.04 & 0.04 & 0.06 & 0.05 & 0.06 & 0.03 & 0.04 & 0.05 & 0.05 & 0.04 & 0.07 & 0.03 \\
\hline $\mathrm{F}$ & 0.10 & 0.23 & 0.12 & 0.01 & 0.20 & 0.31 & 0.36 & 0.29 & 0.24 & 0.37 & 0.25 & 0.08 \\
\hline $\mathrm{Cl}$ & 0.02 & 0.01 & 0.00 & 0.00 & 0.00 & 0.00 & 0.01 & 0.00 & 0.00 & 0.00 & 0.01 & 0.00 \\
\hline $\mathrm{H}_{2} \mathrm{O}^{*}$ & 3.50 & 3.24 & 3.42 & 3.76 & 3.28 & 3.29 & 3.29 & 3.35 & 3.24 & 3.10 & 3.26 & 3.29 \\
\hline$-(\mathrm{O}=\mathrm{F}, \mathrm{Cl})$ & -0.05 & -0.10 & -0.05 & 0.00 & -0.09 & -0.13 & -0.15 & -0.12 & -0.10 & -0.16 & -0.11 & -0.04 \\
\hline Total & 100.64 & 100.66 & 100.01 & 101.96 & 99.27 & 100.34 & 100.14 & 99.41 & 99.01 & 99.61 & 100.54 & 99.93 \\
\hline T Si (apfu) & 5.944 & 5.990 & 5.927 & 6.000 & 5.874 & 5.868 & 5.873 & 5.858 & 5.875 & 5.892 & 5.902 & 5.935 \\
\hline T Al & 0.056 & 0.010 & 0.073 & 0.000 & 0.126 & 0.132 & 0.127 & 0.142 & 0.125 & 0.108 & 0.098 & 0.065 \\
\hline B & 3 & 3 & 3 & 3 & 3 & 3 & 3 & 3 & 3 & 3 & 3 & 3 \\
\hline Z Al & 6.000 & 6.000 & 6.000 & 6.000 & 6.000 & 6.000 & 6.000 & 6.000 & 6.000 & 6.000 & 6.000 & 6.000 \\
\hline Y Ti & 0.038 & 0.152 & 0.113 & 0.041 & 0.054 & 0.073 & 0.042 & 0.042 & 0.063 & 0.060 & 0.059 & 0.076 \\
\hline Y Al & 0.363 & 0.007 & 0.036 & 0.260 & 0.415 & 0.344 & 0.320 & 0.320 & 0.412 & 0.514 & 0.387 & 0.399 \\
\hline Y Cr & 0.001 & 0.004 & 0.000 & 0.003 & 0.003 & 0.001 & 0.000 & 0.008 & 0.000 & 0.005 & 0.001 & 0.001 \\
\hline $\mathrm{YFe}^{3+}$ & 0.000 & 0.000 & 0.000 & 0.399 & 0.000 & 0.000 & 0.000 & 0.000 & 0.000 & 0.000 & 0.000 & 0.000 \\
\hline $\mathrm{Y} \mathrm{Fe}^{2+}$ & 1.019 & 1.059 & 1.161 & 0.482 & 1.087 & 1.092 & 1.102 & 1.085 & 1.104 & 1.055 & 1.142 & 1.132 \\
\hline Y Mn & 0.022 & 0.029 & 0.018 & 0.030 & 0.005 & 0.014 & 0.013 & 0.005 & 0.006 & 0.012 & 0.009 & 0.011 \\
\hline Y Zn & 0.001 & 0.007 & 0.003 & 0.002 & 0.000 & 0.002 & 0.003 & 0.002 & 0.000 & 0.000 & 0.007 & 0.000 \\
\hline Y Mg & 1.556 & 1.742 & 1.669 & 1.563 & 1.437 & 1.475 & 1.520 & 1.539 & 1.416 & 1.353 & 1.394 & 1.381 \\
\hline Y Li & 0.000 & 0.000 & 0.000 & 0.000 & 0.000 & 0.000 & 0.000 & 0.000 & 0.000 & 0.000 & 0.000 & 0.000 \\
\hline X Ca & 0.096 & 0.213 & 0.184 & 0.083 & 0.122 & 0.132 & 0.157 & 0.156 & 0.120 & 0.110 & 0.101 & 0.107 \\
\hline $\mathrm{X} \mathrm{Na}$ & 0.553 & 0.576 & 0.577 & 0.522 & 0.594 & 0.596 & 0.588 & 0.546 & 0.609 & 0.618 & 0.664 & 0.618 \\
\hline x K & 0.009 & 0.008 & 0.013 & 0.010 & 0.012 & 0.006 & 0.009 & 0.011 & 0.010 & 0.009 & 0.014 & 0.007 \\
\hline $\mathrm{X}$ vac & 0.343 & 0.203 & 0.226 & 0.385 & 0.271 & 0.266 & 0.245 & 0.286 & 0.261 & 0.263 & 0.221 & 0.268 \\
\hline $\mathrm{VOH}$ & 3.000 & 3.000 & 3.000 & 3.000 & 3.000 & 3.000 & 3.000 & 3.000 & 3.000 & 3.000 & 3.000 & 3.000 \\
\hline VO & 0.000 & 0.000 & 0.000 & 0.000 & 0.000 & 0.000 & 0.000 & 0.000 & 0.000 & 0.000 & 0.000 & 0.000 \\
\hline W F & 0.053 & 0.120 & 0.064 & 0.005 & 0.107 & 0.159 & 0.189 & 0.154 & 0.127 & 0.194 & 0.129 & 0.044 \\
\hline W Cl & 0.004 & 0.001 & 0.001 & 0.000 & 0.000 & 0.001 & 0.002 & 0.000 & 0.000 & 0.001 & 0.002 & 0.001 \\
\hline W OH & 0.808 & 0.563 & 0.788 & 0.995 & 0.642 & 0.617 & 0.620 & 0.706 & 0.602 & 0.428 & 0.579 & 0.628 \\
\hline W O & 0.135 & 0.315 & 0.147 & 0.000 & 0.251 & 0.223 & 0.189 & 0.139 & 0.271 & 0.378 & 0.289 & 0.327 \\
\hline Classif. & dravite & dravite & dravite & dravite & dravite & dravite & dravite & dravite & dravite & dravite & dravite & dravite \\
\hline
\end{tabular}


Appendix D.1 (contd.): Electron-microprobe analyses of tourmaline.

\begin{tabular}{|c|c|c|c|c|c|c|c|c|c|c|c|c|}
\hline \multirow[b]{2}{*}{$\begin{array}{l}\stackrel{n}{0} \\
\tilde{d} \\
\varepsilon \\
\text { ह } \\
\end{array}$} & \multicolumn{5}{|c|}{ GRANITE - S04 (coarse turm) } & \multicolumn{7}{|c|}{ GRANITE - S06 } \\
\hline & 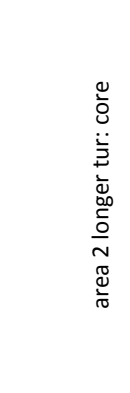 & 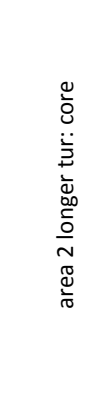 & 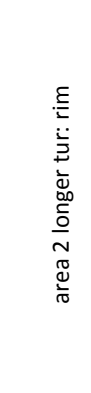 & 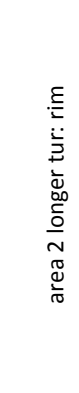 & 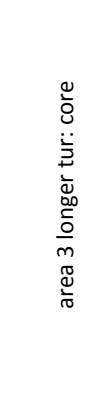 & 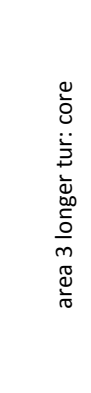 & 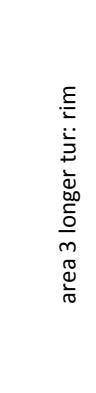 & 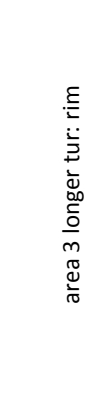 & 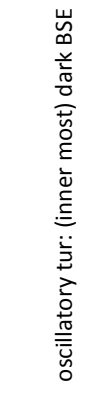 & 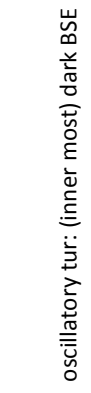 & 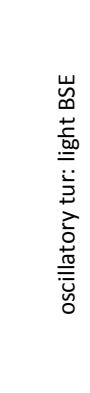 & 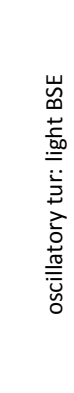 \\
\hline Point & $14 t-1$ & $14 t-2$ & $14 t-3$ & $14 t-4$ & $14 t-5$ & $14 t-6$ & $14 t-7$ & $14 t-8$ & $18 \mathrm{t}-1$ & $18 \mathrm{t}-2$ & $18 \mathrm{t}-3$ & $18 \mathrm{t}-4$ \\
\hline $\mathrm{SiO}_{2}$ (wt.\%) & 34.77 & 34.58 & 34.48 & 34.00 & 34.90 & 34.03 & 34.05 & 34.60 & 33.62 & 33.42 & 33.44 & 33.07 \\
\hline $\mathrm{TiO}_{2}$ & 0.44 & 0.45 & 0.56 & 0.60 & 0.53 & 0.49 & 0.38 & 0.54 & 0.64 & 0.65 & 0.72 & 0.80 \\
\hline $\mathrm{B}_{2} \mathrm{O}_{3}^{*}$ & 10.52 & 10.45 & 10.42 & 10.32 & 10.55 & 10.42 & 10.43 & 10.45 & 10.30 & 10.24 & 10.27 & 10.27 \\
\hline $\mathrm{Al}_{2} \mathrm{O}_{3}$ & 33.98 & 33.89 & 33.80 & 33.57 & 34.04 & 33.95 & 33.63 & 33.70 & 33.43 & 33.52 & 33.41 & 33.85 \\
\hline $\mathrm{Cr}_{2} \mathrm{O}_{3}$ & 0.00 & 0.02 & 0.03 & 0.03 & 0.02 & 0.00 & 0.00 & 0.00 & 0.01 & 0.00 & 0.04 & 0.00 \\
\hline \multicolumn{13}{|l|}{$\mathrm{Bi}_{2} \mathrm{O}_{3}$} \\
\hline $\mathrm{Fe}_{2} \mathrm{O}_{3}{ }^{*}$ & 0.00 & 0.00 & 0.00 & 0.00 & 0.00 & 0.52 & 1.15 & 0.00 & 0.09 & 0.00 & 0.00 & 0.00 \\
\hline $\mathrm{FeO} *$ & 8.18 & 7.92 & 9.68 & 9.29 & 7.86 & 7.49 & 7.75 & 9.06 & 8.77 & 8.69 & 8.98 & 9.25 \\
\hline $\mathrm{FeO}$ (tot) & 8.18 & 7.92 & 9.68 & 9.29 & 7.86 & 7.96 & 8.79 & 9.06 & 8.85 & 8.69 & 8.98 & 9.25 \\
\hline $\mathrm{MnO}$ & 0.06 & 0.05 & 0.16 & 0.09 & 0.08 & 0.08 & 0.10 & 0.10 & 0.13 & 0.07 & 0.12 & 0.04 \\
\hline $\mathrm{ZnO}$ & 0.02 & 0.03 & 0.00 & 0.04 & 0.00 & 0.07 & 0.03 & 0.02 & 0.05 & 0.00 & 0.04 & 0.01 \\
\hline $\mathrm{MgO}$ & 5.86 & 5.80 & 4.66 & 4.78 & 6.01 & 5.89 & 5.75 & 5.24 & 5.25 & 5.10 & 5.11 & 4.87 \\
\hline $\mathrm{Li}_{2} \mathrm{O}^{*}$ & 0.00 & 0.00 & 0.00 & 0.00 & 0.00 & 0.00 & 0.00 & 0.00 & 0.00 & 0.00 & 0.00 & 0.00 \\
\hline $\mathrm{CaO}$ & 0.68 & 0.69 & 0.38 & 0.47 & 0.74 & 0.69 & 0.52 & 0.58 & 0.65 & 0.54 & 0.67 & 0.68 \\
\hline $\mathrm{Na}_{2} \mathrm{O}$ & 1.89 & 1.80 & 1.82 & 1.87 & 1.84 & 1.66 & 1.89 & 1.88 & 1.78 & 1.80 & 1.82 & 1.95 \\
\hline $\mathrm{K}_{2} \mathrm{O}$ & 0.05 & 0.05 & 0.02 & 0.04 & 0.05 & 0.05 & 0.04 & 0.06 & 0.05 & 0.05 & 0.04 & 0.04 \\
\hline $\mathrm{F}$ & 0.22 & 0.28 & 0.31 & 0.36 & 0.22 & 0.28 & 0.35 & 0.20 & 0.29 & 0.20 & 0.24 & 0.31 \\
\hline $\mathrm{Cl}$ & 0.00 & 0.00 & 0.00 & 0.00 & 0.00 & 0.00 & 0.00 & 0.00 & 0.00 & 0.00 & 0.01 & 0.00 \\
\hline $\mathrm{H}_{2} \mathrm{O}^{*}$ & 3.46 & 3.39 & 3.43 & 3.33 & 3.44 & 3.47 & 3.43 & 3.45 & 3.41 & 3.42 & 3.41 & 3.35 \\
\hline$-(\mathrm{O}=\mathrm{F}, \mathrm{Cl})$ & -0.09 & -0.12 & -0.13 & -0.15 & -0.09 & -0.12 & -0.15 & -0.08 & -0.12 & -0.08 & -0.10 & -0.13 \\
\hline Total & 100.03 & 99.28 & 99.62 & 98.63 & 100.18 & 98.97 & 99.35 & 99.81 & 98.36 & 97.61 & 98.22 & 98.35 \\
\hline T Si (apfu) & 5.745 & 5.750 & 5.751 & 5.728 & 5.751 & 5.674 & 5.675 & 5.753 & 5.674 & 5.674 & 5.658 & 5.599 \\
\hline TAl & 0.255 & 0.250 & 0.249 & 0.272 & 0.249 & 0.326 & 0.325 & 0.247 & 0.326 & 0.326 & 0.342 & 0.401 \\
\hline B & 3 & 3 & 3 & 3 & 3 & 3 & 3 & 3 & 3 & 3 & 3 & 3 \\
\hline $\mathrm{ZAl}$ & 6.000 & 6.000 & 6.000 & 6.000 & 6.000 & 6.000 & 6.000 & 6.000 & 6.000 & 6.000 & 6.000 & 6.000 \\
\hline Y Ti & 0.054 & 0.056 & 0.070 & 0.075 & 0.065 & 0.061 & 0.047 & 0.068 & 0.081 & 0.083 & 0.091 & 0.101 \\
\hline Y Al & 0.362 & 0.392 & 0.394 & 0.394 & 0.361 & 0.346 & 0.281 & 0.356 & 0.322 & 0.381 & 0.322 & 0.354 \\
\hline $\mathrm{YCr}$ & 0.000 & 0.002 & 0.005 & 0.005 & 0.003 & 0.000 & 0.000 & 0.000 & 0.002 & 0.000 & 0.005 & 0.000 \\
\hline $\mathrm{Y} \mathrm{Fe}^{3+}$ & 0.000 & 0.000 & 0.000 & 0.000 & 0.000 & 0.065 & 0.144 & 0.000 & 0.011 & 0.000 & 0.000 & 0.000 \\
\hline $\mathrm{Y} \mathrm{Fe}^{2+}$ & 1.131 & 1.101 & 1.350 & 1.308 & 1.084 & 1.045 & 1.081 & 1.260 & 1.238 & 1.234 & 1.271 & 1.310 \\
\hline Y Mn & 0.009 & 0.007 & 0.022 & 0.013 & 0.011 & 0.011 & 0.015 & 0.014 & 0.019 & 0.010 & 0.016 & 0.005 \\
\hline $\mathrm{YZn}$ & 0.002 & 0.003 & 0.000 & 0.005 & 0.000 & 0.009 & 0.004 & 0.003 & 0.007 & 0.000 & 0.005 & 0.002 \\
\hline Y Mg & 1.443 & 1.438 & 1.159 & 1.200 & 1.476 & 1.463 & 1.429 & 1.299 & 1.320 & 1.291 & 1.289 & 1.228 \\
\hline Y Li & 0.000 & 0.000 & 0.000 & 0.000 & 0.000 & 0.000 & 0.000 & 0.000 & 0.000 & 0.000 & 0.000 & 0.000 \\
\hline X Ca & 0.120 & 0.123 & 0.069 & 0.084 & 0.131 & 0.123 & 0.094 & 0.103 & 0.118 & 0.099 & 0.121 & 0.123 \\
\hline $\mathrm{XNa}$ & 0.605 & 0.579 & 0.587 & 0.612 & 0.589 & 0.537 & 0.610 & 0.606 & 0.582 & 0.594 & 0.598 & 0.641 \\
\hline$x K$ & 0.011 & 0.011 & 0.004 & 0.008 & 0.011 & 0.010 & 0.008 & 0.013 & 0.012 & 0.011 & 0.009 & 0.008 \\
\hline$X$ vac & 0.264 & 0.287 & 0.341 & 0.295 & 0.268 & 0.330 & 0.288 & 0.278 & 0.289 & 0.297 & 0.271 & 0.227 \\
\hline $\mathrm{VOH}$ & 3.000 & 3.000 & 3.000 & 3.000 & 3.000 & 3.000 & 3.000 & 3.000 & 3.000 & 3.000 & 3.000 & 3.000 \\
\hline Vo & 0.000 & 0.000 & 0.000 & 0.000 & 0.000 & 0.000 & 0.000 & 0.000 & 0.000 & 0.000 & 0.000 & 0.000 \\
\hline W F & 0.113 & 0.146 & 0.163 & 0.193 & 0.114 & 0.145 & 0.183 & 0.104 & 0.156 & 0.108 & 0.129 & 0.168 \\
\hline W Cl & 0.001 & 0.000 & 0.000 & 0.000 & 0.000 & 0.000 & 0.000 & 0.000 & 0.000 & 0.000 & 0.002 & 0.000 \\
\hline W OH & 0.815 & 0.762 & 0.819 & 0.740 & 0.778 & 0.855 & 0.817 & 0.826 & 0.844 & 0.869 & 0.850 & 0.780 \\
\hline Wo & 0.072 & 0.093 & 0.018 & 0.067 & 0.108 & 0.000 & 0.000 & 0.070 & 0.000 & 0.023 & 0.018 & 0.052 \\
\hline Classif. & dravite & dravite & schorl & schorl & dravite & dravite & dravite & dravite & dravite & dravite & dravite & schorl \\
\hline
\end{tabular}


Appendix D.1 (contd.): Electron-microprobe analyses of tourmaline.

\begin{tabular}{|c|c|c|c|c|c|c|c|c|c|c|c|c|}
\hline Site & & & & & & & & & & & & \\
\hline 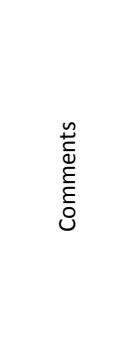 & 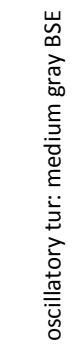 & 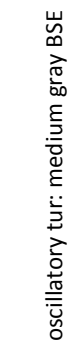 & 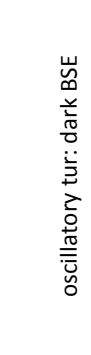 & 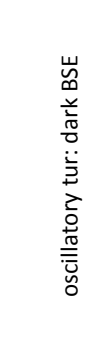 & 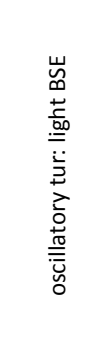 & 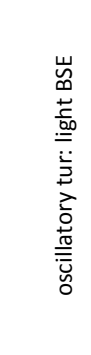 & 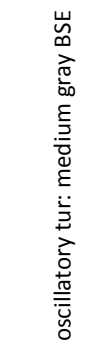 & 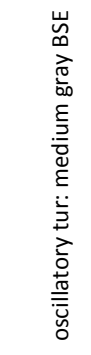 & 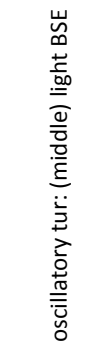 & 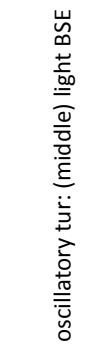 & 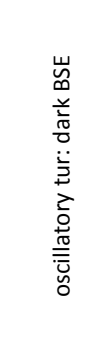 & 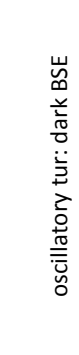 \\
\hline Point & $18 \mathrm{t}-5$ & $18 \mathrm{t}-6$ & $18 \mathrm{t}-7$ & $18 \mathrm{t}-8$ & $18 \mathrm{t}-9$ & $18 \mathrm{t}-10$ & $18 \mathrm{t}-11$ & $18 \mathrm{t}-12$ & $18 \mathrm{t}-13$ & $18 \mathrm{t}-14$ & $18 \mathrm{t}-15$ & $18 \mathrm{t}-16$ \\
\hline $\mathrm{SiO}_{2}$ (wt.\%) & 33.49 & 32.31 & 33.26 & 33.55 & 32.79 & 33.05 & 33.11 & 33.37 & 32.76 & 32.52 & 32.59 & 32.67 \\
\hline $\mathrm{TiO}_{2}$ & 0.63 & 0.61 & 0.66 & 0.69 & 0.61 & 0.75 & 0.56 & 0.69 & 0.69 & 0.73 & 0.59 & 0.64 \\
\hline $\mathrm{B}_{2} \mathrm{O}_{3} *$ & 10.29 & 10.07 & 10.24 & 10.26 & 10.15 & 10.15 & 10.23 & 10.30 & 10.19 & 10.12 & 10.17 & 10.20 \\
\hline $\mathrm{Al}_{2} \mathrm{O}_{3}$ & 33.90 & 33.54 & 33.57 & 33.39 & 34.17 & 33.78 & 33.81 & 33.92 & 34.20 & 34.37 & 34.09 & 34.09 \\
\hline $\mathrm{Cr}_{2} \mathrm{O}_{3}$ & 0.04 & 0.02 & 0.02 & 0.00 & 0.03 & 0.02 & 0.01 & 0.05 & 0.00 & 0.05 & 0.01 & 0.03 \\
\hline $\mathrm{Bi}_{2} \mathrm{O}_{3}$ & & & & & & & & & & & & \\
\hline $\mathrm{Fe}_{2} \mathrm{O}_{3}{ }^{*}$ & 0.26 & 0.36 & 0.00 & 0.23 & 0.00 & 0.00 & 0.35 & 0.61 & 0.43 & 0.00 & 0.44 & 0.64 \\
\hline $\mathrm{FeO} *$ & 9.56 & 10.32 & 8.69 & 8.67 & 12.16 & 12.14 & 10.05 & 9.83 & 10.86 & 11.92 & 10.26 & 10.14 \\
\hline $\mathrm{FeO}$ (tot) & 9.80 & 10.64 & 8.69 & 8.87 & 12.16 & 12.14 & 10.36 & 10.38 & 11.24 & 11.92 & 10.65 & 10.71 \\
\hline $\mathrm{MnO}$ & 0.13 & 0.15 & 0.11 & 0.11 & 0.13 & 0.11 & 0.11 & 0.11 & 0.15 & 0.17 & 0.12 & 0.09 \\
\hline $\mathrm{ZnO}$ & 0.02 & 0.05 & 0.03 & 0.00 & 0.00 & 0.00 & 0.04 & 0.04 & 0.00 & 0.05 & 0.10 & 0.04 \\
\hline $\mathrm{MgO}$ & 4.38 & 3.74 & 5.11 & 5.11 & 2.55 & 2.62 & 4.10 & 4.12 & 3.22 & 2.41 & 3.66 & 3.77 \\
\hline $\mathrm{Li}_{2} \mathrm{O}^{*}$ & 0.00 & 0.00 & 0.00 & 0.00 & 0.00 & 0.00 & 0.00 & 0.00 & 0.00 & 0.00 & 0.00 & 0.00 \\
\hline $\mathrm{CaO}$ & 0.51 & 0.63 & 0.57 & 0.56 & 0.42 & 0.46 & 0.55 & 0.49 & 0.53 & 0.44 & 0.48 & 0.46 \\
\hline $\mathrm{Na}_{2} \mathrm{O}$ & 1.66 & 1.73 & 1.80 & 1.67 & 1.68 & 1.59 & 1.76 & 1.65 & 1.54 & 1.59 & 1.80 & 1.79 \\
\hline $\mathrm{K}_{2} \mathrm{O}$ & 0.04 & 0.06 & 0.05 & 0.05 & 0.05 & 0.04 & 0.06 & 0.04 & 0.03 & 0.04 & 0.04 & 0.06 \\
\hline $\mathrm{F}$ & 0.38 & 0.03 & 0.22 & 0.26 & 0.19 & 0.21 & 0.22 & 0.33 & 0.25 & 0.16 & 0.08 & 0.28 \\
\hline $\mathrm{Cl}$ & 0.01 & 0.01 & 0.00 & 0.00 & 0.01 & 0.01 & 0.00 & 0.00 & 0.01 & 0.00 & 0.00 & 0.00 \\
\hline $\mathrm{H}_{2} \mathrm{O}^{*}$ & 3.37 & 3.46 & 3.43 & 3.42 & 3.41 & 3.37 & 3.42 & 3.40 & 3.39 & 3.40 & 3.47 & 3.39 \\
\hline$-(\mathrm{O}=\mathrm{F}, \mathrm{Cl})$ & -0.16 & -0.01 & -0.09 & -0.11 & -0.08 & -0.09 & -0.09 & -0.14 & -0.11 & -0.07 & -0.03 & -0.12 \\
\hline Total & 98.50 & 97.08 & 97.66 & 97.85 & 98.25 & 98.22 & 98.28 & 98.81 & 98.13 & 97.91 & 97.85 & 98.16 \\
\hline T Si (apfu) & 5.658 & 5.574 & 5.649 & 5.684 & 5.613 & 5.659 & 5.625 & 5.633 & 5.590 & 5.584 & 5.571 & 5.566 \\
\hline TAl & 0.342 & 0.426 & 0.351 & 0.316 & 0.387 & 0.341 & 0.375 & 0.367 & 0.410 & 0.416 & 0.429 & 0.434 \\
\hline B & 3 & 3 & 3 & 3 & 3 & 3 & 3 & 3 & 3 & 3 & 3 & 3 \\
\hline $\mathrm{ZAl}$ & 6.000 & 6.000 & 6.000 & 6.000 & 6.000 & 6.000 & 6.000 & 6.000 & 6.000 & 6.000 & 6.000 & 6.000 \\
\hline $\mathrm{YTi}$ & 0.080 & 0.079 & 0.085 & 0.087 & 0.078 & 0.097 & 0.071 & 0.088 & 0.088 & 0.094 & 0.076 & 0.082 \\
\hline Y Al & 0.407 & 0.393 & 0.368 & 0.350 & 0.508 & 0.476 & 0.396 & 0.382 & 0.468 & 0.539 & 0.438 & 0.411 \\
\hline $\mathrm{YCr}$ & 0.005 & 0.003 & 0.002 & 0.000 & 0.004 & 0.003 & 0.001 & 0.006 & 0.000 & 0.007 & 0.001 & 0.004 \\
\hline $\mathrm{Y} \mathrm{Fe}^{3+}$ & 0.033 & 0.046 & 0.000 & 0.029 & 0.000 & 0.000 & 0.044 & 0.078 & 0.055 & 0.000 & 0.057 & 0.082 \\
\hline $\mathrm{Y} \mathrm{Fe}^{2+}$ & 1.351 & 1.489 & 1.234 & 1.228 & 1.741 & 1.739 & 1.428 & 1.388 & 1.549 & 1.711 & 1.466 & 1.445 \\
\hline Y Mn & 0.019 & 0.022 & 0.016 & 0.016 & 0.018 & 0.016 & 0.016 & 0.015 & 0.022 & 0.025 & 0.017 & 0.013 \\
\hline $\mathrm{YZn}$ & 0.002 & 0.007 & 0.003 & 0.000 & 0.000 & 0.000 & 0.005 & 0.005 & 0.000 & 0.006 & 0.012 & 0.005 \\
\hline Y Mg & 1.103 & 0.961 & 1.293 & 1.290 & 0.650 & 0.669 & 1.038 & 1.038 & 0.818 & 0.618 & 0.933 & 0.958 \\
\hline Y Li & 0.000 & 0.000 & 0.000 & 0.000 & 0.000 & 0.000 & 0.000 & 0.000 & 0.000 & 0.000 & 0.000 & 0.000 \\
\hline X Ca & 0.093 & 0.117 & 0.104 & 0.102 & 0.077 & 0.085 & 0.100 & 0.089 & 0.097 & 0.081 & 0.088 & 0.084 \\
\hline $\mathrm{XNa}$ & 0.542 & 0.578 & 0.592 & 0.550 & 0.557 & 0.528 & 0.578 & 0.538 & 0.511 & 0.529 & 0.598 & 0.592 \\
\hline$x K$ & 0.008 & 0.013 & 0.012 & 0.010 & 0.011 & 0.008 & 0.013 & 0.009 & 0.006 & 0.009 & 0.008 & 0.013 \\
\hline$X$ vac & 0.357 & 0.291 & 0.291 & 0.339 & 0.354 & 0.379 & 0.309 & 0.364 & 0.386 & 0.381 & 0.307 & 0.311 \\
\hline $\mathrm{VOH}$ & 3.000 & 3.000 & 3.000 & 3.000 & 3.000 & 3.000 & 3.000 & 3.000 & 3.000 & 3.000 & 3.000 & 3.000 \\
\hline Vo & 0.000 & 0.000 & 0.000 & 0.000 & 0.000 & 0.000 & 0.000 & 0.000 & 0.000 & 0.000 & 0.000 & 0.000 \\
\hline W F & 0.201 & 0.017 & 0.116 & 0.137 & 0.102 & 0.113 & 0.120 & 0.174 & 0.136 & 0.089 & 0.041 & 0.149 \\
\hline W Cl & 0.003 & 0.002 & 0.000 & 0.000 & 0.002 & 0.002 & 0.000 & 0.000 & 0.002 & 0.000 & 0.000 & 0.000 \\
\hline W OH & 0.796 & 0.981 & 0.884 & 0.862 & 0.890 & 0.847 & 0.880 & 0.826 & 0.861 & 0.892 & 0.959 & 0.850 \\
\hline wo & 0.000 & 0.000 & 0.001 & 0.000 & 0.005 & 0.038 & 0.000 & 0.000 & 0.000 & 0.019 & 0.000 & 0.000 \\
\hline Classif. & schorl & schorl & dravite & dravite & schorl & schorl & schorl & schorl & schorl & schorl & schorl & schorl \\
\hline
\end{tabular}


Appendix D.1 (contd.): Electron-microprobe analyses of tourmaline.

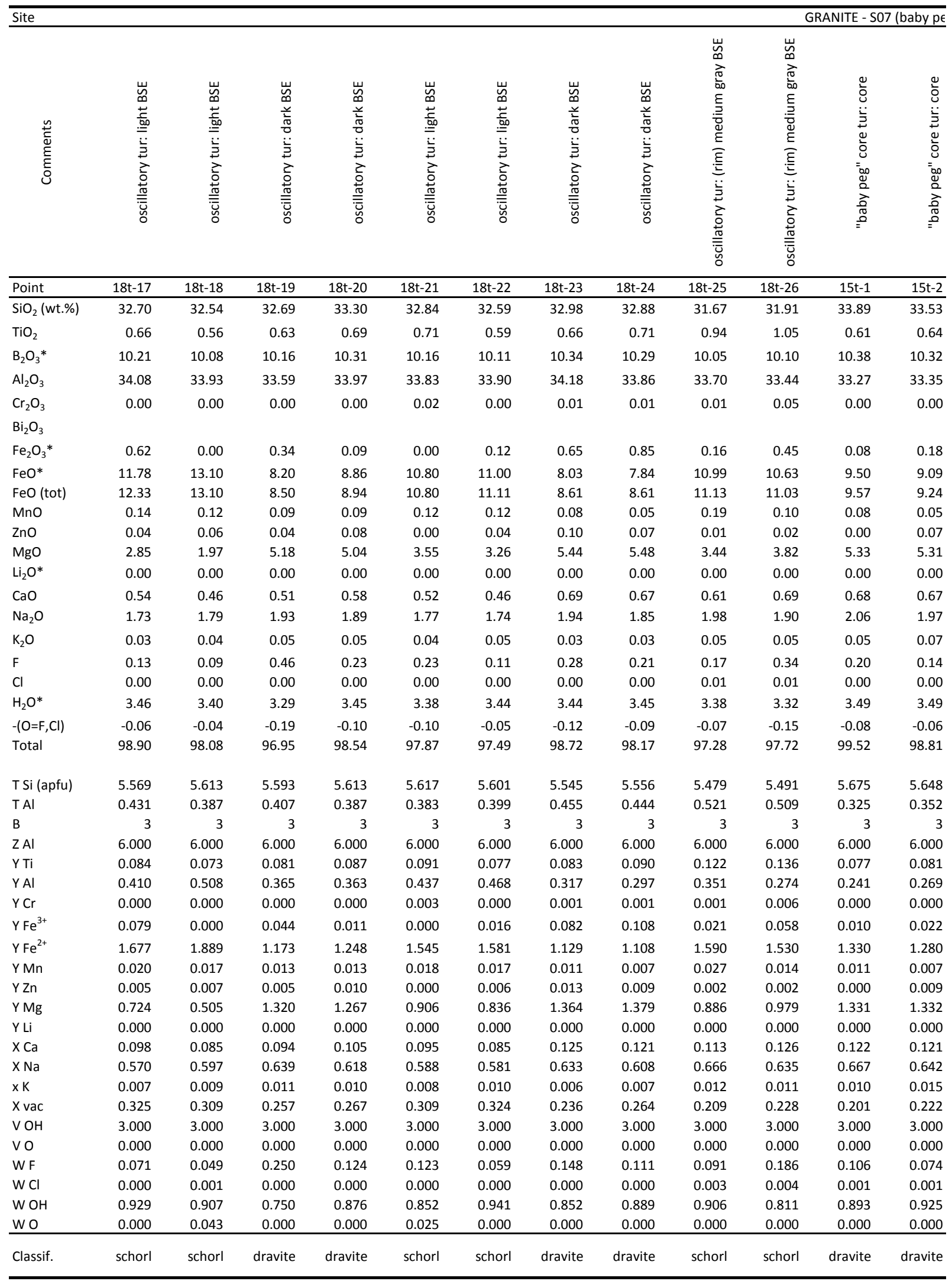


Appendix D.1 (contd.): Electron-microprobe analyses of tourmaline.

\begin{tabular}{|c|c|c|c|c|c|c|c|c|c|c|c|c|}
\hline \multirow[b]{2}{*}{$\begin{array}{ll}\text { Site } \\
\end{array}$} & \multicolumn{3}{|c|}{ gmatite) } & \multicolumn{2}{|c|}{ GRANITE-S07 } & \multicolumn{4}{|c|}{ GRANITE - S07 (normal) } & \multicolumn{3}{|c|}{$\begin{array}{ll}\text { GRANITE } & \text { S08-1 } \\
\end{array}$} \\
\hline & 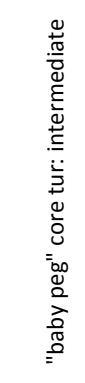 & 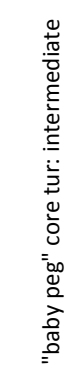 & 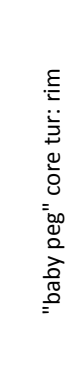 & 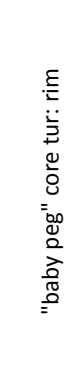 & 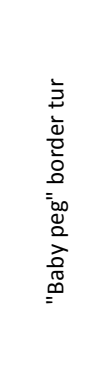 & 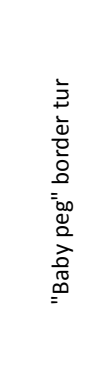 & 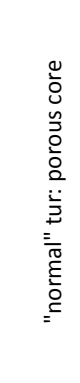 & 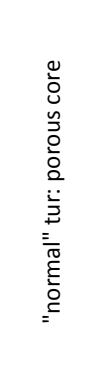 & 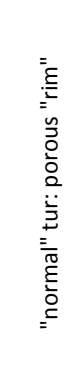 & 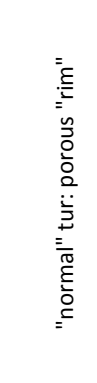 & 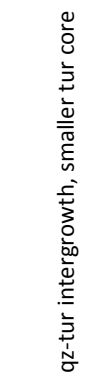 & 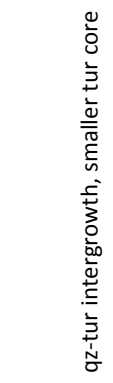 \\
\hline Point & $15 t-3$ & $15 \mathrm{t}-4$ & $15 t-5$ & $15 \mathrm{t}-6$ & $16 \mathrm{t}-1$ & $16 \mathrm{t}-2$ & $19 t-1$ & $19 t-2$ & $19 t-3$ & $19 t-4$ & GN8-1 & GN8-2 \\
\hline $\mathrm{SiO}_{2}$ (wt.\%) & 32.57 & 32.93 & 33.94 & 33.97 & 35.55 & 35.35 & 33.60 & 33.16 & 33.52 & 34.18 & 35.98 & 35.84 \\
\hline $\mathrm{TiO}_{2}$ & 0.36 & 0.50 & 0.64 & 0.68 & 0.30 & 0.46 & 0.76 & 1.01 & 0.66 & 0.54 & 0.08 & 0.18 \\
\hline $\mathrm{B}_{2} \mathrm{O}_{3} *$ & 10.11 & 10.15 & 10.28 & 10.26 & 10.46 & 10.46 & 10.34 & 10.30 & 10.24 & 10.37 & 10.49 & 10.47 \\
\hline $\mathrm{Al}_{2} \mathrm{O}_{3}$ & 33.02 & 32.87 & 31.99 & 31.94 & 32.89 & 32.78 & 34.31 & 34.30 & 33.46 & 32.66 & 33.71 & 33.82 \\
\hline $\mathrm{Cr}_{2} \mathrm{O}_{3}$ & 0.00 & 0.02 & 0.06 & 0.01 & 0.01 & 0.00 & 0.00 & 0.00 & 0.02 & 0.01 & 0.04 & 0.00 \\
\hline \multicolumn{13}{|l|}{$\mathrm{Bi}_{2} \mathrm{O}_{3}$} \\
\hline $\mathrm{Fe}_{2} \mathrm{O}_{3} *$ & 1.59 & 1.28 & 0.96 & 0.34 & 0.00 & 0.00 & 0.00 & 0.00 & 0.00 & 0.37 & 0.00 & 0.00 \\
\hline $\mathrm{FeO} *$ & 12.50 & 12.40 & 10.31 & 10.69 & 7.89 & 8.74 & 9.56 & 10.14 & 9.00 & 8.54 & 8.65 & 8.37 \\
\hline $\mathrm{FeO}$ (tot) & 13.93 & 13.54 & 11.18 & 11.00 & 7.89 & 8.74 & 9.56 & 10.14 & 9.00 & 8.88 & 8.65 & 8.37 \\
\hline $\mathrm{MnO}$ & 0.44 & 0.39 & 0.25 & 0.19 & 0.00 & 0.06 & 0.12 & 0.19 & 0.04 & 0.06 & 0.10 & 0.05 \\
\hline $\mathrm{ZnO}$ & 0.07 & 0.08 & 0.04 & 0.06 & 0.01 & 0.01 & 0.05 & 0.00 & 0.00 & 0.00 & 0.00 & 0.00 \\
\hline $\mathrm{MgO}$ & 2.30 & 2.56 & 4.69 & 4.70 & 6.15 & 5.75 & 4.33 & 3.99 & 4.91 & 5.97 & 4.94 & 5.04 \\
\hline $\mathrm{Li}_{2} \mathrm{O}^{*}$ & 0.00 & 0.00 & 0.00 & 0.00 & 0.00 & 0.00 & 0.00 & 0.00 & 0.00 & 0.00 & 0.00 & 0.00 \\
\hline $\mathrm{CaO}$ & 0.30 & 0.29 & 0.47 & 0.49 & 0.78 & 0.69 & 0.59 & 0.73 & 0.59 & 0.76 & 0.38 & 0.38 \\
\hline $\mathrm{Na}_{2} \mathrm{O}$ & 2.09 & 2.04 & 2.09 & 2.16 & 1.84 & 1.91 & 1.82 & 1.72 & 1.70 & 1.92 & 1.73 & 1.82 \\
\hline $\mathrm{K}_{2} \mathrm{O}$ & 0.04 & 0.03 & 0.03 & 0.04 & 0.07 & 0.05 & 0.03 & 0.05 & 0.02 & 0.03 & 0.04 & 0.06 \\
\hline $\mathrm{F}$ & 0.25 & 0.22 & 0.40 & 0.25 & 0.36 & 0.23 & 0.20 & 0.15 & 0.27 & 0.44 & 0.10 & 0.02 \\
\hline $\mathrm{Cl}$ & 0.01 & 0.00 & 0.00 & 0.00 & 0.00 & 0.00 & 0.00 & 0.00 & 0.02 & 0.00 & 0.00 & 0.00 \\
\hline $\mathrm{H}_{2} \mathrm{O}^{*}$ & 3.37 & 3.40 & 3.36 & 3.42 & 3.25 & 3.36 & 3.38 & 3.40 & 3.37 & 3.37 & 3.35 & 3.35 \\
\hline$-(\mathrm{O}=\mathrm{F}, \mathrm{Cl})$ & -0.11 & -0.09 & -0.17 & -0.10 & -0.15 & -0.10 & -0.08 & -0.06 & -0.12 & -0.19 & -0.04 & -0.01 \\
\hline Total & 98.90 & 99.07 & 99.36 & 99.09 & 99.40 & 99.74 & 99.00 & 99.07 & 97.71 & 99.02 & 99.55 & 99.38 \\
\hline T Si (apfu) & 5.598 & 5.639 & 5.736 & 5.754 & 5.904 & 5.875 & 5.651 & 5.593 & 5.692 & 5.731 & 5.964 & 5.947 \\
\hline T Al & 0.402 & 0.361 & 0.264 & 0.246 & 0.096 & 0.125 & 0.349 & 0.407 & 0.308 & 0.269 & 0.036 & 0.053 \\
\hline B & 3 & 3 & 3 & 3 & 3 & 3 & 3 & 3 & 3 & 3 & 3 & 3 \\
\hline $\mathrm{Z} \mathrm{Al}$ & 6.000 & 6.000 & 6.000 & 6.000 & 6.000 & 6.000 & 6.000 & 6.000 & 6.000 & 6.000 & 6.000 & 6.000 \\
\hline Y Ti & 0.046 & 0.064 & 0.082 & 0.086 & 0.037 & 0.057 & 0.096 & 0.128 & 0.085 & 0.068 & 0.010 & 0.023 \\
\hline Y Al & 0.288 & 0.272 & 0.107 & 0.132 & 0.341 & 0.295 & 0.450 & 0.412 & 0.387 & 0.186 & 0.551 & 0.561 \\
\hline $\mathrm{YCr}$ & 0.000 & 0.003 & 0.008 & 0.001 & 0.001 & 0.000 & 0.000 & 0.000 & 0.002 & 0.001 & 0.005 & 0.000 \\
\hline $\mathrm{Y} \mathrm{Fe}^{3+}$ & 0.205 & 0.164 & 0.122 & 0.043 & 0.000 & 0.000 & 0.000 & 0.000 & 0.000 & 0.047 & 0.000 & 0.000 \\
\hline $\mathrm{Y} \mathrm{Fe}^{2+}$ & 1.798 & 1.775 & 1.457 & 1.515 & 1.095 & 1.215 & 1.344 & 1.431 & 1.277 & 1.198 & 1.199 & 1.161 \\
\hline Y Mn & 0.065 & 0.057 & 0.036 & 0.027 & 0.000 & 0.009 & 0.017 & 0.027 & 0.005 & 0.008 & 0.014 & 0.007 \\
\hline Y Zn & 0.009 & 0.010 & 0.005 & 0.007 & 0.001 & 0.001 & 0.007 & 0.000 & 0.000 & 0.000 & 0.000 & 0.000 \\
\hline Y Mg & 0.590 & 0.653 & 1.182 & 1.188 & 1.524 & 1.424 & 1.087 & 1.002 & 1.244 & 1.492 & 1.221 & 1.248 \\
\hline Y Li & 0.000 & 0.000 & 0.000 & 0.000 & 0.000 & 0.000 & 0.000 & 0.000 & 0.000 & 0.000 & 0.000 & 0.000 \\
\hline X Ca & 0.056 & 0.053 & 0.085 & 0.090 & 0.139 & 0.123 & 0.106 & 0.131 & 0.108 & 0.136 & 0.067 & 0.067 \\
\hline $\mathrm{X} \mathrm{Na}$ & 0.696 & 0.678 & 0.685 & 0.708 & 0.592 & 0.614 & 0.593 & 0.562 & 0.561 & 0.623 & 0.557 & 0.584 \\
\hline x K & 0.008 & 0.007 & 0.006 & 0.009 & 0.014 & 0.010 & 0.006 & 0.011 & 0.005 & 0.006 & 0.009 & 0.013 \\
\hline $\mathrm{X}$ vac & 0.240 & 0.261 & 0.223 & 0.194 & 0.255 & 0.253 & 0.294 & 0.296 & 0.326 & 0.236 & 0.367 & 0.336 \\
\hline $\mathrm{VOH}$ & 3.000 & 3.000 & 3.000 & 3.000 & 3.000 & 3.000 & 3.000 & 3.000 & 3.000 & 3.000 & 3.000 & 3.000 \\
\hline Vo & 0.000 & 0.000 & 0.000 & 0.000 & 0.000 & 0.000 & 0.000 & 0.000 & 0.000 & 0.000 & 0.000 & 0.000 \\
\hline WF & 0.136 & 0.118 & 0.214 & 0.132 & 0.191 & 0.123 & 0.105 & 0.079 & 0.145 & 0.233 & 0.051 & 0.010 \\
\hline W Cl & 0.003 & 0.001 & 0.000 & 0.000 & 0.000 & 0.001 & 0.000 & 0.000 & 0.005 & 0.000 & 0.001 & 0.000 \\
\hline $\mathrm{WOH}$ & 0.860 & 0.882 & 0.786 & 0.868 & 0.604 & 0.721 & 0.792 & 0.823 & 0.818 & 0.767 & 0.708 & 0.705 \\
\hline wo & 0.000 & 0.000 & 0.000 & 0.000 & 0.205 & 0.155 & 0.103 & 0.097 & 0.031 & 0.000 & 0.240 & 0.285 \\
\hline Classif. & schorl & schorl & schorl & schorl & dravite & dravite & schorl & schorl & schorl & dravite & dravite & dravite \\
\hline
\end{tabular}


Appendix D.1 (contd.): Electron-microprobe analyses of tourmaline.

\begin{tabular}{|c|c|c|c|c|c|c|c|c|c|c|c|c|}
\hline \multicolumn{5}{|l|}{ Site } & \multicolumn{5}{|c|}{ GRANITE-S08 } & \multicolumn{3}{|c|}{ GRANITE-S09 } \\
\hline 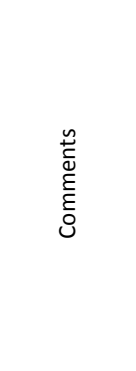 & 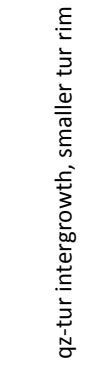 & 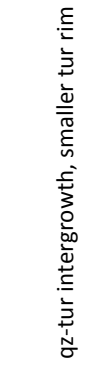 & 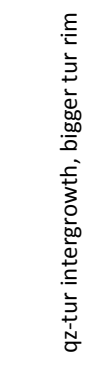 & 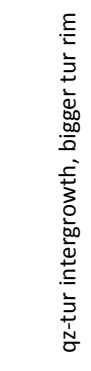 & 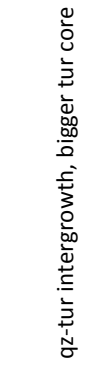 & 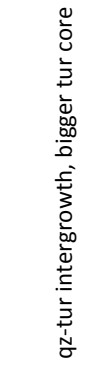 & 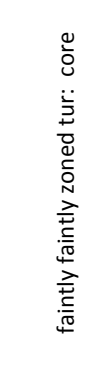 & 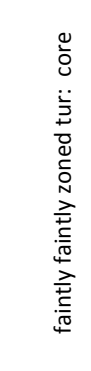 & 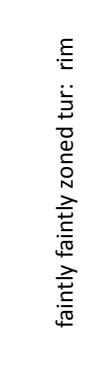 & 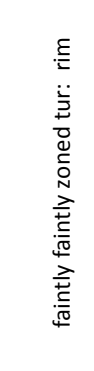 & $\begin{array}{l}\stackrel{5}{+} \\
\stackrel{5}{0} \\
\frac{\pi}{0}\end{array}$ & $\begin{array}{l}\text { 产 } \\
\stackrel{丷}{0} \\
\frac{\pi}{0}\end{array}$ \\
\hline Point & GN8-3 & GN8-4 & GN8-5 & GN8-6 & GN8-7 & GN8-8 & $20 \mathrm{t}-1$ & $20 t-2$ & $20 \mathrm{t}-3$ & $20 \mathrm{t}-4$ & $21 \mathrm{t}-1$ & $21 \mathrm{t}-2$ \\
\hline $\mathrm{SiO}_{2}$ (wt.\%) & 35.12 & 34.78 & 35.01 & 35.35 & 35.56 & 35.34 & 36.32 & 35.82 & 35.61 & 34.73 & 34.35 & 34.40 \\
\hline $\mathrm{TiO}_{2}$ & 0.42 & 0.36 & 0.35 & 0.31 & 0.16 & 0.10 & 0.10 & 0.09 & 0.35 & 0.41 & 0.48 & 0.58 \\
\hline $\mathrm{B}_{2} \mathrm{O}_{3} *$ & 10.43 & 10.36 & 10.46 & 10.45 & 10.45 & 10.43 & 10.58 & 10.49 & 10.51 & 10.40 & 10.27 & 10.33 \\
\hline $\mathrm{Al}_{2} \mathrm{O}_{3}$ & 33.16 & 32.92 & 33.42 & 33.25 & 33.78 & 33.65 & 34.21 & 33.99 & 33.16 & 33.07 & 32.12 & 32.30 \\
\hline $\mathrm{Cr}_{2} \mathrm{O}_{3}$ & 0.03 & 0.02 & 0.03 & 0.00 & 0.00 & 0.00 & 0.00 & 0.05 & 0.00 & 0.03 & 0.00 & 0.03 \\
\hline \multicolumn{13}{|l|}{$\mathrm{Bi}_{2} \mathrm{O}_{3}$} \\
\hline $\mathrm{Fe}_{2} \mathrm{O}_{3} *$ & 0.00 & 0.00 & 0.00 & 0.00 & 0.00 & 0.00 & 0.00 & 0.00 & 0.00 & 0.00 & 0.00 & 0.06 \\
\hline $\mathrm{FeO} *$ & 8.85 & 8.99 & 8.91 & 8.76 & 8.42 & 8.35 & 8.17 & 8.27 & 9.04 & 8.96 & 9.37 & 9.82 \\
\hline $\mathrm{FeO}$ (tot) & 8.85 & 8.99 & 8.91 & 8.76 & 8.42 & 8.35 & 8.17 & 8.27 & 9.04 & 8.96 & 9.37 & 9.87 \\
\hline $\mathrm{MnO}$ & 0.11 & 0.09 & 0.04 & 0.04 & 0.09 & 0.05 & 0.09 & 0.08 & 0.08 & 0.15 & 0.10 & 0.13 \\
\hline $\mathrm{ZnO}$ & 0.00 & 0.05 & 0.01 & 0.04 & 0.00 & 0.06 & 0.07 & 0.04 & 0.05 & 0.01 & 0.02 & 0.00 \\
\hline $\mathrm{MgO}$ & 5.38 & 5.33 & 5.44 & 5.36 & 5.09 & 5.29 & 5.12 & 5.05 & 5.43 & 5.44 & 5.45 & 5.27 \\
\hline $\mathrm{Li}_{2} \mathrm{O}^{*}$ & 0.00 & 0.00 & 0.00 & 0.00 & 0.00 & 0.00 & 0.00 & 0.00 & 0.00 & 0.00 & 0.00 & 0.00 \\
\hline $\mathrm{CaO}$ & 0.69 & 0.72 & 0.77 & 0.77 & 0.40 & 0.43 & 0.31 & 0.38 & 0.81 & 0.78 & 0.82 & 0.71 \\
\hline $\mathrm{Na}_{2} \mathrm{O}$ & 1.90 & 1.79 & 1.96 & 1.75 & 1.70 & 1.56 & 1.69 & 1.67 & 1.83 & 1.82 & 1.78 & 1.83 \\
\hline $\mathrm{K}_{2} \mathrm{O}$ & 0.06 & 0.07 & 0.04 & 0.06 & 0.04 & 0.03 & 0.05 & 0.04 & 0.07 & 0.07 & 0.07 & 0.03 \\
\hline $\mathrm{F}$ & 0.10 & 0.12 & 0.28 & 0.23 & 0.14 & 0.10 & 0.16 & 0.07 & 0.19 & 0.23 & 0.28 & 0.42 \\
\hline $\mathrm{Cl}$ & 0.00 & 0.01 & 0.02 & 0.01 & 0.00 & 0.00 & 0.00 & 0.00 & 0.00 & 0.00 & 0.01 & 0.01 \\
\hline $\mathrm{H}_{2} \mathrm{O}^{*}$ & 3.38 & 3.41 & 3.31 & 3.30 & 3.37 & 3.49 & 3.36 & 3.39 & 3.34 & 3.38 & 3.36 & 3.36 \\
\hline$-(\mathrm{O}=\mathrm{F}, \mathrm{Cl})$ & -0.04 & -0.05 & -0.12 & -0.10 & -0.06 & -0.04 & -0.07 & -0.03 & -0.08 & -0.10 & -0.12 & -0.18 \\
\hline Total & 99.59 & 98.97 & 99.92 & 99.58 & 99.16 & 98.83 & 100.14 & 99.40 & 100.39 & 99.40 & 98.36 & 99.12 \\
\hline T Si (apfu) & 5.850 & 5.832 & 5.817 & 5.882 & 5.913 & 5.888 & 5.967 & 5.935 & 5.889 & 5.802 & 5.814 & 5.787 \\
\hline TAl & 0.150 & 0.168 & 0.183 & 0.118 & 0.087 & 0.112 & 0.033 & 0.065 & 0.111 & 0.198 & 0.186 & 0.213 \\
\hline B & 3 & 3 & 3 & 3 & 3 & 3 & 3 & 3 & 3 & 3 & 3 & 3 \\
\hline $\mathrm{ZAl}$ & 6.000 & 6.000 & 6.000 & 6.000 & 6.000 & 6.000 & 6.000 & 6.000 & 6.000 & 6.000 & 6.000 & 6.000 \\
\hline $\mathrm{YTi}$ & 0.053 & 0.046 & 0.044 & 0.039 & 0.021 & 0.012 & 0.012 & 0.011 & 0.043 & 0.052 & 0.061 & 0.074 \\
\hline Y Al & 0.359 & 0.339 & 0.360 & 0.402 & 0.533 & 0.497 & 0.591 & 0.573 & 0.351 & 0.314 & 0.220 & 0.192 \\
\hline $\mathrm{YCr}$ & 0.005 & 0.002 & 0.004 & 0.000 & 0.000 & 0.000 & 0.000 & 0.006 & 0.000 & 0.004 & 0.000 & 0.004 \\
\hline $\mathrm{YFe}^{3+}$ & 0.000 & 0.000 & 0.000 & 0.000 & 0.000 & 0.000 & 0.000 & 0.000 & 0.000 & 0.000 & 0.000 & 0.007 \\
\hline $\mathrm{Y} \mathrm{Fe}^{2+}$ & 1.233 & 1.261 & 1.238 & 1.219 & 1.171 & 1.163 & 1.122 & 1.146 & 1.251 & 1.252 & 1.327 & 1.382 \\
\hline Y Mn & 0.015 & 0.013 & 0.005 & 0.005 & 0.013 & 0.006 & 0.012 & 0.012 & 0.012 & 0.021 & 0.014 & 0.019 \\
\hline Y Zn & 0.000 & 0.006 & 0.001 & 0.005 & 0.000 & 0.008 & 0.009 & 0.005 & 0.006 & 0.001 & 0.003 & 0.000 \\
\hline Y Mg & 1.335 & 1.333 & 1.348 & 1.329 & 1.262 & 1.314 & 1.254 & 1.248 & 1.338 & 1.355 & 1.376 & 1.322 \\
\hline Y Li & 0.000 & 0.000 & 0.000 & 0.000 & 0.000 & 0.000 & 0.000 & 0.000 & 0.000 & 0.000 & 0.000 & 0.000 \\
\hline X Ca & 0.123 & 0.130 & 0.137 & 0.137 & 0.072 & 0.076 & 0.055 & 0.067 & 0.143 & 0.140 & 0.148 & 0.129 \\
\hline $\mathrm{XNa}$ & 0.614 & 0.582 & 0.632 & 0.564 & 0.547 & 0.505 & 0.537 & 0.536 & 0.588 & 0.590 & 0.585 & 0.597 \\
\hline$x K$ & 0.012 & 0.015 & 0.008 & 0.012 & 0.008 & 0.007 & 0.011 & 0.009 & 0.015 & 0.014 & 0.015 & 0.007 \\
\hline$X$ vac & 0.251 & 0.273 & 0.222 & 0.287 & 0.372 & 0.411 & 0.397 & 0.388 & 0.254 & 0.256 & 0.252 & 0.267 \\
\hline $\mathrm{VOH}$ & 3.000 & 3.000 & 3.000 & 3.000 & 3.000 & 3.000 & 3.000 & 3.000 & 3.000 & 3.000 & 3.000 & 3.000 \\
\hline Vo & 0.000 & 0.000 & 0.000 & 0.000 & 0.000 & 0.000 & 0.000 & 0.000 & 0.000 & 0.000 & 0.000 & 0.000 \\
\hline W F & 0.051 & 0.065 & 0.145 & 0.119 & 0.072 & 0.053 & 0.081 & 0.037 & 0.098 & 0.121 & 0.150 & 0.226 \\
\hline W Cl & 0.000 & 0.003 & 0.006 & 0.001 & 0.000 & 0.000 & 0.000 & 0.000 & 0.000 & 0.000 & 0.003 & 0.002 \\
\hline W OH & 0.755 & 0.810 & 0.665 & 0.667 & 0.742 & 0.874 & 0.678 & 0.748 & 0.687 & 0.771 & 0.796 & 0.772 \\
\hline wo & 0.193 & 0.122 & 0.185 & 0.212 & 0.187 & 0.073 & 0.240 & 0.215 & 0.215 & 0.108 & 0.052 & 0.000 \\
\hline Classif. & dravite & dravite & dravite & dravite & dravite & dravite & dravite & dravite & dravite & dravite & dravite & schorl \\
\hline
\end{tabular}


Appendix D.1 (contd.): Electron-microprobe analyses of tourmaline.

\begin{tabular}{llllll}
\hline Site & JAN-S01 & JUNCT-S02 & JUNCT-S02 & LENS-S01 & LENS-S01 \\
\hline
\end{tabular}

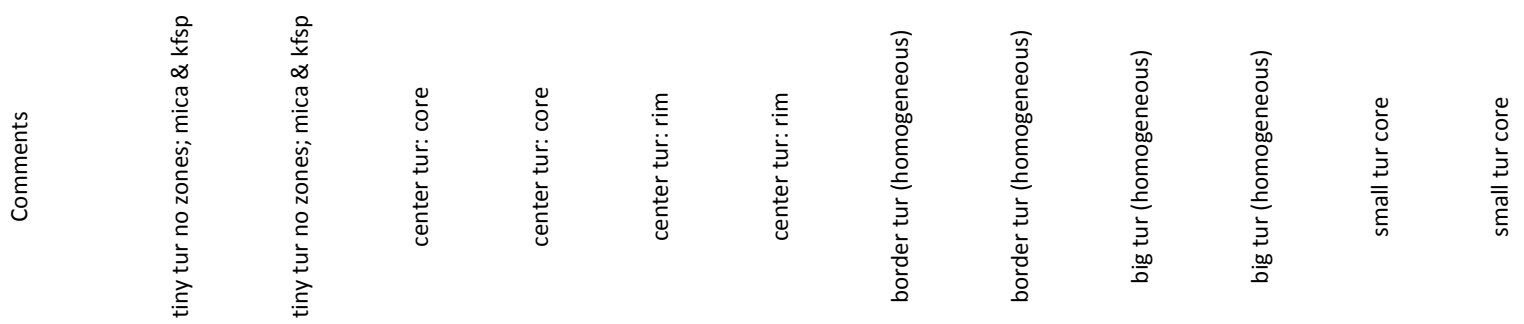

\begin{tabular}{|c|c|c|c|c|c|c|c|c|c|c|c|c|}
\hline Point & $55 t-1$ & $55 t-2$ & $56 \mathrm{t}-1$ & $56 \mathrm{t}-2$ & $56 t-3$ & $56 t-4$ & $57 \mathrm{t}-1$ & $57 \mathrm{t}-2$ & $58 \mathrm{t}-1$ & $58 \mathrm{t}-2$ & $59 t-1$ & $59 t-2$ \\
\hline $\mathrm{SiO}_{2}$ (wt.\%) & 33.78 & 34.05 & 34.96 & 34.94 & 35.74 & 35.24 & 35.21 & 35.43 & 33.76 & 33.68 & 34.44 & 34.81 \\
\hline $\mathrm{TiO}_{2}$ & 0.25 & 0.33 & 1.00 & 0.91 & 0.87 & 1.06 & 0.23 & 0.26 & 0.74 & 0.84 & 0.81 & 0.81 \\
\hline $\mathrm{B}_{2} \mathrm{O}_{3} *$ & 10.29 & 10.36 & 10.51 & 10.47 & 10.62 & 10.57 & 10.56 & 10.61 & 10.27 & 10.29 & 10.44 & 10.47 \\
\hline $\mathrm{Al}_{2} \mathrm{O}_{3}$ & 35.12 & 35.05 & 34.90 & 34.18 & 33.20 & 33.14 & 34.90 & 35.00 & 34.21 & 34.23 & 34.34 & 34.15 \\
\hline $\mathrm{Cr}_{2} \mathrm{O}_{3}$ & 0.03 & 0.04 & 0.05 & 0.03 & 0.04 & 0.00 & 0.00 & 0.00 & 0.01 & 0.00 & 0.02 & 0.00 \\
\hline \multicolumn{13}{|l|}{$\mathrm{Bi}_{2} \mathrm{O}_{3}$} \\
\hline $\mathrm{Fe}_{2} \mathrm{O}_{3} *$ & 0.00 & 0.00 & 0.00 & 0.00 & 0.00 & 0.00 & 0.00 & 0.00 & 0.00 & 0.00 & 0.00 & 0.00 \\
\hline $\mathrm{FeO}^{*}$ & 13.54 & 13.89 & 8.16 & 8.62 & 6.03 & 6.17 & 6.96 & 6.90 & 13.86 & 14.06 & 10.11 & 9.95 \\
\hline $\mathrm{FeO}$ (tot) & 13.54 & 13.89 & 8.16 & 8.62 & 6.03 & 6.17 & 6.96 & 6.90 & 13.86 & 14.06 & 10.11 & 9.95 \\
\hline $\mathrm{MnO}$ & 0.64 & 0.71 & 0.07 & 0.08 & 0.13 & 0.07 & 0.01 & 0.01 & 0.13 & 0.26 & 0.08 & 0.11 \\
\hline $\mathrm{ZnO}$ & 0.04 & 0.12 & 0.08 & 0.07 & 0.04 & 0.03 & 0.04 & 0.02 & 0.06 & 0.09 & 0.00 & 0.02 \\
\hline $\mathrm{MgO}$ & 0.57 & 0.58 & 4.62 & 4.76 & 7.31 & 7.27 & 5.90 & 5.95 & 1.16 & 1.05 & 3.74 & 3.69 \\
\hline $\mathrm{Li}_{2} \mathrm{O}^{*}$ & 0.16 & 0.15 & 0.00 & 0.00 & 0.00 & 0.00 & 0.00 & 0.00 & 0.13 & 0.12 & 0.13 & 0.19 \\
\hline $\mathrm{CaO}$ & 0.28 & 0.23 & 0.63 & 0.62 & 1.35 & 1.37 & 0.89 & 0.90 & 0.15 & 0.17 & 0.34 & 0.39 \\
\hline $\mathrm{Na}_{2} \mathrm{O}$ & 1.60 & 1.74 & 1.78 & 1.76 & 1.76 & 1.64 & 1.53 & 1.49 & 1.80 & 1.82 & 1.70 & 1.68 \\
\hline $\mathrm{K}_{2} \mathrm{O}$ & 0.06 & 0.05 & 0.06 & 0.05 & 0.05 & 0.05 & 0.04 & 0.05 & 0.05 & 0.04 & 0.05 & 0.03 \\
\hline $\mathrm{F}$ & 0.19 & 0.19 & 0.00 & 0.17 & 0.21 & 0.27 & 0.21 & 0.13 & 0.31 & 0.35 & 0.21 & 0.18 \\
\hline $\mathrm{Cl}$ & 0.00 & 0.02 & 0.00 & 0.00 & 0.00 & 0.00 & 0.01 & 0.01 & 0.00 & 0.01 & 0.00 & 0.01 \\
\hline $\mathrm{H}_{2} \mathrm{O}^{*}$ & 3.46 & 3.48 & 3.24 & 3.24 & 3.22 & 3.24 & 3.34 & 3.38 & 3.40 & 3.38 & 3.50 & 3.52 \\
\hline$-(\mathrm{O}=\mathrm{F}, \mathrm{Cl})$ & -0.08 & -0.08 & 0.00 & -0.07 & -0.09 & -0.11 & -0.09 & -0.06 & -0.13 & -0.15 & -0.09 & -0.08 \\
\hline Total & 99.91 & 100.90 & 100.09 & 99.84 & 100.47 & 100.02 & 99.74 & 100.07 & 99.92 & 100.25 & 99.80 & 99.93 \\
\hline T Si (apfu) & 5.707 & 5.713 & 5.780 & 5.800 & 5.852 & 5.798 & 5.793 & 5.807 & 5.712 & 5.692 & 5.732 & 5.779 \\
\hline T Al & 0.293 & 0.287 & 0.220 & 0.200 & 0.148 & 0.202 & 0.207 & 0.193 & 0.288 & 0.308 & 0.268 & 0.221 \\
\hline B & 3 & 3 & 3 & 3 & 3 & 3 & 3 & 3 & 3 & 3 & 3 & 3 \\
\hline $\mathrm{ZAl}$ & 6.000 & 6.000 & 6.000 & 6.000 & 6.000 & 6.000 & 6.000 & 6.000 & 6.000 & 6.000 & 6.000 & 6.000 \\
\hline Y Ti & 0.031 & 0.042 & 0.124 & 0.114 & 0.107 & 0.131 & 0.028 & 0.032 & 0.095 & 0.106 & 0.102 & 0.101 \\
\hline Y Al & 0.700 & 0.642 & 0.581 & 0.487 & 0.257 & 0.223 & 0.560 & 0.566 & 0.533 & 0.510 & 0.468 & 0.460 \\
\hline $\mathrm{YCr}$ & 0.004 & 0.005 & 0.007 & 0.004 & 0.005 & 0.000 & 0.000 & 0.000 & 0.001 & 0.000 & 0.003 & 0.000 \\
\hline $\mathrm{YFe}^{3+}$ & 0.000 & 0.000 & 0.000 & 0.000 & 0.000 & 0.000 & 0.000 & 0.000 & 0.000 & 0.000 & 0.000 & 0.000 \\
\hline $\mathrm{YFe}^{2+}$ & 1.913 & 1.949 & 1.129 & 1.196 & 0.825 & 0.849 & 0.958 & 0.946 & 1.960 & 1.987 & 1.407 & 1.382 \\
\hline Y Mn & 0.091 & 0.100 & 0.010 & 0.011 & 0.018 & 0.010 & 0.001 & 0.001 & 0.019 & 0.037 & 0.011 & 0.015 \\
\hline Y Zn & 0.006 & 0.015 & 0.010 & 0.009 & 0.005 & 0.004 & 0.004 & 0.002 & 0.008 & 0.012 & 0.000 & 0.002 \\
\hline Y Mg & 0.145 & 0.146 & 1.139 & 1.178 & 1.784 & 1.784 & 1.448 & 1.454 & 0.294 & 0.265 & 0.927 & 0.914 \\
\hline Y Li & 0.109 & 0.101 & 0.000 & 0.000 & 0.000 & 0.000 & 0.000 & 0.000 & 0.091 & 0.083 & 0.084 & 0.126 \\
\hline X Ca & 0.050 & 0.042 & 0.112 & 0.111 & 0.236 & 0.242 & 0.157 & 0.157 & 0.028 & 0.031 & 0.060 & 0.069 \\
\hline X Na & 0.523 & 0.565 & 0.572 & 0.568 & 0.559 & 0.523 & 0.488 & 0.474 & 0.590 & 0.596 & 0.548 & 0.542 \\
\hline x K & 0.012 & 0.010 & 0.013 & 0.010 & 0.011 & 0.011 & 0.009 & 0.010 & 0.010 & 0.009 & 0.010 & 0.006 \\
\hline $\mathrm{X}$ vac & 0.415 & 0.384 & 0.303 & 0.311 & 0.194 & 0.224 & 0.346 & 0.359 & 0.372 & 0.363 & 0.381 & 0.383 \\
\hline $\mathrm{VOH}$ & 3.000 & 3.000 & 3.000 & 3.000 & 3.000 & 3.000 & 3.000 & 3.000 & 3.000 & 3.000 & 3.000 & 3.000 \\
\hline V O & 0.000 & 0.000 & 0.000 & 0.000 & 0.000 & 0.000 & 0.000 & 0.000 & 0.000 & 0.000 & 0.000 & 0.000 \\
\hline W F & 0.102 & 0.100 & 0.000 & 0.090 & 0.108 & 0.140 & 0.108 & 0.065 & 0.164 & 0.190 & 0.109 & 0.096 \\
\hline W Cl & 0.001 & 0.006 & 0.000 & 0.000 & 0.001 & 0.000 & 0.003 & 0.002 & 0.000 & 0.004 & 0.001 & 0.001 \\
\hline $\mathrm{WOH}$ & 0.898 & 0.893 & 0.576 & 0.591 & 0.521 & 0.560 & 0.669 & 0.698 & 0.836 & 0.807 & 0.890 & 0.902 \\
\hline WO & 0.000 & 0.000 & 0.424 & 0.318 & 0.370 & 0.300 & 0.221 & 0.234 & 0.000 & 0.000 & 0.000 & 0.000 \\
\hline Classif. & schorl & schorl & dravite & schorl & dravite & dravite & dravite & dravite & schorl & schorl & schorl & schorl \\
\hline
\end{tabular}


Appendix D.1 (contd.): Electron-microprobe analyses of tourmaline.

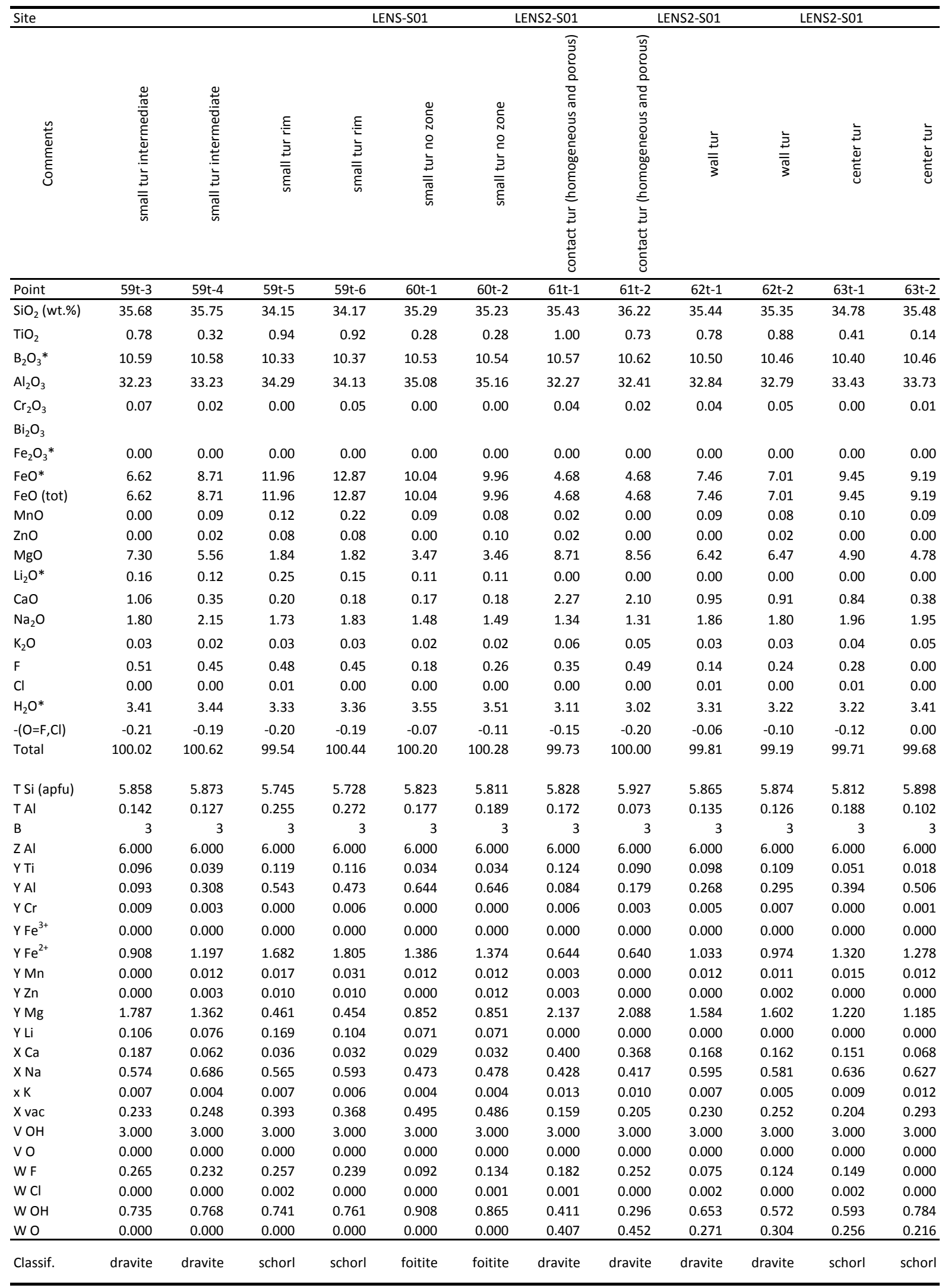


Appendix D.1 (contd.): Electron-microprobe analyses of tourmaline.$$
\text { Site LI S01-2 }
$$

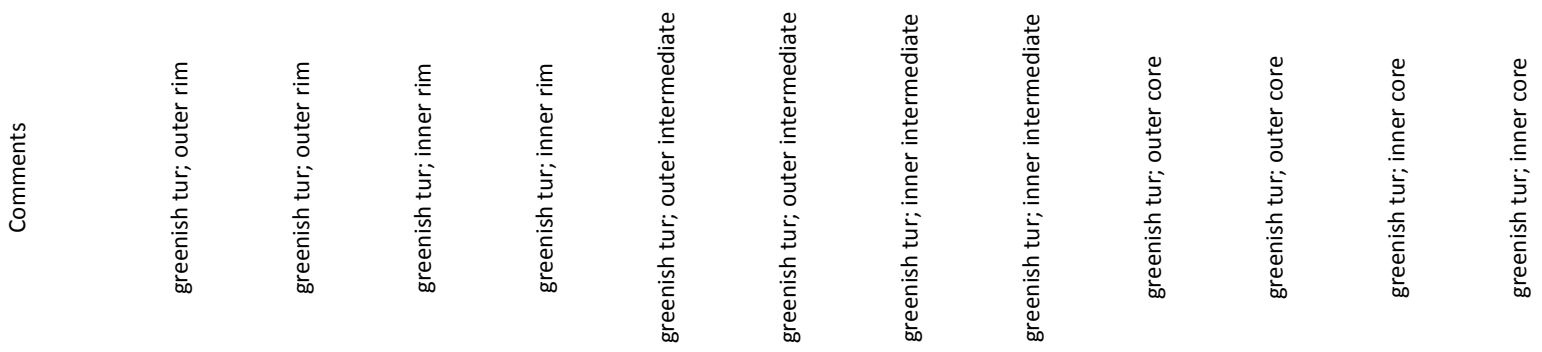

\begin{tabular}{|c|c|c|c|c|c|c|c|c|c|c|c|c|}
\hline Point & 2LI-1 & $2 \mathrm{LI}-2$ & $2 \mathrm{LI}-3$ & $2 \mathrm{LI}-4$ & $2 \mathrm{LI}-5$ & $2 \mathrm{LI}-6$ & 2LI-7 & $2 \mathrm{LI}-8$ & 2LI-9 & 2LI-10 & 2LI-11 & 2LI-12 \\
\hline $\mathrm{SiO}_{2}$ (wt.\%) & 36.60 & 35.99 & 36.22 & 36.18 & 35.78 & 35.62 & 35.27 & 35.32 & 35.99 & 35.90 & 35.77 & 36.41 \\
\hline $\mathrm{TiO}_{2}$ & 0.11 & 0.06 & 0.10 & 0.10 & 0.15 & 0.12 & 0.22 & 0.28 & 0.21 & 0.24 & 0.21 & 0.15 \\
\hline $\mathrm{B}_{2} \mathrm{O}_{3} *$ & 10.75 & 10.73 & 10.79 & 10.77 & 10.69 & 10.63 & 10.59 & 10.57 & 10.62 & 10.57 & 10.66 & 10.75 \\
\hline $\mathrm{Al}_{2} \mathrm{O}_{3}$ & 39.07 & 40.04 & 40.01 & 39.74 & 38.73 & 38.66 & 37.94 & 37.89 & 37.34 & 37.11 & 38.92 & 38.93 \\
\hline $\mathrm{Cr}_{2} \mathrm{O}_{3}$ & 0.04 & 0.04 & 0.00 & 0.03 & 0.00 & 0.00 & 0.00 & 0.04 & 0.00 & 0.01 & 0.00 & 0.03 \\
\hline \multicolumn{13}{|l|}{$\mathrm{Bi}_{2} \mathrm{O}_{3}$} \\
\hline $\mathrm{Fe}_{2} \mathrm{O}_{3} *$ & 0.00 & 0.00 & 0.00 & 0.00 & 0.00 & 0.00 & 0.00 & 0.00 & 0.00 & 0.00 & 0.00 & 0.00 \\
\hline $\mathrm{FeO} *$ & 1.58 & 1.49 & 1.44 & 1.69 & 3.36 & 3.05 & 5.48 & 5.22 & 4.97 & 5.10 & 2.31 & 2.80 \\
\hline $\mathrm{FeO}$ (tot) & 1.58 & 1.49 & 1.44 & 1.69 & 3.36 & 3.05 & 5.48 & 5.22 & 4.97 & 5.10 & 2.31 & 2.80 \\
\hline $\mathrm{MnO}$ & 2.12 & 1.80 & 2.34 & 2.31 & 2.18 & 2.31 & 1.41 & 1.34 & 1.54 & 1.33 & 2.38 & 2.03 \\
\hline $\mathrm{ZnO}$ & 0.03 & 0.06 & 0.06 & 0.04 & 0.06 & 0.07 & 0.36 & 0.37 & 0.42 & 0.47 & 0.13 & 0.13 \\
\hline MgO & 0.00 & 0.01 & 0.01 & 0.01 & 0.01 & 0.02 & 0.01 & 0.01 & 0.01 & 0.01 & 0.01 & 0.01 \\
\hline $\mathrm{Li}_{2} \mathrm{O}^{*}$ & 1.71 & 1.62 & 1.60 & 1.59 & 1.50 & 1.46 & 1.30 & 1.30 & 1.41 & 1.40 & 1.53 & 1.54 \\
\hline $\mathrm{CaO}$ & 0.31 & 0.23 & 0.22 & 0.23 & 0.25 & 0.25 & 0.16 & 0.14 & 0.25 & 0.23 & 0.32 & 0.24 \\
\hline $\mathrm{Na}_{2} \mathrm{O}$ & 2.21 & 2.05 & 2.14 & 2.19 & 2.54 & 2.31 & 2.62 & 2.42 & 2.52 & 2.42 & 2.19 & 2.20 \\
\hline $\mathrm{K}_{2} \mathrm{O}$ & 0.01 & 0.00 & 0.02 & 0.01 & 0.02 & 0.03 & 0.02 & 0.02 & 0.02 & 0.02 & 0.03 & 0.03 \\
\hline $\mathrm{F}$ & 1.57 & 1.40 & 1.58 & 1.82 & 1.73 & 1.35 & 1.23 & 1.31 & 1.70 & 1.63 & 1.57 & 1.65 \\
\hline $\mathrm{Cl}$ & 0.00 & 0.00 & 0.00 & 0.00 & 0.00 & 0.02 & 0.00 & 0.00 & 0.00 & 0.00 & 0.00 & 0.00 \\
\hline $\mathrm{H}_{2} \mathrm{O}^{*}$ & 2.97 & 3.04 & 2.97 & 2.85 & 2.87 & 3.02 & 3.07 & 3.03 & 2.86 & 2.87 & 2.93 & 2.93 \\
\hline$-(\mathrm{O}=\mathrm{F}, \mathrm{Cl})$ & -0.66 & -0.59 & -0.67 & -0.77 & -0.73 & -0.57 & -0.52 & -0.55 & -0.72 & -0.69 & -0.66 & -0.70 \\
\hline Total & 98.43 & 97.98 & 98.86 & 98.81 & 99.14 & 98.34 & 99.17 & 98.68 & 99.16 & 98.63 & 98.29 & 99.15 \\
\hline T Si (apfu) & 5.917 & 5.831 & 5.834 & 5.840 & 5.816 & 5.826 & 5.785 & 5.808 & 5.891 & 5.905 & 5.832 & 5.885 \\
\hline T Al & 0.083 & 0.169 & 0.166 & 0.160 & 0.184 & 0.174 & 0.215 & 0.192 & 0.109 & 0.095 & 0.168 & 0.115 \\
\hline B & 3 & 3 & 3 & 3 & 3 & 3 & 3 & 3 & 3 & 3 & 3 & 3 \\
\hline Z Al & 6.000 & 6.000 & 6.000 & 6.000 & 6.000 & 6.000 & 6.000 & 6.000 & 6.000 & 6.000 & 6.000 & 6.000 \\
\hline Y Ti & 0.013 & 0.008 & 0.012 & 0.012 & 0.019 & 0.014 & 0.028 & 0.034 & 0.026 & 0.030 & 0.026 & 0.018 \\
\hline Y Al & 1.361 & 1.476 & 1.428 & 1.399 & 1.235 & 1.277 & 1.122 & 1.151 & 1.094 & 1.100 & 1.310 & 1.299 \\
\hline $\mathrm{Y} \mathrm{Cr}$ & 0.005 & 0.005 & 0.000 & 0.003 & 0.000 & 0.000 & 0.000 & 0.005 & 0.000 & 0.001 & 0.000 & 0.004 \\
\hline$Y \mathrm{Fe}^{3+}$ & 0.000 & 0.000 & 0.000 & 0.000 & 0.000 & 0.000 & 0.000 & 0.000 & 0.000 & 0.000 & 0.000 & 0.000 \\
\hline $\mathrm{Y} \mathrm{Fe}^{2+}$ & 0.214 & 0.202 & 0.194 & 0.228 & 0.457 & 0.417 & 0.751 & 0.718 & 0.681 & 0.702 & 0.315 & 0.378 \\
\hline Y Mn & 0.291 & 0.247 & 0.319 & 0.316 & 0.300 & 0.319 & 0.196 & 0.186 & 0.214 & 0.186 & 0.329 & 0.278 \\
\hline Y Zn & 0.003 & 0.007 & 0.008 & 0.004 & 0.007 & 0.009 & 0.044 & 0.044 & 0.051 & 0.057 & 0.015 & 0.015 \\
\hline Y Mg & 0.000 & 0.002 & 0.003 & 0.003 & 0.004 & 0.004 & 0.003 & 0.003 & 0.003 & 0.002 & 0.002 & 0.004 \\
\hline Y Li & 1.113 & 1.053 & 1.035 & 1.035 & 0.978 & 0.959 & 0.856 & 0.857 & 0.931 & 0.923 & 1.003 & 1.004 \\
\hline $\mathrm{XCa}$ & 0.054 & 0.041 & 0.037 & 0.040 & 0.043 & 0.044 & 0.028 & 0.024 & 0.045 & 0.041 & 0.056 & 0.042 \\
\hline $\mathrm{X} \mathrm{Na}$ & 0.693 & 0.645 & 0.669 & 0.687 & 0.800 & 0.733 & 0.834 & 0.772 & 0.800 & 0.772 & 0.691 & 0.689 \\
\hline x K & 0.003 & 0.000 & 0.005 & 0.003 & 0.004 & 0.006 & 0.004 & 0.003 & 0.005 & 0.004 & 0.006 & 0.006 \\
\hline $\mathrm{X}$ vac & 0.250 & 0.315 & 0.289 & 0.271 & 0.154 & 0.217 & 0.135 & 0.200 & 0.150 & 0.183 & 0.247 & 0.262 \\
\hline $\mathrm{VOH}$ & 3.000 & 3.000 & 3.000 & 3.000 & 3.000 & 3.000 & 3.000 & 3.000 & 3.000 & 3.000 & 3.000 & 3.000 \\
\hline Vo & 0.000 & 0.000 & 0.000 & 0.000 & 0.000 & 0.000 & 0.000 & 0.000 & 0.000 & 0.000 & 0.000 & 0.000 \\
\hline W F & 0.802 & 0.716 & 0.805 & 0.928 & 0.892 & 0.699 & 0.636 & 0.682 & 0.882 & 0.847 & 0.811 & 0.843 \\
\hline W Cl & 0.000 & 0.001 & 0.000 & 0.001 & 0.000 & 0.005 & 0.001 & 0.000 & 0.000 & 0.000 & 0.001 & 0.001 \\
\hline $\mathrm{WOH}$ & 0.198 & 0.283 & 0.195 & 0.071 & 0.108 & 0.296 & 0.363 & 0.318 & 0.118 & 0.153 & 0.188 & 0.156 \\
\hline wo & 0.000 & 0.000 & 0.000 & 0.000 & 0.000 & 0.000 & 0.000 & 0.000 & 0.000 & 0.000 & 0.000 & 0.000 \\
\hline Classif. & $\begin{array}{l}\text { fluor- } \\
\text { elbaite }\end{array}$ & $\begin{array}{l}\text { fluor- } \\
\text { elbaite }\end{array}$ & $\begin{array}{l}\text { fluor- } \\
\text { elbaite }\end{array}$ & $\begin{array}{l}\text { fluor- } \\
\text { elbaite }\end{array}$ & $\begin{array}{l}\text { fluor- } \\
\text { elbaite }\end{array}$ & $\begin{array}{l}\text { fluor- } \\
\text { elbaite }\end{array}$ & $\begin{array}{l}\text { fluor- } \\
\text { elbaite }\end{array}$ & $\begin{array}{l}\text { fluor- } \\
\text { elbaite }\end{array}$ & $\begin{array}{l}\text { fluor- } \\
\text { elbaite }\end{array}$ & $\begin{array}{l}\text { fluor- } \\
\text { elbaite }\end{array}$ & $\begin{array}{l}\text { fluor- } \\
\text { elbaite }\end{array}$ & $\begin{array}{l}\text { fluor- } \\
\text { elbaite }\end{array}$ \\
\hline
\end{tabular}


Appendix D.1 (contd.): Electron-microprobe analyses of tourmaline.

\begin{tabular}{|c|c|c|c|c|c|c|c|c|c|c|c|c|}
\hline Site & LI S01-4 & & & 501-5 & & & & & & & & \\
\hline 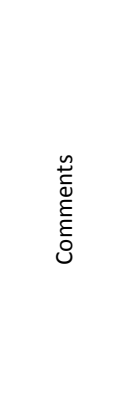 & 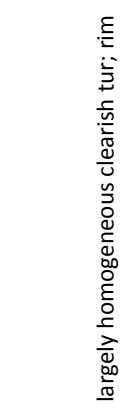 & 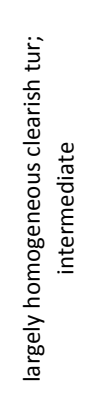 & 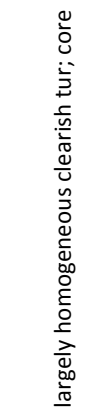 & 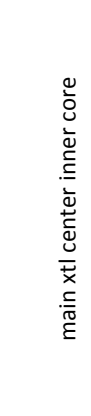 & 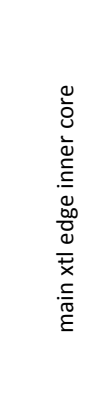 & 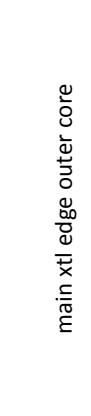 & 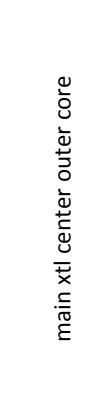 & 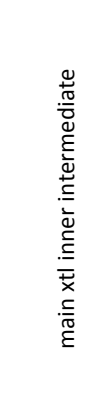 & 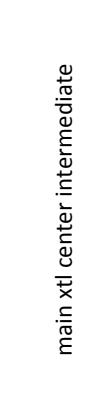 & 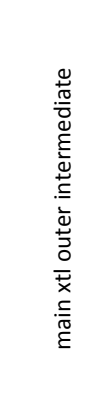 & 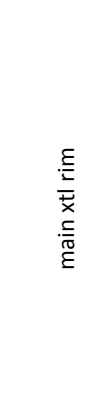 & 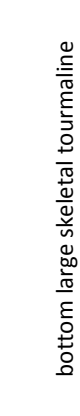 \\
\hline Point & $4 \mathrm{LI}-1$ & $4 \mathrm{LL}-2$ & $4 \mathrm{LI}-3$ & $5 \mathrm{LI}-1$ & $5 \mathrm{LI}-2$ & $5 \mathrm{LI}-3$ & $5 \mathrm{Ll}-4$ & $5 \mathrm{LI}-5$ & $5 \mathrm{LI}-6$ & $5 \mathrm{LI}-7$ & 5 LLI-8 & $5 \mathrm{LI}-9$ \\
\hline $\mathrm{SiO}_{2}$ (wt.\%) & 37.94 & 37.85 & 38.21 & 35.86 & 35.67 & 35.30 & 34.25 & 35.05 & 34.96 & 35.07 & 35.54 & 37.72 \\
\hline $\mathrm{TiO}_{2}$ & 0.11 & 0.03 & 0.13 & 0.35 & 0.14 & 0.50 & 0.50 & 0.61 & 0.52 & 0.49 & 0.25 & 0.04 \\
\hline $\mathrm{B}_{2} \mathrm{O}_{3} *$ & 10.99 & 10.98 & 11.07 & 10.50 & 10.44 & 10.47 & 10.26 & 10.41 & 10.43 & 10.41 & 10.61 & 10.93 \\
\hline $\mathrm{Al}_{2} \mathrm{O}_{3}$ & 38.59 & 40.25 & 40.49 & 33.92 & 34.12 & 33.91 & 33.57 & 33.67 & 33.99 & 33.89 & 36.66 & 36.83 \\
\hline $\mathrm{Cr}_{2} \mathrm{O}_{3}$ & 0.00 & 0.00 & 0.07 & 0.02 & 0.07 & 0.02 & 0.00 & 0.00 & 0.02 & 0.00 & 0.00 & 0.00 \\
\hline \multicolumn{13}{|l|}{$\mathrm{Bi}_{2} \mathrm{O}_{3}$} \\
\hline $\mathrm{Fe}_{2} \mathrm{O}_{3} *$ & 0.98 & 0.00 & 0.34 & 0.00 & 0.00 & 0.00 & 0.00 & 0.00 & 0.00 & 0.00 & 0.00 & 2.01 \\
\hline $\mathrm{FeO} *$ & 2.93 & 1.08 & 0.98 & 14.17 & 13.65 & 14.42 & 14.57 & 14.81 & 14.66 & 14.67 & 9.31 & 3.50 \\
\hline $\mathrm{FeO}$ (tot) & 3.81 & 1.08 & 1.28 & 14.17 & 13.65 & 14.42 & 14.57 & 14.81 & 14.66 & 14.67 & 9.31 & 5.31 \\
\hline $\mathrm{MnO}$ & 0.90 & 0.94 & 0.70 & 0.60 & 0.56 & 0.74 & 0.77 & 0.80 & 0.90 & 0.88 & 1.58 & 2.73 \\
\hline $\mathrm{ZnO}$ & 0.17 & 0.08 & 0.10 & 0.09 & 0.12 & 0.11 & 0.10 & 0.07 & 0.12 & 0.12 & 0.30 & 0.07 \\
\hline $\mathrm{MgO}$ & 0.02 & 0.01 & 0.01 & 0.97 & 0.86 & 0.80 & 0.71 & 0.66 & 0.51 & 0.41 & 0.13 & 0.01 \\
\hline $\mathrm{Li}_{2} \mathrm{O}^{*}$ & 1.80 & 1.90 & 1.91 & 0.14 & 0.21 & 0.19 & 0.10 & 0.14 & 0.17 & 0.19 & 0.78 & 1.57 \\
\hline $\mathrm{CaO}$ & 0.20 & 0.23 & 0.14 & 0.06 & 0.02 & 0.09 & 0.10 & 0.07 & 0.09 & 0.08 & 0.10 & 0.13 \\
\hline $\mathrm{Na}_{2} \mathrm{O}$ & 2.41 & 2.01 & 1.92 & 1.50 & 1.60 & 1.86 & 1.79 & 1.81 & 1.88 & 1.81 & 2.19 & 2.59 \\
\hline $\mathrm{K}_{2} \mathrm{O}$ & 0.01 & 0.03 & 0.01 & 0.02 & 0.03 & 0.06 & 0.06 & 0.06 & 0.04 & 0.03 & 0.03 & 0.03 \\
\hline$F$ & 1.48 & 1.32 & 1.25 & 0.24 & 0.14 & 0.47 & 0.45 & 0.42 & 0.27 & 0.23 & 0.88 & 1.29 \\
\hline $\mathrm{Cl}$ & 0.00 & 0.00 & 0.00 & 0.00 & 0.00 & 0.00 & 0.00 & 0.00 & 0.00 & 0.01 & 0.01 & 0.00 \\
\hline $\mathrm{H}_{2} \mathrm{O}^{*}$ & 3.09 & 3.16 & 3.23 & 3.51 & 3.53 & 3.39 & 3.33 & 3.40 & 3.47 & 3.48 & 3.24 & 3.16 \\
\hline$-(\mathrm{O}=\mathrm{F}, \mathrm{Cl})$ & -0.62 & -0.56 & -0.53 & -0.10 & -0.06 & -0.20 & -0.19 & -0.18 & -0.11 & -0.10 & -0.37 & -0.54 \\
\hline Total & 101.00 & 99.31 & 100.03 & 101.86 & 101.09 & 102.11 & 100.36 & 101.81 & 101.91 & 101.68 & 101.22 & 102.08 \\
\hline T Si (apfu) & 6.000 & 5.995 & 6.000 & 5.939 & 5.937 & 5.861 & 5.801 & 5.849 & 5.827 & 5.855 & 5.820 & 6.000 \\
\hline T Al & 0.000 & 0.005 & 0.000 & 0.061 & 0.063 & 0.139 & 0.199 & 0.151 & 0.173 & 0.145 & 0.180 & 0.000 \\
\hline B & 3 & 3 & 3 & 3 & 3 & 3 & 3 & 3 & 3 & 3 & 3 & 3 \\
\hline $\mathrm{ZAl}$ & 6.000 & 6.000 & 6.000 & 6.000 & 6.000 & 6.000 & 6.000 & 6.000 & 6.000 & 6.000 & 6.000 & 6.000 \\
\hline$Y \mathrm{Ti}$ & 0.013 & 0.003 & 0.015 & 0.044 & 0.017 & 0.063 & 0.064 & 0.077 & 0.066 & 0.062 & 0.030 & 0.005 \\
\hline Y Al & 1.193 & 1.506 & 1.494 & 0.560 & 0.630 & 0.495 & 0.503 & 0.472 & 0.506 & 0.523 & 0.896 & 0.904 \\
\hline $\mathrm{YCr}$ & 0.000 & 0.000 & 0.009 & 0.003 & 0.009 & 0.003 & 0.000 & 0.000 & 0.002 & 0.000 & 0.000 & 0.000 \\
\hline $\mathrm{YFe}^{3+}$ & 0.116 & 0.000 & 0.040 & 0.000 & 0.000 & 0.000 & 0.000 & 0.000 & 0.000 & 0.000 & 0.000 & 0.241 \\
\hline $\mathrm{Y} \mathrm{Fe}^{2+}$ & 0.387 & 0.143 & 0.129 & 1.963 & 1.900 & 2.002 & 2.063 & 2.068 & 2.044 & 2.048 & 1.275 & 0.466 \\
\hline Y Mn & 0.121 & 0.127 & 0.093 & 0.085 & 0.079 & 0.104 & 0.110 & 0.114 & 0.127 & 0.124 & 0.219 & 0.368 \\
\hline Y Zn & 0.019 & 0.010 & 0.012 & 0.011 & 0.015 & 0.013 & 0.013 & 0.009 & 0.015 & 0.015 & 0.037 & 0.008 \\
\hline Y Mg & 0.005 & 0.002 & 0.002 & 0.238 & 0.213 & 0.197 & 0.180 & 0.164 & 0.128 & 0.103 & 0.031 & 0.002 \\
\hline Y Li & 1.146 & 1.210 & 1.208 & 0.096 & 0.137 & 0.124 & 0.068 & 0.097 & 0.113 & 0.125 & 0.513 & 1.006 \\
\hline X Ca & 0.035 & 0.039 & 0.024 & 0.011 & 0.003 & 0.015 & 0.018 & 0.012 & 0.016 & 0.015 & 0.018 & 0.023 \\
\hline $\mathrm{X} \mathrm{Na}$ & 0.739 & 0.618 & 0.586 & 0.482 & 0.515 & 0.597 & 0.587 & 0.585 & 0.607 & 0.587 & 0.695 & 0.798 \\
\hline $\mathrm{xK}$ & 0.003 & 0.005 & 0.002 & 0.004 & 0.006 & 0.013 & 0.014 & 0.014 & 0.008 & 0.006 & 0.006 & 0.006 \\
\hline $\mathrm{X}$ vac & 0.223 & 0.337 & 0.388 & 0.503 & 0.476 & 0.375 & 0.381 & 0.390 & 0.369 & 0.392 & 0.281 & 0.172 \\
\hline $\mathrm{VOH}$ & 3.000 & 3.000 & 3.000 & 3.000 & 3.000 & 3.000 & 3.000 & 3.000 & 3.000 & 3.000 & 3.000 & 3.000 \\
\hline Vo & 0.000 & 0.000 & 0.000 & 0.000 & 0.000 & 0.000 & 0.000 & 0.000 & 0.000 & 0.000 & 0.000 & 0.000 \\
\hline W F & 0.741 & 0.663 & 0.621 & 0.126 & 0.076 & 0.245 & 0.238 & 0.220 & 0.142 & 0.121 & 0.456 & 0.648 \\
\hline W Cl & 0.000 & 0.001 & 0.000 & 0.000 & 0.000 & 0.000 & 0.000 & 0.000 & 0.001 & 0.002 & 0.004 & 0.000 \\
\hline $\mathrm{WOH}$ & 0.258 & 0.336 & 0.379 & 0.874 & 0.924 & 0.754 & 0.762 & 0.780 & 0.857 & 0.877 & 0.540 & 0.352 \\
\hline wo & 0.000 & 0.000 & 0.000 & 0.000 & 0.000 & 0.000 & 0.000 & 0.000 & 0.000 & 0.000 & 0.000 & 0.000 \\
\hline Classif. & $\begin{array}{l}\text { fluor- } \\
\text { elbaite }\end{array}$ & $\begin{array}{l}\text { fluor- } \\
\text { elbaite }\end{array}$ & $\begin{array}{l}\text { fluor- } \\
\text { elbaite }\end{array}$ & foitite & schorl & schorl & schorl & schorl & schorl & schorl & schorl & $\begin{array}{l}\text { fluor- } \\
\text { elbaite }\end{array}$ \\
\hline
\end{tabular}


Appendix D.1 (contd.): Electron-microprobe analyses of tourmaline.

\begin{tabular}{|c|c|c|c|c|c|c|c|c|c|c|c|c|}
\hline Site & & & & $1-6$ & & & & & & & & \\
\hline 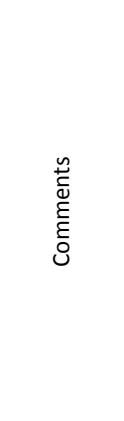 & 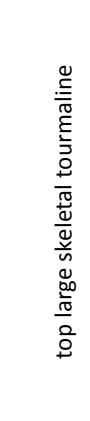 & 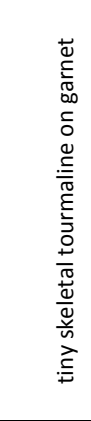 & 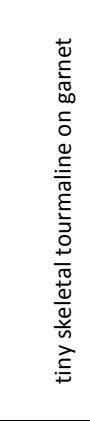 & 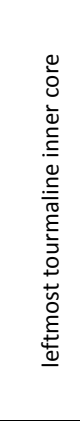 & 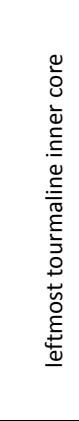 & 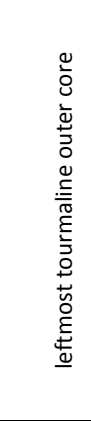 & 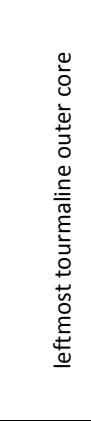 & 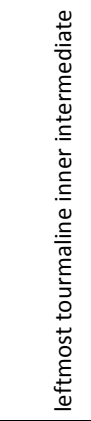 & 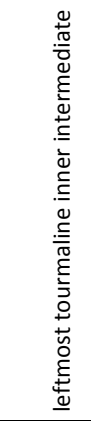 & 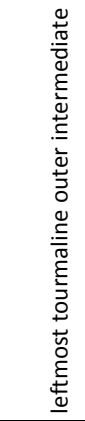 & 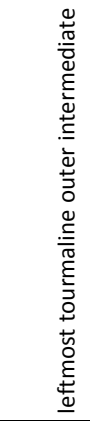 & 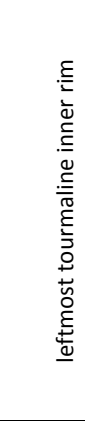 \\
\hline Point & $5 \mathrm{LI}-10$ & $5 \mathrm{LI}-12$ & $5 \mathrm{LI}-13$ & $6 \mathrm{Ll}-1$ & $6 \mathrm{LI}-2$ & $6 \mathrm{LI}-3$ & $6 \mathrm{Ll}-4$ & $6 \mathrm{LI}-5$ & $6 \mathrm{LI}-6$ & $6 \mathrm{LI}-7$ & $6 \mathrm{LI}-8$ & $6 \mathrm{LLI}-9$ \\
\hline $\mathrm{SiO}_{2}$ (wt.\%) & 37.10 & 36.68 & 37.07 & 33.69 & 34.07 & 35.73 & 35.84 & 36.77 & 36.97 & 36.82 & 36.72 & 37.05 \\
\hline $\mathrm{TiO}_{2}$ & 0.12 & 0.06 & 0.00 & 0.43 & 0.56 & 0.41 & 0.53 & 0.22 & 0.22 & 0.53 & 0.38 & 0.35 \\
\hline $\mathrm{B}_{2} \mathrm{O}_{3} *$ & 10.83 & 10.72 & 10.75 & 10.31 & 10.33 & 10.67 & 10.71 & 10.92 & 10.93 & 10.83 & 10.80 & 10.81 \\
\hline $\mathrm{Al}_{2} \mathrm{O}_{3}$ & 37.33 & 37.05 & 36.91 & 35.41 & 35.22 & 37.77 & 37.92 & 39.90 & 39.82 & 38.87 & 39.09 & 38.68 \\
\hline $\mathrm{Cr}_{2} \mathrm{O}_{3}$ & 0.00 & 0.00 & 0.02 & 0.04 & 0.01 & 0.05 & 0.03 & 0.00 & 0.04 & 0.04 & 0.00 & 0.00 \\
\hline \multicolumn{13}{|l|}{$\mathrm{Bi}_{2} \mathrm{O}_{3}$} \\
\hline $\mathrm{Fe}_{2} \mathrm{O}_{3} *$ & 0.00 & 0.00 & 0.00 & 0.00 & 0.00 & 0.00 & 0.00 & 0.00 & 0.00 & 0.00 & 0.00 & 0.00 \\
\hline $\mathrm{FeO} *$ & 4.76 & 4.45 & 5.44 & 11.72 & 11.39 & 5.29 & 5.37 & 2.46 & 2.37 & 3.03 & 3.11 & 2.94 \\
\hline $\mathrm{FeO}$ (tot) & 4.76 & 4.45 & 5.44 & 11.72 & 11.39 & 5.29 & 5.37 & 2.46 & 2.37 & 3.03 & 3.11 & 2.94 \\
\hline $\mathrm{MnO}$ & 3.12 & 3.41 & 2.84 & 1.14 & 1.12 & 1.39 & 1.34 & 1.35 & 1.20 & 0.46 & 0.37 & 0.74 \\
\hline $\mathrm{ZnO}$ & 0.00 & 0.05 & 0.04 & 0.14 & 0.07 & 0.19 & 0.24 & 0.03 & 0.03 & 0.00 & 0.00 & 0.05 \\
\hline MgO & 0.00 & 0.01 & 0.01 & 0.68 & 0.65 & 0.38 & 0.34 & 0.16 & 0.12 & 0.26 & 0.31 & 0.28 \\
\hline $\mathrm{Li}_{2} \mathrm{O}^{*}$ & 1.41 & 1.36 & 1.29 & 0.32 & 0.42 & 1.29 & 1.29 & 1.69 & 1.74 & 1.77 & 1.67 & 1.71 \\
\hline $\mathrm{CaO}$ & 0.20 & 0.23 & 0.18 & 0.09 & 0.09 & 0.13 & 0.14 & 0.37 & 0.32 & 0.28 & 0.16 & 0.22 \\
\hline $\mathrm{Na}_{2} \mathrm{O}$ & 2.72 & 2.60 & 2.41 & 2.03 & 2.00 & 2.51 & 2.47 & 2.29 & 2.31 & 2.38 & 2.19 & 2.25 \\
\hline $\mathrm{K}_{2} \mathrm{O}$ & 0.02 & 0.04 & 0.01 & 0.04 & 0.05 & 0.02 & 0.03 & 0.01 & 0.02 & 0.02 & 0.04 & 0.02 \\
\hline$F$ & 1.84 & 1.55 & 1.42 & 0.64 & 0.77 & 1.67 & 1.76 & 1.37 & 1.78 & 1.59 & 1.60 & 1.59 \\
\hline $\mathrm{Cl}$ & 0.01 & 0.00 & 0.01 & 0.00 & 0.00 & 0.00 & 0.00 & 0.00 & 0.01 & 0.01 & 0.01 & 0.00 \\
\hline $\mathrm{H}_{2} \mathrm{O}^{*}$ & 2.86 & 2.96 & 3.03 & 3.25 & 3.20 & 2.89 & 2.86 & 3.12 & 2.92 & 2.98 & 2.97 & 2.98 \\
\hline$-(\mathrm{O}=\mathrm{F}, \mathrm{Cl})$ & -0.78 & -0.65 & -0.60 & -0.27 & -0.32 & -0.70 & -0.74 & -0.58 & -0.75 & -0.67 & -0.67 & -0.67 \\
\hline Total & 101.56 & 100.54 & 100.86 & 99.67 & 99.63 & 99.67 & 100.13 & 100.09 & 100.05 & 99.21 & 98.73 & 99.00 \\
\hline T Si (apfu) & 5.952 & 5.945 & 5.992 & 5.681 & 5.730 & 5.821 & 5.814 & 5.853 & 5.881 & 5.908 & 5.912 & 5.955 \\
\hline T Al & 0.048 & 0.055 & 0.008 & 0.319 & 0.270 & 0.179 & 0.186 & 0.147 & 0.119 & 0.092 & 0.088 & 0.045 \\
\hline B & 3 & 3 & 3 & 3 & 3 & 3 & 3 & 3 & 3 & 3 & 3 & 3 \\
\hline Z Al & 6.000 & 6.000 & 6.000 & 6.000 & 6.000 & 6.000 & 6.000 & 6.000 & 6.000 & 6.000 & 6.000 & 6.000 \\
\hline$Y \mathrm{Ti}$ & 0.015 & 0.007 & 0.000 & 0.055 & 0.071 & 0.050 & 0.064 & 0.027 & 0.027 & 0.064 & 0.046 & 0.043 \\
\hline Y Al & 1.011 & 1.023 & 1.023 & 0.718 & 0.712 & 1.074 & 1.065 & 1.340 & 1.347 & 1.258 & 1.330 & 1.283 \\
\hline $\mathrm{Y} \mathrm{Cr}$ & 0.000 & 0.000 & 0.002 & 0.005 & 0.002 & 0.007 & 0.004 & 0.000 & 0.005 & 0.005 & 0.000 & 0.000 \\
\hline $\mathrm{YFe}^{3+}$ & 0.000 & 0.000 & 0.000 & 0.000 & 0.000 & 0.000 & 0.000 & 0.000 & 0.000 & 0.000 & 0.000 & 0.000 \\
\hline $\mathrm{Y} \mathrm{Fe}^{2+}$ & 0.638 & 0.604 & 0.735 & 1.653 & 1.603 & 0.720 & 0.728 & 0.327 & 0.315 & 0.407 & 0.418 & 0.395 \\
\hline Y Mn & 0.424 & 0.469 & 0.389 & 0.163 & 0.159 & 0.192 & 0.183 & 0.182 & 0.162 & 0.063 & 0.050 & 0.101 \\
\hline Y Zn & 0.000 & 0.006 & 0.005 & 0.018 & 0.009 & 0.022 & 0.029 & 0.004 & 0.004 & 0.000 & 0.000 & 0.006 \\
\hline Y Mg & 0.000 & 0.002 & 0.004 & 0.171 & 0.162 & 0.092 & 0.082 & 0.038 & 0.028 & 0.062 & 0.073 & 0.068 \\
\hline Y Li & 0.912 & 0.889 & 0.842 & 0.218 & 0.281 & 0.843 & 0.844 & 1.082 & 1.112 & 1.142 & 1.082 & 1.104 \\
\hline X Ca & 0.034 & 0.041 & 0.032 & 0.016 & 0.016 & 0.023 & 0.025 & 0.064 & 0.054 & 0.048 & 0.028 & 0.038 \\
\hline $\mathrm{X} \mathrm{Na}$ & 0.845 & 0.816 & 0.756 & 0.664 & 0.653 & 0.794 & 0.775 & 0.706 & 0.712 & 0.742 & 0.683 & 0.701 \\
\hline$x \mathrm{~K}$ & 0.005 & 0.009 & 0.003 & 0.008 & 0.010 & 0.004 & 0.007 & 0.002 & 0.004 & 0.005 & 0.009 & 0.004 \\
\hline $\mathrm{X}$ vac & 0.116 & 0.134 & 0.209 & 0.311 & 0.321 & 0.180 & 0.193 & 0.228 & 0.230 & 0.205 & 0.280 & 0.257 \\
\hline $\mathrm{VOH}$ & 3.000 & 3.000 & 3.000 & 3.000 & 3.000 & 3.000 & 3.000 & 3.000 & 3.000 & 3.000 & 3.000 & 3.000 \\
\hline Vo & 0.000 & 0.000 & 0.000 & 0.000 & 0.000 & 0.000 & 0.000 & 0.000 & 0.000 & 0.000 & 0.000 & 0.000 \\
\hline W F & 0.933 & 0.796 & 0.726 & 0.343 & 0.408 & 0.860 & 0.903 & 0.691 & 0.898 & 0.809 & 0.814 & 0.807 \\
\hline W Cl & 0.002 & 0.000 & 0.003 & 0.000 & 0.000 & 0.000 & 0.000 & 0.001 & 0.002 & 0.002 & 0.002 & 0.000 \\
\hline W OH & 0.065 & 0.204 & 0.271 & 0.656 & 0.592 & 0.140 & 0.097 & 0.309 & 0.100 & 0.188 & 0.184 & 0.193 \\
\hline wo & 0.000 & 0.000 & 0.000 & 0.000 & 0.000 & 0.000 & 0.000 & 0.000 & 0.000 & 0.000 & 0.000 & 0.000 \\
\hline Classif. & $\begin{array}{l}\text { fluor- } \\
\text { elbaite }\end{array}$ & $\begin{array}{l}\text { fluor- } \\
\text { elbaite }\end{array}$ & $\begin{array}{l}\text { fluor- } \\
\text { elbaite }\end{array}$ & schorl & schorl & $\begin{array}{l}\text { fluor- } \\
\text { elbaite }\end{array}$ & $\begin{array}{l}\text { fluor- } \\
\text { elbaite }\end{array}$ & $\begin{array}{l}\text { fluor- } \\
\text { elbaite }\end{array}$ & $\begin{array}{l}\text { fluor- } \\
\text { elbaite }\end{array}$ & $\begin{array}{l}\text { fluor- } \\
\text { elbaite }\end{array}$ & $\begin{array}{l}\text { fluor- } \\
\text { elbaite }\end{array}$ & $\begin{array}{l}\text { fluor- } \\
\text { elbaite }\end{array}$ \\
\hline
\end{tabular}


Appendix D.1 (contd.): Electron-microprobe analyses of tourmaline.

\begin{tabular}{|c|c|c|c|c|c|c|c|c|c|c|c|c|}
\hline Site & & & & & & & & & & & \multicolumn{2}{|c|}{ LI S01-7 } \\
\hline 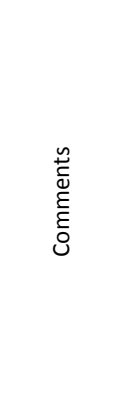 & 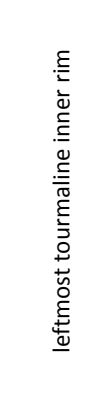 & 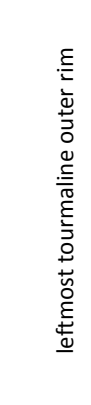 & 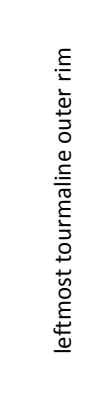 & 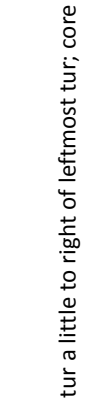 & 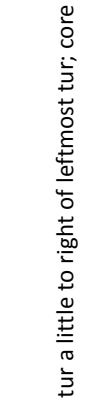 & 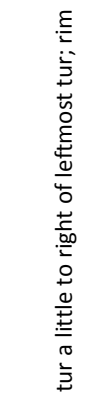 & 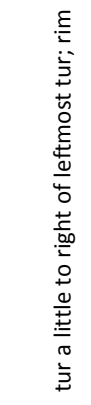 & 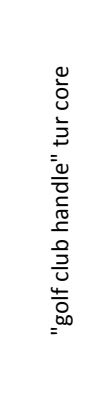 & 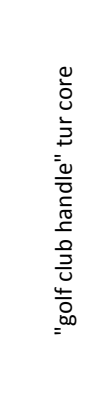 & 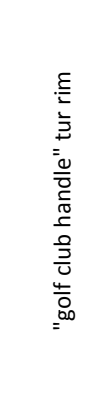 & 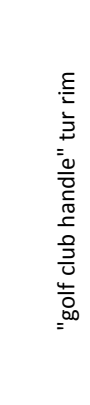 & 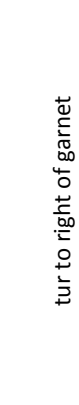 \\
\hline Point & $6 \mathrm{LI}-10$ & $6 \mathrm{LI}-11$ & $6 \mathrm{LI}-12$ & $6 \mathrm{LL}-13$ & $6 \mathrm{LI}-14$ & $6 \mathrm{LI}-15$ & $6 \mathrm{LI}-16$ & $6 \mathrm{LI}-17$ & $6 \mathrm{LI}-18$ & $6 \mathrm{LL}-19$ & $6 \mathrm{LI}-20$ & 7LI-1 \\
\hline $\mathrm{SiO}_{2}$ (wt.\%) & 37.01 & 36.70 & 36.87 & 36.65 & 36.71 & 36.95 & 37.42 & 36.29 & 36.79 & 36.72 & 37.56 & 34.87 \\
\hline $\mathrm{TiO}_{2}$ & 0.53 & 0.20 & 0.27 & 0.17 & 0.38 & 0.02 & 0.14 & 0.33 & 0.25 & 0.13 & 0.29 & 0.17 \\
\hline $\mathrm{B}_{2} \mathrm{O}_{3}{ }^{*}$ & 10.80 & 10.82 & 10.84 & 10.85 & 10.81 & 10.83 & 10.97 & 10.73 & 10.76 & 10.78 & 10.97 & 10.41 \\
\hline $\mathrm{Al}_{2} \mathrm{O}_{3}$ & 38.39 & 39.47 & 39.20 & 39.69 & 38.76 & 39.85 & 40.47 & 38.34 & 37.96 & 38.88 & 39.67 & 36.22 \\
\hline $\mathrm{Cr}_{2} \mathrm{O}_{3}$ & 0.00 & 0.03 & 0.00 & 0.00 & 0.04 & 0.01 & 0.04 & 0.00 & 0.03 & 0.00 & 0.00 & 0.00 \\
\hline \multicolumn{13}{|l|}{$\mathrm{Bi}_{2} \mathrm{O}_{3}$} \\
\hline $\mathrm{Fe}_{2} \mathrm{O}_{3}{ }^{*}$ & 0.00 & 0.00 & 0.00 & 0.00 & 0.00 & 0.00 & 0.00 & 0.00 & 0.00 & 0.00 & 0.00 & 0.00 \\
\hline $\mathrm{FeO}^{*}$ & 3.01 & 2.05 & 2.43 & 2.27 & 3.14 & 1.41 & 1.32 & 4.03 & 4.23 & 1.87 & 2.31 & 8.67 \\
\hline $\mathrm{FeO}$ (tot) & 3.01 & 2.05 & 2.43 & 2.27 & 3.14 & 1.41 & 1.32 & 4.03 & 4.23 & 1.87 & 2.31 & 8.67 \\
\hline $\mathrm{MnO}$ & 0.57 & 1.23 & 1.00 & 1.13 & 0.92 & 1.54 & 1.21 & 0.66 & 0.76 & 1.82 & 0.75 & 1.67 \\
\hline $\mathrm{ZnO}$ & 0.01 & 0.07 & 0.05 & 0.00 & 0.00 & 0.00 & 0.00 & 0.00 & 0.00 & 0.05 & 0.00 & 0.14 \\
\hline MgO & 0.31 & 0.30 & 0.34 & 0.33 & 0.39 & 0.04 & 0.09 & 0.31 & 0.28 & 0.05 & 0.32 & 0.03 \\
\hline $\mathrm{Li}_{2} \mathrm{O}^{*}$ & 1.76 & 1.67 & 1.70 & 1.68 & 1.64 & 1.74 & 1.78 & 1.61 & 1.62 & 1.78 & 1.77 & 0.83 \\
\hline $\mathrm{CaO}$ & 0.26 & 0.28 & 0.23 & 0.24 & 0.26 & 0.17 & 0.23 & 0.29 & 0.31 & 0.66 & 0.25 & 0.18 \\
\hline $\mathrm{Na}_{2} \mathrm{O}$ & 2.30 & 2.13 & 2.31 & 2.32 & 2.32 & 2.11 & 1.94 & 2.48 & 2.45 & 2.10 & 2.17 & 2.05 \\
\hline $\mathrm{K}_{2} \mathrm{O}$ & 0.02 & 0.02 & 0.02 & 0.01 & 0.02 & 0.02 & 0.01 & 0.03 & 0.02 & 0.00 & 0.01 & 0.05 \\
\hline $\mathrm{F}$ & 1.40 & 1.34 & 1.52 & 1.27 & 1.59 & 1.42 & 1.30 & 1.64 & 1.71 & 1.41 & 1.49 & 0.91 \\
\hline $\mathrm{Cl}$ & 0.00 & 0.00 & 0.00 & 0.00 & 0.00 & 0.00 & 0.00 & 0.00 & 0.00 & 0.00 & 0.00 & 0.00 \\
\hline $\mathrm{H}_{2} \mathrm{O}^{*}$ & 3.06 & 3.10 & 3.02 & 3.14 & 2.98 & 3.07 & 3.17 & 2.92 & 2.90 & 3.05 & 3.08 & 3.16 \\
\hline$-(\mathrm{O}=\mathrm{F}, \mathrm{Cl})$ & -0.59 & -0.56 & -0.64 & -0.53 & -0.67 & -0.60 & -0.55 & -0.69 & -0.72 & -0.59 & -0.63 & -0.38 \\
\hline Total & 98.83 & 98.85 & 99.16 & 99.22 & 99.27 & 98.56 & 99.55 & 98.96 & 99.36 & 98.70 & 100.03 & 98.99 \\
\hline T Si (apfu) & 5.958 & 5.896 & 5.912 & 5.871 & 5.903 & 5.930 & 5.929 & 5.880 & 5.943 & 5.923 & 5.949 & 5.822 \\
\hline TAl & 0.042 & 0.104 & 0.088 & 0.129 & 0.097 & 0.070 & 0.071 & 0.120 & 0.057 & 0.077 & 0.051 & 0.178 \\
\hline B & 3 & 3 & 3 & 3 & 3 & 3 & 3 & 3 & 3 & 3 & 3 & 3 \\
\hline $\mathrm{ZAl}$ & 6.000 & 6.000 & 6.000 & 6.000 & 6.000 & 6.000 & 6.000 & 6.000 & 6.000 & 6.000 & 6.000 & 6.000 \\
\hline $\mathrm{YTi}$ & 0.064 & 0.024 & 0.033 & 0.020 & 0.046 & 0.002 & 0.017 & 0.040 & 0.031 & 0.016 & 0.035 & 0.022 \\
\hline Y Al & 1.241 & 1.368 & 1.320 & 1.363 & 1.247 & 1.467 & 1.487 & 1.202 & 1.168 & 1.314 & 1.355 & 0.950 \\
\hline $\mathrm{Y} \mathrm{Cr}$ & 0.000 & 0.003 & 0.000 & 0.000 & 0.005 & 0.002 & 0.005 & 0.000 & 0.003 & 0.000 & 0.000 & 0.000 \\
\hline $\mathrm{YFe}^{3+}$ & 0.000 & 0.000 & 0.000 & 0.000 & 0.000 & 0.000 & 0.000 & 0.000 & 0.000 & 0.000 & 0.000 & 0.000 \\
\hline $\mathrm{Y} \mathrm{Fe}^{2+}$ & 0.405 & 0.275 & 0.326 & 0.304 & 0.422 & 0.189 & 0.175 & 0.547 & 0.572 & 0.253 & 0.306 & 1.211 \\
\hline Y Mn & 0.077 & 0.167 & 0.136 & 0.153 & 0.125 & 0.209 & 0.162 & 0.090 & 0.104 & 0.248 & 0.101 & 0.236 \\
\hline Y Zn & 0.001 & 0.008 & 0.006 & 0.000 & 0.000 & 0.000 & 0.000 & 0.000 & 0.000 & 0.006 & 0.000 & 0.017 \\
\hline Y Mg & 0.075 & 0.073 & 0.082 & 0.079 & 0.092 & 0.010 & 0.021 & 0.075 & 0.067 & 0.012 & 0.076 & 0.008 \\
\hline Y Li & 1.137 & 1.082 & 1.098 & 1.080 & 1.062 & 1.121 & 1.133 & 1.047 & 1.054 & 1.151 & 1.128 & 0.555 \\
\hline X Ca & 0.044 & 0.049 & 0.040 & 0.042 & 0.044 & 0.029 & 0.040 & 0.050 & 0.054 & 0.114 & 0.042 & 0.033 \\
\hline $\mathrm{X} \mathrm{Na}$ & 0.719 & 0.665 & 0.717 & 0.720 & 0.723 & 0.656 & 0.596 & 0.778 & 0.767 & 0.656 & 0.667 & 0.663 \\
\hline x K & 0.004 & 0.004 & 0.005 & 0.003 & 0.003 & 0.004 & 0.002 & 0.007 & 0.004 & 0.000 & 0.003 & 0.011 \\
\hline$X$ vac & 0.233 & 0.282 & 0.239 & 0.236 & 0.230 & 0.311 & 0.362 & 0.165 & 0.176 & 0.230 & 0.287 & 0.293 \\
\hline $\mathrm{VOH}$ & 3.000 & 3.000 & 3.000 & 3.000 & 3.000 & 3.000 & 3.000 & 3.000 & 3.000 & 3.000 & 3.000 & 3.000 \\
\hline Vo & 0.000 & 0.000 & 0.000 & 0.000 & 0.000 & 0.000 & 0.000 & 0.000 & 0.000 & 0.000 & 0.000 & 0.000 \\
\hline W F & 0.710 & 0.681 & 0.772 & 0.643 & 0.809 & 0.719 & 0.653 & 0.839 & 0.871 & 0.717 & 0.745 & 0.481 \\
\hline W Cl & 0.000 & 0.000 & 0.001 & 0.000 & 0.000 & 0.000 & 0.000 & 0.000 & 0.000 & 0.000 & 0.001 & 0.001 \\
\hline W OH & 0.289 & 0.319 & 0.227 & 0.357 & 0.191 & 0.281 & 0.347 & 0.161 & 0.129 & 0.283 & 0.255 & 0.518 \\
\hline Wo & 0.000 & 0.000 & 0.000 & 0.000 & 0.000 & 0.000 & 0.000 & 0.000 & 0.000 & 0.000 & 0.000 & 0.000 \\
\hline Classif. & $\begin{array}{l}\text { fluor- } \\
\text { elbaite }\end{array}$ & $\begin{array}{l}\text { fluor- } \\
\text { elbaite }\end{array}$ & $\begin{array}{l}\text { fluor- } \\
\text { elbaite }\end{array}$ & $\begin{array}{l}\text { fluor- } \\
\text { elbaite }\end{array}$ & $\begin{array}{l}\text { fluor- } \\
\text { elbaite }\end{array}$ & $\begin{array}{l}\text { fluor- } \\
\text { elbaite }\end{array}$ & $\begin{array}{l}\text { fluor- } \\
\text { elbaite }\end{array}$ & $\begin{array}{l}\text { fluor- } \\
\text { elbaite }\end{array}$ & $\begin{array}{l}\text { fluor- } \\
\text { elbaite }\end{array}$ & $\begin{array}{l}\text { fluor- } \\
\text { elbaite }\end{array}$ & $\begin{array}{l}\text { fluor- } \\
\text { elbaite }\end{array}$ & schorl \\
\hline
\end{tabular}


Appendix D.1 (contd.): Electron-microprobe analyses of tourmaline.

\begin{tabular}{|c|c|c|c|c|c|c|c|c|c|c|c|c|}
\hline \multicolumn{13}{|l|}{ Site } \\
\hline 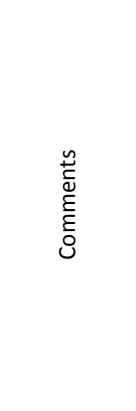 & 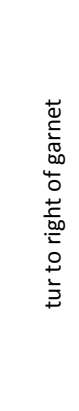 & 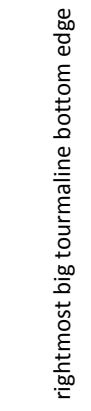 & 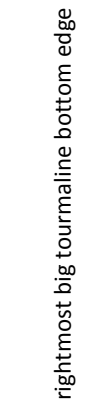 & 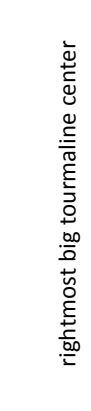 & 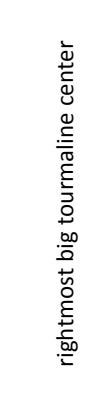 & 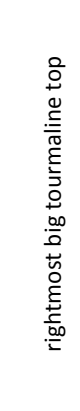 & 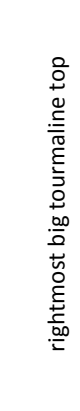 & 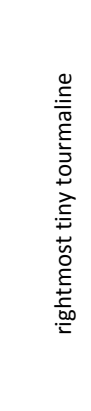 & 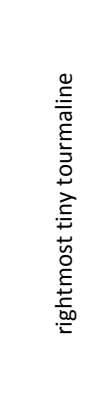 & 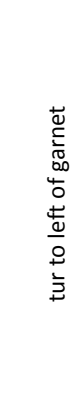 & 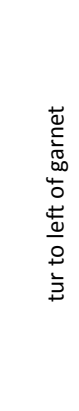 & 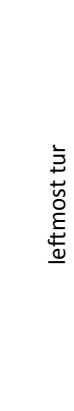 \\
\hline Point & 7니-2 & 7Ll-3 & $7 \mathrm{LI}-4$ & 7니-5 & 7니-6 & 7니-7 & 7니-8 & 7니-9 & 7니-10 & 7니-11 & 7니-12 & 7LII-13 \\
\hline $\mathrm{SiO}_{2}$ (wt.\%) & 35.06 & 36.21 & 35.93 & 35.05 & 35.09 & 34.51 & 34.46 & 35.17 & 35.57 & 34.48 & 34.89 & 34.91 \\
\hline $\mathrm{TiO}_{2}$ & 0.39 & 0.13 & 0.22 & 0.46 & 0.45 & 0.32 & 0.38 & 0.20 & 0.14 & 0.21 & 0.14 & 0.20 \\
\hline $\mathrm{B}_{2} \mathrm{O}_{3} *$ & 10.40 & 10.82 & 10.76 & 10.47 & 10.50 & 10.42 & 10.43 & 10.56 & 10.59 & 10.31 & 10.31 & 10.36 \\
\hline $\mathrm{Al}_{2} \mathrm{O}_{3}$ & 35.39 & 40.21 & 39.99 & 36.59 & 36.64 & 36.61 & 36.47 & 37.63 & 37.93 & 35.37 & 35.00 & 35.52 \\
\hline $\mathrm{Cr}_{2} \mathrm{O}_{3}$ & 0.03 & 0.04 & 0.00 & 0.02 & 0.01 & 0.00 & 0.05 & 0.00 & 0.03 & 0.00 & 0.01 & 0.02 \\
\hline \multicolumn{13}{|l|}{$\mathrm{Bi}_{2} \mathrm{O}_{3}$} \\
\hline $\mathrm{Fe}_{2} \mathrm{O}_{3}{ }^{*}$ & 0.00 & 0.00 & 0.00 & 0.00 & 0.00 & 0.00 & 0.00 & 0.00 & 0.00 & 0.00 & 0.00 & 0.00 \\
\hline $\mathrm{FeO}^{*}$ & 8.78 & 1.85 & 2.06 & 7.23 & 7.16 & 8.06 & 8.34 & 6.20 & 4.08 & 9.93 & 8.91 & 9.03 \\
\hline $\mathrm{FeO}$ (tot) & 8.78 & 1.85 & 2.06 & 7.23 & 7.16 & 8.06 & 8.34 & 6.20 & 4.08 & 9.93 & 8.91 & 9.03 \\
\hline $\mathrm{MnO}$ & 1.55 & 1.23 & 1.31 & 1.46 & 1.56 & 1.58 & 1.65 & 1.53 & 2.11 & 1.50 & 1.85 & 1.79 \\
\hline $\mathrm{ZnO}$ & 0.10 & 0.03 & 0.08 & 0.17 & 0.05 & 0.16 & 0.18 & 0.11 & 0.00 & 0.02 & 0.02 & 0.09 \\
\hline $\mathrm{MgO}$ & 0.00 & 0.00 & 0.01 & 0.06 & 0.06 & 0.06 & 0.09 & 0.06 & 0.02 & 0.01 & 0.00 & 0.01 \\
\hline $\mathrm{Li}_{2} \mathrm{O}^{*}$ & 0.98 & 1.75 & 1.66 & 1.08 & 1.13 & 0.94 & 0.89 & 1.19 & 1.44 & 0.76 & 0.92 & 0.83 \\
\hline $\mathrm{CaO}$ & 0.15 & 0.43 & 0.34 & 0.16 & 0.18 & 0.20 & 0.17 & 0.20 & 0.24 & 0.13 & 0.07 & 0.14 \\
\hline $\mathrm{Na}_{2} \mathrm{O}$ & 2.51 & 2.25 & 2.16 & 2.32 & 2.49 & 2.38 & 2.39 & 2.45 & 2.55 & 2.30 & 2.59 & 2.23 \\
\hline $\mathrm{K}_{2} \mathrm{O}$ & 0.02 & 0.01 & 0.02 & 0.03 & 0.02 & 0.02 & 0.02 & 0.02 & 0.02 & 0.03 & 0.02 & 0.02 \\
\hline $\mathrm{F}$ & 1.15 & 1.39 & 1.22 & 1.16 & 1.29 & 1.15 & 1.17 & 1.60 & 1.54 & 1.06 & 1.53 & 1.24 \\
\hline $\mathrm{Cl}$ & 0.00 & 0.00 & 0.00 & 0.00 & 0.01 & 0.00 & 0.00 & 0.00 & 0.00 & 0.01 & 0.00 & 0.00 \\
\hline $\mathrm{H}_{2} \mathrm{O}^{*}$ & 3.04 & 3.07 & 3.13 & 3.06 & 3.01 & 3.05 & 3.04 & 2.89 & 2.92 & 3.05 & 2.83 & 2.99 \\
\hline$-(\mathrm{O}=\mathrm{F}, \mathrm{Cl})$ & -0.48 & -0.59 & -0.51 & -0.49 & -0.55 & -0.48 & -0.49 & -0.67 & -0.65 & -0.45 & -0.65 & -0.52 \\
\hline Total & 99.07 & 98.86 & 98.37 & 98.84 & 99.09 & 98.98 & 99.25 & 99.14 & 98.56 & 98.73 & 98.46 & 98.85 \\
\hline T Si (apfu) & 5.858 & 5.816 & 5.807 & 5.818 & 5.810 & 5.754 & 5.745 & 5.789 & 5.837 & 5.813 & 5.881 & 5.854 \\
\hline TAl & 0.142 & 0.184 & 0.193 & 0.182 & 0.190 & 0.246 & 0.255 & 0.211 & 0.163 & 0.187 & 0.119 & 0.146 \\
\hline B & 3 & 3 & 3 & 3 & 3 & 3 & 3 & 3 & 3 & 3 & 3 & 3 \\
\hline $\mathrm{ZAl}$ & 6.000 & 6.000 & 6.000 & 6.000 & 6.000 & 6.000 & 6.000 & 6.000 & 6.000 & 6.000 & 6.000 & 6.000 \\
\hline $\mathrm{YTi}$ & 0.050 & 0.016 & 0.027 & 0.058 & 0.056 & 0.041 & 0.047 & 0.025 & 0.018 & 0.027 & 0.017 & 0.026 \\
\hline Y Al & 0.828 & 1.428 & 1.423 & 0.975 & 0.960 & 0.948 & 0.910 & 1.091 & 1.171 & 0.840 & 0.833 & 0.875 \\
\hline $\mathrm{YCr}$ & 0.004 & 0.005 & 0.000 & 0.002 & 0.002 & 0.001 & 0.006 & 0.000 & 0.004 & 0.000 & 0.001 & 0.002 \\
\hline $\mathrm{Y} \mathrm{Fe}^{3+}$ & 0.000 & 0.000 & 0.000 & 0.000 & 0.000 & 0.000 & 0.000 & 0.000 & 0.000 & 0.000 & 0.000 & 0.000 \\
\hline $\mathrm{Y} \mathrm{Fe}^{2+}$ & 1.227 & 0.249 & 0.279 & 1.003 & 0.992 & 1.124 & 1.163 & 0.854 & 0.560 & 1.400 & 1.256 & 1.267 \\
\hline Y Mn & 0.219 & 0.168 & 0.179 & 0.205 & 0.219 & 0.224 & 0.232 & 0.214 & 0.293 & 0.215 & 0.264 & 0.254 \\
\hline Y Zn & 0.012 & 0.004 & 0.009 & 0.021 & 0.006 & 0.020 & 0.023 & 0.014 & 0.000 & 0.003 & 0.003 & 0.011 \\
\hline Y Mg & 0.000 & 0.000 & 0.002 & 0.016 & 0.015 & 0.014 & 0.023 & 0.014 & 0.005 & 0.003 & 0.001 & 0.003 \\
\hline Y Li & 0.661 & 1.131 & 1.081 & 0.721 & 0.750 & 0.630 & 0.596 & 0.789 & 0.949 & 0.512 & 0.625 & 0.562 \\
\hline X Ca & 0.027 & 0.075 & 0.059 & 0.028 & 0.032 & 0.036 & 0.031 & 0.036 & 0.043 & 0.024 & 0.012 & 0.025 \\
\hline $\mathrm{XNa}$ & 0.813 & 0.700 & 0.676 & 0.747 & 0.798 & 0.770 & 0.773 & 0.783 & 0.811 & 0.752 & 0.847 & 0.726 \\
\hline x K & 0.005 & 0.002 & 0.003 & 0.007 & 0.004 & 0.004 & 0.004 & 0.004 & 0.005 & 0.007 & 0.004 & 0.004 \\
\hline$X$ vac & 0.155 & 0.223 & 0.262 & 0.218 & 0.166 & 0.190 & 0.191 & 0.177 & 0.141 & 0.217 & 0.137 & 0.245 \\
\hline $\mathrm{VOH}$ & 3.000 & 3.000 & 3.000 & 3.000 & 3.000 & 3.000 & 3.000 & 3.000 & 3.000 & 3.000 & 3.000 & 3.000 \\
\hline Vo & 0.000 & 0.000 & 0.000 & 0.000 & 0.000 & 0.000 & 0.000 & 0.000 & 0.000 & 0.000 & 0.000 & 0.000 \\
\hline W F & 0.607 & 0.707 & 0.624 & 0.610 & 0.677 & 0.606 & 0.617 & 0.831 & 0.802 & 0.566 & 0.817 & 0.659 \\
\hline W Cl & 0.000 & 0.001 & 0.000 & 0.000 & 0.001 & 0.001 & 0.000 & 0.000 & 0.000 & 0.002 & 0.000 & 0.000 \\
\hline W OH & 0.393 & 0.292 & 0.376 & 0.390 & 0.322 & 0.394 & 0.382 & 0.169 & 0.198 & 0.431 & 0.183 & 0.341 \\
\hline wo & 0.000 & 0.000 & 0.000 & 0.000 & 0.000 & 0.000 & 0.000 & 0.000 & 0.000 & 0.000 & 0.000 & 0.000 \\
\hline Classif. & $\begin{array}{l}\text { fluor- } \\
\text { schorl }\end{array}$ & $\begin{array}{l}\text { fluor- } \\
\text { elbaite }\end{array}$ & $\begin{array}{l}\text { fluor- } \\
\text { elbaite }\end{array}$ & $\begin{array}{l}\text { fluor- } \\
\text { elbaite }\end{array}$ & $\begin{array}{l}\text { fluor- } \\
\text { elbaite }\end{array}$ & $\begin{array}{l}\text { fluor- } \\
\text { schorl }\end{array}$ & $\begin{array}{l}\text { fluor- } \\
\text { schorl }\end{array}$ & $\begin{array}{l}\text { fluor- } \\
\text { elbaite }\end{array}$ & $\begin{array}{l}\text { fluor- } \\
\text { elbaite }\end{array}$ & $\begin{array}{l}\text { fluor- } \\
\text { schorl }\end{array}$ & $\begin{array}{l}\text { fluor- } \\
\text { schorl }\end{array}$ & $\begin{array}{l}\text { fluor- } \\
\text { schorl }\end{array}$ \\
\hline
\end{tabular}


Appendix D.1 (contd.): Electron-microprobe analyses of tourmaline.

\begin{tabular}{|c|c|c|c|c|c|c|c|c|c|c|c|c|}
\hline \multicolumn{5}{|l|}{ Site } & \multicolumn{3}{|c|}{ LI2-S01 } & \multicolumn{5}{|c|}{ LI2-S01 } \\
\hline 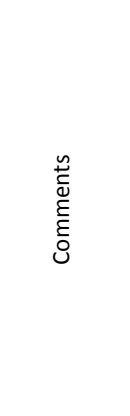 & 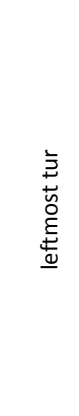 & 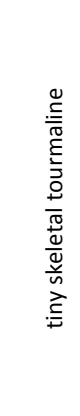 & 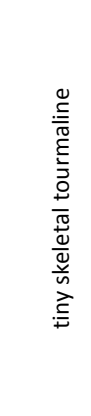 & 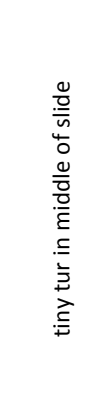 & 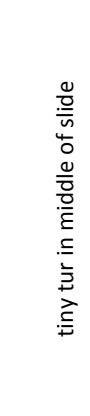 & 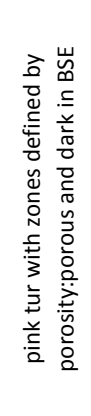 & 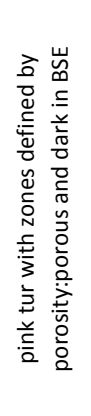 & 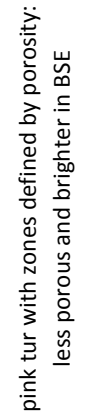 & 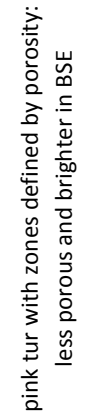 & 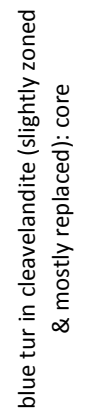 & 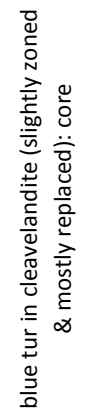 & 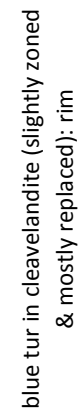 \\
\hline Point & 7LI-14 & 7LI-15 & 7LI-16 & 7LI-17 & 7LI-18 & $64 \mathrm{t}-1$ & $64 t-2$ & $64 t-3$ & $64 t-4$ & $65 \mathrm{t}-1$ & $65 \mathrm{t}-2$ & $65 t-3$ \\
\hline $\mathrm{SiO}_{2}$ (wt.\%) & 34.63 & 34.89 & 35.44 & 35.64 & 35.24 & 37.14 & 37.46 & 36.58 & 37.12 & 35.91 & 35.32 & 36.59 \\
\hline $\mathrm{TiO}_{2}$ & 0.21 & 0.29 & 0.22 & 0.06 & 0.14 & 0.00 & 0.01 & 0.00 & 0.02 & 0.00 & 0.00 & 0.00 \\
\hline $\mathrm{B}_{2} \mathrm{O}_{3}{ }^{*}$ & 10.29 & 10.36 & 10.57 & 10.49 & 10.47 & 11.18 & 11.21 & 11.01 & 11.10 & 10.71 & 10.64 & 10.91 \\
\hline $\mathrm{Al}_{2} \mathrm{O}_{3}$ & 35.23 & 35.45 & 36.53 & 36.31 & 36.70 & 43.80 & 43.67 & 42.85 & 42.76 & 39.27 & 39.28 & 41.34 \\
\hline $\mathrm{Cr}_{2} \mathrm{O}_{3}$ & 0.00 & 0.00 & 0.00 & 0.04 & 0.04 & 0.00 & 0.01 & 0.04 & 0.04 & 0.03 & 0.00 & 0.03 \\
\hline \multicolumn{13}{|l|}{$\mathrm{Bi}_{2} \mathrm{O}_{3}$} \\
\hline $\mathrm{Fe}_{2} \mathrm{O}_{3} *$ & 0.00 & 0.00 & 0.00 & 0.00 & 0.00 & 0.00 & 0.00 & 0.00 & 0.00 & 0.00 & 0.00 & 0.00 \\
\hline $\mathrm{FeO} *$ & 8.87 & 8.55 & 7.42 & 6.20 & 5.93 & 0.00 & 0.00 & 0.00 & 0.02 & 2.02 & 2.93 & 0.21 \\
\hline $\mathrm{FeO}$ (tot) & 8.87 & 8.55 & 7.42 & 6.20 & 5.93 & 0.00 & 0.00 & 0.00 & 0.02 & 2.02 & 2.93 & 0.21 \\
\hline $\mathrm{MnO}$ & 1.75 & 1.98 & 2.51 & 1.97 & 2.05 & 0.62 & 0.62 & 0.87 & 0.86 & 2.83 & 2.25 & 1.74 \\
\hline $\mathrm{ZnO}$ & 0.04 & 0.00 & 0.09 & 0.02 & 0.02 & 0.00 & 0.01 & 0.00 & 0.02 & 0.09 & 0.05 & 0.04 \\
\hline MgO & 0.04 & 0.02 & 0.03 & 0.00 & 0.00 & 0.01 & 0.02 & 0.00 & 0.00 & 0.01 & 0.00 & 0.00 \\
\hline $\mathrm{Li}_{2} \mathrm{O}^{*}$ & 0.87 & 0.91 & 1.03 & 1.29 & 1.25 & 1.78 & 1.81 & 1.79 & 1.85 & 1.50 & 1.44 & 1.77 \\
\hline $\mathrm{CaO}$ & 0.15 & 0.15 & 0.18 & 0.12 & 0.12 & 0.03 & 0.03 & 0.26 & 0.28 & 0.20 & 0.22 & 0.28 \\
\hline $\mathrm{Na}_{2} \mathrm{O}$ & 2.32 & 2.35 & 2.62 & 2.78 & 2.69 & 1.76 & 1.72 & 1.69 & 1.75 & 2.33 & 2.40 & 1.97 \\
\hline $\mathrm{K}_{2} \mathrm{O}$ & 0.04 & 0.03 & 0.04 & 0.04 & 0.02 & 0.00 & 0.01 & 0.02 & 0.01 & 0.03 & 0.02 & 0.02 \\
\hline $\mathrm{F}$ & 1.20 & 1.06 & 1.41 & 1.69 & 1.75 & 0.62 & 0.66 & 1.07 & 1.06 & 1.78 & 1.69 & 1.69 \\
\hline $\mathrm{Cl}$ & 0.00 & 0.01 & 0.00 & 0.00 & 0.00 & 0.00 & 0.00 & 0.00 & 0.01 & 0.00 & 0.00 & 0.00 \\
\hline $\mathrm{H}_{2} \mathrm{O}^{*}$ & 2.98 & 3.07 & 2.98 & 2.82 & 2.78 & 3.56 & 3.56 & 3.29 & 3.32 & 2.85 & 2.87 & 2.96 \\
\hline$-(\mathrm{O}=\mathrm{F}, \mathrm{Cl})$ & -0.50 & -0.45 & -0.60 & -0.71 & -0.74 & -0.26 & -0.28 & -0.45 & -0.45 & -0.75 & -0.71 & -0.71 \\
\hline Total & 98.09 & 98.67 & 100.47 & 98.74 & 98.47 & 100.25 & 100.50 & 99.02 & 99.77 & 98.82 & 98.38 & 98.83 \\
\hline T Si (apfu) & 5.851 & 5.853 & 5.825 & 5.903 & 5.850 & 5.774 & 5.807 & 5.774 & 5.815 & 5.827 & 5.771 & 5.830 \\
\hline T Al & 0.149 & 0.147 & 0.175 & 0.097 & 0.150 & 0.226 & 0.193 & 0.226 & 0.185 & 0.173 & 0.229 & 0.170 \\
\hline B & 3 & 3 & 3 & 3 & 3 & 3 & 3 & 3 & 3 & 3 & 3 & 3 \\
\hline $\mathrm{Z} \mathrm{Al}$ & 6.000 & 6.000 & 6.000 & 6.000 & 6.000 & 6.000 & 6.000 & 6.000 & 6.000 & 6.000 & 6.000 & 6.000 \\
\hline Y Ti & 0.026 & 0.037 & 0.027 & 0.007 & 0.017 & 0.000 & 0.001 & 0.000 & 0.002 & 0.000 & 0.000 & 0.000 \\
\hline Y Al & 0.866 & 0.862 & 0.902 & 0.993 & 1.030 & 1.800 & 1.786 & 1.745 & 1.709 & 1.339 & 1.336 & 1.594 \\
\hline Y Cr & 0.000 & 0.000 & 0.000 & 0.005 & 0.005 & 0.000 & 0.002 & 0.006 & 0.005 & 0.003 & 0.000 & 0.003 \\
\hline $\mathrm{YFe}^{3+}$ & 0.000 & 0.000 & 0.000 & 0.000 & 0.000 & 0.000 & 0.000 & 0.000 & 0.000 & 0.000 & 0.000 & 0.000 \\
\hline $\mathrm{Y} \mathrm{Fe}^{2+}$ & 1.253 & 1.200 & 1.020 & 0.859 & 0.823 & 0.001 & 0.000 & 0.000 & 0.002 & 0.274 & 0.400 & 0.028 \\
\hline Y Mn & 0.250 & 0.281 & 0.349 & 0.276 & 0.288 & 0.082 & 0.081 & 0.116 & 0.115 & 0.389 & 0.311 & 0.234 \\
\hline Y Zn & 0.004 & 0.000 & 0.011 & 0.003 & 0.003 & 0.000 & 0.001 & 0.000 & 0.002 & 0.011 & 0.006 & 0.004 \\
\hline Y Mg & 0.009 & 0.006 & 0.008 & 0.000 & 0.000 & 0.003 & 0.004 & 0.000 & 0.000 & 0.003 & 0.000 & 0.000 \\
\hline Y Li & 0.591 & 0.614 & 0.683 & 0.858 & 0.833 & 1.114 & 1.126 & 1.133 & 1.164 & 0.981 & 0.947 & 1.136 \\
\hline X Ca & 0.027 & 0.027 & 0.031 & 0.021 & 0.022 & 0.005 & 0.004 & 0.044 & 0.048 & 0.035 & 0.039 & 0.048 \\
\hline $\mathrm{X} \mathrm{Na}$ & 0.759 & 0.763 & 0.834 & 0.894 & 0.865 & 0.529 & 0.517 & 0.516 & 0.532 & 0.734 & 0.759 & 0.610 \\
\hline x K & 0.008 & 0.007 & 0.008 & 0.008 & 0.004 & 0.001 & 0.002 & 0.004 & 0.002 & 0.006 & 0.003 & 0.003 \\
\hline $\mathrm{X}$ vac & 0.206 & 0.203 & 0.128 & 0.078 & 0.108 & 0.465 & 0.476 & 0.436 & 0.418 & 0.224 & 0.199 & 0.339 \\
\hline $\mathrm{VOH}$ & 3.000 & 3.000 & 3.000 & 3.000 & 3.000 & 3.000 & 3.000 & 3.000 & 3.000 & 3.000 & 3.000 & 3.000 \\
\hline VO & 0.000 & 0.000 & 0.000 & 0.000 & 0.000 & 0.000 & 0.000 & 0.000 & 0.000 & 0.000 & 0.000 & 0.000 \\
\hline W F & 0.639 & 0.563 & 0.734 & 0.886 & 0.921 & 0.307 & 0.321 & 0.535 & 0.525 & 0.912 & 0.874 & 0.853 \\
\hline W Cl & 0.000 & 0.003 & 0.001 & 0.001 & 0.000 & 0.001 & 0.001 & 0.000 & 0.003 & 0.000 & 0.000 & 0.001 \\
\hline $\mathrm{WOH}$ & 0.361 & 0.435 & 0.265 & 0.113 & 0.079 & 0.692 & 0.678 & 0.465 & 0.472 & 0.088 & 0.126 & 0.146 \\
\hline wo & 0.000 & 0.000 & 0.000 & 0.000 & 0.000 & 0.000 & 0.000 & 0.000 & 0.000 & 0.000 & 0.000 & 0.000 \\
\hline Classif. & $\begin{array}{l}\text { fluor- } \\
\text { schorl }\end{array}$ & $\begin{array}{l}\text { fluor- } \\
\text { schorl }\end{array}$ & $\begin{array}{l}\text { fluor- } \\
\text { schorl }\end{array}$ & $\begin{array}{l}\text { fluor- } \\
\text { elbaite }\end{array}$ & $\begin{array}{l}\text { fluor- } \\
\text { elbaite }\end{array}$ & elbaite & elbaite & $\begin{array}{l}\text { fluor- } \\
\text { elbaite }\end{array}$ & $\begin{array}{l}\text { fluor- } \\
\text { elbaite }\end{array}$ & $\begin{array}{l}\text { fluor- } \\
\text { elbaite }\end{array}$ & $\begin{array}{l}\text { fluor- } \\
\text { elbaite }\end{array}$ & $\begin{array}{l}\text { fluor- } \\
\text { elbaite }\end{array}$ \\
\hline
\end{tabular}


Appendix D.1 (contd.): Electron-microprobe analyses of tourmaline.

\begin{tabular}{|c|c|c|c|c|c|c|c|c|c|c|c|c|}
\hline \multirow[b]{2}{*}{$\begin{array}{l}\text { Site } \\
\end{array}$} & \multicolumn{2}{|c|}{ LI2-S01 } & \multicolumn{6}{|c|}{ LI2-S01 } & \multirow[b]{2}{*}{ 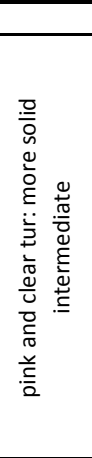 } & \multicolumn{3}{|c|}{$\mathrm{LI} 2-\mathrm{S} 02 \mathrm{~B}$} \\
\hline & 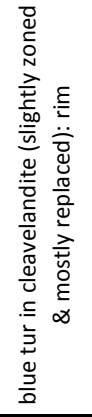 & 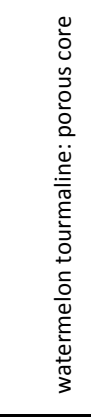 & 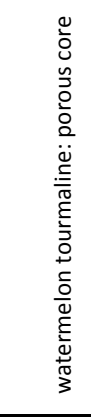 & 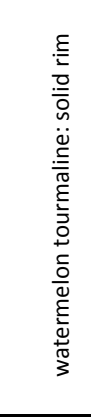 & 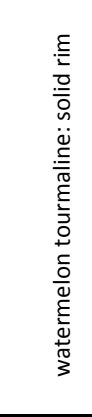 & 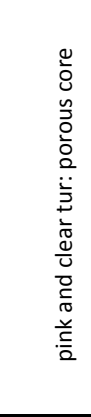 & 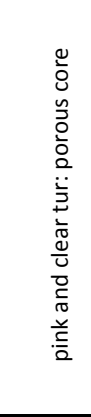 & 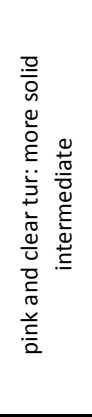 & & 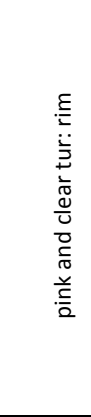 & 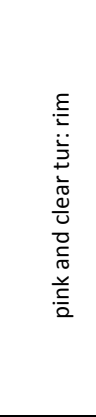 & 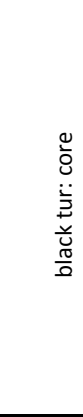 \\
\hline Point & $65 t-4$ & $66 \mathrm{t}-1$ & $66 \mathrm{t}-2$ & $66 \mathrm{t}-3$ & $66 t-4$ & $67 t-1$ & $67 t-2$ & $67 t-3$ & $67 t-4$ & $67 t-5$ & $67 t-6$ & $68 \mathrm{t}-1$ \\
\hline $\mathrm{SiO}_{2}$ (wt.\%) & 36.52 & 37.27 & 37.28 & 36.83 & 36.66 & 37.59 & 37.43 & 36.56 & 36.56 & 36.67 & 37.01 & 35.19 \\
\hline $\mathrm{TiO}_{2}$ & 0.09 & 0.00 & 0.01 & 0.08 & 0.06 & 0.00 & 0.00 & 0.04 & 0.00 & 0.04 & 0.01 & 0.59 \\
\hline $\mathrm{B}_{2} \mathrm{O}_{3} *$ & 10.84 & 11.17 & 11.16 & 10.91 & 10.91 & 11.23 & 11.25 & 10.98 & 10.98 & 11.00 & 11.00 & 10.54 \\
\hline $\mathrm{Al}_{2} \mathrm{O}_{3}$ & 40.19 & 43.59 & 43.52 & 41.13 & 41.33 & 43.98 & 44.19 & 42.46 & 42.39 & 42.39 & 41.98 & 33.90 \\
\hline $\mathrm{Cr}_{2} \mathrm{O}_{3}$ & 0.00 & 0.00 & 0.02 & 0.02 & 0.00 & 0.00 & 0.00 & 0.00 & 0.01 & 0.03 & 0.00 & 0.00 \\
\hline \multicolumn{13}{|l|}{$\mathrm{Bi}_{2} \mathrm{O}_{3}$} \\
\hline $\mathrm{Fe}_{2} \mathrm{O}_{3}^{*}$ & 0.00 & 0.00 & 0.00 & 0.00 & 0.00 & 0.00 & 0.00 & 0.00 & 0.00 & 0.00 & 0.00 & 0.00 \\
\hline $\mathrm{FeO} *$ & 0.71 & 0.02 & 0.01 & 0.84 & 0.73 & 0.02 & 0.00 & 0.01 & 0.02 & 0.03 & 0.00 & 8.11 \\
\hline $\mathrm{FeO}$ (tot) & 0.71 & 0.02 & 0.01 & 0.84 & 0.73 & 0.02 & 0.00 & 0.01 & 0.02 & 0.03 & 0.00 & 8.11 \\
\hline $\mathrm{MnO}$ & 2.29 & 0.39 & 0.39 & 1.18 & 1.15 & 0.17 & 0.16 & 1.05 & 0.94 & 1.04 & 0.95 & 0.03 \\
\hline $\mathrm{ZnO}$ & 0.01 & 0.02 & 0.01 & 0.02 & 0.01 & 0.01 & 0.06 & 0.00 & 0.04 & 0.00 & 0.00 & 0.05 \\
\hline $\mathrm{MgO}$ & 0.00 & 0.00 & 0.00 & 0.00 & 0.00 & 0.00 & 0.00 & 0.00 & 0.00 & 0.00 & 0.00 & 5.71 \\
\hline $\mathrm{Li}_{2} \mathrm{O}^{*}$ & 1.75 & 1.83 & 1.84 & 1.75 & 1.78 & 1.83 & 1.84 & 1.80 & 1.83 & 1.84 & 1.90 & 0.00 \\
\hline $\mathrm{CaO}$ & 0.34 & 0.02 & 0.04 & 0.17 & 0.13 & 0.04 & 0.02 & 0.35 & 0.44 & 0.40 & 0.39 & 0.55 \\
\hline $\mathrm{Na}_{2} \mathrm{O}$ & 2.15 & 1.79 & 1.76 & 1.89 & 2.10 & 1.57 & 1.74 & 1.68 & 1.72 & 1.77 & 1.81 & 1.81 \\
\hline $\mathrm{K}_{2} \mathrm{O}$ & 0.02 & 0.02 & 0.03 & 0.00 & 0.01 & 0.00 & 0.00 & 0.01 & 0.00 & 0.02 & 0.02 & 0.04 \\
\hline $\mathrm{F}$ & 1.47 & 0.50 & 0.75 & 1.31 & 1.32 & 0.63 & 0.47 & 1.13 & 1.42 & 1.44 & 1.29 & 0.18 \\
\hline $\mathrm{Cl}$ & 0.00 & 0.00 & 0.00 & 0.00 & 0.01 & 0.00 & 0.00 & 0.00 & 0.00 & 0.00 & 0.00 & 0.01 \\
\hline $\mathrm{H}_{2} \mathrm{O}^{*}$ & 3.04 & 3.61 & 3.50 & 3.14 & 3.14 & 3.57 & 3.66 & 3.25 & 3.12 & 3.11 & 3.18 & 3.43 \\
\hline$-(\mathrm{O}=\mathrm{F}, \mathrm{Cl})$ & -0.62 & -0.21 & -0.32 & -0.55 & -0.56 & -0.27 & -0.20 & -0.48 & -0.60 & -0.61 & -0.54 & -0.08 \\
\hline Total & 98.80 & 100.02 & 100.00 & 98.72 & 98.77 & 100.37 & 100.62 & 98.84 & 98.88 & 99.17 & 99.01 & 100.06 \\
\hline T Si (apfu) & 5.858 & 5.800 & 5.805 & 5.868 & 5.838 & 5.817 & 5.783 & 5.787 & 5.788 & 5.791 & 5.847 & 5.805 \\
\hline $\mathrm{T}$ Al & 0.142 & 0.200 & 0.195 & 0.132 & 0.162 & 0.183 & 0.217 & 0.213 & 0.212 & 0.209 & 0.153 & 0.195 \\
\hline B & 3 & 3 & 3 & 3 & 3 & 3 & 3 & 3 & 3 & 3 & 3 & 3 \\
\hline Z Al & 6.000 & 6.000 & 6.000 & 6.000 & 6.000 & 6.000 & 6.000 & 6.000 & 6.000 & 6.000 & 6.000 & 6.000 \\
\hline Y Ti & 0.011 & 0.000 & 0.001 & 0.010 & 0.008 & 0.000 & 0.000 & 0.004 & 0.000 & 0.005 & 0.001 & 0.073 \\
\hline Y Al & 1.455 & 1.797 & 1.792 & 1.591 & 1.596 & 1.838 & 1.830 & 1.710 & 1.698 & 1.683 & 1.665 & 0.394 \\
\hline $\mathrm{Y} \mathrm{Cr}$ & 0.000 & 0.001 & 0.002 & 0.003 & 0.000 & 0.000 & 0.000 & 0.000 & 0.001 & 0.003 & 0.001 & 0.000 \\
\hline $\mathrm{YFe}^{3+}$ & 0.000 & 0.000 & 0.000 & 0.000 & 0.000 & 0.000 & 0.000 & 0.000 & 0.000 & 0.000 & 0.000 & 0.000 \\
\hline $\mathrm{Y} \mathrm{Fe}^{2+}$ & 0.095 & 0.002 & 0.001 & 0.112 & 0.097 & 0.002 & 0.000 & 0.001 & 0.003 & 0.004 & 0.000 & 1.119 \\
\hline Y Mn & 0.312 & 0.052 & 0.052 & 0.160 & 0.155 & 0.023 & 0.021 & 0.141 & 0.126 & 0.139 & 0.127 & 0.004 \\
\hline Y Zn & 0.001 & 0.002 & 0.001 & 0.002 & 0.001 & 0.001 & 0.006 & 0.000 & 0.004 & 0.000 & 0.000 & 0.006 \\
\hline Y Mg & 0.000 & 0.000 & 0.000 & 0.000 & 0.000 & 0.000 & 0.000 & 0.000 & 0.000 & 0.000 & 0.000 & 1.403 \\
\hline Y Li & 1.126 & 1.146 & 1.150 & 1.123 & 1.143 & 1.136 & 1.142 & 1.144 & 1.167 & 1.167 & 1.206 & 0.000 \\
\hline $\mathrm{XCa}$ & 0.059 & 0.003 & 0.006 & 0.030 & 0.022 & 0.006 & 0.004 & 0.060 & 0.075 & 0.067 & 0.067 & 0.097 \\
\hline $\mathrm{X} \mathrm{Na}$ & 0.670 & 0.540 & 0.530 & 0.583 & 0.647 & 0.470 & 0.521 & 0.516 & 0.529 & 0.542 & 0.555 & 0.580 \\
\hline x K & 0.004 & 0.004 & 0.006 & 0.000 & 0.001 & 0.000 & 0.000 & 0.003 & 0.000 & 0.004 & 0.003 & 0.009 \\
\hline X vac & 0.267 & 0.454 & 0.458 & 0.387 & 0.329 & 0.524 & 0.475 & 0.421 & 0.396 & 0.387 & 0.375 & 0.314 \\
\hline $\mathrm{VOH}$ & 3.000 & 3.000 & 3.000 & 3.000 & 3.000 & 3.000 & 3.000 & 3.000 & 3.000 & 3.000 & 3.000 & 3.000 \\
\hline Vo & 0.000 & 0.000 & 0.000 & 0.000 & 0.000 & 0.000 & 0.000 & 0.000 & 0.000 & 0.000 & 0.000 & 0.000 \\
\hline W F & 0.744 & 0.248 & 0.368 & 0.658 & 0.665 & 0.311 & 0.231 & 0.568 & 0.709 & 0.719 & 0.647 & 0.096 \\
\hline W Cl & 0.000 & 0.000 & 0.001 & 0.000 & 0.002 & 0.000 & 0.000 & 0.000 & 0.001 & 0.000 & 0.000 & 0.003 \\
\hline $\mathrm{WOH}$ & 0.256 & 0.752 & 0.632 & 0.342 & 0.333 & 0.689 & 0.769 & 0.432 & 0.290 & 0.281 & 0.353 & 0.775 \\
\hline Wo & 0.000 & 0.000 & 0.000 & 0.000 & 0.000 & 0.000 & 0.000 & 0.000 & 0.000 & 0.000 & 0.000 & 0.127 \\
\hline Classif. & $\begin{array}{l}\text { fluor- } \\
\text { elbaite }\end{array}$ & elbaite & elbaite & $\begin{array}{l}\text { fluor- } \\
\text { elbaite }\end{array}$ & $\begin{array}{l}\text { fluor- } \\
\text { elbaite }\end{array}$ & $\begin{array}{r}\text { ssmanit } \\
\mathrm{e}\end{array}$ & elbaite & $\begin{array}{l}\text { fluor- } \\
\text { elbaite }\end{array}$ & $\begin{array}{l}\text { fluor- } \\
\text { elbaite }\end{array}$ & $\begin{array}{l}\text { fluor- } \\
\text { elbaite }\end{array}$ & $\begin{array}{l}\text { fluor- } \\
\text { elbaite }\end{array}$ & dravite \\
\hline
\end{tabular}


Appendix D.1 (contd.): Electron-microprobe analyses of tourmaline.

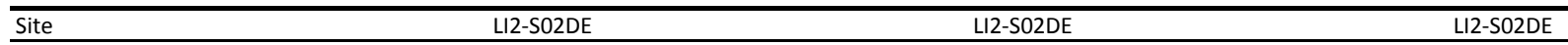

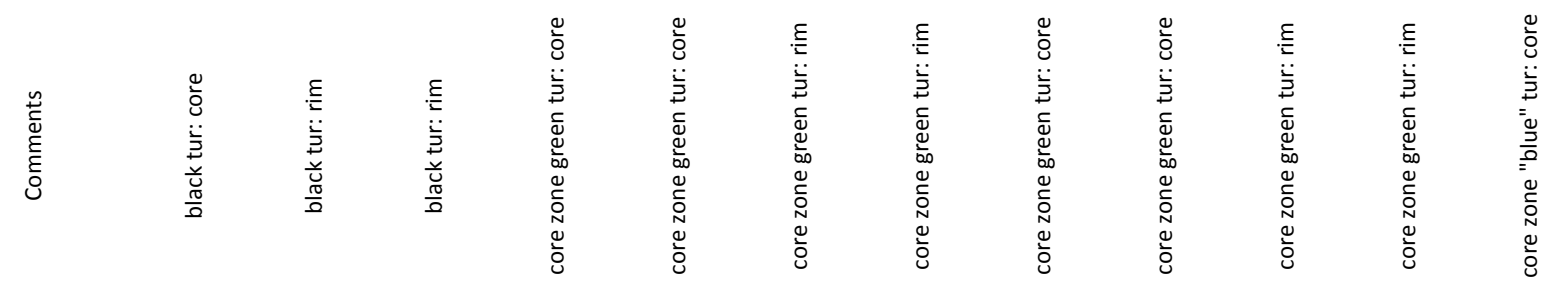

\begin{tabular}{|c|c|c|c|c|c|c|c|c|c|c|c|c|}
\hline Point & $68 \mathrm{t}-2$ & $68 \mathrm{t}-3$ & $68 \mathrm{t}-4$ & $69 t-1$ & $69 t-2$ & $69 \mathrm{t}-3$ & $69 t-4$ & 70t-1 & $70 t-2$ & $70 \mathrm{t}-3$ & 70t-4 & $71 \mathrm{t}-1$ \\
\hline $\mathrm{SiO}_{2}$ (wt.\%) & 35.75 & 34.79 & 35.10 & 37.49 & 37.52 & 37.66 & 37.06 & 37.12 & 37.27 & 37.26 & 37.17 & 35.86 \\
\hline $\mathrm{TiO}_{2}$ & 0.42 & 0.58 & 0.61 & 0.07 & 0.09 & 0.11 & 0.10 & 0.11 & 0.09 & 0.09 & 0.08 & 0.24 \\
\hline $\mathrm{B}_{2} \mathrm{O}_{3} *$ & 10.57 & 10.37 & 10.44 & 10.92 & 10.92 & 11.06 & 10.97 & 10.86 & 10.90 & 10.96 & 10.95 & 10.67 \\
\hline $\mathrm{Al}_{2} \mathrm{O}_{3}$ & 33.57 & 32.30 & 33.19 & 39.04 & 38.93 & 41.00 & 40.64 & 38.96 & 39.11 & 40.24 & 40.25 & 37.11 \\
\hline $\mathrm{Cr}_{2} \mathrm{O}_{3}$ & 0.04 & 0.09 & 0.00 & 0.00 & 0.01 & 0.00 & 0.01 & 0.00 & 0.00 & 0.02 & 0.00 & 0.00 \\
\hline $\mathrm{Bi}_{2} \mathrm{O}_{3}$ & & & & 0.78 & 0.75 & 0.43 & 0.40 & 0.96 & 0.95 & 0.37 & 0.31 & 0.01 \\
\hline $\mathrm{Fe}_{2} \mathrm{O}_{3}{ }^{*}$ & 0.00 & 0.33 & 0.00 & 0.00 & 0.00 & 0.00 & 0.00 & 0.00 & 0.00 & 0.00 & 0.00 & 0.00 \\
\hline $\mathrm{FeO}^{*}$ & 8.12 & 9.86 & 7.92 & 1.61 & 1.57 & 0.90 & 1.31 & 2.00 & 1.89 & 1.55 & 1.36 & 7.19 \\
\hline $\mathrm{FeO}$ (tot) & 8.12 & 10.16 & 7.92 & 1.61 & 1.57 & 0.90 & 1.31 & 2.00 & 1.89 & 1.55 & 1.36 & 7.19 \\
\hline $\mathrm{MnO}$ & 0.03 & 0.19 & 0.03 & 2.52 & 2.57 & 1.21 & 1.77 & 1.71 & 1.84 & 1.75 & 1.96 & 1.19 \\
\hline $\mathrm{ZnO}$ & 0.12 & 0.00 & 0.09 & 0.10 & 0.06 & 0.09 & 0.10 & 0.11 & 0.09 & 0.11 & 0.08 & 0.83 \\
\hline MgO & 5.82 & 5.01 & 5.84 & 0.00 & 0.00 & 0.00 & 0.00 & 0.00 & 0.01 & 0.00 & 0.01 & 0.06 \\
\hline $\mathrm{Li}_{2} \mathrm{O}^{*}$ & 0.00 & 0.00 & 0.00 & 1.78 & 1.80 & 1.87 & 1.74 & 1.84 & 1.84 & 1.74 & 1.73 & 1.14 \\
\hline $\mathrm{CaO}$ & 0.46 & 0.21 & 0.55 & 0.17 & 0.18 & 0.14 & 0.14 & 0.34 & 0.24 & 0.12 & 0.09 & 0.13 \\
\hline $\mathrm{Na}_{2} \mathrm{O}$ & 1.87 & 2.05 & 1.92 & 2.41 & 2.47 & 2.08 & 2.21 & 2.35 & 2.44 & 2.19 & 2.23 & 2.61 \\
\hline $\mathrm{K}_{2} \mathrm{O}$ & 0.05 & 0.06 & 0.06 & 0.02 & 0.02 & 0.01 & 0.01 & 0.02 & 0.03 & 0.02 & 0.03 & 0.03 \\
\hline $\mathrm{F}$ & 0.27 & 0.36 & 0.23 & 1.48 & 1.52 & 1.06 & 1.06 & 1.37 & 1.28 & 1.20 & 1.07 & 1.17 \\
\hline $\mathrm{Cl}$ & 0.00 & 0.00 & 0.00 & 0.00 & 0.00 & 0.00 & 0.01 & 0.00 & 0.00 & 0.00 & 0.00 & 0.00 \\
\hline $\mathrm{H}_{2} \mathrm{O}^{*}$ & 3.39 & 3.41 & 3.33 & 3.04 & 3.02 & 3.30 & 3.27 & 3.06 & 3.12 & 3.20 & 3.26 & 3.13 \\
\hline$-(\mathrm{O}=\mathrm{F}, \mathrm{Cl})$ & -0.11 & -0.15 & -0.10 & -0.62 & -0.64 & -0.45 & -0.45 & -0.58 & -0.54 & -0.51 & -0.45 & -0.49 \\
\hline Total & 100.37 & 99.46 & 99.21 & 100.81 & 100.79 & 100.46 & 100.35 & 100.24 & 100.56 & 100.31 & 100.12 & 100.87 \\
\hline T Si (apfu) & 5.877 & 5.832 & 5.843 & 5.966 & 5.971 & 5.920 & 5.869 & 5.941 & 5.944 & 5.908 & 5.901 & 5.842 \\
\hline T Al & 0.123 & 0.168 & 0.157 & 0.034 & 0.029 & 0.080 & 0.131 & 0.059 & 0.056 & 0.092 & 0.099 & 0.158 \\
\hline B & 3 & 3 & 3 & 3 & 3 & 3 & 3 & 3 & 3 & 3 & 3 & 3 \\
\hline $\mathrm{ZAl}$ & 6.000 & 6.000 & 6.000 & 6.000 & 6.000 & 6.000 & 6.000 & 6.000 & 6.000 & 6.000 & 6.000 & 6.000 \\
\hline Y Ti & 0.052 & 0.074 & 0.077 & 0.008 & 0.011 & 0.013 & 0.012 & 0.013 & 0.011 & 0.011 & 0.010 & 0.029 \\
\hline Y Al & 0.383 & 0.213 & 0.356 & 1.287 & 1.272 & 1.516 & 1.455 & 1.289 & 1.295 & 1.427 & 1.433 & 0.967 \\
\hline $\mathrm{Y} \mathrm{Cr}$ & 0.005 & 0.011 & 0.000 & 0.000 & 0.001 & 0.000 & 0.001 & 0.000 & 0.000 & 0.003 & 0.000 & 0.000 \\
\hline $\mathrm{YFe}^{3+}$ & 0.000 & 0.042 & 0.000 & 0.000 & 0.000 & 0.000 & 0.000 & 0.000 & 0.000 & 0.000 & 0.000 & 0.000 \\
\hline $\mathrm{Y} \mathrm{Fe}^{2+}$ & 1.117 & 1.382 & 1.102 & 0.214 & 0.209 & 0.118 & 0.174 & 0.268 & 0.252 & 0.206 & 0.181 & 0.980 \\
\hline Y Mn & 0.004 & 0.027 & 0.004 & 0.340 & 0.346 & 0.161 & 0.237 & 0.232 & 0.249 & 0.235 & 0.264 & 0.164 \\
\hline$Y Z n$ & 0.015 & 0.000 & 0.011 & 0.012 & 0.007 & 0.010 & 0.012 & 0.013 & 0.011 & 0.013 & 0.009 & 0.100 \\
\hline Y Mg & 1.425 & 1.251 & 1.450 & 0.000 & 0.000 & 0.000 & 0.000 & 0.000 & 0.002 & 0.000 & 0.002 & 0.015 \\
\hline Y Li & 0.000 & 0.000 & 0.000 & 1.139 & 1.154 & 1.181 & 1.110 & 1.185 & 1.181 & 1.107 & 1.102 & 0.745 \\
\hline X Ca & 0.082 & 0.038 & 0.099 & 0.029 & 0.031 & 0.024 & 0.024 & 0.058 & 0.041 & 0.020 & 0.015 & 0.023 \\
\hline $\mathrm{XNa}$ & 0.595 & 0.667 & 0.621 & 0.744 & 0.762 & 0.634 & 0.679 & 0.729 & 0.754 & 0.673 & 0.686 & 0.824 \\
\hline x K & 0.010 & 0.012 & 0.012 & 0.004 & 0.004 & 0.002 & 0.002 & 0.004 & 0.006 & 0.004 & 0.006 & 0.006 \\
\hline$X$ vac & 0.313 & 0.283 & 0.268 & 0.223 & 0.203 & 0.340 & 0.296 & 0.208 & 0.198 & 0.302 & 0.292 & 0.147 \\
\hline $\mathrm{VOH}$ & 3.000 & 3.000 & 3.000 & 3.000 & 3.000 & 3.000 & 3.000 & 3.000 & 3.000 & 3.000 & 3.000 & 3.000 \\
\hline Vo & 0.000 & 0.000 & 0.000 & 0.000 & 0.000 & 0.000 & 0.000 & 0.000 & 0.000 & 0.000 & 0.000 & 0.000 \\
\hline W F & 0.140 & 0.192 & 0.119 & 0.745 & 0.765 & 0.527 & 0.531 & 0.693 & 0.646 & 0.602 & 0.537 & 0.603 \\
\hline W Cl & 0.000 & 0.001 & 0.000 & 0.000 & 0.000 & 0.000 & 0.003 & 0.000 & 0.000 & 0.000 & 0.000 & 0.000 \\
\hline W OH & 0.723 & 0.808 & 0.698 & 0.223 & 0.204 & 0.456 & 0.450 & 0.267 & 0.315 & 0.383 & 0.450 & 0.397 \\
\hline wo & 0.137 & 0.000 & 0.183 & 0.032 & 0.031 & 0.017 & 0.016 & 0.040 & 0.039 & 0.015 & 0.013 & 0.000 \\
\hline Classif. & dravite & schorl & dravite & $\begin{array}{l}\text { fluor- } \\
\text { elbaite }\end{array}$ & $\begin{array}{l}\text { fluor- } \\
\text { elbaite }\end{array}$ & $\begin{array}{l}\text { fluor- } \\
\text { elbaite }\end{array}$ & $\begin{array}{l}\text { fluor- } \\
\text { elbaite }\end{array}$ & $\begin{array}{l}\text { fluor- } \\
\text { elbaite }\end{array}$ & $\begin{array}{l}\text { fluor- } \\
\text { elbaite }\end{array}$ & $\begin{array}{l}\text { fluor- } \\
\text { elbaite }\end{array}$ & $\begin{array}{l}\text { fluor- } \\
\text { elbaite }\end{array}$ & $\begin{array}{l}\text { fluor- } \\
\text { elbaite }\end{array}$ \\
\hline
\end{tabular}


Appendix D.1 (contd.): Electron-microprobe analyses of tourmaline.

\begin{tabular}{|c|c|c|c|c|c|c|c|c|c|c|c|c|}
\hline Site & & & & & & SO2DE & & SO2DE & & & & \\
\hline 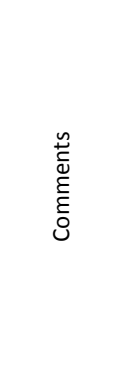 & 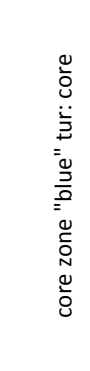 & 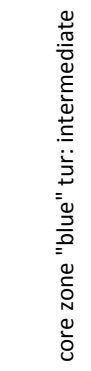 & 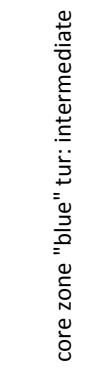 & 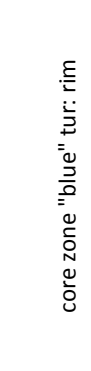 & 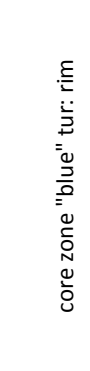 & 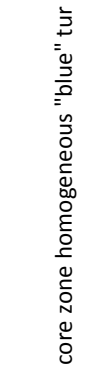 & 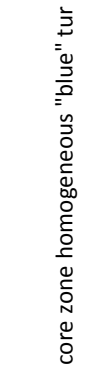 & 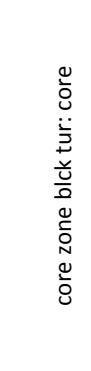 & 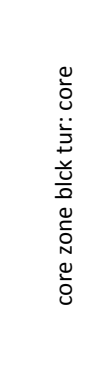 & 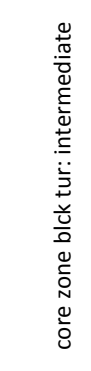 & 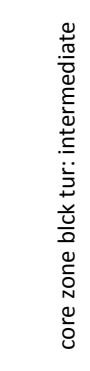 & 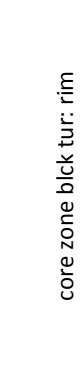 \\
\hline Point & $71 t-2$ & $71 t-3$ & $71 \mathrm{t}-4$ & $71 \mathrm{t}-5$ & $71 \mathrm{t}-6$ & $72 \mathrm{t}-1$ & $72 t-2$ & $73 t-1$ & $73 t-2$ & $73 t-3$ & $73 t-4$ & $73 t-5$ \\
\hline $\mathrm{SiO}_{2}$ (wt.\%) & 36.22 & 36.64 & 36.54 & 37.93 & 37.68 & 36.26 & 35.89 & 34.81 & 34.63 & 36.40 & 36.40 & 36.00 \\
\hline $\mathrm{TiO}_{2}$ & 0.26 & 0.32 & 0.38 & 0.07 & 0.06 & 0.24 & 0.26 & 0.45 & 0.46 & 0.37 & 0.39 & 0.32 \\
\hline $\mathrm{B}_{2} \mathrm{O}_{3}{ }^{*}$ & 10.70 & 10.80 & 10.80 & 11.07 & 11.05 & 10.76 & 10.71 & 10.32 & 10.30 & 10.69 & 10.68 & 10.70 \\
\hline $\mathrm{Al}_{2} \mathrm{O}_{3}$ & 36.84 & 37.70 & 37.69 & 40.49 & 40.87 & 37.81 & 37.68 & 33.27 & 33.25 & 36.27 & 36.18 & 37.16 \\
\hline $\mathrm{Cr}_{2} \mathrm{O}_{3}$ & 0.00 & 0.00 & 0.00 & 0.00 & 0.00 & 0.00 & 0.00 & 0.00 & 0.00 & 0.00 & 0.01 & 0.01 \\
\hline $\mathrm{Bi}_{2} \mathrm{O}_{3}$ & 0.02 & 0.00 & 0.00 & 0.45 & 0.57 & 0.00 & 0.00 & 0.04 & 0.02 & 0.02 & 0.02 & 0.02 \\
\hline $\mathrm{Fe}_{2} \mathrm{O}_{3} *$ & 0.00 & 0.00 & 0.00 & 0.00 & 0.00 & 0.00 & 0.00 & 0.00 & 0.00 & 0.00 & 0.00 & 0.00 \\
\hline $\mathrm{FeO} *$ & 7.73 & 5.09 & 5.55 & 1.26 & 0.79 & 6.27 & 6.57 & 14.26 & 14.55 & 7.70 & 7.69 & 6.58 \\
\hline $\mathrm{FeO}$ (tot) & 7.73 & 5.09 & 5.55 & 1.26 & 0.79 & 6.27 & 6.57 & 14.26 & 14.55 & 7.70 & 7.69 & 6.58 \\
\hline $\mathrm{MnO}$ & 1.14 & 1.49 & 1.50 & 1.09 & 1.06 & 1.03 & 1.03 & 0.71 & 0.86 & 0.82 & 0.72 & 1.51 \\
\hline $\mathrm{ZnO}$ & 0.70 & 0.42 & 0.50 & 0.10 & 0.03 & 0.69 & 0.60 & 0.09 & 0.05 & 0.09 & 0.07 & 0.26 \\
\hline $\mathrm{MgO}$ & 0.07 & 0.06 & 0.07 & 0.01 & 0.00 & 0.08 & 0.09 & 0.82 & 0.83 & 0.49 & 0.48 & 0.16 \\
\hline $\mathrm{Li}_{2} \mathrm{O}^{*}$ & 1.10 & 1.48 & 1.39 & 1.92 & 1.96 & 1.28 & 1.24 & 0.21 & 0.15 & 1.21 & 1.25 & 1.26 \\
\hline $\mathrm{CaO}$ & 0.11 & 0.22 & 0.21 & 0.31 & 0.41 & 0.13 & 0.13 & 0.07 & 0.09 & 0.09 & 0.10 & 0.17 \\
\hline $\mathrm{Na}_{2} \mathrm{O}$ & 2.49 & 2.71 & 2.65 & 2.12 & 1.97 & 2.57 & 2.63 & 1.99 & 1.97 & 2.74 & 2.80 & 2.72 \\
\hline $\mathrm{K}_{2} \mathrm{O}$ & 0.03 & 0.04 & 0.03 & 0.01 & 0.02 & 0.06 & 0.05 & 0.08 & 0.06 & 0.06 & 0.04 & 0.08 \\
\hline$F$ & 0.95 & 1.56 & 1.46 & 1.47 & 1.19 & 1.15 & 1.11 & 0.31 & 0.30 & 1.22 & 1.17 & 1.46 \\
\hline $\mathrm{Cl}$ & 0.00 & 0.00 & 0.00 & 0.00 & 0.00 & 0.01 & 0.01 & 0.03 & 0.00 & 0.00 & 0.02 & 0.02 \\
\hline $\mathrm{H}_{2} \mathrm{O}^{*}$ & 3.24 & 2.99 & 3.04 & 3.10 & 3.23 & 3.17 & 3.17 & 3.40 & 3.41 & 3.11 & 3.12 & 2.99 \\
\hline$-(\mathrm{O}=\mathrm{F}, \mathrm{Cl})$ & -0.40 & -0.66 & -0.61 & -0.62 & -0.50 & -0.49 & -0.47 & -0.14 & -0.13 & -0.51 & -0.50 & -0.62 \\
\hline Total & 101.20 & 100.85 & 101.20 & 100.78 & 100.38 & 101.02 & 100.69 & 100.73 & 100.81 & 100.76 & 100.64 & 100.81 \\
\hline T Si (apfu) & 5.885 & 5.898 & 5.879 & 5.957 & 5.928 & 5.856 & 5.826 & 5.864 & 5.841 & 5.920 & 5.925 & 5.848 \\
\hline T Al & 0.115 & 0.102 & 0.121 & 0.043 & 0.072 & 0.144 & 0.174 & 0.136 & 0.159 & 0.080 & 0.075 & 0.152 \\
\hline B & 3 & 3 & 3 & 3 & 3 & 3 & 3 & 3 & 3 & 3 & 3 & 3 \\
\hline $\mathrm{ZAl}$ & 6.000 & 6.000 & 6.000 & 6.000 & 6.000 & 6.000 & 6.000 & 6.000 & 6.000 & 6.000 & 6.000 & 6.000 \\
\hline$Y \mathrm{Ti}$ & 0.032 & 0.039 & 0.046 & 0.008 & 0.007 & 0.029 & 0.032 & 0.057 & 0.058 & 0.045 & 0.048 & 0.039 \\
\hline Y Al & 0.940 & 1.051 & 1.025 & 1.452 & 1.506 & 1.053 & 1.034 & 0.470 & 0.451 & 0.872 & 0.865 & 0.963 \\
\hline $\mathrm{YCr}$ & 0.000 & 0.000 & 0.000 & 0.000 & 0.000 & 0.000 & 0.000 & 0.000 & 0.000 & 0.000 & 0.001 & 0.001 \\
\hline $\mathrm{YFe}^{3+}$ & 0.000 & 0.000 & 0.000 & 0.000 & 0.000 & 0.000 & 0.000 & 0.000 & 0.000 & 0.000 & 0.000 & 0.000 \\
\hline $\mathrm{Y} \mathrm{Fe}^{2+}$ & 1.050 & 0.685 & 0.747 & 0.166 & 0.104 & 0.847 & 0.892 & 2.009 & 2.052 & 1.047 & 1.047 & 0.894 \\
\hline Y Mn & 0.157 & 0.203 & 0.204 & 0.145 & 0.141 & 0.141 & 0.142 & 0.101 & 0.123 & 0.113 & 0.099 & 0.208 \\
\hline Y Zn & 0.084 & 0.050 & 0.059 & 0.012 & 0.003 & 0.082 & 0.072 & 0.011 & 0.006 & 0.011 & 0.008 & 0.031 \\
\hline Y Mg & 0.017 & 0.014 & 0.017 & 0.002 & 0.000 & 0.019 & 0.022 & 0.206 & 0.209 & 0.119 & 0.116 & 0.039 \\
\hline Y Li & 0.720 & 0.957 & 0.901 & 1.215 & 1.238 & 0.829 & 0.807 & 0.145 & 0.100 & 0.792 & 0.815 & 0.825 \\
\hline X Ca & 0.019 & 0.038 & 0.036 & 0.052 & 0.069 & 0.022 & 0.023 & 0.013 & 0.016 & 0.016 & 0.017 & 0.030 \\
\hline $\mathrm{X} \mathrm{Na}$ & 0.784 & 0.846 & 0.827 & 0.646 & 0.601 & 0.805 & 0.828 & 0.650 & 0.644 & 0.864 & 0.884 & 0.857 \\
\hline$x \mathrm{~K}$ & 0.006 & 0.008 & 0.006 & 0.002 & 0.004 & 0.012 & 0.010 & 0.017 & 0.013 & 0.012 & 0.008 & 0.017 \\
\hline $\mathrm{X}$ vac & 0.190 & 0.108 & 0.131 & 0.300 & 0.326 & 0.160 & 0.139 & 0.320 & 0.327 & 0.108 & 0.091 & 0.097 \\
\hline $\mathrm{VOH}$ & 3.000 & 3.000 & 3.000 & 3.000 & 3.000 & 3.000 & 3.000 & 3.000 & 3.000 & 3.000 & 3.000 & 3.000 \\
\hline Vo & 0.000 & 0.000 & 0.000 & 0.000 & 0.000 & 0.000 & 0.000 & 0.000 & 0.000 & 0.000 & 0.000 & 0.000 \\
\hline W F & 0.488 & 0.794 & 0.743 & 0.730 & 0.592 & 0.587 & 0.570 & 0.165 & 0.160 & 0.628 & 0.602 & 0.750 \\
\hline W Cl & 0.000 & 0.000 & 0.000 & 0.000 & 0.000 & 0.003 & 0.003 & 0.009 & 0.000 & 0.000 & 0.006 & 0.006 \\
\hline $\mathrm{WOH}$ & 0.511 & 0.206 & 0.257 & 0.252 & 0.385 & 0.410 & 0.427 & 0.825 & 0.839 & 0.372 & 0.391 & 0.244 \\
\hline wo & 0.001 & 0.000 & 0.000 & 0.018 & 0.023 & 0.000 & 0.000 & 0.002 & 0.001 & 0.001 & 0.001 & 0.001 \\
\hline Classif. & elbaite & $\begin{array}{l}\text { fluor- } \\
\text { elbaite }\end{array}$ & $\begin{array}{l}\text { fluor- } \\
\text { elbaite }\end{array}$ & $\begin{array}{l}\text { fluor- } \\
\text { elbaite }\end{array}$ & $\begin{array}{l}\text { fluor- } \\
\text { elbaite }\end{array}$ & $\begin{array}{l}\text { fluor- } \\
\text { elbaite }\end{array}$ & $\begin{array}{l}\text { fluor- } \\
\text { elbaite }\end{array}$ & schorl & schorl & $\begin{array}{l}\text { fluor- } \\
\text { elbaite }\end{array}$ & $\begin{array}{l}\text { fluor- } \\
\text { elbaite }\end{array}$ & $\begin{array}{l}\text { fluor- } \\
\text { elbaite }\end{array}$ \\
\hline
\end{tabular}


Appendix D.1 (contd.): Electron-microprobe analyses of tourmaline.

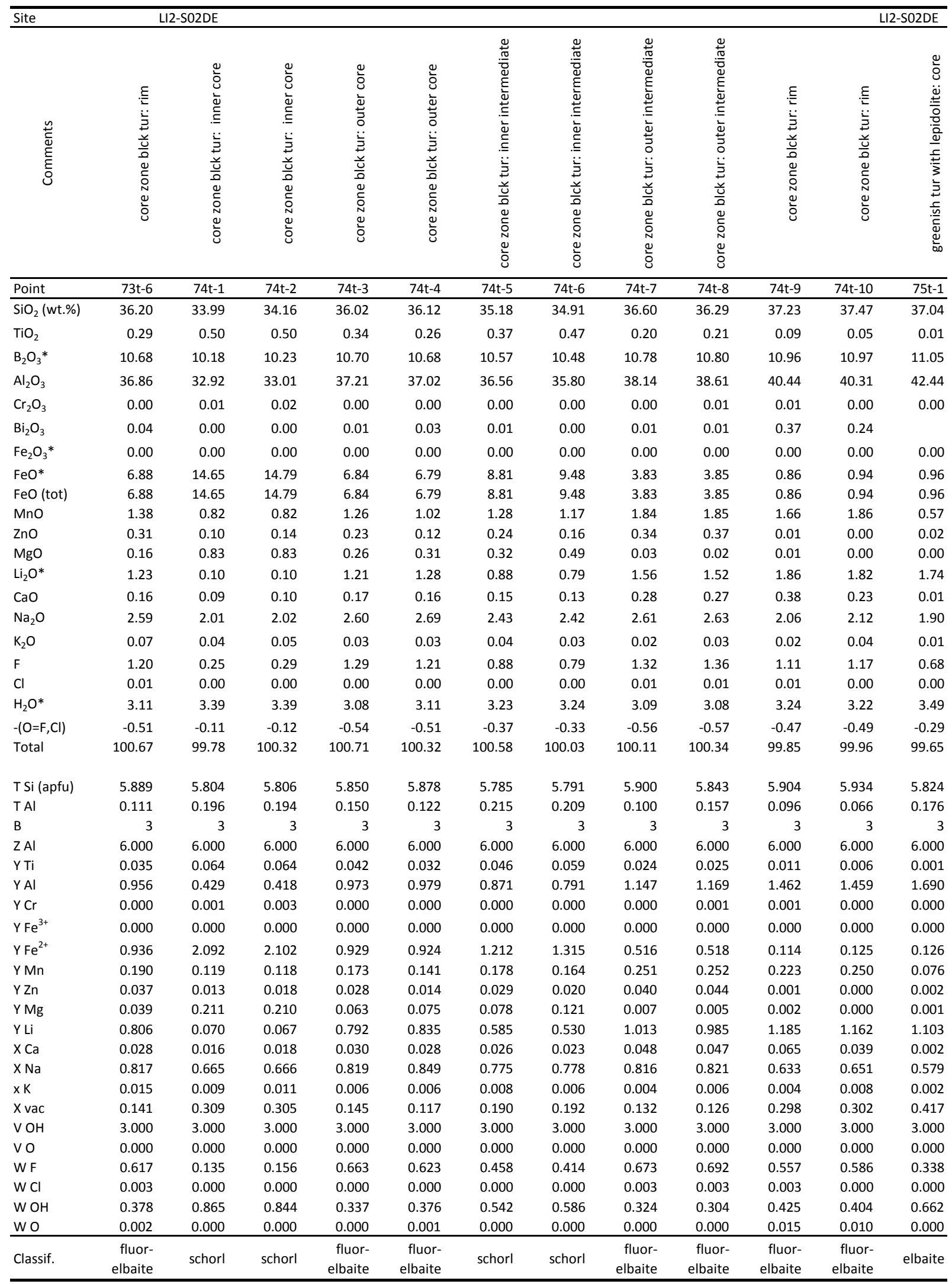


Appendix D.1 (contd.): Electron-microprobe analyses of tourmaline.

\begin{tabular}{|c|c|c|c|c|c|c|c|c|c|c|c|c|}
\hline \multicolumn{5}{|l|}{ Site } & \multicolumn{2}{|c|}{ LI2-S03 } & \multicolumn{2}{|c|}{ LONG-S01 } & \multicolumn{3}{|c|}{ LONG-S01 } & \multirow[b]{2}{*}{ 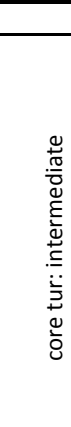 } \\
\hline 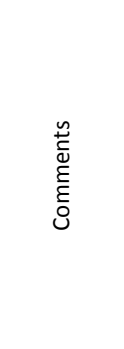 & 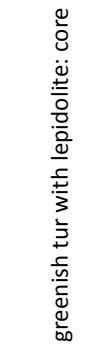 & 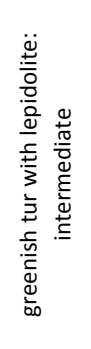 & 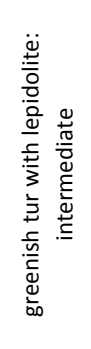 & 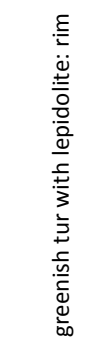 & 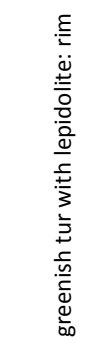 & 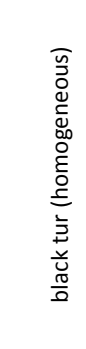 & 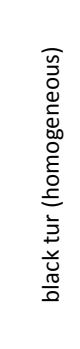 & 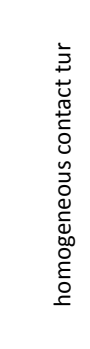 & 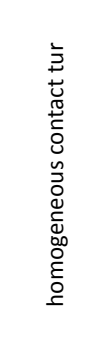 & 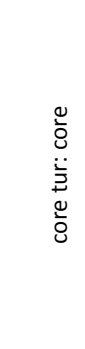 & 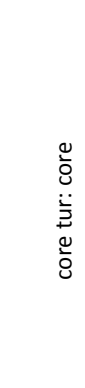 & \\
\hline Point & $75 t-2$ & $75 t-3$ & $75 t-4$ & $75 t-5$ & $75 t-6$ & $76 t-1$ & $76 \mathrm{t}-2$ & $7 \mathrm{t}-1$ & $7 \mathrm{t}-2$ & $8 \mathrm{t}-1$ & $8 \mathrm{t}-2$ & $8 t-3$ \\
\hline $\mathrm{SiO}_{2}$ (wt.\%) & 37.16 & 36.58 & 36.42 & 36.71 & 36.72 & 34.60 & 34.74 & 34.33 & 34.21 & 34.65 & 33.93 & 33.77 \\
\hline $\mathrm{TiO}_{2}$ & 0.08 & 0.00 & 0.11 & 0.08 & 0.04 & 0.46 & 0.70 & 0.49 & 0.40 & 0.41 & 0.56 & 0.60 \\
\hline $\mathrm{B}_{2} \mathrm{O}_{3}{ }^{*}$ & 11.04 & 10.85 & 10.83 & 10.89 & 10.88 & 10.34 & 10.34 & 10.47 & 10.40 & 10.42 & 10.41 & 10.28 \\
\hline $\mathrm{Al}_{2} \mathrm{O}_{3}$ & 42.04 & 40.38 & 40.49 & 40.58 & 40.67 & 33.15 & 33.12 & 34.09 & 33.95 & 33.40 & 33.78 & 33.67 \\
\hline $\mathrm{Cr}_{2} \mathrm{O}_{3}$ & 0.01 & 0.00 & 0.00 & 0.00 & 0.00 & 0.02 & 0.07 & 0.03 & 0.00 & 0.01 & 0.04 & 0.01 \\
\hline \multicolumn{13}{|l|}{$\mathrm{Bi}_{2} \mathrm{O}_{3}$} \\
\hline $\mathrm{Fe}_{2} \mathrm{O}_{3} *$ & 0.00 & 0.00 & 0.00 & 0.00 & 0.00 & 0.00 & 0.00 & 0.00 & 0.00 & 0.00 & 0.00 & 0.00 \\
\hline $\mathrm{FeO} *$ & 0.88 & 1.88 & 1.89 & 1.23 & 1.08 & 12.30 & 11.99 & 8.00 & 8.17 & 8.30 & 8.01 & 10.55 \\
\hline $\mathrm{FeO}$ (tot) & 0.88 & 1.88 & 1.89 & 1.23 & 1.08 & 12.30 & 11.99 & 8.00 & 8.17 & 8.30 & 8.01 & 10.55 \\
\hline $\mathrm{MnO}$ & 0.48 & 1.31 & 1.14 & 1.51 & 1.50 & 0.19 & 0.24 & 0.02 & 0.09 & 0.05 & 0.05 & 0.15 \\
\hline $\mathrm{ZnO}$ & 0.03 & 0.15 & 0.14 & 0.03 & 0.02 & 0.01 & 0.04 & 0.07 & 0.00 & 0.00 & 0.03 & 0.05 \\
\hline MgO & 0.00 & 0.02 & 0.01 & 0.00 & 0.01 & 3.18 & 3.08 & 5.86 & 5.58 & 5.80 & 5.93 & 3.93 \\
\hline $\mathrm{Li}_{2} \mathrm{O}^{*}$ & 1.82 & 1.66 & 1.64 & 1.75 & 1.74 & 0.00 & 0.00 & 0.00 & 0.00 & 0.00 & 0.00 & 0.00 \\
\hline $\mathrm{CaO}$ & 0.03 & 0.11 & 0.11 & 0.20 & 0.13 & 0.13 & 0.16 & 0.80 & 0.75 & 0.76 & 0.86 & 0.45 \\
\hline $\mathrm{Na}_{2} \mathrm{O}$ & 2.04 & 2.23 & 2.07 & 2.20 & 2.15 & 2.08 & 2.00 & 1.80 & 1.84 & 1.87 & 1.91 & 1.88 \\
\hline $\mathrm{K}_{2} \mathrm{O}$ & 0.02 & 0.02 & 0.01 & 0.01 & 0.02 & 0.03 & 0.04 & 0.06 & 0.04 & 0.05 & 0.06 & 0.05 \\
\hline $\mathrm{F}$ & 0.70 & 1.22 & 1.37 & 1.37 & 1.25 & 0.42 & 0.22 & 0.17 & 0.18 & 0.24 & 0.25 & 0.08 \\
\hline $\mathrm{Cl}$ & 0.00 & 0.00 & 0.00 & 0.00 & 0.00 & 0.00 & 0.00 & 0.00 & 0.00 & 0.00 & 0.01 & 0.00 \\
\hline $\mathrm{H}_{2} \mathrm{O}^{*}$ & 3.48 & 3.16 & 3.09 & 3.11 & 3.16 & 3.33 & 3.33 & 3.47 & 3.42 & 3.38 & 3.41 & 3.45 \\
\hline$-(\mathrm{O}=\mathrm{F}, \mathrm{Cl})$ & -0.29 & -0.52 & -0.58 & -0.58 & -0.53 & -0.18 & -0.09 & -0.07 & -0.07 & -0.10 & -0.10 & -0.03 \\
\hline Total & 99.49 & 99.06 & 98.73 & 99.08 & 98.84 & 100.06 & 99.96 & 99.58 & 98.97 & 99.24 & 99.12 & 98.89 \\
\hline T Si (apfu) & 5.850 & 5.858 & 5.845 & 5.860 & 5.867 & 5.816 & 5.841 & 5.698 & 5.717 & 5.778 & 5.668 & 5.707 \\
\hline T Al & 0.150 & 0.142 & 0.155 & 0.140 & 0.133 & 0.184 & 0.159 & 0.302 & 0.283 & 0.222 & 0.332 & 0.293 \\
\hline B & 3 & 3 & 3 & 3 & 3 & 3 & 3 & 3 & 3 & 3 & 3 & 3 \\
\hline $\mathrm{Z} \mathrm{Al}$ & 6.000 & 6.000 & 6.000 & 6.000 & 6.000 & 6.000 & 6.000 & 6.000 & 6.000 & 6.000 & 6.000 & 6.000 \\
\hline Y Ti & 0.009 & 0.000 & 0.013 & 0.010 & 0.004 & 0.059 & 0.089 & 0.061 & 0.051 & 0.051 & 0.070 & 0.076 \\
\hline Y Al & 1.651 & 1.478 & 1.502 & 1.494 & 1.526 & 0.383 & 0.404 & 0.366 & 0.404 & 0.342 & 0.318 & 0.413 \\
\hline $\mathrm{YCr}$ & 0.001 & 0.000 & 0.000 & 0.000 & 0.001 & 0.003 & 0.009 & 0.004 & 0.000 & 0.001 & 0.005 & 0.002 \\
\hline $\mathrm{Y} \mathrm{Fe}^{3+}$ & 0.000 & 0.000 & 0.000 & 0.000 & 0.000 & 0.000 & 0.000 & 0.000 & 0.000 & 0.000 & 0.000 & 0.000 \\
\hline $\mathrm{Y} \mathrm{Fe}^{2+}$ & 0.116 & 0.252 & 0.253 & 0.164 & 0.145 & 1.730 & 1.686 & 1.110 & 1.142 & 1.157 & 1.119 & 1.491 \\
\hline Y Mn & 0.064 & 0.178 & 0.155 & 0.204 & 0.203 & 0.028 & 0.033 & 0.003 & 0.012 & 0.007 & 0.008 & 0.022 \\
\hline Y Zn & 0.004 & 0.017 & 0.017 & 0.004 & 0.002 & 0.001 & 0.005 & 0.008 & 0.000 & 0.000 & 0.004 & 0.006 \\
\hline Y Mg & 0.000 & 0.004 & 0.002 & 0.000 & 0.003 & 0.797 & 0.772 & 1.449 & 1.391 & 1.441 & 1.477 & 0.990 \\
\hline Y Li & 1.155 & 1.071 & 1.058 & 1.124 & 1.116 & 0.000 & 0.000 & 0.000 & 0.000 & 0.000 & 0.000 & 0.000 \\
\hline X Ca & 0.004 & 0.019 & 0.019 & 0.035 & 0.023 & 0.023 & 0.028 & 0.143 & 0.135 & 0.136 & 0.153 & 0.082 \\
\hline $\mathrm{X} \mathrm{Na}$ & 0.622 & 0.693 & 0.643 & 0.680 & 0.665 & 0.677 & 0.651 & 0.579 & 0.597 & 0.605 & 0.619 & 0.616 \\
\hline x K & 0.004 & 0.003 & 0.003 & 0.001 & 0.004 & 0.007 & 0.009 & 0.012 & 0.009 & 0.011 & 0.013 & 0.010 \\
\hline $\mathrm{X}$ vac & 0.370 & 0.284 & 0.335 & 0.284 & 0.309 & 0.294 & 0.312 & 0.266 & 0.259 & 0.247 & 0.215 & 0.292 \\
\hline $\mathrm{VOH}$ & 3.000 & 3.000 & 3.000 & 3.000 & 3.000 & 3.000 & 3.000 & 3.000 & 3.000 & 3.000 & 3.000 & 3.000 \\
\hline Vo & 0.000 & 0.000 & 0.000 & 0.000 & 0.000 & 0.000 & 0.000 & 0.000 & 0.000 & 0.000 & 0.000 & 0.000 \\
\hline W F & 0.348 & 0.619 & 0.696 & 0.692 & 0.632 & 0.221 & 0.117 & 0.090 & 0.092 & 0.128 & 0.130 & 0.043 \\
\hline W Cl & 0.000 & 0.000 & 0.000 & 0.000 & 0.000 & 0.001 & 0.000 & 0.000 & 0.001 & 0.000 & 0.002 & 0.000 \\
\hline $\mathrm{WOH}$ & 0.652 & 0.381 & 0.304 & 0.308 & 0.368 & 0.729 & 0.733 & 0.844 & 0.807 & 0.760 & 0.800 & 0.893 \\
\hline wo & 0.000 & 0.000 & 0.000 & 0.000 & 0.000 & 0.049 & 0.150 & 0.066 & 0.099 & 0.112 & 0.069 & 0.063 \\
\hline Classif. & elbaite & $\begin{array}{l}\text { fluor- } \\
\text { elbaite }\end{array}$ & $\begin{array}{l}\text { fluor- } \\
\text { elbaite }\end{array}$ & $\begin{array}{l}\text { fluor- } \\
\text { elbaite }\end{array}$ & $\begin{array}{l}\text { fluor- } \\
\text { elbaite }\end{array}$ & schorl & schorl & dravite & dravite & dravite & dravite & schorl \\
\hline
\end{tabular}


Appendix D.1 (contd.): Electron-microprobe analyses of tourmaline.

\begin{tabular}{|c|c|c|c|c|c|c|c|c|c|c|c|c|}
\hline Site & & & & & & SC-S01 & & GMA-S01 & & & & \\
\hline 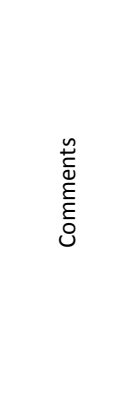 & 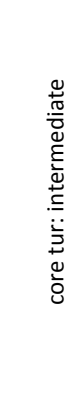 & 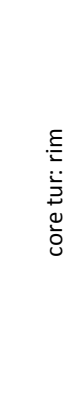 & 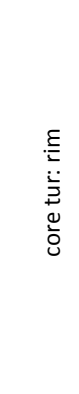 & 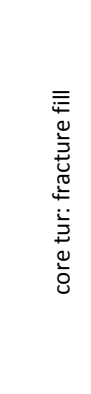 & 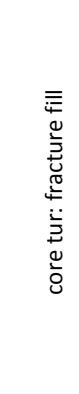 & 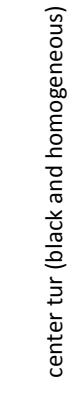 & 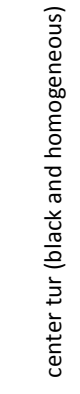 & 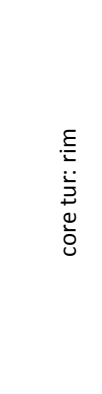 & 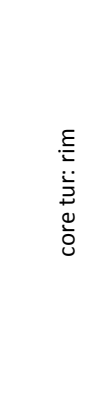 & 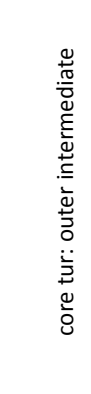 & 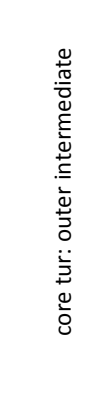 & 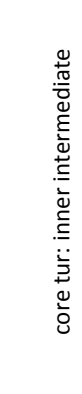 \\
\hline Point & $8 \mathrm{t}-4$ & $8 t-5$ & $8 \mathrm{t}-6$ & $8 t-7$ & $8 \mathrm{t}-8$ & $77 \mathrm{t}-1$ & $77 t-2$ & $1 \mathrm{t}-1$ & $1 \mathrm{t}-2$ & $1 \mathrm{t}-3$ & $1 \mathrm{t}-4$ & $1 \mathrm{t}-5$ \\
\hline $\mathrm{SiO}_{2}$ (wt.\%) & 34.17 & 33.39 & 33.27 & 34.52 & 33.59 & 34.41 & 34.07 & 34.60 & 34.75 & 34.46 & 34.57 & 34.54 \\
\hline $\mathrm{TiO}_{2}$ & 0.65 & 0.30 & 0.52 & 0.35 & 0.47 & 0.48 & 0.55 & 0.52 & 0.57 & 0.57 & 0.54 & 0.53 \\
\hline $\mathrm{B}_{2} \mathrm{O}_{3} *$ & 10.35 & 10.15 & 10.18 & 10.33 & 10.23 & 10.26 & 10.25 & 10.46 & 10.52 & 10.46 & 10.43 & 10.46 \\
\hline $\mathrm{Al}_{2} \mathrm{O}_{3}$ & 33.97 & 32.68 & 32.82 & 32.62 & 32.71 & 32.64 & 32.71 & 33.91 & 33.99 & 33.82 & 33.60 & 33.74 \\
\hline $\mathrm{Cr}_{2} \mathrm{O}_{3}$ & 0.00 & 0.03 & 0.00 & 0.00 & 0.05 & 0.00 & 0.00 & 0.00 & 0.00 & 0.00 & 0.03 & 0.05 \\
\hline \multicolumn{13}{|l|}{$\mathrm{Bi}_{2} \mathrm{O}_{3}$} \\
\hline $\mathrm{Fe}_{2} \mathrm{O}_{3} *$ & 0.00 & 0.72 & 1.05 & 0.53 & 1.21 & 0.00 & 0.00 & 0.00 & 0.00 & 0.00 & 0.00 & 0.00 \\
\hline $\mathrm{FeO}^{*}$ & 10.35 & 12.77 & 12.69 & 12.23 & 12.65 & 9.35 & 9.44 & 7.70 & 7.81 & 8.74 & 8.72 & 9.12 \\
\hline $\mathrm{FeO}$ (tot) & 10.35 & 13.42 & 13.63 & 12.71 & 13.74 & 9.35 & 9.44 & 7.70 & 7.81 & 8.74 & 8.72 & 9.12 \\
\hline $\mathrm{MnO}$ & 0.10 & 0.41 & 0.43 & 0.21 & 0.30 & 0.07 & 0.05 & 0.04 & 0.10 & 0.11 & 0.07 & 0.08 \\
\hline $\mathrm{ZnO}$ & 0.04 & 0.09 & 0.08 & 0.07 & 0.08 & 0.00 & 0.02 & 0.00 & 0.05 & 0.02 & 0.00 & 0.06 \\
\hline $\mathrm{MgO}$ & 3.90 & 2.58 & 2.47 & 3.38 & 2.63 & 4.97 & 5.03 & 5.90 & 5.98 & 5.42 & 5.43 & 5.25 \\
\hline $\mathrm{Li}_{2} \mathrm{O}^{*}$ & 0.00 & 0.00 & 0.00 & 0.00 & 0.00 & 0.00 & 0.00 & 0.00 & 0.00 & 0.00 & 0.00 & 0.00 \\
\hline $\mathrm{CaO}$ & 0.41 & 0.28 & 0.26 & 0.37 & 0.33 & 0.73 & 0.73 & 0.62 & 0.61 & 0.51 & 0.58 & 0.49 \\
\hline $\mathrm{Na}_{2} \mathrm{O}$ & 1.94 & 2.08 & 2.00 & 1.87 & 1.88 & 1.98 & 1.75 & 1.88 & 1.77 & 1.84 & 2.02 & 1.86 \\
\hline $\mathrm{K}_{2} \mathrm{O}$ & 0.06 & 0.04 & 0.04 & 0.05 & 0.04 & 0.05 & 0.07 & 0.04 & 0.05 & 0.03 & 0.06 & 0.05 \\
\hline $\mathrm{F}$ & 0.13 & 0.37 & 0.50 & 0.34 & 0.47 & 0.13 & 0.37 & 0.39 & 0.21 & 0.37 & 0.07 & 0.34 \\
\hline $\mathrm{Cl}$ & 0.00 & 0.00 & 0.00 & 0.00 & 0.00 & 0.00 & 0.01 & 0.00 & 0.00 & 0.00 & 0.00 & 0.01 \\
\hline $\mathrm{H}_{2} \mathrm{O}^{*}$ & 3.36 & 3.33 & 3.27 & 3.40 & 3.31 & 3.28 & 3.29 & 3.32 & 3.50 & 3.42 & 3.45 & 3.45 \\
\hline$-(\mathrm{O}=\mathrm{F}, \mathrm{Cl})$ & -0.05 & -0.16 & -0.21 & -0.14 & -0.20 & -0.06 & -0.16 & -0.16 & -0.09 & -0.16 & -0.03 & -0.14 \\
\hline Total & 99.37 & 99.05 & 99.36 & 100.12 & 99.74 & 98.29 & 98.18 & 99.22 & 99.81 & 99.61 & 99.54 & 99.85 \\
\hline T Si (apfu) & 5.741 & 5.716 & 5.682 & 5.810 & 5.709 & 5.831 & 5.776 & 5.752 & 5.741 & 5.728 & 5.759 & 5.738 \\
\hline TAl & 0.259 & 0.284 & 0.318 & 0.190 & 0.291 & 0.169 & 0.224 & 0.248 & 0.259 & 0.272 & 0.241 & 0.262 \\
\hline B & 3 & 3 & 3 & 3 & 3 & 3 & 3 & 3 & 3 & 3 & 3 & 3 \\
\hline $\mathrm{ZAl}$ & 6.000 & 6.000 & 6.000 & 6.000 & 6.000 & 6.000 & 6.000 & 6.000 & 6.000 & 6.000 & 6.000 & 6.000 \\
\hline Y Ti & 0.083 & 0.038 & 0.067 & 0.045 & 0.060 & 0.061 & 0.070 & 0.065 & 0.071 & 0.072 & 0.068 & 0.066 \\
\hline Y Al & 0.466 & 0.309 & 0.286 & 0.281 & 0.261 & 0.349 & 0.311 & 0.397 & 0.358 & 0.353 & 0.356 & 0.344 \\
\hline $\mathrm{YCr}$ & 0.000 & 0.004 & 0.000 & 0.000 & 0.006 & 0.000 & 0.000 & 0.000 & 0.000 & 0.000 & 0.004 & 0.006 \\
\hline $\mathrm{YFe}^{3+}$ & 0.000 & 0.093 & 0.134 & 0.067 & 0.154 & 0.000 & 0.000 & 0.000 & 0.000 & 0.000 & 0.000 & 0.000 \\
\hline $\mathrm{Y} \mathrm{Fe}^{2+}$ & 1.454 & 1.828 & 1.812 & 1.721 & 1.799 & 1.325 & 1.338 & 1.070 & 1.079 & 1.215 & 1.215 & 1.267 \\
\hline Y Mn & 0.015 & 0.059 & 0.063 & 0.030 & 0.043 & 0.010 & 0.007 & 0.005 & 0.014 & 0.015 & 0.010 & 0.011 \\
\hline YZn & 0.005 & 0.011 & 0.010 & 0.008 & 0.010 & 0.000 & 0.003 & 0.000 & 0.006 & 0.002 & 0.000 & 0.007 \\
\hline Y Mg & 0.977 & 0.657 & 0.629 & 0.847 & 0.667 & 1.256 & 1.272 & 1.463 & 1.472 & 1.342 & 1.347 & 1.300 \\
\hline Y Li & 0.000 & 0.000 & 0.000 & 0.000 & 0.000 & 0.000 & 0.000 & 0.000 & 0.000 & 0.000 & 0.000 & 0.000 \\
\hline $\mathrm{XCa}$ & 0.073 & 0.052 & 0.047 & 0.066 & 0.061 & 0.132 & 0.132 & 0.110 & 0.108 & 0.092 & 0.103 & 0.088 \\
\hline $\mathrm{XNa}$ & 0.633 & 0.690 & 0.661 & 0.609 & 0.621 & 0.650 & 0.574 & 0.607 & 0.568 & 0.593 & 0.653 & 0.598 \\
\hline$x K$ & 0.013 & 0.008 & 0.009 & 0.011 & 0.009 & 0.011 & 0.014 & 0.009 & 0.010 & 0.007 & 0.012 & 0.010 \\
\hline$X$ vac & 0.281 & 0.250 & 0.283 & 0.314 & 0.310 & 0.207 & 0.279 & 0.274 & 0.314 & 0.309 & 0.231 & 0.304 \\
\hline $\mathrm{VOH}$ & 3.000 & 3.000 & 3.000 & 3.000 & 3.000 & 3.000 & 3.000 & 3.000 & 3.000 & 3.000 & 3.000 & 3.000 \\
\hline Vo & 0.000 & 0.000 & 0.000 & 0.000 & 0.000 & 0.000 & 0.000 & 0.000 & 0.000 & 0.000 & 0.000 & 0.000 \\
\hline W F & 0.067 & 0.199 & 0.270 & 0.182 & 0.251 & 0.071 & 0.197 & 0.204 & 0.108 & 0.196 & 0.038 & 0.178 \\
\hline W Cl & 0.000 & 0.000 & 0.001 & 0.001 & 0.000 & 0.000 & 0.002 & 0.000 & 0.000 & 0.000 & 0.000 & 0.002 \\
\hline $\mathrm{WOH}$ & 0.768 & 0.801 & 0.729 & 0.818 & 0.749 & 0.703 & 0.722 & 0.681 & 0.857 & 0.797 & 0.836 & 0.818 \\
\hline wo & 0.165 & 0.000 & 0.000 & 0.000 & 0.000 & 0.225 & 0.079 & 0.115 & 0.035 & 0.008 & 0.127 & 0.002 \\
\hline Classif. & schorl & schorl & schorl & schorl & schorl & schorl & schorl & dravite & dravite & dravite & dravite & dravite \\
\hline
\end{tabular}


Appendix D.1 (contd.): Electron-microprobe analyses of tourmaline.

\begin{tabular}{|c|c|c|c|c|c|c|c|c|c|c|c|c|}
\hline Site & & & & A-S01 & & $\mathrm{A}-\mathrm{S} 02$ & & & & & & \\
\hline 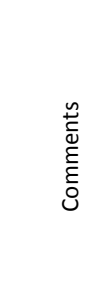 & 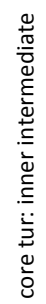 & 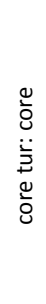 & 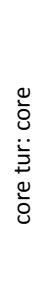 & $\begin{array}{l}\frac{1}{2} \\
\frac{0}{0} \\
0 \\
0 \\
0 \\
\frac{0}{0} \\
\frac{\pi}{0}\end{array}$ & $\begin{array}{l}\frac{1}{2} \\
\dot{0} \\
\frac{0}{0} \\
\frac{0}{0} \\
\frac{0}{0} \\
\frac{\pi}{0}\end{array}$ & 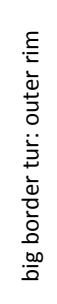 & 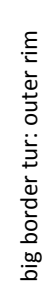 & 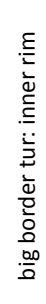 & 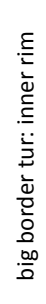 & 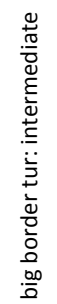 & 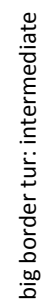 & 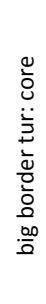 \\
\hline
\end{tabular}

\begin{tabular}{|c|c|c|c|c|c|c|c|c|c|c|c|c|}
\hline Point & $1 \mathrm{t}-6$ & $1 \mathrm{t}-7$ & $1 \mathrm{t}-8$ & $2 \mathrm{t}-1$ & $2 t-2$ & $5 t-1$ & $5 t-2$ & $5 t-3$ & $5 t-4$ & $5 t-5$ & $5 t-6$ & $5 t-7$ \\
\hline $\mathrm{SiO}_{2}$ (wt.\%) & 34.52 & 34.50 & 34.90 & 35.46 & 35.43 & 34.41 & 34.53 & 34.36 & 34.09 & 34.77 & 35.11 & 35.11 \\
\hline $\mathrm{TiO}_{2}$ & 0.60 & 0.50 & 0.46 & 0.21 & 0.13 & 0.63 & 0.74 & 0.68 & 0.75 & 0.52 & 0.35 & 0.35 \\
\hline $\mathrm{B}_{2} \mathrm{O}_{3} *$ & 10.44 & 10.47 & 10.52 & 10.59 & 10.58 & 10.41 & 10.43 & 10.39 & 10.36 & 10.53 & 10.56 & 10.54 \\
\hline $\mathrm{Al}_{2} \mathrm{O}_{3}$ & 33.54 & 33.63 & 33.79 & 34.62 & 34.62 & 33.14 & 33.35 & 33.02 & 33.28 & 33.68 & 33.77 & 33.85 \\
\hline $\mathrm{Cr}_{2} \mathrm{O}_{3}$ & 0.01 & 0.00 & 0.00 & 0.02 & 0.03 & 0.02 & 0.00 & 0.00 & 0.04 & 0.02 & 0.00 & 0.00 \\
\hline \multicolumn{13}{|l|}{$\mathrm{Bi}_{2} \mathrm{O}_{3}$} \\
\hline $\mathrm{Fe}_{2} \mathrm{O}_{3} *$ & 0.40 & 0.01 & 0.00 & 0.00 & 0.00 & 0.02 & 0.00 & 0.00 & 0.00 & 0.00 & 0.00 & 0.00 \\
\hline $\mathrm{FeO}^{*}$ & 8.84 & 7.85 & 7.88 & 6.57 & 6.57 & 9.59 & 9.25 & 10.99 & 11.96 & 6.96 & 6.96 & 6.66 \\
\hline $\mathrm{FeO}$ (tot) & 9.20 & 7.86 & 7.88 & 6.57 & 6.57 & 9.60 & 9.25 & 10.99 & 11.96 & 6.96 & 6.96 & 6.66 \\
\hline $\mathrm{MnO}$ & 0.09 & 0.11 & 0.04 & 0.02 & 0.06 & 0.14 & 0.12 & 0.16 & 0.18 & 0.05 & 0.00 & 0.05 \\
\hline $\mathrm{ZnO}$ & 0.04 & 0.00 & 0.00 & 0.00 & 0.06 & 0.00 & 0.05 & 0.00 & 0.03 & 0.00 & 0.03 & 0.02 \\
\hline $\mathrm{MgO}$ & 5.23 & 6.16 & 6.11 & 6.31 & 6.27 & 5.21 & 5.23 & 4.38 & 3.59 & 6.80 & 6.80 & 6.76 \\
\hline $\mathrm{Li}_{2} \mathrm{O}^{*}$ & 0.00 & 0.00 & 0.00 & 0.00 & 0.00 & 0.00 & 0.00 & 0.00 & 0.00 & 0.00 & 0.00 & 0.00 \\
\hline $\mathrm{CaO}$ & 0.49 & 0.65 & 0.62 & 0.39 & 0.47 & 0.50 & 0.51 & 0.51 & 0.46 & 0.89 & 0.85 & 0.89 \\
\hline $\mathrm{Na}_{2} \mathrm{O}$ & 1.69 & 1.86 & 1.87 & 1.55 & 1.49 & 1.98 & 1.99 & 1.94 & 1.91 & 2.03 & 1.90 & 1.79 \\
\hline $\mathrm{K}_{2} \mathrm{O}$ & 0.04 & 0.06 & 0.04 & 0.02 & 0.04 & 0.05 & 0.02 & 0.06 & 0.09 & 0.06 & 0.05 & 0.04 \\
\hline $\mathrm{F}$ & 0.17 & 0.31 & 0.32 & 0.18 & 0.15 & 0.56 & 0.44 & 0.36 & 0.29 & 0.36 & 0.33 & 0.18 \\
\hline $\mathrm{Cl}$ & 0.00 & 0.00 & 0.00 & 0.00 & 0.01 & 0.00 & 0.00 & 0.01 & 0.00 & 0.00 & 0.01 & 0.00 \\
\hline $\mathrm{H}_{2} \mathrm{O}^{*}$ & 3.52 & 3.47 & 3.43 & 3.54 & 3.54 & 3.33 & 3.33 & 3.41 & 3.43 & 3.34 & 3.39 & 3.43 \\
\hline$-(\mathrm{O}=\mathrm{F}, \mathrm{Cl})$ & -0.07 & -0.13 & -0.14 & -0.08 & -0.07 & -0.23 & -0.19 & -0.15 & -0.12 & -0.15 & -0.14 & -0.07 \\
\hline Total & 99.55 & 99.44 & 99.86 & 99.40 & 99.39 & 99.74 & 99.81 & 100.09 & 100.34 & 99.86 & 99.97 & 99.58 \\
\hline T Si (apfu) & 5.746 & 5.727 & 5.766 & 5.821 & 5.822 & 5.744 & 5.752 & 5.750 & 5.717 & 5.739 & 5.777 & 5.789 \\
\hline T Al & 0.254 & 0.273 & 0.234 & 0.179 & 0.178 & 0.256 & 0.248 & 0.250 & 0.283 & 0.261 & 0.223 & 0.211 \\
\hline B & 3 & 3 & 3 & 3 & 3 & 3 & 3 & 3 & 3 & 3 & 3 & 3 \\
\hline $\mathrm{ZAl}$ & 6.000 & 6.000 & 6.000 & 6.000 & 6.000 & 6.000 & 6.000 & 6.000 & 6.000 & 6.000 & 6.000 & 6.000 \\
\hline Y Ti & 0.075 & 0.063 & 0.057 & 0.026 & 0.016 & 0.079 & 0.093 & 0.086 & 0.094 & 0.064 & 0.043 & 0.043 \\
\hline Y Al & 0.327 & 0.306 & 0.345 & 0.520 & 0.526 & 0.263 & 0.298 & 0.262 & 0.294 & 0.291 & 0.327 & 0.368 \\
\hline $\mathrm{YCr}$ & 0.002 & 0.000 & 0.000 & 0.003 & 0.004 & 0.002 & 0.000 & 0.000 & 0.006 & 0.002 & 0.000 & 0.000 \\
\hline$Y \mathrm{Fe}^{3+}$ & 0.050 & 0.001 & 0.000 & 0.000 & 0.000 & 0.002 & 0.000 & 0.000 & 0.000 & 0.000 & 0.000 & 0.000 \\
\hline $\mathrm{Y} \mathrm{Fe}^{2+}$ & 1.231 & 1.090 & 1.088 & 0.903 & 0.903 & 1.338 & 1.288 & 1.537 & 1.677 & 0.961 & 0.958 & 0.919 \\
\hline Y Mn & 0.013 & 0.015 & 0.006 & 0.003 & 0.008 & 0.020 & 0.016 & 0.023 & 0.026 & 0.007 & 0.000 & 0.007 \\
\hline Y Zn & 0.005 & 0.001 & 0.000 & 0.000 & 0.007 & 0.000 & 0.006 & 0.000 & 0.004 & 0.000 & 0.004 & 0.002 \\
\hline Y Mg & 1.298 & 1.524 & 1.504 & 1.545 & 1.536 & 1.296 & 1.298 & 1.092 & 0.899 & 1.673 & 1.668 & 1.661 \\
\hline Y Li & 0.000 & 0.000 & 0.000 & 0.000 & 0.000 & 0.000 & 0.000 & 0.000 & 0.000 & 0.000 & 0.000 & 0.000 \\
\hline X Ca & 0.087 & 0.115 & 0.110 & 0.068 & 0.082 & 0.089 & 0.092 & 0.091 & 0.082 & 0.157 & 0.149 & 0.156 \\
\hline $\mathrm{X} \mathrm{Na}$ & 0.544 & 0.599 & 0.600 & 0.492 & 0.476 & 0.642 & 0.643 & 0.629 & 0.620 & 0.651 & 0.606 & 0.573 \\
\hline x K & 0.008 & 0.012 & 0.008 & 0.003 & 0.009 & 0.010 & 0.005 & 0.012 & 0.020 & 0.012 & 0.011 & 0.008 \\
\hline$X$ vac & 0.361 & 0.274 & 0.282 & 0.437 & 0.433 & 0.259 & 0.261 & 0.268 & 0.278 & 0.180 & 0.234 & 0.263 \\
\hline $\mathrm{VOH}$ & 3.000 & 3.000 & 3.000 & 3.000 & 3.000 & 3.000 & 3.000 & 3.000 & 3.000 & 3.000 & 3.000 & 3.000 \\
\hline VO & 0.000 & 0.000 & 0.000 & 0.000 & 0.000 & 0.000 & 0.000 & 0.000 & 0.000 & 0.000 & 0.000 & 0.000 \\
\hline W F & 0.087 & 0.162 & 0.168 & 0.094 & 0.080 & 0.294 & 0.234 & 0.189 & 0.155 & 0.188 & 0.173 & 0.092 \\
\hline W Cl & 0.000 & 0.000 & 0.000 & 0.000 & 0.002 & 0.000 & 0.001 & 0.003 & 0.001 & 0.000 & 0.001 & 0.000 \\
\hline $\mathrm{WOH}$ & 0.913 & 0.838 & 0.779 & 0.880 & 0.885 & 0.706 & 0.699 & 0.802 & 0.835 & 0.672 & 0.720 & 0.772 \\
\hline Wo & 0.000 & 0.000 & 0.053 & 0.027 & 0.032 & 0.000 & 0.067 & 0.006 & 0.009 & 0.140 & 0.105 & 0.136 \\
\hline Classif. & dravite & dravite & dravite & dravite & dravite & schorl & dravite & schorl & schorl & dravite & dravite & dravite \\
\hline
\end{tabular}


Appendix D.1 (contd.): Electron-microprobe analyses of tourmaline.

\begin{tabular}{llll}
\hline Site & PEGMA-S02 & POCKET-S01 & POCKET-SO: \\
\hline
\end{tabular}

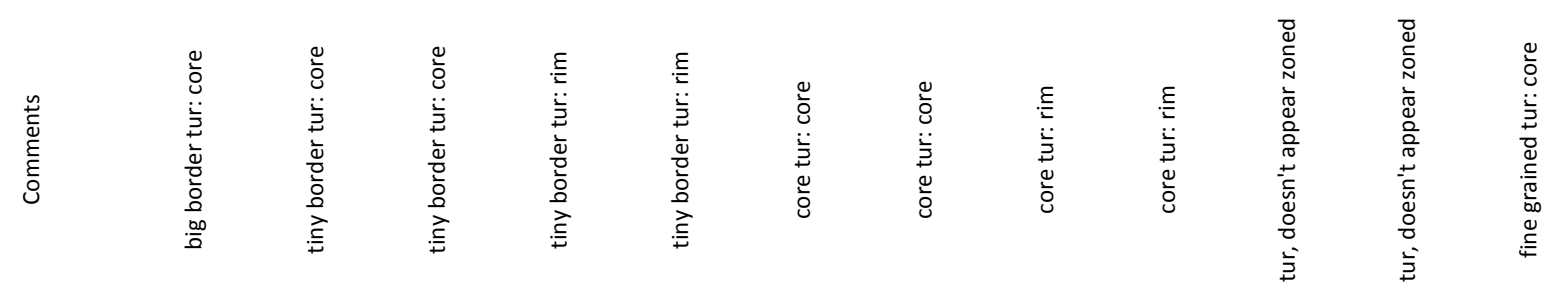

\begin{tabular}{|c|c|c|c|c|c|c|c|c|c|c|c|c|}
\hline Point & $5 t-8$ & $5 t-9$ & $5 t-10$ & $5 t-11$ & $5 t-12$ & $6 t-1$ & $6 t-2$ & $6 t-3$ & $6 t-4$ & $78 t-1$ & $78 t-2$ & $79 t-1$ \\
\hline $\mathrm{SiO}_{2}$ (wt.\%) & 34.92 & 34.07 & 33.81 & 34.61 & 34.68 & 34.53 & 34.43 & 34.06 & 34.15 & 34.01 & 33.72 & 35.22 \\
\hline $\mathrm{TiO}_{2}$ & 0.39 & 0.35 & 0.47 & 0.49 & 0.70 & 0.51 & 0.69 & 0.57 & 0.68 & 0.25 & 0.27 & 0.69 \\
\hline $\mathrm{B}_{2} \mathrm{O}_{3} *$ & 10.57 & 10.29 & 10.23 & 10.45 & 10.41 & 10.27 & 10.28 & 10.27 & 10.26 & 10.14 & 10.09 & 10.45 \\
\hline $\mathrm{Al}_{2} \mathrm{O}_{3}$ & 34.08 & 31.74 & 31.71 & 31.16 & 31.19 & 32.81 & 32.79 & 33.89 & 32.84 & 34.15 & 33.90 & 34.57 \\
\hline $\mathrm{Cr}_{2} \mathrm{O}_{3}$ & 0.02 & 0.02 & 0.00 & 0.05 & 0.00 & 0.04 & 0.00 & 0.00 & 0.01 & 0.00 & 0.00 & 0.02 \\
\hline $\mathrm{Bi}_{2} \mathrm{O}_{3}$ & & & & & & & & & & & & 0.00 \\
\hline $\mathrm{Fe}_{2} \mathrm{O}_{3} *$ & 0.00 & 0.71 & 0.46 & 0.99 & 0.00 & 0.00 & 0.00 & 0.00 & 0.00 & 0.00 & 0.00 & 0.00 \\
\hline $\mathrm{FeO}^{*}$ & 6.73 & 10.99 & 10.92 & 6.43 & 7.29 & 11.46 & 12.30 & 13.29 & 13.00 & 7.92 & 7.83 & 9.43 \\
\hline $\mathrm{FeO}$ (tot) & 6.73 & 11.62 & 11.33 & 7.32 & 7.29 & 11.46 & 12.30 & 13.29 & 13.00 & 7.92 & 7.83 & 9.43 \\
\hline $\mathrm{MnO}$ & 0.05 & 0.24 & 0.22 & 0.03 & 0.05 & 0.18 & 0.18 & 1.03 & 0.30 & 0.08 & 0.13 & 0.07 \\
\hline $\mathrm{ZnO}$ & 0.06 & 0.05 & 0.05 & 0.00 & 0.03 & 0.01 & 0.00 & 0.09 & 0.03 & 0.02 & 0.00 & 0.00 \\
\hline $\mathrm{MgO}$ & 6.82 & 4.73 & 4.71 & 8.25 & 7.83 & 3.54 & 3.14 & 1.41 & 2.70 & 4.26 & 4.38 & 3.88 \\
\hline $\mathrm{Li}_{2} \mathrm{O}^{*}$ & 0.00 & 0.00 & 0.00 & 0.00 & 0.00 & 0.00 & 0.00 & 0.00 & 0.00 & 0.00 & 0.00 & 0.00 \\
\hline $\mathrm{CaO}$ & 0.79 & 0.80 & 0.80 & 1.85 & 1.76 & 0.29 & 0.25 & 0.14 & 0.23 & 0.09 & 0.08 & 0.40 \\
\hline $\mathrm{Na}_{2} \mathrm{O}$ & 1.82 & 2.08 & 2.05 & 1.41 & 1.54 & 2.08 & 2.02 & 2.10 & 2.16 & 1.46 & 1.56 & 1.91 \\
\hline $\mathrm{K}_{2} \mathrm{O}$ & 0.06 & 0.06 & 0.05 & 0.04 & 0.05 & 0.05 & 0.04 & 0.03 & 0.05 & 0.02 & 0.00 & 0.05 \\
\hline $\mathrm{F}$ & 0.18 & 0.19 & 0.06 & 0.37 & 0.57 & 0.11 & 0.11 & 0.29 & 0.23 & 0.15 & 0.31 & 0.12 \\
\hline $\mathrm{Cl}$ & 0.00 & 0.00 & 0.01 & 0.00 & 0.00 & 0.00 & 0.00 & 0.00 & 0.00 & 0.00 & 0.01 & 0.00 \\
\hline $\mathrm{H}_{2} \mathrm{O}^{*}$ & 3.52 & 3.46 & 3.50 & 3.43 & 3.28 & 3.34 & 3.39 & 3.24 & 3.34 & 3.30 & 3.22 & 3.16 \\
\hline$-(\mathrm{O}=\mathrm{F}, \mathrm{Cl})$ & -0.08 & -0.08 & -0.03 & -0.15 & -0.24 & -0.05 & -0.05 & -0.12 & -0.10 & -0.06 & -0.13 & -0.05 \\
\hline Total & 99.93 & 99.70 & 99.01 & 99.41 & 99.16 & 99.17 & 99.59 & 100.28 & 99.87 & 95.79 & 95.38 & 99.93 \\
\hline T Si (apfu) & 5.739 & 5.757 & 5.747 & 5.757 & 5.793 & 5.844 & 5.821 & 5.768 & 5.785 & 5.830 & 5.809 & 5.855 \\
\hline T Al & 0.261 & 0.243 & 0.253 & 0.243 & 0.207 & 0.156 & 0.179 & 0.232 & 0.215 & 0.170 & 0.191 & 0.145 \\
\hline B & 3 & 3 & 3 & 3 & 3 & 3 & 3 & 3 & 3 & 3 & 3 & 3 \\
\hline $\mathrm{ZAl}$ & 6.000 & 6.000 & 6.000 & 5.866 & 5.932 & 6.000 & 6.000 & 6.000 & 6.000 & 6.000 & 6.000 & 6.000 \\
\hline Y Ti & 0.048 & 0.044 & 0.059 & 0.061 & 0.088 & 0.065 & 0.088 & 0.072 & 0.087 & 0.032 & 0.036 & 0.086 \\
\hline Y Al & 0.340 & 0.078 & 0.098 & 0.000 & 0.000 & 0.388 & 0.356 & 0.531 & 0.340 & 0.729 & 0.693 & 0.629 \\
\hline $\mathrm{YCr}$ & 0.002 & 0.003 & 0.000 & 0.006 & 0.000 & 0.006 & 0.000 & 0.000 & 0.002 & 0.000 & 0.000 & 0.003 \\
\hline$Y \mathrm{Fe}^{3+}$ & 0.000 & 0.090 & 0.059 & 0.124 & 0.000 & 0.000 & 0.000 & 0.000 & 0.000 & 0.000 & 0.000 & 0.000 \\
\hline $\mathrm{Y} \mathrm{Fe}^{2+}$ & 0.926 & 1.552 & 1.552 & 0.894 & 1.019 & 1.622 & 1.739 & 1.881 & 1.842 & 1.136 & 1.128 & 1.311 \\
\hline Y Mn & 0.006 & 0.035 & 0.031 & 0.004 & 0.007 & 0.026 & 0.026 & 0.148 & 0.043 & 0.012 & 0.019 & 0.010 \\
\hline Y Zn & 0.007 & 0.006 & 0.006 & 0.000 & 0.004 & 0.001 & 0.000 & 0.012 & 0.003 & 0.002 & 0.000 & 0.000 \\
\hline Y Mg & 1.671 & 1.191 & 1.193 & 2.045 & 1.950 & 0.892 & 0.791 & 0.356 & 0.682 & 1.088 & 1.124 & 0.962 \\
\hline Y Li & 0.000 & 0.000 & 0.000 & 0.000 & 0.000 & 0.000 & 0.000 & 0.000 & 0.000 & 0.000 & 0.000 & 0.000 \\
\hline X Ca & 0.139 & 0.145 & 0.145 & 0.330 & 0.316 & 0.052 & 0.046 & 0.025 & 0.041 & 0.016 & 0.015 & 0.071 \\
\hline $\mathrm{X} \mathrm{Na}$ & 0.580 & 0.681 & 0.676 & 0.456 & 0.500 & 0.682 & 0.663 & 0.688 & 0.708 & 0.484 & 0.520 & 0.616 \\
\hline x K & 0.013 & 0.013 & 0.011 & 0.008 & 0.011 & 0.011 & 0.009 & 0.007 & 0.010 & 0.004 & 0.001 & 0.011 \\
\hline$X$ vac & 0.269 & 0.161 & 0.168 & 0.205 & 0.173 & 0.255 & 0.282 & 0.280 & 0.241 & 0.496 & 0.464 & 0.303 \\
\hline $\mathrm{VOH}$ & 3.000 & 3.000 & 3.000 & 3.000 & 3.000 & 3.000 & 3.000 & 3.000 & 3.000 & 3.000 & 3.000 & 3.000 \\
\hline VO & 0.000 & 0.000 & 0.000 & 0.000 & 0.000 & 0.000 & 0.000 & 0.000 & 0.000 & 0.000 & 0.000 & 0.000 \\
\hline W F & 0.092 & 0.103 & 0.032 & 0.192 & 0.300 & 0.061 & 0.060 & 0.157 & 0.125 & 0.080 & 0.170 & 0.063 \\
\hline W Cl & 0.001 & 0.000 & 0.003 & 0.000 & 0.000 & 0.000 & 0.000 & 0.001 & 0.000 & 0.000 & 0.002 & 0.000 \\
\hline $\mathrm{WOH}$ & 0.859 & 0.897 & 0.966 & 0.808 & 0.657 & 0.773 & 0.823 & 0.654 & 0.773 & 0.776 & 0.703 & 0.509 \\
\hline Wo & 0.048 & 0.000 & 0.000 & 0.000 & 0.044 & 0.166 & 0.118 & 0.188 & 0.102 & 0.144 & 0.125 & 0.428 \\
\hline Classif. & dravite & schorl & schorl & dravite & dravite & schorl & schorl & schorl & schorl & foitite & schorl & schorl \\
\hline
\end{tabular}


Appendix D.1 (contd.): Electron-microprobe analyses of tourmaline.

\begin{tabular}{llllll}
\hline Site $L$ & POCKET-S01 & SIMPLE-S01 & SIMPLE-S02 & SIMPLE2-S01 & SIMPLE3-SC \\
\hline
\end{tabular}

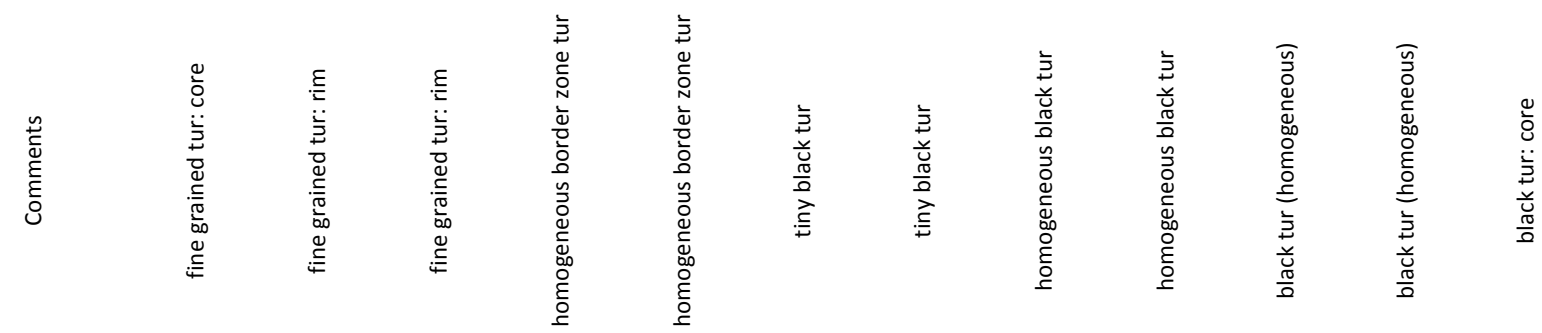

\begin{tabular}{|c|c|c|c|c|c|c|c|c|c|c|c|c|}
\hline Point & $79 t-2$ & $79 t-3$ & $79 t-4$ & $80 \mathrm{t}-1$ & $80 t-2$ & $81 t-1$ & $81 t-2$ & $82 t-1$ & $82 t-2$ & $83 t-1$ & $83 t-2$ & $138 \mathrm{t}-1$ \\
\hline $\mathrm{SiO}_{2}$ (wt.\%) & 35.04 & 35.66 & 35.64 & 35.87 & 35.86 & 34.57 & 33.95 & 36.07 & 35.83 & 34.50 & 34.64 & 35.66 \\
\hline $\mathrm{TiO}_{2}$ & 0.70 & 0.98 & 0.98 & 0.56 & 0.47 & 0.63 & 0.54 & 0.31 & 0.31 & 0.83 & 0.78 & 1.12 \\
\hline $\mathrm{B}_{2} \mathrm{O}_{3} *$ & 10.44 & 10.57 & 10.58 & 10.60 & 10.63 & 10.41 & 10.42 & 10.59 & 10.51 & 10.25 & 10.35 & 10.54 \\
\hline $\mathrm{Al}_{2} \mathrm{O}_{3}$ & 34.56 & 34.22 & 34.21 & 34.25 & 33.90 & 33.04 & 33.53 & 34.07 & 33.89 & 29.98 & 31.28 & 30.66 \\
\hline $\mathrm{Cr}_{2} \mathrm{O}_{3}$ & 0.01 & 0.00 & 0.02 & 0.01 & 0.00 & 0.00 & 0.04 & 0.00 & 0.00 & 0.04 & 0.00 & 0.02 \\
\hline $\mathrm{Bi}_{2} \mathrm{O}_{3}$ & 0.00 & 0.04 & 0.01 & 0.02 & 0.02 & & & 0.00 & 0.02 & & & \\
\hline $\mathrm{Fe}_{2} \mathrm{O}_{3} *$ & 0.00 & 0.00 & 0.00 & 0.00 & 0.00 & 0.00 & 0.41 & 0.00 & 0.00 & 0.76 & 0.00 & 0.00 \\
\hline $\mathrm{FeO}^{*}$ & 9.42 & 7.14 & 7.23 & 6.09 & 5.14 & 8.11 & 7.72 & 8.66 & 8.51 & 10.17 & 10.40 & 6.35 \\
\hline $\mathrm{FeO}$ (tot) & 9.42 & 7.14 & 7.23 & 6.09 & 5.14 & 8.11 & 8.08 & 8.66 & 8.51 & 10.86 & 10.40 & 6.35 \\
\hline $\mathrm{MnO}$ & 0.06 & 0.06 & 0.08 & 0.03 & 0.02 & 0.06 & 0.04 & 0.06 & 0.04 & 0.13 & 0.11 & 0.17 \\
\hline $\mathrm{ZnO}$ & 0.04 & 0.00 & 0.05 & 0.02 & 0.02 & 0.00 & 0.07 & 0.02 & 0.05 & 0.00 & 0.00 & 0.09 \\
\hline $\mathrm{MgO}$ & 3.92 & 5.65 & 5.65 & 6.48 & 7.52 & 6.06 & 6.16 & 5.13 & 5.06 & 5.88 & 5.67 & 8.59 \\
\hline $\mathrm{Li}_{2} \mathrm{O}^{*}$ & 0.00 & 0.00 & 0.00 & 0.00 & 0.00 & 0.00 & 0.00 & 0.00 & 0.00 & 0.00 & 0.00 & 0.00 \\
\hline $\mathrm{CaO}$ & 0.37 & 0.43 & 0.39 & 0.79 & 1.10 & 0.62 & 0.79 & 0.30 & 0.28 & 0.70 & 0.69 & 1.25 \\
\hline $\mathrm{Na}_{2} \mathrm{O}$ & 1.91 & 2.09 & 2.09 & 1.93 & 2.06 & 1.91 & 1.86 & 1.79 & 1.76 & 2.18 & 2.23 & 2.02 \\
\hline $\mathrm{K}_{2} \mathrm{O}$ & 0.05 & 0.05 & 0.05 & 0.05 & 0.08 & 0.05 & 0.05 & 0.03 & 0.03 & 0.06 & 0.04 & 0.05 \\
\hline $\mathrm{F}$ & 0.17 & 0.09 & 0.16 & 0.21 & 0.14 & 0.16 & 0.46 & 0.18 & 0.17 & 0.30 & 0.31 & 0.47 \\
\hline $\mathrm{Cl}$ & 0.00 & 0.00 & 0.00 & 0.01 & 0.00 & 0.00 & 0.00 & 0.00 & 0.00 & 0.01 & 0.00 & 0.00 \\
\hline $\mathrm{H}_{2} \mathrm{O}^{*}$ & 3.18 & 3.20 & 3.21 & 3.16 & 3.20 & 3.47 & 3.38 & 3.40 & 3.37 & 3.39 & 3.42 & 3.33 \\
\hline$-(\mathrm{O}=\mathrm{F}, \mathrm{Cl})$ & -0.07 & -0.04 & -0.07 & -0.09 & -0.06 & -0.07 & -0.19 & -0.08 & -0.07 & -0.13 & -0.13 & -0.20 \\
\hline Total & 99.80 & 100.14 & 100.28 & 99.99 & 100.10 & 99.02 & 99.23 & 100.54 & 99.76 & 99.05 & 99.78 & 100.14 \\
\hline T Si (apfu) & 5.833 & 5.866 & 5.856 & 5.883 & 5.865 & 5.771 & 5.662 & 5.919 & 5.923 & 5.852 & 5.817 & 5.879 \\
\hline T Al & 0.167 & 0.134 & 0.144 & 0.117 & 0.135 & 0.229 & 0.338 & 0.081 & 0.077 & 0.148 & 0.183 & 0.121 \\
\hline B & 3 & 3 & 3 & 3 & 3 & 3 & 3 & 3 & 3 & 3 & 3 & 3 \\
\hline $\mathrm{ZAl}$ & 6.000 & 6.000 & 6.000 & 6.000 & 6.000 & 6.000 & 6.000 & 6.000 & 6.000 & 5.845 & 6.000 & 5.837 \\
\hline Y Ti & 0.088 & 0.121 & 0.121 & 0.069 & 0.058 & 0.079 & 0.068 & 0.038 & 0.039 & 0.106 & 0.098 & 0.139 \\
\hline Y Al & 0.613 & 0.501 & 0.481 & 0.503 & 0.400 & 0.272 & 0.253 & 0.508 & 0.525 & 0.000 & 0.007 & 0.000 \\
\hline $\mathrm{YCr}$ & 0.001 & 0.000 & 0.003 & 0.001 & 0.000 & 0.000 & 0.005 & 0.000 & 0.000 & 0.005 & 0.000 & 0.003 \\
\hline $\mathrm{YFe}^{3+}$ & 0.000 & 0.000 & 0.000 & 0.000 & 0.000 & 0.000 & 0.051 & 0.000 & 0.000 & 0.097 & 0.000 & 0.000 \\
\hline $\mathrm{YFe}^{2+}$ & 1.311 & 0.982 & 0.994 & 0.835 & 0.703 & 1.132 & 1.076 & 1.188 & 1.176 & 1.443 & 1.460 & 0.875 \\
\hline Y Mn & 0.008 & 0.008 & 0.011 & 0.004 & 0.003 & 0.008 & 0.006 & 0.008 & 0.006 & 0.018 & 0.016 & 0.024 \\
\hline Y Zn & 0.005 & 0.000 & 0.006 & 0.002 & 0.002 & 0.000 & 0.009 & 0.002 & 0.006 & 0.000 & 0.000 & 0.012 \\
\hline Y Mg & 0.973 & 1.386 & 1.384 & 1.584 & 1.834 & 1.508 & 1.531 & 1.255 & 1.247 & 1.486 & 1.418 & 2.111 \\
\hline Y Li & 0.000 & 0.000 & 0.000 & 0.000 & 0.000 & 0.000 & 0.000 & 0.000 & 0.000 & 0.000 & 0.000 & 0.000 \\
\hline X Ca & 0.066 & 0.076 & 0.069 & 0.139 & 0.193 & 0.111 & 0.140 & 0.053 & 0.050 & 0.128 & 0.125 & 0.221 \\
\hline X Na & 0.616 & 0.667 & 0.666 & 0.614 & 0.653 & 0.617 & 0.600 & 0.569 & 0.564 & 0.718 & 0.724 & 0.647 \\
\hline x K & 0.011 & 0.010 & 0.010 & 0.010 & 0.017 & 0.010 & 0.011 & 0.006 & 0.006 & 0.014 & 0.008 & 0.010 \\
\hline $\mathrm{X}$ vac & 0.307 & 0.247 & 0.255 & 0.237 & 0.137 & 0.262 & 0.248 & 0.371 & 0.380 & 0.140 & 0.143 & 0.122 \\
\hline $\mathrm{VOH}$ & 3.000 & 3.000 & 3.000 & 3.000 & 3.000 & 3.000 & 3.000 & 3.000 & 3.000 & 3.000 & 3.000 & 3.000 \\
\hline Vo & 0.000 & 0.000 & 0.000 & 0.000 & 0.000 & 0.000 & 0.000 & 0.000 & 0.000 & 0.000 & 0.000 & 0.000 \\
\hline W F & 0.089 & 0.047 & 0.083 & 0.109 & 0.072 & 0.086 & 0.242 & 0.093 & 0.089 & 0.163 & 0.163 & 0.243 \\
\hline W Cl & 0.000 & 0.000 & 0.000 & 0.003 & 0.000 & 0.000 & 0.001 & 0.000 & 0.000 & 0.002 & 0.001 & 0.001 \\
\hline $\mathrm{WOH}$ & 0.528 & 0.513 & 0.521 & 0.461 & 0.491 & 0.864 & 0.757 & 0.722 & 0.715 & 0.835 & 0.833 & 0.659 \\
\hline W O & 0.382 & 0.440 & 0.396 & 0.427 & 0.437 & 0.050 & 0.000 & 0.184 & 0.196 & 0.000 & 0.003 & 0.096 \\
\hline Classif. & schorl & dravite & dravite & dravite & dravite & dravite & dravite & dravite & dravite & dravite & schorl & dravite \\
\hline
\end{tabular}


Appendix D.1 (contd.): Electron-microprobe analyses of tourmaline.

\begin{tabular}{llllll}
\hline Site & 1 & SIMPLE 4 & SIMPLE 5 & SIMPLE6-S01 & SIMPLE7-SC \\
\hline
\end{tabular}

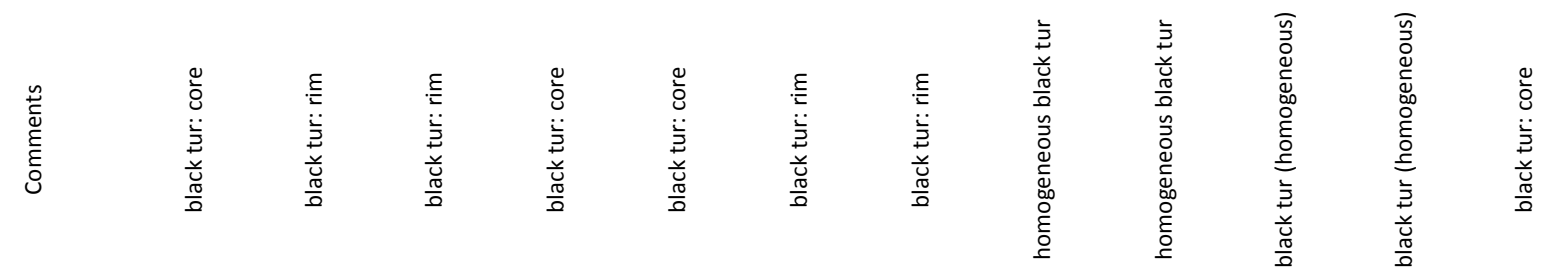

\begin{tabular}{|c|c|c|c|c|c|c|c|c|c|c|c|c|}
\hline Point & $138 \mathrm{t}-2$ & $138 \mathrm{t}-3$ & $138 \mathrm{t}-4$ & $84 t-1$ & $84 t-2$ & $84 t-3$ & $84 t-4$ & $85 t-1$ & $85 t-2$ & $86 \mathrm{t}-1$ & $86 \mathrm{t}-2$ & $87 \mathrm{t}-1$ \\
\hline $\mathrm{SiO}_{2}$ (wt.\%) & 35.15 & 35.22 & 35.19 & 36.24 & 35.51 & 35.91 & 35.43 & 36.57 & 35.88 & 34.44 & 34.70 & 36.05 \\
\hline $\mathrm{TiO}_{2}$ & 1.14 & 1.03 & 0.80 & 0.50 & 0.48 & 0.86 & 0.90 & 0.69 & 0.78 & 0.89 & 0.77 & 0.32 \\
\hline $\mathrm{B}_{2} \mathrm{O}_{3} *$ & 10.43 & 10.38 & 10.33 & 10.63 & 10.54 & 10.45 & 10.45 & 10.65 & 10.55 & 10.40 & 10.39 & 10.58 \\
\hline $\mathrm{Al}_{2} \mathrm{O}_{3}$ & 30.39 & 29.89 & 29.74 & 32.69 & 32.68 & 30.67 & 30.98 & 33.26 & 33.01 & 32.05 & 31.89 & 34.20 \\
\hline $\mathrm{Cr}_{2} \mathrm{O}_{3}$ & 0.06 & 0.01 & 0.00 & 0.03 & 0.00 & 0.04 & 0.01 & 0.00 & 0.04 & 0.00 & 0.02 & 0.01 \\
\hline \multicolumn{13}{|l|}{$\mathrm{Bi}_{2} \mathrm{O}_{3}$} \\
\hline $\mathrm{Fe}_{2} \mathrm{O}_{3} *$ & 0.00 & 0.00 & 0.12 & 0.00 & 0.00 & 0.00 & 0.00 & 0.00 & 0.00 & 0.31 & 0.00 & 0.00 \\
\hline $\mathrm{FeO}^{*}$ & 7.14 & 8.78 & 8.78 & 7.80 & 7.79 & 9.08 & 9.07 & 6.84 & 6.96 & 7.78 & 8.01 & 7.61 \\
\hline $\mathrm{FeO}$ (tot) & 7.14 & 8.78 & 8.90 & 7.80 & 7.79 & 9.08 & 9.07 & 6.84 & 6.96 & 8.06 & 8.01 & 7.61 \\
\hline $\mathrm{MnO}$ & 0.14 & 0.12 & 0.11 & 0.03 & 0.04 & 0.14 & 0.14 & 0.05 & 0.02 & 0.08 & 0.10 & 0.04 \\
\hline $\mathrm{ZnO}$ & 0.00 & 0.00 & 0.00 & 0.07 & 0.03 & 0.01 & 0.01 & 0.00 & 0.00 & 0.00 & 0.10 & 0.00 \\
\hline $\mathrm{MgO}$ & 8.08 & 7.34 & 7.24 & 6.70 & 6.75 & 6.53 & 6.61 & 6.59 & 6.59 & 6.72 & 6.64 & 5.57 \\
\hline $\mathrm{Li}_{2} \mathrm{O}^{*}$ & 0.00 & 0.00 & 0.00 & 0.00 & 0.00 & 0.00 & 0.00 & 0.00 & 0.00 & 0.00 & 0.00 & 0.00 \\
\hline $\mathrm{CaO}$ & 1.26 & 1.26 & 1.12 & 0.87 & 0.87 & 0.81 & 0.78 & 0.63 & 0.64 & 0.72 & 0.69 & 0.52 \\
\hline $\mathrm{Na}_{2} \mathrm{O}$ & 1.98 & 1.90 & 1.94 & 2.01 & 2.13 & 2.10 & 2.12 & 1.82 & 2.13 & 1.96 & 2.06 & 1.74 \\
\hline $\mathrm{K}_{2} \mathrm{O}$ & 0.05 & 0.06 & 0.05 & 0.05 & 0.05 & 0.05 & 0.06 & 0.05 & 0.06 & 0.05 & 0.05 & 0.06 \\
\hline$F$ & 0.39 & 0.27 & 0.29 & 0.27 & 0.25 & 0.18 & 0.24 & 0.24 & 0.28 & 0.26 & 0.31 & 0.18 \\
\hline $\mathrm{Cl}$ & 0.00 & 0.00 & 0.00 & 0.01 & 0.00 & 0.00 & 0.01 & 0.00 & 0.01 & 0.00 & 0.00 & 0.00 \\
\hline $\mathrm{H}_{2} \mathrm{O}^{*}$ & 3.34 & 3.42 & 3.43 & 3.33 & 3.36 & 3.38 & 3.44 & 3.27 & 3.20 & 3.46 & 3.42 & 3.30 \\
\hline$-(\mathrm{O}=\mathrm{F}, \mathrm{Cl})$ & -0.17 & -0.12 & -0.12 & -0.12 & -0.10 & -0.07 & -0.10 & -0.10 & -0.12 & -0.11 & -0.13 & -0.08 \\
\hline Total & 99.37 & 99.58 & 99.03 & 101.12 & 100.38 & 100.14 & 100.17 & 100.55 & 100.03 & 99.01 & 99.02 & 100.10 \\
\hline T Si (apfu) & 5.858 & 5.895 & 5.919 & 5.924 & 5.852 & 5.972 & 5.892 & 5.971 & 5.909 & 5.758 & 5.806 & 5.922 \\
\hline T Al & 0.142 & 0.105 & 0.081 & 0.076 & 0.148 & 0.028 & 0.108 & 0.029 & 0.091 & 0.242 & 0.194 & 0.078 \\
\hline B & 3 & 3 & 3 & 3 & 3 & 3 & 3 & 3 & 3 & 3 & 3 & 3 \\
\hline $\mathrm{Z} \mathrm{Al}$ & 5.828 & 5.792 & 5.816 & 6.000 & 6.000 & 5.984 & 5.964 & 6.000 & 6.000 & 6.000 & 6.000 & 6.000 \\
\hline Y Ti & 0.142 & 0.130 & 0.102 & 0.061 & 0.060 & 0.108 & 0.112 & 0.085 & 0.097 & 0.112 & 0.097 & 0.039 \\
\hline Y Al & 0.000 & 0.000 & 0.000 & 0.222 & 0.200 & 0.000 & 0.000 & 0.371 & 0.318 & 0.074 & 0.095 & 0.544 \\
\hline $\mathrm{YCr}$ & 0.007 & 0.001 & 0.000 & 0.004 & 0.000 & 0.005 & 0.002 & 0.000 & 0.005 & 0.001 & 0.003 & 0.002 \\
\hline $\mathrm{Y} \mathrm{Fe}^{3+}$ & 0.000 & 0.000 & 0.016 & 0.000 & 0.000 & 0.000 & 0.000 & 0.000 & 0.000 & 0.039 & 0.000 & 0.000 \\
\hline $\mathrm{YFe}^{2+}$ & 0.995 & 1.228 & 1.236 & 1.067 & 1.073 & 1.263 & 1.262 & 0.935 & 0.958 & 1.087 & 1.122 & 1.045 \\
\hline Y Mn & 0.020 & 0.016 & 0.015 & 0.004 & 0.005 & 0.019 & 0.019 & 0.006 & 0.003 & 0.012 & 0.015 & 0.006 \\
\hline Y Zn & 0.000 & 0.000 & 0.000 & 0.008 & 0.004 & 0.002 & 0.002 & 0.000 & 0.000 & 0.000 & 0.012 & 0.000 \\
\hline Y Mg & 2.007 & 1.832 & 1.816 & 1.634 & 1.658 & 1.619 & 1.639 & 1.603 & 1.618 & 1.676 & 1.656 & 1.364 \\
\hline Y Li & 0.000 & 0.000 & 0.000 & 0.000 & 0.000 & 0.000 & 0.000 & 0.000 & 0.000 & 0.000 & 0.000 & 0.000 \\
\hline X Ca & 0.225 & 0.227 & 0.201 & 0.153 & 0.154 & 0.145 & 0.139 & 0.109 & 0.112 & 0.129 & 0.124 & 0.092 \\
\hline X Na & 0.639 & 0.617 & 0.633 & 0.638 & 0.680 & 0.676 & 0.685 & 0.575 & 0.679 & 0.635 & 0.669 & 0.553 \\
\hline x K & 0.011 & 0.014 & 0.011 & 0.011 & 0.011 & 0.012 & 0.013 & 0.011 & 0.012 & 0.010 & 0.010 & 0.012 \\
\hline $\mathrm{X}$ vac & 0.125 & 0.143 & 0.156 & 0.198 & 0.155 & 0.167 & 0.163 & 0.305 & 0.196 & 0.225 & 0.197 & 0.343 \\
\hline $\mathrm{VOH}$ & 3.000 & 3.000 & 3.000 & 3.000 & 3.000 & 3.000 & 3.000 & 3.000 & 3.000 & 3.000 & 3.000 & 3.000 \\
\hline VO & 0.000 & 0.000 & 0.000 & 0.000 & 0.000 & 0.000 & 0.000 & 0.000 & 0.000 & 0.000 & 0.000 & 0.000 \\
\hline W F & 0.207 & 0.144 & 0.155 & 0.141 & 0.129 & 0.092 & 0.124 & 0.125 & 0.143 & 0.139 & 0.163 & 0.093 \\
\hline W Cl & 0.000 & 0.001 & 0.000 & 0.004 & 0.000 & 0.000 & 0.002 & 0.000 & 0.002 & 0.001 & 0.000 & 0.000 \\
\hline $\mathrm{WOH}$ & 0.716 & 0.823 & 0.844 & 0.628 & 0.699 & 0.753 & 0.816 & 0.558 & 0.512 & 0.860 & 0.812 & 0.612 \\
\hline W O & 0.077 & 0.032 & 0.000 & 0.227 & 0.171 & 0.155 & 0.058 & 0.316 & 0.343 & 0.000 & 0.025 & 0.295 \\
\hline Classif. & dravite & dravite & dravite & dravite & dravite & dravite & dravite & dravite & dravite & dravite & dravite & dravite \\
\hline
\end{tabular}


Appendix D.1 (contd.): Electron-microprobe analyses of tourmaline.

\begin{tabular}{|c|c|c|c|c|c|c|c|c|c|c|c|c|}
\hline Site & & & & & & APLE9-S0 & & & & & & \\
\hline 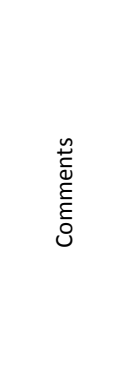 & 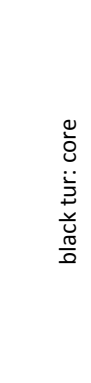 & 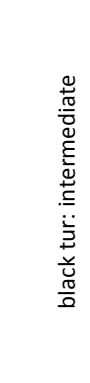 & 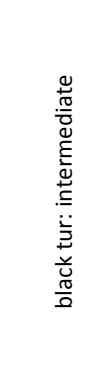 & 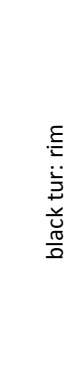 & 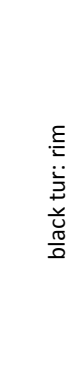 & 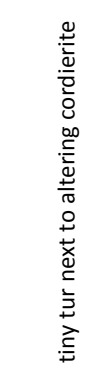 & 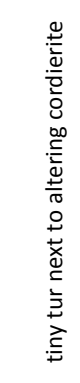 & 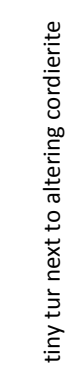 & 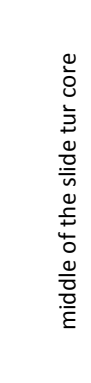 & 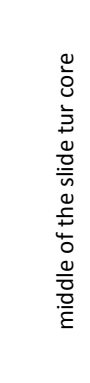 & 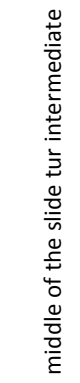 & 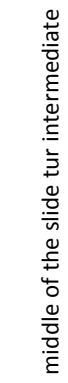 \\
\hline Point & $87 \mathrm{t}-2$ & $87 t-3$ & $87 \mathrm{t}-4$ & $87 t-5$ & $87 \mathrm{t}-6$ & $94 \mathrm{~S}-1$ & $94 \mathrm{~S}-2$ & $945-3$ & $94 \mathrm{~S}-4$ & $94 \mathrm{~S}-5$ & $94 \mathrm{~S}-6$ & $94 S-7$ \\
\hline $\mathrm{SiO}_{2}$ (wt.\%) & 35.65 & 34.22 & 34.86 & 34.51 & 34.36 & 33.93 & 33.79 & 34.42 & 35.06 & 34.48 & 33.96 & 33.90 \\
\hline $\mathrm{TiO}_{2}$ & 0.21 & 0.69 & 0.53 & 0.26 & 0.24 & 0.10 & 0.28 & 0.34 & 0.22 & 0.26 & 0.57 & 0.60 \\
\hline $\mathrm{B}_{2} \mathrm{O}_{3} *$ & 10.56 & 10.39 & 10.49 & 10.33 & 10.31 & 10.30 & 10.23 & 10.32 & 10.45 & 10.39 & 10.26 & 10.28 \\
\hline $\mathrm{Al}_{2} \mathrm{O}_{3}$ & 34.20 & 33.20 & 33.36 & 33.39 & 33.82 & 32.70 & 32.95 & 33.28 & 34.38 & 34.53 & 33.58 & 33.53 \\
\hline $\mathrm{Cr}_{2} \mathrm{O}_{3}$ & 0.00 & 0.03 & 0.01 & 0.05 & 0.00 & 0.03 & 0.00 & 0.00 & 0.06 & 0.00 & 0.00 & 0.00 \\
\hline \multicolumn{13}{|l|}{$\mathrm{Bi}_{2} \mathrm{O}_{3}$} \\
\hline $\mathrm{Fe}_{2} \mathrm{O}_{3} *$ & 0.00 & 0.00 & 0.00 & 0.72 & 0.18 & 1.17 & 0.41 & 0.00 & 0.00 & 0.00 & 0.00 & 0.00 \\
\hline $\mathrm{FeO}^{*}$ & 7.87 & 8.59 & 8.61 & 12.29 & 11.58 & 8.75 & 9.19 & 9.74 & 8.32 & 8.38 & 10.06 & 9.43 \\
\hline $\mathrm{FeO}$ (tot) & 7.87 & 8.59 & 8.61 & 12.93 & 11.75 & 9.81 & 9.56 & 9.74 & 8.32 & 8.38 & 10.06 & 9.43 \\
\hline $\mathrm{MnO}$ & 0.07 & 0.08 & 0.11 & 0.10 & 0.08 & 0.12 & 0.04 & 0.10 & 0.12 & 0.03 & 0.10 & 0.09 \\
\hline $\mathrm{ZnO}$ & 0.00 & 0.08 & 0.12 & 0.00 & 0.00 & 0.06 & 0.00 & 0.00 & 0.07 & 0.06 & 0.00 & 0.00 \\
\hline $\mathrm{MgO}$ & 5.61 & 5.70 & 5.75 & 2.80 & 3.12 & 5.35 & 4.99 & 4.67 & 4.91 & 4.84 & 4.10 & 4.62 \\
\hline $\mathrm{Li}_{2} \mathrm{O}^{*}$ & 0.00 & 0.00 & 0.00 & 0.00 & 0.00 & 0.00 & 0.00 & 0.00 & 0.00 & 0.00 & 0.00 & 0.00 \\
\hline $\mathrm{CaO}$ & 0.35 & 0.78 & 0.76 & 0.14 & 0.15 & 0.42 & 0.52 & 0.33 & 0.28 & 0.30 & 0.40 & 0.45 \\
\hline $\mathrm{Na}_{2} \mathrm{O}$ & 1.95 & 1.90 & 1.90 & 1.68 & 1.66 & 2.16 & 1.81 & 1.86 & 1.80 & 1.68 & 1.84 & 2.02 \\
\hline $\mathrm{K}_{2} \mathrm{O}$ & 0.05 & 0.05 & 0.05 & 0.04 & 0.03 & 0.03 & 0.06 & 0.05 & 0.03 & 0.05 & 0.04 & 0.04 \\
\hline$F$ & 0.15 & 0.08 & 0.23 & 0.12 & 0.21 & 0.23 & 0.26 & 0.25 & 0.21 & 0.19 & 0.14 & 0.19 \\
\hline $\mathrm{Cl}$ & 0.00 & 0.00 & 0.00 & 0.00 & 0.00 & 0.00 & 0.00 & 0.01 & 0.00 & 0.00 & 0.01 & 0.00 \\
\hline $\mathrm{H}_{2} \mathrm{O}^{*}$ & 3.41 & 3.49 & 3.43 & 3.51 & 3.46 & 3.44 & 3.41 & 3.43 & 3.37 & 3.43 & 3.38 & 3.34 \\
\hline$-(\mathrm{O}=\mathrm{F}, \mathrm{Cl})$ & -0.06 & -0.03 & -0.10 & -0.05 & -0.09 & -0.10 & -0.11 & -0.11 & -0.09 & -0.08 & -0.06 & -0.08 \\
\hline Total & 100.02 & 99.25 & 100.10 & 99.88 & 99.11 & 98.72 & 97.82 & 98.70 & 99.19 & 98.56 & 98.39 & 98.41 \\
\hline T Si (apfu) & 5.868 & 5.723 & 5.776 & 5.805 & 5.795 & 5.726 & 5.741 & 5.796 & 5.830 & 5.767 & 5.750 & 5.732 \\
\hline TAl & 0.132 & 0.277 & 0.224 & 0.195 & 0.205 & 0.274 & 0.259 & 0.204 & 0.170 & 0.233 & 0.250 & 0.268 \\
\hline B & 3 & 3 & 3 & 3 & 3 & 3 & 3 & 3 & 3 & 3 & 3 & 3 \\
\hline $\mathrm{ZAl}$ & 6.000 & 6.000 & 6.000 & 6.000 & 6.000 & 6.000 & 6.000 & 6.000 & 6.000 & 6.000 & 6.000 & 6.000 \\
\hline $\mathrm{YTi}$ & 0.026 & 0.087 & 0.066 & 0.033 & 0.031 & 0.013 & 0.035 & 0.043 & 0.028 & 0.033 & 0.073 & 0.077 \\
\hline Y Al & 0.504 & 0.266 & 0.290 & 0.425 & 0.516 & 0.228 & 0.337 & 0.399 & 0.566 & 0.574 & 0.452 & 0.413 \\
\hline $\mathrm{YCr}$ & 0.000 & 0.004 & 0.001 & 0.006 & 0.000 & 0.004 & 0.000 & 0.000 & 0.008 & 0.000 & 0.000 & 0.000 \\
\hline $\mathrm{YFe}^{3+}$ & 0.000 & 0.000 & 0.000 & 0.091 & 0.023 & 0.149 & 0.052 & 0.000 & 0.000 & 0.000 & 0.000 & 0.000 \\
\hline $\mathrm{Y} \mathrm{Fe}^{2+}$ & 1.084 & 1.201 & 1.193 & 1.729 & 1.633 & 1.235 & 1.306 & 1.372 & 1.157 & 1.172 & 1.425 & 1.334 \\
\hline Y Mn & 0.010 & 0.011 & 0.016 & 0.014 & 0.011 & 0.017 & 0.006 & 0.014 & 0.016 & 0.004 & 0.015 & 0.013 \\
\hline Y Zn & 0.000 & 0.010 & 0.014 & 0.000 & 0.000 & 0.008 & 0.000 & 0.000 & 0.008 & 0.008 & 0.000 & 0.000 \\
\hline Y Mg & 1.377 & 1.421 & 1.421 & 0.702 & 0.785 & 1.346 & 1.263 & 1.171 & 1.216 & 1.208 & 1.035 & 1.164 \\
\hline Y Li & 0.000 & 0.000 & 0.000 & 0.000 & 0.000 & 0.000 & 0.000 & 0.000 & 0.000 & 0.000 & 0.000 & 0.000 \\
\hline $\mathrm{XCa}$ & 0.061 & 0.140 & 0.135 & 0.025 & 0.028 & 0.077 & 0.095 & 0.060 & 0.050 & 0.054 & 0.073 & 0.081 \\
\hline $\mathrm{X} \mathrm{Na}$ & 0.623 & 0.615 & 0.610 & 0.548 & 0.543 & 0.707 & 0.597 & 0.607 & 0.580 & 0.544 & 0.603 & 0.662 \\
\hline$x \mathrm{~K}$ & 0.011 & 0.011 & 0.011 & 0.008 & 0.006 & 0.006 & 0.013 & 0.011 & 0.007 & 0.011 & 0.010 & 0.009 \\
\hline $\mathrm{X}$ vac & 0.305 & 0.234 & 0.245 & 0.418 & 0.424 & 0.210 & 0.296 & 0.322 & 0.363 & 0.392 & 0.314 & 0.248 \\
\hline $\mathrm{VOH}$ & 3.000 & 3.000 & 3.000 & 3.000 & 3.000 & 3.000 & 3.000 & 3.000 & 3.000 & 3.000 & 3.000 & 3.000 \\
\hline Vo & 0.000 & 0.000 & 0.000 & 0.000 & 0.000 & 0.000 & 0.000 & 0.000 & 0.000 & 0.000 & 0.000 & 0.000 \\
\hline W F & 0.079 & 0.040 & 0.123 & 0.062 & 0.110 & 0.123 & 0.138 & 0.132 & 0.112 & 0.101 & 0.072 & 0.100 \\
\hline W Cl & 0.000 & 0.000 & 0.000 & 0.000 & 0.000 & 0.000 & 0.000 & 0.002 & 0.000 & 0.000 & 0.002 & 0.000 \\
\hline W OH & 0.742 & 0.888 & 0.788 & 0.938 & 0.890 & 0.877 & 0.862 & 0.846 & 0.741 & 0.829 & 0.818 & 0.769 \\
\hline wo & 0.180 & 0.072 & 0.089 & 0.000 & 0.000 & 0.000 & 0.000 & 0.020 & 0.147 & 0.070 & 0.108 & 0.131 \\
\hline Classif. & dravite & dravite & dravite & schorl & schorl & dravite & schorl & schorl & dravite & dravite & schorl & schorl \\
\hline
\end{tabular}


Appendix D.1 (contd.): Electron-microprobe analyses of tourmaline.

\begin{tabular}{|c|c|c|c|c|c|c|c|c|c|c|c|c|}
\hline \multicolumn{2}{|l|}{ Site } & \multicolumn{11}{|c|}{ SIMPLE9-S04-3 } \\
\hline 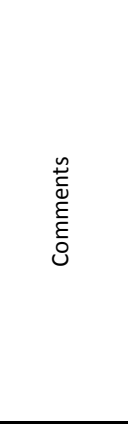 & 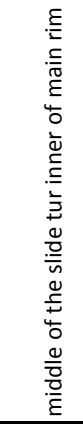 & 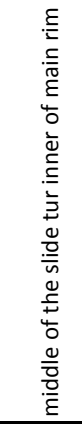 & 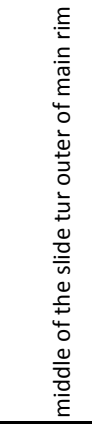 & 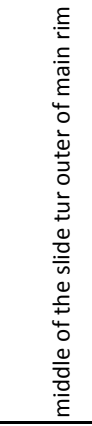 & 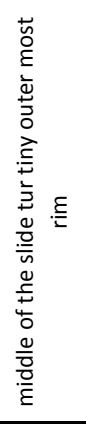 & 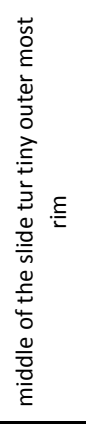 & 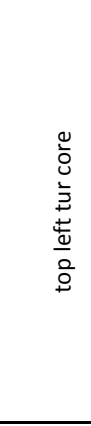 & 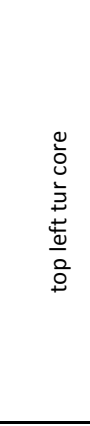 & 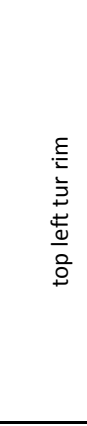 & 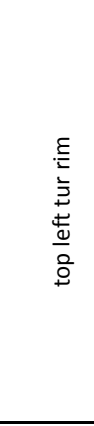 & 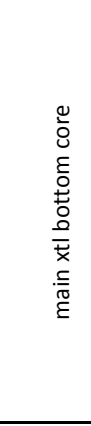 & 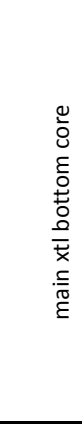 \\
\hline Point & $94 S-8$ & $94 S-9$ & $94 \mathrm{~S}-10$ & $94 \mathrm{~S}-11$ & $94 \mathrm{~S}-12$ & $94 \mathrm{~S}-13$ & 94S3-1 & $94 \mathrm{~S} 3-2$ & $9453-3$ & $94 S 3-4$ & $94 S 3-5$ & $94 S 3-6$ \\
\hline $\mathrm{SiO}_{2}$ (wt.\%) & 32.73 & 32.75 & 33.14 & 33.27 & 33.94 & 34.31 & 35.58 & 35.72 & 35.23 & 34.83 & 34.88 & 35.15 \\
\hline $\mathrm{TiO}_{2}$ & 0.70 & 0.61 & 0.46 & 0.54 & 0.53 & 0.56 & 0.35 & 0.25 & 0.53 & 0.54 & 0.47 & 0.46 \\
\hline $\mathrm{B}_{2} \mathrm{O}_{3} *$ & 10.11 & 10.14 & 10.13 & 10.14 & 10.33 & 10.30 & 10.52 & 10.59 & 10.47 & 10.38 & 10.41 & 10.45 \\
\hline $\mathrm{Al}_{2} \mathrm{O}_{3}$ & 33.75 & 33.93 & 33.47 & 33.47 & 32.85 & 32.72 & 33.93 & 34.24 & 33.16 & 33.34 & 33.10 & 33.09 \\
\hline $\mathrm{Cr}_{2} \mathrm{O}_{3}$ & 0.01 & 0.00 & 0.00 & 0.06 & 0.02 & 0.00 & 0.00 & 0.05 & 0.06 & 0.04 & 0.03 & 0.00 \\
\hline \multicolumn{13}{|l|}{$\mathrm{Bi}_{2} \mathrm{O}_{3}$} \\
\hline $\mathrm{Fe}_{2} \mathrm{O}_{3} *$ & 0.00 & 0.00 & 0.00 & 0.00 & 0.91 & 0.00 & 0.00 & 0.00 & 0.00 & 0.00 & 0.00 & 0.00 \\
\hline $\mathrm{FeO}^{*}$ & 12.73 & 12.94 & 11.96 & 12.00 & 9.39 & 9.79 & 7.97 & 8.10 & 9.49 & 8.85 & 8.14 & 8.37 \\
\hline $\mathrm{FeO}$ (tot) & 12.73 & 12.94 & 11.96 & 12.00 & 10.21 & 9.79 & 7.97 & 8.10 & 9.49 & 8.85 & 8.14 & 8.37 \\
\hline $\mathrm{MnO}$ & 0.19 & 0.23 & 0.23 & 0.17 & 0.12 & 0.10 & 0.07 & 0.05 & 0.10 & 0.06 & 0.07 & 0.03 \\
\hline $\mathrm{ZnO}$ & 0.00 & 0.02 & 0.01 & 0.07 & 0.05 & 0.04 & 0.00 & 0.07 & 0.06 & 0.00 & 0.05 & 0.03 \\
\hline $\mathrm{MgO}$ & 2.26 & 2.21 & 2.85 & 2.72 & 4.95 & 4.87 & 5.55 & 5.51 & 5.04 & 5.10 & 5.83 & 5.80 \\
\hline $\mathrm{Li}_{2} \mathrm{O}^{*}$ & 0.00 & 0.00 & 0.00 & 0.00 & 0.00 & 0.00 & 0.00 & 0.00 & 0.00 & 0.00 & 0.00 & 0.00 \\
\hline $\mathrm{CaO}$ & 0.44 & 0.46 & 0.38 & 0.35 & 0.50 & 0.49 & 0.41 & 0.42 & 0.50 & 0.50 & 0.75 & 0.73 \\
\hline $\mathrm{Na}_{2} \mathrm{O}$ & 1.94 & 2.03 & 2.00 & 1.88 & 1.89 & 1.80 & 1.80 & 1.74 & 1.98 & 1.86 & 1.93 & 1.89 \\
\hline $\mathrm{K}_{2} \mathrm{O}$ & 0.04 & 0.06 & 0.05 & 0.06 & 0.05 & 0.06 & 0.04 & 0.04 & 0.05 & 0.05 & 0.04 & 0.06 \\
\hline$F$ & 0.07 & 0.19 & 0.21 & 0.22 & 0.30 & 0.43 & 0.19 & 0.27 & 0.07 & 0.31 & 0.19 & 0.43 \\
\hline $\mathrm{Cl}$ & 0.00 & 0.00 & 0.00 & 0.00 & 0.00 & 0.00 & 0.00 & 0.01 & 0.01 & 0.00 & 0.00 & 0.00 \\
\hline $\mathrm{H}_{2} \mathrm{O}^{*}$ & 3.37 & 3.33 & 3.32 & 3.31 & 3.42 & 3.33 & 3.39 & 3.40 & 3.43 & 3.29 & 3.34 & 3.24 \\
\hline$-(\mathrm{O}=\mathrm{F}, \mathrm{Cl})$ & -0.03 & -0.08 & -0.09 & -0.09 & -0.13 & -0.18 & -0.08 & -0.12 & -0.03 & -0.13 & -0.08 & -0.18 \\
\hline Total & 98.31 & 98.83 & 98.12 & 98.19 & 99.13 & 98.61 & 99.72 & 100.37 & 100.13 & 99.02 & 99.14 & 99.55 \\
\hline T Si (apfu) & 5.629 & 5.612 & 5.688 & 5.706 & 5.712 & 5.792 & 5.876 & 5.863 & 5.851 & 5.829 & 5.823 & 5.846 \\
\hline TAl & 0.371 & 0.388 & 0.312 & 0.294 & 0.288 & 0.208 & 0.124 & 0.137 & 0.149 & 0.171 & 0.177 & 0.154 \\
\hline B & 3 & 3 & 3 & 3 & 3 & 3 & 3 & 3 & 3 & 3 & 3 & 3 \\
\hline Z Al & 6.000 & 6.000 & 6.000 & 6.000 & 6.000 & 6.000 & 6.000 & 6.000 & 6.000 & 6.000 & 6.000 & 6.000 \\
\hline Y Ti & 0.091 & 0.079 & 0.059 & 0.070 & 0.067 & 0.072 & 0.043 & 0.031 & 0.067 & 0.068 & 0.059 & 0.058 \\
\hline Y Al & 0.469 & 0.465 & 0.459 & 0.470 & 0.228 & 0.303 & 0.479 & 0.486 & 0.341 & 0.405 & 0.335 & 0.333 \\
\hline $\mathrm{YCr}$ & 0.002 & 0.000 & 0.000 & 0.009 & 0.003 & 0.000 & 0.000 & 0.007 & 0.007 & 0.006 & 0.004 & 0.000 \\
\hline $\mathrm{YFe}^{3+}$ & 0.000 & 0.000 & 0.000 & 0.000 & 0.115 & 0.000 & 0.000 & 0.000 & 0.000 & 0.000 & 0.000 & 0.000 \\
\hline $\mathrm{Y} \mathrm{Fe}^{2+}$ & 1.831 & 1.855 & 1.717 & 1.721 & 1.322 & 1.382 & 1.101 & 1.111 & 1.318 & 1.239 & 1.136 & 1.164 \\
\hline Y Mn & 0.028 & 0.033 & 0.034 & 0.025 & 0.017 & 0.015 & 0.010 & 0.007 & 0.014 & 0.009 & 0.010 & 0.005 \\
\hline $\mathrm{Y} Z \mathrm{n}$ & 0.000 & 0.002 & 0.001 & 0.009 & 0.006 & 0.004 & 0.000 & 0.009 & 0.007 & 0.000 & 0.006 & 0.004 \\
\hline Y Mg & 0.579 & 0.566 & 0.730 & 0.696 & 1.243 & 1.225 & 1.367 & 1.349 & 1.247 & 1.273 & 1.450 & 1.438 \\
\hline Y Li & 0.000 & 0.000 & 0.000 & 0.000 & 0.000 & 0.000 & 0.000 & 0.000 & 0.000 & 0.000 & 0.000 & 0.000 \\
\hline X Ca & 0.080 & 0.084 & 0.070 & 0.065 & 0.090 & 0.088 & 0.073 & 0.074 & 0.090 & 0.089 & 0.134 & 0.129 \\
\hline $\mathrm{X} \mathrm{Na}$ & 0.645 & 0.676 & 0.666 & 0.626 & 0.617 & 0.589 & 0.577 & 0.554 & 0.638 & 0.604 & 0.623 & 0.610 \\
\hline x K & 0.008 & 0.013 & 0.011 & 0.013 & 0.011 & 0.013 & 0.008 & 0.009 & 0.010 & 0.010 & 0.009 & 0.013 \\
\hline X vac & 0.267 & 0.228 & 0.253 & 0.296 & 0.282 & 0.310 & 0.342 & 0.363 & 0.263 & 0.298 & 0.234 & 0.247 \\
\hline $\mathrm{VOH}$ & 3.000 & 3.000 & 3.000 & 3.000 & 3.000 & 3.000 & 3.000 & 3.000 & 3.000 & 3.000 & 3.000 & 3.000 \\
\hline Vo & 0.000 & 0.000 & 0.000 & 0.000 & 0.000 & 0.000 & 0.000 & 0.000 & 0.000 & 0.000 & 0.000 & 0.000 \\
\hline W F & 0.040 & 0.102 & 0.113 & 0.118 & 0.159 & 0.231 & 0.098 & 0.142 & 0.035 & 0.165 & 0.098 & 0.227 \\
\hline W Cl & 0.000 & 0.001 & 0.000 & 0.000 & 0.000 & 0.000 & 0.000 & 0.003 & 0.002 & 0.001 & 0.000 & 0.001 \\
\hline $\mathrm{WOH}$ & 0.865 & 0.806 & 0.805 & 0.789 & 0.841 & 0.754 & 0.730 & 0.726 & 0.802 & 0.667 & 0.722 & 0.596 \\
\hline W O & 0.095 & 0.091 & 0.082 & 0.094 & 0.000 & 0.015 & 0.172 & 0.129 & 0.160 & 0.167 & 0.179 & 0.176 \\
\hline Classif. & schorl & schorl & schorl & schorl & schorl & schorl & dravite & dravite & schorl & dravite & dravite & dravite \\
\hline
\end{tabular}


Appendix D.1 (contd.): Electron-microprobe analyses of tourmaline.

Site SIMPLE9-S04-4 contact between pegmatite and host rock

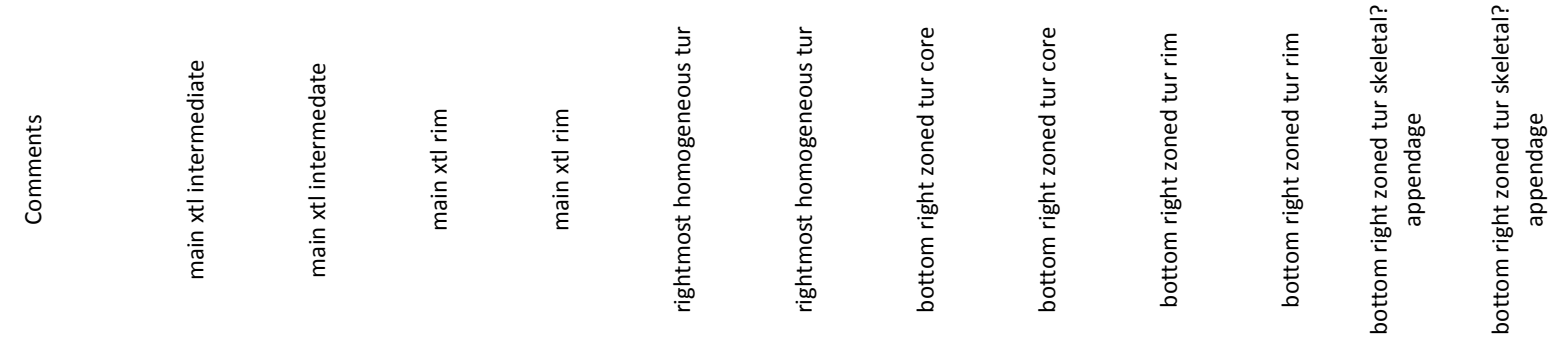

\begin{tabular}{|c|c|c|c|c|c|c|c|c|c|c|c|c|}
\hline Point & 94S3-7 & $94 S 3-8$ & 94S3-9 & $94 S 3-10$ & 94S4-1 & $9454-2$ & 94S4-3 & 94S4-4 & 94S4-5 & $94 S 4-6$ & 94S4-7 & $9454-8$ \\
\hline $\mathrm{SiO}_{2}$ (wt.\%) & 35.24 & 34.48 & 36.05 & 36.57 & 35.23 & 34.76 & 35.32 & 35.62 & 35.02 & 34.91 & 34.59 & 34.83 \\
\hline $\mathrm{TiO}_{2}$ & 0.28 & 0.51 & 0.06 & 0.08 & 0.57 & 0.51 & 0.17 & 0.24 & 0.36 & 0.52 & 0.48 & 0.43 \\
\hline $\mathrm{B}_{2} \mathrm{O}_{3} *$ & 10.41 & 10.29 & 10.56 & 10.59 & 10.46 & 10.44 & 10.50 & 10.57 & 10.48 & 10.47 & 10.35 & 10.33 \\
\hline $\mathrm{Al}_{2} \mathrm{O}_{3}$ & 32.58 & 33.44 & 32.91 & 32.77 & 32.56 & 33.55 & 34.52 & 34.73 & 33.75 & 33.27 & 33.02 & 32.38 \\
\hline $\mathrm{Cr}_{2} \mathrm{O}_{3}$ & 0.02 & 0.03 & 0.01 & 0.00 & 0.06 & 0.07 & 0.01 & 0.00 & 0.00 & 0.00 & 0.01 & 0.02 \\
\hline \multicolumn{13}{|l|}{$\mathrm{Bi}_{2} \mathrm{O}_{3}$} \\
\hline $\mathrm{Fe}_{2} \mathrm{O}_{3} *$ & 0.00 & 0.00 & 0.00 & 0.00 & 0.00 & 0.00 & 0.00 & 0.00 & 0.00 & 0.00 & 0.00 & 0.00 \\
\hline $\mathrm{FeO}^{*}$ & 9.44 & 10.19 & 7.36 & 7.30 & 8.57 & 8.12 & 7.53 & 7.57 & 8.22 & 8.41 & 9.94 & 9.68 \\
\hline $\mathrm{FeO}$ (tot) & 9.44 & 10.19 & 7.36 & 7.30 & 8.57 & 8.12 & 7.53 & 7.57 & 8.22 & 8.41 & 9.94 & 9.68 \\
\hline $\mathrm{MnO}$ & 0.11 & 0.05 & 0.28 & 0.22 & 0.03 & 0.09 & 0.05 & 0.06 & 0.04 & 0.06 & 0.16 & 0.14 \\
\hline $\mathrm{ZnO}$ & 0.08 & 0.00 & 0.04 & 0.06 & 0.03 & 0.00 & 0.01 & 0.03 & 0.05 & 0.00 & 0.06 & 0.04 \\
\hline $\mathrm{MgO}$ & 5.35 & 3.98 & 6.61 & 6.57 & 6.05 & 5.72 & 5.47 & 5.43 & 5.64 & 5.90 & 4.65 & 5.08 \\
\hline $\mathrm{Li}_{2} \mathrm{O}^{*}$ & 0.00 & 0.00 & 0.00 & 0.00 & 0.00 & 0.00 & 0.00 & 0.00 & 0.00 & 0.00 & 0.00 & 0.00 \\
\hline $\mathrm{CaO}$ & 0.43 & 0.31 & 0.21 & 0.19 & 0.76 & 0.67 & 0.32 & 0.36 & 0.62 & 0.81 & 0.42 & 0.43 \\
\hline $\mathrm{Na}_{2} \mathrm{O}$ & 2.04 & 1.78 & 2.16 & 2.03 & 1.96 & 1.95 & 1.59 & 1.69 & 1.88 & 1.94 & 1.97 & 2.16 \\
\hline $\mathrm{K}_{2} \mathrm{O}$ & 0.04 & 0.06 & 0.05 & 0.02 & 0.05 & 0.05 & 0.03 & 0.03 & 0.05 & 0.05 & 0.05 & 0.03 \\
\hline$F$ & 0.21 & 0.19 & 0.42 & 0.36 & 0.22 & 0.18 & 0.07 & 0.17 & 0.25 & 0.12 & 0.08 & 0.53 \\
\hline $\mathrm{Cl}$ & 0.01 & 0.00 & 0.00 & 0.00 & 0.00 & 0.00 & 0.00 & 0.00 & 0.01 & 0.01 & 0.00 & 0.00 \\
\hline $\mathrm{H}_{2} \mathrm{O}^{*}$ & 3.43 & 3.33 & 3.41 & 3.43 & 3.38 & 3.37 & 3.50 & 3.41 & 3.36 & 3.42 & 3.46 & 3.20 \\
\hline$-(\mathrm{O}=\mathrm{F}, \mathrm{Cl})$ & -0.09 & -0.08 & -0.18 & -0.15 & -0.09 & -0.07 & -0.03 & -0.07 & -0.11 & -0.05 & -0.03 & -0.23 \\
\hline Total & 99.59 & 98.54 & 99.96 & 100.04 & 99.83 & 99.41 & 99.08 & 99.83 & 99.62 & 99.84 & 99.21 & 99.06 \\
\hline T Si (apfu) & 5.881 & 5.825 & 5.931 & 6.000 & 5.852 & 5.784 & 5.844 & 5.858 & 5.809 & 5.794 & 5.810 & 5.861 \\
\hline T Al & 0.119 & 0.175 & 0.069 & 0.000 & 0.148 & 0.216 & 0.156 & 0.142 & 0.191 & 0.206 & 0.190 & 0.139 \\
\hline B & 3 & 3 & 3 & 3 & 3 & 3 & 3 & 3 & 3 & 3 & 3 & 3 \\
\hline $\mathrm{Z} \mathrm{Al}$ & 6.000 & 6.000 & 6.000 & 6.000 & 6.000 & 6.000 & 6.000 & 6.000 & 6.000 & 6.000 & 6.000 & 6.000 \\
\hline Y Ti & 0.036 & 0.065 & 0.008 & 0.010 & 0.071 & 0.064 & 0.021 & 0.029 & 0.045 & 0.064 & 0.061 & 0.055 \\
\hline Y Al & 0.289 & 0.484 & 0.312 & 0.337 & 0.226 & 0.365 & 0.577 & 0.588 & 0.408 & 0.300 & 0.347 & 0.283 \\
\hline $\mathrm{YCr}$ & 0.003 & 0.004 & 0.001 & 0.000 & 0.007 & 0.009 & 0.002 & 0.000 & 0.000 & 0.000 & 0.002 & 0.002 \\
\hline$Y \mathrm{Fe}^{3+}$ & 0.000 & 0.000 & 0.000 & 0.000 & 0.000 & 0.000 & 0.000 & 0.000 & 0.000 & 0.000 & 0.000 & 0.000 \\
\hline $\mathrm{Y} \mathrm{Fe}^{2+}$ & 1.318 & 1.439 & 1.013 & 1.002 & 1.191 & 1.130 & 1.041 & 1.041 & 1.140 & 1.167 & 1.396 & 1.362 \\
\hline Y Mn & 0.015 & 0.007 & 0.040 & 0.031 & 0.004 & 0.013 & 0.007 & 0.008 & 0.005 & 0.008 & 0.023 & 0.020 \\
\hline Y Zn & 0.009 & 0.000 & 0.004 & 0.007 & 0.004 & 0.000 & 0.002 & 0.004 & 0.006 & 0.000 & 0.008 & 0.005 \\
\hline Y Mg & 1.330 & 1.002 & 1.622 & 1.606 & 1.497 & 1.418 & 1.350 & 1.330 & 1.395 & 1.461 & 1.164 & 1.274 \\
\hline Y Li & 0.000 & 0.000 & 0.000 & 0.000 & 0.000 & 0.000 & 0.000 & 0.000 & 0.000 & 0.000 & 0.000 & 0.000 \\
\hline X Ca & 0.077 & 0.055 & 0.037 & 0.034 & 0.136 & 0.119 & 0.056 & 0.063 & 0.110 & 0.145 & 0.076 & 0.078 \\
\hline $\mathrm{X} \mathrm{Na}$ & 0.661 & 0.583 & 0.690 & 0.645 & 0.632 & 0.630 & 0.509 & 0.539 & 0.604 & 0.624 & 0.641 & 0.705 \\
\hline x K & 0.008 & 0.013 & 0.012 & 0.004 & 0.011 & 0.011 & 0.007 & 0.007 & 0.010 & 0.010 & 0.011 & 0.006 \\
\hline $\mathrm{X}$ vac & 0.254 & 0.349 & 0.262 & 0.317 & 0.221 & 0.240 & 0.428 & 0.392 & 0.276 & 0.221 & 0.272 & 0.210 \\
\hline $\mathrm{VOH}$ & 3.000 & 3.000 & 3.000 & 3.000 & 3.000 & 3.000 & 3.000 & 3.000 & 3.000 & 3.000 & 3.000 & 3.000 \\
\hline Vo & 0.000 & 0.000 & 0.000 & 0.000 & 0.000 & 0.000 & 0.000 & 0.000 & 0.000 & 0.000 & 0.000 & 0.000 \\
\hline W F & 0.111 & 0.103 & 0.220 & 0.185 & 0.117 & 0.092 & 0.039 & 0.087 & 0.132 & 0.064 & 0.044 & 0.284 \\
\hline W Cl & 0.002 & 0.000 & 0.001 & 0.000 & 0.000 & 0.000 & 0.001 & 0.000 & 0.002 & 0.002 & 0.000 & 0.001 \\
\hline $\mathrm{WOH}$ & 0.819 & 0.749 & 0.743 & 0.756 & 0.741 & 0.742 & 0.867 & 0.738 & 0.723 & 0.788 & 0.871 & 0.592 \\
\hline Wo & 0.068 & 0.149 & 0.035 & 0.059 & 0.142 & 0.166 & 0.093 & 0.175 & 0.143 & 0.146 & 0.085 & 0.123 \\
\hline Classif. & dravite & schorl & dravite & dravite & dravite & dravite & dravite & dravite & dravite & dravite & schorl & schorl \\
\hline
\end{tabular}


Appendix D.1 (contd.): Electron-microprobe analyses of tourmaline.

\begin{tabular}{|c|c|c|c|c|c|c|c|c|c|c|c|c|}
\hline Site & & & & & & & & & & & & \\
\hline 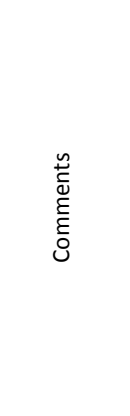 & 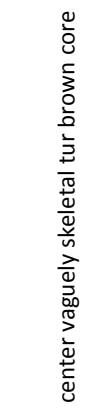 & 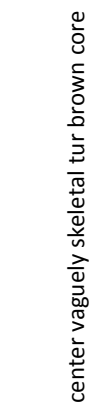 & 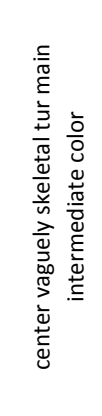 & 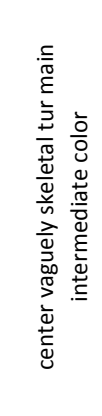 & 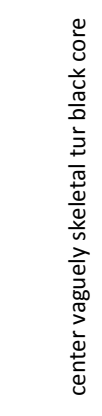 & 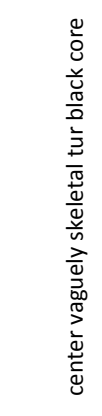 & 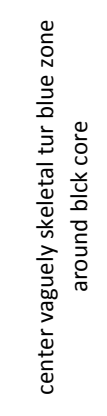 & 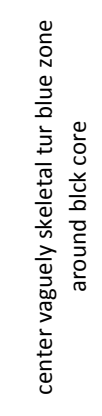 & 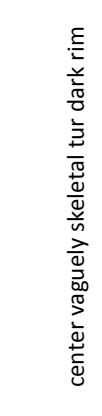 & 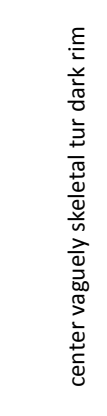 & 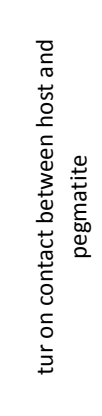 & 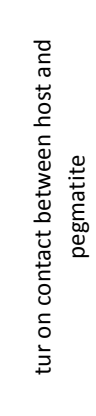 \\
\hline Point & 94S4-9 & $94 S 4-10$ & $9454-11$ & $9454-12$ & $9454-13$ & $9454-14$ & $94 S 4-15$ & $9454-16$ & 94S4-17 & 94S4-18 & 94S4-19 & 94S4-20 \\
\hline $\mathrm{SiO}_{2}$ (wt.\%) & 35.05 & 34.78 & 34.67 & 35.04 & 35.00 & 34.87 & 35.07 & 35.17 & 34.76 & 34.93 & 35.22 & 34.58 \\
\hline $\mathrm{TiO}_{2}$ & 0.74 & 0.81 & 0.52 & 0.45 & 0.73 & 0.54 & 0.24 & 0.38 & 0.34 & 0.41 & 0.52 & 0.51 \\
\hline $\mathrm{B}_{2} \mathrm{O}_{3}{ }^{*}$ & 10.46 & 10.40 & 10.45 & 10.43 & 10.35 & 10.36 & 10.50 & 10.56 & 10.38 & 10.40 & 10.47 & 10.41 \\
\hline $\mathrm{Al}_{2} \mathrm{O}_{3}$ & 33.00 & 32.59 & 33.53 & 33.34 & 31.45 & 31.67 & 34.65 & 34.77 & 32.84 & 32.81 & 33.52 & 33.18 \\
\hline $\mathrm{Cr}_{2} \mathrm{O}_{3}$ & 0.03 & 0.05 & 0.00 & 0.01 & 0.00 & 0.06 & 0.01 & 0.01 & 0.00 & 0.01 & 0.03 & 0.04 \\
\hline \multicolumn{13}{|l|}{$\mathrm{Bi}_{2} \mathrm{O}_{3}$} \\
\hline $\mathrm{Fe}_{2} \mathrm{O}_{3}{ }^{*}$ & 0.00 & 0.00 & 0.00 & 0.00 & 0.00 & 0.00 & 0.00 & 0.00 & 0.00 & 0.00 & 0.00 & 0.00 \\
\hline $\mathrm{FeO} *$ & 8.23 & 8.19 & 8.15 & 8.09 & 9.39 & 9.35 & 7.62 & 7.87 & 8.52 & 8.48 & 7.90 & 8.29 \\
\hline $\mathrm{FeO}$ (tot) & 8.23 & 8.19 & 8.15 & 8.09 & 9.39 & 9.35 & 7.62 & 7.87 & 8.52 & 8.48 & 7.90 & 8.29 \\
\hline $\mathrm{MnO}$ & 0.07 & 0.02 & 0.01 & 0.07 & 0.10 & 0.14 & 0.06 & 0.08 & 0.09 & 0.10 & 0.03 & 0.09 \\
\hline $\mathrm{ZnO}$ & 0.01 & 0.05 & 0.04 & 0.00 & 0.04 & 0.00 & 0.06 & 0.03 & 0.02 & 0.05 & 0.05 & 0.01 \\
\hline $\mathrm{MgO}$ & 5.88 & 6.03 & 5.84 & 5.72 & 5.84 & 5.90 & 5.42 & 5.41 & 5.83 & 5.79 & 5.77 & 5.86 \\
\hline $\mathrm{Li}_{2} \mathrm{O}^{*}$ & 0.00 & 0.00 & 0.00 & 0.00 & 0.00 & 0.00 & 0.00 & 0.00 & 0.00 & 0.00 & 0.00 & 0.00 \\
\hline $\mathrm{CaO}$ & 0.61 & 0.70 & 0.65 & 0.63 & 0.63 & 0.68 & 0.35 & 0.36 & 0.64 & 0.69 & 0.68 & 0.75 \\
\hline $\mathrm{Na}_{2} \mathrm{O}$ & 1.81 & 2.05 & 1.79 & 1.85 & 1.97 & 1.97 & 1.81 & 1.65 & 2.06 & 1.74 & 1.85 & 1.83 \\
\hline $\mathrm{K}_{2} \mathrm{O}$ & 0.06 & 0.07 & 0.05 & 0.04 & 0.05 & 0.04 & 0.05 & 0.04 & 0.05 & 0.04 & 0.07 & 0.05 \\
\hline $\mathrm{F}$ & 0.27 & 0.44 & 0.25 & 0.19 & 0.23 & 0.25 & 0.16 & 0.19 & 0.25 & 0.27 & 0.14 & 0.20 \\
\hline $\mathrm{Cl}$ & 0.01 & 0.00 & 0.00 & 0.01 & 0.01 & 0.00 & 0.00 & 0.00 & 0.00 & 0.00 & 0.00 & 0.00 \\
\hline $\mathrm{H}_{2} \mathrm{O}^{*}$ & 3.37 & 3.21 & 3.43 & 3.35 & 3.41 & 3.45 & 3.42 & 3.49 & 3.37 & 3.41 & 3.35 & 3.43 \\
\hline$-(\mathrm{O}=\mathrm{F}, \mathrm{Cl})$ & -0.11 & -0.18 & -0.11 & -0.08 & -0.10 & -0.10 & -0.07 & -0.08 & -0.10 & -0.11 & -0.06 & -0.08 \\
\hline Total & 99.49 & 99.21 & 99.28 & 99.15 & 99.10 & 99.17 & 99.37 & 99.93 & 99.05 & 99.02 & 99.52 & 99.15 \\
\hline T Si (apfu) & 5.825 & 5.814 & 5.769 & 5.838 & 5.879 & 5.852 & 5.802 & 5.786 & 5.818 & 5.837 & 5.843 & 5.773 \\
\hline TAl & 0.175 & 0.186 & 0.231 & 0.162 & 0.121 & 0.148 & 0.198 & 0.214 & 0.182 & 0.163 & 0.157 & 0.227 \\
\hline B & 3 & 3 & 3 & 3 & 3 & 3 & 3 & 3 & 3 & 3 & 3 & 3 \\
\hline $\mathrm{ZAl}$ & 6.000 & 6.000 & 6.000 & 6.000 & 6.000 & 6.000 & 6.000 & 6.000 & 6.000 & 6.000 & 6.000 & 6.000 \\
\hline$Y \mathrm{Ti}$ & 0.093 & 0.102 & 0.065 & 0.057 & 0.092 & 0.068 & 0.030 & 0.048 & 0.043 & 0.051 & 0.065 & 0.064 \\
\hline Y Al & 0.290 & 0.235 & 0.344 & 0.384 & 0.106 & 0.115 & 0.559 & 0.527 & 0.296 & 0.300 & 0.398 & 0.300 \\
\hline $\mathrm{YCr}$ & 0.004 & 0.006 & 0.000 & 0.001 & 0.001 & 0.008 & 0.002 & 0.001 & 0.000 & 0.001 & 0.004 & 0.005 \\
\hline $\mathrm{YFe}^{3+}$ & 0.000 & 0.000 & 0.000 & 0.000 & 0.000 & 0.000 & 0.000 & 0.000 & 0.000 & 0.000 & 0.000 & 0.000 \\
\hline $\mathrm{Y} \mathrm{Fe}^{2+}$ & 1.144 & 1.145 & 1.135 & 1.127 & 1.319 & 1.313 & 1.054 & 1.082 & 1.192 & 1.185 & 1.096 & 1.157 \\
\hline Y Mn & 0.010 & 0.003 & 0.002 & 0.010 & 0.014 & 0.020 & 0.009 & 0.011 & 0.012 & 0.014 & 0.004 & 0.013 \\
\hline Y Zn & 0.002 & 0.006 & 0.005 & 0.000 & 0.005 & 0.000 & 0.008 & 0.003 & 0.003 & 0.006 & 0.006 & 0.001 \\
\hline Y Mg & 1.458 & 1.503 & 1.449 & 1.421 & 1.463 & 1.476 & 1.338 & 1.328 & 1.454 & 1.443 & 1.427 & 1.459 \\
\hline Y Li & 0.000 & 0.000 & 0.000 & 0.000 & 0.000 & 0.000 & 0.000 & 0.000 & 0.000 & 0.000 & 0.000 & 0.000 \\
\hline X Ca & 0.109 & 0.125 & 0.116 & 0.113 & 0.113 & 0.123 & 0.061 & 0.063 & 0.116 & 0.123 & 0.120 & 0.135 \\
\hline $\mathrm{X} \mathrm{Na}$ & 0.582 & 0.664 & 0.576 & 0.597 & 0.642 & 0.643 & 0.581 & 0.527 & 0.667 & 0.565 & 0.594 & 0.593 \\
\hline x K & 0.012 & 0.015 & 0.010 & 0.008 & 0.011 & 0.008 & 0.010 & 0.009 & 0.011 & 0.008 & 0.014 & 0.011 \\
\hline$X$ vac & 0.296 & 0.196 & 0.297 & 0.283 & 0.234 & 0.227 & 0.348 & 0.401 & 0.207 & 0.303 & 0.272 & 0.262 \\
\hline $\mathrm{VOH}$ & 3.000 & 3.000 & 3.000 & 3.000 & 3.000 & 3.000 & 3.000 & 3.000 & 3.000 & 3.000 & 3.000 & 3.000 \\
\hline Vo & 0.000 & 0.000 & 0.000 & 0.000 & 0.000 & 0.000 & 0.000 & 0.000 & 0.000 & 0.000 & 0.000 & 0.000 \\
\hline W F & 0.139 & 0.231 & 0.133 & 0.102 & 0.123 & 0.132 & 0.082 & 0.098 & 0.130 & 0.142 & 0.072 & 0.103 \\
\hline $\mathrm{WCl}$ & 0.002 & 0.000 & 0.000 & 0.004 & 0.003 & 0.000 & 0.001 & 0.000 & 0.000 & 0.001 & 0.000 & 0.000 \\
\hline W OH & 0.742 & 0.582 & 0.805 & 0.728 & 0.825 & 0.861 & 0.780 & 0.830 & 0.761 & 0.796 & 0.704 & 0.818 \\
\hline wo & 0.117 & 0.188 & 0.062 & 0.167 & 0.049 & 0.007 & 0.137 & 0.072 & 0.109 & 0.061 & 0.224 & 0.080 \\
\hline Classif. & dravite & dravite & dravite & dravite & dravite & dravite & dravite & dravite & dravite & dravite & dravite & dravite \\
\hline
\end{tabular}


Appendix D.1 (contd.): Electron-microprobe analyses of tourmaline.

\begin{tabular}{|c|c|c|c|c|c|c|c|c|c|c|c|c|}
\hline \multicolumn{2}{|l|}{ Site } & \multicolumn{11}{|c|}{ SIMPLE9-S05-1 } \\
\hline 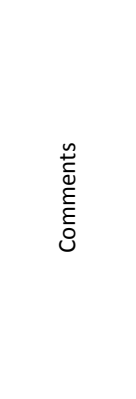 & 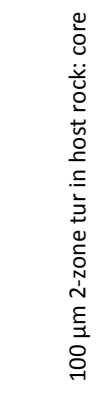 & 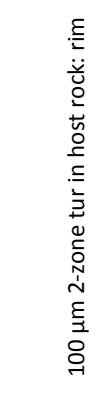 & 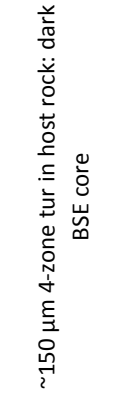 & 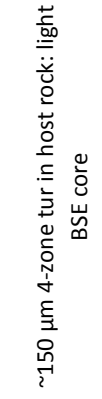 & 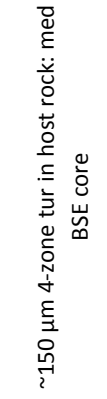 & 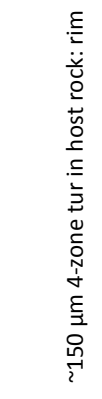 & 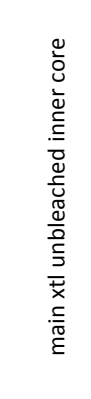 & 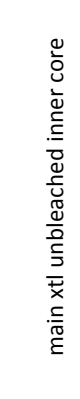 & 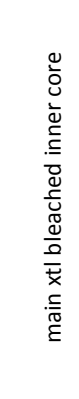 & 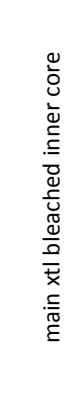 & 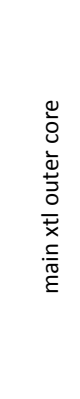 & 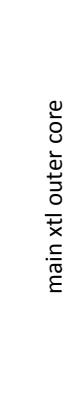 \\
\hline Point & $9454-21$ & $9454-22$ & $9454-23$ & $9454-24$ & $9454-25$ & $9454-26$ & $95 \mathrm{~S}-1$ & $95 \mathrm{~S}-2$ & $95 \mathrm{~S}-3$ & $95 \mathrm{~S}-4$ & $95 \mathrm{~S}-5$ & $95 \mathrm{~s}-6$ \\
\hline $\mathrm{SiO}_{2}$ (wt.\%) & 34.95 & 33.55 & 35.32 & 35.47 & 34.21 & 34.57 & 34.90 & 34.80 & 34.45 & 34.63 & 33.96 & 34.71 \\
\hline $\mathrm{TiO}_{2}$ & 0.39 & 0.21 & 0.40 & 0.37 & 0.41 & 0.27 & 0.27 & 0.35 & 0.32 & 0.35 & 0.63 & 0.69 \\
\hline $\mathrm{B}_{2} \mathrm{O}_{3}^{*}$ & 10.51 & 10.38 & 10.48 & 10.55 & 10.56 & 10.45 & 10.29 & 10.37 & 10.26 & 10.27 & 10.21 & 10.27 \\
\hline $\mathrm{Al}_{2} \mathrm{O}_{3}$ & 32.41 & 34.34 & 31.59 & 31.96 & 34.78 & 33.66 & 33.19 & 33.44 & 33.10 & 33.07 & 32.56 & 32.40 \\
\hline $\mathrm{Cr}_{2} \mathrm{O}_{3}$ & 0.01 & 0.02 & 0.08 & 0.05 & 0.02 & 0.05 & 0.00 & 0.01 & 0.05 & 0.00 & 0.02 & 0.00 \\
\hline \multicolumn{13}{|l|}{$\mathrm{Bi}_{2} \mathrm{O}_{3}$} \\
\hline $\mathrm{Fe}_{2} \mathrm{O}_{3} *$ & 0.00 & 0.00 & 0.00 & 0.00 & 0.00 & 0.00 & 0.00 & 0.10 & 0.00 & 0.00 & 0.00 & 0.00 \\
\hline $\mathrm{FeO}^{*}$ & 5.57 & 6.99 & 5.54 & 6.20 & 5.51 & 7.03 & 11.72 & 11.84 & 10.98 & 11.01 & 11.79 & 11.63 \\
\hline $\mathrm{FeO}$ (tot) & 5.57 & 6.99 & 5.54 & 6.20 & 5.51 & 7.03 & 11.72 & 11.93 & 10.98 & 11.01 & 11.79 & 11.63 \\
\hline $\mathrm{MnO}$ & 0.02 & 0.03 & 0.05 & 0.03 & 0.05 & 0.00 & 0.15 & 0.26 & 0.14 & 0.12 & 0.14 & 0.19 \\
\hline $\mathrm{ZnO}$ & 0.01 & 0.06 & 0.09 & 0.02 & 0.06 & 0.01 & 0.05 & 0.00 & 0.04 & 0.08 & 0.05 & 0.00 \\
\hline MgO & 8.43 & 6.38 & 8.55 & 8.28 & 7.35 & 6.57 & 3.11 & 3.25 & 3.69 & 3.64 & 3.56 & 3.55 \\
\hline $\mathrm{Li}_{2} \mathrm{O}^{*}$ & 0.00 & 0.00 & 0.00 & 0.00 & 0.00 & 0.00 & 0.00 & 0.00 & 0.00 & 0.00 & 0.00 & 0.00 \\
\hline $\mathrm{CaO}$ & 2.04 & 1.09 & 1.25 & 2.01 & 1.46 & 0.90 & 0.19 & 0.16 & 0.20 & 0.19 & 0.33 & 0.33 \\
\hline $\mathrm{Na}_{2} \mathrm{O}$ & 1.47 & 1.86 & 1.77 & 1.26 & 1.56 & 1.91 & 1.73 & 1.74 & 1.75 & 1.81 & 1.98 & 2.07 \\
\hline $\mathrm{K}_{2} \mathrm{O}$ & 0.11 & 0.06 & 0.07 & 0.10 & 0.06 & 0.06 & 0.06 & 0.04 & 0.05 & 0.05 & 0.04 & 0.05 \\
\hline$F$ & 0.59 & 0.35 & 0.67 & 0.63 & 0.31 & 0.18 & 0.30 & 0.19 & 0.11 & 0.30 & 0.28 & 0.20 \\
\hline $\mathrm{Cl}$ & 0.00 & 0.00 & 0.00 & 0.01 & 0.00 & 0.00 & 0.00 & 0.00 & 0.00 & 0.00 & 0.00 & 0.00 \\
\hline $\mathrm{H}_{2} \mathrm{O}^{*}$ & 3.17 & 3.35 & 3.26 & 3.22 & 3.38 & 3.41 & 3.31 & 3.49 & 3.47 & 3.34 & 3.36 & 3.26 \\
\hline$-(\mathrm{O}=\mathrm{F}, \mathrm{Cl})$ & -0.25 & -0.15 & -0.28 & -0.27 & -0.13 & -0.08 & -0.12 & -0.08 & -0.04 & -0.12 & -0.12 & -0.08 \\
\hline Total & 99.43 & 98.54 & 98.84 & 99.88 & 99.59 & 99.01 & 99.15 & 99.95 & 98.54 & 98.74 & 98.81 & 99.27 \\
\hline T Si (apfu) & 5.781 & 5.615 & 5.860 & 5.845 & 5.628 & 5.750 & 5.893 & 5.832 & 5.835 & 5.858 & 5.779 & 5.876 \\
\hline T Al & 0.219 & 0.385 & 0.140 & 0.155 & 0.372 & 0.250 & 0.107 & 0.168 & 0.165 & 0.142 & 0.221 & 0.124 \\
\hline B & 3 & 3 & 3 & 3 & 3 & 3 & 3 & 3 & 3 & 3 & 3 & 3 \\
\hline Z Al & 6.000 & 6.000 & 6.000 & 6.000 & 6.000 & 6.000 & 6.000 & 6.000 & 6.000 & 6.000 & 6.000 & 6.000 \\
\hline$Y \mathrm{Ti}$ & 0.049 & 0.026 & 0.050 & 0.046 & 0.050 & 0.034 & 0.034 & 0.044 & 0.041 & 0.044 & 0.080 & 0.088 \\
\hline Y Al & 0.098 & 0.388 & 0.037 & 0.052 & 0.373 & 0.349 & 0.500 & 0.436 & 0.443 & 0.453 & 0.310 & 0.342 \\
\hline $\mathrm{YCr}$ & 0.001 & 0.003 & 0.010 & 0.006 & 0.002 & 0.007 & 0.000 & 0.001 & 0.006 & 0.001 & 0.003 & 0.000 \\
\hline $\mathrm{YFe}^{3+}$ & 0.000 & 0.000 & 0.000 & 0.000 & 0.000 & 0.000 & 0.000 & 0.012 & 0.000 & 0.000 & 0.000 & 0.000 \\
\hline $\mathrm{Y} \mathrm{Fe}^{2+}$ & 0.771 & 0.979 & 0.769 & 0.854 & 0.758 & 0.978 & 1.656 & 1.659 & 1.555 & 1.558 & 1.678 & 1.647 \\
\hline Y Mn & 0.002 & 0.004 & 0.007 & 0.005 & 0.007 & 0.000 & 0.021 & 0.036 & 0.020 & 0.017 & 0.021 & 0.027 \\
\hline Y Zn & 0.002 & 0.007 & 0.011 & 0.002 & 0.007 & 0.002 & 0.006 & 0.000 & 0.004 & 0.010 & 0.006 & 0.000 \\
\hline Y Mg & 2.078 & 1.593 & 2.116 & 2.035 & 1.803 & 1.630 & 0.784 & 0.811 & 0.931 & 0.918 & 0.902 & 0.895 \\
\hline Y Li & 0.000 & 0.000 & 0.000 & 0.000 & 0.000 & 0.000 & 0.000 & 0.000 & 0.000 & 0.000 & 0.000 & 0.000 \\
\hline X Ca & 0.361 & 0.196 & 0.223 & 0.355 & 0.257 & 0.161 & 0.035 & 0.029 & 0.036 & 0.034 & 0.060 & 0.059 \\
\hline $\mathrm{X} \mathrm{Na}$ & 0.473 & 0.605 & 0.569 & 0.401 & 0.498 & 0.616 & 0.568 & 0.565 & 0.575 & 0.595 & 0.653 & 0.681 \\
\hline$x \mathrm{~K}$ & 0.022 & 0.013 & 0.015 & 0.022 & 0.012 & 0.013 & 0.012 & 0.008 & 0.010 & 0.011 & 0.009 & 0.012 \\
\hline $\mathrm{X}$ vac & 0.144 & 0.186 & 0.194 & 0.222 & 0.232 & 0.211 & 0.385 & 0.398 & 0.379 & 0.360 & 0.278 & 0.248 \\
\hline $\mathrm{VOH}$ & 3.000 & 3.000 & 3.000 & 3.000 & 3.000 & 3.000 & 3.000 & 3.000 & 3.000 & 3.000 & 3.000 & 3.000 \\
\hline Vo & 0.000 & 0.000 & 0.000 & 0.000 & 0.000 & 0.000 & 0.000 & 0.000 & 0.000 & 0.000 & 0.000 & 0.000 \\
\hline W F & 0.309 & 0.188 & 0.353 & 0.329 & 0.161 & 0.094 & 0.159 & 0.102 & 0.056 & 0.158 & 0.149 & 0.107 \\
\hline W Cl & 0.000 & 0.000 & 0.000 & 0.004 & 0.001 & 0.001 & 0.000 & 0.001 & 0.001 & 0.000 & 0.000 & 0.000 \\
\hline W OH & 0.496 & 0.745 & 0.610 & 0.539 & 0.709 & 0.782 & 0.731 & 0.897 & 0.921 & 0.768 & 0.816 & 0.687 \\
\hline wo & 0.194 & 0.068 & 0.036 & 0.128 & 0.130 & 0.124 & 0.111 & 0.000 & 0.022 & 0.074 & 0.035 & 0.206 \\
\hline Classif. & dravite & dravite & dravite & dravite & dravite & dravite & schorl & schorl & schorl & schorl & schorl & schorl \\
\hline
\end{tabular}


Appendix D.1 (contd.): Electron-microprobe analyses of tourmaline.

\begin{tabular}{|c|c|c|c|c|c|c|c|c|c|c|c|c|}
\hline \multicolumn{13}{|l|}{ Site } \\
\hline 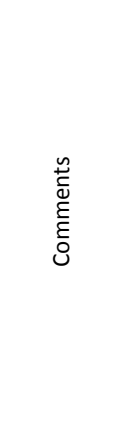 & 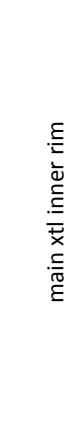 & 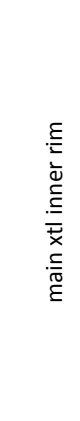 & 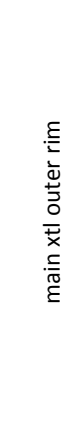 & 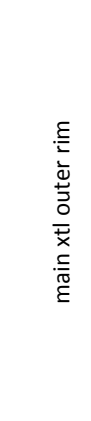 & 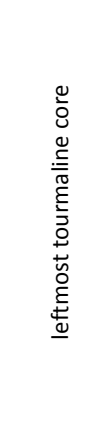 & 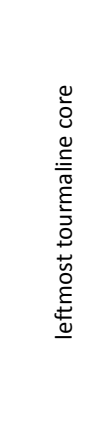 & 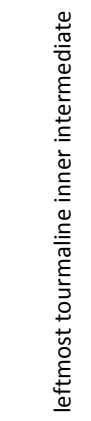 & 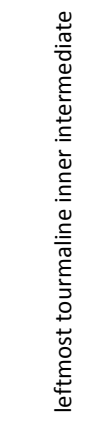 & 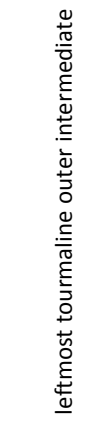 & 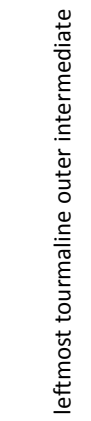 & 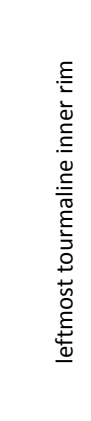 & 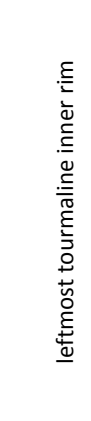 \\
\hline Point & $95 \mathrm{~S}-7$ & $95 \mathrm{~S}-8$ & $95 \mathrm{~S}-9$ & $95 \mathrm{~S}-10$ & $95 \mathrm{~S}-11$ & $95 \mathrm{~S}-12$ & $95 \mathrm{~S}-13$ & $95 \mathrm{~S}-14$ & 95S-15 & $95 \mathrm{~S}-16$ & $95 \mathrm{~S}-17$ & 95S-18 \\
\hline $\mathrm{SiO}_{2}$ (wt.\%) & 34.30 & 33.93 & 34.07 & 34.27 & 34.58 & 34.59 & 34.06 & 34.63 & 33.94 & 33.77 & 33.52 & 33.73 \\
\hline $\mathrm{TiO}_{2}$ & 0.69 & 0.76 & 0.76 & 0.73 & 0.61 & 0.69 & 0.60 & 0.82 & 0.71 & 0.56 & 0.35 & 0.51 \\
\hline $\mathrm{B}_{2} \mathrm{O}_{3}{ }^{*}$ & 10.27 & 10.16 & 10.18 & 10.26 & 10.35 & 10.32 & 10.21 & 10.38 & 10.20 & 10.19 & 10.14 & 10.20 \\
\hline $\mathrm{Al}_{2} \mathrm{O}_{3}$ & 32.71 & 32.56 & 32.48 & 32.66 & 32.27 & 32.26 & 32.01 & 32.31 & 31.91 & 31.96 & 32.85 & 33.16 \\
\hline $\mathrm{Cr}_{2} \mathrm{O}_{3}$ & 0.00 & 0.01 & 0.00 & 0.00 & 0.00 & 0.05 & 0.00 & 0.04 & 0.02 & 0.00 & 0.00 & 0.05 \\
\hline \multicolumn{13}{|l|}{$\mathrm{Bi}_{2} \mathrm{O}_{3}$} \\
\hline $\mathrm{Fe}_{2} \mathrm{O}_{3}{ }^{*}$ & 0.00 & 0.00 & 0.00 & 0.00 & 0.08 & 0.00 & 0.00 & 0.00 & 0.00 & 0.54 & 0.00 & 0.00 \\
\hline $\mathrm{FeO} *$ & 12.13 & 12.82 & 13.00 & 13.48 & 11.14 & 10.89 & 11.18 & 11.52 & 11.49 & 11.01 & 14.27 & 14.34 \\
\hline $\mathrm{FeO}$ (tot) & 12.13 & 12.82 & 13.00 & 13.48 & 11.21 & 10.89 & 11.18 & 11.52 & 11.49 & 11.49 & 14.27 & 14.34 \\
\hline $\mathrm{MnO}$ & 0.24 & 0.30 & 0.27 & 0.36 & 0.13 & 0.15 & 0.09 & 0.09 & 0.16 & 0.12 & 0.43 & 0.46 \\
\hline $\mathrm{ZnO}$ & 0.06 & 0.07 & 0.00 & 0.02 & 0.02 & 0.06 & 0.00 & 0.01 & 0.00 & 0.05 & 0.04 & 0.10 \\
\hline $\mathrm{MgO}$ & 3.26 & 2.55 & 2.54 & 2.46 & 4.55 & 4.43 & 4.29 & 4.37 & 4.16 & 4.28 & 1.81 & 1.55 \\
\hline $\mathrm{Li}_{2} \mathrm{O}^{*}$ & 0.00 & 0.00 & 0.00 & 0.00 & 0.00 & 0.00 & 0.00 & 0.00 & 0.00 & 0.00 & 0.00 & 0.00 \\
\hline $\mathrm{CaO}$ & 0.28 & 0.26 & 0.24 & 0.26 & 0.45 & 0.46 & 0.41 & 0.41 & 0.42 & 0.41 & 0.24 & 0.20 \\
\hline $\mathrm{Na}_{2} \mathrm{O}$ & 1.95 & 2.09 & 1.99 & 1.86 & 2.05 & 2.14 & 2.23 & 2.09 & 2.12 & 2.09 & 2.10 & 1.90 \\
\hline $\mathrm{K}_{2} \mathrm{O}$ & 0.06 & 0.04 & 0.04 & 0.06 & 0.06 & 0.06 & 0.07 & 0.06 & 0.05 & 0.04 & 0.03 & 0.04 \\
\hline $\mathrm{F}$ & 0.17 & 0.17 & 0.16 & 0.36 & 0.15 & 0.25 & 0.17 & 0.25 & 0.70 & 0.12 & 0.20 & 0.23 \\
\hline $\mathrm{Cl}$ & 0.00 & 0.00 & 0.00 & 0.00 & 0.00 & 0.00 & 0.01 & 0.00 & 0.00 & 0.00 & 0.01 & 0.00 \\
\hline $\mathrm{H}_{2} \mathrm{O}^{*}$ & 3.40 & 3.29 & 3.32 & 3.34 & 3.50 & 3.34 & 3.37 & 3.44 & 3.17 & 3.46 & 3.39 & 3.41 \\
\hline$-(\mathrm{O}=\mathrm{F}, \mathrm{Cl})$ & -0.07 & -0.07 & -0.07 & -0.15 & -0.06 & -0.10 & -0.07 & -0.10 & -0.30 & -0.05 & -0.09 & -0.10 \\
\hline Total & 99.44 & 98.94 & 98.99 & 99.99 & 99.90 & 99.58 & 98.63 & 100.32 & 98.77 & 98.55 & 99.29 & 99.79 \\
\hline T Si (apfu) & 5.807 & 5.802 & 5.820 & 5.803 & 5.804 & 5.827 & 5.801 & 5.798 & 5.781 & 5.758 & 5.746 & 5.748 \\
\hline TAl & 0.193 & 0.198 & 0.180 & 0.197 & 0.196 & 0.173 & 0.199 & 0.202 & 0.219 & 0.242 & 0.254 & 0.252 \\
\hline B & 3 & 3 & 3 & 3 & 3 & 3 & 3 & 3 & 3 & 3 & 3 & 3 \\
\hline $\mathrm{ZAl}$ & 6.000 & 6.000 & 6.000 & 6.000 & 6.000 & 6.000 & 6.000 & 6.000 & 6.000 & 6.000 & 6.000 & 6.000 \\
\hline$Y \mathrm{Ti}$ & 0.088 & 0.097 & 0.098 & 0.094 & 0.077 & 0.087 & 0.077 & 0.103 & 0.092 & 0.072 & 0.045 & 0.066 \\
\hline Y Al & 0.332 & 0.365 & 0.358 & 0.321 & 0.188 & 0.232 & 0.227 & 0.175 & 0.189 & 0.179 & 0.381 & 0.409 \\
\hline $\mathrm{YCr}$ & 0.000 & 0.001 & 0.000 & 0.000 & 0.000 & 0.007 & 0.000 & 0.005 & 0.003 & 0.000 & 0.000 & 0.007 \\
\hline $\mathrm{YFe}^{3+}$ & 0.000 & 0.000 & 0.000 & 0.000 & 0.011 & 0.000 & 0.000 & 0.000 & 0.000 & 0.069 & 0.000 & 0.000 \\
\hline $\mathrm{Y} \mathrm{Fe}^{2+}$ & 1.717 & 1.834 & 1.857 & 1.909 & 1.563 & 1.534 & 1.593 & 1.613 & 1.636 & 1.569 & 2.045 & 2.044 \\
\hline Y Mn & 0.034 & 0.044 & 0.039 & 0.052 & 0.019 & 0.022 & 0.013 & 0.013 & 0.023 & 0.018 & 0.062 & 0.067 \\
\hline Y Zn & 0.007 & 0.008 & 0.000 & 0.003 & 0.003 & 0.007 & 0.000 & 0.001 & 0.000 & 0.006 & 0.005 & 0.013 \\
\hline Y Mg & 0.823 & 0.651 & 0.648 & 0.622 & 1.139 & 1.111 & 1.090 & 1.090 & 1.058 & 1.087 & 0.461 & 0.395 \\
\hline Y Li & 0.000 & 0.000 & 0.000 & 0.000 & 0.000 & 0.000 & 0.000 & 0.000 & 0.000 & 0.000 & 0.000 & 0.000 \\
\hline X Ca & 0.051 & 0.047 & 0.044 & 0.048 & 0.082 & 0.083 & 0.074 & 0.074 & 0.077 & 0.075 & 0.044 & 0.036 \\
\hline $\mathrm{X} \mathrm{Na}$ & 0.640 & 0.693 & 0.660 & 0.612 & 0.667 & 0.698 & 0.737 & 0.678 & 0.701 & 0.692 & 0.698 & 0.628 \\
\hline x K & 0.014 & 0.008 & 0.008 & 0.012 & 0.012 & 0.013 & 0.016 & 0.014 & 0.011 & 0.009 & 0.007 & 0.010 \\
\hline$X$ vac & 0.295 & 0.252 & 0.287 & 0.328 & 0.239 & 0.206 & 0.172 & 0.234 & 0.212 & 0.224 & 0.250 & 0.327 \\
\hline $\mathrm{VOH}$ & 3.000 & 3.000 & 3.000 & 3.000 & 3.000 & 3.000 & 3.000 & 3.000 & 3.000 & 3.000 & 3.000 & 3.000 \\
\hline Vo & 0.000 & 0.000 & 0.000 & 0.000 & 0.000 & 0.000 & 0.000 & 0.000 & 0.000 & 0.000 & 0.000 & 0.000 \\
\hline W F & 0.092 & 0.094 & 0.088 & 0.195 & 0.082 & 0.131 & 0.090 & 0.130 & 0.378 & 0.063 & 0.109 & 0.123 \\
\hline $\mathrm{WCl}$ & 0.000 & 0.000 & 0.000 & 0.000 & 0.000 & 0.001 & 0.002 & 0.000 & 0.000 & 0.000 & 0.002 & 0.000 \\
\hline W OH & 0.838 & 0.748 & 0.781 & 0.775 & 0.918 & 0.751 & 0.824 & 0.844 & 0.601 & 0.937 & 0.879 & 0.872 \\
\hline wo & 0.069 & 0.158 & 0.131 & 0.030 & 0.000 & 0.117 & 0.085 & 0.026 & 0.021 & 0.000 & 0.010 & 0.005 \\
\hline Classif. & schorl & schorl & schorl & schorl & schorl & schorl & schorl & schorl & schorl & schorl & schorl & schorl \\
\hline
\end{tabular}


Appendix D.1 (contd.): Electron-microprobe analyses of tourmaline.

\begin{tabular}{|c|c|c|c|c|c|c|c|c|c|c|c|c|}
\hline \multicolumn{13}{|l|}{ Site } \\
\hline 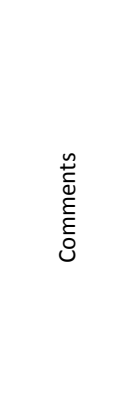 & 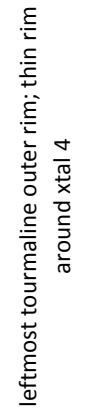 & 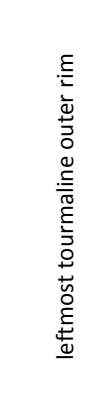 & 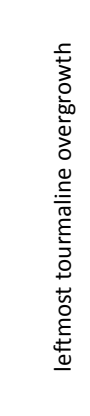 & 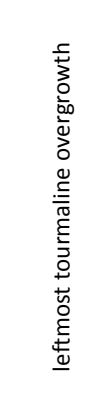 & 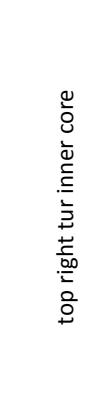 & 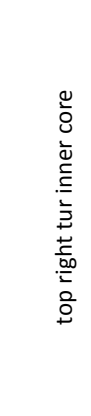 & 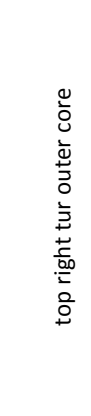 & 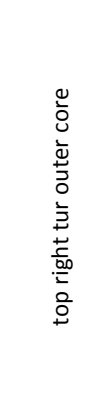 & 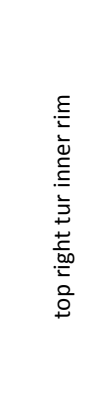 & 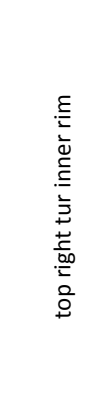 & 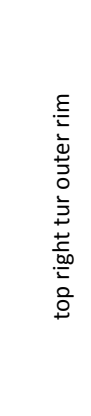 & 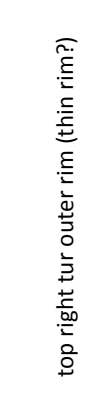 \\
\hline Point & 95S-19 & $95 \mathrm{~S}-20$ & $95 \mathrm{~S}-21$ & $95 \mathrm{~S}-22$ & $95 \mathrm{~S}-23$ & $95 \mathrm{~S}-24$ & $95 \mathrm{~S}-25$ & $95 \mathrm{~S}-26$ & $95 \mathrm{~S}-27$ & $95 \mathrm{~S}-28$ & $95 \mathrm{~S}-29$ & $95 \mathrm{~S}-30$ \\
\hline $\mathrm{SiO}_{2}$ (wt.\%) & 32.96 & 33.66 & 33.00 & 33.47 & 35.11 & 34.47 & 34.91 & 34.29 & 34.09 & 34.18 & 33.45 & 33.68 \\
\hline $\mathrm{TiO}_{2}$ & 0.68 & 0.68 & 0.74 & 0.60 & 0.42 & 0.47 & 0.40 & 0.32 & 0.82 & 0.55 & 0.67 & 0.80 \\
\hline $\mathrm{B}_{2} \mathrm{O}_{3} *$ & 10.19 & 10.27 & 10.19 & 10.19 & 10.39 & 10.29 & 10.31 & 10.24 & 10.25 & 10.24 & 10.19 & 10.26 \\
\hline $\mathrm{Al}_{2} \mathrm{O}_{3}$ & 34.43 & 34.31 & 34.58 & 34.06 & 33.18 & 33.22 & 33.18 & 33.19 & 32.75 & 33.18 & 34.12 & 34.15 \\
\hline $\mathrm{Cr}_{2} \mathrm{O}_{3}$ & 0.02 & 0.00 & 0.04 & 0.01 & 0.00 & 0.02 & 0.00 & 0.00 & 0.01 & 0.02 & 0.03 & 0.00 \\
\hline \multicolumn{13}{|l|}{$\mathrm{Bi}_{2} \mathrm{O}_{3}$} \\
\hline $\mathrm{Fe}_{2} \mathrm{O}_{3}{ }^{*}$ & 0.00 & 0.00 & 0.00 & 0.00 & 0.00 & 0.00 & 0.00 & 0.00 & 0.00 & 0.00 & 0.00 & 0.00 \\
\hline $\mathrm{FeO}^{*}$ & 12.45 & 12.55 & 13.02 & 12.67 & 12.48 & 12.27 & 12.34 & 12.34 & 13.38 & 13.29 & 12.83 & 13.09 \\
\hline $\mathrm{FeO}$ (tot) & 12.45 & 12.55 & 13.02 & 12.67 & 12.48 & 12.27 & 12.34 & 12.34 & 13.38 & 13.29 & 12.83 & 13.09 \\
\hline $\mathrm{MnO}$ & 0.82 & 0.66 & 0.95 & 1.02 & 0.20 & 0.22 & 0.20 & 0.19 & 0.23 & 0.20 & 0.89 & 0.80 \\
\hline $\mathrm{ZnO}$ & 0.07 & 0.11 & 0.04 & 0.10 & 0.03 & 0.06 & 0.01 & 0.05 & 0.09 & 0.07 & 0.07 & 0.23 \\
\hline $\mathrm{MgO}$ & 1.51 & 1.59 & 0.84 & 1.33 & 3.00 & 2.91 & 2.80 & 2.84 & 2.50 & 2.23 & 1.49 & 1.51 \\
\hline $\mathrm{Li}_{2} \mathrm{O}^{*}$ & 0.11 & 0.13 & 0.15 & 0.10 & 0.00 & 0.00 & 0.00 & 0.00 & 0.00 & 0.00 & 0.00 & 0.00 \\
\hline $\mathrm{CaO}$ & 0.11 & 0.13 & 0.20 & 0.14 & 0.17 & 0.16 & 0.18 & 0.16 & 0.24 & 0.22 & 0.13 & 0.09 \\
\hline $\mathrm{Na}_{2} \mathrm{O}$ & 2.07 & 1.91 & 1.87 & 1.81 & 1.88 & 1.90 & 1.64 & 1.83 & 1.95 & 1.74 & 2.00 & 1.96 \\
\hline $\mathrm{K}_{2} \mathrm{O}$ & 0.03 & 0.06 & 0.04 & 0.03 & 0.04 & 0.03 & 0.03 & 0.04 & 0.05 & 0.07 & 0.04 & 0.04 \\
\hline $\mathrm{F}$ & 0.40 & 0.56 & 0.52 & 0.60 & 0.02 & 0.20 & 0.14 & 0.23 & 0.27 & 0.22 & 0.50 & 0.61 \\
\hline $\mathrm{Cl}$ & 0.00 & 0.00 & 0.00 & 0.02 & 0.00 & 0.00 & 0.00 & 0.00 & 0.01 & 0.00 & 0.00 & 0.00 \\
\hline $\mathrm{H}_{2} \mathrm{O}^{*}$ & 3.32 & 3.28 & 3.27 & 3.23 & 3.50 & 3.40 & 3.43 & 3.40 & 3.36 & 3.38 & 3.14 & 3.15 \\
\hline$-(\mathrm{O}=\mathrm{F}, \mathrm{Cl})$ & -0.17 & -0.24 & -0.22 & -0.26 & -0.01 & -0.08 & -0.06 & -0.10 & -0.12 & -0.09 & -0.21 & -0.26 \\
\hline Total & 99.02 & 99.67 & 99.23 & 99.11 & 100.41 & 99.55 & 99.52 & 99.04 & 99.88 & 99.49 & 99.33 & 100.11 \\
\hline T Si (apfu) & 5.623 & 5.695 & 5.630 & 5.706 & 5.876 & 5.821 & 5.884 & 5.819 & 5.779 & 5.802 & 5.706 & 5.704 \\
\hline TAl & 0.377 & 0.305 & 0.370 & 0.294 & 0.124 & 0.179 & 0.116 & 0.181 & 0.221 & 0.198 & 0.294 & 0.296 \\
\hline B & 3 & 3 & 3 & 3 & 3 & 3 & 3 & 3 & 3 & 3 & 3 & 3 \\
\hline $\mathrm{ZAl}$ & 6.000 & 6.000 & 6.000 & 6.000 & 6.000 & 6.000 & 6.000 & 6.000 & 6.000 & 6.000 & 6.000 & 6.000 \\
\hline$Y \mathrm{Ti}$ & 0.087 & 0.087 & 0.095 & 0.077 & 0.053 & 0.059 & 0.051 & 0.040 & 0.104 & 0.071 & 0.086 & 0.102 \\
\hline Y Al & 0.545 & 0.538 & 0.582 & 0.551 & 0.420 & 0.433 & 0.475 & 0.455 & 0.322 & 0.440 & 0.564 & 0.520 \\
\hline $\mathrm{YCr}$ & 0.003 & 0.000 & 0.006 & 0.001 & 0.000 & 0.002 & 0.001 & 0.000 & 0.001 & 0.002 & 0.004 & 0.000 \\
\hline $\mathrm{YFe}^{3+}$ & 0.000 & 0.000 & 0.000 & 0.000 & 0.000 & 0.000 & 0.000 & 0.000 & 0.000 & 0.000 & 0.000 & 0.000 \\
\hline $\mathrm{Y} \mathrm{Fe}^{2+}$ & 1.776 & 1.776 & 1.857 & 1.806 & 1.746 & 1.733 & 1.739 & 1.751 & 1.897 & 1.886 & 1.830 & 1.853 \\
\hline Y Mn & 0.119 & 0.095 & 0.138 & 0.147 & 0.028 & 0.032 & 0.029 & 0.028 & 0.032 & 0.029 & 0.129 & 0.115 \\
\hline Y Zn & 0.009 & 0.014 & 0.005 & 0.012 & 0.004 & 0.008 & 0.001 & 0.006 & 0.011 & 0.008 & 0.009 & 0.028 \\
\hline Y Mg & 0.383 & 0.400 & 0.214 & 0.337 & 0.749 & 0.733 & 0.705 & 0.719 & 0.633 & 0.564 & 0.378 & 0.381 \\
\hline Y Li & 0.077 & 0.091 & 0.105 & 0.068 & 0.000 & 0.000 & 0.000 & 0.000 & 0.000 & 0.000 & 0.000 & 0.000 \\
\hline X Ca & 0.020 & 0.023 & 0.036 & 0.026 & 0.030 & 0.028 & 0.032 & 0.029 & 0.043 & 0.040 & 0.023 & 0.017 \\
\hline $\mathrm{X} \mathrm{Na}$ & 0.685 & 0.627 & 0.617 & 0.597 & 0.611 & 0.624 & 0.536 & 0.603 & 0.641 & 0.573 & 0.660 & 0.643 \\
\hline x K & 0.007 & 0.012 & 0.009 & 0.006 & 0.009 & 0.007 & 0.006 & 0.009 & 0.011 & 0.015 & 0.008 & 0.008 \\
\hline$X$ vac & 0.288 & 0.338 & 0.337 & 0.371 & 0.350 & 0.342 & 0.426 & 0.360 & 0.305 & 0.372 & 0.309 & 0.333 \\
\hline $\mathrm{VOH}$ & 3.000 & 3.000 & 3.000 & 3.000 & 3.000 & 3.000 & 3.000 & 3.000 & 3.000 & 3.000 & 3.000 & 3.000 \\
\hline Vo & 0.000 & 0.000 & 0.000 & 0.000 & 0.000 & 0.000 & 0.000 & 0.000 & 0.000 & 0.000 & 0.000 & 0.000 \\
\hline W F & 0.217 & 0.300 & 0.281 & 0.323 & 0.009 & 0.104 & 0.073 & 0.123 & 0.143 & 0.118 & 0.269 & 0.329 \\
\hline $\mathrm{WCl}$ & 0.001 & 0.000 & 0.000 & 0.004 & 0.000 & 0.001 & 0.000 & 0.000 & 0.003 & 0.001 & 0.001 & 0.001 \\
\hline W OH & 0.782 & 0.700 & 0.718 & 0.672 & 0.908 & 0.834 & 0.859 & 0.853 & 0.804 & 0.828 & 0.570 & 0.557 \\
\hline wo & 0.000 & 0.000 & 0.000 & 0.000 & 0.083 & 0.061 & 0.067 & 0.024 & 0.050 & 0.054 & 0.160 & 0.114 \\
\hline Classif. & schorl & schorl & schorl & schorl & schorl & schorl & schorl & schorl & schorl & schorl & schorl & schorl \\
\hline
\end{tabular}


Appendix D.1 (contd.): Electron-microprobe analyses of tourmaline.

\begin{tabular}{|c|c|c|c|c|c|c|c|c|c|c|c|}
\hline Site & SIMPLE9-S05 "west" & & SIMPLE11-S01 & & PLE12-S0 & & & & PLLE12-S & & \\
\hline 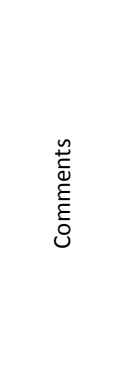 & 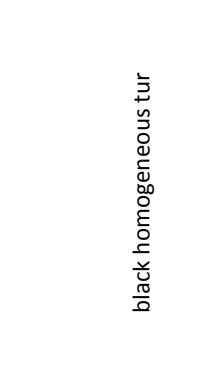 & 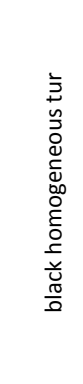 & 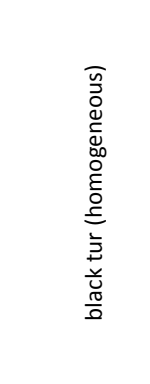 & 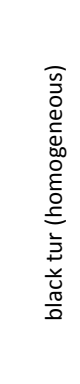 & 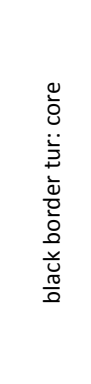 & 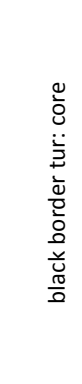 & 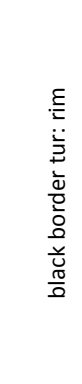 & 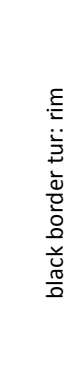 & 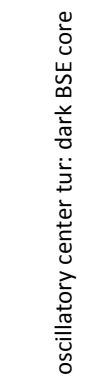 & 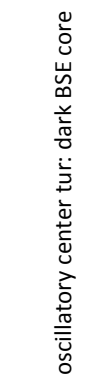 & 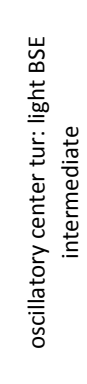 \\
\hline Point & $88 \mathrm{t}-1$ & $88 t-2$ & $91 t-1$ & $91 t-2$ & $92 t-1$ & $92 t-2$ & $92 t-3$ & $92 t-4$ & $93 t-1$ & $93 t-2$ & $93 t-3$ \\
\hline $\mathrm{SiO}_{2}$ (wt.\%) & 32.82 & 33.34 & 34.73 & 34.42 & 35.13 & 34.82 & 34.16 & 34.50 & 35.31 & 35.30 & 34.08 \\
\hline $\mathrm{TiO}_{2}$ & 0.78 & 0.75 & 0.44 & 0.37 & 0.22 & 0.35 & 0.71 & 0.64 & 0.60 & 0.60 & 0.71 \\
\hline $\mathrm{B}_{2} \mathrm{O}_{3} *$ & 10.12 & 10.17 & 10.48 & 10.42 & 10.43 & 10.39 & 10.37 & 10.40 & 10.41 & 10.41 & 10.23 \\
\hline $\mathrm{Al}_{2} \mathrm{O}_{3}$ & 33.02 & 32.91 & 33.48 & 33.50 & 33.53 & 33.21 & 32.87 & 33.12 & 33.28 & 33.24 & 33.58 \\
\hline $\mathrm{Cr}_{2} \mathrm{O}_{3}$ & 0.02 & 0.00 & 0.00 & 0.00 & 0.04 & 0.02 & 0.00 & 0.08 & 0.02 & 0.01 & 0.01 \\
\hline $\mathrm{Bi}_{2} \mathrm{O}_{3}$ & & & & & & & & & 0.00 & 0.01 & 0.00 \\
\hline $\mathrm{Fe}_{2} \mathrm{O}_{3} *$ & 0.79 & 0.61 & 0.00 & 0.00 & 0.00 & 0.05 & 0.14 & 0.00 & 0.00 & 0.00 & 0.00 \\
\hline $\mathrm{FeO} *$ & 13.76 & 13.77 & 8.24 & 8.24 & 9.52 & 9.57 & 10.42 & 10.32 & 10.47 & 10.58 & 15.61 \\
\hline $\mathrm{FeO}$ (tot) & 14.48 & 14.32 & 8.24 & 8.24 & 9.52 & 9.61 & 10.55 & 10.32 & 10.47 & 10.58 & 15.61 \\
\hline $\mathrm{MnO}$ & 0.44 & 0.40 & 0.04 & 0.02 & 0.19 & 0.17 & 0.16 & 0.17 & 0.15 & 0.17 & 0.26 \\
\hline $\mathrm{ZnO}$ & 0.02 & 0.07 & 0.03 & 0.00 & 0.03 & 0.09 & 0.03 & 0.00 & 0.03 & 0.04 & 0.05 \\
\hline $\mathrm{MgO}$ & 1.71 & 1.82 & 6.01 & 5.92 & 4.73 & 4.82 & 4.78 & 4.66 & 4.01 & 3.96 & 0.53 \\
\hline $\mathrm{Li}_{2} \mathrm{O}^{*}$ & 0.00 & 0.00 & 0.00 & 0.00 & 0.00 & 0.00 & 0.00 & 0.00 & 0.00 & 0.00 & 0.00 \\
\hline $\mathrm{CaO}$ & 0.22 & 0.22 & 0.87 & 0.87 & 0.22 & 0.27 & 0.57 & 0.57 & 0.30 & 0.30 & 0.23 \\
\hline $\mathrm{Na}_{2} \mathrm{O}$ & 1.96 & 1.84 & 2.02 & 1.79 & 1.85 & 1.85 & 2.00 & 1.88 & 2.00 & 1.99 & 1.68 \\
\hline $\mathrm{K}_{2} \mathrm{O}$ & 0.05 & 0.07 & 0.07 & 0.04 & 0.06 & 0.04 & 0.06 & 0.04 & 0.03 & 0.03 & 0.02 \\
\hline $\mathrm{F}$ & 0.05 & 0.30 & 0.41 & 0.27 & 0.16 & 0.11 & 0.16 & 0.21 & 0.21 & 0.12 & 0.06 \\
\hline $\mathrm{Cl}$ & 0.00 & 0.00 & 0.00 & 0.00 & 0.00 & 0.00 & 0.00 & 0.00 & 0.00 & 0.00 & 0.00 \\
\hline $\mathrm{H}_{2} \mathrm{O}^{*}$ & 3.47 & 3.37 & 3.29 & 3.42 & 3.49 & 3.53 & 3.50 & 3.46 & 3.27 & 3.33 & 3.39 \\
\hline$-(\mathrm{O}=\mathrm{F}, \mathrm{Cl})$ & -0.02 & -0.13 & -0.17 & -0.11 & -0.07 & -0.05 & -0.07 & -0.09 & -0.09 & -0.05 & -0.03 \\
\hline Total & 99.21 & 99.50 & 99.92 & 99.16 & 99.53 & 99.25 & 99.85 & 99.95 & 100.01 & 100.04 & 100.42 \\
\hline T Si (apfu) & 5.634 & 5.698 & 5.761 & 5.741 & 5.852 & 5.825 & 5.724 & 5.764 & 5.893 & 5.892 & 5.789 \\
\hline $\mathrm{T}$ Al & 0.366 & 0.302 & 0.239 & 0.259 & 0.148 & 0.175 & 0.276 & 0.236 & 0.107 & 0.108 & 0.211 \\
\hline B & 3 & 3 & 3 & 3 & 3 & 3 & 3 & 3 & 3 & 3 & 3 \\
\hline $\mathrm{ZAl}$ & 6.000 & 6.000 & 6.000 & 6.000 & 6.000 & 6.000 & 6.000 & 6.000 & 6.000 & 6.000 & 6.000 \\
\hline Y Ti & 0.100 & 0.096 & 0.055 & 0.047 & 0.027 & 0.044 & 0.089 & 0.080 & 0.075 & 0.075 & 0.091 \\
\hline Y Al & 0.316 & 0.326 & 0.306 & 0.328 & 0.437 & 0.372 & 0.214 & 0.283 & 0.438 & 0.432 & 0.512 \\
\hline $\mathrm{YCr}$ & 0.002 & 0.000 & 0.000 & 0.000 & 0.006 & 0.002 & 0.000 & 0.010 & 0.003 & 0.001 & 0.001 \\
\hline$Y \mathrm{Fe}^{3+}$ & 0.102 & 0.078 & 0.000 & 0.000 & 0.000 & 0.006 & 0.018 & 0.000 & 0.000 & 0.000 & 0.000 \\
\hline $\mathrm{YFe}^{2+}$ & 1.976 & 1.968 & 1.142 & 1.150 & 1.326 & 1.338 & 1.461 & 1.442 & 1.461 & 1.477 & 2.218 \\
\hline $\mathrm{Y} M \mathrm{Mn}$ & 0.064 & 0.059 & 0.006 & 0.003 & 0.026 & 0.023 & 0.022 & 0.024 & 0.021 & 0.024 & 0.037 \\
\hline Y Zn & 0.002 & 0.009 & 0.003 & 0.000 & 0.003 & 0.011 & 0.003 & 0.000 & 0.004 & 0.005 & 0.006 \\
\hline Y Mg & 0.437 & 0.463 & 1.487 & 1.473 & 1.174 & 1.203 & 1.193 & 1.160 & 0.998 & 0.985 & 0.134 \\
\hline Y Li & 0.000 & 0.000 & 0.000 & 0.000 & 0.000 & 0.000 & 0.000 & 0.000 & 0.000 & 0.000 & 0.000 \\
\hline X Ca & 0.041 & 0.040 & 0.154 & 0.155 & 0.040 & 0.049 & 0.102 & 0.101 & 0.054 & 0.054 & 0.042 \\
\hline X Na & 0.651 & 0.609 & 0.648 & 0.578 & 0.597 & 0.599 & 0.650 & 0.609 & 0.647 & 0.644 & 0.553 \\
\hline x K & 0.012 & 0.015 & 0.015 & 0.008 & 0.012 & 0.009 & 0.012 & 0.008 & 0.006 & 0.006 & 0.004 \\
\hline$X$ vac & 0.296 & 0.336 & 0.183 & 0.259 & 0.350 & 0.343 & 0.236 & 0.282 & 0.293 & 0.296 & 0.400 \\
\hline $\mathrm{VOH}$ & 3.000 & 3.000 & 3.000 & 3.000 & 3.000 & 3.000 & 3.000 & 3.000 & 3.000 & 3.000 & 3.000 \\
\hline Vo & 0.000 & 0.000 & 0.000 & 0.000 & 0.000 & 0.000 & 0.000 & 0.000 & 0.000 & 0.000 & 0.000 \\
\hline W F & 0.029 & 0.163 & 0.213 & 0.140 & 0.086 & 0.059 & 0.087 & 0.110 & 0.111 & 0.063 & 0.032 \\
\hline W Cl & 0.000 & 0.000 & 0.000 & 0.000 & 0.000 & 0.000 & 0.001 & 0.000 & 0.000 & 0.000 & 0.000 \\
\hline $\mathrm{WOH}$ & 0.971 & 0.837 & 0.639 & 0.801 & 0.875 & 0.941 & 0.912 & 0.852 & 0.644 & 0.703 & 0.842 \\
\hline W O & 0.000 & 0.000 & 0.149 & 0.059 & 0.039 & 0.000 & 0.000 & 0.038 & 0.245 & 0.234 & 0.126 \\
\hline Classif. & schorl & schorl & dravite & dravite & schorl & schorl & schorl & schorl & schorl & schorl & schorl \\
\hline
\end{tabular}


Appendix D.1 (contd.): Electron-microprobe analyses of tourmaline.

\begin{tabular}{|c|c|c|c|c|c|c|c|c|c|c|c|c|}
\hline Site & & & & IPLE12-SC & & & & & & APLE12-S01 & & \\
\hline 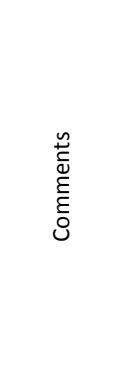 & 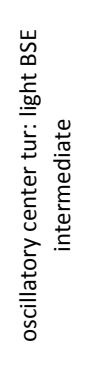 & 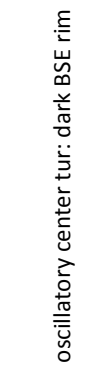 & 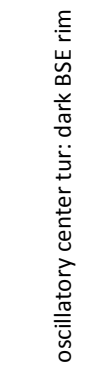 & 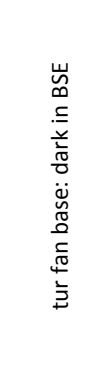 & 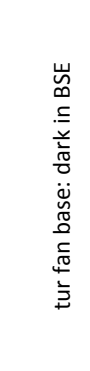 & 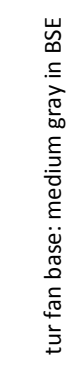 & 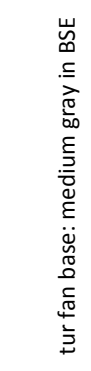 & 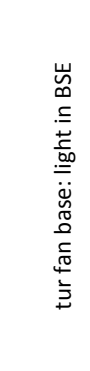 & 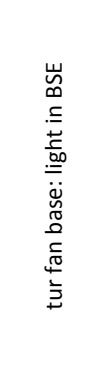 & 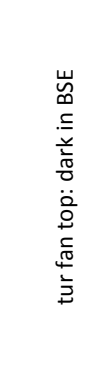 & 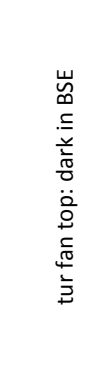 & 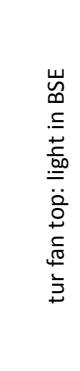 \\
\hline Point & $93 \mathrm{t}-4$ & $93 \mathrm{t}-5$ & $93 \mathrm{t}-6$ & $94 \mathrm{t}-1$ & $94 \mathrm{t}-2$ & $94 t-3$ & $94 t-4$ & $94 t-5$ & $94 \mathrm{t}-6$ & $95 \mathrm{t}-1$ & $95 \mathrm{t}-2$ & $95 \mathrm{t}-3$ \\
\hline $\mathrm{SiO}_{2}$ (wt.\%) & 34.27 & 36.18 & 35.97 & 34.87 & 34.69 & 34.05 & 34.27 & 35.11 & 35.15 & 34.70 & 34.74 & 34.09 \\
\hline $\mathrm{TiO}_{2}$ & 0.58 & 0.54 & 0.47 & 0.46 & 0.45 & 0.73 & 0.66 & 0.22 & 0.33 & 0.62 & 0.50 & 0.65 \\
\hline $\mathrm{B}_{2} \mathrm{O}_{3}{ }^{*}$ & 10.21 & 10.55 & 10.53 & 10.46 & 10.48 & 10.38 & 10.33 & 10.45 & 10.44 & 10.41 & 10.44 & 10.34 \\
\hline $\mathrm{Al}_{2} \mathrm{O}_{3}$ & 33.57 & 32.77 & 32.73 & 33.21 & 33.51 & 33.16 & 32.99 & 35.09 & 34.96 & 33.20 & 33.75 & 34.49 \\
\hline $\mathrm{Cr}_{2} \mathrm{O}_{3}$ & 0.00 & 0.00 & 0.00 & 0.00 & 0.02 & 0.03 & 0.00 & 0.06 & 0.00 & 0.00 & 0.02 & 0.00 \\
\hline $\mathrm{Bi}_{2} \mathrm{O}_{3}$ & 0.00 & 0.00 & 0.00 & & & & & & & & & \\
\hline $\mathrm{Fe}_{2} \mathrm{O}_{3} *$ & 0.00 & 0.00 & 0.00 & 0.00 & 0.00 & 0.27 & 0.00 & 0.00 & 0.00 & 0.00 & 0.00 & 0.00 \\
\hline $\mathrm{FeO} *$ & 15.93 & 7.34 & 7.74 & 8.37 & 8.29 & 9.66 & 9.18 & 10.53 & 10.37 & 9.10 & 8.97 & 10.67 \\
\hline $\mathrm{FeO}$ (tot) & 15.93 & 7.34 & 7.74 & 8.37 & 8.29 & 9.90 & 9.18 & 10.53 & 10.37 & 9.10 & 8.97 & 10.67 \\
\hline $\mathrm{MnO}$ & 0.29 & 0.04 & 0.04 & 0.08 & 0.06 & 0.13 & 0.12 & 0.12 & 0.16 & 0.08 & 0.10 & 0.11 \\
\hline $\mathrm{ZnO}$ & 0.03 & 0.03 & 0.00 & 0.00 & 0.07 & 0.08 & 0.01 & 0.02 & 0.03 & 0.00 & 0.03 & 0.07 \\
\hline MgO & 0.18 & 6.49 & 6.37 & 5.91 & 5.97 & 5.01 & 5.20 & 3.10 & 3.16 & 5.28 & 5.10 & 3.31 \\
\hline $\mathrm{Li}_{2} \mathrm{O}^{*}$ & 0.00 & 0.00 & 0.00 & 0.00 & 0.00 & 0.00 & 0.00 & 0.00 & 0.00 & 0.00 & 0.00 & 0.00 \\
\hline $\mathrm{CaO}$ & 0.26 & 0.36 & 0.33 & 0.59 & 0.76 & 0.64 & 0.62 & 0.23 & 0.21 & 0.59 & 0.54 & 0.44 \\
\hline $\mathrm{Na}_{2} \mathrm{O}$ & 1.60 & 2.16 & 2.13 & 2.01 & 1.77 & 1.83 & 1.96 & 1.71 & 1.55 & 2.10 & 1.95 & 1.83 \\
\hline $\mathrm{K}_{2} \mathrm{O}$ & 0.03 & 0.02 & 0.02 & 0.05 & 0.06 & 0.08 & 0.07 & 0.06 & 0.07 & 0.06 & 0.05 & 0.05 \\
\hline $\mathrm{F}$ & 0.02 & 0.23 & 0.14 & 0.47 & 0.43 & 0.22 & 0.40 & 0.41 & 0.16 & 0.38 & 0.29 & 0.21 \\
\hline $\mathrm{Cl}$ & 0.00 & 0.00 & 0.00 & 0.00 & 0.00 & 0.00 & 0.01 & 0.01 & 0.00 & 0.01 & 0.00 & 0.00 \\
\hline $\mathrm{H}_{2} \mathrm{O}^{*}$ & 3.36 & 3.32 & 3.43 & 3.31 & 3.40 & 3.48 & 3.27 & 3.18 & 3.33 & 3.25 & 3.34 & 3.26 \\
\hline$-(\mathrm{O}=\mathrm{F}, \mathrm{Cl})$ & -0.01 & -0.10 & -0.06 & -0.20 & -0.18 & -0.09 & -0.17 & -0.17 & -0.07 & -0.16 & -0.12 & -0.09 \\
\hline Total & 100.32 & 99.94 & 99.84 & 99.59 & 99.78 & 99.65 & 98.90 & 100.11 & 99.84 & 99.63 & 99.69 & 99.42 \\
\hline T Si (apfu) & 5.833 & 5.959 & 5.936 & 5.797 & 5.751 & 5.698 & 5.765 & 5.837 & 5.850 & 5.794 & 5.782 & 5.731 \\
\hline T Al & 0.167 & 0.041 & 0.064 & 0.203 & 0.249 & 0.302 & 0.235 & 0.163 & 0.150 & 0.206 & 0.218 & 0.269 \\
\hline B & 3 & 3 & 3 & 3 & 3 & 3 & 3 & 3 & 3 & 3 & 3 & 3 \\
\hline $\mathrm{Z} \mathrm{Al}$ & 6.000 & 6.000 & 6.000 & 6.000 & 6.000 & 6.000 & 6.000 & 6.000 & 6.000 & 6.000 & 6.000 & 6.000 \\
\hline Y Ti & 0.074 & 0.067 & 0.058 & 0.058 & 0.056 & 0.092 & 0.083 & 0.028 & 0.041 & 0.078 & 0.062 & 0.082 \\
\hline Y Al & 0.567 & 0.319 & 0.301 & 0.303 & 0.299 & 0.240 & 0.305 & 0.714 & 0.706 & 0.325 & 0.402 & 0.565 \\
\hline $\mathrm{YCr}$ & 0.000 & 0.000 & 0.000 & 0.000 & 0.003 & 0.004 & 0.000 & 0.008 & 0.000 & 0.000 & 0.003 & 0.000 \\
\hline $\mathrm{Y} \mathrm{Fe}^{3+}$ & 0.000 & 0.000 & 0.000 & 0.000 & 0.000 & 0.034 & 0.000 & 0.000 & 0.000 & 0.000 & 0.000 & 0.000 \\
\hline $\mathrm{Y} \mathrm{Fe}^{2+}$ & 2.268 & 1.011 & 1.068 & 1.164 & 1.149 & 1.352 & 1.291 & 1.464 & 1.443 & 1.270 & 1.249 & 1.500 \\
\hline Y Mn & 0.042 & 0.006 & 0.006 & 0.011 & 0.009 & 0.019 & 0.017 & 0.016 & 0.023 & 0.011 & 0.014 & 0.015 \\
\hline $\mathrm{YZn}$ & 0.004 & 0.004 & 0.000 & 0.000 & 0.008 & 0.010 & 0.001 & 0.003 & 0.003 & 0.000 & 0.004 & 0.009 \\
\hline Y Mg & 0.046 & 1.593 & 1.567 & 1.464 & 1.475 & 1.250 & 1.304 & 0.767 & 0.783 & 1.315 & 1.266 & 0.829 \\
\hline Y Li & 0.000 & 0.000 & 0.000 & 0.000 & 0.000 & 0.000 & 0.000 & 0.000 & 0.000 & 0.000 & 0.000 & 0.000 \\
\hline X Ca & 0.047 & 0.064 & 0.058 & 0.105 & 0.135 & 0.115 & 0.111 & 0.040 & 0.037 & 0.105 & 0.097 & 0.080 \\
\hline $\mathrm{X} \mathrm{Na}$ & 0.528 & 0.690 & 0.681 & 0.649 & 0.569 & 0.594 & 0.639 & 0.551 & 0.500 & 0.681 & 0.629 & 0.595 \\
\hline x K & 0.007 & 0.004 & 0.004 & 0.010 & 0.013 & 0.016 & 0.015 & 0.012 & 0.015 & 0.014 & 0.010 & 0.010 \\
\hline $\mathrm{X}$ vac & 0.418 & 0.243 & 0.256 & 0.236 & 0.283 & 0.275 & 0.234 & 0.397 & 0.449 & 0.200 & 0.264 & 0.315 \\
\hline $\mathrm{VOH}$ & 3.000 & 3.000 & 3.000 & 3.000 & 3.000 & 3.000 & 3.000 & 3.000 & 3.000 & 3.000 & 3.000 & 3.000 \\
\hline VO & 0.000 & 0.000 & 0.000 & 0.000 & 0.000 & 0.000 & 0.000 & 0.000 & 0.000 & 0.000 & 0.000 & 0.000 \\
\hline W F & 0.011 & 0.120 & 0.073 & 0.245 & 0.226 & 0.117 & 0.214 & 0.213 & 0.082 & 0.202 & 0.151 & 0.114 \\
\hline W Cl & 0.000 & 0.000 & 0.000 & 0.001 & 0.000 & 0.000 & 0.002 & 0.002 & 0.000 & 0.002 & 0.000 & 0.001 \\
\hline $\mathrm{WOH}$ & 0.812 & 0.647 & 0.771 & 0.670 & 0.755 & 0.883 & 0.672 & 0.527 & 0.692 & 0.616 & 0.706 & 0.659 \\
\hline wo & 0.178 & 0.233 & 0.156 & 0.085 & 0.018 & 0.000 & 0.113 & 0.257 & 0.226 & 0.180 & 0.143 & 0.226 \\
\hline Classif. & schorl & dravite & dravite & dravite & dravite & schorl & dravite & schorl & schorl & dravite & dravite & schorl \\
\hline
\end{tabular}


Appendix D.1 (contd.): Electron-microprobe analyses of tourmaline.

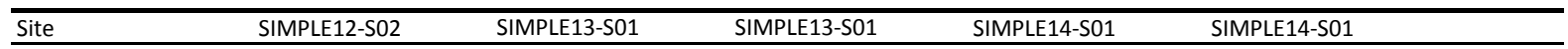

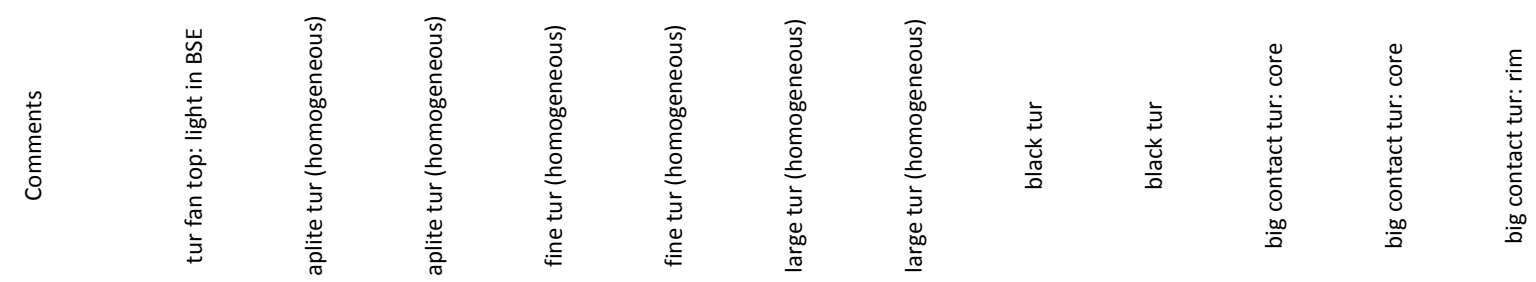

\begin{tabular}{|c|c|c|c|c|c|c|c|c|c|c|c|c|}
\hline Point & $95 t-4$ & $96 \mathrm{t}-1$ & $96 \mathrm{t}-2$ & $97 \mathrm{t}-1$ & $97 \mathrm{t}-2$ & $98 \mathrm{t}-1$ & $98 \mathrm{t}-2$ & $99 t-1$ & $99 t-2$ & $100 t-1$ & $100 \mathrm{t}-2$ & $100 t-3$ \\
\hline $\mathrm{SiO}_{2}$ (wt.\%) & 34.52 & 34.56 & 34.62 & 34.15 & 34.83 & 33.64 & 33.74 & 34.43 & 34.37 & 35.24 & 35.24 & 34.29 \\
\hline $\mathrm{TiO}_{2}$ & 0.37 & 0.41 & 0.41 & 0.97 & 0.87 & 0.44 & 0.46 & 0.45 & 0.47 & 0.45 & 0.42 & 1.03 \\
\hline $\mathrm{B}_{2} \mathrm{O}_{3} *$ & 10.37 & 10.42 & 10.40 & 10.20 & 10.23 & 10.10 & 10.10 & 10.32 & 10.33 & 10.49 & 10.53 & 10.35 \\
\hline $\mathrm{Al}_{2} \mathrm{O}_{3}$ & 34.38 & 33.39 & 33.24 & 29.32 & 29.29 & 32.69 & 32.68 & 34.54 & 34.65 & 34.34 & 34.80 & 33.75 \\
\hline $\mathrm{Cr}_{2} \mathrm{O}_{3}$ & 0.00 & 0.00 & 0.02 & 0.01 & 0.00 & 0.01 & 0.05 & 0.04 & 0.04 & 0.01 & 0.04 & 0.01 \\
\hline \multicolumn{13}{|l|}{$\mathrm{Bi}_{2} \mathrm{O}_{3}$} \\
\hline $\mathrm{Fe}_{2} \mathrm{O}_{3} *$ & 0.00 & 0.00 & 0.00 & 1.87 & 1.09 & 0.00 & 0.07 & 0.00 & 0.00 & 0.00 & 0.00 & 0.00 \\
\hline $\mathrm{FeO}^{*}$ & 10.67 & 9.30 & 8.99 & 11.95 & 12.53 & 14.83 & 14.64 & 12.75 & 12.46 & 7.48 & 7.59 & 12.29 \\
\hline $\mathrm{FeO}$ (tot) & 10.67 & 9.30 & 8.99 & 13.64 & 13.51 & 14.83 & 14.71 & 12.75 & 12.46 & 7.48 & 7.59 & 12.29 \\
\hline $\mathrm{MnO}$ & 0.08 & 0.10 & 0.11 & 0.42 & 0.46 & 1.57 & 1.60 & 0.16 & 0.22 & 0.05 & 0.02 & 0.17 \\
\hline $\mathrm{ZnO}$ & 0.16 & 0.01 & 0.04 & 0.00 & 0.04 & 0.13 & 0.06 & 0.03 & 0.00 & 0.00 & 0.00 & 0.03 \\
\hline $\mathrm{MgO}$ & 3.37 & 5.28 & 5.39 & 4.58 & 4.42 & 0.54 & 0.58 & 1.86 & 1.99 & 5.47 & 5.29 & 2.69 \\
\hline $\mathrm{Li}_{2} \mathrm{O}^{*}$ & 0.00 & 0.00 & 0.00 & 0.00 & 0.00 & 0.00 & 0.00 & 0.00 & 0.00 & 0.00 & 0.00 & 0.00 \\
\hline $\mathrm{CaO}$ & 0.49 & 0.67 & 0.60 & 0.45 & 0.45 & 0.10 & 0.11 & 0.32 & 0.32 & 0.83 & 0.74 & 0.26 \\
\hline $\mathrm{Na}_{2} \mathrm{O}$ & 1.82 & 1.90 & 1.89 & 2.44 & 2.33 & 1.94 & 1.76 & 1.74 & 1.71 & 1.72 & 1.77 & 1.81 \\
\hline $\mathrm{K}_{2} \mathrm{O}$ & 0.04 & 0.07 & 0.05 & 0.06 & 0.06 & 0.04 & 0.03 & 0.05 & 0.04 & 0.04 & 0.03 & 0.03 \\
\hline$F$ & 0.17 & 0.25 & 0.38 & 0.28 & 0.32 & 0.18 & 0.14 & 0.29 & 0.06 & 0.10 & 0.25 & 0.35 \\
\hline $\mathrm{Cl}$ & 0.00 & 0.00 & 0.01 & 0.00 & 0.00 & 0.00 & 0.00 & 0.00 & 0.00 & 0.01 & 0.00 & 0.00 \\
\hline $\mathrm{H}_{2} \mathrm{O}^{*}$ & 3.28 & 3.43 & 3.36 & 3.39 & 3.38 & 3.38 & 3.42 & 3.19 & 3.33 & 3.24 & 3.20 & 3.27 \\
\hline$-(\mathrm{O}=\mathrm{F}, \mathrm{Cl})$ & -0.07 & -0.10 & -0.16 & -0.12 & -0.13 & -0.08 & -0.06 & -0.12 & -0.02 & -0.05 & -0.10 & -0.15 \\
\hline Total & 99.65 & 99.68 & 99.34 & 99.99 & 100.18 & 99.51 & 99.39 & 100.05 & 99.97 & 99.41 & 99.80 & 100.17 \\
\hline T Si (apfu) & 5.789 & 5.763 & 5.784 & 5.818 & 5.915 & 5.791 & 5.803 & 5.796 & 5.782 & 5.841 & 5.819 & 5.760 \\
\hline T Al & 0.211 & 0.237 & 0.216 & 0.182 & 0.085 & 0.209 & 0.197 & 0.204 & 0.218 & 0.159 & 0.181 & 0.240 \\
\hline B & 3 & 3 & 3 & 3 & 3 & 3 & 3 & 3 & 3 & 3 & 3 & 3 \\
\hline $\mathrm{Z} \mathrm{Al}$ & 6.000 & 6.000 & 6.000 & 5.707 & 5.778 & 6.000 & 6.000 & 6.000 & 6.000 & 6.000 & 6.000 & 6.000 \\
\hline Y Ti & 0.046 & 0.052 & 0.051 & 0.125 & 0.111 & 0.057 & 0.059 & 0.058 & 0.060 & 0.056 & 0.052 & 0.130 \\
\hline Y Al & 0.583 & 0.324 & 0.329 & 0.000 & 0.000 & 0.422 & 0.429 & 0.649 & 0.652 & 0.549 & 0.590 & 0.443 \\
\hline $\mathrm{YCr}$ & 0.000 & 0.000 & 0.002 & 0.002 & 0.000 & 0.001 & 0.007 & 0.005 & 0.005 & 0.001 & 0.005 & 0.001 \\
\hline $\mathrm{YFe}^{3+}$ & 0.000 & 0.000 & 0.000 & 0.240 & 0.139 & 0.000 & 0.009 & 0.000 & 0.000 & 0.000 & 0.000 & 0.000 \\
\hline $\mathrm{YFe}^{2+}$ & 1.497 & 1.296 & 1.256 & 1.702 & 1.780 & 2.135 & 2.107 & 1.796 & 1.753 & 1.037 & 1.048 & 1.726 \\
\hline Y Mn & 0.012 & 0.014 & 0.016 & 0.060 & 0.067 & 0.229 & 0.234 & 0.022 & 0.032 & 0.007 & 0.003 & 0.024 \\
\hline Y Zn & 0.020 & 0.002 & 0.005 & 0.000 & 0.006 & 0.017 & 0.008 & 0.004 & 0.000 & 0.000 & 0.000 & 0.003 \\
\hline Y Mg & 0.842 & 1.312 & 1.341 & 1.164 & 1.120 & 0.139 & 0.149 & 0.467 & 0.498 & 1.350 & 1.302 & 0.673 \\
\hline Y Li & 0.000 & 0.000 & 0.000 & 0.000 & 0.000 & 0.000 & 0.000 & 0.000 & 0.000 & 0.000 & 0.000 & 0.000 \\
\hline X Ca & 0.089 & 0.120 & 0.107 & 0.083 & 0.082 & 0.019 & 0.020 & 0.058 & 0.057 & 0.147 & 0.130 & 0.047 \\
\hline X Na & 0.592 & 0.614 & 0.611 & 0.806 & 0.768 & 0.647 & 0.588 & 0.569 & 0.557 & 0.552 & 0.566 & 0.588 \\
\hline x K & 0.009 & 0.014 & 0.010 & 0.012 & 0.013 & 0.008 & 0.008 & 0.010 & 0.009 & 0.009 & 0.007 & 0.007 \\
\hline$X$ vac & 0.310 & 0.252 & 0.272 & 0.099 & 0.136 & 0.326 & 0.385 & 0.363 & 0.377 & 0.292 & 0.296 & 0.358 \\
\hline $\mathrm{VOH}$ & 3.000 & 3.000 & 3.000 & 3.000 & 3.000 & 3.000 & 3.000 & 3.000 & 3.000 & 3.000 & 3.000 & 3.000 \\
\hline VO & 0.000 & 0.000 & 0.000 & 0.000 & 0.000 & 0.000 & 0.000 & 0.000 & 0.000 & 0.000 & 0.000 & 0.000 \\
\hline W F & 0.092 & 0.129 & 0.202 & 0.150 & 0.170 & 0.096 & 0.076 & 0.155 & 0.031 & 0.054 & 0.129 & 0.187 \\
\hline W Cl & 0.000 & 0.000 & 0.002 & 0.001 & 0.000 & 0.001 & 0.000 & 0.000 & 0.000 & 0.002 & 0.000 & 0.000 \\
\hline $\mathrm{WOH}$ & 0.664 & 0.812 & 0.743 & 0.850 & 0.830 & 0.883 & 0.924 & 0.585 & 0.731 & 0.586 & 0.520 & 0.660 \\
\hline W O & 0.244 & 0.059 & 0.052 & 0.000 & 0.000 & 0.020 & 0.000 & 0.260 & 0.238 & 0.358 & 0.351 & 0.153 \\
\hline Classif. & schorl & dravite & dravite & schorl & schorl & schorl & schorl & schorl & schorl & dravite & dravite & schorl \\
\hline
\end{tabular}


Appendix D.1 (contd.): Electron-microprobe analyses of tourmaline.

\begin{tabular}{|c|c|c|c|c|c|c|c|c|c|c|c|}
\hline \multirow[b]{2}{*}{$\begin{array}{ll}\text { Site } \\
\end{array}$} & \multicolumn{3}{|c|}{ SIMPLE14-S01 } & \multirow[b]{2}{*}{ 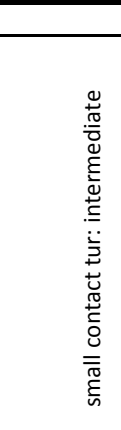 } & \multicolumn{7}{|c|}{ SIMPLE16-S02 } \\
\hline & 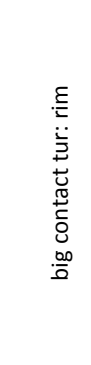 & 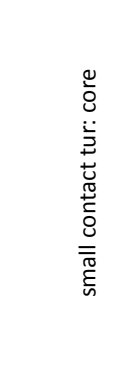 & 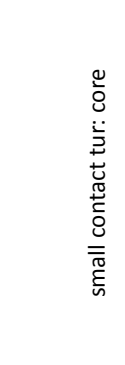 & & 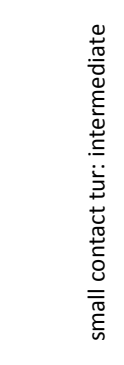 & 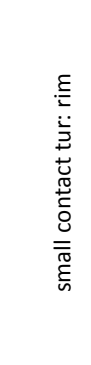 & 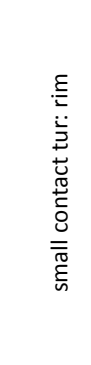 & 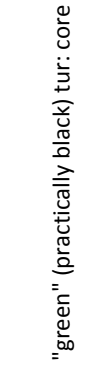 & 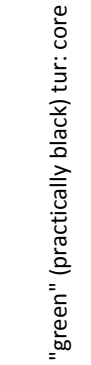 & 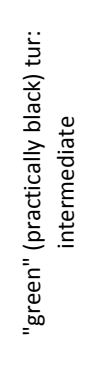 & 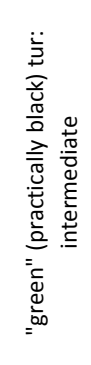 \\
\hline Point & $100 t-4$ & $101 \mathrm{t}-1$ & $101 \mathrm{t}-2$ & $101 t-3$ & $101 \mathrm{t}-4$ & $101 t-5$ & $101 \mathrm{t}-6$ & $102 \mathrm{t}-1$ & $102 t-2$ & $102 \mathrm{t}-3$ & $102 t-4$ \\
\hline $\mathrm{SiO}_{2}$ (wt.\%) & 34.33 & 32.44 & 33.20 & 31.71 & 31.91 & 34.02 & 33.93 & 34.50 & 34.33 & 34.42 & 34.97 \\
\hline $\mathrm{TiO}_{2}$ & 0.98 & 0.43 & 0.43 & 0.49 & 0.53 & 0.50 & 0.45 & 0.49 & 0.60 & 0.56 & 0.48 \\
\hline $\mathrm{B}_{2} \mathrm{O}_{3}{ }^{*}$ & 10.32 & 9.61 & 9.62 & 9.18 & 9.35 & 10.12 & 10.12 & 10.35 & 10.40 & 10.39 & 10.45 \\
\hline $\mathrm{Al}_{2} \mathrm{O}_{3}$ & 34.04 & 32.78 & 31.09 & 30.33 & 30.98 & 33.83 & 33.82 & 34.54 & 34.79 & 34.55 & 34.35 \\
\hline $\mathrm{Cr}_{2} \mathrm{O}_{3}$ & 0.01 & 0.00 & 0.01 & 0.07 & 0.01 & 0.00 & 0.00 & 0.00 & 0.04 & 0.00 & 0.00 \\
\hline \multicolumn{12}{|l|}{$\mathrm{Bi}_{2} \mathrm{O}_{3}$} \\
\hline $\mathrm{Fe}_{2} \mathrm{O}_{3}^{*}$ & 0.00 & 0.00 & 0.00 & 0.00 & 0.00 & 0.00 & 0.00 & 0.00 & 0.00 & 0.00 & 0.00 \\
\hline $\mathrm{FeO} *$ & 12.16 & 6.57 & 7.81 & 6.47 & 6.99 & 9.73 & 9.94 & 9.79 & 9.71 & 7.93 & 8.02 \\
\hline $\mathrm{FeO}$ (tot) & 12.16 & 6.57 & 7.81 & 6.47 & 6.99 & 9.73 & 9.94 & 9.79 & 9.71 & 7.93 & 8.02 \\
\hline $\mathrm{MnO}$ & 0.21 & 0.06 & 0.06 & 0.00 & 0.01 & 0.08 & 0.07 & 0.04 & 0.05 & 0.04 & 0.03 \\
\hline $\mathrm{ZnO}$ & 0.03 & 0.04 & 0.04 & 0.00 & 0.02 & 0.02 & 0.08 & 0.03 & 0.14 & 0.03 & 0.00 \\
\hline MgO & 2.34 & 4.00 & 4.20 & 3.88 & 3.99 & 3.25 & 3.19 & 3.72 & 3.83 & 4.96 & 5.13 \\
\hline $\mathrm{Li}_{2} \mathrm{O}^{*}$ & 0.00 & 0.00 & 0.00 & 0.00 & 0.00 & 0.00 & 0.00 & 0.00 & 0.00 & 0.00 & 0.00 \\
\hline $\mathrm{CaO}$ & 0.24 & 0.56 & 0.50 & 0.47 & 0.48 & 0.40 & 0.45 & 0.40 & 0.44 & 0.65 & 0.63 \\
\hline $\mathrm{Na}_{2} \mathrm{O}$ & 1.80 & 1.61 & 1.68 & 1.64 & 1.63 & 1.77 & 1.48 & 1.78 & 1.95 & 1.80 & 1.95 \\
\hline $\mathrm{K}_{2} \mathrm{O}$ & 0.03 & 0.02 & 0.03 & 0.05 & 0.02 & 0.04 & 0.05 & 0.07 & 0.05 & 0.09 & 0.07 \\
\hline $\mathrm{F}$ & 0.16 & 0.24 & 0.04 & 0.04 & 0.31 & 0.11 & 0.05 & 0.29 & 0.13 & 0.16 & 0.21 \\
\hline $\mathrm{Cl}$ & 0.00 & 0.01 & 0.02 & 0.00 & 0.00 & 0.00 & 0.00 & 0.00 & 0.01 & 0.01 & 0.00 \\
\hline $\mathrm{H}_{2} \mathrm{O}^{*}$ & 3.26 & 2.68 & 2.86 & 2.64 & 2.60 & 3.08 & 3.21 & 3.19 & 3.28 & 3.23 & 3.19 \\
\hline$-(\mathrm{O}=\mathrm{F}, \mathrm{Cl})$ & -0.07 & -0.10 & -0.02 & -0.02 & -0.13 & -0.05 & -0.02 & -0.12 & -0.06 & -0.07 & -0.09 \\
\hline Total & 99.84 & 90.96 & 91.57 & 86.94 & 88.70 & 96.93 & 96.83 & 99.06 & 99.70 & 98.76 & 99.38 \\
\hline T Si (apfu) & 5.782 & 5.867 & 5.997 & 6.000 & 5.935 & 5.843 & 5.829 & 5.791 & 5.734 & 5.760 & 5.816 \\
\hline T Al & 0.218 & 0.133 & 0.003 & 0.000 & 0.065 & 0.157 & 0.171 & 0.209 & 0.266 & 0.240 & 0.184 \\
\hline B & 3 & 3 & 3 & 3 & 3 & 3 & 3 & 3 & 3 & 3 & 3 \\
\hline $\mathrm{ZAl}$ & 6.000 & 6.000 & 6.000 & 6.000 & 6.000 & 6.000 & 6.000 & 6.000 & 6.000 & 6.000 & 6.000 \\
\hline Y Ti & 0.124 & 0.059 & 0.058 & 0.070 & 0.075 & 0.065 & 0.059 & 0.061 & 0.076 & 0.071 & 0.060 \\
\hline Y Al & 0.540 & 0.855 & 0.615 & 0.765 & 0.725 & 0.689 & 0.676 & 0.625 & 0.584 & 0.573 & 0.549 \\
\hline $\mathrm{YCr}$ & 0.002 & 0.000 & 0.001 & 0.010 & 0.002 & 0.000 & 0.000 & 0.000 & 0.006 & 0.000 & 0.000 \\
\hline $\mathrm{Y} \mathrm{Fe}^{3+}$ & 0.000 & 0.000 & 0.000 & 0.000 & 0.000 & 0.000 & 0.000 & 0.000 & 0.000 & 0.000 & 0.000 \\
\hline $\mathrm{Y} \mathrm{Fe}^{2+}$ & 1.713 & 0.994 & 1.179 & 1.023 & 1.087 & 1.398 & 1.428 & 1.375 & 1.356 & 1.109 & 1.116 \\
\hline Y Mn & 0.030 & 0.010 & 0.008 & 0.000 & 0.001 & 0.012 & 0.009 & 0.005 & 0.007 & 0.006 & 0.004 \\
\hline $\mathrm{YZn}$ & 0.004 & 0.005 & 0.006 & 0.000 & 0.003 & 0.003 & 0.010 & 0.004 & 0.018 & 0.004 & 0.000 \\
\hline Y Mg & 0.588 & 1.078 & 1.132 & 1.095 & 1.106 & 0.833 & 0.818 & 0.930 & 0.954 & 1.238 & 1.271 \\
\hline Y Li & 0.000 & 0.000 & 0.000 & 0.000 & 0.000 & 0.000 & 0.000 & 0.000 & 0.000 & 0.000 & 0.000 \\
\hline X Ca & 0.043 & 0.108 & 0.096 & 0.095 & 0.095 & 0.074 & 0.083 & 0.071 & 0.078 & 0.117 & 0.113 \\
\hline $\mathrm{X} \mathrm{Na}$ & 0.588 & 0.566 & 0.589 & 0.600 & 0.587 & 0.591 & 0.493 & 0.579 & 0.631 & 0.583 & 0.628 \\
\hline x K & 0.006 & 0.005 & 0.008 & 0.012 & 0.006 & 0.010 & 0.011 & 0.015 & 0.011 & 0.019 & 0.014 \\
\hline $\mathrm{X}$ vac & 0.363 & 0.321 & 0.308 & 0.293 & 0.312 & 0.326 & 0.412 & 0.335 & 0.280 & 0.281 & 0.245 \\
\hline $\mathrm{VOH}$ & 3.000 & 3.000 & 3.000 & 3.000 & 3.000 & 3.000 & 3.000 & 3.000 & 3.000 & 3.000 & 3.000 \\
\hline Vo & 0.000 & 0.000 & 0.000 & 0.000 & 0.000 & 0.000 & 0.000 & 0.000 & 0.000 & 0.000 & 0.000 \\
\hline WF & 0.085 & 0.137 & 0.025 & 0.022 & 0.181 & 0.061 & 0.025 & 0.153 & 0.070 & 0.084 & 0.109 \\
\hline W Cl & 0.000 & 0.004 & 0.005 & 0.001 & 0.000 & 0.000 & 0.001 & 0.000 & 0.004 & 0.002 & 0.000 \\
\hline $\mathrm{WOH}$ & 0.663 & 0.233 & 0.452 & 0.336 & 0.223 & 0.529 & 0.680 & 0.573 & 0.652 & 0.605 & 0.537 \\
\hline wo & 0.252 & 0.627 & 0.519 & 0.642 & 0.596 & 0.410 & 0.294 & 0.274 & 0.274 & 0.309 & 0.354 \\
\hline Classif. & schorl & oxy-FALSE & oxy-FALSE & oxy-FALSE & oxy-FALSE & schorl & schorl & schorl & schorl & dravite & dravite \\
\hline
\end{tabular}


Appendix D.1 (contd.): Electron-microprobe analyses of tourmaline.

\begin{tabular}{|c|c|c|c|c|c|c|c|c|c|c|c|c|}
\hline \multirow[b]{2}{*}{ 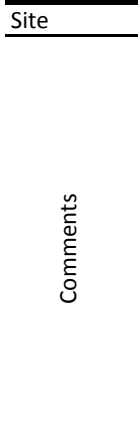 } & \multicolumn{5}{|c|}{ SIMPLE17-S01 } & \multicolumn{7}{|c|}{ SIMPLE17-S01 } \\
\hline & 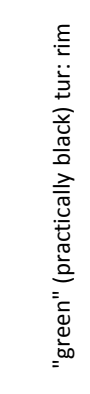 & 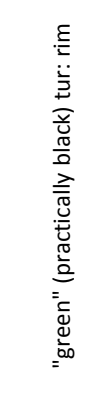 & 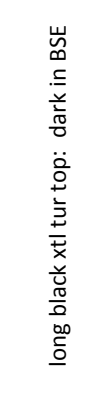 & 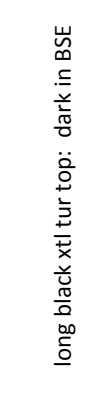 & 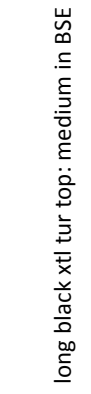 & 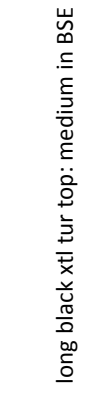 & 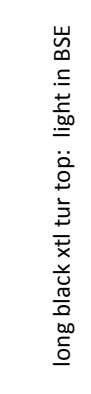 & 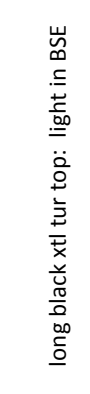 & 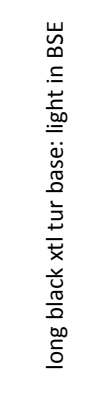 & 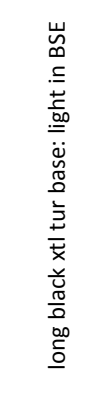 & 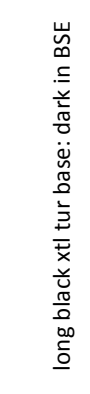 & 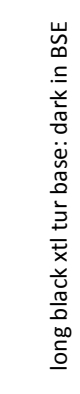 \\
\hline Point & $102 t-5$ & $102 t-6$ & $103 t-1$ & $103 t-2$ & $103 t-3$ & $103 t-4$ & $103 t-5$ & $103 t-6$ & $104 t-1$ & $104 t-2$ & $104 t-3$ & $104 t-4$ \\
\hline $\mathrm{SiO}_{2}$ (wt.\%) & 35.12 & 34.91 & 34.61 & 34.73 & 34.62 & 34.52 & 34.11 & 33.87 & 34.22 & 34.43 & 35.30 & 35.09 \\
\hline $\mathrm{TiO}_{2}$ & 0.47 & 0.52 & 0.81 & 0.81 & 1.12 & 1.03 & 0.64 & 0.61 & 0.65 & 0.69 & 0.88 & 0.98 \\
\hline $\mathrm{B}_{2} \mathrm{O}_{3} *$ & 10.56 & 10.51 & 10.29 & 10.38 & 10.28 & 10.30 & 10.08 & 10.10 & 10.29 & 10.37 & 10.47 & 10.39 \\
\hline $\mathrm{Al}_{2} \mathrm{O}_{3}$ & 34.57 & 34.46 & 32.93 & 33.30 & 31.96 & 32.12 & 32.58 & 32.64 & 33.55 & 33.73 & 30.32 & 29.89 \\
\hline $\mathrm{Cr}_{2} \mathrm{O}_{3}$ & 0.00 & 0.02 & 0.02 & 0.03 & 0.05 & 0.01 & 0.00 & 0.01 & 0.00 & 0.03 & 0.00 & 0.00 \\
\hline \multicolumn{13}{|l|}{$\mathrm{Bi}_{2} \mathrm{O}_{3}$} \\
\hline $\mathrm{Fe}_{2} \mathrm{O}_{3} *$ & 0.00 & 0.00 & 0.00 & 0.00 & 0.00 & 0.00 & 0.00 & 0.00 & 0.00 & 0.00 & 0.00 & 0.00 \\
\hline $\mathrm{FeO}^{*}$ & 5.51 & 5.70 & 10.67 & 11.45 & 6.35 & 6.25 & 10.61 & 10.78 & 10.94 & 11.07 & 5.21 & 5.43 \\
\hline $\mathrm{FeO}$ (tot) & 5.51 & 5.70 & 10.67 & 11.45 & 6.35 & 6.25 & 10.61 & 10.78 & 10.94 & 11.07 & 5.21 & 5.43 \\
\hline $\mathrm{MnO}$ & 0.02 & 0.00 & 0.20 & 0.15 & 0.09 & 0.06 & 0.13 & 0.17 & 0.12 & 0.14 & 0.02 & 0.08 \\
\hline $\mathrm{ZnO}$ & 0.08 & 0.19 & 0.00 & 0.07 & 0.07 & 0.00 & 0.00 & 0.07 & 0.11 & 0.00 & 0.05 & 0.04 \\
\hline $\mathrm{MgO}$ & 6.90 & 6.64 & 3.80 & 3.52 & 6.76 & 7.00 & 3.39 & 3.44 & 3.53 & 3.60 & 9.55 & 9.37 \\
\hline $\mathrm{Li}_{2} \mathrm{O}^{*}$ & 0.00 & 0.00 & 0.00 & 0.00 & 0.00 & 0.00 & 0.00 & 0.00 & 0.00 & 0.00 & 0.00 & 0.00 \\
\hline $\mathrm{CaO}$ & 1.03 & 1.06 & 0.64 & 0.63 & 0.84 & 0.81 & 0.58 & 0.66 & 0.61 & 0.65 & 2.42 & 2.42 \\
\hline $\mathrm{Na}_{2} \mathrm{O}$ & 1.78 & 1.86 & 1.78 & 1.84 & 1.93 & 2.02 & 1.88 & 1.85 & 1.84 & 1.68 & 1.39 & 1.27 \\
\hline $\mathrm{K}_{2} \mathrm{O}$ & 0.05 & 0.07 & 0.04 & 0.02 & 0.05 & 0.04 & 0.06 & 0.07 & 0.05 & 0.05 & 0.02 & 0.02 \\
\hline $\mathrm{F}$ & 0.22 & 0.23 & 0.16 & 0.16 & 0.22 & 0.37 & 0.14 & 0.20 & 0.29 & 0.11 & 0.44 & 0.39 \\
\hline $\mathrm{Cl}$ & 0.00 & 0.00 & 0.00 & 0.00 & 0.01 & 0.01 & 0.00 & 0.01 & 0.00 & 0.00 & 0.01 & 0.00 \\
\hline $\mathrm{H}_{2} \mathrm{O}^{*}$ & 3.25 & 3.18 & 3.22 & 3.29 & 3.15 & 3.14 & 3.06 & 3.11 & 3.21 & 3.37 & 3.23 & 3.25 \\
\hline$-(\mathrm{O}=\mathrm{F}, \mathrm{Cl})$ & -0.09 & -0.10 & -0.07 & -0.07 & -0.09 & -0.16 & -0.06 & -0.09 & -0.12 & -0.05 & -0.19 & -0.16 \\
\hline Total & 99.48 & 99.26 & 99.11 & 100.32 & 97.41 & 97.52 & 97.21 & 97.49 & 99.29 & 99.85 & 99.11 & 98.46 \\
\hline T Si (apfu) & 5.777 & 5.771 & 5.846 & 5.813 & 5.856 & 5.826 & 5.879 & 5.830 & 5.778 & 5.772 & 5.861 & 5.870 \\
\hline T Al & 0.223 & 0.229 & 0.154 & 0.187 & 0.144 & 0.174 & 0.121 & 0.170 & 0.222 & 0.228 & 0.139 & 0.130 \\
\hline B & 3 & 3 & 3 & 3 & 3 & 3 & 3 & 3 & 3 & 3 & 3 & 3 \\
\hline $\mathrm{Z} \mathrm{Al}$ & 6.000 & 6.000 & 6.000 & 6.000 & 6.000 & 6.000 & 6.000 & 6.000 & 6.000 & 6.000 & 5.795 & 5.762 \\
\hline Y Ti & 0.058 & 0.064 & 0.103 & 0.102 & 0.143 & 0.130 & 0.083 & 0.079 & 0.082 & 0.087 & 0.109 & 0.124 \\
\hline Y Al & 0.480 & 0.485 & 0.400 & 0.384 & 0.227 & 0.215 & 0.498 & 0.452 & 0.455 & 0.437 & 0.000 & 0.000 \\
\hline $\mathrm{YCr}$ & 0.000 & 0.003 & 0.003 & 0.004 & 0.007 & 0.002 & 0.000 & 0.001 & 0.000 & 0.004 & 0.000 & 0.000 \\
\hline $\mathrm{Y} \mathrm{Fe}^{3+}$ & 0.000 & 0.000 & 0.000 & 0.000 & 0.000 & 0.000 & 0.000 & 0.000 & 0.000 & 0.000 & 0.000 & 0.000 \\
\hline $\mathrm{Y} \mathrm{Fe}^{2+}$ & 0.758 & 0.788 & 1.507 & 1.603 & 0.898 & 0.882 & 1.529 & 1.552 & 1.545 & 1.552 & 0.723 & 0.760 \\
\hline Y Mn & 0.003 & 0.000 & 0.029 & 0.021 & 0.013 & 0.009 & 0.019 & 0.024 & 0.017 & 0.019 & 0.003 & 0.012 \\
\hline Y Zn & 0.010 & 0.023 & 0.000 & 0.008 & 0.009 & 0.000 & 0.000 & 0.009 & 0.013 & 0.000 & 0.006 & 0.005 \\
\hline Y Mg & 1.691 & 1.637 & 0.957 & 0.879 & 1.704 & 1.762 & 0.870 & 0.883 & 0.888 & 0.901 & 2.363 & 2.338 \\
\hline Y Li & 0.000 & 0.000 & 0.000 & 0.000 & 0.000 & 0.000 & 0.000 & 0.000 & 0.000 & 0.000 & 0.000 & 0.000 \\
\hline $\mathrm{XCa}$ & 0.182 & 0.188 & 0.116 & 0.114 & 0.153 & 0.146 & 0.107 & 0.123 & 0.110 & 0.116 & 0.430 & 0.434 \\
\hline $\mathrm{X} \mathrm{Na}$ & 0.568 & 0.595 & 0.584 & 0.598 & 0.632 & 0.661 & 0.629 & 0.619 & 0.601 & 0.547 & 0.448 & 0.412 \\
\hline x K & 0.011 & 0.015 & 0.008 & 0.005 & 0.011 & 0.010 & 0.013 & 0.015 & 0.011 & 0.010 & 0.005 & 0.005 \\
\hline $\mathrm{X}$ vac & 0.239 & 0.202 & 0.291 & 0.283 & 0.203 & 0.184 & 0.251 & 0.244 & 0.277 & 0.327 & 0.117 & 0.149 \\
\hline $\mathrm{VOH}$ & 3.000 & 3.000 & 3.000 & 3.000 & 3.000 & 3.000 & 3.000 & 3.000 & 3.000 & 3.000 & 3.000 & 3.000 \\
\hline vo & 0.000 & 0.000 & 0.000 & 0.000 & 0.000 & 0.000 & 0.000 & 0.000 & 0.000 & 0.000 & 0.000 & 0.000 \\
\hline WF & 0.116 & 0.119 & 0.086 & 0.086 & 0.118 & 0.198 & 0.077 & 0.109 & 0.156 & 0.060 & 0.232 & 0.204 \\
\hline W Cl & 0.001 & 0.000 & 0.000 & 0.000 & 0.002 & 0.002 & 0.000 & 0.003 & 0.000 & 0.000 & 0.001 & 0.000 \\
\hline $\mathrm{WOH}$ & 0.567 & 0.507 & 0.633 & 0.679 & 0.557 & 0.535 & 0.524 & 0.569 & 0.613 & 0.764 & 0.579 & 0.632 \\
\hline wo & 0.316 & 0.374 & 0.281 & 0.235 & 0.324 & 0.265 & 0.399 & 0.319 & 0.231 & 0.176 & 0.188 & 0.164 \\
\hline Classif. & dravite & dravite & schorl & schorl & dravite & dravite & schorl & schorl & schorl & schorl & dravite & uvite \\
\hline
\end{tabular}


Appendix D.1 (contd.): Electron-microprobe analyses of tourmaline.

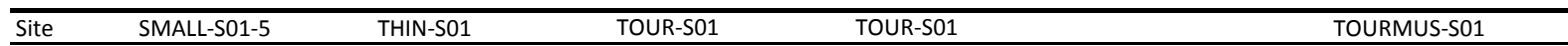

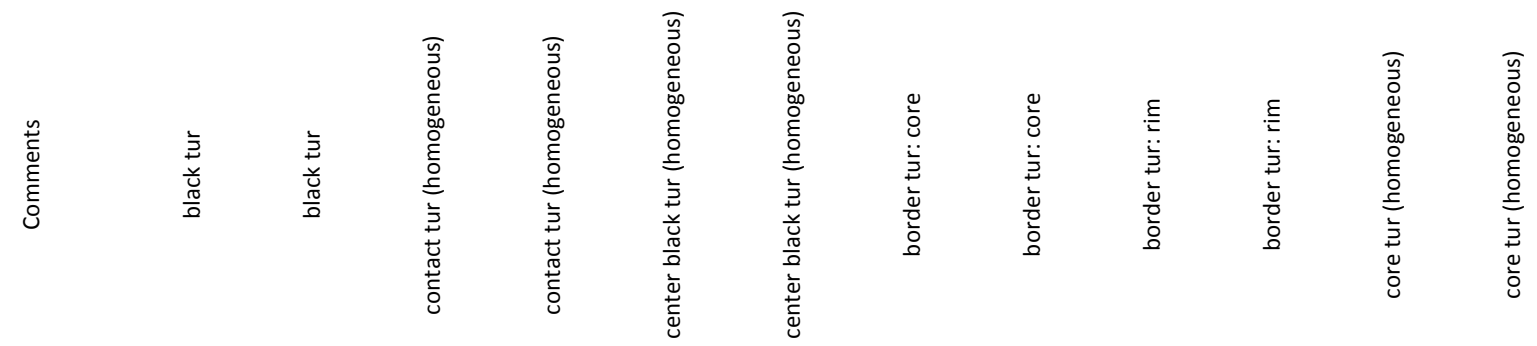

\begin{tabular}{|c|c|c|c|c|c|c|c|c|c|c|c|c|}
\hline Point & $105 t-1$ & $105 t-2$ & $106 \mathrm{t}-1$ & $106 \mathrm{t}-2$ & $107 \mathrm{t}-1$ & $107 \mathrm{t}-2$ & $108 \mathrm{t}-1$ & $108 \mathrm{t}-2$ & $108 \mathrm{t}-3$ & $108 \mathrm{t}-4$ & $109 \mathrm{t}-1$ & $109 t-2$ \\
\hline $\mathrm{SiO}_{2}$ (wt.\%) & 34.49 & 34.19 & 33.92 & 34.38 & 34.72 & 34.75 & 34.42 & 34.75 & 34.59 & 35.04 & 34.28 & 34.03 \\
\hline $\mathrm{TiO}_{2}$ & 0.41 & 0.51 & 0.72 & 0.44 & 0.12 & 0.13 & 0.63 & 0.50 & 0.78 & 0.49 & 0.16 & 0.16 \\
\hline $\mathrm{B}_{2} \mathrm{O}_{3} *$ & 10.40 & 10.42 & 10.29 & 10.37 & 10.34 & 10.34 & 10.45 & 10.51 & 10.34 & 10.44 & 10.18 & 10.19 \\
\hline $\mathrm{Al}_{2} \mathrm{O}_{3}$ & 33.46 & 33.67 & 31.78 & 32.73 & 35.40 & 35.38 & 34.74 & 34.81 & 33.59 & 34.31 & 33.46 & 33.56 \\
\hline $\mathrm{Cr}_{2} \mathrm{O}_{3}$ & 0.00 & 0.00 & 0.00 & 0.00 & 0.06 & 0.03 & 0.03 & 0.04 & 0.06 & 0.02 & 0.01 & 0.04 \\
\hline \multicolumn{13}{|l|}{$\mathrm{Bi}_{2} \mathrm{O}_{3}$} \\
\hline $\mathrm{Fe}_{2} \mathrm{O}_{3} *$ & 0.00 & 0.27 & 0.87 & 0.00 & 0.00 & 0.00 & 0.00 & 0.00 & 0.00 & 0.00 & 0.00 & 0.00 \\
\hline $\mathrm{FeO}^{*}$ & 8.32 & 8.18 & 8.93 & 9.27 & 11.35 & 11.46 & 6.45 & 6.83 & 10.45 & 7.41 & 14.25 & 14.51 \\
\hline $\mathrm{FeO}$ (tot) & 8.32 & 8.42 & 9.71 & 9.27 & 11.35 & 11.46 & 6.45 & 6.83 & 10.45 & 7.41 & 14.25 & 14.51 \\
\hline $\mathrm{MnO}$ & 0.04 & 0.08 & 0.11 & 0.10 & 0.12 & 0.09 & 0.00 & 0.00 & 0.15 & 0.07 & 0.82 & 0.73 \\
\hline $\mathrm{ZnO}$ & 0.04 & 0.04 & 0.00 & 0.06 & 0.04 & 0.00 & 0.03 & 0.00 & 0.03 & 0.00 & 0.03 & 0.16 \\
\hline $\mathrm{MgO}$ & 5.68 & 5.72 & 5.83 & 5.60 & 2.06 & 2.00 & 5.95 & 5.89 & 3.70 & 5.35 & 0.91 & 0.90 \\
\hline $\mathrm{Li}_{2} \mathrm{O}^{*}$ & 0.00 & 0.00 & 0.00 & 0.00 & 0.00 & 0.00 & 0.00 & 0.00 & 0.00 & 0.00 & 0.00 & 0.00 \\
\hline $\mathrm{CaO}$ & 0.59 & 0.65 & 0.82 & 0.82 & 0.07 & 0.06 & 1.09 & 1.41 & 0.18 & 0.20 & 0.06 & 0.05 \\
\hline $\mathrm{Na}_{2} \mathrm{O}$ & 1.73 & 1.75 & 1.89 & 2.03 & 1.53 & 1.45 & 1.62 & 1.44 & 1.92 & 1.92 & 1.65 & 1.75 \\
\hline $\mathrm{K}_{2} \mathrm{O}$ & 0.03 & 0.07 & 0.05 & 0.08 & 0.02 & 0.04 & 0.05 & 0.06 & 0.02 & 0.03 & 0.05 & 0.03 \\
\hline $\mathrm{F}$ & 0.28 & 0.23 & 0.19 & 0.16 & 0.09 & 0.00 & 0.08 & 0.22 & 0.62 & 0.37 & 0.46 & 0.12 \\
\hline $\mathrm{Cl}$ & 0.00 & 0.00 & 0.00 & 0.01 & 0.00 & 0.01 & 0.00 & 0.02 & 0.00 & 0.00 & 0.01 & 0.00 \\
\hline $\mathrm{H}_{2} \mathrm{O}^{*}$ & 3.45 & 3.49 & 3.46 & 3.44 & 3.31 & 3.35 & 3.25 & 3.17 & 3.11 & 3.23 & 3.23 & 3.45 \\
\hline$-(\mathrm{O}=\mathrm{F}, \mathrm{Cl})$ & -0.12 & -0.10 & -0.08 & -0.07 & -0.04 & 0.00 & -0.04 & -0.10 & -0.26 & -0.16 & -0.19 & -0.05 \\
\hline Total & 98.80 & 99.16 & 98.78 & 99.42 & 99.19 & 99.09 & 98.75 & 99.55 & 99.27 & 98.72 & 99.37 & 99.63 \\
\hline T Si (apfu) & 5.766 & 5.703 & 5.728 & 5.761 & 5.834 & 5.843 & 5.727 & 5.748 & 5.816 & 5.833 & 5.854 & 5.805 \\
\hline T Al & 0.234 & 0.297 & 0.272 & 0.239 & 0.166 & 0.157 & 0.273 & 0.252 & 0.184 & 0.167 & 0.146 & 0.195 \\
\hline B & 3 & 3 & 3 & 3 & 3 & 3 & 3 & 3 & 3 & 3 & 3 & 3 \\
\hline $\mathrm{ZAl}$ & 6.000 & 6.000 & 6.000 & 6.000 & 6.000 & 6.000 & 6.000 & 6.000 & 6.000 & 6.000 & 6.000 & 6.000 \\
\hline Y Ti & 0.052 & 0.064 & 0.091 & 0.056 & 0.015 & 0.016 & 0.079 & 0.062 & 0.098 & 0.061 & 0.021 & 0.021 \\
\hline Y Al & 0.359 & 0.323 & 0.054 & 0.225 & 0.845 & 0.854 & 0.540 & 0.534 & 0.472 & 0.566 & 0.589 & 0.550 \\
\hline $\mathrm{YCr}$ & 0.000 & 0.000 & 0.000 & 0.000 & 0.009 & 0.004 & 0.004 & 0.005 & 0.008 & 0.003 & 0.002 & 0.005 \\
\hline $\mathrm{YFe}^{3+}$ & 0.000 & 0.033 & 0.110 & 0.000 & 0.000 & 0.000 & 0.000 & 0.000 & 0.000 & 0.000 & 0.000 & 0.000 \\
\hline $\mathrm{YFe}^{2+}$ & 1.164 & 1.141 & 1.260 & 1.299 & 1.595 & 1.612 & 0.898 & 0.945 & 1.470 & 1.031 & 2.034 & 2.070 \\
\hline Y Mn & 0.006 & 0.011 & 0.016 & 0.014 & 0.016 & 0.013 & 0.000 & 0.000 & 0.022 & 0.010 & 0.118 & 0.105 \\
\hline Y Zn & 0.005 & 0.005 & 0.000 & 0.007 & 0.005 & 0.000 & 0.004 & 0.000 & 0.003 & 0.000 & 0.004 & 0.021 \\
\hline Y Mg & 1.415 & 1.423 & 1.468 & 1.400 & 0.515 & 0.501 & 1.475 & 1.453 & 0.926 & 1.329 & 0.232 & 0.228 \\
\hline Y Li & 0.000 & 0.000 & 0.000 & 0.000 & 0.000 & 0.000 & 0.000 & 0.000 & 0.000 & 0.000 & 0.000 & 0.000 \\
\hline X Ca & 0.106 & 0.116 & 0.148 & 0.147 & 0.013 & 0.011 & 0.194 & 0.250 & 0.032 & 0.035 & 0.011 & 0.009 \\
\hline X Na & 0.559 & 0.565 & 0.619 & 0.660 & 0.499 & 0.471 & 0.523 & 0.463 & 0.626 & 0.619 & 0.546 & 0.579 \\
\hline x K & 0.005 & 0.015 & 0.010 & 0.018 & 0.005 & 0.009 & 0.010 & 0.012 & 0.004 & 0.006 & 0.011 & 0.007 \\
\hline $\mathrm{X}$ vac & 0.329 & 0.304 & 0.223 & 0.175 & 0.483 & 0.508 & 0.273 & 0.275 & 0.338 & 0.339 & 0.432 & 0.405 \\
\hline $\mathrm{VOH}$ & 3.000 & 3.000 & 3.000 & 3.000 & 3.000 & 3.000 & 3.000 & 3.000 & 3.000 & 3.000 & 3.000 & 3.000 \\
\hline Vo & 0.000 & 0.000 & 0.000 & 0.000 & 0.000 & 0.000 & 0.000 & 0.000 & 0.000 & 0.000 & 0.000 & 0.000 \\
\hline W F & 0.147 & 0.120 & 0.101 & 0.085 & 0.047 & 0.000 & 0.044 & 0.114 & 0.328 & 0.196 & 0.248 & 0.065 \\
\hline W Cl & 0.000 & 0.000 & 0.000 & 0.002 & 0.000 & 0.002 & 0.000 & 0.004 & 0.000 & 0.000 & 0.002 & 0.000 \\
\hline $\mathrm{WOH}$ & 0.846 & 0.880 & 0.899 & 0.842 & 0.705 & 0.761 & 0.605 & 0.495 & 0.485 & 0.584 & 0.685 & 0.929 \\
\hline W O & 0.006 & 0.000 & 0.000 & 0.071 & 0.248 & 0.237 & 0.351 & 0.386 & 0.187 & 0.221 & 0.066 & 0.006 \\
\hline Classif. & dravite & dravite & dravite & dravite & schorl & foitite & dravite & dravite & schorl & dravite & schorl & schorl \\
\hline
\end{tabular}


Appendix D.1 (contd.): Electron-microprobe analyses of tourmaline.

\begin{tabular}{|c|c|c|c|c|c|c|c|c|c|c|c|c|}
\hline \multirow[b]{2}{*}{$\begin{array}{l}\text { Site } \\
\end{array}$} & \multirow[b]{2}{*}{ 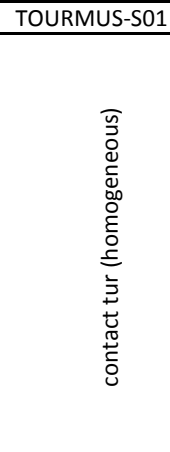 } & \multicolumn{4}{|c|}{ TOURMUS-S01 } & \multicolumn{4}{|c|}{ TOURMUS-S01 } & \multirow[b]{2}{*}{ 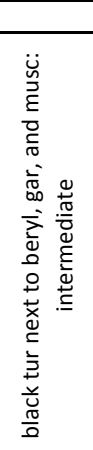 } & \multirow[b]{2}{*}{ 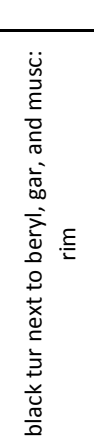 } & \multirow[b]{2}{*}{ 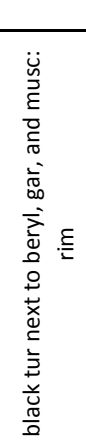 } \\
\hline & & 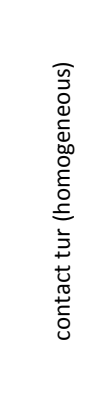 & 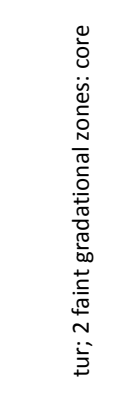 & 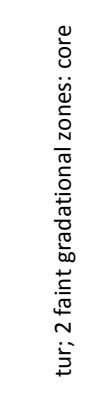 & 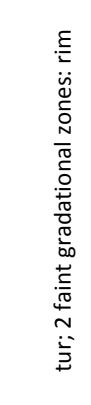 & 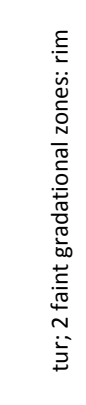 & 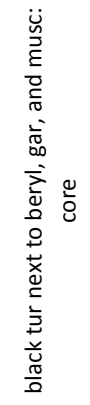 & 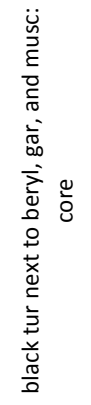 & 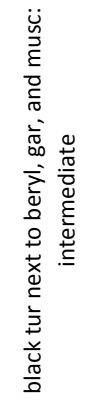 & & & \\
\hline Point & $110 \mathrm{t}-1$ & $110 \mathrm{t}-2$ & $111 \mathrm{t}-1$ & $111 \mathrm{t}-2$ & $111 \mathrm{t}-3$ & $111 \mathrm{t}-4$ & $112 \mathrm{t}-1$ & $112 \mathrm{t}-2$ & $112 t-3$ & $112 t-4$ & $112 t-5$ & $112 \mathrm{t}-6$ \\
\hline $\mathrm{SiO}_{2}$ (wt.\%) & 35.36 & 35.31 & 34.24 & 34.26 & 33.60 & 33.68 & 35.23 & 35.31 & 34.31 & 33.75 & 34.71 & 34.60 \\
\hline $\mathrm{TiO}_{2}$ & 0.29 & 0.34 & 0.22 & 0.23 & 0.50 & 0.51 & 0.20 & 0.22 & 0.53 & 0.54 & 0.57 & 0.51 \\
\hline $\mathrm{B}_{2} \mathrm{O}_{3} *$ & 10.49 & 10.48 & 10.32 & 10.27 & 10.21 & 10.23 & 10.53 & 10.47 & 10.38 & 10.27 & 10.52 & 10.54 \\
\hline $\mathrm{Al}_{2} \mathrm{O}_{3}$ & 34.06 & 33.87 & 33.92 & 33.47 & 32.75 & 32.71 & 34.50 & 34.21 & 34.98 & 34.83 & 36.61 & 36.89 \\
\hline $\mathrm{Cr}_{2} \mathrm{O}_{3}$ & 0.02 & 0.01 & 0.02 & 0.00 & 0.05 & 0.00 & 0.00 & 0.00 & 0.07 & 0.03 & 0.00 & 0.01 \\
\hline \multicolumn{13}{|l|}{$\mathrm{Bi}_{2} \mathrm{O}_{3}$} \\
\hline $\mathrm{Fe}_{2} \mathrm{O}_{3}{ }^{*}$ & 0.00 & 0.00 & 0.38 & 0.56 & 0.53 & 0.82 & 0.14 & 0.00 & 0.00 & 0.00 & 0.00 & 0.00 \\
\hline $\mathrm{FeO} *$ & 7.69 & 7.77 & 10.73 & 10.61 & 11.98 & 11.76 & 8.58 & 8.74 & 11.48 & 11.57 & 8.25 & 7.90 \\
\hline $\mathrm{FeO}$ (tot) & 7.69 & 7.77 & 11.07 & 11.11 & 12.46 & 12.49 & 8.71 & 8.74 & 11.48 & 11.57 & 8.25 & 7.90 \\
\hline $\mathrm{MnO}$ & 0.02 & 0.04 & 0.11 & 0.17 & 0.21 & 0.21 & 0.14 & 0.05 & 0.80 & 0.79 & 1.43 & 1.49 \\
\hline $\mathrm{ZnO}$ & 0.04 & 0.02 & 0.06 & 0.04 & 0.09 & 0.02 & 0.01 & 0.06 & 0.04 & 0.03 & 0.00 & 0.02 \\
\hline $\mathrm{MgO}$ & 5.58 & 5.67 & 3.55 & 3.56 & 3.26 & 3.36 & 4.99 & 4.82 & 1.38 & 1.42 & 1.26 & 1.01 \\
\hline $\mathrm{Li}_{2} \mathrm{O}^{*}$ & 0.00 & 0.00 & 0.00 & 0.00 & 0.00 & 0.00 & 0.00 & 0.00 & 0.31 & 0.23 & 0.64 & 0.77 \\
\hline $\mathrm{CaO}$ & 0.43 & 0.43 & 0.15 & 0.19 & 0.26 & 0.26 & 0.24 & 0.25 & 0.14 & 0.13 & 0.18 & 0.14 \\
\hline $\mathrm{Na}_{2} \mathrm{O}$ & 1.77 & 1.59 & 1.75 & 1.61 & 2.09 & 2.01 & 1.56 & 1.70 & 1.91 & 1.79 & 1.94 & 2.34 \\
\hline $\mathrm{K}_{2} \mathrm{O}$ & 0.05 & 0.04 & 0.02 & 0.02 & 0.05 & 0.05 & 0.04 & 0.03 & 0.02 & 0.04 & 0.03 & 0.03 \\
\hline $\mathrm{F}$ & 0.19 & 0.21 & 0.09 & 0.40 & 0.38 & 0.10 & 0.34 & 0.03 & 0.67 & 0.49 & 0.80 & 0.97 \\
\hline $\mathrm{Cl}$ & 0.00 & 0.00 & 0.00 & 0.00 & 0.00 & 0.00 & 0.00 & 0.01 & 0.00 & 0.01 & 0.00 & 0.00 \\
\hline $\mathrm{H}_{2} \mathrm{O}^{*}$ & 3.37 & 3.44 & 3.52 & 3.35 & 3.34 & 3.48 & 3.47 & 3.50 & 3.27 & 3.31 & 3.25 & 3.18 \\
\hline$-(\mathrm{O}=\mathrm{F}, \mathrm{Cl})$ & -0.08 & -0.09 & -0.04 & -0.17 & -0.16 & -0.04 & -0.14 & -0.02 & -0.28 & -0.21 & -0.34 & -0.41 \\
\hline Total & 99.28 & 99.14 & 99.03 & 98.61 & 99.14 & 99.15 & 99.83 & 99.40 & 100.01 & 99.03 & 99.85 & 100.01 \\
\hline T Si (apfu) & 5.859 & 5.853 & 5.766 & 5.796 & 5.719 & 5.724 & 5.815 & 5.861 & 5.744 & 5.712 & 5.733 & 5.704 \\
\hline T Al & 0.141 & 0.147 & 0.234 & 0.204 & 0.281 & 0.276 & 0.185 & 0.139 & 0.256 & 0.288 & 0.267 & 0.296 \\
\hline B & 3 & 3 & 3 & 3 & 3 & 3 & 3 & 3 & 3 & 3 & 3 & 3 \\
\hline $\mathrm{ZAl}$ & 6.000 & 6.000 & 6.000 & 6.000 & 6.000 & 6.000 & 6.000 & 6.000 & 6.000 & 6.000 & 6.000 & 6.000 \\
\hline Y Ti & 0.036 & 0.043 & 0.027 & 0.030 & 0.063 & 0.066 & 0.025 & 0.028 & 0.067 & 0.069 & 0.071 & 0.063 \\
\hline Y Al & 0.510 & 0.470 & 0.497 & 0.470 & 0.288 & 0.274 & 0.526 & 0.552 & 0.646 & 0.658 & 0.858 & 0.873 \\
\hline $\mathrm{YCr}$ & 0.003 & 0.001 & 0.002 & 0.000 & 0.006 & 0.000 & 0.000 & 0.000 & 0.010 & 0.004 & 0.000 & 0.002 \\
\hline $\mathrm{YFe}^{3+}$ & 0.000 & 0.000 & 0.048 & 0.071 & 0.068 & 0.104 & 0.017 & 0.000 & 0.000 & 0.000 & 0.000 & 0.000 \\
\hline $\mathrm{Y} \mathrm{Fe}^{2+}$ & 1.065 & 1.077 & 1.511 & 1.501 & 1.706 & 1.671 & 1.185 & 1.213 & 1.606 & 1.638 & 1.139 & 1.089 \\
\hline Y Mn & 0.002 & 0.005 & 0.015 & 0.025 & 0.030 & 0.030 & 0.020 & 0.007 & 0.114 & 0.114 & 0.199 & 0.208 \\
\hline Y Zn & 0.005 & 0.002 & 0.007 & 0.006 & 0.011 & 0.003 & 0.001 & 0.008 & 0.005 & 0.004 & 0.000 & 0.003 \\
\hline Y Mg & 1.379 & 1.402 & 0.891 & 0.899 & 0.828 & 0.851 & 1.227 & 1.192 & 0.345 & 0.359 & 0.309 & 0.249 \\
\hline Y Li & 0.000 & 0.000 & 0.000 & 0.000 & 0.000 & 0.000 & 0.000 & 0.000 & 0.208 & 0.154 & 0.423 & 0.513 \\
\hline X Ca & 0.076 & 0.077 & 0.028 & 0.035 & 0.047 & 0.046 & 0.043 & 0.044 & 0.025 & 0.024 & 0.032 & 0.026 \\
\hline $\mathrm{X} \mathrm{Na}$ & 0.569 & 0.512 & 0.572 & 0.529 & 0.689 & 0.662 & 0.500 & 0.549 & 0.621 & 0.587 & 0.620 & 0.749 \\
\hline x K & 0.010 & 0.009 & 0.004 & 0.005 & 0.010 & 0.011 & 0.008 & 0.007 & 0.004 & 0.008 & 0.007 & 0.007 \\
\hline$X$ vac & 0.345 & 0.402 & 0.396 & 0.431 & 0.254 & 0.281 & 0.449 & 0.400 & 0.350 & 0.381 & 0.341 & 0.219 \\
\hline $\mathrm{VOH}$ & 3.000 & 3.000 & 3.000 & 3.000 & 3.000 & 3.000 & 3.000 & 3.000 & 3.000 & 3.000 & 3.000 & 3.000 \\
\hline Vo & 0.000 & 0.000 & 0.000 & 0.000 & 0.000 & 0.000 & 0.000 & 0.000 & 0.000 & 0.000 & 0.000 & 0.000 \\
\hline W F & 0.100 & 0.108 & 0.049 & 0.215 & 0.203 & 0.056 & 0.175 & 0.017 & 0.352 & 0.262 & 0.416 & 0.505 \\
\hline W Cl & 0.000 & 0.000 & 0.000 & 0.001 & 0.000 & 0.000 & 0.001 & 0.001 & 0.000 & 0.002 & 0.001 & 0.000 \\
\hline W OH & 0.725 & 0.807 & 0.951 & 0.785 & 0.797 & 0.944 & 0.824 & 0.870 & 0.648 & 0.736 & 0.583 & 0.495 \\
\hline wo & 0.174 & 0.085 & 0.000 & 0.000 & 0.000 & 0.000 & 0.000 & 0.111 & 0.000 & 0.000 & 0.000 & 0.000 \\
\hline Classif. & dravite & dravite & schorl & schorl & schorl & schorl & dravite & schorl & schorl & schorl & schorl & $\begin{array}{l}\text { fluor- } \\
\text { schorl }\end{array}$ \\
\hline
\end{tabular}


Appendix D.1 (contd.): Electron-microprobe analyses of tourmaline.

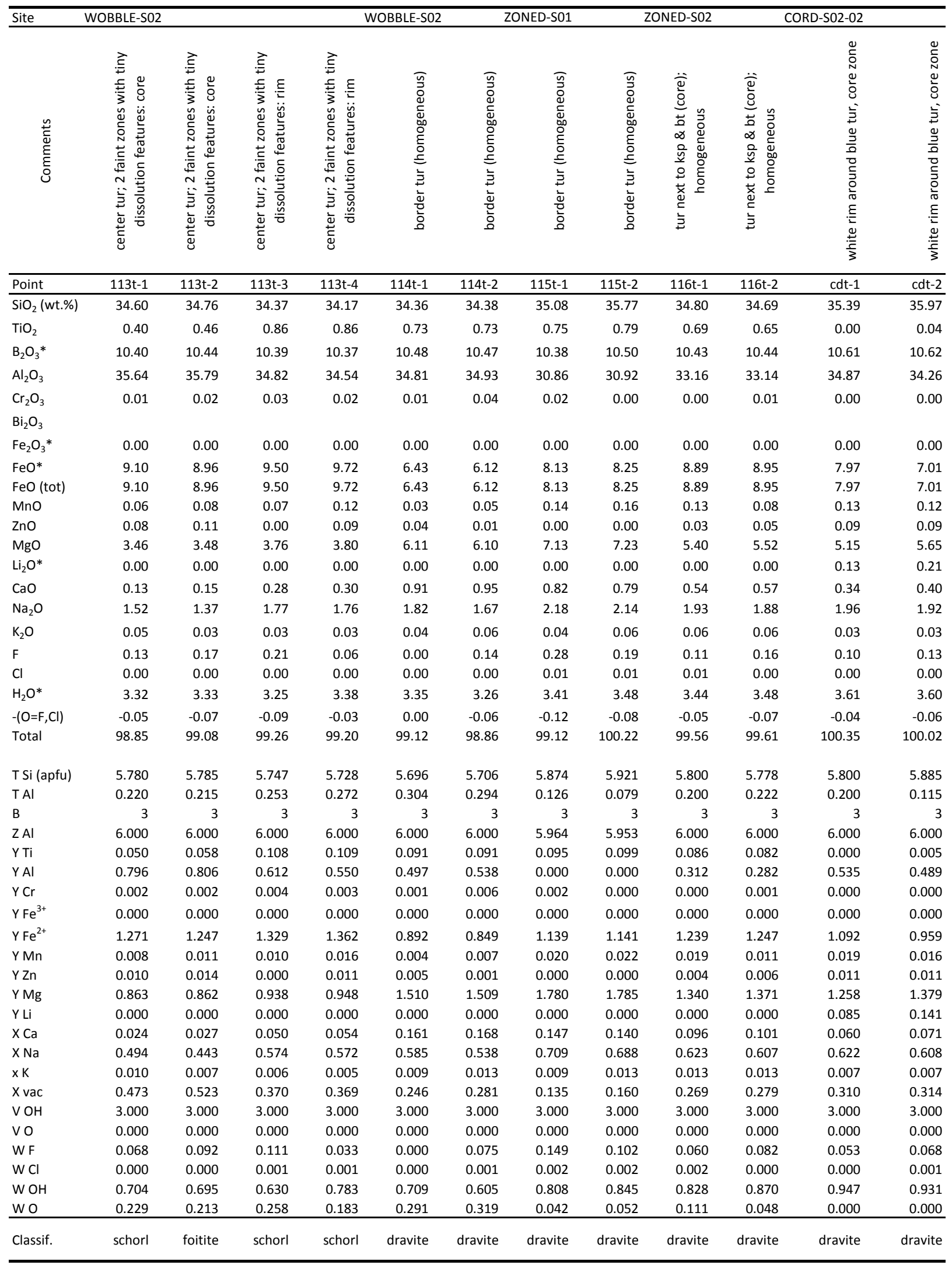


Appendix D.1 (contd.): Electron-microprobe analyses of tourmaline.

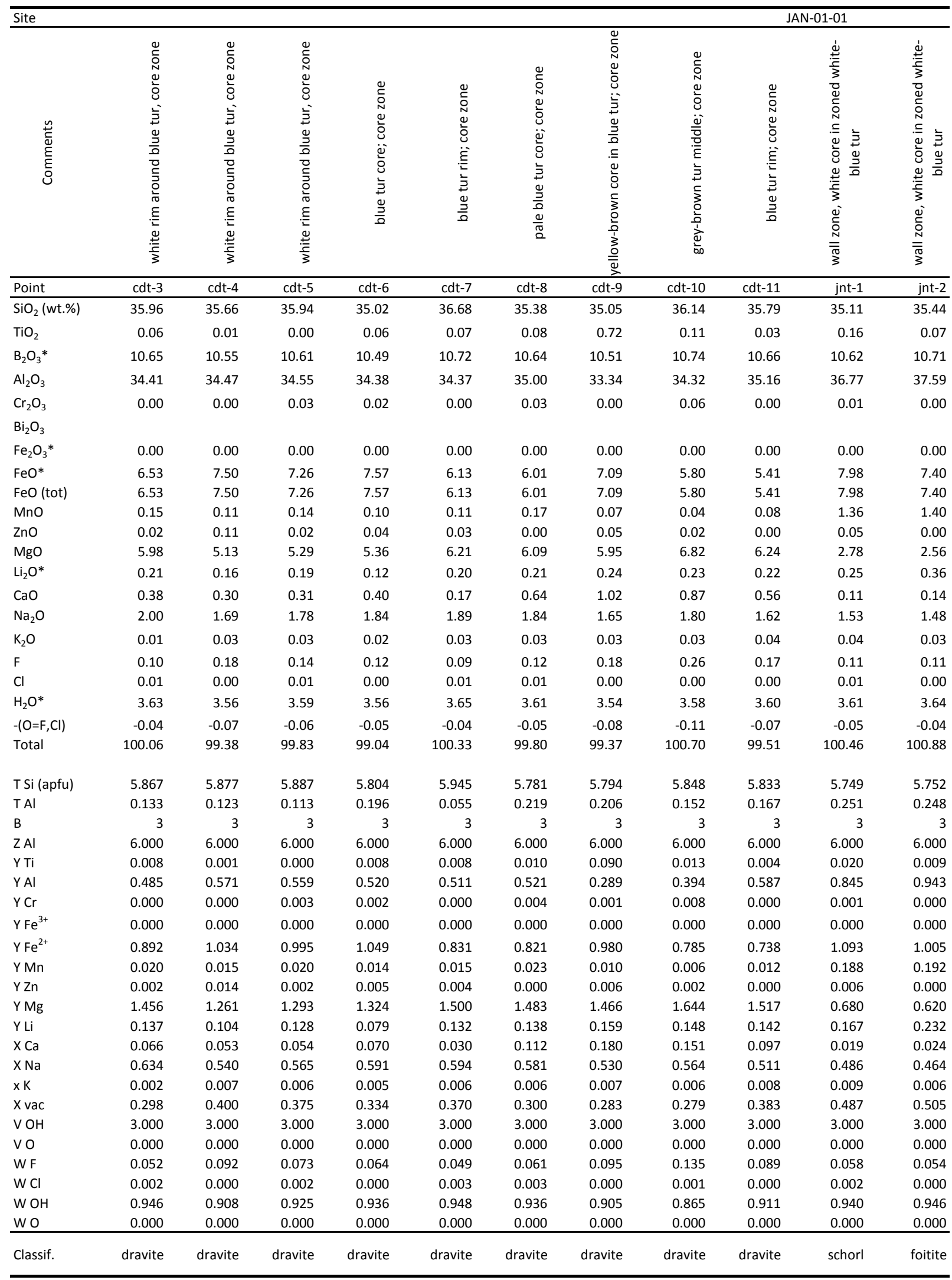


Appendix D.1 (contd.): Electron-microprobe analyses of tourmaline.

\begin{tabular}{|c|c|c|c|c|c|c|c|c|c|c|c|}
\hline \multicolumn{12}{|l|}{ Site } \\
\hline 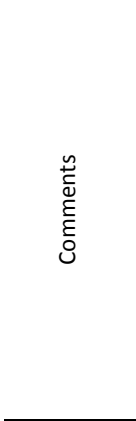 & 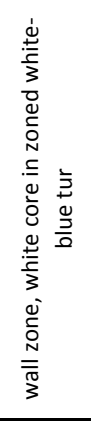 & 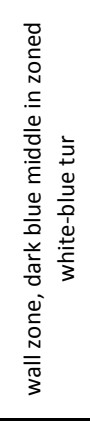 & 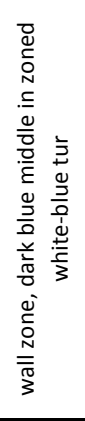 & 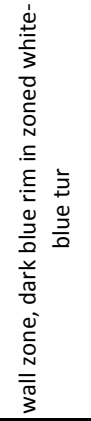 & 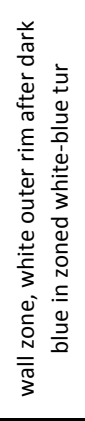 & 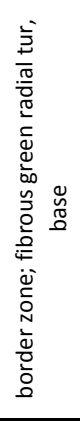 & 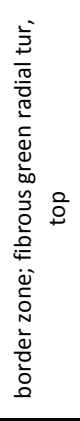 & 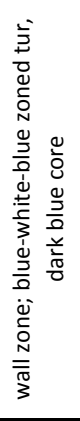 & 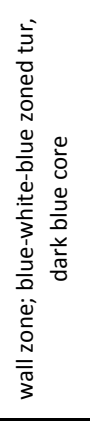 & 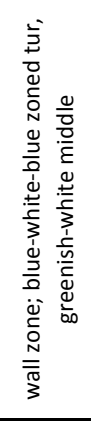 & 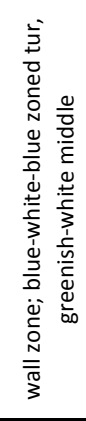 \\
\hline Point & jnt-3 & jnt-4 & jnt-5 & jnt- 6 & jnt-7 & jnt-8 & jnt-9 & jnt-10 & jnt-11 & jnt-12 & jnt-13 \\
\hline $\mathrm{SiO}_{2}$ (wt.\%) & 35.55 & 34.63 & 34.67 & 34.88 & 34.42 & 32.71 & 33.32 & 34.71 & 34.55 & 34.75 & 34.12 \\
\hline $\mathrm{TiO}_{2}$ & 0.15 & 0.18 & 0.19 & 0.15 & 0.14 & 0.58 & 0.40 & 0.13 & 0.05 & 0.11 & 0.28 \\
\hline $\mathrm{B}_{2} \mathrm{O}_{3} *$ & 10.65 & 10.28 & 10.22 & 10.21 & 10.27 & 10.27 & 10.31 & 10.37 & 10.39 & 10.70 & 10.55 \\
\hline $\mathrm{Al}_{2} \mathrm{O}_{3}$ & 36.79 & 32.05 & 31.47 & 30.90 & 33.27 & 34.71 & 34.62 & 34.74 & 35.08 & 37.74 & 37.03 \\
\hline $\mathrm{Cr}_{2} \mathrm{O}_{3}$ & 0.00 & 0.00 & 0.00 & 0.00 & 0.00 & 0.03 & 0.04 & 0.00 & 0.00 & 0.05 & 0.02 \\
\hline \multicolumn{12}{|l|}{$\mathrm{Bi}_{2} \mathrm{O}_{3}$} \\
\hline $\mathrm{Fe}_{2} \mathrm{O}_{3}{ }^{*}$ & 0.00 & 0.90 & 0.77 & 0.75 & 0.00 & 0.00 & 0.00 & 0.00 & 0.00 & 0.00 & 0.00 \\
\hline $\mathrm{FeO}^{*}$ & 7.39 & 13.07 & 13.30 & 13.42 & 11.35 & 9.80 & 10.37 & 11.41 & 11.36 & 7.11 & 7.88 \\
\hline $\mathrm{FeO}$ (tot) & 7.39 & 13.88 & 13.99 & 14.09 & 11.35 & 9.80 & 10.37 & 11.41 & 11.36 & 7.11 & 7.88 \\
\hline $\mathrm{MnO}$ & 1.45 & 0.27 & 0.36 & 0.32 & 0.11 & 0.57 & 0.48 & 0.58 & 0.64 & 1.24 & 1.31 \\
\hline $\mathrm{ZnO}$ & 0.01 & 0.07 & 0.07 & 0.08 & 0.00 & 0.00 & 0.01 & 0.04 & 0.00 & 0.08 & 0.00 \\
\hline $\mathrm{MgO}$ & 2.58 & 2.90 & 2.82 & 3.08 & 3.58 & 3.97 & 3.67 & 2.05 & 2.13 & 2.94 & 2.72 \\
\hline $\mathrm{Li}_{2} \mathrm{O}^{*}$ & 0.41 & 0.00 & 0.00 & 0.00 & 0.00 & 0.00 & 0.00 & 0.17 & 0.12 & 0.37 & 0.33 \\
\hline $\mathrm{CaO}$ & 0.08 & 0.28 & 0.20 & 0.26 & 0.51 & 1.07 & 0.90 & 0.22 & 0.18 & 0.36 & 0.47 \\
\hline $\mathrm{Na}_{2} \mathrm{O}$ & 1.65 & 1.94 & 2.01 & 2.06 & 1.96 & 1.82 & 1.88 & 1.54 & 1.58 & 1.77 & 1.72 \\
\hline $\mathrm{K}_{2} \mathrm{O}$ & 0.05 & 0.05 & 0.06 & 0.06 & 0.07 & 0.05 & 0.07 & 0.04 & 0.03 & 0.04 & 0.02 \\
\hline $\mathrm{F}$ & 0.05 & 0.00 & 0.18 & 0.06 & 0.24 & 0.06 & 0.01 & 0.12 & 0.05 & 0.15 & 0.14 \\
\hline $\mathrm{Cl}$ & 0.00 & 0.01 & 0.00 & 0.00 & 0.01 & 0.01 & 0.00 & 0.00 & 0.00 & 0.01 & 0.00 \\
\hline $\mathrm{H}_{2} \mathrm{O}^{*}$ & 3.65 & 3.55 & 3.44 & 3.49 & 3.28 & 3.40 & 3.41 & 3.52 & 3.56 & 3.62 & 3.57 \\
\hline$-(\mathrm{O}=\mathrm{F}, \mathrm{Cl})$ & -0.02 & 0.00 & -0.07 & -0.03 & -0.10 & -0.03 & 0.00 & -0.05 & -0.02 & -0.06 & -0.06 \\
\hline Total & 100.44 & 100.17 & 99.68 & 99.70 & 99.13 & 99.02 & 99.47 & 99.58 & 99.70 & 100.97 & 100.11 \\
\hline T Si (apfu) & 5.800 & 5.853 & 5.898 & 5.938 & 5.824 & 5.533 & 5.616 & 5.816 & 5.782 & 5.647 & 5.620 \\
\hline TAl & 0.200 & 0.147 & 0.102 & 0.062 & 0.176 & 0.467 & 0.384 & 0.184 & 0.218 & 0.353 & 0.380 \\
\hline B & 3 & 3 & 3 & 3 & 3 & 3 & 3 & 3 & 3 & 3 & 3 \\
\hline $\mathrm{ZAl}$ & 6.000 & 6.000 & 6.000 & 6.000 & 6.000 & 6.000 & 6.000 & 6.000 & 6.000 & 6.000 & 6.000 \\
\hline $\mathrm{YTi}$ & 0.018 & 0.023 & 0.024 & 0.019 & 0.018 & 0.074 & 0.051 & 0.016 & 0.006 & 0.014 & 0.035 \\
\hline Y Al & 0.875 & 0.238 & 0.208 & 0.138 & 0.457 & 0.454 & 0.492 & 0.675 & 0.702 & 0.874 & 0.808 \\
\hline $\mathrm{YCr}$ & 0.000 & 0.000 & 0.000 & 0.000 & 0.000 & 0.004 & 0.005 & 0.000 & 0.000 & 0.007 & 0.003 \\
\hline $\mathrm{Y} \mathrm{Fe}^{3+}$ & 0.000 & 0.114 & 0.098 & 0.096 & 0.000 & 0.000 & 0.000 & 0.000 & 0.000 & 0.000 & 0.000 \\
\hline $\mathrm{Y} \mathrm{Fe}^{2+}$ & 1.009 & 1.848 & 1.892 & 1.910 & 1.606 & 1.386 & 1.462 & 1.599 & 1.590 & 0.966 & 1.085 \\
\hline Y Mn & 0.200 & 0.038 & 0.052 & 0.046 & 0.016 & 0.082 & 0.068 & 0.082 & 0.090 & 0.171 & 0.183 \\
\hline $\mathrm{YZn}$ & 0.001 & 0.009 & 0.009 & 0.010 & 0.000 & 0.000 & 0.001 & 0.005 & 0.000 & 0.010 & 0.000 \\
\hline Y Mg & 0.627 & 0.731 & 0.716 & 0.780 & 0.903 & 1.000 & 0.921 & 0.512 & 0.532 & 0.713 & 0.667 \\
\hline Y Li & 0.270 & 0.000 & 0.000 & 0.000 & 0.000 & 0.000 & 0.000 & 0.112 & 0.079 & 0.245 & 0.219 \\
\hline X Ca & 0.014 & 0.051 & 0.036 & 0.048 & 0.093 & 0.194 & 0.162 & 0.039 & 0.032 & 0.062 & 0.083 \\
\hline $\mathrm{XNa}$ & 0.521 & 0.637 & 0.662 & 0.681 & 0.644 & 0.598 & 0.614 & 0.501 & 0.512 & 0.557 & 0.548 \\
\hline$x K$ & 0.009 & 0.010 & 0.013 & 0.013 & 0.016 & 0.010 & 0.015 & 0.010 & 0.007 & 0.008 & 0.005 \\
\hline$X$ vac & 0.455 & 0.302 & 0.289 & 0.258 & 0.247 & 0.198 & 0.209 & 0.451 & 0.449 & 0.373 & 0.364 \\
\hline $\mathrm{VOH}$ & 3.000 & 3.000 & 3.000 & 3.000 & 3.000 & 3.000 & 3.000 & 3.000 & 3.000 & 3.000 & 3.000 \\
\hline Vo & 0.000 & 0.000 & 0.000 & 0.000 & 0.000 & 0.000 & 0.000 & 0.000 & 0.000 & 0.000 & 0.000 \\
\hline W F & 0.025 & 0.000 & 0.095 & 0.034 & 0.129 & 0.030 & 0.003 & 0.065 & 0.026 & 0.075 & 0.075 \\
\hline W Cl & 0.001 & 0.003 & 0.000 & 0.000 & 0.003 & 0.003 & 0.000 & 0.000 & 0.001 & 0.002 & 0.000 \\
\hline W OH & 0.974 & 0.997 & 0.905 & 0.966 & 0.705 & 0.832 & 0.829 & 0.935 & 0.973 & 0.923 & 0.925 \\
\hline wo & 0.000 & 0.000 & 0.000 & 0.000 & 0.162 & 0.135 & 0.168 & 0.000 & 0.000 & 0.000 & 0.000 \\
\hline Classif. & schorl & schorl & schorl & schorl & schorl & schorl & schorl & schorl & schorl & schorl & schorl \\
\hline
\end{tabular}


Appendix D.1 (contd.): Electron-microprobe analyses of tourmaline.

\begin{tabular}{|c|c|c|c|c|c|c|c|c|c|c|c|}
\hline \multicolumn{12}{|l|}{ Site } \\
\hline 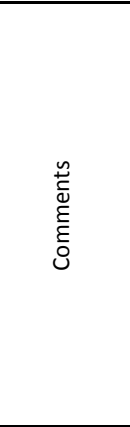 & 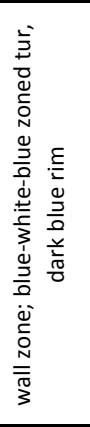 & 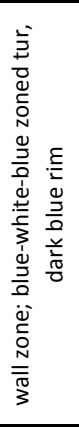 & 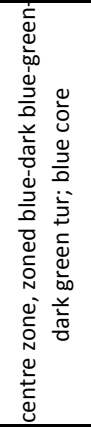 & 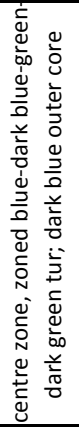 & 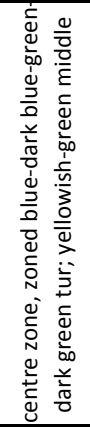 & 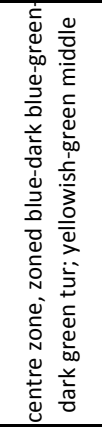 & 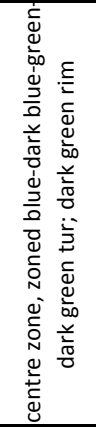 & 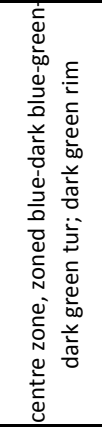 & 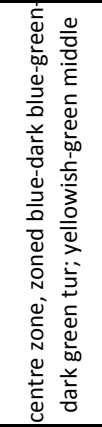 & 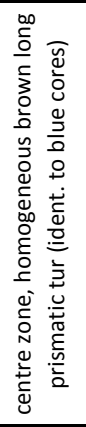 & 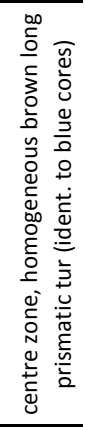 \\
\hline Point & jnt-14 & jnt-15 & jnt-16 & jnt-17 & jnt-18 & jnt-19 & jnt-20 & jnt-21 & jnt-22 & jnt-23 & jnt-24 \\
\hline $\mathrm{SiO}_{2}$ (wt.\%) & 34.48 & 34.33 & 35.12 & 34.08 & 34.91 & 35.74 & 35.06 & 35.17 & 35.79 & 33.80 & 33.83 \\
\hline $\mathrm{TiO}_{2}$ & 0.27 & 0.23 & 0.16 & 0.42 & 0.96 & 1.06 & 0.93 & 1.02 & 0.95 & 0.31 & 0.16 \\
\hline $\mathrm{B}_{2} \mathrm{O}_{3} *$ & 10.33 & 10.29 & 10.36 & 10.20 & 10.44 & 10.53 & 10.36 & 10.40 & 10.59 & 10.18 & 10.20 \\
\hline $\mathrm{Al}_{2} \mathrm{O}_{3}$ & 33.46 & 32.88 & 32.64 & 32.36 & 31.35 & 31.25 & 29.31 & 29.78 & 31.84 & 32.49 & 32.65 \\
\hline $\mathrm{Cr}_{2} \mathrm{O}_{3}$ & 0.07 & 0.03 & 0.01 & 0.05 & 0.01 & 0.00 & 0.04 & 0.00 & 0.00 & 0.03 & 0.05 \\
\hline \multicolumn{12}{|l|}{$\mathrm{Bi}_{2} \mathrm{O}_{3}$} \\
\hline $\mathrm{Fe}_{2} \mathrm{O}_{3} *$ & 0.00 & 0.00 & 0.30 & 0.00 & 0.00 & 0.00 & 0.00 & 0.00 & 0.00 & 0.00 & 0.48 \\
\hline $\mathrm{FeO} *$ & 11.65 & 12.18 & 12.22 & 13.38 & 6.33 & 5.66 & 8.54 & 7.96 & 5.61 & 12.81 & 12.22 \\
\hline $\mathrm{FeO}$ (tot) & 11.65 & 12.18 & 12.49 & 13.38 & 6.33 & 5.66 & 8.54 & 7.96 & 5.61 & 12.81 & 12.65 \\
\hline $\mathrm{MnO}$ & 0.10 & 0.10 & 0.15 & 0.16 & 0.10 & 0.02 & 0.00 & 0.04 & 0.02 & 0.14 & 0.10 \\
\hline $\mathrm{ZnO}$ & 0.06 & 0.05 & 0.07 & 0.09 & 0.01 & 0.00 & 0.04 & 0.03 & 0.00 & 0.07 & 0.00 \\
\hline $\mathrm{MgO}$ & 3.43 & 3.50 & 3.39 & 2.71 & 8.15 & 8.56 & 8.00 & 8.03 & 8.48 & 3.10 & 3.29 \\
\hline $\mathrm{Li}_{2} \mathrm{O}^{*}$ & 0.00 & 0.00 & 0.00 & 0.00 & 0.00 & 0.00 & 0.00 & 0.00 & 0.00 & 0.00 & 0.00 \\
\hline $\mathrm{CaO}$ & 0.54 & 0.62 & 0.26 & 0.44 & 1.51 & 1.46 & 2.18 & 2.01 & 1.42 & 0.48 & 0.41 \\
\hline $\mathrm{Na}_{2} \mathrm{O}$ & 1.80 & 1.98 & 1.76 & 2.02 & 1.72 & 1.78 & 1.36 & 1.59 & 1.60 & 1.96 & 1.96 \\
\hline $\mathrm{K}_{2} \mathrm{O}$ & 0.04 & 0.05 & 0.06 & 0.08 & 0.06 & 0.04 & 0.09 & 0.07 & 0.05 & 0.05 & 0.05 \\
\hline$F$ & 0.11 & 0.01 & 0.09 & 0.27 & 0.31 & 0.17 & 0.14 & 0.25 & 0.20 & 0.22 & 0.08 \\
\hline $\mathrm{Cl}$ & 0.00 & 0.02 & 0.00 & 0.00 & 0.00 & 0.01 & 0.00 & 0.00 & 0.00 & 0.01 & 0.01 \\
\hline $\mathrm{H}_{2} \mathrm{O}^{*}$ & 3.42 & 3.46 & 3.53 & 3.32 & 3.35 & 3.34 & 3.47 & 3.35 & 3.41 & 3.41 & 3.48 \\
\hline$-(\mathrm{O}=\mathrm{F}, \mathrm{Cl})$ & -0.04 & -0.01 & -0.04 & -0.12 & -0.13 & -0.07 & -0.06 & -0.10 & -0.09 & -0.09 & -0.04 \\
\hline Total & 99.71 & 99.72 & 100.09 & 99.47 & 99.08 & 99.53 & 99.46 & 99.60 & 99.89 & 98.98 & 98.95 \\
\hline T Si (apfu) & 5.802 & 5.799 & 5.893 & 5.809 & 5.810 & 5.899 & 5.881 & 5.880 & 5.875 & 5.771 & 5.763 \\
\hline $\mathrm{TAl}$ & 0.198 & 0.201 & 0.107 & 0.191 & 0.190 & 0.101 & 0.119 & 0.120 & 0.125 & 0.229 & 0.237 \\
\hline B & 3 & 3 & 3 & 3 & 3 & 3 & 3 & 3 & 3 & 3 & 3 \\
\hline $\mathrm{Z} \mathrm{Al}$ & 6.000 & 6.000 & 6.000 & 6.000 & 5.961 & 5.978 & 5.675 & 5.747 & 6.000 & 6.000 & 6.000 \\
\hline Y Ti & 0.034 & 0.029 & 0.020 & 0.054 & 0.121 & 0.132 & 0.117 & 0.128 & 0.118 & 0.040 & 0.020 \\
\hline Y Al & 0.436 & 0.344 & 0.347 & 0.309 & 0.000 & 0.000 & 0.000 & 0.000 & 0.034 & 0.309 & 0.319 \\
\hline $\mathrm{YCr}$ & 0.009 & 0.004 & 0.001 & 0.007 & 0.001 & 0.000 & 0.005 & 0.001 & 0.000 & 0.004 & 0.007 \\
\hline $\mathrm{YFe}^{3+}$ & 0.000 & 0.000 & 0.038 & 0.000 & 0.000 & 0.000 & 0.000 & 0.000 & 0.000 & 0.000 & 0.062 \\
\hline $\mathrm{Y} \mathrm{Fe}^{2+}$ & 1.639 & 1.721 & 1.715 & 1.908 & 0.881 & 0.782 & 1.198 & 1.113 & 0.770 & 1.830 & 1.740 \\
\hline Y Mn & 0.014 & 0.014 & 0.021 & 0.023 & 0.014 & 0.002 & 0.000 & 0.005 & 0.003 & 0.021 & 0.015 \\
\hline Y Zn & 0.008 & 0.007 & 0.009 & 0.011 & 0.001 & 0.000 & 0.005 & 0.004 & 0.000 & 0.009 & 0.000 \\
\hline Y Mg & 0.861 & 0.882 & 0.849 & 0.688 & 2.022 & 2.106 & 2.001 & 2.002 & 2.075 & 0.788 & 0.836 \\
\hline Y Li & 0.000 & 0.000 & 0.000 & 0.000 & 0.000 & 0.000 & 0.000 & 0.000 & 0.000 & 0.000 & 0.000 \\
\hline $\mathrm{XCa}$ & 0.098 & 0.112 & 0.048 & 0.081 & 0.269 & 0.257 & 0.392 & 0.360 & 0.250 & 0.088 & 0.074 \\
\hline $\mathrm{X} \mathrm{Na}$ & 0.588 & 0.648 & 0.574 & 0.668 & 0.556 & 0.570 & 0.443 & 0.515 & 0.510 & 0.650 & 0.649 \\
\hline x K & 0.008 & 0.011 & 0.012 & 0.018 & 0.012 & 0.008 & 0.019 & 0.015 & 0.011 & 0.011 & 0.011 \\
\hline X vac & 0.306 & 0.229 & 0.366 & 0.233 & 0.163 & 0.164 & 0.146 & 0.110 & 0.229 & 0.251 & 0.266 \\
\hline $\mathrm{V} \mathrm{OH}$ & 3.000 & 3.000 & 3.000 & 3.000 & 3.000 & 3.000 & 3.000 & 3.000 & 3.000 & 3.000 & 3.000 \\
\hline vo & 0.000 & 0.000 & 0.000 & 0.000 & 0.000 & 0.000 & 0.000 & 0.000 & 0.000 & 0.000 & 0.000 \\
\hline W F & 0.056 & 0.008 & 0.049 & 0.148 & 0.163 & 0.091 & 0.073 & 0.130 & 0.104 & 0.118 & 0.042 \\
\hline W Cl & 0.001 & 0.005 & 0.000 & 0.001 & 0.000 & 0.002 & 0.001 & 0.001 & 0.001 & 0.002 & 0.003 \\
\hline $\mathrm{WOH}$ & 0.837 & 0.900 & 0.951 & 0.770 & 0.718 & 0.672 & 0.886 & 0.737 & 0.730 & 0.879 & 0.955 \\
\hline wo & 0.106 & 0.087 & 0.000 & 0.081 & 0.119 & 0.235 & 0.039 & 0.133 & 0.165 & 0.001 & 0.000 \\
\hline Classif. & schorl & schorl & schorl & schorl & dravite & dravite & dravite & dravite & dravite & schorl & schorl \\
\hline
\end{tabular}


Appendix D.1 (contd.): Electron-microprobe analyses of tourmaline.

\begin{tabular}{|c|c|c|c|c|c|c|c|c|c|}
\hline \multicolumn{10}{|l|}{ Site } \\
\hline 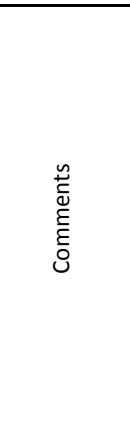 & 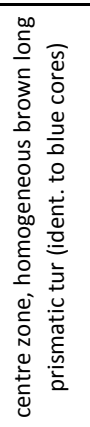 & 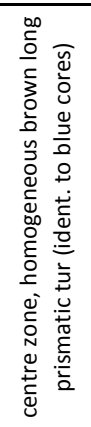 & 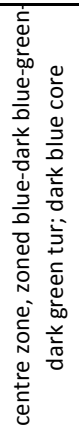 & 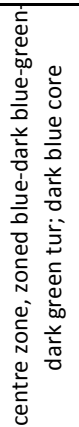 & 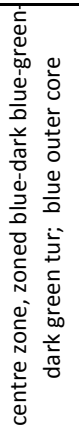 & 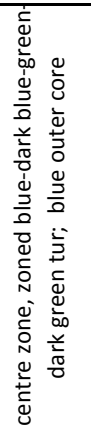 & 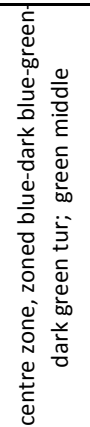 & 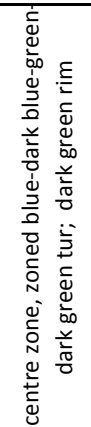 & 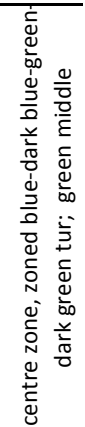 \\
\hline Point & jnt-25 & jnt-26 & jnt-27 & jnt-28 & jnt-29 & jnt-30 & jnt-31 & jnt-32 & jnt-33 \\
\hline $\mathrm{SiO}_{2}$ (wt.\%) & 33.62 & 34.25 & 33.81 & 34.27 & 33.77 & 33.52 & 35.04 & 34.89 & 35.27 \\
\hline $\mathrm{TiO}_{2}$ & 0.33 & 0.21 & 0.38 & 0.44 & 0.69 & 0.68 & 0.71 & 1.06 & 0.92 \\
\hline $\mathrm{B}_{2} \mathrm{O}_{3} *$ & 10.20 & 10.33 & 10.23 & 10.28 & 10.15 & 10.07 & 10.45 & 10.37 & 10.54 \\
\hline $\mathrm{Al}_{2} \mathrm{O}_{3}$ & 32.53 & 33.07 & 32.34 & 32.84 & 32.48 & 32.26 & 32.23 & 29.97 & 32.33 \\
\hline $\mathrm{Cr}_{2} \mathrm{O}_{3}$ & 0.01 & 0.00 & 0.00 & 0.00 & 0.00 & 0.00 & 0.00 & 0.00 & 0.00 \\
\hline \multicolumn{10}{|l|}{$\mathrm{Bi}_{2} \mathrm{O}_{3}$} \\
\hline $\mathrm{Fe}_{2} \mathrm{O}_{3} *$ & 0.60 & 0.67 & 0.69 & 0.00 & 0.00 & 0.00 & 0.00 & 0.00 & 0.00 \\
\hline $\mathrm{FeO} *$ & 12.61 & 11.95 & 12.86 & 12.72 & 14.68 & 14.47 & 6.46 & 8.27 & 4.81 \\
\hline $\mathrm{FeO}$ (tot) & 13.15 & 12.56 & 13.48 & 12.72 & 14.68 & 14.47 & 6.46 & 8.27 & 4.81 \\
\hline $\mathrm{MnO}$ & 0.16 & 0.12 & 0.14 & 0.29 & 0.56 & 0.55 & 0.00 & 0.03 & 0.03 \\
\hline $\mathrm{ZnO}$ & 0.10 & 0.12 & 0.07 & 0.15 & 0.09 & 0.05 & 0.01 & 0.00 & 0.00 \\
\hline $\mathrm{MgO}$ & 3.08 & 3.43 & 3.09 & 2.94 & 1.45 & 1.51 & 7.51 & 7.73 & 8.61 \\
\hline $\mathrm{Li}_{2} \mathrm{O}^{*}$ & 0.00 & 0.00 & 0.00 & 0.00 & 0.00 & 0.00 & 0.00 & 0.00 & 0.00 \\
\hline $\mathrm{CaO}$ & 0.48 & 0.48 & 0.45 & 0.40 & 0.25 & 0.27 & 0.82 & 2.00 & 1.00 \\
\hline $\mathrm{Na}_{2} \mathrm{O}$ & 1.99 & 1.85 & 2.02 & 1.93 & 1.95 & 2.08 & 2.04 & 1.55 & 2.27 \\
\hline $\mathrm{K}_{2} \mathrm{O}$ & 0.05 & 0.05 & 0.07 & 0.05 & 0.05 & 0.07 & 0.07 & 0.09 & 0.05 \\
\hline$F$ & 0.08 & 0.19 & 0.14 & 0.05 & 0.18 & 0.22 & 0.10 & 0.20 & 0.13 \\
\hline $\mathrm{Cl}$ & 0.00 & 0.00 & 0.00 & 0.00 & 0.00 & 0.00 & 0.00 & 0.00 & 0.01 \\
\hline $\mathrm{H}_{2} \mathrm{O}^{*}$ & 3.48 & 3.47 & 3.46 & 3.48 & 3.36 & 3.27 & 3.45 & 3.37 & 3.35 \\
\hline$-(\mathrm{O}=\mathrm{F}, \mathrm{Cl})$ & -0.03 & -0.08 & -0.06 & -0.02 & -0.07 & -0.09 & -0.04 & -0.08 & -0.06 \\
\hline Total & 99.28 & 100.10 & 99.70 & 99.83 & 99.60 & 98.92 & 98.84 & 99.43 & 99.26 \\
\hline T Si (apfu) & 5.730 & 5.762 & 5.746 & 5.797 & 5.786 & 5.785 & 5.829 & 5.849 & 5.818 \\
\hline $\mathrm{TAl}$ & 0.270 & 0.238 & 0.254 & 0.203 & 0.214 & 0.215 & 0.171 & 0.151 & 0.182 \\
\hline B & 3 & 3 & 3 & 3 & 3 & 3 & 3 & 3 & 3 \\
\hline $\mathrm{Z} \mathrm{Al}$ & 6.000 & 6.000 & 6.000 & 6.000 & 6.000 & 6.000 & 6.000 & 5.772 & 6.000 \\
\hline Y Ti & 0.042 & 0.026 & 0.048 & 0.056 & 0.088 & 0.089 & 0.088 & 0.133 & 0.114 \\
\hline Y Al & 0.264 & 0.316 & 0.223 & 0.343 & 0.344 & 0.346 & 0.149 & 0.000 & 0.102 \\
\hline $\mathrm{YCr}$ & 0.002 & 0.000 & 0.000 & 0.000 & 0.000 & 0.000 & 0.000 & 0.000 & 0.000 \\
\hline $\mathrm{Y} \mathrm{Fe}^{3+}$ & 0.077 & 0.085 & 0.088 & 0.000 & 0.000 & 0.000 & 0.000 & 0.000 & 0.000 \\
\hline $\mathrm{Y} \mathrm{Fe}^{2+}$ & 1.797 & 1.682 & 1.827 & 1.799 & 2.104 & 2.089 & 0.898 & 1.160 & 0.663 \\
\hline Y Mn & 0.023 & 0.017 & 0.021 & 0.041 & 0.082 & 0.080 & 0.000 & 0.004 & 0.004 \\
\hline Y Zn & 0.012 & 0.014 & 0.009 & 0.019 & 0.012 & 0.007 & 0.001 & 0.000 & 0.000 \\
\hline Y Mg & 0.784 & 0.860 & 0.784 & 0.742 & 0.370 & 0.389 & 1.862 & 1.931 & 2.117 \\
\hline Y Li & 0.000 & 0.000 & 0.000 & 0.000 & 0.000 & 0.000 & 0.000 & 0.000 & 0.000 \\
\hline $\mathrm{XCa}$ & 0.088 & 0.086 & 0.083 & 0.073 & 0.047 & 0.049 & 0.147 & 0.359 & 0.177 \\
\hline $\mathrm{X} \mathrm{Na}$ & 0.657 & 0.602 & 0.665 & 0.632 & 0.646 & 0.696 & 0.658 & 0.505 & 0.727 \\
\hline x K & 0.011 & 0.011 & 0.015 & 0.011 & 0.012 & 0.014 & 0.014 & 0.019 & 0.010 \\
\hline $\mathrm{X}$ vac & 0.244 & 0.301 & 0.237 & 0.284 & 0.295 & 0.240 & 0.182 & 0.117 & 0.085 \\
\hline $\mathrm{VOH}$ & 3.000 & 3.000 & 3.000 & 3.000 & 3.000 & 3.000 & 3.000 & 3.000 & 3.000 \\
\hline vo & 0.000 & 0.000 & 0.000 & 0.000 & 0.000 & 0.000 & 0.000 & 0.000 & 0.000 \\
\hline W F & 0.042 & 0.102 & 0.076 & 0.028 & 0.096 & 0.122 & 0.052 & 0.104 & 0.068 \\
\hline W Cl & 0.001 & 0.000 & 0.000 & 0.001 & 0.001 & 0.000 & 0.000 & 0.001 & 0.002 \\
\hline $\mathrm{WOH}$ & 0.957 & 0.898 & 0.924 & 0.930 & 0.845 & 0.762 & 0.828 & 0.765 & 0.690 \\
\hline wo & 0.000 & 0.000 & 0.000 & 0.041 & 0.059 & 0.117 & 0.120 & 0.130 & 0.239 \\
\hline Classif. & schorl & schorl & schorl & schorl & schorl & schorl & dravite & dravite & dravite \\
\hline
\end{tabular}


Appendix D.2: Electron microprobe analyses of K-feldspar.

\begin{tabular}{|c|c|c|c|c|c|c|c|c|c|c|}
\hline Site & 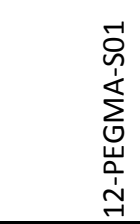 & 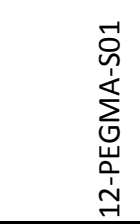 & 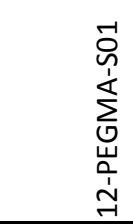 & 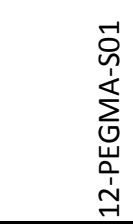 & 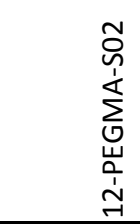 & 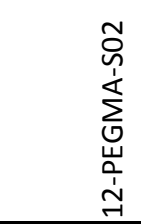 & 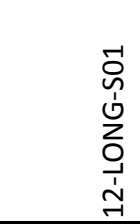 & 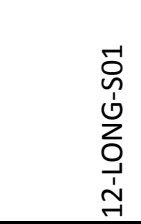 & 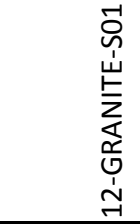 & 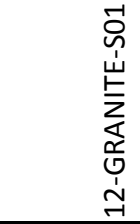 \\
\hline Comment & 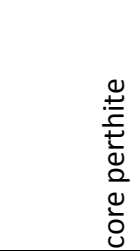 & 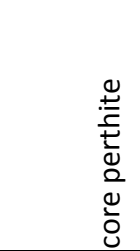 & 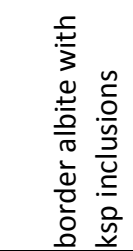 & 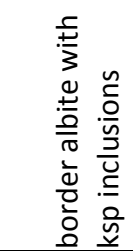 & 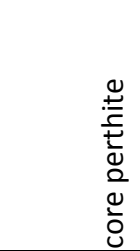 & 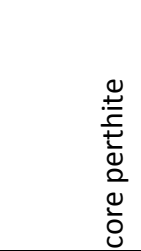 & $\begin{array}{l}\frac{0}{n} \\
\frac{n}{n} \\
\frac{0}{0} \\
\frac{0}{2}\end{array}$ & $\begin{array}{l}\frac{0}{v} \\
\frac{\hat{v}}{0} \\
\frac{0}{0} \\
\frac{0}{2}\end{array}$ & 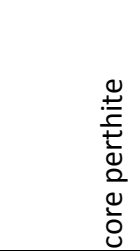 & 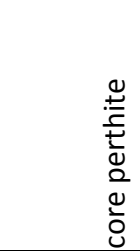 \\
\hline Point & $1 \mathrm{f}-1$ & $1 \mathrm{f}-2$ & $2 f-1$ & $2 f-2$ & $6 f-1$ & $6 f-2$ & $8 f-1$ & $8 f-2$ & $10 \mathrm{f}-1$ & $10 f-2$ \\
\hline $\mathrm{P}_{2} \mathrm{O}_{5}$ (wt.\%) & 0.18 & 0.16 & 0.09 & 0.09 & 0.17 & 0.21 & 0.00 & 0.00 & 0.06 & 0.07 \\
\hline $\mathrm{SiO}_{2}$ & 63.47 & 63.89 & 63.74 & 63.55 & 63.05 & 62.76 & 64.06 & 64.05 & 64.10 & 63.46 \\
\hline $\mathrm{TiO}_{2}$ & 0.02 & 0.00 & 0.01 & 0.00 & 0.00 & 0.00 & 0.00 & 0.00 & 0.00 & 0.03 \\
\hline $\mathrm{Al}_{2} \mathrm{O}_{3}$ & 18.69 & 18.68 & 18.41 & 18.55 & 18.36 & 18.42 & 18.45 & 18.42 & 18.66 & 18.62 \\
\hline $\mathrm{MgO}$ & 0.00 & 0.00 & 0.00 & 0.01 & 0.00 & 0.00 & 0.00 & 0.01 & 0.00 & 0.00 \\
\hline $\mathrm{MnO}$ & 0.00 & 0.01 & 0.02 & 0.01 & 0.02 & 0.03 & 0.01 & 0.00 & 0.00 & 0.02 \\
\hline $\mathrm{FeO}$ & 0.01 & 0.00 & 0.00 & 0.02 & 0.03 & 0.00 & 0.02 & 0.05 & 0.01 & 0.02 \\
\hline $\mathrm{ZnO}$ & 0.06 & 0.03 & 0.02 & 0.03 & 0.00 & 0.05 & 0.00 & 0.02 & 0.02 & 0.00 \\
\hline $\mathrm{BaO}$ & 0.07 & 0.00 & 0.04 & 0.11 & 0.00 & 0.00 & 0.01 & 0.23 & 0.27 & 0.14 \\
\hline $\mathrm{PbO}$ & 0.01 & 0.00 & 0.00 & 0.00 & 0.00 & 0.00 & 0.00 & 0.03 & 0.00 & 0.01 \\
\hline $\mathrm{CaO}$ & 0.04 & 0.05 & 0.03 & 0.03 & 0.03 & 0.00 & 0.00 & 0.00 & 0.09 & 0.09 \\
\hline $\mathrm{Na}_{2} \mathrm{O}$ & 0.84 & 0.96 & 0.64 & 0.75 & 1.02 & 0.75 & 0.87 & 0.81 & 1.36 & 1.20 \\
\hline $\mathrm{K}_{2} \mathrm{O}$ & 15.79 & 15.65 & 16.01 & 15.91 & 15.41 & 16.00 & 15.69 & 15.81 & 14.79 & 15.14 \\
\hline $\mathrm{Rb}_{2} \mathrm{O}$ & 0.77 & 0.78 & 0.79 & 0.74 & 0.81 & 0.85 & 0.78 & 0.81 & 0.78 & 0.78 \\
\hline $\mathrm{Cs}_{2} \mathrm{O}$ & 0.03 & 0.02 & 0.02 & 0.00 & 0.03 & 0.01 & 0.02 & 0.03 & 0.03 & 0.02 \\
\hline Total & 99.98 & 100.23 & 99.82 & 99.80 & 98.93 & 99.08 & 99.91 & 100.27 & 100.17 & 99.60 \\
\hline P (apfu) & 0.007 & 0.006 & 0.004 & 0.004 & 0.007 & 0.008 & 0.000 & 0.000 & 0.002 & 0.003 \\
\hline $\mathrm{Si}$ & 2.958 & 2.965 & 2.975 & 2.967 & 2.966 & 2.957 & 2.982 & 2.980 & 2.972 & 2.964 \\
\hline $\mathrm{Ti}$ & 0.001 & 0.000 & 0.000 & 0.000 & 0.000 & 0.000 & 0.000 & 0.000 & 0.000 & 0.001 \\
\hline $\mathrm{Al}$ & 1.027 & 1.022 & 1.013 & 1.021 & 1.018 & 1.023 & 1.012 & 1.010 & 1.020 & 1.025 \\
\hline $\mathrm{Mg}$ & 0.000 & 0.000 & 0.000 & 0.001 & 0.000 & 0.000 & 0.000 & 0.001 & 0.000 & 0.000 \\
\hline $\mathrm{Mn}^{2+}$ & 0.000 & 0.000 & 0.001 & 0.000 & 0.001 & 0.001 & 0.000 & 0.000 & 0.000 & 0.001 \\
\hline $\mathrm{Fe}^{2+}$ & 0.000 & 0.000 & 0.000 & 0.001 & 0.001 & 0.000 & 0.001 & 0.002 & 0.000 & 0.001 \\
\hline $\mathrm{Zn}$ & 0.002 & 0.001 & 0.001 & 0.001 & 0.000 & 0.002 & 0.000 & 0.001 & 0.001 & 0.000 \\
\hline $\mathrm{Ba}$ & 0.001 & 0.000 & 0.001 & 0.002 & 0.000 & 0.000 & 0.000 & 0.004 & 0.005 & 0.003 \\
\hline $\mathrm{Pb}^{2+}$ & 0.000 & 0.000 & 0.000 & 0.000 & 0.000 & 0.000 & 0.000 & 0.000 & 0.000 & 0.000 \\
\hline $\mathrm{Ca}$ & 0.002 & 0.002 & 0.002 & 0.002 & 0.002 & 0.000 & 0.000 & 0.000 & 0.004 & 0.005 \\
\hline $\mathrm{Na}$ & 0.076 & 0.086 & 0.058 & 0.068 & 0.093 & 0.069 & 0.079 & 0.073 & 0.122 & 0.109 \\
\hline $\mathrm{K}$ & 0.939 & 0.926 & 0.953 & 0.948 & 0.925 & 0.962 & 0.932 & 0.938 & 0.875 & 0.902 \\
\hline $\mathrm{Rb}$ & 0.023 & 0.023 & 0.024 & 0.022 & 0.024 & 0.026 & 0.023 & 0.024 & 0.023 & 0.023 \\
\hline Cs & 0.001 & 0.000 & 0.000 & 0.000 & 0.001 & 0.000 & 0.000 & 0.001 & 0.001 & 0.000 \\
\hline 0 & 8.000 & 8.000 & 8.000 & 8.000 & 8.000 & 8.000 & 8.000 & 8.000 & 8.000 & 8.000 \\
\hline
\end{tabular}

Note: formula recalculated on the basis of 8 anions. 
Appendix D.2 (contd.): Electron microprobe analyses of K-feldspar.

\begin{tabular}{|c|c|c|c|c|c|c|c|c|c|c|}
\hline Site & 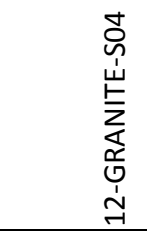 & 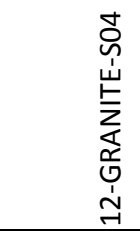 & 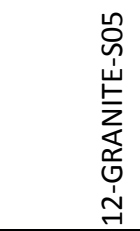 & 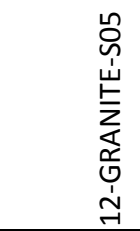 & 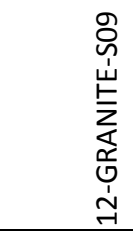 & 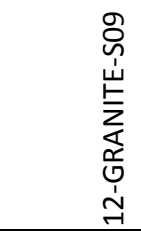 & 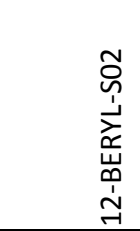 & 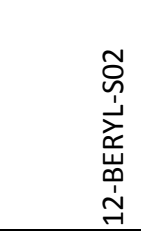 & 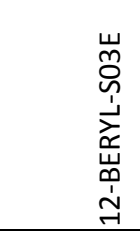 & 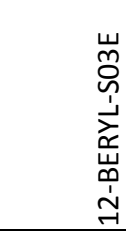 \\
\hline Comment & 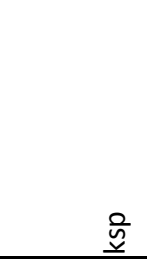 & 啇 & 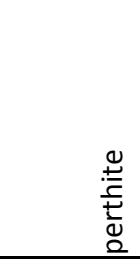 & 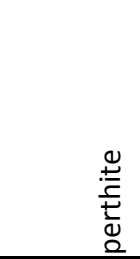 & 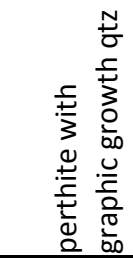 & 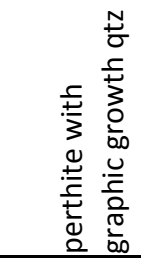 & 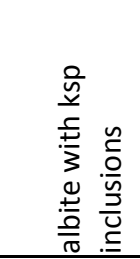 & 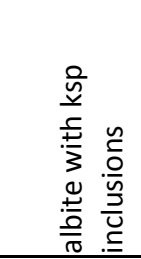 & 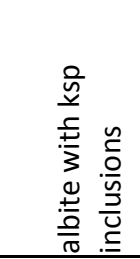 & 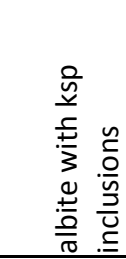 \\
\hline Point & $13 f-1$ & $13 f-2$ & $17 f-1$ & $17 f-2$ & $21 \mathrm{f}-1$ & $21 \mathrm{f}-2$ & $117 \mathrm{f}-1$ & $117 f-2$ & $120 \mathrm{f}-1$ & $120 \mathrm{f}-2$ \\
\hline $\mathrm{P}_{2} \mathrm{O}_{5}$ (wt.\%) & 0.16 & 0.15 & 0.16 & 0.15 & 0.16 & 0.17 & 0.08 & 0.09 & 0.34 & 0.49 \\
\hline $\mathrm{SiO}_{2}$ & 63.63 & 63.47 & 63.85 & 64.10 & 63.87 & 63.68 & 64.04 & 64.15 & 63.34 & 63.25 \\
\hline $\mathrm{TiO}_{2}$ & 0.00 & 0.02 & 0.00 & 0.01 & 0.00 & 0.00 & 0.02 & 0.01 & 0.00 & 0.01 \\
\hline $\mathrm{Al}_{2} \mathrm{O}_{3}$ & 18.77 & 18.80 & 18.76 & 18.70 & 18.76 & 18.70 & 18.57 & 18.53 & 18.77 & 19.13 \\
\hline MgO & 0.00 & 0.01 & 0.01 & 0.00 & 0.00 & 0.00 & 0.00 & 0.00 & 0.00 & 0.00 \\
\hline $\mathrm{MnO}$ & 0.00 & 0.00 & 0.02 & 0.02 & 0.00 & 0.00 & 0.01 & 0.00 & 0.02 & 0.00 \\
\hline $\mathrm{FeO}$ & 0.03 & 0.01 & 0.04 & 0.01 & 0.00 & 0.01 & 0.01 & 0.00 & 0.02 & 0.01 \\
\hline $\mathrm{ZnO}$ & 0.00 & 0.00 & 0.01 & 0.00 & 0.00 & 0.03 & 0.06 & 0.00 & 0.00 & 0.00 \\
\hline $\mathrm{BaO}$ & 0.07 & 0.00 & 0.09 & 0.04 & 0.15 & 0.10 & 0.09 & 0.00 & 0.00 & 0.12 \\
\hline $\mathrm{PbO}$ & 0.01 & 0.00 & 0.02 & 0.00 & 0.00 & 0.05 & 0.00 & 0.02 & 0.00 & 0.00 \\
\hline $\mathrm{CaO}$ & 0.03 & 0.02 & 0.03 & 0.03 & 0.01 & 0.02 & 0.00 & 0.00 & 0.00 & 0.00 \\
\hline $\mathrm{Na}_{2} \mathrm{O}$ & 1.31 & 1.02 & 1.18 & 1.27 & 1.16 & 1.16 & 0.88 & 0.83 & 0.73 & 0.61 \\
\hline $\mathrm{K}_{2} \mathrm{O}$ & 15.02 & 15.56 & 15.27 & 15.11 & 15.31 & 15.26 & 15.68 & 15.84 & 15.80 & 16.05 \\
\hline $\mathrm{Rb}_{2} \mathrm{O}$ & 0.78 & 0.76 & 0.76 & 0.75 & 0.75 & 0.75 & 0.86 & 0.84 & 0.82 & 0.79 \\
\hline $\mathrm{Cs}_{2} \mathrm{O}$ & 0.03 & 0.02 & 0.00 & 0.02 & 0.00 & 0.01 & 0.09 & 0.06 & 0.06 & 0.05 \\
\hline Total & 99.84 & 99.84 & 100.20 & 100.21 & 100.17 & 99.94 & 100.39 & 100.37 & 99.90 & 100.51 \\
\hline P (apfu) & 0.006 & 0.006 & 0.006 & 0.006 & 0.006 & 0.007 & 0.003 & 0.004 & 0.013 & 0.019 \\
\hline $\mathrm{Si}$ & 2.960 & 2.957 & 2.962 & 2.968 & 2.963 & 2.962 & 2.972 & 2.976 & 2.952 & 2.933 \\
\hline $\mathrm{Ti}$ & 0.000 & 0.001 & 0.000 & 0.000 & 0.000 & 0.000 & 0.001 & 0.000 & 0.000 & 0.000 \\
\hline Al & 1.029 & 1.032 & 1.026 & 1.020 & 1.026 & 1.025 & 1.016 & 1.013 & 1.031 & 1.045 \\
\hline $\mathrm{Mg}$ & 0.000 & 0.001 & 0.001 & 0.000 & 0.000 & 0.000 & 0.000 & 0.000 & 0.000 & 0.000 \\
\hline $\mathrm{Mn}^{2+}$ & 0.000 & 0.000 & 0.001 & 0.001 & 0.000 & 0.000 & 0.000 & 0.000 & 0.001 & 0.000 \\
\hline $\mathrm{Fe}^{2+}$ & 0.001 & 0.000 & 0.002 & 0.000 & 0.000 & 0.000 & 0.000 & 0.000 & 0.001 & 0.000 \\
\hline $\mathrm{Zn}$ & 0.000 & 0.000 & 0.000 & 0.000 & 0.000 & 0.001 & 0.002 & 0.000 & 0.000 & 0.000 \\
\hline $\mathrm{Ba}$ & 0.001 & 0.000 & 0.002 & 0.001 & 0.003 & 0.002 & 0.002 & 0.000 & 0.000 & 0.002 \\
\hline $\mathrm{Pb}^{2+}$ & 0.000 & 0.000 & 0.000 & 0.000 & 0.000 & 0.001 & 0.000 & 0.000 & 0.000 & 0.000 \\
\hline $\mathrm{Ca}$ & 0.001 & 0.001 & 0.001 & 0.001 & 0.000 & 0.001 & 0.000 & 0.000 & 0.000 & 0.000 \\
\hline $\mathrm{Na}$ & 0.118 & 0.092 & 0.106 & 0.114 & 0.104 & 0.105 & 0.079 & 0.075 & 0.066 & 0.055 \\
\hline $\mathrm{K}$ & 0.891 & 0.925 & 0.904 & 0.893 & 0.906 & 0.906 & 0.928 & 0.937 & 0.939 & 0.949 \\
\hline $\mathrm{Rb}$ & 0.023 & 0.023 & 0.023 & 0.022 & 0.022 & 0.022 & 0.026 & 0.025 & 0.025 & 0.024 \\
\hline Cs & 0.001 & 0.000 & 0.000 & 0.000 & 0.000 & 0.000 & 0.002 & 0.001 & 0.001 & 0.001 \\
\hline 0 & 8.000 & 8.000 & 8.000 & 8.000 & 8.000 & 8.000 & 8.000 & 8.000 & 8.000 & 8.000 \\
\hline
\end{tabular}


Appendix D.2 (contd.): Electron microprobe analyses of K-feldspar.

\begin{tabular}{|c|c|c|c|c|c|c|c|c|c|c|}
\hline Site & 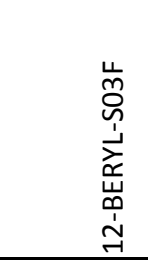 & 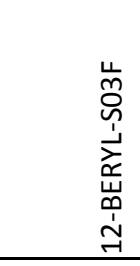 & 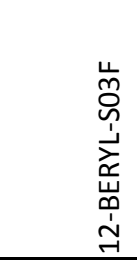 & 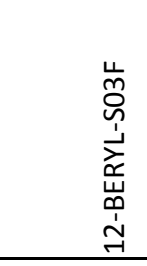 & 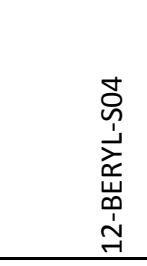 & 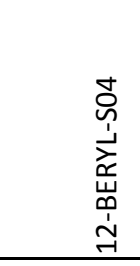 & 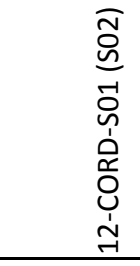 & 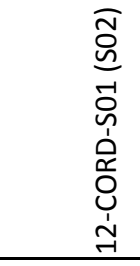 & 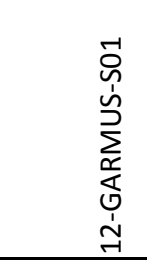 & 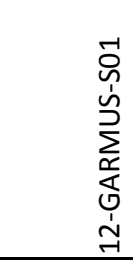 \\
\hline Comment & 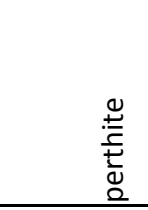 & 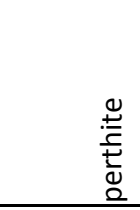 & 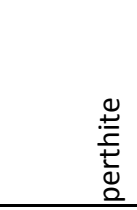 & 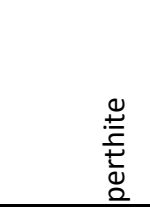 & 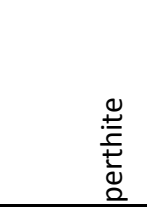 & 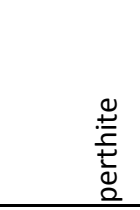 & 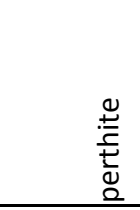 & 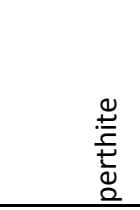 & 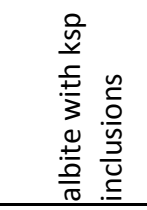 & 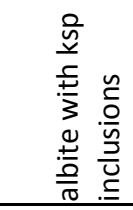 \\
\hline Point & $121 \mathrm{f}-1$ & $121 \mathrm{f}-2$ & $122 \mathrm{f}-1$ & $122 \mathrm{f}-2$ & $123 f-1$ & $123 f-2$ & $124 f-1$ & $124 f-2$ & $125 f-1$ & $125 \mathrm{f}-2$ \\
\hline $\mathrm{P}_{2} \mathrm{O}_{5}$ (wt.\%) & 0.39 & 0.34 & 0.37 & 0.33 & 0.33 & 0.35 & 0.21 & 0.23 & 0.34 & 0.32 \\
\hline $\mathrm{SiO}_{2}$ & 63.72 & 63.73 & 63.71 & 63.55 & 63.65 & 63.62 & 63.93 & 63.77 & 64.08 & 63.71 \\
\hline $\mathrm{TiO}_{2}$ & 0.00 & 0.00 & 0.00 & 0.01 & 0.01 & 0.00 & 0.00 & 0.00 & 0.00 & 0.00 \\
\hline $\mathrm{Al}_{2} \mathrm{O}_{3}$ & 18.72 & 18.73 & 18.97 & 18.99 & 18.85 & 18.80 & 19.01 & 18.78 & 18.82 & 18.66 \\
\hline $\mathrm{MgO}$ & 0.00 & 0.00 & 0.01 & 0.00 & 0.00 & 0.00 & 0.01 & 0.00 & 0.00 & 0.00 \\
\hline $\mathrm{MnO}$ & 0.03 & 0.00 & 0.01 & 0.01 & 0.00 & 0.00 & 0.00 & 0.00 & 0.00 & 0.01 \\
\hline $\mathrm{FeO}$ & 0.00 & 0.00 & 0.00 & 0.01 & 0.00 & 0.00 & 0.00 & 0.01 & 0.02 & 0.00 \\
\hline $\mathrm{ZnO}$ & 0.01 & 0.02 & 0.03 & 0.01 & 0.02 & 0.00 & 0.06 & 0.00 & 0.02 & 0.00 \\
\hline $\mathrm{BaO}$ & 0.00 & 0.15 & 0.00 & 0.00 & 0.01 & 0.00 & 0.04 & 0.00 & 0.10 & 0.09 \\
\hline $\mathrm{PbO}$ & 0.00 & 0.00 & 0.03 & 0.03 & 0.00 & 0.00 & 0.04 & 0.02 & 0.00 & 0.02 \\
\hline $\mathrm{CaO}$ & 0.00 & 0.00 & 0.02 & 0.00 & 0.00 & 0.00 & 0.04 & 0.04 & 0.00 & 0.00 \\
\hline $\mathrm{Na}_{2} \mathrm{O}$ & 0.81 & 1.12 & 1.32 & 1.51 & 1.11 & 1.31 & 1.15 & 1.12 & 1.29 & 1.14 \\
\hline $\mathrm{K}_{2} \mathrm{O}$ & 15.78 & 15.35 & 14.90 & 14.83 & 15.31 & 15.05 & 15.32 & 15.36 & 14.98 & 15.29 \\
\hline $\mathrm{Rb}_{2} \mathrm{O}$ & 0.88 & 0.89 & 0.89 & 0.93 & 0.95 & 0.90 & 0.77 & 0.77 & 0.77 & 0.80 \\
\hline $\mathrm{Cs}_{2} \mathrm{O}$ & 0.05 & 0.04 & 0.01 & 0.02 & 0.00 & 0.01 & 0.02 & 0.01 & 0.19 & 0.18 \\
\hline Total & 100.39 & 100.37 & 100.27 & 100.23 & 100.24 & 100.04 & 100.60 & 100.11 & 100.61 & 100.22 \\
\hline P (apfu) & 0.015 & 0.013 & 0.014 & 0.013 & 0.013 & 0.014 & 0.008 & 0.009 & 0.013 & 0.013 \\
\hline $\mathrm{Si}$ & 2.955 & 2.955 & 2.948 & 2.945 & 2.952 & 2.953 & 2.953 & 2.959 & 2.958 & 2.958 \\
\hline $\mathrm{Ti}$ & 0.000 & 0.000 & 0.000 & 0.000 & 0.000 & 0.000 & 0.000 & 0.000 & 0.000 & 0.000 \\
\hline $\mathrm{Al}$ & 1.023 & 1.024 & 1.035 & 1.037 & 1.030 & 1.028 & 1.035 & 1.027 & 1.024 & 1.021 \\
\hline $\mathrm{Mg}$ & 0.000 & 0.000 & 0.001 & 0.000 & 0.000 & 0.000 & 0.001 & 0.000 & 0.000 & 0.000 \\
\hline $\mathrm{Mn}^{2+}$ & 0.001 & 0.000 & 0.000 & 0.000 & 0.000 & 0.000 & 0.000 & 0.000 & 0.000 & 0.000 \\
\hline $\mathrm{Fe}^{2+}$ & 0.000 & 0.000 & 0.000 & 0.000 & 0.000 & 0.000 & 0.000 & 0.000 & 0.001 & 0.000 \\
\hline $\mathrm{Zn}$ & 0.000 & 0.001 & 0.001 & 0.000 & 0.001 & 0.000 & 0.002 & 0.000 & 0.001 & 0.000 \\
\hline $\mathrm{Ba}$ & 0.000 & 0.003 & 0.000 & 0.000 & 0.000 & 0.000 & 0.001 & 0.000 & 0.002 & 0.002 \\
\hline $\mathrm{Pb}^{2+}$ & 0.000 & 0.000 & 0.000 & 0.000 & 0.000 & 0.000 & 0.000 & 0.000 & 0.000 & 0.000 \\
\hline $\mathrm{Ca}$ & 0.000 & 0.000 & 0.001 & 0.000 & 0.000 & 0.000 & 0.002 & 0.002 & 0.000 & 0.000 \\
\hline $\mathrm{Na}$ & 0.073 & 0.101 & 0.118 & 0.136 & 0.100 & 0.118 & 0.103 & 0.101 & 0.115 & 0.103 \\
\hline K & 0.933 & 0.908 & 0.880 & 0.877 & 0.906 & 0.891 & 0.903 & 0.909 & 0.882 & 0.906 \\
\hline $\mathrm{Rb}$ & 0.026 & 0.027 & 0.026 & 0.028 & 0.028 & 0.027 & 0.023 & 0.023 & 0.023 & 0.024 \\
\hline Cs & 0.001 & 0.001 & 0.000 & 0.000 & 0.000 & 0.000 & 0.000 & 0.000 & 0.004 & 0.004 \\
\hline 0 & 8.000 & 8.000 & 8.000 & 8.000 & 8.000 & 8.000 & 8.000 & 8.000 & 8.000 & 8.000 \\
\hline
\end{tabular}


Appendix D.2 (contd.): Electron microprobe analyses of K-feldspar.

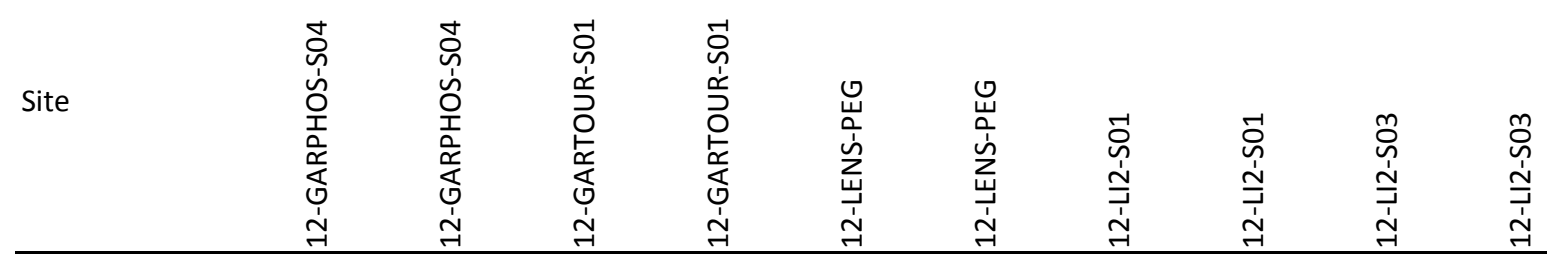

\begin{tabular}{|c|c|c|c|c|c|c|c|c|c|c|}
\hline Comment & 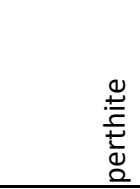 & 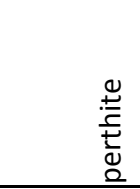 & 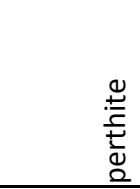 & 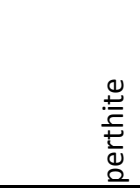 & 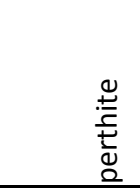 & 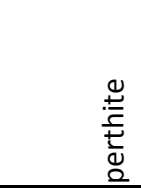 & $\begin{array}{l}\frac{0}{2} \\
\frac{0}{0} \\
\frac{8}{0} \\
\frac{\pi}{50} \\
\frac{0}{0} \\
\end{array}$ & $\begin{array}{l}\frac{0}{2} \\
\frac{0}{0} \\
\frac{d}{0} \\
\frac{0}{00} \\
\frac{0}{0}\end{array}$ & 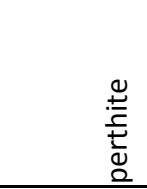 & 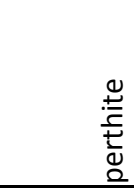 \\
\hline Point & $126 f-1$ & $126 f-2$ & $127 f-1$ & $127 f-2$ & $128 f-1$ & $128 \mathrm{f}-2$ & $129 f-1$ & $129 \mathrm{f}-2$ & $130 \mathrm{f}-1$ & $130 f-2$ \\
\hline $\mathrm{P}_{2} \mathrm{O}_{5}$ (wt.\%) & 0.57 & 0.56 & 0.35 & 0.35 & 0.33 & 0.33 & 0.05 & $\quad 0.07$ & 0.49 & 0.52 \\
\hline $\mathrm{SiO}_{2}$ & 63.37 & 63.00 & 64.15 & 63.75 & 63.79 & 63.56 & 63.48 & 63.23 & 63.24 & 63.09 \\
\hline $\mathrm{TiO}_{2}$ & 0.00 & 0.00 & 0.00 & 0.00 & 0.00 & 0.01 & 0.04 & 0.01 & 0.00 & 0.02 \\
\hline $\mathrm{Al}_{2} \mathrm{O}_{3}$ & 18.84 & 18.91 & 19.05 & 18.87 & 18.73 & 18.77 & 18.43 & 18.51 & 18.77 & 18.82 \\
\hline $\mathrm{MgO}$ & 0.01 & 0.00 & 0.00 & 0.01 & 0.00 & 0.00 & 0.00 & 0.01 & 0.00 & 0.00 \\
\hline $\mathrm{MnO}$ & 0.00 & 0.00 & 0.01 & 0.00 & 0.00 & 0.02 & 0.01 & 0.00 & 0.00 & 0.00 \\
\hline $\mathrm{FeO}$ & 0.01 & 0.03 & 0.03 & 0.02 & 0.03 & 0.00 & 0.03 & 0.02 & 0.02 & 0.02 \\
\hline $\mathrm{ZnO}$ & 0.02 & 0.00 & 0.01 & 0.00 & 0.00 & 0.05 & 0.00 & 0.00 & 0.04 & 0.00 \\
\hline $\mathrm{BaO}$ & 0.00 & 0.04 & 0.00 & 0.04 & 0.00 & 0.12 & 0.15 & 0.00 & 0.00 & 0.00 \\
\hline $\mathrm{PbO}$ & 0.03 & 0.03 & 0.05 & 0.03 & 0.05 & 0.00 & 0.00 & 0.00 & 0.00 & 0.00 \\
\hline $\mathrm{CaO}$ & 0.00 & 0.00 & 0.01 & 0.02 & 0.00 & 0.00 & 0.00 & 0.00 & 0.00 & 0.00 \\
\hline $\mathrm{Na}_{2} \mathrm{O}$ & 1.08 & 0.92 & 1.51 & 1.60 & 0.69 & 0.67 & 0.23 & 0.27 & 1.25 & 1.04 \\
\hline $\mathrm{K}_{2} \mathrm{O}$ & 15.27 & 15.47 & 14.88 & 14.70 & 15.98 & 16.06 & 16.23 & 16.27 & 15.22 & 15.51 \\
\hline $\mathrm{Rb}_{2} \mathrm{O}$ & 0.97 & 1.03 & 0.78 & 0.75 & 0.83 & 0.81 & 1.46 & 1.42 & 0.87 & 0.89 \\
\hline $\mathrm{Cs}_{2} \mathrm{O}$ & 0.02 & 0.12 & 0.02 & 0.01 & 0.00 & 0.02 & 0.20 & 0.18 & 0.02 & 0.01 \\
\hline Total & 100.19 & 100.11 & 100.85 & 100.15 & 100.43 & 100.42 & 100.31 & 99.99 & 99.92 & 99.92 \\
\hline P (apfu) & 0.022 & 0.022 & 0.014 & 0.014 & 0.013 & 0.013 & 0.002 & 0.003 & 0.019 & 0.021 \\
\hline $\mathrm{Si}$ & 2.941 & 2.934 & 2.950 & 2.951 & 2.957 & 2.952 & 2.972 & 2.967 & 2.942 & 2.938 \\
\hline $\mathrm{Ti}$ & 0.000 & 0.000 & 0.000 & 0.000 & 0.000 & 0.000 & 0.001 & 0.000 & 0.000 & 0.001 \\
\hline $\mathrm{Al}$ & 1.030 & 1.038 & 1.032 & 1.029 & 1.023 & 1.027 & 1.017 & 1.024 & 1.029 & 1.033 \\
\hline $\mathrm{Mg}$ & 0.001 & 0.000 & 0.000 & 0.001 & 0.000 & 0.000 & 0.000 & 0.001 & 0.000 & 0.000 \\
\hline $\mathrm{Mn}^{2+}$ & 0.000 & 0.000 & 0.000 & 0.000 & 0.000 & 0.001 & 0.000 & 0.000 & 0.000 & 0.000 \\
\hline $\mathrm{Fe}^{2+}$ & 0.000 & 0.001 & 0.001 & 0.001 & 0.001 & 0.000 & 0.001 & 0.001 & 0.001 & 0.001 \\
\hline $\mathrm{Zn}$ & 0.001 & 0.000 & 0.000 & 0.000 & 0.000 & 0.002 & 0.000 & 0.000 & 0.001 & 0.000 \\
\hline $\mathrm{Ba}$ & 0.000 & 0.001 & 0.000 & 0.001 & 0.000 & 0.002 & 0.003 & 0.000 & 0.000 & 0.000 \\
\hline $\mathrm{Pb}^{2+}$ & 0.000 & 0.000 & 0.001 & 0.000 & 0.001 & 0.000 & 0.000 & 0.000 & 0.000 & 0.000 \\
\hline $\mathrm{Ca}$ & 0.000 & 0.000 & 0.000 & 0.001 & 0.000 & 0.000 & 0.000 & 0.000 & 0.000 & 0.000 \\
\hline $\mathrm{Na}$ & 0.097 & 0.083 & 0.135 & 0.144 & 0.062 & 0.060 & 0.021 & 0.025 & 0.113 & 0.094 \\
\hline$K$ & 0.904 & 0.919 & 0.873 & 0.868 & 0.945 & 0.951 & 0.969 & 0.974 & 0.903 & 0.921 \\
\hline $\mathrm{Rb}$ & 0.029 & 0.031 & 0.023 & 0.022 & 0.025 & 0.024 & 0.044 & 0.043 & 0.026 & 0.027 \\
\hline Cs & 0.000 & 0.002 & 0.000 & 0.000 & 0.000 & 0.000 & 0.004 & 0.004 & 0.000 & 0.000 \\
\hline 0 & 8.000 & 8.000 & 8.000 & 8.000 & 8.000 & 8.000 & 8.000 & 8.000 & 8.000 & 8.000 \\
\hline
\end{tabular}


Appendix D.2 (contd.): Electron microprobe analyses of K-feldspar.

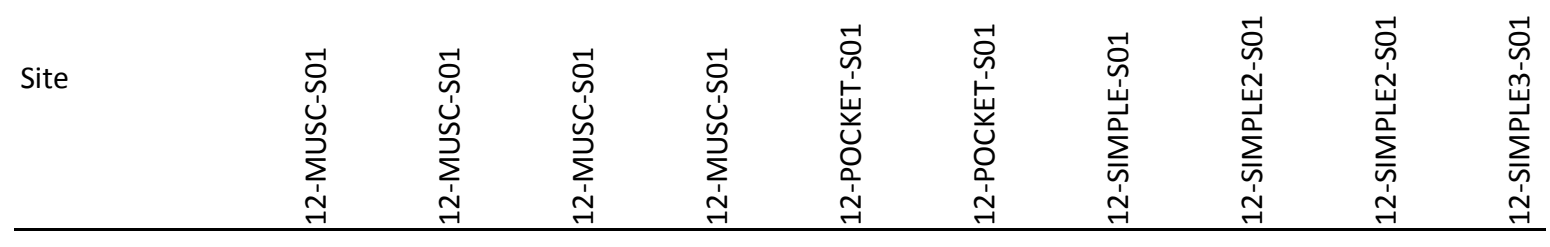

Comment

\begin{tabular}{|c|c|c|c|c|c|c|c|c|c|c|}
\hline 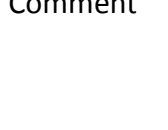 & 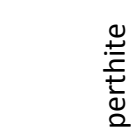 & 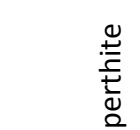 & 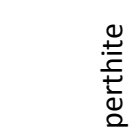 & 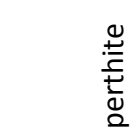 & 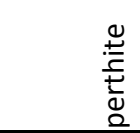 & 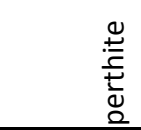 & 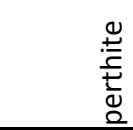 & 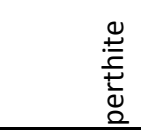 & 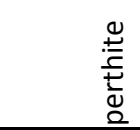 & 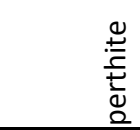 \\
\hline Point & $131 \mathrm{f}-1$ & $131 \mathrm{f}-2$ & $132 \mathrm{f}-1$ & $132 f-2$ & $135 f-1$ & $135 f-2$ & $136 f-1$ & $137 f-1$ & $137 f-2$ & $139 \mathrm{f}-1$ \\
\hline $\mathrm{P}_{2} \mathrm{O}_{5}$ (wt.\%) & 0.16 & 0.14 & 0.14 & 0.14 & 0.57 & 0.51 & 0.08 & 0.07 & 0.09 & 0.12 \\
\hline $\mathrm{SiO}_{2}$ & 63.76 & 63.45 & 63.87 & 64.36 & 63.19 & 63.15 & 63.75 & 63.24 & 64.36 & 63.48 \\
\hline $\mathrm{TiO}_{2}$ & 0.01 & 0.01 & 0.00 & 0.00 & 0.00 & 0.00 & 0.02 & 0.02 & 0.00 & 0.00 \\
\hline $\mathrm{Al}_{2} \mathrm{O}_{3}$ & 18.92 & 18.79 & 18.81 & 18.82 & 19.00 & 18.87 & 18.73 & 18.68 & 18.81 & 18.75 \\
\hline $\mathrm{MgO}$ & 0.00 & 0.00 & 0.00 & 0.00 & 0.00 & 0.00 & 0.00 & 0.01 & 0.00 & 0.01 \\
\hline $\mathrm{MnO}$ & 0.00 & 0.00 & 0.00 & 0.00 & 0.01 & 0.01 & 0.03 & 0.03 & 0.02 & 0.01 \\
\hline $\mathrm{FeO}$ & 0.03 & 0.00 & 0.01 & 0.00 & 0.02 & 0.01 & 0.02 & 0.00 & 0.02 & 0.03 \\
\hline $\mathrm{ZnO}$ & 0.00 & 0.00 & 0.00 & 0.05 & 0.00 & 0.02 & 0.00 & 0.04 & 0.03 & 0.00 \\
\hline $\mathrm{BaO}$ & 0.04 & 0.08 & 0.07 & 0.00 & 0.00 & 0.11 & 0.34 & 0.22 & 0.09 & 0.14 \\
\hline $\mathrm{PbO}$ & 0.00 & 0.01 & 0.01 & 0.05 & 0.00 & 0.05 & 0.03 & 0.02 & 0.02 & 0.01 \\
\hline $\mathrm{CaO}$ & 0.05 & 0.05 & 0.08 & 0.06 & 0.01 & 0.01 & 0.04 & 0.01 & 0.06 & 0.00 \\
\hline $\mathrm{Na}_{2} \mathrm{O}$ & 0.91 & 0.95 & 2.41 & 2.22 & 1.17 & 1.00 & 1.36 & 0.48 & 1.25 & 0.74 \\
\hline $\mathrm{K}_{2} \mathrm{O}$ & 15.57 & 15.60 & 13.50 & 13.76 & 15.41 & 15.56 & 14.96 & 16.20 & 15.11 & 15.83 \\
\hline $\mathrm{Rb}_{2} \mathrm{O}$ & 0.76 & 0.79 & 0.78 & 0.79 & 0.77 & 0.79 & 0.76 & 0.78 & 0.81 & 0.77 \\
\hline $\mathrm{Cs}_{2} \mathrm{O}$ & 0.02 & 0.00 & 0.02 & 0.00 & 0.03 & 0.02 & 0.03 & 0.00 & 0.03 & 0.03 \\
\hline Total & 100.23 & 99.87 & 99.70 & 100.25 & 100.18 & 100.11 & 100.15 & 99.80 & 100.70 & 99.92 \\
\hline P (apfu) & 0.006 & 0.006 & 0.005 & 0.005 & 0.022 & 0.020 & 0.003 & 0.003 & 0.004 & 0.005 \\
\hline $\mathrm{Si}$ & 2.957 & 2.957 & 2.960 & 2.966 & 2.932 & 2.937 & 2.963 & 2.960 & 2.969 & 2.961 \\
\hline $\mathrm{Ti}$ & 0.000 & 0.000 & 0.000 & 0.000 & 0.000 & 0.000 & 0.001 & 0.001 & 0.000 & 0.000 \\
\hline Al & 1.034 & 1.032 & 1.027 & 1.022 & 1.039 & 1.034 & 1.026 & 1.031 & 1.023 & 1.031 \\
\hline $\mathrm{Mg}$ & 0.000 & 0.000 & 0.000 & 0.000 & 0.000 & 0.000 & 0.000 & 0.001 & 0.000 & 0.001 \\
\hline $\mathrm{Mn}^{2+}$ & 0.000 & 0.000 & 0.000 & 0.000 & 0.000 & 0.000 & 0.001 & 0.001 & 0.001 & 0.000 \\
\hline $\mathrm{Fe}^{2+}$ & 0.001 & 0.000 & 0.000 & 0.000 & 0.001 & 0.000 & 0.001 & 0.000 & 0.001 & 0.001 \\
\hline $\mathrm{Zn}$ & 0.000 & 0.000 & 0.000 & 0.002 & 0.000 & 0.001 & 0.000 & 0.001 & 0.001 & 0.000 \\
\hline $\mathrm{Ba}$ & 0.001 & 0.001 & 0.001 & 0.000 & 0.000 & 0.002 & 0.006 & 0.004 & 0.002 & 0.003 \\
\hline $\mathrm{Pb}^{2+}$ & 0.000 & 0.000 & 0.000 & 0.001 & 0.000 & 0.001 & 0.000 & 0.000 & 0.000 & 0.000 \\
\hline $\mathrm{Ca}$ & 0.002 & 0.002 & 0.004 & 0.003 & 0.000 & 0.000 & 0.002 & 0.001 & 0.003 & 0.000 \\
\hline $\mathrm{Na}$ & 0.082 & 0.086 & 0.217 & 0.198 & 0.105 & 0.090 & 0.123 & 0.044 & 0.112 & 0.067 \\
\hline $\mathrm{K}$ & 0.921 & 0.928 & 0.798 & 0.809 & 0.912 & 0.923 & 0.887 & 0.967 & 0.889 & 0.942 \\
\hline $\mathrm{Rb}$ & 0.023 & 0.024 & 0.023 & 0.023 & 0.023 & 0.024 & 0.023 & 0.023 & 0.024 & 0.023 \\
\hline Cs & 0.000 & 0.000 & 0.000 & 0.000 & 0.001 & 0.000 & 0.001 & 0.000 & 0.001 & 0.001 \\
\hline 0 & 8.000 & 8.000 & 8.000 & 8.000 & 8.000 & 8.000 & 8.000 & 8.000 & 8.000 & 8.000 \\
\hline
\end{tabular}


Appendix D.2 (contd.): Electron microprobe analyses of K-feldspar.

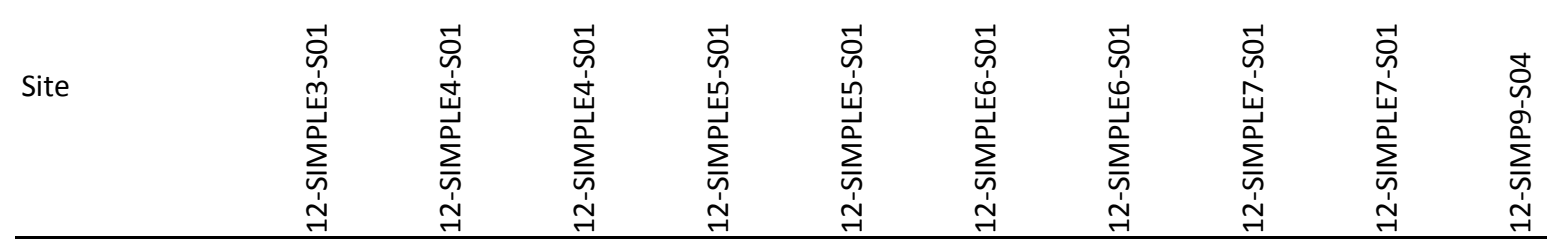

\begin{tabular}{|c|c|c|c|c|c|c|c|c|c|c|}
\hline Comment & 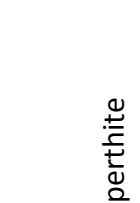 & 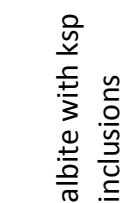 & 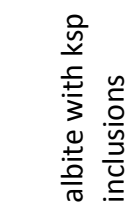 & 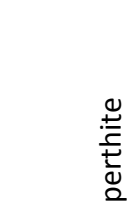 & 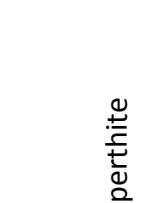 & 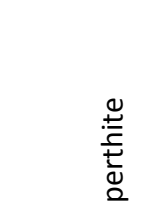 & 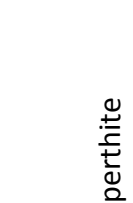 & 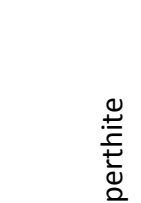 & 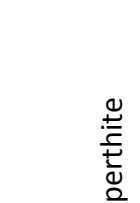 & 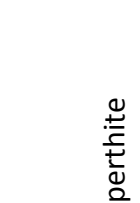 \\
\hline Point & $139 \mathrm{f}-2$ & $140 f-1$ & $140 \mathrm{f}-2$ & $141 \mathrm{f}-1$ & $141 \mathrm{f}-2$ & $142 \mathrm{f}-1$ & $142 \mathrm{f}-2$ & $143 \mathrm{f}-1$ & $143 \mathrm{f}-2$ & $144 \mathrm{f}-1$ \\
\hline $\mathrm{P}_{2} \mathrm{O}_{5}$ (wt.\%) & 0.11 & 0.02 & 0.02 & 0.07 & 0.08 & 0.35 & 0.37 & 0.20 & 0.20 & 0.19 \\
\hline $\mathrm{SiO}_{2}$ & 63.30 & 63.92 & 63.79 & 64.47 & 63.52 & 63.16 & 63.44 & 64.24 & 63.90 & 63.42 \\
\hline $\mathrm{TiO}_{2}$ & 0.00 & 0.02 & 0.01 & 0.00 & 0.01 & 0.01 & 0.00 & 0.00 & 0.00 & 0.00 \\
\hline $\mathrm{Al}_{2} \mathrm{O}_{3}$ & 18.84 & 18.69 & 18.61 & 18.91 & 18.65 & 18.92 & 19.15 & 18.60 & 18.71 & 18.72 \\
\hline $\mathrm{MgO}$ & 0.00 & 0.00 & 0.00 & 0.00 & 0.00 & 0.00 & 0.00 & 0.00 & 0.00 & 0.00 \\
\hline $\mathrm{MnO}$ & 0.00 & 0.00 & 0.01 & 0.02 & 0.01 & 0.01 & 0.00 & 0.00 & 0.02 & 0.01 \\
\hline $\mathrm{FeO}$ & 0.00 & 0.00 & 0.00 & 0.02 & 0.03 & 0.01 & 0.02 & 0.00 & 0.00 & 0.00 \\
\hline ZnO & 0.01 & 0.02 & 0.04 & 0.06 & 0.03 & 0.00 & 0.03 & 0.00 & 0.00 & 0.00 \\
\hline $\mathrm{BaO}$ & 0.19 & 0.06 & 0.11 & 0.12 & 0.13 & 0.00 & 0.02 & 0.15 & 0.00 & 0.13 \\
\hline $\mathrm{PbO}$ & 0.00 & 0.04 & 0.01 & 0.03 & 0.03 & 0.05 & 0.06 & 0.02 & 0.00 & 0.01 \\
\hline $\mathrm{CaO}$ & 0.04 & 0.02 & 0.02 & 0.06 & 0.06 & 0.05 & 0.03 & 0.00 & 0.00 & 0.00 \\
\hline $\mathrm{Na}_{2} \mathrm{O}$ & 1.10 & 0.88 & 0.87 & 1.36 & 1.04 & 1.35 & 1.30 & 0.80 & 0.83 & 0.77 \\
\hline $\mathrm{K}_{2} \mathrm{O}$ & 15.31 & 15.72 & 15.71 & 14.86 & 15.34 & 15.05 & 15.17 & 15.87 & 15.76 & 15.78 \\
\hline $\mathrm{Rb}_{2} \mathrm{O}$ & 0.79 & 0.74 & 0.75 & 0.80 & 0.82 & 0.79 & 0.81 & 0.80 & 0.80 & 0.82 \\
\hline $\mathrm{Cs}_{2} \mathrm{O}$ & 0.04 & 0.02 & 0.00 & 0.02 & 0.04 & 0.02 & 0.03 & 0.03 & 0.02 & 0.01 \\
\hline Total & 99.73 & 100.15 & 99.95 & 100.80 & 99.79 & 99.77 & 100.43 & 100.71 & 100.24 & 99.86 \\
\hline P (apfu) & 0.004 & 0.001 & 0.001 & 0.003 & 0.003 & 0.014 & 0.015 & 0.008 & 0.008 & 0.008 \\
\hline $\mathrm{Si}$ & 2.955 & 2.970 & 2.971 & 2.968 & 2.964 & 2.942 & 2.937 & 2.970 & 2.965 & 2.959 \\
\hline $\mathrm{Ti}$ & 0.000 & 0.001 & 0.000 & 0.000 & 0.000 & 0.000 & 0.000 & 0.000 & 0.000 & 0.000 \\
\hline Al & 1.037 & 1.024 & 1.022 & 1.026 & 1.026 & 1.039 & 1.045 & 1.014 & 1.023 & 1.029 \\
\hline $\mathrm{Mg}$ & 0.000 & 0.000 & 0.000 & 0.000 & 0.000 & 0.000 & 0.000 & 0.000 & 0.000 & 0.000 \\
\hline $\mathrm{Mn}^{2+}$ & 0.000 & 0.000 & 0.000 & 0.001 & 0.000 & 0.000 & 0.000 & 0.000 & 0.001 & 0.000 \\
\hline $\mathrm{Fe}^{2+}$ & 0.000 & 0.000 & 0.000 & 0.001 & 0.001 & 0.000 & 0.001 & 0.000 & 0.000 & 0.000 \\
\hline $\mathrm{Zn}$ & 0.000 & 0.001 & 0.001 & 0.002 & 0.001 & 0.000 & 0.001 & 0.000 & 0.000 & 0.000 \\
\hline $\mathrm{Ba}$ & 0.003 & 0.001 & 0.002 & 0.002 & 0.002 & 0.000 & 0.000 & 0.003 & 0.000 & 0.002 \\
\hline $\mathrm{Pb}^{2+}$ & 0.000 & 0.001 & 0.000 & 0.000 & 0.000 & 0.001 & 0.001 & 0.000 & 0.000 & 0.000 \\
\hline $\mathrm{Ca}$ & 0.002 & 0.001 & 0.001 & 0.003 & 0.003 & 0.002 & 0.001 & 0.000 & 0.000 & 0.000 \\
\hline $\mathrm{Na}$ & 0.100 & 0.079 & 0.079 & 0.121 & 0.094 & 0.122 & 0.117 & 0.072 & 0.075 & 0.070 \\
\hline $\mathrm{K}$ & 0.912 & 0.932 & 0.934 & 0.873 & 0.913 & 0.894 & 0.896 & 0.936 & 0.933 & 0.939 \\
\hline $\mathrm{Rb}$ & 0.024 & 0.022 & 0.022 & 0.024 & 0.025 & 0.024 & 0.024 & 0.024 & 0.024 & 0.025 \\
\hline Cs & 0.001 & 0.000 & 0.000 & 0.000 & 0.001 & 0.000 & 0.001 & 0.001 & 0.000 & 0.000 \\
\hline 0 & 8.000 & 8.000 & 8.000 & 8.000 & 8.000 & 8.000 & 8.000 & 8.000 & 8.000 & 8.000 \\
\hline
\end{tabular}


Appendix D.2 (contd.): Electron microprobe analyses of K-feldspar.

\begin{tabular}{|c|c|c|c|c|c|c|c|c|c|c|}
\hline Site & 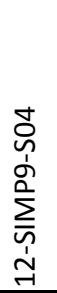 & 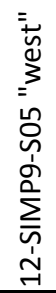 & 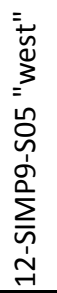 & 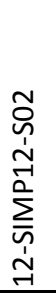 & 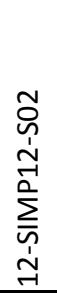 & 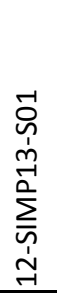 & 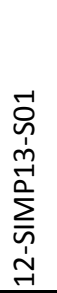 & 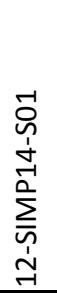 & 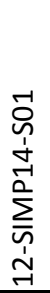 & 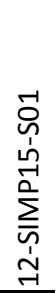 \\
\hline
\end{tabular}

\begin{tabular}{|c|c|c|c|c|c|c|c|c|c|c|}
\hline Comment & 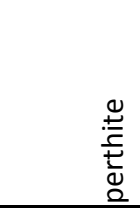 & 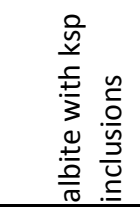 & 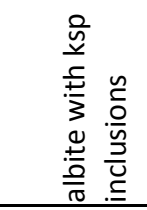 & 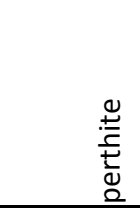 & 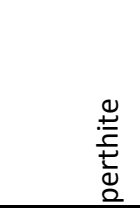 & 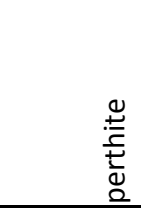 & 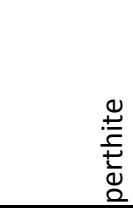 & 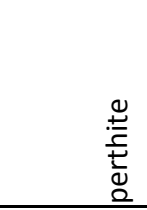 & 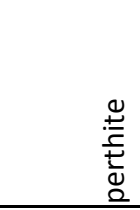 & 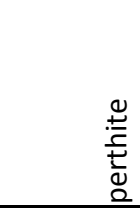 \\
\hline Point & $144 f-2$ & $145 \mathrm{f}-1$ & $145 f-2$ & $146 f-1$ & $146 f-2$ & $147 f-1$ & $147 f-2$ & $148 \mathrm{f}-1$ & $148 \mathrm{f}-2$ & $149 f-1$ \\
\hline $\mathrm{P}_{2} \mathrm{O}_{5}$ (wt.\%) & 0.20 & 0.33 & 0.32 & 0.10 & 0.13 & 0.11 & 0.06 & 0.09 & 0.11 & 0.40 \\
\hline $\mathrm{SiO}_{2}$ & 64.03 & 63.25 & 63.38 & 63.50 & 64.52 & 64.12 & 63.78 & 63.77 & 64.11 & 63.09 \\
\hline $\mathrm{TiO}_{2}$ & 0.00 & 0.00 & 0.00 & 0.03 & 0.00 & 0.00 & 0.02 & 0.00 & 0.00 & 0.00 \\
\hline $\mathrm{Al}_{2} \mathrm{O}_{3}$ & 18.89 & 18.86 & 18.75 & 18.83 & 19.01 & 18.57 & 18.61 & 18.69 & 18.95 & 18.92 \\
\hline $\mathrm{MgO}$ & 0.00 & 0.00 & 0.00 & 0.01 & 0.01 & 0.00 & 0.00 & 0.01 & 0.00 & 0.01 \\
\hline $\mathrm{MnO}$ & 0.00 & 0.00 & 0.01 & 0.00 & 0.00 & 0.01 & 0.00 & 0.01 & 0.01 & 0.00 \\
\hline $\mathrm{FeO}$ & 0.00 & 0.00 & 0.00 & 0.01 & 0.05 & 0.01 & 0.02 & 0.00 & 0.00 & 0.04 \\
\hline $\mathrm{ZnO}$ & 0.03 & 0.00 & 0.04 & 0.00 & 0.03 & 0.00 & 0.00 & 0.00 & 0.03 & 0.00 \\
\hline $\mathrm{BaO}$ & 0.11 & 0.01 & 0.03 & 0.00 & 0.00 & 0.00 & 0.05 & 0.00 & 0.16 & 0.17 \\
\hline $\mathrm{PbO}$ & 0.04 & 0.00 & 0.00 & 0.02 & 0.00 & 0.02 & 0.04 & 0.00 & 0.02 & 0.02 \\
\hline $\mathrm{CaO}$ & 0.00 & 0.00 & 0.00 & 0.05 & 0.03 & 0.02 & 0.01 & 0.10 & 0.06 & 0.03 \\
\hline $\mathrm{Na}_{2} \mathrm{O}$ & 0.79 & 1.15 & 1.09 & 1.38 & 1.59 & 1.11 & 1.28 & 1.39 & 1.08 & 1.44 \\
\hline $\mathrm{K}_{2} \mathrm{O}$ & 15.84 & 15.31 & 15.44 & 14.87 & 14.57 & 15.33 & 14.98 & 14.87 & 15.25 & 14.87 \\
\hline $\mathrm{Rb}_{2} \mathrm{O}$ & 0.77 & 0.85 & 0.89 & 0.81 & 0.79 & 0.91 & 0.92 & 0.79 & 0.77 & 0.77 \\
\hline $\mathrm{Cs}_{2} \mathrm{O}$ & 0.00 & 0.03 & 0.02 & 0.02 & 0.02 & 0.02 & 0.07 & 0.00 & 0.02 & 0.02 \\
\hline Total & 100.70 & 99.79 & 99.97 & 99.63 & 100.75 & 100.23 & 99.84 & 99.72 & 100.57 & 99.78 \\
\hline P (apfu) & 0.008 & 0.013 & 0.013 & 0.004 & 0.005 & 0.004 & 0.002 & 0.004 & 0.004 & 0.016 \\
\hline $\mathrm{Si}$ & 2.960 & 2.947 & 2.951 & 2.958 & 2.964 & 2.974 & 2.970 & 2.966 & 2.962 & 2.939 \\
\hline $\mathrm{Ti}$ & 0.000 & 0.000 & 0.000 & 0.001 & 0.000 & 0.000 & 0.001 & 0.000 & 0.000 & 0.000 \\
\hline $\mathrm{Al}$ & 1.029 & 1.036 & 1.029 & 1.034 & 1.029 & 1.015 & 1.021 & 1.025 & 1.032 & 1.039 \\
\hline Mg & 0.000 & 0.000 & 0.000 & 0.001 & 0.001 & 0.000 & 0.000 & 0.001 & 0.000 & 0.001 \\
\hline $\mathrm{Mn}^{2+}$ & 0.000 & 0.000 & 0.000 & 0.000 & 0.000 & 0.000 & 0.000 & 0.000 & 0.000 & 0.000 \\
\hline $\mathrm{Fe}^{2+}$ & 0.000 & 0.000 & 0.000 & 0.000 & 0.002 & 0.000 & 0.001 & 0.000 & 0.000 & 0.002 \\
\hline $\mathrm{Zn}$ & 0.001 & 0.000 & 0.001 & 0.000 & 0.001 & 0.000 & 0.000 & 0.000 & 0.001 & 0.000 \\
\hline $\mathrm{Ba}$ & 0.002 & 0.000 & 0.001 & 0.000 & 0.000 & 0.000 & 0.001 & 0.000 & 0.003 & 0.003 \\
\hline $\mathrm{Pb}^{2+}$ & 0.000 & 0.000 & 0.000 & 0.000 & 0.000 & 0.000 & 0.001 & 0.000 & 0.000 & 0.000 \\
\hline $\mathrm{Ca}$ & 0.000 & 0.000 & 0.000 & 0.002 & 0.001 & 0.001 & 0.000 & 0.005 & 0.003 & 0.001 \\
\hline $\mathrm{Na}$ & 0.071 & 0.104 & 0.098 & 0.125 & 0.142 & 0.100 & 0.116 & 0.125 & 0.097 & 0.130 \\
\hline K & 0.934 & 0.910 & 0.917 & 0.884 & 0.854 & 0.907 & 0.890 & 0.882 & 0.899 & 0.884 \\
\hline $\mathrm{Rb}$ & 0.023 & 0.025 & 0.027 & 0.024 & 0.023 & 0.027 & 0.028 & 0.024 & 0.023 & 0.023 \\
\hline Cs & 0.000 & 0.001 & 0.000 & 0.000 & 0.000 & 0.000 & 0.001 & 0.000 & 0.000 & 0.000 \\
\hline 0 & 8.000 & 8.000 & 8.000 & 8.000 & 8.000 & 8.000 & 8.000 & 8.000 & 8.000 & 8.000 \\
\hline
\end{tabular}


Appendix D.2 (contd.): Electron microprobe analyses of K-feldspar.

\begin{tabular}{|c|c|c|c|c|c|c|c|c|c|c|}
\hline Site & 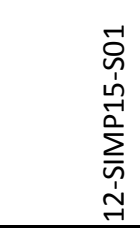 & 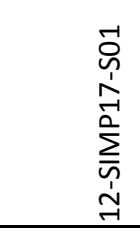 & 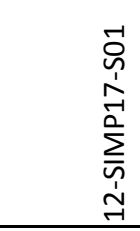 & 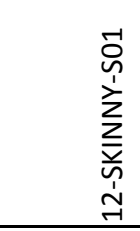 & 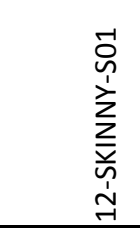 & 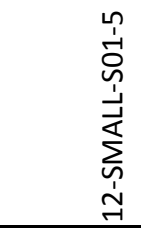 & 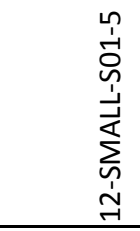 & 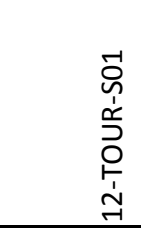 & 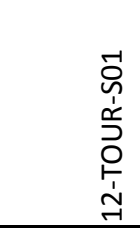 & 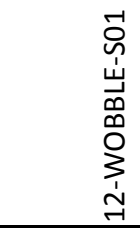 \\
\hline Comment & 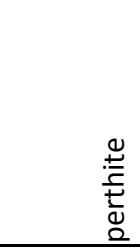 & 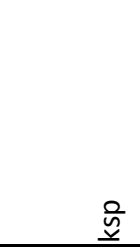 & $\frac{\hat{n}}{\underline{\underline{y}}}$ & 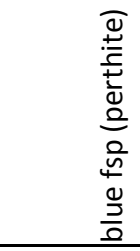 & 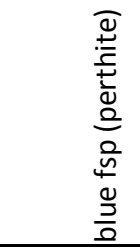 & 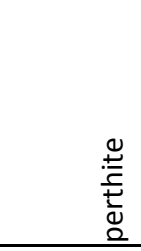 & 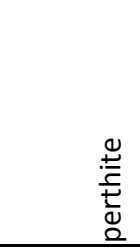 & 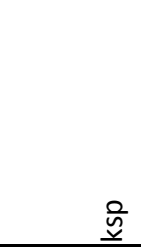 & 谷 & 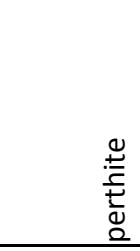 \\
\hline Point & $149 f-2$ & $150 f-1$ & $150 f-2$ & $151 \mathrm{f}-1$ & $151 \mathrm{f}-2$ & $153 f-1$ & $153 f-2$ & $154 f-1$ & $154 f-2$ & $155 f-1$ \\
\hline $\mathrm{P}_{2} \mathrm{O}_{5}$ (wt.\%) & 0.40 & 0.10 & 0.09 & 0.21 & 0.64 & 0.33 & 0.29 & 0.00 & 0.01 & 0.19 \\
\hline $\mathrm{SiO}_{2}$ & 62.66 & 63.26 & 63.86 & 63.15 & 62.61 & 63.47 & 63.64 & 63.51 & 63.52 & 63.38 \\
\hline $\mathrm{TiO}_{2}$ & 0.00 & 0.01 & 0.03 & 0.00 & 0.00 & 0.00 & 0.00 & 0.01 & 0.01 & 0.02 \\
\hline $\mathrm{Al}_{2} \mathrm{O}_{3}$ & 18.80 & 18.73 & 18.63 & 18.61 & 18.93 & 18.99 & 18.73 & 18.76 & 18.70 & 18.65 \\
\hline $\mathrm{MgO}$ & 0.00 & 0.00 & 0.00 & 0.01 & 0.00 & 0.00 & 0.01 & 0.00 & 0.00 & 0.01 \\
\hline $\mathrm{MnO}$ & 0.00 & 0.00 & 0.00 & 0.00 & 0.00 & 0.00 & 0.00 & 0.00 & 0.00 & 0.01 \\
\hline $\mathrm{FeO}$ & 0.02 & 0.02 & 0.01 & 0.00 & 0.03 & 0.00 & 0.02 & 0.00 & 0.00 & 0.00 \\
\hline $\mathrm{ZnO}$ & 0.01 & 0.02 & 0.04 & 0.00 & 0.00 & 0.05 & 0.07 & 0.03 & 0.00 & 0.04 \\
\hline $\mathrm{BaO}$ & 0.00 & 0.00 & 0.02 & 0.00 & 0.12 & 0.00 & 0.00 & 0.42 & 0.57 & 0.08 \\
\hline $\mathrm{PbO}$ & 0.03 & 0.02 & 0.04 & 0.01 & 0.00 & 0.00 & 0.00 & 0.00 & 0.00 & 0.01 \\
\hline $\mathrm{CaO}$ & 0.03 & 0.07 & 0.07 & 0.00 & 0.00 & 0.00 & 0.01 & 0.02 & 0.02 & 0.03 \\
\hline $\mathrm{Na}_{2} \mathrm{O}$ & 1.10 & 1.34 & 1.40 & 1.09 & 1.11 & 1.59 & 0.98 & 1.03 & 1.00 & 1.05 \\
\hline $\mathrm{K}_{2} \mathrm{O}$ & 15.41 & 15.04 & 14.89 & 15.38 & 15.34 & 14.85 & 15.64 & 15.38 & 15.35 & 15.47 \\
\hline $\mathrm{Rb}_{2} \mathrm{O}$ & 0.80 & 0.77 & 0.80 & 0.85 & 0.87 & 0.84 & 0.79 & 0.77 & 0.76 & 0.78 \\
\hline $\mathrm{Cs}_{2} \mathrm{O}$ & 0.03 & 0.01 & 0.00 & 0.06 & 0.05 & 0.03 & 0.00 & 0.02 & 0.01 & 0.03 \\
\hline Total & 99.29 & 99.39 & 99.88 & 99.37 & 99.70 & 100.15 & 100.18 & 99.95 & 99.95 & 99.75 \\
\hline P (apfu) & 0.016 & 0.004 & 0.004 & 0.008 & 0.025 & 0.013 & 0.011 & 0.000 & 0.000 & 0.008 \\
\hline $\mathrm{Si}$ & 2.938 & 2.958 & 2.968 & 2.958 & 2.925 & 2.943 & 2.955 & 2.963 & 2.965 & 2.958 \\
\hline $\mathrm{Ti}$ & 0.000 & 0.000 & 0.001 & 0.000 & 0.000 & 0.000 & 0.000 & 0.000 & 0.000 & 0.001 \\
\hline Al & 1.039 & 1.032 & 1.020 & 1.027 & 1.042 & 1.038 & 1.025 & 1.032 & 1.029 & 1.026 \\
\hline Mg & 0.000 & 0.000 & 0.000 & 0.001 & 0.000 & 0.000 & 0.001 & 0.000 & 0.000 & 0.001 \\
\hline $\mathrm{Mn}^{2+}$ & 0.000 & 0.000 & 0.000 & 0.000 & 0.000 & 0.000 & 0.000 & 0.000 & 0.000 & 0.000 \\
\hline $\mathrm{Fe}^{2+}$ & 0.001 & 0.001 & 0.000 & 0.000 & 0.001 & 0.000 & 0.001 & 0.000 & 0.000 & 0.000 \\
\hline $\mathrm{Zn}$ & 0.000 & 0.001 & 0.001 & 0.000 & 0.000 & 0.002 & 0.002 & 0.001 & 0.000 & 0.001 \\
\hline $\mathrm{Ba}$ & 0.000 & 0.000 & 0.000 & 0.000 & 0.002 & 0.000 & 0.000 & 0.008 & 0.010 & 0.001 \\
\hline $\mathrm{Pb}^{2+}$ & 0.000 & 0.000 & 0.001 & 0.000 & 0.000 & 0.000 & 0.000 & 0.000 & 0.000 & 0.000 \\
\hline $\mathrm{Ca}$ & 0.002 & 0.004 & 0.003 & 0.000 & 0.000 & 0.000 & 0.000 & 0.001 & 0.001 & 0.002 \\
\hline $\mathrm{Na}$ & 0.100 & 0.121 & 0.126 & 0.099 & 0.101 & 0.143 & 0.088 & 0.093 & 0.091 & 0.095 \\
\hline K & 0.922 & 0.897 & 0.883 & 0.919 & 0.914 & 0.878 & 0.927 & 0.915 & 0.914 & 0.921 \\
\hline $\mathrm{Rb}$ & 0.024 & 0.023 & 0.024 & 0.026 & 0.026 & 0.025 & 0.024 & 0.023 & 0.023 & 0.023 \\
\hline Cs & 0.001 & 0.000 & 0.000 & 0.001 & 0.001 & 0.001 & 0.000 & 0.000 & 0.000 & 0.001 \\
\hline 0 & 8.000 & 8.000 & 8.000 & 8.000 & 8.000 & 8.000 & 8.000 & 8.000 & 8.000 & 8.000 \\
\hline
\end{tabular}


Appendix D.2 (contd.): Electron microprobe analyses of K-feldspar.

\begin{tabular}{|c|c|c|c|c|c|}
\hline Site & 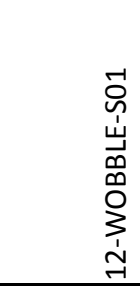 & 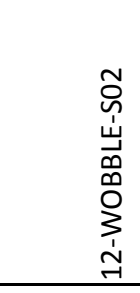 & 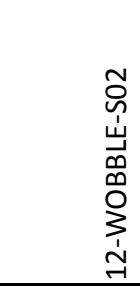 & 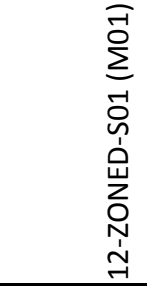 & 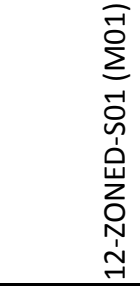 \\
\hline Comment & 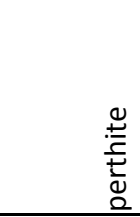 & 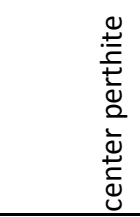 & 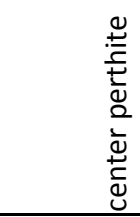 & 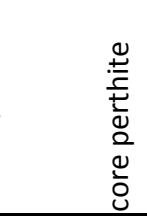 & 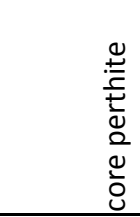 \\
\hline Point & $155 f-2$ & $156 f-1$ & $156 f-2$ & $157 f-1$ & $157 f-2$ \\
\hline $\mathrm{P}_{2} \mathrm{O}_{5}$ (wt.\%) & 0.18 & 0.29 & 0.28 & 0.13 & 0.16 \\
\hline $\mathrm{SiO}_{2}$ & 63.33 & 63.42 & 63.11 & 62.95 & 63.77 \\
\hline $\mathrm{TiO}_{2}$ & 0.03 & 0.00 & 0.00 & 0.00 & 0.00 \\
\hline $\mathrm{Al}_{2} \mathrm{O}_{3}$ & 18.59 & 18.99 & 18.96 & 18.71 & 18.74 \\
\hline $\mathrm{MgO}$ & 0.00 & 0.00 & 0.00 & 0.01 & 0.01 \\
\hline $\mathrm{MnO}$ & 0.01 & 0.00 & 0.00 & 0.01 & 0.00 \\
\hline $\mathrm{FeO}$ & 0.01 & 0.00 & 0.00 & 0.03 & 0.03 \\
\hline $\mathrm{ZnO}$ & 0.00 & 0.00 & 0.05 & 0.02 & 0.04 \\
\hline $\mathrm{BaO}$ & 0.05 & 0.06 & 0.00 & 0.01 & 0.09 \\
\hline $\mathrm{PbO}$ & 0.02 & 0.00 & 0.02 & 0.06 & 0.02 \\
\hline $\mathrm{CaO}$ & 0.02 & 0.01 & 0.01 & 0.07 & 0.08 \\
\hline $\mathrm{Na}_{2} \mathrm{O}$ & 0.92 & 0.93 & 0.89 & 1.35 & 1.32 \\
\hline $\mathrm{K}_{2} \mathrm{O}$ & 15.75 & 15.70 & 15.81 & 15.01 & 14.87 \\
\hline $\mathrm{Rb}_{2} \mathrm{O}$ & 0.77 & 0.76 & 0.80 & 0.76 & 0.80 \\
\hline $\mathrm{Cs}_{2} \mathrm{O}$ & 0.02 & 0.01 & 0.02 & 0.01 & 0.02 \\
\hline Total & 99.70 & 100.17 & 99.95 & 99.13 & 99.95 \\
\hline P (apfu) & 0.007 & 0.011 & 0.011 & 0.005 & 0.006 \\
\hline $\mathrm{Si}$ & 2.959 & 2.946 & 2.942 & 2.953 & 2.962 \\
\hline $\mathrm{Ti}$ & 0.001 & 0.000 & 0.000 & 0.000 & 0.000 \\
\hline Al & 1.024 & 1.040 & 1.042 & 1.034 & 1.026 \\
\hline $\mathrm{Mg}$ & 0.000 & 0.000 & 0.000 & 0.001 & 0.001 \\
\hline $\mathrm{Mn}^{2+}$ & 0.000 & 0.000 & 0.000 & 0.000 & 0.000 \\
\hline $\mathrm{Fe}^{2+}$ & 0.000 & 0.000 & 0.000 & 0.001 & 0.001 \\
\hline $\mathrm{Zn}$ & 0.000 & 0.000 & 0.002 & 0.001 & 0.001 \\
\hline $\mathrm{Ba}$ & 0.001 & 0.001 & 0.000 & 0.000 & 0.002 \\
\hline $\mathrm{Pb}^{2+}$ & 0.000 & 0.000 & 0.000 & 0.001 & 0.000 \\
\hline $\mathrm{Ca}$ & 0.001 & 0.000 & 0.000 & 0.004 & 0.004 \\
\hline $\mathrm{Na}$ & 0.083 & 0.084 & 0.080 & 0.123 & 0.119 \\
\hline K & 0.939 & 0.930 & 0.940 & 0.898 & 0.881 \\
\hline $\mathrm{Rb}$ & 0.023 & 0.023 & 0.024 & 0.023 & 0.024 \\
\hline Cs & 0.000 & 0.000 & 0.000 & 0.000 & 0.000 \\
\hline 0 & 8.000 & 8.000 & 8.000 & 8.000 & 8.000 \\
\hline
\end{tabular}


Appendix D.3: Electron microprobe analyses of biotite (Bt), muscovite (Ms), and lepidolite (Lpd).

\begin{tabular}{|c|c|c|c|c|c|c|c|c|}
\hline Mineral & Ms & Ms & $\mathrm{Bt}$ & $\mathrm{Bt}$ & $\mathrm{Ms}$ & $\mathrm{Ms}$ & $\mathrm{Ms}$ & $\mathrm{Ms}$ \\
\hline Sample & 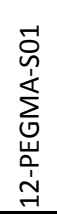 & 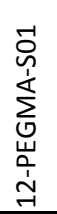 & 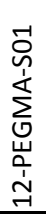 & 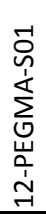 & 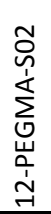 & 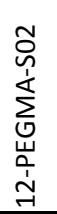 & 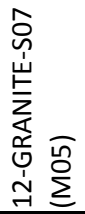 & 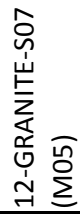 \\
\hline
\end{tabular}

\begin{tabular}{|c|c|c|c|c|c|c|c|c|}
\hline Comment & 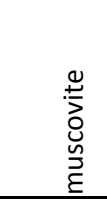 & 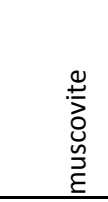 & $\begin{array}{l}\stackrel{ \pm}{ \pm} \\
.0 \\
.0 \\
\end{array}$ & $\begin{array}{l}\stackrel{0}{ \pm} \\
.0 \\
.0 \\
\end{array}$ & 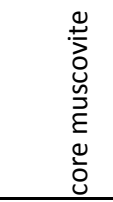 & 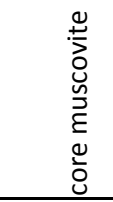 & 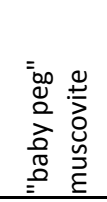 & 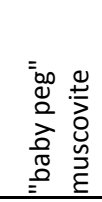 \\
\hline Point & $1 \mathrm{~m}-1$ & $1 m-2$ & $2 m-1$ & $2 m-2$ & $4 m-1$ & $4 m-2$ & $16 \mathrm{~m}-1$ & $16 m-2$ \\
\hline $\mathrm{P}_{2} \mathrm{O}_{5}$ (wt.\%) & 0.01 & 0.03 & 0.03 & 0.04 & 0.02 & 0.02 & 0.03 & 0.03 \\
\hline $\mathrm{SiO}_{2}$ & 44.86 & 45.64 & 35.23 & 35.66 & 44.70 & 45.03 & 44.70 & 45.10 \\
\hline $\mathrm{TiO}_{2}$ & 0.69 & 0.76 & 2.47 & 2.47 & 1.01 & 0.94 & 0.76 & 0.67 \\
\hline $\mathrm{Al}_{2} \mathrm{O}_{3}$ & 33.57 & 34.14 & 18.42 & 18.55 & 33.63 & 33.85 & 33.70 & 33.67 \\
\hline $\mathrm{MgO}$ & 0.78 & 0.61 & 10.47 & 10.21 & 0.49 & 0.53 & 0.54 & 0.51 \\
\hline $\mathrm{MnO}$ & 0.03 & 0.04 & 0.59 & 0.52 & 0.08 & 0.11 & 0.05 & 0.06 \\
\hline $\mathrm{FeO}$ & 3.42 & 3.02 & 17.38 & 17.08 & 3.28 & 3.25 & 3.31 & 3.32 \\
\hline $\mathrm{ZnO}$ & 0.02 & 0.00 & 0.08 & 0.11 & 0.01 & 0.00 & 0.00 & 0.01 \\
\hline $\mathrm{CaO}$ & 0.00 & 0.00 & 0.01 & 0.01 & 0.00 & 0.00 & 0.00 & 0.00 \\
\hline $\mathrm{BaO}$ & 0.03 & 0.00 & 0.00 & 0.00 & 0.06 & 0.00 & 0.00 & 0.00 \\
\hline $\mathrm{PbO}$ & 0.00 & 0.05 & 0.02 & 0.00 & 0.00 & 0.00 & 0.01 & 0.06 \\
\hline $\mathrm{Li}_{2} \mathrm{O}^{* *}$ & 0.07 & 0.04 & 0.12 & 0.13 & 0.11 & 0.08 & 0.05 & 0.03 \\
\hline $\mathrm{Na}_{2} \mathrm{O}$ & 0.74 & 0.65 & 0.10 & 0.10 & 0.78 & 0.78 & 0.70 & 0.76 \\
\hline $\mathrm{K}_{2} \mathrm{O}$ & 10.39 & 10.50 & 9.72 & 9.68 & 10.32 & 10.33 & 10.39 & 10.32 \\
\hline $\mathrm{Rb}_{2} \mathrm{O}$ & 0.60 & 0.63 & 0.46 & 0.52 & 0.57 & 0.59 & 0.63 & 0.61 \\
\hline $\mathrm{Cs}_{2} \mathrm{O}$ & 0.01 & 0.00 & 0.02 & 0.02 & 0.01 & 0.04 & 0.02 & 0.00 \\
\hline$F$ & 0.33 & 0.23 & 0.69 & 0.65 & 0.47 & 0.37 & 0.25 & 0.19 \\
\hline $\mathrm{H}_{2} \mathrm{O}^{*}$ & 4.26 & 4.36 & 3.60 & 3.63 & 4.19 & 4.26 & 4.28 & 4.33 \\
\hline$-O=F$ & -0.14 & -0.10 & -0.29 & -0.27 & -0.20 & -0.16 & -0.11 & -0.08 \\
\hline Total & 99.66 & 100.60 & 99.12 & 99.11 & 99.52 & 100.02 & 99.31 & 99.59 \\
\hline P (apfu) & 0.001 & 0.002 & 0.002 & 0.003 & 0.001 & 0.001 & 0.002 & 0.002 \\
\hline $\mathrm{Si}$ & 3.048 & 3.062 & 2.687 & 2.712 & 3.040 & 3.045 & 3.046 & 3.063 \\
\hline $\mathrm{Ti}$ & 0.035 & 0.038 & 0.142 & 0.141 & 0.052 & 0.048 & 0.039 & 0.034 \\
\hline Al & 2.689 & 2.700 & 1.656 & 1.663 & 2.696 & 2.698 & 2.707 & 2.695 \\
\hline $\mathrm{Mg}$ & 0.079 & 0.061 & 1.191 & 1.157 & 0.050 & 0.053 & 0.055 & 0.052 \\
\hline$M n$ & 0.002 & 0.002 & 0.038 & 0.033 & 0.005 & 0.006 & 0.003 & 0.003 \\
\hline $\mathrm{Fe}$ & 0.194 & 0.169 & 1.109 & 1.086 & 0.187 & 0.184 & 0.189 & 0.189 \\
\hline $\mathrm{Zn}$ & 0.001 & 0.000 & 0.005 & 0.006 & 0.001 & 0.000 & 0.000 & 0.001 \\
\hline $\mathrm{Ca}$ & 0.000 & 0.000 & 0.001 & 0.001 & 0.000 & 0.000 & 0.000 & 0.000 \\
\hline $\mathrm{Ba}$ & 0.001 & 0.000 & 0.000 & 0.000 & 0.002 & 0.000 & 0.000 & 0.000 \\
\hline $\mathrm{Pb}$ & 0.000 & 0.001 & 0.000 & 0.000 & 0.000 & 0.000 & 0.000 & 0.001 \\
\hline Li & 0.018 & 0.011 & 0.037 & 0.038 & 0.029 & 0.021 & 0.013 & 0.009 \\
\hline $\mathrm{Na}$ & 0.097 & 0.085 & 0.015 & 0.015 & 0.103 & 0.102 & 0.092 & 0.100 \\
\hline K & 0.901 & 0.899 & 0.946 & 0.939 & 0.895 & 0.891 & 0.903 & 0.894 \\
\hline $\mathrm{Rb}$ & 0.026 & 0.027 & 0.023 & 0.025 & 0.025 & 0.026 & 0.028 & 0.027 \\
\hline Cs & 0.000 & 0.000 & 0.001 & 0.001 & 0.000 & 0.001 & 0.001 & 0.000 \\
\hline $\mathrm{F}$ & 0.071 & 0.049 & 0.166 & 0.156 & 0.101 & 0.079 & 0.054 & 0.041 \\
\hline $\mathrm{OH}$ & 1.929 & 1.951 & 1.834 & 1.844 & 1.899 & 1.921 & 1.946 & 1.959 \\
\hline 0 & 10.000 & 10.000 & 10.000 & 10.000 & 10.000 & 10.000 & 10.000 & 10.000 \\
\hline
\end{tabular}

${ }^{*}$ Note: formula calculation based on 12 anions and $(\mathrm{F}+\mathrm{OH})=2$.

**Note: empirical equations of Tischendorf (1997) were used to estimate $\mathrm{Li}_{2} \mathrm{O}$ contents: equation [di1] for muscovite (Ms), equation [tri 1] for lepidolite (Lpd), and equation [tri 2] for biotite (Bt). 
Appendix D.3 (contd.): Electron microprobe analyses of biotite (Bt), muscovite (Ms), and lepidolite (Lpd).

\begin{tabular}{|c|c|c|c|c|c|c|c|c|}
\hline Mineral & $\mathrm{Ms}$ & $\mathrm{Ms}$ & $\mathrm{Ms}$ & $\mathrm{Ms}$ & $\mathrm{Ms}$ & $\mathrm{Ms}$ & $\mathrm{Ms}$ & $\mathrm{Ms}$ \\
\hline Sample & 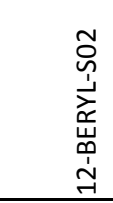 & 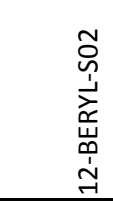 & 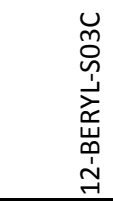 & 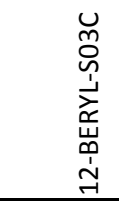 & 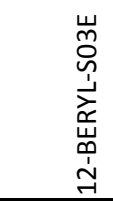 & 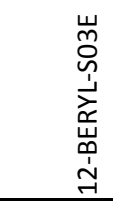 & 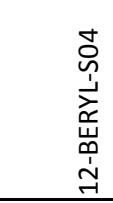 & 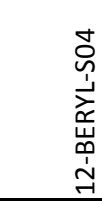 \\
\hline Comment & 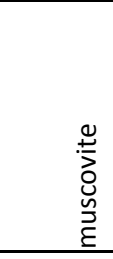 & 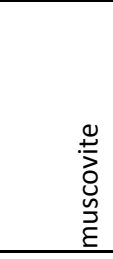 & $\begin{array}{l}\bar{\sigma} \\
\bar{E} \\
=\end{array}$ & 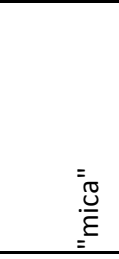 & 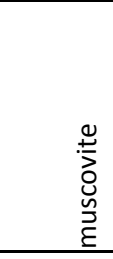 & 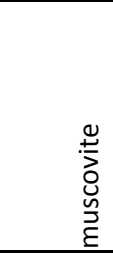 & 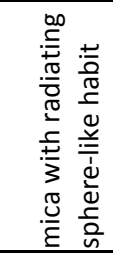 & 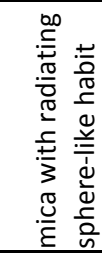 \\
\hline Point & $158 \mathrm{~m}-1$ & $158 m-2$ & $159 \mathrm{~m}-1$ & $159 m-2$ & $160 m-1$ & $160 m-2$ & $161 \mathrm{~m}-1$ & $161 \mathrm{~m}-2$ \\
\hline$\overline{\mathrm{P}_{2} \mathrm{O}_{5} \text { (wt.\%) }}$ & 0.01 & 0.00 & 0.01 & 0.02 & 0.03 & 0.04 & 0.02 & 0.02 \\
\hline $\mathrm{SiO}_{2}$ & 44.89 & 44.78 & 45.24 & 45.10 & 46.03 & 45.34 & 45.24 & 45.22 \\
\hline $\mathrm{TiO}_{2}$ & 0.12 & 0.07 & 0.41 & 0.35 & 0.14 & 0.14 & 0.13 & 0.15 \\
\hline $\mathrm{Al}_{2} \mathrm{O}_{3}$ & 33.57 & 33.98 & 35.68 & 36.03 & 36.63 & 36.29 & 33.33 & 33.76 \\
\hline $\mathrm{MgO}$ & 0.30 & 0.30 & 0.44 & 0.42 & 0.09 & 0.09 & 0.45 & 0.43 \\
\hline $\mathrm{MnO}$ & 0.17 & 0.15 & 0.03 & 0.04 & 0.12 & 0.14 & 0.24 & 0.20 \\
\hline $\mathrm{FeO}$ & 3.51 & 3.19 & 1.54 & 1.49 & 1.60 & 1.71 & 3.86 & 3.35 \\
\hline $\mathrm{ZnO}$ & 0.00 & 0.00 & 0.02 & 0.00 & 0.02 & 0.03 & 0.05 & 0.01 \\
\hline $\mathrm{CaO}$ & 0.00 & 0.00 & 0.00 & 0.00 & 0.00 & 0.00 & 0.01 & 0.01 \\
\hline $\mathrm{BaO}$ & 0.04 & 0.09 & 0.06 & 0.01 & 0.00 & 0.00 & 0.00 & 0.13 \\
\hline $\mathrm{PbO}$ & 0.05 & 0.00 & 0.00 & 0.00 & 0.00 & 0.00 & 0.00 & 0.03 \\
\hline $\mathrm{Li}_{2} \mathrm{O} * *$ & 0.11 & 0.08 & 0.28 & 0.26 & 0.03 & 0.05 & 0.06 & 0.06 \\
\hline $\mathrm{Na}_{2} \mathrm{O}$ & 0.35 & 0.41 & 0.89 & 0.88 & 0.92 & 0.93 & 0.45 & 0.42 \\
\hline $\mathrm{K}_{2} \mathrm{O}$ & 10.80 & 10.82 & 10.30 & 10.30 & 10.09 & 10.10 & 10.45 & 10.50 \\
\hline $\mathrm{Rb}_{2} \mathrm{O}$ & 0.73 & 0.76 & 0.64 & 0.60 & 0.78 & 0.75 & 0.77 & 0.74 \\
\hline $\mathrm{Cs}_{2} \mathrm{O}$ & 0.05 & 0.04 & 0.02 & 0.03 & 0.02 & 0.05 & 0.09 & 0.09 \\
\hline $\mathrm{F}$ & 0.48 & 0.39 & 0.96 & 0.93 & 0.17 & 0.27 & 0.32 & 0.29 \\
\hline $\mathrm{H}_{2} \mathrm{O}^{*}$ & 4.15 & 4.20 & 4.03 & 4.04 & 4.45 & 4.36 & 4.24 & 4.27 \\
\hline$-\mathrm{O}=\mathrm{F}$ & -0.20 & -0.16 & -0.40 & -0.39 & -0.07 & -0.11 & -0.13 & -0.12 \\
\hline Total & 99.13 & 99.10 & 100.14 & 100.12 & 101.05 & 100.17 & 99.58 & 99.55 \\
\hline P (apfu) & 0.001 & 0.000 & 0.001 & 0.001 & 0.002 & 0.002 & 0.001 & 0.001 \\
\hline $\mathrm{Si}$ & 3.075 & 3.065 & 3.027 & 3.015 & 3.044 & 3.031 & 3.085 & 3.079 \\
\hline $\mathrm{Ti}$ & 0.006 & 0.004 & 0.021 & 0.018 & 0.007 & 0.007 & 0.007 & 0.008 \\
\hline Al & 2.710 & 2.741 & 2.814 & 2.839 & 2.855 & 2.859 & 2.679 & 2.709 \\
\hline $\mathrm{Mg}$ & 0.031 & 0.031 & 0.044 & 0.042 & 0.009 & 0.009 & 0.046 & 0.044 \\
\hline $\mathrm{Mn}$ & 0.010 & 0.009 & 0.002 & 0.002 & 0.007 & 0.008 & 0.014 & 0.012 \\
\hline $\mathrm{Fe}$ & 0.201 & 0.183 & 0.086 & 0.083 & 0.088 & 0.096 & 0.220 & 0.191 \\
\hline $\mathrm{Zn}$ & 0.000 & 0.000 & 0.001 & 0.000 & 0.001 & 0.001 & 0.003 & 0.001 \\
\hline $\mathrm{Ca}$ & 0.000 & 0.000 & 0.000 & 0.000 & 0.000 & 0.000 & 0.001 & 0.001 \\
\hline $\mathrm{Ba}$ & 0.001 & 0.002 & 0.002 & 0.000 & 0.000 & 0.000 & 0.000 & 0.003 \\
\hline $\mathrm{Pb}$ & 0.001 & 0.000 & 0.000 & 0.000 & 0.000 & 0.000 & 0.000 & 0.001 \\
\hline $\mathrm{Li}$ & 0.030 & 0.023 & 0.074 & 0.071 & 0.007 & 0.014 & 0.018 & 0.015 \\
\hline $\mathrm{Na}$ & 0.046 & 0.054 & 0.115 & 0.114 & 0.118 & 0.121 & 0.060 & 0.055 \\
\hline K & 0.944 & 0.945 & 0.879 & 0.879 & 0.851 & 0.861 & 0.909 & 0.912 \\
\hline $\mathrm{Rb}$ & 0.032 & 0.033 & 0.028 & 0.026 & 0.033 & 0.032 & 0.034 & 0.032 \\
\hline Cs & 0.001 & 0.001 & 0.001 & 0.001 & 0.001 & 0.001 & 0.003 & 0.003 \\
\hline $\mathrm{F}$ & 0.104 & 0.084 & 0.203 & 0.197 & 0.036 & 0.057 & 0.069 & 0.062 \\
\hline $\mathrm{OH}$ & 1.896 & 1.916 & 1.797 & 1.803 & 1.964 & 1.943 & 1.931 & 1.938 \\
\hline 0 & 10.000 & 10.000 & 10.000 & 10.000 & 10.000 & 10.000 & 10.000 & 10.000 \\
\hline
\end{tabular}


Appendix D.3 (contd.): Electron microprobe analyses of biotite (Bt), muscovite (Ms), and lepidolite (Lpd).

\begin{tabular}{|c|c|c|c|c|c|c|c|c|}
\hline Mineral & Ms & Ms & Ms & Ms & Ms & $\mathrm{Ms}$ & $\mathrm{Ms}$ & $\mathrm{Ms}$ \\
\hline Sample & 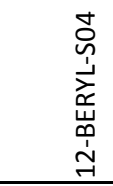 & 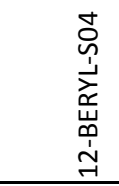 & 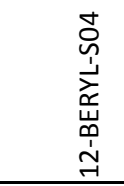 & 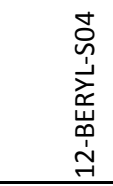 & 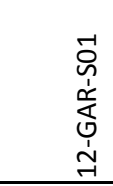 & 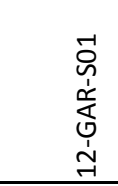 & 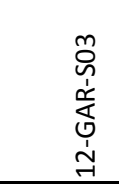 & 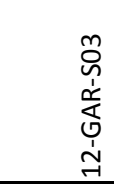 \\
\hline Comment & 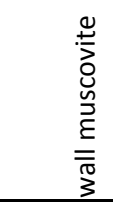 & 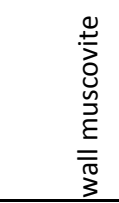 & 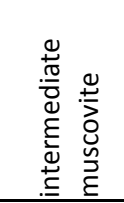 & 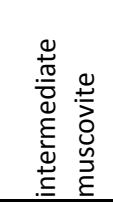 & 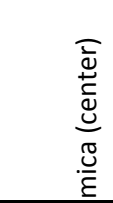 & 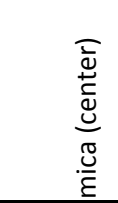 & $\frac{\widetilde{U}}{\varepsilon}$ & $\frac{\pi}{\varepsilon}$ \\
\hline Point & $162 m-1$ & $162 m-2$ & $163 m-1$ & $163 m-2$ & $164 m-1$ & $164 m-2$ & $165 m-1$ & $165 m-2$ \\
\hline $\mathrm{P}_{2} \mathrm{O}_{5}$ (wt.\%) & 0.01 & 0.04 & 0.00 & 0.01 & 0.03 & 0.03 & 0.02 & 0.02 \\
\hline $\mathrm{SiO}_{2}$ & 45.22 & 44.91 & 45.94 & 45.39 & 44.90 & 44.93 & 44.64 & 44.84 \\
\hline $\mathrm{TiO}_{2}$ & 0.11 & 0.22 & 0.46 & 0.49 & 0.46 & 0.51 & 0.53 & 0.53 \\
\hline $\mathrm{Al}_{2} \mathrm{O}_{3}$ & 35.98 & 36.07 & 35.63 & 35.31 & 34.23 & 34.01 & 33.97 & 33.84 \\
\hline $\mathrm{MgO}$ & 0.28 & 0.27 & 0.44 & 0.52 & 0.61 & 0.60 & 0.79 & 0.78 \\
\hline $\mathrm{MnO}$ & 0.12 & 0.16 & 0.06 & 0.05 & 0.04 & 0.05 & 0.07 & 0.09 \\
\hline $\mathrm{FeO}$ & 1.51 & 1.55 & 1.39 & 1.60 & 3.39 & 3.32 & 2.95 & 3.09 \\
\hline $\mathrm{ZnO}$ & 0.03 & 0.00 & 0.00 & 0.00 & 0.01 & 0.00 & 0.01 & 0.04 \\
\hline $\mathrm{CaO}$ & 0.00 & 0.00 & 0.00 & 0.00 & 0.00 & 0.00 & 0.00 & 0.00 \\
\hline $\mathrm{BaO}$ & 0.00 & 0.00 & 0.12 & 0.05 & 0.00 & 0.00 & 0.00 & 0.00 \\
\hline $\mathrm{PbO}$ & 0.01 & 0.04 & 0.00 & 0.00 & 0.00 & 0.01 & 0.04 & 0.00 \\
\hline $\mathrm{Li}_{2} \mathrm{O}^{* *}$ & 0.09 & 0.14 & 0.29 & 0.33 & 0.10 & 0.07 & 0.11 & 0.12 \\
\hline $\mathrm{Na}_{2} \mathrm{O}$ & 0.75 & 0.75 & 0.87 & 0.81 & 0.77 & 0.81 & 0.77 & 0.78 \\
\hline $\mathrm{K}_{2} \mathrm{O}$ & 10.47 & 10.48 & 10.28 & 10.32 & 10.32 & 10.24 & 10.42 & 10.36 \\
\hline $\mathrm{Rb}_{2} \mathrm{O}$ & 0.62 & 0.60 & 0.63 & 0.59 & 0.58 & 0.58 & 0.59 & 0.63 \\
\hline $\mathrm{Cs}_{2} \mathrm{O}$ & 0.02 & 0.00 & 0.02 & 0.01 & 0.01 & 0.01 & 0.03 & 0.02 \\
\hline $\mathrm{F}$ & 0.40 & 0.57 & 1.01 & 1.11 & 0.45 & 0.34 & 0.47 & 0.50 \\
\hline $\mathrm{H}_{2} \mathrm{O}^{*}$ & 4.28 & 4.19 & 4.04 & 3.95 & 4.22 & 4.26 & 4.18 & 4.18 \\
\hline$-\mathrm{O}=\mathrm{F}$ & -0.17 & -0.24 & -0.43 & -0.47 & -0.19 & -0.14 & -0.20 & -0.21 \\
\hline Total & 99.72 & 99.75 & 100.76 & 100.08 & 99.93 & 99.63 & 99.39 & 99.60 \\
\hline P (apfu) & 0.001 & 0.002 & 0.000 & 0.001 & 0.002 & 0.002 & 0.001 & 0.001 \\
\hline $\mathrm{Si}$ & 3.036 & 3.017 & 3.050 & 3.038 & 3.038 & 3.047 & 3.037 & 3.045 \\
\hline $\mathrm{Ti}$ & 0.006 & 0.011 & 0.023 & 0.025 & 0.023 & 0.026 & 0.027 & 0.027 \\
\hline Al & 2.847 & 2.856 & 2.788 & 2.785 & 2.730 & 2.719 & 2.724 & 2.708 \\
\hline $\mathrm{Mg}$ & 0.028 & 0.027 & 0.044 & 0.052 & 0.062 & 0.061 & 0.080 & 0.079 \\
\hline $\mathrm{Mn}$ & 0.007 & 0.009 & 0.003 & 0.003 & 0.002 & 0.003 & 0.004 & 0.005 \\
\hline $\mathrm{Fe}$ & 0.085 & 0.087 & 0.077 & 0.090 & 0.192 & 0.188 & 0.168 & 0.175 \\
\hline $\mathrm{Zn}$ & 0.001 & 0.000 & 0.000 & 0.000 & 0.000 & 0.000 & 0.001 & 0.002 \\
\hline $\mathrm{Ca}$ & 0.000 & 0.000 & 0.000 & 0.000 & 0.000 & 0.000 & 0.000 & 0.000 \\
\hline $\mathrm{Ba}$ & 0.000 & 0.000 & 0.003 & 0.001 & 0.000 & 0.000 & 0.000 & 0.000 \\
\hline $\mathrm{Pb}$ & 0.000 & 0.001 & 0.000 & 0.000 & 0.000 & 0.000 & 0.001 & 0.000 \\
\hline $\mathrm{Li}$ & 0.023 & 0.037 & 0.079 & 0.090 & 0.027 & 0.019 & 0.029 & 0.032 \\
\hline $\mathrm{Na}$ & 0.098 & 0.098 & 0.112 & 0.105 & 0.101 & 0.107 & 0.102 & 0.103 \\
\hline K & 0.897 & 0.898 & 0.871 & 0.881 & 0.891 & 0.886 & 0.904 & 0.897 \\
\hline $\mathrm{Rb}$ & 0.027 & 0.026 & 0.027 & 0.025 & 0.025 & 0.025 & 0.026 & 0.027 \\
\hline Cs & 0.001 & 0.000 & 0.001 & 0.000 & 0.000 & 0.000 & 0.001 & 0.001 \\
\hline $\mathrm{F}$ & 0.085 & 0.121 & 0.212 & 0.235 & 0.096 & 0.073 & 0.101 & 0.107 \\
\hline $\mathrm{OH}$ & 1.915 & 1.879 & 1.788 & 1.765 & 1.904 & 1.927 & 1.899 & 1.893 \\
\hline 0 & 10.000 & 10.000 & 10.000 & 10.000 & 10.000 & 10.000 & 10.000 & 10.000 \\
\hline
\end{tabular}


Appendix D.3 (contd.): Electron microprobe analyses of biotite (Bt), muscovite (Ms), and lepidolite (Lpd).

\begin{tabular}{|c|c|c|c|c|c|c|c|c|}
\hline Mineral & $\mathrm{Ms}$ & Ms & $\mathrm{Ms}$ & Ms & Ms & Ms & Lpd & Lpd \\
\hline Sample & 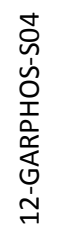 & 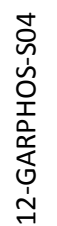 & 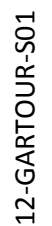 & 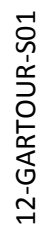 & 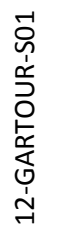 & 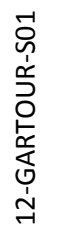 & 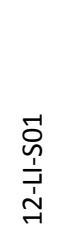 & 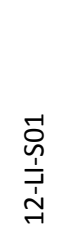 \\
\hline
\end{tabular}

\begin{tabular}{|c|c|c|c|c|c|c|c|c|}
\hline Comment & 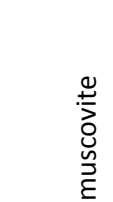 & 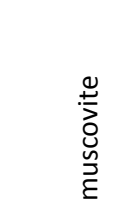 & 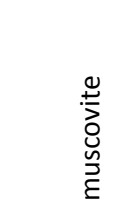 & 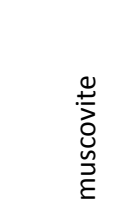 & 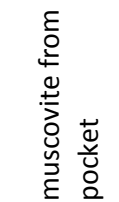 & 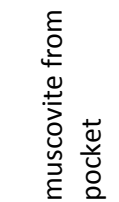 & $\begin{array}{l}\stackrel{\Perp}{ \pm} \\
\frac{0}{0} \\
\stackrel{0}{0} \\
\stackrel{0}{Q}\end{array}$ & 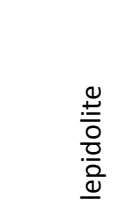 \\
\hline Point & $166 \mathrm{~m}-1$ & $166 m-2$ & $167 \mathrm{~m}-1$ & $167 m-2$ & $168 m-1$ & $168 m-2$ & $169 m-1$ & $169 m-2$ \\
\hline $\mathrm{P}_{2} \mathrm{O}_{5}$ (wt.\%) & 0.03 & 0.02 & 0.02 & 0.03 & 0.03 & 0.03 & 0.04 & 0.04 \\
\hline $\mathrm{SiO}_{2}$ & 45.33 & 44.53 & 45.27 & 45.56 & 46.06 & 44.99 & 51.69 & 50.50 \\
\hline $\mathrm{TiO}_{2}$ & 0.40 & 0.40 & 0.27 & 0.25 & 0.04 & 0.06 & 0.00 & 0.00 \\
\hline $\mathrm{Al}_{2} \mathrm{O}_{3}$ & 34.58 & 34.43 & 35.89 & 37.03 & 36.70 & 36.46 & 27.28 & 26.78 \\
\hline $\mathrm{MgO}$ & 0.30 & 0.31 & 0.32 & 0.25 & 0.26 & 0.33 & 0.00 & 0.01 \\
\hline $\mathrm{MnO}$ & 0.08 & 0.06 & 0.04 & 0.04 & 0.02 & 0.03 & 0.42 & 0.37 \\
\hline $\mathrm{FeO}$ & 3.45 & 3.30 & 1.64 & 1.30 & 0.95 & 0.95 & 0.02 & 0.02 \\
\hline ZnO & 0.00 & 0.05 & 0.01 & 0.06 & 0.00 & 0.01 & 0.03 & 0.01 \\
\hline $\mathrm{CaO}$ & 0.00 & 0.00 & 0.00 & 0.00 & 0.01 & 0.00 & 0.00 & 0.02 \\
\hline $\mathrm{BaO}$ & 0.00 & 0.07 & 0.00 & 0.00 & 0.00 & 0.00 & 0.04 & 0.00 \\
\hline $\mathrm{PbO}$ & 0.00 & 0.04 & 0.00 & 0.02 & 0.03 & 0.00 & 0.00 & 0.01 \\
\hline $\mathrm{Li}_{2} \mathrm{O} * *$ & 0.21 & 0.19 & 0.05 & 0.03 & 0.00 & 0.00 & 5.28 & 4.94 \\
\hline $\mathrm{Na}_{2} \mathrm{O}$ & 0.77 & 0.70 & 0.77 & 0.69 & 0.74 & 0.76 & 0.40 & 0.39 \\
\hline $\mathrm{K}_{2} \mathrm{O}$ & 10.19 & 10.39 & 10.34 & 10.34 & 10.23 & 10.34 & 10.59 & 10.63 \\
\hline $\mathrm{Rb}_{2} \mathrm{O}$ & 0.63 & 0.64 & 0.56 & 0.63 & 0.59 & 0.60 & 1.56 & 1.59 \\
\hline $\mathrm{Cs}_{2} \mathrm{O}$ & 0.04 & 0.03 & 0.00 & 0.02 & 0.01 & 0.03 & 0.30 & 0.26 \\
\hline $\mathrm{F}$ & 0.78 & 0.72 & 0.26 & 0.17 & 0.00 & 0.00 & 6.24 & 5.56 \\
\hline $\mathrm{H}_{2} \mathrm{O}^{*}$ & 4.09 & 4.07 & 4.35 & 4.45 & 4.52 & 4.45 & 1.69 & 1.90 \\
\hline$-\mathrm{O}=\mathrm{F}$ & -0.33 & -0.30 & -0.11 & -0.07 & 0.00 & 0.00 & -2.63 & -2.34 \\
\hline Total & 100.55 & 99.64 & 99.67 & 100.79 & 100.19 & 99.04 & 102.95 & 100.69 \\
\hline P (apfu) & 0.002 & 0.001 & 0.001 & 0.002 & 0.002 & 0.002 & 0.002 & 0.002 \\
\hline $\mathrm{Si}$ & 3.045 & 3.027 & 3.037 & 3.017 & 3.056 & 3.028 & 3.336 & 3.337 \\
\hline $\mathrm{Ti}$ & 0.020 & 0.020 & 0.014 & 0.012 & 0.002 & 0.003 & 0.000 & 0.000 \\
\hline Al & 2.738 & 2.758 & 2.838 & 2.890 & 2.870 & 2.892 & 2.075 & 2.086 \\
\hline $\mathrm{Mg}$ & 0.030 & 0.031 & 0.032 & 0.025 & 0.026 & 0.033 & 0.000 & 0.001 \\
\hline $\mathrm{Mn}$ & 0.005 & 0.003 & 0.002 & 0.002 & 0.001 & 0.002 & 0.023 & 0.021 \\
\hline $\mathrm{Fe}$ & 0.194 & 0.188 & 0.092 & 0.072 & 0.053 & 0.053 & 0.001 & 0.001 \\
\hline $\mathrm{Zn}$ & 0.000 & 0.003 & 0.000 & 0.003 & 0.000 & 0.000 & 0.001 & 0.000 \\
\hline $\mathrm{Ca}$ & 0.000 & 0.000 & 0.000 & 0.000 & 0.001 & 0.000 & 0.000 & 0.001 \\
\hline $\mathrm{Ba}$ & 0.000 & 0.002 & 0.000 & 0.000 & 0.000 & 0.000 & 0.001 & 0.000 \\
\hline $\mathrm{Pb}$ & 0.000 & 0.001 & 0.000 & 0.000 & 0.001 & 0.000 & 0.000 & 0.000 \\
\hline $\mathrm{Li}$ & 0.056 & 0.051 & 0.013 & 0.007 & 0.000 & 0.000 & 1.371 & 1.312 \\
\hline $\mathrm{Na}$ & 0.100 & 0.092 & 0.100 & 0.089 & 0.095 & 0.099 & 0.050 & 0.050 \\
\hline $\mathrm{K}$ & 0.873 & 0.901 & 0.885 & 0.874 & 0.866 & 0.888 & 0.872 & 0.896 \\
\hline $\mathrm{Rb}$ & 0.027 & 0.028 & 0.024 & 0.027 & 0.025 & 0.026 & 0.065 & 0.068 \\
\hline Cs & 0.001 & 0.001 & 0.000 & 0.001 & 0.000 & 0.001 & 0.008 & 0.007 \\
\hline $\mathrm{F}$ & 0.166 & 0.155 & 0.055 & 0.036 & 0.000 & 0.000 & 1.274 & 1.162 \\
\hline $\mathrm{OH}$ & 1.834 & 1.845 & 1.945 & 1.964 & 2.000 & 2.000 & 0.726 & 0.838 \\
\hline $\mathrm{O}$ & 10.000 & 10.000 & 10.000 & 10.000 & 10.000 & 10.000 & 10.000 & 10.000 \\
\hline
\end{tabular}


Appendix D.3 (contd.): Electron microprobe analyses of biotite (Bt), muscovite (Ms), and lepidolite (Lpd).

\begin{tabular}{|c|c|c|c|c|c|c|c|c|}
\hline Mineral & Lpd & Lpd & Ms & Ms & Lpd & Lpd & Lpd & Lpd \\
\hline Sample & 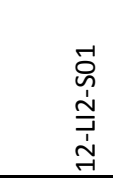 & 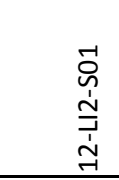 & 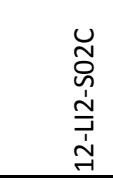 & 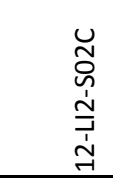 & 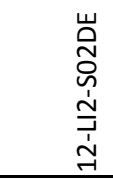 & 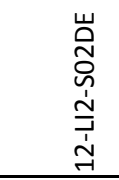 & 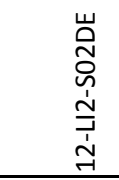 & 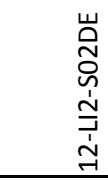 \\
\hline Comment & $\begin{array}{l}\stackrel{ \pm}{ \pm} \\
\stackrel{ \pm}{0} \\
.0 \\
\stackrel{0}{0}\end{array}$ & $\begin{array}{l}\stackrel{\oplus}{ \pm} \\
\stackrel{ \pm}{0} \\
. \frac{0}{0} \\
\underline{0}\end{array}$ & 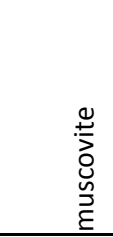 & 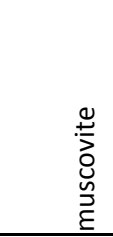 & 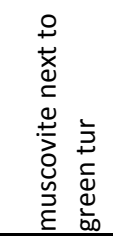 & 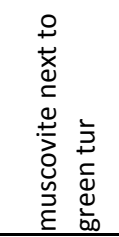 & 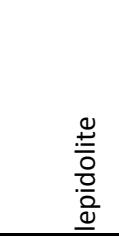 & $\begin{array}{l}\stackrel{0}{ \pm} \\
\stackrel{ \pm}{0} \\
\stackrel{0}{0} \\
\stackrel{0}{0}\end{array}$ \\
\hline Point & $170 m-1$ & $170 m-2$ & $171 m-1$ & $171 m-2$ & $172 m-1$ & $172 m-2$ & $173 m-1$ & $173 m-2$ \\
\hline $\mathrm{P}_{2} \mathrm{O}_{5}$ (wt.\%) & 0.05 & 0.01 & 0.02 & 0.03 & 0.04 & 0.00 & 0.01 & 0.03 \\
\hline $\mathrm{SiO}_{2}$ & 49.64 & 49.81 & 44.76 & 45.19 & 53.03 & 53.21 & 51.03 & 51.10 \\
\hline $\mathrm{TiO}_{2}$ & 0.04 & 0.00 & 0.75 & 0.78 & 0.05 & 0.03 & 0.01 & 0.00 \\
\hline $\mathrm{Al}_{2} \mathrm{O}_{3}$ & 28.73 & 28.27 & 33.31 & 34.16 & 25.24 & 25.35 & 27.12 & 27.23 \\
\hline $\mathrm{MgO}$ & 0.00 & 0.01 & 0.83 & 0.80 & 0.01 & 0.01 & 0.00 & 0.00 \\
\hline $\mathrm{MnO}$ & 1.06 & 1.04 & 0.05 & 0.03 & 0.87 & 0.86 & 0.59 & 0.66 \\
\hline $\mathrm{FeO}$ & 0.04 & 0.01 & 2.60 & 2.52 & 0.08 & 0.10 & 0.05 & 0.05 \\
\hline $\mathrm{ZnO}$ & 0.02 & 0.06 & 0.04 & 0.00 & 0.00 & 0.04 & 0.03 & 0.00 \\
\hline $\mathrm{CaO}$ & 0.00 & 0.00 & 0.01 & 0.00 & 0.00 & 0.00 & 0.00 & 0.00 \\
\hline $\mathrm{BaO}$ & 0.00 & 0.00 & 0.00 & 0.00 & 0.00 & 0.00 & 0.01 & 0.00 \\
\hline $\mathrm{PbO}$ & 0.00 & 0.01 & 0.02 & 0.03 & 0.01 & 0.06 & 0.00 & 0.01 \\
\hline $\mathrm{Li}_{2} \mathrm{O}^{* *}$ & 4.69 & 4.74 & 0.12 & 0.15 & 5.67 & 5.72 & 5.09 & 5.11 \\
\hline $\mathrm{Na}_{2} \mathrm{O}$ & 0.28 & 0.29 & 0.70 & 0.67 & 0.24 & 0.19 & 0.27 & 0.30 \\
\hline $\mathrm{K}_{2} \mathrm{O}$ & 10.74 & 10.83 & 10.35 & 10.38 & 10.80 & 10.91 & 10.50 & 10.44 \\
\hline $\mathrm{Rb}_{2} \mathrm{O}$ & 1.45 & 1.49 & 0.60 & 0.60 & 1.52 & 1.48 & 1.61 & 1.50 \\
\hline $\mathrm{Cs}_{2} \mathrm{O}$ & 0.33 & 0.37 & 0.03 & 0.00 & 0.26 & 0.28 & 0.72 & 0.71 \\
\hline $\mathrm{F}$ & 5.67 & 6.26 & 0.51 & 0.60 & 7.17 & 7.28 & 6.53 & 6.38 \\
\hline $\mathrm{H}_{2} \mathrm{O}^{*}$ & 1.90 & 1.61 & 4.14 & 4.16 & 1.25 & 1.22 & 1.50 & 1.58 \\
\hline$-\mathrm{O}=\mathrm{F}$ & -2.39 & -2.64 & -0.21 & -0.25 & -3.02 & -3.07 & -2.75 & -2.69 \\
\hline Total & 102.25 & 102.17 & 98.63 & 99.85 & 103.22 & 103.67 & 102.32 & 102.41 \\
\hline P (apfu) & 0.003 & 0.001 & 0.001 & 0.002 & 0.002 & 0.000 & 0.001 & 0.002 \\
\hline $\mathrm{Si}$ & 3.245 & 3.264 & 3.062 & 3.048 & 3.417 & 3.416 & 3.332 & 3.329 \\
\hline $\mathrm{Ti}$ & 0.002 & 0.000 & 0.039 & 0.040 & 0.002 & 0.001 & 0.000 & 0.000 \\
\hline Al & 2.214 & 2.184 & 2.686 & 2.715 & 1.917 & 1.918 & 2.087 & 2.091 \\
\hline $\mathrm{Mg}$ & 0.000 & 0.001 & 0.085 & 0.080 & 0.001 & 0.001 & 0.000 & 0.000 \\
\hline $\mathrm{Mn}$ & 0.059 & 0.058 & 0.003 & 0.002 & 0.047 & 0.047 & 0.033 & 0.036 \\
\hline $\mathrm{Fe}$ & 0.002 & 0.001 & 0.149 & 0.142 & 0.004 & 0.005 & 0.003 & 0.003 \\
\hline $\mathrm{Zn}$ & 0.001 & 0.003 & 0.002 & 0.000 & 0.000 & 0.002 & 0.001 & 0.000 \\
\hline $\mathrm{Ca}$ & 0.000 & 0.000 & 0.001 & 0.000 & 0.000 & 0.000 & 0.000 & 0.000 \\
\hline $\mathrm{Ba}$ & 0.000 & 0.000 & 0.000 & 0.000 & 0.000 & 0.000 & 0.000 & 0.000 \\
\hline $\mathrm{Pb}$ & 0.000 & 0.000 & 0.000 & 0.001 & 0.000 & 0.001 & 0.000 & 0.000 \\
\hline $\mathrm{Li}$ & 1.232 & 1.249 & 0.033 & 0.040 & 1.469 & 1.477 & 1.336 & 1.339 \\
\hline $\mathrm{Na}$ & 0.035 & 0.037 & 0.093 & 0.088 & 0.030 & 0.024 & 0.034 & 0.038 \\
\hline K & 0.896 & 0.905 & 0.903 & 0.893 & 0.888 & 0.894 & 0.875 & 0.868 \\
\hline $\mathrm{Rb}$ & 0.061 & 0.063 & 0.026 & 0.026 & 0.063 & 0.061 & 0.068 & 0.063 \\
\hline Cs & 0.009 & 0.010 & 0.001 & 0.000 & 0.007 & 0.008 & 0.020 & 0.020 \\
\hline $\mathrm{F}$ & 1.172 & 1.298 & 0.110 & 0.128 & 1.461 & 1.478 & 1.348 & 1.314 \\
\hline $\mathrm{OH}$ & 0.828 & 0.702 & 1.890 & 1.872 & 0.539 & 0.522 & 0.652 & 0.686 \\
\hline 0 & 10.000 & 10.000 & 10.000 & 10.000 & 10.000 & 10.000 & 10.000 & 10.000 \\
\hline
\end{tabular}


Appendix D.3 (contd.): Electron microprobe analyses of biotite (Bt), muscovite (Ms), and lepidolite (Lpd).

\begin{tabular}{|c|c|c|c|c|c|c|c|c|}
\hline Mineral & Ms & Ms & Ms & Ms & Ms & $\mathrm{Ms}$ & Ms & $\mathrm{Ms}$ \\
\hline Sample & 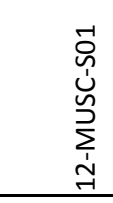 & 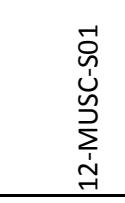 & 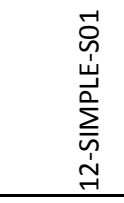 & 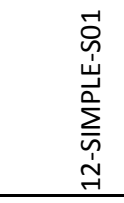 & 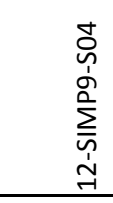 & 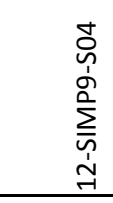 & 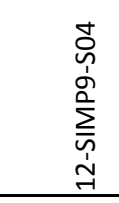 & 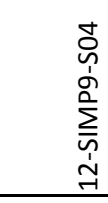 \\
\hline Comment & $\stackrel{\overparen{U}}{E}$ & $\frac{\widetilde{J}}{\varepsilon}$ & $\frac{\pi}{\varepsilon}$ & $\frac{\pi}{\varepsilon}$ & $\frac{\pi}{\varepsilon}$ & $\stackrel{\widetilde{\mathscr{U}}}{E}$ & 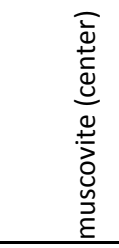 & 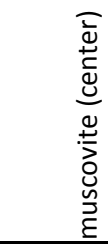 \\
\hline Point & $174 m-1$ & $174 m-2$ & $175 \mathrm{~m}-1$ & $175 m-2$ & $176 m-1$ & $176 m-2$ & $177 m-1$ & $177 m-2$ \\
\hline $\mathrm{P}_{2} \mathrm{O}_{5}$ (wt.\%) & 0.01 & 0.00 & 0.00 & 0.02 & 0.08 & 0.03 & 0.05 & 0.01 \\
\hline $\mathrm{SiO}_{2}$ & 44.61 & 44.96 & 45.82 & 45.62 & 44.69 & 44.78 & 45.31 & 45.61 \\
\hline $\mathrm{TiO}_{2}$ & 0.54 & 0.63 & 0.54 & 0.56 & 0.62 & 0.75 & 0.53 & 0.65 \\
\hline $\mathrm{Al}_{2} \mathrm{O}_{3}$ & 33.40 & 33.64 & 34.13 & 33.94 & 34.47 & 34.63 & 35.13 & 34.73 \\
\hline $\mathrm{MgO}$ & 0.66 & 0.65 & 0.86 & 0.87 & 0.64 & 0.63 & 0.49 & 0.57 \\
\hline $\mathrm{MnO}$ & 0.03 & 0.05 & 0.02 & 0.00 & 0.03 & 0.04 & 0.05 & 0.06 \\
\hline $\mathrm{FeO}$ & 3.58 & 3.66 & 2.92 & 3.03 & 3.02 & 2.99 & 2.89 & 2.90 \\
\hline $\mathrm{ZnO}$ & 0.01 & 0.07 & 0.00 & 0.04 & 0.05 & 0.00 & 0.01 & 0.06 \\
\hline $\mathrm{CaO}$ & 0.00 & 0.00 & 0.00 & 0.00 & 0.00 & 0.00 & 0.00 & 0.00 \\
\hline $\mathrm{BaO}$ & 0.00 & 0.00 & 0.16 & 0.02 & 0.08 & 0.07 & 0.03 & 0.01 \\
\hline $\mathrm{PbO}$ & 0.03 & 0.02 & 0.00 & 0.05 & 0.00 & 0.02 & 0.02 & 0.00 \\
\hline $\mathrm{Li}_{2} \mathrm{O}^{* *}$ & 0.04 & 0.03 & 0.03 & 0.00 & 0.04 & 0.02 & 0.04 & 0.05 \\
\hline $\mathrm{Na}_{2} \mathrm{O}$ & 0.70 & 0.74 & 0.71 & 0.70 & 0.82 & 0.79 & 0.72 & 0.71 \\
\hline $\mathrm{K}_{2} \mathrm{O}$ & 10.48 & 10.49 & 10.53 & 10.41 & 10.27 & 10.34 & 10.34 & 10.36 \\
\hline $\mathrm{Rb}_{2} \mathrm{O}$ & 0.60 & 0.59 & 0.53 & 0.53 & 0.60 & 0.59 & 0.57 & 0.57 \\
\hline $\mathrm{Cs}_{2} \mathrm{O}$ & 0.00 & 0.04 & 0.05 & 0.02 & 0.03 & 0.02 & 0.03 & 0.01 \\
\hline $\mathrm{F}$ & 0.21 & 0.19 & 0.18 & 0.00 & 0.23 & 0.13 & 0.23 & 0.28 \\
\hline $\mathrm{H}_{2} \mathrm{O}^{*}$ & 4.28 & 4.33 & 4.39 & 4.46 & 4.32 & 4.38 & 4.37 & 4.35 \\
\hline$-O=F$ & -0.09 & -0.08 & -0.08 & 0.00 & -0.10 & -0.05 & -0.10 & -0.12 \\
\hline Total & 99.09 & 100.01 & 100.80 & 100.27 & 99.90 & 100.16 & 100.72 & 100.82 \\
\hline P (apfu) & 0.001 & 0.000 & 0.000 & 0.001 & 0.005 & 0.002 & 0.003 & 0.001 \\
\hline $\mathrm{Si}$ & 3.053 & 3.050 & 3.069 & 3.069 & 3.023 & 3.021 & 3.032 & 3.048 \\
\hline $\mathrm{Ti}$ & 0.028 & 0.032 & 0.027 & 0.028 & 0.032 & 0.038 & 0.027 & 0.033 \\
\hline $\mathrm{Al}$ & 2.694 & 2.690 & 2.694 & 2.691 & 2.748 & 2.753 & 2.770 & 2.736 \\
\hline $\mathrm{Mg}$ & 0.067 & 0.066 & 0.086 & 0.087 & 0.065 & 0.063 & 0.049 & 0.057 \\
\hline $\mathrm{Mn}$ & 0.002 & 0.003 & 0.001 & 0.000 & 0.002 & 0.002 & 0.003 & 0.003 \\
\hline $\mathrm{Fe}$ & 0.205 & 0.208 & 0.164 & 0.170 & 0.171 & 0.169 & 0.162 & 0.162 \\
\hline $\mathrm{Zn}$ & 0.001 & 0.004 & 0.000 & 0.002 & 0.002 & 0.000 & 0.000 & 0.003 \\
\hline $\mathrm{Ca}$ & 0.000 & 0.000 & 0.000 & 0.000 & 0.000 & 0.000 & 0.000 & 0.000 \\
\hline $\mathrm{Ba}$ & 0.000 & 0.000 & 0.004 & 0.001 & 0.002 & 0.002 & 0.001 & 0.000 \\
\hline $\mathrm{Pb}$ & 0.001 & 0.000 & 0.000 & 0.001 & 0.000 & 0.000 & 0.000 & 0.000 \\
\hline $\mathrm{Li}$ & 0.010 & 0.009 & 0.008 & 0.000 & 0.011 & 0.005 & 0.011 & 0.014 \\
\hline $\mathrm{Na}$ & 0.093 & 0.097 & 0.092 & 0.091 & 0.108 & 0.103 & 0.093 & 0.092 \\
\hline K & 0.915 & 0.908 & 0.900 & 0.893 & 0.886 & 0.890 & 0.883 & 0.883 \\
\hline $\mathrm{Rb}$ & 0.026 & 0.026 & 0.023 & 0.023 & 0.026 & 0.026 & 0.025 & 0.024 \\
\hline Cs & 0.000 & 0.001 & 0.001 & 0.001 & 0.001 & 0.001 & 0.001 & 0.000 \\
\hline $\mathrm{F}$ & 0.045 & 0.041 & 0.038 & 0.000 & 0.049 & 0.028 & 0.049 & 0.059 \\
\hline $\mathrm{OH}$ & 1.955 & 1.959 & 1.962 & 2.000 & 1.951 & 1.972 & 1.951 & 1.941 \\
\hline 0 & 10.000 & 10.000 & 10.000 & 10.000 & 10.000 & 10.000 & 10.000 & 10.000 \\
\hline
\end{tabular}


Appendix D.3 (contd.): Electron microprobe analyses of biotite (Bt), muscovite (Ms), and lepidolite (Lpd).

\begin{tabular}{|c|c|c|c|c|c|c|c|c|}
\hline Mineral & $\mathrm{Ms}$ & $\mathrm{Ms}$ & $\mathrm{Ms}$ & $\mathrm{Ms}$ & $\mathrm{Ms}$ & $\mathrm{Ms}$ & $\mathrm{Ms}$ & $\mathrm{Ms}$ \\
\hline Sample & 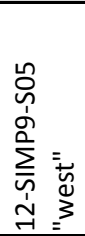 & 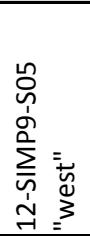 & 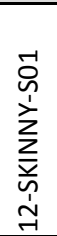 & 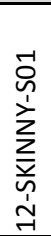 & 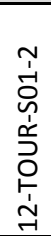 & 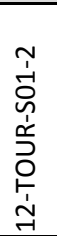 & 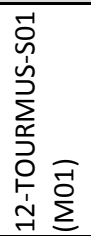 & 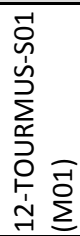 \\
\hline
\end{tabular}

\begin{tabular}{|c|c|c|c|c|c|c|c|c|}
\hline Comment & 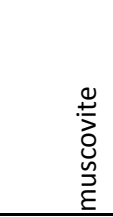 & 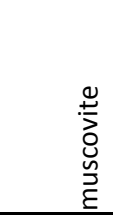 & 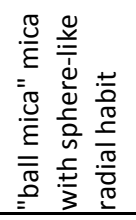 & 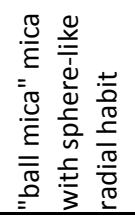 & 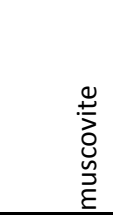 & 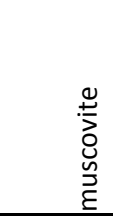 & 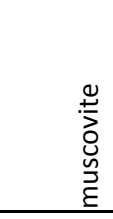 & 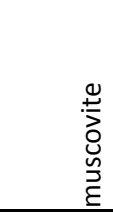 \\
\hline Point & $178 m-1$ & $178 m-2$ & $179 m-1$ & $179 m-2$ & $180 \mathrm{~m}-1$ & $180 \mathrm{~m}-2$ & $181 \mathrm{~m}-1$ & $181 \mathrm{~m}-2$ \\
\hline $\mathrm{P}_{2} \mathrm{O}_{5}$ (wt.\%) & 0.04 & 0.03 & 0.00 & 0.03 & 0.01 & 0.03 & 0.02 & 0.04 \\
\hline $\mathrm{SiO}_{2}$ & 45.29 & 44.72 & 45.54 & 44.67 & 45.74 & 45.67 & 44.89 & 44.58 \\
\hline $\mathrm{TiO}_{2}$ & 0.60 & 0.50 & 0.05 & 0.00 & 0.27 & 0.31 & 0.23 & 0.30 \\
\hline $\mathrm{Al}_{2} \mathrm{O}_{3}$ & 35.05 & 34.51 & 34.81 & 33.11 & 36.43 & 36.57 & 35.16 & 34.67 \\
\hline $\mathrm{MgO}$ & 0.14 & 0.15 & 0.34 & 0.37 & 0.11 & 0.12 & 0.11 & 0.12 \\
\hline $\mathrm{MnO}$ & 0.10 & 0.16 & 0.06 & 0.07 & 0.01 & 0.02 & 0.12 & 0.15 \\
\hline $\mathrm{FeO}$ & 3.03 & 2.83 & 1.50 & 1.62 & 1.45 & 1.54 & 2.67 & 2.80 \\
\hline $\mathrm{ZnO}$ & 0.04 & 0.03 & 0.04 & 0.04 & 0.02 & 0.07 & 0.04 & 0.00 \\
\hline $\mathrm{CaO}$ & 0.00 & 0.03 & 0.03 & 0.03 & 0.00 & 0.01 & 0.00 & 0.00 \\
\hline $\mathrm{BaO}$ & 0.00 & 0.01 & 0.00 & 0.00 & 0.08 & 0.16 & 0.00 & 0.00 \\
\hline $\mathrm{PbO}$ & 0.00 & 0.04 & 0.01 & 0.00 & 0.01 & 0.00 & 0.02 & 0.00 \\
\hline $\mathrm{Li}_{2} \mathrm{O}^{* *}$ & 0.00 & 0.02 & 0.01 & 0.02 & 0.01 & 0.02 & 0.37 & 0.45 \\
\hline $\mathrm{Na}_{2} \mathrm{O}$ & 0.85 & 0.65 & 0.10 & 0.07 & 0.90 & 0.93 & 0.88 & 0.91 \\
\hline $\mathrm{K}_{2} \mathrm{O}$ & 9.95 & 10.26 & 10.12 & 9.29 & 9.95 & 9.96 & 10.14 & 10.09 \\
\hline $\mathrm{Rb}_{2} \mathrm{O}$ & 0.63 & 0.68 & 0.60 & 0.63 & 0.65 & 0.62 & 0.71 & 0.74 \\
\hline $\mathrm{Cs}_{2} \mathrm{O}$ & 0.01 & 0.04 & 0.01 & 0.01 & 0.01 & 0.02 & 0.01 & 0.04 \\
\hline $\mathrm{F}$ & 0.03 & 0.14 & 0.08 & 0.13 & 0.05 & 0.15 & 1.20 & 1.38 \\
\hline $\mathrm{H}_{2} \mathrm{O}^{*}$ & 4.45 & 4.34 & 4.36 & 4.20 & 4.48 & 4.44 & 3.88 & 3.76 \\
\hline$-\mathrm{O}=\mathrm{F}$ & -0.01 & -0.06 & -0.03 & -0.05 & -0.02 & -0.06 & -0.51 & -0.58 \\
\hline Total & 100.20 & 99.08 & 97.63 & 94.23 & 100.15 & 100.58 & 99.94 & 99.45 \\
\hline P (apfu) & 0.002 & 0.002 & 0.000 & 0.002 & 0.001 & 0.002 & 0.001 & 0.002 \\
\hline $\mathrm{Si}$ & 3.042 & 3.046 & 3.105 & 3.146 & 3.046 & 3.033 & 3.027 & 3.025 \\
\hline $\mathrm{Ti}$ & 0.030 & 0.026 & 0.003 & 0.000 & 0.014 & 0.015 & 0.012 & 0.015 \\
\hline Al & 2.775 & 2.770 & 2.797 & 2.748 & 2.859 & 2.862 & 2.794 & 2.773 \\
\hline $\mathrm{Mg}$ & 0.014 & 0.015 & 0.035 & 0.039 & 0.011 & 0.012 & 0.011 & 0.012 \\
\hline $\mathrm{Mn}$ & 0.006 & 0.009 & 0.003 & 0.004 & 0.001 & 0.001 & 0.007 & 0.009 \\
\hline $\mathrm{Fe}$ & 0.170 & 0.161 & 0.086 & 0.095 & 0.081 & 0.086 & 0.151 & 0.159 \\
\hline $\mathrm{Zn}$ & 0.002 & 0.002 & 0.002 & 0.002 & 0.001 & 0.003 & 0.002 & 0.000 \\
\hline $\mathrm{Ca}$ & 0.000 & 0.002 & 0.002 & 0.002 & 0.000 & 0.001 & 0.000 & 0.000 \\
\hline $\mathrm{Ba}$ & 0.000 & 0.000 & 0.000 & 0.000 & 0.002 & 0.004 & 0.000 & 0.000 \\
\hline $\mathrm{Pb}$ & 0.000 & 0.001 & 0.000 & 0.000 & 0.000 & 0.000 & 0.000 & 0.000 \\
\hline Li & 0.001 & 0.006 & 0.003 & 0.005 & 0.001 & 0.006 & 0.100 & 0.121 \\
\hline $\mathrm{Na}$ & 0.111 & 0.086 & 0.013 & 0.010 & 0.116 & 0.120 & 0.115 & 0.120 \\
\hline $\mathrm{K}$ & 0.853 & 0.891 & 0.880 & 0.835 & 0.845 & 0.844 & 0.872 & 0.874 \\
\hline $\mathrm{Rb}$ & 0.027 & 0.030 & 0.026 & 0.029 & 0.028 & 0.026 & 0.031 & 0.032 \\
\hline Cs & 0.000 & 0.001 & 0.000 & 0.000 & 0.000 & 0.001 & 0.000 & 0.001 \\
\hline $\mathrm{F}$ & 0.006 & 0.030 & 0.017 & 0.029 & 0.011 & 0.032 & 0.256 & 0.296 \\
\hline $\mathrm{OH}$ & 1.994 & 1.970 & 1.983 & 1.971 & 1.989 & 1.968 & 1.744 & 1.704 \\
\hline 0 & 10.000 & 10.000 & 10.000 & 10.000 & 10.000 & 10.000 & 10.000 & 10.000 \\
\hline
\end{tabular}


Appendix D.3 (contd.): Electron microprobe analyses of biotite (Bt), muscovite (Ms), and lepidolite (Lpd).

\begin{tabular}{|c|c|c|c|c|c|c|c|c|}
\hline Mineral & $\mathrm{Bt}$ & $\mathrm{Bt}$ & $\mathrm{Bt}$ & $\mathrm{Bt}$ & $\mathrm{Bt}$ & $\mathrm{Bt}$ & $\mathrm{Bt}$ & $\mathrm{Bt}$ \\
\hline Sample & 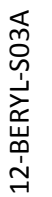 & 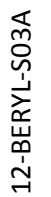 & 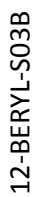 & 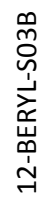 & 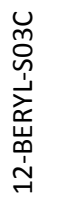 & 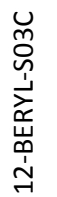 & 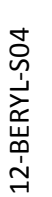 & 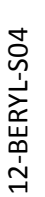 \\
\hline
\end{tabular}

Comment

\begin{tabular}{|c|c|c|c|c|c|c|c|c|}
\hline & 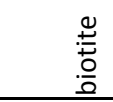 & $\begin{array}{l}\stackrel{0}{*} \\
.0 \\
0\end{array}$ & $\begin{array}{r}\stackrel{0}{*} \\
.0 \\
.0 \\
\end{array}$ & 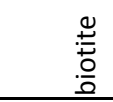 & $\begin{array}{r}\stackrel{0}{ \pm} \\
.0 \\
0\end{array}$ & $\begin{array}{l}\stackrel{ \pm}{ \pm} \\
.0 \\
0\end{array}$ & $\begin{array}{l}\stackrel{0}{ \pm} \\
.0 \\
0\end{array}$ & $\stackrel{\stackrel{ \pm}{ \pm}}{\stackrel{ \pm}{0}}$ \\
\hline Point & $182 m-1$ & $182 m-2$ & $183 \mathrm{~m}-1$ & $183 m-2$ & $184 m-1$ & $184 m-2$ & $185 \mathrm{~m}-1$ & $185 \mathrm{~m}-2$ \\
\hline $\mathrm{P}_{2} \mathrm{O}_{5}$ (wt.\%) & 0.00 & 0.02 & 0.01 & 0.01 & 0.01 & 0.00 & 0.01 & 0.03 \\
\hline $\mathrm{SiO}_{2}$ & 34.24 & 34.76 & 34.79 & 34.91 & 37.77 & 37.38 & 34.57 & 34.11 \\
\hline $\mathrm{TiO}_{2}$ & 2.53 & 2.58 & 2.60 & 2.57 & 1.68 & 1.38 & 2.48 & 2.45 \\
\hline $\mathrm{Al}_{2} \mathrm{O}_{3}$ & 19.53 & 19.46 & 19.54 & 19.62 & 20.07 & 20.33 & 20.25 & 19.77 \\
\hline $\mathrm{MgO}$ & 6.70 & 6.86 & 6.67 & 6.61 & 3.68 & 3.60 & 5.70 & 5.71 \\
\hline $\mathrm{MnO}$ & 0.43 & 0.42 & 0.45 & 0.45 & 0.83 & 0.81 & 0.48 & 0.53 \\
\hline $\mathrm{FeO}$ & 20.86 & 20.76 & 20.04 & 20.21 & 20.07 & 20.79 & 20.79 & 21.06 \\
\hline $\mathrm{ZnO}$ & 0.05 & 0.05 & 0.06 & 0.10 & 0.00 & 0.11 & 0.05 & 0.09 \\
\hline $\mathrm{CaO}$ & 0.00 & 0.00 & 0.00 & 0.00 & 0.00 & 0.02 & 0.02 & 0.02 \\
\hline $\mathrm{BaO}$ & 0.00 & 0.14 & 0.00 & 0.00 & 0.11 & 0.04 & 0.00 & 0.06 \\
\hline $\mathrm{PbO}$ & 0.00 & 0.00 & 0.00 & 0.03 & 0.00 & 0.04 & 0.01 & 0.00 \\
\hline $\mathrm{Li}_{2} \mathrm{O} * *$ & 0.25 & 0.24 & 0.25 & 0.26 & 0.54 & 0.55 & 0.32 & 0.32 \\
\hline $\mathrm{Na}_{2} \mathrm{O}$ & 0.20 & 0.21 & 0.30 & 0.29 & 0.07 & 0.07 & 0.31 & 0.32 \\
\hline $\mathrm{K}_{2} \mathrm{O}$ & 9.54 & 9.45 & 9.28 & 9.19 & 9.64 & 9.67 & 9.54 & 9.46 \\
\hline $\mathrm{Rb}_{2} \mathrm{O}$ & 0.49 & 0.53 & 0.49 & 0.49 & 0.82 & 0.76 & 0.50 & 0.48 \\
\hline $\mathrm{Cs}_{2} \mathrm{O}$ & 0.01 & 0.02 & 0.03 & 0.02 & 0.31 & 0.28 & 0.03 & 0.02 \\
\hline $\mathrm{F}$ & 1.58 & 1.88 & 2.35 & 2.50 & 1.50 & 1.28 & 0.95 & 1.00 \\
\hline $\mathrm{H}_{2} \mathrm{O}^{*}$ & 3.11 & 3.00 & 2.76 & 2.70 & 3.22 & 3.32 & 3.43 & 3.36 \\
\hline$-\mathrm{O}=\mathrm{F}$ & -0.67 & -0.79 & -0.99 & -1.05 & -0.63 & -0.54 & -0.40 & -0.42 \\
\hline Total & 98.86 & 99.59 & 98.63 & 98.90 & 99.69 & 99.89 & 99.03 & 98.37 \\
\hline P (apfu) & 0.000 & 0.001 & 0.001 & 0.001 & 0.001 & 0.000 & 0.001 & 0.002 \\
\hline $\mathrm{Si}$ & 2.660 & 2.678 & 2.694 & 2.696 & 2.881 & 2.855 & 2.674 & 2.666 \\
\hline $\mathrm{Ti}$ & 0.148 & 0.150 & 0.151 & 0.149 & 0.096 & 0.079 & 0.144 & 0.144 \\
\hline $\mathrm{Al}$ & 1.788 & 1.767 & 1.783 & 1.786 & 1.804 & 1.830 & 1.846 & 1.821 \\
\hline $\mathrm{Mg}$ & 0.776 & 0.788 & 0.770 & 0.761 & 0.418 & 0.410 & 0.657 & 0.665 \\
\hline $\mathrm{Mn}$ & 0.028 & 0.027 & 0.030 & 0.029 & 0.054 & 0.052 & 0.031 & 0.035 \\
\hline $\mathrm{Fe}$ & 1.355 & 1.338 & 1.298 & 1.305 & 1.280 & 1.328 & 1.345 & 1.377 \\
\hline $\mathrm{Zn}$ & 0.003 & 0.003 & 0.003 & 0.006 & 0.000 & 0.006 & 0.003 & 0.005 \\
\hline $\mathrm{Ca}$ & 0.000 & 0.000 & 0.000 & 0.000 & 0.000 & 0.002 & 0.002 & 0.002 \\
\hline $\mathrm{Ba}$ & 0.000 & 0.004 & 0.000 & 0.000 & 0.003 & 0.001 & 0.000 & 0.002 \\
\hline $\mathrm{Pb}$ & 0.000 & 0.000 & 0.000 & 0.001 & 0.000 & 0.001 & 0.000 & 0.000 \\
\hline $\mathrm{Li}$ & 0.079 & 0.076 & 0.079 & 0.080 & 0.166 & 0.170 & 0.098 & 0.099 \\
\hline $\mathrm{Na}$ & 0.030 & 0.031 & 0.045 & 0.043 & 0.010 & 0.010 & 0.046 & 0.048 \\
\hline $\mathrm{K}$ & 0.945 & 0.929 & 0.917 & 0.905 & 0.938 & 0.942 & 0.941 & 0.943 \\
\hline $\mathrm{Rb}$ & 0.024 & 0.026 & 0.024 & 0.024 & 0.040 & 0.037 & 0.025 & 0.024 \\
\hline Cs & 0.000 & 0.001 & 0.001 & 0.001 & 0.010 & 0.009 & 0.001 & 0.001 \\
\hline $\mathrm{F}$ & 0.388 & 0.458 & 0.575 & 0.611 & 0.362 & 0.309 & 0.232 & 0.247 \\
\hline $\mathrm{OH}$ & 1.612 & 1.542 & 1.425 & 1.389 & 1.638 & 1.691 & 1.768 & 1.753 \\
\hline 0 & 10.000 & 10.000 & 10.000 & 10.000 & 10.000 & 10.000 & 10.000 & 10.000 \\
\hline
\end{tabular}


Appendix D.3 (contd.): Electron microprobe analyses of biotite (Bt), muscovite (Ms), and lepidolite (Lpd).

\begin{tabular}{|c|c|c|c|c|c|c|c|c|}
\hline Mineral & $\mathrm{Bt}$ & $\mathrm{Bt}$ & $\mathrm{Bt}$ & $\mathrm{Bt}$ & $\mathrm{Bt}$ & $\mathrm{Bt}$ & $\mathrm{Bt}$ & $\mathrm{Bt}$ \\
\hline Sample & 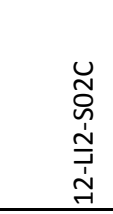 & 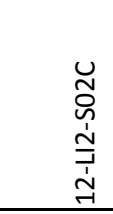 & 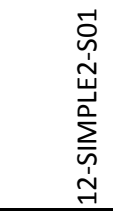 & 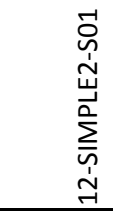 & 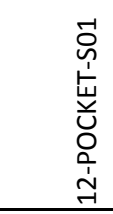 & 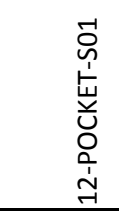 & 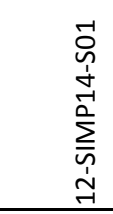 & 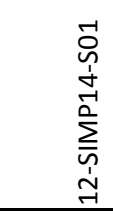 \\
\hline Comment & $\begin{array}{l}\stackrel{y}{ \pm} \\
\stackrel{0}{0} \\
.0\end{array}$ & $\begin{array}{l}\stackrel{y}{ \pm} \\
\stackrel{0}{0} \\
\stackrel{0}{a}\end{array}$ & $\begin{array}{l}\stackrel{y}{ \pm} \\
\stackrel{0}{0} \\
.0\end{array}$ & $\begin{array}{l}\stackrel{ \pm}{ \pm} \\
.0 \\
.0\end{array}$ & 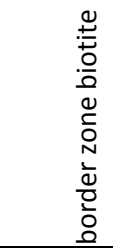 & 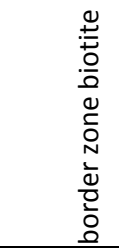 & 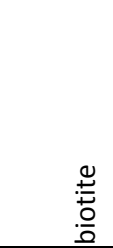 & 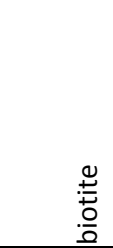 \\
\hline Point & $186 m-1$ & $186 m-2$ & $187 \mathrm{~m}-1$ & $187 \mathrm{~m}-2$ & $188 \mathrm{~m}-1$ & $188 m-2$ & $189 m-1$ & $189 m-2$ \\
\hline $\mathrm{P}_{2} \mathrm{O}_{5}$ (wt.\%) & 0.02 & 0.01 & 0.01 & 0.01 & 0.02 & 0.01 & 0.02 & 0.00 \\
\hline $\mathrm{SiO}_{2}$ & 35.49 & 35.51 & 35.27 & 35.69 & 34.36 & 34.60 & 34.57 & 34.10 \\
\hline $\mathrm{TiO}_{2}$ & 2.23 & 2.29 & 2.17 & 2.12 & 2.79 & 2.74 & 1.72 & 1.82 \\
\hline $\mathrm{Al}_{2} \mathrm{O}_{3}$ & 19.11 & 19.14 & 18.47 & 18.53 & 19.60 & 19.43 & 20.04 & 19.78 \\
\hline $\mathrm{MgO}$ & 7.15 & 7.18 & 11.03 & 10.91 & 8.02 & 7.92 & 7.13 & 7.13 \\
\hline $\mathrm{MnO}$ & 1.47 & 1.46 & 0.30 & 0.31 & 0.34 & 0.38 & 0.53 & 0.54 \\
\hline $\mathrm{FeO}$ & 18.44 & 18.68 & 16.57 & 16.67 & 19.26 & 19.25 & 21.29 & 21.11 \\
\hline $\mathrm{ZnO}$ & 0.05 & 0.07 & 0.00 & 0.04 & 0.06 & 0.05 & 0.02 & 0.07 \\
\hline $\mathrm{CaO}$ & 0.00 & 0.00 & 0.00 & 0.00 & 0.00 & 0.00 & 0.00 & 0.01 \\
\hline $\mathrm{BaO}$ & 0.00 & 0.00 & 0.05 & 0.06 & 0.13 & 0.06 & 0.02 & 0.16 \\
\hline $\mathrm{PbO}$ & 0.02 & 0.04 & 0.05 & 0.02 & 0.00 & 0.00 & 0.00 & 0.00 \\
\hline $\mathrm{Li}_{2} \mathrm{O}^{* *}$ & 0.23 & 0.23 & 0.11 & 0.11 & 0.19 & 0.20 & 0.23 & 0.23 \\
\hline $\mathrm{Na}_{2} \mathrm{O}$ & 0.17 & 0.21 & 0.17 & 0.19 & 0.16 & 0.20 & 0.19 & 0.20 \\
\hline $\mathrm{K}_{2} \mathrm{O}$ & 9.36 & 9.43 & 9.61 & 9.60 & 9.42 & 9.43 & 9.36 & 9.31 \\
\hline $\mathrm{Rb}_{2} \mathrm{O}$ & 0.56 & 0.51 & 0.51 & 0.49 & 0.45 & 0.51 & 0.43 & 0.46 \\
\hline $\mathrm{Cs}_{2} \mathrm{O}$ & 0.00 & 0.02 & 0.03 & 0.01 & 0.02 & 0.03 & 0.00 & 0.02 \\
\hline $\mathrm{F}$ & 1.52 & 1.33 & 0.85 & 0.80 & 0.24 & 0.21 & 0.35 & 0.29 \\
\hline $\mathrm{H}_{2} \mathrm{O}^{*}$ & 3.16 & 3.26 & 3.52 & 3.56 & 3.78 & 3.79 & 3.73 & 3.72 \\
\hline$-\mathrm{O}=\mathrm{F}$ & -0.64 & -0.56 & -0.36 & -0.34 & -0.10 & -0.09 & -0.15 & -0.12 \\
\hline Total & 98.34 & 98.81 & 98.35 & 98.78 & 98.74 & 98.72 & 99.48 & 98.83 \\
\hline P (apfu) & 0.001 & 0.001 & 0.001 & 0.001 & 0.001 & 0.001 & 0.001 & 0.000 \\
\hline $\mathrm{Si}$ & 2.743 & 2.735 & 2.699 & 2.716 & 2.648 & 2.666 & 2.662 & 2.650 \\
\hline $\mathrm{Ti}$ & 0.130 & 0.133 & 0.125 & 0.121 & 0.162 & 0.159 & 0.100 & 0.106 \\
\hline Al & 1.741 & 1.738 & 1.666 & 1.662 & 1.780 & 1.765 & 1.819 & 1.812 \\
\hline $\mathrm{Mg}$ & 0.824 & 0.825 & 1.258 & 1.238 & 0.921 & 0.910 & 0.818 & 0.826 \\
\hline $\mathrm{Mn}$ & 0.096 & 0.095 & 0.019 & 0.020 & 0.022 & 0.025 & 0.035 & 0.036 \\
\hline $\mathrm{Fe}$ & 1.192 & 1.203 & 1.060 & 1.061 & 1.241 & 1.240 & 1.371 & 1.372 \\
\hline $\mathrm{Zn}$ & 0.003 & 0.004 & 0.000 & 0.002 & 0.003 & 0.003 & 0.001 & 0.004 \\
\hline $\mathrm{Ca}$ & 0.000 & 0.000 & 0.000 & 0.000 & 0.000 & 0.000 & 0.000 & 0.001 \\
\hline $\mathrm{Ba}$ & 0.000 & 0.000 & 0.001 & 0.002 & 0.004 & 0.002 & 0.001 & 0.005 \\
\hline $\mathrm{Pb}$ & 0.000 & 0.001 & 0.001 & 0.000 & 0.000 & 0.000 & 0.000 & 0.000 \\
\hline $\mathrm{Li}$ & 0.071 & 0.071 & 0.033 & 0.034 & 0.060 & 0.061 & 0.072 & 0.072 \\
\hline $\mathrm{Na}$ & 0.025 & 0.031 & 0.025 & 0.028 & 0.024 & 0.030 & 0.028 & 0.030 \\
\hline K & 0.923 & 0.927 & 0.938 & 0.932 & 0.926 & 0.927 & 0.919 & 0.923 \\
\hline $\mathrm{Rb}$ & 0.028 & 0.025 & 0.025 & 0.024 & 0.022 & 0.025 & 0.021 & 0.023 \\
\hline Cs & 0.000 & 0.001 & 0.001 & 0.000 & 0.001 & 0.001 & 0.000 & 0.001 \\
\hline $\mathrm{F}$ & 0.372 & 0.324 & 0.206 & 0.193 & 0.058 & 0.051 & 0.085 & 0.071 \\
\hline $\mathrm{OH}$ & 1.628 & 1.676 & 1.794 & 1.807 & 1.942 & 1.949 & 1.915 & 1.929 \\
\hline 0 & 10.000 & 10.000 & 10.000 & 10.000 & 10.000 & 10.000 & 10.000 & 10.000 \\
\hline
\end{tabular}


Appendix D.4: Electron microprobe analyses of beryl.

\begin{tabular}{|c|c|c|c|c|c|c|c|}
\hline Sample site & 12-BERYL-S01 & & & 3ERYL-S01 & & & \\
\hline Point & B1-1 & B1-2 & B1-3 & B2-8 & B2-9 & B2-10 & B2-11 \\
\hline Description & 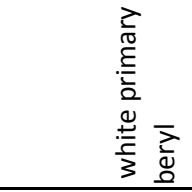 & 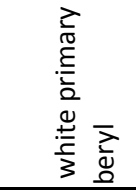 & 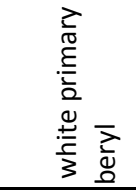 & 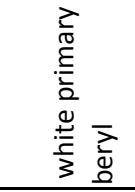 & 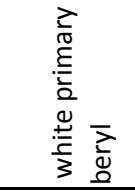 & 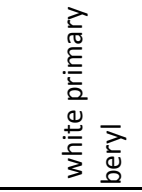 & 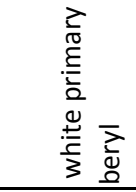 \\
\hline $\mathrm{SiO}_{2}$ & 65.18 & 64.94 & 65.46 & 63.61 & 66.43 & 64.48 & 65.32 \\
\hline $\mathrm{Al}_{2} \mathrm{O}_{3}$ & 18.68 & 18.30 & 18.55 & 18.40 & 18.65 & 18.64 & 18.70 \\
\hline $\mathrm{BeO}^{\pi}$ & 13.54 & 13.47 & 13.55 & 13.27 & 13.73 & 13.46 & 13.57 \\
\hline MgO & -- & -- & -- & -- & -- & -- & -- \\
\hline $\mathrm{MnO}$ & -- & -- & -- & 0.11 & -- & -- & -- \\
\hline $\mathrm{FeO}$ & 0.22 & 0.31 & 0.28 & 0.26 & 0.22 & 0.30 & 0.27 \\
\hline $\mathrm{Li}_{2} \mathrm{O}^{*}$ & 0.05 & 0.04 & 0.07 & 0.04 & 0.06 & 0.03 & 0.05 \\
\hline $\mathrm{Na}_{2} \mathrm{O}$ & 0.22 & 0.23 & 0.27 & 0.27 & 0.25 & 0.22 & 0.24 \\
\hline $\mathrm{K}_{2} \mathrm{O}$ & -- & -- & -- & -- & -- & -- & -- \\
\hline $\mathrm{Cs}_{2} \mathrm{O}$ & -- & -- & 0.16 & -- & -- & -- & -- \\
\hline $\mathrm{H}_{2} \mathrm{O}^{\S}$ & 1.02 & 1.03 & 1.07 & 1.07 & 1.05 & 1.02 & 1.04 \\
\hline Total & 98.91 & 98.32 & 99.41 & 97.03 & 100.39 & 98.15 & 99.19 \\
\hline $\mathrm{Si}^{4+}$ & 5.973 & 5.990 & 5.983 & 5.955 & 5.998 & 5.959 & 5.972 \\
\hline $\mathrm{Al}^{3+}$ & 2.018 & 1.989 & 1.998 & 2.030 & 1.985 & 2.030 & 2.015 \\
\hline $\mathrm{Be}^{2+}$ & 2.982 & 2.985 & 2.974 & 2.985 & 2.978 & 2.989 & 2.982 \\
\hline $\mathrm{Mg}^{2+}$ & 0.000 & 0.000 & 0.000 & 0.000 & 0.000 & 0.000 & 0.000 \\
\hline $\mathrm{Mn}^{2+}$ & 0.000 & 0.000 & 0.000 & 0.009 & 0.000 & 0.000 & 0.000 \\
\hline $\mathrm{Fe}^{2+}$ & 0.017 & 0.024 & 0.021 & 0.020 & 0.017 & 0.023 & 0.021 \\
\hline $\mathrm{Li}^{+}$ & 0.018 & 0.015 & 0.026 & 0.015 & 0.022 & 0.011 & 0.018 \\
\hline $\mathrm{Na}^{+}$ & 0.039 & 0.041 & 0.048 & 0.049 & 0.044 & 0.039 & 0.043 \\
\hline $\mathrm{K}^{+}$ & 0.000 & 0.000 & 0.000 & 0.000 & 0.000 & 0.000 & 0.000 \\
\hline $\mathrm{Cs}^{+}$ & 0.000 & 0.000 & 0.006 & 0.000 & 0.000 & 0.000 & 0.000 \\
\hline $\mathrm{H}_{2} \mathrm{O}$ & 0.185 & 0.186 & 0.192 & 0.192 & 0.189 & 0.185 & 0.188 \\
\hline Cation sum & 11.047 & 11.044 & 11.056 & 11.063 & 11.044 & 11.051 & 11.051 \\
\hline
\end{tabular}

*Determined by stoichiometery, where $\mathrm{Li}=(\mathrm{Na}+\mathrm{K}+\mathrm{Cs})-(\mathrm{Mg}+\mathrm{Fe}+\mathrm{Mn})$

"BeO calculated assuming $3\left(\mathrm{Be}^{+2}, \mathrm{Li}^{+}\right)$

${ }^{\S}$ calculated after Giuliani et al . (1997)

Normalized on a basis of 18 anions

Other elements sought but found to be below detection limits include: $\mathrm{Ca}, \mathrm{Sc}, \mathrm{Ti}, \mathrm{V}$, and $\mathrm{Cr}$. 
Appendix D.4 (contd.): Electron microprobe analyses of beryl.

\begin{tabular}{|c|c|c|c|c|c|c|c|}
\hline Sample site & 12-BERYL-S01 & & & GAR-S01 & & & \\
\hline Point & 22be-1 & 22 be- 2 & 22 be- 3 & GR2-1 & GR3-1 & GR3-2 & GR3-3 \\
\hline Description & 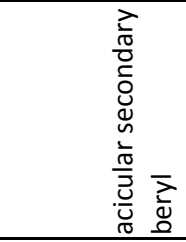 & 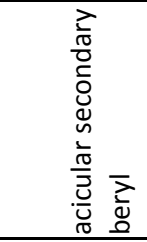 & 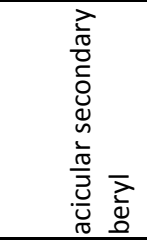 & 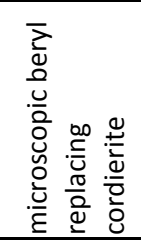 & 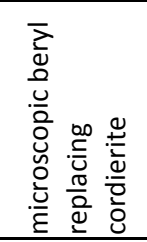 & 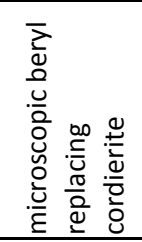 & 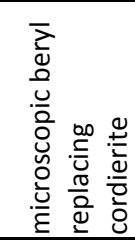 \\
\hline $\mathrm{SiO}_{2}$ & 66.36 & 66.04 & 65.86 & 65.52 & 65.85 & 66.19 & 66.60 \\
\hline $\mathrm{Al}_{2} \mathrm{O}_{3}$ & 18.52 & 18.49 & 18.60 & 18.25 & 18.06 & 18.27 & 18.00 \\
\hline $\mathrm{BeO}^{\pi}$ & 13.80 & 13.70 & 13.69 & 13.76 & 13.75 & 13.81 & 13.85 \\
\hline $\mathrm{MgO}$ & -- & -- & -- & 0.31 & 0.31 & 0.22 & 0.29 \\
\hline $\mathrm{MnO}$ & -- & -- & -- & 0.20 & -- & -- & - \\
\hline $\mathrm{FeO}$ & 0.37 & 0.34 & 0.34 & 0.98 & 0.72 & 0.65 & 0.60 \\
\hline $\mathrm{Li}_{2} \mathrm{O}^{*}$ & 0.01 & 0.03 & 0.03 & -- & -- & -- & - \\
\hline $\mathrm{Na}_{2} \mathrm{O}$ & 0.19 & 0.22 & 0.22 & 0.48 & 0.48 & 0.39 & 0.45 \\
\hline $\mathrm{K}_{2} \mathrm{O}$ & -- & -- & -- & 0.04 & 0.03 & -- & - \\
\hline $\mathrm{Cs}_{2} \mathrm{O}$ & -- & -- & -- & -- & -- & -- & - \\
\hline $\mathrm{H}_{2} \mathrm{O}^{\S}$ & 1.00 & 1.02 & 1.02 & 1.25 & 1.25 & 1.17 & 1.22 \\
\hline Total & 100.25 & 99.84 & 99.76 & 100.79 & 100.45 & 100.70 & 101.01 \\
\hline $\mathrm{Si}^{4+}$ & 5.999 & 5.996 & 5.986 & 5.948 & 5.980 & 5.984 & 6.004 \\
\hline $\mathrm{Al}^{3+}$ & 1.973 & 1.979 & 1.992 & 1.952 & 1.933 & 1.947 & 1.912 \\
\hline $\mathrm{Be}^{2+}$ & 2.996 & 2.989 & 2.989 & 3.000 & 3.000 & 3.000 & 3.000 \\
\hline $\mathrm{Mg}^{2+}$ & 0.000 & 0.000 & 0.000 & 0.042 & 0.042 & 0.030 & 0.039 \\
\hline $\mathrm{Mn}^{2+}$ & 0.000 & 0.000 & 0.000 & 0.015 & 0.000 & 0.000 & 0.000 \\
\hline $\mathrm{Fe}^{2+}$ & 0.028 & 0.026 & 0.026 & 0.074 & 0.055 & 0.049 & 0.045 \\
\hline $\mathrm{Li}^{+}$ & 0.004 & 0.011 & 0.011 & 0.000 & 0.000 & 0.000 & 0.000 \\
\hline $\mathrm{Na}^{+}$ & 0.033 & 0.039 & 0.039 & 0.084 & 0.085 & 0.068 & 0.079 \\
\hline $\mathrm{K}^{+}$ & 0.000 & 0.000 & 0.000 & 0.005 & 0.003 & 0.000 & 0.000 \\
\hline $\mathrm{Cs}^{+}$ & 0.000 & 0.000 & 0.000 & 0.000 & 0.000 & 0.000 & 0.000 \\
\hline $\mathrm{H}_{2} \mathrm{O}$ & 0.180 & 0.185 & 0.185 & 0.224 & 0.224 & 0.211 & 0.220 \\
\hline Cation sum & 11.033 & 11.039 & 11.043 & 11.120 & 11.098 & 11.078 & 11.079 \\
\hline
\end{tabular}


Appendix D.4 (contd.): Electron microprobe analyses of beryl.

\begin{tabular}{|c|c|c|c|c|c|c|c|}
\hline Sample site & 12-GAR-S01-4 & & GAR-S01-5 & & 12-GARMUS-SC & & \\
\hline Point & GR4-3 & GR4-2 & GR5-1 & GR5-2 & 26 be- 1 & 26 be- 2 & 26 be- 3 \\
\hline Description & 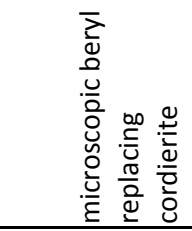 & 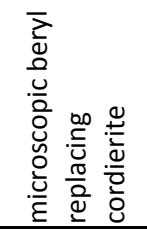 & 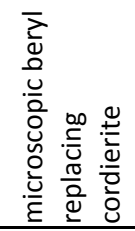 & 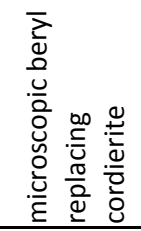 & 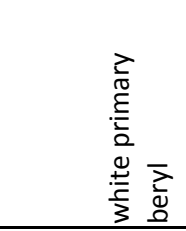 & 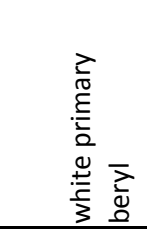 & 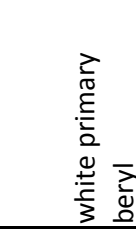 \\
\hline $\mathrm{SiO}_{2}$ & 63.65 & 65.84 & 65.47 & 65.05 & 66.25 & 65.54 & 65.80 \\
\hline $\mathrm{Al}_{2} \mathrm{O}_{3}$ & 17.93 & 17.72 & 17.73 & 17.79 & 18.06 & 17.83 & 17.91 \\
\hline $\mathrm{BeO}^{\pi}$ & 13.30 & 13.71 & 13.64 & 13.58 & $13.8^{x}$ & $13.64^{x}$ & $13.69^{*}$ \\
\hline MgO & 0.30 & 0.41 & 0.25 & 0.26 & 0.14 & 0.15 & 0.13 \\
\hline $\mathrm{MnO}$ & -- & -- & -- & -- & -- & -- & - \\
\hline $\mathrm{FeO}$ & 0.59 & 0.62 & 0.93 & 0.87 & 0.88 & 0.75 & 0.75 \\
\hline $\mathrm{Li}_{2} \mathrm{O}^{*}$ & 0.03 & -- & -- & -- & -- & -- & - \\
\hline $\mathrm{Na}_{2} \mathrm{O}$ & 0.46 & 0.57 & 0.39 & 0.47 & 0.40 & 0.40 & 0.38 \\
\hline $\mathrm{K}_{2} \mathrm{O}$ & -- & -- & -- & -- & -- & -- & - \\
\hline $\mathrm{Cs}_{2} \mathrm{O}$ & 0.07 & -- & -- & -- & 0.16 & 0.18 & 0.17 \\
\hline $\mathrm{H}_{2} \mathrm{O}^{\S}$ & 1.23 & 1.32 & 1.17 & 1.24 & 1.18 & 1.18 & 1.16 \\
\hline Total & 97.56 & 100.19 & 99.58 & 99.26 & 100.87 & 99.67 & 99.95 \\
\hline $\mathrm{Si}^{4+}$ & 5.955 & 5.997 & 5.995 & 5.982 & 5.994 & 5.999 & 6.000 \\
\hline $\mathrm{Al}^{3+}$ & 1.977 & 1.902 & 1.913 & 1.928 & 1.926 & 1.923 & 1.925 \\
\hline $\mathrm{Be}^{2+}$ & 2.989 & 3.000 & 3.000 & 3.000 & 3.000 & 3.000 & 3.000 \\
\hline $\mathrm{Mg}^{2+}$ & 0.042 & 0.056 & 0.034 & 0.036 & 0.019 & 0.020 & 0.018 \\
\hline $\mathrm{Mn}^{2+}$ & 0.000 & 0.000 & 0.000 & 0.000 & 0.000 & 0.000 & 0.000 \\
\hline $\mathrm{Fe}^{2+}$ & 0.046 & 0.047 & 0.071 & 0.067 & 0.067 & 0.057 & 0.057 \\
\hline $\mathrm{Li}^{+}$ & 0.011 & 0.000 & 0.000 & 0.000 & 0.000 & 0.001 & 0.000 \\
\hline $\mathrm{Na}^{+}$ & 0.083 & 0.101 & 0.069 & 0.084 & 0.070 & 0.071 & 0.067 \\
\hline $\mathrm{K}^{+}$ & 0.000 & 0.000 & 0.000 & 0.000 & 0.000 & 0.000 & 0.000 \\
\hline $\mathrm{Cs}^{+}$ & 0.003 & 0.000 & 0.000 & 0.000 & 0.006 & 0.007 & 0.007 \\
\hline $\mathrm{H}_{2} \mathrm{O}$ & 0.221 & 0.238 & 0.211 & 0.223 & 0.212 & 0.212 & $0.20 s$ \\
\hline Cation sum & 11.106 & 11.103 & 11.082 & 11.097 & 11.081 & 11.078 & 11.074 \\
\hline
\end{tabular}


Appendix D.4 (contd.): Electron microprobe analyses of beryl.

\begin{tabular}{|c|c|c|c|c|c|c|c|}
\hline Sample site & 12-GARMUS-S01 & & & 12-GARPHOS-S & & $12-\mathrm{LI} 2-\mathrm{S} 02 \mathrm{C}$ & \\
\hline Point & GM1-8 & GM1-9 & GM1-10 & 244be-1 & 244be-2 & 245be-1 & $245 b e-2$ \\
\hline Description & 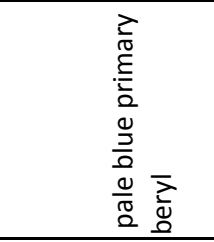 & 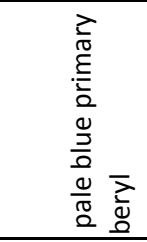 & 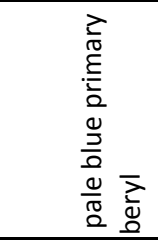 & 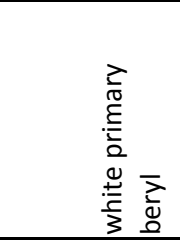 & 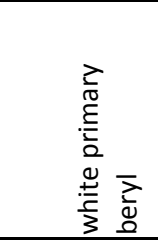 & 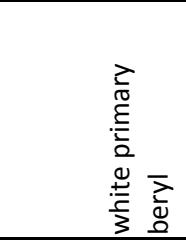 & 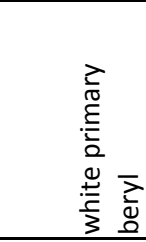 \\
\hline $\mathrm{SiO}_{2}$ & 65.68 & 64.72 & 65.45 & 66.03 & 66.48 & 65.92 & 65.70 \\
\hline $\mathrm{Al}_{2} \mathrm{O}_{3}$ & 17.95 & 18.33 & 18.35 & 18.66 & 18.46 & 17.91 & 18.04 \\
\hline $\mathrm{BeO}^{\pi}$ & 13.68 & 13.51 & 13.62 & 13.71 & 13.83 & $13.72^{x}$ & $13.7^{x}$ \\
\hline $\mathrm{MgO}$ & 0.12 & 0.06 & 0.06 & -- & 0.01 & 0.16 & 0.15 \\
\hline $\mathrm{MnO}$ & -- & -- & -- & -- & -- & -- & - \\
\hline $\mathrm{FeO}$ & 0.76 & 0.53 & 0.57 & 0.30 & 0.39 & 0.78 & 0.78 \\
\hline $\mathrm{Li}_{2} \mathrm{O}^{*}$ & -- & 0.02 & 0.03 & 0.04 & -- & -- & - \\
\hline $\mathrm{Na}_{2} \mathrm{O}$ & 0.36 & 0.30 & 0.35 & 0.21 & 0.17 & 0.38 & 0.36 \\
\hline $\mathrm{K}_{2} \mathrm{O}$ & 0.02 & -- & -- & -- & -- & -- & - \\
\hline $\mathrm{Cs}_{2} \mathrm{O}$ & 0.23 & 0.15 & 0.13 & 0.11 & -- & -- & - \\
\hline $\mathrm{H}_{2} \mathrm{O}^{\S}$ & 1.14 & 1.09 & 1.13 & 1.02 & 0.98 & 1.16 & 1.14 \\
\hline Total & 99.94 & 98.71 & 99.69 & 100.08 & 100.32 & 100.03 & 99.87 \\
\hline $\mathrm{Si}^{4+}$ & 5.996 & 5.968 & 5.979 & 5.987 & 6.004 & 6.001 & 5.990 \\
\hline $\mathrm{Al}^{3+}$ & 1.931 & 1.992 & 1.975 & 1.994 & 1.965 & 1.922 & 1.939 \\
\hline $\mathrm{Be}^{2+}$ & 3.000 & 2.993 & 2.989 & 2.985 & 3.000 & 3.000 & 3.000 \\
\hline $\mathrm{Mg}^{2+}$ & 0.016 & 0.008 & 0.008 & 0.000 & 0.001 & 0.022 & 0.020 \\
\hline $\mathrm{Mn}^{2+}$ & 0.000 & 0.000 & 0.000 & 0.000 & 0.000 & 0.000 & 0.000 \\
\hline $\mathrm{Fe}^{2+}$ & 0.058 & 0.041 & 0.044 & 0.023 & 0.029 & 0.059 & 0.059 \\
\hline $\mathrm{Li}^{+}$ & 0.000 & 0.007 & 0.011 & 0.015 & 0.000 & 0.000 & 0.000 \\
\hline $\mathrm{Na}^{+}$ & 0.064 & 0.054 & 0.062 & 0.037 & 0.030 & 0.067 & 0.064 \\
\hline $\mathrm{K}^{+}$ & 0.002 & 0.000 & 0.000 & 0.000 & 0.000 & 0.000 & 0.000 \\
\hline $\mathrm{Cs}^{+}$ & 0.009 & 0.006 & 0.005 & 0.004 & 0.000 & 0.000 & 0.000 \\
\hline $\mathrm{H}_{2} \mathrm{O}$ & 0.206 & 0.197 & 0.204 & 0.183 & 0.177 & 0.209 & 0.206 \\
\hline Cation sum & 11.076 & 11.069 & 11.070 & 11.045 & 11.029 & 11.071 & 11.072 \\
\hline
\end{tabular}


Appendix D.4 (contd.): Electron microprobe analyses of beryl.

\begin{tabular}{|c|c|c|c|c|c|c|c|}
\hline Sample site & 12-SIMPLE9-S05 & & & -SIMPLE9-SO & west" & & \\
\hline Point & 24be-1 & 24be-2 & 24 be-3 & 25be-1 & 25be-2 & 25 be-3 & 246be-1 \\
\hline Description & 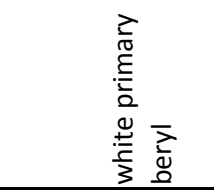 & 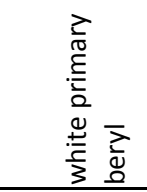 & 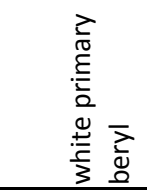 & 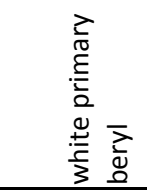 & 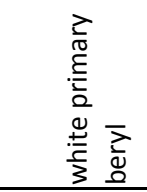 & 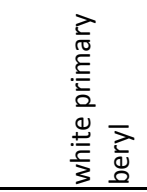 & 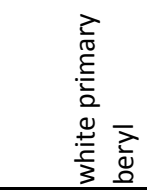 \\
\hline $\mathrm{SiO}_{2}$ & 66.23 & 65.95 & 65.70 & 65.76 & 66.33 & 66.10 & 66.32 \\
\hline $\mathrm{Al}_{2} \mathrm{O}_{3}$ & 18.37 & 18.14 & 18.26 & 18.37 & 18.32 & 18.56 & 17.94 \\
\hline $\mathrm{BeO}^{\pi}$ & $13.77^{*}$ & $13.72^{x}$ & $13.69^{x}$ & $13.7^{x}$ & $13.78^{*}$ & $13.79^{x}$ & $13.76^{*}$ \\
\hline $\mathrm{MgO}$ & 0.02 & 0.07 & 0.04 & 0.02 & 0.02 & 0.03 & 0.05 \\
\hline $\mathrm{MnO}$ & -- & -- & -- & -- & -- & -- & -- \\
\hline $\mathrm{FeO}$ & 0.41 & 0.58 & 0.66 & 0.50 & 0.38 & 0.44 & 0.70 \\
\hline $\mathrm{Li}_{2} \mathrm{O}^{*}$ & -- & -- & -- & -- & -- & -- & -- \\
\hline $\mathrm{Na}_{2} \mathrm{O}$ & 0.14 & 0.23 & 0.19 & 0.15 & 0.14 & 0.18 & 0.23 \\
\hline $\mathrm{K}_{2} \mathrm{O}$ & -- & -- & -- & -- & -- & -- & -- \\
\hline $\mathrm{Cs}_{2} \mathrm{O}$ & 0.03 & 0.05 & 0.00 & 0.04 & 0.00 & 0.06 & -- \\
\hline $\mathrm{H}_{2} \mathrm{O}^{\S}$ & 0.96 & 1.03 & 1.00 & 0.96 & 0.96 & 0.99 & 1.03 \\
\hline Total & 99.93 & 99.77 & 99.54 & 99.50 & 99.93 & 100.15 & 100.03 \\
\hline $\mathrm{Si}^{4+}$ & 6.005 & 6.003 & 5.992 & 5.993 & 6.011 & 5.987 & 6.020 \\
\hline $\mathrm{Al}^{3+}$ & 1.963 & 1.946 & 1.963 & 1.973 & 1.957 & 1.981 & 1.919 \\
\hline $\mathrm{Be}^{2+}$ & 3.000 & 3.000 & 3.000 & 3.000 & 3.000 & 3.000 & 3.000 \\
\hline $\mathrm{Mg}^{2+}$ & 0.003 & 0.009 & 0.005 & 0.003 & 0.003 & 0.004 & 0.007 \\
\hline $\mathrm{Mn}^{2+}$ & 0.000 & 0.000 & 0.000 & 0.000 & 0.000 & 0.000 & 0.000 \\
\hline $\mathrm{Fe}^{2+}$ & 0.031 & 0.044 & 0.050 & 0.038 & 0.029 & 0.033 & 0.053 \\
\hline $\mathrm{Li}^{+}$ & 0.000 & 0.000 & 0.000 & 0.000 & 0.000 & 0.000 & 0.000 \\
\hline $\mathrm{Na}^{+}$ & 0.025 & 0.041 & 0.034 & 0.027 & 0.025 & 0.032 & 0.040 \\
\hline $\mathrm{K}^{+}$ & 0.000 & 0.000 & 0.000 & 0.000 & 0.000 & 0.000 & 0.000 \\
\hline $\mathrm{Cs}^{+}$ & 0.001 & 0.002 & 0.000 & 0.002 & 0.000 & 0.002 & 0.000 \\
\hline $\mathrm{H}_{2} \mathrm{O}$ & 0.172 & 0.186 & 0.180 & 0.174 & 0.172 & 0.178 & 0.186 \\
\hline Cation sum & 11.027 & 11.045 & 11.044 & 11.035 & 11.023 & 11.039 & 11.040 \\
\hline
\end{tabular}


Appendix D.4 (contd.): Electron microprobe analyses of beryl.

\begin{tabular}{|c|c|c|c|c|c|}
\hline \multicolumn{3}{|l|}{ Sample site } & \multicolumn{3}{|c|}{ 12-TOURMUS-S01 } \\
\hline Point & 246be-2 & 247be-1 & 247be-2 & 248be-1 & 248be-2 \\
\hline Description & 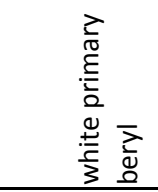 & 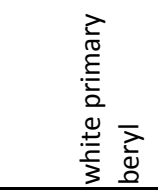 & 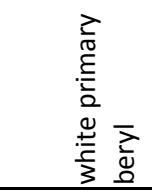 & 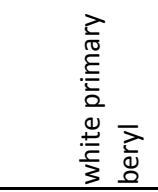 & 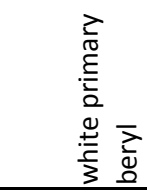 \\
\hline $\mathrm{SiO}_{2}$ & 66.03 & 66.39 & 66.58 & 65.68 & 65.97 \\
\hline $\mathrm{Al}_{2} \mathrm{O}_{3}$ & 18.25 & 18.30 & 18.34 & 18.27 & 18.42 \\
\hline $\mathrm{BeO}^{\pi}$ & $13.76^{\star}$ & $13.8^{*}$ & $13.84^{\star}$ & 12.94 & 13.01 \\
\hline $\mathrm{MgO}$ & 0.04 & 0.03 & 0.02 & -- & -- \\
\hline $\mathrm{MnO}$ & -- & -- & -- & -- & - \\
\hline $\mathrm{FeO}$ & 0.75 & 0.49 & 0.49 & 0.40 & 0.40 \\
\hline $\mathrm{Li}_{2} \mathrm{O}^{*}$ & -- & -- & -- & 0.40 & 0.40 \\
\hline $\mathrm{Na}_{2} \mathrm{O}$ & 0.27 & 0.16 & 0.20 & 0.25 & 0.25 \\
\hline $\mathrm{K}_{2} \mathrm{O}$ & -- & -- & -- & -- & -- \\
\hline $\mathrm{Cs}_{2} \mathrm{O}$ & -- & -- & -- & 0.10 & 0.10 \\
\hline $\mathrm{H}_{2} \mathrm{O}^{\S}$ & 1.07 & 0.97 & 1.01 & 1.05 & 1.05 \\
\hline Total & 100.17 & 100.14 & 100.48 & 99.09 & 99.60 \\
\hline $\mathrm{Si}^{4+}$ & 5.993 & 6.008 & 6.008 & 6.027 & 6.023 \\
\hline $\mathrm{Al}^{3+}$ & 1.952 & 1.952 & 1.951 & 1.976 & 1.982 \\
\hline $\mathrm{Be}^{2+}$ & 3.000 & 3.000 & 3.000 & 2.852 & 2.853 \\
\hline $\mathrm{Mg}^{2+}$ & 0.005 & 0.004 & 0.003 & 0.000 & 0.000 \\
\hline $\mathrm{Mn}^{2+}$ & 0.000 & 0.000 & 0.000 & 0.000 & 0.000 \\
\hline $\mathrm{Fe}^{2+}$ & 0.057 & 0.037 & 0.037 & 0.031 & 0.031 \\
\hline $\mathrm{Li}^{+}$ & 0.000 & 0.000 & 0.000 & 0.148 & 0.147 \\
\hline $\mathrm{Na}^{+}$ & 0.048 & 0.028 & 0.035 & 0.044 & 0.044 \\
\hline $\mathrm{K}^{+}$ & 0.000 & 0.000 & 0.000 & 0.000 & 0.000 \\
\hline $\mathrm{Cs}^{+}$ & 0.000 & 0.000 & 0.000 & 0.004 & 0.004 \\
\hline $\mathrm{H}_{2} \mathrm{O}$ & 0.192 & 0.175 & 0.181 & 0.189 & 0.189 \\
\hline Cation sum & 11.055 & 11.030 & 11.034 & 11.043 & 11.044 \\
\hline
\end{tabular}


Appendix D.5: Electron microprobe analyses of bertrandite

\begin{tabular}{lrr}
\hline Locality & 12-SIMPLE9-S05 \\
\hline Point & $24-1-4$ & $24-1-5$ \\
\hline $\mathrm{SiO}_{2}$ & 49.34 & 49.68 \\
$\mathrm{AL}_{2} \mathrm{O}_{3}$ & 0.08 & 0.38 \\
$\mathrm{CaO}$ & 0.26 & 0.69 \\
$\mathrm{BeO}{ }^{*}$ & 41.25 & 41.95 \\
$\mathrm{H}_{2} \mathrm{O}^{*}$ & 7.43 & 7.55 \\
$\mathrm{TOTAL}^{*}$ & 98.36 & 100.25 \\
$\mathrm{Si}^{4+}$ & & \\
$\mathrm{Al}^{3+}$ & 1.992 & 1.972 \\
$\mathrm{Ca}^{2+}$ & 0.004 & 0.018 \\
$\mathrm{Be}^{2+}$ & 0.011 & 0.029 \\
$\mathrm{OH}^{-}$ & 4 & 4 \\
$\mathrm{O}^{2+}$ & 2 & 2 \\
\hline
\end{tabular}

* Determined by stoichiometry

-Formula contents on a basis of 9 anions 
Appendix D.6: Electron microprobe analyses of chrysoberyl.

\begin{tabular}{lrrrr}
\hline Locality & \multicolumn{2}{l}{ 12-GARMUS-S01 } & & \\
Point & GM1-2 & GM1-3 & GM1-4 & \multicolumn{2}{c}{ GM1-5 } \\
\hline $\mathrm{TiO}_{2}$ & 0.04 & 0.26 & 0.00 & 0.08 \\
$\mathrm{Al}_{2} \mathrm{O}_{3}$ & 78.66 & 78.06 & 79.38 & 77.90 \\
$\mathrm{FeO}$ & 1.57 & 1.41 & 1.12 & 1.92 \\
$\mathrm{BeO}{ }^{*}$ & 19.49 & 19.37 & 19.60 & 19.35 \\
$\mathrm{Total}$ & 99.76 & 99.1 & 100.1 & 99.25 \\
& & & & \\
$\mathrm{Ti}^{4+}$ & 0.001 & 0.004 & 0.000 & 0.001 \\
$\mathrm{Al}^{3+}$ & 1.980 & 1.977 & 1.987 & 1.975 \\
$\mathrm{Fe}^{2+}$ & 0.028 & 0.025 & 0.020 & 0.035 \\
$\mathrm{Be}^{2+}$ & 1 & 1 & 1 & 1 \\
$\mathrm{O}$ & 4 & 4 & 4 & 4 \\
\hline
\end{tabular}

* Determined by stoichiometry

-Formula contents on a basis of 4 anions 
Appendix D.7: Electron microprobe analyses of columbite-group minerals ( $\mathrm{Clb})$, rutile (Rt), cassiterite (cst), hübnerite (Hub), and qitianlingite (Qit)

\begin{tabular}{|c|c|c|c|c|c|c|c|c|c|}
\hline Mineral & $\mathrm{Clb}$ & $\mathrm{Clb}$ & $\mathrm{Clb}$ & $\mathrm{Clb}$ & $\mathrm{Clb}$ & $\mathrm{Clb}$ & $\mathrm{Clb}$ & $\mathrm{Clb}$ & $\mathrm{Clb}$ \\
\hline Site & 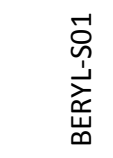 & 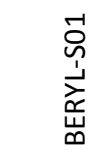 & 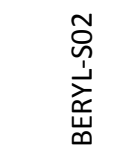 & 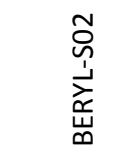 & 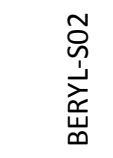 & 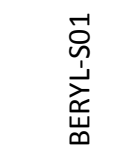 & 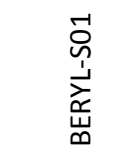 & 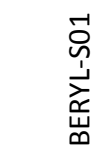 & 官 \\
\hline Point & $222 c-1$ & $222 c-2$ & $224 c-1$ & $224 c-2$ & $225 c-2$ & $219 c-1$ & $219 c-2$ & $221 c-1$ & $221 c-2$ \\
\hline $\mathrm{WO}_{3}$ & 15.64 & 13.69 & 17.53 & 7.65 & 12.43 & 2.58 & 1.73 & 8.05 & 7.20 \\
\hline $\mathrm{Nb}_{2} \mathrm{O}_{5}$ & 39.04 & 39.77 & 53.54 & 60.83 & 55.54 & 51.71 & 55.37 & 42.98 & 43.83 \\
\hline $\mathrm{Ta}_{2} \mathrm{O}_{5}$ & 22.82 & 23.64 & 6.39 & 9.78 & 6.75 & 20.09 & 22.63 & 26.57 & 27.57 \\
\hline $\mathrm{TiO}_{2}$ & 1.08 & 1.23 & 1.13 & 1.16 & 1.13 & 1.63 & 1.40 & 1.59 & 1.43 \\
\hline $\mathrm{ZrO}_{2}$ & 0.35 & 0.33 & 0.23 & 0.15 & 0.33 & 0.94 & 0.15 & 0.44 & 0.37 \\
\hline $\mathrm{SnO}_{2}$ & 1.16 & 0.91 & 0.29 & 0.28 & 0.59 & 0.10 & 0.08 & 0.98 & 0.73 \\
\hline $\mathrm{UO}_{2}$ & 0.03 & 0.01 & 0.00 & 0.00 & 0.02 & 0.07 & 0.07 & 0.11 & 0.00 \\
\hline $\mathrm{Al}_{2} \mathrm{O}_{3}$ & 0.03 & 0.06 & 0.00 & 0.02 & 0.03 & 0.02 & 0.01 & 0.01 & 0.00 \\
\hline $\mathrm{Sc}_{2} \mathrm{O}_{3}$ & 0.00 & 0.00 & 0.35 & 0.23 & 0.34 & 0.00 & 0.02 & 0.01 & 0.00 \\
\hline $\mathrm{Bi}_{2} \mathrm{O}_{3}$ & 0.00 & 0.00 & 0.00 & 0.00 & 0.00 & 0.00 & 0.00 & 0.00 & 0.00 \\
\hline $\mathrm{MgO}$ & 0.02 & 0.02 & 0.01 & 0.01 & 0.01 & 0.01 & 0.01 & 0.07 & 0.07 \\
\hline $\mathrm{CaO}$ & 0.00 & 0.00 & 0.00 & 0.00 & 0.02 & 0.02 & 0.00 & 0.01 & 0.03 \\
\hline $\mathrm{Fe}_{2} \mathrm{O}_{3} *$ & 1.43 & 0.93 & 0.94 & 0.20 & 2.05 & 2.63 & 1.29 & 0.97 & 0.88 \\
\hline $\mathrm{FeO}^{*}$ & 9.27 & 9.32 & 9.60 & 9.72 & 9.03 & 9.84 & 8.63 & 8.64 & 8.10 \\
\hline $\mathrm{Mn}_{2} \mathrm{O}_{3}{ }^{*}$ & 0.00 & 0.00 & 0.00 & 0.00 & 0.00 & 0.00 & 0.00 & 0.00 & 0.00 \\
\hline MnO* & 9.02 & 8.91 & 10.58 & 10.31 & 9.64 & 6.87 & 9.81 & 9.09 & 9.77 \\
\hline Total & 99.75 & 98.72 & 100.50 & 100.32 & 97.71 & 96.25 & 101.07 & 99.42 & 99.90 \\
\hline W & 0.265 & 0.234 & 0.275 & 0.118 & 0.197 & 0.042 & 0.027 & 0.135 & 0.120 \\
\hline $\mathrm{Nb}$ & 1.154 & 1.184 & 1.464 & 1.635 & 1.536 & 1.481 & 1.522 & 1.257 & 1.276 \\
\hline Ta & 0.406 & 0.423 & 0.105 & 0.158 & 0.112 & 0.346 & 0.374 & 0.468 & 0.483 \\
\hline $\mathrm{Ti}$ & 0.053 & 0.061 & 0.051 & 0.052 & 0.052 & 0.078 & 0.064 & 0.077 & 0.069 \\
\hline $\mathrm{Zr}$ & 0.011 & 0.011 & 0.007 & 0.004 & 0.010 & 0.029 & 0.004 & 0.014 & 0.012 \\
\hline Sn & 0.030 & 0.024 & 0.007 & 0.007 & 0.014 & 0.003 & 0.002 & 0.025 & 0.019 \\
\hline $\mathrm{U}^{4+}$ & 0.000 & 0.000 & 0.000 & 0.000 & 0.000 & 0.001 & 0.001 & 0.002 & 0.000 \\
\hline Al & 0.002 & 0.005 & 0.000 & 0.001 & 0.002 & 0.001 & 0.001 & 0.001 & 0.000 \\
\hline Sc & 0.000 & 0.000 & 0.018 & 0.012 & 0.018 & 0.000 & 0.001 & 0.001 & 0.000 \\
\hline $\mathrm{Bi}$ & 0.000 & 0.000 & 0.000 & 0.000 & 0.000 & 0.000 & 0.000 & 0.000 & 0.000 \\
\hline $\mathrm{Mg}$ & 0.002 & 0.002 & 0.001 & 0.001 & 0.001 & 0.001 & 0.001 & 0.007 & 0.007 \\
\hline $\mathrm{Ca}$ & 0.000 & 0.000 & 0.000 & 0.000 & 0.001 & 0.001 & 0.000 & 0.001 & 0.002 \\
\hline $\mathrm{Fe}^{3+}$ & 0.070 & 0.046 & 0.043 & 0.009 & 0.095 & 0.125 & 0.059 & 0.047 & 0.043 \\
\hline $\mathrm{Fe}^{2+}$ & 0.507 & 0.513 & 0.486 & 0.483 & 0.462 & 0.522 & 0.439 & 0.468 & 0.437 \\
\hline $\mathrm{Mn}^{3+}$ & 0.000 & 0.000 & 0.000 & 0.000 & 0.000 & 0.000 & 0.000 & 0.000 & 0.000 \\
\hline $\mathrm{Mn}^{2+}$ & 0.499 & 0.497 & 0.542 & 0.519 & 0.499 & 0.369 & 0.505 & 0.498 & 0.533 \\
\hline O & 6 & 6 & 6 & 6 & 6 & 6 & 6 & 6 & 6 \\
\hline Sum $R^{4,5,6+}$ & 1.919 & 1.937 & 1.910 & 1.974 & 1.922 & 1.980 & 1.994 & 1.978 & 1.979 \\
\hline Sum $R^{1,2,3+}$ & 1.081 & 1.063 & 1.090 & 1.026 & 1.078 & 1.020 & 1.006 & 1.022 & 1.021 \\
\hline $\mathrm{Mn} /(\mathrm{Fe}+\mathrm{Mn})$ & 0.464 & 0.471 & 0.506 & 0.513 & 0.473 & 0.363 & 0.504 & 0.492 & 0.526 \\
\hline $\mathrm{Ta} /(\mathrm{Nb}+\mathrm{Ta})$ & 0.260 & 0.263 & 0.067 & 0.088 & 0.068 & 0.189 & 0.197 & 0.271 & 0.275 \\
\hline
\end{tabular}

*Note: data were recalculated on the basis of fully occupied cation and anion

sites and electroneutral formula. 
Appendix D.7 (contd.): Electron microprobe analyses of columbite-group minerals (Clb), rutile (Rt), cassiterite (cst), hübnerite (Hub), and qitianlingite (Qit)

\begin{tabular}{|c|c|c|c|c|c|c|c|c|c|}
\hline Mineral & $\mathrm{Clb}$ & $\mathrm{Clb}$ & $\mathrm{Clb}$ & $\mathrm{Clb}$ & $\mathrm{Clb}$ & $\mathrm{Clb}$ & $\mathrm{Clb}$ & $\mathrm{Clb}$ & $\mathrm{Clb}$ \\
\hline Site & 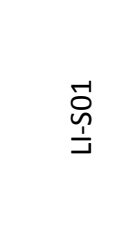 & $\begin{array}{l}\text { ó } \\
\stackrel{\leftrightarrow}{ \pm}\end{array}$ & $\begin{array}{l}\text { 오 } \\
\stackrel{\leftrightarrow}{ \pm}\end{array}$ & 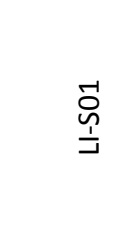 & 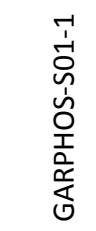 & 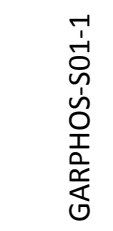 & 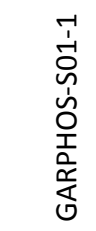 & 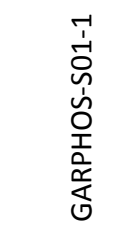 & 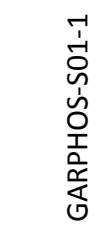 \\
\hline Point & $231 c-1$ & $231 c-2$ & 231ta-1 & 231ta-2 & GPc-1 & GPc-2 & GPc-3 & GPc-4 & GPc-5 \\
\hline $\mathrm{WO}_{3}$ & 2.81 & 2.57 & 1.13 & 1.52 & 7.24 & 7.14 & 3.73 & 7.89 & 15.99 \\
\hline $\mathrm{Nb}_{2} \mathrm{O}_{5}$ & 46.70 & 46.15 & 15.31 & 15.69 & 58.34 & 57.52 & 57.14 & 59.07 & 51.65 \\
\hline $\mathrm{Ta}_{2} \mathrm{O}_{5}$ & 29.71 & 30.54 & 64.66 & 64.32 & 9.66 & 12.36 & 15.36 & 9.60 & 8.51 \\
\hline $\mathrm{TiO}_{2}$ & 2.02 & 1.86 & 2.11 & 2.15 & 3.50 & 3.13 & 2.80 & 3.72 & 2.52 \\
\hline $\mathrm{ZrO}_{2}$ & 0.32 & 0.31 & 0.40 & 0.50 & 0.58 & 0.58 & 0.29 & 0.46 & 0.47 \\
\hline $\mathrm{SnO}_{2}$ & 0.00 & 0.00 & 0.02 & 0.02 & 0.23 & 0.30 & 0.26 & 0.28 & 0.31 \\
\hline $\mathrm{UO}_{2}$ & 0.39 & 0.29 & 0.50 & 0.48 & 0.33 & 0.22 & 0.29 & 0.41 & 0.33 \\
\hline $\mathrm{Al}_{2} \mathrm{O}_{3}$ & 0.01 & 0.04 & 0.02 & 0.02 & 0.00 & 0.15 & 0.02 & 0.02 & 0.61 \\
\hline $\mathrm{Sc}_{2} \mathrm{O}_{3}$ & 0.03 & 0.00 & 0.00 & 0.00 & 0.03 & 0.46 & 0.37 & 0.04 & 0.16 \\
\hline $\mathrm{Bi}_{2} \mathrm{O}_{3}$ & 0.00 & 0.00 & 0.00 & 0.05 & 0.00 & 0.00 & 0.00 & 0.00 & 0.10 \\
\hline $\mathrm{MgO}$ & 0.09 & 0.09 & 0.09 & 0.08 & 0.00 & 0.01 & 0.00 & 0.01 & 0.02 \\
\hline $\mathrm{CaO}$ & 0.01 & 0.01 & 0.01 & 0.01 & 0.02 & 0.00 & 0.00 & 0.00 & 0.02 \\
\hline $\mathrm{Fe}_{2} \mathrm{O}_{3} *$ & 0.80 & 1.45 & 1.29 & 1.39 & 1.46 & 1.42 & 1.39 & 1.20 & 1.76 \\
\hline $\mathrm{FeO} *$ & 5.45 & 4.99 & 4.23 & 4.15 & 3.05 & 1.86 & 0.55 & 3.56 & 0.75 \\
\hline $\mathrm{Mn}_{2} \mathrm{O}_{3}{ }^{*}$ & 0.00 & 0.00 & 0.00 & 0.00 & 0.00 & 0.00 & 0.00 & 0.00 & 0.00 \\
\hline $\mathrm{MnO}^{*}$ & 12.16 & 12.24 & 9.87 & 10.09 & 15.63 & 16.69 & 17.49 & 15.62 & 17.94 \\
\hline Total & 100.42 & 100.39 & 99.52 & 100.33 & 99.93 & 101.70 & 99.55 & 101.76 & 100.96 \\
\hline W & 0.046 & 0.042 & 0.022 & 0.029 & 0.111 & 0.108 & 0.058 & 0.118 & 0.248 \\
\hline $\mathrm{Nb}$ & 1.338 & 1.324 & 0.522 & 0.530 & 1.555 & 1.518 & 1.548 & 1.548 & 1.395 \\
\hline Тa & 0.512 & 0.527 & 1.327 & 1.306 & 0.155 & 0.196 & 0.250 & 0.151 & 0.138 \\
\hline $\mathrm{Ti}$ & 0.096 & 0.089 & 0.120 & 0.121 & 0.155 & 0.137 & 0.126 & 0.162 & 0.113 \\
\hline $\mathrm{Zr}$ & 0.010 & 0.010 & 0.015 & 0.018 & 0.017 & 0.017 & 0.008 & 0.013 & 0.014 \\
\hline Sn & 0.000 & 0.000 & 0.001 & 0.001 & 0.005 & 0.007 & 0.006 & 0.006 & 0.007 \\
\hline $\mathrm{U}^{4+}$ & 0.006 & 0.004 & 0.008 & 0.008 & 0.004 & 0.003 & 0.004 & 0.005 & 0.004 \\
\hline $\mathrm{Al}$ & 0.001 & 0.003 & 0.002 & 0.002 & 0.000 & 0.010 & 0.001 & 0.001 & 0.043 \\
\hline Sc & 0.002 & 0.000 & 0.000 & 0.000 & 0.002 & 0.023 & 0.019 & 0.002 & 0.008 \\
\hline $\mathrm{Bi}$ & 0.000 & 0.000 & 0.000 & 0.001 & 0.000 & 0.000 & 0.000 & 0.000 & 0.002 \\
\hline $\mathrm{Mg}$ & 0.009 & 0.009 & 0.010 & 0.009 & 0.000 & 0.001 & 0.000 & 0.001 & 0.002 \\
\hline $\mathrm{Ca}$ & 0.001 & 0.001 & 0.001 & 0.001 & 0.001 & 0.000 & 0.000 & 0.000 & 0.001 \\
\hline $\mathrm{Fe}^{3+}$ & 0.038 & 0.069 & 0.074 & 0.078 & 0.065 & 0.062 & 0.062 & 0.052 & 0.079 \\
\hline $\mathrm{Fe}^{2+}$ & 0.289 & 0.265 & 0.267 & 0.259 & 0.150 & 0.091 & 0.028 & 0.172 & 0.037 \\
\hline $\mathrm{Mn}^{3+}$ & 0.000 & 0.000 & 0.000 & 0.000 & 0.000 & 0.000 & 0.000 & 0.000 & 0.000 \\
\hline $\mathrm{Mn}^{2+}$ & 0.653 & 0.658 & 0.631 & 0.638 & 0.780 & 0.825 & 0.888 & 0.767 & 0.908 \\
\hline $\mathrm{O}$ & 6 & 6 & 6 & 6 & 6 & 6 & 6 & 6 & 6 \\
\hline Sum $R^{4,5,6+}$ & 2.008 & 1.996 & 2.015 & 2.012 & 2.002 & 1.987 & 2.001 & 2.004 & 1.920 \\
\hline Sum $R^{1,2,3+}$ & 0.992 & 1.004 & 0.985 & 0.988 & 0.998 & 1.013 & 0.999 & 0.996 & 1.080 \\
\hline $\mathrm{Mn} /(\mathrm{Fe}+\mathrm{Mn})$ & 0.666 & 0.663 & 0.649 & 0.654 & 0.784 & 0.843 & 0.908 & 0.773 & 0.886 \\
\hline $\mathrm{Ta} /(\mathrm{Nb}+\mathrm{Ta})$ & 0.277 & 0.285 & 0.718 & 0.711 & 0.091 & 0.114 & 0.139 & 0.089 & 0.090 \\
\hline
\end{tabular}


Appendix D.7 (contd.): Electron microprobe analyses of columbite-group minerals (Clb), rutile (Rt), cassiterite (cst), hübnerite (Hub), and qitianlingite (Qit)

\begin{tabular}{|c|c|c|c|c|c|c|c|c|c|}
\hline Mineral & $\mathrm{Clb}$ & $\mathrm{Clb}$ & $\mathrm{Clb}$ & $\mathrm{Clb}$ & $\mathrm{Clb}$ & $\mathrm{Clb}$ & $\mathrm{Clb}$ & $\mathrm{Clb}$ & $\mathrm{Clb}$ \\
\hline Site & 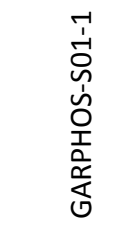 & 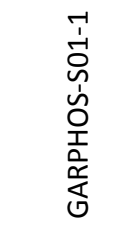 & 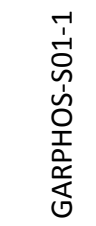 & 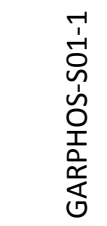 & 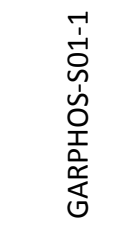 & 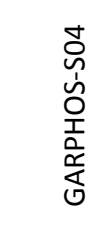 & 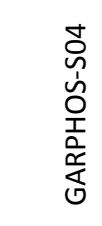 & 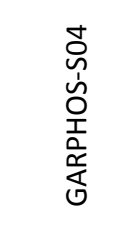 & 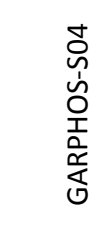 \\
\hline Point & GPc-6 & GPc-7 & GPc-8 & GPC-9 & GPc-10 & $198 c-1$ & $198 c-2$ & $198 c-3$ & $198 c-4$ \\
\hline $\mathrm{WO}_{3}$ & 2.68 & 4.62 & 2.46 & 2.85 & 3.04 & 17.01 & 9.98 & 14.47 & 11.10 \\
\hline $\mathrm{Nb}_{2} \mathrm{O}_{5}$ & 47.39 & 54.16 & 37.37 & 47.50 & 36.96 & 47.24 & 52.01 & 48.72 & 50.98 \\
\hline $\mathrm{Ta}_{2} \mathrm{O}_{5}$ & 26.05 & 15.11 & 40.02 & 26.29 & 37.31 & 13.17 & 16.43 & 14.28 & 16.12 \\
\hline $\mathrm{TiO}_{2}$ & 4.42 & 4.85 & 1.77 & 4.55 & 4.58 & 1.30 & 1.07 & 1.14 & 1.27 \\
\hline $\mathrm{ZrO}_{2}$ & 0.44 & 0.63 & 0.18 & 0.36 & 0.41 & 0.35 & 0.10 & 0.15 & 0.14 \\
\hline $\mathrm{SnO}_{2}$ & 0.52 & 0.67 & 0.19 & 0.48 & 0.65 & 0.03 & 0.01 & 0.00 & 0.10 \\
\hline $\mathrm{UO}_{2}$ & 0.07 & 1.25 & 0.24 & 0.03 & 0.43 & 0.19 & 0.11 & 0.16 & 0.09 \\
\hline $\mathrm{Al}_{2} \mathrm{O}_{3}$ & 0.01 & 0.03 & 0.02 & 0.02 & 0.01 & 0.01 & 0.00 & 0.00 & 0.02 \\
\hline $\mathrm{Sc}_{2} \mathrm{O}_{3}$ & 1.82 & 0.23 & 0.13 & 2.06 & 1.76 & 0.00 & 0.00 & 0.00 & 0.00 \\
\hline $\mathrm{Bi}_{2} \mathrm{O}_{3}$ & 0.00 & 0.00 & 0.00 & 0.00 & 0.00 & 0.00 & 0.00 & 0.00 & 0.00 \\
\hline $\mathrm{MgO}$ & 0.00 & 0.00 & 0.00 & 0.00 & 0.00 & 0.01 & 0.02 & 0.00 & 0.01 \\
\hline $\mathrm{CaO}$ & 0.01 & 0.00 & 0.01 & 0.01 & 0.00 & 0.00 & 0.01 & 0.00 & 0.01 \\
\hline $\mathrm{Fe}_{2} \mathrm{O}_{3} *$ & 0.74 & 1.34 & 0.54 & 0.41 & 0.16 & 1.05 & 0.84 & 0.27 & 0.62 \\
\hline $\mathrm{FeO} *$ & 0.05 & 0.47 & 0.00 & 0.00 & 0.00 & 4.79 & 4.41 & 5.18 & 4.80 \\
\hline $\mathrm{Mn}_{2} \mathrm{O}_{3}{ }^{*}$ & 0.00 & 0.00 & 0.01 & 0.33 & 0.33 & 0.00 & 0.00 & 0.00 & 0.00 \\
\hline MnO* & 16.32 & 17.09 & 16.81 & 16.35 & 15.65 & 14.71 & 14.80 & 14.49 & 14.53 \\
\hline Total & 100.44 & 100.32 & 99.70 & 101.17 & 101.24 & 99.75 & 99.70 & 98.83 & 99.73 \\
\hline W & 0.043 & 0.071 & 0.043 & 0.045 & 0.050 & 0.277 & 0.161 & 0.237 & 0.179 \\
\hline $\mathrm{Nb}$ & 1.312 & 1.457 & 1.132 & 1.304 & 1.071 & 1.340 & 1.459 & 1.393 & 1.434 \\
\hline Тa & 0.434 & 0.245 & 0.729 & 0.434 & 0.650 & 0.225 & 0.277 & 0.246 & 0.273 \\
\hline $\mathrm{Ti}$ & 0.204 & 0.217 & 0.089 & 0.208 & 0.221 & 0.061 & 0.050 & 0.054 & 0.059 \\
\hline $\mathrm{Zr}$ & 0.013 & 0.018 & 0.006 & 0.011 & 0.013 & 0.011 & 0.003 & 0.005 & 0.004 \\
\hline Sn & 0.013 & 0.016 & 0.005 & 0.012 & 0.017 & 0.001 & 0.000 & 0.000 & 0.002 \\
\hline $\mathrm{U}^{4+}$ & 0.001 & 0.017 & 0.004 & 0.000 & 0.006 & 0.003 & 0.002 & 0.002 & 0.001 \\
\hline $\mathrm{Al}$ & 0.001 & 0.002 & 0.002 & 0.001 & 0.001 & 0.001 & 0.000 & 0.000 & 0.001 \\
\hline Sc & 0.097 & 0.012 & 0.008 & 0.109 & 0.098 & 0.000 & 0.000 & 0.000 & 0.000 \\
\hline $\mathrm{Bi}$ & 0.000 & 0.000 & 0.000 & 0.000 & 0.000 & 0.000 & 0.000 & 0.000 & 0.000 \\
\hline $\mathrm{Mg}$ & 0.000 & 0.000 & 0.000 & 0.000 & 0.000 & 0.001 & 0.002 & 0.000 & 0.001 \\
\hline $\mathrm{Ca}$ & 0.001 & 0.000 & 0.001 & 0.001 & 0.000 & 0.000 & 0.001 & 0.000 & 0.001 \\
\hline $\mathrm{Fe}^{3+}$ & 0.034 & 0.060 & 0.027 & 0.019 & 0.008 & 0.050 & 0.039 & 0.013 & 0.029 \\
\hline $\mathrm{Fe}^{2+}$ & 0.002 & 0.024 & 0.000 & 0.000 & 0.000 & 0.251 & 0.229 & 0.274 & 0.250 \\
\hline $\mathrm{Mn}^{3+}$ & 0.000 & 0.000 & 0.001 & 0.015 & 0.016 & 0.000 & 0.000 & 0.000 & 0.000 \\
\hline $\mathrm{Mn}^{2+}$ & 0.846 & 0.861 & 0.954 & 0.841 & 0.850 & 0.782 & 0.778 & 0.776 & 0.766 \\
\hline $\mathrm{O}$ & 6 & 6 & 6 & 6 & 6 & 6 & 6 & 6 & 6 \\
\hline Sum $R^{4,5,6+}$ & 2.019 & 2.041 & 2.008 & 2.014 & 2.028 & 1.916 & 1.952 & 1.937 & 1.953 \\
\hline Sum $R^{1,2,3+}$ & 0.981 & 0.959 & 0.992 & 0.986 & 0.972 & 1.084 & 1.048 & 1.063 & 1.047 \\
\hline $\mathrm{Mn} /(\mathrm{Fe}+\mathrm{Mn})$ & 0.959 & 0.912 & 0.972 & 0.979 & 0.991 & 0.722 & 0.744 & 0.730 & 0.733 \\
\hline $\mathrm{Ta} /(\mathrm{Nb}+\mathrm{Ta})$ & 0.248 & 0.144 & 0.392 & 0.250 & 0.378 & 0.144 & 0.160 & 0.150 & 0.160 \\
\hline
\end{tabular}


Appendix D.7 (contd.): Electron microprobe analyses of columbite-group minerals (Clb), rutile (Rt), cassiterite (cst), hübnerite (Hub), and qitianlingite (Qit)

\begin{tabular}{|c|c|c|c|c|c|c|c|c|c|}
\hline Mineral & $\mathrm{Clb}$ & $\mathrm{Clb}$ & $\mathrm{Clb}$ & $\mathrm{Clb}$ & $\mathrm{Rt}$ & $\mathrm{Rt}$ & $\mathrm{Rt}$ & $\mathrm{Rt}$ & $\mathrm{Rt}$ \\
\hline Site & 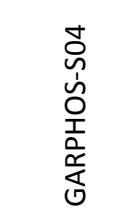 & 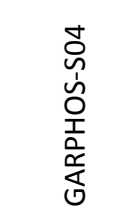 & 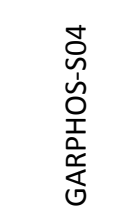 & 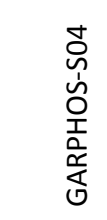 & 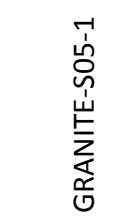 & 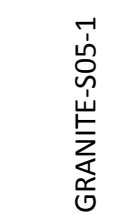 & 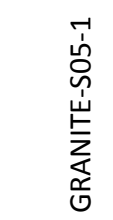 & 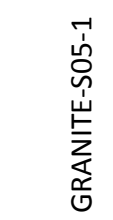 & 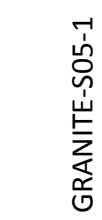 \\
\hline Point & $195 c-1$ & $195 c-2$ & $195 c-3$ & $196 c-1$ & $5 \mathrm{GNr}-1$ & $5 \mathrm{GNr}-2$ & $5 \mathrm{GNr}-3$ & $5 \mathrm{GNr}-4$ & $5 G N r-5$ \\
\hline $\mathrm{WO}_{3}$ & 0.90 & 3.81 & 4.99 & 1.78 & 0.07 & 0.35 & 1.73 & 0.55 & 0.81 \\
\hline $\mathrm{Nb}_{2} \mathrm{O}_{5}$ & 57.20 & 59.03 & 56.70 & 62.52 & 1.15 & 1.21 & 1.93 & 1.84 & 2.12 \\
\hline $\mathrm{Ta}_{2} \mathrm{O}_{5}$ & 5.89 & 15.98 & 16.60 & 14.20 & 0.00 & 0.00 & 0.29 & 0.32 & 0.26 \\
\hline $\mathrm{TiO}_{2}$ & 14.12 & 1.16 & 1.20 & 1.64 & 94.68 & 94.73 & 91.96 & 94.07 & 93.78 \\
\hline $\mathrm{ZrO}_{2}$ & 0.81 & 0.09 & 0.09 & 0.31 & 0.06 & 0.03 & 0.01 & 0.00 & 0.05 \\
\hline $\mathrm{SnO}_{2}$ & 0.46 & 0.00 & 0.05 & 0.06 & 0.27 & 0.21 & 0.68 & 0.49 & 0.79 \\
\hline $\mathrm{UO}_{2}$ & 0.19 & 0.06 & 0.00 & 0.02 & 0.00 & 0.00 & 0.01 & 0.00 & 0.00 \\
\hline $\mathrm{Al}_{2} \mathrm{O}_{3}$ & 0.01 & 0.00 & 0.02 & 0.02 & 0.22 & 0.18 & 0.11 & 0.10 & 0.07 \\
\hline $\mathrm{Sc}_{2} \mathrm{O}_{3}$ & 0.00 & 0.00 & 0.01 & 0.00 & 0.39 & 0.31 & 0.01 & 0.01 & 0.01 \\
\hline $\mathrm{Bi}_{2} \mathrm{O}_{3}$ & 0.00 & 0.00 & 0.00 & 0.00 & 0.00 & 0.00 & 0.00 & 0.00 & 0.00 \\
\hline $\mathrm{MgO}$ & 0.00 & 0.00 & 0.01 & 0.00 & 0.01 & 0.01 & 0.00 & 0.00 & 0.00 \\
\hline $\mathrm{CaO}$ & 0.13 & 0.01 & 0.01 & 0.03 & 0.14 & 0.06 & 0.02 & 0.03 & 0.02 \\
\hline $\mathrm{Fe}_{2} \mathrm{O}_{3} *$ & 6.03 & 0.64 & 1.34 & 3.09 & 0.40 & 0.51 & 2.12 & 1.51 & 1.68 \\
\hline $\mathrm{FeO}^{*}$ & 2.37 & 3.65 & 2.94 & 4.32 & 0.00 & 0.00 & 0.02 & 0.00 & 0.03 \\
\hline $\mathrm{Mn}_{2} \mathrm{O}_{3}{ }^{*}$ & 0.00 & 0.00 & 0.00 & 0.00 & 0.03 & 0.00 & 0.00 & 0.03 & 0.00 \\
\hline MnO* & 11.30 & 15.58 & 15.78 & 13.82 & 0.00 & 0.00 & 0.02 & 0.00 & 0.00 \\
\hline Total & 98.80 & 99.95 & 99.60 & 101.50 & 97.38 & 97.55 & 98.70 & 98.80 & 99.45 \\
\hline W & 0.013 & 0.060 & 0.079 & 0.027 & 0.000 & 0.001 & 0.006 & 0.002 & 0.003 \\
\hline $\mathrm{Nb}$ & 1.406 & 1.611 & 1.560 & 1.640 & 0.007 & 0.007 & 0.012 & 0.011 & 0.013 \\
\hline Тa & 0.087 & 0.262 & 0.275 & 0.224 & 0.000 & 0.000 & 0.001 & 0.001 & 0.001 \\
\hline $\mathrm{Ti}$ & 0.578 & 0.053 & 0.055 & 0.072 & 0.976 & 0.977 & 0.952 & 0.965 & 0.959 \\
\hline $\mathrm{Zr}$ & 0.021 & 0.003 & 0.003 & 0.009 & 0.000 & 0.000 & 0.000 & 0.000 & 0.000 \\
\hline Sn & 0.010 & 0.000 & 0.001 & 0.001 & 0.001 & 0.001 & 0.004 & 0.003 & 0.004 \\
\hline$U^{4+}$ & 0.002 & 0.001 & 0.000 & 0.000 & 0.000 & 0.000 & 0.000 & 0.000 & 0.000 \\
\hline $\mathrm{Al}$ & 0.001 & 0.000 & 0.001 & 0.001 & 0.004 & 0.003 & 0.002 & 0.002 & 0.001 \\
\hline Sc & 0.000 & 0.000 & 0.001 & 0.000 & 0.005 & 0.004 & 0.000 & 0.000 & 0.000 \\
\hline $\mathrm{Bi}$ & 0.000 & 0.000 & 0.000 & 0.000 & 0.000 & 0.000 & 0.000 & 0.000 & 0.000 \\
\hline $\mathrm{Mg}$ & 0.000 & 0.000 & 0.001 & 0.000 & 0.000 & 0.000 & 0.000 & 0.000 & 0.000 \\
\hline $\mathrm{Ca}$ & 0.008 & 0.001 & 0.001 & 0.002 & 0.002 & 0.001 & 0.000 & 0.000 & 0.000 \\
\hline $\mathrm{Fe}^{3+}$ & 0.247 & 0.029 & 0.061 & 0.135 & 0.004 & 0.005 & 0.022 & 0.016 & 0.017 \\
\hline $\mathrm{Fe}^{2+}$ & 0.108 & 0.184 & 0.150 & 0.210 & 0.000 & 0.000 & 0.000 & 0.000 & 0.000 \\
\hline $\mathrm{Mn}^{3+}$ & 0.000 & 0.000 & 0.000 & 0.000 & 0.000 & 0.000 & 0.000 & 0.000 & 0.000 \\
\hline $\mathrm{Mn}^{2+}$ & 0.520 & 0.797 & 0.813 & 0.679 & 0.000 & 0.000 & 0.000 & 0.000 & 0.000 \\
\hline $\mathrm{O}$ & 6 & 6 & 6 & 6 & 2 & 2 & 2 & 2 & 2 \\
\hline Sum $R^{4,5,6+}$ & 2.117 & 1.989 & 1.972 & 1.973 & 0.985 & 0.987 & 0.975 & 0.982 & 0.981 \\
\hline Sum $R^{1,2,3+}$ & 0.883 & 1.011 & 1.028 & 1.027 & 0.015 & 0.013 & 0.025 & 0.018 & 0.019 \\
\hline $\mathrm{Mn} /(\mathrm{Fe}+\mathrm{Mn})$ & 0.595 & 0.789 & 0.794 & 0.663 & 0.078 & 0.000 & 0.010 & 0.022 & 0.000 \\
\hline $\mathrm{Ta} /(\mathrm{Nb}+\mathrm{Ta})$ & 0.058 & 0.140 & 0.150 & 0.120 & 0.000 & 0.000 & 0.083 & 0.095 & 0.069 \\
\hline
\end{tabular}


Appendix D.7 (contd.): Electron microprobe analyses of columbite-group minerals (Clb), rutile (Rt), cassiterite (cst), hübnerite (Hub), and qitianlingite (Qit)

\begin{tabular}{|c|c|c|c|c|c|c|c|c|c|}
\hline Mineral & $\mathrm{Rt}$ & $\mathrm{Rt}$ & Cst & Cst & Cst & Cst & Cst & Hub & Hub \\
\hline Site & 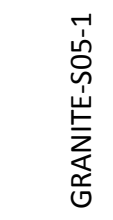 & 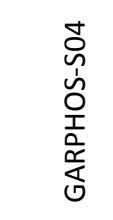 & 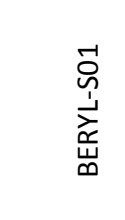 & 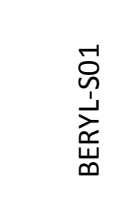 & 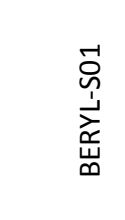 & 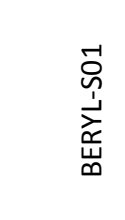 & 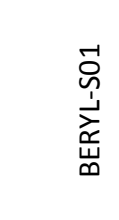 & 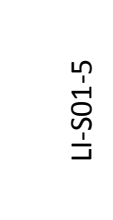 & $\begin{array}{l}\stackrel{n}{1} \\
\stackrel{1}{0} \\
\stackrel{\leftrightarrow}{1} \\
\frac{1}{4}\end{array}$ \\
\hline Point & $5 \mathrm{GNr}-6$ & $195 r-1$ & $221 c s-2$ & $222 c s-1$ & $222 c s-2$ & $221 \mathrm{cs}-1$ & $221 \mathrm{cs}-2$ & 5LIh-1 & 5LIh-2 \\
\hline $\mathrm{WO}_{3}$ & 2.03 & 0.01 & 0.01 & 0.11 & 0.01 & 0.00 & 0.00 & 78.64 & 75.61 \\
\hline $\mathrm{Nb}_{2} \mathrm{O}_{5}$ & 2.36 & 19.14 & 0.23 & 1.37 & 0.67 & 0.68 & 0.81 & 0.85 & 1.19 \\
\hline $\mathrm{Ta}_{2} \mathrm{O}_{5}$ & 0.52 & 3.11 & 1.50 & 4.99 & 2.41 & 2.68 & 2.49 & 0.00 & 0.00 \\
\hline $\mathrm{TiO}_{2}$ & 90.86 & 65.01 & 0.13 & 0.29 & 0.16 & 0.17 & 0.20 & 0.01 & 0.00 \\
\hline $\mathrm{ZrO}_{2}$ & 0.01 & 0.20 & 0.00 & 0.16 & 0.16 & 0.06 & 0.00 & 0.32 & 0.36 \\
\hline $\mathrm{SnO}_{2}$ & 0.70 & 0.09 & 97.82 & 91.82 & 95.64 & 95.59 & 95.12 & 0.06 & 0.14 \\
\hline $\mathrm{UO}_{2}$ & 0.00 & 0.00 & 0.00 & 0.00 & 0.00 & 0.00 & 0.00 & 0.00 & 0.02 \\
\hline $\mathrm{Al}_{2} \mathrm{O}_{3}$ & 0.07 & 0.06 & 0.00 & 0.03 & 0.00 & 0.00 & 0.12 & 0.00 & 0.00 \\
\hline $\mathrm{Sc}_{2} \mathrm{O}_{3}$ & 0.01 & 0.00 & 0.00 & 0.00 & 0.00 & 0.00 & 0.00 & 0.01 & 0.00 \\
\hline $\mathrm{Bi}_{2} \mathrm{O}_{3}$ & 0.00 & 0.00 & 0.00 & 0.00 & 0.00 & 0.00 & 0.00 & 0.00 & 0.02 \\
\hline $\mathrm{MgO}$ & 0.00 & 0.00 & 0.00 & 0.00 & 0.00 & 0.00 & 0.00 & 0.00 & 0.01 \\
\hline $\mathrm{CaO}$ & 0.01 & 0.02 & 0.00 & 0.00 & 0.00 & 0.00 & 0.00 & 0.01 & 0.02 \\
\hline $\mathrm{Fe}_{2} \mathrm{O}_{3} *$ & 2.21 & 11.08 & 0.25 & 0.39 & 0.21 & 0.29 & 0.38 & 0.00 & 0.90 \\
\hline $\mathrm{FeO}^{*}$ & 0.29 & 0.00 & 0.16 & 0.91 & 0.43 & 0.42 & 0.35 & 0.68 & 0.17 \\
\hline $\mathrm{Mn}_{2} \mathrm{O}_{3} *$ & 0.00 & 0.06 & 0.00 & 0.00 & 0.00 & 0.00 & 0.00 & 0.00 & 0.00 \\
\hline MnO* & 0.00 & 0.59 & 0.04 & 0.11 & 0.05 & 0.07 & 0.02 & 23.47 & 22.84 \\
\hline Total & 98.85 & 98.26 & 100.11 & 100.14 & 99.72 & 99.93 & 99.45 & 104.05 & 101.19 \\
\hline W & 0.007 & 0.000 & 0.000 & 0.001 & 0.000 & 0.000 & 0.000 & 0.984 & 0.966 \\
\hline $\mathrm{Nb}$ & 0.015 & 0.128 & 0.003 & 0.015 & 0.008 & 0.008 & 0.009 & 0.019 & 0.027 \\
\hline Ta & 0.002 & 0.013 & 0.010 & 0.034 & 0.016 & 0.018 & 0.017 & 0.000 & 0.000 \\
\hline $\mathrm{Ti}$ & 0.944 & 0.724 & 0.002 & 0.005 & 0.003 & 0.003 & 0.004 & 0.000 & 0.000 \\
\hline $\mathrm{Zr}$ & 0.000 & 0.001 & 0.000 & 0.002 & 0.002 & 0.001 & 0.000 & 0.008 & 0.009 \\
\hline Sn & 0.004 & 0.001 & 0.976 & 0.913 & 0.957 & 0.954 & 0.952 & 0.001 & 0.003 \\
\hline $\mathrm{U}^{4+}$ & 0.000 & 0.000 & 0.000 & 0.000 & 0.000 & 0.000 & 0.000 & 0.000 & 0.000 \\
\hline Al & 0.001 & 0.001 & 0.000 & 0.001 & 0.000 & 0.000 & 0.004 & 0.000 & 0.000 \\
\hline Sc & 0.000 & 0.000 & 0.000 & 0.000 & 0.000 & 0.000 & 0.000 & 0.000 & 0.000 \\
\hline $\mathrm{Bi}$ & 0.000 & 0.000 & 0.000 & 0.000 & 0.000 & 0.000 & 0.000 & 0.000 & 0.000 \\
\hline $\mathrm{Mg}$ & 0.000 & 0.000 & 0.000 & 0.000 & 0.000 & 0.000 & 0.000 & 0.000 & 0.001 \\
\hline $\mathrm{Ca}$ & 0.000 & 0.000 & 0.000 & 0.000 & 0.000 & 0.000 & 0.000 & 0.001 & 0.001 \\
\hline $\mathrm{Fe}^{3+}$ & 0.023 & 0.123 & 0.005 & 0.007 & 0.004 & 0.006 & 0.007 & 0.000 & 0.034 \\
\hline $\mathrm{Fe}^{2+}$ & 0.003 & 0.000 & 0.003 & 0.019 & 0.009 & 0.009 & 0.007 & 0.027 & 0.007 \\
\hline $\mathrm{Mn}^{3+}$ & 0.000 & 0.001 & 0.000 & 0.000 & 0.000 & 0.000 & 0.000 & 0.000 & 0.000 \\
\hline $\mathrm{Mn}^{2+}$ & 0.000 & 0.007 & 0.001 & 0.002 & 0.001 & 0.001 & 0.000 & 0.960 & 0.954 \\
\hline $\mathrm{O}$ & 2 & 2 & 2 & 2 & 2 & 2 & 2 & 4 & 4 \\
\hline Sum $R^{4,5,6+}$ & 0.972 & 0.867 & 0.991 & 0.971 & 0.986 & 0.984 & 0.982 & 1.012 & 1.004 \\
\hline Sum $R^{1,2,3+}$ & 0.028 & 0.133 & 0.009 & 0.029 & 0.014 & 0.016 & 0.018 & 0.988 & 0.996 \\
\hline $\mathrm{Mn} /(\mathrm{Fe}+\mathrm{Mn})$ & 0.000 & 0.062 & 0.096 & 0.081 & 0.076 & 0.094 & 0.029 & 0.972 & 0.959 \\
\hline $\mathrm{Ta} /(\mathrm{Nb}+\mathrm{Ta})$ & 0.117 & 0.089 & 0.797 & 0.687 & 0.684 & 0.703 & 0.649 & 0.000 & 0.000 \\
\hline
\end{tabular}


Appendix D.7 (contd.): Electron microprobe analyses of columbite-group minerals (Clb), rutile (Rt), cassiterite (cst), hübnerite (Hub), and qitianlingite (Qit)

\begin{tabular}{|c|c|c|c|c|c|c|c|c|c|}
\hline Mineral & Hub & Hub & Qit & Qit & Qit & Qit & Qit & Qit & Qit \\
\hline Site & 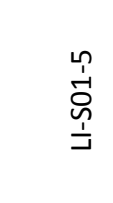 & 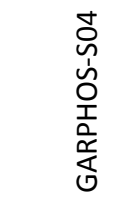 & 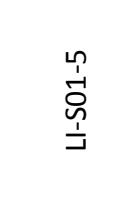 & 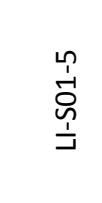 & 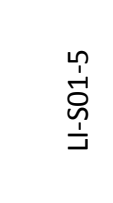 & 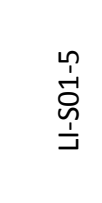 & 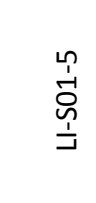 & 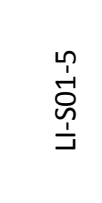 & 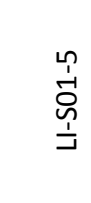 \\
\hline Point & 5 LIC-3 & $195 w-2$ & 5LIC-1 & 5LIC-2 & 5 Llc-4 & 5LIC-5 & 5LIc-6 & 5LIc-7 & $5 \mathrm{LIC}-8$ \\
\hline $\mathrm{WO}_{3}$ & 70.86 & 67.85 & 31.06 & 36.52 & 35.71 & 42.72 & 42.92 & 42.59 & 41.00 \\
\hline $\mathrm{Nb}_{2} \mathrm{O}_{5}$ & 4.58 & 6.59 & 42.84 & 31.10 & 38.27 & 16.47 & 17.64 & 16.36 & 17.65 \\
\hline $\mathrm{Ta}_{2} \mathrm{O}_{5}$ & 0.18 & 1.23 & 3.93 & 2.75 & 3.49 & 1.47 & 1.61 & 1.35 & 1.49 \\
\hline $\mathrm{TiO}_{2}$ & 0.16 & 0.64 & 1.46 & 1.56 & 1.15 & 1.06 & 1.10 & 0.95 & 1.13 \\
\hline $\mathrm{ZrO}_{2}$ & 0.63 & 0.42 & 0.36 & 1.12 & 0.55 & 1.62 & 1.85 & 1.74 & 1.76 \\
\hline $\mathrm{SnO}_{2}$ & 0.29 & 0.18 & 0.15 & 0.25 & 0.34 & 0.33 & 0.32 & 0.33 & 0.34 \\
\hline $\mathrm{UO}_{2}$ & 0.00 & 0.01 & 0.08 & 0.51 & 0.13 & 0.67 & 0.65 & 0.52 & 0.63 \\
\hline $\mathrm{Al}_{2} \mathrm{O}_{3}$ & 0.33 & 0.01 & 0.00 & 0.25 & 0.03 & 2.38 & 2.38 & 1.80 & 1.68 \\
\hline $\mathrm{Sc}_{2} \mathrm{O}_{3}$ & 0.03 & 0.00 & 0.03 & 0.05 & 0.04 & 0.06 & 0.05 & 0.06 & 0.05 \\
\hline $\mathrm{Bi}_{2} \mathrm{O}_{3}$ & 0.33 & 0.00 & 0.00 & 0.76 & 0.00 & 4.51 & 4.57 & 3.52 & 3.53 \\
\hline $\mathrm{MgO}$ & 0.00 & 0.00 & 0.00 & 0.01 & 0.00 & 0.08 & 0.09 & 0.10 & 0.12 \\
\hline $\mathrm{CaO}$ & 0.03 & 0.06 & 0.01 & 0.13 & 0.00 & 0.45 & 0.48 & 0.65 & 0.55 \\
\hline $\mathrm{Fe}_{2} \mathrm{O}_{3} *$ & 4.13 & 1.83 & 0.77 & 5.72 & 1.93 & 10.32 & 10.52 & 10.65 & 11.04 \\
\hline $\mathrm{FeO} *$ & 0.78 & 5.96 & 0.86 & 1.97 & 1.84 & 0.00 & 0.00 & 0.00 & 0.00 \\
\hline $\mathrm{Mn}_{2} \mathrm{O}_{3}{ }^{*}$ & 0.00 & 0.00 & 0.00 & 0.00 & 0.00 & 6.00 & 6.01 & 9.42 & 7.58 \\
\hline MnO* & 19.99 & 15.94 & 20.35 & 14.93 & 18.98 & 7.34 & 7.58 & 5.83 & 6.55 \\
\hline Total & 101.91 & 100.53 & 101.82 & 97.06 & 102.27 & 93.84 & 96.11 & 93.85 & 93.22 \\
\hline W & 0.869 & 0.846 & 0.831 & 1.040 & 0.965 & 1.259 & 1.232 & 1.236 & 1.199 \\
\hline $\mathrm{Nb}$ & 0.098 & 0.143 & 2.000 & 1.545 & 1.804 & 0.847 & 0.884 & 0.828 & 0.900 \\
\hline Тa & 0.002 & 0.016 & 0.110 & 0.082 & 0.099 & 0.045 & 0.049 & 0.041 & 0.046 \\
\hline $\mathrm{Ti}$ & 0.006 & 0.023 & 0.113 & 0.129 & 0.090 & 0.091 & 0.092 & 0.080 & 0.096 \\
\hline $\mathrm{Zr}$ & 0.015 & 0.010 & 0.018 & 0.060 & 0.028 & 0.090 & 0.100 & 0.095 & 0.097 \\
\hline Sn & 0.005 & 0.003 & 0.006 & 0.011 & 0.014 & 0.015 & 0.014 & 0.015 & 0.015 \\
\hline $\mathrm{U}^{4+}$ & 0.000 & 0.000 & 0.002 & 0.012 & 0.003 & 0.017 & 0.016 & 0.013 & 0.016 \\
\hline $\mathrm{Al}$ & 0.018 & 0.001 & 0.000 & 0.032 & 0.004 & 0.319 & 0.311 & 0.237 & 0.223 \\
\hline Sc & 0.001 & 0.000 & 0.003 & 0.005 & 0.004 & 0.006 & 0.005 & 0.006 & 0.005 \\
\hline $\mathrm{Bi}$ & 0.004 & 0.000 & 0.000 & 0.022 & 0.000 & 0.132 & 0.131 & 0.102 & 0.103 \\
\hline Mg & 0.000 & 0.000 & 0.000 & 0.002 & 0.000 & 0.014 & 0.015 & 0.017 & 0.020 \\
\hline $\mathrm{Ca}$ & 0.002 & 0.003 & 0.001 & 0.015 & 0.000 & 0.055 & 0.057 & 0.078 & 0.066 \\
\hline $\mathrm{Fe}^{3+}$ & 0.147 & 0.066 & 0.060 & 0.473 & 0.151 & 0.884 & 0.877 & 0.897 & 0.937 \\
\hline $\mathrm{Fe}^{2+}$ & 0.031 & 0.240 & 0.074 & 0.181 & 0.161 & 0.000 & 0.000 & 0.000 & 0.000 \\
\hline $\mathrm{Mn}^{3+}$ & 0.000 & 0.000 & 0.000 & 0.000 & 0.000 & 0.520 & 0.507 & 0.803 & 0.651 \\
\hline $\mathrm{Mn}^{2+}$ & 0.801 & 0.649 & 1.780 & 1.390 & 1.677 & 0.707 & 0.711 & 0.553 & 0.626 \\
\hline $\mathrm{O}$ & 4 & 4 & 10 & 10 & 10 & 10 & 10 & 10 & 10 \\
\hline Sum $R^{4,5,6+}$ & 0.995 & 1.041 & 3.082 & 2.880 & 3.004 & 2.364 & 2.386 & 2.307 & 2.369 \\
\hline Sum $R^{1,2,3+}$ & 1.005 & 0.959 & 1.918 & 2.120 & 1.996 & 2.636 & 2.614 & 2.693 & 2.631 \\
\hline $\mathrm{Mn} /(\mathrm{Fe}+\mathrm{Mn})$ & 0.818 & 0.680 & 0.930 & 0.680 & 0.843 & 0.581 & 0.581 & 0.602 & 0.577 \\
\hline $\mathrm{Ta} /(\mathrm{Nb}+\mathrm{Ta})$ & 0.023 & 0.101 & 0.052 & 0.051 & 0.052 & 0.051 & 0.052 & 0.047 & 0.048 \\
\hline
\end{tabular}


Appendix D.7 (contd.): Electron microprobe analyses of columbite-group minerals (Clb), rutile (Rt), cassiterite (cst), hübnerite (Hub), and qitianlingite (Qit)

\begin{tabular}{|c|c|c|c|c|c|c|c|}
\hline Mineral & Qit & Qit & Qit & Qit & Qit & Qit & Qit \\
\hline Site & 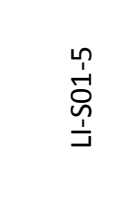 & 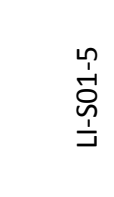 & 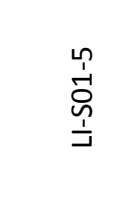 & 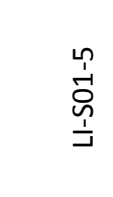 & 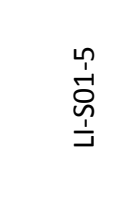 & 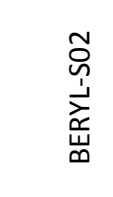 & 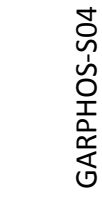 \\
\hline Point & 5LIC-9 & 5LIc-10 & 5LIc-11 & 5LIc-12 & 5LIc-13 & $225 c-1$ & $195 w-1$ \\
\hline $\mathrm{WO}_{3}$ & 39.09 & 39.74 & 43.31 & 41.96 & 30.05 & 32.84 & 38.35 \\
\hline $\mathrm{Nb}_{2} \mathrm{O}_{5}$ & 33.22 & 31.32 & 19.15 & 23.19 & 33.06 & 37.16 & 34.00 \\
\hline $\mathrm{Ta}_{2} \mathrm{O}_{5}$ & 2.80 & 2.68 & 1.63 & 1.93 & 1.55 & 4.80 & 4.40 \\
\hline $\mathrm{TiO}_{2}$ & 1.63 & 1.49 & 1.06 & 1.21 & 0.91 & 1.74 & 1.30 \\
\hline $\mathrm{ZrO}_{2}$ & 1.27 & 1.21 & 1.80 & 1.61 & 0.19 & 1.24 & 0.23 \\
\hline $\mathrm{SnO}_{2}$ & 0.26 & 0.21 & 0.42 & 0.35 & 0.09 & 0.29 & 0.18 \\
\hline $\mathrm{UO}_{2}$ & 0.53 & 0.44 & 0.42 & 0.37 & 0.06 & 0.27 & 0.00 \\
\hline $\mathrm{Al}_{2} \mathrm{O}_{3}$ & 0.07 & 0.21 & 1.79 & 1.34 & 5.80 & 0.02 & 0.00 \\
\hline $\mathrm{Sc}_{2} \mathrm{O}_{3}$ & 0.04 & 0.04 & 0.07 & 0.07 & 0.02 & 0.40 & 0.00 \\
\hline $\mathrm{Bi}_{2} \mathrm{O}_{3}$ & 0.47 & 0.52 & 3.29 & 2.65 & 0.00 & 0.00 & 0.00 \\
\hline MgO & 0.01 & 0.02 & 0.12 & 0.09 & 0.00 & 0.01 & 0.00 \\
\hline $\mathrm{CaO}$ & 0.05 & 0.08 & 0.42 & 0.36 & 0.06 & 0.01 & 0.17 \\
\hline $\mathrm{Fe}_{2} \mathrm{O}_{3} *$ & 2.35 & 3.65 & 8.92 & 9.36 & 2.85 & 1.95 & 1.07 \\
\hline $\mathrm{FeO}^{*}$ & 4.47 & 3.20 & 0.00 & 0.00 & 0.00 & 9.94 & 5.87 \\
\hline $\mathrm{Mn}_{2} \mathrm{O}_{3} *$ & 0.00 & 0.00 & 4.37 & 2.19 & 10.15 & 0.00 & 0.00 \\
\hline MnO* & 15.60 & 15.78 & 10.17 & 12.21 & 8.32 & 9.80 & 15.03 \\
\hline Total & 101.62 & 100.23 & 95.61 & 97.73 & 91.79 & 100.28 & 100.49 \\
\hline W & 1.078 & 1.110 & 1.259 & 1.190 & 0.814 & 0.902 & 1.073 \\
\hline $\mathrm{Nb}$ & 1.598 & 1.526 & 0.971 & 1.147 & 1.563 & 1.780 & 1.660 \\
\hline Та & 0.081 & 0.079 & 0.050 & 0.057 & 0.044 & 0.138 & 0.129 \\
\hline $\mathrm{Ti}$ & 0.130 & 0.121 & 0.089 & 0.100 & 0.072 & 0.139 & 0.106 \\
\hline $\mathrm{Zr}$ & 0.066 & 0.064 & 0.098 & 0.086 & 0.010 & 0.064 & 0.012 \\
\hline Sn & 0.011 & 0.009 & 0.019 & 0.015 & 0.004 & 0.012 & 0.008 \\
\hline$U^{4+}$ & 0.013 & 0.011 & 0.010 & 0.009 & 0.001 & 0.006 & 0.000 \\
\hline Al & 0.009 & 0.027 & 0.237 & 0.173 & 0.715 & 0.002 & 0.000 \\
\hline Sc & 0.004 & 0.004 & 0.007 & 0.007 & 0.002 & 0.037 & 0.000 \\
\hline $\mathrm{Bi}$ & 0.013 & 0.014 & 0.095 & 0.075 & 0.000 & 0.000 & 0.000 \\
\hline $\mathrm{Mg}$ & 0.002 & 0.003 & 0.020 & 0.015 & 0.000 & 0.002 & 0.000 \\
\hline $\mathrm{Ca}$ & 0.006 & 0.009 & 0.050 & 0.042 & 0.007 & 0.001 & 0.020 \\
\hline $\mathrm{Fe}^{3+}$ & 0.188 & 0.296 & 0.753 & 0.770 & 0.224 & 0.156 & 0.087 \\
\hline $\mathrm{Fe}^{2+}$ & 0.397 & 0.289 & 0.000 & 0.000 & 0.000 & 0.881 & 0.530 \\
\hline $\mathrm{Mn}^{3+}$ & 0.000 & 0.000 & 0.374 & 0.183 & 0.808 & 0.000 & 0.000 \\
\hline $\mathrm{Mn}^{2+}$ & 1.406 & 1.440 & 0.966 & 1.132 & 0.737 & 0.880 & 1.375 \\
\hline $\mathrm{O}$ & 10 & 10 & 10 & 10 & 10 & 10 & 10 \\
\hline Sum $R^{4,5,6+}$ & 2.976 & 2.918 & 2.497 & 2.604 & 2.508 & 3.042 & 2.988 \\
\hline Sum $\mathrm{R}^{1,2,3+}$ & 2.024 & 2.082 & 2.503 & 2.396 & 2.492 & 1.958 & 2.012 \\
\hline $\mathrm{Mn} /(\mathrm{Fe}+\mathrm{Mn})$ & 0.706 & 0.711 & 0.640 & 0.630 & 0.873 & 0.459 & 0.690 \\
\hline $\mathrm{Ta} /(\mathrm{Nb}+\mathrm{Ta})$ & 0.048 & 0.049 & 0.049 & 0.048 & 0.027 & 0.072 & 0.072 \\
\hline
\end{tabular}


Appendix D.8: Electron microprobe analyses of monazite (Mnz) and xenotime (Xnt).

\begin{tabular}{|c|c|c|c|c|c|c|c|c|c|c|c|c|c|c|c|}
\hline Mineral & $\mathrm{Mnz}$ & $\mathrm{Mnz}$ & $\mathrm{Mnz}$ & $\mathrm{Mnz}$ & $\mathrm{Mnz}$ & $\mathrm{Mnz}$ & $\mathrm{Mnz}$ & $\mathrm{Mnz}$ & Xnt & Xnt & Xnt & Xnt & Xnt & Xnt & Xnt \\
\hline Comment & & & & & & & & & & $\begin{array}{l}\text { verelap w } \\
\text { iotite }\end{array}$ & & & & & \\
\hline Sample & 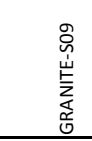 & 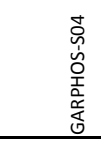 & 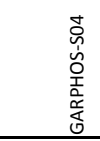 & 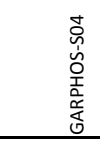 & 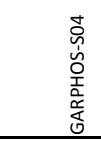 & 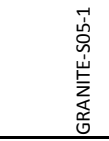 & 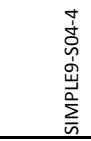 & 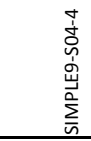 & 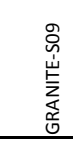 & 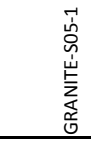 & 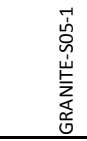 & 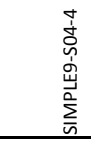 & 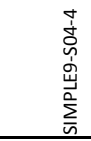 & 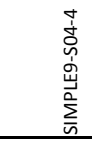 & 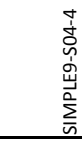 \\
\hline Point & $21 m z-1$ & $198 \mathrm{mz}-1$ & $198 \mathrm{mz}-2$ & $198 \mathrm{mz}-3$ & $198 \mathrm{mz}-4$ & $5 \mathrm{GNmz}-1$ & $4 S 94 x-5$ & $4 S 94 x-6$ & $21 x-1$ & $5 \mathrm{GNx}-1$ & $5 \mathrm{GNx}-2$ & $4 S 94 x-1$ & $4 S 94 x-2$ & $4 S 94 x-3$ & $4 S 94 x-4$ \\
\hline $\mathrm{P}_{2} \mathrm{O}_{5}$ (wt.\%) & 30.95 & 30.25 & 30.67 & 30.47 & 30.49 & 27.50 & 29.53 & 29.37 & 27.75 & 23.28 & 33.18 & 35.38 & 33.53 & 35.10 & 35.83 \\
\hline $\mathrm{SiO}_{2}$ & 0.15 & 0.37 & 0.17 & 0.21 & 0.19 & 9.92 & 1.04 & 1.13 & & & 2.20 & 0.72 & 1.47 & 0.79 & 0.56 \\
\hline $\mathrm{TiO}_{2}$ & 0.00 & 0.00 & 0.00 & 0.00 & 0.00 & 2.35 & 0.00 & 0.00 & 0.00 & 1.81 & 1.26 & 0.00 & 0.00 & 0.00 & 0.00 \\
\hline $\mathrm{SnO}_{2}$ & 0.00 & 0.00 & 0.00 & 0.00 & 0.00 & 1.32 & 0.00 & 0.02 & 0.00 & 0.11 & 0.00 & 0.00 & 0.00 & 0.00 & 0.00 \\
\hline $\mathrm{ThO}_{2}$ & 2.20 & 14.87 & 12.02 & 15.76 & 14.99 & 0.00 & 5.45 & 5.05 & 0.15 & 0.04 & 0.00 & 0.15 & 0.45 & 0.20 & 0.08 \\
\hline $\mathrm{UO}_{2}$ & 0.63 & 6.97 & 4.25 & 6.51 & 5.34 & 0.44 & 0.11 & 0.16 & 3.45 & 0.57 & 0.29 & 3.46 & 7.38 & 4.65 & 3.82 \\
\hline $\mathrm{Al}_{2} \mathrm{O}_{3}$ & 0.00 & 0.00 & 0.00 & 0.00 & 0.00 & 0.55 & 0.00 & 0.01 & & & 0.00 & 0.00 & 0.00 & 0.00 & 0.00 \\
\hline $\mathrm{Sc}_{2} \mathrm{O}_{3}$ & 0.00 & 0.00 & 0.00 & 0.00 & 0.00 & 0.00 & 0.01 & 0.00 & 0.03 & 0.27 & 0.13 & 0.04 & 0.03 & 0.03 & 0.03 \\
\hline $\mathrm{As}_{2} \mathrm{O}_{3}$ & 0.00 & 0.04 & 0.05 & 0.01 & 0.02 & 0.08 & 0.13 & 0.17 & 0.00 & 0.00 & 0.00 & 0.00 & 0.01 & 0.00 & 0.00 \\
\hline $\mathrm{Y}_{2} \mathrm{O}_{3}$ & 1.69 & 0.07 & 0.00 & 0.08 & 0.06 & 1.88 & 1.15 & 0.70 & 33.66 & 29.18 & 40.65 & 40.06 & 38.53 & 40.19 & 40.94 \\
\hline $\mathrm{La}_{2} \mathrm{O}_{3}$ & 16.98 & 7.14 & 7.98 & 6.89 & 7.23 & 3.32 & 14.24 & 14.34 & 0.03 & 0.04 & 0.04 & 0.00 & 0.05 & 0.00 & 0.01 \\
\hline $\mathrm{Ce}_{2} \mathrm{O}_{3}$ & 31.74 & 21.07 & 24.66 & 20.77 & 22.53 & 22.05 & 30.75 & 31.34 & 0.13 & 0.06 & 0.19 & 0.12 & 0.09 & 0.03 & 0.03 \\
\hline $\mathrm{Pr}_{2} \mathrm{O}_{3}$ & 3.09 & 2.26 & 2.99 & 2.49 & 2.50 & 4.42 & 3.33 & 3.40 & 0.00 & 0.05 & 0.00 & 0.00 & 0.00 & 0.23 & 0.00 \\
\hline $\mathrm{Nd}_{2} \mathrm{O}_{3}$ & 6.79 & 6.23 & 7.25 & 6.12 & 6.61 & 21.77 & 11.45 & 12.00 & 0.14 & 0.11 & 0.35 & 0.43 & 0.30 & 0.30 & 0.53 \\
\hline SmO & 2.20 & 3.81 & 4.18 & 3.72 & 3.60 & 6.04 & 2.52 & 2.23 & 0.58 & 0.30 & 0.71 & 0.78 & 0.75 & 0.82 & 0.64 \\
\hline EuO & 0.00 & 0.00 & 0.00 & 0.00 & 0.00 & 0.00 & 0.00 & 0.00 & 0.66 & 0.00 & 0.00 & 0.00 & 0.00 & 0.00 & 0.00 \\
\hline $\mathrm{Gd}_{2} \mathrm{O}_{3}$ & 0.51 & 0.62 & 0.52 & 0.58 & 0.73 & 1.94 & 0.84 & 0.99 & 3.38 & 2.14 & 4.36 & 4.00 & 4.14 & 3.90 & 4.41 \\
\hline $\mathrm{Tb}_{2} \mathrm{O}_{3}$ & 0.00 & 0.00 & 0.00 & 0.00 & 0.00 & 0.19 & 0.22 & 0.11 & 0.24 & 0.38 & 0.65 & 0.67 & 0.58 & 0.60 & 0.69 \\
\hline $\mathrm{Dy}_{2} \mathrm{O}_{3}$ & 0.33 & 0.01 & 0.00 & 0.08 & 0.00 & 0.38 & 0.31 & 0.35 & 4.39 & 2.71 & 5.54 & 5.22 & 4.91 & 4.70 & 5.22 \\
\hline $\mathrm{Ho}_{2} \mathrm{O}_{3}$ & 0.00 & 0.00 & 0.33 & 0.00 & 0.18 & 0.00 & 0.23 & 0.00 & 0.00 & 0.24 & 0.82 & 0.20 & 0.52 & 0.67 & 0.49 \\
\hline $\mathrm{Er}_{2} \mathrm{O}_{3}$ & 0.05 & 0.00 & 0.03 & 0.00 & 0.00 & 0.12 & 0.06 & 0.00 & 2.46 & 1.92 & 4.12 & 3.76 & 3.83 & 4.06 & 3.98 \\
\hline $\mathrm{Tm}_{2} \mathrm{O}_{3}$ & 0.13 & 0.62 & 0.58 & 0.51 & 0.56 & 0.68 & 0.31 & 0.30 & 0.00 & 0.00 & 0.41 & 0.41 & 0.43 & 0.34 & 0.35 \\
\hline $\mathrm{Yb}_{2} \mathrm{O}_{3}$ & 0.00 & 0.00 & 0.00 & 0.00 & 0.00 & 0.03 & 0.00 & 0.00 & 5.91 & 3.16 & 7.37 & 7.53 & 6.69 & 7.23 & 7.01 \\
\hline $\mathrm{Bi}_{2} \mathrm{O}_{3}$ & 1.66 & 1.34 & 1.55 & 1.19 & 1.44 & 1.14 & 1.51 & 1.70 & 0.00 & 0.00 & 0.00 & 0.00 & 0.00 & 0.00 & 0.00 \\
\hline $\mathrm{MgO}$ & 0.00 & 0.00 & 0.00 & 0.00 & 0.00 & 0.00 & 0.00 & 0.00 & 0.00 & 0.29 & 0.00 & 0.00 & 0.00 & 0.00 & 0.00 \\
\hline $\mathrm{CaO}$ & 0.61 & 4.52 & 3.44 & 4.65 & 4.21 & 0.48 & 0.44 & 0.23 & 0.61 & 0.16 & 0.10 & 0.28 & 0.40 & 0.29 & 0.27 \\
\hline $\mathrm{FeO}$ & 0.00 & 0.00 & 0.00 & 0.00 & 0.00 & 0.00 & 0.00 & 0.00 & & 0.72 & 0.00 & 0.00 & 0.00 & 0.00 & 0.00 \\
\hline $\mathrm{K}_{2} \mathrm{O}$ & 0.00 & 0.00 & 0.00 & 0.00 & 0.00 & 0.13 & 0.00 & 0.00 & & & 0.00 & 0.00 & 0.00 & 0.00 & 0.00 \\
\hline $\mathrm{F}$ & 0.52 & 0.33 & 0.37 & 0.34 & 0.31 & 0.20 & 0.29 & 0.43 & 0.00 & 0.00 & 0.05 & 0.00 & 0.02 & 0.00 & 0.00 \\
\hline Total & 100.22 & 100.53 & 101.07 & 100.39 & 101.08 & 106.93 & 103.93 & 104.05 & 96.24 & 100.09 & 102.45 & 103.25 & 104.14 & 104.14 & 104.88 \\
\hline $\mathrm{P}^{5+}(\mathrm{apfu})$ & 1.017 & 0.998 & 1.007 & 1.005 & 1.003 & 0.773 & 0.957 & 0.956 & 0.966 & 0.944 & 0.921 & 0.990 & 0.951 & 0.981 & 0.989 \\
\hline $\mathrm{Si}^{4+}$ & 0.006 & 0.014 & 0.007 & 0.008 & 0.007 & 0.329 & 0.040 & 0.043 & 0.000 & 0.000 & 0.072 & 0.024 & 0.049 & 0.026 & 0.018 \\
\hline $\mathrm{Ti}^{4+}$ & 0.000 & 0.000 & 0.000 & 0.000 & 0.000 & 0.059 & 0.000 & 0.000 & 0.000 & 0.065 & 0.031 & 0.000 & 0.000 & 0.000 & 0.000 \\
\hline $\mathrm{Sn}^{4+}$ & 0.000 & 0.000 & 0.000 & 0.000 & 0.000 & 0.017 & 0.000 & 0.000 & 0.000 & 0.002 & 0.000 & 0.000 & 0.000 & 0.000 & 0.000 \\
\hline $\mathrm{Th}^{4+}$ & 0.019 & 0.132 & 0.106 & 0.140 & 0.133 & 0.000 & 0.047 & 0.044 & 0.001 & 0.000 & 0.000 & 0.001 & 0.003 & 0.002 & 0.001 \\
\hline$U^{4+}$ & 0.005 & 0.060 & 0.037 & 0.056 & 0.046 & 0.003 & 0.001 & 0.001 & 0.032 & 0.006 & 0.002 & 0.025 & 0.055 & 0.034 & 0.028 \\
\hline $\mathrm{Al}^{3+}$ & 0.000 & 0.000 & 0.000 & 0.000 & 0.000 & 0.022 & 0.000 & 0.000 & 0.000 & 0.000 & 0.000 & 0.000 & 0.000 & 0.000 & 0.000 \\
\hline $\mathrm{Sc}^{3+}$ & 0.000 & 0.000 & 0.000 & 0.000 & 0.000 & 0.000 & 0.000 & 0.000 & 0.001 & 0.011 & 0.004 & 0.001 & 0.001 & 0.001 & 0.001 \\
\hline $\mathrm{As}^{3+}$ & 0.000 & 0.001 & 0.001 & 0.000 & 0.000 & 0.002 & 0.003 & 0.004 & 0.000 & 0.000 & 0.000 & 0.000 & 0.000 & 0.000 & 0.000 \\
\hline $\mathrm{Y}^{3+}$ & 0.035 & 0.001 & 0.000 & 0.002 & 0.001 & 0.033 & 0.023 & 0.014 & 0.737 & 0.743 & 0.709 & 0.705 & 0.687 & 0.706 & 0.711 \\
\hline $\mathrm{La}^{3+}$ & 0.243 & 0.103 & 0.114 & 0.099 & 0.104 & 0.041 & 0.201 & 0.203 & 0.000 & 0.001 & 0.000 & 0.000 & 0.001 & 0.000 & 0.000 \\
\hline $\mathrm{Ce}^{3+}$ & 0.451 & 0.301 & 0.350 & 0.296 & 0.320 & 0.268 & 0.431 & 0.441 & 0.002 & 0.001 & 0.002 & 0.001 & 0.001 & 0.000 & 0.000 \\
\hline $\mathrm{Pr}^{3+}$ & 0.044 & 0.032 & 0.042 & 0.035 & 0.035 & 0.053 & 0.046 & 0.048 & 0.000 & 0.001 & 0.000 & 0.000 & 0.000 & 0.003 & 0.000 \\
\hline $\mathrm{Nd}^{3+}$ & 0.094 & 0.087 & 0.100 & 0.085 & 0.092 & 0.258 & 0.157 & 0.165 & 0.002 & 0.002 & 0.004 & 0.005 & 0.004 & 0.004 & 0.006 \\
\hline $\mathrm{Sm}^{2+}$ & 0.031 & 0.054 & 0.059 & 0.052 & 0.051 & 0.072 & 0.035 & 0.031 & 0.009 & 0.005 & 0.008 & 0.009 & 0.009 & 0.010 & 0.008 \\
\hline $\mathrm{Eu}^{2+}$ & 0.000 & 0.000 & 0.000 & 0.000 & 0.000 & 0.000 & 0.000 & 0.000 & 0.010 & 0.000 & 0.000 & 0.000 & 0.000 & 0.000 & 0.000 \\
\hline $\mathrm{Gd}^{3+}$ & 0.007 & 0.008 & 0.007 & 0.007 & 0.009 & 0.021 & 0.011 & 0.013 & 0.046 & 0.034 & 0.047 & 0.044 & 0.046 & 0.043 & 0.048 \\
\hline $\mathrm{Tb}^{3+}$ & 0.000 & 0.000 & 0.000 & 0.000 & 0.000 & 0.002 & 0.003 & 0.001 & 0.003 & 0.006 & 0.007 & 0.007 & 0.006 & 0.007 & 0.007 \\
\hline $\mathrm{Dy}^{3+}$ & 0.004 & 0.000 & 0.000 & 0.001 & 0.000 & 0.004 & 0.004 & 0.004 & 0.058 & 0.042 & 0.059 & 0.056 & 0.053 & 0.050 & 0.055 \\
\hline $\mathrm{Ho}^{3+}$ & 0.000 & 0.000 & 0.004 & 0.000 & 0.002 & 0.000 & 0.003 & 0.000 & 0.000 & 0.004 & 0.009 & 0.002 & 0.006 & 0.007 & 0.005 \\
\hline $\mathrm{Er}^{3+}$ & 0.001 & 0.000 & 0.000 & 0.000 & 0.000 & 0.001 & 0.001 & 0.000 & 0.032 & 0.029 & 0.042 & 0.039 & 0.040 & 0.042 & 0.041 \\
\hline $\mathrm{Tm}^{3+}$ & 0.002 & 0.008 & 0.007 & 0.006 & 0.007 & 0.007 & 0.004 & 0.004 & 0.000 & 0.000 & 0.004 & 0.004 & 0.004 & 0.003 & 0.004 \\
\hline $\mathrm{Yb}^{3+}$ & 0.000 & 0.000 & 0.000 & 0.000 & 0.000 & 0.000 & 0.000 & 0.000 & 0.074 & 0.046 & 0.074 & 0.076 & 0.068 & 0.073 & 0.070 \\
\hline $\mathrm{Bi}^{3+}$ & 0.017 & 0.013 & 0.016 & 0.012 & 0.014 & 0.010 & 0.015 & 0.017 & 0.000 & 0.000 & 0.000 & 0.000 & 0.000 & 0.000 & 0.000 \\
\hline $\mathrm{Mg}^{2+}$ & 0.000 & 0.000 & 0.000 & 0.000 & 0.000 & 0.000 & 0.000 & 0.000 & 0.000 & 0.021 & 0.000 & 0.000 & 0.000 & 0.000 & 0.000 \\
\hline $\mathrm{Ca}^{2+}$ & 0.025 & 0.189 & 0.143 & 0.194 & 0.175 & 0.017 & 0.018 & 0.009 & 0.027 & 0.008 & 0.004 & 0.010 & 0.014 & 0.010 & 0.009 \\
\hline $\mathrm{Fe}^{2+}$ & 0.000 & 0.000 & 0.000 & 0.000 & 0.000 & 0.000 & 0.000 & 0.000 & 0.000 & 0.029 & 0.000 & 0.000 & 0.000 & 0.000 & 0.000 \\
\hline $\mathrm{K}^{+}$ & 0.000 & 0.000 & 0.000 & 0.000 & 0.000 & 0.006 & 0.000 & 0.000 & 0.000 & 0.000 & 0.000 & 0.000 & 0.000 & 0.000 & 0.000 \\
\hline$F^{-}$ & 0.064 & 0.041 & 0.045 & 0.042 & 0.038 & 0.021 & 0.035 & 0.052 & 0.000 & 0.000 & 0.005 & 0.000 & 0.002 & 0.000 & 0.000 \\
\hline
\end{tabular}


Appendix D.9: Electron microprobe analyses of topaz from the GARPHOS pegmatite.

\begin{tabular}{lrrrrrr}
\hline Sample & GP3-27 & GP3-28 & GP3-29 & GP3-30 & GP2-29 & \multicolumn{1}{c}{ GP2-30 } \\
\hline $\mathrm{SiO}_{2}$ & 31.69 & 31.59 & 31.60 & 31.68 & 31.09 & 31.59 \\
$\mathrm{Al}_{2} \mathrm{O}_{3}$ & 55.74 & 55.50 & 55.54 & 55.45 & 55.44 & 55.46 \\
$\mathrm{FeO}$ & 0.02 & 0.01 & 0.04 & 0.00 & 0.02 & 0.00 \\
$\mathrm{Na}_{2} \mathrm{O}$ & 0.01 & 0.02 & 0.03 & 0.00 & 0.00 & 0.05 \\
$\mathrm{~F}$ & 20.88 & 19.18 & 20.19 & 18.94 & 18.74 & 18.69 \\
$\mathrm{H}_{2} \mathrm{O}{ }^{*}$ & 0.00 & 0.58 & 0.11 & 0.70 & 0.72 & 0.81 \\
$\mathrm{O}=\mathrm{F}$ & -8.79 & -8.08 & -8.50 & -7.98 & -7.89 & -7.87 \\
$\mathrm{Total}^{2}$ & 99.55 & 98.8 & 99.01 & 98.79 & 98.12 & 98.73 \\
$\mathrm{Si}^{4+}$ & & & & & & \\
$\mathrm{Al}^{3+}$ & 0.975 & 0.979 & 0.979 & 0.982 & 0.970 & 0.980 \\
$\mathrm{Fe}^{2+}$ & 2.020 & 2.027 & 2.027 & 2.025 & 2.039 & 2.027 \\
$\mathrm{Na}^{+}$ & 0.001 & 0.000 & 0.001 & 0.000 & 0.001 & 0.000 \\
$\mathrm{~F}^{-}$ & 0.001 & 0.001 & 0.002 & 0.000 & 0.000 & 0.003 \\
$\mathrm{OH}^{-}$ & 2.031 & 1.880 & 1.978 & 1.856 & 1.850 & 1.833 \\
$\mathrm{O}$ & 0.000 & 0.120 & 0.023 & 0.144 & 0.150 & 0.168 \\
\hline
\end{tabular}

*Note: formula calculation on basis of 6 anions and $\mathrm{OH}=(2-\mathrm{F})$. 


\begin{tabular}{|c|c|c|c|c|c|c|c|c|c|c|}
\hline Site & 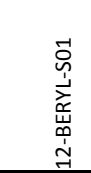 & 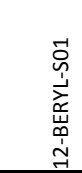 & 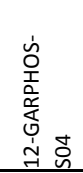 & 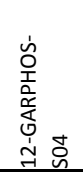 & 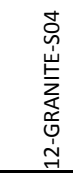 & 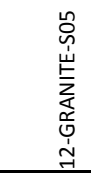 & 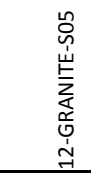 & 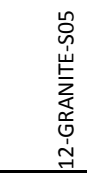 & 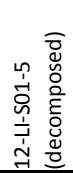 & 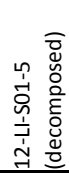 \\
\hline Point & $254 z-1$ & $254 z-2$ & $198 z-1$ & $198 z-2$ & $13 z-1$ & $5 G N z-1$ & $5 \mathrm{GNz}-2$ & $5 \mathrm{GNz}-3$ & $5 \mathrm{LIz}-1$ & $5 \mathrm{LIz}-2$ \\
\hline $\mathrm{SiO}_{2}$ (wt.\%) & 27.32 & 29.61 & 31.86 & 31.57 & 31.69 & 32.00 & 31.53 & 30.81 & 19.26 & 18.79 \\
\hline $\mathrm{TiO}_{2}$ & 0.00 & 0.00 & 0.00 & 0.00 & 0.01 & 0.00 & 0.00 & 0.00 & 0.08 & 0.06 \\
\hline $\mathrm{ZrO}_{2}$ & 51.36 & 53.26 & 62.58 & 61.25 & 63.80 & 64.52 & 63.70 & 61.47 & 38.04 & 40.31 \\
\hline $\mathrm{HfO}_{2}$ & 3.18 & 4.14 & 5.08 & 5.70 & 1.75 & 2.32 & 2.10 & 1.70 & 2.06 & 2.61 \\
\hline $\mathrm{ThO}_{2}$ & 0.22 & 0.12 & 0.00 & 0.03 & 0.00 & 0.00 & 0.04 & 0.00 & 0.41 & 0.19 \\
\hline $\mathrm{UO}_{2}$ & 18.37 & 11.10 & 0.09 & 0.18 & 0.43 & 0.33 & 0.87 & 1.59 & 6.99 & 5.59 \\
\hline $\mathrm{Al}_{2} \mathrm{O}_{3}$ & 0.04 & 0.00 & 0.00 & 0.02 & 0.00 & 0.02 & 0.01 & 0.00 & 6.54 & 5.22 \\
\hline $\mathrm{Sc}_{2} \mathrm{O}_{3}$ & 0.07 & 0.08 & 0.04 & 0.00 & 0.12 & 0.15 & 0.29 & 0.37 & 0.12 & 0.18 \\
\hline $\mathrm{Y}_{2} \mathrm{O}_{3}$ & 0.32 & 0.31 & 0.01 & 0.02 & 0.14 & 0.17 & 0.51 & 1.21 & 3.39 & 3.11 \\
\hline $\mathrm{La}_{2} \mathrm{O}_{3}$ & 0.00 & 0.00 & 0.05 & 0.09 & 0.00 & 0.02 & 0.00 & 0.03 & 0.00 & 0.00 \\
\hline $\mathrm{Ce}_{2} \mathrm{O}_{3}$ & 0.05 & 0.04 & 0.01 & 0.00 & 0.00 & 0.00 & 0.00 & 0.00 & 0.03 & 0.11 \\
\hline $\mathrm{Pr}_{2} \mathrm{O}_{3}$ & 0.18 & 0.00 & 0.00 & 0.00 & 0.05 & 0.10 & 0.13 & 0.00 & 0.05 & 0.03 \\
\hline $\mathrm{Nd}_{2} \mathrm{O}_{3}$ & 0.00 & 0.02 & 0.00 & 0.00 & 0.00 & 0.02 & 0.03 & 0.03 & 0.00 & 0.00 \\
\hline Smo & 0.08 & 0.17 & 0.17 & 0.09 & 0.00 & 0.00 & 0.00 & 0.12 & 0.02 & 0.14 \\
\hline EuO & 0.00 & 0.06 & 0.00 & 0.00 & 0.03 & 0.05 & 0.00 & 0.00 & 0.01 & 0.09 \\
\hline $\mathrm{Gd}_{2} \mathrm{O}_{3}$ & 0.35 & 0.00 & 0.00 & 0.01 & 0.09 & 0.00 & 0.18 & 0.07 & 0.34 & 0.00 \\
\hline $\mathrm{Tb}_{2} \mathrm{O}_{3}$ & 0.00 & 0.09 & 0.03 & 0.01 & 0.00 & 0.03 & 0.00 & 0.00 & 0.06 & 0.00 \\
\hline $\mathrm{Dy}_{2} \mathrm{O}_{3}$ & 0.10 & 0.13 & 0.17 & 0.05 & 0.00 & 0.02 & 0.17 & 0.05 & 0.42 & 0.30 \\
\hline $\mathrm{Ho}_{2} \mathrm{O}_{3}$ & 0.00 & 0.00 & 0.00 & 0.05 & 0.00 & 0.11 & 0.00 & 0.00 & 0.04 & 0.02 \\
\hline $\mathrm{Er}_{2} \mathrm{O}_{3}$ & 0.04 & 0.01 & 0.10 & 0.11 & 0.00 & 0.08 & 0.09 & 0.14 & 0.17 & 0.13 \\
\hline $\mathrm{Tm}_{2} \mathrm{O}_{3}$ & 0.00 & 0.07 & 0.00 & 0.05 & 0.01 & 0.00 & 0.00 & 0.00 & 0.00 & 0.00 \\
\hline $\mathrm{Yb}_{2} \mathrm{O}_{3}$ & 0.02 & 0.00 & 0.02 & 0.02 & 0.15 & 0.15 & 0.40 & 0.71 & 0.00 & 0.00 \\
\hline $\mathrm{Bi}_{2} \mathrm{O}_{3}$ & 0.00 & 0.00 & 0.00 & 0.03 & 0.00 & 0.00 & 0.00 & 0.00 & 2.19 & 2.08 \\
\hline $\mathrm{MnO}$ & 0.11 & 0.08 & 0.00 & 0.00 & 0.00 & 0.00 & 0.00 & 0.00 & 0.15 & 0.23 \\
\hline $\mathrm{FeO}$ & 0.10 & 0.01 & 0.00 & 0.01 & 0.09 & 0.02 & 0.05 & 0.02 & 1.03 & 0.98 \\
\hline $\mathrm{PbO}$ & 0.13 & 0.00 & 0.00 & 0.03 & 0.09 & 0.06 & 0.01 & 0.09 & 0.05 & 0.10 \\
\hline Total & 102.04 & 99.30 & 100.21 & 99.32 & 98.45 & 100.17 & 100.11 & 98.41 & 81.45 & 80.27 \\
\hline $\mathrm{Si}^{4+}(\mathrm{apfu})$ & 0.939 & 0.991 & 0.995 & 0.997 & 0.994 & 0.990 & 0.981 & 0.978 & 0.746 & 0.746 \\
\hline $\mathrm{Ti}^{4+}$ & 0.000 & 0.000 & 0.000 & 0.000 & 0.000 & 0.000 & 0.000 & 0.000 & 0.002 & 0.002 \\
\hline $\mathrm{Zr}^{4+}$ & 0.861 & 0.869 & 0.953 & 0.943 & 0.975 & 0.973 & 0.966 & 0.952 & 0.718 & 0.781 \\
\hline $\mathrm{Hf}^{4+}$ & 0.031 & 0.040 & 0.045 & 0.051 & 0.016 & 0.020 & 0.019 & 0.015 & 0.023 & 0.030 \\
\hline $\mathrm{Th}^{4+}$ & 0.002 & 0.001 & 0.000 & 0.000 & 0.000 & 0.000 & 0.000 & 0.000 & 0.004 & 0.002 \\
\hline$U^{4+}$ & 0.141 & 0.083 & 0.001 & 0.001 & 0.003 & 0.002 & 0.006 & 0.011 & 0.060 & 0.049 \\
\hline $\mathrm{Al}^{3+}$ & 0.002 & 0.000 & 0.000 & 0.001 & 0.000 & 0.001 & 0.000 & 0.000 & 0.298 & 0.244 \\
\hline $\mathrm{Sc}^{3+}$ & 0.002 & 0.002 & 0.001 & 0.000 & 0.003 & 0.004 & 0.008 & 0.010 & 0.004 & 0.006 \\
\hline $\mathrm{Y}^{3+}$ & 0.006 & 0.006 & 0.000 & 0.000 & 0.002 & 0.003 & 0.008 & 0.020 & 0.070 & 0.066 \\
\hline $\mathrm{La}^{3+}$ & 0.000 & 0.000 & 0.001 & 0.001 & 0.000 & 0.000 & 0.000 & 0.000 & 0.000 & 0.000 \\
\hline $\mathrm{Ce}^{3+}$ & 0.001 & 0.000 & 0.000 & 0.000 & 0.000 & 0.000 & 0.000 & 0.000 & 0.000 & 0.002 \\
\hline $\mathrm{Pr}^{3+}$ & 0.002 & 0.000 & 0.000 & 0.000 & 0.001 & 0.001 & 0.001 & 0.000 & 0.001 & 0.000 \\
\hline $\mathrm{Nd}^{3+}$ & 0.000 & 0.000 & 0.000 & 0.000 & 0.000 & 0.000 & 0.000 & 0.000 & 0.000 & 0.000 \\
\hline $\mathrm{Sm}^{2+}$ & 0.001 & 0.002 & 0.002 & 0.001 & 0.000 & 0.000 & 0.000 & 0.001 & 0.000 & 0.002 \\
\hline $\mathrm{Eu}^{2+}$ & 0.000 & 0.001 & 0.000 & 0.000 & 0.000 & 0.001 & 0.000 & 0.000 & 0.000 & 0.001 \\
\hline $\mathrm{Gd}^{3+}$ & 0.004 & 0.000 & 0.000 & 0.000 & 0.001 & 0.000 & 0.002 & 0.001 & 0.004 & 0.000 \\
\hline $\mathrm{Tb}^{3+}$ & 0.000 & 0.001 & 0.000 & 0.000 & 0.000 & 0.000 & 0.000 & 0.000 & 0.001 & 0.000 \\
\hline $\mathrm{Dy}^{3+}$ & 0.001 & 0.001 & 0.002 & 0.001 & 0.000 & 0.000 & 0.002 & 0.001 & 0.005 & 0.004 \\
\hline $\mathrm{Ho}^{3+}$ & 0.000 & 0.000 & 0.000 & 0.001 & 0.000 & 0.001 & 0.000 & 0.000 & 0.000 & 0.000 \\
\hline $\mathrm{Er}^{3+}$ & 0.000 & 0.000 & 0.001 & 0.001 & 0.000 & 0.001 & 0.001 & 0.001 & 0.002 & 0.002 \\
\hline $\mathrm{Tm}^{3+}$ & 0.000 & 0.001 & 0.000 & 0.000 & 0.000 & 0.000 & 0.000 & 0.000 & 0.000 & 0.000 \\
\hline $\mathrm{Yb}^{3+}$ & 0.000 & 0.000 & 0.000 & 0.000 & 0.001 & 0.001 & 0.004 & 0.007 & 0.000 & 0.000 \\
\hline $\mathrm{Bi}^{3+}$ & 0.000 & 0.000 & 0.000 & 0.000 & 0.000 & 0.000 & 0.000 & 0.000 & 0.022 & 0.021 \\
\hline $\mathrm{Mn}^{2+}$ & 0.003 & 0.002 & 0.000 & 0.000 & 0.000 & 0.000 & 0.000 & 0.000 & 0.005 & 0.008 \\
\hline $\mathrm{Fe}^{2+}$ & 0.003 & 0.000 & 0.000 & 0.000 & 0.002 & 0.001 & 0.001 & 0.001 & 0.033 & 0.033 \\
\hline $\mathrm{Pb}^{2+}$ & 0.001 & 0.000 & 0.000 & 0.000 & 0.001 & 0.000 & 0.000 & 0.001 & 0.001 & 0.001 \\
\hline $\mathrm{Zr} / \mathrm{Hf}$ & 27.6 & 22.0 & 21.0 & 18.4 & 62.3 & 47.5 & 51.8 & 61.8 & 31.5 & 26.4 \\
\hline
\end{tabular}

Note: formula calculation based on the sum of cations $=2$. 
Appendix D.10 (contd.): Electron microprobe analyses of zircon.

\begin{tabular}{|c|c|c|c|c|c|c|c|}
\hline Site & 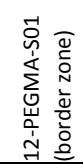 & 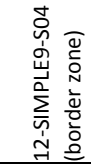 & 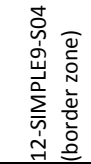 & 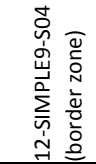 & 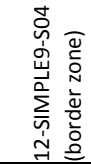 & 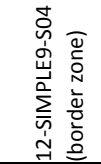 & 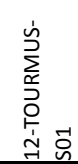 \\
\hline Point & $2 z-1$ & $4594 z-1$ & $4 S 94 z-2$ & $4594 z-3$ & $4594 z-4$ & 4S94z-5 & $201 z-1$ \\
\hline $\mathrm{SiO}_{2}$ (wt.\%) & 31.26 & 31.97 & 32.85 & 32.31 & 31.78 & 32.70 & 31.60 \\
\hline $\mathrm{TiO}_{2}$ & 0.01 & 0.00 & 0.00 & 0.00 & 0.00 & 0.02 & 0.00 \\
\hline $\mathrm{ZrO}_{2}$ & 66.80 & 65.23 & 66.21 & 65.61 & 63.64 & 66.06 & 61.17 \\
\hline $\mathrm{HfO}_{2}$ & 1.52 & 1.87 & 1.69 & 2.23 & 2.29 & 1.67 & 2.73 \\
\hline $\mathrm{ThO}_{2}$ & 0.00 & 0.00 & 0.00 & 0.00 & 0.00 & 0.02 & 0.00 \\
\hline $\mathrm{UO}_{2}$ & 0.00 & 0.58 & 0.05 & 0.35 & 0.72 & 0.02 & 1.22 \\
\hline $\mathrm{Al}_{2} \mathrm{O}_{3}$ & 0.00 & 0.06 & 0.01 & 0.00 & 0.00 & 0.01 & 0.00 \\
\hline $\mathrm{Sc}_{2} \mathrm{O}_{3}$ & 0.00 & 0.22 & 0.00 & 0.11 & 0.27 & 0.02 & 0.02 \\
\hline $\mathrm{Y}_{2} \mathrm{O}_{3}$ & 0.08 & 0.36 & 0.07 & 0.44 & 0.32 & 0.03 & 0.20 \\
\hline $\mathrm{La}_{2} \mathrm{O}_{3}$ & 0.05 & 0.00 & 0.00 & 0.00 & 0.05 & 0.02 & 0.08 \\
\hline $\mathrm{Ce}_{2} \mathrm{O}_{3}$ & 0.00 & 0.03 & 0.00 & 0.00 & 0.00 & 0.00 & 0.00 \\
\hline $\mathrm{Pr}_{2} \mathrm{O}_{3}$ & 0.04 & 0.04 & 0.00 & 0.00 & 0.00 & 0.00 & 0.00 \\
\hline $\mathrm{Nd}_{2} \mathrm{O}_{3}$ & 0.00 & 0.00 & 0.00 & 0.00 & 0.00 & 0.00 & 0.00 \\
\hline $\mathrm{SmO}$ & 0.09 & 0.00 & 0.18 & 0.01 & 0.00 & 0.07 & 0.07 \\
\hline EuO & 0.05 & 0.02 & 0.02 & 0.01 & 0.00 & 0.02 & 0.05 \\
\hline $\mathrm{Gd}_{2} \mathrm{O}_{3}$ & 0.08 & 0.04 & 0.00 & 0.23 & 0.00 & 0.00 & 0.00 \\
\hline $\mathrm{Tb}_{2} \mathrm{O}_{3}$ & 0.00 & 0.00 & 0.04 & 0.00 & 0.00 & 0.00 & 0.05 \\
\hline $\mathrm{Dy}_{2} \mathrm{O}_{3}$ & 0.07 & 0.00 & 0.00 & 0.00 & 0.16 & 0.13 & 0.00 \\
\hline $\mathrm{Ho}_{2} \mathrm{O}_{3}$ & 0.00 & 0.09 & 0.00 & 0.00 & 0.00 & 0.09 & 0.04 \\
\hline $\mathrm{Er}_{2} \mathrm{O}_{3}$ & 0.09 & 0.04 & 0.05 & 0.23 & 0.16 & 0.10 & 0.07 \\
\hline $\mathrm{Tm}_{2} \mathrm{O}_{3}$ & 0.02 & 0.02 & 0.01 & 0.08 & 0.04 & 0.00 & 0.00 \\
\hline $\mathrm{Yb}_{2} \mathrm{O}_{3}$ & 0.09 & 0.28 & 0.08 & 0.20 & 0.24 & 0.00 & 0.00 \\
\hline $\mathrm{Bi}_{2} \mathrm{O}_{3}$ & 0.00 & 0.01 & 0.00 & 0.04 & 0.03 & 0.00 & 0.00 \\
\hline $\mathrm{MnO}$ & 0.00 & 0.00 & 0.00 & 0.02 & 0.00 & 0.00 & 1.81 \\
\hline $\mathrm{FeO}$ & 0.01 & 0.64 & 0.02 & 0.02 & 0.02 & 0.08 & 0.53 \\
\hline $\mathrm{PbO}$ & 0.01 & 0.03 & 0.11 & 0.01 & 0.01 & 0.00 & 0.00 \\
\hline Total & 100.27 & 101.53 & 101.39 & 101.90 & 99.73 & 101.06 & 99.64 \\
\hline $\mathrm{Si}^{4+}(\mathrm{apfu})$ & 0.969 & 0.974 & 0.998 & 0.985 & 0.989 & 0.996 & 0.977 \\
\hline $\mathrm{Ti}^{4+}$ & 0.000 & 0.000 & 0.000 & 0.000 & 0.000 & 0.000 & 0.000 \\
\hline $\mathrm{Zr}^{4+}$ & 1.010 & 0.969 & 0.981 & 0.975 & 0.966 & 0.981 & 0.922 \\
\hline $\mathrm{Hf}^{4+}$ & 0.013 & 0.016 & 0.015 & 0.019 & 0.020 & 0.015 & 0.024 \\
\hline $\mathrm{Th}^{4+}$ & 0.000 & 0.000 & 0.000 & 0.000 & 0.000 & 0.000 & 0.000 \\
\hline $\mathrm{U}^{4+}$ & 0.000 & 0.004 & 0.000 & 0.002 & 0.005 & 0.000 & 0.008 \\
\hline $\mathrm{Al}^{3+}$ & 0.000 & 0.002 & 0.000 & 0.000 & 0.000 & 0.000 & 0.000 \\
\hline $\mathrm{Sc}^{3+}$ & 0.000 & 0.006 & 0.000 & 0.003 & 0.007 & 0.001 & 0.001 \\
\hline $\mathrm{Y}^{3+}$ & 0.001 & 0.006 & 0.001 & 0.007 & 0.005 & 0.000 & 0.003 \\
\hline $\mathrm{La}^{3+}$ & 0.001 & 0.000 & 0.000 & 0.000 & 0.001 & 0.000 & 0.001 \\
\hline $\mathrm{Ce}^{3+}$ & 0.000 & 0.000 & 0.000 & 0.000 & 0.000 & 0.000 & 0.000 \\
\hline $\mathrm{Pr}^{3+}$ & 0.000 & 0.000 & 0.000 & 0.000 & 0.000 & 0.000 & 0.000 \\
\hline $\mathrm{Nd}^{3+}$ & 0.000 & 0.000 & 0.000 & 0.000 & 0.000 & 0.000 & 0.000 \\
\hline $\mathrm{Sm}^{2+}$ & 0.001 & 0.000 & 0.002 & 0.000 & 0.000 & 0.001 & 0.001 \\
\hline $\mathrm{Eu}^{2+}$ & 0.001 & 0.000 & 0.000 & 0.000 & 0.000 & 0.000 & 0.001 \\
\hline $\mathrm{Gd}^{3+}$ & 0.001 & 0.000 & 0.000 & 0.002 & 0.000 & 0.000 & 0.000 \\
\hline $\mathrm{Tb}^{3+}$ & 0.000 & 0.000 & 0.000 & 0.000 & 0.000 & 0.000 & 0.001 \\
\hline $\mathrm{Dy}^{3+}$ & 0.001 & 0.000 & 0.000 & 0.000 & 0.002 & 0.001 & 0.000 \\
\hline $\mathrm{Ho}^{3+}$ & 0.000 & 0.001 & 0.000 & 0.000 & 0.000 & 0.001 & 0.000 \\
\hline $\mathrm{Er}^{3+}$ & 0.001 & 0.000 & 0.000 & 0.002 & 0.002 & 0.001 & 0.001 \\
\hline $\mathrm{Tm}^{3+}$ & 0.000 & 0.000 & 0.000 & 0.001 & 0.000 & 0.000 & 0.000 \\
\hline $\mathrm{Yb}^{3+}$ & 0.001 & 0.003 & 0.001 & 0.002 & 0.002 & 0.000 & 0.000 \\
\hline $\mathrm{Bi}^{3+}$ & 0.000 & 0.000 & 0.000 & 0.000 & 0.000 & 0.000 & 0.000 \\
\hline $\mathrm{Mn}^{2+}$ & 0.000 & 0.000 & 0.000 & 0.001 & 0.000 & 0.000 & 0.047 \\
\hline $\mathrm{Fe}^{2+}$ & 0.000 & 0.016 & 0.001 & 0.001 & 0.001 & 0.002 & 0.014 \\
\hline $\mathrm{Pb}^{2+}$ & 0.000 & 0.000 & 0.001 & 0.000 & 0.000 & 0.000 & 0.000 \\
\hline $\mathrm{Zr} / \mathrm{Hf}$ & 75.1 & 59.6 & 66.9 & 50.3 & 47.5 & 67.6 & 38.3 \\
\hline
\end{tabular}


Appendix D.11: Electron microprobe analyses of sekaninaite.

\begin{tabular}{|c|c|c|c|c|c|c|c|c|}
\hline $\begin{array}{l}\text { Position } \\
\text { within } \\
\text { sekan. } \\
\text { crystal }\end{array}$ & 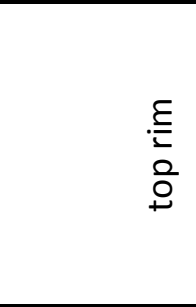 & 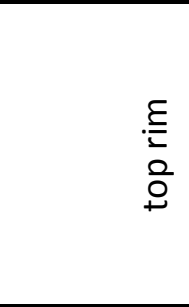 & 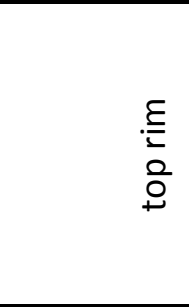 & $\frac{\frac{\omega}{\overline{0}}}{\frac{0}{\xi}}$ & $\frac{\frac{0}{\overline{0}}}{\frac{0}{E}}$ & 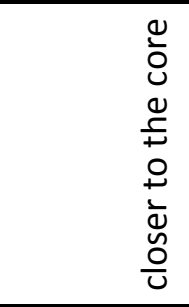 & 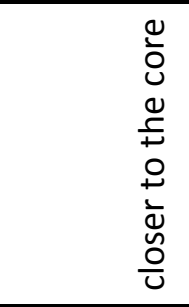 & ปั \\
\hline Sample & GAR1c-1 & GAR1c-2 & GAR1c-3 & GAR1c-4 & GAR1c-5 & GAR1c-6 & GAR1c-7 & GAR2c-1 \\
\hline $\mathrm{SiO}_{2}$ & 46.18 & 46.25 & 45.25 & 46.24 & 45.03 & 45.63 & 45.78 & 45.20 \\
\hline $\mathrm{Al}_{2} \mathrm{O}_{3}$ & 29.23 & 29.48 & 29.22 & 29.67 & 29.41 & 29.65 & 29.53 & 29.46 \\
\hline $\mathrm{BeO} *$ & 1.06 & 0.74 & 0.37 & 0.72 & 0.00 & 0.09 & 0.31 & 0.00 \\
\hline $\mathrm{MgO}$ & 3.92 & 3.94 & 3.86 & 3.98 & 3.97 & 3.95 & 3.96 & 3.87 \\
\hline $\mathrm{MnO}$ & 2.79 & 2.79 & 2.66 & 3.81 & 2.74 & 2.88 & 2.78 & 2.73 \\
\hline $\mathrm{FeO}$ & 10.54 & 10.55 & 10.53 & 9.43 & 10.44 & 10.86 & 10.71 & 10.78 \\
\hline $\mathrm{CaO}$ & 0.06 & 0.03 & 0.04 & 0.05 & 0.03 & 0.05 & 0.03 & 0.07 \\
\hline $\mathrm{Li}_{2} \mathrm{O}^{*}$ & 0.35 & 0.48 & 0.54 & 0.43 & 0.68 & 0.54 & 0.54 & 0.63 \\
\hline $\mathrm{Na}_{2} \mathrm{O}$ & 1.99 & 2.15 & 2.02 & 1.92 & 2.09 & 1.92 & 2.05 & 2.03 \\
\hline Total & 96.12 & 96.40 & 94.48 & 96.25 & 94.39 & 95.58 & 95.69 & 94.77 \\
\hline $\mathrm{Si}$ & 5 & 5 & 5 & 5 & 5 & 5 & 5 & 5 \\
\hline Al & 3.730 & 3.757 & 3.804 & 3.781 & 3.850 & 3.829 & 3.801 & 3.841 \\
\hline $\mathrm{Be}$ & 0.276 & 0.191 & 0.099 & 0.188 & 0.000 & 0.024 & 0.082 & 0.000 \\
\hline $\mathrm{Mg}$ & 0.632 & 0.636 & 0.636 & 0.642 & 0.656 & 0.644 & 0.644 & 0.637 \\
\hline $\mathrm{Mn}$ & 0.256 & 0.255 & 0.249 & 0.349 & 0.258 & 0.267 & 0.257 & 0.256 \\
\hline $\mathrm{Fe}^{2+}$ & 0.955 & 0.953 & 0.973 & 0.853 & 0.970 & 0.996 & 0.978 & 0.997 \\
\hline $\mathrm{Ca}$ & 0.006 & 0.003 & 0.004 & 0.005 & 0.004 & 0.005 & 0.003 & 0.008 \\
\hline $\mathrm{Li}$ & 0.151 & 0.209 & 0.239 & 0.187 & 0.302 & 0.240 & 0.237 & 0.282 \\
\hline $\mathrm{Na}$ & 0.419 & 0.451 & 0.433 & 0.403 & 0.450 & 0.407 & 0.434 & 0.436 \\
\hline 0 & 18.005 & 18.002 & 18.003 & 18.004 & 18.038 & 18.004 & 18.002 & 18.020 \\
\hline
\end{tabular}

*Note : formula calculated on the basis of $\mathrm{Si}=5$. $\mathrm{Li}$ and $\mathrm{Be}$ contents were calculated using formula of Bertoldi et al. (2004). 
Appendix D.11 (contd.): Electron microprobe analyses of sekaninaite.

\begin{tabular}{|c|c|c|c|c|c|c|c|c|}
\hline $\begin{array}{l}\text { Position } \\
\text { within } \\
\text { sekan. } \\
\text { crystal }\end{array}$ & 잉 & ปั & $\frac{\frac{0}{\bar{g}}}{\frac{\mathrm{O}}{\xi}}$ & $\frac{\frac{0}{\bar{D}}}{\frac{\mathrm{O}}{\mathrm{E}}}$ & $\frac{\frac{0}{\bar{g}}}{\frac{\mathrm{O}}{\mathrm{E}}}$ & $\frac{\frac{\omega}{\bar{g}}}{\frac{\mathrm{O}}{\xi}}$ & $\frac{\frac{\varrho}{\bar{g}}}{\frac{\mathrm{O}}{E}}$ & $\frac{\frac{0}{\bar{g}}}{\frac{\mathrm{O}}{\mathrm{E}}}$ \\
\hline Sample & GAR2c-2 & GAR2c-3 & GAR2c-4 & GAR2c-5 & GAR2c-6 & GAR2c-7 & GAR2c-8 & GAR2c-9 \\
\hline $\mathrm{SiO}_{2}$ & 45.54 & 46.18 & 44.68 & 45.80 & 45.29 & 45.60 & 45.36 & 45.63 \\
\hline $\mathrm{Al}_{2} \mathrm{O}_{3}$ & 29.67 & 29.56 & 29.62 & 29.72 & 29.34 & 29.40 & 29.48 & 29.38 \\
\hline $\mathrm{BeO} *$ & 0.00 & 0.83 & 0.00 & 0.11 & 0.17 & 0.59 & 0.00 & 0.32 \\
\hline MgO & 3.81 & 3.89 & 3.89 & 3.88 & 3.85 & 3.87 & 3.95 & 3.95 \\
\hline $\mathrm{MnO}$ & 2.84 & 2.89 & 2.85 & 2.99 & 2.81 & 3.18 & 2.84 & 2.65 \\
\hline $\mathrm{FeO}$ & 10.69 & 10.63 & 10.76 & 10.87 & 10.46 & 9.88 & 11.05 & 10.71 \\
\hline $\mathrm{CaO}$ & 0.05 & 0.04 & 0.05 & 0.05 & 0.07 & 0.05 & 0.06 & 0.03 \\
\hline $\mathrm{Li}_{2} \mathrm{O}^{*}$ & 0.67 & 0.36 & 0.71 & 0.56 & 0.62 & 0.48 & 0.60 & 0.57 \\
\hline $\mathrm{Na}_{2} \mathrm{O}$ & 2.14 & 1.82 & 1.89 & 1.98 & 2.11 & 1.92 & 2.02 & 2.14 \\
\hline Total & 95.42 & 96.21 & 94.45 & 95.96 & 94.71 & 94.97 & 95.35 & 95.37 \\
\hline $\mathrm{Si}$ & 5 & 5 & 5 & 5 & 5 & 5 & 5 & 5 \\
\hline Al & 3.839 & 3.772 & 3.906 & 3.825 & 3.818 & 3.799 & 3.830 & 3.794 \\
\hline $\mathrm{Be}$ & 0.000 & 0.216 & 0.000 & 0.028 & 0.046 & 0.156 & 0.000 & 0.083 \\
\hline $\mathrm{Mg}$ & 0.624 & 0.627 & 0.649 & 0.632 & 0.634 & 0.633 & 0.649 & 0.645 \\
\hline $\mathrm{Mn}$ & 0.264 & 0.265 & 0.270 & 0.277 & 0.263 & 0.295 & 0.265 & 0.246 \\
\hline $\mathrm{Fe}^{2+}$ & 0.982 & 0.962 & 1.007 & 0.992 & 0.965 & 0.906 & 1.019 & 0.981 \\
\hline $\mathrm{Ca}$ & 0.006 & 0.005 & 0.006 & 0.006 & 0.008 & 0.006 & 0.007 & 0.003 \\
\hline $\mathrm{Li}$ & 0.298 & 0.157 & 0.319 & 0.247 & 0.275 & 0.211 & 0.265 & 0.251 \\
\hline $\mathrm{Na}$ & 0.455 & 0.383 & 0.410 & 0.420 & 0.452 & 0.409 & 0.432 & 0.455 \\
\hline 0 & 18.011 & 18.004 & 18.155 & 18.004 & 18.006 & 18.004 & 18.034 & 18.002 \\
\hline
\end{tabular}


Appendix D.11 (contd.): Electron microprobe analyses of sekaninaite.

\begin{tabular}{|c|c|c|c|c|c|}
\hline $\begin{array}{l}\text { Position } \\
\text { within } \\
\text { sekan. } \\
\text { crystal }\end{array}$ & $\frac{\frac{o}{\bar{g}}}{\frac{\mathrm{O}}{\xi}}$ & $\frac{\frac{\omega}{\bar{g}}}{\frac{\bar{O}}{\xi}}$ & $\underline{\underline{E}}$ & .气 & . \\
\hline Sample & GAR2c-10 & GAR2c-11 & GAR2c-12 & GAR2c-13 & GAR2c-14 \\
\hline $\mathrm{SiO}_{2}$ & 45.52 & 45.79 & 45.12 & 45.70 & 45.52 \\
\hline $\mathrm{Al}_{2} \mathrm{O}_{3}$ & 29.75 & 29.63 & 29.57 & 29.40 & 29.68 \\
\hline $\mathrm{BeO}^{*}$ & 0.00 & 0.25 & 0.00 & 0.70 & 0.13 \\
\hline MgO & 3.94 & 3.89 & 3.89 & 3.97 & 4.33 \\
\hline $\mathrm{MnO}$ & 2.74 & 2.76 & 3.04 & 2.97 & 3.73 \\
\hline $\mathrm{FeO}$ & 10.83 & 10.66 & 9.87 & 9.84 & 8.67 \\
\hline $\mathrm{CaO}$ & 0.05 & 0.06 & 0.05 & 0.05 & 0.05 \\
\hline $\mathrm{Li}_{2} \mathrm{O}^{*}$ & 0.61 & 0.59 & 0.69 & 0.46 & 0.62 \\
\hline $\mathrm{Na}_{2} \mathrm{O}$ & 1.94 & 2.08 & 2.05 & 1.92 & 2.00 \\
\hline Total & 95.38 & 95.71 & 94.28 & 95.01 & 94.73 \\
\hline $\mathrm{Si}$ & 5 & 5 & 5 & 5 & 5 \\
\hline $\mathrm{Al}$ & 3.851 & 3.814 & 3.862 & 3.791 & 3.843 \\
\hline $\mathrm{Be}$ & 0.000 & 0.066 & 0.000 & 0.185 & 0.033 \\
\hline $\mathrm{Mg}$ & 0.645 & 0.633 & 0.643 & 0.647 & 0.709 \\
\hline $\mathrm{Mn}$ & 0.255 & 0.255 & 0.285 & 0.275 & 0.347 \\
\hline $\mathrm{Fe}^{2+}$ & 0.995 & 0.974 & 0.915 & 0.901 & 0.796 \\
\hline $\mathrm{Ca}$ & 0.006 & 0.006 & 0.005 & 0.005 & 0.006 \\
\hline $\mathrm{Li}$ & 0.268 & 0.258 & 0.307 & 0.201 & 0.272 \\
\hline $\mathrm{Na}$ & 0.414 & 0.440 & 0.441 & 0.407 & 0.426 \\
\hline $\mathrm{O}$ & 18.019 & 18.005 & 18.016 & 18.004 & 18.004 \\
\hline
\end{tabular}

